\title{
Entrevistas cualitativas:
}

A continuación se adjunta la transcripción completa de las cincuenta entrevistas realizadas en la investigación doctoral por orden alfabético, incluyendo los datos relativos a la identidad del entrevistado, su ocupación, lugar, fecha y duración estimada de la grabación original. La disposición de los documentos cualitativos es la siguiente:

\begin{tabular}{|l|l|}
\hline 1. Francisco Aguirre Sacasa. & 26. Luís Humberto Guzmán. \\
\hline 2. María Dolores Alemán. & 27. Manuel Ortega Hegg. \\
\hline 3. Gabriel Álvarez. & 28. René Herrera Zúñiga. \\
\hline 4. Manuel Aráuz. & 29. Edmundo Jarquín. \\
\hline 5. José Antonio Alvarado. & 30. Antonio Lacayo. \\
\hline 6. Carlos Arroyo. & 31. Cairo Manuel López. \\
\hline 7. Mónica Baltodano. & 32. Orlando López Selva. \\
\hline 8. Reinaldo Balladares. & 33. Félix Madariaga. \\
\hline 9. Enrique Bolaños Geyer. & 34. Dionisio Marenco. \\
\hline 10. Roberto Cajina. & 35. Adolfo Martínez Cole. \\
\hline 11. Fernando Caldera. & 36. Sofía Montenegro. \\
\hline 12. Luís Carrión Cruz. & 37. Carlos Noguera. \\
\hline 13. Edwin Castro Rivera. & 38. José Pallais. \\
\hline 14. Alfredo César. & 39. Indalecio Rodríguez. \\
\hline 15. Rafael Córdova Álvarez. & 40. Enrique Sainz. \\
\hline 16. Elvira Cuadra. & 41. María Eugenia Sequeira. \\
\hline 17. Sergio Cuarezma Terán. & 42. Alejandro Serrano Caldera. \\
\hline 18. Carlos Fernando Chamorro. & 43. Ada Esperanza Silva y Azahalea Solís. \\
\hline 19. Eduardo Enríquez. & 44. Rafael Solís. \\
\hline 20. Iván Escobar Fornos. & 45. Dora María Téllez. \\
\hline 21. Roberto Evert. & 46. Víctor Hugo Tinoco. \\
\hline 22. José Figueroa. & 47. Carlos Tünnerman. \\
\hline 23. Omar García. & 48. Arnaldo Zambrana Fonseca. \\
\hline 24. Violeta Granera. & 49. Rosa Marina Zelaya. \\
\hline 25. Roger Guevara-Mena. & 50. Mauricio Zúñiga. \\
\hline & \\
\hline
\end{tabular}




\section{ENTREVISTA $1^{1}$ :}

Nombre del entrevistado: D. Francisco Aguirre Sacasa.

Cargo actual: Diputado del Partido Liberal Constitucionalista (PLC) en la Asamblea Nacional (2007-2011).

Fecha de realización de la entrevista: Managua, 9 de noviembre de 2009.

Lugar: Asamblea Nacional de la República de Nicaragua.

Duración estimada: 2 horas y 10 minutos.

\section{TEXTO - Transcripción 1:}

R: Me interesa sobre todo, como le comentaba antes, su reflexión a propósito de los cambios constitucionales que se han producido en Nicaragua desde los años 90 hasta la fecha, en este periodo de transición, que se inició, además, con el debate profundo entre reforma total o reforma parcial a la Constitución del 87. ¿Cómo ve usted esta secuencia compleja de transformaciones?

F.A.: Bueno, en primer lugar, me gusta que estés dándole un enfoque histórico a esto, en el año 1990 comienza o renace la democracia en Nicaragua, con una inesperada victoria de algo que se llamaba la UNO, Unión Nacional Opositora, en un momento, que, entre ejes dictados más que nada por las convulsiones que vivía el marxismoleninismo en el mundo, estamos celebrando ahora el 20 aniversario de la caída del Muro de Berlín, verdad, pero, en realidad, ya en la época de Andropov, y, definitivamente, después de Mijail Gorbachov, los líderes de la Unión Soviética comprendían que el sistema de ellos estaba en franca degradación, y que habían perdido, por decirlo así, una carrera tecnológica más que nada, y económica con lo países de occidente, lo que yo llamo las democracias liberales. Entonces, en ese momento, como recordarás, hay una especie de entente entre el líder de los Estados Unidos, Ronald Reagan, y el presidente de la Unión Soviética, Mijail Gorbachov y de un día al otro, prácticamente, acaba la Guerra Fría, hablándote metafóricamente. Al acabar la Guerra Fría aquellos países que habían sido peones en la Guerra Fría comienzan a perder sus patrones, por llamarlo así, internacionales, pero los primeros que perdieron a esos amos, a esos patrones, a esas metrópolis, fueron justamente los países que habían abrazado en tierra propia el marxismo-leninismo con los gobiernos totalitarios, en el caso de Centroamérica, principalmente Nicaragua, pero Daniel Ortega, como todo gobernante, porque nunca te voy a hablar del sandinismo como un problema, te voy a hablar de Daniel Ortega como el problema para la democracia, la reconciliación nacional, la transparencia y la gobernabilidad, el Estado de Derecho, todas esas cuestiones que nosotros vinculamos con lo que yo llamo las democracias liberales del mundo, también Ortega vivía en una cápsula, él era un hombre que viajaba a dar las grandes conferencias en los países no alineados, y era recibido como un rey, era un hombre que a pesar de ser relativamente joven llenaba un espacio considerable en el elenco, digamos, de las personas conocidas mundialmente, y Daniel no comprendía la magnitud del, ¿cómo te diría yo?, del desgaste que había tenido el Frente Sandinista durante la década de los 80, por el mal

\footnotetext{
1 Entrevista muy larga, con un discurso-monólogo desarrollado por el entrevistado sin la interrupción correspondiente del guión de preguntas. No obstante, es de gran interés, a pesar del sesgo político, por su estilo directo, pragmático, y conocedor del juego entre los actores institucionales en la democracia nicaragüense, especialmente, en temas de liderazgo partidario y relaciones Ejecutivo-Legislativo, y algunas cuestiones de Derecho Constitucional Comparado.
} 
manejo de la economía, por el mal manejo de la paz que se dio inmediatamente después del derrocamiento de la dictadura somocista, porque en aquél momento Daniel y el Frente contaba con el 99,9\% de los nicaragüenses, tal vez estoy exagerándolo un poco, pero en las zonas urbanas era muy, muy popular o muy impopular Anastasio Somoza Debayle, y el pueblo estaba hastiado de las dinastías familiares. Entonces, Daniel acepta controlando a todas las palancas del poder del país, él acepta ir a una contienda electoral, nunca imaginándose él y me atrevería a decir nunca imaginándose la mayoría de los nicaragüenses que podría perder Daniel y podría perder el Frente Sandinista, era inconcebible para la vasta mayoría de los nicaragüenses, pero no para la vasta mayoría, o no para una minoría, pongámoslo así, de extranjeros, que seguía muy de cerca lo que ocurría en Nicaragua, y que veían o percibían el desgaste de ese poder. Yo, en ese entonces, trabajaba, yo era un alto funcionario en el Banco Mundial, en Washington, y me acuerdo que yo me reunía con un senador en particular, que había estudiado conmigo en un liceo en los Estados Unidos, que para mí es el hombre que más conoce de Latinoamérica en el Senado norteamericano, me refiero al senador norteamericano Christopher Darth, demócrata, enemigo de la guerra Contra, pero no enemigo, más bien partidario del apoyo a la democracia representativa, y Christopher me dijo a mí que se iban a dar una gran sorpresa los sandinistas con el resultado de las elecciones, y, efectivamente, se lo dieron, porque hasta donde recuerdo Doña Violeta Barrios de Chamorro sacó alrededor de un $60 \%$ del voto, a pesar de que el sandinismo controlaba las mayores palancas del poder, no dudo yo en que Daniel da esas lecciones, no porque él se había convertido en un demócrata, pero porque le habían dicho sus antiguos amos, aquí habían venido el mismo Gorbachov y había venido Shevardnadze, que era el Canciller de la URSS a decirle que Daniel tenía que aceptar el estado de cosas, palabra antigua que tenemos meses y años tal vez de no escucharla, de no usarla, perestroika, porque ya la ayuda rusa y de todo el bloque soviético iba a dejar de apoyarlo, y, obviamente, si no iba a apoyarlo la metrópoli, tampoco lo iba a hacer Cuba, que dependía totalmente de la Unión Soviética, entonces, él da esas lecciones, al mejor estilo nicaragüense, deja de un lado la Constitución Política, y como él estaba seguro de que él iba a ganar en un cosa que creo que se llamaba la Ley Marco decide que el período de la presidenta o del presidente no iba a ser de 5 años como estipula nuestra Constitución Política, sino que de 6 años y medio, porque iba a completar lo que le quedaba, creo yo, que éste era el punto, lo que quedaba del período de Daniel y después los 5 años adicionales, se dan las elecciones, es abrumadora la victoria de la Violeta, era grande, y, realmente, importante y seria la observación internacional también, y lo que, indiscutiblemente, presionó enormemente a Daniel en todo lo que pasa allí es el abandono de la Unión Soviética, que le dice: "buscá un arreglo, porque ya nosotros no te vamos a apoyar más", como dice algún artista de cine, "chao, baby", gran elección, gran sorpresa, arranca la UNO con, en ese entonces, podríamos hablar todavía del Frente Sandinista, y aunque el partido al que pertenezco yo, y al que pertenece José Pallais, sólo nos toca algo, como cuatro o cinco escaños en el parlamento que sale electo, la vasta mayoría de los diputados eran lo que podríamos llamar demócratas, miembros de la UNO, muchos de ellos representando a partiditos pequeñitos inconsecuentes en Nicaragua, era el "parlamento de las bisagras", le digo yo, porque estos partiditos políticos pequeños, no sé cómo será en España, pues, pero yo sé que allá está el Partido Popular y está el PSOE, no sé cuán importantes sean los terceros y cuartos partidos, pero aquí en Nicaragua, en ese entonces, como dijo Mao Tse Tum, que había que dejar que florecieran mil flores, pues, aquí en Nicaragua habían florecido no mil pero sí veinte partidos, algunos de ellos, la vasta mayoría de ellos, lo que yo llamaría "partidos de salón", pero estos partidos de salón podían tener dos o tres, y 
tuvieron, de hecho, dos o tres diputados y si vos ves quiénes eran los presidentes, en ese entonces, en la Asamblea nacional, te vas a dar cuenta que todos los de esos partidos pequeños, ninguno venía de los dos partidos que hoy en día constituyen las dos grandes corrientes políticas de nuestro país: una, es el Frente Sandinista de Liberación Nacional, y no voy a hablar más de eso, y el otro el Partido Liberal, cuyo portabanderas es el Partido Liberal Constitucionalista, del cual soy Secretario Nacional. Entonces, se desmorona toda la estructura, para mí, del Frente Sandinista, pero no antes de haberse robado, literalmente, todo lo que pertenecía al Estado y que no estaba clavado al piso o al cemento, porque aquí hubo algo que se llama la "piñata", que hubo una repartición de bienes, y se dio, incluso, como parte de los Acuerdos de Transición una amnistía y aquí muchísimos, pero muchísimos sandinistas se quedaron con fincas, se quedaron con casas, se quedaron con escritorios, máquinas de escribir, en ese entonces, no había muchas computadores u ordenadores, como seguramente le dicen ustedes en España, se quedaron con todo, al llevarse todos ellos esto, cuando te digo todos me refiero a la cúpula, porque no quiero que vayas a creer que aquí hubo una distribución que bajó a las bases del sandinismo, estoy hablándote, tal vez, de los 1000 o 1500 más influyentes del antiguo sandinismo, y al ver, y esto es muy importante, que Daniel no les podía dar nada más, lo que quedaba del Frente Sandinista, políticamente, se empezó a desbaratar, hasta el punto que ahora, si adelantamos la película al año 2009, de la antigua cúpula del Frente Sandinista la vasta mayoría, y, sobre todo, la parte que representaba la materia gris del sandinismo, abandonó a Daniel Ortega Saavedra, e hizo sus pasos con el nuevo sistema democrático de Nicaragua. Yo creo que en ese parlamento bien empezaron con 38 diputados, el Frente, terminaron con 8, y no es que los otros 30 desaparecieran, sino que los otros 30 se aglutinaron alrededor de otras fuerzas políticas, dis que sandinistas, lo cual significaba con el pasar del tiempo, socialistas pero demócratas, tipo PSOE en tu país, pero no con las pretensiones políticas que tenía Daniel Ortega, y ya sin lealtad hacia el cacique Daniel Ortega, creo que el peor momento, sólo para que te des una idea de lo mal que estaba el sandinismo, pierde la vasta mayoría de sus diputados, te repito, no mueren, no es que salen de la Asamblea Nacional, pero se reagrupan ellos en diferentes movimientos, el más importante del cual era el Movimiento Renovador Sandinista, MRS, y Daniel Ortega por falta de fondos, por falta de apoyo de la Unión Soviética, se ve obligado, por ejemplo, a cerrar el periódico que tenía el partido y que se llamaba Barricada, y cuyo director era Carlos Fernando Chamorro, que es un periodista prominente ahora de Nicaragua y cuyo sub-director era Javier Ríos Alba, otro prominente periodista nicaragüense, ambos ahora identificados claramente con lo que yo llamaría la corriente democrática del país, se daban las elecciones del año 1996, y esta vez sí para un período de 5 años, pero con una Constitución, que facilitaba la participación, otra vez, de los partidos micro, y se presentan candidatos por 24 partidos, si mal no recuerdo, 22 no 24, esa fue la boleta que nosotros llamábamos aquí en Nicaragua como "la sábana", porque era de este largo, entonces, allí las aguas regresan a sus cauces normales y tradicionales en nuestro país, porque nuestro país ha tenido, tradicionalmente, y, entonces, a pesar de que había 22 o 24 partidos, todos, existía una ley, en ese entonces, que permitía la Ley Electoral que ellos recibiesen un anticipo de 300.000 dólares por partido, te dije que la Ley Electoral favorecía a los micro-partidos, a las micro-agrupaciones, hasta el punto de vista financiero, pero 300.000 dólares ex ante, no a posteriori, no después de las elecciones, sino que antes, entonces, Francisco Aguirre Sacasa creaba el movimiento "Vamos con Francisco", y llegaba al Consejo Supremo Electoral, y, entonces, recibía 300.000 dólares, que, a lo mejor, con esos 300.000 dólares, yo a lo mejor hice una campaña, esos 300.000 más lo que podía haber conseguido de otros, pero a lo mejor no hice campaña, a lo mejor, me quedé con la 
plata, gasté $10.000,15.000,20.000$, poniendo unas cuantas mantas aquí en Managua para hacer la mueca, como decimos nosotros, de la elección, y los otros 280.000 yo me los metí en la bolsa, ¿qué pasa?, entre el sandinismo y el liberalismo, es la primera vez que se articula desde la época de los Somoza el liberalismo como una fuerza, porque antes fuimos en la UNO, ¿verdad?, el liberalismo y el sandinismo sacan aproximadamente el $90 \%$ de los votos, era más que $90 \%$, pero ponle tú entre el $90 \%$ y el $95 \%$, y los otros 22 o 20 partidos se quedan con el resto, pero se quedan cada uno de ellos con 300.000 dólares, quiero decirte que uno de los que sacó muy pocos votos fue el vice-presidente de Daniel Ortega, Sergio Ramírez Mercado, premiado en tu país por sus habilidades literarias, que se lleva con él a toda la inteligencia, podríamos decir, del sandinismo, o una buena parte por lo menos, y que comete el grave error de creer de que por escribir bien le llegás a la persona en los barrios, o le llegás al campesino de la montaña, este era el hombre, que durante mucho tiempo fue como un Primer Ministro de Daniel Ortega, era el que le manejaba el gobierno, porque a Daniel no le interesa gobernar, el estilo de Daniel es, primero, el figureo y, sobre todo, internacionalmente, y, segundo, el poder y como manejar el poder, se dan fenómenos como el siguiente, perdón, esto es importante mencionarlo en la entrevista, en el período de finales del 96, cuando están las elecciones se dan dos cosas bien importantes en nuestro país, primero, se profesionaliza en Ejército y por primera vez en la historia de nuestro país el Ejército Nacional es un Ejército nacional de los nicaragüenses y no un Ejército afiliado a un partido, y por otro lado, se profesionaliza también la Policía, entonces, eso es importantísimo porque se empieza a crear la institucionalidad, la independencia en dos instituciones, que en nuestro país, normalmente, han sido una, y que han sido la palanca principal del poder. La Asamblea, donde estoy yo, en el período pre Daniel Ortega y pre Somoza, o, perdón, antes del período de Violeta, no contaba para nada, estaba pintado en la pared, era una institución sin ningunas facultades reales, muy poco diferente a lo que era, digamos, el parlamento, Duma, creo que le dicen en ruso, en la época del marxismo-leninismo, a lo mejor en ese entonces, ya no se llamaba la Duma, a lo mejor, se llamaba otra cosa, entonces, aquí se crean dos instituciones que tienen el monopolio de la violencia, y se encaminan hacia el profesionalismo, muy importante, para mí quizás el logro más importante del período 90-2002, en lo que siento la reconciliación de la familia nicaragüense, ustedes pasaron por una tremenda y cruenta guerra civil, y con el tiempo, aunque sé que todavía sé están abriendo algunas de las heridas, estoy siguiendo el caso de la tumba de Federico García Lorca, cuando yo visité por primera vez tu país en el año 64 estaba Francisco Franco de caudillo de España, y yo detectaba que todavía había una cierta tensión entre algunos grupos de españoles, porque todavía estaba relativamente fresca la guerra civil, pero nosotros a pesar de que habíamos vivido una guerra mucho más cruenta, en términos relativos a la de ustedes, habíamos progresado enormemente en ese proceso de reconciliación, o sea, que si hay dos logros importantes en ese período fue la reconciliación de la mayoría de la familia nicaragüense, y el establecimiento y la institucionalización y la despolitización de esas dos instituciones que tenían el monopolio de la violencia, de la capacidad de la violencia en nuestro país, y mal que bien el país empezó a salir adelante, el sandinismo no desapareció a nivel de las bases, pero a nivel de la cúpula sí, yo te podría decir quiénes de los sandinistas que pretendieron democratizar el partido de los sandinistas, pero se encontraron con una resistencia muy fuerte por parte de Daniel, pero Daniel no tenía ninguna ilusión, ninguna expectativa, a lo mejor, de volverse presidente de Nicaragua, él estaba satisfecho con ser una persona que controlaba al partido, que, por diversas razones, también ejercía y proyectaba su poder en otros poderes sobre todo el judicial, cuando el sandinismo pierde en el 90, Daniel empieza a meter lo que nosotros 
llamamos la universidades de garaje, a una cantidad de los militantes más allegados a él, y empiezan a estudiar "entre comillas" Derecho, y empiezan a definirse como abogados, algunos de ellos llegan a ser hasta Magistrados de la Corte Suprema, pero muchos otros, muchísimos más se colocan en los niveles de jueces de Primera Instancia, y jueces de los Tribunales de Apelación. Los otros lugares donde se logra atrincherar el sandinismo, que ahora llamamos el danielismo, son las universidades y las ONGs. En el 2001, vamos otra vez a las elecciones, es la última vez que el partido liberal juega unas elecciones nacionales, realmente, unido alrededor de un candidato, que muchos de nosotros pensábamos que iba a acabar con la democracia en este país, me refiero al ingeniero Enrique Bolaños Geyer, no era, realmente, liberal, él era del otro partido contrincante, es más, a través de la historia ha sido el principal contrincante del Partido Liberal, que se llama el Partido Conservador, pero él, muy astutamente, había logrado proyectarse como un elemento valioso y había sido el vice-presidente de Arnoldo Alemán, y fue junto con Sergio Ramírez Mercado los únicos vice-presidentes en la historia de este país, en la historia de este país, que tuvieron atribuciones reales, Enrique Bolaños tuvo, por ejemplo, responsabilidades de presidente del ENEL, que es la empresa nacional de electricidad de Nicaragua, entre otras cosas, porque Alemán elegía a una persona de mucha integridad a cargo de uno de los sectores en donde más plata se maneja, y él tuvo muchas otras atribuciones, pero esa es una que te menciono, él fue el zar en la lucha contra la corrupción, él tenía a su cargo asegurarle a la población de Nicaragua de que no se iba a dar corrupción en esa época, Bolaños se hace presidente y saca algo así como el $54 \%$ o el $55 \%$ del voto, pero ahí voy a abrirte un poco más el asunto para que lo entendás, muchísima gente, así como no sabían quien era el señor Sergio Ramírez Mercado, aunque fuera muy popular y muy leído, y muy popular, es la palabra, en España, en Nicaragua, en esa elección de 1996, cuando él va como el candidato del MRS, yo creo que no llega ni siquiera al $1 \%$ del voto, con toda la intelligentsia, prácticamente, del Frente Sandinista con él, ni el 1\% del voto, en el año 2001, Bolaños, ex-presidente del Consejo de la Empresa Privada, el COSEP, un hombre de empresa destacado, una persona que en los años 80 había luchado contra el sandinismo, en ese entonces, sí podíamos hablar del sandinismo, y no del danielismo, nadie lo conocía aquí, dentro de los recintos en donde está el voto duro del Partido Liberal, porque si hay algo que nosotros tenemos en común con el sandinismo es que los dos grandes partidos en este país son partidos cuyas bases son populares, hay una interesante anécdota que me contó una persona de aquí, conservadora, pero que abandonó el partido, porque yo le dije una vez: “¿cuál es la diferencia entre vos y yo?, ¿entre los conservadores y los liberales?". Entonces, ella me dice: "mira hay una importantísima, pero sutil, importante diferencia”. "¿Y cuál es?" - le dije-. "Que los liberales quieren educar a los hijos de los lustradores de zapatos para que logren algo más que su padre, y los conservadores temen que los hijos o los nietos de los lustradores de zapatos aprendan alguna otra profesión, porque entonces nadie les va a lustrar los zapatos, y ellos no saben cómo hacerlo". Pero Bolaños vino con esa mentalidad de tecnócrata conservador, pero había aquí un pánico, porque nadie dudaba que Alemán iba a ganar las elecciones del año 1996, pero había mucha gente que dudaba de que Bolaños podía ganarle a Daniel, a pesar, Raquel, que Daniel había sufrido un revés casi fatal, el momento más bajo para él se da como en el año, a ojo de buen cubero, en el año 2000, finales de 1999, cuando su hijastra Zoilamérica Ortega lo acusa a él de haberse aprovechado de ella sexualmente desde la época en que ella era una joven adolescente, en otras palabras, no una niña de 17 o 18, o 19 años, sino una niña de unos 13 o 14 años, y yo nunca olvidaré, en ese entonces, yo era embajador de Nicaragua en Washington haber estado acá cuando se destapa ese escándalo, ella misma lo hace, y, entonces, hay 
una conferencia de prensa, todos los medios allí, y Daniel Ortega rodeado de su familia se sienta delante de esos micrófonos y su mujer, Rosario Murillo, es la que toma todas las preguntas, y contesta todas las preguntas, y, esencialmente, respalda a su marido, entre comillas, su compañero, y, por otro lado, prácticamente, trata de desmentir a su propia hija. Ese fue quizá el peor momento, políticamente, para Daniel Ortega, con eso se le fueron todavía más sandinistas, pero aún así Daniel Ortega, y sobre todo por la debilidad de Enrique Bolaños, y las encuestas, que demostraban que había un empate virtual entre los dos, se veía como un eventual ganador, y yo recuerdo que, en ese entonces, a mí me pusieron a cargo de la campaña electoral en el departamento de Río San Juan, que es uno de los más pobres de Nicaragua, y un departamento fuertemente rural, y me acuerdo que nosotros teníamos nuestras propias encuestas, en las que nosotros confiábamos, no las que salen aquí publicadas en los periódicos, que demostraban que en ese departamento, efectivamente, nadie conocía a Enrique Bolaños, nadie sabía quien era, Daniel era muy conocido, y según las encuestas que nosotros teníamos en septiembre Daniel tenía una ventaja de 60 a 40, entonces, y eso se estaba dando en todos los departamentos del país, no así en los diferentes estratos sociales, porque mientras entre más alto subías en la pirámide social en Nicaragua más gente conocía a Bolaños y más gente se identificaba con Bolaños, que era una especie de Cid Campeador, que iba a transformar de un solo golpe, revolucionar la cultura política de Nicaragua, que como, seguramente, sabés Raquel es uno de los países más tradicionales de Latinoamérica, pero lo que nosotros sabíamos, como liberales, era que como partido éramos conocidos, apreciados, apoyados por la mayoría de la población, sobre todo en esos reductos rurales, entonces, ¿qué hacía yo?, que era mi campaña, porque Bolaños nunca se quiso identificar con el Partido Liberal Constitucionalista, él decía, no lo decía abiertamente, pero él creía que Alemán le hacía sombra, que Alemán tenía la imagen de corrupto y que, por ende, el Partido Liberal también era retratado por la corrupción, eso era el juego de Bolaños, entonces, no sé si en algún momento ha ideado Bolaños ir a San Juan, pero sí sé que yo llegué, y llegué varias veces, y, entonces, visité a los principales municipios del río, y me acuerdo que llevaba yo camisetas rojas, gorras rojas, pancartas rojas, llevaba el barril de pilones de pintura roja, banderas rojas, y les dije a la gente:"bueno muchachos, ya viene la elección, a votar por el Partido Liberal y su plancha". Porque no les iba a decir: "quiero que voten por Enrique Bolaños, porque me iban a decir: "¿y quién es ese?”. Yo les tenía que decir: "ustedes tienen que votar ahora con el Partido Liberal, hay elecciones y ese día, ¡vámonos, organización, todo el mundo a votar ese día!". Y me acuerdo que hice eso desde San Carlos de Nicaragua, lástima que no tenemos un mapa de Nicaragua acá, hasta San Juan de Nicaragua, es decir, en la parte más occidental, desde la ciudad más importante del Río San Juan, que queda en el propio lago, del Cocibolca de Nicaragua, hasta San Juan de Nicaragua, que es el municipio más pequeño de Nicaragua, con menos de 600 personas, como tantos, entonces, terminamos ganando ese municipio con el $60 \%$ del voto, y el otro con un $40 \%$, a nivel nacional, ¿eh?, el Partido Liberal logró una victoria, como te dije de, aproximadamente, 54,5\% del voto, Daniel sacó algo así como el 42\%, y Daniel había sufrido otro golpe durísimo y se le fueron alejando todavía más sandinistas, ¿por qué?, porque ya veían que estaba desgastado el sandinismo, que no tenía porvenir el sandinismo, y porque estaba ocurriendo una cosa extremadamente interesante, sociológicamente, en el sandinismo, y es que ya había más y más sandinistas de la cúpula del partido que tenían algo que perder en Nicaragua, muchos que eran millonarios, no voy a mencionar nombres ahí, pero estoy seguro que vos podrías indagar, y te darás cuanta de quienes son y quienes eran, paradójicamente, la persona que nunca fue acusada de ser uno de los grandes beneficiados de todo esto era Daniel, 
porque se decía que Daniel, en el fondo, no le importaba la plata, se decía, porque ahora estamos clarísimos que sí le interesa, y que él era el pobre, y, por ende, el envidioso de los sandinistas que se quedaban en el poder, pero él tenía el partido, él manejaba la retórica de la guerra de clases, él manejaba un Mercedes Benz o dos, o tres, porque tiene una flota de Mercedes Benz del año, pero el pueblo, o una parte importante del pueblo, en esta sociedad que es tan tradicional veía a Daniel como el campeón de los pobres, que es la imagen que a él le gusta proyectar, viene Bolaños, y lo que el señor Bolaños trata de hacer es reformar durante sus 5 años a 500 años de cultura política y social nicaragüense, remontando a la época en que el señor Pedrarias Dávila es nombrado el primer Gobernador de Nicaragua, y una de sus primeras acciones es mandar decapitar a Francisco Hernández de Córdoba, que fue el conquistador entre comillas de Nicaragua, no el primer español en venir acá, pero el que, se dice, pues, que es el que conquistó, militarmente, a Nicaragua, porque él pretendía, Hernández de Córdoba pretendía reemplazar a Pedrarias Dávila como Gobernador, o sea, que aquí la solución a los problemas políticos desde la época de la colonia, literalmente, los momentos en que nace la patria moderna nicaragüense, se establecen, claramente, reglas de juego en que se apuesta todo a ganar, y que se juega muy duro, ¿verdad?, "vos le arrecias", como hablamos nosotros, Pedrarias Dávila, por cierto, llegó a los 87 años y fue el Gobernador de Nicaragua, de la provincia de Nicaragua, que en ese entonces incluía todo lo que es ahora Nicaragua, todo lo que ahora es Guatemala, una parte de Panamá, la mitad de El Salvador y como la mitad de Honduras, y su sede estaba en León de Nicaragua, fue capaz de llegar a los 87 años, en ese entonces, no te quiero aburrir con estas cuestiones históricas, pero he tratado de introducir en esto, cosas que te permitirán tal vez analizar quizás mejor por qué estamos como estamos ahora, muy rápidamente, en cuanto a Bolaños, el mismo Bolaños monta una especie de campaña en contra de Arnoldo Alemán, donde le acusa a Arnoldo Alemán de haberse robado 100 millones de dólares, te dije que trabajé en el Banco Mundial, soy un economista, me gustan los números, se lo que esta economía representa, estoy ubicado, este país no puede darle a nadie 100 millones de dólares en 5 años, ni siquiera la mitad de eso, porque no da abasto para esto, vuelvo al tema de la plata y de donde salga, ¿verdad?, obviamente, con personas como Enrique Bolaños a cargo de los sectores más lucrativos del sector público, y con los donantes, incluyendo España, a cargo del financiamiento del $85 \%$ de la inversión pública, que es la otra gran vaca lechera de acá, no hay mucho en donde ordeñar, sobre todo que el PIB de Nicaragua era tal vez, en ese entonces, de 4.000 millones de dólares, y la vasta mayoría del presupuesto del Estado va directamente para pagarle a maestros, trabajadores de salud, funcionarios de la cosa pública, el 75\% del gasto corriente, que Alemán, seguramente, hizo algunos negocios, por supuesto que los hizo, pero los hizo también Bolaños, y los hizo, se hizo de manera requeteabundante en la época de Doña Violeta, pero todo esto a una escala mínima en comparación con lo que se está dando ahora en Nicaragua, porque ahora entraba un nuevo jugador, que se llama Hugo Chávez Frías, y que le ha dado a Nicaragua cantidades desconocidas, pero, indiscutiblemente, mucho mayores que lo que ha recibido cualquier gobernante en la historia de Nicaragua y sobre todo sin control alguno aparentemente, quiero contarte una anécdota de Anastasio Somoza García, fundador de la dinastía. Anastasio Somoza García tenía una fuente principal de ingresos, cada dos semanas llegaba el administrador del ferrocarril del Pacífico de Nicaragua, con un maletín negro, como ese que usaban los médicos, y en ese maletín había el equivalente en córdobas de 400 dólares, a veces 480 , a veces 410 , pero, digamos, que promediaba en unos 400 dólares, y entonces Somoza recibía a este señor, chequeaba qué por qué habían bajado los recursos del ferrocarril, que qué pasaba, que la reparación de tal y tal línea, de tal y tal puente, o que la locomotora se jodió, o 
cualquier cosa, y entonces así, éste se hizo de la fortuna de los Somozas, que algunos estimaban en 500 millones de dólares al final, pero que yo estimaría como el cúmulo de 40 años en el poder, como un máximo de 100 millones de dólares, lo cual estaba en su enorme mayoría invertida en tierras en Nicaragua, es decir, no era portátil, no era transportable, por eso es que la mayoría de los hijos de Anastasio Somoza y de Luís Somoza, que fueron los dos últimos miembros de esa familia que ocuparon la Presidencia de la República, muchos de ellos son pobres, no tienen, como decimos nosotros, en qué caerse muertos, porque fuera del país no tenían nada, tenían fincas por todos lados, pero no tenían grandes fortunas, este señor puede tener, en este momento, no sé donde, 400, 350 millones de dólares.

\section{$R:$ ¿En bancos del extranjero?, ¿se refiere a Daniel Ortega?}

F.A.: Me refiero a la familia Ortega, porque ya para estas fechas, cuando él gana, ahí le cae la sorpresa ésta muy grata para él, de que el señor Bolaños decide transformar a la sociedad más tradicional, o una de las tres o cuatro más tradicionales de Latinoamérica, y de tratar de crear un sistema político utópico, ¿tú sabes lo que significa la palabra "utopía"?, ¿sabés lo que es eso?, el país que no existe, entonces, él decide hacer a Nicaragua más pura que la nieve recién caída, más pura que España, que Italia, o que los Estados Unidos, y casi tan pura, tal vez, como dicen que es Finlandia y Noruega y Suecia. Desde luego que nosotros estaríamos felices de tener los niveles de eficiencia y de integridad que puede haber en tu país, pero este señor no se satisfacía con eso, él quería que fuera el país más adelantado, y decide y pone como blanco el Partido Liberal Constitucionalista y Arnoldo Alemán, para no cansarte el cuento, Daniel Ortega que estaba muerto y servil, de repente, dice: "¡hombre! El enemigo de mi enemigo es mi amigo", eso es uno de los principios que vos como politóloga aprendés, y él se da cuenta que el enemigo de su enemigo, ¿quién es su enemigo?, el PLC y Arnoldo Alemán, porque él nunca le ha podido ganar, de repente, tiene un nuevo aliado que se llama Enrique Bolaños, y él le pone a la disposición de Enrique Bolaños dos cosas importantísimas: 38 votos sandinistas en la Asamblea Nacional más el Poder Judicial. Acuérdate que él se había atrincherado en el Poder Judicial, en las universidades y en las ONGs, y de que estaba, bueno, un cierto grupo de incondicionales en el partido, pero de base, en 2002 empieza también a retroceder ese proceso de la reconciliación nacional, y se abre ya la división no entre el sandinismo y los demócratas o el liberalismo sino que entre liberales, y aquél segmento de la cúpula social de este país que, a lo mejor, sería el equivalente, la mayoría de ellos, a la clase media acomodada en tu país, que nunca se han metido en política, porque lo consideran una cosa demasiado sucia para ellos, y que creen todo lo que dicen los periódicos, otro día si quieres hablamos de los medios, yo no soy periodista, pero, de todas maneras, y que por diferentes razones detestaban a Arnoldo Alemán, y, entonces, encuentran en Bolaños una caja de resonancia en esta cúpula social del país, pero internacionalmente también, y sobre todo en los Estados Unidos, con el gobierno de George Bush, gobierno republicano, y, entonces, encarcelan a Alemán, prácticamente, proscriben el Partido Liberal, logran crear fisuras, divisiones en nuestro partido, y, para no cansarte el cuento, a las elecciones de 2006 el partido va dividido, en esa elección ocurre lo que tenía que haber ocurrido, dividido el liberalismo, Daniel gana, lo que yo creo que sorprende a mucha gente es que el Partido Liberal Constitucionalista, fijáte bien lo que te voy a decir ahorita, queda en segundo lugar, vos vas a decir, Francisco Aguirre Sacasa tiene una mezcla de aserrín y telaraña en la cabeza, porque cualquiera que conoce los resultados de la elección del 2006 se daría cuenta que el Partido Liberal quedó en tercer 
lugar y ALN, así se llamaba, de Eduardo Montealegre, quedó en segundo lugar, pero si vos lográs, de alguna manera mágica, de conseguir los resultados de la elección de 2006 , te vas a dar cuenta de algo de lo que no nos dimos cuenta la mayoría de los nicaragüenses, incluso los políticos nicaragüenses, en ese momento, y es que nunca se contó el 8,5\% de los votos, es decir, sólo llegaron a contarse el 91,2\% de los votos, y ese último $8,5 \%$, sencillamente, desaparece, y nadie sabe a quien le tocaba, pero, ¿de donde venía, Raquel, ese $8,5 \%$ ?, de los lugares más recónditos y más rurales de Nicaragua, precisamente, los lugares en donde el Partido Liberal Constitucionalista tiene su mayor fuerza. Yo recuerdo, que yo recibía llamadas de personas de la cúpula más grande y más alta social y financiera de nuestro país el día lunes y martes, después de las elecciones, que siempre son el primer domingo en noviembre, diciéndome que era importantísimo que José Rizo, que era el candidato del PLC fuera a conceder la derrota a Daniel Ortega, fíjate bien, a como lo había hecho Eduardo Montealegre la mañana del lunes, las elecciones fueron el domingo, si vos entrás a los periódicos vas a ver que el martes en la mañana, después de esas elecciones, vas a ver que va a salir la fotografía de un estadista, Eduardo Montealegre, felicitando a otro estadista, Daniel Ortega, por su victoria, entre tanto, la prensa estaba dando a conocer, paulatinamente, los resultados, y, naturalmente, la prensa al igual que el Consejo Supremo Electoral al inicio publicaba los resultados de los grandes centros urbanos de Nicaragua, y allí el Partido Liberal Constitucionalita estaba sufriendo una derrota humillante, en lugares como Managua, pues, pero, yo estaba como Secretario General de Partido, creo que para ese entonces era Secretario Nacional, tal vez no, pero yo estaba, yo era el Secretario de Relaciones Exteriores, pero fui el diputado nacional número dos en nuestra plancha, una persona de consecuencia en mi partido, en una palabra, yo estaba en el bunquer del partido, recibiendo las actas que nos estaban llegando de Jinotega, de Matagalpa, de Nueva Segovia, de la Región Autónoma Atlántica Norte, y yo me daba cuenta que en esas Juntas Receptoras de Votos nosotros estábamos sacando el 70\% del voto, como mínimo, y, entonces, cuando me llamaban estas personas que son gente que serían ricas en tu país o en cualquier país, yo les tenía que decir que nosotros no íbamos a conceder nada, porque ¿cuál era nuestra expectativa?, ¿cuál era la mía?, de que esta cosa podría llegar a ser tan cerrada que no ganaría en primera vuelta Daniel, porque acuérdate de que Daniel para salir electo en primera vuelta, con un 35\%, primero tenía que alcanzar el $35 \%$ del voto, y segundo, y esto es muy importante, tenía que tener al menos el $5 \%$ de margen por encima del segundo partido, y yo veía eso muy difícil con unos resultados que nos estaban empezando a llegar, pero, curiosamente, estas personas de mucho dinero me estaba presionando a mí porque me ven de la misma clase donde están ellos, a que nosotros fuéramos a reconocer el triunfo de Daniel y cerrar el capítulo de quién había ganado y quién había perdido, el Consejo Supremo Electoral con mucha significación estaba dando conferencias de prensa, prácticamente, toda la noche, aparecían todos ellos solemnemente, y allá dando los resultados, el Partido Liberal estaba el primer día, el segundo día, y todo esto lo podés ver en la prensa, o sea que no es que te lo estoy inventando, pero vos como estudiante tenés que trabajar un poco en esto, ¿verdad?, vos vas a ver como van cambiando los titulares de la prensa, PLC derrotado, horroroso, de repente, empiezan a cambiar los resultados día por día, y no olvidaré nunca la última conferencia de prensa de Roberto Rivas en donde él como el divino Augusto está citado allí con nosotros, o vos que sos española, el divino Adriano, y dice: "bueno, aquí ya tenemos el 92,2\% de los votos, las tendencias son irreversibles, y esta es nuestra última conferencia de prensa". Nadie dijo nada, ¿por qué?, porque ellos tenían su página web donde ellos podían, perfectamente, estar actualizando y declararon que iban a seguir actualizando esta información, pero ya para ese entonces habían 
ocurrido dos cosas bien interesantes: número uno, el PLC se había acercado al número de votos de la ALN, al partido que había creado Eduardo Montealegre, en cuanto a votos para presidente, pero había superado al partido de Eduardo Montealegre en los votos para diputados, y eso para mí es bien interesante, porque nuestro pueblo, la vasta mayoría de nuestro pueblo no tiene la sofisticación, cuando entra a votar y le entregan tres boletas, una para presidente y vice-presidente, una segunda para diputados nacionales, como soy yo, y una tercera para diputados departamentales, esas personas no tienen tiempo para estar cruzando el voto a como dicen acá los "rabiblancos", entonces, ellos lo que hacen es que están esperando allí en el sol o en la lluvia, como sea verdad, ellos están, finalmente, entran, le ponen un poco de tinta en los dedos, le mutilan la cédula, toman toda clase de precauciones para evitar el fraude, para después perpetuar el fraude más grande dentro de las entrañas del Consejo Supremo Electoral, y lo más rápidamente posible llenan las tres boletas y las tiran en tres cajas diferentes, entonces, el hecho de que hubiera una diferencia importante entre los votos para diputados liberales y el candidato liberal, que era José Rizo Castellón, para mí, al menos, como espectador, era algo curiosísimo, curiosísimo, pero te debo de admitir, que al igual que la mayoría de los nicaragüenses, como a los 10 días, ya no seguíamos, no nos dábamos cuenta por qué no entraba ese último $8,5 \%$ pero tampoco lo reclamamos, el Centro Carter había dicho que estaban extraordinarias las elecciones, la OEA y sus observadores había dicho que estaba estupenda, los de la Unión Europea, que vinieron aquí a hacer turismo electoral, dijeron, exactamente, lo mismo, porque a eso es a lo que vienen aquí, ¿verdad?, cuando vienen aquí toda esta gente a observar no hacen ni mierda, entre bujíos, que se hacen ver, de repente ahí estaba un tipo que trabajó para mí en el Banco Mundial, este presidente del Perú, que era como el precursor de Evo Morales, ¿te acuerdas?, casado con una belga, que trabajó para mí, una belga-judía, Alberto, no era Fujimori, era, bueno, ahí te acordarás luego, Alejandro Toledo, ese llega allí, y da la casualidad de que se encuentra conmigo en el Junta Receptora de Votos donde estoy sentado yo, y nos pusimos a platicar alegremente, y "ay, ¿te acordás, Francisco?", "magnífico, qué bueno verte acá”, pero, ¿qué más iba a hacer ese tipo?, desde luego que no se iba a meter allí en la sala de cómputo de los diferentes municipios, y, sobre todo, en el Consejo Supremo Electoral a contar votos, o a asegurarse de que se estaba haciendo bien la cosa, eso no es lo que hacen estos observadores, los observadores lo que hacen, y eso es una cosa que vos deberías de escribir, vos deberías, yo no sé si todo esto es para una tesis tuya.

\section{R: Exactamente, la tesis doctoral.}

F.A.: Pero la tesis tuya debería ser sobre las limitaciones de la observación internacional, porque esta gente viene con enormes expectativas, pero con una capacidad mínima para, realmente, avalar o garantizar lo que pasa en las elecciones, pueden asegurarse, a lo mejor, por su presencia no vaya a haber violencia en un centro de votación, y después regresarán y dirán: "hombre, todo se llevó a cabo de una manera tal, ví mucha gente o no ví mucha gente, fue una fiesta cívica o no", pero ellos no entran, realmente, a cómo debería entrar, por ejemplo, una firma de auditoria a decir esta cosa está bien hecha o no está bien hecha, entonces, en el fondo, a lo que te estoy llevando es a lo siguiente, yo tengo grandes dudas de que Daniel logró ganar con ese 5\% mayores de lo que obliga la Constitución Política de Nicaragua, y, segundo, eso es una duda que tengo, lo que no me cabe la menor duda es que José Rizo sacó más votos para presidente que Eduardo Montealegre, y tampoco me cabe la menor duda de que Eduardo fue magnánimamente a reconocer el voto de Daniel, porque él quería cerrar el 
capítulo del conteo de los votos, la tercera cosa que no se puede escapar, es que todo este problema que ha pasado, que hace que yo vaya con esta cuestión negra de duelo ${ }^{2}$, verdad, empieza a darse de una manera seria en las elecciones de 2006, cuando el Frente, de hecho colaborando con algunos políticos de partidos de oposición, ya te dije cuál creo yo que era, se da cuenta de que la observación nacional e internacional no tiene la astucia para preguntar: ¿y qué paso con el 8,5\% de los votos?, entonces, ya allí se percata Daniel de que el Consejo Supremo Electoral representa para él otra poderosa herramienta para consolidarse él en el poder y para perpetuarse él en el poder, muy importante esa elección de 2006, adelantando el cuadro en el 2008, elecciones municipales, esta vez van unidos los liberales, según las informaciones que nosotros como partido manejamos, nosotros sacamos más de la mitad de los votos en esas elecciones, que eso es un porcentaje relativamente bajo, pero se explica porque en las elecciones municipales de Nicaragua, tradicionalmente, ha habido un abstencionismo grande, y los que se abstienen, típicamente, son los demócratas, yo me imagino que lo mismo ocurre en tu país, sólo que en tu país casi todos son demócratas, entonces, pero hay una votación más lineal, me imagino, en las elecciones municipales que en las nacionales, lo mismo pasa aquí, el abstencionismo es muy claro, entonces, en ese momento, el partido más disciplinado, que es el Frente Sandinista, pero que ya para el año 2008 se está convirtiendo en el movimiento danielista, no sólo tiene a una cierta base disciplinada, sino que tiene ya este enorme chorro de dinero de Venezuela, que lo puede usar Daniel a su entera discreción, y puede, incluso, utilizar esos fondos para movilizar a gente, en el sentido muy amplio de la palabra, para que lleguen a votar, entre tanto sigue la corrupción interna del sandinismo, y eso lo estábamos viendo, el alcalde muy popular del sandinismo de Managua, que se llamaba Dionisio Marenco, en su momento, uno de los dos o tres hombres más cercanos a Daniel Ortega, el que consigue, el que hace el vínculo, el "clic", con Hugo Chávez, y que consigue el compromiso de Hugo Chávez de facilitarle plata a los municipios sandinistas, de repente, es aislado y separado del círculo de los que mandan en el danielismo por ser, tal vez, demasiado independiente de pensamiento, entonces, es bueno tener a gente que toman iniciativa, bueno, entonces, Marenco es separado, y es el último o uno de los últimos de una larga lista del quién es quién del Frente Sandinista de Liberación Nacional, si vos hubieras venido acá a levantar un inventario del elenco del Frente en el año 1984, por decirte algo, y fueras a ver ese elenco en el año 2009, vos verías una transformación extraordinaria y masiva, Daniel ahora está creando un nuevo partido, que usa los símbolos, la música testimonial, las consignas del viejo sandinismo, pero que, en el fondo, es muy diferente al partido en donde él es uno de nueve comandantes en el año 1979, y Daniel Ortega sobrevive a la crisis que representa la derrota que le da Violeta, la derrota de Arnoldo Alemán, la tercera derrota que se la da Enrique Bolaños, el escándalo de la Zoilamérica Ortega, que ahora tomó el nombre de su padre verdadero, Narváez, la derrota que significa el quedar desamparado sin la ayuda de la Unión Soviética, encuentra un nuevo socio internacional, un socio que tiene reglas de juego muy diferentes y menos rigurosas que las que tenía la Unión Soviética, y está trabajando como un castor, este es mi análisis personal, por crear una nueva fuerza que es incondicional a él y a su familia personalmente, en el año 2007, ya siendo él presidente, y gozando de una cierta luna de miel, que nosotros los partidos de oposición dijimos, a ver, es la esperanza, si tú estás adentro como estábamos todos los nicaragüenses, y a lo mejor, Daniel sin tener los problemas de la guerra civil de los años 80 iba a ser un buen gobernante en época de paz, él nos plantea a nosotros, a nosotros siendo el PLC, nos

\footnotetext{
2 El entrevistado llevaba una banda negra alrededor del brazo sobre la camisa blanca en señal de duelo.
} 
plantea a nosotros algo que se llamaba la reforma parlamentaria, esencialmente, era una cortina de humo en donde Nicaragua dejaba de ser una república presidencial y se convierte en una república parlamentaria como lo es España, por ejemplo, a pesar de que la vasta mayoría de los ideólogos sandinistas o danielistas, que estaban trabajando en este proyecto, no tenían la menor idea, cuando empezaron, de lo que era el parlamentarismo, pero no importaba, porque en el fondo lo que querían era abrir la llave o quitar el candado a la no reelección, porque nuestra Constitución Política dice que nadie puede ser presidente más de dos veces en su vida, y que nadie puede reelegirse sin un período por lo menos, sin dejar pasar un período, y Daniel ya había sido electo dos veces y pretendía ser reelecto sucesivamente, entonces, como era demasiado tosco ese mecanismo, en el año 2007, él busca todo este esquema ambicioso de la reforma parlamentaria, porque iba a ser más democrática para disfrazar el hecho que él quería permanecer en el poder, en el año 2007 no funciona eso, intenta otra vez en el año 2008, y otra vez no logra lo que él necesitaba, que es el $56 \%$ del voto, el $60 \%$ de los diputados para esa reforma parlamentaria, y empieza a ponerse impaciente Daniel, pero sigue hablando de las bondades de la reforma parlamentaria y no del tema de su reelección, porque, repito, era una especie de mampara o de cortina de humo para disfrazar lo que, realmente, quería él, y, finalmente, después de haber robado las elecciones de 2008, la tesis personal mía, que lo hizo porque él se sentía que el pueblo de Nicaragua no le había dado el mandato que él buscaba con las elecciones presidenciales, pero quería tener algún tipo de mandato, dice: "hombre, vamos a conseguirlo con las elecciones municipales", y así yo puedo decir, yo tengo legitimidad, yo tengo el mandato, yo tengo el respaldo de la mayoría de los nicaragüenses, aquí están los resultados de las elecciones municipales, él busca eso, y, paradójicamente, lo que hace es acabar con la legitimidad que tenía su gobierno, porque tanto en el país como internacionalmente, creo yo, que la mayoría de la gente no cree que esas elecciones fueron transparentes, entonces, ya este año él se destapa, pierde la paciencia con sus operadores políticos aquí en la Asamblea Nacional, pierde la paciencia con el Partido Liberal Constitucionalista y da el golpe, decide, a como dice un Alejandro Magno, cortar el nudo gordiano de la noreelección y en una actuación totalmente ilegal e inconstitucional de una sala, la Sala de lo Constitucional de la Corte Suprema de Justicia, creo que fue un 19 de octubre, decide que lo que está escrito en blanco y negro, lástima que no te lo puedo enseñar ya porque se nos fue la luz, y se fue la luz porque ya apagan las luces aquí en la Asamblea, porque estamos aquí en austeridad, los lunes y los viernes a la $1.00 \mathrm{~h}$. la apagan, dice, categóricamente, y sin lugar a ningún vacío o malentendido ni nada, "nadie podrá ser presidente de la República si ha ocupado ese cargo dos veces y nadie puede ser electo en dos períodos sucesivos", Daniel estaba muerto, en cuanto a sus aspiraciones de reelección, pero antes de tomar esa acción voceros de él empiezan a decir, porque aquí se especulaba mucho que podría ser Rosario Murillo la candidata, voceros de él empiezan a decir, no, aquí el candidato de Frente Sandinista va a ser y tiene que ser Daniel Ortega Saavedra, lo cual es interesante, parece que Daniel no quiere que su esposa sea la candidata, a pesar de que hay muchos nicaragüenses que piensan que no puede ser tampoco porque hay otra cláusula de nuestra Constitución que pareciera prohibir que la esposa de una persona que ha ocupado ciertos cargos sea candidata, entonces, nos mete el bolo más torpe, menos creíble a nosotros los nicaragüenses y a toda la comunidad internacional, y, básicamente, le da un golpe de Estado al Poder Legislativo, porque también la Constitución dice que el único que puede enmendar o modificar parcialmente la Constitución Política es la Asamblea Nacional, no es la Corte Suprema de Justicia o la Sala Constitucional, no es el Ejecutivo, sólo la Asamblea Nacional, entonces, al tomar esa acción totalmente ilegal e inconstitucional, y en un 
tiempo record, porque aquí si vos metés algo en nuestro sistema judicial, aunque lubriqués el mecanismo no va a tener una conclusión favorable o desfavorable en menos de años, aquí el sistema judicial es muy lento, muy ineficiente, en este caso, en cuestión de 48 horas ya llegaba este infeliz remedo de sentencia como decimos nosotros, entonces, para mí, ahí es donde está la palabrita, con un país en donde la gobernabilidad, la transparencia, la reconciliación nacional, la institucionalidad, la democracia representativa, el Estado de Derecho están en un franco retroceso en Nicaragua, Daniel presiona, lo vas a ver en estos días, persiguiendo a los intentos de la oposición a protestar, una de las doctrinas del nuevo gobierno, es que el gobierno danielista controla las calles y que nadie más tiene el derecho a manifestarse pacíficamente en las calles, si vos y yo salimos con una manta que dice: "abajo Daniel Ortega", en cuestión de 15 o 20 minutos nos caen 40 o 30 pandilleros, nos agreden, nos golpean, y después llegan unos policías y nos meten a nosotros en la cárcel por haber causado un bochinche, algún motín, alguna actividad ilícita en el país, y ellos, los que te agredieron a vos, los que te negaron a vos tu derecho constitucional de manifestarte en la calle, se van tranquilamente a sus casas, esa es la Nicaragua que estamos viviendo, en España el país parece que comprende lo que está pasando en el país, en nuestro país, contando con sus editoriales, pero me imagino que hay muchos españoles preguntándose: bueno, ¿pero dónde están las grandes manifestaciones de la oposición acá?, ¿dónde están los muertos de la oposición acá?, y yo lo que te contestaría es que, en la medida en que se vaya profundizando la desesperación en este país, se puede llegar a esos fenómenos, nunca como en Caracas, porque nosotros leímos y vimos y comprendimos lo que pasó en Venezuela, mataron a cierto número de manifestantes y no se cambió absolutamente nada, y nuestro sector privado que está abandonando el país muy rápidamente, vendiendo sus activos más valiosos acá, no va a financiar actividades de la oposición, ni mucho menos los europeos y los norteamericanos, porque Daniel Ortega, paradójicamente, tiene no sólo, hasta cierto punto, intimidada y desarticulada la oposición política del país, sino que ha logrado acalambrar, como decimos nosotros, a la misma comunidad internacional, aquí hubo una manifestación en contra del embajador norteamericano y su embajada, yo no sé si vos estuviste acá cuando se produjo, pero lo que fue más importante para mí fue la emboscada que le hicieron a él cuando llega a la UCA, y vos ves la cara de un embajador Callaghan que está, realmente, asustado, se siente intimidado por las imágenes que pasaron por la televisión y en los periódicos, por lo que él temía iba a ser una paliza que le iban a dar a él mismo, él dijo después que su preocupación era por sus acompañantes, pero, la verdad, es que, por un lado, el gobierno se dio cuenta que había ido muy lejos con eso, y que corría el peligro de que iban a perder el respaldo del Fondo Monetario, porque el problema en la UCA, creo que fue un sábado, y la votación del Fondo fue el lunes, y, entonces, decidieron bajarle el gas, pero ya la lección se había dado, yo soy criador de caballos, $\mathrm{y}$, entonces, cuando vos le enseñás a un caballo un truco o alguna cuestión, pues ese caballo no lo olvida nunca, yo no creo que el señor Callaghan se vaya a olvidar tan fácilmente de lo que le pasó esos días acá, entonces, no he abordado, como te digo, temas constitucionales, pero he tratado de darte un poco mi lectura como volando a 50.000 pies de altura sobre la topografía de mi país, de un país que, mal que bien, andaba por un camino favorable y positivo, y que ahora está como consolidándose aquí una dictadura familiar, pero mucho más poderosa que la que tenía la familia Somoza, por ejemplo, a pesar de que la familia Somoza controlaba el Ejército, y éste, hasta la fecha, lo que ha podido, obviamente, socavar es la Policía, pero todavía está muy respetuoso del Ejército, aquí viene un evento que se va a dar antes de fines de este año que es el nombramiento del próximo jefe del Ejército Nacional, o del Ejército de 
Nicaragua, yo tengo una idea bastante clara de quién va a recomendar el Ejército, y durante los gobiernos democráticos la persona que ha sido recomendada por la institución es la persona escogida por el presidente, no estoy nada seguro que, en este caso, el presidente va a acatar la recomendación del Ejército, y no me siento optimista de que el Ejército vaya a querer hacer valer su recomendación, ahí podría darse una situación complicada, pero no veo yo gran respaldo internacional para un Ejército que le diga al presidente de la República: "hombre, porque vos no escogiste a la persona que te recomendamos, pues vos te vas a montar en un avión y vas a parar en el aeropuerto Santa María en Costa Rica con tu pijama", eso no va a pasar acá, veo paradójica la posición de las instituciones financieras internacionales, te lo tengo que confesar, porque yo se que esas instituciones financieras internacionales, Raquel, le dan mucha importancia a la gobernabilidad, y no desde ahora, sino que desde los años 80, cuando recuerdo que yo presidía un grupo de representantes del Fondo Monetario, del Banco Interamericano, del Banco Mundial, de la Unión Europea, algunos donantes importantes bilaterales, que nos dedicamos a tratar de entender por qué estaba subdesarrollada África a pesar de toda la plata que ha recibido durante años y años de ayuda a los países africanos, y, naturalmente, ahí abundaban las pendejadas, con perdón tuyo, que son políticamente correctos, verdad, se decía que uno de los problemas que había era que las naciones africanas tenían fronteras que fueron trazadas por las potencias europeas, y que no reflejaban de alguna manera, realmente, a la composición étnica del continente, y mi respuesta a eso era siempre: "pues, por lo menos ahora tenemos un África con 40 naciones y no una África de 800 naciones", porque hay 800 tribus grandes, pequeñas y medianas en África, que vos agarrás un país como Nigeria y podrías dividirla fácilmente en 10, en 10, si un país como Togo o Benín podías dividirlo en 4 o 5 grandes tribus, imagínate lo que podría pasar en un país de 100 millones de habitantes como ese, Nigeria, o hablemos de Sudáfrica, podrías dividirla en al menos en 2 tribus blancas, los africaners y los otros, que serían, principalmente, los ingleses, y después tendrías grupos como los zulús, y los otros, que son un número enorme de tribus importantes, verdad, entonces, después de eso, después de hacer el saludo de la bandera de la crítica a los países europeos por haber dividido conforme a jurisdicciones coloniales a África, pues se observaban diferentes fenómenos, como la debilidad de las instituciones, etc., etc., pero después dijimos, bueno, pero aquí hay otros problemas, porque esto no explica el por qué África anda tan mal, y, entonces, llegamos a la conclusión de que una parte del problema era la falta de gobernabilidad. Yo no soy una de las personas que creo, Raquel, y con esto yo termino mi monólogo y tomo cualquier pregunta que vos querrás, que no es imprescindible tener democracia para tener desarrollo económico, y mejor ejemplo de eso la República Popular China, ahí no hay democracia política, pero hay un desarrollo económico muy superior al que hay en Europa y en Estados Unidos, y hasta el mismo Japón en su mejor momento, Vietnam, tampoco hay democracia política, pero sí hay crecimiento acelerado, y después vos podés tener un país democrático y eso no asegura, no asegura desarrollo económico o no asegura el tipo de desarrollo económico que se pueden dar en estos países comunistas o dictatoriales, pero sí creo yo que si las reglas de juego no están claramente establecidas, si no hay un buen clima de inversión, entonces, no hay ninguna probabilidad de progresar, y no creo yo que un país se pueda manejar como una hacienda grande y familiar, no, no creo eso, los Somoza, como te digo, pretendían eso, así al menos decían sus críticos, pero, te repito, los Somoza nunca tuvieron el poder económico, ni el poder político, que, en este momento, tiene Daniel Ortega, lo que pasa es que Daniel está solo con una rosca y con una manguera calibre ancho que lo está alimentando por ahora de plata de Venezuela, pierde ese patrón, a como perdió, inesperadamente, a la Unión Soviética, y quien sabe como le va a ir, pero 
ya tiene una reserva que nunca ha soñado ningún partido de la historia de Nicaragua tener.

R: Bueno, en su discurso ha mencionado aspectos muy interesantes de la crónica política reciente en la democracia nicaragüense, que, obviamente, está muy fragilizada, no solamente por la actuación de algunos de sus actores políticos, sino sobre todo por la ruptura con el principio de seguridad jurídica, que yo creo que concentra un poco esta evolución institucional más próxima. Ya para terminar, porque llevamos un buen rato hablando y no quisiera tampoco quitarle el resto de tiempo de la mañana, sí ha habido una desconcentración de poder de manos del Ejecutivo presidencial, que consolidaba la Constitución del 87, la original, aumentando las facultades de la Asamblea Nacional, una de las críticas a la evolución constitucional del 2000 en adelante fue el acuerdo entre el líder del PLC, Arnoldo Alemán, y de Ortega para tratar de amarrar esa dificultad de gobernabilidad que ha tenido el pais, porque siempre ha habido crisis institucionales entre Ejecutivo y Legislativo a propósito de la reforma constitucional, se observa como Violeta Chamorro o Enrique Bolaños, que usted ha referido muy específicamente, las crisis a las que se vieron sometidos ambos presidentes, convirtiéndolos en presidentes débiles, porque no contaban con el apoyo de su partido, en el caso de Violeta Chamorro, porque se vio sola ante una coalición gubernamental que, realmente, no era un partido político, ella no tuvo la capacidad que tuvo Arnoldo Alemán para articular el partido, para darle fuerza al PLC como fuerza integral, en el sentido de controlar a los miembros de su partido, y en el caso de Bolaños porque divide el liberalismo, que además es la causa fundamental del triunfo de Ortega, porque si el liberalismo hubiera ido unido pues, obviamente, habríamos tenido otro gobierno liberal, ¿no? Ahora se está produciendo esa concentración de poder de manos del Ejecutivo desde que Ortega llega a la presidencia, él ha controlado el Poder Judicial, que fue como usted ha dicho su bastión, algo que han referido casi todos los entrevistados, el Frente, siendo un partido bien organizado, cuando dice Ortega: "vamos a gobernar desde abajo", controla buena parte de las organizaciones sociales, en el caso de los sindicatos me asombra verlos ahora en televisión del lado de Ortega, con todo lo que está sucediendo en el país, yo no sé si todos, pero por lo menos la mayoría...

\section{F.A.: La mayoría de los grandes.}

R: Yo además los veo con las banderas cuando salgo a las rotondas, he encontrado algunas banderitas de la CNT entre las personas que se colocan del lado del Frente, ¿no? Si no se produce una unión del liberalismo de aquí a las próximas presidenciales, la victoria de Ortega, prácticamente, es una victoria anunciada de acuerdo con las reglas con las que contamos ahora, y nadie va a poder hacerle frente, digamos, electoralmente, si no hay un candidato único de lo que llaman las fuerzas democráticas, porque además ya hay como una oposición anti-sandinista que reclama para sí la esencia de los valores democráticos y de que haya tolerancia política, que yo creo que es lo que se ha perdido, ¿no?, la tolerancia, finalmente, de una oposición, en democracia unas veces gobierna un partido y otras veces gobierna otro, y uno debe aceptar también las reglas de juego, este continuo cambio, y ya regresando, y por ahí va un poco la reflexión final que me gustaría que comentase, a la Constitución, la ausencia de un consenso constitucional, hay la ausencia de un pacto constitucional serio, porque esta sentencia, de hecho, esta aberración jurídica ya es, finalmente, la puntilla que le faltaba a una Constitución que ha sido parcheada desde los 90 hasta 
ahora, en el 95, en el 2000, en el 2005 y ahora, finalmente, con esta sentencia, que hace con malas artes, en el sentido jurídico, o ya en el sentido político estricto, romper, como decía, con el principio de supremacía que es lo que garantiza que una Constitución sea respetada y tenga un valor normativo.

F.A.: Bueno, yo detecté ahí dos o tres preguntas, y voy a tratar de contestártelas. Primero, ¿qué puede pasar en el año 2011?, primero, creo que se tiene que dar para que triunfe la democracia en Nicaragua una polarización del voto, hay mucha gente, sobre todo aquellos que leen las encuestas, que, en este país, no son confiables, por eso es que yo cuando estaba a cargo de actividades electorales de nuestro partido insistía en contratar mis propios encuestadores porque a mí me interesaba conocer la verdad, conocer dónde estábamos fuertes, dónde estábamos débiles, cuáles iban a ser los candidatos de los muchos que se postulaban que tenían mayores posibilidades de ganar, aquí da la impresión de que hay una gran cantidad de nicaragüenses, que no son ni liberales ni danielistas, y yo creo que eso es cierto, pero también creo que es cierto que la vasta mayoría de grupos amorfos de libre pensadores, o de personas que no militan en los partidos, invariablemente, se oponen al partido liberal en una votación, ¿por qué?, porque no tienen otro árbol o palo en que ahuecarse, como decimos nosotros, no tienen ellos, no participan en la vida política del país, no ponen fiscales, no conocen las reglas del juego de la política, y no les gusta molestarse por asegurarse de que llegue una gran cantidad de votantes a las urnas, ellos llegan, hacen su fila, como en España, me imagino, la mayoría de la gente, y confían en que todos los otros ciudadanos tienen el mismo nivel de patriotismo que tienen los de la clase media alta, y que ya con eso están haciendo su trabajo, nunca van a las manifestaciones, nunca exponen su pellejo a las represalias, más bien suelen ser tímidos, pero cuando hay un marco como el que existió en Nicaragua en el 90, y acordate que Nicaragua estaba saliendo, en ese momento, de una guerra que le había costado, literalmente, a decenas de miles de nicaragüenses sus vidas, salieron a votar en números abrumadores. Pero necesitan ellos tener un líder o una lideresa, porque yo creo que la lección que han aprendido es que la división es igual a la victoria de Daniel, o sea que estoy de acuerdo con vos, que necesitamos un solo candidato para presidente y ese candidato tiene que surgir esencialmente de las entrañas de un partido, porque si no hay un partido que ponga a los fiscales y la organización territorial, la labor de los otros que no se dedican a la política a tiempo completo, pues, entonces, de nada le sirve a nadie eso, ¿verdad?, mi esperanza y mi expectativa es que con todas las debilidades que tenemos nosotros los demócratas ya esa lección la aprendimos, el Partido Liberal Constitucionalista pretende tratar de darle confianza a la gente a través de un sistema de primarias basado en el modelo norteamericano, en la medida en que ese sistema funcione y es percibido por la población como un sistema, realmente, transparente, pues, yo creo que la maquinaria o la locomotora de esta unión va a ser, justamente, el Partido Liberal Constitucionalista, porque yo, honestamente, creo que es el único partido que puede hacerle frente al danielismo, o sea, que con eso te contesto a una de tus preguntas, pero déjame añadir un corolario a eso, el votante independiente, como te dije, es una persona que vive por diversas razones en la frontera de la política, no le gusta entrar al centro de ella, y es una persona que busca cualquier pretexto para no votar, por ejemplo, en las elecciones municipales, cuando el alcalde, típicamente, es el político que más directamente puede afectar la vida de un ciudadano, pero ellos no lo ven así, entonces, si está lloviendo, ¿para qué ir a votar?, si hay sol y un día muy bueno, ¿para qué voy a ir a votar?, aquí hay una relación inversa entre el número de votantes y la fortuna de los demócratas, entre menos votantes más baja la posibilidad de ganar de los demócratas, que es lo que creo yo que anda buscando el 
Frente Sandinista, el Frente Sandinista cuenta con el desencanto del electorado, todos estos fraudes están fríamente calculados para desincentivar al votante, sobre todo a aquél votante independiente, porque el Frente sabe, que con el dinero que ahora tiene Daniel, perdoname, cada vez que diga Daniel o el Frente, estoy refiriéndome a Daniel Ortega, ellos saben que, en la medida en que no voten muchos independientes, ellos tienen la plata para llevar a aquellas personas que por diversas razones puedan ser afines a Daniel a las urnas, entonces, nosotros necesitamos como nación darle credibilidad otra vez al sistema o al tercer o al cuarto poder del Estado, que es el Poder Electoral, si vamos con el mismo Consejo Supremo Electoral y con la misma cosa, no estoy hablando solamente de los Magistrados, te estoy hablando de toda la infraestructura del Consejo Supremo Electoral, no lograremos convencer a los independientes de que vale la pena ir a votar, con eso cuenta Daniel, si hay una participación van a tirar, porque tienen los recursos financieros que no tienen los demócratas, porque tiene cierta estructura que ha ido creando a través de un mecanismo que se llaman los CPC, no sé si ya los conocés o no, y con eso, él pretende obtener una mayoría de votos, o sea, que nosotros necesitamos llevar un solo candidato bajo la bandera que todavía tiene un cierto arraigo en el país, que yo creo que es el PLC, y con un Consejo Supremo Electoral totalmente, a mi criterio, vaciado de las estructuras y de las personas que tiene ahora, y que inspire confianza, sin esas dos condiciones no ganamos, primera respuesta. Segunda, el pacto o lo que llaman aquí el pacto, a mí siempre me llama la atención que hablan de pacto porque en Nicaragua hemos tenido pactos desde la guerra nacional, que fue a mediados del siglo XIX, hasta el presente, y todos los países tienen pactos, los Estados Unidos ahorita están metidos en una tremenda contienda para ver si establecen un sistema de medicina o de atención médica pública de estilo socialista, y hay una tremenda, pero tremenda pugna ahí, y se están haciendo pactos todos los días, arreglos todos los días, pero lo que aquí llaman el pacto se resume, esencialmente, a unas negociaciones que se dieron entre el PLC y el Frente Sandinista de Liberación Nacional, que, entre otras cosas, cambiaban el porcentaje que se requería para salir electo el presidente, hay otros aspectos del pacto, por ejemplo, se hizo más difícil el que existiesen 20 o 24 partidos de salón, y que recibieran 300.000 dólares por participar cada uno, eso es una parte del pacto que nadie menciona, ¿verdad?, porque el pacto, claramente, como ocurre en los Estados Unidos apunta hacia el bipartidismo y no el multipartidismo, pero bien, lo que más le molesta a la gente cuando se habla del pacto, es que se bajó ese porcentaje de, creo que era de $40 \%$ o $45 \%$, no recuerdo cual era el porcentaje al 35\% si es que había cinco puntos porcentuales de diferencia, pero es con ese mismo porcentaje que ganó Bolaños, y con ese mismo porcentaje hubiera ganado, con ese mismo pacto, Violeta, y con ese mismo porcentaje ganó Arnoldo Alemán, entonces, si hubiéramos ido unidos no hubiera sido un problema eso, quiero decirte que yo siempre fui crítico del pacto, y recuerdo que en una ocasión estuve yo en una limusina en Washington que me puso el gobierno norteamericano a las órdenes de Arnoldo Alemán, cuando él hacía una visita allá de trabajo, y que yo leyendo los periódicos, inocentemente, y sin saber nada de la política nicaragüense, le digo yo a Arnoldo que yo estaba, que no entendía el por qué del pacto, y estaba con él el asesor más cercano de él para las cuestiones del pacto, que es el actual vice-presidente de la República, Jaime Morales Carazo, y, entonces, ellos, esencialmente, me dicen a mí: "mirá, el Frente es una realidad, no nos dejan gobernar", como, de hecho, aquí andaban continuamente con lo que llaman "tranques" y cuestiones, "con esto compramos paz", y ellos absolutamente seguros que el liberalismo iba a ser la bolsa mayoritaria para el resto de la historia republicana de Nicaragua, y que, entonces, no había, que no se estaba concediendo nada, se equivocaron, no contaron con una serie de errores políticos, 
de cálculo político, de Alemán, que resultaron el que llegara al poder el señor Enrique Bolaños y que él desarmara a la arquitectura política que habíamos armado nosotros, pero la respuesta sencilla a tu pregunta es que el pacto responde, aparentemente, a un deseo de neutralizar a ese gobierno de abajo, y de darle a los nicaragüenses más tranquilidad, y al gobierno más tranquilidad para llevar a cabo su programa, en lugar de estar con los "tranques" continuos que había antes, y con manifestaciones de estudiantes y de sindicatos todo el tiempo, ¿cuál fue la tercera pregunta?

R: Ah, bueno, lo del pacto constitucional, ¿qué valor tiene la Constitución en un contexto donde cada una de las fuerzas políticas trata de hacer una reforma un poco "a la medida" de sus intereses?

F.A.: Nuestra Constitución, y creo que te comenté ahí que aparecen todas, la Constitución Política es una bandera, aquí al igual que en otros países, que se usa continuamente para justificar políticamente a lo que ciertas personas pueden hacer, yo recuerdo que cuando estaba estudiando en la Universidad leía un libro sobre constituciones modernas, en donde decía que las constituciones rara vez, generalmente, encapsulaban las aspiraciones nobles de las poblaciones, sino que eran instrumentos que utilizaban los gobiernos y los grupos políticos para lograr sus objetivos, por ejemplo, la rusa, o la de la Unión Soviética, era una Constitución Política que en muchas cosas era loable, sin embargo, en la aplicación de ella los rusos o los soviéticos hacían lo que querían y bajo, ese dilema, esa idea de la Constitución de ellos se cometían barbaridades, masacres de millones y millones de personas, los Estados Unidos, 1776, y después 1789, cuando escriben su primera Constitución protegen a los intereses que tenían no sólo los comerciantes de la Nueva Inglaterra y los industriales y los financieros de Pensilvania y de Nueva York, sino también aquellos que eran los terratenientes grandes del sur, que tenían una cantidad grande de esclavos negros, entonces, una cosa es la retórica, la música, y otra cosa es la realidad de las constituciones, entonces, aquí en Nicaragua las constituciones, al igual que muchos otros países latinoamericanos, han sido abusadas, nuestra Constitución es una, quiero que sepás, Raquel, que yo me crié en una cultura intelectual, si querés, muy diferente de la nicaragüense y a la hispana, yo estudié Derecho, pero lo estudié en los Estados Unidos, yo hice mi formación académica, esencialmente, fue en los Estados Unidos, entonces, por ejemplo, allá en los Estados Unidos cuando uno estudia Derecho Constitucional uno se da cuenta que hay una interpretación de las constituciones escritas cuando hay artículos de esas constituciones que tienen vacíos, que se prestan a una interpretación diferente, $\mathrm{y}$ una necesidad social que requiere de una acción, $\mathrm{y}$, entonces, se busca al hilo de alguna parte de la Constitución que a lo mejor no está bien definida para lograr ese objetivo, o hay partes de la Constitución que son inconsistentes con la realidad objetiva del país, $y$, entonces, se enmienda la Constitución pero a través de un proceso muy engorroso, y entro a lo segundo, se viene la Guerra Civil, pierde el sur, un retroceso fuerte para toda clase de agricultores acaudalados que dependían de la esclavitud para ser prósperos y su poder estaba en función de esto, entonces, la Constitución que no le daba el voto a los negros, de repente, se enmienda por los revanchistas del norte, verdad, para darle poder político a los negros, ahí no había exactamente ni una falta de transparencia en la Constitución, pero ya la Constitución no estaba conforme a la correlación de fuerzas que existía en el país, entonces, en ese momento hubo una reforma, las enmiendas que le dicen a la Constitución norteamericana, pero que pasan por un proceso de consulta popular y en el Legislativo, que son muy engorrosas, muy extensas, pero hay otra cosa que produce cambios en la 
Constitución, y que tiene su raíz en el modelo inglés, en donde no hay una Constitución escrita, y esos son los temas que no están abordados en la Constitución de los Estados Unidos, por ejemplo, todas las leyes que pasa la Corte Suprema de Justicia de los Estados Unidos para darle mayores derechos civiles a los individuos, porque eso no está estipulado en la Constitución, la Constitución norteamericana es muy diferente a la nuestra, la de Nicaragua quiere legislar hasta tu derecho a cagar, perdoname la brutalidad, pero si vos lees la Constitución, vas a darte cuenta que dice, bueno, es un derecho de los nicaragüenses una educación gratuita, servicio de salud gratuito, entiendes, tenemos miles y miles de derechos, muchos de los cuales no son ni siquiera importantes, y la mayoría de los cuales nunca los pueden ejercer los nicaragüenses, la Constitución va mucho más allá de la capacidad del país de cumplir con ella, pero en los Estados Unidos la Constitución es, relativamente, corta, para una sociedad tan grande, y sobre todo tan compleja como es la norteamericana, entonces, al llenar esos vacíos en la Constitución entra la Corte Suprema de Justicia y la Corte de Apelaciones y hasta la Corte a nivel de instancia federal y estatales para dar a los norteamericanos algunos derechos que no tenían, ejemplo, algo que se llaman los derechos de miranda, que cuando un policía te afecta, vos, lo primero que te tiene que decir es: "Raquel, usted tiene derecho a no contestar ninguna pregunta que nosotros le hacemos y no dar ninguna declaración sin tener el apoyo de un abogado". Eso no está escrito en ninguna parte de la Constitución Política de los Estados Unidos, pero ahora es parte de la Constitución no escrita de los Estados Unidos por los fallos a múltiples niveles de las Cortes de los Estados Unidos, aquí en Nicaragua el problema es que tenemos una Constitución Política parcheada como decís vos, una Constitución Política que se enmienda con una facilidad, ahora tenemos una manera grotesca de enmendarla, que es a través del voto de seis jueces de la Sala Constitucional, haciendo una convocatoria totalmente incorrecta, cuando, al igual que ahora que la luz se fue acá a las $12.00 \mathrm{~h}$., ¿te diste cuenta?, se fue también en la Corte Suprema de Justicia, aquí en esta Asamblea Nacional acaban de cerrar la puerta, no sé ni por dónde vamos a salir vos y yo, pero así como está esto, quedó una Corte Suprema si vas allá te vas a dar cuenta que muy pocos de ellos tienen acceso a ventana, o sea, que aquí tenemos un poquito de luz que entra, entonces, los Magistrados nuestros del PLC, sencillamente, pensaban que ya se había acabado el día, no habían sido convocados a esa reunión, entonces, yo creo que sería una gran cosa si nosotros fuéramos un país menos polarizado, más maduro políticamente, menos tradicional, que nosotros agarráramos esta Constitución y la rearmáramos totalmente.

\section{$R:$ ¿Con una constituyente se refiere?}

F.A.: Tendría que ser con una constituyente, que es prevista en la Constitución Política del Estado, pero en Nicaragua cuando la palabra "constituyente" se utiliza, y quiero que sepas que ha habido muchas constituyentes en nuestra historia, es decir, que es parte del andamiaje que hay en Nicaragua, siempre ha sido con algún fin político, o sea, que nuestra Constitución, como la Constitución Política en la basta mayoría de los países latinoamericanos, responde a la voluntad de aquél grupo o de aquél individuo que en el momento en que se escribe la Constitución responde a los intereses de ese individuo o de ese grupo, $\mathrm{y}$, desgraciadamente, en los países latinoamericanos, con la excepción de uno o dos casos que te voy a mencionar, la Constitución Política es papel mojado, Bolivia, no se cuantas ha tenido, yo creo que anda por unas 30 o 40, país que tiene un sistema ordenado o constitucional es Chile, están de ahí en adelante otros países hispano-parlantes, en Centroamérica, probablemente, el país que más adelantado está en ese tema es Costa Rica, y, sin embargo, allí se creó el precedente que está utilizando 
Daniel Ortega para perpetuarse en el poder al permitir la sala $4^{\circ}$ de la Corte Suprema de Justicia de Costa Rica la reelección, pero no sucesiva, de Óscar Arias, ahora elegimos lo mismo al señor Álvaro Uribe, pretendiendo lograr su tercer período arreglando la Constitución también, entonces, como que estas personas, ya sean de derecha o de izquierdas, en Latinoamérica, ya sean buenos o malos, ya sean populares o impopulares, lo que quieren es perpetuarse en el poder, los mexicanos buscaron una solución muy interesante a ese problema, la Constitución de ellos, en donde el partido, el PRI, es determinante y no los individuos, que es la gran diferencia entre México y la gran mayoría de los países nuestros, en donde el caudillismo es muy importante, no se le permite a nadie ser reelecto ni una sola vez, pero el período que se le da es de 6 años y el presidente durante esos seis años tiene un poder enorme, y casi siempre es utilizado para enriquecimiento personal, pero el partido es el que manda, el presidente después de que logra ser el candidato del PRI, por lo menos hasta hace poco, pues, que ganó Fox y el PAN empezó a tener cierta relevancia política, el presidente tenía dos grandes funciones: primero, ser el tapado del PRI, y, segundo, nombrar a su sucesor, pero durante el tiempo que estaba de presidente dependía totalmente de su partido, el PRI, y el PRI, a su vez, se lucraba totalmente de la cosa pública, había una relación simbiótica, digamos, entre el Estado y el partido, y un monopolio del poder, es decir, el PRI se parecía mucho a los partidos comunistas, y, en general, a los países de Europa, de Rusia, pues, y de Europa oriental, en el sentido de que tenía un poder enorme, pero cedió espacios porque México estaba contiguo a los Estados Unidos, se fue modernizando mal que bien, más y más mexicanos fueron a estudiar a Europa y a los Estados Unidos, y, en fin, la evolución de la sociedad mexicana lo llevó en un cierto momento a tener un partido contrincante, que llegó al poder dos veces consecutivas, pero el señor Calderón llegó con un margen por encima de López Obrador mínimo, y logró menos que el 38\% del voto, que, teóricamente, sacó Daniel Ortega, porque la Constitución Mexicana no establece un porcentaje mínimo para ser electo, entonces, es una larga manera de decirte que yo creo que, desgraciadamente, la mayoría de las constituciones políticas escritas de las naciones responden a los intereses creados, ya sea de grupos, de partidos, o de individuos, en países muy sofisticados, bueno, tal vez a los escandinavos, a lo mejor, la política es un poco menos exigente, sucia, que en nuestro país, a lo mejor, realmente, son ya para alcanzar niveles en donde el ciudadano es, realmente, el soberano, y a lo mejor podríamos hacer como una especie de, crear un espectro entre los países en donde la Constitución y el Estado político responde al individuo, y en donde el voto cuenta, y en donde los derechos de los ciudadanos se respetan, y ahí podríamos poner algunos cuantos, y después podríamos terminar en el otro extremo, donde estarían algunos países africanos, el Congo, se me ocurre, verdad, o Zimbawe, como un país en donde no vale absolutamente nada el Estado de Derecho ni nada, y a lo mejor Suiza estaría por este lado, Estados Unidos estaría por acá, porque en Estados Unidos, bueno, pero en Suiza ¿los bancos no mandan?, España no se dónde estaría, España ha progresado mucho, ha progresado mucho, pero no sé dónde ubicarla, ¿dónde la pondrías vos en el espectro ese?

R: Digamos, ¿respecto al valor normativo de la Constitución?, ¿su adaptación a la sociedad y a los intereses de la sociedad? Bueno, yo creo que la Constitución del 78 fue el verdadero pacto de la unión, digamos, del Estado español con los dos principales conflictos: el político-ideológico, izquierda-derecha, y el tema de los nacionalismos, ¿no? Entonces, yo creo que es el ancla fundamental en un país en el que también la polarización política existe y donde la memoria histórica está viva, como antes refería, al principio, respecto al tema de los represaliados, la guerra civil, de hecho, el gran 
pacto entre los españoles después de la guerra es la Constitución del 78. Aunque yo no soy constitucionalista ni abogada, pero sí, un poco, como ciudadana, yo pertenezco además a la generación que nació en la transición, en los años 70, la primera generación que no conoce a Franco, que crece en libertad, sí, obviamente, me cuentan mis padres, y mis abuelos, que vivieron la guerra.

F.A.: Como te digo, la primera vez que visité tu país, todavía rascabas un poco la superficie de la sociedad española y brotaba, salían otra vez las llagas de la guerra civil española, pero ustedes claramente han adelantado enormemente, o sea, que tal vez en ese espectro lo pondríamos, si el centro es el número 50, pues, ustedes estarían en el número 40 o algo así, tal vez, incluso un poco más alto, como viene siendo la isla de Malta, que es un país independiente, pero, de alguna manera, tiene una gran vinculación a Gran Bretaña, ¿no?, y que tiene algo que se llama el "team", que es el parlamento de ellos, que en una isla pequeña donde, o un cantón suizo, en donde todo el mundo se para y dice: "yo estoy a favor de esto o en contra aquello".

R: Además con la institución del referéndum, que en Suiza es una institución fuerte que forma parte de su Constitución, allí se votan hasta las políticas públicas.

F.A.: Así es, aquí en Nicaragua existe el referéndum, existe en la Constitución nuestra, pero no sé, no se explica para qué, con qué reglas de juego se utilizaría, o sea, que cuando estamos definiendo a veces cosas que no son muy importantes.

R: Pues yo creo que nos vamos a tener que marchar ya porque están cerrando la Asamblea.

F.A.: Pues sí, pero ha sido un gran placer Raquel. 


\section{ENTREVISTA $2^{3}$ :}

Nombre del entrevistado: Dña. María Dolores Alemán.

Cargo actual: Diputada del Partido Liberal Constitucionalista (PLC) en la Asamblea Nacional (2007-2011), hija del ex-presidente Arnoldo Alemán.

Fecha de realización de la entrevista: Managua, 20 de noviembre de 2009.

Lugar: Sede Central del Partido Liberal Constitucionalista (PLC).

Duración estimada: 54 minutos.

\section{TEXTO - Transcripción 2:}

R: ¿Cuál sería tu visión sobre los cambios constitucionales recientes desde el 90 hasta la fecha en el marco de la transición democrática, pensando siempre en la consolidación de las instituciones democráticas en el país?

M.D.A.: Bueno, yo creo que han sido necesarias, porque en la medida en que estábamos experimentando una democracia, que es algo incipiente, algo nuevo, algo que mi generación, por lo menos, nunca la había vivido, yo nazco en una dictadura, crezco en un gobierno de una dictadura militar revolucionaria, y comienzo, ya como mi vida de adulta, a conocer lo que es una democracia, entonces, sí creo que eran necesarios ciertos cambios para ir avanzando en esta democracia, la democracia estable, y muchas de estas reformas se dan para que el país pudiera seguir en este juego democrático sin tener que recurrir a la guerra, puede ser que hayan sido buenas, puede ser que hayan sido malas, pero en ese momento eran necesarias, porque se preservaran las instituciones, se pusieron limitantes, se pusieron candados, pero en ese momento eran necesarias, se hizo de la manera que la Constitución lo establece, y nos gustaran o no nos gustaran, se hicieron creo yo por el beneficio del desarrollo del país en paz.

$R: Y$, sin embargo, hay diferencias también, porque hay varios procesos de reforma, la del 95 es la más amplia, al principio, incluso, hubo un debate sobre reforma total o reforma parcial a la Constitución, ¿por qué piensa que al final se optó por la ley reforma parcial en un momento muy delicado de transición política?

M.D.A.: Yo creo que porque no se tenían los votos suficientes en la Asamblea, además de que una reforma total implicaba ir a una Constituyente, formar una Asamblea Constituyente, que era un proceso más elaborado, más complicado de hacer, una reforma parcial era más sencilla, se hacía en dos legislaturas, con el 60\% de los votos, votación por mayoría calificada, y creo que optaron por eso, y esta reforma constitucional pensaron que estas reformas iban a poder instalar concesiones políticas, porque también en Nicaragua muchas de las leyes que incluyen las reformas constitucionales tienen nombre y apellidos, entonces, se hacen pensando en a que les van a favorecer, y al final se dieron cuenta de que no fue así.

\section{R: ¿Y piensa, por ejemplo, en la figura de Antonio Lacayo?}

\footnotetext{
3 Entrevista de interés por el discurso centrado en la importancia de las estructuras partidarias en la formación del liderazgo político, así como la articulación de las relaciones entre los poderes Ejecutivo y Legislativo.
} 
M.D.A.: Bueno, Antonio Lacayo en ese momento, si no me equivoco, no tenía los votos suficientes, él no apoyaba las reformas porque estaba apostando a ser el sucesor de Doña Violeta, sin embargo, su cuñado, Alfredo César, que no sé si estaba todavía de presidente de la Asamblea, pero sí era uno de los actores principales en la política nicaragüense, pensaba que tenía posibilidades de bloquear a su cuñado para que no compitiera y no fuera su contrapeso y él salir como una figura reconciliadora, o una figura que va a llevar adelante el proceso de transición o de democracia, porque decir de transición, creo que no sería la palabra adecuada, se dan pugnas internas entre parientes y también actores que a medida que va avanzando van perdiendo protagonismo político al no tener la consolidación de un partido fuerte, en ese momento, el Frente Sandinista está sumamente debilitado porque se le han ido 30 de sus diputados, 38 creo que tenía en la Asamblea, entonces, sólo quedan 8, y comienzan a hacer la alianza para reestructurarse, nosotros los miembros del PLC, teníamos a dos o tres, que iban dentro de la Unión Nacional Opositora (UNO), pues, y ni siquiera eran figuras partidarias activas, es decir, que tuvieran un peso político, no, eran figuras históricas, figuras que su nombre demostraba algo en contra del régimen sandinista, bueno, cuando fueron seleccionados en esa lista, ¿no?, entonces, el Partido Liberal, en ese momento, tenemos una gran desventaja, como partido no estamos consolidados, no tenemos eso que tenemos ahora, el peso político, es decir, no teníamos el peso político que tenemos ahora en esas reformas del 95, lo cual nos causa mucha gracia ahora, por ejemplo, de que nos digan: "es que el PLC es el responsable del pacto", ¿ya te encontraste con la figura del pacto?, es que al PLC le acusan del pacto, y nosotros no teníamos ese peso político en el momento en que se hicieron las reformas constitucionales de Nicaragua, por lo tanto, fuimos cumplidores o ejecutores del pacto, pero no cómplices ni partícipes en la elaboración de ese pacto. Pero, básicamente es eso, es buscar cómo liderazgos salieran adelante y hundir a otros, eso es en lo que consiste la ley de reforma parcial.

$R: Y$, por otra parte, también hay conflicto entre el Ejecutivo y el Legislativo en el 95, entre la presidenta Doña Violeta, que no quería aceptar las reformas, quería seguir gobernando con la Constitución del 87, que habian elaborado los sandinistas en el régimen revolucionario, y una Asamblea que lideró todo el proyecto de reforma constitucional.

M.D.A.: Claro, porque la Constitución del 87 era meramente presidencialista para un presidente fuerte, con poder, con mayor beligerancia mientras que en las reformas se le va quitando poder al Ejecutivo y la Asamblea Nacional va recobrando un rol mucho más preponderante, se involucra mucho más, tiene mayores facultades, en lo personal, creo que es mejor, lo podemos ver a lo largo de nuestra historia, además de que en los 80, cuando se da esto, el rol de la Asamblea Nacional, se queda más bien de títere, ¿no?, "necesitamos una ley, entonces, ustedes háganmela", pero era un solo partido, una sola voz, no había esa independencia o esa libertad que existe ahora, y claro, además de que Doña Violeta apoyaba a su yerno para que fuera su sucesor, y estaba en contra de las inhibiciones que le iban a hacer, y de la falta de poder que iba a experimentar.

$R: Y$, de hecho, incluso, en esa reforma, la cuestión de la reelección presidencial fue muy debatida, además fue una de las cláusulas que se aprobó finalmente después de un intenso debate para que no fuese continua, sino que pasara un período entre gobierno y gobierno. 
M.D.A.: Creo que eso ha sido lo más sabio que se pudo hacer en esa reforma constitucional, ¿por qué sabio?, es decir, mucha gente te dice, bueno, en cuatro o cinco años que dura el período presidencial no se pueden lograr hacer todos esos cambios tan trascendentales, pero en una historia como la nuestra, en una democracia tan frágil, tal débil, como la nuestra, en donde estamos acostumbrados a tener cacicazgos, es decir, a nosotros nos dicen, es que ustedes tienen caudillo tras caudillo, pues, la verdad es que desde la época de nuestros antepasados, desde la época pre-colonial teníamos a los caciques que ejercían cierto poder, después vino la época de la colonia y teníamos desde el virreinato hasta la Capitanía General de Guatemala, que era la más cercana a la nuestra, donde mandaban los criollos, y después una vez que llega la independencia nos volvemos liberales y conservadores, en caudillos liberales y en caudillos conservadores, entonces, eso históricamente lo hemos venido cargando, pero han sido épocas en donde estos caudillos, o estos líderes, se han perpetuado en el poder, teníamos en caso, por ejemplo, de Zelaya, que se pasó 17 años en el poder, yo te puedo hablar maravillas de Zelaya, porque es, digamos, el padre del liberalismo, pero, sin embargo, era un dictador, que pasó 17 años en el gobierno, trajo progreso y beneficios a Nicaragua, y tal vez la puso al mejor nivel de América Latina o mejoró ciertas cosas, pero es mucho tiempo, entonces, el hacer eso, creo que a Nicaragua le viene a marcar una señal de decirle: no más índices de dictadura, no más problemas que generen guerra y que generen violencia, "sos buen presidente, hiciste un trabajo bueno, esperáte un tiempo y volverte a lanzar". Lo que pasa es que, bueno, ha habido problemas personales o intereses personales, pero para mí una de las mejoras cosas que hubiéramos podido tener es eso, y eso que mi padre fue presidente, pues, y yo le aplaudo a él y le admiro en el sentido de que nunca hubo, te podrán decir miles de cosas de Arnoldo Alemán, pero jamás nadie te va a poder decir que él quiso reelegirse consecutivamente, entonces, esos son principios de democracia que tenemos que respetar, tal vez en un futuro no digo que no, la reelección continua sea buena, pero, en estos momentos, en que nuestra democracia es incipiente, en que nuestra democracia es bien frágil, creo que no es prudente, hubo demasiada sangre derramada, demasiada muerte, guerras civiles, guerrilla ideológica, que no vale la pena volver a lo mismo.

R: Y, sin embargo, da la impresión de que Nicaragua se asoma un poco a los ciclos históricos que ha vivido, y no es que trate de repetirlos, pero a veces si se registran paralelismos históricos, como regresiones que son peligrosas, sobre todo este último momento político muy delicado que estamos viviendo y del cual yo he sido testigo por estos tres meses que me ha tocado estar aquí. Pero ya pasando de la reforma del 95 a la del 2000, si hay una diferencia importante y es que, si bien el arco parlamentario del 95 por las propias reglas electorales contenía a múltiples partidos, muchos de ellos muy pequeñitos, en el año 2000 ya hay dos fuerzas de poder, el PLC y el Frente Sandinista, el PLC logra bajo el liderazgo de Arnoldo Alemán reconstituirse como partido fuerte frente a la UNO, que nunca dio del todo el apoyo a Doña Violeta, yo creo que además uno de los rasgos de su presidencia, además de la coyuntura política que le tocó vivir, especialmente, delicada y difícil, fue que no tuvo el apoyo de la coalición gubernamental.

M.D.A.: Pero es que lo que pasa es que había múltiples ideologías, desde la extrema derecha hasta la extrema izquierda en la UNO, y Doña Violeta, en mi opinión, cometió un error gravísimo y fue competir con los partidos políticos, porque ella no, es decir, ella llega ahí como un símbolo de reconciliación, la madre de los nicaragüenses, viuda, esposa de un hombre mártir, es decir, ella no es una persona política, ella no es alguien 
que ha militado y que sepa de la estructura de un partido, políticamente, los que participamos y que tenemos una vida activa en un partido, conocemos, no te digo, la necesidad del pueblo, pero conocemos cómo se maneja eso, y si querés tener una representación política fuerte tenés que estar arraigado a un partido político, entonces, ella ve a los partidos políticos como sus enemigos, no quisiera decir sus enemigos, no es la palabra, pero sí sus contrincantes, sus opositores, ella no trabaja con ellos, entonces, hubo mucho resentimiento por parte de aquellos que habían militado en un partido, que habían estado frente o de cara abierta y visible contra el régimen sandinista, y ella, pues, sí es verdad que era viuda de este mártir de las libertades públicas, pero era conocida por su marido y por ser dueña de La Prensa, al principio de su origen, o de su vida, había apoyado a los sandinistas, que era lo que mucha gente le reclamaba, entonces, vienen los partidos políticos que lograron mantenerse hasta el 89 o el 88, que fueron los que lograron, de cierta manera, presionar junto con la Contra y todo, que hubiera elecciones, sale ella y no le da apoyo a los partidos, entonces, hay mucho resentimiento por parte de los diputados políticos, entonces, y después pone a su yerno, que ha sido el super-Ministro, es decir, tenía un poder, y comienza una corrupción interna de la Asamblea, a comprar conciencias, a comprar votos, entonces, en ese momento ella tiene los votos, luego se le rebelan, y los de la Asamblea se dan cuenta de que ellos también pueden conseguir financiamiento por otro lado, $y$, entonces, comienzan a comprar otros votos dentro de la Asamblea, eso se vuelve una pugna entre el Ejecutivo y el Legislativo, claro, el Frente está debilitado en ese momento, no hay un Frente Sandinista fuerte, pero sí levantando conflictos, haciendo manifestaciones, quemando llantas, quemando la alcaldía de Alemán, estos disturbios, pero a lo interno del partido hay una intensa lucha de poder, $\mathrm{y}$, entonces, eso hace que haya tensión y ella nunca pensó, como si el ejercicio del poder fuera eterno, que eso se le iba a acabar, entonces, fue demasiado tarde que ellos constituyeron el PRONAL, ya fue cuando comprendió que tenía que haber partidos políticos con coaliciones para discutir, y ninguno de los que estaba conformando la UNO las aceptaron, entonces, fue diferente. Yo creo que, bueno, también en las reformas que se dieron en el 2000, hubo, en las elecciones hubo veinte y pico de partidos, 24 o 25 partidos, entonces, el Consejo Electoral los financió pre-campaña, es decir, te quedás con un sabor amargo, la población en ese momento estaba descontenta, diciendo: "mire, este señor salió diputado con 1.800 votos cuando este otro, que iba por este otro partido, tenía 10.000 o 15.000 votos y no salió de diputado", entonces, hubo cierto descontento, ya la sociedad también estaba presionando cuando algo no le gusta, porque quedó el esposo de la presidenta del Consejo Electoral quedó electo con 900 votos, entonces, se dijo: "no, aquí, ya no hay recibos electorales, y si querés presentarte hay una serie de reglas que tenés que seguir". Lo que pasa es que ha prevalecido la política mediática no la política por la iniciativa estructural de la sociedad, entonces, encontrás muchas cosas que tienen peso en los medios de comunicación, pero que, en las estructuras, podrán tener simpatías, pero yo no llego a decir: "bueno, vos me vas a contar un voto", entonces, ahí viene el resurgimiento de los partidos, diría yo, y nace, no es que nace pero da la fuerza a un partido, Camino Cristiano Nicaragüense, que en las elecciones del 96 logra sacar 5 diputados y nadie ni siquiera los tomaba en cuenta, por ejemplo, gracias a su trabajo organizativo, ellos se sirvieron también de la religión para conseguir votos, pero por eso es que nace la organización de los partidos.

R: Sin embargo, una de las críticas constantes que yo he registrado en la mayor parte de los entrevistados y también en el cultura politica del país es que ésta es una democracia más de hombres fuertes, de líderes fuertes, que de partidos políticos. ¿Cuál 
sería tu reflexión?, porque han sido muy interesantes las cuestiones que has abordado, no sé si como mujer de partido conoces bien la estructura de un partido y trabajas a diario en él.

M.D.A.: Yo más bien creo, nuevamente, en que hay liderazgos fuertes cada rato, y nosotros dentro del PLC tenemos a Arnoldo Alemán, que a muchos no les gusta, pero que es un líder de partido que se hace trabajando, entonces, no es únicamente un líder mediático, sino que es un líder que ha logrado mantener fusionado y unido al Partido Liberal, nosotros en el trienio pasado el partido sufrió una crisis sumamente fuerte, porque fue el presidente que nosotros llevamos el que nos declaró la guerra a nosotros en el partido, echó preso al líder a punta de calumnias y mentiras, y a pesar de todo, y a pesar de que pensábamos que el PLC iba a desaparecer, logramos mantenernos, y eso a mí me hace ver un avance en base al liderazgo partidario, el mantener un partido estructurado, vos podés ir a cualquier municipio, donde vayás, a cualquier municipio del territorio nacional, y podés conocer al presidente del Partido Liberal y vos lo vas a encontrar, y no solamente a nivel municipal, sino que nosotros hemos tratado de abrir nuestra estructura y de llevar, inclusive, de forma militante, porque nosotros tenemos un presidente departamental, un presidente municipal, el presidente de barrio, es decir, vamos en una pirámide de liderazgo, muchas veces nos dicen: ¿y por qué no haces esto o lo otro?, es decir, yo, que soy mujer de partido, si mi presidenta departamental no me autoriza no me voy a mover, no me voy a enfrentar con el partido.

\section{R: O sea, que hay disciplina de partido.}

M.D.A.: Hay disciplina de partido en el PLC, y eso que yo soy diputada, y soy diputada nacional, tengo un peso político diferente por ser hija del líder, llevo muchos años participando en política, sin embargo, al igual que yo hay muchos que hemos militado, bueno, yo no comencé en el partido desde arriba, yo empecé desde abajo, pegando pósteres y haciendo propaganda hasta pasar por las juventudes, ahora estoy de Secretaria de la Mujer, y soy diputada, antes fui diputada suplente, es decir, he venido escalando los cargos en el partido, y mucha gente critica al PLC, pero, la verdad, es que nosotros tenemos una estructura, y sin esa estructura no pudiéramos estar donde estamos, y hemos venido ganando elecciones y hemos estado presentes en elecciones, menos en el 90, que estábamos dentro de una coalición y ahí participó el PLC, pero luego en el 93 fuimos por primera vez solos, y ganamos las elecciones regionales, que fue el primer gran triunfo, luego vamos y ganamos las nacionales con la Presidencia, y después seguimos participando en las alcaldías, que eso es, porque para mí es uno de los mayores errores que tenemos, tener tantas elecciones, tenemos elecciones regionales, elecciones municipales, elecciones presidenciales, hay elecciones al parlamento Centroamericano, un país pobre que no tiene los recursos, es verdad que las elecciones son la base y el principio de una democracia, pero el partido recibe muchas críticas, pero es que no conocen el procedimiento, creo que también los que critican son los que desconocen las ventajas organizativas de esa estructura, y ponen, por ejemplo, a los del MRS, que la gente tiene una gran aceptación y que sea conocida, pero a la hora de la organización no tienen la base de una buena estructura, entonces, van a las elecciones nacionales y no pueden llenar los cargos que la ley determina, nosotros aunque sepamos que el concejal número 20 no va a salir electo tenemos a una persona ocupando ese puesto, ellos llegan al cuarto o quinto, son ciertas cositas que critican, pero que a la hora de ponerlas en práctica los que las critican no lo pueden hacer, eso le pasa al Partido Conservador, eso le pasa al Partido Socialcristiano, eso le pasa al APRE, bueno, y si 
ves, Eduardo Montealegre, por ejemplo, es un liderazgo personal no es un liderazgo de partido, logra formar o consolidar un partido, y luego el partido que había logrado fundar se lo quitan y la gente lo sigue a él, no sigue al partido, entonces, es otra vez imágenes de liderazgo de personas, que yo creo que también eso es parte de nuestra incipiente democracia, a medida que vayamos avanzando y tengamos más madurez en el sistema democrático esto también va a ir cambiando.

R: Sobre todo, porque el hilo conductor de las reformas constitucionales ha sido el de conceder mayores facultades a la Asamblea en detrimento del Ejecutivo, y esto pasa también por un trabajo de partido en el órgano legislativo, y tú que eres diputada debes saberlo perfectamente, el desarrollar una cultura política que favorezca, o sea, la palabra "pacto" no es negativa en sí misma, el concepto de negociación política está en la base del ejercicio democrático de cualquier país, ¿no?, pero sí es cierto que quizá a los liberales les hizo mucho daño el pacto con Ortega, a raíz del pacto entre Alemán y Ortega es cuando surgen estas fuerzas anti-pacto de los bloques, es decir, tanto del sandinista como del liberal, y ahora, de alguna forma, esa división de liberalismo, yo recuerdo que leía los titulares en España cuando la victoria reciente de Ortega en el 2006, y decían que Ortega no había ganado, sino que sus enemigos perdieron, realmente, fue una victoria con una minoría relativa, que, sin embargo, lleva, en vez de desconcentrar el poder en favor de una Asamblea, a una concentración en la figura del Ejecutivo presidencial, que es lo que estamos viviendo ahora, incluso, una regresión en términos democráticos.

M.D.A.: Sí, en 2005 se hizo una reforma pequeña a la Constitución, con un procedimiento legal, primera vuelta, segunda vuelta, votaron los diputados, se le quitaron algunas atribuciones al presidente, los ministros tenían que ser ratificados por la Asamblea, los diplomáticos también, eran unas reformas que iban a cambiar la vida, esas reformas que se hicieron en 2005, vinieron de la OEA, por eso es que yo no tengo mucho respeto a estos organismos internacionales porque tendrán sus intereses personales, ¿no?, pero vinieron a crear la figura de una Ley Marco, que es anticonstitucional, para suspender, inhibir, y parte de lo que yo les digo a la oposición y a los medios de comunicación es que pueden revisar el actuar en el historial del Partido Liberal, y nosotros hemos sido consistentes con nuestras posiciones y nuestra manera de actuar, mucha gente nos dice: "es que ustedes pactaron con el Frente, porque eligen Magistrados, Contralores,...", en fin, eso se hizo en el 95, y yo como liberal jamás se me va a ocurrir apoyar a alguien con una mentalidad conservadora, porque yo como política quiero que haya más personas que piensen como yo, es decir, o como piensa la institución, y las personas que nosotros proponemos cumplen con todos los puntos que establece la Constitución, pero aquí el político, son muy pocos los políticos estudiados, los políticos de carrera, por eso yo les digo: "váyanse a estudiar", nosotros no apoyamos esa Ley Marco porque es inconstitucional, y no sólo no la apoyamos cuando vino el señor Caputo, no la apoyamos en la segunda vuelta, la votación en la segunda legislatura, o sea, ahí vas viendo a diferencia de lo que son los partidos estructurados y los políticos incipientes.

\section{R: Por la línea del partido en relación a determinadas votaciones.}

M.D.A.: Claro, sin embargo, una vez que el partido toma una decisión lo más lógico es que hay que acatar lo que el partido dice, y luego vos encontrás: "ah, es que nos ahora conviene irnos por aquí, pues, vámonos por aquí", no, nosotros ya lo hemos dicho, lo 
que es inconstitucional es inconstitucional, lo que no es correcto, no es correcto, esto que se hizo en la Corte, que no quiero decir reforma porque no es una reforma, es un atropello jurídico, es un atropello jurídico, no lo puedo llamar de otra manera, Daniel Ortega, nosotros como partido podemos reconocerlo, sin embargo, no reconocemos la elección que se hicieron en las últimas elecciones municipales, no es como oposición diga: "ah, es que me ganó", no, si ganaron de manera legal y correcta yo lo reconozco, pero en unas elecciones municipales donde te queda un sabor amargo, donde hubo fraude, donde vos tenés la evidencia de que se robaron las elecciones no podemos nosotros aplaudirlo, sin embargo, han tratado de decir: "es que esto es por culpa del PLC”.

\section{R: Por el tema del pacto sobre la regla electoral del 35\%.}

M.D.A.: Pero es que el presidente Bolaños se eligió con esa misma regla, no es que las reglas se hicieron aquí, y cuando vos entrás a una elección entrás con unas reglas de juego que ya están, no con unas nuevas, pero con estas reglas el presidente Bolaños las gana, y si hubiera sido Eduardo el que gana o José Rizo el que gana el 35\%, ¿no sería diferente la reacción?, entonces, es falta de madurez política y es falta de seriedad política todo esto.

R: Bueno, también el hecho de que el liberalismo se dividió, porque el liberalismo unido nunca habría perdido las elecciones.

\section{M.D.A.: También los intereses personales.}

R: ¿Cuáles son tus hipótesis sobre la división del liberalismo?, porque siempre leo el tema de la cuestión del pacto y la disconformidad con esa actuación, que es la que motiva, digamos, el cisma del liberalismo, y también tu visión acerca de una posible presentación de una candidatura liberal única en las próximas elecciones presidenciales, si al final se da vía libre a Ortega de poder ser candidato.

M.D.A.: Bueno, yo creo que la división se da yo creo también que por falta de madurez política por parte de ambos bandos, por un lado, Eduardo Montealegre queda trabajando con el presidente Bolaños cuando el Partido Liberal decide irse a la oposición, y hacemos un acto masivo, y el PLC dice que le declara la oposición al gobierno por la persecución que se está haciendo al líder, entonces, Eduardo era un miembro alto de la estructura del PLC, y le dijimos: "Eduardo, renunciá a tu cargo y ven con nosotros a trabajar dentro del partido", y, en ese momento, él dijo: "no, Nicaragua me necesita", dentro de una estructura de resentimiento, porque Eduardo no se volvió el aliado que nosotros esperábamos sino un opositor más. Luego, tristemente, el gobierno norteamericano comienza a intervenir para evitar el pacto con los sandinistas, claro, para ustedes quizás sea menos importante la influencia de Estados Unidos, pero para Nicaragua, que es un país que estamos al lado de ellos, que toda negociación, todo negocio con ellos es un impacto, entonces, comienzan a marcarlo, a perseguir a un montón de gente inocente que nada tiene que ver, entonces, comenzamos a una serie de sobrevivencia, de ataques, y Eduardo logra muchísimo dinero, agrupar a una clase sin partido, que no sólo hay los liberales, ahí están los sin-partido junto con los liberales que se habían ido del PLC por alguna razón, y se van, se hacen unos intentos de unidad y no se lograron, por error de ambos, y con la poca madurez de ambos, y, bueno, terminamos yéndonos a la división completa en las elecciones que las hubiéramos 
podido ganar con un margen bastante alto, yo creo que la unidad no es algo que si queremos o no, yo creo que eso ya el pueblo de Nicaragua se ha dado cuenta de que es una obligación, de que es una necesidad de mucha exigencia por parte de nuestras estructuras y por parte de la estructura de ellos y la base de ellos, porque ahora necesitás tener carné de sandinista para poder trabajar en el Estado, han corrido a miles de personas, yo tengo un amigo doctor que es cardiólogo que consiguió la financiación para una máquina y van y lo corren, porque no era del FSLN, "bueno, yo tengo mi consultorio privado, ahí puedo seguir trabajando, a mí no me van a afectar", y el tiempo que había estado en el hospital, casi como voluntario, porque para lo que le pagan a estos doctores no es nada con lo que él puede hacer en su clínica privada, "pero bueno, me corren, me voy", y así como ese caso, hay miles de gentes, de profesores, médicos, creo que en el único lugar donde no se han metido ha sido en el Banco Central porque hay gente con muchísima experiencia, con muchísimo compromiso técnico, pues, y no los pueden tocar, pero vos vas a cualquier institución y no encontrás a gente, vas a Aduanas, por ejemplo, gente que los gobiernos anteriores habían capacitado para manejar la Ley de Aduanas, y te encontrás a gente que no sabe ni manejar la ley, gente que es sumamente inoperante, $\mathrm{y}$ son personas que no deberían tener una filiación política, sino que deberían estar ejerciendo un trabajo técnico, entonces, creo que la unidad es algo obligatorio, algo que ya ahora que ambos líderes se han sentado y han recapacitado, claro que todavía hay cierta cantidad de personas que tienen problemas personales, "y es que yo nunca lo voy a aceptar", poco a poco se irá a una mayor tolerancia, también Ortega a medida que vaya infringiendo la ley ha logrado, ha despertado ese sentimiento de unidad, al final yo sí creo que deberían ser Alemán y Montealegre los que sean la fórmula presidencial, pues, se verá, nosotros como partido estamos proponiendo que haya elecciones primarias.

\section{R: ¿En el partido?}

M.D.A.: No, para escoger candidato tanto los diputados como al candidato a la presidencia, es decir, esa es la propuesta nuestra, que se pongan las reglas de juego, para que tengan sus campañas, interna o nacional, o lo que sea, pero es lo que ha propuesto el PLC, que haya elecciones primarias y que con el tiempo se vea quien queda.

\section{R: Elecciones primarias entre los diferentes partidos, te refieres a todo el bloque} antisandinista, ¿o dentro del PLC solamente?

M.D.A.: No, elecciones primarias entre los partidos liberales, nosotros invitamos, por ejemplo, a los partidos que tienen líneas de pensamiento, la misma filosofía, tenemos problemas personales pero los liberales, digamos, en la Asamblea, por lo menos a la hora de aprobar leyes no hay problemas en ponernos de acuerdo, creo que entre liberales podemos abrir y hacer alianzas con partidos políticos diferentes, el MRS, el Partido Conservador, y hay una diferencia filosófica, ya son cosas diferentes, pero no podemos pensar o aspirar a tener otra coalición si, digamos, los hermanos mayores no se ponen de acuerdo, pues, entonces creo que es un proceso que necesita de varios pasos, no es uno solo.

$R$ : $Y$, sin embargo, antes hacías referencia a las leyes Marco, cuando uno examina la evolución constitucional reciente de Nicaragua da la impresión de que la política está por encima del Derecho, ¿no?, como que hay una tentación fuerte a no apegarse a la norma jurídica, incluso, a congelarla en el tiempo, que como tú misma señalabas antes 
es, claramente, inconstitucional, porque no se respeta el principio de supremacía normativa ni de seguridad jurídica tampoco, puesto que una ley ordinaria no puede detener temporalmente la aplicación de una norma constitucional que además es la Ley Fundamental, la Constitución es la ley suprema del Estado, ¿no?

M.D.A.: Por eso te digo que para mí fue una gran desilusión cuando vienen representantes de estos organismos internacionales y ponen a un lado el marco jurídico, ¿no?, y dicen que es para la estabilidad del país, para que no haya disturbios, pero es debido a la malacrianza de los políticos, es decir, para mí fue una realidad bien triste, y yo como política trato de que se respete, porque sin un orden jurídico no hay una democracia, y parte de la democracia es aprender a aceptar cuando uno gana y cuando uno pierde, y a ser tolerante de las diferentes percepciones y puntos de vista, es decir, incluso yo se lo digo a mis colegas y a mis correligionarios, yo no le veo liderazgo a Daniel Ortega, pero, sin embargo, yo lo respeto, porque hay gente que lo sigue y lo vota, y hay gente que le ve liderazgo a él, que a mí no me guste no significa que él no lo tenga, y eso es algo que tenemos que aprender los nicaragüenses, a convivir y a desarrollarnos, nos tomará tiempo, bueno, pero esos son los pasos que se tienen que seguir, y parte de la desilusión que me llevo con estos organismos es que están defendiendo la democracia y vienen a jugar con todos estos conceptos, si hacen eso en otros países.

\section{R: Sí, pero este es un procedimiento que ya data del 95.}

M.D.A.: Por eso, pero si ayer fue malo, hoy sigue siendo malo, y, entonces, ¿para qué vas a reformar la Constitución si la puedes cambiar con una ley ordinaria?, no hay una lógica.

$R$ : No, definitivamente, y esto último de la sentencia prueba que ya el conflicto ni siquiera se da entre el Ejecutivo y el Legislativo, sino ahora entre el Legislativo y el Judicial, ¿no?, cuando a través de una sentencia puede interpretar un artículo y le usurpa a la Asamblea, que es quien, realmente, tiene la legitimidad para reformar la Constitución.

M.D.A.: Se convierten no ya en el Legislativo, se convierten ya en una Sala Constituyente, como se dice.

R: Y, sin embargo, es una muestra de que el Poder Judicial no solamente está totalmente politizado, sino que el Frente Sandinista ha tenido una enorme capacidad para hacer penetrar, digamos, a esos cuadros afines al partido en toda la composición del Poder Judicial, bueno, desde los juzgados de distrito, hasta los juzgados de apelación.

M.D.A.: Cuando pierde Daniel se comienza, nuevamente, a reestructurar el Poder Judicial, porque desaparecen los tribunales populares, todas esas cosas, el Frente Sandinista a sus estructuras las mete y ellos comienzan a gobernar desde abajo, y tuvieron la visión de entender el Poder Judicial como una institución sumamente poderosa, comienzan a capacitar a sus cuadros y ahí es donde ves vos que se dan cosas impensables, por ejemplo, Francisco Rosales, que es el autor de la sentencia fue Ministro de Trabajo de Doña Violeta por muchos años, y es Doña Violeta la que lo lleva a la Corte, porque en esa época sólo el presidente tenía la facultad de proponer a los 
Magistrados de la Corte Suprema, y ahí ves que Doña Violeta propone a gente que era afín al Frente Sandinista.

R: ¿Y tú crees que ha influido un poco la reforma del 2000, cuando hacen esa crítica al reparto de la representación paritaria, ese bipartidismo institucional, al que se refieren, normalmente, los críticos de esta reforma del 2000?, ¿ha influido en la partidización de los principales órganos del Estado? Me refiero, fundamentalmente, al Poder Electoral y al Poder Judicial.

M.D.A.: Creo que sí, pero también en defensa nuestra es una manera de sobrevivir, y de estar en una posición del partido más fuerte, porque hubo un momento histórico en que nosotros teníamos los suficientes recursos legales como para hacer unas reformas legales y de hecho a la Constitución, si no es por el presidente Bolaños, en vez de aprovechar estas ventajas, se fue contra el PLC, lo primero que hizo fue de una bancada de 53 diputados la dividió, entonces, ha sido creo yo la respuesta que nosotros hemos encontrado para sobrevivir como partido.

$R: Y$, sin embargo, a la vocación hegemónica del Frente ante el PLC ha sido clara, quiero decir, que el PLC se ha convertido un poco en el socio minoritario de se bipartidismo, actualmente, me refiero, por la preeminencia que tiene el Frente, bueno, de hecho tiene mayor concentración de poder que en cualquier otro momento, incluso, de la revolución.

M.D.A.: Sí, sí, por eso, no quisiera yo, liberal, que fuera así, pero la necesidad nos ha hecho avanzar de este modo.

R: ¿Y cuál es tu visión sobre el futuro, que es complicado por el nivel de incertidumbre?

M.D.A.: Yo soy bastante positiva, no me gusta ser tan negativa, en el sentido de ver que Nicaragua va hacia el deterioro, yo tengo un poco más de esperanza, yo creo que tenemos que jugar un papel importantísimo en la Asamblea Nacional, tenemos que mantenernos unidos los liberales y hacer presión, ahorita el Frente no consigue los votos suficientes para elegir a los Magistrados que ya se vencen en el mes de marzo, y si nosotros creamos redes en estos poderes podemos hacer cambios pequeños, por ejemplo, que el Consejo Supremo Electoral vuelva a ser un Consejo creíble, que no siga a Daniel y se acabó, que se modernice o que se agilice la función, si vos cumplís 16 años es casi que ganarse la lotería sacarte una cédula, que debería ser algo como la licencia de conducir que si tenés todos los trámites te la dan en 10 o 15 minutos, es un documento que hasta para conseguir un trabajo, para poder ir a un banco lo necesitás, la cédula es casi no se me olvide, y después sacále fotocopia a tu cédula y guardála porque si se te pierde no puedes hacer nada, entonces, cosas sencillas, cambios oportunos, por ejemplo, el registro civil de las personas está manipulado, una reposición de las partidas de nacimiento, o una reposición o cambio de nombre, eso se dilata hasta dos años, cuando eso debería de ser inmediato, cosas sencillas, ¿no?, que se pudieran llegar a acuerdos, que podamos tener unas elecciones libres para 2011 y se decida quiénes van a ser los mandatarios de turno, yo creo que si jugamos un papel inteligente, con dignidad, no nos rajamos, como decimos los nicas, fácilmente, podemos llegar a buenos resultados, va a ser duro, va a ser difícil, hay mucho dinero de por medio, mucha compra de conciencias, pero yo tengo fe en que sea posible superar esta crisis. 
$R: Y$, no obstante, es cierto que si no se renuevan los liderazgos de los 80, que todavía siguen en el candelero, ¿no?, como dicen en España, si no hay una nueva generación de políticos, digamos, que trate de impulsar el proceso político sin regresiones al pasado, porque sí me hacen, incluso, paralelismos históricos entre el momento actual y los principios de la dictadura de Somoza, por la referencia a utilizar al Estado como recurso de poder económico, el vincular a los familiares directos en el ejercicio del poder presidencial, el cierre de espacios políticos, y me sorprende mucho la limitación de la libertad de expresión de los ciudadanos.

M.D.A.: A ver si el próximo sábado no nos salen a dar palos, yo estuve recién pasadas las elecciones municipales que se mal planeó una concentración, a mí me llegó a decir la policía: "por favor, diputada, salga, no la podemos proteger, no podemos", y ahí toda la gente, "por favor, se lo pedimos", ya cuando llega la policía diciéndole a una: "salga", claro, si una quiere que no le den palos y quiere seguir viviendo, me fui, pero eso es muy feo, yo no soy de las que van a agarrar un garrote y me voy a poner a pelear, yo puedo sentarme a dialogar, a platicar, expresar mi punto de vista y ser fuerte y firme, pero no soy de las que soy violenta y van a dar palos y ponerse a pelear, aquí para que vengan a darme pedradas y garrotazos y me vayan a matar, me fui.

R: Pues ya sí la última pregunta, ¿más reformas constitucionales o no?, porque sí siento, y es al menos la reflexión de la mayor parte de las personas a las que he entrevistado, que la Constitución ha tenido muchos parches en sus reformas, ha sido una Constitución que, en cierto modo, ha perdido parte de su valor normativo por el acomodo a los intereses de las élites, por intereses políticos coyunturales, también, y porque siempre hay como la ausencia de un verdadero consenso constitucional de todos los nicaragüenses, o sea, en la Constitución del 87 hubo una parte de Nicaragua que quedó fuera del proyecto revolucionario, que no se identificó con el régimen de Ortega, y luego, en las leyes de reforma parcial siempre hay conflicto entre las fuerzas partidarias que quieren llevar a cabo el proceso.

M.D.A.: Yo creo que no es el momento oportuno, en un futuro sí sería bueno tener una Constituyente, y hacer una reforma de la Constitución, pero, en este momento, yo creo que no es correcto ni pertinente, porque cada reforma deja un sabor amargo, entonces, aunque no sea la Constitución perfecta, sí creo que no se debería de tocar por un cierto período, sí creo que cuando pase este torbellino que se ha vivido, se debería hacer, hay cosas que están en la Constitución, por ejemplo, yo no estoy de acuerdo con eso de que a los 16 años podás votar, me parece aberrante, porque un joven, un muchacho de 16 años no tiene derecho a casarse, no tiene derecho a nada, a heredar, a ser ciudadano, es decir, ciudadano sí porque puede votar, pero no tiene derecho a hacer una transacción legal, a tener un negocio desde un punto de vista jurídico, pero sí puede votar, en su momento se dio por eso, pues, por dar un derecho a la juventud que iba a la guerra, la introducción: "por los héroes y mártires y no sé qué", eso no es ni de héroes ni de mártires es de ellos, "la sangre de los revolucionarios y no sé qué", el preámbulo, esas cosas sencillas, pues, no me quiero meter a puntos más específicos ni más polémicos, pero creo que tendría que ser una Constitución más clara, una Constitución con derechos más reales, que se puedan conseguir.

R: Pues si tiene algo más que añadir, yo creo que ha sido una entrevista muy completa e interesante. M.D.A.: No, muchas gracias. 


\section{ENTREVISTA $3^{4}$ :}

Nombre del entrevistado: D. José Antonio Alvarado.

Cargo actual: Ex - Diputado del Partido Liberal Constitucionalista (PLC). Ministro de Educación durante el gobierno del presidente Alemán (1997-2001). Ministro de Salud durante el gobierno del presidente Bolaños (2001-2007).

Fecha de realización de la entrevista: Managua, 18 de noviembre de 2009.

Lugar: Bufete jurídico "Alvarado y Asociados”.

Duración estimada: 57 minutos.

\section{TEXTO - Transcripción 3:}

R: ¿Qué recorrido hace examinando un poco desde los años 90 hasta la fecha los cambios constitucionales que se han producido en el contexto de la transición democrática? Especialmente, desde el punto de vista de la consolidación de las instituciones democráticas en el país.

J.A.A.: Bien, yo creo que los cambios en sí no han sido malos, incluso, las diferentes reformas, la reforma del 95, donde hubo transformaciones muy fuertes a la Constitución para quitarle poderes a la presidencia, o sea, el presidencialismo, para mí, el tema es que ni el presidencialismo ni el parlamentarismo son malos, los que pueden ser malos son los abusos de poder, los ejercicios de poder que pueden darse, pues, a veces, aquí creemos que reformando las leyes cambiamos el sistema, y yo creo que se nos olvida que tenemos que cambiar un poco nosotros para que las cosas, verdaderamente, cambien, la ley, por supuesto, es un mecanismo de control social y establece tanto las garantías como limitaciones en los ejercicios de los derechos que puedan tener los ciudadanos, o de las responsabilidades que tengan los ciudadanos, creo que las reformas, en ese sentido, han venido buscando ciertos mecanismos, hay reformas que se han dado, posiblemente, innecesarias, por ejemplo, la del 99, diríamos, yo era el Secretario Nacional del PLC, y yo me opuse, fui no solo el único que me opuse a las reformas, porque pensé que no tenía ningún sentido más que, estrictamente, intereses personales, pues. Las reformas que se dieron con Doña Violeta en el 95 fueron los resultados más bien de partidos minoritarios que trataron de eliminar el ejercicio del poder desde la presidencia ante la posibilidad de que no pudieran alcanzarla los partidos minoritarios, entonces, las reformas en sí, los cambios en sí se han dado con una visión, eminentemente, coyuntural, no con una visión de largo plazo, yo creo que ese es uno de los grandes temas de debate que todavía no se han iniciado en nuestro país como es el hecho de que nosotros nos hemos dedicado a construir historia y nos hemos olvidado de construir futuro, y seguimos construyendo la historia, pero construyendo la historia no sólo en el sentido de hacer nosotros la historia, sino, lo más grave, de que cada quien inventa la historia a su modo, cada quien la cuenta como cree, y se ha ido perdiendo el concepto de una historia nacional, $y$, entonces, la historia tiene el encaje coyuntural y la visión del momento, entonces, eso ha hecho, ha construido una limitante enorme en salir de la historia, en poder dejar el pasado, entonces, se vuelve a renovar el pasado, y se vuelven a hacer las mismas cosas, y a desempolvar hasta las tristezas y los dolores, las heridas abiertas que ha tenido el país, entonces, se ha vivido en esas frustraciones, y en el aspecto jurídico, en este caso, me refiero al aspecto legal, al marco conceptual del

\footnotetext{
4 Entrevista menos centrada en el discurso detallado de los procesos recientes de cambio constitucional, como en el interesante análisis político de los pactos inter-partidarios para el logro de las mayorías calificadas necesarias para reformar la Constitución.
} 
Derecho, ha sufrido muchísimo en ese aspecto, ya no digamos la implementación de justicia, donde el sistema de justicia está altamente politizado, con una inclinación, un peso enorme hacia el Frente Sandinista, como podemos ver en las últimas decisiones o cuasi-decisiones de la Corte Suprema, entonces, es un país que, en cierta manera, necesitamos reinventarnos, y como no pasamos de la historia, entonces, hay mucha gente, se va a encontrar de que, incluso, la culpa se la echan todavía a España, o, mejor dicho, a los españoles cuando vinieron, ¿qué tienen que ver los españoles con los cambios constituciones?, ¿con las decisiones de hoy de la Corte, etc.?, no, no, pero la excusa que se busca, normalmente, está en la historia y no en la responsabilidad del presente, $y$, de esa manera, se elude la responsabilidad del presente, que debemos de tener todos. Es muy difícil entender las reformas y los cambios y las perspectivas que pueden darse, mi criterio, puede llegar un momento en que se convoque a un diálogo nacional.

\section{$R:$ ¿Actualmente, se refiere?}

J.A.A.: Sí, sí, sí, tal vez no ahorita, dos meses, tres meses, seis meses, a lo mejor un año, pero puede darse, ¿por qué?, porque creo yo que la crisis se va acentuando, y creo que el entendimiento ético de lo que está pasando es muy pobre, ¿por qué?, porque la ética y la política tienen rato de estar bastante separaditas, y el ejercicio del poder se ha convertido en una cuestión vinculada a la coerción, a la imposición de normas, a la imposición de decisiones, y no a un aspecto moral o de actualidad, y, normalmente, cuando, si se incrementa mucho el poder, se disminuye, sustancialmente, la autoridad, yo creo que es más o menos la circunstancia en que estamos, y, claro, cuando se pierde la autoridad la búsqueda de alianzas para el mantenimiento del poder es una constante, y eso hace cambios y transformaciones de carácter político que obvian por completo los sentidos de justicia o de juridicidad, o el mismo sentido del ejercicio pleno del Derecho.

R: Usted que ha ocupado además cargos politicos importantes en las sucesivas administraciones del momento reciente de la democracia en este país, y ha podido observar cómo ha caminado ese dificil cauce, digamos, entre la política y el Derecho, a veces da la impresión de que la política está por encima del Derecho, o sea, que el ejercicio del poder por parte de algunos actores en Nicaragua tienen una fuerte tentación extra-institucional, es decir, a no respetar o a no ajustarse a la norma jurídica, ¿no? ¿Cuál ha sido su impresión?

J.A.A.: Sí, yo creo que, en gran parte, en vez de que los ciudadanos estemos sujetos a la ley, y que la ley sea, realmente, el elemento de resguardo de las libertades, de las garantías, y también de los deberes y obligaciones, la política se ha convertido en el instrumento legislador, los intereses políticos son los que legislan, los intereses políticos son los que la mayoría fomentan las decisiones de carácter jurídico, incluso, decisiones en el ámbito primario judicial, pues, a nivel de juzgados locales, o juzgados de distrito, sin entrar ni siquiera en las decisiones de las Cortes de Apelaciones, o de la Corte Suprema, o de la Sala Constitucional, es muy lamentable, pero, realmente, eso es, pues, y lo vemos en la Asamblea Nacional, el ejercicio de la función política en la Asamblea Nacional y, por supuesto, el ejercicio del poder conlleva, hasta cierta manera, el tratar de atemorizar a la gente.

R: ¿Actualmente? 
J.A.A.: Sí, pero también aún en diferentes épocas, en época de Doña Violeta, en época de Arnoldo, en época de Don Enrique, siempre ha habido deseos de influenciar en las decisiones parlamentarias.

\section{$R:$ ¿Por parte del Ejecutivo?}

J.A.A.: Por parte del Ejecutivo, sí, sí, es decir, que le digan que en una época fueron santos y en la otra fueron diablos, mire nosotros no venimos ni de la Luna ni de Marte, venimos de las mismas casas, y los funcionarios públicos salen de las casas de todos los nicaragüenses, lo que sucede es una cultura perversa desvinculada de la ética. Hoy conversaba con dos amigos, dicho sea de paso, los tres vivimos un tiempo fuera, uno vivió en Londres, muchos años, yo viví en Madrid, en Londres, en Italia, en Suiza, viví en Estados Unidos mucho tiempo, y el otro vivió en Francia, y, bueno, decían: "lo trágico nuestro es que somos extranjeros en nuestro propio país", porque quizás por la influencia de fuera, la influencia de los valores, la influencia del estudio, la influencia de ver uno lo que es un mundo moderno, y lo que requiere de cambios, de transformaciones, el modelo de una sociedad moderna, nos encontramos desajustados en un mundo que, en cierta manera, es bastante primitivo, y se actúa de forma primitiva, entonces, hay latente ese virus vinculado al autoritarismo, vinculado a la dictadura, a la continuidad del ejercicio del poder, y no, necesariamente, a que podamos todos entender de que, hombre, ese es mi trabajo, lo hice bien, y gracias a Dios y sigo adelante, y si hay otra oportunidad lo hago y si no, pues, me dedico a mis cosas, o de que tiene que haber relevos generacionales, decían estos amigos, de que nosotros casi tenemos la pirámide del gobierno como si fuéramos un país europeo, en el sentido de que Europa, en su gran mayoría, la población es bastante mayor, la población joven es un porcentaje bajo, ofrece datos muy pequeños, aquí es todo lo contrario, aquí el $63 \%$ es menor de 20 años, entonces, debería ser razonable pensar que en las estructuras de gobierno, en las diferentes formas de liderazgo y de aspiraciones, pues, estuviese permeado, mayormente, por la juventud, pero nos encontramos que los actores son los mismos, y por más que uno dice: "no, no me quiero meter en esto, dejemos chance a otra gente, impulsemos a otros", como que la gente también se cansa, repito, de ver qué es lo que está pasando, y, entonces, "no me quiero meter, no me meto en nada, no hago esto, no hago lo otro", ¿y en qué se mete?, pues, ese tuvo chance y no hizo nada, ese ni lo votan, el otro es un zángano, el otro compró diputados, el otro tal cosa, entonces, hay diferentes elementos de crítica, y muchos de esos elementos son contundentes, en relación a los actores políticos, entonces, mientras no haya una renovación de la clase política, que tenga un entendimiento de que el sistema judicial es la columna vertebral de una nación, es la que te da el marco de seguridad, de estabilidad de las cosas que pueden y deben ser, es muy difícil pensar en cambios y en transformaciones, porque, yo personalmente, concibo como imposible pensar en cambios y transformaciones con actores y con reglas de juego manipuladas por el factor político.

R: Y en relación al Poder Judicial y al Poder Electoral, que han quedado enormemente dañados ante la opinión pública, y desde el punto de vista de su funcionamiento institucional, ¿no?

J.A.A.: El Poder Electoral, le digo yo con honestidad, está lleno de zánganos, yo le cuento esta historia, yo me tomé 15 días en el Consejo Supremo Electoral, me metí al 
Consejo, yo fui, junto con Toño ${ }^{5}$, una de las personas que fue inhibida por el Consejo Supremo para correr para la presidencia, y yo también, a mí me declararon apátrida, habiendo sido Ministro de tres carteras diferentes me dijeron que no era ciudadano nicaragüense, y tuve que poner un recurso e ir a la Corte Suprema y luché y gané en la Corte, pero me resolvieron cuando ya no podía inscribirme, cuando ya el Consejo me había dicho que no podía inscribirme hasta que no saliera la resolución, cuando es una cosa tan obvia, porque es obvia, mi cédula, mi fecha de nacimiento, nacido aquí, todos los cargos, pero uno de los Magistrados me dijo, es un sistema, el Consejo Supremo Electoral está muchísimo peor que el sistema judicial.

\section{$R:$ ¿Siendo una institución tan importante?}

J.A.A.: Por supuesto, las dos, son vitales, pero la mínima confidencialidad no hay, por lo menos uno puede encontrar Magistrados y jueces que son honestos y que pueden ser imparciales, contados con la mano, pero en el Consejo Supremo uno no encuentra a nadie que tenga el menor viso de imparcialidad y objetividad.

$R$ : Y en relación a las reformas constitucionales, es cierto que la gran reforma del 95 es la que, según la mayor parte de los entrevistados, tiene mayor legitimidad, por la necesidad jurídica de adaptar el marco constitucional del 87 al momento de la transición política, y de incluir a todos los sectores de la sociedad nicaragüense, que quedaron excluidos del proyecto revolucionario, que no se identificaron nunca, y que eran también ciudadanos de Nicaragua.

J.A.A.: Bueno, la reforma del 95 fue también bien complicada, porque el presidente de la república proponía a los Magistrados, a los candidatos a Magistrados de la Corte Suprema, o de la Contraloría, o de los organismos colegiados, el mismo Consejo Supremo Electoral, en la propuesta del presidente, basada en la propuesta del presidente, la Asamblea la aceptaba o no la aceptaba, "el presidente no nos gusta, propónganos otro", pero tenía esa potestad, le quita esa potestad y se la da a la Asamblea Nacional, pero además de que se la da a la Asamblea Nacional, se establece que tiene que hacerse por mayoría calificada, que son las dos terceras partes, entonces, quiera o no quiera cualquier partido en el poder, o en la oposición, sus decisiones en la Asamblea tienen que ser con los partidos que representan mayoría, por ejemplo, ahorita, ahorita ALN, el movimiento "Vamos con Eduardo", el MRS, y el Frente juntos hacen 60 votos, el Frente y el PLC juntos hacen 60 votos, los movimientos, todos, y partidos, sin el Frente no hacen los 60 votos, entonces, el Frente tiene que estar en todas las decisiones para los nombramientos, ¿va el Frente a prestar sus votos en una decisión que no le conviene?, jamás, seamos prácticos, seamos realistas, jamás lo va a hacer, porque ahora el Frente quiere una reforma constitucional, por supuesto que quiere, pero, ¿va a acceder a una reforma que no le conviene?, no, porque sin sus votos no la hacen, entonces, el Frente busca con quién se entiende, es una cuestión práctica, pues, y, en ese sentido, o se entiende con un grupo o se entiende con el otro, o si los dos grupos deciden no entenderse con el Frente y llega la solidaridad, que lo dudo, de no entenderse, o sea, crean una crisis, porque se venció el período de algunos Magistrados y no hay nuevos Magistrados, y se venció el período de otro, y se venció el período de otro, y habrá un momento en que se puede decir: "no hay Magistrados de la Corte Suprema", "no hay Magistrados del Consejo Supremo Electoral", "no hay

Se refiere a Antonio Lacayo. 
Magistrados", ¿qué puede suceder?, que si los vencimientos son de tal forma que el Frente pueda tener todavía la posibilidad de convocar acuerdos con los 12 Magistrados, 7 de ellos y 5 del PLC, por la fecha de vencimiento, el Frente está feliz de la vida, porque tiene mayoría automáticamente, entonces, establecer la crisis puede ser interesante, pero ¿qué tipo de decisiones se irán a tomar en esa Corte?, no se sabe, es difícil la situación, o se lleva la crisis hasta el final donde haya un momento en que ya no haya quórum para nada, y, entonces, a ver qué se hace, a lo mejor se puede hacer en el Consejo Supremo Electoral, a lo mejor se puede hacer en la Contraloría, en uno o en la otra, pero que para hacer los nombramientos no los pueden hacer las fuerzas no sandinistas, aunque se unan todas, no pueden. Ahora, esa es la base fundamental por la cual el PLC ha tenido su entendimiento con el Frente para los nombramientos, entonces, que si el pacto, que si se distribuyen, no hay otra forma de hacerlo.

\section{$R:$ ¿Ese es el sentido del pacto?, ¿qué no hay otra fórmula?}

J.A.A.: Es que no hay otra forma de hacer los nombramientos, jurídicamente, pues, no hay, no hay manera de hacer nombramientos si no...

\section{$R:$ ¿Hay un acuerdo de reparto paritario?}

J.A.A.: No, si no están los votos, o, digamos, ¿en base a qué se hace?, si es paritario, si es de una forma, no importa en qué base eso, pero no puede haber elecciones en la Asamblea si no tienen los 56 votos, y los 56 votos sólo lo reúnen ahora o unos o los otros con el Frente, pero las fuerzas que son de oposición, o que se llaman de oposición solas no pueden hacerlo, entonces, por fuerza necesitás del concurso de los votos del Frente, "bueno, entonces te doy los votos, vos decís qué querrás, yo nombro los míos", "son seis cargos, aquí están mis tres, vos escoged otros tres", "ah, bueno, es que vos no tenés derecho a tres, tenés derecho a dos, son cuatro míos", no te los dan los votos, no hay nombramiento, es tan sencillo, despoliticemos la cuestión, supongamos que estamos los dos en esa circunstancia, y hay un tercero más, y nosotros dos juntos hacemos mayoría calificada, primero, no tenemos por qué tomar en cuenta a éste, acordémonos de la dinámica a lo interno de los partidos, verás, si éste es opositor a vos y diferente al mío, ¿por qué yo le voy a dar chance de un cargo mío?, ¿y por qué vos le vas a dar chance de un cargo tuyo?, en política práctica, no se lo das, entonces, entendámonos, nos entendemos, y son cuatro cargos: dos tuyos y dos míos.

R: ¿Y cómo visualiza usted, cuál es su reflexión a propósito del pacto entre Ortega y Alemán, que precede a las reformas del 2000?, ¿cuál cree usted que ha sido el sentido de esa reforma constitucional?

J.A.A.: El sentido de ese pacto era, uno, que Alemán se garantizaba la diputación como ex-presidente, tremendo error, y la segunda consideración es que Alemán nunca pensó que el liberalismo se iba a dividir, entonces, dijo: "ah, estos tienen $35 \%$, no van a pasar de ahí, jamás van a llegar", la prueba es que cuando se hizo la elección de Bolaños se hizo con esas mismas reglas de juego, y no ganaron, porque iban unidos todas las fuerzas democráticas, casi todas, entonces, el Frente no ganó, pero el Frente comenzó a trabajar en la desunión, entonces, el pecado es la desunión, es como si yo te digo, hipotéticamente, supongamos que hay una reforma constitucional, y te dice: "se permite la reelección, pero se permite la reelección solamente si el candidato a la presidencia gana el 50\% más uno de los votos”, ¿ganará Ortega con el 50\% más uno de los votos?, 
no lo creo, no lo veo, entonces, si le das la reelección pero le ponés eso no hay manera de que gane, pero ya viene la suspicacia, y ¿quién le está dando la reelección?, y, entonces, ¿qué están buscando?, y ¿cuál es el sentido?, pero además con este Consejo Supremo Electoral, que no tiene credibilidad, cualquiera te dice que ellos fabrican los votos hasta conseguir el 52\%, entonces, y no es tanto la reforma al Consejo ni al marco jurídico, que se puede y admite cambios sustanciales, pero son los seres humanos, los ciudadanos, que son responsables o irresponsables de su actuar ahí, entonces, fue un error tremendo porque pensó que no iba a haber desunión de las fuerzas democráticas, y en parte yo creo que también pensó que al establecer ese criterio forzaba a la democracia a mantenerse unida, porque la democracia iba a decir: "hombre, si andamos desunidos, perdemos", así que por fuerza obligaba al bipartidismo, pero se quiso forzar la división, y hasta ahí puede decirse que el PLC no más llegaba al 12\%, lo cual, pues, era una insensatez pensarlo de otra manera, una insensatez, pero vendieron esa idea para tratar de decir que Eduardo podía ganar, Montealegre, jamás tenía chance, no había manera, no había forma posible, y eso que gastó veintitantos millones de dólares, treinta millones de dólares en la campaña, no había manera, los números no daban, entonces, las reformas, como te digo, se han hecho con una visión coyuntural, una visión coyuntural es que los diputados en el siguiente período ya los tengo garantizados, y voy como presidente de la Asamblea, y como presidente de la Asamblea voy a tener control, esa fue la, yo estuve distanciadísimo, peleado con él, y aún peleado con él yo le mandé a decir con alguien que era la estupidez más grande que estaba cometiendo de buscar la presidencia de la Asamblea, que se dedicara a buscar cómo fortalecer el liberalismo, pero que la presidencia de la Asamblea lo que iba a hacer era llevarle a una confrontación directa con Don Enrique Bolaños, con quien a mí me unía cierta amistad, porque Don Enrique y yo habíamos sido compañeros de colegio, entonces, lo conocía desde chavalo, pero como estábamos distantes y no sólo distantes, yo era de los que llamaba a los programas de radio, cuando él estaba en un programa de la radio lo llamaba y me daban casi tanto espacio como a él porque armamos un debate, y, entonces, Nicaragua necesita retomar una visión de largo plazo, en todo, estoy tan consciente de eso, cuando estuve de Ministro de Educación logré hacer con el apoyo de todos los sindicatos, 11.000 maestros que participaron directamente, los rectores de las universidades públicas y privadas, todas, convoqué a lo que era el Plan Nacional de Educación, a 20 años plazo, para darle al país una visión, una educación de largo plazo, y cuando estuve en salud hice exactamente lo mismo, y se formaron reuniones de salud también donde participó todo el mundo, pero todo el mundo, hasta las ONGs involucradas en temas de salud, y el país necesita eso, es eso, consensos de largo plazo donde todos podamos coincidir y entender cuáles son los intereses que compartimos, aunque los matices para efectuarlos, porque varíen dependiendo de quién esté en el gobierno, pero que vamos todos en una misma ruta crítica, hasta ahora las reformas y los cambios que se han hecho no representan una ruta crítica de nación, sino la ruta crítica de los intereses políticos o personales coyunturales, y, entonces, entre una visión de nación y un interés personal, ni siquiera partidario, ni siquiera partidario.

\section{R: ¿Hay una debilidad de los partidos políticos en Nicaragua?}

J.A.A.: Sí, sí, total, la clase política es totalmente, yo le digo, vengo poco a Managua, antes, obviamente, venía todos los días, ahora vengo una vez cada 15 días, lo que pasa es que hoy vine cuando me localizaron y me contaron, porque tenía un desayuno, después tenía una reunión, después tenía un almuerzo, tengo otro en la tarde y después otra más tarde, entonces, ¿ves?, podemos perfectamente encajar la entrevista, yo vivo en 
Granada, es preciosa la ciudad, entonces, se necesita refundar un poco nuestra nación con una visión bien clara de hacia donde queremos ir, con escritos compartidos, con propuestas consensuadas más allá de los intereses políticos, partidarios, y personales.

R: La reforma del 2005 es la que culmina un poco ese proceso de debilitar al Ejecutivo presidencial en aras de aumentar las facultades de la Asamblea, bajo el gobierno del presidente Bolaños, y él se resiste, es un presidente que además tiene enormes dificultades para sacar adelante su agenda de gobierno, enfrentado a la bancada del liberalismo que se va con Arnoldo Alemán y, por otro lado, el Frente, que aprovecha esa división del liberalismo para poder pactar en función de su propio interés político, ¿no?

J.A.A.: Y el Frente pactó con los dos, pactó con Don Enrique para ciertas cosas, y pactó con Arnoldo para otras cosas, el Frente pactó con los dos, y, en el pacto con el gobierno, utilizó al gobierno para procesar a Alemán y en el pacto con el PLC, con Alemán, para darle cierto espacio y al mismo tiempo limitar la agenda, en gran parte, que tenía el gobierno de Don Enrique Bolaños, es decir, por eso te digo, han sido unas cuestiones coyunturales complicadísimas donde han regido más las emociones que el pensamiento, todo esto que vemos, los problemas de Alemán y el ingeniero Bolaños han sido cuestiones emotivas, tanto personales como en el ejercicio del poder, sin lugar a dudas, la división del liberalismo ha estado vinculado a eso mismo, y el Frente igual, nada más que con un nivel de aprovechamiento mayor.

R: Es cierto también que el Frente Sandinista durante 16 años de oposición, antes de llegar al gobierno en 2007, supo aprovechar bien, digamos, en términos de penetración institucional, de dominio, de "gobierno desde abajo", que fue también contar con su presencia en los principales poderes del Estado, ¿no?

J.A.A.: Sí, el Frente tiene una capacidad conspirativa tremenda, pero es que nacieron en la conspiración, es natural, sería ilógico pensar que no la tienen, definitivamente, y tienen una capacidad de crear crisis tremenda, no tanto buscar soluciones, precisamente por eso es que estamos como estamos con el gobierno actual, la capacidad, la iniciativa de búsqueda de soluciones para ellos no está vinculada con su modus operandi, ellos están más vinculados a la creación de crisis, pero aún así, tienen la capacidad de generar respuestas también, de planificar respuestas, pero sus cuadros más no están necesariamente acostumbrados a eso, y ese es una de las enormes debilidades del Frente, por eso es que a veces se habla de la falta de operatividad, del ejercicio muy pobre en términos presupuestarios, etc., etc., verdad, pero el problema es que la curva de aprendizaje de una metodología a otra toma mucho tiempo, y nuestros países no están para curvas de aprendizaje, nuestros países están para que al día siguiente que comencemos la función comenzás a hacer lo que tengas que hacer, ¿por qué?, porque estamos tanto tiempo atrás, que no podemos seguir demorando el progreso, las respuestas tienen que venir de inmediato.

R: Y en el caso del actual gobierno y de esta interpretación del artículo 147 a través de la sentencia de la Corte Suprema, amparándose en un precedente como el de Costa Rica, con el cual tiene enormes diferencias, y que no es más que una coartada jurídica para hacer algo que es absolutamente ilegal desde cualquier punto de vista, y usted, que es jurista, lo sabe mucho mejor que yo, ¿no? 
J.A.A.: Mira, vos podés tomar, incluso, el Derecho Constitucional moderno y podés establecer mecanismos de respuesta parecidos a la cuasi-respuesta que dio la Corte, el problema no está sólo en la respuesta, el problema está en cómo se dio la respuesta también, es decir, no se respetaron las formalidades, es decir, no se dio la citatoria correspondiente, no participaron los Magistrados que debían de participar, etc., etc., entonces, ese es un vicio profundo, sustancial, más que adjetivo, pues, podría pensarse que es adjetivo porque es una cuestión también de procedimiento, pero está tocando en la resolución problemas de fondo, por un lado, por otro lado, podría tratar de buscar una salida en el ámbito constitucional, pero muy difícil ante una normativa tan expresa, tan expresa, sobre la cual ya ha habido decisiones judiciales anteriores, entonces, te das cuenta que es una decisión política más que jurídica, y que salvaguardar la forma jurídica procedimental para hacerla no ocupó ninguna prioridad, porque la prioridad es la decisión política, a mí me da la impresión de que hay una combinación de elementos, posiblemente, problemas internos del Frente, se venía hablando que si Doña Rosario iba a ser la candidata, que si esto, que si lo otro, y eso iba creando una serie de problemas a lo interno, tenés la impresión porque Daniel dice, para que la gente no esté especulando, "yo voy a ser el candidato", o por lo menos, "yo voy a decirlo", dejar la alternativa de serlo, y la única manera de hacerlo es que estoy tan decidido a hacerlo que hicimos tal cosa, calcularon que con una oposición fragmentada y con un control enorme del Estado iba a ser muy difícil revertir eso, y que una protesta o dos protestas o tres protestas, pues, tampoco la van a revertir, hoy me decía un amigo: "oye, ve a la manifestación del sábado". ¿Y después?, ay, yo quiero saber qué tienen en mente ustedes después, a partir del 29 Nicaragua empieza a celebrar el novenario de la Virgen y muchos lo tomamos pero muy en serio, concluye el 7 de diciembre, del 7 de diciembre en adelante, con el espíritu navideño y los "gingle bells", pues, muy poca gente está pensando en otra cosa, ya para entonces surgió otra crisis y otra cosa, otra circunstancia, porque recordemos que esta gente es extraordinariamente capaz para crear crisis, y para distraer de las crisis existentes.

$R$ : Sí, porque la crisis tiene unos réditos, ¿no?, tiene unos beneficios, me refiero, de las crisis se benefician también algunos políticos.

J.A.A.: Por supuesto, ¿cómo decían los chinos?, las crisis son oportunidades, y son oportunidades de diferente manera, hay unos que salen de inmediato en los medios y comienzan a criticar, y hay mucha hipocresía, muchos comienzan a criticar por las cámaras más que por los sentimientos, ¿no?, otros lo hacen con honestidad y sinceridad, sin lugar a dudas, pero da un margen de desconfianza en la población, entonces, no es fácil.

R: Y ya para terminar, porque estamos llegando al tiempo, en el caso del pacto constitucional, ¿usted piensa que ha habido, realmente, un contrato constitucional que incluya a todos los ciudadanos de este país? Porque la Constitución del 87 representa un proyecto político, el 89 abre paso a la democracia liberal, que es un poco el fruto tardio de la revolución y paradójico también.

J.A.A.: Mirá Raquel, por ningún momento, en todo el análisis que tenés que hacer de esto, por ningún momento, perdás un punto que te mencioné que es clave: no puede haber reforma constitucional si no es contando con los votos del Frente Sandinista, ergo si la reforma constitucional no encaja en los intereses del Frente Sandinista, no hay reforma, y si la hay va a encajar en los intereses del Frente. Si se hace o se convoca una 
Asamblea Nacional Constituyente para elegir a los miembros de una Constituyente y entrarle a una reforma total de la Constitución, a mi criterio, podría, y te pongo el podría con la $i$ y la $a$ varias veces repetida, podrííaaa, ser apropiada, con un Consejo Supremo Electoral diferente, es decir, elegir a las personas para una Constituyente con un Consejo Supremo Electoral diferente, porque la Constituyente con mayoría simple, no necesitás mayoría calificada, y en esas circunstancias dudaría enormemente que el Frente pueda tener mayoría en un escenario limpio, y podría ser lo apropiado para el país.

\section{R: ¿Una Constituyente?}

J.A.A.: Podría ser, pero con un Consejo Supremo Electoral diferente, para que se sentaran las bases y decidan, comencemos de nuevo, comenzar con un Consejo Supremo Electoral diferente ya es un gran paso, y con una Constituyente, haciendo una Constitución, elegir también desde una Asamblea nueva y diferente los miembros de la Contraloría, los Magistrados del Consejo Supremo Electoral, los Magistrados de la Corte Suprema, etc., etc., y ya eso se permite hacer unos cambios tremendos en la legislación, y, por supuesto, ahí ya invitás a concurso para los jueces, etc., pero con reglas del juego claras. ¿Cómo partís?, ¿cómo podés hacer cambios sin partir de lo que estás, de lo que tenés? Si nosotros queremos volar, muy difícilmente lo vamos a hacer desde estas dos sillas, tenemos que hacer una reservación en una línea aérea, verdad, para poder salir tenemos que hacer algo diferente, con las reglas del juego actual no hay manera que se puedan hacer cambios justos, libres, independientes, que representen los intereses de la nación, y a veces la tristeza es que la historia de nuestro país nos demuestra que, precisamente, por estas circunstancias que, normalmente, los cambios llegan cuando la salida no es la más inteligente ni la más pacífica, la violencia ha sido determinante en los inicios de las transformaciones, entonces, ¿se irán a cerrar los espacios?, ¿se seguirán cerrando los espacios y llegará, entonces, a explotar la caldera?, puede ser, ¿se abrirán los espacios ante la presión y dará la oportunidad a que se hagan cambios y transformaciones que sean justos y equitativos para la nación?, es posible, el problema cuando la caldera se calienta es que sabés que se comienza a calentar, pero muy difícilmente sabés cómo va a terminar.

\section{$R:$ ¿Y cómo ve usted el futuro de su país a mediano plazo?}

J.A.A.: Ja, ja, ja, mirá, mi amor, hoy en la plática que tenía, estaba con estos amigos, y uno de ellos tiene un grupo de reflexión bien interesante, $y$, entonces, después de hacer todos los análisis le decía yo a este señor mayor: "Maestro, ¿cómo ve usted el futuro del país a corto plazo?", fue un poco duro si vos querés, porque me dice: "lo veo mal", "Maestro, ¿y cómo lo ve en el mediano plazo?", le digo yo, "pues, también lo veo mal, pésimo", y, entonces, le digo yo medio en serio, medio bromeando, irónicamente si vos querés, "no le pregunto a largo plazo, Maestro, porque a lo mejor no lo vemos", ja, ja, ja, el Maestro es un señor mayor, que tiene ochenta y tantos años, "así es, tenés razón", me dice, pero, en la realidad, entonces, se pueden acelerar las transformaciones políticas, va a depender en gran parte de las transformaciones sociales, en nuestro país, el metabolismo social en Nicaragua es un poco errático, pero hay que leer un poco todo esto en el contexto, uno, de la crisis económica internacional, la fuga de capitales, los problemas de inversión, la liquidez del sistema, etc., hay que entender esto en el contexto de las relaciones del gobierno con los organismos financieros internacionales, hay que entender esto en relación con los donantes que están un poco "erizos" con todas 
las cosas que pasan y las cosas que les dicen además, y, luego, todo eso hay que entenderlo en términos también de la crisis social, de la pobreza, del aumento de la pobreza, de la falta de recursos para seguir atendiendo los problemas de salud, de educación, de los problemas serios con respecto a la vivienda, etc., etc., entonces, esos son elementos o que pueden preocupar a un gobierno y hacerlo ocuparse de las transformaciones y abrir los espacios, o que no vea las cosas de esa manera y, entonces, las cosas vienen a calentarse hasta el extremo que sea muy complicado para todos, y al final de eso sucede que no te das cuenta cuál es la respuesta, saltan instituciones, saltan personas, surgen ideas, es decir, es muy difícil, el que te diga que tiene una bolita de cristal que ve bien claro toda esta cosa te quiere engañar, Raquel, yo le digo, nuevamente, a los embajadores, a algunos embajadores de España, a algunos embajadores de Estados Unidos, a algunos embajadores amigos, sobre todo a los gringos que vienen con unos estudios impresionantes de todo, les digo: "pero bueno, ustedes vienen con unos estudios, seis meses de estar pero estudiando el país al pie de la letra, vienen sabiendo la historia del país completo, la geografía de Nicaragua pero extraordinaria, ustedes ven a la persona que está al pie de la escalinata cuando se bajan del avión y ya lo conocen, porque tienen una información tremenda, sin embargo, ustedes se dan cuenta que están comenzando a conocer Nicaragua cuando les avisan que lo han transferido a otro país", siempre aquí se sorprende todo el mundo, "ah, ¿y pasó eso?, ¿y cómo es posible?, no me digás”, ¿por qué?”, porque no hay una visión compartida, consensuada, del destino que queremos imprimirle al país, eso falta fundamentalmente, pero consensuado, no importa si es sandinista o no es sandinista, yo me acuerdo que cuando hacíamos el Plan Nacional de Educación, Arnoldo, con el que tenía una magnífica relación, y ahora hemos mantenido un cierto nivel de comunicación, pero, entonces, era una relación bien estrecha, "no, es que toda esa gente es comunista", me dice, en ese trabajo, el Plan Nacional de Educación, "no, la gran mayoría es gente que estuvo metida en eso, pero que están comprometidos con la educación, y la educación no sólo es ideológica, la educación es de compromiso con las transformaciones educativas de un Estado", y, en efecto, se hizo el Plan Nacional de Educación casi gratis, fue impresionante la participación de ellos, cómo será que no creían que lo que yo le proponía podía hacerse o que había algo detrás de mi propuesta, nunca lo creyeron, hasta que comenzaron a ver los cambios en los guiones que ellos traían, yo les fui franco, "mire, yo convoco a esto, y voy a hacer la convocatoria nacional, pero quería consultarles a ustedes primero", reuní como a unas 30 personas de actores de universidades, etc., "yo quiero saber la opinión de ustedes sobre esto, quiero decirles que yo sólo voy a comentar algunas cosas reaccionando a cosas que ustedes aporten, pero el Plan lo van a escribir ustedes, me gustaría que ustedes eligieran quién va a ser el relator o la relatora”, y así se hizo, y al final fue una maravilla, cómo será que la UNESCO lo calificó como el mejor plan de educación de América Latina, en 8 meses, los 11 sindicatos de educación trabajaron escuela por escuela, padres de familia, chavalos, etc., impresionante, si lo hubiera hecho de otra manera, quién sabe cómo hubiese salido, y nadie protestó, más bien, yo devolví el Plan Nacional de Educación en la presentación final por dos razones, en un centro de convenciones, me lo entregaron, me acuerdo, a las siete de la noche, como a la una de la mañana terminé de analizarlo, y llegué a la conclusión de que le faltaban dos temas: el tema de educación especial y el tema de la educación rural y de adultos, vinculados, y dije: "quiero que, por favor, esto vamos a imprimirlo, quiero que, por favor, ustedes enfoquen esto y manden todos los que están aquí presentes sus ideas sobre estos dos temas, no podemos seguir marginando a niños de educación especial, ni podemos dejar de asignar recursos para ellos", entonces, les conté la historia de un muchacho de una señora que me llamó a mí 
para decirme que en un centro de educación especial, yo aún no era Ministro de Educación, fue un año antes, que lo iban a cerrar, que si yo podía ayudarle a conseguir fondos para mantenerlo, yo conocía a esa señora perfectamente bien porque habíamos vivido enfrente, ya sabes como son las calles nuestras, a cinco metros ahí está la casa, y además todo el mundo sale a la calle, se platica, y todo el mundo se conoce, y, entonces, me fui y llamé a unos empresarios para conseguir la ayuda, le garantizamos dos años, eso a nivel personal no del gobierno, pero me quedé con una pregunta, qué alegre que esta señora que nunca me di cuenta de que estuviera involucrada en un centro de educación especial. Hablando con mi madre, que vive en Estados Unidos, "fíjate mamá que ví a la Chepita y me dio mucha alegría", "sí pero es que sabes, ella tiene un hijo con enormes discapacidades", viví enfrente de la casa de ella hasta los 19 en que me fui a estudiar a Europa y en esos 19 años yo jamás me di cuenta, en la educación especial a los niños los ponen en la parte de atrás, en lo último de las casas, ni siquiera lo sacaban, porque consideraban que era como una maldición, que era un castigo de Dios, no sé qué cosa, entonces, había que darle a los niños con esas dificultades el primer lugar, la primera fila, para que pudieran aprender, para que pudieran ser motivo de alegría no de sufrimiento, entonces, ¿cómo la educación podía contribuir a hacer eso?, ese fue el motivo por el cual, entonces, les expliqué, hasta hice reuniones con psicólogos, padres de familia, y maestros, para ver cómo hacíamos cursos para capacitar a los padres de familia y capacitar a los maestros en la relación con niños de educación especial.

R: Pues, ya tengo que marcharme porque tengo otra entrevista enseguida. Pero gracias por todo.

J.A.A.: Bueno, ya sabes que tienes mi teléfono, cuando quieras me llamas. 


\section{ENTREVISTA $4^{6}$ :}

Nombre del entrevistado: Dr. Gabriel Álvarez.

Cargo actual: Profesor de Derecho Constitucional de la Universidad de León (UNAN).

Fecha de realización de la entrevista: Managua, 18 de septiembre de 2009.

Lugar: Oficina privada de su centro de asesores jurídicos en Managua.

Duración estimada: 1 hora y 45 minutos.

\section{TEXTO - Transcripción 4:}

$R$ : ¿Cuál crees que ha sido la contribución que desde el cambio constitucional se ha hecho a la transición democrática en este país, el diseño institucional del marco de la política democrática? Me refiero a los cambios constitucionales que se han producido desde los 90 hasta el momento actual.

G.A.: Yo creo que, lamentablemente, ha sido muy poco, Raquel, pero esto se puede, obviamente, como siempre ocurre, matizar, y sobre todo ver desde de qué referentes partimos, mira yo escucho decir a muchos nicaragüenses, por supuesto que muchas de las veces con algún interés, pero podrían ser otras razones de buena fe, pero sobre todo a los extranjeros comparar el estado actual de cosas con una época de guerra, de contrarrevolución, de un conflicto bélico, y desde ese punto de vista casi cualquier diseño o modelo institucional sale mejor parado que otro momento histórico político en donde las demandas sociales y las contradicciones se procesan a través de las balas, cuando se hacen con balas y con guerra cualquier cosa, en principio, es mejor. Siendo eso cierto, para mí puede ser peligroso si se utiliza como punto de partida ad infinitum, no puede ser que siempre los nicaragüenses estemos diciendo: "sí, pero antes era guerra", de acuerdo, antes era guerra, señor, ya la guerra pasó hace rato y ahora empecemos a pensar en construir algo y estarlo evaluando, ajustando y mejorando, no teniendo como referente la guerra, ni una dictadura somocista, entonces, tal vez algo que, metodológicamente, al menos, puede servir, yo no parto, no tengo como premisa comparar la evolución constitucional nicaragüense desde el 87, con una Constitución, o más específicamente del 95, que hubo la primera reforma constitucional significativa, hubo otra antes, pero que tuvo menor significación, no la comparo ni con dictaduras militares, ni con guerras, la comparo o la contrasto con referentes más o menos universalmente aceptados en lo que es un Estado democrático de Derecho, sin olvidar nuestra propia historia, nuestros propios déficits democráticos, etc. Entonces, desde este último punto de vista, yo creo que salvo la reforma de 1995 en que, de alguna manera, en términos generales, puede decirse que vino a reequilibrar las relaciones entre los poderes, que vino a reubicar la posición hegemónica del Poder Ejecutivo, y a posicionarlo más de acuerdo a cánones clásicos de un Estado liberal democrático, salvo eso y con el asterisco que ya te voy a comentar en próximos segundos, todas las demás han respondido a criterios de poca legitimación política, de poca o ninguna aceptación social, de poca o ninguna finalidad de fortalecimiento de la institucionalidad

\footnotetext{
6 Entrevista de larga duración, aunque resulta de interés el discurso desarrollado al hilo de las preguntas planteadas, manteniendo el tono académico en el análisis político y jurídico de la evolución reciente de la democracia nicaragüense y sus cambios constitucionales, junto a una orientación crítica, que diferencia el modelo de "pacto" como estrategia política, que precede a cada proceso constitucional desde 2000 hasta el momento actual.
} 
democrática, de solución de los problemas económicos y sociales del pueblo, de creación de condiciones para apuntalar el desarrollo económico de Nicaragua, etc., han sido arreglos de élites, han sido componendas de cúpulas, que tratan sobre todo de garantizar la continuidad de un estatus quo, de un establishment, que no ha resuelto los problemas de la gente ni los problemas de la democracia, cuando te decía que te iba a comentar un asterisco sobre las reformas del 95 me refiero a que, lamentablemente, introdujeron una técnica que luego se siguió usando, y que se ha seguido usando en Nicaragua, y es que, en un sentido menos político que jurídico, es decir, en un sentido estrictamente jurídico, desde mi punto de vista, fueron unas reformas inconstitucionales, en el sentido, en un doble sentido, en el sentido de que se modificaron aspectos que solamente podían modificarse a través de una Asamblea Constituyente, pero que, sin embargo, se hizo a través de una reforma parcial, como vos debés saber, Raquel, en Nicaragua existen dos tipos, dos mecanismos, dos procedimientos de reforma constitucional, la total y la parcial, entonces, la total tiene un procedimiento que implica, en uno de esos momentos, convocar elecciones a la Asamblea Constituyente, en cambio la parcial la hace la misma Asamblea Nacional con un procedimiento, por supuesto, más gravoso, que implica entre otras cosas dos legislaturas, la aprobación en dos legislaturas, legislatura en Nicaragua es un período anual de sesiones ordinarias de una Asamblea Nacional, no como en España que, si no recuerdo mal, una legislatura es todo el mandato legislativo, digamos, bueno, dos años legislativos, pero como no tenían los votos necesarios y además no se querían arriesgar a unas elecciones, entonces, aprobaron como reforma parcial lo que fue, en realidad, una reforma total, y también produjo una grave crisis política entre el Ejecutivo, presidido por Doña Violeta de Chamorro, y con su yerno, Antonio Lacayo, como su principal asesor, Ministro de la Presidencia fue y toda la cosa, fue el candidato presidencial para las siguientes elecciones, y, digamos, el resto del espectro partidario, este conflicto llegó a que unos aceptaban las reformas constitucionales, otros no, Doña Violeta, básicamente, sobre todo porque le impedían a Antonio Lacayo ser candidato presidencial, entonces, para salvar esta situación, para resolver esa crisis profunda, se dictó una Ley Marco, así se les llama en Nicaragua, a partir de ese momento se le llamó Ley Marco a aquella ley que difería la entrada en vigencia de la Constitución, entonces, llegaron a ese acuerdo porque ellos, "vamos a aceptar estas reformas constitucionales", dice el gobierno en ese momento, "pero no van a entrar en vigencia en este momento, van a entrar en vigencia con el nuevo gobierno", es decir, que un acuerdo político se juridificó a través de una ley llamada, como te digo, Ley Marco, y ¿qué significaba eso?, que una norma de inferior jerarquía, según la clásica pirámide kelseniana, condicionaba la vigencia de la norma suprema, eso es un contrasentido, como bien puede verse a lo lejos, pero que en Nicaragua bastó y que siguió funcionando como precedente, hace poco tuvimos otra Ley Marco, luego leyes marquito, bueno, tenemos aquí, ya te vas a ir dando cuenta, una fauna de leyes y de tipologías normativas impresionante todas ellas, cada una de ellas más cuestionable y criticable que la otra, pero bueno, aparte de estas cosas que no son menores si vos querés, en términos políticos ni jurídicos, en términos generales, en términos de los contenidos materiales, que introdujo la reforma constitucional debemos de constatar nada más que los enormes poderes del Ejecutivo se redujeron, por ejemplo, la potestad de legislar, en cada receso de la Asamblea Nacional legislaba el presidente de la República, la Constitución decía que se le iba a delegar, pero se interpretó como que la delegación era automática, entonces, en cada receso el presidente legislaba, el presidente dictaba normas con fuerza de ley en materia tributaria, en materia administrativa, sin controles previos ni posteriores, ni parlamentarios, es decir, no era necesario una habilitación de la Asamblea ni era necesario luego someter las leyes por 
delegación dictadas por el presidente de la República a la Asamblea para que éstas fueran validadas, digamos, y tuvieran carta de naturaleza normal, por ejemplo, el presidente dictaba el Estado de emergencia y aprobaba durante el período de emergencia el presupuesto general de la república, y varias otras cosas, yo ahorita sólo te estoy dando ejemplos de poderes normativos, de las potestades normativas que el presidente tenía, pero tenía una enorme influencia institucional en distintos ámbitos materiales e institucionales, esto en el 95, como te decía, en la reforma del 95 esto fue racionalizado, se le disminuyeron un poco estas potestades, se revalorizó, digamos, se recompuso la función o el rol de la Asamblea Nacional, se fortaleció de alguna manera la función institucional, se organizaron salas, se creó la Sala de lo ContenciosoAdministrativo, que no funcionaba, bueno, sigue sin funcionar bien, pero la Constitución lo creó, se intentó nacionalizar y profesionalizar lo que se llamaban las Fuerzas Armadas, el Ejército, la Policía, se establecieron algunos mecanismos que tendían a proteger los Derechos Humanos de manera vinculante, por ejemplo, la Procuraduría para la atención de los Derechos Humanos, algo muy parecido al Ombudsman, yo creo, el Defensor del Pueblo, algo parecido a eso, pero también en materia de derechos se logró delimitar mejor, configurar mejor algunos derechos de propiedad, sobre todo, a mí me parece que no estaba muy bien configurado, pues, perfilado, por ejemplo, el derecho de propiedad, algunos principios fundamentales se desideologizó un poco con un sesgo bastante acusado de lucha de clase, de un Estado a favor de las clases más pobres, etc., al margen de que podás estar de acuerdo o no en ello, quiero decir que se intentó, pues, en general, llegar a una Constitución más clásica de tipo liberal más tradicional, y que yo creo que sentó las bases para una transición política ya juridificada, es decir, la transición política empieza desde el 90 con muchas complicaciones en las calles, en las asonadas, en las negociaciones, los protocolos de transición, las organizaciones de base sandinistas muy activas, muy beligerantes para presionar, condicionar las políticas públicas de manera directa, etc., etc., pero que, bueno, se logró ir sorteando, tal vez, haciéndose concesiones, algunas veces más de la cuenta, tal vez otras veces menos criticadas, pero al final de cuentas del 90 hasta el 95 es que se dan estas reformas y que se dan con una cierta lógica de partido pequeño, es decir, que una escisión de lo que fue la UNO y una escisión de lo que era el FSLN dominada, básicamente, por los socialcristianos y por lo que después fue el MRS, en ese momento Sergio Ramírez, Dora Téllez y una buena cantidad de diputados, son los que marcaron los ejes principales de las reformas y como partidos pequeños, entonces, hicieron cambios en las circunscripciones electorales, en los umbrales electorales para acceder a ser presidentes, pues, los requisitos para ser candidatos a presidente, pensando que iban a pasar como bisagras y que aunque no fueran partidos grandes iban a funcionar, de cierto modo, como el Partido Liberal alemán o algún partido que siendo pequeño terminan decidiendo, terminan abriendo o cerrando puertas en relación a sus razones políticas, te cuento esto porque al final tuvo una regresión, lamentablemente, nefasta, muy regresiva, muy conservadora, pero que fueron los partidos mayoritarios los que volvieron con sus fueros y cerraron el grifo, tratando, entonces, de, siguiendo una cierta lógica pendular, hace un momento estaba un partido dominante, el FSLN, luego con la reforma del 95 se pretende darle un espacio importante así como tipo bisagra a los partidos pequeños, luego en el 2000, con las reformas del año 2000, que es la institucionalización del pacto, que, prácticamente, se induce a volver al sistema bipartito excluyente de dudoso carácter democrático, pero, en fin, se mantiene, pues, en términos formales, por lo menos, el principio del pluralismo político, pero en el año 2000 hay una reforma electoral, una reforma constitucional, en donde como te decía, se da también creo, en este momento, un incremento cuantitativo de los órganos de los supremos 
poderes del Estado, y otros órganos de relevancia constitucional, a fin de que el FSLN y el PLC puedan manejar paritariamente estos órganos, y a través de estos órganos o poderes, pues, controlar la vida política e institucional del país hasta niveles bastante, bastante perniciosos para un Estado democrático excluyente y que ha terminado siendo un sistema basado en el prebendarismo, el clientelismo, la corrupción, el funcionamiento de los poderes sobre todo por criterios de oportunidad política, o de orientación de los intereses políticos-partidarios, esto, incluso, para algunos ha llegado a decir, ya ni siquiera políticos o partidarios sino personales de los grupos dominantes en cada uno de los partidos, léase, de Ortega y de Alemán, por tanto, los Magistrados del Consejo Supremo Electoral, los Magistrados de la Corte Suprema de Justicia, los contralores del Consejo General de la República, el Ministerio Público, etc., obedecen, obedecen así, literalmente, aunque se escucha muy fuerte y sin tapujos, además no se ruborizan mucho ni es que lo pretendan como disimular y hacer elaboraciones, elucubraciones históricas, no, no, no, sin mayores problemas, sin mayores incomodidades, públicamente, en programas de televisión, queda claro que la función que juegan en las instituciones que integran, y las instituciones en el sistema político es un la legitimación de un sistema político francamente excluyente y que cada vez puede estarse saliendo de la mano para los mismos que han diseñado este modelo, en la medida en que no han garantizado ni mucho menos, no se ha visto que la gobernabilidad, la estabilidad y el consenso y la paz y el desarrollo eso no se ve, lo quiera o no aceptar, y ha llegado al extremo en los últimos años de un fraude electoral municipal, eso significa que el sistema no está funcionando, y no está creando mayores consensos, que no está resolviendo los problemas, que no está dando mayor gobernabilidad democrática sino todo lo contrario, y que si tenés que salir a garrotear a un grupo por muy pequeño que sea, pequeño, mediano o grande de individuos que protestan por un fraude, entonces, tenés que exponer a otros ciudadanos para que no los dejen salir, entonces, eso te dice que si, en algún momento, para darles el margen de la duda, pensaron que este modelo bipartito inducido, porque el problema no es el bipartidismo, si un bipartidismo funciona porque la tradición de un país, de un pueblo, y porque unos partidos son mucho más fuertes que otros pero que no se trata de meterles zancadillas, groseras y burdas, a otras expresiones legítimas de la sociedad que tienen derecho a expresarse partidariamente, como es el caso nuestro, entonces, este bipartidismo no ha producido, como te decía, gobernabilidad, en el 2005, este pacto, este pacto tiene también sus referentes, o debe leerse en clave política, histórica, para entender mejor la normatividad, Alemán era un tipo muy cuestionado por sus malos manejos de los fondos públicos desde que era alcalde, desde que era alcalde algunos concejales en ese momento lo denunciaron y lo acusaron de ladrón, de ladrón para decirlo con todas sus letras y de malversación pública, etc., y por su parte Ortega tenía el tema de la hija, de la hijastra, pues, de la hija de su señora Murillo, de la señora Rosario Murillo, entonces, los dos tenían, por un lado, casos eventualmente pendientes en la justicia, que podía tener su proyección nacional o incluso internacional, pero a la vez la tradición caudillesca nicaragüense, la poca tradición democrática, la poca, más bien la precariedad de la institucionalidad democrática a partir de una guerra o de una dictadura militar que terminó de existir hasta el 79, porque además la historia está llena de eso, de dictaduras, de golpes de Estado, de revoluciones, de contrarrevoluciones, que no ha habido nunca en nuestra historia, tal vez, salvo los treinta años conservadores, así se llama el período, los treinta años conservadores, seguramente has oído hablar de él, que tal vez hubo una suerte de estabilidad política, en muy pocos períodos de la historia que no han podido los nicaragüenses gozar del privilegio, casi, para nosotros, quizá no para otros lugares del derecho común y corriente, pues, de confiar en la justicia, de 
confiar en el que cuenta los votos, de confiar en los órganos a los que los ciudadanos acuden a resolver sus conflictos, a procesar sus demandas, aquí no lo hemos tenido, y, por lo tanto, también la poca o ninguna democratización interna de los partidos, la falta de legislación adecuada, además, como te digo de los problemas personales de los líderes que presentaban, y además de como una reacción a la reforma del 95, que había sido más bien hecha desde una visión de partidos pequeños un poco más modernos, un poco más, no importa si de derechas o de izquierdas, pero más progresistas y con más claridad de lo que es una andadura hacia un modelo democrático, entonces, éstos en el 2000 vinieron y se repartieron, ves aquí no hay historias de pluralismo real, va a seguir habiendo partidos comparsas o partiditos que los vamos a hacer satélites, los compramos, porque hoy en Nicaragua es muy fácil comprar partidos y diputados, etc.,, y nosotros dos vamos a encargarnos de esto, ubicá a Ortega como oposición en ese momento, no lo ubiqués como poder, probablemente, si hubiera estado en el poder eso no hubiera existido nunca, porque el talante autoritario de Ortega es si cabe mayor que el de Alemán, pero el talante corrupto y, digamos, insensible, de lo que su supuesta ideología, los principios de su supuesta ideología lo llamaría a actuar también, en el caso de Alemán, no lo hubiera permitido nunca, si el presidente hubiese sido Ortega, entonces, eso es el 2000, el gobierno de Alemán, los dos se garantizaron un poco, Alemán tranquilidad en su gobierno, sin que haya asonadas, ni movimientos en la calle, ni todos los organismos de masas del Frente haciendo ingobernable el asunto como un momento que tuvo que lidiar Doña Violeta, y, por otro lado, Ortega iba a permitir recomponer su base, porque, en realidad, después de la derrota electoral el Frente queda muy golpeado, empieza a verse problemas internos que termina en la división del MRS y otras cosas, a Ortega le permite dedicarse a recomponer este asunto, en un entendimiento, digamos, si no estratégico a largo plazo sí, por lo menos, a mediano plazo, pues, tiene una visión, pero cuando llega el presidente Bolaños al poder, el presidente Bolaños, vice-presidente de Arnoldo Alemán, gana con amplio margen de diferencia sobre Ortega y pretende recomponer la situación a través del mecanismo del pacto, Bolaños empieza a entenderse bien con Ortega, Ortega le presenta una oposición razonablemente aceptable, digamos, pero da un momento que coincide con un encuentro que tuvo con el Secretario de Estado, Collin Powell, que incluso le dio "right", yo creo, Collin Powell, cuando él estaba en Panamá, y se lo trajo para Nicaragua a su regreso para Estados Unidos y aunque, probablemente, de esas cosas no son tan conscientes uno en el momento, pues, debe haber habido todos unos antecedentes, el caso es que a partir de ahí se ubicó un cambio en la política de Enrique Bolaños, un poco se aleja del Frente Sandinista como oposición leal, digamos, como una oposición constructiva y leal a su gobierno y a su mandato, y de alguna manera, pero en este momento no estoy entrando a la racionalidad política de lo que hizo el presidente Bolaños, además ahí cada quien lo analizará a su manera, sino un poco más a los hechos, que después los podemos interpretar si vos querés, pero eso produjo que Alemán y Ortega se reencontraran y fortalecieran su pacto, entonces, Alemán ya está preso, Ortega ve que Bolaños no va a permitir mantener los controles institucionales que se han venido formando sobre todo en el Poder Judicial, se introducen iniciativas para la reforma de la estructura normativa, digamos, de la estructura judicial, y eso Ortega lo siente muy fuerte, porque es en el Poder Judicial donde él tiene su principal fuerza, entonces, no es que se había perdido, fijáte bien, no estoy diciendo, Raquel, que se había roto el pacto iniciado en el 2000, o en el 99, con los acuerdos políticos del 99 que se formalizan en la reforma constitucional del 2000, que se había roto, y que ese pacto ahora se había sustituido por un entendimiento normal, razonable, cívico, entre el gobierno de Bolaños y la oposición crítica, constructiva, de Ortega, no estoy diciendo 
eso, el pacto siempre se mantenía porque, al final de cuentas, la Asamblea fue dominada por el FSLN de Ortega y el PLC de Alemán, el presidente Bolaños casi a lo inmediato de haber llegado al poder perdió los apoyos parlamentarios necesarios para gobernar, su partido se declaró de oposición, se peleó con Alemán, papapá, todo ese rollo que vos lo conocés bien, y eso significa que los Magistrados que requieren voto cualificado en la Asamblea, que los fiscales, que las reformas constitucionales, que las decisiones políticas fundamentales que requieren más consenso, y aún aquellas que no requieren más consenso parlamentario sino la legislación ordinaria, las tomaban el Frente Sandinista y el PLC de Ortega y Alemán, respectivamente, como líderes de ambas fuerzas, lo que yo decía es que Alemán preso, Bolaños de presidente, Ortega haciendo una oposición relativamente constructiva, este cuadro se difumina al momento de que el presidente Bolaños se aleja de esa relación, de ese esquema, entonces, los otros sin haber perdido nunca, sin haber matado nunca el pacto, lo fortalecen, lo fortalecen y lo endurecen, y se expresa en las reformas constitucionales del 2005, las reformas constitucionales del 2005, que no son más que eso, pues, no son más que una profundización del pacto y obliga, por ejemplo, a que los ministros del presidente tengan que ser ratificados por la Asamblea Nacional, que la Asamblea Nacional puede destituir a los ministros del presidente, tratan de maniatar al presidente, efectivamente, es decir, te estoy dando dos cosas que tienen que ver con el ámbito del Ejecutivo, los nombramientos del Ejecutivo como todo sistema presidencial en Nicaragua ha sido al libre arbitrio del presidente de la República, a partir del 2005 se introdujo que tenía que ser ratificado por la Asamblea Nacional, y, claro, la Asamblea Nacional la manejan Ortega y Alemán, hubo otra crisis institucional como la que hubo para la reforma del 95, donde a Doña Violeta le reformaron la Constitución lo que fue el MRS y la escisión de la UNO, que formaban los socialcristianos y que tuvo que dar una Ley Marco porque había dos constituciones vigentes, etc., otra vez ocurre eso en el 2005, el presidente Bolaños no aceptó las reformas constitucionales de Ortega y de Alemán, se llamó a la Corte, a la OEA, la Corte Centroamérica de Justicia dio su fallo, contrario con el fallo que dio la Corte Suprema nicaragüense, en fin, otra Ley Marco, una Ley Marco que se aceptaba, pero que no se iban a aplicar para el gobierno del presidente Bolaños, sino que se iban a aplicar para empezar a aplicar con el nuevo gobierno que surgiera de las elecciones de 2006 y en 2007 tomara el nuevo gobierno, entonces, si te fijas estas últimas reformas tampoco responden a una visión estratégica, sino que responden, a una visión estratégica sobre una propuesta nacional de desarrollo, de un marco de desarrollo de un país, discutida, consensuada con todos los actores, no, no es eso, son dos élites, dos grupos que controlan las instituciones del país, ¿por qué también?, porque los votos se cuentan no como lo aprendiste en la aritmética Galdós, sino porque se cuentan a la manera de los Magistrados que son puestos por Daniel Ortega y Arnoldo Alemán, también así, que hoy por hoy, yo lo he oído muchas veces, no se ha dado la totalidad, no se ha publicado por el Consejo Electoral la totalidad de los votos que hubo en las elecciones de 2006 en las que ganó Ortega, y en todas las elecciones siempre se negocia un diputado aquí, un diputado allá para que no haya mayoría, para que el Frente no pudiera perder la capacidad de veto de unas reformas constitucionales, o de un nombramiento de los que requieren mayoría calificada, normalmente, se queda con dos o tres diputados más de los que un escrutinio estricto del sufragio hubiera arrojado, eso lo hace con visto bueno de Alemán, Alemán le tiene un odio personal a Bolaños, bueno, probablemente razonable, y es humano, que ve que la persona que lo lleva allí, por las razones que fuese, contribuye para andar en la cárcel, entonces, Alemán y Ortega profundizan su alianza, su pacto, que no tiene el mismo sentido que cuando lo juntás con la palabra "Moncloa", en Nicaragua el pacto es, obviamente, no sólo el acuerdo 
político, que es lo normal que se ve en las fuerzas políticas y entre fuerzas parlamentarias, los pactos, entiendo yo, en un parlamento, o en un sistema político en general, negociando, acordando, cediendo y pactando, a final de cuentas, en Nicaragua vos sabés bien que la palabra "pacto" tiene un sentido muy peyorativo, sobre todo, si no recuerdo mal a raíz de lo se llamó el "Pacto del Espino Negro", ¿ya lo has oído hablar?, bueno, el Pacto del Espino Negro se dio en la época de la lucha de Sandino, entonces, se supone que, en ese momento hubo, los actores políticos nacionales de ese momento se reunieron ante las tropas del imperio norteamericano, en ese momento, y, entonces, fue una día de traición, pero que, en ese momento, también Sandino dijo: "bueno, yo no me rindo y la soberanía de un pueblo se defiende con las armas en la mano", entonces, el espino negro lo firmaron, llegaron a ese acuerdo bajo un árbol, un espino, entonces, pacto, el Pacto del Espino Negro, implica el acuerdo político en donde los criterios que lo impulsan y que diseña su contenido no son criterios de interés nacional, ni mucho menos, sino elitistas, excluyentes, todo lo que te podás imaginar, prebendario, en algunos casos hasta de corrupción se puede hablar, entonces, así sucesivamente Nicaragua se funcionó a través de las "paralelas históricas", las "paralelas históricas" se les llamaba al sistema de partidos compuesto por dos partidos, los liberales y los conservadores, entonces, los liberales y los conservadores excluyeron a todos los demás partidos, los conservadores se aseguraron una parte del pastel, una tajada del pastel institucionalmente establecido, acordado con los liberales, en la dictadura somocista de cuarenta y pico de años dejaba que los conservadores fueran un tercio de los poderes del Estado, el 40\% de la Asamblea Nacional, del Congreso, cosas por el estilo, pues, entonces, cada vez que había una crisis social o una crisis política los líderes conservadores y los líderes somocistas se ponían de acuerdo, reformaban la Constitución para tal vez poder permitirle a alguien la elección que quizá la tenía para ese momento para poder apaciguar las críticas y las demandas sociales, entonces, el pueblo dice, ah, ves, eso es un pacto, el Pacto del Espino Negro, el Pacto de Somoza con Cuadra Pasos, el pacto Agüero-Somoza, que es otro líder conservador importante, el llamado Pacto Kupia-Kumi, entonces, el pacto en Nicaragua no es un acuerdo político, verdad, para tratar de resolver problemas nacionales, sino que es el acuerdo político que se da entre dos élites muy excluyentes para satisfacer sus necesidades, sus intereses más inmediatos y espurios, pues, la verdad es que a eso me refiero cuando hablo de pacto, pues, yo y los nicaragüenses, en general, si fuera no se entendería por qué el pacto se critica si lo normal es eso, ¿no?, pero íbamos entonces que Alemán y Ortega vieron en el 2005 ya la necesidad de profundizar su pacto, maniatar al presidente Bolaños, y retomar ellos dos una vez que terminara la pesadilla, entre comillas, del gobierno del ingeniero Bolaños, pues, recomponer la situación de acuerdo al diseño originalmente previsto en las reformas del 2000, de un sistema bipartito, básicamente, con dos o tres partidos de membrete o satélites, que le hacen el juego, como ahorita se ve, o podés ver, en las últimas elecciones el partido "Alternativa por el cambio" participó en las elecciones municipales, sencillamente, para que sus miembros formaran parte de las mesas electorales, de las juntas electorales, de los consejos electorales, fiscales, y eran miembros todos del Frente Sandinista, ¿ya?, pero es un partido que perdió la personalidad jurídica, porque la ley dice que si no tenés el $4 \%$ de votos en las elecciones generales vos perdés la personalidad jurídica, no obtuvieron ni el 1\%, pero no le quitan la personalidad jurídica porque juega un papel importante para integrar los organismos electorales y quitarle ese espacio a los otros partidos que sí la han de tener, el Partido Conservador y el partido MRS no tienen por qué haber perdido la personalidad jurídica, pero se la quitan, ¿ para qué?, para lo que te estoy diciendo, y eso lo hacen los dos partidos, el PLC y el Frente Sandinista, no sólo lo hacen los 
sandinistas, lo hacen estos dos partidos, entonces, si vos me decís, contribución de los cambios constitucionales para la democratización de Nicaragua, yo te digo: ninguna, lamentablemente, en un análisis evolutivo, tal vez, la del 95, como te decía, con todos los cuestionamientos que se le pueden hacer desde el punto de vista del procedimiento que se siguió no constituyente, sino reforma parcial, y que tuvo esa famosa Ley Marco y que ha servido después para utilizarla de mecanismo para resolver problemas, porque es inconstitucional, es ilegal, eso no tiene racionalidad jurídica, las demás reflejan una clase política pobre, una clase política prebendaria, clientelar, que no tiene un proyecto de desarrollo nacional, que sí tiene mucha capacidad para llegar a acuerdos de la noche a la mañana, muy coyunturales, muy excluyentes, pero que no tiene capacidad para formar y construir consensos a largo plazo, pues eso es lo que vemos, una frivolidad, incluso, diríamos extraordinaria, una frivolidad política de decir, bueno, pues si no funciona la volvemos a cambiar, como los últimos, que te dicen, propongamos un sistema parlamentario para cualquier disparate que se les ocurra, porque eso va a eliminarnos un presidente fuerte, el caudillismo, qué se yo, han dicho que fortalece la democracia directa, pero eso es un verdadero disparate, en los sistemas presidenciales es tan democrático como cualquiera, y tan autoritario, sobre todo en América Latina han existido como en cualquiera y viceversa, no todos los sistemas parlamentarios han producido ejemplos de sistemas democráticos, si no recuerdo mal, hay sistemas semiparlamentarios, creo yo, con la figura del presidente y del primer ministro, no me creas mucho ese ejemplo, Hitler, pues, todo el mundo sabe que surgió de un sistema parlamentario, no produjo el parlamentarismo alemán de ese momento no logró evitar, fue elegido democráticamente, etc., entonces, la verdad es que cada pueblo, cada país tiene su tradición, sus necesidades, sus realidades, y muy seguramente los sistemas parlamentarios funcionan razonablemente bien allá donde existen las condiciones para que así suceda, y el sistema presidencial funciona o puede funcionar razonablemente bien allá donde existen las condiciones que lo permitan, siempre y cuando los actores políticos jueguen de buena fe, y estemos todos jugando las reglas de la democracia, porque un presidente que ni siquiera respeta la legalidad, y unos diputados serviles y sumisos que le hacen el juego al presidente, o que se hacen de la vista gorda de las ilegalidades, de los atropellos a la Constitución y a la ley, de los atropellos a la propia dignidad institucional del parlamento, y que me digan después que quieren ser parlamentarios eso lo veo absurdo, y si el presidente no respeta las competencias ni los límites, ni se somete a los controles políticos, parlamentarios o no, parlamentarios o de otro tipo, que un sistema presidencial establece como el nuestro, yo no veo la razón por la que cambiándonos a un sistema parlamentario, ahora se iba a cambiar al presidente y ahora se iba a hacer respetuoso de los límites de su poder y se va a someter a los controles, mecanismos, que garanticen efectivamente la introducción desde el poder político que hace la Constitución, la verdad es que no era más que una manera de disfrazar una de las posibles alternativas, o un escenario posible para que Ortega y Alemán mantuvieran el control de las instituciones, sea uno u otro, porque el esquema de ellos, efectivamente, es de compartir, se han dado cuenta de que no puede uno imponerse al otro, Alemán gobernó con el cincuenta y pico por ciento de votos, no Alemán, los liberales, y en el FSLN se dan cuenta de esto, entonces, ambos dicen: "hombre, no nos peleemos, pues, entendámonos, comprendámonos así, y busquemos cómo, comé y comamos". Sin embargo, el Frente tampoco está mucho, no es que esté convencido de que ese sea un enfoque permanente y sostenible de Estado, así es que va a ir hasta donde las circunstancias políticas lo detengan, ¿ya?, eso es un riesgo para Alemán, y para los liberales, porque ellos sí pudieran aceptar ese esquema como un sistema estable, pues, sostenible, un sistema permanente, ¿no?, como lo está 
demostrando con creces, yo creo que en términos generales y muy rápido eso te podría comentar sobre las reformas constitucionales, en general, ha habido otras reformas de relativa menor importancia, alguna de ellas va a hacer Ortega pronto, de este mes, porque se refiere a las exoneraciones de los medios de comunicación, a las exenciones fiscales de los medios de comunicación escritos sobre todo, entonces, hay un recurso de La Prensa, hay un recurso de amparo de inconstitucionalidad que metió el diario La Prensa en la Corte Suprema, que los Magistrados cada rato dicen que la van a sacar, que no, bueno, a ver, ahí hay una reforma constitucional en ese sentido, otra reforma en cuanto al procedimiento de ratificación de los tratados internacionales, que yo creo que ha perdido todo interés ahorita, en el sentido de que en el momento en que lo aprobaron venía el CAFTA, se estaba negociando el CAFTA, estaba el presidente Bolaños, entonces, una reforma como para quitarle un margen de maniobra política al presidente Bolaños y pasarlo un poco a la Asamblea, la Constitución decía que si en X período de tiempo la Asamblea no lo ratificaba se daba por aprobada, eso se eliminó como para que la Asamblea no estuviera ahí negociando y presionando, pero bueno, ya se aprobó el CAFTA, ya empezó otra etapa, también hubo otra reforma antes, que todavía tiene alguna importancia después para mejorar el procedimiento de reforma parcial.

$R$ : Eso sí es interesante, y te iba a preguntar, aunque ya lo has referido en parte, y lo decías al principio de tu intervención, el tema de la flexibilización del procedimiento mismo de reforma, no solamente porque en vez de hacer una reforma total a través de la creación de una Asamblea Constituyente, como debería haber ocurrido, ¿no?, y que el propio Luís Humberto Guzmán, que, en ese momento, presidía la Asamblea legislativa que arranca en el 90, por la propia situación delicada del país, o sea, no sé si es un argumento este de la reconciliación, de la paz, de lograr apuntalar una institucionalidad democrática todavía muy débil, y quizá la convocatoria de una Asamblea Constituyente para hacer una nueva Constitución frente a la del 87, que sostiene además el andamiaje institucional de la revolución, y los representantes de la revolución sandinista están sentados del otro lado de la mesa de reconciliación cuando se firman los acuerdos de paz, y en esas transacciones, imagino, que hay un intercambio de permanencias de las instituciones politicas a cambio también de la transición a un régimen liberal-democrático, que también venía acompañado de una serie de reformas estructurales a la economía, que daban un poco al traste con toda la filosofía, por decirlo de algún modo, el concepto de crecimiento económico que tenía el sandinismo en los años 80, más allá de la contextualización de esto en la Guerra Fría, de que Nicaragua fuera un país que sufrió mucho el bloqueo, es decir, que la revolución fue un experimento condicionado también por factores externos, ¿no?, y no solamente por la situación interna del país, pero sí se flexibiliza el procedimiento de revisión constitucional a través de mandar a publicar por parte del presidente de la Asamblea lo que el presidente del Ejecutivo se había negado, porque la propia Violeta Chamorro se negaba a aceptar la ley de reforma parcial de la Constitución, y eso es indicativo de una irregularidad, que luego permanece ahí, seguro que como jurista podrás aclararme esto mucho mejor que yo, que vengo de la Ciencia Política.

G.A.: No, pero yo suscribo plenamente y con facilidad lo que vos estás diciendo, lo que quiero recordar es el asunto de la firma, bueno, mirá, yo creo que quienes piensan eso lo hacen desde una posición sesgada, toman partido, a ver, no es lo malo, no critico que alguien tome partido, sino que son actores directamente involucrados, Luís Humberto es el que hizo eso, es decir, Luís Humberto justifica eso, a ojos cerrados justifica eso, entre otras cosas, porque él es el responsable, pues, él era el presidente de la Asamblea, 
entonces, él dice: "está bien, había que hacerlo", se flexibilizó un poco, yo creo que en el fondo eso es inaceptable e injustificable, desde mi punto de vista, por algunas razones, pues, tal vez no se me ocurren en este momento varias, pero sí algunas, mirá, en primer lugar, políticamente, Raquel, yo soy de los que creen que políticamente todo se puede justificar, en principio, en principio, incluso cosas muy difíciles de sostener desde los valores aceptados socialmente, incluso esas se pueden, un tipo muy talentoso, muy culto, muy leído y conocedor de muchas experiencias, también te puede dar una, si no una justificación, una explicación interesante de luchar y de debatir, entonces, tal vez eso tenga sus límites, pues, yo creo que todo lo demás es justificable o susceptible de justificación política, por eso para mí el Derecho no es una mera técnica jurídica, sino que es un acuerdo político de cómo se convive humanamente, es decir, si empezamos a decir, bueno, si no hacemos esto tal cosa, también Ortega lo puede decir, o también Alemán, o también Montealegre, o también yo o también vos, y entonces esto se hace un alboroto, a mí me parece claro que cuando se reforman los principios fundamentales que definen la esencia de un sistema político-jurídico, pasado o no por el tamiz del pueblo a través de unas elecciones constituyentes es un tema que está íntimamente conectado con un concepto elemental de democracia, yo no puedo, a ver si usted quiere cambiar esas reglas del juego no puede hacerlo usted ni cualquier iluminado, pues, $60 \mathrm{u}$ 80 diputados lo que sea, usted no lo puede hacer, entonces, si bien el Derecho constitucional de un Estado democrático no es puro procedimiento, no sólo es procedimiento ni mucho menos, en ese sentido, yo soy menos positivista y yo sí me creo, concuerdo con aquellos que piensan que el Estado democrático está integrado por principios y valores, pero los procedimientos no sólo son procedimientos, por supuesto, los procedimientos expresan o se construyen, precisamente, para buscar la mejor realización de determinados principios y valores, entonces, yo no justifico políticamente las reformas del 95 de la manera en que se hicieron, es un enfoque si querés muy rígido, te acepto que me lo critiqués, está bien, fijáte que te dije que tal vez las mejores reformas, desde un punto de vista global, que sí se puede encontrar una visión de racionalización, de democratización, de redimensionamiento, de un diseño institucional que tal vez dejaba al Poder Ejecutivo muy por encima de los demás, son las del 95, eso estoy de acuerdo, o sea, no es que esté en contra de todo lo que se hizo en el 95, creo que no se hizo de la mejor manera, y creo que, en el fondo, eso coincide con uno de los principales pecados y vicios de los latinoamericanos, que es matizar, relativizar, a conveniencia política, reglas claves y básicas de la convivencia democrática, para mí eso es muy peligroso, para mí son mayores los riesgos que los beneficios de ese pensamiento, ese pensamiento tiene más riesgos que beneficios, yo no puedo creer si la Constitución cuando hace un procedimiento sí está distribuyendo poder político, y ese poder político tiene, por lo tanto, un cauce, tiene unos límites, tiene unos controles, una sociedad post-bélica, de poca tradición democrática, de mucha fragilidad institucional, de pueblo no muy educado, ni informado, con unas tasas de analfabetismo muy fuertes, muy lesivas a la dignidad humana, ya ni siquiera hablo de informados a un cierto nivel, no, hablo del analfabetismo, entonces, los políticos se aprovechan de eso y vienen y estiran tanto la interpretación, las posibilidades de la interpretación jurídica que creo que la rompen, entonces, yo no pienso que el planteamiento y la visión que está implícita en eso le ayude a nuestros países a fortalecer una visión democrática, yo creo que, yo no lo veo como un prurito de jurista, en mi opinión, no lo veo como un jurista técnico-jurídico, lo veo como que tengo que aprender a respetar las reglas del juego, y que si hay un consenso en que no funcionan las cambiamos y actuamos conforme a las nuevas reglas del juego, pero que haya reglas del juego, que las incumplimos, las violamos, con un eufemismo de flexibilización, porque decir: "esto es flexible", eso se 
puede aceptar razonablemente, pero para mí no es más que un eufemismo que esconde lo que es una actitud de ruptura de las reglas del juego básicas de una sociedad, que la presidenta luego no la firmó, digamos, ya los mecanismos, efectivamente, no la firmó, y la firmó Luís Humberto en un diario común, pero eso ocurre mucho, eso piensan también, eso piensan aquellas personas que abiertamente no concuerdan con el sistema democrático, y también lo piensan personas que concordando, formalmente al menos, lo flexibilizan cada vez y cuando en sus análisis, cálculos, y sus interpretaciones políticas creen que hay que hacerlo, como la reelección de Chávez y Uribe, bueno, para mi gusto tan dañina es la una como la otra, Uribe le hace un daño a la región y a su país al pretender reelegirse tanto como lo hace Chávez, entonces, igual reformar la Constitución violentando los límites que la Constitución establece para su reforma y los procedimientos para hacerlo no es más que imponer una mayoría parlamentaria coyuntural y que está sometida a los vaivenes políticos naturales y normales de toda evolución política de cualquier país, entonces la impuso violentando y no se puede decir es que para la paz, la estabilidad, la gobernabilidad, y te puedo decir mil cosas para justificar, dis que para justificar, yo sin llegar a ser llegar a ser fundamentalista creo yo, sí me creo que el Estado de Derecho, entre otras cosas, ofrece las reglas y los mecanismos para buscar los consensos, y dentro de esas reglas y mecanismos y consensos, Sartori, bueno, vos sos especialista en esto, pero yo creo que es Sartori el que decía la democracia es la mayoría y el respeto de las minorías, pues esos procedimientos entre otras cosas están diseñados para respetar a las minorías, no puede existir el predominio de la mayoría, no es el predominio ilimitado y, para decirlo en términos más técnicos y usuales, no es la tiranía de las mayorías, la tiranía de las mayorías te lleva a ese planteamiento disfrazado de una retórica de flexibilidad y de pragmatismo político, no señor, eso se llama tiranía de las mayorías, si usted me reforma la Constitución a su manera y no como la Constitución lo dice lo que estás es imponiendo la tiranía de las mayorías, esa es mi opinión, si te contesté bien a lo que planteabas.

R: Sí, sí, además, a propósito de tu intervención de ahora, sí es cierto que se ha justificado, como decías antes, en términos de gobernabilidad democrática, muchas de las reformas constitucionales en este país, es más, incluso este planteamiento de darle mayor poder a la Asamblea y de semi-parlamentarización del régimen político viene justificado por el hecho de que no existen mecanismos en el sistema presidencial para garantizar un acuerdo entre el Ejecutivo y el Legislativo.

G.A.: Lo cual es falso, lo cual es falso, Raquel, si quieres lo podemos platicar, pero además ese fue el fundamento o el argumento para las reformas del 95, para las reformas del 2000, para las del 2005, para estos pretendidos intentos de ahora, en un país como este hablar de gobernabilidad democrática es muy sencillo, es muy fácil, porque, mira en los países pobres, con poca tradición democrática, con partidos políticos muy beligerantes, con cierta idea de vanguardia todavía, todavía no terminan de hallar su propia identidad, en el sentido de saber qué es lo que quieren, esa impresión me da a mí, proponen algo que es incompatible con lo que antes habían propuesto, o de que quieren ser democráticos, pero actúan también en otro modelo a veces, y con mucha capacidad de convocatoria para un electorado, que aunque no es mayoritario es muy respetuoso y activo, entonces, y sobre todo cuando ha vivido una guerra, en Nicaragua habría que hacer las cuentas, pues, pero en Nicaragua hace como dos y media guerras por siglo, yo creo que cada siglo, guerras nuestras, pues, no como ustedes, que se han peleado a veces con los alemanes, con los franceses y luego ustedes, pues, el 
franquismo y todo eso, pero aquí por razones más elementales, más básicas, por razones de ambición de poder personal, ¿ya?, no porque halla aquí izquierda y derecha, no es cierto hoy por hoy, el Frente Sandinista sí tuvo en un momento un planteamiento de ser la izquierda, la izquierda progresista, nació a la historia de Nicaragua con mucha nobleza política y humana, digamos, pues, incluso en los 80 yo creo que es parte de eso, aunque muchos no lo creen, yo creo que sí, hubo guerra, Guerra Fría, actores externos, errores internos, poca tolerancia, poca concepción, bueno, muchas cosas, pero ya hoy de eso poco o nada, igual la derecha, los que se llaman demócratas, los que se autodenominan demócratas, en Nicaragua demócrata es casi equivalente a no-sandinista o anti-sandinista, entonces en Nicaragua existen los sandinistas y los demócratas, estos demócratas tampoco, muy deficientes en su talante democrático tanto o igual que como los sandinistas o los que se llaman sandinistas, entonces, guerras, tiranicio, etc., vos hablás de paz y de gobernabilidad democrática, y es un concepto que suena bonito a los oídos, entonces, por la gobernabilidad democrática, papapá, vamos a hacer esta barbaridad, no haga esa barbaridad por la gobernabilidad democrática y condúzcase conforme a lo que dice un Estado democrático de Derecho y tal vez ojala más temprano que tarde vamos a llegar a esa gobernabilidad, en Nicaragua ni somos gobernables, claro, si vos comparás con lo que ocurrió en Honduras, ahorita, entonces, decís, ves, aquí no está tan mal esto, Guatemala es terrible la seguridad, pero yo creo que mal de terceros, ¿cómo es el dicho?

\section{R: Mal de muchos, consuelo de tontos.}

G.A.: Mal de muchos, consuelo de pendejos, entonces, aquí en Nicaragua, está bien ubicarte y tener referentes de tus vecinos, las políticas internacionales o el Derecho comparado, pero también tus propios referentes internos, tu nación, tus dolores, ¿no?, tus llantos, tus risas, tus anhelos, y yo creo que en Nicaragua ya hemos sufrido suficiente como para seguir comparándonos con guerras, o con dictaduras, o con golpes de Estado, ¿no?, pues, yo creo que, fíjate, yo creo que esto responde no sólo a condiciones objetivas, ya, de las que hemos hablado, sino también a visiones personales y subjetivas, yo creo que hasta inventos.

R: Una cuestión que también me interesa en lo que has mencionado, y que aparece también en otros entrevistados, es la referencia al consenso y al pacto, que son dos conceptos muy distintos para hacer una nueva Constitución, incluso para reformar la Constitución tiene que haber, en términos de legitimidad, un consenso de las élites políticas que participan y que representan al pueblo, pero también a la propia ciudadanía que contempla el marco constitucional en el que se desenvuelve la vida pública, esto no creo que haya pasado en Nicaragua salvo en el caso de la Constitución del 87, y tampoco, porque había una parte, que era la otra Nicaragua, en este caso, los liberales, los que se auto-denominaban demócratas, porque entendian que el proyecto sandinista era un proyecto excluyente, $y$, de hecho, la propia Constitución del 87 tuvo sus propias sanciones y su intentos reformistas, prácticamente, recién aprobada, ¿no? El pacto ha sido el que ha permitido que los líderes no solamente favorezcan la tarea de gobierno, que tiene su urgencia, ¿no?, la de gobernar un país, sino también de sacar adelante reformas que carecian de consenso. ¿Cuál es tu visión?

G.A.: Yo creo, yo creo que eso si me lo aprendo lo repetiría igual que tú, sí, tal vez, no en todos los casos, porque en la Constitución del 87 no hubo pacto, es decir, ha habido pactos en la acepción que te comenté en distintos momentos de la historia, en el 87 hubo 
un partido hegemónico, un partido dominante, ¿verdad?, no tuvo la necesidad de pactar, en el entendido, otra vez, de que el pacto es entre un par de fuerzas o élites, en donde más o menos se distribuye lo que tiene que distribuirse en términos paritarios, en el 87 había un partido político dominante, hegemónico, no te voy a decir como el PRI, no sé, pues, el partido del Congreso, no quiero, a uno se le vienen automáticamente a la cabeza referentes, quiero decirlo como el Frente Sandinista, que fue el que encabezó el derrocamiento de la dictadura somocista, tenía mucho prestigio político, por su valor, por su heroísmo, por lo desgastadas que estaban las élites de derecha, que le hacían la comparsa y el juego a Somoza, pero, claro, en el 87 ya aquí hay una crisis importante, hay una guerra civil, cuando yo te digo esto me refiero, cuando yo te digo este prestigio y este heroísmo te hablo de más cercano, más buscando el 79 que el 87, pero en el parlamento, la Asamblea Nacional, producto de las elecciones del 84, es prácticamente un $60 \%$, no te lo puedo decir en este momento exacto cuál es la composición, pero el Frente Sandinista es una amplísima mayoría, que tal vez no me equivoco si te digo que era capaz de reformar él solo la Constitución, la reforma parcial, pues, el $60 \%$, es posible, y si no lo lograba quedaba a un pelito, por lo tanto, no necesitaba pactar, pactar, repito, en el sentido nicaragüense, pero sí integraba, tomaba en cuenta, no es que se impuso y pasó como una aplanadora contra los otros siete u ocho partidos de los que había dos o tres diputados, o un diputado, creo que el que más tenía era el Partido Conservador, el Partido Conservador tenía nueve diputados, digamos, esa era la segunda fuerza política, nueve diputados de una Asamblea de 90 diputados, imagínate, por lo tanto, la diferencia, en Nicaragua se pacta cuando el gobernante o dos fuerzas, pues, el gobernante y la oposición más importante está en una crisis importante, digamos, o relativamente, y que entonces tienen que rehacer una ingeniería, renovar los acuerdos, plasmarlos, distribuir los planes, etc., entonces, yo creo que, en algunos momentos, sobre todo en el 79, o en la Constitución del 87 fue una Constitución del modelo o la visión que el Frente Sandinista tiene, no está tranzando con nadie, no está negociando con nadie, tiene unos reales políticos, sí, hay debate parlamentario, hay varios partidos, hay una disposición o precepto constitucional, se gobierna y se incluyen y se aprueban, muchos artículos fueron aprobados, probablemente, con, no sólo con los votos sandinistas, que ya hubiese sido suficiente para aprobarlo, sino con la mayoría de los votos, eso sí es, pero en los momentos en que ha habido pactos, en los momentos, porque tampoco con Somoza, a ver, Somoza, la del 74 sí hubo, fue el resultado de un pacto, pero tal vez, la del 50 también, la verdad es que muchas veces ha habido pactos previos a las constituciones, OK, en cualquier caso, la del 87 es discutible, no digamos que no era un pacto, pero es un poco discutible, pero sobre todo porque había una guerra civil que, Raquel, hay una mitad de Nicaragua que no está de acuerdo con lo que está ocurriendo, y hay otra mitad, bueno hay una parte importante de nicaragüenses que están en armas, enfrentados a un gobierno que ha cerrado el paso, y dentro de los que están en el gobierno y participan de la institucionalidad formal, digamos, del estatus quo, hay un amplio predominio de uno de los partidos, yo no estoy muy seguro si en ese contexto pueda funcionar la palabra pacto, yo creo que tal vez no, en todos los otros contextos sí, hay un par de fuerzas, a una se le dice "zancuda", normalmente, ¿ya has oído eso, ¿no?, la otra gobierno o mayoría, pero que, en todo caso, lo dijiste de una manera genial y sencilla: los pactos han sustituido los consensos, verdad, no hemos tenido en la historia de Nicaragua, creo yo, una Constitución que sea el producto de un consenso social, cuando digo consenso, lo aplico no sólo al consenso de los actores políticos, es decir, que las distintas maneras de expresión, de organización, los canales institucionales, formales o no tan formales, en donde sepamos los nicaragüenses que se está aprobando y luego se aprobó una Constitución que en la cual estamos más o menos 
de acuerdo una gran mayoría, que se plasma, se consagra formalmente en sede parlamentaria, eso no ha existido, y yo casi me atrevería a decir que nunca, y sí ha sido sustituido por pactos de élites, que no piensan más que en sus bolsillos, es decir, o en el poder político.

R: Pero el socio perdedor del pacto Ortega-Alemán yo creo que ha sido Alemán, porque su libertad le convierte en un reo de Ortega.

G.A.: Sin lugar a dudas, sin lugar a dudas.

R: De esos sandinistas que además controlan el Poder Judicial. Piensas que el Frente, y esta es una hipótesis que habría que madurar mucho, a través del aprendizaje que ha tenido desde el régimen anterior, desde el régimen sandinista, que se conforma como un Partido-Estado, y tiene un rol en las instituciones, ha sabido desde la oposición, que son 16 años, que es un tiempo largo, ir penetrando en las instituciones hasta llegar a la Presidencia de la República, que, es verdad, que es producto de un pacto, ¿no?, de rebajar el techo electoral necesario para ganar en primera vuelta, pero sí es cierto que, bueno, te comentaba el primer día la hipótesis de estos politólogos norteamericanos, de Shugart y Mainwaring, cuando dicen que el presidente de la República tiene poderes partidarios y poderes constitucionales. Las atribuciones constitucionales se han ido reduciendo en aras de un mayor peso de la Asamblea, pero los poderes partidarios del presidente si diferencian, claramente, la actitud de Violeta Chamorro o de Enrique Bolaños, que fueron presidentes débiles, en el sentido de que no tuvieron el apoyo en la arena parlamentaria de sus respectivos partidos, y, sin embargo, Ortega y Alemán son hombres fuertes de sus partidos, ¿no?, y tienen, en ese sentido, una ascendencia sobre las instituciones ya conforme a ese reparto paritario del control que les hace todavía más fuertes, a pesar de que son Ejecutivos presidenciales, que, constitucionalmente, están debilitados, es decir, que no tienen esa tendencia presidencialista que consolidaba la Constitución del 87.

G.A.: ¿Te referías a Alemán en su momento de presidente o actualmente también?

R: Actualmente, creo que sigue manteniendo un importante control del PLC pero Alemán parte de algo difícil, seguir en la carrera política activa, y, sin embargo, Ortega está ahí, planeando su reelección.

G.A.: Otra vez, otra vez, creo no es difícil concordar con tu opinión y compartirla, son hombres fuertes en el sentido más duro del término, más clásico, son líderes indiscutidos e indiscutibles de sus partidos, nadie osa hacerles frente, y al que se atreva, al que tenga la osadía de hacerlo, es prácticamente defenestrado políticamente, ha ocurrido con varios de ellos, algunos muy importantes en sus momentos respectivos, esencialmente, no lo pueden confrontar y menos aún cuando están en la Presidencia, es decir, Ortega es, prácticamente, un soberano, Ortega en Nicaragua hace lo que le da la gana y punto, no hay, los límites que tenga Ortega se deben a su buen juicio, si no tal vez, y lo digo en su beneficio, si fuera un desquiciado integral y total, estuviéramos bastante peor, porque no existen los mecanismos institucionales formales, informales, partidarios, sociales, en la desarticulación de la sociedad civil, no hay la cohesión de un liderazgo, no hay una oposición parlamentaria o no parlamentaria, Ortega hace lo que hace porque su buen juicio, porque su instinto, porque su experiencia, porque sus 
sueños atormentados, por lo que fuese, no se detiene ni ante la ley, porque lo controla todo.

\section{R: ¿Pero él lo hace todo de forma legal?}

G.A.: No, por supuesto que no lo ha hecho todo de forma legal, algunas veces lo hace de forma claramente ilegal, absolutamente ilegal, pero no hay un partido que lo denuncie, ni políticamente siquiera, no siempre, pues, por ejemplo, la ratificación de los ministros eso no es legal, incluso es abierta y claramente inconstitucional, pero no le da la gana de hacerlo y cuando le dé la gana los va a mandar a la Asamblea y los va a mandar a la Asamblea cuando ya sepa que Alemán le va a dar los votos para ratificarlos, si Alemán no le garantiza eso no los manda y punto, no pasa nada, no va a pasar nada, la ayuda de Venezuela no la mete al presupuesto y eso no es legal, eso no es legal, eso es ilegal, pero no pasa nada tampoco, que su esposa sea funcionaria de gobierno eso es ilegal, y no pasa nada.

R: Y los CPC, incluso, como estructura paralela del Poder Ejecutivo, materialmente hablando, porque formalmente ya la Corte tomó esa decisión salomónica para decir que no recibía presupuesto público.

G.A.: Además una decisión aberrante, una sentencia sin fundamento jurídico, ya, una opinión política que le pusieron forma de sentencia como la de ayer, tres Magistrados que firman porque los otros no hacen quórum, lo del Cartel de Sinaloa, bueno, lo que te quiero decir es que si tu posición, si tu hipótesis o tu enunciado es que Ortega hace lo que hace legalmente porque es presidente no es así, algunas cosas las hace legalmente y otras las hace ilegalmente de acuerdo a lo que quiera hacer, a lo él estima que vale la pena o no hacer, los CPC son legales, son estructuras, nacieron ilegalmente, pero luego se acotaron, y hubo críticas, y aprobaron unas reformas a la Ley 290 que creó la posibilidad de que el presidente creara estos consejos por medio de decretos, luego funcionan de manera ilegal, porque la ley que los creó dice que son instancias de participación, de coordinación interinstitucional, y que no deben ejercer desde ningún punto de vista facultades administrativas que correspondan a otras instituciones, pero la verdad es que lo hacen, lo hacen y se ponen por encima, incluso, de las distintas instancias, por decir algo, un ejemplo, por otro lado, son instituciones adscritas al ámbito del Ejecutivo, lo regula la ley que regula el Poder Ejecutivo, les gusta mucho el ámbito municipal, violentando la ley que regula los municipios, hay muchas ilegalidades de los CPC en su funcionamiento real, pero sí se les dio una base jurídica, porque los había creado el presidente por decreto en contra de lo que la ley del Ejecutivo decía, entonces, dictaron el decreto, se vio que era ilegal, entonces, luego reformaron la ley para darle sostenibilidad jurídica, en fin, no es cierto que lo que hace el presidente es legal. ¿Por qué razón?, sólo ellos lo saben, porque todo lo que han hecho lo podrían hacer legalmente, hace poco vinieron aquí unos buques rusos, unas cosas, bueno, lo hicieron ilegalmente, ¿por qué?, no se sabe, al principio, casi un año entero, los decretos del presidente no se refrendaban, ¿por qué razón?, por tonterías, porque si el presidente le dice a un ministro: "refréndame esto", y se lo refrenda, el refrendo de los decretos del Presidente, pero además de eso, además de eso, el presidente tiene una enorme incidencia e influencia, maneja una cantidad impresionante de mecanismos de poder fáctico para usar, o sea, los factores reales de poder, los que no están en los ministerios, también los maneja, y además maneja una cantidad impresionante de dinero sin control, ni sujeto a control de nadie, todo eso dependerá del 
estado de ánimo del presidente, si hoy gobierna sujeto a la ley o contra la ley, o al margen de la ley, o lo que sea, el presidente Ortega, y eso puede sonar muy fuerte, y, de hecho, suena, pero te estaba dando ejemplos que lo podés constatar, ha dicho públicamente hasta a los jueces, a la Policía ha dicho: "no acate resoluciones judiciales en tal y tal sentido", eso no solo es ilegal al país, hay muchas cosas que podría, pues, aparecer alguna figura delictiva, obviamente, eso lo verá el Ministerio Público y el juez, pero desde un punto de vista técnico se puede aceptar indicios de actuaciones del presidente ilegales y, eventualmente, delictivas, Alemán, como vos dices, mantiene mucho poder, mucha influencia, pero incomparablemente menor que la de Ortega, sin lugar a dudas, e, incluso, incomparablemente menor a la de él mismo hace unos años, ya tiene una escisión importante, Montealegre tiene la mitad del liberalismo, la fuerza de Alemán ahorita es Daniel Ortega, el principal factor que le permite a Alemán ser un interlocutor y un actor importante en política en Nicaragua es Ortega, y cuando Ortega le quite su apoyo se acabó Alemán, ¿por qué?, porque la fuerza de Alemán son sus 8 Magistrados de la Corte, sus 5 Magistrados del Consejo, bueno, la mitad de contralores, la mitad de Magistrados, la mitad de esto y sus diputados, ahí es donde Ortega tiene que negociar con él para sacar estas sentencias de manera camuflada o no para dictar sentencias tan absurdas como las que te podás imaginar o correctas en donde hay intereses económicos en juego, y no se firma si no me das, pero además para mantener la red clientelar en las bases liberales, en las estructuras liberales, que son las que reciben de su jefe estas migajas, estas cositas, Daniel Ortega le mantiene ciento y pico, doscientos cargos dentro del Ejecutivo al liberalismo, las da a Arnoldo Alemán y Arnoldo las distribuye y las maneja, y luego quita las comisiones correspondientes, por lo tanto, el día en que se rompa el pacto, y el día en que Alemán se las tenga que ver sin Daniel, y Daniel se las tenga que ver sin Alemán, los dos se friegan, porque Ortega no tiene la mitad del electorado como el que tiene Chávez, o Evo, el electorado de Daniel es relativamente bajo, y su fuerza es que sus Magistrados junto con los Magistrados de Arnoldo hacen las cuentas que les corresponden, y resultan que lo que ellos les interese sean electos, y eligen a los Magistrados que a ellos les interesa y a partir de ahí, es un poder muy precario si tomamos como referente la aceptabilidad en la gente, las bases, y es muy fuerte si tomás en cuenta que si quieren cerrarte un negocio, un periódico, a ese Carlos Fernando Chamorro vienen y le mandan a sacar todas sus computadoras y se las sacan y no hay manera ni de evitarlo, ni de que le revisen su disco duro y sus cosas se las pueden devolver, o cierran un partido político y no pasa nada, o le quitan un escaño a Alejandro Bolaños y no pasa nada, entonces, es un poder el de ambos, los dos son los elementos de poder más importantes para el otro, ambos viven por el otro, y por eso es que no pueden romperlo, ahorita todo esto que estás viendo y leyendo en los medios diciendo que Montealegre está pactando con Daniel, eso son pura especulación, pura fanfarria de cara a las elecciones regionales, y sobre todo de cara al esfuerzo de unidad que quiere hacer bajo su égida, bajo su liderazgo Alemán, y para ello necesita un poquito quitarse el color de pactista con Ortega, pero es imposible, pues, es difícil.

R: ¿Y sí crees que se ha dado un giro de Ortega después de estas reformas que limitaban el Ejecutivo gobernando por decreto y reformando esta Ley 290 para tener mayor capacidad, digamos, mayor fortaleza en la decisión del Ejecutivo presidencial respecto a los anteriores gobiernos liberales?

G.A.: Ah sí, totalmente, totalmente, el gobierno de Ortega, a ver, por varias razones, primero porque Daniel Ortega no está diciendo nada nuevo de sus antecedentes, de su formación, él mismo se ha confesado en muchos momentos, pues, no marxista, sino que 
sus fuentes doctrinarias vienen, pues, del marxismo, dice que hasta de Jefferson, pues, la verdad es que es muy amplia, pues, no un marxista radical puro y duro, pero sí su formación, poca, por cierto, pero alguna, su experiencia guerrillera, sus alianzas estratégicas en los 80 , su retórica, sus actuaciones actuales, todo te indica, además él lo dice, el mejor sistema es el de partido único, él dice que una sociedad como el ejemplo o el paradigma de una sociedad sana sea de partido único, entonces, además de que él nunca se creyó el cuento de la democracia occidental, si querés democracia capitalista, y, digamos, la democracia burguesa o liberal, es decir, además de un poco de autenticidad y de ingenuidad en su comportamiento hay un cierto elemento esotérico, mesiánico, ¿cómo decirte?, se cree como un iluminado, casi como una voluntad providencial, te puede parecer en el fondo, aunque no lo querrás demostrar, hasta cómico, pero así es, existe esa idea, pero también...

\section{R: Es como Chávez en Venezuela.}

G.A.: Sí, no, igual, igualito, igualito, pero también sabe que si ahorita no consolida su poder para un proyecto largo, no sólo pierde el poder, pierde la viabilidad de seguir jugando un papel, Ortega no se concibe de abuelito, pues, regando un jardín, una flor, eso no puede ser, eso se lo puede concebir Zapatero, pues, Zapatero puede decir: "¿y qué vamos a hacer cuando nos vayamos de aquí de la Moncloa? Nos vamos a ir a vivir a allá, que es bien lindo, y vamos a tener una huerta o...", no, no, Ortega no lo concibe, y el error que cometió en el 90 de entregar unas simples elecciones, que además era un juego de la oligarquía y la derecha, eso no lo hace, él concibe las elecciones como una técnica organizativa no como una expresión política de soberanía ni de democracia, entonces, él organiza unas elecciones y de acuerdo a esas reglas las gana, está bien, no importa que la voluntad de electorado sea otra, si moviendo ciertas fichas y ciertas cosas él gana, él tiene que ganar, ¿qué te quiero decir con esto?, pero además te voy a decir lo último, además no tiene la oposición que los otros sí han tenido, que era él, ¿ya?, Alemán, la Violeta y Bolaños lo han tenido a él de oposición, y él como oposición ¿qué significa?, que ha quemado la alcaldía, que a veces va y para los tranques, y que hace desastres, y los otros que tienen una formación, pues, si querés, más cercana a las creencias de un régimen democrático, pues, o tal vez tienen menos testosterona de la que se debería de tener para ejercer un cargo en ciertas, no estoy hablando para reprimir, no estoy hablando para hacer cuestiones contrarias a un estadista de un Estado democrático de Derecho, estoy hablando para mantener el orden público, respetando los derechos y garantías, garantizando los derechos de los ciudadanos, de sus opositores, etc., entonces aquí todos los negocios, la mayoría de ellos mal habidos, la mayoría de ellos oscuros todavía, oscuros entre comillas, porque son públicos en general, pasan tres gobiernos y básicamente se quedan ahí, hasta ahora están saliendo algunas cosas de corrupción, y los jueces aquí rápido te inscriben en esa bolsa que la compraron, que otro la compró y que vos te la llevás, y te sacan un título supletorio, entonces, ni los gobiernos anteriores tenían la visión, ni la formación doctrinaria, ni las aspiraciones, ni la oposición que tiene Daniel Ortega, por lo tanto, sí que ha habido un vuelco fundamental, un giro total de 180 grados, sí, en el estilo de gobernar, pero no sólo a raíz de las reformas a la Ley 290, aún antes de las reformas, porque Ortega, vos debés de conocer bien, dijo: "vamos a gobernar desde abajo", ¿te acordás o no te acordás?, bueno, cuando él perdió las elecciones y entregó el gobierno a Doña Violeta, dijo, bueno, vamos a gobernar desde abajo, y gobernaba desde abajo, cuando no quería que algo hiciera el gobierno recurría de amparo y los jueces detenían al gobierno o le daban un derecho a no sé quién, entonces, ha utilizado el Poder Judicial, cuando estaba en la 
oposición, a sus fuerzas de choque, a sus organismos de masas, y la oposición actual no puede ni enfrentar eso, pero ni siquiera tienen el primer paso, que es unidad, la articulación de la unidad liberal, un liderazgo coherente, no tienen propuesta clara, saben que son anti-danielistas, porque Daniel es autoritario, Daniel es un disparate, bueno, estamos de acuerdo en eso, pero además dígame usted, señor $\mathrm{X}$ o señor $\mathrm{Z}$ o señora oposición, ¿cuál es su propuesta sistematizada, procesada, consultada, que le dice al pueblo nicaragüense que va a tomar qué camino?, ¿qué modelo?, ¿qué es lo que vamos a construir?, ¿quiénes?, ¿cómo?, ¿por qué?, ¿bajo qué organización?, es decir, eso se le hace todo facilísimo a Ortega.

R: Sin embargo, el límite de Ortega sí son los recursos económicos de Chávez, sí hay un límite material al gobierno de Ortega. ¿Cuál es tu apunte final de reflexión sobre el último año o año y medio que resta para las próximas elecciones presidenciales?

G.A.: Bueno, yo creo que el gobierno de Ortega es un gobierno fracasado, y lo digo en este momento que faltan dos años, un gobierno fracasado desde el siguiente punto de vista, tiene dos opciones, o da un golpe de timón importante, fuerte, que Daniel ha demostrado la historia que es capaz de olfatear los peligros y las cercanías de los abismos, y pone contramarcha, etc., lo cual no se está viendo en estas circunstancias, hay algún elemento que no le está permitiendo a él desarrollar eso, que, en mi opinión, pues, lo tenía desarrollado, pero mirá, Daniel, y en las últimas encuestas esto se nota bien, se nota que ya se abre un problema de preocupación seria en cuanto a la capacidad de resolver las necesidades materiales, no hay plata, y vos no podés, a ver para el año 2010 el FMI ya dijo que no podía darle plata si no financiamos el presupuesto de 2010, OK, se están yendo, Europa, te doy 10 millones, dio una cantidad claramente superior a esa, se están yendo los organismos bilaterales, la inversión empieza a notarse una tendencia a un descenso...

\section{R: Por falta de confianza de los inversores en las instituciones políticas.}

G.A.: Claro, claro, el origen de todo está en la falta de un clima de negocios, si querés que lo hablemos en términos de inversionistas privados, o de institucionalidad democrática, de seguridad jurídica, de gobernabilidad democrática, si lo hablamos en términos de ciudadanos, pues, en general, eso ha hecho que se hayan perdido cientos de miles, y que se vayan a perder más empleos, creo que el cálculo que se hace es de 250.000 , esta cifra que hay que verificarla, habría que chequearla, hay una baja importante en los niveles productivos de algunos rubros, hay un manejo bueno de la macroeconomía, un buen manejo, yo creo que es el mejor ámbito de desempeño del gobierno, pero creo que también existe un peligro si no se revierten las otras tendencias, le estás quitando a tu mercado más natural servicios que son buques insignia, bueno, ya hemos visto los problemas de salud que han salido últimamente, problemas de educación, las reformas presupuestarias que ha habido hasta la fecha afectan a la salud y a la educación, y no afectan a otros sectores.

\section{R: ¿La propuesta de reforma tributaria?}

G.A.: Las dos reformas que ha habido así han sido, y también en la propuesta que al final habrá que ver, pues, no, ahorita es la propuesta de reforma fiscal no presupuestaria, te hablaba de reformas presupuestarias que ha habido, entonces, yo lo que creo es que Ortega se creyó mucho la historia de formar un nuevo liderazgo mundial, siguiendo a 
Chávez, a Rusia, a Irán, que esto le bastaría, que esto le iba a dar los fondos necesarios mínimamente necesarios para manejarse en esas propuestas, pero que no iba a perder tampoco los fondos tradicionales de Estados Unidos, de Europa, pero también los está viendo reducidos a raíz del fraude en las elecciones municipales, entonces, una de dos, $\mathrm{y}$, por último, el propio concepto, el propio estilo de gestión administrativa del Estado, pues, de la Administración Pública es muy ineficiente, es muy inoperante, es excesivamente burocrático, y muy, digamos, poco capaz de satisfacer las necesidades y las demandas de los ciudadanos, se ve desde los ejemplos más pequeños hasta gestiones más importantes, pero eso no es un problema sólo de gestión cotidiana ni estratégica, el problema es conceptual, es un problema de centralización de todos los hilos, manejos, y los ministros no pueden hacer nada, pues, si la $\mathrm{Chayo}^{7}$ no le dice donde puede ir su viceministro a no sé donde, a otro país, o sea, cosas ridículas, absurdas, pero que afectan, y esto hace, las tendencias, a mi juicio, marcan que no va a poder resolver los problemas económicos del país, no hay manera, Chávez también tiene problemas, bueno, Chávez tiene una cartera importante, le ha dado dinero, según las propias fuentes de Ortega, casi 500 millones de dólares en los últimos años, pero hemos visto, por lo menos en Nicaragua, hemos visto que no es suficiente, se empiezan a ver nuevamente los apagones, no sé si por donde vos vivís se va el servicio eléctrico, porque hay algunos sectores que parece que sí, sí conozco algunos sectores donde se da esto, y sobre todo la inversión, yo creo que el problema de la desaceleración de la inversión extranjera y nacional es importante, las pérdidas, las idas de las zonas francas, en países como Nicaragua las zonas francas desempeñan un papel muy importante de su dinámica económica, y se han perdido miles de empleos a través del cierre de zonas francas, entonces, yo no veo ahorita ni una propuesta o líneas estratégicas del gobierno, no las ha dicho, no las comparte, hay una política secretista le dicen aquí en Nicaragua, hay un secretismo que se maneja, que no se sabe muy bien lo que quieren hacer, entonces, las relaciones con la Unión Europea no se conocen bien, con el FMI, se conocen porque vos tenés un amigo que trabaja en el FMI y sabés, pero eso, el pueblo no sabe a cuenta de qué la Unión Europea le dio 10 millones, uno puede saber por qué, parece que se comprometió a hacer un saneamiento electoral, va a haber observación internacional y poca cosa más, el fraude del 2008 quedó enterrado y todo de cara al 2012, bueno, eso no lo sabe nadie, eso lo sabe la Unión Europea y los nicaragüenses, que es lamentable el papel de la Unión Europea en este sentido, y te voy a comentar algo terrible en el caso del Sr. Moratinos, pero, en fin, lo que te quiero decir es que o se da cuenta que su modelo no es viable, y, por lo tanto, empieza a construir un consenso verdadero, no como el de ahorita, que dice concertación tributaria y nadie ha sido ha sido convocado, o nadie ha hablado, o no dice nada, no plantea nada, no se pone de acuerdo con el FMI y punto, o este gobierno va a caer por su propio peso, no hay manera de si vos ganaste con el 38\% de los votos, y a los dos años tuviste que hacer un fraude, en dos años, y, entre otras cosas, es por eso pues, la gente piensa con el estómago, entonces, yo no le veo ni muchas salidas ni muchas posibilidades, lamentablemente, ¿y por qué digo lamentablemente?, porque el que peor sale parado es el pueblo, ¿no?

\section{R: Entonces, ¿reformas sí o reformas no?}

G.A.: Mira yo creo que el tema del sistema parlamentario está postergado, yo creo que ese tema nadie lo compró, al mismo Ortega parece que le haya dejado de interesar porque significa someterse a controles a los que él no está acostumbrado ni le interesa

Nombre coloquial de Rosario Murillo, esposa del presidente Daniel Ortega. 
someterse a cierto control parlamentario, si no ha ratificado, menos un sistema parlamentario, no le interesa eso, eso él lo vendió en un momento para la reelección, pero no cuajó, y él va a seguir con su tema de la reelección, no está garantizado, pero sí desde mi punto de vista todo indica que hay un acuerdo renovado, básico, entre Alemán y él, dejando fuera a los otros actores políticos de interés o de importancia, pero no hay garantía de que Alemán pueda tener los votos suficientes, él y su bancada, para lograrlo, yo creo que no han surgido en la mesa todos los elementos disuasorios para ellos y hay muchas maneras de prorrogarlo, de todas maneras, de todas maneras, él está jugando un doble frente, está queriendo hacerle ver a Alemán y a los demás como que está en contacto con Montealegre para decirle a Alemán: "mirá, si vos no te ponés de acuerdo conmigo, me pongo de acuerdo con Montealegre", obviamente, a Ortega no le interesa ponerse de acuerdo con Montealegre, es decir, no es su mejor socio, son visiones radicalmente distintas, además se ha demostrado que es para que Alemán se asuste, que Alemán se quedaría fuera, incluso, pactando o renovando el pacto con Alemán, probablemente, incluso tenga su tiempo en política contado, ya no tiene muchas, pues, posibilidades de convertirse nuevamente en el líder que fue y no es, pero bueno, él pretenderá darle un poquito de largas al asunto, así es que si no lograra las reformas, que yo no las descarto ni muchísimo menos, yo creo que no hay nada en la abdicación de Alemán, no significa mucho para descartarlas, sin embargo, si no se dieran, que tampoco se puede descartar que no logre los votos necesarios, está claro que su continuidad se va a dar a través Rosario Murillo, y eso lo que significaría es compartir el poder de una manera más importante y eventualmente estratégica con Rosario y con cualquier otro, Rosario no tiene la capacidad que tiene de cohesionar el partido, pues, no le quedaría otra alternativa.

$R:$ ¿Y se puede constitucionalmente?

G.A.: Se puede constitucionalmente postular ella, no hay nada que lo impida.

R: Pues, si tienes algo más que añadir en esta entrevista tan larga e interesante.

G.A.: No, no, bueno, siempre se podrían añadir muchas más cosas. 


\section{ENTREVISTA 5 $5^{8}$ :}

Nombre del entrevistado: Dr. Manuel Aráuz.

Cargo actual: Decano de la Facultad de Derecho de la Universidad Centroamericana (UCA).

Fecha de realización de la entrevista: Managua, 5 de noviembre de 2009.

Lugar: Facultad de Derecho de la Universidad Centroamericana (UCA).

Duración estimada: 1 hora y 12 minutos.

\section{TEXTO - Transcripción 5:}

R: ¿Cuál es su visión sobre el recorrido que ha hecho la joven democracia nicaragüense desde el punto de vista del cambio constitucional? Como el andamiaje jurídico ha servido o no a la consolidación de las instituciones democráticas, digo, por la facilidad con la que, aparentemente, un observador externo entiende que se ha reformado la Constitución desde los años 90 hasta ahora.

M.A.: Desde los años 90, mira, porque hablamos, en esencial, de la Constitución de 1987, esta Constitución ha tenido cuatro reformas, verdad, como tú ya sabes, pero si nosotros nos remontamos hacia atrás solamente para tener una breve referencia histórica, Antonio Esgueva, ya, seguramente, te lo habrá dicho, el constitucionalismo nicaragüense no ha sido un constitucionalismo estático, en el sentido de que la Constitución esta ahí y es una norma inamovible, parece que en Nicaragua, en el devenir histórico siempre se ha considerado a la Constitución como algo, como un conjunto de reglas, que, de acuerdo a la coyuntura, y cuando se da, digamos, el clima propicio, se puede cambiar, es decir, que, más bien, en el ámbito de las reformas ha sido más bien dinámica, y sobre todo, también te habrán dicho que las reformas se han utilizado más que para fortalecer las instituciones democráticas del Estado, para favorecer los intereses de determinadas personas o determinados partidos. Esto que ha sido la historia tradicional de Nicaragua, y que está documentado, pues, que Somoza cambiaba, reformaba la Constitución para que se le pudiera reelegir, que los Sacasa hacían lo mismo, que José Santos Zelaya en la Constitución de 1893 la reformó luego para poderse reelegir para continuar, etc., ¿no?, entonces, lo digo, que esto es un mal que han padecido liberales, conservadores, y que ha existido en la historia de Nicaragua. A partir de los años 90, creo que la Constitución de 1987 es un buen texto constitucional para su época, creo que desarrolló un importante catálogo de derechos y garantías, creo que estableció las bases de un régimen, un sistema democrático con una división de poderes, con una independencia de poderes, aunque la Constitución del año 87 era una Constitución extremadamente presidencialista, es decir, donde el presidente, como tú sabes, tenía enormes facultades, y el presidente era quien podía proponer a los magistrados de la Corte Suprema de Justicia, tenía la exclusividad de proponer las ternas, ¿no?, y por tanto, era una facultad que utilizaba, generalmente, como un medio de dar premios o castigos de carácter político, y también de tener a las personas de su confianza en otro poder del Estado, pues, y eso, naturalmente, hace que se hable de un equilibrio de poder un poco blando, ¿no?, y al mismo tiempo, pues, obviamente, tenía

\footnotetext{
8 Entrevista muy interesante, con un análisis político de los pactos intra-partidarios en el contexto de las reformas constitucionales, y referencias detalladas en torno a la fragilidad de las instituciones democráticas en Nicaragua.
} 
una Constitución de corte presidencialista, donde todas las facultades estaban alrededor del presidente. La primera reforma de eso fue simplemente generar el paso a las elecciones de 1990, seguramente, Edwin Castro te lo habrá puesto como, es decir, el primer gran ejemplo de la democracia del Frente Sandinista en el poder, del Comandante Ortega en el poder fue haber permitido, producto de los Acuerdos de Esquipulas, que no sé si permitido o haber cedido, de acuerdo a las circunstancias, que existían unas circunstancias de guerra y demás, el Frente cedió en el sentido de reformar la Constitución para poder permitir que las elecciones se adelantaran, y acortar el período de gobierno constitucionalmente establecido, verdad, al presidente Ortega, para que se dieran las elecciones de 1990, donde, obviamente, como sabemos también, ganó una coalición de partidos de todo tipo, no eran ni partidos de derecha, había partidos de derecha, había partidos conservadores, había partidos de izquierda, había partidos comunistas, socialistas, todos esos formaron una gran coalición, era una gran coalición que tenía como eje central el anti-sandinismo, verdad, era una gran coalición que pretendía cambiar las cosas, que pretendía cambiar las cosas, y no era, precisamente, una lucha frontal de carácter partidario, fíjate que esa gran coalición que ganó las elecciones, las ganó por muchos factores, muchos factores que no sé si concernían, únicamente, a los factores políticos, yo creo también a los factores sociales, a los económicos, al proceso de paz social que teníamos, un proceso del que veíamos saliendo, iniciando el regreso a la paz, a la tranquilidad, veníamos saliendo de una guerra, donde murió mucha gente, veníamos saliendo de una fragmentación social terrible, donde mucha gente tuvo también que irse del país, donde los campesinos sufrieron mucho las consecuencias de la guerra, y, entonces, la pacificación y aquél bloque que ofrecía una alternativa de pacificación era, digamos, quien tenía las posibilidades de ganar, independientemente, de su agenda política o su estructura política, la UNO era un crisol de partidos, un crisol de visiones, etc., también el tema económico, que era importante, y eso es lo que dio lugar a que la UNO ganara, porque estableció un planteamiento económico distinto al planteamiento de la época, un planteamiento económico en el que estábamos viviendo de las donaciones extranjeras, en el que estábamos bloqueados, o sea, había un bloqueo económico, como el que existe en Cuba o en otros países, puesto por Estados Unidos en ese tiempo, y había una situación económica con una devaluación galopante, una hiperinflación impresionante, etc., todos esos factores ayudaron o condicionaron que se diera un cambio en el aspecto político, en el ámbito del gobierno, e inmediatamente, inmediatamente, empezaron a tratarse temas de que era necesario cambiar el sistema político existente, era necesario también al mismo tiempo cambiar las normas constitucionales, era necesario cambiar, igualmente, la dependencia partidaria del Ejército, porque desde el punto de vista constitucional, el Ejército se llamaba: Ejército Popular Sandinista, es decir, era el Ejército del partido, y que desde la nomenclatura, ¿no?, desde el nomen iuri, que se le daba en la Constitución, esa institución nacía arraigada en un partido, y todo esto se dio en este proceso que dio lugar luego a las reformas constitucionales, tú sabes, que eran sí ya reformas de fondo, las reformas constitucionales de 1995, que se legalizaron a través de la Ley No. 192 de esa época, y que cambió muchas cosas, la reforma del 95 tenía una misión fundamental y era atenuar el extremado presidencialismo de la Constitución del 87, en el año que se produjeron las reformas constitucionales, en el año 95, ya existía, en el ámbito de los partidos políticos que las aprobaron y que las promovieron, existían ya problemas estructurales, el Frente Sandinista ya se había dividido, la gran escisión que se produjo en el año 94, donde se dividió el sandinismo ortodoxo del Movimiento Renovador Sandinista, en el parlamento sólo quedaron 3 diputados del Frente Sandinista ortodoxo de hoy, mientras que la mayoría eran diputados que pertenecían al 
bloque del Movimiento Renovador Sandinista, encabezado, en ese momento, por Sergio Ramírez Mercado, que fue vice-presidente de la República de Daniel Ortega, y que, en ese tiempo, era, pues, quien encabezaba la bancada. También había problemas en los otros partidos, digamos, que conformaban la gran coalición de la denominada Unión Nacional Opositora, ya había fricciones importantes entre los partidos que formaban esta coalición por varias cosas, en primer lugar, porque el entonces alcalde de Managua, Arnoldo Alemán, ya había manifestado sus intenciones presidencialistas, de postularse en las presidenciales, por una parte, por otra parte, existía la intención, igualmente, del Ministro de la Presidencia de entonces, el Ingeniero Antonio Lacayo, yerno de Doña Violeta Barrios, presidenta en ese momento, de postularse también a la presidencia, entonces, ya había, el establecimiento de la reforma constitucional del año 95 prohibir la reelección continua de manera sucesiva, verdad, o prohibir que el presidente se reeligiera por más de dos mandatos no sucesivos, de prohibir que personas que no tuvieran 4 años de haber regresado al país, verdad, participaran como candidatos, Alvarado, recuerdo en ese entonces, el propio Edén Pastora, que no tenía 4 años de haber vuelto del exilio, de Costa Rica o de Miami en esos casos, y de prohibir que personas que hayan estado ligadas con vínculos de consanguinidad o de afinidad con el presidente anterior pudieran presentarse, eso dio lugar a que existiera un rompimiento completo en el ámbito de la Unión Nacional Opositora, y los que, digamos, eran aliados de Doña Violeta reclamaban a los demás el haber allanado el camino al alcalde de Managua, verdad, para que se presentara, un poco, digamos, como representante de la oposición al sandinismo, eso en el ámbito de la reforma al tema electoral, pero hubo reformas también en el tema, digamos, se amplió el número de Magistrados a la Corte Suprema y se redujo el período en el que éstos, digamos, por el que éstos podían ser Magistrados de 7 a 5 años, de la misma manera, la reforma cambió el nombre del Ejército por el de Ejército Nacional con sometimiento y subordinación a la sociedad civil, también al tema de la Policía Nacional, que, entonces, se llamaba Policía Sandinista, entonces, se restringió, y esto no era más que el reflejo de cambios que se habían dado ya a partir de 1992, que se acordó la salida ya del General Humberto Ortega para el año 94, y cuando se estableció un ámbito de sucesión en el ámbito militar de cara a su institucionalización y también en el ámbito de la Policía. Yo creo que eso es importante, fíjate que los acuerdos después del año 90, se dieron más o menos en el año 92, los acuerdos de concertación en ese entonces, que dieron lugar a la profesionalización del Ejército y de la Policía, fueron aspectos muy importantes, creo que en eso avanzamos, desde el punto de vista democrático, y luego esto se consolida en las reformas del 95, y también que estas instituciones tuvieran sus propias leyes orgánicas, y se generara un sistema de cambios, ¿no?, en el ámbito de estas dos instituciones importantes, y al mismo tiempo, también, en el ámbito económico existían compromisos del gobierno para con el Fondo Monetario, etc., el cambio de 1990 determinó un cambio de régimen económico trascendental, Nicaragua se adhirió a los postulados del Fondo Monetario Internacional, el denominado "Consenso de Washington", el establecimiento de un sistema, de un plan, digamos, de reforma estructural en el ámbito económico, que establecía que nosotros nos teníamos que ceñir, si el Producto Interno Bruto era de tanto, la inversión en educación no puede estar más allá de tanto, ¿no?, entonces, un corsé desde el punto de vista económico que ayudó a ir un poco cambiando las cosas, de la misma manera, se crearon las bases para, digamos, un fortalecimiento de las instituciones existentes en el primer período, y las reformas del 95, obviamente, fueron un gran vuelco, fueron un gran vuelco en ese sentido, es la reforma más grande que ha tenido la Constitución, tú lo sabes perfectamente, la Constitución del 87, me refiero. Y al mismo tiempo, también, fue conflictiva, verdad, 
fue conflictiva, en ese entonces, después de que se aprobó la reforma y se mandó publicar, en ese entonces, se discutía si había o no dos constituciones, porque unos la aceptaban y otros no, esto se comentaba en los diarios, que unos aceptaban esas reformas como legítimas y otros no, y eso dio lugar a una fuerte tensión entre el Ejecutivo y el Legislativo, obviamente, el Ejecutivo veía limitadas sus capacidades a través de las reformas, obviamente, se le quitaba la facultad al presidente de poder poner al Magistrados de los demás poderes del Estado, aunque él podía proponerlos, pero al mismo tiempo también lo podían hacer los diputados, y, entonces, se habría un poco más el abanico, limitaba, como decía, sus poderes, y eso dio lugar luego, que, seguramente, Luís Humberto Guzmán te lo debe haber comentado, a que existiera un acuerdo entre el parlamento y el Ejecutivo, que dio lugar a la primera Ley Marco, entonces, en Nicaragua es especial, hemos tenido dos leyes de ese tipo, de que una reforma parcial aprobada con respecto a lo establecido en el artículo 191 y siguiente de la Constitución vigente de 1987, es decir, con el voto favorable de dos tercios del total de miembros del parlamento, una ley de reforma constitucional, que, ni siquiera, admite el control constitucional por parte del pleno de la Corte Suprema de Justicia, porque la Corte Suprema de Justicia se puede pronunciar sobre todos los temas de constitucionalidad de las leyes, pero no sobre la Constitución y sus reformas, porque eso es, digamos, una facultad del Constituyente o del Constituyente derivado, en su caso, y entonces, la validez, la aplicación, el tiempo de aplicación de esa ley de reforma de la Constitución fue determinada por una Ley Marco, que es una ley de carácter ordinario, que viene de un acuerdo político. Entonces, esa es una cuestión, que lo tienes que leer no en sentido jurídico, sino en sentido político, o más bien en sentido de Derecho político, verdad, una cosa muy, muy especial, que se utilizó en el año 1995, y eso dio lugar, luego, a que las reformas entraran en vigor, a que el texto fuera incorporado en la Constitución, y, obviamente, también, pues, eso eliminó las aspiraciones presidenciales del entonces, digamos, primer candidato por parte del Ejecutivo, que era el Ministro de la Presidencia, Antonio Lacayo, ahora, lo habrás escuchado, que suena, nuevamente, como una alternativa este señor. La otra gran reforma, y creo yo, que la más perjudicial para Nicaragua, es la reforma del 2000. La reforma del año 2000 proviene del pacto, de un pacto que no es un pacto escrito, mucha gente habla del pacto, del pacto entre Daniel y Alemán, sabemos que en el año 96 Arnoldo Alemán ganó las elecciones, sabemos que el gobierno de Alemán es un gobierno tildado de corrupción, que además, también, era demostrable, pero además era evidente, es decir, porque no solamente que puedas revisar los libros contables, o puedas revisar los presupuestos de los ministerios y de los entes, para ver adonde circulaba el dinero y hacia donde llegaba, sino que además era evidente, a la vista pública, nosotros decimos, con Ángel Saldomando estamos trabajando en un diagnóstico sobre la corrupción, entonces, decimos que en el caso de Arnoldo Alemán la corrupción no solamente existió, sino que además era evidente, era tal la ostentosidad, en donde el funcionario público se sentía con el poder de disponer de la cosa pública, verdad, y que existía más o menos una autorización por parte del presidente para disponer de ello, a diferencia de otros gobiernos, en el gobierno del doctor Alemán, él ponía, digamos, nombraba a los ministros para que administraran eso, entonces, era como una especie de premio, ¿no?, con una, digamos, con una cierta racionalidad en el uso de los recursos y una cierta moderación en el uso de los recursos para beneficio personal, en una ocasión, incluso, que recuerdo yo, estábamos en un almuerzo que fui con un profesor español invitado, y, entonces, el Dr. Alemán decía: "bueno, yo ya no estoy en el gobierno, cuando yo estaba en el gobierno, yo le daba a las personas, y para que ellos administraran eso, y tomaran algo para ellos, pero yo ya no tengo poder”, él estaba en la Asamblea en ese entonces, eso demuestra, ¿no?, que había 
una especie de autorización, y había una ostentosidad bastante grande, las personas se vio como se enriquecieron de forma ilícita, también un gobierno que tuvo la desgracia de hacerse cargo del tema del huracán Mitch, verdad, de ese desastre nacional, digo, fue una desgracia, porque los recursos que vinieron, como no eran presupuestados, sino que venían, directamente, fondos de cooperación para la mitigación, fueron utilizados de forma corrupta, y, al mismo, tiempo, era un poder alrededor de él, eso dio lugar a que el Frente Sandinista siempre peleó por sus espacios, el Partido Sandinista en la oposición siempre peleó por sus espacios y existía el eslogan de "gobernar desde abajo", es decir, a través de las clases sociales, a través de los movimientos sindicales, a través de las universidades, movimientos estudiantiles, los movimientos populares, los campesinos, es decir, una gran estructura, además era un partido que tenía estructuras en todos los sectores, $\mathrm{y}$, entonces, también podía hacer presión hacia fuera, también el propio Alemán, pero, teniendo en cuenta, Arnoldo Alemán, teniendo en cuenta que la Constitución le prohibía reelegirse, que debía buscar a alguien para que le sucediera, y, además, teniendo en cuenta que su partido político representaba un gran potencial electoral, el PLC tenía una enorme cantidad de población y el Frente Sandinista también, pero que ellos dos, a diferencia de los partidos conservadores, o incluso otros partidos que se entienden liberales, el consenso entre estos dos líderes es que ellos representan a la mayoría de nuestra sociedad en Nicaragua, Daniel y Alemán dicen: "entre nosotros representamos más del 90\%", y entre los liberales del PLC y los sandinistas del Frente Sandinista no hay diferencias sociales marcadas, es decir, son gentes del mismo estrato social, de las mismas clases, de los mismos recursos económicos, del mismo nivel educativo, son gente de clase media baja, que es la inmensa mayoría de la población, y gente pobre, y gente que está en extrema pobreza, esa es la inmensa mayoría de la población nicaragüense, y esa es la inmensa mayoría que los partidos liberal y sandinista dicen representar. Entonces, si nosotros representamos a la mayoría de la población, es decir, lo lógico es que haya entre nosotros una alternancia en el poder, ¿no?, no es conveniente, no tiene razón de ser, porque un $8 \%$ de la población, que son la clase media alta y alta en Nicaragua, y que están aglutinados en partidos conservadores, verdad, los conservadores, digamos, de antaño, y algunas estructuras del partido liberal, ¿esos por qué van a gobernar si ellos son apenas el 10\% o el $8 \%$ de la población? Entonces, lo que tenemos que crear es un acuerdo de forma tal que permita que nosotros cogobernemos, y cogobernaron. Ese pacto, que no está escrito en ningún lado, sólo hay fotografías de él, no está escrito en ningún lado, en realidad, no es, incluso, no es un acuerdo estático, sino que yo conversaba con alguien, ahora por la mañana, y decía, el pacto entre Alemán y Daniel es un acuerdo de procedimiento, es que, $\mathrm{OK}$, nosotros vamos a cogobernar, vamos, cada quien de acuerdo a su fuerza, en el momento concreto, de acuerdo a la coyuntura, cada quien va a tener su cuota de acuerdo a su propio poder político que tenga en su momento, es decir, que si yo tengo más poder político ahora para nombrar a todos los Magistrados del Consejo Supremo Electoral, o, por lo menos, a 4 de los 7, yo voy a nombrar a 4 de los 7 , y vos vas a nombrar sólo a 3 , porque yo tengo más poder que vos, pero si en otra circunstancia tú tienes más poder para proponer y nombrar a más Magistrados de la Corte que yo lo harás, entonces, es un acuerdo de procedimiento basado en la coyuntura y en la fuerza que cada uno tenga, eso es lo que ha hecho que desde el 2000 hasta esta fecha ese pacto continúe vivo, y se revitaliza en cada crisis, cada crisis nacional da lugar a un resurgir del pacto, a una aplicación de ese procedimiento, entonces, te decía yo que la reforma del 2000 fue la más dura, porque significó el asalto de las instituciones del Estado por parte de los partidos políticos, significó la politización de las instituciones, eso se determinó de que la única forma en 
que podamos cogobernar es que establezcamos que para nombrar al Contralor, a los Contralores, de hecho, se estableció una Contraloría colegiada, porque antes era individual, en el año 2000 se estableció la Contraloría colegiada por los problemas que le había causado Agustín Jarquín Anaya, Contralor de su tiempo, a Arnoldo Alemán, que estaba denunciado por corrupción, entonces, para quitarse ese problema de en medio se estableció una Contraloría colegiada, propuesta por 5 contralores, en el que para nombrar a cada uno de ellos se requiere mayoría calificada en el parlamento, o mínimo de 56 votos, y que ni los liberales ni los sandinistas los tienen, entonces, la única forma en que podamos nombrar a esas personas en esas estructuras de poder es que nos pongamos de acuerdo, esa es la vitalidad del pacto, entonces, significó que ese acuerdo político se trasladó a las instituciones, en la Contraloría, en el Consejo Supremo Electoral, en la Corte Suprema de Justicia, en el nombramiento del Fiscal General, el Fiscal General Adjunto, en el nombramiento del Superintendente y el Vice-intendente de bancos, etc., o sea, eso se tradujo en que el acuerdo político se trasladó a las instituciones, y las instituciones, entonces, comenzaron a resolver los asuntos públicos en base a los acuerdos políticos, es por eso que las reformas del 2000 fueron, para el ámbito del fortalecimiento democrático y el fortalecimiento de las instituciones, un tiro casi mortal, y eso es lo que hemos venido viendo ahora. Y las instituciones responden a intereses políticos, y responden a intereses políticos de carácter coyuntural, de carácter coyuntural, igualmente, pueden resolver de una manera hoy y de una manera distinta mañana, aunque se contradiga no les importa, porque a ellos les importa más la coherencia política que la coherencia institucional o administrativa. Lo otro, la otra gran reforma que conocemos, es la reforma del año 2005, que fue hecha también a espaldas del Ejecutivo, fue hecha, igualmente, con la complicidad de los partidos políticos hegemónicos. ¿Por qué se dio la reforma del año 2005? Arnoldo Alemán se equivocó cuando propuso como candidato a presidente al Ingeniero Enrique Bolaños, se equivocó porque creyó que Bolaños iba a ser una persona que iba a responder a lo que él dijera, ¿no?, hay un artículo ahí, lo puedes encontrar en un libro, que se llama "El sistema del figureo", fue publicado en La Prensa, de un escritor nacional que se llama Leo Núñez. Leo Núñez escribió, en ese entonces, que había personas que eran serviles, el servilismo al presidente Alemán, y que una de las personas más serviles, el "cuello más flexible del liberalismo" se llama el artículo, es decir, que la persona siempre es complaciente, era el Magistrado Iván Escobar Fornos. Iván Escobar Fornos estaba destinado a ser el sucesor de Alemán, pero, porque era una persona obediente, o sea, Alemán se miraba que él seguiría mandando, gobernando a través de Iván Escobar, pero la presión de los grupos políticos y de los grupos económicos determinó que fuera una persona distinta, ¿por qué no podía ser su vice-presidente que era el Ingeniero Bolaños? Y se nombró, pues, a Bolaños como candidato, y comenzó la campaña, etc., Alemán tenía desconfianza de Bolaños, Alemán tenía desconfianza de Bolaños, pero no creyó, no creyó nunca que Bolaños iba a tener un cambio tan radical, un cambio tan radical en el que se le metió el tema de que él tenía que dejar un legado, que lo dejó en Nicaragua, de que tenía que hacer algo trascendente, y lo trascendente era afrontar el delito de la corrupción y perseguir a Alemán y a todos sus cómplices, lo hizo, lo hizo hasta donde pudo, porque luego no pudo soportar el poder político de otros grupos, y el poder económico o el poder de la Iglesia, cuando Alberto Novoa llegó hasta decir que en el ámbito de la corrupción de Alemán también estaba metida la Iglesia a través de una ONG, que se llama COPROSA, que le pertenece al Cardenal, cuyo director y presidente es el Dr. Roberto Rivas, entonces, ahí, bueno, había que frenar al Procurador de ese tiempo, igualmente, cuando se determinó que aparte de la corrupción pública, esto repica en el ámbito de la corrupción privada, porque todo lo que sale de lo público va al ámbito 
privado, y había ahí también empresas privadas, y, entonces, ahí se puso freno a esa lucha contra la corrupción del Ingeniero Bolaños. Pero la lucha contra la corrupción, que inició el Ingeniero Bolaños, que era legítima, lo llevó, obviamente a tener una desgracia sobre el parlamento, y, en un primer momento, la lucha contra la corrupción tuvo éxito, y yo creo que ahí el Ingeniero Bolaños cayó en manos del Frente Sandinista, tuvo éxito porque el Frente Sandinista lo apoyó, el Frente Sandinista lo apoyó para desaforar a Alemán, el Frente Sandinista apoyó a Bolaños para procesar a Alemán, porque fueron los jueces sandinistas los que procesaron a Alemán, y ese apoyo duró un año, luego, cuando se venían ya los nombramientos, Bolaños no tenía respaldo en el parlamento, y, entonces, el Frente tenía que buscar con quien pactaba para poder nombrar a tantos otros funcionarios, para poder seguir conservando el poder político en las instituciones, entonces, el Frente Sandinista estaba con Bolaños para atacar a Alemán, pero cuando se dio cuenta que había un frente abierto en el ámbito del parlamento, porque había que nombrar a otra gente, y no tenía socios más que Alemán, volvió con Alemán, y, entonces, comenzó a suavizarse un poco el tema de la lucha contra la corrupción y el tratamiento al presidente Alemán fue, digamos, un poco más suave, más moldeable, yo creo que Bolaños no supo que al iniciar la lucha contra la corrupción de Alemán ponía a Alemán en manos del Frente Sandinista, no supo calcular hasta ahí, y quien más ganó con eso fue el Frente Sandinista, porque pudo someter a Alemán y a los acuerdos políticos de acuerdo a su propia conveniencia, y fue eso lo que hizo luego que el Frente Sandinista recuperara, por lo menos, equiparara su representación igualitaria en las instituciones, por lo menos, eso fue lo que hizo, que el Frente Sandinista llegara a tener 8 Magistrados en la Corte Suprema contra 8 de los liberales, porque, en algún momento, los liberales eran mayoría en la Suprema, entonces, fue el haberle apretado el cuello a Alemán lo que hizo que el Frente Sandinista recobrara posiciones en las instituciones, estoy hablando, indistintamente, del ámbito político. Así las cosas, se dieron las reformas de 2005, que tenían que dar un segundo paso de cara a limitar aún más el poder del Ejecutivo, y era obvio que Bolaños se opusiera, limitar el poder del Ejecutivo porque eso significaba el control parlamentario por vía de ratificación del nombramiento de ministros, que es una facultad exclusiva del presidente, y del nombramiento de embajadores, o de representantes diplomáticos en el extranjero, es una facultad del presidente, y la reforma proponía que eso lo hiciera el parlamento, acercándonos, en cierta forma, a algunos destellos de los regímenes parlamentarios europeos, ¿no?. De la misma forma, algo bueno que traían las reformas, para mí creo que eso era bueno, el hecho de que se reformara la tramitación de un veto presidencial, la facultad presidencial de vetar la ley, el parlamento sólo la podía o aprobar el veto, todo lo que decía el presidente, o rechazarlo por completo, cuando a lo mejor había cosas buenas que se podían tomar en cuenta, ¿no? Esa reforma al tema del veto sí fue, yo creo que era un paso positivo, venía en la reforma del 2005, y también venía la facultad de interpelar a los ministros, y proponer su destitución y todo ese tema. El presidente se opuso, hubo una gran crisis nacional, crisis de poderes, y dio lugar al surgimiento de la otra Ley Marco, esa fue la segunda Ley Marco, que como ya la habíamos hecho en el año 95, pues, si la hicimos en el 95, ¿por qué no lo íbamos a hacer en el 2005, diez años después? Y, efectivamente, se hicieron, se hicieron las reformas, se hizo la Ley Marco, que suspendía la aplicación de las reformas, y el acuerdo básico era que durante el gobierno del presidente Bolaños, los dos años que le faltaban a esas reformas para entrar en vigor sino hasta el año 2007. Esas reformas se hicieron, por una parte, porque los liberales querían, digamos, limitar el poder de Bolaños, en segundo lugar, porque eso trasladaba muchas facultades presidenciales al poder del parlamento, eso significaba que el Frente 
Sandinista si no ganaba las elecciones seguiría teniendo poder en el parlamento, igualmente, el partido liberal si no ganaba las elecciones seguiría teniendo poder en el parlamento, poder de limitar y de controlar el poder político real, pero que había que darle una salida a la crisis y, entonces, no se aplicaron durante ese tiempo, también el Frente Sandinista había propugnado, desde hacía ya cierto tiempo, la entrada a un régimen de tipo parlamentario, con democracia directa, a su manera, ¿verdad?, no, específicamente, de los regímenes europeos o de democracia directa, ni mucho menos, sino, como ellos dicen, algunos políticos dicen, algo más tropical. Entonces, posponer eso para el año 2007 y como sabemos luego en el año 2007, que ganó Ortega la presidencia, que ganó en las elecciones de 2006 y tomó posesión el 10 de enero del año 2007, se decidió en el parlamento, con el apoyo de la Alianza Liberal Nicaragüense, en ese entonces encabezada por Eduardo Montealegre, apoyar la prórroga por un año más, es decir, que ese acuerdo político de suspensión de la vigencia de las reformas a la Constitución se pospuso, hasta que, como sabemos, en enero de 2009 la Corte Suprema declaró nula la Ley Marco y da aplicación actual a las reformas. La reforma del año 2005, que también forman parte de la Constitución, no se han aplicado, el partido del gobierno ha cooptado a las otras fuerzas políticas, con otro montón de medios, y ellos no han tenido ni la beligerancia para ratificar a ministros que se han nombrado después de enero del año 2009, para ratificar a representantes diplomáticos que se han nombrado, o sea, es un tema que ha quedado, no se ha aplicado, la inaplicabilidad material de las reformas, que tienen vigencia formal, por la coyuntura política, por la situación política. Es interesante el fenómeno, que la política está por encima de la ley en Nicaragua, es increíble, y, bueno, ya sabemos, ahora mismo, el enorme poder y la vigencia del pacto, y como, incluso, la Sala de lo Constitucional de la Corte Suprema por encima de sus propias facultades, concedidas por la Constitución y por la ley, se retrotrae hasta las reformas de 1995 para declarar la inaplicabilidad de un artículo de esas reformas, entonces, ¿cómo se ha manifestado eso en la historia reciente de Nicaragua?, yo creo que Nicaragua ha experimentado un cambio tumultuoso, de avances y retrocesos, en el ámbito democrático, de fortalecimiento de las instituciones democráticas, y de que, más bien, yo creo que luego de un período de avances lentos, pero avances al final, hemos tenido períodos largos de retrocesos, la democracia en Nicaragua, yo creo que no ha logrado madurar, es que más bien yo creo que seguimos en una larga transición y yo he expresado, pues, o sea, sí en comentarios con profesores y nos ponemos a analizar la situación y es que a lo mejor lo que algunos que dicen que estamos volviendo al ámbito de las dictaduras de los 70, y que a lo mejor necesitamos, a lo mejor la historia de Nicaragua, el futuro de Nicaragua requiere el avance hacia un sistema de dictadura para volver a surgir en un nuevo intento por reconstruir el régimen democrático, y que a lo mejor estamos en eso, y que a lo mejor las instituciones, yo creo, tal y como estamos ahora, las instituciones no están respondiendo a su razón de ser, las instituciones no están respondiendo al ideal democrático, el Estado nicaragüense no es un Estado que uno pueda decir que es un Estado que tiene, digamos, cumple con un conjunto de indicadores que determinen que es un Estado democrático, yo creo que no es así, quizá, a lo mejor, seguimos estando en una fase de transición, pero que yo no veo, cómo los partidos políticos, cómo vayan a hacer para que los partidos políticos saquen sus manos del ámbito de las instituciones. Como ves las reformas son cíclicas, cada 5 años, ¿verdad?, a lo mejor estamos, también, frente a una gran reforma para el próximo año 2010, a lo mejor, la crisis de los poderes, las crisis de las resoluciones de la Corte, el fraude electoral, la paralización del parlamento va a determinar, a lo mejor, estamos en un nuevo, digamos, germen de otras reformas, que, a lo mejor, puede ser, incluso, una reforma total de quienes están proponiendo la refundación del Estado a 
través de una reforma total, ¿y qué tanto se acomode esto al ámbito democrático? No lo sé, porque de acuerdo a como están los partidos políticos y la coyuntura política actual, no se ve, o no veo yo, por lo menos, que se haga una reforma de refundación del Estado nicaragüense, en base a los parámetros democráticos, a lo mejor, es para seguir conservando estructuras de poder político de los partidos políticos Eso es más o menos lo que yo veo, como sabrás, las observaciones más que de contenido técnico-jurídico, son históricas, y de lo que ha sido, pues, la realidad de las reformas constitucionales en Nicaragua, en los espacios de poder y la influencia de los partidos políticos en las instituciones.

R: Has tocado casi todos los puntos que yo traía preparados en mi guión, prácticamente, pero sí me gustaría comentar algunas cuestiones, por ejemplo, el hilo conductor de las reformas, desde el punto de vista del discurso que legitima la conveniencia jurídica de reformar la Constitución, en función de determinados factores políticos, es esa semi-parlamentarización del excesivo presidencialismo que consolidaba la Constitución original del 87, y que se ha traducido, desde el punto de vista de la praxis institucional, digamos, en un dominio o una preeminencia, como un vicio formal fuerte, de las cúpulas de los partidos políticos en la Asamblea y por extensión en los restantes poderes del Estado. Hay una tentación a solucionar los problemas que tienen que ver con lo público en Nicaragua en el ámbito extrainstitucional, ese poder de facto es algo que sale, cuando uno observa no solamente la historia del país, sino esta democracia reciente, que se fundó además de forma dramática, porque después de un proceso revolucionario que termina con la dictadura, $y$ después de diez años de régimen revolucionario que no colmaba tampoco las expectativas de todos los ciudadanos nicaragüenses, ¿tú tienes la impresión de que el pacto constitucional, mejor el consenso constitucional no se ha dado?, porque siempre hay una parte de Nicaragua que queda fuera, en el caso del 87, pues, toda la oposición al régimen sandinista, y en el caso reciente, porque siempre ha habido conflictos entre Ejecutivo y Legislativo a la hora de reformar la Constitución, y luego también ahora, nuevamente, entre Legislativo y Judicial, al convertirse un poco esto en una situación de "gobierno de los jueces", como decía un entrevistado muy acertadamente.

M.A.: Sí, sí, mira, en realidad es que el tema de las reformas que han existido en la historia, incluso, las constituciones se han hecho solamente para un sector, para las clases dominantes políticamente, no económicamente, ni socialmente, no nos referimos a eso, en realidad, cuando hablo de estos temas me abstraigo completamente de los temas de clase, ¿no?, porque no tienen trascendencia ninguna, yo creo que sólo existen en la cabeza de algunas personas, de si la oligarquía esto o lo otro, pero eso son tonterías, las cosas como son en Nicaragua, en realidad, es que ha sido para beneficiar a unos en detrimento de otros, y que no ha existido como tú dices, efectivamente, no hemos redactado un texto constitucional con carácter o condición de nación, qué queremos nosotros los ciudadanos nicaragüenses, porque los políticos son ciudadanos, en realidad, hacer del Estado nicaragüense para beneficio de todos, alguien me preguntaba que si en Nicaragua había o no había equilibrio de poderes, que si más allá del aspecto formal, que dice la Constitución de que estos poderes son, digamos, tienen una armonía entre ellos y tienen una relación de que cada quien con sus propias facultades, y hay un equilibrio de poderes, si eso era real, y yo le dije que no, porque el tema es que el poder formal ha sido copado por el poder material, que representan los partidos políticos y los grupos de poder, y los grupos económicos, militares, etc., y que el problema es que el equilibrio de poderes ha sido, se encuentra extraído, más bien se 
encuentra fuera de la ley y de las instituciones, y ya está en la arena de los partidos políticos, y, entonces, el equilibrio que nos ha salido está fuera de la ley, y eso es complicadísimo de cómo restituirlo, la ley no importa, lo que importa son que el equilibrio de poderes no es el poder de la ley, en base a la ley y en base a los procedimientos establecidos por la ley, no, sino el equilibrio de poder real, ¿qué tanto poder tenés vos como partido político, como grupo de presión?, y ¿qué tanto de poder tengo yo?, que, como tú sabes, eso está fuera de la ley, yo tengo poder, no en tanto que la ley dice que yo lo tengo, sino en tanto que yo te puedo poner 50.000 personas en una calle, y te paralizo el país, no importa lo que diga la ley, ese es mi poder, y es un poder que me tienes que respetar, entonces, está fuera de las instituciones. Yo hice una consultoría hace un año, esto que te comento, te lo comento, porque, en realidad, me tocó estudiarlo un poquito, no es porque sea mi especialidad, y yo decía eso, precisamente, cuando hablábamos del equilibrio formal en la Nicaragua actual, decía: "el tema del equilibrio formal y el equilibrio material de poderes nos coloca de cara a una conclusión muy importante, el problema está ubicado más en la forma de hacer política, más en la forma de hacer política que en el marco jurídico-institucional, el problema fundamental de Nicaragua es que el poder que se trata de equilibrar, no reside en las instituciones, sino en los partidos políticos, que, deliberadamente, han tomado el control de ellas". El tema del poder y del control de poder está fuera de las instituciones.

$R: Y$, sin embargo, en relación a los partidos políticos, ayer, cuando hacía esta entrevista al diputado José Pallais, y le planteaba, en términos críticos, la responsabilidad liberal, un poco, de todo lo que está pasando ahora en este proceso de concentración de poder en el Frente, muy diplomáticamente, claro está, ellos no aceptan la responsabilidad politica, ¿no?, ni como partido, ni, finalmente, como actor de la esfera pública en Nicaragua, y ellos, pues, sí comentan que, en relación a los países europeos, está la negociación y ponía, por ejemplo, el caso español, que yo acepto, toda esta crisis que hay en el Tribunal Constitucional por la renovación de los Magistrados, porque no se ponen de acuerdo el Partido Popular y el Partido Socialista, esto se da en otros países, es cierto que la partitocracia, ya era un defecto que los politólogos europeos señalan en las modernas democracias occidentales, pero, ¿qué ocurre cuando ni siquiera los partidos políticos tienen entidad como tales?, quiero decir, que aqui da la impresión, o al menos el término "caudillismo" o la palabra "clientelismo político" prefiguran la cultura política en este contexto. No sé si fue un argumento de él para justificarse, porque yo tampoco entiendo bien lo que pasa en otros escenarios, pero sí creo que, al final, las instituciones son más fuertes y que el Tribunal no deja de actuar, en este caso, la última sentencia, claramente es un abuso de poder desde todos los puntos de vista.

M.A.: Lo que pasa es que aquí hay muchos funcionarios, sobre todo, que el poder político produce en los funcionarios públicos y en los políticos también una pérdida de la vergüenza, no existen controles en el ámbito político, de los partidos políticos, y de la responsabilidad política, nadie, nadie, no existe en el ámbito de los partidos políticos un procedimiento que determine que vamos a sancionar, a castigar a esta persona, en base a su responsabilidad política, no existe ninguno, es decir, los partidos políticos no tienen control ni entre ellos mismos, institucionalmente hablando, y, al mismo tiempo, tampoco los partidos políticos tienen la autoridad para determinar responsabilidad política de los funcionarios públicos, verdad, y porque quienes eligen a los Magistrados es el parlamento, y si los magistrados de la Corte Suprema realizan una barbaridad jurídica, si no tienen, por lo menos, responsabilidad jurídica, por lo menos que tengan 
una responsabilidad política, y los partidos políticos tampoco tienen eso en la mente, que aquí, y es normal, pues, el transfuguismo, eso ni se lo preguntas, es decir, ¿mi responsabilidad política?, yo tengo responsabilidad ética, que está muy en entredicho, entonces, ¿qué pasa?, tienden a justificarse las actuaciones que, a veces, son contradictorias de los propios partidos políticos y de los propios políticos como personas, entonces, tiende a justificarse, a encontrar una posición cómoda, ¿no?, o a darle vuelta a la situación, y te va a encontrar con ese tipo de funcionarios, me imagino, en la Asamblea, yo al presidente de la Comisión de Justicia le conozco, le conozco muy bien, he estado trabajando con él sobre algunos proyectos de reforma, obviamente, sé de su procedencia política, he conversado con él sobre algunas cosas, y me dice, bueno, yo tengo que decir esto, pues, porque tengo que decir esto.

R: No, no, y es la tarea de cualquier político en cualquier lugar del mundo, o sea, esto no es algo inherente a esta persona, ni a Nicaragua, ni al partido liberal.

M.A.: Naturalmente que sí, pero en otros lados hay responsabilidad política, los partidos políticos toman cartas en el asunto, es algo propio de la coyuntura española de hoy, ¿verdad?, cómo un partido acusa al otro de que sus políticos realizan determinados actos.

\section{R: Que se convierte en la base del discurso político nacional.}

M.A.: Exactamente, ese es el gran problema, ¿no?, y que lo que se hace es interpelar al partido político para que sea él el que controle, el que sancione a sus funcionarios, ¿no?, a los funcionarios que, en realidad, pertenecen al partido, eso no lo vas a encontrar en Nicaragua, eso no lo vas a encontrar en Nicaragua que un partido le diga, que el Frente Sandinista le diga a los liberales, "oiga y ustedes llamen a Fulano de tal que está acusado por tal cosa, o cometió tal otra", en la racionalidad de los partidos eso no existe, Luís Humberto Guzmán ha trabajado mucho el tema de los partidos políticos, incluso, publicó un libro el año pasado, me parece, sobre el tema de los partidos políticos en Nicaragua, y tiene más o menos documentado, Luís Humberto es un tipo serio, y un análisis bien interesante, que te podía ayudar un poco a esto, hay un joven de Salamanca que hizo un trabajo.

R: Ah, sí, me parece a mí, pero en Centroamérica, que es su tesis doctoral, un análisis comparado sobre la institucionalización y consolidación de los partidos políticos en Centroamérica, lo que es la articulación del sistema de partidos, lo he leído.

M.A.: Él hizo un trabajo ahí muy interesante, yo lo leí, porque se entrevistó conmigo aquí, luego me envió el borrador, y lo leí, hizo un buen trabajo.

R: Bueno, yo creo que es salvadoreño, no es español el que yo tengo en mi cabeza. No sé si estamos hablando de personas diferentes.

M.A.: Estamos hablando de personas diferentes.

R: Yo creo que también, porque este chico es salvadoreño, es centroamericano, el que yo había leído. 
M.A.: No, no, estamos hablando de personas diferentes, me mandó su trabajo pero me dijo que no lo podía citar. Este es un documento que yo preparé para un organismo internacional, entonces, no es de mi autoría, es decir, es de mi autoría intelectual, pero no tengo los derechos sobre el documento porque están cedidos. Entonces, hablo yo del marco institucional y hablo de la Constitución desde el año, desde la revolución, del Estatuto Fundamental del 79, hasta hoy, hasta hoy, un borrador, obviamente.

\section{$R:$ ¿Y sí podría tener acceso a este documento?}

M.A.: Yo te lo puedo prestar para que tengas una idea, lo lees y si te sirve de algo tomes alguna referencia, lo que no puedes es citar, como fuente si aparece en la entrevista de acuerdo, pero el documento no, porque lo hice para una embajada, entonces, está aquí hasta, pues, tú quieres todas las reformas de la Constitución hasta el proyecto de reforma actual, el que el Frente Sandinista ha dicho que quiere una reforma mucho más profunda, más integral, o sea, que vaya mucho más allá de cambios cosméticos, ¿no?, que lo que quiere es un cambio de sistema, de un sistema presidencialista como el que tenemos a un sistema parlamentario con democracia directa, incluso, con la extravagancia hasta de decir que aquí tendría que haber un parlamento, un primer ministro y un presidente, trató esas cosas, ¿no?

R: Sí, con esta división de la estructura del Poder Ejecutivo, que daría lugar a ese reparto paritario entre el PLC y el Frente Sandinista, pero ese pacto ya se rompió, o ¿cómo ves tú el pacto?, porque, desde luego, cuando hablaba con Dora María Téllez, ella con su enfoque histórico, decía que Alemán había pensado en el "pacto de caballeros" de Somoza, y Ortega no tiene esa mentalidad, por su propia psicología, por la misma cultura politica, por su procedencia guerrillera, es otra visión, ¿no?, y, entonces, Ortega, como decía ella, se va arriba, es decir, tiene una vocación hegemónica, que ha demostrado, y Alemán se convierte además en socio minoritario del pacto, porque, bueno, con su miedo a perder la libertad, prácticamente, se ha convertido en un rehén de los sandinistas.

M.A.: Claro, pero Alemán ha aprendido el juego, o sea, cuando Alemán ya lleva 9 años en el juego ha aprendido el juego, tú aprendes a conocer a tu adversario, y, entonces, sabes cuáles son las reglas del adversario, y sabes que el adversario no tiene reglas, y, entonces, es por eso que el pacto ha devenido en un procedimiento, en una forma de actuar de acuerdo a la coyuntura, verdad, yo no creo que Alemán, digamos, esté en posición de desventaja en el pacto, yo creo que él sabe, claramente, cuál es su posición, él sabe, claramente, qué es lo que es capaz de cumplir Daniel y lo que no, y sabe también cuál es la forma o el procedimiento para hacer que Daniel cumpla, lo ha probado consigo mismo.

R: Sí, pero, de todos modos, la solución de cara al futuro, ¿cuál sería?, porque ayer José Pallais me hablaba de un candidato común presidencial de todo el liberalismo, incluso, con la colaboración de MRS, es decir, una oposición anti-sandinista.

M.A.: Eso podría ser.

R: Pero Alemán va a ser un obstáculo ahí, quiere postularse también como candidato. 
M.A.: Alemán quiere construir un bloque en torno a él, un bloque de poder en torno a él, no es un bloque opositor, y que de ahí se elija un candidato, Alemán no está dispuesto a hacer eso, a nadie, es más, la sentencia de Corte, que fue el detonante, el último detonante, ya no digo varios detonantes, es el último detonante, $\mathrm{y}$, seguramente, habrá otros más adelante, la sentencia de la Corte sobre el tema de la reelección presidencial, la posibilidad de la reelección presidencial con la colaboración y complicidad directa de Alemán y del PLC, o sea, eso yo lo tengo claro, o sea, que no me digan, se hacen ahora los que no, si está, es un compromiso de Alemán, de permitir, sea por el parlamento o por cualquier otro medio, que la reelección, por lo menos el correr como candidato Daniel Ortega sea una realidad. Ese es un compromiso entre ellos, un compromiso asumido una vez que Daniel cumplió con la iniciativa de liberarlo de los cargos en enero de este año a través del mismo procedimiento, verdad, Magistrados que no llegan, no asisten a la sesión, que buscan a los suplentes y se vota la resolución, a través del mismo procedimiento, entonces, yo creo que los otros partidos políticos, el MRS, incluso, el propio Eduardo Montealegre, el movimiento "Vamos con Eduardo", los que estaban en la reunión del Hotel Intercontinental no tenían, en ese primer momento, claro, que el PLC había participado por omisión, verdad, participación por omisión en el hecho, y que más bien veían que había que formar ese gran bloque, lo que viene esto más bien es a darle oxígeno a un Alemán, que estaba enfrente de ellos, en medio de la mesa, donde estaban todos, incluido el MRS, entonces, lo fortalece, porque ellos comenzaron a girar alrededor de Alemán, es muy difícil lograr un candidato único que no sea Alemán, es muy difícil.

\section{R: Pero, entonces, no se produce la renovación del liderazgo en este país.}

M.A.: No se produce, es difícil, y el Frente Sandinista está interesado en que eso no se produzca, o está interesado en que haya varios candidatos, porque ahora la preocupación del Frente es dividir a la derecha, es dividirla, la única forma en que Daniel puede ganar es que ellos no estén unidos, sea con quien sea, pero Arnoldo Alemán tiene en su cabeza que él, él, es capaz de derrotar a Daniel, si todos los demás están con él, y, además, él cree que es el único que puede hacerlo, entonces, ahora vamos a una lucha, que es algo del pacto, el pacto está determinado en que los dos vamos a gobernar, quien tenga más votos gobierna, vamos a enfrentarnos tú y yo, eso es lo que viene, eso es lo que viene, y en eso, pues, no hay una concesión de que vos vas a ganar, no, no, va a ganar cualquiera de los dos, pero vamos a ir los dos. Entonces, el Frente, pues, tiene claro eso, pero también el Frente, uno de los mecanismos políticos es que ojala haya otras alternativas distintas al bloque de Alemán, que haya terceros o cuartos candidatos, dividirlo, lo hicieron bien en el año 2006, cuando iba Rizo por un lado y Montealegre por otro, y Edmundo Jarquín del MRS por otro, y, entonces, metieron a Pastora, por otro lado, para tratar de diluir el bloque anti-andinista, ¿no?

R: Sí, en un escenario formalmente pluripartidista, porque, realmente, hay un bipartidismo institucional.

M.A.: Exactamente, exactamente, y eso es así, y se da. Yo quisiera que eso no fuera así, obviamente, ¿no?, yo quisiera que eso no fuera así, pero no tengo elementos para pensar y decirte que aquí hay una voluntad auténtica del bloque anti-sandinista de conformar un bloque unitario para presentar un candidato único. En Nicaragua hay otro problema, todos quieren ser candidatos, o sea, todos quieren ser primeros en la lista, todos quieren 
estar ahí, entonces, yo creo que por el bien de la democracia, y por el bien del país, uno tiene que ceder espacios.

R: Sobre todo porque se ha producido en el último gobierno de Ortega un cierre de espacios tanto a nivel institucional, como, sobre todo, en el terreno de la sociedad civil, ¿no? He tenido la oportunidad de darme cuenta de los partidarios del Frente en las rotondas, del discurso, por ejemplo, de Violeta Granera y de personas que han participado en manifestaciones, de las noticias que llegan sobre estas fuerzas antichoque, que son métodos, claramente, fascistas, es cerrarle la boca al que no está de acuerdo conmigo en un ejercicio de intolerancia política sin precedentes. Entonces, si esto sigue así, el paralelismo histórico, salvando los contextos, entre los primeros años de Somoza y esta deriva peligrosa del régimen de Ortega, ¿coincides en eso?, porque hablan de la utilización del Estado como forma de enriquecerse o de tener un patrimonio empresarial insospechado, y sobre todo, el núcleo familiar, la familia, como escenario del poder más directo.

M.A: Sí, exactamente, es colaborador directo, y, además, son los verdaderos colaboradores, efectivamente, estamos volviendo luego de un período difuso a las paralelas históricas, como tú dices, efectivamente, salvando los contextos, de personas que se sienten, en aquél tiempo, liberales y conservadores se sentían representantes de toda la sociedad nicaragüense, en este momento, sandinistas y liberales, se siente representantes de la sociedad nicaragüense y ellos son el bipartidismo que tiene que seguir instituido, además, si lo hacen, porque es fácil hacer la comparación, aunque no tenga nada que ver, si lo hacen los Estados Unidos, que hay un bipartidismo entre republicanos y demócratas, ¿por qué no vamos a hacerlo nosotros si aquella es la primera democracia del mundo?, aparte de la demagogia política, obviamente, que saben. Entonces, ese discurso es cómodo para esta coyuntura, y, efectivamente, tal vez habría que analizar las implicaciones entre poder político y poder económico, ¿qué papel juega el poder económico en esta coyuntura?, sería interesante preguntárselo, ¿no?, a nivel académico, pues, un análisis serio, me refiero.

\section{R: Esa es otra tesis doctoral, francamente.}

M.A.: Sí, sí, ¿cuál ha sido el papel de la empresa, pues, del poder económico, más que la empresa del poder económico en Nicaragua?, y te vas a dar cuenta que el poder económico fluctúa a sus propios intereses, y tiene sus propios intereses, y tiene su propia agenda, y que en Nicaragua se puede tener poder político y no poder económico, y se puede tener poder económico y no poder político, pero si tienes poder político y poder económico no hay quien te venza, $y$, entonces, a lo mejor lo que se trata de construir es un partido alrededor de un grupo de personas en las que coincida el poder político y el poder económico emergente, para conversar tú a tú, no, solamente, con los políticos, sino también con los empresarios. Por lo que te digo, tú concentras el poder político, y yo veo, claramente, que Ortega lo que quiere es concentrar el poder político, que lo tiene, pero además eso respaldado por un poder económico, de forma tal que pueda gobernar en todos los sentidos, en todos los sentidos, es decir, tener, no gobernar en el sentido democrático, sino tener poder en todos los sentidos. $\mathrm{Y}$ a lo mejor eso es lo que él está construyendo, es lo que es busca, eso es lo que tú observas sin tener los elementos, ni analizar los libros contables de estas empresas que seguramente están muchos ceros ahí, ¿no? 
R: Y, una de las últimas preguntas, el Frente ha aprendido a hacer durante 16 años de oposición, a tener una penetración institucional fuerte, de hecho, el propio acuerdo de transición, de alguna forma, garantizaba la preeminencia del Frente, que además era un Partido-Estado, el régimen revolucionario, ya conocía los resortes del poder institucional, y por eso ese: "vamos a gobernar desde abajo", no fue solamente utilizado en los grupos de interés, o la propia sociedad civil, asociaciones de trabajadores, la organizaciones de estudiantes, en fin, toda esa voluntad organizativa que le puso el Frente a la sociedad de Nicaragua, sino también el Poder Judicial, copar el Poder Judicial desde abajo desde los juzgados de distrito, a los tribunales de apelación hasta la Corte Suprema, es decir, el formar a cuadros del Frente que se quedaron sin empleo cuando desaparecen los servicios de inteligencia, cuando desaparece el Ejército o también la movilización armada y mucha gente se queda sin su función en la vida, no solamente profesional, sino también, de alguna forma, personal, ¿no?, y el Frente se dedica a ubicar a estas personas, a formarlas, eso es interesantísimo, yo lo he oído en muchos entrevistados, ¿si conoces algo al respecto?

M.A.: Sí, claro que sí, pero fíjate que eso no fue pensado, es decir, no hay una, digamos, estrategia, que el Frente Sandinista después de perder el poder haya diseñado una estrategia que para "gobernar desde abajo" no, no es así, sino que se perdió el poder y fue un exabrupto de Daniel en ese momento, diciendo: "vamos a gobernar desde abajo, porque tenemos la fuerza de las estructuras sociales, que son la mayoría, y a defender las conquistas revolucionarias", es decir, la tierra de las personas, el pedir una manzana de tierra para alguien, pues, se iba defender eso, ¿no?, de que cada quien se iba a sentir impactado, es decir, si el período revolucionario te permitió obtener una casa pequeña, modesta, cómoda a un bajo precio, porque el Estado siempre las subsidiaba, pues, directamente, con fondos del Estado, pues, entonces, que vos tenías que defender eso, pero no hubo una estrategia de decir, bueno, ahora nosotros vamos a meter a nuestros cuadros en el entramado institucional, vino poco a poco, y poco a poco, y, poco a poco, y, efectivamente, no ha estado comentado de como el Frente Sandinista logró tomar el poder del Poder Judicial, por ejemplo, porque estaba diezmado el Poder Judicial, y así en otras instituciones, el reacomodo que ha habido ha sido a través de los pactos, a través de las reformas, desde el punto de vista político es interesantísimo, por supuesto que sí, lo que pasa es que uno sufre porque uno ve las cosas desde el ámbito jurídico, los juristas somos así, y vemos el ser y el deber ser, ¿no?, entonces, los políticos lo ven desde el ámbito político, en la política lo que existen son oportunidades y desafíos, victorias y derrotas, entonces, desde lo político tienen esa visión, para los que ejercen el poder político el Derecho es un medio, un medio que debe estar a favor de los intereses políticos de quien domina, el Derecho no es una institución para ellos en la cual las reglas ya están claras, el Derecho las ha definido, ahí vamos a jugar, no, el político ve cuáles son las reglas y ve cuáles son las oportunidades de cambiarlas a su favor, para que le sirvan a su juego, entonces, para ellos el Derecho es un medio, y, entonces, todos los políticos tienen esa tentación, pero tenemos políticos un poco más respetuosos de la ley, algunos que se acomodan a la ley, y otros que no le tienen ningún respeto.

$R$ : ¿Y da igual la ideología?, porque ayer el diputado Pallais me decía que el Frente utiliza el Derecho como un instrumento, mientras que los liberales tienen más apego a la institucionalidad, me decía él a propósito de los pactos.

M.A.: En tanto le conviene, ¿verdad?, tienen más respeto a la institucionalidad en tanto le conviene, pero son capaces de romperla en la medida en que lo necesiten, es decir, 
efectivamente, los partidos de derecha tienen en el mundo, porque los liberales son de derechas, pues, en Nicaragua no es que sean liberales socialistas, ni nada por el estilo, los liberales actuales son un gobierno de derecha, tienen un poco más de respeto hacia esa, pero si lo necesitan son capaces de romperla, ¿eh?, efectivamente, el partido liberal ha dado muestras de rompimiento de la ley de manera clara y flagrante, es el partido más corrupto que ha existido en los últimos 20 años, o sus funcionarios y todos sus miembros, y todos los miembros del CEN, y todos, pues, son personas que se han enriquecido del Estado, no puede haber un mayor rompimiento de las reglas de convivencia democrática que el utilizar recursos del pueblo para beneficiarse a sí mismo, o sea, no más es cualquier cosa, nada más que por ahí se podría comenzar, y eso demuestra también la frágil democracia que tenemos, porque creo yo que una democracia se puede tildar de frágil si las bases mismas de la democracia están en entredicho cada día, si el respeto por el erario público, si el respeto por las garantías y los derechos de la gente están en entredicho cada día, eso demuestra que es una democracia frágil, controlada y administrada por instituciones, igualmente, frágiles. Me parece a mí que eso es lo que hay.

R: Pues si tienes algo más que añadir, yo creo que hemos hablado de casi todo...

M.A.: No, no, está bien. 


\section{ENTREVISTA 69:}

Nombre del entrevistado: D. Carlos Arroyo.

Cargo actual: Profesor de Ciencia Política de la Universidad Americana (UAM). Asesor del PNUD en la Asamblea Nacional de Nicaragua.

Fecha de realización de la entrevista: Managua, 11 de septiembre de 2009.

Lugar: Facultad de Diplomacia y Relaciones Internacionales de la Universidad Americana (UAM).

Duración estimada: 47 minutos.

\section{TEXTO - Transcripción 6:}

$R$ : ¿Cuál es tu visión sobre los cambios constitucionales experimentados en Nicaragua durante el período democrático?

C.A.: Perfecto, bueno, en el caso de Nicaragua, creo que la historia nos demuestra que, en términos generales, los procesos de reformas constitucionales, que se han dado a través de la historia en Nicaragua siempre han estado caracterizados por ser procesos de reforma orientados a beneficiar a aquellos sectores políticos que los promueven, creo que es difícil pensar, tal vez algún constitucionalista o un historiador, ¿no?, podría de pronto encontrar alguna experiencia en particular que diga lo contrario, pero en lo personal, desde mi conocimiento, es decir las experiencias de reformas constitucionales han sido, diríamos, o han tenido consecuencias, fundamentalmente negativas para la institucionalidad del país, porque como son, precisamente, procesos de reforma pensados para beneficiar sectores políticos o actores políticos en particular, difícilmente, se conciben como procesos orientados a la modernización del aparato público, ¿no?, u orientados a establecer reglas del juego que permitan, diríamos, una estabilidad a largo plazo, ¿no?, es decir, son reformas constitucionales, que además de estar pensadas para beneficiar intereses muy particulares, también son reformas constitucionales bastante coyunturales, que, de una u otra forma, hacen que al pasar de los años, ¿verdad?, pierdan validez, pierdan lógica, y, entonces, genere un círculo vicioso, ¿no?, de comenzar a explorar nuevas reformas, nuevas reformas, no tengo, diríamos, el dato específico, pero tal vez no me equivoco si digo que la Constitución de Nicaragua ha sido una de las constituciones más reformadas, ¿no?, a través de la historia, entonces, en ese sentido, diríamos, ha habido una incapacidad de la clase política de pensar las reformas constitucionales con una visión estratégica, con una visión de país, ¿no?, como te decía, orientada a construir institucionalidad, muy por el contrario, las reformas constitucionales tienden a minar la institucionalidad en tanto, diríamos, llevan a que las distintas instituciones del Estado operen bajo una lógica clientelista, ¿no?, es decir, una lógica que responde, precisamente, a los intereses particulares de aquellos actores que se empeñan en modificar la Constitución para beneficio propio, ¿no?, entonces, en ese sentido, pues, sí ha sido, diríamos, casi una debilidad estructural, ¿no?, del país.

\footnotetext{
9 Entrevista interrumpida al final de la grabación, aunque no se consideró necesaria su repetición en una segunda cita, dada la suficiencia del material de análisis aportado por el entrevistado, en cuyo discurso destaca, especialmente, la referencia al aprendizaje institucional de las fuerzas políticas en la arena parlamentaria en el contexto de la transición democrática, así como el proceso de neutralización del conflicto social a través de los pactos políticos entre las élites, que, posteriormente, se han traducido en cambios constitucionales específicos.
} 
R: Otra cuestión, que me llama la atención también en el caso de Nicaragua es que en el proceso de reforma puede haber un hilo conductor, que se centra, fundamentalmente, en debilitar ese presidencialismo exacerbado de la Constitución del 87, ¿no?, con la que gobierna el presidente Ortega bajo el régimen sandinista, a darle mayores facultades y atribuciones a la Asamblea Nacional. Tú que además tienes mayor relación con el Poder Legislativo, ¿cómo han aprendido los actores a hacer política, diríamos, en la arena parlamentaria, que habia estado tan débil y tiene tan poca tradición en la propia historia política del país?

C.A.: Claro, bueno, precisamente, creo que esa ha sido una de las debilidades en el sentido de que, desde la Asamblea, creo que son muy pocos los legisladores que tienen, diríamos, una perspectiva más o menos clara de las facultades y de las competencias de las cuales disponen desde el punto de vista jurídico para, diríamos, hacer un efectivo contrapeso, ¿no?, al poder del Ejecutivo, en ese sentido, diríamos que desde la Asamblea hay muy poca capacidad técnica y ya no se diga política para administrar esas facultades que desde las reformas constitucionales del 95 se le dieron, ¿no?, a la Asamblea, y eso, fundamentalmente, porque adolecemos de una clase política, diríamos, con un cierto nivel de preparación en el ejercicio de la profesión política, es decir, entonces, generalmente, la agenda de los legisladores fluctúa, ¿no?, entre la agenda de la bancada oficialista, que es, básicamente, la agenda del Ejecutivo, y, diríamos, la posición casi de confrontación que existe desde las bancadas del Legislativo, pero sin ningún ejercicio de construir, ¿no?, por ejemplo, propuestas que rebatan, que complementen, que puedan significar, por ejemplo, opciones alternas a veces a las propuestas del Ejecutivo, sino que es una oposición por oponerse, ¿no?, es decir, es una oposición que no tiene, diríamos, una propuesta alternativa desde el Ejecutivo, ¿no?, y, por ejemplo, las labores de fiscalización, de control, que puede ejercer el Legislativo en relación a la labor que desempeña el Ejecutivo es muy poca, es decir, los diputados están muy poco interesados, verdad, en monitorear, diríamos, exhaustivamente, la labor del Ejecutivo, únicamente, reparan en aquellos hechos que son mediáticamente trascendentales, ¿no?, y que pueden significarles algún incremento en la popularidad, o proyectarlos políticamente, pero no es un trabajo legislativo profesional en el sentido estricto, ¿no?, entonces, ha habido también mucha oportunidad perdida desde el Legislativo para potenciar las facultades y los poderes que la misma ley les concede, ¿no?, y, en efecto, es decir, no es por falta de legislación, sino solamente es por falta de pericia técnica y de incapacidad política de los mismos legisladores de poder cumplir, ¿no?, con estas funciones, es decir, básicamente el legislador nicaragüense entiende que su competencia fundamental es aprobar leyes, ¿no?, presentar iniciativas de ley, aprobar la ley, pero, es decir, hasta ahí, no existe, incluso, ni siquiera, incluso, una labor de seguimiento a la aplicación de la ley, por ejemplo, o a la aplicación de la labor de las instituciones encargadas de aplicar una determinada ley, las interpelaciones, por ejemplo, a los Ministros de Estado son, fundamentalmente, con motivaciones políticas, no existe tampoco, por ejemplo, agendas de trabajo común entre los legisladores y algunos sectores del Ejecutivo en temas que les son afines, por ejemplo, en las Comisiones de Economía, o las Comisiones de Producción, de Relaciones Exteriores, es decir, no existe ese vínculo, verdad, vínculo en el mejor de los casos, ni seguimiento o fiscalización y control desde el Legislativo al Ejecutivo, entonces, hay un enorme vacío también en ese sentido, y eso hace que, de una u otra forma, en tanto, diríamos, la ley se convierte en una camisa de fuerza para el Ejecutivo en ciertas cosas, porque se necesita aprobar con determinada cantidad de votos y tal vez el Ejecutivo no tiene, digamos, esos votos en la Asamblea, en esa medida, el Ejecutivo comienza a buscar, ¿no?, rutas 
alternas que no siempre están debidamente sustentadas en términos legales, ¿no?, en términos jurídicos, entonces, creo que las facultades que las reformas constitucionales le han dado a la Asamblea a partir del 95 no han sido debidamente utilizadas, pero al convertirse a la vez, diríamos, en una restricción formal a ciertas acciones, verdad, del Ejecutivo, hace que el Ejecutivo comience a buscar rutas alternas que no siempre, diríamos, son adecuadas para la estabilidad del país, es decir, empieza a haber un juego más de control de otros poderes del Estado, la cooptación, por ejemplo, del Poder Judicial para amparar o para respaldar actuaciones del Ejecutivo de muy dudosa legalidad, verdad, o de la Contraloría General de la República para evitar cualquier labor de fiscalización, si es que, en algún momento, existe desde el Legislativo algún interés de hacerlo, que muy poco se ha visto, verdad, desde el 95 a la fecha, y empiezan, precisamente, a pensarse, entonces, en reformas que, de una u otra forma, lo que intentan es fortalecer nuevamente el presidencialismo, eso a grandes rasgos.

R: La reforma del 2000 sí establece un punto de inflexión, ¿no?, la del 95 era una reforma necesaria porque se inaugura el tránsito a la democracia después del régimen sandinista que rompe con la dictadura, y es un camino hacia la democracia muy arduo el que tiene el sistema político nicaragüense. Las reformas del 2000 suponen ya un pacto entre los dos grandes líderes de los partidos mayoritarios y la consolidación también de un reparto paritario de sus cuotas de poder en los principales órganos del Estado, de ahi la deriva hacia la del 2005 y a la situación reciente que estamos viviendo en el momento actual, con todo este debate sobre la reelección presidencial o, incluso, la parlamentarización de la democracia presidencial nicaragüense. ¿Cuál es tu opinión al respecto?

C.A.: Correcto, bueno, en esencia, las reformas constitucionales, mejor dicho, el debate que está planteado alrededor de las reformas constitucionales, actualmente, creo que, realmente, dista mucho de un debate serio alrededor de la consolidación de un sistema presidencialista o de un semi-parlamentarismo o parlamentarismo, creo que, realmente, de eso hay poco o nada, es decir, hay, básicamente, un interés manifiesto del partido de gobierno de impulsar una reforma constitucional única y exclusivamente con el fin de obtener la posibilidad de una reelección presidencial, creo que el tema del semiparlamentarismo fue hasta cierto punto, diríamos, una fachada, ¿no?, para tratar de despertar cierto interés en los partidos de oposición, que podrían, eventualmente, mirar ese cambio de sistema como un sistema que fortalezca todavía más la labor del Legislativo, y que le permita, diríamos, controlar los excesos de poder del Ejecutivo, pero creo que eso al día de hoy está, prácticamente, descartado, incluso, el Magistrado Rafael Solís, que ha sido uno de los operadores políticos, digamos, más cercanos al presidente Ortega durante los últimos años, y que ha estado involucrado, es decir, bastante en el proceso de negociaciones con el Partido Liberal Constitucionalista, y que ha desembocado en los pactos, porque mucha gente habla de los pactos, ¿no?, OrtegaAlemán, ya él, públicamente, ha admitido que el tema del cambio de sistema político es algo que ya no se contempla dentro de las negociaciones, creo que lo dijo hace un par de meses en una entrevista que dio a un medio nacional, y, básicamente, el tema ahora se concentra ahora en el tema de la reelección, y por eso a partir de la reflexión que hacías, inicialmente, por ejemplo, del cambio entre las reformas del 95, que, en efecto, fueron necesarias en su momento, pero que alguna de ellas, por ejemplo, llevaban nombre y apellidos, y el caso, por ejemplo, de Antonio Lacayo, ¿no?, para inhibirlo de correr a las elecciones presidenciales, verdad, del 96, efectivamente, marcan una diferencia con las reformas del 2000, ¿no?, que ya son unas reformas que surgen, precisamente, del pacto, 
de la negociación entre Alemán y Ortega, y por eso a partir de esa reflexión un poco regreso a lo que te decía inicialmente, es decir, ese tipo de ejercicios demuestran que las reformas, los procesos de reforma constitucional en Nicaragua no son procesos pensados en función de la institucionalidad del país, hay quienes dicen, por ejemplo, que, bueno, en un país como Nicaragua donde la polarización política ha sido, diríamos, una característica de nuestra cultura política, esta especie de acuerdos, ¿no?, políticos, que tienen una traducción jurídica que llega, como en estos casos, hasta tocar y modificar la Carta Magna del país, son una forma de darle estabilidad al país, es decir, en un país donde a partir de esa polarización existente nuestra cultura política parte de aquél principio de que el que gana lo gana todo, y el que lo pierde lo pierde todo, ¿no?, entonces, eso hace que desde la oposición, básicamente, te dediques a sabotear o a boicotear la gestión del gobierno de turno mientras pasa el tiempo para que puedas nuevamente optar, ¿no?, a ganarlo todo nuevamente, entonces, hay quienes lo ven así, y, en lo personal, creo que es una forma muy, diríamos, muy burda de tratar de justificar acuerdos políticos, que están cimentados, únicamente, sobre una lógica clientelista, y una lógica prebendaria, ¿no?, pero bueno, y esto que te comento a lo mejor lo escucharás, seguramente lo vas a escuchar en algunas de las entrevistas, si no es que ya lo has escuchado, y no, diríamos de cualquier personas, sino, incluso, de académicos, que dicen, bueno, este país sin el pacto, básicamente, se cae, verdad, porque son las dos principales fuerzas políticas, y son las que, de una u otra forma, le han dado estabilidad al país, y prueba de ello es que durante los primeros años de Doña Violeta, mientras no hubo esos acuerdos, este país era un país que iba de crisis en crisis, pero si uno revisa, realmente, la historia te das cuenta, es decir, no son crisis, diríamos, producto, necesariamente, de la gestión gubernamental, o de la impopularidad de los gobiernos, o de alguna política impuesta o alguna decisión impuesta desde el Ejecutivo, las crisis en Nicaragua desde el 90, y las crisis institucionales de mayor repercusión han sido, básicamente, generadas por el Frente Sandinista, es decir, que es un partido que tiene una capacidad de movilización bastante grande, ¿no?, entonces, es un partido que tiene, realmente, la capacidad de paralizar el país, sea con el sector transporte, sea con los estudiantes, sea con los sindicatos de maestros o los sindicatos de médicos, pero no han tenido, diríamos, motivaciones más allá que, realmente, generar una situación de caos en la cual el Frente Sandinista se posiciona mejor para negociar, verdad, que ha sido como, diríamos, la tradición en cuanto a cómo opera el Frente Sandinista, ¿no?, es decir, un partido que está acostumbrado a negociar en el límite, en el caos, ¿no?, donde siempre tiene mayores réditos, entonces, si lo ves desde esa perspectiva, se podría decir, sí, la estabilidad que le ha dado el pacto y las reformas del 2002 al país podría ser un argumento válido, ¿no?, pero yo difiero mucho de esa posición en tanto la inestabilidad no ha sido una inestabilidad ocasionada por el propio sistema, ¿no?, es decir, o producto de una gestión gubernamental, diríamos, autoritaria, o de un descontento social masivo con ciertas políticas de gobierno, ha sido, fundamentalmente, una inestabilidad producto de una estrategia política del partido, en ese tiempo, de oposición, que era el Frente Sandinista, con una gran capacidad de movilización, que, prácticamente, te paralizaba el país, pero, incluso, el mismo pacto Arnoldo Alemán- Daniel Ortega tiene su raíz, diríamos, en una concepción desde la cual Arnoldo Alemán, básicamente, asume que para poder gobernar sin los problemas que tuvo Doña Violeta anteriormente, necesita negociar con el Frente Sandinista, y el Frente Sandinista ve esa negociación como una oportunidad para recuperar espacios de poder que no tuvo durante el gobierno de Doña Violeta, más allá de aquellos que dicen, bueno, era también, diríamos, como una carta en blanco que el Frente Sandinista le daba a Alemán para que pudiese saquear el país, que fue, finalmente, lo que hizo, sin que eso fuese, diríamos, a significarle esa 
movilización social que sí había en otros temas, es decir, aquí nunca hubo de parte del Frente Sandinista, por ejemplo, ninguna movilización, ninguna marcha, ninguna actividad beligerante en contra del gobierno de Alemán por actos de corrupción, nunca la hubo, es decir, y fue, básicamente, pura retórica, verdad, show mediático, ¿no?, acusaciones en los medios, etc., pero nunca hubo, por ejemplo, una movilización, a pesar que toda Nicaragua estaba clara del mal manejo que hacía Arnoldo Alemán del erario público, por ejemplo, y nunca hubo ningún tipo de movilización al respecto, como sí lo había, por ejemplo, cuando el Frente argumentaba que no se le daba el 6\% constitucional a las universidades, por ejemplo, y salían los estudiantes a la calle y paralizaban, prácticamente, el país, entonces, creo que el propio pacto, y las reformas constitucionales que se derivan de él en el 2000, está cimentado en esa lógica de, diríamos, comprar cierta estabilidad Alemán, por un lado, y el Frente adquirir o recuperar algunos espacios de poder que no tenía, o que no tuvo durante el gobierno de Doña Violeta, pero, es decir, a partir de beneficios muy puntuales, verdad, para sus partidos, no veo yo que haya ese razonamiento de fondo, de, OK, vamos a darle estabilidad al país, vamos a hacer un acuerdo, vamos a reformar la Constitución en la lógica de fortalecer las instituciones, en función de modernizar el Estado, eso no, eso no, no, no está pensado de esa manera, pues, o por lo menos yo no lo veo así, y prueba de ello es que la división paritaria que hay en los poderes del Estado, me parece que es una prueba de ello, pues, porque, al fin y al cabo, no estamos hablando de Magistrados que puedan tener algún tipo de simpatía hacia uno u otro partido, que nos parece que resulta natural, ¿no?, en cualquier país del mundo resultaría algo perfectamente natural, el problema es que estamos hablando de que no son simpatizantes son militantes, verdad, es decir, activos de sus partidos políticos que van a las actividades políticas de sus respectivos partidos, que reciben instrucciones de sus partidos políticos, y que actúan conforme a esas instrucciones, y que su actuar en el cargo, es decir, está totalmente condicionado por criterios políticos, no es que soy simpatizante, pero a la hora de ejercer mi cargo eso queda a un lado, no, es decir, está claramente evidenciado por las pruebas del Poder Judicial, como hay numerosos casos, numerosas sentencias, que, claramente, apuestan a beneficiar los intereses de uno u otro partido, verdad, entonces, yo no veo, por ejemplo, que las reformas constitucionales del 2000 hayan estado pensadas, es decir, bajo esa lógica, que algunos señalan, de darle estabilidad al país, y que sin eso se cae, es decir, creo que lo que ha habido ha sido una neutralización de la conflictividad social, en tanto el Frente Sandinista desde el 2000 hasta que se convirtió en gobierno, porque, pues, ahora es difícil pensar que haya alguna marcha de maestros, de sindicatos y demás cosas por el estilo, pero, diríamos, que lo que ha habido es una neutralización de la conflictividad social, en tanto el Frente Sandinista a partir del acuerdo con el PLC decide, verdad, diríamos, cambiar su estrategia, ¿no?, de movilización y de desestabilización social por una estrategia orientada a posicionarse, primero, en los espacios de poder que le dio Alemán, y, luego, de irlos incrementando cada vez más, ¿no?, que es lo que al final ha terminado sucediendo, pero, si bien, uno podría decir, la estabilidad está derivada de esa neutralización de la conflictividad social también es un hecho que eso no ha servido para nada, o ha servido muy poco para darle estabilidad real al país a partir de un acuerdo político de consenso, de interés para todos, y sobre todo de un proceso de fortalecimiento institucional, ¿verdad?

R: A mí me llama mucho la atención cuando estudio la historia constitucional de Nicaragua, que la palabra "consenso", y "pacto", esa necesidad de aunar, digamos, la capacidad de diálogo entre los distintos actores políticos para diseñar unas reglas de juego con las cuales todos estén de acuerdo, discurre de una forma muy conflictiva, de 
hecho, en los tres procesos de reforma actuales el Ejecutivo presidencial se ha enfrentado siempre al Legislativo, en el primer caso, incluso, flexibilizando las propias cláusulas de revisión constitucional, y necesitando de ese instrumento jurídicamente controvertido que son las leyes Marco, que no hacen sino ampliar congelando temporalmente la vigencia de las normas constitucionales reformadas para que los actores politicamente enfrentados negocien, sigan negociando, entonces, hay una lectura siempre política, en el fondo, de los cambios constitucionales.

C.A.: Exactamente, yo creo que esa ha sido una de las grandes incapacidades de la clase política nicaragüense, es decir, el poder despartidizar, diríamos, desideologizar, ¿no?, el debate, y tratar de pensar como fuerzas políticas constructivas, ¿no?, en función de cumplir con esa labor a las que están llamadas a cumplir los partidos políticos que es servir, fundamentalmente, de intermediarios entre las demandas de la ciudadanía, y creo que, en ese sentido, es notoria esa incapacidad, es decir, esa concepción de que prime la cultura política nicaragüense de ganarlo todo, o perderlo todo, del juego suma cero, hace que los mismos procesos de reforma política, de reformas constitucionales, estén siempre impregnados de un alto nivel de desconfianza entre las fuerzas políticas, ¿no?, es decir, ninguna fuerza política se cree que la propuesta de la otra es una propuesta que aspira a construir institucionalidad, que aspira a construir gobernabilidad, siempre, diríamos, la desconfianza termina siendo como el factor fundamental, ¿no?, y aunque a simple vista pueda percibirse, digamos, una propuesta que, en apariencia, representaría los intereses de amplios sectores, al final siempre las fuerzas políticas tienden a verla con desconfianza, y tienden a ver intereses ocultos, que, a veces, incluso, son hasta incapaces de explicar o de encontrar, verdad, por otro lado, también, es decir, existe, a mí me parece que existe una lógica perversa en las fuerzas políticas de, diríamos, debilitar, deteriorar al máximo, la gestión política del gobierno de turno para posicionarse ellos mejor de cara a la próxima contienda electoral, es decir, en un país que adolece mucho del debate serio, del debate responsable, pero, evidentemente, en un país, diríamos, con unas tasas de escolaridad muy bajas, donde tampoco la población logra procesar muy bien un debate de altura, es decir, ni siquiera procesar muy bien, muchas veces es incapaz de comprender un debate de altura, las fuerzas políticas entienden, entonces, que ese es un ejercicio como inútil, es decir, ¿de qué sirve, por ejemplo, discutir o rebatir las propuestas del Ejecutivo a partir de argumentos técnicos, de factibilidad y habilidades políticas, de beneficios reales?, es decir, no sirve de mucho entrar en ese tema de discusión, porque también a la gente muy poco le importa y eso genera muy poco voto, ¿no?, entonces, acá lo que sirve es, fundamentalmente, oponerse porque esa ley está en contra de los pobres, verdad, y está a favor del gran capital, verdad, o me opongo porque esa ley es una ley que está al margen de la legalidad, etc., o sea, uno de los grandes problemas del país, y, particularmente, de la clase política, en este sentido, es la falta de discusión sustantiva, ¿no?, es decir, aquí, fundamentalmente, las discusiones de la clase política en torno a las reformas constitucionales, en torno a cualquier tipo de tema casi siempre son procedimentales, son cuestiones de procedimiento y no son sustantivas, realmente, entonces, y por eso te decía, por un lado, tiene que ver con la cultura política del juego suma cero, o de la desconfianza permanente, de boicotear, de desgastar al máximo la gestión de gobierno para posicionarme y venderme mejor yo de cara a las próximas elecciones, pero, por otro lado, tiene que ver también con deficiencias históricas y estructurales del país, y que, en este caso, yo las asocio, fundamentalmente, a los niveles de escolaridad de la mayoría de la población nicaragüense, que tampoco, me parece, está preparada, pero no lo quisiera poner como que no está preparada, yo diría más bien que tampoco entiende, o 
que tampoco demanda o exige a la clase política ese debate de altura, ese debate sustantivo, o ese ejercicio democrático, sino que, básicamente, una población que está, diríamos, también altamente politizada, ideologizada, fragmentada, y que sobretodo tiene problemas, diríamos, excesivamente básicos como para entrar en niveles de discusión sofisticados, ¿no?, es decir, aquí lo que me interesa es que a mí me resuelvan el tema de cómo baja la luz, cómo baja el agua, cómo puedo pagar menos en tal servicio, cómo me den educación gratuita, cómo me den salud, son problemas tan básicos que también hacen que la clase política termine concentrando sus discursos en cuestiones excesivamente básicas, ¿no?, y sobre todo procedimentales, porque el debate sustantivo me parece que al final queda más en manos de los académicos, ¿no?

R: Otro asunto, ya para ir muy rápido, porque ya no tenemos mucho tiempo, es el tema de la ausencia de un programa coherente de reformas, es algo que tú has apuntado hablando, fundamentalmente, de la connotación interesada que tienen muchos de los cambios institucionales, pero si hay como planteamientos dispersos, que ni siquiera reflejan no una necesidad ya de fondo, sino, digamos, una prioridad, ¿no?, un argumento que esté detrás de la propuesta.

C.A.: En efecto, es decir, un poco, pues, por lo que hablábamos anteriormente, cuando las reformas están concebidas desde un inicio, desde su concepción original están pensadas para satisfacer intereses particulares es difícil tener propuestas de reforma de carácter estratégico, ¿no?, es decir, reformamos la Constitución ahorita para que, únicamente, para habilitar la reelección presidencial continua, ¿y después qué?, ¿qué hay de fondo?, ¿qué otras cosas vamos a discutir?, ¿vamos a discutir la Ley Electoral?, ¿las reformas al sistema electoral?, ¿vamos a discutir, realmente, y con seriedad un cambio de sistema y qué implica eso?, ¿vamos a discutir creación o supresión de instituciones?, o sea, ¿vamos a discutir qué otras cosas?, es decir, por eso es que hay quienes son del argumento de que las reformas constitucionales que se plantean ahorita son reformas innecesarias, es decir, con lo que existe, sabiéndolo aplicar o más que sabiéndolo aplicar aplicándolo como lo dice la propia Constitución se podría dar un salto cualitativo, ¿no?, y un salto importante en la dirección de fortalecer la institucionalidad y la gobernabilidad del país, es decir, pero si las reformas están pensadas, únicamente, para habilitar la reelección presidencial continua, es decir, son reformas totalmente innecesarias, no son una prioridad para la mayoría de los nicaragüenses, y además de eso son vistas como un tema que genera, que exacerba la polarización, y que, eventualmente, puede convertirse en un factor de inestabilidad, de mayor inestabilidad en el país, entonces, por ejemplo, en el 2000, cuando la reforma se hablaba, bueno, de la ampliación de cargos en los diferentes poderes del Estado, y eso fue un tema, bueno, pasar la Corte de 7 Magistrados a 9, luego a 12 y luego a 16, simplemente, para dar más espacio, verdad, a los dos partidos mayoritarios y poder colocar a sus gentes, a los afines, ¿no?, es decir, se discutía alrededor de eso, yo creo que hoy en día, por ejemplo, ni siquiera ese tipo de cosas están en discusión, bueno, y en aquella oportunidad cometimos el error de ampliar, es decir, lo que le está significando al Estado, año con año, verdad, una cantidad $\mathrm{X}$ de recursos, verdad, $\mathrm{OK}$, bueno, pensemos en compactar los poderes, es decir, en un país como Nicaragua, el segundo más pobre de América Latina, es decir, con la crisis que se vive, la crisis económica, pensemos en hacer poderes más compactos, regresar tal vez al esquema original, es decir, pero ni siquiera eso está planteado, pues, ni siquiera esa discusión está planteada, la discusión está planteada únicamente en términos de reforma para que haya o no haya reelección, entonces, en efecto, no hay dentro de las fuerzas políticas una 
visión de reforma como, diríamos, como un ejercicio que contribuya a mejorar la institucionalidad del país, o a iniciar un proceso serio, estratégico, de modernización del Estado, es decir no existe ese tipo de lógica dentro de las fuerzas políticas, ¿no?, entonces, las reformas, por eso, un poco, retomando ideas iniciales las reformas, es decir, se vuelven reformas coyunturales, ¿verdad?, a partir de los intereses del momento de las principales fuerzas políticas, y reformas que una vez cumplido ese objetivo, una vez satisfechos esos intereses, es decir, pierden razón de ser, pierden, diríamos, importancia, y al final uno no termina percibiendo, uno como ciudadano, ¿no?, no termina percibiendo el beneficio de esas reformas, es decir, por ejemplo, yo al día de hoy me pregunto si las reformas del 2000, es decir, han servido, realmente, para tener un país con mucho más nivel de institucionalización, con mayor estabilidad, es decir, aquí lo que veo más bien es que cada vez que tocan elecciones de Magistrados y de, existe siempre la posibilidad o la probabilidad de una crisis institucional y la paralización de un poder del Estado, entonces...

R: Sobre todo porque los bloqueos que se dan en la propia Asamblea Nacional por desacuerdos entre los principales partidos se han traducido a los órganos constitucionales, ¿no?

\section{C.A.: Exactamente.}

R: Es decir, si no hay acuerdo en la elección de los Magistrados de la Corte Suprema, o del Consejo Supremo Electoral, cuya legitimidad y afectación, digamos, en términos de opinión pública ha disminuido mucho a raíz de las últimas elecciones, ¿no? Cómo interpretas, ya para finalizar, el funcionamiento de estos órganos que supusieron un logro, en términos de diseño puro institucional, muy interesante para un país como Nicaragua, o para otros países, como es el caso de México, el Instituto Federal Electoral es uno de los primeros que se crean en América Latina, y que encarna la esperanza de la celebración de elecciones transparentes y objetivas, es verdad que una democracia no se reduce, exclusivamente, a un proceso electoral, pero sí la decisión de los ciudadanos a través del voto y la elección de las élites en ese proceso dice mucho del mecanismo a la hora de dirimir los conflictos a través de la política democrática, ¿no?, después de haber vivido una guerra.

C.A.: Claro, claro, es que precisamente el tema acá de fondo es que es difícil pensar que, precisamente, los poderes del Estado, verdad, puedan convertirse, precisamente, en instancias para dirimir, verdad, diríamos, poderes, conflictos, ¿no?, y poder hasta cierto punto atender anhelos, demandas y expectativas de la sociedad, porque en tanto están conducidas desde una lógica partidaria, verdad, el órgano en sí, la institución no puede considerarse como ese espacio, precisamente, para resolver ese conflicto, más bien puede ser el foco del conflicto o puede ser el origen del conflicto, puede surgir de la misma institución, del mismo órgano, es decir, al final todo termina resolviéndose en la arena, estrictamente, político-partidaria, y si no logra resolverse ahí, más bien termina, diríamos, trasladándose a los poderes, entonces, evidentemente, diríamos, que eso es un mecanismo bastante perverso, ¿no?, porque deja todo en manos de, es que es incluso difícil de decir, de los partidos políticos, deja todo en manos de las cúpulas partidarias, verdad, que de no encontrar un entendimiento político, prácticamente, tiran al traste la institucionalidad o más que tiran al traste paralizan la institucionalidad, entonces, las instituciones lejos, diríamos, lejos de ser un espacio, o podríamos decir, de propiciar mecanismos para la solución de problemas, de crisis y eso, más bien se convierte o en 
víctimas de crisis que no logran resolverse en el ámbito estrictamente políticopartidario, o terminan siendo orígenes mismos de crisis, en tanto desacuerdos internos entre, verdad, entre Magistrados, entre funcionarios de un partido o del otro, porque al final terminan viéndose así, ¿no?, es decir, vos de un partido y yo de un partido, pero no somos, verdad, diríamos, no existe esa visión de cuerpo, ¿no?, ese sentido de cuerpo, de pertenecer a la misma institución, al final trabajamos en la misma institución, pero somos de partidos diferentes, verdad, y esto funciona en la medida en que nuestros partidos, o las cúpulas de nuestros partidos logran entenderse, entonces, es difícil, porque las instituciones aquí no están pensadas ni están creadas, por menos desde la lógica de cómo opera el país, para dirimir conflictos, verdad, es decir, al final los conflictos se resuelven a partir de la negociación entre las cúpulas partidarias, y, entonces, de pronto, los nicaragüenses nos vemos en la triste situación, como decimos, de cruzar los dedos, ¿no?, de pedir para que las cúpulas se entiendan, porque si no se entienden, es decir, esto se vuelve, y, entonces, viene el argumento de aquellos que dicen: "ah, por eso el pacto es necesario para la estabilidad del país", ¿verdad?

R: Sí, ese es el argumento de excepción que se ha dado además a todos los pactos de la historia constitucional de Nicaragua, ¿no?

\section{C.A.: Exactamente, exactamente.}

R: Incluso hay partidarios del régimen de Somoza porque dio la estabilidad política que permitió el crecimiento económico.

C.A.: Exactamente, exactamente, pero al final todo esto termina operando, desde mi punto de vista, como una especie de chantaje social, ¿no?, es decir, un chantaje social en donde el pacto, el acuerdo, es decir, aunque esté sustentado o cimentado en una lógica estrictamente prebendaria y clientelista se torna necesaria para garantizar la estabilidad del país, ¿verdad?, entonces, me parece que eso resulta bastante perverso, ¿no?

R: ¿Y qué futuro auguras en el próximo año de dificultades?, al menos esa es la percepción de casi todos los entrevistados, por este cierre de los espacios politicos, ¿no?, pienso en la figura de la oposición tanto en la arena parlamentaria como en la protesta social, que ha sido muy restringida, y el gobierno de Ortega que quiere ampararse, digamos, en el núcleo además familiar, porque no hay una falta de vínculo con el partido, pero si hay un cierto personalismo en el ejercicio del Ejecutivo presidencial. ¿Cuál es tu opinión?

C.A.: OK, si te parece, me gustaría que nos viéramos una segunda vez y conversamos, porque ahora sí estoy en tiempo, me toca comenzar la clase y ya sabes como son los chicos, ¿no?

$R$ : Si, no te preocupes, si te retrasas cinco minutos se van todos. 
ENTREVISTA $7^{10}$ :

Nombre del entrevistado: $D^{a}$. Mónica Baltodano.

Cargo actual: Diputada de la Asamblea Nacional (2007-2011), perteneciente al partido Rescate del Sandinismo.

Fecha de realización de la entrevista: Managua, 11 de noviembre de 2009.

Lugar: Fundación Popolnah.

Duración estimada: 48 minutos.

\section{TEXTO - Transcripción 7:}

R: ¿Cuál sería su visión sobre los cambios constitucionales que se han producido en el país?

M.B.: Bueno, para la Constitución del año 1987 estábamos viviendo una guerra de agresión, había triunfado una revolución, que eso puede darte una idea sobre lo que costó bajar al dictador, tengo un trabajo sobre esto, te lo puedo dar después, entonces, la Constitución, pasamos un período entre el 80 y el 87 que estábamos regidos por una Carta, digamos, pero no era, propiamente, una Constitución, es decir, nosotros lo que hicimos fue desconocer la Constitución existente durante la dictadura y se empezó a trabajar en una nueva Constitución en un ambiente, como te digo, de guerra, de confrontación con los Estados Unidos, influidos muchísimo por el modelo de las revoluciones en América Latina, por Cuba, digamos, y aunque el escenario para nosotros fue muy diferente desde el principio, porque nosotros tuvimos tres pilares fundamentales: pluralismo político, economía mixta y no alineamiento, como pilares de la revolución, entonces, eso implicaba, el tema del pluralismo político, el respeto, nunca pensamos, nunca tuvimos una idea de partido único, y en el año 84 hicimos por primera vez elecciones, entonces, la Constitución, insisto, expresa una situación, una correlación, y, por ende, tenía un sesgo profundamente presidencialista, en donde el parlamento aparecía con funciones muy débiles, no se tutelaban de manera suficiente las garantías individuales, y estaban planteadas algunas prerrogativas para el Estado en relación al tema de la propiedad, estaba establecida la existencia de una banca, por ejemplo, sólo estatal, habíamos hecho una nacionalización de los recursos naturales y del sistema financiero y del comercio exterior, entonces, el modelo que protegía o tutelaba esta Constitución era un modelo de economía mixta, que quiere decir convivencia de la propiedad privada, pero con una fuerte propiedad estatal, en donde el Estado se reservaba el dominio de sectores importantes de la vida económica del país, entonces, las reformas constitucionales del 95 tuvo dos grandes aspectos: el aspecto de la reforma del modelo político, en donde se establecieron, con más claridad, los derechos de los partidos políticos, las facultades de la Asamblea Nacional se emplearon, y se disminuyeron y limitaron las del Ejecutivo, se estableció una manera de elegir a los Magistrados, porque dentro del poder que tenía el presidente estaba el de nombrar a los Magistrados de la Corte Suprema, bueno, hay otros sistemas que lo tienen así también, yo no sé si fue peor lo que nos quedó, pero al final, implicó todo un paquete de reformas

\footnotetext{
10 Entrevista de menor duración, pero enormemente interesante por el discurso desarrollado en torno al análisis de las reformas constitucionales, los pactos políticos, y el deterioro del principio de equilibrio de poderes en el Estado de Derecho, desde un ángulo menos común, en algunos aspectos, que enriquece el habitualmente referido por otros entrevistados.
} 
en lo que se refiere al modelo político, pero también se modificaron aspectos sustanciales del modelo económico, yo, incluso, en varias de esas cosas estoy de acuerdo, por ejemplo, al haber nosotros tenido una gran intervención en materia de confiscaciones de tierras agrícolas, porque teníamos una Ley de Reforma Agraria en los años 80, que permitía al Estado apropiarse de determinados latifundios, o latifundios ociosos, después eso se derivó en abuso, diría yo, porque se empezó a abusar de la ley como un mecanismo de castigo por las diferencias políticas, pero, originalmente, la Ley de Reforma Agraria tenía una base de una justicia total, porque había una enorme concentración de la tierra en Nicaragua, una concentración exagerada de tierra en pocas manos, pero, entonces, el derecho del Estado, por ejemplo, a disponer de la tierra cuando fuese de interés social, se pasó de una apertura total a un cierre exagerado, que hoy día les genera enormes problemas, por ejemplo, a las municipalidades para disponer de bancos de tierra, por ejemplo, para sorteos populares, o para ordenar el territorio de su municipalidad, porque dejaron prácticamente prohibida las confiscaciones si no es por medio de previo pago, verdad, y, es decir, pasamos de un extremo a otro, y se abrió completamente la economía al mercado, se desreguló totalmente el país, de manera que eso favoreció las privatizaciones de la energía, de la telefonía, del acceso a los recursos naturales a través de las famosas concesiones, e, incluso, hasta dejó un poco abierto hasta el recurso agua, pues, que nosotros consideramos que es vital, ya ahora hay una ley que regula un poco lo del agua, pero aún así los candados fueron quitados desde la reforma constitucional, de manera que para mí tenía dos partes esas reformas, algunas que fueron puros avances, pero otras, que también hay que decirlo, y yo se lo digo a los renovadores, como crítica, porque yo estuve en desacuerdo con estos aspectos de la reforma electoral, también fue muy debatido el tema de la reelección, en la Constitución del 87 no se tocaba para nada, o sea, había apertura total a la reelección, y en la del 95 se limitó la reelección para los presidentes y para los alcaldes, y, por ejemplo, nunca estuve a favor de que los alcaldes no se pudieran reelegir, verdad, por lo menos uno o dos o hasta tres períodos, porque además son períodos de cuatro años, y como municipalista, que soy experta en temas municipales, me parece que era una exageración prohibir la reelección de los munícipes cuando teníamos en la anterior Constitución la apertura de que hubiesen existido candidatos que pudieran presentarse por suscripción popular, que para mí fue uno de los principales avances de esa reforma del 95, que dejó establecida la posibilidad de presentar a nivel local candidatos por la vía de suscripción popular, o sea, sin la camisa de fuerza de tener que organizar partidos políticos, quedó muy abierto en la reforma constitucional del 95 la posibilidad de crear partidos políticos con una gran flexibilidad, que me parece que abonaba en la dirección del pluralismo político, entonces, el balance para mí de las reformas constitucionales del 95, en términos políticos, es muy positivo, en términos económicos, con sus retrocesos, diría yo, porque creo que, aunque estaba en auge o en boga el tema del neoliberalismo, la verdad es que había otras constituciones en países capitalistas, que no habían abrazado el socialismo, como el propio México o Costa Rica, que tenían, había ejemplos de una mayor protección del Estado a la prestación de determinados servicios, y que a la vuelta de la esquina ya hemos visto, pues, realmente, que las privatizaciones de algunos rubros en el país genera un monopolio, ¿verdad?, genera un monopolio frente al cual no hay ninguna posibilidad del Estado por muchas leyes de defensa del consumidor que haya y que puedan operar, entonces, esas reformas constitucionales para mí juicio tuvieron una gran falla, que les ha servido a los pactistas ahora, y es que ni siquiera se pensó en la consulta popular, verdad, la Constitución del 87 había sido un ejercicio de consulta increíblemente amplio, cientos y cientos de asambleas por sectores, de manera que la gente sentía que esa Constitución era consultada con la gente, 
la reforma del 95 no se consultó y después fue objeto de procesos de negociación, que generaron una aberración que se ha repetido, que fue la famosa Ley Marco, verdad, como no, que tuvo errores de hacer algunas reformas que tenían nombre y apellidos, aunque los reformadores de la Constitución expresaron una apertura en materia de derechos civiles y de derechos políticos, a la vez no pudieron resistir la tentación de establecer algunos artículos de la Constitución que estaban orientados a impedir, por ejemplo, determinadas candidaturas, y todo el mundo sabía, entonces, que tenía nombre y apellidos, y eso ya genera cierta debilidad y le quita fuerza, le generó cierta complicación al discurso posterior contra las reformas constitucionales del 99 y del 2000, verdad, porque los nuevos reformadores le decían a los otros: "pero ustedes hicieron lo mismo", hicieron una reforma de fondo, era de fondo, era una reforma, que en algunos aspectos parecía casi una reforma total de la Constitución, sin pasar por procesos de diálogo y de consulta con la gente, eso fue un error muy grande, entonces, en el año 2000 o el 99, desde el 98 se comenzó a pensar en otra reforma constitucional, y esa reforma constitucional tuvo ya un claro sesgo de reparto de poder, ¿verdad?, entre Daniel Ortega y Arnoldo Alemán, Daniel Ortega había venido jugando un rol de presión muy fuerte con los demás gobiernos, y Arnoldo Alemán decidió, bueno, buscar cómo controlar eso, las batallas campales que organizaba Ortega para darla a través de un proceso de negociación, entonces, supuestamente la institucionalidad con la que se escondió todo eso es la de la gobernabilidad, pero, al final, terminó siendo un vulgar reparto de cuotas de poder entre ambas fuerzas, y se centró muchísimo en el tema de las instituciones, verdad, de las instituciones y de cómo iban a elegirse o nombrarse los cargos dentro de las instituciones, y a partir de ahí, esa es la parte constitucional, la otra escondía esos arreglos que se expresaban en la Constitución y otras que se expresaban en otros instrumentos legales, por ejemplo, en la Ley de Propiedad, que ya había tenido una revisión, una o dos revisiones en el gobierno de Doña Violeta, y, entonces, Arnoldo, ese fue el primer paso, antes de las reformas constitucionales se pactó, digamos, una Ley de la Propiedad, buscando como dar estabilidad al tema de la propiedad, que había sido conmovida, fuertemente, por las confiscaciones de los años 80 y por las devoluciones de los años 90, de los primeros años del 90, verdad, que realizó el gobierno de Doña Violeta, entonces, quedó un paquete de bienes que habían sido del Estado y que comenzaron a ser privatizados, es decir, las privatizaciones en Nicaragua no fue como en otros países bajo la ola neoliberal, sobre todo de los servicios, sino que, en el caso de Nicaragua, el sector del Estado incluía grandes haciendas, incluía comercio, empresas de comercio, incluía fábricas, que venían de las confiscaciones a la familia Somoza, verdad, a los Somoza y sus allegados, entonces, todo eso se administraba en un paquete que se llamaba "área de propiedad del pueblo", y se administraba como bienes estatales, entonces, todo ese paquete de propiedades se pasaron a ser administrados por una entidad que se llamaba CORNAP, y, entonces, la privatización de ello constituyó un proceso durísimo en donde los obreros y los trabajadores pelearon para que no se les regresaran a los antiguos dueños, o no se les vendieran al mejor postor, es decir, que era a precio ridículo, porque el gobierno no estaba interesado tanto en recoger dinero como en privatizar, en deshacerse de todas esas entidades, porque había un dogma neoliberal de que lo estatal, lo administrado por el Estado es ineficiente, y había que deshacerse, entonces, ese paquete de millones de dólares, millones y millones en propiedades, se convirtió como en una especie de tesoro también a repartir, y ese es un aspecto que casi nadie aborda respecto del pacto, el pacto tuvo su componente institucional y de reparto del poder, pero también tuvo su parte económica, que fue, bueno, "distribuyámonos esto, vos no me protestás y yo lo vendo, y vos me decís a quien se lo vendo", esa es una parte, que yo la he denunciado 
innumerables veces, tengo escritos y todo, que es lo que yo llamo la base de construcción de los nuevos grupos económicos del pacto, ¿verdad?, nuevos capitales, tanto de danielistas, porque yo no les llamo sandinistas, como de capital arnoldista, porque los liberales habían sido muchos de ellos despojados y otros, simplemente, nunca habían tenido, el propio Arnoldo Alemán no tenía ningún gran capital, y se convirtió en un millonario, ¿verdad?, a través de estos procesos y a través de estas tomas y dacas, "pues vos tomás algo y yo tomo algo, y ninguno protestamos, verdad, y nos quedamos callados", entonces, en el año 99 se empezó a procesar todo ese esquema de las reformas constitucionales, yo te voy a dar un libro donde presenté un estudio a la Red de Legisladores de las Américas, está bastante detallado, todos los artículos que fueron reformados y por qué yo me opuse, verdad, fui de los cuatro diputados que nos opusimos y votamos en contra, porque hubo otros que se opusieron y al final votaron a favor, verdad, porque Víctor Hugo Tinoco estuvo en contra, pero votó a favor de las reformas constitucionales, entonces, nosotros cuatro nos opusimos, pero además hicimos una batalla campal, que está también reflejada en ese libro, a través de mis exposiciones en el parlamento, y a partir de entonces, prácticamente, rompimos, pues, con el gobierno, yo rompí con Daniel Ortega, pues, verdad, de ahí que, eso fue en el 2000, el Partido Renovador Sandinista, contrariamente, después de que estuvo denunciándolas, desgraciadamente, se alió en las elecciones del 2001 y del 2004 con Daniel Ortega, verdad, y estuvo ahí, de alguna manera, en ese período se bajó completamente su rol, casi llegó a la extinción, porque había mucha gente que no estaba de acuerdo con que ellos se hubieran aliado después del pacto, después de que Daniel hace el pacto con Alemán, que ellos hayan regresado a entenderse, de alguna manera, con Daniel, verdad, pero a partir de estas reformas constitucionales la institucionalidad del país dio un retroceso brutal, pero ha sido indetenible, o sea, comenzó un poco, pero ahora los retrocesos son, yo digo que a la época de las cavernas, yo digo que antes de la revolución y de nada, porque aún, y lo digo también en el texto que te voy a enseñar ahí, Somoza fue una dictadura de 43 años, pero muchos creen que la dictadura de Somoza estaba basada exclusivamente en el poder de las armas, no, no fue así, el poder de las armas él lo desplegó con fuerza ya en la década de los 50, a finales de los 50 y todos los 60, pero el poderío de Somoza estuvo basado en un régimen de aparente democracia, es decir, ejercicios periódicos electorales, incluso, fijáte que yo quiero analizar, pero creo que Somoza no se reeligió ni una vez de manera continua, porque es que había tal rechazo al tema de la reelección continua, y por eso es que esta cuestión es peligrosísima, porque hay en la conciencia ciudadana tal nivel de rechazo a la reelección continua de los presidentes, que el propio Somoza siempre utilizó subterfugios para poner títeres, por ejemplo, elegir un presidente títere, que le hacía todo caso, pero era otro, era otro nombre, otro apellido, o en una ocasión, incluso, se generó un período de transición con un pacto, por cierto, donde quedó un gobierno de tres patas, un triunvirato, que se llama, ¿no?, donde estaba un representante de la oposición, un representante del partido de Somoza, y etc., es decir, que hasta Somoza tuvo su cuidado de no abusar del tema de la reelección descarada, por así decirlo, poniéndose él mismo, de nuevo, de nuevo, de nuevo, para que te hagas una idea de la importancia de este tema de la reelección aquí en Nicaragua, de las condiciones concretas, entonces, estas reformas constitucionales del 2000 sellaron un acuerdo de largo aliento entre Alemán y Ortega, un acuerdo que a mi juicio no ha terminado, y que es lo que permite que la Corte Suprema saque ese fallo y que aquí no pase nada, ¿me entendés?, si aquí, realmente, hubiera una ruptura de ese pacto, una ruptura real, vos tendrías a las bases del Partido Liberal en las calles peleando, pero, no es verdad, es una estratagema para mantener el acuerdo sin quemarse mucho o sin perder demasiado, porque Arnoldo 
Alemán con la división que se le dio en el Partido Liberal él ha tenido más cuidado de no aparecer descaradamente en los acuerdos con Daniel Ortega, pero, porque él tiene una competencia muy grande que es Montealegre, y si él se presenta demasiado abiertamente en la continuidad de estos acuerdos, se debilita dentro del propio partido y dentro de los propios sectores liberales, entonces, las reformas del 2000 fueron, esencialmente, eso, y otra cosa que fue fundamental, después de la reforma a la Constitución, vino la reforma de la Ley Electoral, y en esa reforma de la Ley Electoral se retrocedió muchísimo en materia de pluralismo político, porque se crearon en la Ley Electoral, que es de rango constitucional, no en la Constitución, se crearon una serie de trabas para la construcción de nuevas fuerzas políticas, como decía yo en mis discursos cuando me opuse a esa reforma de la Ley Electoral también, en Nicaragua para hacer fuerza política o partido tenés que nacer en estado de adultez y ya casi de vejez, verdad, o sea, cuando toda fuerza que comienza, pues, nace pequeña, no quiero decir que estoy a favor de los mini-partidos, que negociaban con los financiamientos del Estado, no, simplemente, cerremos financiamientos del Estado, pero permitamos que un partido que tenga presencia en 5 de los 16 departamentos exista, no, aquí tenés que tener en el $80 \%$ del territorio nacional, en el $85 \%$ de los municipios tenés que tener juntas directivas, y tiene que ir el Consejo Supremo Electoral a validar esas asambleas, entonces, tenés que recoger una cantidad inmensa de firmas, y después en el Consejo Supremo Electoral revisa y dice cuáles son válidas y cuáles no son válidas, y si una persona cuando sacó su cédula no sabía leer y escribir y puso una firma $\mathrm{X}$ y ya no coincide, ya dicen que no, que no vale esa firma para pedir la personalidad jurídica, eliminaron la suscripción popular en los municipios, y además vos perdés la personalidad jurídica si no te presentás, por ejemplo, a los comicios municipales, o si no te presentás a los comicios regionales, verdad, entonces, la reforma de la Ley Electoral terminó de sellar un esquema de poder en el cual los dos se reparten no sólo el poder, sino las posibilidades de acceder al poder por la vía de los partidos políticos, al tener el control del Consejo Supremo Electoral y de la autoridad que otorga personalidad jurídica, etc., entonces, ellos no le dan o quitan la personalidad jurídica sin que haya ninguna base jurídica, verdad, como pasó con el partido renovador (MRS) y el Partido Conservador, eso fue un atropello brutal, porque mientras se la negaban al partido renovador, que, juntos, pues, porque nosotros íbamos a ir también en esa alianza, habíamos sacado el $8 \%$ de los votos, el doble de lo que se necesita para conservar la personalidad que es el $4 \%$, y en cambio el partido de Acción Ciudadana, que no sacó ni el $1 \%$ ahí está con su personalidad jurídica de la manera más arbitraria e ilegal que te podás imaginar, ¿por qué?, porque no puedes recurrir a la Corte, no hay justicia en Nicaragua, desde la reforma constitucional más los procedimientos posteriores con los que se construyeron otras leyes, porque no sólo es la Constitución, porque resulta que esa alianza se expresó posteriormente en un montón de leyes, incluyendo la ley del Poder Judicial, ¿verdad?, la forma de tomar decisiones en el Poder Judicial, donde ellos, con supuesta viveza de ratón, verdad, entonces, ponen que un sistema de reparto de las salas que hace que nada se pueda mover si no es que estos dos individuos se pongan de acuerdo, entonces, no hay justicia en Nicaragua, y cuando te digo "no hay justicia" me refiero no sólo a los fallos de la Sala de lo Constitucional, de la Sala Penal, de la Sala Civil, de la Corte, sino que además ellos a su vez pasan por encima de la Ley de Carrera Judicial, que no la han aplicado, verdad, no la han aplicado, pasan por encima de ella, para nombrar todo lo que es el cuerpo de los jueces, entonces, cada uno de ellos tiene su cuerpo de jueces, verdad, los jueces de Daniel y los jueces de Alemán, con la debilidad de Alemán de que los otros son más viejos, verdad, más vivos, y han venido copando y no solo copando sino comprando a los de Alemán, es decir, que si hay alguno que hace más caso a Arnoldo 
Alemán terminan de cooptarlo, o de comprarlo, o de crearle un cerco por la vía de empleos para los familiares, etc., entonces, vos no tenés ninguna garantía, ninguna garantía de la justicia, ahora que estaba en el canal de televisión llega un hombre y me dice: "yo me vine de mi casa, porque yo tenía, yo alquilaba un local en un espacio que pasó a ser del Frente Sandinista que se llama el Centro Recreativo La Piñata, hice mi inversiones, inscribí mis mejoras, y después vino el Frente y alquiló mi local por 20 años, entonces, mis mejoras están siendo alquiladas y yo no recibo absolutamente nada, y no he podido encontrar en estos 20 años a alguien, un abogado, que me ayude, todos tienen terror", entonces, también hay un sistema, que te lo pueden decir los abogados en secreto, de que aquí los propios abogados tienen limitadas sus facultades para defender, para acusar, si no están formando parte de una especie de red, verdad, que yo llamo las mafias, que actúan literalmente como mafias, entonces, como decía hoy en la mañana en la televisión, hombre, si lo principal, yo creo que lo principal en un país, fijáte que podés tener una Asamblea Nacional que tenga potestades disminuidas, pero si vos no tenés un sistema de justicia autónomo, independiente, no hay democracia, no hay, Nicaragua no tiene, no hay, es pura apariencia la democracia, porque el Estado de Derecho no está funcionando, el Estado, la separación de poderes no está funcionando, verdad, y los equilibrios que brinda a todo sistema la existencia de una robusta sociedad civil no está funcionando, la existencia de una oposición que tiene sus derechos no está funcionando, entonces, yo creo que estamos retrocediendo a la época de las cavernas.

R: Sí es cierto, aunque ha referido así muy rápidamente y con mucho acierto casi todo el proceso, en 2005 se culmina este debilitamiento de la figura presidencial en favor de la Asamblea cooptada por las cúpulas partidarias del PLC y el Frente Sandinista, y Bolaños se convierte en el presidente, posiblemente, más débil de la democracia reciente en Nicaragua.

M.B.: ¡Ah!, sí claro, porque es que, sí, sí, se me olvidaba la famosa reforma del 2005, que, en el 2005, como te digo, verdad, tienen nombre y apellidos las reformas, entonces, debido a que Bolaños procesa a Alemán y lo procesa porque Alemán se quiere convertir desde el parlamento en el presidente del país, verdad, porque él, una de las reformas constitucionales fue la famosa diputación regalada, entonces, él pasa de la presidencia al parlamento, entonces, ya en la presidencia de la Asamblea Nacional, él comienza a torpedear la gestión del presidente desde su partido, entonces, eso hace que Bolaños decida enfrentarlo y le abre juicio por malversación, fraude, lavado de dinero, en perjuicio del Estado nicaragüense, durante mucho tiempo, muchos meses, Daniel no dijo una palabra contra Alemán, hasta que los Estados Unidos presionaron a Bolaños, en ese período Daniel hizo una especie de pacto con Bolaños, verdad, de gobernabilidad, y eligieron una junta directiva en el parlamento entre las fuerzas de Bolaños que quedaban en el parlamento, porque una parte del PLC respaldó a Bolaños y la otra se fue con Arnoldo Alemán, entonces, Daniel hace un acuerdo con Bolaños y elige una junta directiva del parlamento equilibrada, entonces, los Estados Unidos presionan a Bolaños para que rompa su acuerdo con, un error del embajador, porque, ¿qué pasó?, que al presionar a Bolaños a esa ruptura Bolaños se entiende con Alemán y excluye al Frente de la junta directiva, entonces, Daniel volvió a pactar con Alemán, en el período en que hacen ese arreglo, ahí desaforan a Alemán, verdad, pero después viene, cuando lo excluyen, entonces se arregla con Alemán, y en el siguiente período se juntan en el parlamento, ¿a cambio de qué?, de casa por cárcel, porque ya para entonces él está ya, y empieza todo el re-juego de la cárcel de Alemán, verdad, que los liberales te lo describirían así, Ortega manda a la cárcel a Alemán con una jueza danielista, que 
después la premia como Magistrada de la Corte Suprema, o sea, la jueza que condena a Alemán es una jueza que le hicieron prácticamente el fallo desde las oficinas de Ortega, verdad, Juana Méndez, y de ahí empieza el "muñequeo" con el tema famoso del celular, que te lo doy, te lo describe así la gente, ¿verdad?, porque si tenía derecho a celular o no en la cárcel Alemán, que si la televisión, que si la casa por cárcel, que si municipio por cárcel, y, finalmente, Nicaragua por cárcel, y todo ese período, verdad, se fortalecen de nuevo las relaciones de Daniel con Alemán, o sea, el período de ruptura de las relaciones con Alemán para entenderse con Bolaños fue muy corto, de unos 10 meses, verdad, y después vuelve el arreglo con Alemán y, entonces, se arreglan para quitarle poder a Bolaños, verdad, con el propósito, Arnoldo, porque además era el que lo había enjuiciado, y el que le había atacado duramente, el tema de la corrupción jamás Daniel Ortega lo había asumido como una bandera, él nunca lo ha asumido como una bandera, el que metió a Alemán en la cárcel con el juicio fue este señor que brindó todas las pruebas y todo, y, obviamente, le convino a Daniel y lo mandó a la cárcel para convertirlo en una especie de rehén, verdad, manipulando la justicia, porque yo creo que Alemán era culpable de todas esas tropelías, yo lo habría sentado en el banquillo de los acusados desde que era alcalde, porque él empezó a robar desde que estaba en la municipalidad, entonces, esas reformas constitucionales del 2005 tienen nombre y apellidos, debilitar al máximo a Bolaños, no solamente con el tema del nombramiento de los ministros y el tema del nombramiento de los embajadores, que quedó como una prerrogativa a ser ratificada por la Asamblea Nacional, sobre todo porque creaba lo que se llamaba la Superintendencia de los Servicios Públicos, que eran unos elefantes blancos que estaban por encima de las instituciones que habían quedado como las instituciones reguladoras, entonces, al darse las privatizaciones se crean entidades reguladoras y encima de esas entidades reguladoras se crean unos elefantes blancos, que se llaman las Superintendencias, que tenía como propósito quitarle al Ejecutivo el poder de la regulación que se ejercía a través de las Intendencias, pero a la vez crear espacios para contratar personas, verdad, y para repartirse esos espacios, entonces, ¿qué pasó?, que después cuando se quitó la Ley Marco, se quedó sin efecto, ¿qué ha pasado?, de facto, Daniel Ortega nombra y quita ministros y embajadores, y nada pasa, o sea, que la reforma de la Constitución, que iba orientada a disminuir poderes no le ha disminuido a él, porque ahí está, pero no se aplica, no se aplica y no hay nadie que la vaya a aplicar, porque los que deberían hacerla aplicar están en esa misma dinámica, que es la Corte Suprema, y la oposición que no termina de ser una oposición de facto.

$R:$ No, se está avanzando en este país peligrosamente hacia el "gobierno de los jueces”, es decir, que esta concentración de poder y esta ruptura del principio de equilibrio de poderes, ¿no?, se traduzca en que Ortega pueda gobernar a través de las sentencias de la Corte Suprema.

M.B.: Exactamente, exactamente, porque esta sentencia, yo te voy a decir, si aquí hubiera un aparato electoral honrado, que no se hubiera robado ya, para mí, dos elecciones, porque yo creo que Daniel no sacó el 38\%, Daniel no sacó 38 diputados, nos robó diputados a las otras fuerzas, nada más que él robó como $3 \%$ o el 4\%, ¿me entendés?, y en las elecciones del 2008 se robó más del 10\%, ¿verdad?, entonces, es que es por eso el escándalo, porque en el 4\%, el 3\% o 4\%, se nota menos, pero lo hizo, yo no creo que él haya ganado en primera vuelta, ni que haya sacado esos diputados, entonces, ya lleva dos elecciones con manejos fraudulentos, entonces, para mí el problema no es la reelección en sí, si él ha conseguido convencer a los liberales y ha 
reformado la Constitución para que se permitiera la reelección, ya sería, no tendríamos más que hacer, el problema es reelección, fraude y reelección.

\section{R. Que ha sido una constante en este país.}

M.B.: Y el problema es cómo sacan esa resolución, porque yo te voy a decir, si ellos pueden hacer eso con ese artículo constitucional, ellos pueden hacer cualquier otra cosa con cualquier otro artículo constitucional hasta que alguien vaya y recurra, y ese recurso ellos le quieran dar pase, y lo hacen, porque si lo hicieron con esto, ¿por qué no?, fijáte que ahí no había ni siquiera agraviados, verdad, es un recurso rarísimo, porque no había agravio.

\section{R: No había acto.}

M.B.: Efectivamente, no había un acto frente al cual recurrir, porque tendrían que haber esperado a que él fuera al Consejo Supremo Electoral a inscribirse dentro del calendario electoral, y, entonces, el Consejo denegarles la inscripción en base al artículo 147 de la Constitución, y, entonces, ellos recurrir, por lo menos hubieran guardado un poco la apariencia, pero no lo hicieron así, o sea, que es un fallo totalmente sacado sin ningún fundamento jurídico, lo que dicen nuestros abogados es que es nulo.

\section{$R:$ ¿Y cómo ve el futuro de su país?}

M.B.: Bastante negativo, verdad, yo hago un esfuerzo inmenso para ser optimista, para ver el vaso medio lleno, para seguir luchando, para no desmayar, verdad, todos los días, pero, de repente, uno se siente como en un callejón sin salida, verdad, porque es una especie de círculo vicioso, ¿verdad?, de repetición del pasado, y a veces vos decís, fijáte que la gente dice que quisiera estar en el 78, porque por lo menos estábamos con la posibilidad de que estábamos luchando, ahora ni para luchar hay condiciones, tenés que llevar un proceso con la gente que, de alguna manera, es un proceso muy lento, verdad, entonces, es difícil, es difícil, el control que está ejerciendo Ortega en todos los órdenes es grave, porque además no es una dictadura descarada, ¿ya?, sino que son procesos subterráneos, hay un temor, ya se está perdiendo credibilidad en la Policía, el propio Ejército está sometido a fuertes presiones, fuertes halagos, fuertes chantajes, para convertirse en una entidad de "ordeno y mando", verdad, entonces, el futuro es bastante negativo, yo creo que lo único que puede modificar el rumbo de las cosas es el fortalecimiento de las organizaciones del propio pueblo, de la sociedad civil, de las distintas formas de sociedad civil, que sea, digamos, la gente, obviamente, eso no surge por generación espontánea, implica, y es uno de los aspectos que yo creo que una cierta oposición no entiende, cree que basta con poner un caudillo, o un caudillito, o una persona simpática y que salga en la televisión y en los medios, aquí en Nicaragua eso no funciona, el impacto de las construcciones mediáticas de liderazgo no funcionan aquí, se necesita gente que vaya a los barrios, que vaya a las comunidades, que hable con la gente, que conquiste, digamos, la confianza de la gente para ponerse al frente de una lucha cívica, que, a mi juicio, tiene que ser cívica, no violenta, porque este país es un polvorín, verdad, cualquier cosa puede encender la llama de la confrontación, hay mucha experiencia militar de todos lados, apenas hace 20 años estábamos enfrentados, o menos de 20 años, a muerte, verdad, y, entonces, aquí cualquier desliz te puede provocar un escenario de violencia. 
R: Pues si tiene algo más que añadir, porque entiendo que su tiempo es muy breve.

M.B.: Sí, hoy tengo una agenda complicadísima. 


\section{ENTREVISTA 8 ${ }^{11}$ :}

Nombre del entrevistado: Dr. Reinaldo Balladares.

Cargo actual: Profesor de Derecho Constitucional de la Universidad Centroamericana (UCA).

Fecha de realización de la entrevista: Managua, 9 de septiembre de 2009.

Lugar: Facultad de Derecho de la Universidad Centroamericana (UCA).

Duración estimada: 50 minutos.

\section{TEXTO - Transcripción 8:}

$R$ : ¿Cuál es tu visión sobre los recientes procesos de reforma constitucional en Nicaragua?

R.B.: Te repito, entonces, el artículo 130, ¿no?, que se reformó en el año 95, introdujo una cláusula del Estado Social de Derecho, como modelo de Estado a seguir por parte de Nicaragua, introdujo una serie de cambios o una serie de consecuencias jurídicas, y también en otros ámbitos de los cuales yo creo que no se percató mucho ni la élite económica, ni la clase política nicaragüense, hay que ver, tú sabes que la reforma del 95 fue, profundamente, impulsada, si no me equivoco, por el Partido Socialcristiano en ese instante, y de influencia conceptual a la alemana, por así decirlo, entonces, claro, se produce esta cláusula y la gente dice: "bueno, un Estado Social de Derecho", pero claro, ¿qué implica un Estado Social de Derecho?, yo creo que no estaba muy claro, excepto para quienes introdujeron esa frase en ese artículo 130 de la Constitución, de las consecuencias que eso implica desde el punto de vista jurídico, económico, etc., etc., el asumir como modelo de Estado el Estado Social de Derecho, ¿no?, ahora, en el ámbito económico, lo financiero y lo tributario, el parlamento es ni más ni menos que la caja de resonancia de la población que vos tenés, vos no le podés pedir a la población nicaragüense que sea experta, ni mucho menos, o versada en temas financieros y tributarios, consecuentemente, muchas de las soluciones que se han llevado en este tema, que son un instrumento técnico y neurálgico, pues, hayan sido soluciones coyunturales para problemas del momento. Ha habido tres a partir del año 95, tres intentos de reforma en el ámbito tributario, una en el año 97, con la Ley de Justicia Tributaria y Comercial del gobierno del presidente Alemán, en el año 2003 la Ley de Equidad Fiscal del gobierno de Bolaños, y la actual propuesta de reforma tributaria, que se supone que tiene que ser aprobada dentro de los próximos 20 días, y que ha mi modo de ver, yo tengo aquí unas declaraciones sobre ésta, no sé si las has leído, no tienen un fundamento jurídico sólido, no me terminan de convencer, el tema aquí es, efectivamente, que la estructuración del sistema tributario te indica que el sistema hoy es netamente regresivo, las recaudaciones provienen, fundamentalmente, de impuestos indirectos, en vez de impuestos directos, lo que contradice la tendencia de los países de la OCDE y también de España, y, en ese sentido, las propuestas de reforma han intentado ampliar la base del contribuyente, pero no se ha logrado, efectivamente, por

11 Entrevista más centrada en el tema de especialización del informante, los aspectos tributarios de la reforma constitucional, que en el marco de interés planteado por la investigadora en el guión de preguntas generales, aunque algunas respuestas son significativas y pueden cobrar sentido como citas de relevancia en el discurso sobre el cambio constitucional de las atribuciones en los órganos ejecutivo y legislativo respectivamente. 
cuanto se mantienen los vicios del sistema en cuanto a que una clase en particular, ya sea la élite económica, ya sea de forma inmediata o de forma mediata, a través de los actores políticos que tienen en el Congreso han logrado, de una u otra forma, mantener ciertos resquicios o privilegios fiscales que a ellos permite no tributar de la misma forma que lo hacen, por ejemplo, las personas naturales a través de las nóminas, como es el caso español, es decir, en Nicaragua el sistema de tributación personal, al contrario de lo que sucede en España, que tenemos un IRPF, un impuesto de sociedades, el impuesto de sociedades para nuevos residentes no existe, lo que existe es, en aras de una simplicidad, una conjunción de los tres sistemas que más que simplicidad lo que crea es más confusión, número uno, número dos, que permite, de esa manera, dentro del régimen de deducciones y supuestos de no sujeción ciertos supuestos de privilegios fiscales, que no constituyen la lógica que la Constitución te da, porque te dice en el artículo 114 que el sistema tributario debe tomar en consideración la distribución de las rentas y la riqueza, es decir, lo que en España y en Europa se conoce como capacidad contributiva. Ejemplos claros de ellos pueden ser el tema de supuestos de no sujeción en la Ley de diversidad fiscal del impuesto sobre la renta, en la cual se establece que los dividendos del partido por utilidad, es decir, las reglas de capital que van hacia los socios no están gravadas por el Impuesto sobre la Renta, pero si están gravados todos los ingresos que perciben los asalariados, y que por vía de retención en la cuenta, pues, van poco a poco tributando en ese sentido. El otro problema en el ámbito de la imposición directa es que el mínimo de existencia en Nicaragua se cifra en 50.000 córdobas anuales, es decir, 4. 167 córdobas mensuales, es decir, ese nivel de dignidad del ser humano el Estado en Nicaragua lo cifra, jurídicamente, en 4.167 córdobas al mes, es decir, que es absurdo, no tiene ni pies ni cabeza, nosotros hicimos un estudio al respecto y determinamos sobre la base de un parámetro objetivo, que es, en este caso, la canasta básica real, que no la legal, que ese mínimo de existencia para una familia de dos hijos debiera ser, por lo menos, 144.000 córdobas al año, eso te da una idea de por donde está la inequidad del sistema en la imposición indirecta, y si a esto le sumamos el hecho de que la mayoría de la recaudación se obtiene por imposiciones indirectas, pues, nos queda como resultado un sistema regresivo en vez de progresivo. Entonces, a mi modo de ver, yo opino que los grandes lineamientos constitucionales que se establecen respecto de la justicia tributaria o justicia fiscal, que es lo que nosotros conocemos como principios de justicia tributaria, material o formal, en el caso que nos ocupa no se cumplen, no se cumplen porque no se respeta ni el principio de igualdad, ni mucho menos en el de capacidad contributiva, ni tampoco el de progresividad, en tanto que el resultado que te da la aplicación de ese sistema te dice que, efectivamente, las rentas de capital no se gravan de la manera como debieran estar gravadas, y que al final el que termina pagando los platos rotos es el asalariado, quien empieza a pagar impuestos a partir del mínimo nivel de existencia.

\section{R: Y cómo funciona, en el caso de las facultades del presidente de la República, Violeta Chamorro todavía tenía la facultad de emitir decretos en materia tributaria, es una facultad que pierde el siguiente presidente a favor de la Asamblea Nacional.}

R.B.: Hay una discusión, el origen de la reforma del artículo 138.27, digo, el 150.4, que es donde está esto, ¿no?, en el año 95 surge respecto de la discusión que existe ahí, en ese instante, respecto de las facultades que tenía el Poder Ejecutivo, porque se decía que podía normar en materia fiscal el Poder Ejecutivo, pero, ¿con qué rango y con qué alcance?, no estaba claro, la confusión conceptual llegó a que en la práctica, pues, al final el presidente legislara con rango de ley en materia fiscal hasta el año 95, a mi 
modo de ver, eso no estaba claro en ese instante, ni sigue estando claro todavía, hoy en día sigue siendo discutible el hecho de que esa facultad del Ejecutivo de normar en materia tributaria fuese verdaderamente absoluta o compartida con el Poder Legislativo, porque la redacción anterior de estos artículos no te dejaba claro al respecto. Para salvar esa confusión, entonces, fue que se determinó, se hizo la reforma del artículo 150.4 y del $138.27 \mathrm{y}$ del 114, que te dicen, básicamente, y te lo resumo con lo que dice el 114: la potestad de crear, suprimir, o derogar tributos corresponde exclusivamente y de manera indelegable a la Asamblea Nacional, ese precepto no se cumple, o no se cumplió a lo largo de los períodos del Presidente, cómo te puedo decir, de los gobiernos de Alemán, Bolaños y el actual, ¿por qué?, porque el Ejecutivo, los gobiernos han legislado en materia tributaria.

\section{$R:$ ¿A través de qué instrumentos?}

R.B.: A través de decretos, el problema de fondo, también, que hay aquí es el siguiente: el sistema de fuentes en Nicaragua no está claro, cuando en el año 79 se da la revolución, ¿no?, y empiezan a ser compartidas las facultades legislativas entre un Ejecutivo y un Legislativo, etc., etc., surgen categorías mixtas que hoy en día, a mí por lo menos, no me quedan claras, y entre ellas se encuentra el decreto, y el decreto es objeto de control de constitucionalidad a través de la Ley de Amparo, y te lo dice la Ley de Amparo, que es del año 88, y te dice, bueno, que existe el decreto, decretos-leyes, etc., etc. En materia fiscal, vas a encontrar hoy en día decretos que tienen rango de ley, y decretos que tienen rango de reglamento, a partir de la reforma del año 95, entonces, claro, ¿cómo sitúas en el sistema de fuentes, en esa jerarquización piramidal que señala el decreto como fuente del Derecho?, es imposible, porque hay dos elementos distintos en esta categoría, entonces, a mi modo de ver, el decreto no constituye una fuente dentro del sistema nicaragüense, sino que constituye un vehículo que lleva a introducir o bien una ley o bien un reglamento, y así todos los ejemplos claros en materia fiscal, el Decreto 3/95, que es que crea el Impuesto sobre bienes Inmuebles, firmado por Doña Violeta Barrios de Chamorro en el año 95, a inicios, en enero, antes de las reformas, que fueron a finales de ese año 95, y que crea el Impuesto sobre Bienes Inmuebles en favor de los municipios, y el Decreto 46/2003, que es el Reglamento de la Ley de Equidad Fiscal, que firma Don Enrique Bolaños Geyer y el Ministro de Hacienda del momento, que viene a reglamentar la Ley de Equidad Fiscal, que es la que crea el Impuesto sobre la Renta, el Impuesto del Valor Agregado, y el Impuesto sobre el Consumo y el Impuesto de Bienes Fiscales. Ambos son decretos, pero tienen un rango en el sistema distinto, el primero, el 3/95 tiene rango de ley y el segundo, el 46/2003 tiene rango de reglamento. La Corte Suprema de Justicia se ha pronunciado sobre este punto en dos sentencias, bueno, en dos sentencias que regresan sobre el mismo tema, la Sentencia No. 5 del año 2005 de la Sala de lo Constitucional, y la Sentencia No. 48 de la Corte en pleno del mismo año 2005, en la cual se determinó la inconstitucionalidad del artículo 81.4 del reglamento de la Ley de Equidad Fiscal por determinar en ese mismo artículo el régimen de retenciones en las fuentes de rentas ocasionales por compraventa de bienes inmuebles, el tema aquí es el siguiente, toda la lógica jurídica que persiguió la Corte a lo largo de todos esos considerandos que se daban en Nicaragua, el equivalente de lo que es en España los fundamentos jurídicos, se llega a determinar que todos el régimen de retenciones en las fuentes que están en el reglamento, así como los anticipos a cuenta, es decir, todo lo que implica la determinación de la carga que se encuentra en el reglamento es inconstitucional, pues plantea un sistema tributario inoperante, desde el punto de vista estrictamente constitucional, porque te vas a encontrar en el reglamento 
de la Ley de Equidad Fiscal, definiciones de qué es renta, es decir, definición o elementos que forman parte, valga la redundancia, de los elementos de cuantificación de los tributos, o sea, de decidir la base imponible, el tipo de gravamen, o exenciones, que están en el reglamento y que, en aras de reglamentar lo que dice la ley, al final de cuentas lo que están haciendo es legislar en materia tributaria con una vía que no es la correcta, que es el decreto, es decir, viene del Poder Ejecutivo. Esta situación ha pervivido desde el año 97, 2003, y la actual propuesta de reforma tributaria nadie plantea nada al respecto, me parece que no quieren darse cuenta, no se quieren percatar del hecho de que existe un problema de reserva de ley, que en realidad, desde el punto de vista tributario, condiciona todo el sistema tributario nacional, porque si vos no tenés un régimen de retención, de anticipos, es decir, de cuantificación de la base imponible del Impuesto sobre la Renta en la ley sino en el reglamento, y el reglamento es inconstitucional, eso te lleva a que el Impuesto sobre la Renta y demás impuestos que están en la Ley de Equidad Fiscal son inconstitucionales, son inaplicables, y la propia Constitución, y la Corte así lo ha dicho que los funcionarios deben en su actuar en el ejercicio de sus potestades administrativas deben respetar la Constitución, $y$, consecuentemente, un funcionario público que esté llamado a respetar la Constitución, lo primero que debiera decir es: "oiga, mire, esto yo no lo aplico, porque es inconstitucional, porque viola la reserva de ley y la legalidad", el problema, entonces, es de forma y los principios de justicia tributaria formal en Nicaragua es que no se respeta la legalidad ni la reserva de ley, ni mucho menos la seguridad jurídica, que son los tres grandes principios en materia formal. Desde el punto de vista de fondo, bueno, la capacidad contributiva y la igualdad configuran un sistema tributario jurídicamente regresivo con los resultados que da la recaudación.

R: ¿Y qué opinas, ya hablando de irregularidades desde el punto de vista formal, de los procesos de reforma constitucional?, las Leyes Marco, que han supuesto una postergación de la norma constitucional reformada y al mismo tiempo ampliar el plazo de la negociación política de los actores enfrentados por esos preceptos que se intentan reformar, ¿no? Sobre todo el conflicto entre los poderes Ejecutivo y Legislativo, porque en todos los procesos de reforma el presidente de la República en funciones nunca ha estado de acuerdo con la Ley de Reforma Parcial aprobada por la Asamblea.

R.B.: Bueno, las Leyes Marco surgen como una solución a un problema de crisis política, precisamente, por las reformas del año 95, y han sido una herramienta recurrente en los demás procesos de reforma, uno de los ex-presidentes de la Asamblea Nacional a quien le hice esta misma pregunta me dijo que él partía de la tesis de un autor alemán, cuyo nombre no recuerdo ahora, que decía que si no tenemos una Constitución en sentido material de nada nos sirve el texto de la misma, y que, consecuentemente, si la idea de una Constitución en sentido material es ordenar la vida política, económica y jurídica de un país, si en el proceso de reforma no se llega a consensuar tal situación eso le da un clima a la existencia de un instrumento llamado Ley-Marco, cuyo sentido o significado pues ya sabemos cual es, ¿verdad? Entonces, esa es la explicación política de este ex-presidente, que te lo voy a presentar también, para que hables con él sobre el tema y que te lo explique, Luís Humberto Guzmán. Ahora bien, esa es la explicación política, la explicación jurídica, pues, yo no la encuentro, el $\mathrm{ABC}$ del Derecho Constitucional, esto te lo dice cualquier chico de segundo año, o sea, es técnicamente insostenible, el tema, jurídicamente, de las Leyes Marco, jurídicamente, repito, políticamente, pues la explicación que te puede dar Don Luís es otra, ¿no?, y muy bien fundamentada, porque él es politólogo también. 
R: Y, de hecho, incluso la propia reforma a la Ley Marco, que se aplicó bajo el gobierno actual de Ortega, que ya es postergar un año más una reforma constitucional aplazada, que yo sepa es algo que solamente ha pasado aqui en Nicaragua.

R.B.: OK, eso nos lleva un poco al inicio del tema, ¿por qué pasan esas cosas en Nicaragua?, y empezamos por el inicio que te había dicho, es decir, el parlamento, pues, es la caja de resonancia del pueblo nicaragüense, "no le puedes pedir", como se dice en buen castellano, "peras al olmo", ¿qué es Nicaragua objetivamente?, es un niño de cuarto o quinto grado de primaria, ¿me explico?, hay que empezar por ahí, no le pidamos a ese niño de cuarto o quinto grado de primaria que explique la supremacía constitucional, o que sepa de los principios de justicia tributaria, y es un poco el signo de los tiempos que hay que empezar de cero, hay que empezar de cero, que es el caso nuestro, de esa revolución del año 79 que rompe con todo y que crea un vacío profesional, porque alguna gente se fue al exilio y la que se quedó fue del gobierno, mientras tanto aquí, pues, en las aulas de clase en la Universidad encontrabas a los alumnos de los cursos superiores enseñando a los de los años inferiores, fue un proceso de iniciar, ¿no?, y este niño te va a hacer travesuras, por decirlo en ese sentido, entonces, claro, ustedes que tienen ya un andar bien definido, un contexto europeo que también define las cosas, les puede chocar y les choca este tipo de situaciones, como a mí también me chocan, es decir, yo también viví y estudié seis años en Europa, y lo primero que te surge cuando regresás después de tanto tiempo fuera, pues, el aterrizaje aquí fue sumamente difícil, pero luego uno se tiene que contextualizar y darse cuenta de que son procesos de largo recorrido, entonces, podemos llegar a puntos en común respecto de muchas cosas desde el punto de vista europeo, y estoy totalmente de acuerdo de que es un óptimo a conseguir, pero es que ese óptimo a conseguir en el horizonte nicaragüense está demasiado lejos, entonces, hay que hacer los cambios de una manera paulatina y sin prisa pero sin pausa. Y esa es un poco la explicación de las Leyes Marco y todas estas cosas, por comentártelo en términos sencillos, el problema es que, presupuestariamente, para que nosotros alcancemos los Objetivos del Milenio, en cuanto a educación, mi premisa es que la solución de estos problemas es a largo plazo, uno, y dos, la solución está en la educación, la educación para la población, no seguir exportando asistentes que van a limpiarte las casas a Costa Rica o a donde sea, ¿no?, como mano de obra barata para las maquilas, pero, claro, para que eso se logre el gobierno necesita invertir un 7\% del presupuesto del PIB en educación, actualmente, andamos entre un 3\% y 4\%, entonces, esa solución no está en camino si quiera, esa solución no está en camino, si seguimos, y estoy hablando de educación primaria y secundaria, es decir, punto, hasta ahí, estoy llegando hasta el grado de bachiller, ya no estoy exigiendo, no te estoy planteando la premisa de la educación superior, la educación superior se ha visto este año fuertemente golpeada por los recortes presupuestarios, porque nosotros somos el $6 \%$ del presupuesto, claro si el presupuesto se achica, ese $6 \%$ también, proporcionalmente, se achican las partidas presupuestarias disponibles para las universidades, entonces, si Nicaragua es un Estado Social de Derecho, como dice la Constitución en el artículo 40, y eso supone materializar el conjunto de derechos sociales que se encuentran en la propia Constitución, que es muy pródiga en este tipo de derechos, y uno de ellos, fundamental, es la educación, en ese sentido, yo creo que no se está cumpliendo con lo que determina nuestra propia Constitución. Podemos hablar de reformas estructurales del Estado, de que si quien elige a los cargos públicos, etc., etc., etc., pero si te fijás bien en relación a las reformas constitucionales nadie ha modificado, cuantitativamente, si lo querés ver desde el punto de vista cuantitativo, en demasía, ese apartado de la Constitución de los derechos 
sociales o individuales o laborales o etc., es decir, lo que se denomina en la muy, muy clásica literatura, la parte dogmática, es decir, el conjunto de derechos y de garantías para los ciudadanos nicaragüenses, ¿por qué?, porque todos estamos de acuerdo en que esos son derechos que están ahí, ¿no?, pero no llegamos al otro estadio de análisis que es el siguiente, que la Constitución es una norma en el sentido material, y que si es una norma en sentido material eso significa que tiene la misma virtualidad jurídica que puede tener, por ejemplo, la ley de tránsito que dice que si te cruzás el semáforo en rojo cometés una infracción y tenés una multa, es decir, que todos los catálogos de derechos y garantías que ahí se encuentran podrían hacerse realidad, porque es deber del Estado, o eso digo yo, te voy a leer lo que dice la Constitución en el artículo 48 párrafo segundo: "es obligación del Estado eliminar los obstáculos que impidan de hecho la igual de los nicaragüense y su participación efectiva en la vida social, económica y política del país", este artículo nació en el año 87 y no ha sido reformado nunca, párrafo segundo del artículo 48, igualdad material, en el marco de un Estado Social de Derecho ya sabemos qué es lo que significa la igualdad en sentido material, y me remito aquí a lo que dice el Tribunal Constitucional español sobre los aspectos característicos del principio de igualdad, entonces, no existe esa conciencia de la Constitución en sentido material, ni que se debe hacer realidad ese catálogo de derechos que se ponen ahí, el principio de igualdad, ni lo que implica tampoco el modelo de Estado Social de Derecho, es decir, se introdujo como una reforma muy buena, desde mi punto de vista, en el año 95, la cláusula del Estado Social de Derecho como modelo del Estado nicaragüense, pero hasta ahí, entonces, la clase política no se han percatado, no se han querido percatar, porque al final un Estado Social de Derecho significa gasto público incrementado y mayor presión fiscal, y, en el caso nicaragüense, andamos en el 17\% o $18 \%$, la media de los países europeos debe estar en $34 \%$ o $35 \%$, tampoco son Suecia que andan en $50 \%$, lo que te quiero decir es que no se quieren percatar de ello, no quieren atender a todo esto, porque eso significa al final de todo pagar más impuestos, y a nadie le gusta pagar impuestos, $y$, consecuentemente, la cláusula del Estado Social de Derecho se quedará fuertemente sin nada en tanto en cuanto no esté diseñado un sistema tributario que tienda a realizar los cánones de este modelo de Estado sobre la línea de los principios de justicia pública tributaria. La reforma tributaria que están tramitando urgentemente por causa de las restricciones de financiación de los organismos internacionales, me parece que es una solución coyuntural a un problema que se estaba viendo llegar desde hace mucho tiempo, y que va a tener como resultado que nosotros los nicaragüense de a pie, asalariados, la poca clase media que existe, tengamos que pagar con nuestros impuestos las crisis políticas originadas el año pasado, porque todo se trata, simple y sencillamente, de recorte de los fondos presupuestarios que vienen de la Unión Europea y Estados Unidos, que inyectaban dinero directamente en los presupuestos públicos, y producto de esa crisis política de noviembre, dijeron yo no paso ni un dólar ni un euro más, consecuentemente, ¿esa crisis presupuestaria quién la debe pagar?, los nacionales. Pero bueno, ¿los nacionales por qué tenemos que pagar el fruto de una crisis política y de un mal gobierno?, no tiene sentido.

$R: Y$, otra cosa, un rasgo también muy característico de la historia constitucional de Nicaragua ha sido que los distintos procesos de reforma desde el momento de su independencia han sido precedidos de pactos políticos entre las principales fuerzas, antes eran los liberales y conservadores, y ahora entre sandinistas y liberales, es decir, que el pacto Ortega-Alemán no es un producto sui generis de este tiempo, sino que es algo que ha venido sucediendo antes en muchos otros momentos de la historia del país. ¿Qué te parece? 
R.B.: Bueno, lo que pasa aquí eso ha sido así, lo que pasa es que aquí se ha quedado fuera una palabra muy importante en el momento en que vos pactás políticamente, la palabra "pacto" a mí no me da ni frío ni calor, sino ¿para qué el pacto?, entonces, esta palabra es el bien común, pero el bien común de todos, no el bien común de los que están pactando, ¿me explico?, ustedes tuvieron una experiencia muy bonita que ha sido un ejemplo, ¿no?, los Pactos de la Moncloa, y cuyo resultado ha sido, pues, más o menos, cierta gobernabilidad democrática y todo lo que ha avanzado España en una sola generación, ¿verdad?

\section{R: Sí, la generación mía, la de los setenta.}

R.B.: Claro, esa idea del pacto, en el sentido de los Pactos de la Moncloa, nosotros no la hemos tenido en los procesos de reforma constitucional, históricamente hablando, de Nicaragua, es decir, vos vas a pactar ¿para qué?, ¿para determinar cuotas de poder?, consecuentemente, de dominación económica, ¿para mantener los intereses de unos cuantos?, ¿o vas a pactar para hacer realidad el bien común de todos?, y eso tiene que ver también con la formación de las élites económicas o políticas en nuestro país, porque volvemos otra vez al tema del niño travieso del cuarto grado de primaria, el niño de cuarto grado de primaria pide para sí, es un niño egoísta, porque todos los niños son así, ese niño es el que ha estado gobernando este país, y ha signado los procesos de reforma constitucional, me disculpás el ejemplo así, pero es una de las formas de explicar el por qué de las cosas, el otro tema que ustedes lo explican mucho mejor que nosotros es el tema de las naciones y de los Estados en América Latina, y Nicaragua no ha sido la excepción, lo que ha sucedido en buena parte, que explica la teoría política clásica, ¿no?, en Europa, es decir, que las naciones dan origen a los Estados, aquí fue al contrario, los Estados dieron origen a las naciones, porque que me diga alguien que en el año 1821 había un grupo de personas que se identificaba como la nación nicaragüense, y que pedían, consecuentemente, la independencia, pues mire, yo creo que no, y el concepto de "nación nicaragüense", o "nación guatemalteca", etc., se ha ido forjando con el paso del tiempo, una vez que se delimitó la frontera, y esto es tuyo y esto es mío, y este es el Estado de Nicaragua, este el Estado de la república de El Salvador, etc., etc., y, consecuentemente, ahí es que ha nacido ese concepto de "nación", yo te digo, es decir, la diferencia que puede existir entre un guatemalteco, un hondureño, un tico, un salvadoreño y un nicaragüense son mínimas, mínimas y salvables todas, en relación con que podría ser decir, como me decía un profesor español, más en concreto canario, "ya me dirá usted lo que tengo que ver yo como canario con un finlandés", o vos que sos andaluza con un inglés, ¡ahí está Gibraltar!

\section{R: Sí, es verdad.}

R.B.: Entonces, eso sí, ustedes explican mejor también que nosotros el por qué de las cosas.

R. El proceso de la formación de los Estados le da un peso desproporcionado a las élites políticas nacionales.

R.B.: Nosotros no tenemos tampoco una sociedad tan, si no tenemos una sociedad tan claramente "estamentada" como es el caso europeo, y los estamentos que están ahí, más o menos visibles, no tienen, algunos tienen una visión de Estado en el sentido moderno de la palabra, pero no son aquellos, lamentablemente, que pueden tomar las decisiones 
efectivas que concreticen esa visión de Estado, porque al final de todo ellos también tienen que mantener el estatus quo, y, consecuentemente, son, por definición, conservadores. ¿Me explico?, es decir, es muy difícil que aunque yo tenga toda la educación y el conocimiento de las cosas, y tener el poder de negociar o tomar decisiones en el sentido político, que tenga todo, ¿no?, no vaya yo a tomar decisiones que protejan mis intereses como poder económico o como poder político, entonces, el tema de la realización del bien común en toda Nicaragua, de la nación nicaragüense, en manos de las élites políticas de este país, me parece que se queda fuera, si a eso le sumamos el tema de la falta de capacidad técnica, por así decirlo, para formular correctamente algunas de estas soluciones con un poco de coherencia y raciocinio, pues te da como resultado un caldo de cultivo para todo esto que estás viendo.

R. Y este reparto de las cuotas de poder en las principales instituciones del Estado, la politización de los órganos constitucionales, como la Contraloría, la Corte Suprema de Justicia, el Consejo Supremo Electoral, que, últimamente, además, está muy desprestigiado después del fraude en las últimas elecciones municipales, no ha supuesto también, en el caso de la Corte Suprema, me interesa, especialmente, una instrumentalización de la justicia constitucional para salvar el pellejo, digamos, a esta guerra legislativa entre el Ejecutivo y el Legislativo, me refiero, fundamentalmente, a la guerra entre los dos partidos, en este caso, el que está en el poder es el Frente Sandinista, pero cuando estaban los liberales, pues, los liberales y la bancada de oposición que está enfrentada a ellos en la Asamblea, ¿no?, y que siempre se ha articulado como una lucha entre los dos poderes que muchas veces ha dado lugar a una parálisis institucional. ¿Qué papel piensas que ha cumplido la justicia constitucional en este país?

R.B.: La justicia constitucional, pues, está profundamente signada por los intereses políticos de los partidos gobernantes, quiérase o no, y no te lo digo porque me caiga bien o me caiga mal, te lo digo porque yo tengo en mis manos sentencias de la Corte Suprema de Justicia que confirman este hecho que no tiene ni pies ni cabeza, en materia tributaria, te acabo de hacer mención, la 148, la argumentación jurídica muy bien, decente, ¿no?, etc., pero todo se cae cuando llega ese "por tanto", es decir, cuando llegas al "por tanto" no se resuelve nada, entonces, es decir, te tendría que explicar un poco cómo funciona el control de constitucionalidad, hay sistemas mixtos, como es el caso nicaragüense, tenemos ahí la declaratoria, tenés el amparo al que puede acceder cualquier ciudadano, el recurso de constitucionalidad al que también cualquier ciudadano puede acceder, y tenés la inconstitucionalidad de un caso concreto, lo que te dice la Ley de Amparo y la Ley Orgánica del Poder Judicial es que la autoridad judicial que conoce del caso puede declarar para ese caso en concreto la inconstitucionalidad de una norma, y que pasa el conocimiento de tal declaratoria de inconstitucionalidad pasa el conocimiento de la Corte en pleno, es decir, los 16 Magistrados, para ratificar o no la declaratoria de inconstitucionalidad en el caso concreto. En las sentencias que te pongo yo, por ejemplo, que es una sentencia muy discutida todavía hoy en día, el fallo de la Sala de Lo Constitucional, que es la autoridad judicial que resuelve el caso, y que debe declarar la inconstitucionalidad en el caso concreto, no porque lo diga yo sino porque lo dice la ley, no declaró en el caso concreto la inconstitucionalidad, y mientras tanto te dice, ¿no?, esto es el resorte de la Corte en pleno, cuando no es así, la ley expresamente te dice lo contrario, y la Corte en pleno cuando resuelva dice que se ratifica la declaratoria de inconstitucionalidad que hizo la Sala de lo Constitucional, cosa que en el "por tanto" no existe, ¿por qué se hace eso?, yo tengo ahí la sentencia, te la puedo 
enseñar si querés, eso te da una idea, entonces, claro, los perdidos fueron, en este caso, la Dirección General de Ingresos de la administración tributaria, y fueron a la Corte y dijeron: "mire, acláreme esto porque no lo entiendo", y la Corte respondió: "mire, esto está claro y es así", esto es técnicamente insostenible y, entonces, levanta suspicacias del por qué de las cosas, y muchos otros fallos que te vas a ir encontrando y que tus colegas te van a ir comentando de sus propias especialidades, por ejemplo, de cómo es que funciona, de por qué funciona, de cómo es que se traduce en el plano concreto todas estas situaciones de esta politización de los poderes del Estado y de los órganos constitucionales, que no está mal, no está mal, en el fondo, en tanto en cuanto como sucede en cualquier otra democracia los cargos de elección política, pues, los determina el gobierno de la nación, perfecto, pero lo que sucede aquí es que no existe un estamento limitativo, un funcionariado a la europea, por ponerte el caso más cercano, que te permita estabilidad laboral, que te permita un funcionamiento eminentemente técnico de la Administración Pública, de los poderes y órganos constitucionales, y que, consecuentemente, no suponga la entrada en crisis con los cambios de gobierno, es decir, por los cambios de jefe, es decir, una Ley de Carrera Administrativa, que existe, pero no aplica, la Ley de Carrera Administrativa Municipal que existe, pero tampoco se aplica, es decir, el tema de toda la vida, llega el nuevo gobierno, llega el nuevo jefe, y hace barrida desde los asesores hasta el consejo, entonces, no tiene ni pies ni cabeza, ¿cómo una Administración Pública funciona?, no puede funcionar una Administración Pública cuando cada gobierno hace un cambio, y volvemos un poco al inicio porque, ¿cómo funcionaría esto?, es decir, OK, un régimen de acceso a los cargos de función pública por medio de un proceso de concurso-oposición, como lo suelen hacer en España, nunca se ha hecho en Nicaragua, entonces, la primera pregunta que te surge es: ¿y quién lo va a hacer?, ¿quién va a examinar a esos nuevos funcionarios?, ¿el funcionario que ya está?, perfecto, porque el funcionario que ya está que no entró por oposición va a hacerle el examen a aquellos que sí van a entrar por oposición, claro, ustedes lo ven de una manera sencilla y normal porque han tenido, generacionalmente, ese modo de actuar, y no caen en la idea de que hay que empezar de cero, nosotros no hemos empezado de cero, porque si vamos a empezar de cero, entonces, lo primero que va a decir el que concurra, ¿no?, "bueno, ¿y usted por qué me va a examinar para obtener mi plaza si usted está en esa plaza sin haberse examinado?", entonces, la creación de una administración no puede, un régimen de funcionariado, ¿no?, por oposición, que es importante para fortalecer el Estado, es uno de los puntos neurálgicos que aquí todavía no se ha discutido y no se ha resuelto tampoco o no se quiere aplicar la ley, porque no conviene desde el punto de vista político, por el tema este de que viene el del gobierno y pone al que quiere.

R: Respecto a los poderes del presidente y de la Asamblea, otra de las cuestiones que me llama la atención es que ese ha sido un poco el hilo conductor de las reformas, ¿no?, esa parlamentarización del sistema presidencial excesivo que tenía en Nicaragua, heredado de la revolución, que también era otro contexto político, que necesitaba fortalecer al presidente de la República, entre otras cosas, porque gobernaba un país en guerra, como fue toda la década del 79 al 89 por el conflicto con la Contra, y también por el bloqueo norteamericano, y, sin embargo, esa mayor atribución de facultades a la Asamblea, tú antes cuestionabas el hecho de que el presidente no tuviera capacidad de decisión en materia fiscal, a través de la figura del decreto, y otra cuestión es la ratificación de los altos funcionarios, de los miembros del gobierno y de los diplomáticos que en la reforma del 2005 no cumple actualmente con ese precepto constitucional el gobierno de Ortega. El gobierno de Ortega, por otra 
parte, ha estado fortaleciendo ese Ejecutivo, que, constitucionalmente, se ha ido debilitando, a través de la reducción del poder de veto y el poder de decreto, que es la capacidad fundamental del presidente, en términos puramente constitucionales, $y$, sin embargo, ha tratado a través de la reforma de la ley que regula el Poder Ejecutivo, a través de la creación de los Consejos del Poder Ciudadano, a través del intento de reforma que quiso hacer a la Ley de Amparo, estableciendo una especie de control preventivo, que es el modelo francés, que tienen un control preventivo de la ley, así es posible entender la manera en la que el presidente Ortega ha tratado de recuperar facultades de una forma también jurídicamente controvertida.

R.B.: Sí, lo que pasa es que yo no hablaría de una parlamentarización del sistema nicaragüense, yo lo de lo que hablaría es de un nuevo balance de fuerzas entre los diversos poderes del Estado, porque como vos misma lo dijiste, claro, en la década del 79-89 hubo un período de conflicto bélico en el que, evidentemente, se necesita como consecuencia reforzar las funciones del presidente, ¿no?, digo del presidente como jefe del Estado y como jefe del gobierno en un contexto en el cual se tiende a crear un sistema democrático donde ya no hay conflicto bélico, etc., etc., lo que tenés como resultado es que tenés planteado un esquema constitucional de distribución de los poderes, de un Poder Ejecutivo sumamente fortalecido, el Poder Legislativo con facultades compartidas, cuando en la teoría clásica, tales facultades no deberían ser compartidas sino que deben ser exclusivas del Poder Legislativo, entonces, el proceso de reforma lo que ha venido haciendo, creo yo, es balanceando este conjunto de facultades, como si fueran vasos comunicantes, ¿no?, desde el Poder Ejecutivo hacia el Poder Legislativo, de forma tal que se pudiese normalizar un poco dentro de lo que sería la teoría constitucional la teoría de los pesos y contrapesos entre diversos poderes del Estado, ¿que eso constituye una parlamentarización?, no lo creo, pues, porque siempre tenés una elección directa del jefe del gobierno, que es también la cabeza del Estado, y que, consecuentemente, pues, sí continuará siendo un régimen, eminentemente, presidencialista, con un Legislativo que tiene como facultades las que como Legislativo debe ejercer, sí, efectivamente, ha sido el hilo argumental de las reformas constitucionales, pero ¿quiénes y cuándo?, es decir, cuando el Frente Sandinista estaba en la oposición, verdad, quitaron poder al presidente para trasladarlo al parlamento y ahora el proceso es el inverso, ¿me explico?, entonces, número uno, no creo que el anterior proceso constituya una parlamentarización del sistema nicaragüense, uno, y número dos, que no me parece que hoy en día a través de una reforma el Poder Legislativo vaya a retroceder en cuanto a las cuotas de poder que constitucionalmente ya tiene, el Poder Ejecutivo lo ha hecho o lo ha intentado, pero no lo ha logrado, un tema o una idea muy clara, por ejemplo, es en materia tributaria, en materia tributaria existe una reserva de ley para la Asamblea Nacional, punto, sólo la Asamblea Nacional puede crear tributos, el presidente ha creado hasta la fecha, bueno, sólo este año ha creado treinta y un tributos, por decreto, por decreto, claro, entonces, el ABC de las cosas te dice: "oiga, mire, esto no puede ser, no tiene razón, es decir, no funciona", pero eso es un intento, desde el punto de vista político de volver hacia lo que es agua que ya pasó, entonces, no creo que se pueda retomar eso, bueno, al final es parte del juego político, es decir, requiero de poder y lo necesito para hacer todo lo que tenga que hacer, ¿no?, lo importante aquí es ¿para qué querés el poder?, ¿para qué lo vas a utilizar?, si me vas a decir que para hacer realidad esa bonita palabra que es el bien común, adelante, pero no creo, es decir, los tiempos no me lo demuestran. 
R: El presidente de la República, aunque no tiene facultad para crear decretos en materia tributaria sí lo hace en materia administrativa a través del reglamento, a través de un decreto con rango de reglamento, y no de un decreto-ley, ¿no? Entonces, al final esta pérdida del poder del presidente es muy relativa, ¿no?, en materia tributaria me refiero, ha sido un actor fundamental a la hora de decidir sobre los impuestos de este país.

R.B.: El artículo 150 de la Constitución dice, a ver, sí es muy relativa, en materia tributaria, mira, aquí está el artículo 150 de la Constitución que dice lo siguiente, a ver si lo hallo, "son atribuciones del presidente de la República las siguientes: uno, cumplir la Constitución y las leyes, y hacer que los funcionarios bajo su dependencia también las cumplan; dos, representar a la nación; tres, ejercer la facultad de iniciativa de ley y el derecho al veto según lo establecido por la presente Constitución; cuatro, dictar decretos ejecutivos en materias administrativas", punto, este inciso cuarto ha permitido hacer regulaciones en materia fiscal, y muchos más hasta el 17, vámonos al 138, bueno, vámonos al 114 de la Constitución, que te dice: "corresponde exclusivamente y de forma indelegable a la Asamblea Nacional la potestad para crear, aprobar, modificar o suprimir tributos", punto, se puede decir más alto pero no se puede decir más claro, creo yo, $\mathrm{OK}$, esto, técnicamente, para ponértelo en términos de la doctrina tributaria española se llama reserva de ley, eso significa que el presidente no puede crear tributos, llámese éstos tributos, impuestos o tasas especiales, eso significa que los elementos de la cuantificación de tributos: base imponible, tipo de gravamen, exención, etc., etc., no pueden ser creados por el presidente, en Nicaragua lo hace el presidente a través del reglamento, no este presidente, en el reglamento anterior de la Ley de Equidad Fiscal, que era la que yo te estaba señalando anteriormente, no obstante ello, en este gobierno se han aprobado el decreto sobre los cánones de la Ley de Aguas, que es tributo, por uso privativo de agua potable en pozos privados, etc., y otros tributos, que son técnicamente tasas por servicios, mediante decreto, ya no dispone de lo que le dice la Constitución, ¿por qué?, no lo sé, si hay o no hay capacidad para diferenciar entre una tasa de un impuesto, etc., que son cosas totalmente distintas, y en materia tributaria se resuelve en el año 95 con la redacción del 114, solamente la Asamblea, de forma exclusiva e indelegable, puede crear tributos no el presidente, no obstante, han intentado volver hacia atrás, es decir, reacomodar sus fuerzas políticas en esta materia, se han interpuesto los correspondientes recursos de inconstitucionalidad sobre esta materia, hay que ver lo que ha pasado con las resoluciones de la Corte, la justicia constitucional suele responder en un promedio de 7 años en este tipo de situaciones, ahí estamos esperando todavía.

R: Y ya para terminar, ¿qué futuro aproximas respecto a la consolidación de las instituciones democráticas y de acompañamiento, digamos, de un marco constitucional estable que permite un juego entre los actores más acorde con la gobernabilidad democrática, y también más acorde con lo que es la aplicación específica de la norma constitucional, la eficacia de la norma constitucional, yo creo que hay una especie de divorcio y de deslealtad por parte de las élites políticas de cara a la propia Constitución, ¿no?

R.B.: Yo creo que esto no se va a resolver a corto ni a mediano plazo, esto es una solución que pasa por el tamiz de la educación, que es una generación que nos va a dar una visión nueva y no por la anterior que está profundamente signada por un modo de hacer las cosas, porque la revolución sirvió a un propósito, pero que ya hoy en día en el juego de la democracia, pues, ya no tiene razón de ser, y que lo que determina de cara a 
todas las personas, es decir, muchas veces hablamos de las instituciones como si fueran robots, y no nos acordamos de que quienes están en las instituciones son seres humanos, que son personas con todas sus filias y sus fobias y sus manías, están ahí y ejercen el poder, como decía Zubiri: son unidades bio-psico-sociales, ¿no?, y, consecuentemente, pues, con todo ese bagaje de filias, fobias y manías, pues, van a proyectar el ejercicio del poder político, consecuentemente, no creo yo que vaya a ser una solución el tema de la institucionalidad democrática en este país sea un cambio de la noche a la mañana, lo importante es seguir haciendo el esfuerzo, cada uno dentro de lo suyo, en mi caso, dentro de la Universidad, y tratar de inculcarles ese cambio de "chip", ¿no?, decirles: "oigan, miren, las cosas se hacen de otra manera". 


\section{ENTREVISTA 9 ${ }^{12}$ :}

Nombre del entrevistado: D. Enrique Bolaños Geyer.

Cargo actual: presidente de la República de Nicaragua (2002-2007).

Fecha de realización de la entrevista: Managua, 23 de noviembre de 2009.

Lugar: Casa particular del ex-presidente Bolaños en El Raizon (carretera a Masaya).

Duración estimada: 34 minutos.

\section{TEXTO - Transcripción 9:}

R: ¿Cuál sería su visión, haciendo un recorrido, digamos, en el tiempo, desde principios de los 90, desde la firma de los acuerdos de paz en la transición democrática, con el primer gobierno de Doña Violeta, hasta el momento actual cómo los cambios constitucionales han ido produciendo avances o retrocesos en la consolidación de las instituciones democráticas?

E.B.: Bueno, en realidad, lo que ha habido son, básicamente, dos reformas constitucionales, las dos, digamos, que han sido más de retroceso que de avance, más de retroceso que de avance, si uno revisa la historia de lo que le ha pasado a Nicaragua desde nuestra independencia para acá, 1821, hemos sufrido lo que yo le llamo el poder o la guerra, es el grito del asaltante, "la bolsa o la vida", y aquí el grito ha sido de los caudillos en el poder, o te hago la guerra, entonces, hemos tenido por lo menos cinco o seis mandatarios que hemos asesinado por, muchas veces, ha sido la insistencia de quedarse más tiempo en el poder, y otras hemos tenido una guerra un poco porque lo han querido votar, $y$, entonces, quiere cumplir su período, mientras las reformas que se han hecho son históricamente basadas para que le calcen al caudillo de turno, no es que le calce al país, que vamos a crear instituciones, sino cómo le acomoda al deseo del caudillo de turno, y esas hemos tenido, básicamente, dos reformas basadas en eso, y otras reformas que se han hecho dentro de esas mismas, que han sido avances, por ejemplo, teníamos la Constitución de 1987, que era, totalmente, presidencialista, era un poder enorme central, imperial, del presidente, y dos reformas que se le quitan al presidente correctamente, que se trata de crear su institucionalidad presidencial, como, por ejemplo, él era en la Constitución de 1987, tenía libre autoridad para nombrar y crear los Ministerios que él quisiera, dándole las atribuciones que él deseara, crear la cantidad de Ministerios que él quisiera, eso no es institucional, sino que debería estar más rígido por la conveniencia del país, y así se legisló, de manera que cuando llega Doña Violeta a la presidencia en 1990, que ganó las elecciones, el decreto número uno de ella es, básicamente, con otras palabras, pero yo me voy a organizar así, dos puntos, y comienza a decir cómo se quiere organizar, podía organizar al país como ella quisiera, eso después se legisló dentro de unas reformas en el 95, creo, quitándole esas atribuciones, y ya creando las instituciones, Ministerio de Gobernación, Ministerio de Relaciones Exteriores, etc., pues, ya se crearon doce Ministerios, y otras instituciones del Estado, así que lo que hemos tenido es avances y retrocesos, pero los retrocesos que hemos tenido son de lo más dañinos, porque, precisamente, es lo que hemos sufrido mucho en el país, el caudillismo, y hacemos reformas para que le calcen al caudillo.

12 Entrevista breve, centrada, especialmente, en algunas observaciones del ex-Presidente Bolaños en torno a los procesos de reforma constitucional recientes, así como en los factores históricos, culturales y políticos, que median en las carencias del Estado de Derecho y la débil institucionalidad democrática del país centroamericano. 
R: Para recuperar esa imagen interesante o ese concepto de los caudillos, que aparece en casi todos los entrevistados además, ¿no?, hay que recuperar también la figura de los partidos políticos en Nicaragua. El hilo conductor de las reformas ha sido el de reducir parte de las atribuciones constitucionales del presidente de la República en favor de la Asamblea, del órgano legislativo, pero como un vicio, digamos, en la práctica institucional de la Asamblea, realmente, ha estado cooptada por los intereses de los principales partidos, en este caso, sería el PLC y el Frente Sandinista, ¿no? ¿Cómo ve usted sobre todo a partir de la reforma del 2000?, porque la reforma del 95 es contemplada, digamos, con una amplia legitimidad por el momento político que le tocó vivir al país, porque había que ajustar el marco jurídico a la transición democrática, y, en ese sentido, no se podía seguir gobernando con la Constitución original del 87.

E.B.: Fíjese que le digo que limitó las atribuciones del presidente, porque eran demasiado imperiales, pero sí creó la institucionalidad de la presidencia, con suficiente poder presidencial, pero sin extravagancias, pero ya después 2000, 2001 ahí ya fue, simplemente, para darle el capricho al caudillo, ahora, si vamos más atrás, y que es necesario ver un poquito el espejo retrovisor, la Constitución que hicimos en 1987 es un retroceso enorme comparado con los avances que habíamos tenido hasta la de 1978, o 74, creo que fue la última, la del 74, porque se creaban instituciones, ¿verdad?, limitando bastante el poder presidencial, que no fuera tan omnímodo como lo fue en la del 87, ese era un poder más que imperial, un emperador de Roma en Nicaragua, y eso lo limita el 95.

R: Bueno, también se estaba gobernando un país en guerra, ¿no?, estar bajo un Estado de excepción casi requiere un liderazgo fuerte, digamos, que son circunstancias también extraordinarias, por decirlo así, en el tiempo de la política.

E.B.: Pero son más de siete años después de la guerra, es decir, terminó la guerra en el 79 , te estoy hablando de la del 87, nueve años después, ya no es en guerra, es verdad que tuvimos una guerra consecuencia, precisamente, de ese imperio que se estaba imponiendo en el país, una censura brutal, libertad de expresión censurada, y etc., por una cantidad de cosas adicionales, pero trajo como consecuencia que se pone la Constitución peor, ahora ya no es porque es un régimen revolucionario y vienen a imponer cosas de la revolución, ahora ya es la Constitución que nos va a regir para siempre, digamos, y ya nueve años después, no, si es que para mí fue un gran retroceso.

R: Y hablando de esa reducción de los poderes del Ejecutivo, en el caso de su gobierno, la reforma del 2005, y además usted fue un presidente con enormes dificultades para sacar adelante la agenda de gobierno, experimentó la división del liberalismo, ya estando usted en la presidencia, ¿cómo recuerda ese último proceso de reforma constitucional?

E.B.: Fue teóricamente para amarrarme las manos, porque no quería el caudillo del PLC en el acuerdo, en el pacto que se llama aquí, con el Frente Sandinista o con Daniel Ortega no quería que yo tuviera la capacidad de poder ejecutar todos los proyectos que tenía en mente, que eran no más en beneficio para el país, quise traer electricidad, entonces, pasaron una ley diciendo: "prohibido el uso del agua para generar energía", ¿en qué cabeza cabe?, pero es para que yo no la hiciera, hoy se hace libremente, es decir, sin licitar y sin hacer todo el procedimiento que estaba planeado para hacerlo, lo 
mismo, mucha dificultad para hacer carretera, tenía programas, de manera que dejé 1.851 millones de dólares sin hacer, quedaron para el siguiente período, porque se pasó la legislación y hubo obstáculos en la Asamblea para que pudiera gobernar, esa reforma, pues, que hacen de la Constitución era para amarrarme las manos, obligarme a renunciar o votarme o al menos tenerme de monigote sin poder hacer nada, yo vengo de familia de historiadores y me gusta leer mucho de la historia, etc., especialmente, de mi país, y decidí: "yo no voy a renunciar", yo he visto muchos presidentes, que con mucha facilidad, pues, ponen su renuncia y se van, "te voy a dar amnistía, quedas perdonado de todos tus pecados, y te voy a dar tantos millones y andáte", yo no quería nada de eso, yo voy a tratar de mantener la institucionalidad que existe ahorita con la presidencia, con la institucionalidad con que la recibí, pero dejen que el presidente actúe, esa reforma fue, únicamente, por ese capricho de los dos líderes, y duró desde el 13 de enero del 2005 hasta el 10 de octubre del 2005, siguieron muchas cosas pendientes de ejecutarse después que yo dejara el gobierno, pero no se aplican.

R: Efectivamente, ahora si se da una concentración y un fortalecimiento del Poder Ejecutivo en contraposición a su última presidencia.

E.B.: Pero es porque cada ley que vamos haciendo, no sólo constitucional, en todo orden, es para satisfacer los deseos o caprichos del caudillo de turno.

R: ¿Qué piensa usted de las leyes Marco que han sido un instrumento jurídico muy peculiar de la historia constitucional de Nicaragua y que ha servido para ampliar un poco el proceso de la negociación política en un momento de gran desacuerdo entre el Ejecutivo presidencial y la Asamblea, que propone una ley de reforma parcial a la Constitución?

E.B.: Bueno, legalmente, no valen, si se analizan bajo la lupa jurídica de ustedes los abogados, verdad, es un mamotreto jurídico, pero dentro de los acuerdos no había otra solución más que ese mamotreto. Hablando de los partidos políticos, son una absoluta necesidad, lástima que han funcionado mal, han funcionado, $\mathrm{y}$, precisamente, tiene que ver con eso que le estaba contestando, han funcionado los partidos políticos para satisfacer más que todo los deseos del caudillo de turno, del caudillo del partido de turno, no buscando institucionalidad, yo sé que los partidos y todo necesitan un líder, pero no como caudillo, esa palabra ya pasó de moda, está bien un líder pero que tiene que tomar en cuenta el consenso de su población y de su partido, no sólo los caprichos del líder, y, entonces, esas leyes Marco salen negociadas con líderes que tienen ascendencia sobre las asambleas que las aprueban, pero si uno le pone una lupa legal, jurídica, en realidad, eso es un mamotreto jurídico, pero valen porque todos estábamos de acuerdo que valían.

\section{R: Y porque era la única forma de solucionar el conflicto.}

E.B.: Era la única forma de solucionar, porque la alternativa de los partidos políticos o de la política era la guerra, aquí o se solucionan las cosas vía política a través de partidos políticos y de acuerdos políticos, pues, o la guerra, no hay otro camino en ninguna parte del mundo, solo esos dos caminos, por el bien o por el mal. 
$R: Y$, sin embargo, ese recurso del pacto, que asimismo es algo propio de cualquier democracia, la negociación entre fuerzas políticas de distinto signo, aquí sí se ha pervertido en un juego de intereses como es el que menciona.

E.B.: Porque es para darle gusto al caudillo, no es por soluciones nacionales, ¿para qué se hizo la última en el año 2001, "yo soy presidente", dice uno, Arnoldo Alemán, "el 10 de enero de 2002 voy a dejar la presidencia, me voy a mi casa, yo no quiero irme a mi casa, yo quiero seguir en la lucha política, no puedo reelegirme, quiero reelegirme, no puedo, pero quiero ser diputado, pues, entonces, para ser presidente de la Asamblea y gobernar y seguir mandando desde ahí, entonces, ¿qué me das?, o ¿qué me pedís para que yo sea diputado después que deje la presidencia?, negociemos", "bajáme que con $35 \%$ pueda ganar", "con $35 \%$ que podás ganar, vos me dejás que yo pueda ser diputado", ahí está la reforma constitucional para satisfacer la ambición de una persona.

R: Y ahora que ha hablado del tema de la dificultad de la renovación del liderazgo político en Nicaragua, o sea, da la impresión de que los líderes no quieren renunciar a su posición de poder, y continúan asi hasta que son tan mayores, que no tienen más remedio que salir fuera de la escena política, ¿no?

E.B.: Desde 1821 tenemos lo mismo, el primero que nombró Nicaragua por elecciones imperfectas, porque era de otra forma, pues, 1824, que lo fusilamos, el vice-presidente recogió el poder y lo fusiló, ¿verdad?, pero desde ahí venimos continuamente cometiendo esos actos de la lucha por el poder, y los partidos, entre el Partido Conservador de Granada y el Partido Liberal de León en una continua guerra, cinco, por lo menos, gobernantes fusilados, muertos, asesinados, hay uno, el caudillo que está que lo echa a la cárcel, manda a un asesino de la calle a asesinarlo allí en la celda y lo asesina, y, claro, al que mató, pues, lo matan ahí, pero queda impune, ¿verdad?, y así, quisiéramos poder llegar a tener un cambio de mentalidad como, milagrosamente, se acaba de ver el sábado, una marcha que ya no dejan a uno protestar pacíficamente, a regañadientes, digamos, yo no sé cómo, pero que tuviéramos más de eso, pues, poder salir, no estoy de acuerdo con eso, pues, que salen otros que sí están de acuerdo con eso, bueno, pero solo manifestarnos, tener el derecho a podernos manifestar, ¿qué es lo que acababa de hacer?, como no hay reforma constitucional, ahorita no se puede cambiar la Constitución, hay pugnas entre los líderes políticos, pues, la Corte dice: "ese artículo viola los derechos humanos", porque él quiere reelegirse, ese es un derecho humano, tiene derecho a reelegirse, otro mamotreto jurídico de la Corte, verdad, pero, dijéramos, que esas cosas se compusieran porque eso es lo que nos ha lastimado mucho en la historia, y por eso estamos casi de todas las Américas a la orilla de Haití en pobreza, siendo un país rico.

R: No, hay una coincidencia en el discurso con otros entrevistados, que miran hacia atrás, hacia la historia, para explicar el presente, pero no se convierte ese pasado, que sienta pautas de cultura política muy arraigadas, en una justificación...

E.B.: Pero si lo que yo digo es que necesitamos es vencerlas, no las puedo vencer si no las conozco, pero uno, yo no digo que voy a manejar el carro viendo el espejo retrovisor, yo voy a manejar mirando hacia delante, pero, de repente, dar una miradita para atrás, para orientarme de dónde vengo, él que no sabe hacia dónde quiere ir, no llega a ninguna parte, cualquier camino que tome, es bueno o es malo, pues, no sabe adonde va, el que quiere y sabe adónde quiere ir, hay caminos buenos y caminos malos, 
pero hay que distinguir el bueno y el malo, y de repente dar una miradita al retrovisor para ver que no me vaya a chocar allá, a colisionar con otras cosas que ya el pasado me lo está contando lo que viene atrás, por eso es una miradita nada más, que vale la pena tenerla en cuenta para saber qué errores he cometido, enmendarme y tomar este camino.

$R$ : Y en relación a ese futuro, ¿cómo ve usted el futuro, digamos, a corto plazo en su país?, ¿cree que se va a producir una candidatura presidencial única para las próximas elecciones una vez que se ha abierto esta vía discutible, digamos, de la posibilidad, no, de la presentación de la candidatura de Ortega a las próximas elecciones?

E.B.: ¿Una única, nada más?, ¿solo, como Fidel Castro?

R: Bueno, la posibilidad de unir el liberalismo, que ha sido lo que ha dado la victoria a Ortega. ¿Cree usted que es factible o que la herida es tan fuerte que va a permanecer dividido el bloque liberal?

E.B.: Yo creo que debemos distinguir varios estratos que tenemos en Nicaragua un 30\% de los nicaragüenses votantes, ¿verdad?, 30\% es la base de Daniel Ortega, es un techo no muy alto, pero él comienza con esa base, $30 \%$ más o menos, el liberalismo, Arnoldo Alemán tiene una base de $20 \%$ al $25 \%$, ¿cuál es su techo?, si sumamos estas dos son cincuenta y pico por ciento, $50 \%$ más o menos, pero ahora el resto, no está ni con uno ni con el otro, ahí hay $45 \%, 50 \%$ donde pescar, ¿quién va a pescar?, ¿cómo van a pescar?, el desencanto liberal ha sido grande, los liberales de la revolución para acá por lo menos no hemos ganado ninguna elección, si no es también con otros aliados, porque no sumamos más del 50\%, entonces, el arte está en que hay un caudillo que si ese se separa más unión, pudiera venir un poco de más unión, pero si él se encapricha, que yo soy el único, aquí hay que tener unidad, sí, vengan, vengan todos, no creo que ayude mucho, más que su base que tiene y un poquito más, sucedió en las elecciones del 2006, las presidenciales, los liberales entre Rizo y Eduardo Montealegre se divide el voto liberal más algunos desafectos, ¿verdad?, tal vez lo voy a poner de una manera que me dice uno hace poco, pues, platicando, “¿vas a ir a la marcha?”, le pregunto, me dice, "no”, "pero si vos sos liberal", "sí", me dice, "pero si esa marcha tiene éxito el ganador es Arnoldo Alemán y yo no le voy a ayudar a que sea él", y hay muchos que piensan así, si abrieran el partido a una elección de un nuevo liderazgo, pero con honestidad, con transparencia, tal vez, puede ser otra vez un partido de esperanza, pero el PLC lo que le queda no tiene, tiene más ya el sandinismo que el PLC, el PLC el verdadero, legítimo, pues, de Arnoldo, Eduardo anda con otra parte liberal, pero lo mismo, me pregunto yo a veces, me gusta medio filosofar a veces y preguntarme por qué escoger "Vamos con Eduardo", no hay nada nacional, no hay pensamiento nacional, es Fulano per se, volvemos al caudillismo, ¿qué nos pasa?, ¿por qué escogemos ese nombre?, ¿ese es el que pega?, ¿"Vamos con Eduardo"?, ¿por qué?

R: Y, haciendo una comparación entre los últimos cuatro presidentes que ha tenido Nicaragua, si resulta también hablando de liderazgos fuertes comparar las figuras de Alemán y de Ortega, que han tenido un fuerte control sobre sus bases partidarias, y Doña Violeta y usted que quedaron sin el apoyo, en el caso de ella, de la coalición gubernamental, la UNO, que la llevó a la presidencia, y en el caso de usted, que experimentó la división del liberalismo y el enfrentamiento con el viejo líder del PLC, 
Arnoldo Alemán, ¿no?, ¿cómo ve usted esta comparación entre estos cuatro presidentes?

E.B.: Bueno, ella tuvo más suerte que yo todavía, porque tuvo bastantes más diputados en la Asamblea, yo de noventa tuve nueve, ¿verdad?, es muy difícil, casi imposible gobernar con nueve de noventa, entonces, yo tenía que estar haciendo compromisos con unos para después hacer compromisos con otros para pasar ciertas materias, para pasar otras hacía compromisos con éste, yo sé que la vida es de compromisos, ¿verdad?, los matrimonios también, en todo, pero no con ese chantajismo con que me ví sometido, ella tenía menos chantajes.

\section{$R:$ ¿Por parte de las fuerzas opositoras?}

E.B.: Por parte de las fuerzas opositoras, porque ella tenía más gente, más gente que quedó con ella, yo sólo quedé con nueve.

$R: Y$, en ese sentido, ¿cómo visualiza esa reforma constitucional que debilita al Ejecutivo, por un lado, y por otro, lo somete, digamos, como usted dice, a ajustarse a la negociación individual con los diputados?

E.B.: Pero es que el Ejecutivo es necesario limitarlo y también institucionalmente, que es muy diferente, es decir, esta es una institución que tiene estos límites, así debe ser, igual la Asamblea, tiene estos límites, no es imperial, no es el capricho, pueden gobernar, pero tenés un límite, el Consejo Supremo Electoral tiene un límite también, no es lo que digan ellos porque son los jueces y dicen: "lo blanco es negro porque así digo yo", hay límites, pero el límite es la institucionalidad que hay que poner en el país, y luchamos por eso, yo luché por eso, algunas cosas logré.

$R:$ ¿Y cómo ha visto usted el aprendizaje del Frente durante 16 años de oposición, que ha sabido muy bien mantener el control de las instituciones, ¿no?, perdió en el año 90 y dijo: "ahora vamos a gobernar desde abajo", es algo que han referido también continuamente los entrevistados, ¿no?, también durante casi 10 años de duración del régimen sandinista y de coincidencia entre el partido y las estructuras del Estado, ¿no?, a ellos también les ha dado la visión de que para poder gobernar hace falta controlar las instituciones, hace falta estar en las instituciones, ¿no?, ¿cómo ha visto usted este aprendizaje, digamos, del Frente en la oposición democrática para llegar a la posición cuasi-hegemónica que tiene en la actualidad?

E.B.: Bueno, pero es que ¿qué le ha pasado al Frente?, si decimos de aprendizaje, si fuera aprendizaje el Frente estuviera más fuerte, pero el Frente está bien dividido, es un individuo el que tiene el poder, que él está más fuerte, pero se ha fraccionado, la Dirección Nacional del Frente eran nueve personas cada uno, los demás están en otros lados, se ha fraccionado como Frente Sandinista, ¿verdad?, quiere decir que se ha debilitado, porque si un infarto lo quita a Daniel, se cae el partido, quiere decir que no se ha fortalecido, porque anda fraccionado, vendrá ahí un pleito de perro entre los que quedan por coger el liderazgo, bueno, entonces, yo no creo que se haya fortalecido, el aprendizaje ha sido para el país, ha sido más bien un poco negativo, porque no ha creado ni ha contribuido a crear instituciones, sino caudillos, liderazgos, que eso nos hace retroceder, nos condena al pasado. 
R: Y ya, digamos, como última reflexión, otro aspecto interesante de la Constitución es que no ha logrado convertirse en un paraguas jurídico que abarque a todos los nicaragüenses, siempre ha habido como sectores excluidos del pacto constitucional, ¿no?, en el 87 una parte de los ciudadanos de Nicaragua no se identificaron con el proyecto revolucionario, y quedaron fuera de esa Constitución original del 87, y las sucesivas reformas han supuesto también importantes conflictos a la hora de aprobar las leyes de reforma parcial, ¿no?, esta última sentencia rompe con el principio de seguridad jurídica y del propio valor normativo de la Constitución, he oido desde planteamientos de un nuevo diálogo nacional, si seguía empeorando la situación, ahora esta marcha parece que ha dado cierto oxígeno a la ciudadanía, en el sentido de que no se han cerrado tanto los espacios políticos como parecía...

E.B.: Bueno, es una brisa que refresca, la marcha del sábado, tranquila, que así siguiéramos, poder manifestarnos, estoy de acuerdo, y que no me hagan nada, nada, y los empleados públicos no me obliguen a manifestar que estoy de acuerdo o no estoy de acuerdo con lo que sea, ¿no?, pues, dejar esa, yo pasé esas leyes de los derechos de los empleados públicos, todo el régimen que había bajado sus libertades, desde portarse bien, trabajar bien, ser eficiente y fuera en la política, más que la muy personal de ellos, quisimos hacerlo en la Corte y me salió el tiro por la culata, ya ves, se adelantaron ellos, hicieron una con la mayoría de la Asamblea para tener más control sobre los empleados públicos, pero tenemos que avanzar hacia eso, esta marcha, pues, ya lo hemos tenido, cada vez que hay un problema, diálogo, y no resultan en nada, realmente, positivo, porque todas las fuerzas que concurren ahí, cada quien, o sea, ¿cuántos colores básicos hay?, pues, por lo menos siete, ¿verdad?, pues, si van siete cada quien quiere un color para pintar la casa, si los mezclamos todos juntos, Dios mío, ¿qué color dará?, pero no nos ponemos de acuerdo en intereses de la nación, sino en muy, muy personales.

$R$ : Entonces, ¿no ve posible un nuevo pacto constitucional, o, al menos, recuperar el valor de la Constitución en este contexto de la difícil transición democrática?

E.B.: Yo no creo que permita nadie hoy día en Nicaragua abrir la Constitución para reformarla, porque va a llegar a travesearse y quién sabe qué monstruo va a salir de ahí, hay fuerzas que tienen el poder y que al momento de que se abren para reformar este cuadrito, nada más que lo vamos a pintar en este tal otro color, pintamos otras cosas y quién sabe qué queda, porque no tiene límites, no está prohibido que se abra meter la mano para travesear todo lo que se pueda, y yo creo que nadie está dispuesto a que se abra la Constitución ahora, no, esa no es una vía práctica posible en la Nicaragua de hoy, debería poderse hacer, pero con patriotismo, con fervor patrio de que esto es lo que sabemos que vamos a componer así, y que todos estamos de acuerdo en componer para crear más instituciones, pero, en el momento en que uno la abre, ahí aparecen las manos traviesas, si ni siquiera quiere reformarse la ley del Supremo Electoral, porque necesita algunos cambios, pero quién sabe qué monstruo va a salir a la hora de abrir la Constitución y que todos metamos la mano ahí.

$R$ : ¿Y cree usted que el pacto sigue activo entre Ortega y Alemán?, ¿Qué se ha convertido en una forma de solucionar las cosas a través de esta negociación privada entre los dos líderes?

E.B.: Tristemente, tristemente. 
$R$ : ¿Y que se va a volver a aplicar en la renovación de la composición de la Corte, del Consejo Supremo Electoral que viene dentro de poco?

E.B.: Bueno, yo sé que nadie tiene los 56 votos, entonces, los que tiene el uno y los que tiene el otro, tienen que llegar a algún acuerdo para decir por este sí y por este no, pero como tenemos una gran desconfianza a la palabra pacto, porque siempre llega a un acuerdo, no patriótico, sino de intereses de caudillo, y es tradicional, y eso es lo que nos dice el espejo retrovisor, dice de dónde venimos, más de lo mismo, bueno, tengo temor de que no sea pacto, casi es mejor no tener Corte Suprema, dicen muchos.

R: Pues, por mi parte, casi he finalizado en mis preguntas, ¿si tiene algo más que añadir o algo que le gustaría mencionar como reflexión final, que pudiera aportarme desde su experiencia como presidente de la República?

E.B.: No, bueno, pues, si ahí le estoy dando experiencias propias, pues, observaciones propias, humildes observaciones propias, porque es un país complicado, no se puede uno sustraer de sus propias creencias y deseos, pues, yo tengo convicciones firmes, y, digo yo, con mi conciencia y tranquilidad, que las mías son buscando el mejor interés de la patria, ¿no?, no es nada personal, yo no he buscado nunca nada personal, pues, ese es mi espejo retrovisor, de dónde vengo, nunca le he buscado, estuve ahí y no metí la mano en nada, más que bienestar para el país, y quisiera que así se tratara una reforma constitucional, que, como decía Lincohn, no se puede quedar bien con todos todo el tiempo, sólo se puede quedar bien con todos parte del tiempo, y se puede quedar todo el tiempo bien con parte de la gente, pero nunca se puede quedar bien todo el tiempo con toda la gente.

R: No, pues, muchísimas gracias por su tiempo.

E.B.: No, gracias a tí, aquí tengo unos documentos para darte. 


\section{ENTREVISTA 10 ${ }^{13}$ :}

Nombre del entrevistado: D. Roberto Cajina.

Cargo actual: Profesor e investigador, colaborador de la Universidad Americana (UAM), experto en temas de profesionalización de las Fuerzas Armadas en contextos de transición democrática.

Fecha de realización de la entrevista: Managua, 16 de noviembre de 2009.

Lugar: Facultad de Diplomacia y Relaciones Internacionales de la Universidad Americana (UAM).

Duración estimada: 1 hora y 50 minutos.

\section{TEXTO - Transcripción 10:}

$R$ : ¿Cuál es su visión sobre el reciente proceso de cambio constitucional experimentado por Nicaragua durante el período democrático?

R.C.: Creo que hay una característica general en la historia constitucional de Nicaragua, $\mathrm{y}$ es que las constituciones, como se dice, "self of made", son hechas a la medida, nunca se ha hecho, nunca se ha redactado una Constitución ni se ha reformado con visión estratégica, con visión de futuro, sino que se ha hecho o para personas específicas, o para grupos de poder específicos, ya sean económicos, políticos, o militares, y esto te explica como en la historia constitucional de Nicaragua ha habido tantas constituciones y tantas reformas a las tantas constituciones que ha habido. El régimen de Zelaya que arranca en 1893 en Nicaragua, con la revolución liberal, redacta una Constitución como que Nicaragua iba a ser liberal toda la vida, y se olvidan de principios generales y apuntan, específicamente, a la naturaleza del régimen liberal, lo que significa que estas constituciones también tienen otra característica general, y es que son excluyentes, en buena medida, luego vinieron las reformas posteriores, digamos, hasta llegar a la última reforma de Somoza, igual, hechas a la medida de Somoza, sobre todo desde los años 20, finales de los años 20, comienzos de los años 30 en adelante, 34-37 arranca la dictadura de la familia Somoza, y luego viene un período de, como un área gris, entre el 79 y el 83, que se da la primera Constitución del gobierno sandinista, entre el 79 y el 83 lo que existía era un Estatuto Fundamental que hacía las veces de Constitución, pero tampoco estaba considerado como la norma suprema, ya como la Carta Magna, sino que tenía una serie de índices generales, este Estatuto General no fue aprobado por ninguna Asamblea Constituyente, sino por un Consejo delegado, que existía en esa época hasta la reforma del 83, si no me equivoco, 83, sí, porque eso abrió las puertas a las elecciones del 84 , ya una Constitución, pero igual, hecha a la medida del proyecto político del Frente Sandinista, con una cantidad de limitaciones igual de excluyentes, hechas pensando que el sandinismo iba a ser eterno en Nicaragua, como los liberales pensaron lo mismo, como los conservadores en el siglo XIX pensaron igual, y lo único que se hacía eran pequeños ajustes con reformas parciales a uno o dos artículos, una cosa así, la del 95 fue la reforma a la del 87 abre un poco más el espacio en el ámbito constitucional, y sus efectos en el mundo político, pero también es hecha a la medida, porque son hechas para coartar a quienes no están, no coinciden contigo, pero también

\footnotetext{
13 Entrevista muy larga, con un contenido irregular por su tendencia redundante, aunque es interesante destacar aquellas partes del discurso centradas en el análisis del proceso de institucionalización del Ejército en el marco de la transición democrática, las dificultades de renovación del liderazgo político, así como los rasgos generales de la evolución histórico-constitucional de Nicaragua.
} 
para ampliar espacios a quienes sí están en el poder y quieren estar contigo, es el caso concreto de la reforma a la Constitución del 95, que es, digamos, la más avanzada que se pudo haber logrado en las condiciones particulares del 95, de la postguerra, de la inestabilidad política, de la alta polarización política que existía en Nicaragua, a pesar de que amplía espacios, que introduce principios fundamentales de la convivencia democrática y de la democracia, también está hecha para que alguien no acceda a la candidatura presidencial, que era el Ministro de la Presidencia de Doña Violeta, que era Antonio Lacayo, entonces, la Constitución está hecha, en una buena medida, es decir, políticamente, la intencionalidad es impedir que Lacayo vaya a correr o a presentarse como candidato a las elecciones del 96, sin embargo, si hay cosas, por ejemplo, en términos de defensa, se logra un título único, capítulo único, de la Constitución, en donde se sientan algunos elementos que son trascendentales, como, por ejemplo, expresamente, la subordinación de los militares y los policías al poder civil, o Ejército y Policía al poder civil, la abolición completa del servicio militar obligatorio, el establecimiento, por lo tanto, como consecuencia, de un servicio militar voluntario, el impedimento a las instituciones militar y policial, porque eran instituciones del Estado, a no ejercer labores de espionaje político muy común en los años 80 , y muy común antes de los años 80, básicamente, y el tema de la no reelección, ¿ves?, esos son elementos fundamentales en la reforma del 95. La no reelección, que fue apoyada por el Frente Sandinista en esa época, a pesar de ahora reniega el Frente Sandinista de ese principio que fue aprobado, se hace, básicamente, a partir de un prurito, que tiene mucho de sustento, y es que la reelección es, digamos, semillero o base para el continuismo, ¿verdad?, entonces, como hemos vivido en nuestra historia, al igual que Honduras, y por eso Honduras tiene esos artículos en la Constitución en donde prohíben la reelección absoluta, no hay en la Constitución hondureña, es decir, los que vamos con leche, decimos nosotros, llevamos el queso, ¿ya?, es decir, el queso se da frío, es decir, con la leche caliente quemamos el queso, la cuajada, decimos nosotros en Nicaragua, no sé si la has probado la cuajada.

\section{R: Sí.}

R.C.: Entonces, para tratar de evitar abrir la puerta a la tentación del continuismo se frena la reelección inmediata y se deja la reelección en términos alternos, pero por una vez nada más, y hoy esa sentencia de la Corte, de una Sala mal constituida de la Corte Suprema de Justicia abre ilegalmente, porque la facultad de reformar la Constitución, de reformarla parcialmente, o de redactar una nueva Constitución, una reforma total, le corresponde al Legislativo, en el caso de la reforma parcial a la Asamblea Nacional, y en el caso de la reforma total a una Asamblea Constituyente, esa es una de las razones que te decía, tal vez la razón de fondo, pero también hay otras razones, que es impedir que quien está en el ejercicio del poder haga uso de los recursos que el poder le da para una candidatura presidencial, por eso te pone alterna, no sé si me explico.

R: Sí.

R.C.: Yo no sé, realmente, cómo se hacen esos controles en el caso de Estados Unidos, el presidente ejerciendo el cargo de presidente hace campaña electoral, es decir, y se mueve en el auto presidencial, ¿me explico?, y son recursos del Estado al servicio del candidato de los partidos, que, a la vez, es presidente de la República, eso es lo que se quería evitar, pero también se quería evitar, por ejemplo, que se entronizara en Nicaragua o llegara a Nicaragua una especie de continuismo del gobierno de Doña 
Violeta a través del Ministro de la Presidencia Antonio Lacayo, ha habido reformas del 95 acá, ha habido reformas parciales a la Constitución, algunas interesantes, otras casi de forma, nada más, tal vez, desde mi experiencia y del ámbito de mi trabajo, hay una cosa que fue interesantísima que fue el quitar a la Policía, bueno, en primer lugar, la Constitución del 95 y las reformas que tenemos ahorita tienen un defecto gravísimo, que en el Título V, Capítulo Único de la Defensa Nacional aparece la Policía, es decir, cuando son dos instituciones orgánica y funcionalmente, claramente, diferenciadas, que, teóricamente, dependen de ministerios diferenciados, es decir, el Ejército del Ministerio de Defensa, y la Policía del Ministerio de Gobernación, bueno, además la Policía estaba atrapada en la parte, digamos, de justicia militar, es decir, la Policía estaba sujeta al sistema de justicia militar, y eso se logró, es decir, un delito militar iba a ser juzgado según el procedimiento establecido por la autoridad militar en el Ejército, eso se logró subsanar, también la reforma del 95 terminó con el foro militar efectivo, un civil que cometía un delito en compañía de un militar era atraído, inmediatamente, por el foro militar, y era juzgado como eran juzgados los militares por la autoridad militar, eso desapareció, entonces, el militar si comete un delito común va a los tribunales comunes, y el civil si cometió un delito con un militar va a los tribunales militares, eso es bien importante, y el Ejército en Nicaragua ha avanzado mucho en lo que es el sistema de justicia penal militar, de hecho, el jefe de la asesoría legal del Ejército, que es un Coronel, es presidente de la Asociación Internacional de Justicia Militar y recién acaba de estar en España en un evento, ustedes han promovido mucho el tema de la justicia militar, y, aunque no soy muy chauvinista, pero sí el Ejército de Nicaragua tiene una legislación bien importante y mucho más moderna que muchísimos países de América Latina, en términos de justicia militar, tenemos un Código Penal de justicia militar, tenemos una ley de delitos militares, y, por ejemplo, la auditoría militar depende, orgánicamente, de las estructuras militares, pero, funcionalmente, depende de la Corte Suprema de Justicia, es decir, y esos son elementos que te explican, que es un poco el tema de la subordinación de los militares al poder civil, eso en la reforma constitucional del 95, y después, posteriormente, obra del Ejército, del liderazgo militar para modernizar el sistema de justicia militar, porque el código de los 80 fue totalmente un desastre, es decir, prácticamente, el Ejército se rigió por normativas internas, por órdenes, por ordenanzas, etc., pero si hay un buen avance, en términos de lograr una institución profesional, ha sido en el orden de la justicia militar, dichas esas características generales que te digo de constituciones que no se han hecho con visión estratégica, con visión de futuro, nunca, no hay una, porque el sandinismo se cree que va a ser eterno, Somoza piensa que va a ser eterno, los liberales de Zelaya piensan que van a ser eternos, los conservadores igual, y lo único que hicieron fue a las constituciones irlas reformando de acuerdo con las coyunturas, que iban mostrando algunas necesidades, etc. Creo que una de las falencias, una de las grandes debilidades del régimen constitucional de Nicaragua es que son constituciones hechas a la medida de personas, como te decía, de grupos de poder o de partidos políticos, creo que es el error en el que pretendía caer el Frente Sandinista, con el que quería caer el Frente Sandinista al intentar la reforma a la Constitución, pero al saber que no contaba con la mayoría calificada para la reforma en la Asamblea, entonces, recurrió a ese procedimiento anormal, ilegal, de reformar en la Corte Suprema de Justicia la Constitución. La historia constitucional de Nicaragua, por lo que te he dicho, ha sido muy agitada, vista siempre desde una perspectiva táctica, de corto plazo, es decir, esa sería otra de sus características, es cortoplacista, por eso es que, independientemente, de constituciones sandinistas, del Frente Sandinista, no sandinistas, porque el sandinismo es una cosa y el Frente Sandinista es otra, para el Frente Sandinista, para el Partido 
Liberal de Somoza, para el Partido Liberal de Zelaya, para los conservadores del siglo XIX, por esa visión táctica, es que también las propias constituciones que ellos aprobaban, comenzaban a surgir reformas cuando no cubrían estratégicamente, digamos, un período largo de tiempo, es decir, las constituciones no atendían a, como dicen los historiadores, los movimientos de larga duración, verdad, y sí a movimientos de corta duración, en términos de ciencia histórica, entonces, había que un nuevo movimiento de corta duración demandaba una reforma parcial a la Constitución, entonces, le iban poniendo parches a las constituciones, eso mismo hizo el Frente Sandinista del 87 en adelante, en vista de que hubo que reformar la Constitución del 87 para adelantar las elecciones del 90, presionado el Frente Sandinista por el proceso negociador, que arranca con Contadora y llega a su culminación con Esquipulas II, y, bueno, hay que adelantar las elecciones y hay que reformar la Ley de Municipios, hay que hacer una serie de reformas legales, jurídicas, incluyendo la Constitución, porque la Constitución del 87 estaba pensada, exactamente, como te decía, una Constitución para toda la vida, es decir, nunca se pensó una Constitución para Nicaragua, se pensó en una Constitución para los partidos y para las personas, y para los grupos de poder, $\mathrm{y}$ terminada esa persona, terminado ese partido, terminado ese grupo de poder, ¿qué?, a comenzar el cuento de nuevo, eso sería, digamos, lo más general que yo te podría dar, tal vez, haya algunas cosas más específicas, en términos de mi especialidad, que es seguridad y defensa, pero no sé si tenés alguna pregunta.

R: Sí, la primera pregunta además siempre es más amplia y general, pero, el otro día tuve la oportunidad de entrevistar a Humberto Ortega, y me dijo algo que me gustaría que usted comentase. Decía que la Constitución del 87 fue una Constitución para la paz, que, en realidad, fue un instrumento de la paz en Nicaragua, y también sirvió para consolidar todos los avances de la revolución, digamos, que yo creo que más bien sería como consolidar el aprendizaje institucional que ha tenido el Frente Sandinista desde la oposición democrática, es decir, de cómo los actores pugnan por mantenerse al frente de las instituciones en el nuevo proceso de cambio político. En el terreno, digamos, de las instituciones, ¿cómo ve usted este argumento?

R.C.: Mirá, el 87 es un año clave en la historia, a ver, para Nicaragua y para la revolución del Frente Sandinista, clave porque el año anterior, por darte un dato, el aparato militar nicaragüense había llegado a alcanzar niveles insospechados, 134.400 efectivos entre permanentes, servicio militar, milicia y reserva, es decir, 134.400 hombres en armas, es decir, por muchísimo más grande que cualquiera de Centroamérica, incluso, si se hubiera sumado Guatemala, El Salvador y Honduras no hubiera dado eso en su totalidad, tal vez el que más se le acercaba era el de El Salvador, y un poco el de Guatemala por efecto de que también tenían una guerra civil, un conflicto armado interno, pero desproporcionado el número de efectivos en relación al volumen de la población, ¿verdad? Sin embargo, 86 hay una definición, en términos militares, y esa es de Humberto Ortega que la Contra ha llegado a una situación de "derrota estratégica", es decir, "derrota estratégica" no significa una derrota total de la Contra, sino la incapacidad de la Contra de poder poner en peligro la existencia de la revolución, de poner en peligro la derrota de la estructura militar nicaragüense, porque ya no tenían capacidad estratégica, para hacer el daño estratégico, lo que quiere decir que sí tenían capacidad táctica, para hacer daño táctico, ¿me explico? De tal manera que eso obliga al Frente Sandinista ha redimir estas dos cosas, se comienza a pensar, por ejemplo, que es necesario bajar los volúmenes de reclutamiento para el servicio militar, además del efecto político que eso estaba teniendo, porque un servicio militar en un país 
en paz no tiene mucho problema, pero un servicio militar en un país en guerra es, evidentemente, desastroso el efecto, como, de hecho, lo fue en Nicaragua. Se comenzó a pensar en alguna medida, ¿qué pasaría después de la guerra?, y así, pensando en esas cosas, o a partir de esos elementos, sí se tiene una cierta idea del desarrollo de la institucionalidad en Nicaragua, es decir, porque hasta ese momento, pero también después, la institucionalidad en Nicaragua estaba centrada, básicamente, en el Frente Sandinista, y para darte el mejor ejemplo de todo esto es que las estructuras partidarias estaban descansando en las estructuras del Estado, así de simple, después de la derrota del 90 el Frente Sandinista pierde esas estructuras del Estado, y sufre un descalabro de sus estructuras partidarias, y reconstruye, o construye, prácticamente, desde cero estructuras que estaban fácilmente construidas, porque tenían el Estado, tenían los recursos, tenían las instituciones, tenían el personal, entonces, fue difícil, y entonces se fue pensando un poco, en términos de institucionalidad, pero nunca en una institucionalidad estratégica, sino en una institucionalidad partidaria, es decir, marcada por los intereses partidarios. Yo no coincidiría mucho con Humberto en ese sentido, es decir, yo sería un poco más crítico sobre esto, ¿no?, es decir, no creo que la Constitución del 87 haya sido la base de la paz, es decir, Nicaragua estaba, la base de la paz es bien simple, Nicaragua estaba al borde del colapso en términos económicos, la crisis en los países del Pacto de Varsovia ya comenzaba a bullir, y para el 89, por ejemplo, Nicaragua ya no tenía absolutamente nada, ya no iba a recibir una gota de petróleo de la Unión Soviética, que era el abastecedor, aunque había también una triangulación en lo que se llama el "Pacto de San José", que era Venezuela, Centroamérica, México, la base triangulaba el abastecimiento de petróleo, por supuesto que ya venía en declive, el mundo socialista venía en declive, y el otro elemento es la presión que ejerce el proceso negociador regional, que, te decía, arranca con Contadora en 1983 y culmina con Esquipulas, y el Frente Sandinista se ve obligado, no es su voluntad, se ve obligado a crear una Comisión Nacional de Reconciliación, ¿ya?, y la persona con mayor legitimidad, aunque muy parcial, era el Cardenal Obando en esa época, que era el adversario ideológico y moral de la revolución del Frente Sandinista, se reforma la Ley de Municipios, se reforma la Ley de Medios de Comunicación, se da apertura, se reforma la misma Constitución para adelantar los comicios, de tal manera que, es decir, yo no coincido con Humberto Ortega en ese sentido, la Constitución no fue la base de la paz, la base de la paz fue el deterioro de la economía nacional, la pérdida de legitimidad social y política del Frente Sandinista por la crisis económica, por el servicio militar, y la crisis económica expresada en el desabastecimiento, en la cantidad de gente que salió del país, es decir, entre toda la cantidad de gente una fuga de cerebros extraordinaria, es decir, profesionales que había costado mucho a la sociedad nicaragüense formar, incluso, antes de la revolución y que se fueron, y se fueron las inversiones, entonces, las inversiones estaban en cero, prácticamente, los niveles de inflación eran impresionantes, es decir, al 89-90 llegamos como con 30.000\% de inflación, el poder adquisitivo de la moneda era, absolutamente, era una entelequia, una ficción total, y eso es lo que obliga al Frente Sandinista a recomponer un poco su estrategia política, no es que haya una Constitución y que dice la Constitución que es la base para lograr la paz, la paz es impuesta desde fuera de Nicaragua, y no es producto de condiciones internas y menos de la Constitución del 87, que la Constitución del 87, sí algunos elementos, obviamente, no se puede evitar, pero no es la base fundamental, en el 87, mirá, tantos cambios se van dando que en el 86 en Nicaragua se aprueba una ley en contra de la voluntad de los sectores más radicales del Frente Sandinista, que es la Ley de Conversión de Grados Militares, hasta el 86 primaron los grados militares de la guerrilla, prácticamente, que no tenían ninguna equivalencia con el sistema 
internacional de grados, es decir, o el sistema internacionalmente aceptado de grados militares, es decir, los grados militares llegaban hasta capitán, y el Frente tenía Comandantes, Sub-Comandantes, era más o menos una pequeña adaptación de los grados militares que existían en la época, Humberto Ortega empuja una ley de reforma, la ley integra nuevos grados militares, y se introduce el coronelato, el generalato, en contra de estos radicales, Tomás Borge, por ejemplo, el más vociferante de éstos, también lo es Luís, hoy muy moderado, por cierto, el período 87-89 es un período de definiciones y esa ley de grados militares, con la oposición de estos sectores radicales del Frente Sandinista se aprueba la Ley de Conversión de Grados Militares, y el Ejército ahí arranca un proceso de modernización, arranca su proceso de modernización con dos elementos: uno, empieza a disminuir su número de efectivos, y dos, introduce la ley de grados militares, verdad, en términos de institucionalización de la institución militar, esos dos elementos son bien interesantes, de tal manera que del 86 al 90, de 134.000 al 90 tenéis 86.000 , estás hablando de, prácticamente, la mitad, y se ha reducido mucho el reclutamiento del servicio militar, por otro lado, sí se han recortado un poco las milicias territoriales en las zonas rurales, y pienso que es una combinación de factores, es decir, internos y externos, pero en donde los factores internos no jugaron ese papel relevante que, aparentemente, Humberto le quiere dar. Creo yo que Humberto trata de acomodar un poco las cosas, hay un ejemplo, hace algunas semanas apareció en los medios, sobre todo en la prensa, porque apareció un artículo en la prensa dando una cantidad ínfima de las víctimas de la guerra, entonces, acomodando la realidad, es bien difícil que las guerras tengan contabilidades exactas, tal vez, el caso de Irak, por ejemplo, ha sido el caso, se habla de millones, pero son estimaciones, nada más, y en el caso nuestro que era generación de guerra irregular en donde había gente que podía estar en la milicia, en la reserva, en el servicio militar, o tal vez de los permanentes sí puede haber un registro mayor, del servicio militar un poco menos, y menos de las milicias y menos de las reservas, es difícil dar una cifra exacta, porque se estaba más preocupado por la guerra en sí, que con las bajas de la guerra, es que, lamentablemente, la guerra impone sus víctimas, ¿verdad?, militares y no militares, entonces, en ese sentido, yo creo que ese acomodo es derivado de un intento, que me parece loable, de Humberto de encontrar una especie de equilibrio de las causas, desde que Humberto está en el Ejército, yo lo conozco como una persona con una visión estratégica, con una visión de futuro, de hecho, se le llama el estratega del Frente Sandinista, el estratega de la insurrección, el estratega de la guerra, Humberto Ortega dice que el principal logro de la revolución sandinista fue el haber defendido exitosamente, en términos militares, la revolución, a qué costo humano, a qué costo político y a qué costo económico, ahí ya las cosas varían un poco, es decir, que son factores en donde sí, a mi juicio, sin tratar de buscar un equilibrio, como decimos en Nicaragua, sin tratar de quedar bien con Dios y con el diablo, creo que tuvieron más peso los factores exógenos que los factores internos, los exógenos no solamente el proceso negociador sino la guerra misma, es decir, en tanto que financiada, alentada, entrenada, políticamente apoyada desde fuera, desde el exterior, es decir, desde Washington, y los satélites que en América existían para esa guerra, igualmente, incluso, tu país en la época de Felipe González es un factor exógeno, y, obviamente, constituyó una razón muy buena, y no tengo ninguna evidencia, pero no me cabe la menor duda de que debió de haber alguna recomendación, algún comentario, alguna sugerencia, alguna cosa así. Por otro lado, está otro aspecto inverso, que es la incidencia de algunos países, específicamente, Venezuela en la época de Carlos Andrés Pérez, verdad, que incide, juega un poco en el otro campo, hay una relación con el Frente Sandinista, pero hay una relación con la oposición al Frente Sandinista, verdad, la relación con la oposición al Frente Sandinista le viene de una 
vieja relación que Carlos Andrés Pérez tiene con Pedro Joaquín Chamorro y su viuda, que llega a ser presidenta, Doña Violeta, en los 90, ¿no?, creo que México pudo haber jugado en esa época el PRI, independientemente de que también estaba ya entrando en crisis y que la oposición mexicana interna iba tomando cuerpo, tomando forma, incluso, del factor Estados Unidos, no sólo del factor Washington, y no sólo en una dirección, es decir, son factores exógenos de diversos signos que influyen, y que, a mi juicio, tienen un peso mayor que cualquiera condición interna que pueda haber, sí había condiciones internas, el desencanto de la población con la revolución, el desencanto por razones económicas, de la crisis, del desabastecimiento, el desencanto por ver que tu hijo que iba a cumplir 16 años el próximo año iba a ser llamado al servicio militar y tenía todas las posibilidades de morir, verdad, eso va generando una especie de reacción y eso puede llevar, en alguna medida, explicar el voto, pero el voto no fue simplemente por quitar el servicio militar, el voto fue por terminar la guerra, entendiendo la guerra como la causa fundamental de la crisis económica, ¿me explico?, y, en ultima instancia, es una especie de idea en el inconsciente colectivo que históricamente nuestra relación va a ser con Estados Unidos, queramos o no, como decía aquél famoso refrán mexicano, "pobre México, tan lejos de Dios y tan cerca de los Estados Unidos", ¿verdad?, ellos lo tienen al lado, también igual nosotros, es decir, que en los primeros años del siglo pasado, es decir, en los años 10, 20, 30, fuimos lo que se llamaba "el patio trasero" de los Estados Unidos, no sé, yo creo que habría que sentarse a ser un poco más juiciosos en esto, si vos ves, yo trato de ser un poco, es decir, buscar el balance sin tratar de justificar, y, de hecho, lo que he seguido escribiendo, me pasé de defensa nacional a seguridad pública, seguridad ciudadana, tengo un último artículo sobre "La seguridad del Estado y la inseguridad ciudadana", es decir, tránsito que se da de los años 80 a la transición a la democracia en adelante, casi marcado por el prurito académico de no tomar, bueno, es imposible no tomar posición, si vos leyeras lo que yo escribí en los años 80, dirías, este no pasó nunca por las aulas de la Universidad, o si pasó, pasó para esto, ¿no?, es decir, me parece que hay algunas explicaciones muy simplistas a determinados fenómenos, pero éstos son del orden constitucional, Nicaragua no tiene cultura estratégica, y lo mismo se podría decir en términos de constituciones, yo te lo resumiría en mis reflexiones iniciales, después te he venido poniendo ejemplos, nada más, y si te fijás el hecho de que el frente Sandinista no haya logrado tener los votos necesarios, la mayoría calificada para la reforma de la Constitución, no creás que es, simplemente, porque la oposición está clara que necesitamos una Constitución estratégica de futuro, de largo plazo, con visión de nación, con visión de Estado, no, la oposición está pensando que ésta va a estar hecha a la medida de Daniel Ortega, ¿me explico?, es decir, tampoco es una reacción santa la reacción de la oposición, actualmente, en Nicaragua, porque, además, muchos de ellos son responsables de la situación que tenemos también.

\section{R: Hay una responsabilidad liberal que difícilmente reconocen además en el PLC.}

R.C.: No, claro, no quieren, hoy estaban debatiendo en la televisión, un amigo mío, el Coronel Diego Torres, él fue Jefe de la Dirección Política en el Ejército en los años 80, es decir, cuando el Ejército estaba totalmente partidizado, y luego fue el Jefe de la Dirección para la Defensa, entonces, la idea es que no hay liderazgo político nicaragüense, la clase política en Nicaragua tiene lo que yo le llamo la "visión de gallina", no por miedo, no, sino, si tú a una gallina le pones cinco granos de maíz se los come, si le pones treinta se los come, la gallina no está pensando que la vez pasada le pusiste cinco y luego le pusiste treinta, pues, no va a saber ni cuanto le vas a poner mañana ni cuanto le vas a poner pasado, entonces, ella no va a pensar: "me voy a comer 
cinco como el día anterior y me van a quedar veinticinco, y así puedo tener cinco días más garantizados", no hay visión estratégica, no hay visión de futuro en los políticos nicaragüenses, en la clase política nicaragüense, y es algo totalmente natural, porque no ha habido una clase política seria, capaz, formada, en términos de la responsabilidad de la clase política, es decir, es una clase política sin la responsabilidad por el Estado, sin responsabilidad personal, sin responsabilidad con la sociedad, y más está en la responsabilidad con el liderazgo del segmento político al que pertenezcan, con el líder, con el caudillo, que es otro de los elementos que ha caracterizado la historia constitucional de Nicaragua, el caudillismo está presente desde Zelaya en la Constitución del 93, o en la Constitución de Fruto Chamorro en 1854 para irme más atrás, hay una guerra civil, después de la guerra hay una intervención, no de los Estados Unidos, sino de sectores del sur de los Estados Unidos, que se llamó la Guerra Nacional en Nicaragua, vas a la Constitución del 93 de Zelaya, la Constitución posterior al derrocamiento de Zelaya es una Constitución para Somoza, luego la Constitución del régimen sandinista entre el 83 y el 87 , la reforma del 95 , que es tal vez la más profunda reforma que ha tenido la historia de Nicaragua, fue parcial en términos formales, pero fue casi total en términos reales, es decir, de contenido, fíjate hasta dónde llegó, y, otro problema, en general, otra característica de las constituciones en Nicaragua es la aplicación de aquél principio jurídico muy efectivo que dice que la ley se ha hecho para violarse, entonces, en Nicaragua existe ese principio jurídico pervertido, sí, la Constitución se ha hecho para violarse, y no, únicamente, el Frente Sandinista es el que está violando la Constitución con esa sentencia ahora, con la resolución de una Sala que se hace en llamar Constitucional, claramente, mal constituida, que reformó la Constitución por la vía de hecho, y no por las vías que establece la misma Constitución, es muy difícil de entender a esta clase política que no tiene visión estratégica, no tiene visión de futuro, que no ve más allá de sus narices, como se dice en un lugar común, ¿verdad?, es decir, no tienen en absoluto visión de nación, visión de futuro, visión estratégica, es decir, ¿qué le vas a dejar a las generaciones venideras por lo menos de aquí a los 30, 40 o 50 años?, eso no existe, Humberto Ortega sí tiene esa visión estratégica, y, por ejemplo, Humberto Ortega está claro que Nicaragua mientras esté polarizada, antes entre liberales y conservadores, ahora entre sandinistas y antisandinistas, no va a funcionar, hay un desequilibrio, es inviable, $y$, entonces, Humberto se apunta al centro, ¿ya?, y se ha convertido, como predicando en el desierto, por un centro político en Nicaragua, por una concertación política en Nicaragua, y, de hecho, si Humberto Ortega no hubiera presidido la Comisión negociadora del Frente Sandinista con el nuevo gobierno, que llegaron a la suscripción de los acuerdos de transición, a ver, si hubiera sido Tomás Borge eso no se hubiera logrado nunca, por decir alguien, o cualquier otro miembro de la Dirección Nacional del Frente en esa época, entonces, creo que sí, Humberto tiene un poco más de visión estratégica, porque Daniel es ciego totalmente, éste ni siquiera es miope, es ciego, verdad, porque también otro factor o más bien otro elemento que va dentro del paquete del desarrollo constitucional de Nicaragua aparte del caudillismo es el culto a la personalidad, es decir, difícilmente la Constitución o las constituciones de Nicaragua no expresan en buena medida un cierto culto a la personalidad.

\section{$R:$ ¿Del líder?}

R.C.: De la personalidad dominante, del caudillo, del líder que promueve la reforma constitucional, si vos revisás algunas reformas, que algunas de ellas ha hecho Ortega, específicamente, en el campo... 


\section{R: ¿Ahora?}

R.C.: Sí, ahora, bueno, fue la primera reforma que introdujo Ortega a alguna ley que se aprobó en la época de Arnoldo Alemán, Nicaragua se regía, la Administración del gobierno se regía, básicamente, es decir, del Ejecutivo, se regía por una ley que, históricamente, se le venía llamando Ley de Creación de los Ministerios de Estado, entonces, cada presidente que llegaba tomaba esa ley, y, entonces, sobre la base de esos ministerios de Estado si coincidía entonces venía el nombramiento de los ministros y vice-ministros de Estado, y cada quien a su boliche, como dicen los argentinos, se moderniza la Administración Pública en el sector Ejecutivo por influencia externa, eso con asistencia chilena, el envío a Washington para algún curso, y se estableció una ley más comprehensiva, de más alcance, con todas las debilidades derivadas de la clase política, es decir, de la naturaleza de la clase política y de los alcances de la clase política que hay en Nicaragua, que es la Ley de Organización, Competencias y Procedimientos del Poder Ejecutivo, entonces, ya cambiamos de una ley que crea los Ministerios de Estado a una Ley de Organización, Competencia y Procedimiento del Poder Ejecutivo, entonces, la ley es relativamente corta, explica, primero, establece cuáles son ministerios, señala cuáles son las funciones de los ministros, de los viceministros, de los secretarios generales, que es lo que llaman dirección superior de los ministerios, listas de las funciones, y con las funciones listadas se aprueba, es decir, cada Ministerio trabaja una propuesta para el reglamento de la ley, es decir, si éstas son sus funciones, el reglamento tiene cuál es la estructura, y cuáles son las condiciones de la estructura para el cumplimiento de esas funciones, ¿no sé si me explico?, hay un paso gigante, evidentemente, entre una ley que solamente era para nombrar ministros, y una ley que ya comienza a normar la organización y el funcionamiento del Estado, hay otra cosa muy cierta, en términos de Derecho, digamos, Constitucional, en general, en Nicaragua, y es que es muy común en Nicaragua el reconocer que Nicaragua tiene buenas leyes, como todo país, pero que la gran debilidad, la gran dificultad es la aplicación de la ley, entonces, por eso es que se habla, por ejemplo, de que en Nicaragua no existe el imperio de la ley, una condición de cualquier régimen democrático, evidentemente, entonces, ese hecho es otro elemento fundamental que es bien difícil de entender, bueno, es muy fácil de entender en Nicaragua, pero, es decir, hemos tenido, relativamente, buenas constituciones, con todas sus limitaciones, digamos, para el momento, para la coyuntura, pero el problema es que son violadas, hemos tenido y tenemos buenas leyes, por lo menos, la reforma a la ley de organización del Poder Ejecutivo, y te voy a dar un caso, que es el caso de mi interés, por razones de especialidad, introduce, fijáte, en la reforma a esa ley un artículo que reforma otra ley, que es la Ley de la Policía, y en la reforma de la Ley de la Policía de lo que se trata es de invisibilizar al Ministerio de Gobernación, a pesar que es una militante sandinista la que está al frente del Ministerio, pero invisibiliza al Ministerio de Defensa y por lo tanto a la Ministra, en este caso, o a quien ocupe el cargo de Ministro, y se sobrevisibiliza a Daniel Ortega, el culto a la personalidad es otra de las características, que te digo, generales, como te diría un historiador, sobre todo, pero es la única manera de ver los procesos históricos y los movimientos de larga duración. ¿Cuándo va a terminar esto, Raquel? No tengo la menor idea de cuándo va a terminar esto, un gran amigo mío, granadino, que te encantaría conocerlo, creo yo, decía: "la única manera es que matándolos a todos y quebrando el molde en el que los hicieron para que no vuelva a salir nadie como ellos", es decir, muy caricaturesco, un poco grosero, si vos querés, pero mirá, los partidos políticos no quieren perder, ¿por qué se aferran a Arnoldo Alemán?, ¿por qué se aferran a Daniel Ortega?, porque no hay relevo generacional, 
incluso, la Internacional Liberal ha intentado la formación de líderes juveniles, es decir, claro, no es que "a ver aquí vienen los jovencitos, denle espacio", no, que se vayan abriendo espacio, tú le das las ventajas y herramientas y que ellos vayan al campo a ver cómo es que hay que roturar la tierra para sembrarla, etc., ¿no?, después van a cosechar, pero el problema es que hay un círculo vicioso, podés darle una buena formación política, buenas herramientas, pero venís aquí y te encontrás con la misma tierra, ¿ya?, con los mismos instrumentos primitivos para arar la tierra, es decir, no, y además tenés la mejor escuela de formación, que es el comportamiento político de la gente con la que vos estás relacionada directamente por cuestiones de militancia política, mirá, creo que hay dos experiencias, una muy interesante, sometida a mucha presión y mucha represión, que es el movimiento juvenil universitario y estudiantil en Venezuela, cuando la clase política, prácticamente, como se dice en boxeo, había tirado la toalla, es decir, fueron los jóvenes universitarios, etc., los que rescataron esas banderas, en Nicaragua comenzaron a aparecer grupos de jóvenes, cierto, vinculados a algunos partidos políticos, a la sociedad civil, la sociedad civil en Nicaragua ha dado un vuelco extraordinario, aunque siempre fue contestataria, lamentablemente, por eso te digo, que casi todo el mundo está casi hecho en el mismo molde, lo que pasa es que cada molde lo han pintado de diferentes colores, hay moldes rojinegros, hay moldes rojos, moldes verdes, etc., también hay un movimiento político, un pequeño partido, que se escapa de todo esto, que es el Movimiento Renovador Sandinista, que sí que ha tenido una actitud muy recta, muy consecuente, muy firme en la Asamblea Nacional, con su escasa representación en la Asamblea Nacional, y su comparecencia pública, es decir, tendría que crecer, sería otro tipo de liderazgo, pero eso no quiere decir que no estén exentos de caer en los mismos vicios de la clase política nicaragüense. Tal vez, el mejor ejemplo de esto lo dio, posiblemente, Sergio Ramírez, que es quien concibe el rol de un sandinismo diferente, regresar al sandinismo auténtico, que es el sandinismo de Sandino, por eso te dije antes que el Frente Sandinista es una cosa y el sandinismo es otra, y ahora se habla ya del Frente Sandinista, del sandinismo y del orteguismo, otra cosa, cuando él fue el primero que fundó el Movimiento Renovador Sandinista, y no entró a la reelección, no buscó la reelección, es decir, establecer una suerte de continuismo, de caudillismo, es decir, de liderazgo eterno dentro de los partidos, a propósito yo no tengo militancia política en ningún partido, ni con Frente Sandinista, ni con los liberales, ni con el MRS, puedo tener simpatías, es decir, me llama la atención alguna cosa de alguno, pero no tengo ningún compromiso político partidario, pero volviendo a lo nuestro, yo te decía que es bien difícil pensar en una Constitución como la que vos te podrías estar imaginando, es que el país no lo permite, aquí en Nicaragua la Ciencia Política nunca ha pegado, hay pocas universidades dedicadas a la carrera de estudios en Relaciones Internacionales y Ciencia Política, los que más se aproximan un poco son alguna gente de Derecho, se inclinan un poco, pero lo hacen siempre como abogados en el estudio de la cuestión, no hay una buena formación académica para los líderes políticos.

R: ¿Y qué opina de la complicidad de Alemán en esta última sentencia de la Corte Suprema? Uno de mis entrevistados decía que el pacto no ha desaparecido, que el pacto es un procedimiento político para solventar las crisis de gobernabilidad que se repiten en Nicaragua.

R.C.: Bueno, no las solventa, no las solventa, lo que hace es que las tapan, ¿me explico?, y después sale o por otro lado, o de otra manera, mirá, del 90 para acá hemos vivido, bueno, después de la gran crisis de los 80 por la guerra, los desaciertos, como decía, del liderazgo del Frente Sandinista en esa época, en esos años, en esa década, 
hemos vivido un período de crisis cíclica, es decir, no terminamos de salir de una cuando ya estamos arrancando otra, pero además las buscamos, no es que las crisis se dan solas, no, no, no, las buscamos las crisis, es la crisis entre Corte Suprema y Asamblea Nacional, por ejemplo, un conflicto de poderes por esa sentencia, es buscada, totalmente, y buscada por una ambición política, el contenido, en la medida en que la Constitución no estaba hecha a mi medida y no la podía reformar, entonces, busqué un "by pass", es decir, una vía alterna para poder satisfacer esa ambición política, es bien difícil imaginar siquiera, en esa reforma que yo te decía, de la ley, que es la Ley de la Policía, invisibilizado el Ministerio pero al grado mínimo, yo le decía en broma a la Ministra: "mira, María Isabel, la Policía se te salió de las manos", es decir, la Policía alcanzó, por una reforma que la Policía buscó, alcanzó un grado de autonomía institucional y de autonomía funcional, que le podía erizar los pelos a cualquiera que entiende cómo funciona toda su operación de militarismo, todo por satisfacer egos individuales, ambiciones personales y egos institucionales, y Daniel Ortega aceptó la reforma de la Policía, la aceptó a la Asamblea, y los diputados de la Asamblea Nacional la aprobaron, irresponsablemente, voy a decir, aprobaron esa ley sin darse cuenta que le estaban dando una "patente de corso" a Ortega para tener a la Policía subordinada no a la autoridad del poder civil, sino a la autoridad de los poderes partidarios, por eso es que la Policía no hace nada cuando salen las turbas, entonces, hay una Ley de la Policía, la Policía está para proteger, ¿ya?, la seguridad de los ciudadanos, ahí está la ley, la ley es buena, a pesar de esas reformas que hizo Ortega.

R: Y si las reformas del 95, del 2000 y del 2005 suponen una desconcentración del poder a favor de la Asamblea Nacional, y no tanto de la Asamblea Nacional, como de la perversión institucional de las cúpulas partidarias, que cooptan el debate y se asignan cuotas de representación en los principales poderes del Estado, que pierden total independencia, especialmente, el Poder Electoral y el Poder Judicial.

R.C.: Todo, todo el control de la Asamblea, en donde hay una tercia, pero ha hecho todo lo posible por conseguir una mayoría, incluso comprando votos en la Asamblea, pero no lograron comprar hasta los 56 para hacer la reforma a la Constitución, y por eso es que recurrieron a esa vía alterna de la Corte Suprema de Justicia, o de esa Sala de la Corte Suprema de Justicia.

R: Pero ahora se ha dado una concentración de poder en el Ejecutivo de Ortega, debilitado constitucionalmente, pero fortalecido por ese control institucional que ha mantenido el Frente durante este periodo, de hecho, la frase: "ahora vamos a gobernar desde abajo", de que el sandinismo nunca dejó de gobernar durante la oposición democrática, también el asunto de la formación de los jueces, que salieron muchos de ellos de los servicios de inteligencia, esa es otra tesis doctoral, cómo se conforman los miembros del Poder Judicial, que salen del proceso de reorganización del sistema de inteligencia y también de parte del Ejército, cuando se quedaron sin empleo.

R.C.: Sí, se fueron a estudiar Derecho, guardaron sus identidades partidarias, y ahora son muy útiles al Frente Sandinista, hay una cosa interesante en el Poder Judicial, el pacto estaba funcionando, es decir, el pacto PLC-FSLN estaba funcionando y el PLC estaba muy preocupado por el tema de lo civil, por el tema de la propiedad y esas cosas, $\mathrm{y}$, entonces, descuidaron la parte de lo penal, vos te vas a lo penal y eso está plagado, prácticamente, de lo que son jueces sandinistas, jueces de origen o vinculados al Frente Sandinista, no serían jueces sandinistas, sino jueces vinculados al Frente Sandinista o 
militantes del Frente Sandinista, sí, mirá, control del Poder Ejecutivo, el Poder Judicial controlado, el Poder Electoral controlado, la Contraloría General de la República, no hay manera, como la película de Jack Nicholson que se llama "Atrapado y sin salida", es decir, todas las instituciones del Estado, con excepción de la Asamblea, que todavía no, esa lucha es, digamos, auténtica, es decir, es una lucha más bien por los espacios de poder, y bueno, no tiene mayoría, ahora, no creas que esa es una práctica, la compra de votos, que es una práctica de ahorita de Daniel Ortega, no, también en el gobierno de Doña Violeta se hizo, es decir, la pureza de Doña Violeta, pues, también tuvo sus pecados, hubo momentos en la época de la presidencia de Enrique Bolaños donde también, ahora, intentos permanentemente ha habido, Somoza, el primer Somoza, el fundador de la dinastía decía que el gobernaba Nicaragua con las tres "P": plata para los amigos, palo para los adversarios, y plomo para los enemigos, aquí no hemos llegado a plomo todavía, pero sí la corrupción y el enriquecimiento, digamos, desenfrenado, es extraordinario, y el palo para los adversarios, ahí tenés a la Coordinadora Civil golpeada, toda la gente que ha protestado un poco igual garroteada, apedreada, etc.

R: Se cierran espacios de poder, pero la oposición en la arena política no protesta, eso quiere decir, ¿eso es producto del pacto?

R.C.: Sí ha protestado, porque también ellos han sido, de alguna manera, víctimas de esto, pero también resulta paradójico, reclaman que la Policía no hace nada, pero si ellos le dieron a Ortega la "patente de corso" para hacer de la Policía, es decir, un aparato a su servicio, ayer estaban diciendo Ortega, lo oí hoy en la mañana en las noticias que la Policía no está como servidumbre de sectores económicos poderosos, sino que está al servicio del pueblo, es decir, le estaba entregando no sé cuántas motocicletas, y la Aminta Granera haciendo el papel, la Directora General de la Policía, agradeciendo las motocicletas, no sé qué cosa, y las cuántas cosas que le ha dado este gobierno, pero ahí está pagando la Aminta la factura que Daniel Ortega hizo con la reforma de la ley, que es donde le da a ella y a la institución espacios de autonomía institucional y funcional increíbles, es decir, no va a estar sujeta al control, a la supervisión, al escrutinio de un Ministerio, sino de alguien como Daniel Ortega, y Daniel Ortega no tiene tiempo para esas cosas, Daniel Ortega tiene tiempo para leer lo que declara el estudio de la academia militar para decir que eso está bien o está mal.

$R$ : $Y$, sin embargo, cinco años más de orteguismo son previsibles si no se reunifica la oposición liberal, y Arnoldo Alemán es un obstáculo.

R.C.: Mirá, la única solución aquí es una UNO, es decir, la primera parte de la solución es una UNO, como la de los años 90, el problema que habría después como pasó con la UNO en los años 90 es una especie de fenómeno perverso en las elecciones de Nicaragua, y eso está señalado por Carlos Marx en "El 25 de Brumario" de Luís Bonaparte, plantea, la primera vez que lo leí, pero ya después visto, primero recordado y luego visto en la realidad nicaragüense, usualmente, quienes llegan al poder, usualmente no llegan solos, sino que llegan en alianza con, verdad, usualmente no solos, es decir, siempre tienen el apoyo de alguien, grupos, personas, partidos, etc., porque hay una especie de maldición, un conjuro que al poco tiempo se divide, y, entonces, yo lo señalo en el libro con relación a la UNO, eso pasó exactamente, entonces, hay una coalición en contra de, una alianza en contra de, no a favor de Nicaragua, sino en contra de quien está en la otra acera, llegás al poder e inmediatamente te dividís, entonces, bueno, sería pensar en una posible UNO, es decir, en una alianza democrática en Nicaragua, el 
problema después viene cómo repartir ese pastel, porque todo se ve en términos de botín, entonces, "ah, yo quiero el Ministerio éste, a mí me toca éste", ah, sí hay ministerios que son muy jugosos y rentables, como el Ministerio del Medio Natural donde se autoriza la explotación de los recursos naturales, el sistema de coimas que existe en este Ministerio es increíble, y, en general, en la Administración Pública, o el Ministerio de Fomento y de Comercio, que está relacionado con inversionistas, ya sean nacionales o extranjeros, algo ofrece, el Ministerio de Gobernación, ¿para qué?, ¿para manejar a la Policía?, no, no interesa, entonces, hay Ministerios de primer y segundo y tercer nivel, y están organizados o están jerarquizados no formalmente, pero en la práctica así es, dependiendo de las utilidades o de la rentabilidad, sobre todo económica, que pueda tener ese Ministerio, es bien difícil en Nicaragua, y lo del Ejército, mira, yo te diría que todavía, en primer lugar, Daniel Ortega todavía no ha manoseado al Ejército como ha manoseado a la Policía, porque el Ejército tiene, a diferencia de la Policía, una fortaleza institucional, o el Ejército tiene una fortaleza institucional que la Policía no tiene, yo le llamo, el Ejército tiene un sentido de continuidad estratégica y del rol que desempeña, fíjate que eso no estaba totalmente definido, pero ya después sí está en esa línea de análisis, mirá, por ejemplo, preguntate, ¿por qué está a nivel de agregado militar la relación entre Venezuela y Nicaragua?, el liderazgo militar está claro, que su aliado estratégico, queramos o no, va a ser Washington, no hay más, es decir, existe un sistema interamericano en todos los órdenes, incluso en el orden de lo militar, defensa y seguridad, que, en alguna medida, están dirigidos, coordinados, controlados por Washington alrededor del Departamento de Defensa, y además yo pienso que, hablando con algunos militares también, pero no es que piensen que Washington es infinito y que Venezuela sea finita, ¿verdad?, pero Venezuela es más finita que Washington, es decir, Caracas va a caer antes que Washington, es decir, eso se llama realidad, y, entonces, ¿de qué serviría perder a nuestro aliado estratégico por un aliado táctico con el que no van a tener lo mismo, y que además vamos a perder el tiempo?, volver como el perro con el rabo entre las piernas a tu viejo aliado, por eso, el Ejército se ha manejado muy cautelosamente. Te pongo otro ejemplo, al inicio de la Administración Ortega en la formación del gabinete de gobierno, aparece el nombre, siempre hay expectativas de quien va a ser ministro, vice-ministro, a mí me interesaba saber quién iba para Gobernación y quién iba para Defensa, y desde esa época, de Doña Violeta, hasta acá siempre ha sido una figura decorativa, digamos, o un adorno democrático o un Ministerio de papel, pero sí me interesa ver quién va a llegar, posibles nombres, ¿verdad?, o nombres de posibles candidatos a ministros, y resulta que desde que Daniel Ortega asumió la presidencia de Nicaragua no hay Ministro ni Vice-Ministro de Defensa, la pregunta es por qué, oficialmente, nunca se ha dicho, lo que hay es un funcionario de tercer nivel, que ocupa la Secretaría General del Ministerio, que, usualmente, tiene funciones administrativas, es decir, la ley dice que tiene las funciones que el Ministro delega, vé la parte administrativa, la carpintería, que yo voy a ver la parte seria, es decir, la parte sustantiva, además no tiene ninguna experiencia en el tema, y es una mujer más o menos agradable, relativamente culta, en alguna medida, habla francés, habla español, se educó una parte en Francia, pero cuando va a algún evento internacional tiene pedir información a militares para no dar lástima, aparece un nombre por ahí, y le golpeó la mesa Daniel Ortega, y el Ejército dijo: “no, esa persona no", y hasta ahora no hay Ministro, es decir, el Ejército tiene la fortaleza institucional, pero otra cosa es la debilidad de la democracia, en estas democracias frágiles, y no por nuevas frágiles, sino por todas sus falencias y todas sus debilidades intrínsecas, estructurales, desarrollo de la clase política, que no termina de comprender qué cosa es la democracia, le golpeó la mesa al Ejército Daniel, y, obviamente, después vas 
agarrando de un lado, de otro, la candidata de Daniel Ortega para Ministro de Defensa era la antigua directora general de la seguridad del Estado, la policía represiva, la policía política del régimen sandinista en los 80 , que había sido oficial de Nicaragua, y había pasado a retiro, una de las pocas mujeres que había llegado al grado de TenienteCoronel en el Ejército, pero que siempre había estado también como una figura decorativa, que tuvo relaciones públicas, pero que como para conducir un Ministerio de Defensa, es decir, la conducción política de la Defensa cero, pero no por esa razón el Ejército rechazó la propuesta de Daniel, sino por la contaminación, ¿verdad?, porque esta persona que fue la directora general de la seguridad del Estado, primero, es una de las personas del círculo de hierro de Daniel Ortega, y es la Secretaria de Organización del Frente Sandinista, es decir, la responsable de todos estos ataques garroteados, apedreados, etc., esto puede llevar a la contaminación del Ministerio de Defensa y el Ejército es un Ejército profesional, entonces, Daniel Ortega no encontró a alguien que estuviera totalmente plegado a él que pudiera satisfacer al Ejército, es decir, en estas democracias frágiles, en estas democracias débiles, los Ejércitos, lamentablemente, tienen lo que un politólogo gringo, mucho antes de Samuel Huntington, el teórico de las relaciones civiles-militares, se llama Samuel Finner, escribe un libro que se llama The Horse Man, es decir, el hombre montado a caballo, y habla de una cosa que vos ves en las democracias frágiles, tal vez, Honduras sea el ejemplo más claro, en Nicaragua hay evidencias, pero el Ejército trata de bajar el perfil lo más que se pueda, el moderity power, "el poder moderador del Ejército", ¿por qué no manosea al Ejército?, porque Ortega sabe que el Ejército no se va a dejar manosear, y, en segundo lugar, porque sabe que necesita al Ejército por las circunstancias, es decir, la capacidad disuasiva de un Ejército no es la capacidad disuasiva de la Policía, para comenzar, y hay una cultura militarista en esta sociedad incrustada hasta la última de las circunvalaciones del cerebro y de los genes, creo yo, de los nicaragüenses, ves un policía ahí, pero vemos un militar y rectecito, en el campo de Nicaragua, porque tiene relativa presencia, en problemas como el robo de las cosechas, por ejemplo, los productores pequeños, grandes, medianos, están amparados en el Ejército, cuando es función de la Policía, pero es que la gente no le teme, por ponértelo grueso, a la Policía, y lo extrañísimo en este país es que a partir del 97 el Ejército comienza a obtener legitimidad social y confiabilidad social, hoy por hoy el Ejército es la institución con el mayor grado de legitimidad social y con el mayor grado de aceptación social, sobre la Policía, sobre la Iglesia, es interesantísimo, la última encuesta de hace un mes lo indica, incluso el diario La Prensa puso un titular: "Ejército saca mejores notas que Policía", la Aminta Granera aparece arriba como persona, pero la Aminta es un fenómeno mediático, y todavía como que la gente no hace el vínculo entre la Aminta y todas las barbaridades que está haciendo la Policía, no está cumpliendo con la ley, ¿ya?, ella tiene una carita de monja, y además estuvo en un convento para hacerse monja, en Guatemala estuvo, una carita angelical, una vocecita muy dulce, en fin, qué linda, es como Doña Violeta, una viejecita que no alza la voz, "ay, mis muchachos", entonces, como fenómeno mediático la Aminta es reconocida, pero la institución es otra cosa, y la institución ha comenzado a perder legitimidad social y ha comenzado a perder el reconocimiento y la confianza de los ciudadanos, según la encuesta de hace un mes o un mes y medio, esa que te decía antes, la que sacó el diario La Prensa, La Prensa para a una empresa cada tres meses para que le haga encuesta, y ahí aparece el Ejército, primer lugar, Policía, por supuesto, al final están los partidos políticos, la Asamblea, la Corte Suprema de Justicia, etc., es bien difícil, pero el problema es que la gente lo percibe y no tiene opciones para cambiar eso, no sé si me explico, el problema que te decía de la clase política o del liderazgo político que tiene este país, entonces, el Ejército juega, desde diferentes 
ángulos, juega, a ver, más que desde diferentes ángulos, la gente lo ve o se le ve como ese poder moderador, por ejemplo, hay gente que piensa, que cree que si a Daniel Ortega se le pasa la mano, que tendría que hacerlo y lo haría, de ser alguien sería el Ejército, Daniel Ortega piensa que si alguien le quiere dañar, derrocar o lo que sea, puede hacer uso del Ejército, es decir, cada quien lo ve con la lente de sus intereses, el Ejército mira tuvo una etapa de gran protagonismo político con Humberto, pero vos viste en el libro si te acordás, es decir, el rol de Humberto fue fundamental para la preservación del gobierno de Doña Violeta, a pesar de existir una relación de amor-odio personal entre Doña Violeta y Humberto, mira, Doña Violeta no quería que Humberto fuera ni Ministro de Defensa ni Comandante en Jefe del Ejército, porque tenía varios sombreros, además de miembro de la Dirección Nacional, Jefe Nacional de las Milicias, etc., tenía varios sombreros, además, digamos, Humberto Ortega derrotado Daniel Ortega, la presencia más visible en el gobierno de Doña Violeta del sandinismo derrotado era él, ella tuvo una reunión con Humberto y fue acompañada de otra gente, le invitó a dejar el ente, y él dijo que no, y no por capricho, había una legislación que si bien es cierto fue hecha entre la derrota, lo que llamamos la "piñata jurídica", fue hecha entre la derrota y la toma de posesión de Doña Violeta, y Doña Violeta no podía quitar por sí sola al Comandante en Jefe del Ejército, no lo nombró Ministro de Defensa, asumió ella el Ministerio de Defensa, pero no lo pudo remover del Ejército, de la jefatura del Ejército, en esa época, en esa relación amor-odio, Doña Violeta como un insulto, pero así, bastante despectivo, se refería a Humberto Ortega como el "hombre ese", y Humberto Ortega le decía "la vieja", es decir, pero los dos se necesitaban, Doña Violeta para continuar gobernando, aunque ella no estaba muy consciente de eso, quien estaba consciente era Antonio Lacayo, su Ministro de la Presidencia, y por eso él es el quien funciona, realmente, como Ministro de Defensa, aunque Doña Violeta tiene el nombramiento, pero el Ministro en funciones es él, Antonio Lacayo, y Humberto Ortega necesitaba a Doña Violeta, al gobierno de Doña Violeta, para legitimarse como el Jefe de las Fuerzas Armadas del Estado nicaragüense, y sortear el alto grado de polarización que había, demandas de abolición del Ejército y sustituir al Ejército por la Contra, que menos mal que no sucedió eso, y no por la Contra, sino porque era empezar a hacer algo, no es lo mismo un Ejército irregular, ¿verdad?, convertido por obra y gracia en un Ejército regular de la noche a la mañana, que un Ejército que sí ya tenía una estructura de Ejército regular, y que podía funcionar como Ejército regular, y tener tropas, a la vez, para enfrentar al adversario en lucha irregular, entonces, esa situación lleva a esa relación amor-odio, que, al final, ni modo, bueno, se tienen que aguantar, pero Humberto tuvo esa etapa de protagonismo político, incluso, yo te digo, si el Ejército, a ver, ¿por qué esa diferencia entre Ejército y Policía?, porque el Ejército tuvo el liderazgo de Humberto Ortega y la Policía no tuvo un Humberto Ortega en su liderazgo, sandinista, no sandinista, conservador, cualquiera tiene que reconocer que el rol protagónico de Humberto Ortega en este negocio de la transición política, te caiga bien, te caiga mal, sea monedita tuya o no sea monedita de oro, lo que sea, su liderazgo es vital, es determinante, querrás o no, entonces, fue el gobierno de Doña Violeta y comenzó un proceso de reconversión de la defensa en Nicaragua hasta dejar a un Ejército profesional, apolítico, apartidista, un Ejército que es el que tenemos ahora, eso no pasó con la Policía, que está en papel, en la ley, pero ya ves como está totalmente manoseada, entonces, ese rol moderador, por ejemplo, Antonio Lacayo estaba claro que sin el Ejército esto hubiera sido, es decir, no dura un año Doña Violeta en el gobierno, Daniel Ortega lo sabe ahora, y lo supo Alemán y lo supo Bolaños, Bolaños era de esa gente que hablaba de la abolición del Ejército y convertir al Ejército en una especie de Policía civil con algunas funciones militarizadas, y cuando fue el presidente de la 
República, sobre todo para el Mitch, para el 98, con el Mitch el rol del Ejército fue absolutamente crucial, y me he metido a todas estas cosas ahí, que, aparentemente, no tienen relación con tu tema de investigación, pero sí lo tendrán un poco como contexto, no ha habido una Constitución que haya sido producto de una crisis, esa es otra característica en general, de una crisis, bueno, ahora le llamamos de gobernabilidad, antes de una crisis política, o de una guerra, o de una revolución, o de un golpe de Estado, es decir, no ha sido porque la sociedad nicaragüense diga: "necesitamos aquí ordenarnos para poder trabajar", siempre han sido productos de, ¿verdad?

$R: Y$ ese regreso a los ciclos de la historia, porque antes cuando comentaba lo del Ejército, ¿ve cierto paralelismo entre lo que está sucediendo ahora, en términos de concentración del Poder Ejecutivo y cierre de espacios políticos, a lo que sucedió en los primeros años de Somoza?, salvando los contextos, ¿no?

R.C.: Y lo que sucedía en los años 80 también. Sí, lo que pasa es que en la época de Somoza, en los años 80 y ahora, es decir, si fuera el autoritarismo, que es clásico, hay un elemento que es básico también, que es la exclusión.

\section{R: Sí pero Ortega no tiene el control del Ejército como Somoza sí tenía el de la Guardia Nacional.}

R.C.: ¡Ah!, eso es lo único que no desvela entre comillas a la oposición en Nicaragua, saber que Ortega no tiene el control del Ejército, pero el Ejército, mirá, hay dos elementos que son conservadores por naturaleza: el capital, pongamos la Iglesia, y los militares, por muy funcionario que sea un Ejército la tendencia a conservarse, a conservar, y por eso es conservador, es clarísima, entonces, Somoza tenía la Guardia, el Frente tenía al Ejército, verdad, en el concepto de la conservación del poder, la autoridad máxima, que era la Dirección Nacional del Frente, y la división del trabajo de la administración del poder, que no creas que era una división del trabajo tranquilita, sencilla, sin problemas ni nada, si vos revisás los nombramientos de autoridades, ministros, Policía, Ejército, etc., todo lo que vas a ver es que hay una repartición de papeles en las tres tendencias en las que estaba dividido el Frente, que cada cuál toma su rol, en el sentido que antes te decía, de ver cuál va a ser la parte del botín que va a corresponder a cada quien, cada quien está viendo qué parte del botín le corresponde o le corresponderá, en el caso, y que a mí me parece que es una bendición, por decirlo de alguna manera, de lo poco que queda de esta frágil democracia en Nicaragua es el Ejército.

R: Y ya para terminar, porque llevamos mucho tiempo de entrevista, aunque, como ha dicho al principio, las constituciones en Nicaragua han tenido siempre un sentido excluyente, $y$ han sido hechas con nombres y apellidos, podriamos decir, ese componente coyuntural y de exclusión que han tenido los sucesivos contratos jurídicos para dar una estructura a la acción política, y, en este caso, además, con el sello de construir una democracia, porque la transición de los 90, aunque es discutible, la revolución reclama para sí como un fruto tardio la democracia liberal, es cierto que el sandinismo tiene otro concepto de democracia, de democracia popular, de participación directa del pueblo, que son connotaciones muy distintas de la democracia liberal al uso, entre otras cosas, porque los sectores de la derecha no participaron en el proyecto revolucionario y también son ciudadanos nicaragüenses, y que deben tener un lugar en la sociedad política, ¿no? Entonces, ¿más reformas a la Constitución o no, 
incluso, un nuevo pacto constituyente?, ¿podrá alguna vez salir Nicaragua, digamos, encontrar el camino hacia la modernidad jurídica y política, y dejar de estar siempre saltando de una excepción a otra?

R.C.: Yo, regresando a mi pesimismo, por naturaleza, la clase política, en general, es decir, tanto la oposición actual como los sandinistas, en general, mira yo casi soy militante eterno del pesimismo, lo que significa también que soy militante eterno del realismo, no veo que haya condiciones para que pueda alcanzarse ese contrato jurídico que cobije a todos los nicaragüenses sin que ese contrato jurídico no tenga al menos nombres y apellidos, es bien difícil, porque es parte de una cultura política incrustada hasta casi en los genes de la clase política, bueno, digamos, en los genes políticos de la clase política, es de las cosas que, de repente, esa visión pesimista o pragmática o realista viene a ser un poco una cierta forma de cinismo, de cinismo político, porque no me lleva a una desesperanza en el sentido de entrar en un proceso de depresión política, pero no le veo, es decir, personalmente, veo que es posible un pacto político para un nuevo contrato jurídico, perfectamente, está dentro de las posibilidades, eso a mí no me preocupa ni me llama la atención, lo que me llama la atención es la naturaleza de ese nuevo pacto y la naturaleza de ese nuevo contrato, porque si va a ser para tener más de lo mismo, ¿qué sentido tendría?, es decir, le maquillás algunas partecitas a lo que ya tenés y le hacés una presentación en sociedad al producto de ese pacto político que sería el contrato jurídico, constituciones y leyes en Nicaragua son, básicamente, de carácter coyuntural, y aquí si han durado mucho más ha sido por desidia, como el Código Penal nicaragüense que hasta hace tres o cuatro años teníamos el Código Penal militar del General Zelaya, es decir, de la revolución liberal del siglo XIX, ni siquiera el XX, ¿ya?, entonces, los delitos cibernéticos, por ejemplo, alguien podría hacer cualquier salvajada en delitos cibernéticos y no habría manera de acusarlo, porque no está tipificado el delito, es decir, se habían quedado en los amanuenses todavía, no existían ni siquiera las máquinas de escribir mecánicas, pero, mirá, sí veo una necesidad de ese pacto, el problema es que los pactos en Nicaragua han sido perversos por historia, por tradición, porque son pactos para sentar las bases de la distribución del botín que van a obtener después del pacto, y eso podría ser, perfectamente, el nuevo contrato jurídico, que te llevaría también a un contrato social, es decir, en cierta medida una especie de redefinición de las relaciones a partir del nuevo ordenamiento constitucional, y la necesidad de revisar todo el ordenamiento jurídico para acomodar o para adaptar el ordenamiento jurídico ordinario a la norma suprema, sería genial, si un día pasara esto, agarro un avión a Madrid, te doy un beso, y me regreso, ¿te das cuenta?, no sé si te has encontrado con muchos pesimistas, mira mi optimismo llega hasta la firma de ese pacto que sería el nuevo contrato jurídico, pero ahí termina bruscamente como un acantilado, que al fondo lo que tengo es la posibilidad de estrellarme, es decir, yo voy bien por la carretera hasta que se corta y llego a un abismo, el abismo de cuál va a ser la naturaleza de ese pacto político, cuál va a ser la naturaleza del producto de ese pacto político, y del contrato constitucional jurídico, si es la misma gente que ha creado todas estas circunstancias, todas estas situaciones, todas estas crisis, la gente que ha vivido de las crisis, además, que ese es otro elemento importante, porque toda crisis tiene réditos, San Agustín decía: "bendita crisis", y es cierto, el Mitch, por ejemplo, el huracán Mitch del 98, que hubo en Nicaragua, una tragedia espantosa, tuvo un rédito que nadie imaginaba, las relaciones militares Estados Unidos/Nicaragua en cero, mínimas, congeladas y el Mitch une a las fuerzas militares de Nicaragua con las fuerzas militares de los Estados Unidos, y te das cuenta de que hacen lo mismo, que tienen unos valores similares, que entienden la vida desde la perspectiva militar, y eso es de gran ayuda para la 
institucionalización del Ejército, porque normaliza las relaciones con los Estados Unidos, ¿verdad?, y se dan cuenta de que, bueno, lo que pasó, pasó, ahora, resolvamos esto, ya el Ejército tenía una ley, había un concepto de constitucionalización, que el Ejército en Nicaragua tenía una voluntad de subordinación al poder civil, el Ejército en Nicaragua tenía una voluntad expresa de auto-subordinación, y, por el contrario, el poder civil o las autoridades civiles no tenían el más mínimo interés de ejercer ese Derecho, como parte de la cultura militarista, entonces, sí, veo muy oscuro el panorama, ni siquiera un área gris, yo lo veo claro y se me va poniendo gris, en la medida en que llegamos a un posible pacto político, y el resultado de ese pacto político buscando un contrato jurídico y un resultado constitucional, de ahí para adelante se me oscureció, como una tormenta de octubre, verdad, ahorita, de repente, se oscurece el cielo de la tarde, $\mathrm{y}$, como va a caer un aguacero increíble, se forma un nubarrón negro, eso pasa en octubre, es que es difícil, Raquel, yo lo veo muy, muy difícil, no encuentro una persona que pudiera asumir el liderazgo de la oposición. El Ejército tiene algo que no tienen las demás instituciones del Estado, incluso, ninguna institución del mercado, es decir, de la empresa, del sector privado, que es el sentido de la estrategia institucional, y es saber para donde vas, la Corte Suprema no tiene la menor idea ni adonde está siquiera, ¿verdad?, al menos, por mi trabajo eso me da satisfacciones de tener buenas relaciones dentro del Ejército.

R: Pues, muchas gracias por la entrevista. 


\section{ENTREVISTA $11^{14}$ :}

Nombre del entrevistado: D. Fernando Caldera.

Cargo actual: Director General de la Policía Nacional durante el gobierno de Violeta Chamorro (1990-1997).

Fecha de realización de la entrevista: Managua, 6 de noviembre de 2009.

Lugar: despacho de su actual cargo como director de la entidad bancaria BANPRO.

Duración estimada: 1 hora y 5 minutos.

\section{TEXTO - Transcripción 11:}

$R$ : ¿Cuál es su visión sobre los cambios constitucionales experimentados en Nicaragua durante el período democrático reciente?

F.C.: Estoy revisando la Ley General de Policía, que es del año 96, esta la hicimos ya para mi último año, la presentamos, la aprobó la Asamblea Nacional, y es la ley vigente, ¿verdad?, entonces, dice: "son optados a nombramiento, permanencia, y dotación el Director General de la Policía Nacional será nombrado por el presidente de la República a propuesta del Ministro de Gobernación y de los miembros de la Jefatura Nacional, teniendo como requisito ostentar el grado de Comisionado General. Los subdirectores generales y el subinspector general deberán ser nombrados por el Ministro de Gobernación entre los miembros que ostentan el grado de Comisionado Mayor y el grado general a propuesta del Director General", verdad, entonces, aquí está, "Oficiales Generales, Procedimiento para la obtención del Grado de Comisionado Mayor, aprobado por el presidente de la República, el grado de Primer Comisionado se otorgará por el presidente de la República al Director General, los subdirectores generales y el inspector general obtendrán el grado de Comisionados Generales, estos grados se deberán otorgar después de los nombramientos en los cargos respectivos", esa es la ley, la Constitución dice, más o menos, en relación a la Policía, que la Policía se deberá, verdad, tiene un régimen de disciplina especial, y que se deberá a la jerarquía, deberá estar organizada en base a la jerarquía formal, dice la Constitución, entonces, el presidente de la República ascendió a tres oficiales que no son subdirectores al grado de Comisionado General, y los puso al mismo nivel de los subdirectores sin ser subdirectores y sin ser el inspector de la Policía.

\section{R: ¿El gobierno actual de Ortega?}

F.C.: Ahorita, entonces, cuando hay reuniones uno ve a los siete, vamos a ver lo que dice la Constitución de la Policía.

\section{R: Que esa fue una de las reformas que se hizo en el año 95.}

F.C.: Sí, exactamente, le dedica más al Ejército que a la Policía, aquí está, artículo 97: "la Policía Nacional es un cuerpo armado de naturaleza civil. Tiene por misión garantizar el orden interno, la seguridad de los ciudadanos, la prevención y persecución

\footnotetext{
14 Entrevista centrada, especialmente, en el papel de la Policía Nacional en el contexto de la transición política nicaragüense, contemplando la articulación de sus funciones constitucionales, así como su relación con el Ejecutivo presidencial en los sucesivos gobiernos democráticos desde los años 90 hasta el momento actual.
} 
del delito y los demás que le señale la ley. La Policía Nacional es profesional, apolítica, apartidista, obediente y no deliberante. La Policía Nacional se regirá en estricto apego a la Constitución Política, a la que guardará respeto y obediencia. Estará sometida a la autoridad civil que será ejercida por el presidente de la República a través del ministerio correspondiente. Dentro de sus funciones, la Policía Nacional auxiliará al poder jurisdiccional. La organización interna de la Policía Nacional se fundamenta en la jerarquía y disciplina de sus mandos", se fundamenta en la jerarquía, entonces, si la ley dice que el grado de Primer Comisionado se otorgará por el presidente de la República al director, y los subdirectores generales obtendrán el grado de Comisionado General, estos grados se otorgarán, además dice, después de los nombramientos de los cargos respectivos, y yo nombro tres comisionados generales más que no son, además de los tres subdirectores y el inspector, yo estoy rompiendo con el principio de la jerarquía, porque estoy poniendo al mismo nivel a aquél funcionario que no está en los cargos de subdirector de la Policía, no sé si me estoy explicando.

\section{R: Sí, sí, perfectamente.}

F.C.: Entonces, en mi opinión esa decisión y esa acción que ya se hicieron, que de los tres nombrados uno es su consuegro, verdad, el padre de uno de los hijos de los Ortega que está casado con la hija de este policía, que fue ascendido a Comisionado General, entonces, en mi opinión, viola la ley, que la ley dice que sólo los subdirectores pueden ser Comisionados Generales, y viola la Constitución, porque la Constitución en el último párrafo dice que la organización interna de la Policía Nacional se fundamenta, dice, en la jerarquía y disciplina de sus mandos, ¿qué disciplina y qué jerarquía hay si yo estoy poniendo a un oficial con el mismo grado que el subdirector?, porque la organización en Nicaragua de la Policía es una organización muy similar a la del Ejército, por eso yo te decía la vez que conversábamos, que nosotros nos parecíamos mucho al esquema de la Guardia Civil sin ser militares, porque la Policía es una organización de carrera, el muchacho entra a la Academia, cursa una carrera de cuatro años, tiene que ser bachiller, ¿no?, nosotros le pagamos, es decir, no es al revés, porque en América del Sur, en Colombia, uno paga para ser policía, aquí nosotros le pagamos para darle oportunidad a todos los sectores sociales, de cualquier estrato social, y se gana un salario mientras entra de cadete, estudia cuatro años, y sale graduado con una licenciatura en Administración Policial, y ahí va ascendiendo hasta llegar a director, esa es lo que nosotros le llamamos la carrera de oficiales, entonces, para mí violó la Constitución y violó la ley, en mi opinión personal, pues.

R: ¿Cómo vivió usted cuando ejerció su cargo?, que además fue en un momento político privilegiado de este país, de transición a la democracia, de reorganización también de las fuerzas de orden público, tanto del Ejército, de las Fuerzas Armadas, como de la Policía, ¿no?, que ya no están vinculadas a un partido político, ni al Estado en sí, que constituyó el régimen revolucionario. ¿Cómo lo vivió?

F.C.: Fue una jornada muy intensa, nosotros, realmente, vivimos un momento muy extraordinario, pero también fueron muy dramáticos, ¿no?, significó la reducción del personal militar del gobierno de Nicaragua, que pasó de tener 100.000 hombres, afortunadamente, 90.000 hombres sobre las armas a quedarse con un Ejército de 15.000 y una Policía de 7.000 más o menos, en esos días, y desmovilizar, aproximadamente, 15.000 hombres de la Resistencia Nicaragüense, fue un momento extraordinariamente convulso, porque ningún plan es perfecto, los planes de asistencia para el proceso de 
desmovilización de la OEA, principalmente, no fueron tan eficientes, pues, y los planes del gobierno de encontrarle alternativas laborales a todo este mundo de soldados, de oficiales y miembros de la resistencia, encontrarles alternativas de trabajo, tampoco era posible en un momento en que más bien el proceso de la economía estaba sufriendo un cambio profundo, entonces, eso generaba mucha, por un lado, grandes expectativas y pocas respuestas, y por otro lado, fue aprovechado, políticamente, para tratar de desgastar al gobierno.

R: ¿Y cómo se ha ido produciendo todo este proceso de profesionalización y de condición también apolítica de la Policía, que se está revirtiendo en estos momentos, no?

F.C.: Bueno, la Policía, en aquél momento, jugó un papel muy importante, jugó un papel muy constructivo, en mi opinión, al proceso democrático que estaba viviendo Nicaragua, con un compromiso de servicio a todos los ciudadanos sin distingos de colores políticos, y apegada a la ley y a la Constitución, y surgió esa ley, expresamente, como resultado de ese proceso, y lo que más me alegró a mí a la hora de la promulgación de la ley, es que esa ley fue aprobada por consenso, por las bancadas de todos los partidos políticos representados en la Asamblea Nacional, prácticamente, sin oposición, entonces, yo dije: "esta es una ley de consenso nacional, esta es una ley que tiene que perdurar hasta que las necesidades de la dinámica del cambio legislativo del país lo vayan demandando, pero los principios básicos, fundamentales, que definen esta organización van a seguir inamovibles, pues", porque yo lo que ví fue un consenso nacional, no fue una ley impuesta, no fue elaborada bajo amenaza o coacción, sino dentro de un proceso bien democrático, la Policía hizo su propia propuesta, el gobierno la revisó, la discutió, se modificó con el gobierno, el gobierno la presentó a la Asamblea Nacional, la Asamblea Nacional la revisó, la modificó, verdad, y la aprobó, y en sus partes esenciales quedó aprobada como la Policía lo había propuesto desde un inicio, tanto por el gobierno, el Ejecutivo, como por el Legislativo, entonces, y además de una manera casi unánime la Asamblea Nacional, verdad, lo que refleja que es una ley de consenso nacional, que es el resultado de un proceso, de una dinámica que la Policía venía estableciendo apegada a los nuevos tiempos, y también debo referirte que la Policía durante el régimen sandinista no fue una Policía que se involucró en la coerción política a la oposición en general, porque el régimen sandinista tenía las organizaciones de la seguridad del Estado, y tenía algún cuerpo, que eran los que hacían la labor de inteligencia y detención de personas que estuvieran contra el gobierno, la contrarrevolución o la resistencia, pues, quizá la Policía también venía de una experiencia que se había dedicado durante la década de los 80 , fundamentalmente, a perseguir el crimen común, no había huellas de resentimientos específicos contra la Policía, es decir, mirá, la Policía me torturó, la Policía irrumpió en mi casa, la Policía me interrogó por motivos políticos durante 15 días, no, te decían de la seguridad del Estado, que, prácticamente, desapareció, es decir, se transformó en la división de Información de la Defensa y se redujo, y los aparatos con capacidad de represión y todo desaparecieron, las leyes les quitaron las funciones, y se las dejaron, exclusivamente, a la Policía, entonces, eso ayudó muchísimo, porque no había ese señalamiento, pues, de inculpar a la organización policial de participación, sino que, en todo caso, lo que había era el reclamo de la afiliación política de los miembros de la Policía, que habían nacido bajo la revolución, y que eran sandinistas, y que además se había cometido el error por el gobierno de haberle puesto "Policía Sandinista", ese era su nombre, entonces, es interesante porque se juntaron dos elementos, ¿no?, por un lado, no hay involucramiento 
en el proceso coercitivo político, sino que es una Policía dedicada a perseguir el crimen común, pero, por otro lado, ha habido un sesgo partidista, ¿no?, entonces, hay un momento importante, cuando gana Doña Violeta, que se forma una Comisión del gobierno de Doña Violeta con el gobierno saliente, que se llamó "el equipo de la transición", y, entonces, se establecen los acuerdos de transición, pero en los acuerdos de transición se acuerda despartidizar a la Policía y al Ejército, y, entonces, se inicia un proceso de despartidización, pues, los miembros directos de la Policía son exonerados, no sé cuál es la palabra correcta, de pertenecer a cualquier partido político, es decir, están obligados a no estar, independientemente de que puedan tener simpatía o ideología, están obligados a no tener ningún compromiso político con ningún partido.

R: Antes que refería la comparativa con la Guardia Civil española, esa institución sí sufrió el estigma, además, de la opinión pública y la ciudadanía, por su vinculación con la dictadura del General Franco, ¿no?, entonces, pues, sí ha sido una institución que ha tenido que reincorporar a su cuadro de valores el espíritu democrático que animó la transición.

F.C.: Yo sé, y sé que, por ejemplo, muchos militares que durante un tiempo para salir a la calle se vestían de civil, durante algunos años la gente los miraba con un cierto desprecio en el transporte público, entonces, el militar, el guardia civil se quitaba el uniforme y se vestía de civil para ir a su casa, no es como aquí, que si vos los ves, el policía se va a su casa uniformado de policía, va desarmado, o cuando está libre, o el cadete que acaba de salir de la Academia, uno lo puede ver en la carretera, y van para su casa, y van uniformados, y nadie los ve como enemigos de la sociedad.

\section{R: Pero, ¿se produjo, de alguna forma, una depuración política de la institución?}

F.C.: No, no hubo necesidad, hubo algunos casos, ¿qué es lo que pasó?, no hubo necesidad, bueno, para serte sincero, ¿qué pasó?, en la nueva organización de la Policía no alcanzaban todos los mandos principales que existían, en el momento, que existían en el Ministerio de Gobernación, y, entonces, había que hacer una selección, ¿verdad?, entonces, el gobierno me dio a mí el privilegio de escoger mi equipo, y desechar lo que yo no consideraba apto, entonces, yo conocía, digamos, quiénes eran los que estaban en una posición más intransigente, más politizada, más ideologizada, y, obviamente, prescindí de ellos, y traté de formar mi equipo con funcionarios más accesibles a adaptarse a las circunstancias de los tiempos, entonces, ahí hubo a nivel de mandos, pues, un proceso de selección, además este gobierno pidió a muchos oficiales pasar a retiro, entonces, hubo dos fenómenos, los que se fueron a retiro a solicitud del gobierno o voluntariamente que se ofrecieron, porque no se sentían capaces de trabajar en esta nueva realidad, entonces, salieron otra gente que yo no seleccioné y que también salió de la institución policial, y dentro de la organización hubo gente que, no mucha, hubo gente que dijo: "yo no puedo trabajar, yo tengo, digamos, una posición ideológica, y que no me alcanza a la luz de nuevos tiempos", entonces, de forma natural, fueron solicitando su retiro, otros lo solicitaron, otros casos que hubo, fueron más bien por razones económicas, vieron otras oportunidades, eran abogados, los policías son muchos abogados, y vieron que iban a ganar más litigando que siendo policías, y también se fueron, o a montar empresas de seguridad y vigilancia, y también se fueron, verdad, pero, realmente, un proceso de depuración, de tener que decir: "vamos a prescindir de 300 policías, porque están marcados ideológicamente", no hubo necesidad de eso, prácticamente, nos quedamos con toda la organización. 
$R$ : En otras entrevistas cuando pregunto a propósito de esa preeminencia que ha tenido el Frente sobre el Poder Judicial, ¿no?, que se ha convertido casi en un bastión institucional de la capacidad del Frente Sandinista para, digamos, copar algunas de las instituciones del Estado durante el proceso de oposición política, que fueron estos últimos 16 años, ¿no?, durante los gobiernos liberales, $y$, entonces, me refieren algunos entrevistados que muchos miembros del servicio de inteligencia, de la Policía, que quedaron sin oportunidades profesionales, cuando se reforman estas instituciones, se formaron como abogados y pasaron a ser jueces.

F.C.: Pero no son de la Policía.

R: No, son más bien del servicio de inteligencia, del Ejército.

F.C.: Sí, de la seguridad del Estado.

R: Exactamente.

F.C.: Confunden, algunos políticos confunden.

R: La Policía quedó, entonces, como una institución apartidaria, incluso, desde el período revolucionario.

F.C.: Sí, porque los que eran sandinistas por su nombre eran sandinistas, porque tenían la organización de los comités de base sandinista en la Policía, en la década de los 80, ¿verdad?, pero no estuvo involucrada en los procesos coercitivos, como institución se dedicó a trabajar en la persecución del crimen común, prevenir el delito, esa era su labor, en términos generales, verdad, sí algunas figuras de la Policía, el gobierno en la década de los 80 nos hizo participar en algunos eventos, verdad, coercitivos, algunas figuras de la Policía, eso sí es innegable, pero no a la institución como tal.

R: Entonces, fueron de estas otras instituciones, cuando se forman los cuadros, digamos, de abogados, que luego han accedido al ejercicio de la judicatura.

F.C.: Es que, exactamente, la iniciativa nació de la Policía, pero la formación de abogados se amplió a todos los distintos órganos del Ministerio de Gobernación, y tuvo sus simpatizantes, verdad, entonces, por ejemplo, el otro día oí a un juez, yo ni me imaginé que me estaba dando las gracias a mí, porque yo le había dado la oportunidad de estudiar Derecho por encuentro ${ }^{15}$, entonces, él estaba agradecido conmigo, lo dijo en una declaración, que estaba agradecido conmigo, pues, y yo ni me acordaba de que yo le había dado la oportunidad de estudiar Derecho, entonces, ahí entró mucha gente, policías, no policías, y miembros de Gobernación, y miembros de la seguridad del Estado, en fin, de distintas áreas y simpatizantes de Gobernación, personas relacionadas de Gobernación, como el caso de este juez, que, por alguna razón, lo conocía yo, pidió una solicitud y yo lo apoyé para que estudiara Derecho por encuentro, entonces, fue un proceso muy variado.

$R:$ ¿Y esos cursos cuando se producen o cuanto tiempo, qué periodicidad tuvieron exactamente?

\footnotetext{
${ }^{15}$ Se refiere a los cursos por encuentro durante los fines de semana en los que se impartían los estudios de Derecho.
} 
F.C.: Esos cursos iniciaron en los 80 y concluyeron en los 90 con la Universidad Nacional Autónoma de Nicaragua de León, UNAN-León, un acuerdo que hicimos con ellos en los 80 .

R. No, es muy interesante, porque muchos de los jueces que se han formado, sobre todo en el escalafón básico, digamos, de la jerarquía, ¿no?, de organización del Poder Judicial, los jueces de distrito, y luego también algunos jueces de apelación, y como casi todos tienen una filiación sandinista, es la referencia que me han hecho, porque muchos simpatizantes del Frente o partidarios del Frente se formaron en Derecho.

F.C.: Es que la habilidad política del Frente, no del Frente, del orteguismo, ha sido ganarse a algunos funcionarios liberales para conseguir mayoría en las salas, entonces, vos decís, él está identificado como liberal, pero vota como orteguista, entonces, ¿qué pasa?, eso le ha dado posibilidad a ellos de ir copando los escalafones básicos, ¿verdad?, y de ir eliminando jueces de otras corrientes, porque la habilidad del orteguismo es la capacidad de composición de las estructuras, como el Poder Judicial, el Poder Electoral, la Procuraduría de los Derechos Humanos, que no es ninguna Procuraduría de Derechos Humanos, es una figura, ¿qué más?, la Contraloría General de la República, pues, los liberales votan como sandinistas, es asombroso, los han comprado, es increíble, pues.

R: Y respecto a la Policía, si bien es cierto que las reformas constitucionales, yo me centro en la tesis, fundamentalmente, en lo que es el traspaso de poderes del Ejecutivo al Legislativo, o sea, un poco el horizonte constitucional a partir de los 90, que es el de debilitar ese Ejecutivo presidencial tan fuerte que consolidaba la Constitución original del 87. Sin embargo, la Policía sigue dependiendo, directamente, de la figura del presidente de la República para el nombramiento de su jerarquía, y se sigue conservando, actualmente, esa prerrogativa, o sea, no ha habido una reforma que haya sustituido ese poder del Ejecutivo.

F.C.: Así es, no, no, lamentablemente, lo tiene, ¿qué pasa?, hay que recordar que estaba la figura de Doña Violeta, hubiera sido como un ataque hacia ella, y hacia su figura, que tenía a nivel nacional y a nivel internacional mucha proyección, entonces, era como un golpe bajo a ella, pues, y además yo era su subordinado, y era como un acto de deslealtad, porque lo correcto hubiera sido que el presidente de la República propusiera a la Asamblea Nacional el nombramiento del Director General de la Policía, eso es, realmente, lo correcto, y que la Asamblea Nacional la aprobara, la propuesta del presidente, o la rechazara, pero era un momento bien difícil, y además de eso en Nicaragua, ubicando ese contexto histórico, lo que un sector importante de la sociedad reclamaba, encabezado por Doña Violeta, era que nosotros nos subordináramos a la autoridad civil, que para ella la autoridad civil era el presidente de la República, entonces, ¿qué pasa?, si nosotros hubiéramos promovido que en la reforma a la Ley de Policía se hiciera a través de este proceso era como darle un golpe a ella, no sé si me explico.

\section{R: Perfectamente.}

F.C.: Y era un golpe a un concepto, que, en ese momento, estaba defendiendo, porque ella creía en ese concepto, que ella quería garantizarse plenamente de que el Ejército y la Policía se iban a subordinar al presidente de turno, lo que pasa es que en Nicaragua la 
gente siempre piensa como que yo voy a estar toda la vida en el cargo, y no ven a futuro, no sé si me estoy explicando, entonces, Doña Violeta pensó como que se iba, no es que ella tuviera aspiraciones reeleccionistas ni nada, pero pensó que el modelo iba a seguir estuviera ella o no estuviera, y nunca pensó que Daniel Ortega pudiera volver a ganar las elecciones, y que iba a venir a cobrarse las deudas ajenas, iba a venir con un proyecto ambicioso, ella no lo pensó.

R: Y, de hecho, incluso, la reforma del 2005, bajo la presidencia de Bolaños, que restringe poderes también al Ejecutivo, y obliga a esa ratificación de los funcionarios, no afecta para nada al director de la Policía, ni tampoco a las altas esferas policiales.

F.C.: No, porque todo el mundo hasta ese momento estaba contento con la Policía, porque no es el presidente abusivo que viene, viola la ley, y hace, y toma decisiones que no le corresponden, porque eso es lo que ha venido pasando, pues.

\section{$R$ : Los tres presidentes liberales han sido respetuosos.}

F.C.: Bolaños fue un poco abusivo con la Policía, increíblemente, el más respetuoso fue Alemán, Bolaños llamó a un subdirector de la Policía y lo destituyó porque le dio la gana, y yo me opuse, yo me opuse a eso públicamente, pues, y di mis razones, entonces, mucha gente, amigos míos, también, me criticaron, diciendo: "yo pienso que el presidente puede hacer lo que considere conveniente", entonces, le digo yo: "vos lo decís ahorita sí, pero vamos a ser si en el futuro no te tiran de la lengua", entonces, después vino Daniel y empezó a hacer sus cosas, y le digo yo: "ajá, ahora decíme lo que me decías cuando Bolaños, que el presidente puede hacer lo que le de la gana", "no, hombre, tenés razón", entonces, en Nicaragua la gente se inclina a respaldar si el presidente es de derechas lo que él haga está bien hecho, aún si viola la ley, y después viene el populismo, porque yo no digo izquierda, viene el populismo y la gente con el populismo dice que lo que el presidente haga está bien hecho, entonces, el problema de los nicaragüenses es un problema de que no respetamos la institucionalidad de la sociedad, la pisoteamos, y la pisoteamos aún los principales dirigentes, pues, en este caso, la ley no lo faculta al presidente Bolaños para destituir a un subdirector, pero lo hizo, pero lo hizo el presidente Bolaños, entonces, ahora viene éste, Ortega, y dice: "no, es que él corrió a uno, yo voy a nombrar tres".

R: Y además el presidente Ortega sí ha tenido en todas sus actuaciones, casi desde que llegó a la presidencia, la inclinación a fortalecer el Ejecutivo, un Ejecutivo que habían debilitado las propias reformas constitucionales.

F.C.: Es que él sigue con el discurso de que él quiere un gobierno parlamentarista, pero lo que él quiere es una monarquía simulada, a él lo que le gustaría es ser Juan Carlos de Borbón, con un Primer Ministro, esa es la realidad para mí, yo lo veo así a él, cuando habla del parlamentarismo, ¿qué parlamento?, pero una monarquía todavía más atrasada que las actuales, pues, porque son procesos democráticos, ¿no?, y el jefe de gobierno es el jefe de gobierno en España, entonces, él quiere más bien una suerte de Enrique VIII, o de Isabel I de Inglaterra.

\section{$R:$ Sí, de monarca absoluto.}


F.C.: Donde haya un parlamento que hable tonterías y el Rey soy yo, ¿verdad?, y con un jefe de gobierno, que, en este caso, es la esposa.

R: No, obviamente, a la hora de importar fórmulas institucionales de otras tradiciones politicas este gobierno se ha proliferado en discursos.

F.C.: Sí, sí, pero no te casás con la esencia, porque tenemos dos fórmulas de gobierno: la española, por ejemplo, y la británica, por un lado, y la norteamericana, por el otro, pero en la esencia son las mismas, el respeto a las libertades individuales, el respeto a la democracia, y el orden institucional de la sociedad, y son dos fórmulas diferentes, en una hay un Rey o una Reina, y en la otra hay un presidente, pero la esencia es la misma, y el problema de aquí es que la esencia no es la misma, el problema de Nicaragua es que la esencia no es la misma, la esencia es el irrespeto a los derechos de los ciudadanos, el irrespeto al derecho del voto, se robaron las municipales e irrespetaron a todos los que fueron a votar, aún a los que votaron por ellos mismos, porque el ciudadano va a votar para obtener un resultado, y que ese resultado sea el que la mayoría dictaminó, y yo como minoría debo aceptar que perdí si perdí, entonces, no hay una institucionalidad de la democracia, y de la justicia, pues, sino que lo que hay es la institucionalidad de los, y este es un defecto, yo te insisto, aunque Daniel Ortega es el peor ejemplo, pero este es un defecto de la derecha misma de Nicaragua, Alemán fue arbitrario en su administración, Bolaños fue arbitrario en su administración, la mejor administración ha sido la de Doña Violeta, pero los otros dos fueron arbitrarios en sus respectivas administraciones, no los voy a comparar con Ortega, pues, aún el mismo Alemán, pero si fueron arbitrarios.

\section{$R:$ ¿En qué sentido, abusando de la función presidencial?}

F.C.: Abusando de las funciones del Estado, Alemán si yo lo criticaba me mandaba al fisco, entonces, metió políticos presos para callarlos, les logró montar procesos judiciales, los investigaba, entonces, repetimos lo mismo, pero con distintas modalidades.

R: Lo que pasa es que, en el caso de Ortega, el cierre de espacios políticos ha sido muy fuerte.

F.C.: Es que Ortega es un caso más, pero lo que yo te quiero decir es que todos estamos, todos los políticos nicaragüenses, de una u otra forma, están en las mismas.

R: ¿Y cuál es la alternativa?, porque, por lo menos en casi todas las entrevistas el discurso es, francamente, pesimista de aquí al futuro inmediato.

F.C.: ¡Ah, no!, yo soy optimista, ¿qué es lo que yo pienso?, yo ya tengo dos experiencias concretas, que fueron el derrocamiento de la dictadura somocista de lo cual yo fui partícipe, y después viví el fin del régimen sandinista, y, entonces, yo he encontrado que la dictadura somocista duró casi 40 o 50 años, el gobierno sandinista duró 10 , los procesos se han acelerado, los procesos de cambio, ¿verdad?, el uno fue derrocado de una forma violenta, con una revolución violenta, que, desgraciadamente, pues, no supimos darle su rumbo correcto, y el otro fue derrotado en las urnas electorales, pero el pueblo marcó el paso, y tomó la decisión, y una decisión que nadie esperaba, ni la misma izquierda de aquél entonces, ni la misma derecha, esperaban el 
resultado de las elecciones del 90, y se vio, el pueblo decidió, y el pueblo votó a Somoza, entonces, los procesos son más acelerados, los tiempos son más dinámicos, entonces, el pueblo nicaragüense no protesta todos los días, ni sale a la calle todos los días, no es esa la conducta de la población nicaragüense, sino que actúa en los momentos en que tiene que actuar, es como una suerte, en mi opinión personal, de sabiduría popular, que los politólogos le han dado distintos nombres, "cultura güegüense", dicen, el "güegüense" es una obra de teatro y un baile, no sé si has oído hablar de él.

\section{R: Sí, tengo la obrita, me la regaló una amiga nicaragüense.}

F.C.: Lo que dice el "güegüense", en esencia, es decir una cosa y actuar de otra forma, ¿no?, entonces, dicen que el pueblo nicaragüense es "güegüense", que en las elecciones del 90 dijo, se manifestó sandinista, y votó contra el sandinismo, eso es lo que, yo no creo eso, yo creo más bien que el pueblo nicaragüense en los últimos 20, 30, 40 años de su historia, ha hecho lo que tenía que hacer en el momento preciso, de acuerdo a las circunstancias y oportunidades que se le han dado, el uno fue un derrocamiento violento, verdad, y en el otro fue mediante el voto, verdad, yo manejo el optimismo.

$R: Y$, sin embargo, ahora, y ya para terminar la entrevista, en estas dos décadas que se ha logrado la profesionalización de las Fuerzas Armadas, la legitimidad de las fuerzas de orden público, en el sentido de ser apartidarias, como habíamos dicho antes en el caso de la Policía, este retroceso que se está viendo en las manifestaciones civiles.

\section{F.C.: Es la presión presidencial.}

R: La Primera Comisionada, Aminta Granera, es una señora que debe estar en una posición complicadísima.

F.C.: Complicadísima, mira, yo digo que es un proceso inicial que hay que seguir manteniéndolo unos dos años más, el proceso se va a agravar más.

\section{$R:$ ¿Se refiere al enfrentamiento popular pro-sandinista?}

F.C.: No, me refiero ahorita al proceso de deterioro de la Policía, se va a profundizar más por dos años, y el proceso de deterioro del gobierno se va a profundizar, ¿verdad?, porque el gobierno no va a ser capaz de resolver las demandas sociales, entonces, mi esperanza está no tanto en los partidos políticos como en el movimiento social, verdad, que va a poner las cosas en orden, en mi opinión.

R: Sobre todo, porque sí es verdad que el Frente anda un poco sobornando a pandilleros y a gente que forme parte de las turbas, es como alentar el desorden público, ¿no?, es una cuestión de fomentar la delincuencia o el delito impune, es la impresión que uno tiene, el ciudadano medio, digo.

F.C.: Así es, es lo que está pasando, usted está diciendo lo que yo dije en un canal de televisión hace, ya no recuerdo cuanto, porque el problema es que me amenazaron después de eso, entonces, ya decidí, presionaron a los dueños del banco, presionaron a una empresa donde yo era socio y tuve que vender mis acciones y salirme, $\mathrm{y}$, entonces, bajé un poquito, aunque yo nunca di una opinión política, sino que era una opinión 
técnica, y esta explicación que le di ahorita, la di en la televisión, y hablé frente a eso, yo dije que en América Latina el fenómeno ha sido que los políticos han tenido la responsabilidad del incremento del crimen, y di algunos ejemplos que están relacionados con América Latina, el caso de Colombia, todo se inició con el asesinato de Luís Carlos Galán, lo asesinan, era un abogado, no sé si conoces un poco la historia.

\section{R: No, no, pero sí, el caso colombiano es tremendo.}

F.C.: No, pero el inicio es así, él es un abogado del Partido Liberal, que tiene un arrastre impresionante en Colombia, y que significa el fin del gobierno liberal y el inicio de un proceso democrático popular, y un día saliendo de su oficina un asesino le dispara y lo mata en las calles, y se produce lo que se llama el "Bogotazo", usted lo puede buscar en Internet, y, entonces, la población sale a las calles, saquean los comercios, queman los edificios, la Policía se subleva, la Policía era simpatizante de Luís Carlos Galán y se subleva, verdad, y ese levantamiento popular fue reprimido con el Ejército, pero a partir de ese momento se inicia una persecución del Partido Liberal de todo el territorio colombiano, ahí nace la guerrilla, ahí nace la guerrilla, después del nacimiento de la guerrilla, como respuesta a estas guerrillas, nace el movimiento de los paramilitares, y, en el contexto de esa violencia política, Ejército, guerrilla y paramilitares, se fortalecen los carteles de la droga, nacen y se fortalecen, y ese es un proceso en el que nace el crimen organizado del secuestro, y Colombia se convierte en un caos, pero el origen es político. El caso de Guatemala es similar también, no sé si también conoces un poco la historia, en Guatemala hubo un proceso de una revolución, que fue una revolución democrática, y se dio un golpe de Estado por Carlos Castillo Álamo, eso provocó el surgimiento también de la guerrilla, y luego fue el surgimiento de la "mano blanca", comenzaron los asesinatos políticos, ya uno no sabía quién mataba a quién, en ese contexto, empiezan a nacer las organizaciones criminales, verdad, se da la guerra sucia contra la guerrilla en Guatemala, el Ejército se descompone y la Policía, y comienzan a aparecer organizaciones de crímenes organizados que integraban a militares y a policías, y se introduce el narcotráfico como parte de una ruta hacia el norte, e, inclusive, se comienza a sembrar la amapola en Guatemala, ya no sólo es ruta, sino que también se produce, y están involucrados militares y policías, entonces, los asesinos de los diputados salvadoreños eran policías, es más, el jefe del grupo que mata a los diputados es el jefe del grupo anti-corrupción.

\section{R: Es tremenda la ironía.}

F.C.: Es el jefe del grupo anti-corrupción, y, entonces, lo logran ubicar porque el carro en el que ellos andaban tenía el GPS que el gobierno le había puesto, entonces, lo ubican por el GPS, los detienen, pero uno de ellos se logra escapar, lo llevan a una prisión, y en esa prisión hay un grupo de hombres armados que hasta ahora nadie sabe quiénes son, y matan a todos los policías detenidos, entonces, el gobierno logra detener al que se había escapado, y éste es el que da el nombre del jefe de esta organización criminal que era un diputado, pero el origen es político.

R: Y, sin embargo, la Policía en Nicaragua no ha tenido ni esos grados de corrupción, ni tampoco de vinculación sucia, digamos, con asesinatos políticos.

F.C.: No, no. 


\section{R: En un país que ha vivido un conflicto armado, ¿no?}

F.C.: Sí, pero con otros valores, aquí hubo una revolución, en América Latina ha habido tres revoluciones: la mexicana, la cubana y la nicaragüense, ustedes le pueden buscar cualquier tinte, la mexicana tuvo su tinte, su connotación, Pancho Villa, por un lado, tenía el tinte de bandolero, verdad, y Emiliano Zapata el de agrarista, ¿no?, pero fueron los dos grandes protagonistas de la revolución mexicana. La revolución cubana, también, en un momento determinado, sí hubo la necesidad del pueblo cubano de eliminar un gobierno corrupto, ¿no?, de Fulgencio Batista, y la revolución nicaragüense también, fue una revolución total, donde participó todo el pueblo nicaragüense y todos los sectores sociales, que esa revolución haya devenido en una administración de gobierno que equivocó su rumbo, verdad, es otra cosa, pero que no podemos quitar que fue una revolución, una revolución.

R: No, y además un punto de inflexión en la historia de este pais.

F.C.: Una revolución por la que dieron su vida jóvenes, niños, jóvenes y adultos.

R: No, y además el fruto tardio de la revolución fue la democracia, por eso, resulta asombroso que estén atentando contra la democracia los mismos artífices de la ruptura, digamos, con la dictadura de Somoza, ¿no?

F.C.: Lo que pasa es que ellos se han erigido, se han auto-erigido como, yo tengo un artículo bien interesante, es un artículo que me lo mandaron a mí a mi correo, te lo voy a regalar, para que veas una crítica, te voy a leer algunas partes para que veás una crítica a lo que está pasando en Nicaragua desde la perspectiva de un sandinista, es interesante, a mí me gustó mucho, porque yo no había leído algo así.

R: Sobre todo, porque también en las entrevistas, salvando los contextos, hacen un paralelismo histórico entre los primeros años de Somoza y el régimen actual de Ortega, incluso, la concentración de poder en torno a la familia, el enriquecimiento económico, utilizando el Estado como soporte...

F.C.: Es que nosotros, nosotros durante la revolución sandinista, había valores morales, éticos, para nosotros era intolerable aceptarle un soborno, es decir, quizás estuviéramos equivocados, pero estábamos equivocados con una pureza de espíritu, que no es lo que hay ahora, pues, que aquí se enriquece el que pueda, ese es el fenómeno, ¿verdad?

R: Pero en el caso de Somoza, él sí controlaba a las fuerzas de orden público, al Ejército y a la Guardia Nacional.

F.C.: Es que la Guardia Nacional era la misma Policía.

R: Y en el caso de ahora, la presión del Ejecutivo sobre la Policía es muy fuerte, y ¿cómo ve a Aminta Granera?, ¿cómo le parece que lo está haciendo esta señora desde su posición de haber ostentado el mismo cargo? Es un papel dificil el que tiene esta mujer.

F.C.: Yo, lo primero que digo, es que desde que fue nombrada estaba claro que ella iba a pagar un precio, y que se iba a quemar, ¿verdad?, yo pienso eso, va a salir todavía más 
quemada de lo que está, porque esa era la misión, cuando hicieron la primera encuesta de popularidad, ella salió con el nivel más alto, sobre el presidente, sobre todo el mundo, sobre todas las personalidades que están ahí, eso no podía ser aceptable.

R: Pero eso también prueba que la Policía en Nicaragua goza de buena opinión pública, es decir, que la gente respalda a la Policía.

F.C.: Sí, pero eso no era aceptable por el gobierno, no lo iban a aceptar, que otro ciudadano tuviera más popularidad que el presidente, y un funcionario de relativa confianza, digamos, no lo iban a aceptar, entonces, ellos tendrían que irla comprometiendo poco a poco, para que cuando le tocara el momento de irse no gozara de ningún aprecio, y que no gozara de ese nivel de popularidad, y ella si se iba así no más, sentaba un mal precedente, porque el problema es que si se iba, abandonaba la Policía, y el proceso anterior se vuelve más acelerado.

R: ¿Y cree que este deterioro puede afectar también al Ejército?, bueno, porque las declaraciones de Humberto Ortega...

F.C.: Yo creo que sí.

$R:$ ¿Sí, o sea, ese peligro existe actualmente?

F.C.: Yo creo que sí, yo creo que sí.

R: ¿De que el Ejército se ponga del lado del presidente Ortega?

F.C.: Por lo menos, en el caso de los mandos, el Ejército puede llegar a un nivel de, cómo decirte, de presión fuerte sobre algunos mandos del Ejército. Yo creo que sí.

$R: Y$, bueno, en el caso de que tengamos 5 años más, de acuerdo con la última sentencia de la Corte, a Ortega en el poder, si se presenta como candidato y no se une el liberalismo, francamente, como que es previsible la victoria de Ortega para 5 años más.

F.C.: No.

R.: ¿No lo ve factible? Cinco años más de gobierno de Ortega, tratando de reestructurar el Estado a su imagen y semejanza, la verdad, es que es muy peligroso, ¿no?

F.C.: Sí, se va hacer todo lo posible para que esto no suceda. Aquí está el artículo, se llama "El actual FSLN y la pesadilla de Carlos Fonseca", Carlos Fonseca es el fundador, ¿verdad?, entonces, aquí te va a dar la visión más o menos de lo que el sandinismo, realmente, piensa de este fenómeno.

R: ¿Cómo se llama el autor?

F.C.: Ya te digo, se llama Francisco Javier Gutiérrez, tiene unas partes extraordinarias, dice así, empieza: "han dejado de usar la inteligencia, la estrategia orteguista, el espantajo legal y la violencia de sus turbas, política que apela descaradamente al 
encefalograma plano, estamos ante un FSLN, que bajo las tinieblas de la codicia ha perdido el intelecto, lejos de la luz de Sandino y del resplandor de su artífice principal Carlos Fonseca Amador. La inteligencia, la ética, la superioridad moral, el sacrificio o la modestia fueron virtudes predicadas con el ejemplo del creador del Frente Sandinista, su compromiso con Nicaragua le convirtió en algo que sus compañeros no captaron medir con una sensatez elemental el poder de Estados Unidos para no practicar, según sus propias palabras, un anti-imperialismo ciego, sino un anti-imperialismo responsable. Precisamente, la insensatez y la aplicación de un anti-imperialismo ciego, que condenaba a la Casa Blanca, pero que alababa al Kremlin fue lo que propició en parte la guerra en los años 80. Es polémico, pero estoy seguro de que Carlos Fonseca jamás hubiera permitido aquél enfrentamiento irresponsable, que destruyó Nicaragua, y sacrificó inútilmente su preciosa juventud. El fundador del FSLN predicaba el marxismo-leninismo como herramienta política, pero proclamaba que la revolución nicaragüense debía encontrar su propia identidad en una mezcla de doctrinas. Algo debió de notar en el bloque socialista que le hizo insistir en que las relaciones con estos países debían ser discretas, que permitieran sin caer en diatribas, dar la opinión sobre cuestiones que no aprobábamos. Leer sus escritos hoy sobre Nicaragua hace 40 años y la dictadura que la martirizaba, la distancia revolucionaria izquierdista, definió como vicio que el somocismo era el enriquecimiento ilícito, el empleo de parientes y el ascenso de incapaces, dijo que el terror como sistema lo empleaban solamente las fuerzas reaccionarias, y que las riquezas del país no deberían ser un botín de pandillas explotadoras nacionales. El ejemplo de Carlos Fonseca inspiró a hombres cuyo valor fue decisivo para forjar la victoria en el 79, patriotas de la estatura de Eduardo Contreras, de Ricardo Morales o de Abel Durán, gente con brillo, coraje y prestancia intelectual, esa fue la categoría de las personas que moldearon el prestigio y el respeto por el Frente Sandinista, ellos nunca calcularon cuánto se merecían por ser héroes. Muy pocas cosas en la vida son tan cercanas al como la comparación entre aquél Frente Sandinista y la pesadilla de hoy, un cotejo indispensable, si se toma en cuenta, que los actuales dueños del FSLN se consideran los relevos de aquella generación, que segó su fundador, desafiado en la clandestinidad, el más despiadado terror para crear una nueva Nicaragua donde la justicia y la libertad alcanzaran su pleno florecimiento. Daniel Ortega, ¿es el relevo de Carlos Fonseca?, ¿se puede comparar a Wálmaro Gutiérrez con Eduardo Contreras?, ¿a Leonell con Bayardo Arce?, ¿Herrera Núñez otro Ricardo Morales?, ¿y Edwin Castro otro Julio Buitrago?, ¿Humberto Ortega carga la mística de Pumar y Rosario Murillo la de Lesiu? De acuerdo con la evidencia histórica, ¿con quién es comparable toda esta gente? Daniel Ortega y su cúpula convirtieron al Frente Sandinista en la pesadilla de Carlos Fonseca, el orteguismo es un sistema parasitario y corrupto, que no solamente se parece al somocismo, sino que lo supera, todo es más grande y más numeroso, la corrupción, el robo, los rótulos, las mentiras, las mansiones, los autos, aunque sean Mercedes Benz, la ostentación, la maldad y la pobreza. A 33 años del ruido de pájaros que predijo su muerte, como le cantan los versos de Luís Enrique, de que su sangre dulce florecieran las malinches, le llorara la montaña y el pájaro león, y que el lucero de la aurora sembrara su odio en su frente para que el amor creciera encimita, seguramente, los usurpadores bajarán de sus lujosos autos hacia su desvencijada tumba para profanar de nuevo su nombre. Desde ahí parece alzarse de nuevo su voz para acusar de esta nueva dictadura y hacer las mismas preguntas. Yo acuso a los cabecillas del gobierno somocista de asaltar a lo largo de 30 años al sufrido pueblo de Nicaragua para acumular millones y millones de córdobas, pero esta vez no 
va a preguntar de dónde han salido los bajos de la MAMENIC ${ }^{16}$, Nayer Merlín, (era una naviera de Somoza), los aviones de LANICA $^{17}$ (una línea aérea), Montelimar (no necesito decirte), la fundidora, las 10.000 casas y los 300 latifundios, basta con que preguntes de dónde salió ALBANISA". ¿Está muy bueno, verdad? Yo con gusto te lo paso, ¿qué te parece?

R: No, definitivamente, es muy bueno el artículo, y es muy triste su oportunidad, ¿no?, que, en este país, los ciclos de la historia se repitan con tanta facilidad, diríamos, porque yo creo que la experiencia de una guerra es dramática en cualquier país que haya sufrido, en el caso de Europa, después de la segunda guerra mundial, bueno, de hecho, el espíritu de la Unión Europea es el fruto de una guerra, ¿no?, o sea, es como decir: "nunca más vamos a volver a pasar por esto", y, en el caso de mi país, la guerra civil, la transición es todo un pacto entre fuerzas adversas para decir: "nunca más volveremos a tener una guerra en este país", porque es muy doloroso el enfrentamiento armado. Pues si tienes algo más que añadir.

F.C.: Sí, así es. Pues, no se me ocurre nada más de lo que ya hemos hablado. 


\section{ENTREVISTA $12^{18}$ :}

Nombre del entrevistado: D. Luís Carrión Cruz.

Cargo actual: Ex -Ministro del Interior durante el Régimen Sandinista (1979-1989). Comandante miembro de la Dirección General del FSLN. Miembro actual del Movimiento Renovador Sandinista (MRS) y profesor de la Universidad Americana (UAM).

Fecha de realización de la entrevista: Managua, 17 de septiembre de 2009.

Lugar: Facultad de Diplomacia y Relaciones Internacionales de la UAM.

Duración estimada: 53 minutos.

\section{TEXTO - Transcripción 12:}

$R$ : ¿Cuál es su mirada sobre los procesos de reforma constitucional en el marco de la transición democrática reciente de Nicaragua?

L.C.: ¿Estamos hablando de los últimos procesos de reforma constitucional?

R: Sí, desde el 95 en adelante.

L.C.: Desde la transición en adelante, bien, yo creo que el primer proceso de transformación constitucional se diferencia de los posteriores y del actual intento, ¿no? ¿En qué sentido?, en primer lugar, no fue promovido desde el Ejecutivo, ¿verdad?, fue una propuesta que nació de la propia Asamblea, segundo, por las características de la transición del período revolucionario a la nueva época, bueno, ningún partido tenía control de la Asamblea ni estaba realmente consolidado, el mismo Frente Sandinista, que era, en ese momento, el partido más sólido, más fuerte había tenido una ruptura de su bancada parlamentaria que se separó del, digamos, del pensamiento y de la línea política que el Frente estaba impulsando, y que se metió a impulsar estas reformas pero sin la línea, sin el apoyo del partido Frente Sandinista. Tercero, había una representación, digamos, desde el punto de vista político e ideológico, mucho más variada y plural que las subsiguientes asambleas, entonces, y, por último, el propósito de esas reformas claramente fue disminuir los poderes de un Ejecutivo que era demasiado poderoso, incluso tenía la potestad de establecer impuestos sin pasar por la Asamblea Nacional y buscar un mejor equilibrio entre el Poder Ejecutivo y el Poder Legislativo, así también como abrir espacios democráticos más amplios. Las siguientes reformas han estado dictadas básicamente por el interés, primeros por intereses de grupos muy reducidos, que han sido a veces el de personas, por un lado Arnoldo Alemán y por otro lado Daniel Ortega, y la pequeña cúpula del FSLN, han estado, se caracterizan por ser reformas que formalizan, digamos, acuerdos prebendarios de repartición de puestos, claro, las reformas no hubiesen repartido, liberales tener tantos Magistrados y el Frente Sandinista tener tantos, sino que establecen un mecanismo de elección que obliga a un acuerdo forzoso, ¿no?, que ya está tomado de forma previa, y que, entonces, no han tenido a la vista como un interés particular para reflexionar las instituciones, ninguna de las instituciones, sino más bien consolidar el control que dos partidos tienen sobre los poderes de los principales aparatos del Estado. Entonces, yo separaría la primera reforma de las demás, por el signo, los propósitos y digamos la

18 Entrevista centrada en todo momento en las preguntas planteadas, con una capacidad de síntesis y claves de análisis muy interesantes. 
realidad política mucho más fluida, menos, digamos, menos reducida a dos partidos, que es lo que después vino marcando la dinámica política del país.

R: Y ese punto de inflexión que supone el Pacto entre Ortega y Alemán previo a la reforma constitucional del 2000, sí incluye una reforma electoral, que además restringe la formación de nuevos partidos políticos...

L.C.: Claro, claro, por eso yo le decía que, además son dos cosas, reduce los espacios de participación popular, porque anteriormente se permitía la participación en lo que son las elecciones municipales de lo que se llamaban candidatos por suscripción popular, que no tenían ningún partido político, se presentaban un número de firmas, si había unas voluntades significativas de un sector de la población podía presentar candidato. Eso se eliminó, ¿verdad?, la ley electoral, pues, es una ley bien restrictiva, verdad, está diseñada para, que es una ley constitucional, está diseñada para dificultar lo más posible el crecimiento de minorías. Es decir, cuando haya crecimiento de las fuerzas que son minoritarias en este momento pero que pueden crecer en el futuro, a través de las reglas sobre la formación de alianzas electorales,, de las reglas para perder la personalidad jurídica, que, de todas maneras, son interpretadas arbitrariamente por un Consejo Supremo Electoral que está completamente partidarizado, ¿no?, entonces, como yo dije antes, en esa reforma lo que querían era dos cosas: garantizarse los partidos mayoritarios en ese momento que ellos podrían tener hegemonía en el sistema político por un tiempo indefinido, y, segundo, establecer un mecanismo para que ellos pudieran repartirse la influencia y el acceso a los recursos de la institucionalidad del Estado, que, esto es, como le digo, más bien prebendario, hay una serie de beneficios económicos y materiales que se derivan de estos pactos, para quienes participan en ellos.

R: Pero esto no es tampoco un hecho insólito si recurrimos a la historia constitucional de Nicaragua, que está plagada de pactos detrás de los cuales hay la sanción de un interés político específico.

L.C.: Sí, efectivamente, las constituciones en Nicaragua, bueno, ha habido una cantidad enorme de constituciones, ¿verdad?, y otra cantidad también muy grande de reformas, digamos, en el siglo XX, desde 1931 o 1932 a la fecha actual, como norma todos los procesos de reforma disfuncional estuvieron motivamos por el afán reeleccionista, tenemos el caso de Somoza, ahora Daniel Ortega, y, en general, por el afán de perpetuarse en el poder los caudillos fuertes, ¿verdad?, que ha sido la marca de la experiencia política nicaragüense, bueno, desde antes que yo naciera, y que, desgraciadamente, todavía es una marca muy fuerte en la cultura política nacional.

R: Y llama, sin embargo, poderosamente la atención, en mi caso, además, siendo una estudiosa extranjera del proceso de cambio político y constitucional en Nicaragua, que el hilo conductor de las reformas, tal cual se ha legitimado en el discurso, obviamente, ha sido el de pseudo-parlamentarizar el sistema politico y procurar que haya un equilibrio de poderes cuando, realmente, lo que ha habido es el trasvase de poderes de un Ejecutivo fuerte, presidencial, al dominio de las cúpulas de los partidos, siendo el socio minoritario el PLC, que, además, se ha dividido como rehén de la libertad de Arnoldo Alemán, ¿cuál es su opinión al respecto?, incluso, ese fortalecimiento progresivo del sandinismo, incluso antes de que ganase la presidencia. 
L.C.: Eh, independientemente de que hayan hecho un pacto, verdad, que busca como garantizarle hegemonía a ambos, entre ellos hay una permanente competencia por controlar los espacios de poder y fortalecerse en detrimento del adversario, o sea, por eso es que puede haber un entendimiento y un conflicto simultáneamente, pero el entendimiento, como quien dice, acota el conflicto, le establece los límites, claro, que si el balance de fuerzas se modifica eso también probablemente va a llevar una modificación de los términos del pacto, ¿verdad?, cosa que Somoza no tomaba tan en cuenta, ¿verdad?, porque teniendo un control mucho más fuerte que el que tiene Daniel Ortega ahora estuvo dispuesto a repartir posiciones con los conservadores, que, obviamente, ya no representaban nada pero que le daba una imagen, bien, entonces, el Frente Sandinista como partido tiene más disciplina, son militantes, digamos, más comprometidos con la causa del partido, y esto les ha permitido dentro de las instituciones del Estado avanzar mucho más eficazmente que el PLC, el Frente Sandinista ha fortalecido su poder en el Estado a lo largo de todos estos años, especialmente, de las instituciones autónomas, es decir, el Poder Judicial, el Poder Electoral, verdad, la Contraloría General de la República, y la Fiscalía, verdad, gracias a esta, digamos, capacidad, a la decisión neo-liberal, a la venalidad extrema de algunos de los diputados que han dado su voto a cambio de sobornos y coimas y todo eso, entonces, efectivamente, del arreglo del pacto, el gran ganador ha sido hasta ahora el Frente Sandinista, sin duda, y, en este momento, se puede decir que Daniel Ortega, porque el Frente Sandinista se ha reducido casi a Daniel Ortega y su familia, ¿verdad?, desde el punto de vista de quién controla, quién toma las decisiones, qué intereses prevalecen en el accionar del partido, verdad, y ahora con el grupo de Chávez dentro del gobierno el acceso a millones de millones de millones de dólares, que claramente se están derramando en los bolsillos particulares de una gran cantidad de gente del Frente Sandinista, lo que consolida el control del Ortega, verdad, sobre las estructuras del partido, es decir, yo creo que ese partido es ahora más orteguista que nunca.

R: Y, además, usted que conoce de cerca el Frente por haber participado en él muchos años y haber acompañado al Frente en su proceso revolucionario, que es un poco quizá la seña más auténtica del partido, ¿no?, el de su origen y el de su razón de ser, ¿cómo contempla la andadura democrática del mismo?, ¿cuál ha sido el aprendizaje del Frente en la etapa democrática a hacer oposición, primero, y, en segundo lugar, a gobernar, con todos los desacuerdos que han motivado incluso la escisión del partido, primero en el MRS y luego en otros movimientos que también reclaman para sí lo que es el verdadero sandinismo?

L.C.: Bien, digamos que, a mi me parece que el Frente Sandinista es, por llamarlo de alguna manera, muy débilmente democrático, verdad, yo creo que la derrota asumida por el Frente en 1990 y el camino recorrido hasta las elecciones del 2006 en que gana nuevamente Daniel Ortega, le enseñaron a Ortega de que no se puede deshacer por completo de las instituciones democráticas en este mundo, es decir, que este proceso es imparable, sin embargo, mientras estas instituciones permanezcan débiles y sean manipulables tiene una ventaja sobre cualquier otro partido político, porque tiene una capacidad de movilización de minorías muy grande, de grupos muy pequeños pero muy organizados, no, muy eficaces, y, es decir, tiene una capacidad de presión cuando está en la oposición bastante alta que se fue disminuyendo cuantitativamente desde el noventa hasta 2000,2002, 2003, pero todavía es mucho mayor que la de cualquier otro partido, su habilidad para operar, digamos, tras las cortinas del poder y penetrar en una institución y controlarla, verdad, le permite a Daniel Ortega y al Frente Sandinista como 
tal tener un discurso democrático, y lo pongo entre comillas, mientras operan desde las instituciones democráticas en contra de los principios de la democracia para fortalecer su poder de partido o su poder personal, verdad, para garantizar su impunidad, por ejemplo, frente a una serie de abusos, de corrupción, incluso, habla de moverse hacia un esquema más parlamentarista, sin embargo, la Constitución actual, el cambio que hicieron en la última reforma, verdad, introducen una cosa que es una práctica en los regímenes parlamentarios que es la aprobación por el Congreso de los ministros que son designados por el Ejecutivo, y eso está en una reforma, que incluso estuvo a punto con Arnoldo Alemán en aquél momento con el propósito de cerrar el cerco sobre el Gobierno de Enrique Bolaños, al cual los dos estaban adversando, es decir, él tenía la oposición de Ortega y la oposición de Alemán, verdad, ahora cuando llega a la presidencia, simplemente ignora y no reconoce, no envía los nombramientos a la ratificación de la Asamblea y él opera, es decir, lo que predomina en Ortega y en el Frente es la idea de consolidarse como poder hegemónico en el largo plazo en el plano político y en el plano económico, de eso yo no tengo ninguna duda, verdad, y con unas ciertas restricciones que impone la democracia, o sea está buscando siempre como extender los límites no de las actuaciones democráticas sino de las actuaciones, digamos, autoritarias, hasta donde puede extender eso, por eso es que para mí la resistencia que puede hacer la ciudadanía que está muy débil, muy dispersa y muy desorganizada es enormemente importante, verdad, para determinar si las instituciones democráticas, frágiles, precarias, $\mathrm{y}$, en muchos casos, corruptas, que tenemos van a avanzar hacia un fortalecimiento progresivo o no. Aquí hay que tener en cuenta que el Estado de Derecho en Nicaragua no tiene mucha tradición, que la tradición más bien ha sido el que las élites políticas y económicas han tenido un margen de actuación muy grande, independiente de lo que esté en la ley, eso sigue siendo una realidad, desgraciadamente, en Nicaragua, y si tenemos al árbitro que es el Poder Judicial bajo el control de estos partidos, y te voy a decir, de estos caudillos, pues, de estos líderes de los partidos, pues, entonces, difícilmente, uno puede hablar del Frente Sandinista como un partido democrático, no lo es.

R: ¿Y cómo observa, digamos, la capacidad de supervivencia de los dos líderes, tanto del sandinismo oficial, bueno, del Frente Sandinista, y del PLC, que mantienen, de alguna manera, una cierta incapacidad para que se renueve el liderazgo y se comporten de otra forma?

L.C.: Bueno, más que incapacidad, yo creo que la falta de renovación de liderazgo es producto de una voluntad política de que así ocurra, en el caso, por ejemplo, del Frente Sandinista usted puede observar que cualquier figura que comenzó a destacar ante la opinión popular y que quiso presentarse como un eventual candidato fue rápida $\mathrm{e}$ inmediatamente descabezado, ¿no?, caso de Herty Lewites, caso de Dionisio Marenco, por ejemplo, ¿verdad?, es decir, y pasaron de ser compañeros con toda clase de virtudes a ser lo peor, pues, en el discurso oficial, ahora bien, Daniel Ortega políticamente tiene un control bastante sólido del Frente Sandinista, yo creo que a cinco o seis años plazo no veo yo que vaya fácilmente, esto no quiere decir que no ocurra, pueden pasar cosas imprevistas, pero como tendencia, no lo veo a él perdiendo control, ahora desapareciendo él, ya sea por muerte natural, por enfermedad o incapacidad o lo que sea, es difícil imaginarse qué es lo que ocurriría en el Frente Sandinista, que tiendo a pensar que habría una gran lucha interna, ¿y cuál resultado?, difícil saberlo, ¿verdad? Pero no, porque Daniel Ortega ni siquiera se abre a pensar en la posibilidad de una transición a otro liderazgo que no sea el de ellos, porque ahora lo que hizo él es 
incorporar a Rosario, que, teóricamente, no le había dado ningún espacio, ya Rosario, su esposa, digamos, es otro poder, es co-gobernante con él y ya está en la propaganda, ya se está construyendo, digamos, como figura política dentro del Frente Sandinista, no, así que no veo, pues, que ellos estén interesados en promover algún liderazgo alternativo, o distinto, ¿no? El caso de Alemán, yo creo que Alemán tiene también control del resto del PLC, pero, obviamente, no era tan sólido como el de Daniel Ortega, desde luego que Montealegre se fue más o menos con la mitad del partido, y tampoco tiene el grado, sobre la parte que quedó, no tiene tampoco el grado de control que tiene Daniel Ortega, pero hay que decir si se tiene en cuenta que Alemán estuvo como reo en las condiciones favorables que tenía durante varios años, que toda la prensa lo atacó de todas las formas y que todavía conservó un control bastante sólido de la mitad de su partido indica, algo indica, indica que el tipo tiene mecanismos de distinto tipo para sostener ese control a pesar de todo, los caudillos nicaragüenses siempre han sido sospechosos de cualquier otra figura que comience a emerger, porque no tienen noción del poder institucional, tienen una idea del poder personal, verdad, y cualquiera que emerja, que empiece a atraer apoyos y opinión, o de alguna manera delimita el poder personal de ellos, aunque pueda fortalecer políticamente a la institución partidaria, ¿no?, pero para ellos está siempre su propio poder personal antes que la influencia de la institución, del partido, pues.

R: De todos modos, otro aspecto que me interesa es como los dos presidentes fuertes que ha tenido Nicaragua en el marco de los procesos de reforma constitucional han sido, precisamente, Ortega y Alemán, porque han tenido lo que llama un politólogo norteamericano "poderes partidarios" y no solamente las atribuciones constitucionales, que limitan también la fuerza del Ejecutivo, ¿no? En el caso de Violeta Chamorro, y ya no digamos Enrique Bolaños, que fue un presidente acorralado por su propio partido incluso. Entonces, ambos tuvieron enormes dificultades para desarrollar su agenda de gobierno, ¿no? En el caso de Ortega, que ha tratado de dar un giro, digamos, a este incremento de las facultades de la Asamblea Nacional, fortaleciendo al Poder Ejecutivo de manera un poco contradictoria, al menos desde el punto de vista jurídico, para no entrar ya en el terreno político, como fue el caso del intento de la reforma de la ley de amparo, estableciendo un modelo de control preventivo de la ley del parlamento por el Ejecutivo, que es casi algo totalmente aberrante. Por otra parte, la creación de los CPC, como estructura del Poder Ejecutivo, cuando, realmente, es algo vinculado al partido, y que trata además de hacerse eco de la voz única del pueblo nicaragüense, cuando la sociedad civil es plural, y me imagino que hay un sentimiento diverso, y divergente, además, como debería ser en una sociedad verdaderamente democrática. ¿Cuál es su opinión al respecto, y no digamos ya del intento de Daniel Ortega de proponer la reelección presidencial o esta división de la estructura del Poder Ejecutivo en la figura de un Primer Ministro y el presidente de la República?

L.C.: Vamos a ver, Daniel Ortega empezó a impulsar el proyecto de reforma constitucional que yo pienso que para, de alguna manera, hacer más, cómo decirlo, a ver, lo voy a decir de otra manera, yo creo que Daniel tiene un poder partidario muy grande, muy fuerte, verdad, en un régimen parlamentario que es un régimen de partidos, verdad, creo yo que él se sentía uno, verdad, dos, creo que también por mucho tiempo pensó que era bastante improbable que él volviera a ganar las elecciones, verdad, eso sólo se hizo posible por la división del partido liberal, verdad, y por el pacto, porque hicieron las reformas constitucionales que le permitían volver, Daniel Ortega tuvo 
siempre una visión estratégica de las reformas, yo creo que Arnoldo Alemán no, Arnoldo Alemán lo que quería era poderse quedar en la Asamblea Nacional como diputado por decreto, para desde ahí continuar, él pensaba controlar a Enrique Bolaños y a su gobierno, verdad, pero vuelvo con Daniel Ortega, Daniel Ortega, pero sobre todo como una vía, disimulada de eliminar no sólo la no reelección sino incluso la discusión sobre la reelección, verdad, porque en un régimen parlamentario eso no es un tema, o me parece a mí que eso no es un tema, ahora bien, cuando a él le hicieron en julio de este año hablar en la plaza, ya no habla de las reformas constitucionales, ya sólo habla de una cosa, de la reelección, concretamente, poniendo en evidencia que detrás de todo ese armazón conceptual no hay ningún pensamiento orgánico, verdadero, de la realidad nacional y cómo expresarla mejor, políticamente, sino simple y llanamente, cómo puede él permanecer en el poder, verdad, y entre más, yo ahorita no recuerdo el detalle, pero hubo un documento que circuló con la propuesta de reformas y era una cosa, no como un régimen parlamentario ni nada, era una cosa, verdaderamente, hecha a la medida del deseo, de las necesidades de control, verdad, pero que, afortunadamente, al parecer murió, y él ya declaró, prácticamente, que lo único que le interesa es la reelección, que fue de lo único que habló ese día en el treinta aniversario de la revolución. Así que yo no creo que haya ninguna vocación parlamentaria, sino que, por alguna razón ellos calcularon que ese modelo se prestaba mejor a sus necesidades, y, la verdad, es que en este gobierno de Ortega el Ejecutivo, prácticamente, ha monopolizado la acción política, los poderes, todo, realmente, la Asamblea está muy debilitada, porque además todos los demás poderes del Estado están controlados políticamente por él, así que yo no encuentro ahí ningún interés real, ningún pensamiento.

$R$ : $Y$, por otra parte, también ha habido irregularidades en el procedimiento mismo de revisión de la Constitución, porque se reforma la cláusula de reforma constitucional con una ley ordinaria, que es una cosa absolutamente fantástica...

L.C.: Así es, dos veces, además, en la historia de los noventa para acá, uno con el gobierno de Doña Violeta cuando, se hicieron las primeras reformas constitucionales y se creó una crisis porque el gobierno sentía que la Asamblea quería intervenir en el ámbito propio del Poder Ejecutivo, y salió, primero, cómo es que se llamaba, la primera Ley Marco, que congelaba las reformas, y después ahora con Bolaños, verdad, se hizo la segunda ley, lo que muestra, sabes qué, que en Nicaragua incluso antes ya ocurrió en el ochenta y nueve o en el noventa, que se recortó el período de Daniel Ortega y el período está en la Constitución, y se recortó el período, se adelantaron las elecciones para darle salida a la crisis de guerra, y a la crisis política, y a la crisis de todo tipo que había permanente, verdad, pero bueno, eso fue, digamos, uno puede justificarlo históricamente, porque casi que era indispensable, pero, en los otros casos, el acuerdo político para, es un acuerdo político, no jurídico, aunque le den forma de ley para ignorar la Constitución, entonces, es increíble.

R: Además es una situación en la que quizá se entienda como coartada para ampliar el proceso de negociación de los actores políticos y ponerse de acuerdo sobre la norma constitucional reformada, quiero decir, dar un margen de tiempo no solamente a la norma reformada que a mi me interesa según esté en el poder o no, sino también incluso ampliando el proceso de negociación para reacomodar los intereses, ¿no?, porque siempre ha habido enfrentamiento entre el Ejecutivo presidencial y el Legislativo a la hora de reformar la Constitución en los tres procesos, siempre, siempre ha habido un presidente de la República, incluyendo la propia Violeta Barrios de 
Chamorro, que no quiere aprobar la propuesta de reforma constitucional de la Asamblea, quiere gobernar con la Constitución de la revolución. Es una absoluta paradoja la que se da en Nicaragua.

L.C.: Así es, exactamente. Bueno, yo creo que esto es también muestra la poca confianza que hay entre los mismos líderes políticos, ya no digamos del pueblo, en general, en las instituciones democráticas, verdad, no hay verdadera cultura $\mathrm{y}$ convicción democrática, y Arnoldo Alemán no quedó muy lejos de Daniel Ortega, quizá un poco menos peor, pero no es un líder democrático, su partido lo maneja como autócrata de medio alta, verdad, totalmente, y todo gira alrededor de él, él es la máxima autoridad, igual pasa en el Frente sandinista.

R: Se plantea ante el contexto económico de dificultades internacionales, estamos además en un mundo global también, Nicaragua ya no es la Nicaragua que sufre el bloqueo de parte de Estados Unidos, en un mundo dividido, y está en otra coyuntura histórica, pero sí es cierto que en el momento actual esa negativa tanto de Estados Unidos como de la Unión Europea de seguir apoyando, financiando a través de la cooperación internacional, que supone un peso importante en el presupuesto del país, y que Ortega quiera aliarse con Chávez, porque es la única "plata" que tiene, además de tratar de hacer una reforma tributaria cargando el peso de las dificultades económicas del Estado sobre los asalariados, sobre el pueblo ya de por sí con bastantes problemas. ¿Cómo prevé esa variable económica en el marco actual?

L.C.: Bueno, esa variable, es decir, la crisis económica nacional con todas sus causas, que hay causas nacionales e internacionales, también propias, verdad, como la pérdida de la ayuda al desarrollo ya aprobada de la Unión Europea y de parte de Estados Unidos, por causas de políticos, verdad, le pone presión creciente al gobierno para maniobrar, para hacer maniobras políticas que le den aire, verdad, especialmente, por ejemplo, no especialmente, lo de la reforma tributaria, por ejemplo, que nace de una condicionalidad que tiene el mercado internacional, es cierto, señores ustedes tienen que tener un presupuesto con un nivel de déficit máximo de tanto, y las cuentas nacionales no dan y se tiene que recaudar más, se tiene que hacer una reforma tributaria, esto también porque el dinero de Venezuela no entra a las arcas nacionales, es decir, esas son sumas muy significativas de dinero que no pasan por el presupuesto, están totalmente fuera de control, es manejado por empresas privadas, sí, son privadas, efectivamente, pero de Ortega y compañía, es decir, todas estas Albanisa, y Alba Transportes, y Alba no sé qué, todas esas empresas "Alba" ese dinero lo controla Ortega y su gente, entonces aquí acuerdos entre un Estado de Venezuela y empresas privadas en Nicaragua que además tienen influencia sobre los que gobiernan y los manejan a su vez para darle toda clase de facilidades y ventajas, es tremenda la corrupción. Pero, aún así, con todo eso, y en la parte que usa con fines sociales y políticos, verdad, no hay ningún tipo de control ni nada, y yo me imagino que nadie puede saberlo, porque eso es secreto, verdad, por otra parte, hay otro porcentaje que no sé tampoco de qué tamaño es, que es apropiado individualmente, personalmente, es decir, que ya funcionarios medios del Frente Sandinista están adquiriendo casas lujosísimas de la noche a la mañana, verdad, y eso es ese dinero, no hay de otra, es decir, la única fuente es ese dinero venezolano, hay una apropiación privada, un uso ineficiente en la parte que utilizan, porque yo me imagino que una parte la utilizan por razones políticas y otra la utilizan en apoyo social, verdad, con cierto límite. Me refiero a algunos programas como "Hambre Cero", que a veces le han metido dinero de ahí, todo esto son suposiciones porque no hay 
transparencia, es decir, no sabemos, la ciudadanía nicaragüense no sabe exactamente como se está manejando esto, pero con todo eso la crisis es tan grande que el gobierno no puede equilibrar llevar sus cuentas, que se puede agravar la situación económica porque no pueden cumplir las condiciones del Fondo Monetario Internacional, se hace más fácil para los Estados Unidos, digamos, extender la sequía de financiamiento, verdad, es decir, si no hay un acuerdo con el Fondo Monetario Internacional, con el Banco Mundial, Banco Interamericano de Desarrollo, si la comunidad internacional no le presta más a Nicaragua, es decir, todavía no ha llegado la posibilidad de recorte de apoyos financieros, todavía hay posibilidades donde se puede resistir mucho más, pero el gobierno del país puede traer una crisis verdaderamente, vamos, crisis de divisas, dificultad para importar las cosas necesarias, si se llegara a ese extremo, entonces, yo creo que ellos tienen que hacer algunos gestos políticos, porque está clarísimo, es decir, la parte que tiene que ver del impacto internacional no lo pueden reducir, eso está fuera del control del país, pero la parte que se ha perdido por razones políticas es la podrían recuperar, verdad, ahora, le digo, van a hacer gestos, yo creo que eventualmente van a comenzar a hacer algunos gestos, van a tratar de que sean gestos sin consecuencias reales, verdad, a ver si los gobiernos europeos, probablemente no tenga muchas expectativas con los Estados Unidos, pero más con los gobiernos europeos, se conforman con esos gestos formales, aparentes, superficiales, por ejemplo, ofrecemos observación internacional, porque el mismo Consejo Supremo Electoral que hizo fraude en unas elecciones, qué garantías tiene, además después dice nosotros ya hicimos observación internacional, nosotros no hicimos fraude ahí están los observadores electorales que son el Poder Electoral de Chávez, de Correa, Argentina, entonces, si las cosas se agravan puede ser que se vean obligados a hacer concesiones reales, así que, desgraciadamente, la verdad, sólo una profundización aguda de la crisis económica en el corto plazo, pensando en términos de corto plazo puede llevar a Ortega a hacer concesiones de fondo, y concesiones de fondo que impliquen mejorar las condiciones de la democracia, y quiero tocar otro temita rápido, porque ya se me está acabando el tiempo, y es uno muy delicado, verdad, la democracia requiere un Ejército no deliberante, apartidista, subordinado a las autoridades civiles, pero ante todo subordinado a la ley y una Policía honesta, absolutamente regida por las leyes, ahora, el gobierno de Ortega desde que llegó, ha intentado socavar la autonomía institucional de ambas instituciones, $\mathrm{y}$ ha tratado de volver a colocarlas como subordinadas al partido político y a él, a él no como presidente de la República actuando dentro de un marco jurídico, sino actuando él como caudillo político, y es muy claro que en el caso de la Policía, por ejemplo, ha tenido logros importantes, ha sacado gente, ha promovido a otros, ha logrado que la Policía tenga actuaciones parciales en los casos de conflictos de tipo político facilitando las actuaciones ilegales, violentas, agresivas de la gente vinculada al gobierno, verdad, y permitiendo que opositores sean atacados, no sólo han usado, o sea, el Poder Judicial, porque eso ya se sabía desde antes, ¿no?, en el caso del Ejército, yo creo que los avances han sido menos, creo, no me consta, que han sido menores, pero también el Ejército es una institución que está siempre un poco atrás, ¿no?, no participa de la dinámica social cotidianamente como sí es el caso de la Policía, pero yo creo que esas actuaciones de Ortega con respecto a esas dos instituciones son sumamente peligrosas, verdad, porque el único sentido de hacerlo, verdad, es para ejercer poder y fuerza al margen de la ley, y al margen de los mecanismos del funcionamiento democrático, y si no para qué, para qué quiero yo controlar el cuerpo policial, para qué necesito yo como partido tener control político sobre la Policía, si no es para usarlo, y para usarlo de una forma que contravenga, porque si va, porque si a mí lo que me interesa es que la Policía actúe conforme a la ley yo no necesito controlarla, o 
sea, si yo quiero controlarlo es para hacer cosas con esas fuerzas violentas contra la ley y contra los ciudadanos, etc., y tenerlos ahorita como la protesta civil no es muy masiva la están manejando a través de sus grupos organizados, grupos que empezaron como unos grupos de choque, pero últimamente han ido, en algunos casos, adquiriendo la forma de fuerzas paramilitares, por cierto, que el Jefe del Ejército salió diciendo que las fuerzas paramilitares y dio unas razones, y yo no sí si vio en el diccionario qué quieren decir fuerzas paramilitares, eso no quiere decir que estén ligadas de alguna forma al Ejército, simplemente que tienen formas de actuación y de organización de tipo militar, ¿no?, porque van grupos armados, porque van patrullando a la calle, todo esto sin que la Policía actúe, entonces, qué pasa, y lo que él necesita simplemente que la Policía los deje actuar, pero si en el futuro, verdad, esta situación se modifica y la protesta social crece y no es suficiente y, claro, la violencia se incrementa y ya se empieza a salir de control, entonces es necesaria la Policía como fuerza represiva, cuando ya los grupos éstos no sean suficientes, es la única cosa que hace sentido, ¿no? de porqué es tener control, además tratar de preservar ese control, aún, cuando salga del gobierno, o sea, que le da un poder no democrático, o sea, un poder que no deriva de elecciones legítimamente ganadas, sino de otro control político sobre instituciones de fuerza, pues, sobre instituciones coercitivas, así que eso es un asunto real más allá de reformas constitucionales sí o no, porque aquí se actúa, claro yo sé que el tema suyo es lo de las reformas...

R: No, no, pero en todos los entrevistados hasta el momento hay una preocupación seria, seria, por la evolución a corto plazo, estamos hablando de apenas un año y medio o dos que quedan para finalizar la presidencia de Ortega...

L.C.: Así es, además nosotros venimos de una historia de Fuerzas Armadas subordinadas a la voluntad de los partidos políticos, aquí no ha habido Ejército, porque la Guardia Nacional hacía las funciones de Policía y de semi-Ejército totalmente subordinada a los intereses de Somoza y antes de eso ni siquiera había Fuerzas Armadas nacionales, lo que había eran grupos armados de los partidos políticos, de tal manera que nuestra tradición con un Ejército institucional nacional es muy corta y débil, y la Policía cuando se creó en los años ochenta fue la primera vez en la historia de Nicaragua que un cuerpo policial estuviese separado de las Fuerzas Armadas, la primera vez, y de eso hace treinta años, verdad, aunque no estaba separada del control partidario, o sea, pero bueno, también entonces nuestro recorrido es muy corto y el éxito, los avances que ha logrado Ortega en retomar control muestran que en muchos de los integrantes de estos organismos, realmente, no ha calado una convicción democrática moderna, de responder a la ley, es decir, si no, no habría podido avanzar como ha avanzado.

\section{R: Pues si tiene algo más que añadir.}

L.C.: No, creo que es suficiente. 


\section{ENTREVISTA $13^{19}$ :}

Nombre del entrevistado: D. Edwin Castro Rivera.

Cargo actual: Diputado y actual jefe de la bancada del Frente Sandinista de Liberación Nacional (FSLN) en la Asamblea Nacional (2007-2011).

Fecha de realización de la entrevista: Managua, 18 de septiembre de 2009.

Lugar: Asamblea Nacional de la República de Nicaragua.

Duración estimada: 20 minutos.

\section{TEXTO - Transcripción 13:}

R: Me gustaría saber, ya que es usted quien lidera, o al menos, es la cabeza visible, digamos, de la propuesta sandinista de reciente reforma constitucional. En mi tesis estoy trabajando, fundamentalmente, cómo se produce ese cambio institucional a través de las reformas de ese presidencialismo fuerte, consagrado en la Constitución original del 87, hacia nuevas fórmulas semi-parlamentarias.

E.C.: Bueno, Nicaragua ha tenido, la Constitución del 87 ha tenido cinco reformas y, si analizamos cada una de ellas, ha venido, de una forma u otra, restándole facultades al Ejecutivo, y transfiriéndoselas al Congreso. Esto es lo que Diego Valadés, que él mismo estuvo en Venezuela y fue embajador, una parlamentarización del sistema. En la reforma del 90 se redujeron los períodos presidenciales en nueve meses y se llamaron a elecciones anticipadas de diputados, o sea, que eso sucede únicamente en un régimen parlamentario, pero bueno, en aras de la paz, en aras de esto, se violentó, entre comillas, un principio sacro del presidencialismo que son los períodos estables. En el 95, una serie de funciones fiscales, financieras, económicas, que fueron trasladadas al parlamento, entonces, hubo una creación de impuestos, la modificación de tributos, aprobación y modificación de presupuestos, todo eso fue para el parlamento, fuimos avanzando en fortalecer el parlamentarismo, pero a la vez fuimos avanzando en indicativos de una democracia más participativa, ya en el 2001 inclusive un Magistrado $^{20}$ actual de la Corte Suprema de origen liberal escribió un libro que se llama La democracia representativa y la democracia semi-directa, es decir, diciendo, que ya la democracia representativa pura en el mundo, ya no en Nicaragua, está perdiendo fortaleza, que ya los pueblos exigen una mayor participación, entonces, cuando se incorpora en nuestra Constitución ya como derechos fundamentales el plesbicito o referéndum, de modo, que la soberanía radique en el pueblo, quien ejerce el poder político a través de sus representantes y en forma directa, a través del plesbicito o referéndum $u$ otras formas organizativas, entonces, lo que nos planteamos ahorita, bueno, está en la reforma del 2005, para no dejarla en el tintero, se aprobó ya que todo ministro, vice-ministro, o embajadores fueran ratificados por la Asamblea, eso fortalece muchísimo más, si bien es cierto tan a la par que el presidencialismo originario de Estados Unidos, pues, pero que en América Latina lo que se aplicó fue el presidencialismo plesbicitario, que impuso Napoleón Bonaparte en la Segunda República, donde el presidente no tiene controles directos del parlamento, entonces, lo que, actualmente, está planteando el gobierno de Daniel Ortega es institucionalizar, ya terminar este proceso, de una semi-parlamentarización, llamémosla de alguna manera, pero que va a venir fortaleciendo la participación de la gente, o sea, una democracia más

19 Entrevista breve, con un gran sesgo político, pero tiene utilidad como referente significativo del discurso sandinista respecto de las últimas propuestas de reforma constitucional.

20 Se refiere a D. Iván Escobar Fornos. 
participativa, una democracia más directa, donde el pueblo pensado como ciudadano, dueño del poder, porque todos decimos que la soberanía radica en el pueblo, pero a la hora en que ese pueblo quiere ejercer su poder, le decimos no, lo ejercemos nosotros los representantes, que ese pueblo tenga canales institucionales de participación propia en la definición de políticas nacionales, en la definición de políticas locales, ya sean regionales o municipales, en la determinación del uso del presupuesto, de normas indicativas de salubridad pública, de forma en que no es como algunos lo quieren presentar un, un, un mensaje o un "raqueteo" entre la democracia participativa y la democracia directa, no, es un complemento de ambos, es decir, no es en contra de la institucionalidad, pero esa institucionalidad debe ser fortalecida por una participación de la gente, efectivamente, que tome decisiones, que el representante o los representantes no vengamos cuando nos de la gana, sino que el pueblo tenga esos instrumentos, y lo que aquí es lo que hemos llamado aquí en Nicaragua "devolver ciudadanía", devolver derechos ciudadanos, lo que llamamos el "poder ciudadano", entonces, esa sería por donde queremos hacer la reforma. Eso, obviamente, en un régimen parlamentario menos presidencial, que permite con mayor facilidad esa interacción entre la participación de la gente y la institucionalidad, aquí no se quiere quitar los poderes a los alcaldes, pero se quiere que los alcaldes gobiernen el municipio con la gente, con la decisión de la gente.

\section{R: ¿Y esa sería, perdón, la función de los CPC, por ejemplo?}

E.C.: Esa debería ser la función de los CPC, obviamente, es algo que también se tiene que ir aprendiendo, porque, porque no es fácil que durante un siglo y medio a la gente se le ha dicho que su democracia significa votar y después irse a su casa.

\section{R: Exactamente.}

E.C.: Ahora se le dice, no, tú eres el dueño del poder, ejércelo, hay que también enseñarle a la gente a ejercer el poder, en los Consejos del Poder Ciudadano.

R: Otra cuestión, son las propuestas de la reelección presidencial, o de la división de la estructura del Poder Ejecutivo a través de la creación de la figura de un Primer Ministro.

E.C.: Sí, son propuestas que están en el aire, son propuestas que están en el aire, son las que estamos proponiendo, además de fortalecer el derecho ciudadano, como incorporar el habeas data como un recurso constitucional, fortalecer lo que es la Sala Constitucional, separándola de las otras funciones de la Corte, dejando como una Sala aparte o un Tribunal Constitucional aparte, para que la gente tenga sus derechos resguardados, fortalecer los recursos de quejas por declaración de justicia, entonces, tratar de darle a la gente mayor fortaleza, a sus derechos, porque eso tiene que ser jurídicamente, porque si a la gente se le dice: "si participas, sí tomás el poder sin nombre reforzar jurídicamente ese poder", entonces, lo que queremos es devolverle derechos a los ciudadanos, esa es la lógica de la reforma.

$R$ : ¿Pero en qué medida piensa que, por ejemplo, aspectos como la reelección o la división de la estructura del Poder Ejecutivo contribuyen a consolidar la democracia en Nicaragua? 
E.C.: Porque si creemos en la democracia, lo que queremos es el pueblo decida, no tiene que ser a través de decirle, este no lo reelegí, o este sí lo reelegí, que la democracia se fortalece contra ellos, la democracia se fortalece en la medida en el pueblo decida libremente, sin cortapisas, a esto le estamos agregando algo nuevo, que es del siglo XXI, prácticamente, que son los referéndum revocatorios, que no tenga que esperar para que un electo cumpla su período para el que fue electo, si en medio camino ve la gente que lo eligió, que no esta funcionando, que lo corran, entonces, ahí, realmente, el pueblo va tener el poder, y los funcionarios van a sentirse controlados por el pueblo, porque va a funcionar el premio o castigo del dueño del poder. ¿Por qué el gerente funciona?, ¿por qué el gerente de una empresa funciona?, porque sabe que si no funciona lo corren, y si funciona bien lo premian, entonces, los funcionarios de gobierno no somos más que funcionarios, debemos funcionarle al dueño del poder, ¿y quién es el dueño del poder?, el ciudadano, la ciudadana organizada, entonces, si no estamos funcionando, que nos quiten, pero si sabemos que nos pueden quitar, como sabemos que también nos pueden premiar, yo creo que la eficiencia, la transparencia, que han sido por demás escasas en América Latina, entonces creo que la reelección junto con el referéndum revocatorio, son elementos que contribuyen, precisamente, a fortalecer la democracia, a darle mayor poder a la gente de control y fiscalización, de premios o castigos, si queremos llamarlo de otra manera.

R: ¿Y qué medidas ha aportado el actual gobierno sandinista después de tres gobiernos liberales que inauguran la democracia reciente?

E.C.: Devolverle derechos concretos al pueblo, para comenzar agarrando el país con más del $30 \%$ de analfabetismo y lo tenemos a $3.2 \%$, reconocido por los organismos de Naciones Unidas, es un derecho fundamental, un pueblo inculto es un pueblo que no se desarrolla, y le hemos devuelto, al menos, que aprendan a leer y a escribir, y comenzamos con eso. Le hemos devuelto la salud gratuita a la gente, le hemos devuelto la educación gratuita a la gente, primaria y secundaria, y además hemos creado la educación informal, tenemos casi un millón de jóvenes estudiando la educación informal fuera de aulas, educación de adultos, educación en alfabetización, entonces, creemos que esa devolución de derechos, además de la participación de la gente, ahorita, inauguramos una campaña que es que en los municipios, en cada municipio, los alcaldes consulten con la gente el presupuesto municipal, entonces, ya la gente está decidiendo en qué va a gastar la plata, eso es devolver derechos, eso es devolver democracia.

$R: Y$ además de estos avances, en términos de políticas públicas, que es una respuesta directa a la necesidad de los ciudadanos, y es de lo que se debe ocupar un buen gobierno, si ha habido en los recientes procesos de reforma constitucional un enfrentamiento entre el Ejecutivo presidencial y la Asamblea, nunca se han puesto de acuerdo a la hora de reformar la Constitución.

E.C.: No, hay un, precisamente, porque el Ejecutivo no quiere perder poderes, esta es la primera vez que un Ejecutivo dice: "no me importa perder poder", trasladémoselo a la Asamblea y trasladémoselo al pueblo, entonces, yo creo que hay que aprovechar eso, lo que pasa es que hay grupos de la derecha, que está muy arraigado en ellos la democracia representativa, y tienen miedo a que el pueblo decida. Si coges el argumento de algunos políticos: "quieren poner al pueblo por encima de los alcaldes", pero si el pueblo está por encima de los alcaldes, lo que pasa es que para ellos formalmente el alcalde es la 
autoridad, es el tótem, es el "huistatara" del lugar, y no es el pueblo, entonces, aquí lo que estamos es dándole vuelta a la realidad, y esa es la verdadera democracia, lo otro no es democracia, yo, como dice Diego Valadés, son reyezuelos entre elección y elección.

$R$ : $Y$, sin embargo, sí se ha producido, además, la propia Constitución del 87, yo que he sido un poco estudiosa desde fuera del proceso nicaragüense, insiste mucho en que la seña de identidad de la Constitución original fue la participación popular, ¿no? Es un poco el discurso que recuperan ahora...

E.C.: Sí, sí, es cierto, pero acordáte que esa Constitución hecha con la participación de la gente es una Constitución en medio de una guerra, en medio de una guerra de agresión, y donde el pueblo estaba participando, es decir, había, militarmente o formalmente, un Ejército donde había más de 150.000 hombres, y había más de 300.000 ciudadanos no militares armados, entonces, eso respondía a esa reacción, y el Estado era un Ejecutivo fuerte, rápido, dinámico, de guerra, pues, y eso fue parte del poder, verdad, sin embargo, sí fue una Constitución, yo diría la más o la única totalmente consultada. Ahora lo que queremos es ir avanzando, es decir, esa Constitución fue la que hizo la primera elección pluripartidaria, antes era de dos partidos nada más.

$R$ : Se refiere a las elecciones del 84 .

E.C.: Del 84.

$R$ : Las constituyentes.

E.C.: Sí, fueron las primeras pluripartidarias, y, desde ahí, la Constitución ya dejó establecido el pluripartidismo, y en las del 90 fueron pluripartidistas, en las del 96 fue una sábana de este tamaño, eran 21 partidos políticos los que participaron.

R: La Ley Electoral ha ido restringiendo o endureciendo, mejor dicho, los criterios para la formación de nuevos partidos.

E.C.: No, para la formación de nuevos partidos no, para la existencia, es decir, en base a si tenés votos o no tenés votos, un poco apelando a la idea europea, pues.

R: ¿Pero cree que ese fortalecimiento del bipartidismo mejora la gobernabilidad democrática?

E.C.: No, yo no creo en el bipartidismo, pero creo que el partido debe de tener adeptos, no puede ser un club social, aquí, ahorita, en Nicaragua tenemos 17 partidos, y hay partidos que si no van aliados no alcanzan esta sala, esta sala es muy grande para ellos, entonces, partidos políticos pero que tengan adeptos, es decir, nosotros pusimos un techo del $4 \%$, hay países en Europa que tienen un $6 \%$.

R: Sin embargo, el arco parlamentario de las reformas del 95 fue mucho más amplio, desde el punto de vista de la representación de formaciones políticas, que la del 2000.

E.C.: En teoría, en teoría, porque si ves el resultado de los votos, la campaña fue Frente anti-Frente, el 90\% fue eso, Frente anti-Frente, el Frente Sandinista y un bloque que se formó en la UNO, y después se formó a través del Partido Liberal, donde alcanzaron 
partidos centroamericanistas, partidos socialistas, partidos comunistas, junto con el Partido Liberal.

R: La cesión del poder del actual presidente Ortega a la presidenta Violeta Chamorro cuando ganó las elecciones fue una lección de democracia por parte del Frente, cuando aceptó perder el poder, cuando los ciudadanos nicaragüenses decidieron que gobernase un partido de derechas, ¿no?, ¿cuál ha sido el aprendizaje democrático del Frente durante 16 años de oposición?

E.C.: Que la derecha no sabe perder, nosotros tuvimos en el 96 una serie de irregularidades, de fraudes, les costó aceptar la victoria, y ahora la victoria municipal, es toda una alharaca, y, la verdad, es que de diez Magistrados del Consejo Supremo Electoral nueve firmaron y dijeron que sí, que hubo irregularidades, estamos en un proceso nuevo, reciente, pero que ninguna irregularidad conllevaba derogar las elecciones. Yo creo que en las elecciones recién pasadas de noviembre del año pasado hubo menos irregularidades que en la de Bush y Al Gore.

R: Y, sin embargo, el Consejo Supremo Electoral, que es una institución que garantiza la transparencia en los comicios, y que albergaba la esperanza de muchos ciudadanos ha caído, incluso, en términos de opinión pública.

E.C.: Por, por una insidiosa campaña, porque aquí no puede ganar la izquierda, tiene que ganar la derecha, pero como la izquierda gana, y barre precisamente por estos proyectos, verdad, por programas de campesinos para que llegue alimentación, es decir, en lugares donde nosotros no ganábamos ganamos, y eso fue el avance, entonces, eso es lo que le duele, y la campaña mediática que hay, la misma que hay en Venezuela, la misma que hay en Bolivia, la misma que hay en Ecuador, es decir, hablan del problema de la reelección en Nicaragua, pero luego todo el mundo aplaude ahorita a Uribe que va para su tercera reelección, ¿y entonces?, es decir, hay dos mediciones mundiales, es decir, la medición de la derecha, esa es aplaudida, y la de los gobiernos progresistas de América Latina somos unos salvajes, somos anti-democráticos, yo creo que lo que estamos dando es una muestra de democracia al mundo.

R: ¿Y la última pregunta en qué medida cree que las reformas constitucionales contribuyen a la estabilidad democrática? ¿Más reformas, en este sentido, o no?, porque cambiar las reglas del juego constantemente puede debilitarla.

E.C.: No, yo creo que no es cambiar las reglas del juego constantemente per se, lo que ha cambiado es la sociedad, Nicaragua es una sociedad cambiante, acuérdate que tuvimos 10 años de guerra financiada por los Estados Unidos, nos fuimos reacomodando, definitivamente, y seguimos en ese reacomodo político, si vos lees el periódico, ¿cuál es el discurso del doctor Alemán?, hay que unirse todos contra el Frente, sin ninguna propuesta, esta es una guerra anti, anti, anti, anti, y eso no contribuye, eso no contribuye, yo creo que van a ir prevaleciendo las propuestas en el debate. 


\section{ENTREVISTA $14^{21}$ :}

Nombre del entrevistado: D. Alfredo César.

Cargo actual: presidente de la Asamblea Nacional durante el gobierno de Violeta Chamorro (1991-1992), como miembro de la coalición gubernamental Unión Nacional Opositora (UNO).

Fecha de realización de la entrevista: Managua, 19 de noviembre de 2009.

Lugar: Oficina privada en la empresa URBISA.

Duración estimada: 1 hora y 16 minutos.

\section{TEXTO - Transcripción 14:}

$R$ : ¿Cuál es su visión, el recorrido que hace en perspectiva, digamos, sobre el conjunto de cambios constitucionales que se han producido en el país desde los años 90 hasta la fecha, pensando siempre en la consolidación de las instituciones democráticas, con sus avances y sus retrocesos?

A.C.: La actual Constitución fue promulgada por una Asamblea Nacional Constituyente en enero del año 87, es decir, fue el marco legal nuevo, que quedó en el país después del derrocamiento de la dictadura de Somoza y el advenimiento de la revolución sandinista. Este marco constitucional, en su momento, obviamente, tenía varias características, no muy diferentes de las anteriores en la historia de Nicaragua, de forma interesante, uno podría pensar de que una revolución socialista, autollamada sandinista por Augusto Sandino, pudiera tener una serie de disposiciones muy diferentes con respecto a la historia, entonces, sin embargo, las características no son tremendamente diferentes de otras constituciones en la historia de Nicaragua, lo cual, en mi opinión era un signo temprano de que el concepto del poder de Daniel Ortega, que era el presidente, en ese momento, cuando se promulgó la Constitución, y es el presidente ahora, no era muy diferente de lo que había ocurrido, anteriormente, en la historia, porque eso hubiera sido reflejado en la Constitución, es cierto que vulneraba algunos, digamos, ámbitos por primera vez, vulneraba porque dejaba puertas abiertas, por ejemplo, con respecto a la propiedad privada, se respetaba la propiedad privada, pero dejaba unas puertas abiertas para que el gobierno pudiera expropiar con mucha facilidad o, incluso, confiscar sin ninguna compensación, eso reflejaba, en mi opinión, el signo ideológico del que estaba en el poder en ese momento, que es la revolución sandinista, que ven a la propiedad privada como un tema de descomposición del ser humano, ese es su concepto de ellos, un concepto un poco obsoleto, marxista, pero así es como ellos lo ven, también dejaba, y esto era muy repetitivo en varias constituciones nuestras en nuestra historia, una concentración de poder fortísimo en el Poder Ejecutivo, es decir, en la práctica, en la realidad, eran tantas las atribuciones del presidente de la República, que el Poder Legislativo quedaba disminuido profundamente, y el Poder Judicial quedaba muy sometido, de manera tal de que para dar algunas ideas el presidente de la República ponía y quitaba impuestos por decreto ejecutivo, es la razón de ser fundamental del parlamento, así es como nació en Inglaterra en el siglo XI, XII, el parlamento, la idea

21 Entrevista muy interesante, especialmente, por la descripción y análisis de los factores políticos, que median en los recientes procesos de cambio constitucional experimentados en Nicaragua desde los años 90, haciendo una lectura en clave histórica de la cultura nacional y las propias dificultades asociadas a la construcción de un Estado de Derecho en el país centroamericano. 
inicial con la Carta Magna es, fundamentalmente, de que limitarle al Rey inglés, la capacidad de dictar impuestos sobre sus súbditos sin consulta con los súbditos, y la revuelta, y todo lo que ocasiona eso, lleva a que la Carta Magna de paso a la creación a un embrión de lo que fue el parlamento, posteriormente, en todo el mundo, en donde si la razón principal por la que nació el parlamento es, casualmente, para evitar de que le cargaran los impuestos al pueblo sin que el pueblo tuviera nada que decir, pues, obviamente, hacerlo en el siglo, en el propio finales del siglo XX, una Constitución que el presidente de la República, el jefe del Estado, pudiera con su propia voluntad por un decreto ejecutivo, ni siquiera refrendado en Consejo de Ministros, simplemente, con la firma del presidente pudiera disminuir, poner y quitar impuestos, la cosa era una barbaridad pocas veces vista, sin embargo, así era la Constitución, y, por lo tanto, la concentración de poder, como digo, en el presidente de la República, que, tradicionalmente, en un sistema presidencialista como el que impera en Nicaragua era jefe de Estado y jefe de gobierno a la vez, y Comandante en jefe de las Fuerzas Armadas, o Comandante Supremo de las Fuerzas Armadas, ya con esos tres cargos es bastante poder, ¿no?, y si además le añadimos una de las facultades esenciales del parlamento por decreto ejecutivo sin ni siquiera necesidad de refrendar en Consejo de Ministros, pues, obviamente, nos da una idea de la concentración inmensa de Poder Ejecutivo, que traía esa Constitución, pero hago ver, sin embargo, que aunque esta facultad específica de legislar impuestos por decreto ejecutivo no había ocurrido, anteriormente, en nuestra Constitución, otros vicios de constituciones previas en Nicaragua se volvieron a repetir, por ejemplo, esa Constitución permitía la reelección indefinida, que había sido uno de los grandes motivos de lucha en contra de la dictadura de Somoza, evitar la reelección porque esa dictadura fue dinástica, con dos de sus hijos, $\mathrm{y}$, casualmente, se trataba de por años, por mucho tiempo, se derramó mucha sangre, hubo mucha violencia tratando de evitar la reelección del presidente y la sucesión de parientes del presidente, por la experiencia vivida, y, sin embargo, la Constitución del 87 producto de la revolución sandinista, que tumbó a la dictadura somocista, vuelve a incorporar esos vicios otra vez, no da ninguna limitante para reelegir al presidente ni tampoco ninguna limitante para reelegir a la esposa, a los hijos, o cualquier pariente cercano, repitiendo en la historia los vicios del régimen que fue derrocado por esta revolución, entonces, eso me da a pensar a mí, de que la concepción del poder desde entonces, era más una concepción a la nicaragüense que a la revolución nueva, que venía a asentar toda una serie de nuevos principios y de nuevas libertades $\mathrm{y}$ posibilidades para el pueblo de Nicaragua, ahí está reflejada, entre otras cosas, está con las principales, ¿qué ocurrió entonces?, que a medida que la década revolucionaria fue enfrentando muchas dificultades y problemas, y gran reacción opositora de amplios sectores de la población, entonces, las fuerzas opositoras agrupadas desde un amplísimo espectro ideológico, un espectro desde el partido comunista clásico hasta el partido conservador, pasando por todos, digamos, las sensibilidades y matices del centroderecha y el centro-izquierda, lograron coincidir todas estas fuerzas en 17 reformas que había que efectuarle a esta Constitución de 1987, que pudieran reivindicar, casualmente, las luchas que se habían llevado adelante en contra de la dictadura de Somoza, es decir, que es, verdaderamente, irónico que el régimen revolucionario, que tumbó a la dictadura de Somoza, produce una Constitución con los mismos vicios, en gran medida, de la dictadura somocista y le toca a la oposición al régimen revolucionario sandinista el reivindicar en unas 17 reformas consensuadas las luchas de décadas que se habían llevado a cabo con muchísimo costo de vidas humanas contra la dictadura de Somoza, eso es algo, verdaderamente, irónico, pero es parte de la historia, entonces, ¿qué ocurre?, que estas reformas constitucionales se convierten en la plataforma electoral 
fundamental, que la oposición unida ya, electoralmente, en lo que se llamó Unión Nacional Opositora (UNO), estos 14 partidos, desde el partido comunista hasta el partido conservador, toman como referente esencial de la plataforma de gobierno, es decir, de la plataforma electoral, esta reforma constitucional, obviamente, había otros aspectos políticos, económicos y sociales en el programa de gobierno, como es natural, pero el eje central era éste, porque esto se suponía que una vez puesto en vigor garantizaría un marco jurídico democrático de libertad y de progreso, y así es como después de triunfar en las elecciones del año 90, digamos, la delegación parlamentaria de la UNO es mayoría simple, pero no la mayoría del 60\% que se necesita en Nicaragua para reformar la Constitución, estábamos cortos en un parlamento de noventa diputados, había cincuenta y dos diputados de la UNO, que nos faltaba, pues, todavía tres diputados para lograr la mayoría necesaria para la reforma, por lo tanto, durante los primeros años, el año 90, 91, 92, 93, no fue posible, hacer esas reformas era algo pendiente todavía, y luego ocurrió algo que facilitó las mismas, y es que comenzó el movimiento disidente dentro del sandinismo, lo que ahora se dio en llamar el MRS, uno de los actuales partidos políticos despojado de su personería arbitrariamente, pero que reúne la disidencia dentro del sandinismo, eso comenzó a gestarse en el año 93, 94, producto de conflictos ya internos como oposición, el sandinismo había pasado a oposición, y ya los mecanismos de poder no los tenía a mano, y, entonces, las discusiones internas y el rumbo que debía tomar el partido político, pues, obviamente, comenzaron a generar esta disidencia, y esta disidencia, encabezada por el exvicepresidente, Sergio Ramírez Mercado, tomó contacto con nosotros, específicamente, Sergio Ramírez Mercado me envió un delegado de confianza para ofrecerme que ellos estaban rompiendo con Ortega y el grupo fundamental, y que compartían la mayoría de las diecisiete reformas constitucionales como algo que pudiera cimentar la democracia en Nicaragua, tengo que ser franco que al inicio yo no lo creí, yo no le creí, y al enviado, que era alguien también de mi estima, se lo dije: "no creo esto, así que no sé para qué me mandan a decir esto, pues, no le doy crédito", pero Sergio Ramírez insistió tres veces conmigo, en un período de varias semanas, ¿no?, y la tercera vez, pues, el enviado que tenía credibilidad conmigo, pues, me convenció de que nada perdía por asistir a una reunión Sergio Ramírez conmigo privada, en la cual pudiéramos conversar, cosa que hice, nos reunimos solamente Sergio Ramírez y yo, con la presencia del enviado, y él me explicó todo lo que estaba ocurriendo dentro del sandinismo, el cambio, digamos, de mentalidad que él y el grupo que lo acompañaba tenía, y que como muestra palpable de ese cambio de mentalidad era que ellos querían que se llevara a cabo las reformas constitucionales, porque pensaban que eso iba a preservar, casualmente, la democracia que el país necesitaba y que era parte de la agenda de ellos. Yo creo que, en general, las reformas estaban de acuerdo, no necesariamente en forma puntual cada una de ellas, pero que, en general, por ejemplo, en lo de la reelección estábamos de acuerdo a la hora de modificar, impedir la sucesión de los parientes del presidente, estábamos de acuerdo, y varios temas centrales, y quitarle la facultad de los impuestos al presidente, estábamos de acuerdo, de manera que temas fundamentales, entonces, bueno, yo llevé al grupo parlamentario de la UNO lo que había conversado con Sergio Ramírez, y muy rápidamente se crearon dos comisiones de trabajo, y eso desembocó en las reformas constitucionales, finalmente, vigentes el año siguiente, el año 95, pero se logró, pues, porque la disidencia sandinista acompañó a la UNO en hacer la mayoría de las reformas, luego, logramos hacer, yo diría, el $90 \%$ de las reformas que nos habíamos propuesto en la UNO, y que reivindicaba todas esas décadas de oposición a Somoza, por lo tanto, es un fenómeno político, en mi opinión, muy relevante y de gran calibre. Al incorporar la disidencia sandinista a este esfuerzo de 14 
partidos políticos, desde el partido comunista hasta el partido conservador, entonces, refleja que esa reforma tenía un consenso inmensamente amplio en la población, no sólo en la Asamblea Legislativa, sino en la población, porque, obviamente, estábamos cubriendo el espectro mayoritario, que lo había demostrado la UNO con el 54\% del voto, y un pedazo importante imposible de cuantificar, en ese momento, pero sumamente importante del $40 \%$ que había sacado el Frente Sandinista, por lo tanto, yo pienso que eso reflejaba, sin duda, al menos la opinión del $80 \%$ del electorado de ese momento, del año 95, y fue así como se llevaron a cabo esas reformas. Otra característica que tuvo importante, creo que se lo mencioné cuando nos vimos, es que las reformas constitucionales en Nicaragua han tenido el sello, y me imagino que también en otros países, pero, tal vez, aquí ha sido más marcado, que las efectúa el gobernante de turno con su representación parlamentaria para algo que le interesa, de interés político del partido del gobierno, así han sido la inmensa mayoría de las reformas constitucionales a lo largo de la historia de Nicaragua, por un interés político del gobernante y del partido de gobierno, en este caso, esta reforma no obedecían a un interés político de la presidenta Violeta de Chamorro, ni a su entorno inmediato, de hecho, le limitaba a ella reelegirse y le limitaba a sus parientes, que pudieran elegirse inmediatamente después de ella, por lo tanto, dañaba, eso lo puedes ver ahí, sus facultades, al igual que le daba facultades tan importantes como los impuestos por decreto ejecutivo, entonces, esta reforma tiene esa característica muy diferente a todas las anteriores y posteriores, que reflejaron un amplio consenso de las fuerzas políticas, amplísimo, y además reflejaron el interés nacional, interpretado, en ese momento, por estos legisladores, y no el interés político del gobernante de turno, un interés nacional, $\mathrm{y}$, por lo tanto, son extremadamente valiosas, en mi opinión, en la historia de Nicaragua, y lograron mantener, digamos, o recuperar, pongámosle así mejor, no mantener, recuperar un verdadero equilibrio democrático en el país a través de estas reformas, bien, una vez logrado eso, vino el gobierno de Arnoldo Alemán y el gravísimo y desafortunado pacto que hizo con Daniel Ortega, en el momento en que Ortega estaba muy débil, en una oposición sumamente débil, porque ya se le había desprendido este grupo importante de disidencia sandinista, $\mathrm{y}$, de hecho, es la votación más baja que ha sacado Ortega en todos sus intentos, sacó 36\% del voto, de manera tal de que, en ese momento, sin embargo, Alemán y su gente pactan con un interés político del partido liberal en el poder, ¿cuál era el interés político?, en lugar de tener un marco democrático pluralista como había dejado la reforma del 95, ellos consideran que hay que forzar, forzar, a través de la reforma constitucional y leyes subordinadas un bipartidismo obligado en el país, ellos al estar en el poder, y sentirse el partido más grande dentro del segmento no sandinista, entonces, dijeron: "los sandinistas no llegan ni al 40\%, quiere decir que el segmento no sandinista es mayor del 60\%, nosotros estamos en el poder ahorita somos el más grande, si forzamos el bipartidismo vamos a estar en el poder por mucho tiempo", y una vez más en nuestra historia se vuelve a repetir el error que tanto daño le ha hecho al país, de hacer una reforma constitucional satisfaciendo el interés político del gobernante de turno y su conglomerado político, y así se lleva a cabo la reforma constitucional del año 2000, en la cual, en el 99-2000, entran en vigencia en el año 2000, se establece el bipartidismo por disposición jurídica, prácticamente, lo disfrazan porque no lo eliminan de la Constitución, pero las reglas electorales que se imponen son tan estrictas, que, básicamente, tiende a desaparecer el pluralismo político y a dejar el bipartidismo establecido, y tan es así que por casi 10 años, estamos llegando en enero próximo se cumplirán 10 años de esa reforma constitucional durante 10 años, y lo que ha gobernado a Nicaragua ha sido el bipartidismo, el pacto, como le dicen los nicaragüenses, Alemán-Ortega, ninguna otra fuerza política en estos 10 años ha podido 
más allá de expresar su inconformidad, de tener algún grupo pequeño de diputados, pero ninguna posibilidad real de ejercer o de influenciar el poder en esta última década, de manera tal que sí fue bien concebida esa reforma constitucional, exclusivamente, con interés político de mantener el poder por parte de los liberales, sin embargo, como la historia también lo ha demostrado, en la práctica, fue más valiosa para Ortega y el partido sandinista, que para los liberales, porque, quiere decir, tuvieron mucha mayor habilidad en la negociación y tuvieron más visión y luego más capacidad operativa política, el hecho es que al final de los 10 años del pacto, el pacto está haciendo aguas, está haciendo aguas, no por voluntad de los liberales, sino porque ha traído al pueblo de Nicaragua y al país tantos nuevos problemas, incluyendo que ha permitido el regreso al poder de Daniel Ortega, que jamás hubiera llegado al poder si no hubiera sido por una de las reformas constitucionales del 2000, que disminuyó hasta el 35\% el porcentaje mínimo para salir electo en primera vuelta electoral, cosa que se había dejado en el $45 \%$ en la reforma del 95, y Ortega viendo que había sacado 40\%, 38\%, 36\%, y nunca había sacado menos de $35 \%$, exitosamente, puso el $35 \%$, y la prueba está que con el $38 \%$ ahí está de presidente, con las consecuencias para el pueblo de Nicaragua. Entonces, el pacto, realmente, que fue diseñado por los liberales para mantenerlos a ellos en el poder, muy rápidamente se revirtió, permitió el regreso al poder a Ortega y los sandinistas, y lo que eso ha traído ha llevado a que el pueblo y amplios sectores de la sociedad se han revelado, y se están revelando con mucha fuerza contra el pacto. También Ortega una vez en el poder y que ha consolidado, después de dos años y medio de estar en poder lo ha consolidado, y le interesa cada vez menos la relación con Alemán, es decir, siempre todo gobernante necesita alguien en la oposición que pueda jugar de comparsa, ¿no?, ojala fuera para motivos legítimos, como es lo que la democracia exige, que haya un acuerdo de gobierno y oposición en aspectos que son de interés nacional, y que, efectivamente, pueda avanzarse, sólo un pequeño paréntesis, acabo de leer que el Partido Socialista en el poder en España y el Partido Popular, el principal de la oposición, han llegado a un pacto y van a trabajar dos más, y llegaron a un pacto de cómo enfrentar el período que le toca a España presidir la Unión Europea a partir de enero de 2010 y ya llegaron a un acuerdo, es decir, es de interés general de España que no se desperdicie la presidencia de la Unión Europea durante ese período, y, por lo tanto, es de interés nacional que el gobierno se entienda con el principal opositor, y hablan de hacer algo igual para la educación y para la energía renovable, es decir, es un ejemplo típico, ¿no?, de que en una democracia está bien que el gobierno se entienda con la oposición, pero para temas de interés nacional, para avanzar el país, no para avanzar su agenda partidista en detrimento de las demás fuerzas políticas existentes, que es lo que significan las reformas del 2000, bipartidismo, y dentro del bipartidismo la concesión de bajar al 35\% el requisito electoral para salir electo en primera vuelta, que le ha permitido a Ortega estar de regreso en el poder, le salió el efecto contrario, después de la reforma del 2000, lo único que ha habido son dos reformas adicionales pequeñas, puntuales, que han profundizado el mismo pacto, es decir, que como suele ocurrir, pues, se corta el traje, ¿no?, y a la hora de ponérselo, pues, hay que ajustar un poco aquí, hay que ajustar un poco allá, de manera que esas son las otras dos reformas puntuales que ha habido, son, exclusivamente, ajustes al pacto, que fue concebido y fue puesto en práctica en las reformas del año 2000, por ejemplo, las reformas del año 2005, bueno, trasladaron algunas facultades adicionales al Congreso, al parlamento, a la Asamblea Nacional, porque, en ese momento, les convenía a los dos pactistas debilitar la presidencia de Don Enrique Bolaños, que aunque fue electo por el partido liberal enderezó contra Alemán y su corrupción en forma determinante, y, lógicamente, los diputados fieles a Alemán, y Ortega que estaba todavía en la oposición, pues, querían 
debilitar la presidencia del señor Bolaños, e hicieron esos ajustes, tan está demostrado que no fueron más que ajustes del pacto, que el actual gobierno de Ortega no las ha cumplido, no, no ha pasado a ratificación ningún ministro, no ha pasado a ratificación ningún embajador al día de hoy, $\mathrm{y}$, entonces, los mismos liberales que las aprobaron están ahora promoviendo leyes que anulen esos nombramientos, tratando de desandar el entuerto que hicieron, pero no representan, en mi opinión, verdaderamente, ningún valor objetivo más que pequeños ajustes al concepto, el concepto grande fue el concepto de la reforma del 2000, que lo generaron los liberales, Alemán y su gente para permanecer en el poder mucho tiempo, como, exclusivamente, intereses partidistas y Ortega las aceptó porque le bajaron a él el umbral electoral al 35\%, si no jamás las hubiera aceptado, ese era su interés, y lo logró muy hábilmente y está de regreso en el poder, ¿verdad?, y ahora habrá que ver cuál es el nuevo capítulo que vamos a enfrentar en Nicaragua, si se va a poder salvar un mecanismo electoral democrático, o vamos a regresar otra vez a situaciones de violencia ya superadas, pero ese es otro capítulo, hasta ahí son mis apreciaciones, digamos, tanto de la Constitución del 87, la reforma del 95, la reforma del 2000 y posteriores.

R: Es cierto, y además, como bien ha referido en su reflexión, que la reforma del 95 es la que goza de mayor legitimidad, y la mayor parte de los entrevistados coinciden en que, bueno, siguiendo la frase de un jurista español, que dice que la reforma es políticamente conveniente cuando es jurídicamente necesaria, ¿no?, y en ese momento de la transición política, incluso, el gran debate entre reforma total o reforma parcial a la Constitución se abrió porque era obvio que la transición democrática exigía un nuevo marco jurídico constitucional. Pero ha habido un enfrentamiento también repetido entre Ejecutivo presidencial y Legislativo, en el primer caso, y usted además que presidió la Asamblea Nacional pudo vivir todo ese clima de la Asamblea, liderando un proyecto de reforma parcial que no era aceptado por el Ejecutivo y al final se da lugar a estas Leyes Marco, que son instrumentos jurídicos muy controvertidos, y que se repiten en la historia constitucional del pais, y que supone aplazar temporalmente la entrada en vigor de las normas constitucionales para dar mayor oxígeno a la negociación política, de que se reacomoden los actores políticos en función, como usted bien ha dicho, de intereses muy concretos. ¿Cuál es su opinión al respecto?

A.C.: Las leyes Marco estas han sido, realmente, una sustitución de lo que podríamos llamar un artículo transitorio de una reforma constitucional, es normal que cada vez que se legisla o se reforma una ley, o se aprueba una nueva, y lo mismo en las constituciones, es natural que algunas disposiciones tengan un período para entrar en vigencia, de manera tal de que la sociedad se ajuste y que las instituciones del Estado que van a aplicarla puedan hacer los preparativos para que, efectivamente, una vez que entre en vigencia se aplique y se haga efectiva la ley, de manera que como concepto político no es una aberración ni mucho menos, es decir, es natural que eso se haga, como concepto jurídico se tuvo que recurrir a eso acá, siendo una aberración, evidentemente, una aberración jurídica, para sustituirla porque el texto acordado no llevaba, el texto acordado de la reforma no incluyó ese transitorio, que debió de haber incluido en mi opinión para facilitar, casualmente, que no hubiera ese rechazo tan frontal de parte de la presidenta, el argumento, en mi opinión válido, que usó el equipo de la presidenta Chamorro es que ella había sido electa con un marco constitucional, y con unos poderes, y que no era correcto que a medio camino de su período se le cercenaran esos poderes, entonces, yo creo, francamente, que me parece que es un argumento muy válido, muy válido, y yo lo apoyé, lo ví bien, efectivamente, decir: "sí, 
tenés razón, que termine la presidenta Chamorro su período de gobierno con los poderes que tenía, y que inmediatamente después entre en vigencia para el próximo que venga a ejercer", claro, como no se aprobó ese texto, digo, en la reforma constitucional, se tuvo que utilizar la Ley Marco, como un instrumento ad hoc aberrante jurídicamente, pero que tuvo el mismo efecto, de manera que yo no considero que causó ningún daño, en absoluto, repito, es muy natural que cuando se haga ese tipo de reforma o cambios se diga, bueno, inicia a partir de tal momento, ¿no?, aquí se trataba de reivindicar que el contexto que ella había dicho que había sido electa con unos poderes y se lo querían cercenar en el camino, bien, pero nosotros sabíamos que ese argumento escondía, escondía un propósito oculto, que no se podía decir abiertamente y es que el Ministro de la Presidencia del momento, que era yerno de la señora Chamorro, tenía aspiraciones presidenciales, y la reforma entra en vigencia en el año 95, un año y medio antes de las elecciones generales, por lo tanto si éstas entraban en vigor quedaba inhibido de ser candidato, esa que había sido una de las grandes luchas a través de la historia de Nicaragua, impedir eso, y después de la dictadura de Somoza, con muchas más personas, impedirlo, porque él tuvo la sucesión de dos hijos seguidos, que permitió extender la dictadura tanto tiempo, era un reclamo no dirigido a él, era un reclamo que, incluso, había sido acordado mucho antes de que existiera la candidatura de Doña Violeta, por lo tanto, mucho antes de que existiera el nombre de él en la política, o sea, que era absurdo decir que éstas fueron acordadas con nombre y apellidos, ese es un argumento absurdo, ahí están los documentos históricos que indican que las 17 reformas constitucionales fueron acordadas en el año 1988, prácticamente, un año antes de que se seleccionara la candidatura de Doña Violeta de Chamorro, entonces, ni que fueran personas que pudieran leer el futuro, ¿no?, de que un año después iba a ser ella la candidata, de que ella iba a nombrar de hombre fuerte de su gobierno a su yerno, nadie sabía eso, las reformas contenían el impedimento de sucesión familiar, porque era una reivindicación de décadas de lucha en Nicaragua contra los Somoza, y, entonces, por eso estaba ahí, sin embargo, una vez aprobadas en el año 95, pues, obviamente, se oponían a un caso particular de aspiración presidencial, y como ese argumento no era bien recibido en toda Nicaragua, porque, casualmente, era una reivindicación de luchas de mucho tiempo, pues, no se utilizó, abiertamente, ese argumento, pero nosotros en la UNO sabíamos que el motor fundamental para oponerse a las reformas era ese, aunque el argumento que se utilizó fue el argumento, en mi opinión válido, de no disminuirle los poderes a la presidenta Chamorro a la mitad de su período, solución, pues, es simple, ¿no?, se pusieron en vigencia las reformas a partir de que ella concluyera, pues, su período, pero se dejó bien claro de que las disposiciones electorales contenidas en ellas fungían a partir ya del próximo período electoral, por lo tanto, cuando intentó inscribir candidatura presidencial el Ministro de la Presidencia, el yerno de Doña Violeta, fue rechazada por el Consejo Supremo Electoral, en base a la nueva Constitución, eso es lo que significa, entonces, es que la Ley Marco yo creo que jugó un papel correcto, puede ser criticada desde el punto de vista jurídico, no hay duda, es aberrante jurídicamente, pero políticamente jugó un papel importante para sustituir o reemplazar lo que debió haber sido un artículo transitorio en la reforma constitucional.

$R: Y$, sin embargo, sí marcó un precedente que volvió a utilizarse en el 2005, cuando se vive otra crisis institucional muy fuerte, bajo el gobierno de Enrique Bolaños, y luego esta sentencia, que ya supone también otra irregularidad del procedimiento de reforma constitucional al abrogarse, ilegitimamente, el Poder Judicial la facultad de poder reformar la Constitución, aunque, bueno, según ellos no se ha reformado la Constitución, sino que se ha interpretado un artículo a propósito de una cuestión 
específica, que es el tema de la reelección presidencial, el artículo 147, ¿no?, pero sí, respetar las formas, ha sido una cuestión muy importante desde el punto de vista negativo, me refiero, por excepción, que se ha dado.

A.C.: Estoy de acuerdo con eso, por eso digo que es criticable jurídicamente, ¿no?, no la defiendo jurídicamente, yo no soy jurista, y tiendo, pues, a ver las cosas más políticamente, ¿no?, cuando hay un consenso político total, pues, como fue el caso de la Ley Marco en el año 95, y como al final fue también la Ley Marco en el año 2005, hubo un consenso total, yo estaba ahí presente en la Asamblea Nacional invitado como expresidente en esa sesión, y recuerdo perfectamente bien que hubo un voto en contra de 90 diputados, la Ley Marco del 2005 tuvo también un consenso político inmenso, es muy diferente tener un instrumento jurídico irregular, llamémosle así, que cuenta con un consenso político casi total, como fueron las dos leyes Marco del 95 y del 2005, y ahí están las votaciones que se pueden constatar en la Asamblea, a tener un instrumento jurídico irregular, como el que acaba de producirse con esa sentencia de la Sala Constitucional de la Corte Suprema de Justicia rechazado por la inmensa mayoría de los nicaragüenses, es completamente diferente el efecto que tiene en una sociedad, es radicalmente diferente, por lo tanto, en mi opinión no es válido el precedente, porque todos sabemos de que el marco jurídico es indispensable para la convivencia civilizada de los pueblos, y entre los pueblos, pero todos sabemos también que, en última instancia, es la voluntad del pueblo, manifestada en sus actos, lo que ha cambiado la historia en el mundo, si no hubieran habido destituciones, revoluciones, fusilamientos, guillotina, guerras civiles, como la de España o la que tuvimos aquí también, en fin, si no fuera eso, que al final lo que se impone es la voluntad popular a través de sus actos, entonces, estaríamos desconociendo la realidad de la historia, en otras palabras, yo sin ser jurista, y tal vez me permito esa libertad, no es que le quite el peso, yo aprecio en toda su dimensión la necesidad del orden jurídico, pero lo que hago ver es que cuando el orden jurídico se quebranta en su forma, o en su manera en que debe de hacerse, es muy diferente el efecto que ese quebrantamiento produce en una sociedad, dependiendo de la voluntad del pueblo, si ese quebrantamiento es aceptado por la inmensa mayoría de la sociedad, no produce ningún acto negativo, no debió eso de haberse hecho desde el punto de vista estricto jurídico, pero no produce un acto negativo, como fueron las dos leyes Marco del 95 y del 2005, por lo contrario, si este quebranto jurídico es rechazado por la mayoría del pueblo, va a ocasionar un daño muy serio a la sociedad, y es lo que nos enfrenta, actualmente, a esta sentencia de la Sala Constitucional de la Corte Suprema de Justicia, cosa muy diferente.

R: Incluso, el propio Frente reforma la Ley Marco del 2005, dando también un año más de entrada en vigor, porque no acepta las normas constitucionales, como bien señalaba también, y, bueno, de hecho, ni siquiera las ha aplicado en su actual gobierno, ¿no?

A.C.: Pero, de nuevo, de nuevo, la ley en su origen fue unánime de las fuerzas políticas, no unánime, fue un voto en contra, pero fue amplísima, ¿no?, de las fuerzas políticas existentes en Nicaragua, es decir, esa Ley Marco no fue impuesta, no fue ni siquiera por una mayoría simple, el 90\% o más de los legisladores que la hicieron en el 2005, y eso es lo que le da la legitimidad, en mi opinión, mientras que ahora está esta situación de la sentencia constitucional tiene en contra la mayoría del pueblo, y a la mayoría de la Asamblea también, o sea, están en el proceso de ver si va a avanzar o no va a avanzar esa ley que la deja, supuestamente, sin efecto, pero ahí yo pongo la gran diferencia entre una y otra cosa, el nivel de aceptabilidad o no que tienen los pueblos, una ley que no es 
aceptada por los pueblos solamente en lugares muy disciplinados, y con un orden de la sociedad estricto, puede aplicarse, para que una ley se aplique en la mayoría de los países del mundo tiene que tener el respaldo mayoritario de la población, si no, no hay manera de aplicarlo, eso pasa en todos los países, incluso, en países, y yo pienso que Estados Unidos es uno de los países más extremadamente sometidos, digamos, al respeto de la ley, con instrumentos de aplicación de la ley muy fuertes, y aún ahí hay leyes que la inmensa mayoría las comienza a boicotear y no hay manera de ponerlas en vigor, $y$ tienen que reformarla, tienen que adaptar el instrumento jurídico inmediatamente para que la mayoría de la sociedad lo acepte, entonces, esa subordinación del instrumento jurídico a la voluntad popular está en todos lados, está en todos lados, yo pienso que aquí esa resolución de la Sala Constitucional no ha visto el fin de ese camino, y que aquí puede haber cualquier tipo de situaciones de aquí a las elecciones del 2011 todavía, hay un rechazo además creciente en amplios sectores de la sociedad, así que yo no apostaría a que esa resolución va a aplicarse.

$R$ : $Y$, por otro lado, desde el punto de vista de quiénes hacen las reformas, las reformas del 95 sí estuvieron respaldadas por un arco parlamentario, como usted mismo ha subrayado...

A.C.: Inmensamente amplio.

R: Mientras que las reformas del 2000 y el 2005 ya son acordadas por los dos principales partidos, ¿no?, y, en el momento actual, es el Ejecutivo presidencial el único que está interesado en la reforma, digamos, hay un hilo conductor en las reformas de reducir las facultades del Ejecutivo presidencial y aumentar las de la Asamblea Legislativa, y de esa desconcentración de poder y de tratar de conseguir un equilibrio de poderes en los principales órganos del Estado se ha pasado, digamos, a un giro hacia esa concentración de poder en manos del Frente Sandinista.

A.C.: Sí, que es lo que contenía la Constitución del 87.

\section{R: Hay un movimiento pendular en la evolución constitucional.}

A.C.: Es decir, es un movimiento, yo no le llamaría pendular, sino regresivo, desde el punto de vista de la democracia, la Constitución del 87, en mi comentario hacía ver, de que contenía una serie de vicios tradicionales en la historia de Nicaragua, como la reelección sin límites, la sucesión familiar, pero que contenía además una concentración de poder inmensa en el presidente de la República, y le daba el ejemplo de los impuestos, de poder crear y modificar impuestos, bueno, yo siento que ahora se ha iniciado, verdad, a partir de este año una regresión queriendo llevar de nuevo a la Constitución del 87, que tiene unos inmensos poderes para el presidente de la República, y, prácticamente, anula la representación legislativa, entonces, más que pendular yo le llamo regresivo, un movimiento regresivo hacia la Constitución del 87, que ya fue profundamente reformada en el 95 para democratizarla.

$R: Y$ es muy interesante, porque todos estos términos de "semi-parlamentarismo", de aplicar fórmulas institucionales que proceden de otras tradiciones políticas, como es el caso del parlamentarismo en Europa, ¿no?, y de tratar de atenuar un presidencialismo que, al final, está muy marcado por la cultura política del país, ¿no?, es decir, 

como forma de gobierno, ¿no?

A.C.: Y ahí la explicación es sencilla, ¿no?, es decir, nosotros éramos provincia de Europa, toda América Latina, ¿no?, de España, de Portugal, y los otros, pues, de Inglaterra, y de otras potencias de Europa, bien, de Francia, etc., entonces, esta colonia, pues, a fin de cuentas se comienzan a independizar con la independencia americana, con la independencia de los Estados Unidos, hablando de todo el continente americano, la primera independencia americana es la independencia de los Estados Unidos de Inglaterra en 1776, pero eso genera una dinámica que no termina hasta que termina de independizarse la última colonia española, que es unos 50 años después, pero ese movimiento es inevitable, entonces, ¿qué ocurre?, naturalmente, las colonias o excolonias que ven el experimento americano, que es el primero, y, entonces, ahí hay un presidente Washington y Jefferson y Madison y los que van, y están viendo ellos como se está organizando, entonces, es natural que como reacción política en lugar de duplicar los regímenes parlamentarios europeos, que venían de monarquías, unos habían dejado ya de ser monarquías y otros habían pasado a ser monarquías constitucionales después de las monarquías absolutas, pero en lugar de replicar eso, que es de donde te estás independizando, lógicamente, vas a replicar la primera colonia independizada, o las primeras colonias independizadas de Inglaterra, Estados Unidos, que tienen un nuevo sistema planteado ahí del presidencialismo, que es un nuevo arreglo de poderes y tal y tal y tal, eso, a su vez, respetando las enseñanzas de la revolución francesa, de la separación de poderes, de los tres poderes y todo eso, eso es muy novedoso si uno lo ve, se traslada dos siglos atrás, para las colonias españolas es muy novedoso ver cómo se está organizando el Estado nuevo de los Estados Unidos americanos, y, naturalmente, conlleva a que, entonces, se busque cómo implantar en nuestros países lo mismo, en esos momentos, hay que recordar que no existía ni lo que le llaman imperio americano y ninguna capacidad de influenciar, simplemente, ejemplo, es el ejemplo americano, pero de ahí nace, de ahí nace la tradición presidencialista de América Latina, nace de Estados Unidos, no por imposición del superpoder, sino por ejemplo, a seguir el ejemplo, y, por lo tanto, América Latina jamás ha tenido tradición parlamentaria, jamás, ni siquiera ha pretendido tener la misma tradición parlamentaria, incluso, durante las épocas de la colonia jamás existió un parlamento, era el Poder Ejecutivo delegado por el Rey, pero Poder Ejecutivo, por lo tanto, está en contra de toda nuestra evolución cultural política en América Latina tener un régimen parlamentario, un poco diferente es eso en algunas islas del Caribe, que aunque se le trata de poner en el mismo hemisferio occidental, pero estas islas, algunas islas del Caribe, que se independizaron de Inglaterra, pacíficamente, y mucho más tarde, ya en el siglo XX, realmente, o sea, ellos lo que hicieron fue replicar la tradición parlamentaria inglesa, porque todo su proceso político es muy diferente, por eso es que existen regímenes parlamentarios y primeros ministros en Jamaica, en Barbados, y en las otras islitas, ¿no?, pero fuera de esa experiencia, o de la experiencia haitiana, que es una experiencia mezclada con Francia también, el resto de América Latina tuvo toda su independencia un siglo y pico antes que estas islitas, de forma que se seguía el ejemplo americano, por lo tanto, inventar ahora un régimen parlamentario era tan descabellado, que ni siquiera Cuba, que rompió en su revolución con todos los parámetros americanos de Estados Unidos, por razones obvias, y trató de hacer ver que ese era un sistema absolutamente fracasado, y que venía un nuevo sistema y todo, no se atrevieron ni en Cuba a instalar un régimen parlamentario clásico como el que hay en Europa, ni siquiera en Cuba, hay un sistema presidencial con algunas particularidades soviéticas heredadas de la época, 
pero un sistema presidencial a fin de cuentas, de manera tal que eso indica lo descabellado que era estar planteando un sistema semi-parlamentario, o cuasiparlamentario que hicieron, aquí no era más que una cortina de humo para permitir un orden legal en el cual el actual presidente pudiera continuar en el poder.

R: A través de la división de la estructura del Poder Ejecutivo en la figura de un primer ministro y de un presidente de la República.

A.C.: Un presidente que podía establecer, con que tenga usted, lo iba manteniendo de un presidente fuerte, como es ahora, a un presidente tipo el presidente de Israel, que nadie se entera ni quién es, o el presidente de Italia, nadie sabe quién es, entonces, dependiendo de que si ganaba la presidencia o si lo elegían por mayoría de diputados como primer ministro, entonces, era un mecanismo flexible para mantenerse en el poder, de manera tal de que vemos en el pacto dos protagonistas políticos, lo inician los liberales con unas reformas al sistema jurídico para mantenerse en el poder, eso es el pacto, pero dan una concesión suficientemente importante al Frente Sandinista, que es lo que le permite regresar al poder, que es la concesión del 35\% electoral, el Frente Sandinista ya en el poder, entonces, trata de hacer algo similar, es decir, una reforma que le interese al liberal para ver algunas cosas ahí, pero que para ellos lo fundamental para el Frente Sandinista es permanecer en el poder, y por una serie de razones, entre ellas, que los liberales se dieron cuenta que los sandinistas le sacaron la mejor ventaja al pacto, han desconfiado de esa alternativa muchísimo, y la presión de la opinión pública, y los medios de expresión popular, que era opuesta totalmente a ese planteamiento semi-parlamentario, pues, hizo retroceder eso y lo clausuró, y ante esa clausura, pues, recurrieron a la maniobra de la Corte Suprema, ¿no?, en la Sala Constitucional, en fin.

R: Uno de los estudiosos del presidencialismo, el Profesor Juan Linz, no sé si conoce su obra en Ciencia Política.

A.C.: He leído un par de cosas de él.

R: Y dice que una de las características de los regímenes presidenciales es que la elección presidencial, que está legitimada por votación popular de la figura del presidente, el que gana lo gana todo, y el que pierde lo pierde todo, o sea, no existe esa capacidad que tienen los regímenes parlamentarios para poder pactar entre los partidos politicos en el ámbito de la Asamblea, y las coaliciones de gobierno, que también suponen ciertas concesiones políticas a la hora de determinar la agenda de gobierno, ¿no?, en el caso del presidencialismo no, digamos, que ese elemento de cultura política yo creo que sigue presente en un régimen tradicionalmente presidencial como es el de Nicaragua, y, de hecho, esa conversión, actualmente, de Alemán y el partido liberal, también por su propia condición de socio minoritario del pacto, es una expresión de esa voluntad hegemónica del Frente de querer tenerlo todo, ¿no?, de tener un control casi absoluto sobre todos los poderes del Estado, entonces, el aumentar las facultades de la Asamblea, en realidad, no era más que aumentar, digamos, la capacidad de maniobra de los principales partidos, al estar cooptada por los partidos políticos.

A.C.: Exactamente, exactamente, mantener el monopolio de la acción política y del ejercicio del poder entre ellos dos. 
R: Y en el caso del Poder Judicial, aunque eso da casi para otra tesis doctoral, el Frente Sandinista ha sabido utilizarlo como su principal baza casi desde el principio, ¿no?

A.C.: Fue tal vez una de las maniobras con más visión política que generó el Frente Sandinista desde el año 90 en que pasó a la oposición, con mucha visión política, y es que en la medida en que se desmovilizaron los aparatos represivos, que existían durante la revolución sandinista alrededor de la Policía, de los órganos de inteligencia, quedaban una cantidad de profesionales, muchísimos de ellos entrenados en el bloque soviético, en técnicas de interrogación, en presión psicológica, en todos los regímenes opresivos que utilizan, sin trabajo y afuera en la calle, ¿no?, y alguien dentro del Frente Sandinista tuvo la visión de decir convirtámoslos en jueces y en abogados, entonces, con mucha facilidad, dado el inmenso control sobre las universidades públicas, que el movimiento estudiantil sandinista ha tenido, modificaron currículum y comenzaron a ofrecer la carrera de leyes, y así fue, fue, concretamente, de leyes en clase los sábados, o sea, 4 horas a la semana, yo nunca he visto que un abogado logre graduarse en un período de 4 o 5 años estudiando 4 horas a la semana, no conozco otra experiencia, pero se hizo así, y con un currículum equivalente a un paralegal en otros países, sacaron su título de abogados, una vez sacado el título de abogados, y aprovechando experiencia y tal, fueron copando posiciones de jueces de todo nivel, y no era nada más cuestión de tiempo para que esos jueces fueran Magistrados de Apelaciones, y después Magistrados Supremos, pero fue una operación de gran visión, 20 años casi, de que eso comenzó, vemos el control en el Poder Judicial extraordinario, extraordinario, muchísima visión tuvieron en eso, pero, probablemente, las dos grandes operaciones políticas fue esa, y la negociación del pacto para bajar el 35\% cuando la historia se vaya escribiendo así se verá.

R: ¿Y ve usted la posibilidad de que el liberalismo se una a través de las próximas elecciones presidenciales?, ¿de formular un único candidato?

A.C.: No, no.

R: O sea, que casi Ortega se prefigura como el próximo presidente con las actuales reglas electorales.

A.C.: Por eso es tan importante que no tenga éxito que él pueda ser candidato.

\section{R: A través de la ley que se está tramitando en la Asamblea.}

A.C.: Sí, porque la razón, yo no creo que pueda haber unidad porque mientras esté Arnoldo Alemán en medio, no va a haber unidad, es decir, Arnoldo Alemán ya ha estado en el pacto 10 años, ya ha hecho un daño inmenso a la institucionalidad del país, sin mencionar la desconfianza total por los actos de corrupción de su administración, todo lo que él ha conseguido son ilegalidades, ante la opinión pública y en las pruebas y en la razón de la gente es que el pacto, y ahí está la corrupción, que es lo que representa, entonces, mientras él esté ahí y no se retire, no se aparte, no hay unidad, así de sencillo, y, obviamente, a Ortega le conviene que él esté ahí y continúe estando ahí para evitar la unidad, si Arnoldo Alemán diera mañana una declaración de que por el bienestar del país él se retira con todo y su familia, ¿no?, a ser un verdadero presidente honorario, él es presidente honorario del partido, no es presidente del partido liberal, a ejercer lo que 
debería de ejercer un presidente honorario que es aconsejar, pero fuera de toda política y de toda participación, entonces, sí estaría dando su contribución para que luego, tal vez, tenga alguna reivindicación en los corazones del pueblo de Nicaragua, pero yo no le veo ningún signo de que hacia allá va, todo lo contrario, lo veo peleando por otra nominación presidencial.

\section{R: Exactamente.}

A.C.: Y eso es la razón fundamental de que no habría unidad.

$R$ : $Y$, sin embargo, si comparamos las cuatro presidencias que ha tenido Nicaragua en la etapa democrática, tanto Doña Violeta como Don Enrique fueron presidentes débiles, que no fueron apoyados por su Asamblea, que tuvieron, como dije antes, enormes dificultades para gobernar, y Arnoldo Alemán y Daniel Ortega al tener un amplio control sobre su partido político, $y$, en ese sentido, poder extender sus tentáculos de poder más allá de la esfera del Ejecutivo, ¿no?, dominando el Legislativo, y, en el caso del Frente, el Judicial y el Electoral de manera clarísima, es importante ser dueño del partido, o sea, mantener un partido integrado y verticalizado en torno a la figura del líder. ¿Cómo ve usted los partidos políticos en Nicaragua?

A.C.: Muy, muy débiles, todas las instituciones del país son muy débiles.

$R:$ ¿Y la figura de los caudillos?, que es algo que ha aparecido, enormemente, en las entrevistas, y, bueno, no sé si es un resto del pasado, la necesidad de apoyar y de llamar a estos hombres líderes fuertes de alguna manera.

A.C.: Eso es en toda América Latina, es por la misma historia de nuestra cultura política, o sea, no sólo es Nicaragua, en toda América Latina, los caudillos vienen casualmente de la colonia, ¿por qué?, porque nadie podía controlar, imagínese qué control podía tener un Rey de España de lo que hacía un Capitán General en Perú, entonces, hay cosas en la vida que son, simplemente, no por voluntad, no porque Felipe II haya querido que haya buenos o malos gobernadores, no, no, es que estás a otro mundo, y en esos tiempos con las comunicaciones nulas estás a tres meses de mandar un mensaje, y todos los riesgos de navegar el Atlántico, entonces, de ahí provienen los caudillos, vienen de que un gobernador en una de nuestras provincias era un soberano absoluto, absoluto, dueño de vidas y de bienes, entonces, naturalmente, el poder es así, ¿no?, y eso fue lógico casi 300 años de vida colonial, entonces, de donde acá que no hemos cumplido los siguientes 200 años de vida independiente, ¿ciento y pico de años de vida independiente van a destronar 300 años de tradición política de la colonia?, eso no es tan fácil, por eso es que vemos a duras penas en los últimos 25 o 30 años que países latinoamericanos reencuentran los cauces democráticos y logran instalar instituciones sólidas, que puedan enfrentarse, digamos, a los potenciales caudillos, y por eso tenemos a América Latina dividida en dos, hay países que por su temperamento, por sus líderes, han logrado ya hacer esa transición, yo le llamo los países graduados, como graduarse de un título, ¿no?, ese era un término que se utilizaba en el Fondo Monetario Internacional, y le llamaban un país graduado a un país en desarrollo que llegaba al umbral de la OCDE, verdad, de los países ya desarrollados, entonces, en América Latina todavía nadie se ha graduado, todavía, están cerca varios, pero nadie se ha graduado, por ejemplo, España se graduó hace 25 años, cuando después de entrar en la Unión Europea, pues, verdad, y comenzó e hizo las instituciones y los cambios que 
obligada Europa, Europa obligaba, si no, no podías ser miembro del club, y luego ya se pasó y se graduó, pero sólo tiene 25 años de estar graduada como un país del primer mundo, en América Latina, pues, hay varios países que están muy cerca, yo pienso que ya se han graduado, por ejemplo, Brasil, porque ¿qué implica graduarse?, poder pasar de un régimen de derecha o de centro-derecha a izquierda o de centro-izquierda sin que las instituciones fundamentales sufran, y que continúe la vida institucional democrática del país sin sobresaltos, eso es graduarse, es decir, España ya lo ha logrado, cuando Felipe González le entregó a Aznar, y Aznar gobernó 8 años, y ahora Zapatero está en su segundo período otros 8 años, y, entonces, ya se graduó, ¿quién puede llegar a gobernar en España que vaya a derrumbar las instituciones?, nadie, ya caló, igual es en nuestros países, cuando ya Brasil pasó de dictadura militar a gobiernos de centroderecha democráticos y ahora lo toma Lula 8 años, y, probablemente, lo va a sustituir otro gobierno de centro-derecha, y quedó pisándole los talones el ex-gobernador de Sao Paulo en la última elección, digo, es muy probable, ese es un gobierno graduado, Brasil está muy cerca, México está muy cerca, yo pienso que lo que le falta es que el PRI o el PRD sustituyan al PAN ahora, el PRI estuvo 70 años, ahora llevamos ya 12 años se habrán acumulado de gobiernos de centro-derecha del PAN, yo creo que un pendulazo en México al centro-izquierda terminará de graduar a México, Chile ya lo ha logrado, Panamá lo ha logrado, Panamá pasó de una revolución izquierdosa de Torrijos, de un régimen militar pseudo-revolucionario, pasa después a un gobierno de centro-derecha del señor Endara, luego pasa a un gobierno de centro-izquierda de Pérez Balladares, del Partido Revolucionario Democrático de Panamá, luego pasa a un gobierno de centroderecha de Doña Mireia Moscoso, viuda del dictador, digamos, o del líder o el caudillo de derecha, luego pasa al hijo del general revolucionario, Martín Torrijos, otro régimen de centro-izquierda, y luego pasa a otro régimen de centro-derecha y no pasa nada, el Canal sigue manejándose bien, nadie ha vuelto a decir que se necesita poner otro Ejército, aquí están las fuerzas de defensa de Panamá, que son una Policía, el sistema judicial funciona, la banca funciona, ya está graduado Panamá, está a puntito, Costa Rica estuvo a punto de ser graduado mucho antes que estos países, pero le afectó mucho en los 80, que era una isla en Centroamérica con guerras civiles y revoluciones acechándola, ¿no?, entonces, se atrasó, Costa Rica se atrasó mucho, y por eso ahora ha retomado otra vez el camino y está también cerca de graduarse, pero perdió, por ejemplo, la diferencia que hay ahora entre Panamá y Costa Rica es mínima, Costa Rica está un poquito ahí arriba, pero Panamá está aquí, hace 20 años Panamá estaba más bajo, en fin, menciono algunos, otros que están cerca, República Dominicana también, de una dictadura pasó a un régimen de centro-derecha, luego pasó a ser un régimen de centro-izquierda, luego un régimen de centro-derecha, luego un régimen, y ahí están, y ya no hay grandes sobresaltos, está cerca, República Dominicana, Perú, pues, también, estamos en esa situación, ¿no?, pasaron una guerrilla, luego, un régimen de centroderecha autoritario, luego un régimen de centro-izquierda, y ahí está, uno ve de que, realmente, lo que, en mi opinión muy particular, lo que gradúa a los países latinoamericanos para ser democracias consolidadas y responsables es el poder pasar.

\section{R: La alternancia política.}

A.C.: Exacto, de los signos, sin que sufran las instituciones, naturalmente, siempre va habiendo pequeños ajustes, es natural, y siempre va habiendo que el programa de gobierno de este tiene más énfasis en tal cosa, el programa de aquél tiene más en esto otro, pero son naturales ajustes necesarios sin que pongan en peligro la institucionalidad del país, y, desafortunadamente, mi país no es uno de esos, la tuvo en la mano Ortega, 
pero, evidentemente, ya no, porque El Salvador puede ser si el presidente Funes tiene éxito en imponer sobre el FMLN su concepción, que no sabemos todavía, se habrá acercado mucho a la graduación El Salvador, muy cerca, muy cerca, pero no sabemos todavía, es muy temprano para saber si él va a tener éxito o no, y así podemos analizar cada uno de los países en América Latina, pero, repito, el caudillaje viene de la colonia, todos los países latinoamericanos han tenido caudillos, absolutamente todos, los mismos libertadores son los grandes caudillos, o sea, en la mayoría de los casos se quedaron en el cargo hasta que se murieron, afortunadamente, las expectativas de vida de esos tiempos era mucho más corta, entonces, uno podía aguantar a alguien y tal vez se moría a los 45 años, ¿no?, pero todos fueron caudillos, absolutamente, ahora las expectativas de vida son muy altas, y todo el mundo está preocupado que Daniel Ortega en una entrevista hace unos meses dijo que su madre había muerto de 97 años, y que él tenía genes para vivir esa cantidad, estábamos todos afligidos, ¿no?, porque le faltan 30 años más de llegar ahí, en resumen a su pregunta, en mi opinión, los caudillos vienen de nuestra herencia política colonial, que es natural, toda América Latina los ha tenido, y los países que han logrado imponérsele a los caudillos son los que ya están llegando a graduarse como democracias estables, y, obviamente, el desarrollo socioeconómico va de la mano, eso no es ninguna casualidad, van de la mano, esos mismos países que tienen esa estabilidad ya institucional son los países que tienen mayor ingreso per cápita, son los países que tienen menos pobreza y que están creciendo.

R: Y ya sí que la última pregunta, porque tampoco quiero robarle más tiempo, regresando a la Constitución, ¿es posible que ésta se transforme un poco en el paraguas jurídico de toda la sociedad nicaragüense?, porque siempre ha habido una parte de los ciudadanos que no se han encontrado reflejados ni en el texto jurídico, $n i$ en el proyecto político que sustenta, como sucede en el caso de la Constitución del 87 del proyecto de la revolución sandinista, hubo una parte de los ciudadanos nicaragüenses, que no coincidieron con el proyecto de la revolución, que se vieron abocados al exilio o al enfrentamiento armado, ¿no?, en el caso de las reformas siempre ha habido también una parte que ha discutido, y las reformas se han convertido también en instrumento de intereses partidarios y de fuerzas politicas muy concretas. La Constitución ha perdido gran parte de su valor normativo y, obviamente, el principio de seguridad jurídica, de supremacía formal de la Constitución por encima de la política, de los actores políticos, digamos, que da la impresión de que la política está por encima del Derecho en muchas de las situaciones vividas en Nicaragua, ya pasado mañana hay una marcha de la ciudadania y de la sociedad civil, que se ha dado también la facultad de enfrentar a un poder que cada vez está cerrando más los espacios políticos, y de eso soy testigo como extranjera que ha vivido en Nicaragua estos últimos tres meses, ¿no?, ¿cómo ve usted este tema desde el punto de vista de la Constitución?, hay entrevistados que me hablan, incluso, de una Constituyente, del llamamiento a un nuevo diálogo nacional, si Daniel Ortega sigue conduciendo el país al borde del precipicio, que es otra expresión que ha aparecido varias veces en mis entrevistas.

A.C.: Yo pienso que, insisto, en que la Constitución después de la reforma del 95 es lo más cerca que hemos tenido de una Constitución aceptada por todos, es inmensamente amplio el consenso después de las reformas del 95, inmensamente amplio, más del 85\%, no creo que haya habido una Constitución en Nicaragua en 100 años que tenga esa aceptación, tal vez, al comienzo de la primera Constitución liberal de 1893, que fue una pieza jurídica muy linda, al comienzo, por dos años, y luego el propio gestor de ella la 
comenzó a violar, cuando se le interponía en sus ansias de poder, tal vez, es la única que se pudiera comparar en la aceptabilidad de la Constitución, en la amplitud de consenso, digamos, popular detrás de la Constitución, ahora yo pienso que es muy poco probable, muy poco probable, es difícil predecir el futuro, verdad, y menos el futuro político de Nicaragua, pero no veo yo gran posibilidad de que aquí se logre hacer una nueva Constitución en los próximos años, yo pienso que es mucho más factible que cualquier diálogo, cualquier nueva negociación ajuste otra vez un poco los desajustes sufridos del 2000 para acá, es más fácil de lograr un consenso en eso, los desajustes sufridos del 2000 para acá, pero siempre está de por medio la obsesión reeleccionista de Ortega, yo creo que para lograr eso tendría que darle la posibilidad de que se reelija un período, si no, no vas a obtener nada del Frente Sandinista, absolutamente nada, cero, por lo tanto no lo veo deseable estar tocando la Constitución, actualmente, a pesar de tener esos desajustes que se hicieron en 2000 y en 2005, a pesar de eso, pienso que se puede manejar el país, y sin tocarla por un tiempo para dejar que se asiente un poco, y que no tratemos de resolver eso allí, y luego con un poco más de madurez, tal vez en unos 10 años, ahí sí, hacer con calma y con mucha tranquilidad un cambio constitucional completo, no, no lo veo factible hacerlo muy cerca, esa visión que algunos dicen: "vamos a una Constituyente", lo veo muy difícil, Daniel Ortega nunca ha pasado del $40 \%$, tú vas a elegir a una Constituyente y tampoco vas a pasar del $40 \%$, vas a tener en contra, entonces, el $60 \%$ de los diputados constituyentes y él lo sabe, entonces, de qué palo va a aceptar perder sus diputados actuales, ¿no?, para poder llegar a los 2/3 que requiere convocar a una Asamblea Constituyente, 2/3, o sea, obviamente, sus diputados, sin ellos no hay Constituyente, ¿y cómo me convenzo yo de que él va a ir a meterse en una trampa mortal que es peor que una elección?, porque vas a elaborar la nueva Constitución, y la nueva Constitución podría hasta dejarlo fuera prohibido, pues, al sandinismo, por decirte un extremo, ¿no?, y la nueva Constituyente para él es mucho más peligroso que perder una elección, entonces, no me trago yo que vaya a esa posibilidad, siendo pragmático, pues, no veo que vaya a aceptar e irse a jugar un dado, ¿no?, peligrosísimo, para el futuro del sandinismo y de él mismo, por lo tanto, creo que en la realidad lo que, concretamente, puede aspirarse ahorita en Nicaragua es a aprovechar que se vence el período de las autoridades electorales el próximo año, con tiempo todavía, se vence año y medio antes de la elección próxima general, y ellos no pueden elegirlos solos para más bien negociar ahí, o lograr ahí un cuerpo colegiado electoral creíble, que pueda organizar elecciones limpias al 2011, yo pienso que esa es la aspiración práctica que se puede lograr, de manera tal que el pueblo pueda expresarse libremente en la elección del 2011, no veo ninguna, no veo posibilidad de otra cosa, porque no veo conveniente tampoco abrir la negociación con Ortega, porque él te va a exigir, de entrada, la reelección, entonces, ¿qué ganaríamos con hacer algunos ajustes para realizarlos a la Constitución del 95, y estar legitimando la situación de reelección?, por lo tanto, le digo lo que me parece que podemos aspirar es que a que se logre reconstituir en tiempo un tribunal electoral confiable, justo, que pueda conducir las elecciones de 2011 con seriedad y con limpieza, ¿no?, y ya con eso es suficiente, por el momento ya está, habrá que esperar, creo yo, un poco para volver a ajustar la Constitución.

R: Pues, si tiene algo más añadir, yo creo que ha sido una entrevista, realmente, interesante. 
A.F.: Pues, sí tengo algo más y muy importante, quiero felicitarte porque estás sacando tu tesis doctoral en estudios políticos, ¿no?, en la Universidad de Salamanca, quiero confesarte que es mi aspiración hacer un doctorado a mis 58 años de edad, ¿verdad?

R: Pues, todavía está a tiempo. Muchas gracias por todo. 


\section{ENTREVISTA $15^{22}$ :}

Nombre del entrevistado: D. Rafael Córdova Álvarez.

Cargo actual: Miembro del Partido Conservador. Asesor y Portavoz de la Campaña Electoral de Alianza Liberal Nicaragüense (ALN), bajo la candidatura presidencial de Eduardo Montealegre en 2006. Ex - Auditor y Ex - Director General de la Propiedad en la Contraloría General de la República.

Fecha de realización de la entrevista: Managua, 4 de noviembre de 2009.

Lugar: Facultad de Diplomacia y Relaciones Internacionales de la UAM.

Duración estimada: 1 hora y 22 minutos.

\section{TEXTO - Transcripción 15:}

R: ¿Cuál sería su visión sobre los cambios constitucionales que se han producido recientemente en Nicaragua en el contexto de la transición democrática?

R.C.: Mire, Nicaragua ha tenido toda una lección de Constitución, yo creo que somos el país de América Central o el segundo, no sé en América Latina, que hemos tenido más constituciones y de las cuales algunas las hemos cumplido, y otras han sido non-natas, porque se han promulgado, pero el que las promulgó o el que las impulsó ya en el poder no quiso ejercerla y pasamos a "Estado de sitio", o sea que están muy lindas las normas jurídicas que las contemplan, pero con el "Estado de sitio" o "Ley Marcial" o cualquiera de estas cosas por el estilo, las normas jurídicas no se aplicaban, aunque ellos las hayan impulsado, entonces, hay que ver esa perspectiva de la historia jurídica de Nicaragua, la cantidad de normas que se plasmaron en papel, se firmaron, se aprobaron, y que no se llegaron a aplicar nunca, nunca tuvieron aplicación, o como en el caso de la reelección, $\mathrm{y}$ que nos ocupa actualmente mucho, ha sido una norma que se ha puesto constantemente en la Constitución, y tampoco se ha cumplido, o sea, el dictador de turno o el hombre fuerte del país, es decir, ha buscado la manera de cómo capearla para poder continuar en el poder, y por eso, en el caso de Honduras, pues, lo traigo a colación, porque está actualizado ahora, que prohíbe mencionar que se puede cambiar, verdad, ahí en Nicaragua sí lo necesitamos porque es uno de los males más grandes que hemos tenido. Pero las constituciones en Nicaragua, por ejemplo, la última que tenemos ahorita que fue del 87, con una reforma bastante profunda en el 95, estando en el bloque del Partido Conservador, negociábamos tres cosas muy elementales con el Frente Sandinista, que era el otro partido fuerte en la Asamblea Nacional, uno, la propiedad privada, que quedaran muy claros los términos, los alcances, los márgenes, el marco de la propiedad privada, el segundo, la libertad de expresión, de movilización, de organización, algunas libertades muy propias de los individuos, la no reelección, y que se mencionara a Dios en el preámbulo, que llevaran aquellas cosas que traían todas las constituciones de Nicaragua, "aquí reunidos en nombre de Dios...", dicen las actuales constituciones, de las primeras líneas, el Frente Sandinista en un ateísmo más bien, porque ellos son de izquierda, y, entonces, son ateos, pero la prueba es que al día de hoy pasados algunos cuantos años y se declararon todos muy católicos, apostólicos y romanos, pero bueno, cuando avanza la edad, pues, ya le tienen miedo, a medida que se

22 Entrevista irregular, algo pobre en el análisis a pesar de su duración, pero con numerosas claves de gran interés para la extracción de citas directas, aunque, en general, esté más sostenida en opiniones personales e impresiones vagas del entrevistado, que en una reflexión ordenada sobre el tema objeto de estudio. 
va acercando sus últimos días, entonces, ahora todos se han vuelto muy cristianos. Se negoció en el 86 y logramos dejar algo de la propiedad privada con otros estilos de propiedades, la propiedad estatal y la propiedad mixta, que es un término que al final es una combinación entre la que es área del Estado combinada con la que es el área no de modelos privados, sino áreas de cooperativas, ¿verdad?, es un tema que, ni aún los administradores de empresas, economistas, han terminado de definir, verdad, porque es un limbo, es un limbo entre un Estado paternalista o un socio privado que siempre está perdiendo al lado de un socio colectivo social, la verdad es que nunca se ha discutido ni se ha discutido qué es esto de economía mixta, pero logramos, pues, que se plasmara, pues, el reconocimiento a la propiedad privada, etc., etc., y que si el Estado quería alguna propiedad, pues, se tenía que negociar, indemnizar, y dar todo el proceso, ¿verdad?, para que fuera de uso si era un bien colectivo, luego, lo de la reelección fue imposible, y la prueba es que hoy ha demostrado otra vez, pues, que pasó con esta sentencia que modifica la Constitución de la manera más absurda, que es la forma en que los dictadores han venido a cambiar las normas jurídicas en las constituciones. No hubo manera, no hubo forma, entonces, negociamos, el Partido Conservador, que se pusiera a Dios en el preámbulo lo cambiamos por la no-reelección, ¿bajo qué óptica?, estamos hablando de 1986, porque se aprobó en el 87, había una consigna que decía: "Dirección Nacional ordene", esta Dirección Nacional eran 9 comandantes que eran toda la dirección colectiva del Estado, Daniel Ortega cuando era Coordinador General de la Junta de Gobierno, pero no era el líder único e indiscutible como es ahorita, es una dirección colectiva, pero era una figura como una especie de Fidel Castro, Mao, cualquiera de los dictadores soviéticos, era una cosa como omnipotente, los que hemos vivido en estos sistemas socialistoides, es una cosa increíble, son unos dioses del Olimpo bajados a la tierra, ¿verdad?, intocables, impenetrables y superiores, entonces, de acuerdo a la filosofía conservadora sólo reconocemos a un ser superior, que es Dios, por eso el triángulo que es nuestro símbolo dice: "Dios, Orden y Justicia", y esto de creer en Dios es una filosofía, que indica que si sólo reconocemos a Dios como ser superior, luego las demás personas, o sea, todos los seres humanos que estamos en la tierra, todos somos iguales, nadie es superior a vos, a mí, al que va caminando en la calle, esa es la manera de nosotros de podernos enfrentar contra esta ideología de un culto a la personalidad exacerbado, y como veíamos que lo de la reelección se volvía casi, en relación a este culto a la personalidad, se volvía casi un absurdo, porque no había, sólo había la "Dirección Nacional ordene" y el colectivo, o sea, el resto de los ciudadanos era la sociedad, entonces, conseguimos que se mencionara a Dios en el preámbulo de la Constitución como gran cosa, o sea, y hubo que privarse, pero a ellos no les importó, o sea, "bueno, pues que se diga a Dios, pero yo tengo mi reelección continua", o sea, había reelección continua, etc., esa fue una de las cosas también que se lograron en esa Constitución del 87. Por supuesto, había un Estado presidencialista poderosísimo, los poderes que le dejaba a la Asamblea Nacional y al Poder Judicial casi eran mínimos, no había equilibrio, no había balanza, había roto todas las normas, las tradiciones de las normas jurídicas de las constituciones de Nicaragua, porque si se quiere mal que bien, de todas las constituciones venían avanzando, verdad, su separación con la Iglesia, la Constitución fue un poquito quitándole poder a la Iglesia, volviéndonos del Estado religioso a un Estado amparado, ilustrado, inspirado en la revolución francesa, y todas las ideas del liberalismo, verdad, pero manteniendo, como diríamos, la costumbre, o sea, todo lo que se venía de las otras constituciones, esta Constitución del 87 rompió totalmente el equilibrio de poder, el poder de la presidencia era increíble, prácticamente, sólo le faltaba nombrar a los diputados, pues, de dedo, porque todos los Magistrados de la Corte Suprema los nombraba de ternas que la 
presidencia le mandaba, o sea, los Magistrados del Consejo Supremo Electoral, los Magistrados de Apelaciones, inclusive, los nombraba la Presidencia de la República, ni siquiera la Corte Suprema, entonces, la presidencia tenía ya rasgos de, casi de, ¿cómo decirte?, es bastante, mucha preponderancia sobre los otros poderes, no había equilibrio en lo que podamos llamar de la división de los poderes, ni el equilibrio de poderes de Montesquieu, ni nada por el estilo, era totalmente presidencialista, pero a una máxima, totalmente, no había equilibrio de poder, y ¿qué más te puedo decir de esto? Igualmente la reforma que fue bastante profunda, la del 95, que debió haber sido una reforma total a la Constitución, donde regresamos a la norma jurídica que traíamos, aunque no se cumplieran, verdad, se regresó bastante y se puso la no reelección con un período de por medio, cediéndole un poquito a lo otro, y quedando bien con ambas partes, se amplió mucho de los derechos individuales que en el año 86, como era un Estado socialista estalinista las personas no tenían derechos para nada, o sea, te echaban preso y después averiguaban si eras inocente o si eras culpable y después tenías que demostrar que eras inocente, podían entrar a tu casa, era increíble como en esa Constitución del 87 se violentaban las conquistas mínimas de los ciudadanos que se habían logrado, pues, casi era como en el siglo XVIII, pues, esa Constitución, increíblemente prepotente, diría yo casi, verdad, se estableció, entonces, la Ley de Amparo, se establecieron una cantidad de normas constitucionales sobre los derechos ciudadanos, se reestablecieron normas sobre la protección a la libertad de prensa, y las libertades públicas, en general, de las personas frente a la autoridad, se le manda al Ejército que no se inmiscuya en política, a la Policía se le quita todos los nombres sandinistas, todos los órganos del Estado, el Ejército Popular Sandinista, Policía Nacional Sandinista, etc., etc., verdad, se hace la ley sobre los símbolos patrios, que otra vez volvió este gobierno a pasar encima de ellos, verdad, hay una ley que señala cómo son los símbolos patrios y la presidencia tiene ahora su triángulo, que es así como un mamotreto chueco, la Primera Dama no puede estar siendo Primera Dama y Secretaria de Comunicación y Ministra, porque ella está, pues, eso lo ha definido los conflictos sobre la consanguinidad y la afinidad en el nombramiento de funcionarios y todo esto, y pasaron ahorita encima también, estamos en un Estado que ha violado todas las normas muy elementales del Derecho y de los símbolos, o sea, empezando por los símbolos patrios, y normas sobre el comportamiento de los funcionarios, empleados públicos, normas de probidad, ahí es donde metés contrataciones del Estado, estabilidad de los empleados públicos, el servicio público, corrieron 15.000 empleados del Estado, este gobierno, o sea, prácticamente, estamos en una dictadura donde no, sólo es una mascarada de democracia. Pero han violentado todas las normas jurídicas desde las más elementales, verdad, y ahora estuve escuchando el fin de semana que detuvieron a una periodista activista y no la dejaron pasar, y la metieron al vehículo, Patricia Orozco, y no le dijeron ni por qué estaba detenida, igual que siempre habíamos tenido en los tiempos de Somoza, el dictador, en el tiempo de la revolución, volvemos a la prepotencia desmedida y sin ningunas limitaciones ni garantías ni respeto, que ya teníamos 16 años de asistir a un poquito a esto, bueno, desde comenzar a ponerle una chapa a los policías, verdad, por su número, para que el policía que le faltara al respeto no saber si el número 14 o 20, o lo que sea, en la chapa, una serie de cosas que se habían logrado muy civilistas y todo, y las hemos perdido a una velocidad sorprendente, verdad, los muchachos que estuvieron hablando en la radio salieron y los agarraron en la calle, los detuvieron por una hora de una sala de una de las universidades de la UNAN, que es la que controlan estos movimientos, y para colmo luego lo van a dejar a la estación de policía, entonces, no sé hasta donde el desarrollo de nuestras constituciones tenga una seriedad que el hecho de poner una norma explique un avance. 
R: Es cierto que a pesar de las dificultades que se han registrado sobre todo en este último período, que es el producto de un proceso que tiene su evolución, es decir, las cosas no surgen espontáneamente, sino que tienen causas, y estamos viviendo los efectos de una evolución concreta a nivel jurídico y también a nivel político, ¿no? Pero, si bien la Constitución del 87 resulta muy transformada por la primera gran reforma del 95, que es, a mi juicio y el de la mayor parte de los entrevistados y también usted ha hecho referencia a ello, la más legitima de todas, puesto que era jurídicamente necesaria en un contexto de transición política, había que pasar de un régimen revolucionario en el que no se sentían reconocidos todos los nicaragüenses a un sistema democrático en el que hubiese un espacio político para todas las sensibilidades, la sandinista y la liberal-democrática o la anti-sandinista, o como quisieran llamarla en el momento de la oposición al régimen revolucionario. Pero el pacto entre Ortega y Alemán en el año 2000 significa, en cierto modo, una contrarreforma, ¿cómo ve usted esta experiencia que no es ajena a la historia política de Nicaragua?, porque siempre ha habido pactos entre cúpulas partidarias que se han repartido cuotas de representación, el caso del Partido Conservador, por ejemplo, durante el régimen de Somoza, que permite el gobierno cómodo de uno de ellos, digamos, en el caso de Somoza, este pacto de caballeros no fue tan respetado por los sandinistas que han tenido una vocación hegemónica y, de hecho, el régimen de Ortega y el carácter de socio minoritario que tiene Alemán en este momento es un ejemplo de ello, ¿no? ¿Cómo ve usted todos estos factores?

R.C.: Sí, el pactar en la historia es crisis, se crea una crisis de poderes y de división, etc., y luego viene en consecuencia un pacto, que produce una estabilidad por un tiempo, luego viene otra crisis, y se vuelve a pactar las cosas posteriores, que se van metiendo en el saco de la crisis, verdad, un disidente, otro disidente, otro disidente, de un lado y del otro, verdad, entonces, se van metiendo, ya, últimamente, se le ha cambiado ya los nombres y se le ha puesto "combo", se crean ya tantas cosas que, entonces, uno llega con su oferta y vos llegás con la tuya, entonces, nos volvemos a arreglar y seguimos caminando, efectivamente, pues, el Pacto de los Generales, que hablabas anteriormente, después vinieron otra serie de pactos, verdad, más pequeños, ah, bueno, con Somoza, pero el más grande y que dilató más de 25 años fue el de Emiliano con Somoza García, realmente, le dio estabilidad al Estado por un tiempo, verdad, y como que no hemos, el problema es que nos sentimos los nicaragüenses que estamos en una bicicleta de hacer ejercicio, como dice D. Alejandro Serrano Caldera, sudamos, caminamos, corremos, hacemos, tornamos, y nos detenemos un momento, y vemos que no hemos avanzado para ningún lado. Lo malo de esta evolución es que es una involución que no nos lleva a ningún lado, o sea, no, es cuando más nicaragüenses exiliados hay, nicaragüenses hay en todas las partes del mundo por las constantes guerras y las constantes diferencias, entonces, avanzás y retrocedés, avanzás y retrocedés, llegamos a ser en los 40 años de dictadura somocista el país más fuerte en toda Centroamérica, aunque parece mentira cuando le cuenta usted a los extranjeros, verdad, Costa Rica la veíamos para atrás como que teníamos la industria más desarrollada de todos, etc., pero hubo una estabilidad que es como una olla de presión, que luego estalla, destruye todo lo que hemos hecho y quedamos más atrás, más atrás que de donde empezamos la última vez. Entonces, ¿evolución de qué?, si fuera una cosa, que mal que bien, pues, por ahí va la sociedad a su manera, pues, está bien, verdad, que evolucionemos en este sentido, pero no, son concentraciones de capital que lo que produce son desarrollos sobre ciertas cosas, a ver nosotros tenemos el sistema bancario mejor de Centroamérica, los nicaragüenses son 
dueños de los bancos de Centroamérica, si te vas a fijar bien en las sociedades anónimas, ahí están metidos los nicaragüenses, porque esta explosión de migraciones, de exilios, represiones y todo, ha hecho que esta sociedad desde 1870, que estuvieron los 30 años de los conservadores, y después de los conservadores Celaya, y todo esto, son explosiones de nicaragüenses, estaba viendo una foto ahorita de los diarios del fin de semana de los conservadores en Costa Rica, de un historiador, ¿no?, entonces, en Costa Rica, en Guatemala, en Estados Unidos, en Francia, en Inglaterra, vos te vas aquí y la comida, entonces, los mejores ingenios, cuando el Mercado Común Centroamericano, Somoza parecía un muchachito, entonces todo lo que era fuerte, las destilerías, la metalurgia, todo lo que era industria, los alimentos y comida se lo pasaron a El Salvador, Guatemala agarró todo lo que era tela, Honduras no recuerdo ahorita, Costa Rica se metió a otro rubro, nosotros llegamos a hacer hasta vehículos ahí, se traían el motor y todas las cosas y lo ensamblábamos en Nicaragua, e íbamos muy adelante, pero vino la guerra y todo lo demás, la destrucción, y, entonces, estamos en las mismas, o sea, finalmente, la evolución que en esta Constitución del 95, que debió de haberse hecho un, se debería haber hecho una constituyente y una Constitución nueva, verdad, pero no había tiempo, o sea, estábamos tratando de salir de 9 años de guerra y destrucción, entonces, se hizo algo que nos permitiera caminar, porque había que desmantelar el sistema socialista central, todo centralizado, la economía, etc., ¿no?, todo nacionalizado, devolver a todo el mundo sus cosas, entonces, no había tiempo de ponernos a hacer una reforma total $\mathrm{y}$, realmente, fue una reforma total, porque todo el mundo la aceptó, porque se tocaron elementos muy sensibles en la Constitución y todo, entonces, todo el mundo la aceptó y se hizo, ¿verdad?

\section{R: De todos modos, fue conflictivo el consenso constitucional en el 95.}

R.C.: Bueno, fijáte que, realmente, lo que hubo siempre fue esta suerte de ahora la política y alcanzar el puesto de diputado para solucionar tu vida por el resto de tus días, o sea, había unos diputados que se opusieron para venderse, más que representaciones reales de la sociedad, de intereses reales de la sociedad, o sea, los intereses de la sociedad nicaragüense en su conjunto, como colectivo, estaban expresados y representados por Doña Violeta, en el sentido, de lo que se quería como reforma, pero siempre hay 3, 5 o 10 malandrines, que se dicen: "no, no, no, yo me opongo", que sólo es para trabar las cosas, para que les den dinero, es triste, es una cosa muy triste, y no tenían una mayoría, pues, suficiente, como para lograrlo, verdad, mucho interés personal, mucho interés personal ha habido en todo esto, muy poco desprendimiento, y siempre ves una gran cantidad de gente muy buena, o sea, ahorita, en esta Asamblea Nacional con todo esto, con toda esta crisis y todo, hay una buena cantidad de diputados que están marchando por Nicaragua, pero son los menos siempre, son los menos, había otra cantidad que son borregos, como los del Frente Sandinista, que no, no, por su sistema de organización o de mando, o cómo vos le querrás llamar no, no tienen el más mínimo respeto por su persona, su apellido, su familia, ni por nada, o sea, ellos hacen lo que dice el dictador y se acabó. No, no, no tienen el menor discernimiento, ni nada, dicen, simplemente: "sí, señor, sí, señor", y como la política es, aquí en Nicaragua hay un dicho que es: "vale más un gramo de fidelidad, que cien libras de inteligencia", los líderes políticos agarran gente que les es fiel, aunque sean brutos, aunque no sepan nada, aunque no sean preparados, eso no importa.

R: Pero la disciplina partidaria también es importante a la hora de llegar a acuerdos dentro de la Asamblea, ¿no? 
R.C.: Exactamente, y hacer bloque, etc., pero también es importante la representatividad, porque si este diputado no representa nada, más que él mismo, porque él mismo, en el sentido de que se anda jugando él su destino, pues, y no anda viendo por sus representados, entonces, ¿qué función tiene la disciplina partidaria?, si no andas buscando el bien del país, yo estoy claro que los partidos políticos, dentro del sistema electoral en el que estamos, andan buscando que quede lo mejor posicionado tu partido, inclusive, a veces el líder puede andar medio equivocado, pero vos decís: "no, un momento, el partido y la organización", que es la mecánica o la máquina con la que llegan todos los partidarios, o la que ha costado muchos años, pero muchos años y sudores construir, y que hay que cuidarla, y yo estoy claro en este sentido, porque a mí me ha tocado armar y desarmar partidos, pues, pero la fidelidad es espantosa a la persona, al individuo, no al partido ni a la idea, ¿verdad?

R: Y ese personalismo sobre todo de las cúpulas partidarias convierte en un ejercicio clientelar, en muchos casos, la relación entre los líderes fuertes de los partidos y sus seguidores, puede llevar también a la comparación entre los últimos cuatro presidentes que ha tenido Nicaragua, como Doña Violeta y Don Enrique Bolaños fueron presidentes débiles, porque no contaron con un respaldo mayoritario de su partido en la Asamblea, sino que sus legisladores le dieron la espalda y tuvieron importantes problemas para desarrollar su agenda de gobierno. Sin embargo, Arnoldo Alemán y Daniel Ortega si han sido hombres fuertes de sus respectivos partidos, que han sabido mantener un control importante sobre sus seguidores, ¿no? En lo que se ha repetido varias veces y habría que aclarar, que Nicaragua tiene, tradicionalmente, una especie de historia de "caudillos" o de hombres fuertes en los que se amparan las relaciones políticas. ¿Cómo ve usted todo esto que he comentado?

R.C.: Dice un tío mío, que lo deberías de entrevistar, Emilio Álvarez Montalbán, ya se retiró de la política, tiene 90 años, pero tiene su cabeza muy lúcida, y dice que: "si hay guarasapos es porque hay agua", o sea, no puede haber guarasapos si no hay agua, pues, porque las ranas ponen los huevos donde hay agua, eso lo trae a colación con lo que quiere decir, si hay dictadores y caudillos es porque los nicaragüenses los producimos, los preferimos, o sea, todavía hoy, hay un porcentaje de la población que está defendiendo a Somoza, y me imagino que en España hay franquistas, y dicen: "viva Franco", y hasta la foto de los Somoza la tienen, ¿verdad? Y Daniel Ortega, aunque haya estado en el gobierno hasta el 87, y haya producido una guerra, nos haya empobrecido, hayamos retrocedido a la era de las cavernas, etc., y ahora está de regreso con toda esta prepotencia y todo lo demás, y sintiendo la clase pobre, que si, ahorita, en la última encuesta en todas las familias nicaragüenses hay un desempleado, en todas, la que tenía 5 personas, la de 4 trabajando, la de 3, hoy, cuando salió Don Enrique Bolaños hoy tiene uno menos trabajando, en vez de uno más, y otros que han subido, han pasado a los 18 o 19 años, que ya son mano activa, pues, de la masa activa laboral del país, entonces, ya hay dos desempleados, uno que ya subió en estos dos o tres años, que ya cumplió la mayoría de edad, porque debería estar trabajando, y otro que salió, que es desempleado, entonces, eso lo siente el pueblo, porque es falso lo del $38 \%$, yo he sido jefe electoral de mi partido y es totalmente falso, esto del 38\% se lo inventó el Frente para nunca perder la mayoría en la Asamblea, y que no se puedan hacer las reformas electorales sin ellos, se pudo hacer en el 95 porque una masa importante del Frente Sandinista se pasó de los diputados, y le quedó al Frente orteguistas dos, tres, pero una masa importante se pasó y se hicieron esas reformas electorales. Entonces, el Frente, lo 
del $38 \%$ es porque ellos necesitan tener tantos diputados, como asegurar que la oposición no llegue al $56 \%$, es un número que se han inventado y ellos lo defienden a capa y espada, y siempre sacan los votos suficientes para tener 38 diputados de los 90 , pero es totalmente falso, debe andar como en el $20 \%$ de los votos, toda la vida se ha robado, porque siempre mantiene una estructura mucho más profunda. ¿Los hombres fuertes?, porque como vivimos, a ver, Nicaragua si lo revisás para atrás, y hay varios libros que han estudiado esto, ¿por qué en Nicaragua ha habido tanta guerra?, desde Guatemala o México a Panamá, la cantidad de guerras civiles que ha habido en Nicaragua no tiene comparación, guerras, conflictos locales muy reducidos o muy grandes, como vos querrás, no tiene comparación, la frecuencia, desde antes de la independencia ya estábamos en guerra nosotros, aún bajo la Corona española, y luego de la independencia, somos un crisol de ideología, es una guerra entre Granada y León, entre dos ciudades donde se aceptaron diferentes, y nosotros cualquier filosofía que pasaba por el aire la agarrábamos, la adoptaba Juan o la adoptaba Pedro, verdad, y siempre estuvimos en esa guerra constante, pueda ser que esto, pueda ser que esto haya producido la idea de que es mejor el caudillo, el hombre fuerte, que la república o las leyes, porque el hombre fuerte produce estabilidad, entonces, es mejor pasar 20 años en paz, aunque después nos volvamos a matar, después de los 20 años por 2 o 3 años nos matemos, y vuelva otro hombre fuerte por otros 20 o 30 años. La única razón que nuestra cultura política, porque la política se vuelve cultura, y por eso España tiene reyes e Inglaterra también y Francia no, ¿qué pasó en el devenir del desarrollo de ustedes que hay pueblos que tienen sus reyes? Y les debe servir para algo, bueno, sí les sirvió, pues, con el problema del golpe de Estado que tuvieron, por lo menos los militares se le pararon al Rey, y fue un factor de estabilidad y de unidad, sí que sirve la figura del rey en España. ¿Y en Inglaterra para qué sirve? No sé, pero bueno a alguien le debe servir porque por eso lo tienen, y no lo tiene Francia, no lo tiene Italia, no lo tiene Alemania, etc., entonces, y sí lo tienen lo nórdicos, o sea, que el desarrollo histórico de las sociedades y la política se encarna en la conciencia de los pueblos, y son parte de su cultura, de ahí viene la expresión de mi tío: "si hay guarasapos es porque hay agua", si aquí hay caudillos es porque los nicaragüenses los producimos, puede ser que una élite intelectual del punto cinco por ciento, que nos hemos estudiado todas las corrientes ideológicas, filosóficas y jurídicas, pues, lleguemos con claridad a lo estúpido que es esto, pero eso no significa el sentimiento de la población de Nicaragua, que es analfabeta, que es atrasada culturalmente, intelectualmente, etc., pero tiene su cultura y su riqueza, punto, y entre esas riquezas ha adoptado el hombre fuerte como una medida de estabilidad más que los derechos y libertades de los ciudadanos, pareciera una contradicción, porque el Estado, la república y todo sale del sistema feudal, donde no se respeta al individuo y por eso sucedió la revolución francesa, porque yo ando buscando mi respeto, yo ciudadano, contra el Estado, pero, bueno, aquí, ¿cuál Estado?, es mejor un hombre fuerte porque eso va a producir estabilidad y progreso por un tiempo hasta que nos volvamos a pegar, como dice, porque las diferentes élites de poder siempre están tratando de producir el hombre fuerte, y que éste sea el que sustituya al otro. Entonces, en ese ámbito, en un Estado de Derecho, para poder llegar a ser hombre fuerte, pues, tenés que estás dispuesto a matar, a robar, y a violar todas las leyes y los derechos ciudadanos, seguro que si no estás con esa disposición no podés ser presidente de Nicaragua, porque Alemán y Ortega y Somoza y para atrás han matado o han dado la orden para que maten a alguien, han robado para poder tener suficiente plata, porque parte del caudillismo es el clientelismo también, y si no tenés qué repartir, no sos caudillo de nada, Doña Violeta y Don Enrique pudieron haber repartido, Doña Violeta sobre todo, que vino y privatizó todo el Estado, Doña Violeta pudo desarrollar otro 
partido político en base a la "piñata" del sandinismo, quitársela y dársela a un grupo, y pudo haber creado un partido fuerte, pero ella se ciñó a la idea de la república, porque Pedro Joaquín Chamorro, su marido, era un convencido de que Nicaragua volvería a ser república, él hablaba esto porque los 30 años de conservatismo cambiamos de presidente de acuerdo a la Constitución cada 5 años, sin mayores percances, hasta que el último conservador de los 30 años se quiso quedar, se quiso quedar, y no, entonces, yo eso es lo que veo, que esto de los hombres fuertes en las élites los producimos nosotros, es consecuencia de nuestra historia, y que, poco a poco, espero, que todo el desarrollo de la comunicación y la electrónica, la élite se vuelva más grande y no tan reducida, verdad, por la información, y que podamos, realmente, los nicaragüenses avanzar hacia otros derroteros y dejar nuestra cultura casi feudal de buscar a los hombres fuertes que producimos, esa es una cosa, y la otra, que necesitamos una empresa privada, un sector económico privado, más involucrado con el devenir político del país. Se ponen a hacer dinero, y se olvidan totalmente, prácticamente, de la política, y dejan a un montón de gente haciendo política que no tiene mayor afán que hacer dinero, o sea, que están hay, que no tienen mayor preocupación del Estado, del rumbo que vaya a tener el Estado, entonces, un poco menos de egoísmo, tal vez, verdad, porque esto de las élites, la sociedad política, la sociedad económica nicaragüense le pone una vela a todos los santos, ellos le dan dinero a Daniel, a Alemán, depende de la capacidad del empresario, verdad, le da medio millón a cada uno, tal vez al que le caiga mejor porque es más, le da un poquito más, pero le ponen vela a Dios y al diablo, verdad, ellos para protegerse, para que no le pueda pasar nada y que avance la cosa.

R: Aunque ha comentado esa dificultad que ha tenido Nicaragua en su desarrollo político e institucional también para acomodarse a unas reglas formales y que el juego político siempre se ha dado en un nivel informal de pactos, es decir, de recursos de poder que se reparten de facto, en este caso, entre líderes políticos fuertes, ¿no? Da la impresión de que cuando uno examina los procesos de reforma constitucional recientes, la política siempre ha estado por encima del Derecho, y han sido las élites politicas las que han ido acomodando las normas jurídicas al ejercicio del poder, y esto último que estamos viendo ya es andar sobrepasando con mucho, en el caso de esta sentencia de la Corte Suprema, que a todas luces, y desde un punto de vista jurídico estricto, tiene muchas deficiencias, tanto de forma como de contenido, siendo un abuso, lógicamente, de las facultades que tiene la Sala de lo Constitucional de la Corte Suprema, y de la capacidad que tiene un presidente para gobernar desde el Poder Judicial, y no desde la Asamblea donde están representadas todas las fuerzas políticas. Entiendo que en casi todas las entrevistas se presenta el factor histórico, el factor antropológico, el factor cultural para poder entender una sociedad democrática que termina siempre al borde del precipicio, como me decía uno de los entrevistados, hay que llegar al borde del precipicio para echarse atrás o lanzarse a la destrucción para volver a resurgir. ¿Es este el aprendizaje político dramático que le espera a Nicaragua porque el futuro hoy es incierto?

R.C.: Bueno, lo bueno de esto de que no hay avance y esta bicicleta de la que te hablaba, donde sudábamos y toda la cosa, y no íbamos a ningún lado, en esta ocasión, pues, es lo mismo, es, exactamente, lo mismo, que llegó al poder y se quiere quedar en él, que todo el mundo quiere quedarse en el poder, lo único es que los tiempos van recortándose, el ciclo político de gobierno es más pequeño, es más corto, pareciera que en Nicaragua la teoría del péndulo, que es un método para estudiar la historia se pliega a nosotros, pero con una facilidad, se puede estudiar muy bien la historia de Nicaragua, y 
entonces este péndulo que estudia la historia señala que a medida que va pasando el tiempo estos vaivenes exagerados y catastróficos de una derecha e izquierda, cada vez son menores, y cada vez ese péndulo se mueve más en el centro del reloj, y no da bandazos, entonces, desde una sociedad conservadora en 1870 hasta 1890 , que era totalmente, bueno, en ese tiempo no diríamos de derechas, pero era totalmente conservadora, conservadora, pero religiosa total, verdad, y entonces viene y nos fuimos a una Constitución zelayista, para afuera la Iglesia del Estado totalmente, verdad, y luego vinieron unos gobiernos ahí, que quisieron parar en el centro el péndulo, verdad, que no era ni un Estado totalmente religioso, ni tampoco el Estado totalmente liberal, y luego, ya vino Somoza, pues, por treinta y pico de años, que era de derechas, verdad, podemos hablar de derecha, y se volvió dictadura fascistoide, y después vino el Frente, se va lleva el péndulo totalmente al lado de la izquierda, viene Doña Violeta y lo trata de detener, por decirlo así, en el centro el péndulo, viene Alemán y se lo lleva a la derecha, viene Bolaños y lo trata de detener en el centro, y ahora se lo lleva Daniel a la izquierda, si Daniel no logra concretar sus objetivos, su reelección, etc., y aquí viene un presidente que sea tipo Violeta, Bolaños, estos que tratan de detener el péndulo a la mitad de camino, oíme, en la historia de Nicaragua podemos estudiar el subdesarrollo y todo, clarísimamente.

R: No, es verdad, que el factor de polarización ha sido muy fuerte siempre en la historia del país y es uno de sus rasgos característicos, pero también a la hora de examinar el pacto y los acuerdos que han sido "palabra mágica" en nombre de la reconciliación nacional, del diálogo, de la concertación, usted además que ha vivido de cerca los diálogos en la Asamblea habrá podido examinar todos estos vocablos que aparecian justificando, legitimando el acuerdo, y es cierto que en democracia las fuerzas politicas pactan, ¿no?, pero, en este caso, el pacto entre las fuerzas politicas ha sido un mal sustituto de un verdadero consenso nacional, o sea, nunca ha existido un consenso a propósito del rumbo del país, del concepto de nación, que se refleje también en un marco jurídico estable como es la Constitución. En el 87 quedó excluida una parte de los nicaragüenses que no estuvieron con el proyecto revolucionario, y, luego, en las sucesivas reformas ha habido oposiciones fuertes en el caso de la del 95, fue costosa, pero, al final, se generó, también por la precariedad del momento de transición, un acuerdo en nombre de ese futuro incierto de la democracia, pero en el 2000 hay una serie de fuerzas politicas y de ciudadanos que se oponen al pacto entre Ortega y Alemán, y que se oponen a las reformas constitucionales. Y hoy Daniel Ortega es un presidente que gobierna con una minoría relativa y que tiene una concentración de poder abrumadora. Entonces, ¿cómo explica usted todos estos aspectos que sorprenden al observador externo?

R.C.: Mira, esto no debe sorprender porque es que esto ha pasado constantemente, o sea, no te debe llamar a la sorpresa, pues, a mí me llama sólo a la frustración no a la sorpresa, porque es lo mismo otra vez, otra vez, ¿cómo solucionás el problema?, yo estaría más bien en la posición, una vez contaba el cuento de lo que hacía Daniel ahorita, ya pasó, si Arnoldo estuvo tentado a hacerlo, Arnoldo iba a llamar a Estado de Sitio y de Emergencia, lo que pasa es que el Ejército no se prestó, pero Arnoldo estuvo tentado a quedarse con el poder, el crear una crisis institucional, jurídica, ya sabés, esta es la jugada de póquer, estoy perdiendo, ipam!, y le pego una patada a la mesa para que se caigan las fichas, o sea, no sé cómo va a resultar, pero es mejor que perder. Estuvo tentado, entonces, yo te digo una cosa, no me preocupo tanto por estudiar otra vez por qué está Daniel ahí y todo lo demás, ¿cómo lo solucionamos?, esa es la pregunta. 
R: Sí, porque también hay una responsabilidad liberal, en el sentido de que Arnoldo Alemán pactó y abrió las puertas, en términos democráticos, al sandinismo, a través de una reforma electoral que reducía a un $35 \%$...

R.C.: Creyendo ellos que iban a hacer lo mismo que el General Somoza, vamos a tener al Frente Sandinista como el Partido Conservador, en minoría, debemos llegar a darles de comer a éstos para tenerlos en minoría y lograr que haya estabilidad, pero nosotros vamos a mandar.

\section{$R:$ ¿Por esa mayoría liberal?}

R.C.: La mayoría liberal, y esa fue la idea de ellos, pero es que con Daniel Ortega se les topó el mandado, entonces, era un partido con una mayor agilidad, fortaleza, cohesión, pequeño pero muy fuerte, y con bastantes recursos, al comienzo medio funcionó, pero en cuanto apareció Chávez y todo esto, el dinero que empezó a correr y todo lo demás desequilibró la balanza de poder a como estaba, no tenía Daniel qué repartir, a ver ¿cómo sos caudillo? Arnoldo le estaba dando un tercio, igual que los conservadores, un tercio del poder, entonces, y, probablemente, ahí, un montón de cosas que no se dicen en el pacto sólo sale a la luz pública que los Magistrados son 9, 6 son de uno y 3 del otro, pero no se miran los 500 empleos de 2000 córdobas, los 2000 empleos de 5000 córdobas, que es el Estado, que le das al contrario para que nombre a su gente, y el Partido Conservador y Somoza, eso lo dejaron, por cada tres empleados públicos, desde el que limpia, el que está en la puerta, el celador, la secretaria, de cada tres empleados dos son liberales y otro es conservador.

$R:$ ¿Y eso siempre se respetó?

R.C.: Siempre se respetó.

$R: Y$ sin embargo, se rompen las reglas del pacto, Alemán pierde también, porque él tiene el "pie flaco" de la corrupción, y Ortega tiene una preeminencia importante en el Poder Judicial. Ese es otro de los lineamientos que me interesan, cómo el Frente cuando dice: "vamos a gobernar desde abajo", empieza a ubicar a personas afines al partido dentro de la estructura institucional del Poder Judicial, desde lo Juzgados de distrito...

R.C.: Eso lo hizo porque pierde las elecciones, o sea, él ya tiene, había un panorama negro en caso de que perdiera qué iba a pasar, entonces, quedarse en el Poder Judicial, esto y lo otro, pero sólo usarlo en momentos muy críticos, verdad, en el Poder Judicial se mantuvo esto, jueces sandinistas, ya sabes, un poco trabajando en la norma, verdad, sólo cuando era una cosa crítica que significara algún daño, alguna cosa, uno lo ocupaba, y lo ocupaba y recogía el dinero.

$R:$ ¿Cómo?

R.C.: Sí, recogía el dinero, iba a donde Bayardo Arce, que era el que antes manejaba eso, para ganar juicios.

$R: ¿$ ¿Con sobornos? 
R.C.: O sea, a un miembro del partido, Bayardo Arce, ahora, es el Asesor Económico del presidente, y uno de los ex-nueve comandantes de la revolución, se suponía que tenía un juicio por varios millones de dólares, le decía: "ves, ¿me podés ayudar en esto?", "dejámelo ahí", se lo pasaba yo no sé a quien y te decía: "volvé que mañana es el juicio", entonces, recogían dinero, mientras esa situación estuvo, el Frente aceptó a Alemán el papel de minoritario, Doña Violeta era más dura, no tranzaba, no estaba negociando, no estaba comercializando, pero hubo un convenio de transición, verdad, que se hizo entre Antonio Lacayo, Humberto Ortega y el Gabinete, pues, o íbamos a tener un Beirut aquí, íbamos a dividir al país, y los de un lado y los del otro lado, ahora la decisión era ver si se hacía una transición para que el país quedara unitario y no se desglosara en dos pedazos, o en tres pedazos, qué se yo, entonces, pues que no pasara encima de los perdedores y los acabara a los sandinistas, pues.

R: Bueno, aparte de que uno de los elementos del pacto entre liberales y sandinistas, a la hora de firmar los acuerdos de paz, era mantener parte de la institucionalidad sandinista, es decir, iniciar la transformación democrática desde un Estado que durante 10 años había sido construido por el régimen del Frente Sandinista de Liberación Nacional. Hay un intento, también constante, de refundar un Estado, un intento fallido más bien, de refundar el Estado en cada régimen politico, o sea, por eso quizá el Estado se convierte en objeto de apropiación de recursos por parte de cada fuerza política que llega al poder, ¿no?, y quizá también hay una cierta concepción depredadora de los recursos públicos, y de colocar a la gente afin en el Estado, en vez de que el Estado sea una institucionalidad objetiva.

R. C.: ¿Has leído ya el libro Cultura Política de Nicaragua?

$R: N o$.

R.C.: Apuntálo porque si no, Cultura Política Nicaragüense, es de mi tío, Emilio Álvarez Montalbán, donde habla sobre la cultura del familismo, o sea, desde que llega al poder, pone a todos sus parientes, sobre todo el nepotismo, pero lo extraño de esto, y lo desconsolador es que esta fuerza que se llamó FSLN, que llegó con todo el sacrificio, el heroísmo, la bondad de dar la sangre contra el dictador, jóvenes de 20 años, de 21 años, con toda la buena voluntad, la ilusión y todo, se haya transformado en lo mismo que Somoza, así es, eso es increíble, verdad, y es la razón, te decían empresarios, porque yo fui el vocero de Eduardo Montealegre para las elecciones pasadas, no las municipales, sino las presidenciales, y te decían que había ganado Daniel, pero yo estaba en una radio, pues, las elecciones eran el 4 de noviembre, salgo de la radio y me llama un empresario y me dice: "Don Rafael, déle una oportunidad a Daniel", o sea, "dejá de atacarlo, dejá de tronarlo, no mirás que ahora tiene 60 años, ya no es el muchacho de 35 que llegó al poder", no tenía ni hijos, ahora tiene nietos, no tenía más que la camisa que andaba puesta, ahora tiene propiedades, es empresario, es esto, es lo otro, pero es que tiene una sed de poder y de autoritarismo, que no es democrático, que no le interesa Nicaragua más que en su mente, y yo creo que tiene fantasías, digo yo, porque es un egocentrismo, de una vanidad, de salir, él prefiere 500 veces salir en CNN, o ser líder internacional, tiene un sueño de ser Fidel Castro o no sé qué cosa, bueno, pero en el problema que hay internacional él se va a meter porque le fascina estar en la palestra mundial, o sea, no es un demócrata que va a llegar a gobernar su país por 5 años, hacer bien las cosas, a rendir bien las cuentas y salir de ahí para ser respetado, 
pues, no querido, porque no todo el mundo es monedita de oro para todo el mundo, verdad, pero es respetado por una sociedad, etc., ese no es el ideal de él, pues, como cualquier presidente demócrata, como debería de ser, sus sueños de opio trascienden a ser un gran líder internacional, que va a encontrar no sé qué cosa, que va a derrotar al imperialismo norteamericano y no sé, pues, no sé, realmente, pero está totalmente deformado su proceso mental, entonces, lo más interesante en Nicaragua no es qué ha pasado ni qué está pasando porque ya pasó, y esta última va a pasar, y entonces, es la misma película, la misma película, lo único es que parece que está dilatando menos, la película está dilatando menos, dilatando menos, hoy en día nadie se entiende que estábamos sentados, cómo es posible que existan durante estos dos últimos años mil rótulos de Daniel Ortega a nivel nacional, y sólo estén manchados el $10 \%$ a nivel nacional, y en las ciudades que son, Granada, pues, que es la cuna del conservatismo y estas cosas, cuando Somoza no podía tener ni rótulos porque sólo estaban en las tiendas de los que eran allegados a él, porque había que cuidar el rótulo, que ahí lo tenían, ponía Somoza un rótulo en la calle y no dilataba pero ni qué, cuando ya estaba manchado, y tenía la Guardia Nacional, con mecates, antiterrorismo, con cascos, obuses, con toda la parafernalia militar, una cosa temerosa así con los cascos militares puestos y todo lo demás, y aún así, se las ingeniaban para llenar una bolsa con tinta negra y darle ahí, hoy en día están los rótulos sin mancharse, no hay manchas, etc., ¿no?, y no haya Daniel Ortega donde voltear, donde dar porque no tiene un enemigo, entonces, no haya como justificar que si estaban 5 desempleados en una casa ahora no puede darle trabajo al otro, tiene que buscar una guerra, tiene que buscar algo que justifique que él no puede, o sea, él no puede dejar Nicaragua salir adelante, que lo que hace es dividirla y promover el conflicto, y está desesperado, entonces, esto de la no-reelección no es porque tuviera que tener seguridad ya, dos años y medio antes de las elecciones para él promulgarse, sino que se debe a que tiene un conflicto interno que todo el mundo está hablando de quien va a suceder al Comandante, porque no puede, y toda sucesión crea unas crisis y unas tensiones, inclusive, en el Vaticano, por aquél lado, que son instituciones de 2000 años, y que tiene unos métodos muy estrictos y aún así crea conflictos serios, cualquier sucesión crea conflicto, cualquiera, eso es una máxima, una, y dos, su gallinero, como no tiene enemigos, todas las gallinas están peleando, y se andan peleando en los negocios, buscando qué dinero robar y toda la cosa, entonces, él necesita, primero, quitar lo de la sucesión que él va a continuar para que nadie se esté creyendo que puede sucederlo, y segundo, para que todas las gallinas se pongan a ver al zorro que se está metiendo por una esquina y echárselo, entonces, ya la gente no lo toma por ver quien se queda al frente del partido sino para enfocarlo contra los enemigos estos, o sea, el Quijote, que como decía Cervantes, anda buscando los molinos de viento, anda montado, el líder mundial, buscando al ogro, anda buscando a los caballeros enemigos, a los delincuentes, y salvar a la Dulcinea de la cuestión, y no hay, la gente, no sé porqué el pueblo nicaragüense, que ha sido tan combativo, o está cansado, agotado, o ya maduró.

$R$ : Bueno, ese es otro aspecto, y da para otra tesis, el tema de la desmovilización social, el cierre de espacios políticos en las instituciones, como se ha advertido a través de la concentración de poder en la figura de Ortega y del Frente Sandinista en el Poder Judicial o en el Tribunal Electoral, y también en la Asamblea, donde con la oposición dividida, y gobernando a través de los resortes de los otros poderes del Estado, el Frente parece que se está saliendo con la suya, porque frente a la sentencia no cabe ningún tipo de recurso a pesar de todas las deficiencias que tenga, ¿no? De hecho, el propio gesto de las fuerzas de oposición en la Asamblea ha sido eso: un gesto que no 
parece que vaya a prosperar en que la sentencia no tenga efectividad y Ortega no se pueda presentar como candidato.

R.C.: Pero es que tener unos gobernantes que no respetan el Estado de Derecho, y que menos mal que ahora estamos usando más las leyes, si se puede hablar de desarrollo político del país, ahora estamos usando más las leyes en la contienda del poder, porque antes usábamos más las armas.

R: Bueno, definitivamente, esa es una conquista, pero eso no quiere decir que no haya déficits institucionales.

R.C.: Bueno, sí, han muerto dos o tres, y siempre de este lado, se le achacan a Daniel Ortega.

R: Bueno, aparte de las protestas por las últimas municipales con las fuerzas de choque cada vez que hay un intento de manifestación en Managua.

R.C.: Pero ya ves que Eduardo Montealegre tenía una masa enardecida de 10.000 personas, que se vinieron desde la casa de campaña de "Vamos con Eduardo" al PLC, iban para el Consejo Supremo Electoral, y él los detiene, porque a diferencia de los líderes tradicionales que ha tenido Nicaragua, él no tiene la disposición, la mentalidad de ir a lanzar a la masa para que maten a unas 10 o 15 personas, no se tiene que llevar esos 10 o esos 15 muertos en su conciencia, no sirve, no sirve, y mataron a un muchacho, le metieron un balazo en la espalda, ese es un recorrido kilométrico y ellos iban para otro lado, y ese recorrido que iba a meterse al Consejo, iba a obligar a esta Policía, que no ha actuado, disparado balas, la iba a hacer que, porque esa gente iba enardecida, o sea iban a quemar el Consejo Supremo Electoral, o sea, la norma de Nicaragua, y eso iba a producir varios muertos, o sea, y Eduardo lo sabe y lo detiene, la detiene y la dispersa.

R. ¿Qué última reflexión puede hacer en torno al futuro de su país de aquí a los dos años y medio que restan del gobierno de Ortega?, ¿cuál va a ser la posición de la oposición liberal al régimen de Ortega que parece adivinarse, según la matemática electoral, es decir, las actuales reglas del 35\% y la oposición dividida, el sentido común indica que Daniel será el presidente de Nicaragua por 5 años más? Lo cual sería grave, no tanto porque fuera a degenerar en otro conflicto armado, por el propio contexto internacional, que yo creo que sí apuraría los mecanismos de paz en una Centroamérica que ha vivido la transición democrática, aún con todas sus dificultades, Guatemala y El Salvador, que fueron países que también vivieron la grave experiencia de los conflictos armados, pero sí la polarización social, el incremento de la violencia, sí el cierre de espacios a la expresión libre de la sociedad civil, y sobre todo la crisis económica, creo que va a ser por la incertidumbre que va a generar en los inversores y en las empresas que se han instalado en el país en las dos últimas décadas, ¿no? ¿Qué reflexión haría en torno a esto?

R.C.: Más que reflexión, bueno, decía mi papá que en política tenías que ser adivino, tenés que estar constantemente en un ejercicio de decir qué va a pasar, y si la llegás a pegar en cinco cosas de cada diez que decís que va a pasar, quiere decir que sos un genio, porque el ajedrez de la política es un ajedrez pero sin reglas, o sea, el caballo, de repente, se mueve en vez de tres dos, se mueve seis uno, o lo que sea, entonces, es un 
asunto, verdad, yo me atrevo a predecir que Daniel Ortega no se va a reelegir, porque hay un comportamiento extraño en la sociedad nicaragüense, de todo lo que estamos viendo ahorita, lo único que no ha pasado es la pasividad con la que la sociedad nicaragüense y el pueblo nicaragüense ha tomado este nuevo intento, uno más, en la historia de nosotros, de ahí todo lo demás nunca le ha ganado, nunca le ha ganado a la oposición al dictador, ni con revueltas, oíme, no es asunto que una ley, que una Asamblea, no, antes se armaban, se iban a los países vecinos, le pedían a los presidentes las armas y toda la cosa, y a los seis meses, ochos meses, el Presidente que se quería quedar tenía una revuelta militar en las puertas, estamos ya en el siglo XXI, no veo yo nada de eso, hay muchas otras cosas que están cambiando, o sea, aparte de que el dictador se quiere quedar y cambia una norma constitucional para quedarse, todo eso lo hemos visto, todo eso que implementa todos los órdenes de represión, de miedo, todos esos cierres de espacios sociales, todo eso ya lo vimos, lo extraño es la pasividad del pueblo nicaragüense, porque siempre así como de este lado se rompe la ley del Estado, el pueblo sí ha retomado o han sido líderes que han tratado de hacer fracasar los planes de éstos que se quieren quedar en el poder, nunca se ha logrado, nunca se ha logrado, siempre nos han ganado, la historia siempre nos dice que nos han ganado.

\section{$R:$ ¿Han ganado quiénes?}

R.C.: Los que se quedan en el poder, luego, luego, del tiempo, pues, pierden, verdad, y todos terminan igual.

\section{R: ¿Entonces la alternativa sería una unión liberal fuerte?}

R.C.: Es que mientras con Arnoldo Alemán ahí metido no hay nada que hacer, yo era el director general de probidad en la Contraloría General de la República, y yo descubrí el enriquecimiento ilícito y él tiene unas afinidades con Daniel Ortega, hay un problema aquí, realmente, de lucha de clases, él se siente más cerca de Daniel Ortega que de otros liberales de grandes familias. Hay algún resentimiento social ahí, alguna cosa, los chicos de la oligarquía de que hablaba Daniel Ortega en su discurso. Hay algo, hay algo que él se siente más cerca, mientras Arnoldo Alemán esté inserto, metido como una cuña, dentro del ámbito de la oposición política, la va a estar dividiendo para favorecer a Daniel Ortega, él después del robo, la corrupción, y todo lo que hizo no tiene alternativa de volver al poder y si alguien puede volver al poder, que Daniel lo puede permitir para seguir en este pacto, es Alemán, o sea, que un país viable, democrático, con leyes claras, con respeto al Estado de Derecho y todas estas cosas pueden existir sin la existencia de Alemán, con la existencia de Alemán no nos asustemos, no nos asustemos, que si Daniel Ortega se siente muy, pero que muy presionado económicamente, porque no ha podido conseguir los recursos para sacar este país adelante, porque él se lanza a esta aventura de desprenderse de todas las fuerzas vivas del país, porque el petróleo llega a 150 dólares el barril, y él se siente con el poder, bueno, porque de alguna manera él comparte con Chávez, pero cuando ellos ven ahorita que se les vuelve a bajar a 50 o 60 dólares el barril le corta un poco todas las aspiraciones, a 150 dólares el barril yo no estaría hablando, haciendo conjeturas de nada, yo le diría que aquí Daniel Ortega va a ser el próximo presidente de Nicaragua, pero a 60 o 70 dólares el barril, que no les da mucho la toalla para poder suplir la energía de toda una sociedad, que la tiene diezmada, donde no hay un clima de negocio, donde lo único que vamos es más pobreza, y más pobreza, y más pobreza, pues, ya se paró, se ha reducido el turismo a unos niveles poderosos, porque en todos los países sale 
que estamos tirando bombas contra la embajada americana, y todas estas cosas, o sea, todo eso perjudica, pero, enormemente, verdad, y creo, sinceramente, que mientras esté Arnoldo Alemán, que no sé cuál va a ser ese desenlace, no vamos a poder avanzar aquí en la ruta que llevábamos con Doña Violeta, Enrique Bolaños, de avanzar hacia un Estado de Derecho donde se respete la institucionalidad. Por otro lado, si logramos, no sé, otros métodos de lucha, que no sean los violentos, tipo gandhianos, pudiéramos, pudiésemos allanar otros caminos para hacer que Nicaragua progrese, y decirle, de una vez por todas, a todos los dictadores que ya tenemos una patria nueva, o sea, o que podamos avanzar de acuerdo a las reglas de juego, que de esto se trata la democracia, ¿no?, respetar las reglas de juego, es que aquí no se respetan, y cada uno las maneja y las corta de acuerdo a sus necesidades.

\section{R: $Y$, en ese contexto, la Constitución, ¿qué función cumpliría?, ¿dejaría de ser instrumento?}

R.C.: Deja de ser instrumento y pasa a ser, realmente, el poder hacer muchos cambios, poder hacer que en vez de haber dudas sobre que nadie pueda cambiar lo de la reelección, que la Constitución vayamos a un referéndum y la aprobemos a base de referéndum, como una Constitución moderna, que sólo admita enmiendas tal vez, pequeñas modificaciones, y que esos cambios sean a través de los plesbicitos, de los referéndum, que no ha habido aquí dictador o sistema que haya querido implementarlo, que es una medida muy sana, cambiar todo el sistema electoral de elección de los diputados, yo creo que deberíamos pasar al sistema de territorialidad de los diputados, porque fijáte, que, en el caso de los alcaldes, nos ha resultado maravilloso, a veces se ha escogido hasta alcaldes sandinistas, la gente de los pueblos ha escogido alcaldes sandinistas porque consideran que la persona esa los va a ayudar, y que es una excelente persona, o sea, y votan en contra del alcalde de su partido, entonces, ha funcionado lo de la territorialidad y el conocimiento individual de la persona, entonces, si aquí en Managua son 19 diputados, bien pudiéramos hacer 19 distritos electorales para escoger a los diputados que les demos más seguimiento, porque parte raíz de todo esto es que esa Asamblea Nacional, que es donde se nombra a los Magistrados de la Corte Suprema, del Consejo Supremo Electoral, etc., no, entonces, pudiéramos ir escogiendo gente, que, realmente, tenga alguna conciencia, vergüenza, y preocupación por representar a sus electores, siempre, pues, los sistemas tienen fallas, y vamos a tener a diputados y cosas que no respondan a la patria ni a las necesidades de la sociedad, sino a sus intereses muy, muy individuales, pero, bueno, hasta hoy en día, hasta hoy en día, el sistema democrático es lo que mejor le ha funcionado a la sociedad, mientras no nazca otro Montesquieu, que nos diga un mejor sistema, este que tenemos, ahorita, democrático-republicano, pues, es el que más ha funcionado. Vamos para allá, yo creo que los nicaragüenses con Doña Violeta probamos el sabor de las leyes, de acuerdo a recursos de amparo contra Antonio Lacayo, que era Primer Ministro, deteniéndolo, haciendo que no pudiera hacer cosas, el sabor amargo del que ostenta el poder, de sentir el simple ciudadano que lo puede detener, la alegría de la ciudadanía del valor individual, de que mi voto vale, lo volvimos a sentir con Bolaños, se perdió con Alemán, volvió todo lo de la coima, la corrupción, y la cosa que ya la hemos vivido, y ahora, pues, regresamos, si volvemos, si Daniel no logra, no logra, con todo ese poder que usted está sintiendo aquí en Nicaragua, pues, que tiene, real, de los hilos del poder, verdad, pero si esta sociedad que está callada, que vos dirías que es indiferente, pero no, hay una impresión de una señora que la entrevistan en el Canal de TV y le dice: "¿y 
usted qué piensa de todas estas reformas?”, y dice ella: “y para qué se quiere quedar otros 5 años si no ha hecho nada?". 
ENTREVISTA $16^{23}$ :

Nombre del entrevistado: Dña. Elvira Cuadra.

Cargo actual: Investigadora del Centro de Investigaciones de la Comunicación (CINCO).

Fecha de realización de la entrevista: Managua, 5 de noviembre de 2009.

Lugar: Centro de Investigaciones de la Comunicación (CINCO).

Duración estimada: 58 minutos.

\section{TEXTO - Transcripción 16:}

\section{$R$ : ¿Cuál sería tu visión sobre el los procesos de cambio constitucional experimentados en Nicaragua en el marco de transición a la democracia?}

E.C.: Bueno, nosotros en el análisis que hemos desarrollado, digamos, tenemos una especie de hipótesis que hemos venido verificando en el tiempo en relación con las reformas constitucionales, en el año 87 se elaboró una Constitución bastante moderna, que recogía bastante una especie de acuerdo, o de consenso, verdad, fue consultada ampliamente y era una buena Constitución, verdad, respondía un poco a los intereses del proyecto revolucionario sandinista de los ochenta, pero aún así era una buena Constitución. Se hizo un buen ejercicio para su elaboración, pero resulta que en el noventa, con el cambio que tuvo el país, que no fue nada más un cambio político, sino que fue un cambio mucho más profundo, verdad, y que iba más allá de un cambio en la administración de gobierno, sino que era un cambio completo del proyecto político, verdad, era pasar de un gobierno revolucionario a pasar a un gobierno más de corte democrático-liberal, verdad, entonces allí hay un cambio fuerte, verdad, y eso implica que la institucionalidad que el país tenía y el marco jurídico, como parte de esa institucionalidad, no correspondía necesariamente, no coincidía con este nuevo proyecto y con el tipo de régimen que se estaba arrancando en esos momentos, correspondía más con el proyecto de la revolución sandinista. Entonces, había que hacer un ajuste de toda la institucionalidad para conformar este nuevo régimen, verdad. El problema es que las fuerzas políticas del país no estaban listas para ese cambio tan fuerte que íbamos a tener, y los primeros años del noventa fueron años de constante lucha tratando de establecer una correlación de fuerzas que le permitiera a determinado actor político, verdad, hegemonizar el proceso de transición y el proceso de cambio que se estaba realizando, no, entonces prácticamente hasta el año 95, que fue la primera reforma constitucional, no estaba claro en el panorama quién era el actor que efectivamente iba a liderar ese proceso de transición, había mucho movimiento, estaba, por un lado, la UNO, que ya se había escindido entre los grupos que manejaban el gobierno, por ejemplo, alrededor de Antonio Lacayo y la presidenta Chamorro, verdad, y los que estaban en el parlamento, que estaban alrededor de Alfredo César y algunos otros más, y que tenían posiciones divergentes en relación al rumbo del país, a cómo manejar la relación con el Frente Sandinista, a cómo manejar todo el proceso de reconstrucción de la institucionalidad, etc., y del otro lado, estaba el Frente Sandinista como partido de oposición, partido fuerte, verdad, y que tenía la disposición de no permitir que lo desalojaran de otros espacios de poder, entonces, había una lucha fuerte, dentro del Frente, el Frente no era

\footnotetext{
23 Entrevista que señala interesantes claves de análisis sobre los cambios políticos y constitucionales de la democracia nicaragüense desde 1990, así como la selección de las variables explicativas, implícitas en el proceso objeto de estudio.
} 
monolítico, sino que tenía también diferentes grupos, entonces en esos primeros años el Frente no era monolítico también había diferentes puntos de vista en relación a cómo y cuál iba a ser el rol del partido en este proceso de transición, cómo debería de ser la relación con el gobierno, dentro del parlamento, etc., y eso fue lo que produjo las diferentes escisiones o la salida de la disidencia dentro del Frente, pero bueno, vamos al tema de las reformas constitucionales, verdad, y el punto fundamental es que no, no había en el país una institucionalidad, que, realmente, respondiera a las necesidades de esta nueva situación política, verdad, primero, porque el país estaba saliendo de una guerra, segundo, porque había instituciones que estaban diseñadas en función del proyecto sandinista y ahora era otra cosa, y en tercer lugar, porque también uno de los cambios más importantes fue el cambio en el modelo económico del país, y había que adaptar las instituciones para que funcionara de acuerdo a este modelo económico y al reto que se le estaba planteando a Nicaragua de integrarse al proceso de globalización en el cual íbamos rezagados respecto a otros países de Latinoamérica, verdad. Entonces, era una cosa grande, fuerte, $\mathrm{y}$, este, y no era fácil de manejar, y en medio estaban las pugnas de poder, entonces, la idea que había en un sector, digamos, de la derecha, por llamarle de alguna manera, verdad, de centro-derecha más bien, Toño Lacayo podía ubicarse ahí como el polo hegemónico de la transición, y la primera reforma constitucional lleva, precisamente, a tratar de frenar esas intenciones, porque lo que planteaba Toño Lacayo era ya no con la figura de Doña Violeta, pero con él, como presidente, extender, verdad, su control sobre la administración de gobierno, y seguir con el proceso que ya se había arrancado de cambios económicos, etc., entonces, en ese contexto, hay una negociación entre el Frente Sandinista y las otras fuerzas parlamentarias y se logra empujar una reforma constitucional. Esa reforma constitucional, el nudo de la reforma constitucional tiene dos puntos importantes: uno, abrir la puerta para la formulación y para legalizar una serie de decisiones que se habían tomado ya y que se tenían que tomar en el ámbito económico para empujar las reformas y el programa de ajuste estructural, que se estaba desarrollando en el país, entonces, uno de los objetivos principales era eso. Esa primera reforma constitucional cambia el modelo de Estado del país, verdad, para darle la forma de un Estado que permita tomar todas esas decisiones y hacer todos esos cambios en lo económico, pero además trata de balancear un poco los poderes, el equilibrio entre los poderes, particularmente, trata de limitar las facultades o los privilegios, digamos, del Ejecutivo, porque lo que quería era impedir, verdad, que Antonio Lacayo, con nombre y apellidos, una persona en particular, primero, que se pudiera postular como candidato a la presidencia, y, segundo, que en el caso de que llegara a ganar las elecciones que pudiera administrar el gobierno como lo había hecho Doña Violeta, pues, porque, según los especialistas, esa Constitución tenía, o el régimen que definía esa Constitución era de corte presidencial, verdad, entonces, se trató de balancear un poco, ese fue el primer conjunto de cambios con las reformas constitucionales, y luego durante la administración Alemán y la administración de Bolaños las reformas constitucionales que se hicieron apuntaron más bien a tratar de cambiar esa relación de poderes en el Estado, verdad, ya no tocaban el ámbito económico, sino que tocaban toda la parte, digamos, política, y siempre la intención que tenían era la de limitar aún más, verdad, las facultades y los privilegios del Ejecutivo y esa es la tónica que ha marcado las reformas constitucionales hasta el día de hoy. Y esa es la hipótesis que nosotros sostenemos, cuando uno revisa a qué apuntan las diferentes reformas, qué aspectos tocan, uno ve más o menos cuál es el sentido que tienen, verdad, y en el caso de lo que se intentaba en esta oportunidad, lo que se quería era revertir esa situación y, entonces, era devolver y concentrar más poder en la figura del Ejecutivo, pero como eso no se hizo a través de una reforma 
constitucional, entonces, se decidió resolver a través de la sentencia de la Corte, pues, permitiendo una reelección del presidente, verdad, o en todo caso, que pueda correr nuevamente como candidato, pero, entonces, la intención en el fondo es esa, devolver facultades y poderes al Ejecutivo para deshacer lo que habían hecho las reformas constitucionales, digamos, entre el 95 y el 2005, más o menos.

R: La primera gran reforma, que es, un poco, la que sostiene su legitimidad en la necesidad histórica de afrontar un cambio constitucional importante es la del 95. También hubo un intenso debate sobre si se hacía una reforma parcial o una reforma total a la Constitución, y en la Asamblea se da un verdadero enfrentamiento entre las distintas fuerzas políticas bajo el paraguas muy debilitado de la presidenta Doña Violeta, que además es una mujer que carece del apoyo partidario, es decir, que pierde el apoyo de su coalición gubernamental prácticamente a las pocas de semanas de llegar a la presidencia, ¿no? ¿Cómo se vivieron esos años de incertidumbre política gobernando con una Constitución que fue creada por un régimen revolucionario, y sin un acuerdo o un consenso constitucional serio sobre qué habría que reformar o bien crear un texto nuevo convocando nuevas elecciones? El argumento que yo he escuchado hasta el momento, al menos en la entrevista con Luís Humberto Guzmán, es que el pacto era tan débil, el pacto entre las fuerzas políticas, la situación era tan delicada por la propia cercanía de los procesos de paz, por la memoria de la guerra, porque aún no se habian desmovilizado todos los grupos armados, que no se podía tampoco someter el proceso constitucional a un sentido muy estricto de lo que debería haber sido, es decir, convocar una nueva Asamblea Constituyente y hacer una nueva Constitución para dar pie también a todos los actores que quedaron fuera de la Constitución del 87, que no tuvo toda la legitimidad que debería, porque había una parte de los nicaragüenses que no se identificaban con el proyecto revolucionario, ¿no?

E.C.: Así es, había gente que en ese momento no reconocía como legítima la Constitución del 87, verdad, y había quienes querían que se reformara y vieron bien que se reformara en el 95. Pero, evidentemente, esperaban una reforma más de fondo en el sentido político, y no una reforma que tenía o que tuvo en ese momento como propósito o aparentemente, verdad, al menos lo que se conoce públicamente, era que la intención era frenar la candidatura, la posible candidatura de Antonio Lacayo, entonces, redujo a eso, pero, en realidad, las reformas fueron un poco más al fondo, y, bueno, desde el pragmatismo de los políticos, ellos argumentan porqué el proceso transcurrió como transcurrió, como ocurrió, verdad, pero la verdad es que esos conflictos en la correlación de fuerzas se podían haber resuelto sin tocar la Constitución, verdad, al menos mi punto de vista es ese, que no había necesidad de tocar la Constitución.

\section{R: ¿La Constitución del 87?, ¿se podía gobernar democráticamente con la Constitución} del 87 ?

\section{E.C.: Sí, yo pienso que sí.}

R: A pesar de las enormes facultades de que disponía el Ejecutivo, en términos fiscales, en su posibilidad de emitir decretos, intervenir en la aprobación del presupuesto, o el tema de la reelección, que no estaba bien resuelto en el texto de la Constitución del 87.

E.C.: Yo pienso que sí se podía, se podía si, este, las condiciones de los actores, el nivel de desarrollo de los actores, sobre todo de los partidos que estaban en el parlamento, 
hubiese sido diferente, pero lo que nos ha demostrado también todo este proceso político es que desde el 95 hasta el día de hoy las reformas constitucionales, en realidad, han sido moneda de cambio de negociaciones políticas, verdad, y negociaciones políticas cerradas entre élites y que no representan necesariamente intereses nacionales, en el mejor de los casos representan intereses partidarios, para no hablar de intereses estrictamente personales, que es un caso más grave, pues, verdad, y se ha utilizado, se ha desvirtuado el valor de la Constitución, verdad, con esas negociaciones, por ejemplo, durante el período Bolaños se empujaron una serie de reformas a la Constitución, que el único sentido que tenían era aislar completamente y restarle todas las facultades al Ejecutivo sin pensar en las consecuencias que eso podía tener más adelante para el balance y el equilibrio entre los poderes del Estado, verdad, fue una jugada muy coyuntural que tocó un instrumento que tiene un carácter estratégico, pues, fundamental para el país, para la nación y para el Estado mismo, verdad. Entonces, si es cierto que la institucionalidad en ese momento respondía a otro proyecto, pero las reformas constitucionales no se han hecho necesariamente pensando en reforzar o en construir una institucionalidad para un nuevo régimen democrático, ese es el punto, creo yo.

R: Esa ha sido la coartada que ha servido a las élites políticas para justificar el constante cambio, porque además la palabra "gobernabilidad", y "concertación nacional", y "diálogo", incluso la palabra "pacto", que ha resultado tan desvirtuada después del pacto entre Ortega y Alemán, y que es común a la historia constitucional del país, porque siempre ha habido pactos politicos que preceden a reformas constitucionales a lo largo de la historia política, y jurídica también, de la nación desde su independencia.

E.C.: Sí, así es, y, de hecho, después del pacto que se comenzó a gestar entre Alemán y Ortega en el 98 hubo reformas a las Constitución y hubo reformas a una ley fundamental también como es la ley electoral, verdad, y eso, todas esas reformas han cambiado aspectos importantes del régimen político del país, de tal manera que ahora, pues, en realidad, no sabemos, este, como está armado, porque, además, como ha sido desvirtuado el valor de la Constitución, entonces, fácilmente se convierte en moneda de cambio, pues, en instrumento de transacción o de negociación política y se utilizan procedimientos, este, de dudosa legalidad y legitimidad, verdad, para modificar la Constitución.

R: Piensa que en el caso del pacto entre Ortega y Alemán de 2000, he oído que algún entrevistado menciona esta segunda reforma como una especie de "contrarreforma", es decir, de dar marcha atrás respecto al espíritu de consolidación democrática que alentó, o, por lo menos, legitimó la reforma del 95, que sí, técnicamente, en el sentido jurídico, es una reforma buena, positiva, no hay elementos, digamos, que evolucionen negativamente en lo que respecta a la construcción de la democracia en Nicaragua, ¿no? Pero la del año 2000 sí representa un punto de inflexión importante, que se consolida posteriormente con ese pacto en 2004 entre Ortega y Alemán frente al presidente Bolaños, ¿no?, para debilitar aún más al Ejecutivo, y que además abre las puertas a la elección de Ortega y, bueno, toda esta evolución reciente de concentración de poder que se está dando. ¿Cómo ve esa comparación entre la reforma del 95 y la del 2000 ?

E.C.: Sí, bueno, si ya en el 87 la Constitución que se aprobó era buena, la reforma del 95 no desvirtuaba tanto, verdad, no, no, no cambiaba, aparte del modelo de Estado que 
se estaba, este, redefiniendo en ese momento, la reforma no, no afectaba, digamos, tanto el balance de poder. Pero las reformas posteriores, realmente, yo pienso que no tienen razón de ser, si alguna reforma era legítima y tenía validez era la reforma del 95, pero las posteriores no, y creo que no tienen, este, justificación, ni en términos políticos, ni en términos, este, digamos, de las instituciones, del desarrollo o de la fortaleza de las instituciones democráticas, no han servido para esos propósitos, sino, en realidad, para todo lo contrario. Por eso te decía, han desvirtuado a la Constitución como el pilar fundamental de organización de esta sociedad y de definición del Estado, verdad, pero además la han desvirtuado porque por cualquier motivo, deciden reformarla y la reforman utilizando cualquier tipo de procedimiento, verdad, sin tomar en cuenta las consecuencias que eso tiene, y si realmente eso se corresponde con una necesidad del país, con una necesidad de la maduración del proceso político e institucional que lleva este país, etc., no, no tiene que ver con eso, tiene que ver con intereses a veces muy coyunturales y muy específicos de partidos o de personas, pues, verdad, y ese es el caso, por ejemplo, de las reformas en el período de Bolaños, que te mencionaba antes, y que tenían como único, único propósito hacerle sentir a Bolaños que estaba solo, que no tenía fuerza partidaria, que no tenía posibilidades, este, de maniobra en el parlamento, y que o negociaba con el PLC o negociaba con el Frente para poder terminar su período de gobierno, es decir, que ese fue un propósito muy, muy, este, cómo te diría yo, para no calificarlo mal, o sea, no tiene el nivel de importancia y de significación como para ir a reformar la Constitución, verdad, la Constitución no se reforma por nada, no se reforma por esos intereses, por esos objetivos, se reforma por, este, aspectos fundamentales, cuando hay una necesidad realmente importante, verdad, pero no la había, además que todos esos procesos, todas esas reformas, aunque el procedimiento establece obligadamente consulta ciudadana ninguno de esos procesos ha incluido la consulta ciudadana, entonces, han venido perdiendo legitimidad, también, frente a la ciudadanía, entonces, aquí, si vos le preguntás casi a cualquier ciudadano qué valor tiene para él la Constitución te va a decir que ninguno, porque aquí hacen lo que se les antoja con la Constitución, la Constitución existe pero no tiene ninguna, eh...

\section{R: Ningún valor o supremacía como Ley Fundamental.}

\section{E.C.: Así es.}

R.: Por otra parte, esa flexibilización del procedimiento de reforma al que hiciste referencia desde el principio también ha supuesto la creación de instrumentos jurídicos polémicos, como el caso de las Leyes Marco, ¿no? Realmente, suspendían en el tiempo, congelando la aplicación de las normas constitucionales reformadas hasta el próximo gobierno si quería o no aceptar los cambios constitucionales, entonces, da la impresión propia de que en Nicaragua la política siempre ha estado por encima del Derecho, es decir, de la Constitución. La política, me refiero a la política convencional, a élites que son periódicamente elegidas, en vez de ellas obedecer a la Constitución, que tiene una vocación de permanencia, de atemporalidad, y que, normalmente, siempre tiene procedimientos rígidos, que, además, la propia Constitución nicaragüense contempla, otra cosa es que las élites políticas no hayan respetado ese procedimiento, pero la propia Constitución sí lo señala, ¿no?, que se debe cambiar en función de determinadas cuestiones y hay unas cláusulas que no pueden ser revisadas, pero desde el primer momento se revisó el procedimiento mismo de reforma constitucional. 
E.C.: Sí, porque lo que se ha hecho, en estos casos, es que como son juegos de correlación de fuerzas, verdad, los que motivan esas reformas constitucionales, entonces, muchas veces no tienen, cómo decírtelo en un lenguaje muy simple, no tienen todas las cartas en la mano y entonces lo que hacen es usar recursos y subterfugios legales para darle algún sentido de legitimidad a eso, porque no tienen ni legitimidad política ni legitimidad social, verdad, entonces lo que hacen es recubrir el procedimiento y la acción con un velo de cierta legalidad, verdad, pero mira, hay una cosa interesante, y es que, a raíz del pacto de transición en el año 90, hay como un acuerdo tácito, implícito más bien, un acuerdo implícito entre las diferentes fuerzas del país, las fuerzas políticas, verdad, de no romper, definitivamente, qué diríamos, el orden constitucional, de no romperlo, verdad, hemos llegado a un momento donde ha estado punto, incluso se ha hablado en ciertas crisis, por ejemplo, durante el período de Bolaños, en ciertas crisis, de golpe de Estado, de llamar al Ejército, de etc., verdad, pero no llegan a dar el paso, y eso es lo que les ha limitado, de alguna manera, y los ha obligado a tratar de recubrir de legalidad muchas decisiones y muchas acciones, verdad, que son ilegítimas, y que están fuera del procedimiento establecido, etc., y ese ha sido el caso de las reformas constitucionales que estás viendo.

R: Lo más peligroso es quizás sentar el precedente que luego se repite, porque la primera Ley Marco tuvo su réplica en 2005, y luego además su réplica en 2007, cuando se reforma la propia Ley Marco aplazando un año su entrada en vigor, que tampoco ha servido para nada, porque no se ha ratificado a ningún ministro, embajador o alto funcionario en el actual gobierno de Ortega.

E.C.: Sí, sí, entonces se ha distorsionado todo el valor y la jerarquía de los instrumentos jurídicos y la institucionalidad, verdad, y se ha distorsionado también el poder de las diferentes instituciones o poderes del Estado, porque entonces, ya no sabes realmente cuál es el verdadero rol de la Corte Suprema de Justicia, cuál es el verdadero papel emanado del parlamento, y del Ejecutivo, que son los tres principales entre los cuatro que hay definidos aquí. Ya no sabes quién es, en realidad, quien tiene que marcar la pauta o que sentar, este, o que establecer, verdad, la norma jurídica, pues, se ha trastocado, completamente, todo eso, todos los procedimientos y el rol de cada uno de ellos, de los poderes del Estado. Sí, yo creo que si me preguntan, yo creo que este país, en realidad, necesita una nueva Constitución, pero no con estos actores políticos, ni con estos partidos políticos, porque se necesita rehacer y revalorizar totalmente ese marco jurídico, ese instrumento y también los procedimientos y las maneras de hacer política, algo tenemos que hacer que vuelva a legitimar la Constitución.

$R: Y$ en relación a ello, aunque el hilo conductor de las reformas, bueno, en términos del discurso legitimador, ha sido el de conferir mayores facultades a la Asamblea Nacional en detrimento del Ejecutivo presidencial fuerte que consolidaba la Constitución del 87, realmente, fue un traspaso del poder del presidente al poder de las cúpulas de los partidos, y después además Alemán se convierte en el socio minoritario después del pacto con Ortega, y vemos el poder importante acumulado por el Frente. ¿Ha sabido el Frente Sandinista durante 16 años de oposición hacer un aprendizaje institucional del control de los principales órganos del Estado? Pienso, fundamentalmente, en el Poder Judicial, eso es casi otra tesis doctoral, ¿no? Lo he oído en otras entrevistas, cuando dicen: "vamos a aprender a gobernar desde abajo", y como el Frente va copando los juzgados de distrito, apoyándose también en un vacio legal, porque la Ley del Poder Judicial es relativamente reciente, tampoco tiene total 
aplicación, hay una serie de irregularidades también en ese aspecto, pero, lo cierto es que el Frente Sandinista ha iniciado una secuencia de concentración de poder cuyos resultados son los que estamos viviendo actualmente.

E.C.: Mira yo creo que esa frase de "gobernar desde abajo" muchos creen que fue una frase populista, verdad, agitadora en su momento, pero no, era simplemente la afirmación de una estrategia que se comenzó a desarrollar desde entonces, y una estrategia que tenía como pilar fundamental el control partidario del Frente Sandinista de las principales instituciones y poderes del Estado, y, entonces, efectivamente, cuando uno ve el recorrido de esas instituciones ha visto como eso ha pasado desde formar profesionalmente a cuadros del Frente y ubicarlos en cargos o en puestos estratégicos, en todos los niveles y en todas las instituciones del Estado, particularmente, la administración de justicia y la Corte Suprema, y el Consejo Supremo Electoral. El parlamento no, porque el parlamento se mueve más, un poco, al calor de las elecciones y quienes son los diputados que son elegidos, si o no, verdad, esos dos, pero sobre todo el Poder Judicial, la administración de justicia, eso es claro que fue una estrategia, estrategia de verdad, de mediano y largo plazo que se trazó el Frente y que está teniendo sus resultados en este momento, porque es obvio que los Magistrados que están sentados ahí por el Frente Sandinista están haciendo el trabajo que el partido considera que es necesario, pues.

R: Pero también hay una responsabilidad de los liberales en esta situación actual, quiero decir que cuando yo le pregunto a alguno de los diputados de si hemos llegado a una situación de cuasi-dictadura, que es una frase muy fuerte, los medios de comunicación son muy críticos, pero si es cierto que hay cierre de espacios políticos en este país, aunque haya un clima de normalidad, no se puede comparar con los años 50 ni mucho menos con la dictadura somocista, pero sí algunos de los entrevistados, y muchos de ellos personas inteligentes y cultas, que conocen muy bien la historia de su pais, señalan que hay paralelismos históricos entre la figura actual de Ortega y el propio Somoza, respecto a la concentración de poder, al vínculo familiar que hay en el ejercicio de la presidencia, incluso en el propio enriquecimiento material en la utilización del Estado casi como empresa, ¿no?, con todos los fondos económicos que están llegando de Venezuela y que no están sujetos a una fiscalización. ¿Crees que en este país la historia dramáticamente se repite? Aunque yo creo que el contexto internacional es diferente y debe haber una aprendizaje en la memoria histórica de los nicaragüenses, que ya pasaron por una revolución, que la democracia costó muy cara en términos de personas fallecidas, ¿no?, del dolor, y de la sangre derramada, veo, por ejemplo, la experiencia de la guerra civil en mi país, salvando las distancias, un hecho dramático que desemboca después de cuarenta años de dictadura en una democracia, pero todo el mundo tiene claro que no volvemos atrás, ¿no? ¿Cómo ve todo esto en el caso de Nicaragua?

E.C.: Mira yo creo que hay algunas similitudes, pero hay que tener en cuenta que hay que salvar los contextos, son contextos diferentes, verdad, y hay similitudes entre una época y otra como hay similitudes entre un régimen autoritario en Nicaragua y un régimen autoritario en cualquier otro país del mundo, verdad, ¿por qué?, porque el tipo de comportamiento en un régimen de esa naturaleza, obviamente, es similar, y eso es lo que te permite hacer las comparaciones. En el caso de Nicaragua, ¿qué es lo que pasa?, la dictadura somocista está en el pasado reciente de este país, yo te digo, yo, yo, yo ya voy por la cuarta época, yo conocí la época de la dictadura somocista, yo ví los jeeps de 
la Guardia por las calles, yo viví todo el tiempo de las huelgas estudiantiles y la guerra y todo eso, o sea, yo lo ví, verdad, y sé cuales eran las características de ese régimen en ese momento. Viví también la época de la revolución, y luego la etapa de los noventa de la transición y ahora este regreso del Frente al poder, verdad, yo te digo hay muchas cosas son muy parecidas, solo que este es, es la etapa temprana de lo que se vivió en el tiempo de la dictadura somocista, y hay, yo creo, que una diferencia importante que tiene que ver con el control de las Fuerzas Armadas, estamos hablando del Ejército y de la Policía, verdad, yo creo que esa es una diferencia muy importante. La otra diferencia es que las condiciones económicas durante el régimen de Somoza eran diferentes del contexto económico actual al que se está prestando el gobierno de Ortega, entonces, por mucho que se tomen medidas o disposiciones autoritarias, que cierren los espacios, que traten de controlar a la ciudadanía, verdad, el descontento, etc., hay situaciones diferentes. Y lo otro es que el nivel de organización y de maduración de la sociedad nicaragüense no es el mismo que había durante la dictadura somocista, ahora hay más actores, hay actores más maduros que han hecho todo un camino de aprendizaje en un recorrido que ha sido duro, verdad, y que ya lleva tiempo andando. Lo otro importante también es que ha habido cambios en la cultura política y yo sostengo a partir de lo que hemos visto en las investigaciones nuestras, yo sostengo la tesis de que aquí hay dos culturas políticas, una cultura política tradicional y autoritaria que prevalece sobre todo en las élites económicas y políticas, y una cultura política más democrática que se ha estado extendiendo entre la ciudadanía, entre la población, por eso es que cuando vos ves las encuestas de opinión, vos ves la enorme falta de confianza y la poca legitimidad de las instituciones y de los actores políticos con respecto a la ciudadanía. La gente lo rechaza porque producto de todo este proceso la gente ha tenido un proceso en el cual ha venido asumiendo, apropiándose de una serie de valores democráticos que lo hacen distanciarse de los políticos, ah, bueno, que en períodos de campaña electoral y que a la hora de votar hay cierto tipo de resultados, sí, pero eso tiene que ver con cómo está diseñado el sistema electoral en este país, y no, necesariamente, con la cultura política de los ciudadanos, en las élites todavía prevalecen prácticas e ideas autoritarias sobre la política, pues, en general, verdad, y eso es una diferencia grande también.

R: Pero también el conflicto entre los poderes del Estado ha estado presente como factor de ingobernabilidad y, de hecho, si me gustaría, porque es una de las líneas de investigación tuyas, que pudieras comentar, tanto entre el Ejecutivo y el Legislativo, en el caso de las reformas constitucionales es claro, ¿no?, como siempre la Presidencia de la República no ha aceptado primero en el 95 la propuesta de reforma elaborada por la Asamblea; luego, en el segundo caso, no hay conflicto porque Ortega y Alemán deciden pactar y esa ya es una transacción, es una negociación política de los cambios constitucionales que ambos consideran, el uno como principal fuerza de la oposición, con bancada dominante en la Asamblea, dominante, me refiero en cuanto oposición, como grupo mayoritario, y Alemán porque tiene un control importante de su partido y no gobierna de la forma tan débil como lo había hecho Violeta Chamorro o después Enrique Bolaños, que carecía de ese apoyo partidario. Y, actualmente, Ortega, controlando, a pesar de esa minoría relativa que lo apoyó, y aunque cuenta con una bancada también importante en la Asamblea, y esa división del liberalismo, que tampoco da, digamos, oxígeno para que, en el caso de una futura elección, pudiera ganar un candidato liberal, ¿no?, en esto también han pensado cuando han planteado esta sentencia. ¿Cómo estima estos conflictos entre los poderes del Estado y, que, nuevamente, se están operando ahora entre la Asamblea y el Poder Judicial, que se ha apropiado de una facultad que no le corresponde como la de reformar la Constitución? 
E.C.: Mira, fíjate que yo creo que esos enfrentamientos entre los poderes del Estado han sido la consecuencia también de los enfrentamientos o de los conflictos entre las fuerzas políticas, verdad, por liderar, este, los procesos y por controlar cuotas de poder, verdad. El problema es que igual que la Constitución los poderes y las instituciones del Estado se han desvirtuado con esos conflictos y con esa confrontación de poderes, porque como te decía antes se ha desdibujado completamente, se ha distorsionado el rol y el papel que cada uno de los poderes tiene, verdad, y el famoso equilibrio de poderes que debería de haber para que ninguno de ellos se extralimite de sus funciones, verdad, y pase por encima de la ley y de lo que está establecido. Yo creo que si ya teníamos instituciones débiles al inicio de los noventa, verdad, esto ha deslegitimado, o ha debilitado mucho más a las instituciones, pero, es decir, la percepción que hay, por ejemplo, sobre la Corte Suprema, sobre todo el Poder Judicial, la administración de justicia, es una percepción, este, funesta, pues, para todos los ciudadanos, verdad. Nadie siente el menor respeto ni confianza en un poder que es fundamental, verdad, y que en casi todos los países independientemente de cómo se muevan los juegos políticos en cada lugar tiene una cierta autoridad y respeto. $\mathrm{Y}$ en los diputados en el parlamento tampoco. No hay ningún nivel de confianza, verdad, porque también han sido instrumentos de estos juegos políticos y han respondido más a esos intereses partidarios y personales que a una agenda de país, no han respondido a eso. Entonces, incluso hasta la aprobación o la formulación de alguna ley que a veces no tiene aparentemente nada que ver, allí se ha usado eso como instrumento de negociación y de re-posicionamiento en el parlamento, etc., entonces, yo creo que aparte de que necesitamos una nueva Constitución, aquí prácticamente hay que refundar a todas las instituciones del Estado, a los poderes del Estado, creo que es un trabajo que está pendiente, es grande, tiene un gran reto el país, porque es tratar de rehacer instituciones, y de rehacer, no es el asunto de la re-ingeniería administrativa, no, no, no es eso, es rehacer en términos de confianza y de legitimidad y la imagen que tiene frente a los ciudadanos y el verdadero rol que deben mover esas instituciones en un régimen político.

R: Porque aquí el diseño institucional, y, fundamentalmente, el que a mí me interesa, a través del cambio en la Constitución, está sujeto siempre a intereses partidarios o intereses de las cúpulas políticas, o intereses de las personalidades políticas fuertes del partido. Y ya para terminar, aunque antes hizo una referencia, es verdad que los últimos procesos electorales de 2008 suponen una pérdida de legitimidad fuerte del Consejo Supremo Electoral, ¿no?, que hasta el momento había tenido, había funcionado con relativa eficiencia, incluso legitimidad, al menos asi lo señalaba el director de IPADE, y que salvo alguna pequeña irregularidad en algún proceso con carencias técnicas, el resto habian sido procesos limpios.

E.C.: Sí, era aceptable, era aceptable, no había generado el nivel de impugnación que tiene ahora, pues.

R: Y también me decía la propia Dora María Téllez, que, en este país, la reelección va acompañada siempre de fraude electoral, ¿no?, ¿estamos ante la "primera piedra” del fraude del 2011 que es cuando se celebran las próximas elecciones presidenciales para que Ortega tenga otros cinco años de gobierno?, ¿cómo ve el futuro de su país ante este año y medio difícil de coyuntura? La Asamblea ahora está tomando algunas medidas para, desde la propia institucionalidad democrática, poner freno a la decisión de la Corte, y yo leo en la prensa que, bueno, el Magistrado Solís decía que la decisión de la Corte no tiene vuelta atrás. Haciendo un poco, no sé si de "política-ficción”, porque en 
este país las cosas cambian tan rápido que es muy difícil, realmente, anticipar la incertidumbre, yo no sé cómo los propios actores políticos se manejan, porque aquí puede suceder casi cualquier cosa en un período de tiempo cortísimo.

E.C.: Sí, pero las cosas que suceden tienen sentido y tienen un rumbo, lo que pasa es que en la vorágine, verdad, y en la forma en que se mueven, a veces para el ciudadano común no tienen mucha lógica y son oscuras, verdad, y dicen pero ¿qué locuras están haciendo?, pero tienen un sentido y tienen una dirección, verdad, entonces, lo que nosotros dijimos a inicio del 2007 se ha venido verificando y se ha venido cumpliendo con el tiempo. Nosotros dijimos el régimen de Ortega va a apuntar a un cambio profundo del régimen político, y tuvimos discusiones fuertes con los equipos de investigación de otros centros con los que trabajábamos analizando este tema, $\mathrm{y}$, efectivamente, ese es el rumbo que llevan. Todas las acciones apuntan en esa dirección, porque ellos necesitan cambiar el régimen político para poder mantenerse en la administración del gobierno, en el poder, pues, verdad, como dice la gente, entonces, yo no dudo que van a usar todos sus recursos en todas las instituciones y en todos los poderes del Estado, en función de ese objetivo, verdad, incluido el parlamento. Luego dijimos que iba a haber continuidad en las políticas económicas del modelo económico, y efectivamente, ¿por qué?, porque eso es una condición necesaria para poder obtener poder económico, que es el que se está constituyendo alrededor de los negocios del circulo gobernante, verdad, y también dijimos que iba a modificarse sustantivamente la relación entre el gobierno y la sociedad, o la ciudadanía, y también eso es lo que se ha venido operando a través de los cambios en el ejercicio de ciertos derechos y libertades civiles, en la relación con los diferentes actores como los medios de comunicación, las organizaciones de la sociedad civil, etc., etc., verdad, yo creo que el pacto entre Alemán y Ortega es tan fuerte que va a ser difícil que en el parlamento se pueda revertir esta decisión de la Corte.

\section{R: Eso es muy grave.}

E.C.: Eso es gravísimo, eso es gravísimo, y no me cabe duda, verdad, que en las próximas elecciones si Daniel Ortega corre como candidato él va a ser el ganador, porque el sistema electoral está montado de tal manera que los resultados están anticipados, pero además, con lo que pasó en el 2008 está demostrado que ellos están dispuestos a cometer fraude si es necesario para obtener los resultados que ellos esperan, verdad, entonces, yo no tengo esperanzas, digamos, puestas en términos de revertir esa tendencia pensando en los actores del sistema político, pues, partidos políticos, instituciones, poderes del Estado. Yo creo que, en todo caso, la posibilidad de frenar esa tendencia está en la mayoría de la sociedad nicaragüense, en los ciudadanos, en la medida en que se puedan organizar, y que, en realidad, logren hacer presión tanto sobre los diputados y los diferentes partidos políticos como en relación al mismo gobierno para que las cosas no avancen más allá.

R: Pero esa dificultad para manifestarse, yo he tenido la oportunidad de ver en las rotondas, bueno, éstas no son exactamente las fuerzas de choque, que, por lo visto, son pandillas financiadas por el gobierno, que acuden a apalear a los ciudadanos cuando se manifiestan en contra, que me parece una cuestión muy grave. Entonces, Dora María Téllez apuntaba la tendencia a un nuevo conflicto, o, por lo menos, el incremento de la violencia política del país si no se ofrecen salidas a la situación, quiero decir, si el parlamento o las instituciones no pueden hacer nada y la ciudadanía no puede 
manifestarse por esa cooptación de su derecho a la participación, y a decir que no a determinadas cuestiones, ¿qué es lo que se puede hacer?

E.C.: Pero es que mirá, de algún modo paradójico, porque en la medida en que más controla el poder Daniel Ortega, verdad, y que más autoritario se vuelve, también hay mayor potencialidad de conflicto y mayor potencialidad de presión de parte de la sociedad, porque, como te digo, hay mucha gente de mi edad, incluso un poco menor que yo, que recuerda muy bien la época de Somoza, y nadie quiere volver a esa época, para no hablar de la década de los ochenta, verdad, y todo el sentimiento que generó en otra gran cantidad de gente que no es sandinista, y que ahora es una mayoría en el país, porque en aquél entonces, todavía el proyecto sandinista-revolucionario tenía una amplia base social, bastante amplia, mucho más que ahora, pero esa situación se ha revertido, lo que pasa es que también, pues, eso requiere de que haya propuestas alternativas de organización y liderazgos diferentes, y eso la oposición no lo tiene.

\section{$R$ : La renovación de un liderazgo político.}

E.C.: Sí, porque es lo que te decía, verdad, la cultura política de las élites todavía funciona con esos esquemas autoritarios, pues, entonces, Eduardo Montealegre que es uno de los más moderados, aún él padece de esos vicios, y, entonces, él no reconoce, por ejemplo, liderazgos intermedios, que han estado surgiendo a raíz de todo lo que se generó con las elecciones del 2008, no reconoce gente, y hay gente que está en los departamentos, en las localidades y tiene un liderazgo que bien puede, incluso fortalecerlo a él mismo como líder nacional, verdad, y, sin embargo, tiene una actitud bastante autoritaria para algunas cosas, muy personalista, entonces, este, eso hace, eso dificulta las cosas, eso dificulta, pero yo creo que en la medida en que haya más descontento, y haya mayor presión, sobre todo por la situación económica, por donde se canaliza sobre todo el descontento, entonces, más autoritario va a actuar el gobierno, pero, a la vez, mayor posibilidad de que el conflicto salga a flote. Fíjate que yo, mis trabajos sobre conflictos los he hecho desde el inicio de los 90, y, entonces, una particularidad del período de la transición, de los primeros años de la transición, es que entre el 90 y el 97, digamos, verdad, todavía a inicios del gobierno de Alemán, la variable "conflictos políticos" es una variable permanente, $y$, entonces, si vos hablabas de conflicto obligadamente tenías que hablar de todos los hechos de violencia vinculados con la transición y con todo el proceso de pacificación, de reforma económica, etc., verdad, y ahí tengo yo los datos estadísticos, gráficos y todo, y hay cosas muy curiosas, como, por ejemplo, como cierto tipo de conflictos políticos se incrementaban en determinadas coyunturas, como los cambios de gobierno, verdad, y ahí están los datos, yo tengo los datos, y ahí están los gráficos. Desde el 97 hasta el año 2007 esa variable, prácticamente, desapareció de las estadísticos, disminuyó sensiblemente, $\mathrm{y}$, entonces, prácticamente, lo que encontrabas eran hechos aislados, no es que no existían, pero estaban aislados, pero desde el 2007 para acá, ha aparecido nuevamente como una variable de análisis de la situación política, y es interesante porque se han incrementado los conflictos por la propiedad, los conflictos entre grupos partidarios, las huelgas, los enfrentamientos en la calle, etc.

R: Es muy interesante eso que mencionas. Ya me pasas las referencias de tus propios trabajos. Pues si tienes algo más que añadir, yo creo que hemos hablado de casi todo...

E.C.: Pues no. Creo que está bien. 
ENTREVISTA 17-A ${ }^{24}$ :

Nombre del entrevistado: Dr. Sergio Cuarezma.

Cargo actual: Magistrado de la Corte Suprema de Justicia.

Fecha de realización de la entrevista: Managua, 11 de septiembre de 2009.

Lugar: Corte Suprema de Justicia.

Duración estimada: 50 minutos.

\section{TEXTO - Transcripción 17-A:}

R: ¿Cuál es su opinión sobre el proceso de cambio constitucional que ha registrado el país desde el momento de la transición democrática en los años 90 ?

S.C.: En el 79 se produce un cambio radical del sistema político, se desmantela formalmente el concepto del Estado, con la aparición de la revolución popular sandinista, sin embargo, se deja intacto lo que era el tejido constitucional colonial, que se venía adaptando a lo largo de nuestra historia, sostenido con los diferentes regímenes políticos, aunque fue el mismo con Anastasio, con la familia Somoza García y Somoza Debayle, en la revolución, pues, se hizo un cambio radical de sistema, en esa época histórica hubo aciertos y desaciertos, se incorporaron algunas instituciones de carácter socialista, sin embargo, como te expresaba, anteriormente, se dejaron intactos los sistemas, podríamos decirlo de alguna manera, quizás con una visión un poco arcaica, los sistemas de producción feudales quedaron intactos en el país, lo que no significa que aún hoy todavía no hayan desaparecido completamente, $\mathrm{y}$, por otra parte, las instituciones propias del siglo XIX también quedaron, prácticamente, intactas, en primer lugar, en segundo lugar, a lo largo de estos once años de revolución el país vivió de forma, podríamos decir, sistemática en Estado de Emergencia hasta el año 87 imperaba en el país un Estatuto Fundamental y un Estatuto de Derechos y Garantías donde se concentraba todo el poder en el Poder Ejecutivo, en este antes del 86, en manos de la Junta de Gobierno de Reconstrucción Nacional, y después del 86, entre el titular del Ejecutivo, que fue quien ganó las elecciones, el presidente Ortega Saavedra, hasta en el 87, a no menos, como dice Octavio Paz, con un Estado legal, un Estado formal, con la Constitución del 87, se comenzaron a poner relativamente en orden la institucionalidad, básicamente, la separación de las funciones de los respectivos órganos del Estado, durante estos once años, por ejemplo, el Poder Judicial se denominaba tribunales de justicia, y la mayor parte de sus facultades, de sus potestades, estaban distribuidas en el ámbito de la administración revolucionaria, tanto en el ámbito penal, por ejemplo, la Policía sandinista, denominada en aquél tiempo de aquella manera, controlaba, tenía, se denominaba Justicia Penal Policial, tenía todo el control de la justicia penal en sus manos, y los había tribunales excepcionales para juzgar a los oponentes políticos, también había medidas administrativas muy fuertes contra los ciudadanos en materia económica, por ejemplo, contra usura, robo de ganado, que aquí se le llama hurto a ganado, droga, sobre todo el tema del consumo, porque en aquella época histórica, el tráfico de droga, pues, no era un fenómeno criminal, relativamente, importante, como lo

\footnotetext{
24 Primera entrevista realizada al Magistrado Cuarezma, en la que se refieren aspectos de interés relativos a los diferentes desequilibrios en la estructura de los poderes del Estado, las dificultades de gobernabilidad política y social en Nicaragua, en el contexto de los cambios constitucionales recientes, además de los déficits culturales, que aún pesan en el país de cara a la introducción de fórmulas institucionales procedentes de otras tradiciones políticas como el parlamentarismo.
} 
es ahora, lamentablemente, en definitiva, fueron once años de revolución con sus aciertos y sus desaciertos, como te expresaba, anteriormente, que dejó intacto la institucionalidad, se concentró el poder en una Junta de Gobierno de Reconstrucción Nacional, que, originalmente, se constituyó de forma variopinta, sin embargo, se fue desmantelando conforme iban consolidándose los intereses hegemónicos del sector revolucionario en aquella época histórica, las confrontaciones con el norte, hubo un contexto de guerra fría, quiérase o no, y con la presencia de las tropas que se oponían al régimen revolucionario, denominadas los Contras, pues, con muchísimas muertes en el camino, sobre todo por la imposición del Servicio Militar obligatorio, pues, cuando se adelantaron las elecciones producto de los procesos de paz de aquella época histórica, porque, entonces, el gobierno revolucionario a través del Ejecutivo de los años 90 perdió las elecciones de forma amplia, extremadamente amplia, asumió el poder Doña Violeta Barrios viuda de Chamorro, y a partir de ahí se denomina, a partir de ahí, dicen algunos, que se inicia la transición, personalmente, no estoy muy claro que sea la transición, que inicia a partir de la Constitución del 87, como punto de partida constitucional, quizá, en términos puramente políticos, a partir del 25 de febrero, que es cuando se instala el gobierno de Doña Violeta, eso era en los años 90, luego le sucedió el ex-presidente Arnoldo Alemán, luego le sucedió el presidente Enrique Bolaños Geyer, y, actualmente, está el presidente Ortega Saavedra, durante todos estos años, la vida institucional ha venido desarrollándose, organizándose, estructurándose a partir de la Constitución Política aprobada en 1987, una Constitución, originariamente, presidencialista, que a lo largo de todos estos años de transición, para denominarle, paradójicamente, se han venido dando toda una serie de reformas constitucionales, a mi juicio, algunas importantes, en el 95, donde se crea un peso y contrapeso con los órganos del Estado, que quizás se deba al contexto histórico donde la clase política no estaba tan consolidada, acuérdese en esa época histórica que el Frente Sandinista de Liberación Nacional perdió, por ejemplo, en la Asamblea Nacional una cantidad importante de diputados cuando se crea el Movimiento Renovador Sandinista, el MRS, las aspiraciones que tenía el antes Secretario de la Presidencia, Antonio Lacayo, de ser presidente, eso, igualmente, provoca unas reformas constitucionales para evitar que él corriera como oposición en algunos sectores políticos, pero más allá de eso, quedándonos en el ámbito constitucional y, permíteme la expresión, académico o teórico, me gustaría resaltar, por ejemplo, que la aprobación de los tributos le corresponde, en ese momento, a la Asamblea Nacional, que antes era a propuesta y aprobación del Ejecutivo, dos, los nombramientos de las autoridades de los órganos del Estado, fuera de los que no son de elección popular, como el Poder Judicial, el Consejo Supremo Electoral, entre otros, por ejemplo, ahora con la reforma del 95, además de la propuesta que el Ejecutivo podía presentar, también lo presenta cada diputado en la Asamblea Nacional previa escucha que se le hace a la denominada sociedad civil, porque en aquella época histórica el Ejecutivo presentaba una terna y de los tres se coelegía al Magistrado de la Corte Suprema, o del órgano referido, también se le da, en ese contexto histórico, un nivel de constitucionalidad a la Procuraduría para la defensa de los Derechos Humanos, que, actualmente, está en una situación precaria, también se le da, ¿en el 95 fue?, no, en el 95 no fue, esa fue la reforma del 90, si mal no recuerdo, tanto en el 90, 95, y luego 99 aparecen los conceptos de Procuraduría para la Defensa de los Derechos Humanos, luego, aparecen los conceptos propios del Ministerio Público, por ejemplo, de la Superintendencia de Bancos, es decir, se comienzan otras reformas también a ordenar un poco ese rostro del Estado nicaragüense, como dicen, y, sin perjuicio de otros que se me escapan en este momento de otras cosas importantes, que, a nivel de reforma constitucional, se hicieron, y que ahora, pues, tiene sus réditos 
positivos, y yo creo que todavía no lo han tenido, y otros que quizás no han sido tan positivos como se esperaban para la clase política, en función de los intereses del país.

R: Es cierto que la gran reforma constitucional podría ser la del 95, ¿no?, un poco es la que constituye el marco constitucional vigente actualmente.

S.C.: Hay que hacer notar que esa reforma del 95, te lo habrá expresado Francisco Emilio, aparece el concepto del Estado Social de Derecho, claro, un concepto más traído, quizás, académicamente, teniendo en cuenta que el presidente de la Junta Directiva, que en aquél entonces era Cairo Manuel López, es un constitucionalista y un administrativista muy importante en el país, trajo, a mi juicio, con una buena intención ese concepto de Estado Social de Derecho, que está en el artículo 130 de la Constitución Política, la reforma constitucional se le llamó parcial en aquél momento histórico, a pesar de que era total, habida cuenta de que se ha reformado el modelo de Estado completo, y las instituciones deberían de responder a una nueva visión del modelo de Estado, sin embargo, dado el poco debate de fondo de estos temas, pues, pasó inadvertido, inadvertida también ha pasado la importancia de ese modelo de Estado, sin perjuicio, de las crisis que pueda tener en Europa continental, en el caso de Nicaragua, fue bastante novedosa, la Constitución española influyó bastante en la Constitución nicaragüense del 87, y con esta aparición del modelo del Estado Social de Derecho aparece, por ejemplo, el tema de la responsabilidad patrimonial del Estado, aparece como los servidores tienen que rendir su trabajo al tema de la población, es decir, ya el tema de los controles, el tema de las, ¿cómo se denomina?, de las cuentas, de la rendición de cuentas, $\mathrm{y}$, perdona que no me salía la palabra, quería hacer notar el tema del concepto del Estado Social de Derecho, que fue, a nuestro juicio, y que teóricamente es muy importante, pero que todavía no se le ha dado contenido, ni se le ha dado, capitalizado.

\section{$R:$ ¿En términos de politicas públicas?}

S.C.: A eso me refiero, sobre todo porque, y esto también de los conatos que ha habido de reforma constitucional frente a un nuevo sistema político como el parlamentario, los legisladores, antes, ahora, o antes o durante, no han tenido, a mi juicio, mucha claridad, que a partir de su entidad legislativa se puede, partiendo de este modelo, crear una visión de políticas públicas y no solamente de formulación, sino de seguimiento y de control de su ejecución, en función de los intereses generales de la sociedad, sin perjuicio de que el Ejecutivo se coordine, activamente, con ellos, o como respuesta a su pasividad legislado tendría que salir hacia delante, creando, controlando y ejecutando las políticas públicas que, a mi juicio, no solamente es constitucional, porque está facultado, sino que está obligado constitucionalmente, y, de esa manera, superar un poco la posición reactiva del parlamento nicaragüense ante las propuestas del Ejecutivo, llámese Ejecutivo, tradicionalmente, hablando, de derechas, o cualquiera.

R: En la tesis yo me centro, fundamentalmente, en las reformas que han llevado a tener un hiperpresidencialismo consolidado en la Constitución del 87, que está marcado un poco también por la situación excepcional del gobierno de Nicaragua, en un momento, digamos, de conflicto armado al presidencialismo atenuado, en el que se injertan instituciones procedentes de la tradición parlamentaria, antes además me hablaba, ampliamente, de todo eso su asistente. Ha habido también una comprensión dificultosa por parte de los actores políticos a la hora de aceptar ese hilo conductor de las 
reformas, y se registra un conflicto entre el Ejecutivo presidencial y el Legislativo en cada proceso además de reforma constitucional, el del 95 es claro, también me gustaría que examinara no solamente el conflicto, ¿por qué el presidente de la República nunca ha querido desprenderse de esas atribuciones de poder, que están además consolidadas en la Constitución del 87?, y, por otra parte, ¿por qué se llega a crear esas leyes Marco, que son, al menos, jurídicamente, un instrumento para un europeo bastante sorprendente, porque es como ampliar el proceso de la negociación política congelando la entrada en vigor de las normas constitucionales?, ¿no?

S.C.: Mira, el concepto del presidencialismo en la época de la revolución quizá tuvo su comprensión, o explicado de otra manera, la concentración de poderes en torno al presidencialismo, que se desarrolló a lo largo de los años 80 puede comprenderse, no justificarse, porque históricamente hay quien todavía hoy no recuerda en su memoria histórica, no solamente comprendieron, sino justificaron algunos hechos extremadamente graves que sucedieron en el país, y hoy, sin embargo, les dio, no sé, una amnesia parcial histórica, en aquella época histórica se concentró el presidencialismo, supongo, entre otras cosas, para consolidar un proyecto político compartido con el bloque socialista, primero, en segundo lugar, para tratar de mantener cierto nivel de control y dirección de un país sometido, entre otras cosas, a las contradicciones con el norte, del norte, en el caso de Estados Unidos de Norteamérica, que a través de la contrarrevolución generaba, desarrollaban una intervención militar de facto, a través de lo que la central de inteligencia norteamericana, la CIA, denominaba una "guerra de baja intensidad", en definitiva, para controlar a un país en guerra, en transición y miseria, entre otras características, pues, parece ser que el concepto de presidencialismo, pero reforzado, robusto, que quizá no solamente responde a esa visión caudillesca que tiene la comunidad latinoamericana, que cuanto más seguro el hombre, en términos de concepto de macho, más segura se siente la sociedad, dicen algunos sociólogos, a mí no me creas, entonces, se fortalece ese concepto de presidencialismo, y además, a mi juicio también con una visión de sostenibilidad de mediano y largo plazo, de un proyecto revolucionario, pues, tenía sus aspectos positivos, pero, sin embargo, como toda historia ya habido muchos hechos históricos que demostraban que iba a tener un resultado poco feliz, como, efectivamente, lo tuvo, perdieron muchísimas oportunidades, creo que esa es la deuda histórica más grande que tienen la clase política de aquella época, sobre todo, la que desarrollaba su liderazgo, que perdieron una oportunidad para poder crear una estructura y una organización estatal y social envidiable, no solamente en la región, sino en América Latina, teniendo en cuenta que había una serie de elementos, y que los sigue teniendo el país, que esos eran de muchas ventajas, una población, cuantitativamente, no tan grande, en segundo lugar, un país con bastantes recursos naturales, un país que tiene dos océanos, dos mares en sus costados, más el Caribe, un país que tiene riqueza y turismo, muchísimas otras cosas más, ¿no?, claro, todo esto hay que ubicarlo en el contexto histórico, en lo que sucedía, guerra fría, manejo inadecuado de la política exterior, situaciones innecesarias, etc., etc., etc., sin embargo, este presidencialismo comienza, a mi juicio, a revalorarse sobre todo de dos maneras: una, en el 95, con la reforma constitucional para garantizar un peso y contrapeso desde posiciones políticas, como te advertía anteriormente, que algunos partidos van naciendo, teniendo oportunidad de nacer, pero había que quitarle poder al presidencialismo de aquella época histórica, aunque estuviera Doña Violeta Barrios de Chamorro, o, al contrario, aprovechando ese contexto histórico para poder desmantelar esa fortaleza del presidencialismo, que, en su momento, quizás, tuvo ventajas, como también tuvo resultados extremadamente gravosos, y eso hace también que la situación 
política de la oportunidad a otra participación de sectores políticos, en segundo lugar, ya desde el punto de vista pragmático-institucional, las reformas para ir, en cierta forma, desinflando ese concepto rígido del presidencialismo, para establecer un balance, un peso y un balance entre todas las instituciones, porque el Ejecutivo todavía en el $95 \mathrm{y}$ antes de la reforma tenía, y todavía se siente el poder, no tanto como antes del 95, un poder omnímodo sobre el resto de las instituciones, y, a mi juicio, y comparto el criterio, no sé si tú lo compartes Francisco, pero el 95 más allá de algunos intereses políticos para que no corriera como presidente tal persona, o para yo Ministro político mientras voy creciendo me doy la oportunidad de crecer desde la Asamblea, aprovecho y reformo la Constitución para darme un espacio político, por ejemplo, al margen de todas esas...

\section{R: Cálculos de poder...}

S.C.: Cálculos de poder, exactamente, pues, las reformas constitucionales, algunas de ellas, no todas, a mi juicio fueron bastante acertadas, políticamente hablando, porque ahora, por ejemplo, sin perjuicio de que el Poder Ejecutivo actual se sienta per se, fuerte, lo cierto es que tiene que ir a la Asamblea Nacional a discutir, la reforma del 95 también comenzó a desmantelar el concepto del presidencialismo para crear un sistema criollo, progresivamente, de parlamentarismo, no, a mi juicio, dirigido a ese sistema, sino tratando de que todos los problemas políticos se discutan en la Asamblea, y de esa manera cada quien con reparto poco o mucho del poder que tuvieran, políticamente, administrando, adecuadamente, el poder cada quien desde la Asamblea poder administrar sus propios intereses, como partido y en función de los intereses de la sociedad, que este último concepto te lo he mencionado tres o cuatro veces, pero todavía no tiene contenido en nuestra vida y nuestra vida política, aquí se le llama los intereses del pueblo, en la Constitución española los intereses generales de la sociedad, creo que habla el artículo no recuerdo ahora de la Constitución española, aquí es el 131, y a partir de ahí, pues, se comienza a tratar de fortalecer el balance de poderes, ya en las posteriores reformas constitucionales, vienen acercándose a darle mayor participación a la Asamblea Nacional frente al Ejecutivo, perdiendo la perspectiva, que ese es uno de los elementos, que los legisladores han ido emitiendo, y, a mi juicio, de forma muy delicada, y es que la Asamblea Nacional, como expresión del diálogo político, ha perdido la oportunidad y la sigue perdiendo en la incidencia e implementación de políticas públicas, que, en lo personal, es lo que más me interesa y me importa, en función de diseñar un proyecto de nación, relativamente, pues, articulado, de cara al mediano y largo plazo, y lo que todavía se agota en la Asamblea Nacional es una imposición reactiva en discusiones, no sé, bizantinas, por la pescadilla que se muerde la cola, ¿no?, en el ámbito puramente político, ahora bien, algunos cálculos de poder, como tú lo has expresado no han salido, en su momento, bien, y eso ha hecho que se recurra a la invención política, al invento político, o a la creatividad política, y aparecen las leyes Marco, las leyes Marco, desde el punto de vista constitucional, no existen, desde el punto de vista de la pureza del Estado de Derecho tampoco existen, la teoría pura del Derecho tampoco existen, sin embargo, y estas palabras no quiero que se malinterpreten en el sentido de justificar lo injustificable, quiero poner esto en perspectiva, a mi juicio, Nicaragua es un país, como otros muchos en la región, y esto como producto de muchas investigaciones empíricas, me ha llevado por lo menos a una conclusión preliminar, son países que, literalmente, se están construyendo, literalmente, se están construyendo, y en ese proyecto de construcción, que, a la vez, carga el déficit de no contar con un proyecto de nación, que, a la vez, ha pasado una serie de coyunturas 
radicales muy fuertes, políticas y naturales y bélicas también, durante 180 años de institucionalidad, cuando se marchó la colonia, los denominados próceres no construyeron una visión de futuro de país, como los japoneses, los norteamericanos, los mismos españoles, por ejemplo, los alemanes, para ser ahora la nación que son, con ese déficit de presentación a la sociedad de un proyecto de nación de mediano y largo plazo, con los resabios de esa institucionalidad administrativa feudal en el norte del país, que todavía se mantiene un sistema de producción feudal, en una parte del Pacífico donde todavía se concentra la vida institucional, administrativa y política del país, con instituciones básicamente coloniales, todavía, por ejemplo, en Morimbó, cerca de Masaya, si conocieras, ahí todavía se mantiene la figura del alcalde de vara, que es un concepto puro colonial, cuando me refiero a colonial no me estoy refiriendo en el sentido peyorativo, me estoy refiriendo en términos históricos, y luego tienes ahí una franja del Caribe, que es una franja puramente indígena o étnica, la de una realidad multiétnica, que dice la Constitución en su artículo cinco que tiene nuestra nación, o sea, todos estos factores junto con, antes la guerra fría, ahora la globalización, los posicionamientos del mundo bipolar, las contradicciones económicas, físicas, todos estos grandes problemas que tiene el mundo, imagínate tú, pasados luego a nuestra realidad local es un contexto de debilitamiento de los poderes locales de América Latina, donde se han transferido los poderes locales al territorio nacional, que no los sabe identificar si está en el Grupo de los 8, cuando se reúnen en París, o están en el consenso o el post-consenso de Washington, o estás ahora con algunos experimentos políticos en el Cono Sur, como no sabes donde estás, en esa realidad en que también se desarrolla nuestro país, entonces, nuestro país, sobre todo el caso de Nicaragua, es un país construyéndose, pasó de la guerra a la paz, optó por otra forma de vida que es la democracia, y se pregunta qué instituciones tengo, qué cultura política tengo y qué sociedad tengo, y comenzamos a tratar de construirla, y dentro de ese compromiso, que, te confieso, no sé si es un compromiso formal, serio, o un compromiso, simplemente, para administrar esa visión de poder que tú hacías referencia, pues, entonces, se inicia en nuestro país a fines de los 90, partamos de ahí, aunque yo partiría de lo que sería de los años 79 en adelante, como un antes y un después, pero bien, luego, puedes ver que el Estado sigue siendo el mismo Estado, un Estado que no tiene solidez, que no tiene, que no es un Estado robusto, y luego tienes una sociedad civil, relativamente, vertebrada, pero que, en cierta forma, ese reducto de aquellos sectores que han perdido cuotas de poder, y que hoy aparecen como una expresión de una comunidad que, en lo personal, me cuesta mucho aparecer en público, y decir que yo represento a la justicia o a la sociedad, me suena un poco, una actitud muy soberbia de mi parte, entonces, te decía, es un Estado que todavía no se ha reformado integralmente, se ha reformado de manera parcial y fragmentada, tanto por intereses políticos e institucionales para mejorar el país y de la cooperación internacional, eso hace que luego tengas un Estado que no tenga tanta coherencia, respecto a su rostro como Estado Social de Derecho o Estado Democrático Social de Derecho, también, por ejemplo, no se le ve una gran armonía, respecto a la capacidad de funcionar, porque la naturaleza de las reformas institucionales, en el contexto de una reforma fragmentada del Estado responden en algunas ocasiones a una agenda de las instituciones financieras internacionales, responde a esas cuotas de poder o esas visiones de cuotas de poder de mediano plazo, responde también, bienintencionadamente, algunos cambios institucionales, como algunas reformas de la justicia, que al final del camino entre la propia reforma de la justicia te das cuenta de que hay reformas más acertadas y reformas que profundizan la censura o la cancelación de la independencia de los jueces, por ejemplo, entonces, tienes ahí como una especie de ensalada de frutas tropical, porque en Europa continental es 
muy restringida, aquí las frutas son un poco más amplias, ¿no?, agarras las frutas europeas y las de América Latina y formas toda una ensalada muy rica de fruta, ahora las frutas se han globalizado también, porque, entonces, tienes esa realidad, luego una sociedad civil, como te decía, que quizá más o menos se está vertebrando, hay ya, supuestamente, se han dado pasos hacia la democracia, pero no dejan de eliminarse las tentaciones de las dictaduras, échale un vistazo a la región, en términos generales, una sociedad civil que se está estructurando, a partir de, como te expreso, también con visión de cuotas de poderes habida cuenta de que muchos de sus líderes, por no decir la mayoría, vienen de resabios del pasado, personas que han perdido sus cuotas de poder, personas que están reclamando sus cuotas de poder, personas que vienen de la vida religiosa o del capital, que tienen su intereses bien intencionados, pero, en principio, forman, se mezclan y se apagan o se minimizan en función de una gran colectividad que responde a contradicciones del pasado, a expectativas de tener el poder a mediano plazo, no sé si me explico, una sociedad civil con su propia agenda, perdón, grupos que expresan la sociedad civil con sus propias agendas particulares en relación a la toma del poder, que eso es, precisamente, la Ciencia Política, ¿no?

R: No, y es muy interesante además lo que comenta, porque un elemento común a todas las entrevistas que he realizado hasta el momento es el cierre, incluso, aparecía también en su discurso, el cierre de espacios politicos tanto a las fuerzas partidarias, que no coinciden con los dos partidos mayoritarios, el PLC y el Frente Sandinista, que, a raíz de la reforma del 2000, que se ha apuntado el tema de la contrarreforma del proceso de cambio constitucional, yo lo entendía como un punto de inflexión en la línea que marca la reforma del 95, por ese reparto casi paritario de las cuotas de poder en los principales órganos del Estado, entonces, hay una falta, digamos, de lugar, de espacio politico para las fuerzas partidarias alternativas, pero también hay una dificultad de expresión por parte de la sociedad, y me refiero a los últimos episodios de, bueno, casi apaleamiento de los que se manifiestan, y hablo, concretamente, bueno, del caso de las elecciones municipales del 2008, ¿no?, que es un derecho fundamental la libertad de expresión, y ya no solamente decir: "aqui estoy para protestar", sino que no te dejo que salgas a la calle en una situación, pues, no voy a decir dictatorial, porque es una palabra muy fuerte, pero sí de restricción notable de las posibilidades, oportunidades e instrumentos de participación social y política de la ciudadanía, y de los partidos, ¿cómo examina esto, tanto en la arena parlamentaria, como en la sociedad civil?

S.C.: Pues, eso te decía, las tentaciones de ir, de castigar el disenso, no han desaparecido de la región, y, particularmente, de Nicaragua, sin perjuicio de quien esté en el poder, porque las instituciones y las leyes, lamentablemente, se han utilizado para perseguir al adversario político, en toda la vida institucional del país, lo que está sucediendo ahora es lo que ha sucedido a lo largo y ancho de 180 años de nuestra historia, no es nada nuevo para el país, esto exige al país ver hacia atrás para poder ver su presente y su futuro, sin embargo, nos resistimos a hacer ese ejercicio intelectual, al no hacer ese ejercicio intelectual el discurso de todos los sectores políticos y sociales, desde mi punto de vista, al margen que me solidarizo, porque, igualmente, sucede que dentro del Poder Judicial, que no creas que es una carga extremadamente liviana en un contexto de transición, es una carga muy pesada, pesada no victimizándome gratuitamente, sino que es pesada porque es un poder que está acechado y además está contaminado, ¿no?, por intereses políticos, o intereses económicos, o intereses también de cooperación internacional, al margen de todo eso, la sociedad civil comparte también los mismos 
problemas de quienes administran el poder, político, económico, y es que su discurso es un discurso, cualitativamente, capaz como para poder crear escenarios de diálogo y entendimiento, sino que son, quizás por el momento histórico también, perdona que vuelva a repetir la expresión que vivimos, que son diálogos, o más que diálogos son diatribas, no sé la palabra correcta, o, simplemente, es como una especie de, perdóname la expresión, es como una especie de "cajón de grillos", donde todo el mundo habla, y nadie se escucha, y además lo que todo el mundo habla, cualitativamente, no hay propuestas, lo que hay en cierta forma es un discurso ofensivo, negativo, reactivo, y lo peor, ponte el canal de televisión, vete los comentarios de los periódicos, "maldito ladrón, hijo de...", así no se construye un país, entonces, aquí la calidad del discurso en función de cooperar o de colaborar ahí, aunque sea estéticamente para crear los espacios de consenso, o de diálogo, creo que además son necesarios, obviamente, que esto no justifica ni hace comprensible, ni justifica en lo más mínimo la represión del disenso, de la opinión del contrario, sea mayoritario o sea minoritario, todo lo contrario, y ese es un déficit que crea nuestra cultura democrática, que además también la identifico como producto de que es un país que está naciendo, un país que se está construyendo, no solamente construye una visión de ser algo, como Estado a largo plazo, sino que además esa identificación del estilo de democracia todavía no está muy claro, porque jugar a la democracia es perder los espacios de poder, tanto de los que tienen el poder, como de los que los perdieron y hoy están en la sociedad civil, y hoy a través del discurso confrontativo quieren recuperarlo, es decir, lo que tú tienes, en cierta forma, en la sociedad es la, si tú juntaras el sector político y la mitad de la sociedad civil y los pones en un círculo son los mismos, son los mismos, en términos generales, son los mismos, comparten los mismos intereses, parten de la misma médula espinal históricamente, quítate tú para ponerme yo, igual que los que mantienen el poder económico, el capital criollo, y los espacios políticos, insisto, no proponen un proyecto de país, no se propone un proyecto de país, cada quien tiene su propio espacio, cómo administrarlo y cómo fortalecerlo según los intereses, los vínculos, los enchufes, en definitiva, es una situación bastante variopinta, una situación que requiere de mayor prudencia para hablar, pero, ciertamente, lo espacios de diálogo se están restringiendo en el país, seriamente, seriamente, pero, curiosamente, y ahí viene, por ejemplo, una cuota de responsabilidad de la cooperación internacional, y esto lo conversaba con Manuel en su momento, si mal no recuerdo, y es lo siguiente, recibí un curso de actualización política, que impartieron acá en la UAM, y ahí lo conversábamos, aparece a propósito de uno de los módulos que impartió una de las colegas, por ejemplo, la cooperación tiene, hay dos cooperaciones, ¿no?, la cooperación europea continental y la cooperación del norte, y, sin perjuicio de las buenas intenciones, que está lleno de piedras el camino que asciende hasta el cielo, de buenas intenciones, pero también hay otra serie de aspectos en la cooperación que el apoyo no te lo controla cualitativamente, ¿me explico de otra manera?, aquí el Poder Judicial, discutió y aprobó la Asamblea Nacional la Ley de Carrera Judicial, se suponía que ello garantizaba la independencia interna de los jueces, luego se vino un reglamento para articular los aspectos básicos y fundamentales de aquella ley, y ni la Ley de Carrera Judicial, ni el reglamento superaron un grave problema, que para mí es la parte fundamental, y es garantizarle la seguridad laboral a los judiciales, aquí los judiciales están sometidos por ley y por reglamento a los traslados sin su consentimiento, entonces, tanto la ley, apoyada, financiera y técnicamente, por la cooperación, y el reglamento, igualmente, y ahí estuvieron sentaditos, conversando con mucha tranquilidad, compatriotas tuyos, a mí me unen muchísimos lazos con España, soy ex-becario de la Agencia Española de Cooperación, becario de la Dirección General de Investigación Científica y Técnica del Ministerio de 
Educación, entre otros temas, aquí conversábamos con mucha tranquilidad, y al final le dije ni la ley ni el reglamento que se está discutiendo garantizan la independencia interna, ¿cierto?, cierto, entonces, ¿por qué se obliga al país a aprobar este reglamento?, a cambio de pedir 30 millones de euros a la Unión Europea, cuando, en definitiva, todos sabemos que no solamente no fortalece la independencia interna, sino que viene, oficialmente, a cancelarla, a cancelarla, y la respuesta es ésta, es una responsabilidad de Estado, pues, no, si yo te doy dinero en función de una visión estratégica de la calidad del Estado de Derecho, yo te voy a apoyar para fortalecer el Estado de Derecho, no para un enano totalitario que me desmantele una visión compartida que tú y yo tenemos, es así, ¿no?, bien, entonces, esto es un Estado, una sociedad civil, que está ahí vertebrándose con buenas intenciones, pero con un discurso que todavía tiene que identificar cuál es su propuesta, pero que, de alguna manera, quieren alcanzar el poder como los otros, y una cooperación interna que viene agenciando como socio, y otra vez durante muchísimos años, en toda la cooperación internacional, que tienen una agenda muy positiva, muy provechosa para el país, sin embargo, se ha perdido oportunidad para corregir o para afirmar ciertos aspectos que desde esa capacidad hacia los socios con el Estado nicaragüense se pudieron haber corregido en su momento, no es tarde, se pueden hacer todavía muchas más cosas, pero te hablo de la cooperación internacional, porque en un mundo global yo ya parto del concepto de la soberanía flexible, ¿no?, de tal manera que el posicionamiento de la cooperación como socio para mí no implica, de ninguna manera, ninguna intromisión en las políticas de Nicaragua, habida cuenta de que ya no hay fronteras, ya desde que comenzó el Internet se acabaron las fronteras, ya se borraron las fronteras, que esa es una forma muy simplista de ver las cosas, y, entonces, ya a la cooperación se la puede ver como un par, como un igual, formalmente hablando, aunque, teóricamente, hay una disparidad muy grande, $\mathrm{y}$, entonces, decir: "bueno, señores, ¿van a compartir mi visión?", "sí, la compartimos, pues, administremos, financiemos y seguimos para adelante", pero hoy la cooperación tiene un papel muy importante que jugar en el sentido de que si vamos a construir independencia para los jueces es independencia para los jueces, porque ejercicios de esta naturaleza, por ejemplo, en España jamás se hubiesen, era impensable, o en Alemania, o en Estados Unidos, o en Japón, no sé, entonces, en ese sentido, a propósito de la Ley Marco que me hacía esta pregunta, por eso cuando aparece la Ley Marco, analizas, bueno, no calculamos esto adecuadamente, se nos salió de cauce, se nos salió de control, ¿cómo solucionamos todos estos problemas?, pues, entonces, hay que crear algo con mucha imaginación que es la Ley Marco, entonces, la Ley Marco que es una ley espuria viene a controlar la Constitución Política para darle, entre comillas, gobernanza al país, antes gobernabilidad y ahora gobernanza, y, no sé, esta es una realidad, este es un gran culebrón, como dicen en España, que, finalmente, no tiene un guión articulado, concatenado, y el país vive al día, y veremos a ver qué contenido va a tener nuestra viñeta al día siguiente, para ver qué papel vamos a jugar a medida que vaya avanzando los días.

R: Y ya para terminar, porque sí voy un poco ajustada de tiempo, las reformas del 2005, bueno, parte de la norma, del precepto que se aprobó entonces de ratificar por parte de la Asamblea los funcionarios y altos cargos diplomáticos no ha sido cumplido por el actual presidente Ortega, el Ejecutivo ha tratado de fortalecerse a través de la propia reforma de la organización del Poder Ejecutivo, que es la Ley 290, como la creación de los CPC, en fin, toda una serie de estructuras paralelas al Poder Ejecutivo, ¿qué piensa del debate sobre la reelección presidencial o la transformación de la estructura institucional del Poder Ejecutivo a través de la creación de un Primer 
Ministro?, ¿cómo pueden actores formados en la cultura política presidencialista comportarse como actores parlamentarios?, ¿no?, ¿cuál es su visión de futuro si se pudiera tener una bola de cristal, como me dicen ahora, cuando pregunto por el futuro de Nicaragua?

S.C.: Mira, te voy a pasar algunos trabajos que hacemos en el Instituto de Investigaciones Jurídicas, mira, el sistema parlamentario, como expresión de cultura democrática, en lo personal, y estrictamente, académicamente hablando, me parece positivo, sin embargo, requiere de una serie de factores, que puestos en vigencia en Nicaragua podrían generar sorpresas insospechadas, ahí sí, el propio parlamento y por fuerte presión se convertiría, realmente, en una caja de grillos, porque si, históricamente, cada quien ha manejado la cuota de poder, cuando un diputado se de cuenta en el sistema parlamentario que su voto cuenta, se va a generar una diversidad de intereses no de partido, sino de personas dentro de la Asamblea Nacional que no quiero imaginármelo, si es que logran los sectores políticos identificar que el sistema parlamentarista le da un poder mayúsculo a la presencia de las diputadas y los diputados en el parlamento, no sé si me explico, en primer lugar, en segundo lugar, la Comisión Económica tendría un poder muy importante en la Asamblea Nacional, que tendría que sentarse de igual a igual con el Poder Ejecutivo para establecer las directrices de las políticas públicas macro, e históricamente todavía hoy no se ve, no contando con un sistema puro parlamentarista, pero con algunos atisbos que además van creando un sistema híbrido, tampoco no ha habido cultura hasta el momento de hacer un ejercicio de esta naturaleza, lo que me indica a mí, que no hay un solo elemento que me permita a mí identificar que las cosas van a cambiar, al contrario, se van a ver grandes espacios de poder, que se van a generar hasta contradicciones internas en los partidos políticos mayoritarios bastante fuertes, porque cada voto sí va a contar para tener ministros, para los controles de censura, para voto de censura, y otras cosas más, por ejemplo, y además, luego, se necesita una cultura de esa sociedad general, tomando en cuenta la sociedad civil, que, en cierta forma, le diera a la opinión pública a través de los medios de comunicación, los periódicos y no más de 8 televisiones en el país, el hecho de comprender, perdón, se necesita una cultura de esta sociedad, de nuestra sociedad, que yendo a las urnas a votar por X personas, resulta que en la Asamblea sale nombrado alguien diferente del que votó, y que el que se nombre en la Asamblea como Primer Ministro responde a la minoría, a la cual ella misma ha sancionado con su voto, por ejemplo, entonces, ese impacto, o esa percepción y ese impacto cultural, de cultura política, en la sociedad no sé cómo se iría a digerir en el país, no sé si me explico, cuando la sociedad va y dice: "Francisco Emilio de presidente", el concepto que tiene la cultura nuestra es de este es el hombre o la mujer fuerte, este es el hombre fuerte, que nos va a gobernar, se necesitan personalidades fuertes, prudentes, estadistas, gente muy, y de repente dicen: "oiga, pero no manda Francisco, Francisco solamente dirige el Ejército y la Policía, relativamente, anda organizando partidos de fútbol y de béisbol, anda firmando convenios y tratados, pero la que, realmente, manda es Raquel", como expresión de...

\section{R: Como cualidad del Poder Ejecutivo.}

S.C.: Sí, exactamente, y, además de eso, es nacida de un partido político minoritario que yo repudio, y, entonces, esto, exactamente, es una figura, es una figura, él es una figura, como que si fuera un escaparate de un centro comercial, y tú, realmente, la que hace la ropa, o la dueña del escaparate, entonces, la gente, yo, ciertamente, no pagaría para 
hacerme una, porque me supondría contradicciones más fuertes de las que se están dando en la actualidad, por la sociedad civil frente al poder político, y el poder político reprimiendo con mayor intensidad a la sociedad civil, entonces, como ejercicio académico, como cultura, si tú quieres, pues, democrática, yo te diría: "sí, me parece bien, no tengo inconveniente", ahora tú me preguntas: “¿contextualizado en el país?”, "no", te respondo, "no", Diego Valadés, que tiene una obra publicada sobre el gabinete de gobierno y él es miembro del Instituto de Investigaciones Jurídicas, vamos a publicar una obra de él que se llama Parlamentarización de los sistemas presidenciales, se va a publicar pronto, y aquí ha venido en varias ocasiones, además de las clases y en las conferencias siempre ha sugerido a los actores políticos, que lo hagan con mucha prudencia, mucha prudencia, y que, en todo caso, vayan parcheando la Constitución Política en función de la gobernanza, no en función de los intereses partidarios, primero, $\mathrm{y}$, en segundo lugar, si se necesita una reforma constitucional integral, porque es Sartori el que dice que, bueno, que en la vida un poder gobierna precariamente o con muchas dificultades, pues, con mucha más razón cuando tiene un instrumento político mal diseñado, como es la Constitución Política, la Constitución ya tuvo su vigencia histórica, tuvo su encanto en el contexto histórico, en el 87, y ahora, pues, había que establecer una serie de pautas, pero ya de compromiso de nación con una visión constitucional de largo plazo, y ahí poder establecer ciertas pautas de convivencia institucionales y democráticas para que le den sostenibilidad y gobernabilidad, coyunturalmente hablando, en términos estratégicos, de largo plazo, al país, y tú me preguntarías: “isería prudente, en términos formales, reformar la Constitución?”, tampoco, no, no sería prudente reformarla, porque se abrirían un montón de ventanitas insospechadas, ahora, volviendo a este punto para finalizar, Nicaragua creo que lleva más de 14 constituciones, todas las constituciones políticas han respondido a programas partidarios no es la suma de intereses y de expectativas de una comunidad, que se constituye como nación, es una Constitución Política que, a lo largo de la historia, algunas han nacido, otras no han nacido, las non nata, que se les ha denominado, durante 11 años estuvimos gobernados por estatutos, que no eran constituciones políticas, en los años 80, y la actual Constitución que ha tenido varias reformas constitucionales, en el libro de Edwin Castro aparecen todas las reformas que se han desarrollado, y todas han respondido a mantener el equilibrio político y que el país no se vaya, no se desmantele, y, por otra parte, el reparto de cuotas de poder, y, entonces, todavía no hay una Constitución Política como un espacio común donde todos nos podamos identificar, con esas expectativas y esos intereses comunes a los que te hacía referencia, entonces, para reformar la Constitución, a mi juicio, habría, en todo caso, que inyectar un poco más a la cultura democrática de otra serie de valores, para que cuando lleguemos a esa situación, ya tengamos un estadio cultural que nos permita valorar en la Constitución Política, y poner algunas pautas sobre la mesa, y para comenzar a hacer las cosas en el marco de la Constitución, y no fuera la Constitución Política como, ordinariamente, a lo largo de la historia, y aún hoy, se viene haciendo.

\section{R: Pues, muchas gracias por la entrevista.}




\section{ENTREVISTA $17-\mathrm{B}^{25}$ :}

Nombre del entrevistado: Dr. Sergio Cuarezma.

Cargo actual: Magistrado de la Corte Suprema de Justicia.

Fecha de realización de la entrevista: Managua, 30 de noviembre de 2009.

Lugar: Corte Suprema de Justicia.

Duración estimada: 55 minutos.

\section{TEXTO - Transcripción 17-B:}

$R$ : ¿Cuál sería su reflexión a propósito de esta sentencia de la Corte, que rompe, a mi juicio, el principio de seguridad jurídica y la supremacía constitucional a unos niveles ya, iniciando un nuevo proceso de conflicto entre el Legislativo y el Judicial respecto a la posibilidad de reformar la Constitución, aunque la sentencia no reforma la Constitución, pero sí es una interpretación de un artículo, que, lógicamente, da un sustento jurídico a una actuación política como la reelección presidencial?

S.C.: Hace muchos años advertí del envejecimiento de la primavera de la reforma de la institucionalidad en el país, porque la primavera de la institucionalidad se estaba marchitando, creo que fue la frase que utilicé hace muchos años atrás, la tendencia era bastante clara respecto a la gran pugna que se produce en Nicaragua en cuanto a dos grandes facciones partidarias, por una parte, el ámbito del Frente Sandinista de Liberación Nacional, y, por otra parte, no me gustaría encasillarlo en el ámbito liberal, porque no solamente este sector representa un $65 \%$ o $70 \%$ de la población, que forma el otro gran polo de estas grandes diferencias políticas de nuestro país. Estas contradicciones, que están referidas más que todo al ámbito del Frente Sandinista, tarde o temprano iban a ser, a aparecer comportamientos, conductas o actos que, de alguna $u$ otra manera, iban a rendir con el concepto básico o convencional del Estado de Derecho. La presión que, históricamente, se ha dirigido contra este partido, sobre todo de intereses externos e intereses internos, pues, están referidos a la desaparición casi física del partido como tal, del control de las Fuerzas Armadas por parte de la derecha, en términos técnicos no peyorativos, y en términos también de cómo desarticular los logros, entrecomillados, de una revolución que trató de legalizar, no legitimar una serie de actos disfuncionales o anómalos, cuando perdió las elecciones el Frente Sandinista en los años 90, entonces, tanto las actuales fuerzas políticas externas como las internas, de alguna u otra manera, han querido, han presionado al Frente Sandinista a través de estos tres grandes elementos, que, por cierto, formaron los puntos de referencia en el Protocolo de Transición, que suscribió Doña Violeta Barrios de Chamorro, viuda de Chamorro, con el Frente Sandinista de Liberación Nacional en los años 90 para evitar, en aquél contexto histórico, una guerra civil, dizque era un fantasma que cubría el panorama político en aquél contexto histórico, esas han sido las tres grandes, esa ha sido la característica de la transición política, una presión fuerte hacia el Frente Sandinista, y este grupo partidario, pues, obviamente, como cualquier grupo partidario tiene la necesidad de sobrevivir, y ese llamado, por decirlo como en la novela de London, El llamado de la selva, de alguna manera, ha hecho que venga desarrollando, a través de sus cuotas de poder en las diferentes instituciones del Estado, una serie de

25 Segunda entrevista realizada al Magistrado Cuarezma, a propósito de sus comentarios a la sentencia 504 de la Corte Suprema, que reinterpreta el artículo 147 de la Constitución sobre la reelección presidencial. 
comportamientos que, lamentablemente, riñen con las reglas básica de todo Estado de Derecho Constitucional, aunque desde la posición de este espacio político sea legítimo realizar cualquier acto que les permita sobrevivir, capturar y mantener el poder de corto, mediano y largo plazo. El resultado de todo esto, que es un proceso ya de más de 16 años, y como bien lo refería recientemente un miembro de este partido, hacía referencia a que no vale escatimar ningún costo político para el mantenimiento del poder. Ya contextualizando esto en la Corte Suprema de Justicia, en la Sala de lo Constitucional se produce un acto, que, a mi juicio es producto, precisamente, de ese comportamiento no ahistórico, sino ese comportamiento histórico, que, en cierta forma, era anunciado, al no lograrse en la Asamblea iba a desarrollarse en cualquier otra institución, y le tocó a la Corte Suprema de Justicia. El documento que suscribieron seis Magistrados, denominados popularmente sandinistas, obviamente, que viene a poner en entredicho la situación, viene a poner en entredicho, no solamente la fortaleza del proceso democrático, sino la sinceridad de haber optado por un estilo de vida como es la democracia en nuestro país, como es la democracia como sistema de vida, en la Asamblea Nacional el Frente Sandinista no logró, no logró sumar los votos para una eventual reforma constitucional que permitiría una discusión sobre el tema de la reelección, al fallarle ese mecanismo legislativo, como ya lo había anunciado algún Magistrado denominado sandinista, aquí en la Corte lo había anunciado, de alguna u otra manera, que ya estaba todo calibrado y que, de todos modos, lo iban a hacer, dentro o fuera de la Asamblea lo iban a hacer, tomaron la decisión política de realizar un documento que dejara inaplicable las disposiciones constitucionales y la prohibición de la reelección de las personas que lograran obtener la titulación del Poder Ejecutivo. Luego vienen ya temas de carácter formal y temas de fondo, una resolución que fue tomada, como muy bien lo sabes, con grandes problemas de procedimiento, es decir, con grandes problemas de formalidad para constituir la Sala, que son reglas previas y básicas para poder consolidar el Estado de Derecho, desde el punto de vista de una Sala Constitucional, que a la vez es la atalaya o el guardián para cuidar celosamente el Estado de Derecho, esas reglas previas, precisamente, parte de ese acuerdo del Estado de Derecho, y ese convocar a los propietarios y seguir todo un procedimiento que establece la Ley Orgánica, si deseas, pues, te cuento un poco, te relato un poco el desarrollo de los acontecimientos. El lunes, creo que fue un 19, un lunes 19 de octubre en los despachos de los diferentes Magistrados, y hablo por el mío, recibimos la convocatoria ordinaria a la Sala de lo Contencioso, que son todos los miércoles a las diez de la mañana, posteriormente, solamente esa convocatoria en lo personal recibí, posteriormente, como a eso de las cinco de la tarde recibí una comunicación telefónica del Magistrado presidente, Manuel Martínez, que me decía: "Sergio, ¿dónde estás?, voy en dirección a casa, voy a mitad de camino, hay un complot en la Corte, ¿te vienes a casa, por favor, para que conversemos?". "Está bien", y no era la primera vez que sucedía una cosa similar, ya había sucedido un año y hacia atrás, con la famosa resolución que estas mismas personas tomaron a propósito de los Consejos Populares Ciudadanos (CPC), siempre a la sombra de la ley, nunca mejor dicho, "a la sombra" en sentido del atardecer y del anochecer, han tomado dos decisiones de esta naturaleza, se repitió la historia, yo me dirigí a la casa del Magistrado presidente y a partir de ahí comenzamos a recabar información, él no podía moverse en ese momento porque tiene una otitis aguda, casualmente anda en estos momentos en viajes oficiales, pero viéndose por los médicos fuera del país, y me dijo: "averigüemos qué está pasando, porque me llamó el relacionista público, que me comenta que hay una conferencia de prensa dentro de unos minutos", él llamó al Magistrado Solís, y el Magistrado Solís le expresó, primero le preguntó: "Rafael, ¿qué está sucediendo?”, y, entonces, Rafael le dijo por 
teléfono: "enciende la televisión y te darás cuenta", el spiker estaba escuchando, se puso a reír Payo ${ }^{26}$, bueno, Rafael, se cortó el teléfono, y llamé a la secretaria de la Sala Constitucional, que es Elmira Castro, y le pregunté: “¿qué está sucediendo Elmira?", "no", me dice, "bueno, una notificación extraordinaria para una reunión por la tarde". “¿Y a qué hora me hicieron llegar ese documento, porque a mi oficina no llegó?". "Pues el Magistrado presidente de la Sala de lo Constitucional me pidió que lo hiciera a eso de la una de la tarde", que es por acuerdo del 16 de marzo del 2009, que es la hora a la que se suspenden las actividades laborales en la Corte, por cuestiones de ahorrar energía eléctrica y otras situaciones más, ¿no?, comida, porque aquí se subvencionaba la comida $\mathrm{y}$ otros privilegios que se fueron recortando, $\mathrm{y}$, entonces, la Corte plena decidió que aquí se saliera a la una de la tarde. "El Magistrado presidente, Francisco Rosales, me pidió que a eso de la una de la tarde pasara dejando los documentos de la nota citatoria, el memorándum, a los despachos”. “¿Y a qué hora pasaste dejando el mío?”, le pregunté, "como a eso de las diez para la una de la tarde". "Está bien". Luego, pues, se desarrollaron los hechos, la conferencia de prensa, al día siguiente vine al despacho, busqué ese documento, confieso que por la tarde comencé a llamar a mi equipo de trabajo preguntando si conocían de ese documento extraordinario, esa citación para una reunión extraordinaria, nadie tenía conocimiento, al día siguiente antes del mediodía, pues, a media mañana, no recuerdo muy bien, un colega, Iván Escobar Fornos, que es otro miembro propietario en la Sala Constitucional, tenía el memorándum, estábamos en la oficina de Manuel Martínez, y le dije: "Iván, me lo facilitas, por favor". "Cómo no, Sergio", leí el memorándum, y yo no aparecía en el memorándum en la citación, cometieron un grave error de los tantos que cometieron en el ámbito formal, que estando en Nicaragua, porque había regresado de Barcelona el domingo por la noche, en el vuelo de la American, eso a las ocho de la noche, veníamos de un seminario en Cataluña sobre "Justicia y Autonomía", y estaban todos los propietarios con sus respectivos suplentes, pero no estaba tu servidor citado, de tal manera que ahí hay un vicio de nulidad muy grande, a efectos de la constitución de esta Sala Constitucional, eso como primer punto, es decir, en los aspectos de forma, que no son tan formales, porque son aspectos, son requisitos indispensables, porque hay todo tipo de requisitos, como bien lo sabes, en este caso, es un presupuesto para que la Sala se pueda constituir y desarrollar su actividad propia de guardián de la constitucionalidad y el Estado de Derecho, se necesitan una serie de mecanismos no puramente formales, sino son aspectos de forma de fondo, por llamarlo de alguna manera, para que se constituya, el segundo aspecto, y muy importante, es que una vez constituida esta Sala de manera anómala, la decisión de seis personas, su carácter personal, digo su carácter personal habida cuenta de que no se había conformado bajo los parámetros constitucionales y la Ley Orgánica del Poder Judicial, se asumen, arrogan la facultad, que no está establecida en la Ley de Amparo y mucho menos en la Constitución Política, de declarar inaplicables disposiciones constitucionales, haciendo referencia a una serie de juegos de carácter interpretativo a propósito de la soberanía originaria, que ha sido violentada por el proyectista de la reforma del 95 de la Constitución Política, que limita la reelección de los presidentes, que no había sido contemplada por la Constituyente del 1987. El Magistrado presidente, Francisco Rosales, es de la tesis de que el concepto de soberanía está radicado en el presidente y no en la Asamblea Nacional, debido a que, según su hipótesis para legitimar, bueno, para comprender todo lo que sucedió esa noche es que como producto de las elecciones presidenciales en segundo plano están las elecciones de los diputados y, por lo tanto, donde radica la soberanía originaria es en el presidente y

26

Se refiere al diminutivo de Rafael que se le da al Magistrado Solís en confianza. 
no en los diputados. Sin embargo, como la lectura la hace al margen de la Constitución y no a partir de ella nos encontramos un problema de fondo grave, que fue lo que le sucedió, en cierta forma, a Chávez, aunque Martinelli, ¿Martinelli es el de Honduras?

\section{R: No, Martinelli es el de Panamá, será Micheletti.}

S.C.: Eso, Micheletti, claro, junto con el Ejército no respetaron las formas, pero más o menos sucedió lo mismo en Nicaragua que en el caso de Honduras, que, por cierto, la reacción no fue la misma de la $\mathrm{OEA}^{27}$ en el caso de Nicaragua, porque aquí se alteró el sistema democrático, se rompió el juego democrático, ya explicaré desde mi punto de vista por qué, y, entonces, la lectura que hacen las personas que escriben este documento se desarrolla al margen y no a partir de la Constitución, y se olvida que estamos en un sistema democrático participativo y representativo, que, como establece la Constitución Política, la soberanía reside en el pueblo y se articula o se desarrolla o se operativiza en el espacio natural, que es el foro político que la Constitución conforma como Asamblea Nacional, y a partir de ahí es donde, conforme a la Constitución Política la comunidad nicaragüense comienza a construir su sistema en el juego y rejuego político en ese foro por excelencia, entonces, la soberanía, según la Constitución Política, radica en la Asamblea Nacional, y, en este sentido, sea o no una decisión del Constituyente originario o del legislador de 1995, lo que interesa es la decisión de la población soberanamente en restringir y limitar, en el caso del 95, las reelecciones, a efectos de que se inhiba cualquier tentación de que cualquier "enano totalitario" que ande caminando por ahí en las calles del país, para que deje de tener pensamientos de poder reelegirse, y ciertamente, pues, hay ciertas cabezas que todavía piensan que pueden, que son los Mesías, que son los que en sus alforjas, de alguna manera, tienen las soluciones del país de manera vitalicia. Estas seis personas que suscriben un documento, que se arrogan facultades que no las tienen, declaran inaplicable una disposición constitucional y alteran el orden democrático, ¿por qué lo alteran?, porque un juego cuando comienza, con reglas previas, y se cambian a mitad del juego deja de ser el juego originario que se comenzó, y pasa a ser cualquier otra cosa menos el juego que comenzamos, y podíamos poner ejemplos como en el basket o en el fútbol, si comienzas con 11 jugadores y el árbitro te lo cambia y dice que un equipo va a trabajar con 11 jugadores y el otro con 4 dejó de ser un juego de fútbol para convertirse en una payasada, en ese sentido, pues, ya deja de ser el juego originario, y se convierte en cualquier cosa. En el caso de Nicaragua, pues, mal que bien, ya habíamos tomado una decisión, digo, habíamos tomado una decisión, la nación nicaragüense, en el 90 para abandonar los conflictos bélicos, pasar a un proceso de reconciliación y de unidad nacional, y elegir la democracia como vestimenta de a diario, como estilo de vida a diario, y para eso se establecieron, se reconoce la Constitución del 87, que en materia de derechos civiles, políticos, y de derechos humanos, ha sido reconocida por el Derecho Político o Constitucional como una Constitución bastante buena, sin perjuicio de algunos aspectos perfectibles que la Constitución tiene, como es la centralización presidencialista y otros temas, pero en el tema del ejercicio político es altamente positiva, así lo ha dicho, casualmente, la doctrina jurídica constitucional española lo expresaba con Luís López Reyes entre otros colegas españoles, entonces, dejó de ser democracia, porque ya se rompieron las reglas del juego, y sobre todo por una persona, que siendo titular del Ejecutivo actualmente, constitucionalmente no puede presentarse a las próximas elecciones, de tal manera que de presentarse se presentaría a un juego

27 Organización de Estados Americanos. 
forzado, o forzando al resto que participa, o al concepto democrático previamente establecido por la Constitución en el 87 y en el 95, y ahora estaríamos en un juego que ya deja de ser el juego que estaba establecido previamente por la Constitución, y lo que vamos a parar, el país entraría a un juego diseñado o estructurado por seis personas, que, obviamente, no tuvieron márgenes de acción, porque la subordinación política dentro de la Corte Suprema de Justicia es, permíteme la expresión ordinaria, brutal, ya lo había dicho en aquél entonces, y por eso te hacía con mucho cariño ese llamado de atención cuando hacías la denominación de mi Magistratura, cuando acá se discutía, y te lo advertí en aquél entonces, la reglamentación de la Ley de la Carrera Judicial fui el único Magistrado que se opuso no solamente a la Ley de Carrera Judicial, cuando estaba en "Ética y Transparencia" como directivo, sino que ya siendo Magistrado me opuse a la reglamentación de la Ley de Carrera Judicial, porque ni la ley ni el reglamento garantizan la independencia interna de los jueces en Nicaragua, en el sentido de que cabe todavía la posibilidad de ser trasladado unos jueces de un sitio a otro sin su consentimiento, y eso rompe el presupuesto fundamental para la independencia de los jueces, que es la estabilidad laboral, ahí está en el reglamento mi voto razonado y no voté a favor de ello, sin perjuicio de que quizá a las grandes tendencias le hubiera interesado ese control de los no deseables internamente para cancelarle por esta vía su independencia interna, personalmente me opuse y me opondré siempre, tengo muy claro y no solamente por formación, sino por principios, que si hay independencia es la única forma en la que el país saldrá adelante, la seguridad jurídica, desarrollo económico, seguridad, tranquilidad, etc., y en la medida en que no haya seguridad e independencia interna muy difícilmente va a haber seguridad en las relaciones con el Estado y entre los particulares, y lo que habrá serán escenas bochornosas de cancelaciones de la independencia interna de las cúpulas hacia los jueces internos o de la presión externa de las cúpulas del Poder Judicial, como, ciertamente, sucede en el caso de Nicaragua, que puede explicarse o no, pero no es el tema en este momento, y esos son los dos grandes aspectos de esta resolución, no dudo que mientras no haya estabilidad política del partido de gobierno en la Asamblea Nacional, no dudo, que vuelvan a haber conatos como el del 19 de octubre pasado, por ejemplo, la tentación de no nombrarse a Magistrados en abril por vía de la Sala Constitucional, o mejor dicho, nuevamente, convocada de forma anómala, decidir desde la Corte Suprema de Justicia a través de la Sala el nombramiento de los Magistrados, lo digo por lo siguiente, si este grupo de personas tuvo como punto de referencia la Sala cuarta de Costa Rica para hacer esta travesura, que le está costando muy caro y le costará muy caro al país para volver a recobrarse, como el caso de Honduras, que, felizmente, por mucho que hayan sucedido las cosas, la población salga a la calle y volvió, nuevamente, a restablecer su decisión del juego democrático, si nosotros atendemos a la Sala cuarta, que siempre sale bastante bien parada en las investigaciones del Instituto, que ha venido siempre mi querido profesor Manuel Alcántara, si uno le echa un vistazo a la Sala cuarta y lo proyecta en la visión política de estas seis personas, pues, puede ser que a corto plazo la Sala de lo Constitucional decida que si la Asamblea Nacional no nos da los Magistrados, como es un imperativo constitucional hacerlo inmediatamente después del cese a las funciones de éstos, entonces, la Sala de lo Constitucional, o llámese una sala mal formada, nuevamente, decida que las personas a las que se le termina su período lo continúen, lo continúen en la Corte en los próximos cinco años a partir de que la Constitución Política no solamente no dice que una vez finalizado el cargo se marche, al no decir eso puede caber la interpretación desde la Sala Constitucional que continúe en su cargo hasta que no haya un nombramiento por la Asamblea Nacional, de esa manera presionaría a la Asamblea Nacional para el nombramiento, o por otra vía de facto, siempre 
interpretativa, decidir que ya que la Asamblea no nombró en el momento oportuno, que se entiende en el día en que se cancelen estos nombramientos, pues, esta Sala establece que la Asamblea Nacional no pudo emitir no una facultad sino un deber constitucional, y, en este sentido, la Sala dice que se le amplían los cinco años más a estos Magistrados que se marchan con base a una apreciación interesante, que está en la Constitución en el 129, dice que todos los poderes del Estado son independientes y conviven entre sí, y sólo obedecen al interés de la nación y a la Constitución Política, es decir el interés de la nación está sobre la Constitución Política según la propia Constitución Política, este es un escenario que si hay tensión e inferencia política no dudo, partiendo de la lectura que ha venido realizando, el trabajo que ha venido realizando la Sala Constitucional que nada tiene que ver con la nuestra, entonces, puede ser que la nuestra constituida, nuevamente, anómalamente se llene de valor para realizar actos de esta naturaleza, y así podrán ir marcando algunos comportamientos en los próximos dos años, mientras el partido de gobierno no tenga cohesionados sus votos en la Asamblea Nacional, o consigue el voto 47 para legislar ordinariamente, con mucha más razón los 56 que les permitiría nombrar a todas las personas en los cargos de elección calificada, o bien para la reforma constitucional parcial. En este sentido, no me extraña lo más mínimo que haya conatos de actos de facto de cara a los próximos meses, porque creo que se está jugando es la sobrevivencia, ya no el partido del gobierno, sino de un espacio concreto dentro de ese partido, que, posteriormente, como no tiene sucesión política, y como en el caso de América Latina y, especialmente, de Nicaragua algunos líderes políticos se creen los proto-hombres, entonces, sin ellos es imposible que no haya desarrollo, bonanza, orientación, dirección, más o menos como en la España de los 70, ¿no?, con el extinto Francisco Franco, "si no estoy yo, pues, todo esto es un caos", entonces, mientras no haya sucesión clara de este partido, y además sumado con otros intereses más de carácter económico, porque ya este movimiento político ha dejado de ser, como en los 80, una aspiración de izquierda, ya se ha convertido en un espacio puramente económico, ya es un partido político que tiene anidado un capital en proceso de formación para constituirse quizás otro espacio del capital criollo, con la diferencia de que el capital criollo de Nicaragua está formado por la burguesía pura y dura de dos o tres personas, pues, luego, se aparecerán dos o tres expresiones de capital bastardo, formadas por cúpulas de dos o tres partidos, o de dos o tres personas, o de dos o tres apellidos al margen del capital tradicional, y de ahí, pues, seguir construyéndose ese capital criollo, entonces, ya no son postulados partidarios en función de intereses generales de la comunidad, sino visiones mesiánicas acumulando capital, acumulando riqueza, y esa acumulación de capital, como todo capital, tiene que protegerse cueste lo que cueste, entonces, sobrevivencia política que garantiza la sobrevivencia en la acumulación de su capital, la historia se repite, desde la diferentes dictaduras del siglo pasado en Nicaragua a nuevas tentaciones que ya vienen dando pasos firmes y concretos, si antes se hablaba, bueno, más o menos ahí me voy a quedar, y eso es todo lo que más o menos lo que está sucediendo en el país en este momento, y, un tercer momento, las reacciones de los actores externos han sido, si bien es cierto, firmes, no ha sido tan contundentes como en el caso de Honduras, aunque ya estoy logrando comprender qué fue lo que pasó en el caso de Honduras, por qué las reacciones tan virulentas de algunos sectores que hoy están apoyando, creo que es la primera vez que han actuado con inteligencia, pero eso es ya otro tema, pero en el caso de Nicaragua estamos así. ¿Cómo está el Poder Judicial internamente?, pues, interna y externamente, como siempre lo he dicho antes y durante, antes de ser Magistrado y durante mi actividad como Magistrado, su percepción, su confianza y su estabilidad y su decencia está, como diría Lloró en su novela El 84, evaporizada, esto simplemente es un marco 
formal donde no se desarrollan ni de forma efectiva ni concienzuda, y ni mucho menos respetuosa, las funciones constitucionales del Poder Judicial.

R: Incluso, en una de mis entrevistas que, además, fue después de la sentencia, me decian que en caso de conflictos repetidos en el órgano legislativo se iba a llegar peligrosamente al "gobierno d los jueces" en este país, que era uno de los grandes temores de los constitucionalistas franceses, recuerdo el año pasado en las clases de Derecho Constitucional Comparado, el profesor Díez Picazo hablaba del "gobierno de los jueces" como una cosa terrible, lo peor que le puede pasar a un país, porque la sentencia además no es algo que se pueda invalidar, o por lo menos el intento de la Asamblea no parece que vaya a prosperar, no sé cómo lo ve usted.

S.C.: Primero, te digo que todavía, como en el béisbol, igual que en el fútbol, el juego se cierra hasta que esté el último "out", o hasta que el árbitro diga: "se acabó el juego", por una parte, y, por otra parte, a propósito del "gobierno de los jueces", lo conversaba hace poco con el presidente de la Sala cuarta de lo Constitucional allá en Costa Rica, soy partidario de que algunos temas que no los pueda hacer la Asamblea Nacional los pueda agresivamente cumplir la Sala Constitucional, pero en el sentido literal posible del mandato que tiene la Sala Constitucional, sin desbordar los cauces de legalidad, me explico de otra manera, y esto venido sobre todo en el ámbito de materia de las políticas públicas, y eso lo aprendí con mucha claridad con ustedes en este curso que desarrolló Manuel con la Universidad Americana, en el curso quedaron claras entre otras cosas lo siguiente: si el Poder Ejecutivo, en el caso de nuestros países, fundamentalmente, en el de Nicaragua, tiene la facultad de diseñar las políticas públicas, no menos cierto es que la Asamblea Nacional tiene que superar su posición reactiva frente a las decisiones o iniciativas del Poder Ejecutivo, y, a la vez, tiene que pasar no solamente a formular, sino a supervisar y a ejecutar las políticas públicas desde el parlamento, eso lo puede hacer el parlamento, y ya sea supervisar y obligar al Ejecutivo a que las cumpla, y de no cumplirlas también formularlas en el ámbito del foro de la Asamblea Nacional. Cuando uno y otro no la realizan, creo, quizá estaré equivocado, que la Sala Constitucional, pero claro, estoy pensando en una Sala Constitucional responsable, madura, independiente, puede tomar decisiones para garantizar el cumplimiento, habida cuenta de que estamos en un Estado Social, un Estado intervencionista, no extremadamente liberal, sino intervencionista, un Estado Social de Derecho, para garantizar, a través de la obligación que se le pueda hacer tanto al Ejecutivo como a la Asamblea, del cumplimiento de las políticas públicas en el caso de nuestra realidad, de tal manera que, por ejemplo, por vía de amparo una persona puede ampararse ante la Sala Constitucional y decirle a la alcaldía, por ponerte un ejemplo, no hagas ese obelisco que cuesta 100 millones de córdobas, paren esa obra, y destinen este dinero a las prioridades que tienen en su agenda de la comuna, como puede ser: escuelas, creación de cauces para que el agua fluvial pueda no inundar la ciudad, porque, generalmente, hay muertos, etc., etc., entonces, creo que la Sala Constitucional pudiera hacer mucho en función de operativizar, supervisar, garantizar, como tú quieras llamarle, esas políticas públicas, que ni unos ni otros las hacen, y la Sala obligarlos a que las hagan, pero obligarlas no crearlas, por eso te digo, en el sentido literal posible de tus facultades, ¿cuáles son?, pues, que se respete la Constitución, que si a partir de ésta se desarrollan las políticas públicas, oye Ejecutivo, oye Legislativo, ¿por qué no haces esto?, y te obligo a que lo hagas, no es que yo me lo voy a inventar para que tú lo hagas, que tú hagas lo que yo me invente, que son dos cosas totalmente diferentes, y es peligroso, sobre todo en el caso del hemisferio en América Latina, estas tendencias de anidar el poder en la salas 
constitucionales, porque se van a construir, obviamente, espacios de decisiones políticas partidarias, no políticas constitucionales, porque la Sala Constitucional es política pura, ¿no?, a partir de ciertos parámetros de no desbordar tu legalidad, pero es política constitucional, pero no política partidaria, entonces, ahí hay un fenómeno de anidarse en esos espacios, de atrincherarse, y cueste lo que cueste, sin importar el costo político, tomar decisiones en función del partido y no en función del interés de la comunidad, o como le llama la Constitución española el interés general, y esto viene a destruir todos los conceptos básicos del Estado de Derecho desde la Administración Pública, de la actividad legislativa, del propio Poder Judicial, etc., etc., y eso te abre, pues, otra serie de aristas bastante peligrosas, sin ahondar, simplemente, te las señalaría desde mi punto de vista, nuestros países son periféricos, empobrecidos, no tienen ninguna relevancia en el mundo global, lamentablemente, pero siempre son de interés para las multinacionales para ubicar aquí sus empresas, nunca mejores para algunas visiones "buitrescas", podríamos decir, esas visiones depredadoras, bueno, si en el caso de Nicaragua no hay reglas, pues, entonces, yo me anido, y si lo que implica ahí es la coima, pues, entonces, proyectemos nuestra empresa durante 15 años, hacen coima, saquemos lo que tenemos que sacar del país, y luego nos vamos, entonces, ese es el peligro de los países periféricos que al no haber espacios de seguridad, ciertamente, hay sectores de capital interno y externo que capitalizan y explotan la connivencia con la ausencia de reglas, que es lo más grave todavía, porque se produce más miseria, más desigualdad, y luego tenés problemas como Somalia, Afganistán y Haití, y cada quien en su punto de referencia geográfico, y de ahí los pobres somalíes quedaron asaltando barcos en el mar, espero que esa situación no llegue, porque al final del camino dices, bueno, ¿para qué vamos a seguir invirtiendo plata aquí?, pero como Nicaragua es un punto de referencia territorial en toda América Latina, entonces, pues, nada, invirtamos, pero ya sabemos que tenemos que pagar, en nuestro presupuesto tengamos un rubro para el tema de lo de las coimas, porque no habría en el caso de Nicaragua, eventualmente, si las cosas siguen así, esa es la percepción que se podría generar, no habría reglas, y al no haber reglas, pues, entonces, ya habría un rubro en cada presupuesto de gastos operativos ante las diferentes empresas para pagar la coima, y eso hay que evitarlo a toda costa, esa percepción y esa sensación hay que procurar desvanecerla cuanto antes, ¿será posible o no?, bueno, eso ya dependerá de la responsabilidad de los actores, externos e internos, en el caso de nuestro país. No sé qué más quieres que te aporte.

R: Ya la última cuestión interesante es que en la argumentación jurídica de la sentencia se recupera el precedente de Costa Rica mal interpretado y mal aplicado. ¿Cuál sería su observación al respecto?, porque recuerdo que al entrevistar al Magistrado Solís unos dos días después de la sentencia, yo regresé esa semana, y en la entrevista aparece una cuestión muy grave, ¿no?, al decir que esto se olvidará, esta bulla mediática y ciudadana, a pesar de que la marcha fue un éxito, la gente que protestó contra la sentencia y contra otras cuestiones del abuso del actual gobierno de Daniel Ortega, pero sí la percepción mía al escuchar al magistrado decir: "esto se olvidará, esto pasará", con mucha banalidad, a mí me sorprendía porque era una cuestión muy grave desde el punto de vista jurídico y también político. Pero, ¿qué piensa a propósito de la sentencia costarricense?

S.C.: Mira, antes de reflexionar, rápidamente, sobre este tema, lo que te iba a decir a propósito del profesor al que me hacías referencia sobre la dictadura de los jueces, hace también muchos años, y desempolvo lo que he dicho en el pasado por aquello de la memoria histórica, que es lo que apuestan aquí, a que la memoria histórica se desvanece 
con facilidad en Nicaragua, hace varios años en un programa de televisión del Canal 12, comenzando un año en uno de estos programas de debate, decía: "se nos avecina una dictadura judicial en el país", hace poco conversaba con ese colega periodista, y le dije: "¿te acuerdas cuando hace varios años en tu programa, y me entrevistaste, y estuvimos en el patio conversando un rato, y dije en público, viene, se están creando las condiciones para una dictadura judicial?", hice la reflexión, las dictaduras ya no es necesario sacar los tanques a las calles, ni dar golpes de Estado, sino utilizar el andamiaje formal del Estado de Derecho para fortalecer la visión de poder absoluto de cualquier partido, $\mathrm{y}$, en este caso, es lo que está sucediendo ahora, personalmente, pues, no lo he olvidado, y lo que sucedió el 19 de octubre no se ha olvidado, pero, generalmente, se apuesta al olvido después de tres días, quizás, por las grandes necesidades, las diferentes necesidades que tiene, que están apretadas en la agenda cotidiana del país, ¿no?, de que hay que saciar los alimentos, el vestir, la escuela, pagar la energía eléctrica, el agua potable, y el día a día se te hace insoportable, y a veces se apuesta mal, en el sentido de que la población va a olvidar situaciones como esa, pues no, esto mismo le decía yo, casualmente, a Rafael Solís, cuando sucedió lo del 28 de julio en Honduras, recuerdo que estábamos en la Sala de lo Penal, compartimos también los dos la Sala de lo Penal, y me dijo él: "te doy cuatro días para que Zelaya esté en el poder", y me acuerdo que le contesté: "no, las cosas han cambiado en el mundo, no va a suceder eso", “cómo no?”, “apostemos”, le dije, "ahora mismo, lo que tú quieras”, "apostemos, y no va a suceder de esa manera, Zelaya no volverá al poder", pensé en ese momento, porque así como se utilizan, así como algunos quieren utilizar el Estado de Derecho para controlar, así también, y que fue lo que pasó en Honduras, también externamente han utilizado el Estado de Derecho para quitarte de encima al otro personaje, que fue lo que sucedió, ¿y cuál es la pieza básica también del Estado de Derecho?, los sufragios, el sufragio universal, ¿que en Honduras estuvo mal lo que hicieron?, en términos de forma, sí, ¿que la sanción que se le impuso a Zelaya puede ser discutida?, sí, tanto si es positivo como negativo, sí, porque el caso de Honduras es interesante, cuando salimos de la postguerra, cuando salimos de la guerra en el 90, todos los países de Centroamérica toman la decisión y dicen: "bueno, señores, no más conflicto, no más dictadura, democracia, paz, dignidad, derechos humanos, seguridad económica, etc.", en el Protocolo de Tegucigalpa están todos los principios, y en Honduras dicen: "cierro la posibilidad de reelección, para evitar tentaciones de futuro", para no volver a las dictaduras de Somoza, Trujillo en Dominicana, aunque muy alejado en el tiempo, pero el fantasma siempre recorre la región, etc., y el que pretenda, pretenda, inmediatamente se le cancela su puesto de trabajo, entonces, todo indica que la Constitución Política no solamente era una expresión de ese contexto histórico, de esa, no esa inquietud, esa necesidad, sino esa imperiosa necesidad de cerrar sus espacios a cualquier tentación dictatorial, sino que además en la misma Constitución se pone la sanción, la gente cree que, a mi juicio, debería haberse desarrollado un procedimiento para iniciar esa sanción, y no, fuera, fuera, ¿por qué?, porque era un juego con reglas claras, el jugador que toca la mano con la pelota en el área de la portería es penalti, y se cobra con un gol, el que promueva la reforma en función de esto, de normas que son pétreas, que no se pueden alterar por nadie, se le cancela su nombramiento de inmediato, y eso fue lo que sucedió en Honduras, a mi juicio, claro, la diferencia es que lo sacaron en pijama a San José, se lo debería haber dejado sin puesto en Tegucigalpa, lo hubieran dejado en su casa, y cuando llegue a la presidencia, "mira, ya no tienes trabajo", "¿por qué?”, "porque violaste las normas de tu contrato, que es la Constitución, y se acabó tu trabajo". La propia Constitución, el Estado de Derecho, también te da, visto en blanco, la posibilidad de eliminar ese tipo de tentaciones, así 
como también te permite gobernar al adversario, como está sucediendo en el caso de Nicaragua, aquí la ley se utiliza para perseguir al adversario, lo utilizó Bolaños para perseguir a Alemán, y no por eso tienes que ser o no liberal, eso lo viví yo hace siete u ocho años atrás, yo lo decía: "no utilicen la ley penal para perseguir al adversario, se van a meter en un problema enorme", como decía un profesor mío en un seminario en el País Vasco, Antonio Veristain, un jesuita penalista, "el Derecho Penal es como un artillería, colocas mal tu, y causas desastre", eso es Derecho Penal y se lo he explicado acá, "no utilicen, ni contaminen la ley para intereses de carácter político, porque si no se van a generar costos bilaterales impresionantes", sobre todo en un país cuya democracia todavía está en la etapa que ni siquiera ha llegado a la pubertad, que ni siquiera está apta para reproducir otros valores, porque el propio, que es la democracia, todavía no está internalizado totalmente como estilo de vida, y eso sucedió en el caso de Bolaños, y a partir de ahí se despertó la necesidad de cómo manipular la ley, y se comenzó a desarrollar la ley, cuando se estaba discutiendo el Código Procesal Penal actual, que tiene una serie de disposiciones que te permiten desde el poder controlar al adversario, porque quisieron jugar a la cultura anglo-norteamericana, con instituciones represivas fuertes, con el Ministerio Público y la policía, aislando al juez del control de las investigaciones, ahí lo que tienes ahora es un sistema de justicia penal controlado políticamente, y se los advertí a los gringos, y el embajador norteamericano en su entonces, me dijo: "usted es el peor obstáculo para la aprobación del Código Procesal Penal", entonces, yo le dije: "oiga, no sé, yo me siento extraño, yo no sé si usted es el nica y yo soy el gringo, me siento extraño", y eso advirtiéndole, “¿ustedes quieren jugar a un Ministerio Público como el inglés? Necesita que Nicaragua tenga la cultura inglesa, necesita usted, tener un titular del Ministerio Público, un Procurador, como el norteamericano, pues, necesita el proceso histórico norteamericano, vivirlo intensamente, internalizarlo, y luego proyectarlo en el tiempo y en el espacio, lo que ustedes están atrayendo son instituciones que, académicamente, son excelentes en una fecundación, mejor dicho, en un territorio con una serie de poblaciones que entrecruzan ideas y fecundan una gran idea que es, hombre, parece que la democracia como que funciona, entonces, apostemos, no se sabe ni qué cosa es, $y$, en ese momento histórico, le meten una serie de instituciones que uno y otro lo controla, ¿qué es lo que van a formar?, un Frankenstein, ahí están los resultados", ¿que en cuanto los bancos meten la mano en el ámbito de la justicia la estropean?, ahí está el Banco Interamericano de Desarrollo, ahí está el Fondo Monetario metiéndose en la justicia, ¿aquí no se meten en la justicia?, con préstamos, con esto y con lo otro, ¿y qué es lo que están haciendo?, si tú banco inviertes en la justicia es para tu capital, no es para tus derechos como persona, y como al capital no le importan los derechos humanos, pues, le están dando al más poderoso de Nicaragua el control de los derechos humanos por vía de la protección de capital. Léete una entrevista que le hicieron hace poco a alguien del Banco Mundial, que dijo: "no, no, lo que queremos es seguridad, nada más, y las transacciones de capital", entonces, Pedro, María y Juan, ¿qué pasa con ellos?, entonces, también el proceso de reformas en Nicaragua alimentado por intereses externos del norte y Europa continental, pues, ha venido a dar avances positivos, pero también ha venido, ingenuamente, a meter en problemas al país, y te lo dije la vez pasada, ahí está la cooperación española, y le dije a los responsables españoles: "yo soy becario de la Agencia Española de Cooperación Internacional, becario del departamento de cultura en la cancillería de tu país”, y les dije, ocho años me pasé formándome en tu país, la independencia interna de los jueces en tu país costó sangre y es lo que les garantiza estabilidad y desarrollo, de haber pasado de un país con una situación de desventaja frente al resto de los países europeos para ser la España de ahora, recuerdo todavía que venía la dirección de la 
Comunidad Europea y tal y cuál, ¿y qué pasa con España y Portugal y Grecia?, bajémosle las asignaturas, el tiempo de la carrera, ¿cómo vamos a ser competitivos con los alemanes?, ¿cómo invertimos?, esa preocupación sólo fue posible con una decisión política, que tuvo, entre otros, Adolfo Suárez y tal, es decir, "señores, esta es la España que queremos", instituciones sólidas, eso no se ha preguntado en Nicaragua, "¿qué te cuesta?", le decía yo, "léete la historia de Nicaragua, hermana, no seas una burócrata, por amor de Dios, que estás metiendo en problemas al país", "no, Sergio, tú sabes que tengo que reportar allá lo que estoy haciendo y mis indicadores", "si el país no se maneja por indicadores, por amor de Dios, por indicadores burócratas, por el amor de Dios, esa normativa ¿es buena o es mala?”, ahí estaba, viniendo del Consejo General del Poder Judicial, ahí, donde estás sentada tú, ahora me la encontré otra vez en España, ahora que fui a Madrid hace poco, y me encontré en el pasillo: “¿te acuerdas? No te asustes ahora de lo que pasó en la Sala Constitucional, comparte tu responsabilidad, porque esa parte de la responsabilidad es tuya también, no es mía", entonces, así como dijo el eurodiputado holandés, y le dijo a Ortega con toda claridad, "oye, no seas estúpido, no seas torpe, la democracia no es un país, la democracia ahora es un patrimonio global", en ese sentido, también hasta los problemas son compartidos, y si tú vienes como cooperación y promueves un reglamento, la cooperación española en esta mesa me reconoce a mí y se lo quiere decir a la mesa de justicia, a la cooperación internacional gringos, ingleses, canadienses, españoles, Naciones Unidas, suecos y finlandeses, "señores, van a fortalecer la cancelación de la independencia interna con ese reglamento que ustedes van a aprobar, éste es el momento para protestar y poner en cintura al Poder Judicial", embroncaron a la Comisaria, a la Canciller austriaca, cuando vino a Nicaragua dijo: "damos 30 millones de euros si me apruebas ese reglamento", "bueno", dije yo, "por lo menos no son centenares, son 30 millones de euros", eso fue lo que costó la cancelación de la independencia interna de lo jueces, 30 millones de euros, ¿me vas a venir ahora a hablar con autoridad moral? Hay otro fenómeno curioso, mientras Europa continental invierte en el Estado de Derecho, en términos generales, debo reconocerlo, los gringos lo desmantelan, fortaleciéndote las instituciones represivas sin ningún tipo de control por parte del juez, el fenómeno este en Nicaragua es sorprendente, entonces, todo este relajo, nunca mejor llamado es la suma de todos estos errores.

\section{R: No, y qué tipo de instituciones se están consolidando.}

S.C.: Se están construyendo, se están consolidando, por el amor de Dios, le dije hace poco a los diputados: "este es el momento de poder poner las cosas en orden, quitándole potestad a la policía, controlando la independencia, canceláme, sólo prohíbe los traslados sin consentimiento de los jueces, y vamos a comenzar a observar a corto plazo un distanciamiento de los jueces frente a la subordinación política", porque no te van a poder correr, no hay mecanismo legal, no te van a poder correr.

\section{R: ¿Y la sentencia de Costa Rica que le preguntaba al principio?}

S.C.: Me sumo a lo que decía el presidente Óscar Arias, ¿no?, la diferencia comparativa es que la Sala cuarta de Costa Rica es la Sala cuarta, tanto en conformación histórica, construcción de institucionalidad, decisión y voluntad política respecto a cumplir con los mandatos constitucionales, y a jugar con seriedad a lo que tiene que jugar una Sala Constitucional, es decir, a la independencia respetando los controles constitucionales, sus funciones, que, en el caso de Nicaragua, no tiene esa facultad, o sea, formalmente sí, 
pero materialmente es un hilo de intereses partidarios brutal, que no solamente son partidarios, sino que también los espacios de facto, económicos y externos, se concentran acá, por la Sala Constitucional pasan intereses económicos, etnológicos, religiosos, gremiales, políticos, etc., obviamente, con mayor presencia partidaria, y económicos del capital criollo y también, por qué no decirlo, del capital externo de las grandes multinacionales, otra cosa es que luego te rasgues las vestiduras, aquí se sienta y luego en las entrevistas dicen: "queremos un Poder Judicial independiente", y al día siguiente me toca atenderlos acá, "échame una mano, hazme un favor, qué sé yo, te tendremos en cuenta y tal", ¿qué estamos construyendo?, ¿qué estamos construyendo?, entonces, nada, la realidad institucional y la madurez o la vertebración de esa voluntad política de la Sala cuarta en el caso de Costa Rica, sin entrar en detalles a la sentencia de Óscar Arias, en sentido particular, porque no era ni candidato por aquél entonces, pues, obviamente, que supone una gran diferenciación, aunque sean similares, la confianza es lo que legitima, alguien de ustedes decía en este curso: "la legitimidad es función del proyecto que tú propones en función de los intereses de la población", la seriedad y la responsabilidad de la Sala cuarta, proponiendo un proyecto como el que planteó con esta decisión, no solamente por la confianza que tiene, como no hay tentaciones dictatoriales, pues, la sociedad tica se siente cómoda, en el caso de Nicaragua, es una realidad radicalmente diferente, radicalmente diferente.

R: Pues yo no sé si tiene algo más que añadir...

S.C.: No, no, está bien. 


\section{ENTREVISTA $18^{28}$ :}

Nombre del entrevistado: D. Carlos Fernando Chamorro.

Cargo actual: Periodista, Ex - Director del diario sandinista Barricada, actual Director del Centro de Investigaciones de la Comunicación (CINCO).

Fecha de realización de la entrevista: Managua, 19 de noviembre de 2009.

Lugar: Centro de Investigaciones de la Comunicación.

Duración estimada: 38 minutos.

\section{TEXTO - Transcripción 18:}

\section{R: ¿Cuál es su opinión sobre la reciente sentencia de la Corte Suprema de Justicia respecto a la reelección presidencial en Nicaragua?}

C.F.C.: Lo que te decía es que en esa discusión, lo que se demuestra es que a nadie se le pasó por la mente decir los disparates que han dicho ahora, de que el artículo 147 viola el otro artículo, de que las contradicciones con los derechos humanos y los derechos políticos, de lo único que hablaron los diputados sandinistas en esos debates fue de la segunda vuelta, de que no estaban de acuerdo que se estableciera la segunda vuelta con el $45 \%$ de los votos, verdad, porque eso era costoso, porque eso era, un poco de cosas dijeron, pues, que no era para favorecer a la derecha, nadie dijo esto, nadie se opuso a la no - reelección consecutiva, digamos, o a que sólo hubiera reelección por un período no consecutivo, absolutamente, ni un argumento de ninguna clase, esto fue una cosa inventada de ahorita, pues, y tiene que justificar, entonces, aquí hay unos ingenieros jurídicos, políticos, que le dicen: "justificáme esto”, y ahí se ponen a trabajar.

$R$ : Y comparando los procesos de reforma constitucional, es cierto que la reforma del 95, la que se produce bajo el primer gobierno democrático de la etapa reciente de Violeta Chamorro, si que es la reforma legítima en el sentido de que era jurídicamente necesaria en el contexto de la transición política, ¿no? Pero después a partir del 2000 sí se produce una deriva, digamos, de los cambios constitucionales muy peligrosa, que yo creo, cuyos frutos estamos viviendo ahora, ¿cuál es opinión al respecto?

C.F.C.: La del 95, a ver la del 95 tiene mucha legitimidad, de hecho, hubo bastante consulta, a ver, es el resultado de un proceso político muy complejo, donde hay diferentes alianzas que se hacen para la reforma, luego se producen rupturas, tiene legitimidad porque era necesaria, dado, como dijiste hace un momento, que la Constitución del 87 no sólo es ultra presidencialista, es una Constitución que está hecha bajo el concepto de una visión hegemónica, es decir, un partido que tiene una mayoría completa en la Asamblea dice: "esta es mi Constitución y la que quiero para perpetuarme en el poder, porque yo voy a gobernar largo período", ¿no?, la del 95, bueno, es el resultado de un cambio de régimen, que fue el resultado de la elección del 90, donde las partes tiene que negociar, el mérito que tiene es que las partes tienen que negociar, ahora, tiene un problema, que creo yo que es la crítica que se le hace, de la cual yo no sé mucho, porque yo no soy abogado, que dicen que se cubrió mucho con el mecanismo de la reforma parcial, es decir, que ahí también se estableció el precedente

\footnotetext{
28 Entrevista breve, aunque con un contenido preciso más orientado al análisis periodístico, pero que muestra, en líneas generales, una comprensión rigurosa y crítica, además de una respuesta coherente, clara, y sin redundancias a las preguntas planteadas por la investigadora.
} 
de, prácticamente, hacer una reforma casi total a la Constitución, o, por lo menos, en elementos sustanciales, por el mecanismo de una reforma parcial. Y eso ha sido utilizado posteriormente siempre como argumento para los otros, que han hecho otra clase de abusos, pero yo creo que la reforma del 95 es muy importante, sobre todo por lo que vos estás estudiando, por el tema del equilibrio legislativo-presidencial, lo otro, lo de la reelección, pues, es una cosa histórica en Nicaragua que ha sido importante, pero no es único, es decir, el tema tributario es fundamental, el tema de la fiscalidad en esas reformas es fundamental, que se le devuelve a la Asamblea su prerrogativa, ¿no?, sobre el tema de los impuestos y sobre otras cosas.

R: Y es verdad que si el hilo conductor de las reformas ha sido conceder cada vez mayores facultades a la Asamblea Nacional en un proceso de des-concentración del poder, pero que, en la segunda etapa, se tradujo en una especie de trasvase de poder hacia las cúpulas partidarias, ¿no?, que eran las que en la Asamblea negociaban y se distribuian paritariamente la representación en las principales instituciones del Estado.

C.F.C.: Mirá, eso evidente, si lo tratamos de ver desapasionadamente, pues, si yo soy un marciano que vengo a Nicaragua y veo y trato de escuchar objetivamente el argumento, llamémosle, de los pactistas, pues, de Alemán y Daniel Ortega, que dicen, bueno, hicimos la reforma del 99-2000, verdad, que es la siguiente reforma de esa, el origen de esas reformas está en lo que Alemán describe como una crisis de gobernabilidad, él dice, para gobernar, y que no me sigan haciendo huelgas, y que no me sigan haciendo barricadas con la fuerza que el Frente tiene, digamos, en las calles, con los sectores sociales que puede movilizar, necesito calmarlo, y para calmarlo necesito darle que compartan el poder. El alegato del Frente, ¿cuál era?, el alegato del Frente es: "me quitaron una cuota de representación legítima que yo tenía en el Estado", porque al producirse en el 94 la crisis interna del Frente, que la mayoría de los diputados se fueron a los renovadores, el Frente dice: "me despojaron de mi representación institucional". Y no está pensando en la democracia o en el diseño del Estado, está pensando en sus cuotas de poder, y aquí hay un libro de este muchacho, de Carlitos Fonseca, el hijo de Carlos Fonseca, que se llama "El poder, la propiedad...", este es un nombre enredadísimo, pero él documenta muy bien eso, de cómo el Frente va a esa reforma para recuperar sus cuotas de poder, y Alemán que entiende muy bien de esos mecanismos, dice: "perfecto, ¿cómo lo hacemos?, bueno, hagamos, ensanchemos los poderes". Una Contraloría que es unipersonal hagámosla colegiada, el Consejo Electoral hagámoslo más grande, la otra cosa, y así vamos a tener cada quien, paritariamente, Magistrados, o ese tipo de cosas, el Frente sigue en esa reforma con el interés específico de la segunda vuelta, es decir, el Frente está pensando en el poder, el Frente parte de la premisa de que cuando en la reforma del 95, su preocupación principal, repito, no es la reelección, es la segunda vuelta, sabe que no puede ganar una presidencia en primera vuelta, porque su umbral electoral no llega al $40 \%$, y por lo tanto nunca va a obtener $45 \%$ o más, y por eso es por lo que está luchando, Alemán está pensando en su perpetuación en el poder, Alemán quería una diputación vitalicia como ex-presidente, al final en la transacción le dan una diputación por un período como ex-presidente, que le da inmunidad, aunque en ese momento Alemán no pensaba que nadie le iba a acusar por corrupción, lo que él quería era el control de la Asamblea, como, en efecto, lo obtuvo en el 2001, ¿no?, cuando gana Bolaños Alemán se hace nombrar, pues, con la mayoría de su partido presidente de la Asamblea y eso le genera una crisis con Bolaños, pero eso es otra historia, pero esa era su prioridad, la prioridad de Ortega era lo que Alemán, finalmente, le concedió, que fue la reforma a la Ley Electoral para establecer lo del 35\% y tosa esa 
cuestión, o sea, es una reforma muy pensada en los intereses particulares de los dos grupos, definitivamente, es una reforma prebendaria y es muy fácil documentar eso.

R: $Y$, sin embargo, luego se ha producido una concentración del poder en el Ejecutivo, ¿no?, me refiero al gobierno reciente de Ortega, al tratar de fortalecer un Ejecutivo que, constitucionalmente, ha sido debilitado en favor de la Asamblea, y pienso, fundamentalmente, bueno, en el Poder Judicial que está, absolutamente, politizado.

C.F.C.: Pero, antes de llegar a eso hay una segunda reforma.

\section{R: Que es la de Bolaños.}

C.F.C.: Lo que Bolaños describió como una especie de intento de cercenarle más poder, ¿no?, y esa reforma, nuevamente, es producto de la dinámica política, es decir, yo sostengo que no tiene mucho que ver con el diseño del Estado, con estar pensando, sino que son las bolas políticas que los van llevando a esa situación, ¿qué es lo que ocurre?, 2001, Bolaños está en el gobierno, el Frente tiene su cuota de poder, el Frente colabora con Bolaños para procesar a Alemán, le interesa al Frente, en ese momento, debilitar a Alemán, pero lo mantiene, lo convierte en rehén, lo convierte en rehén y el Frente establece una especie de acuerdo de cooperación con el gobierno de Bolaños, ese acuerdo se rompe, verdad, por el año 2004-2005, a veces las fechas se me pierden un poco, cuando viene a Nicaragua, por la presión norteamericana, la presión norteamericana le dice a Bolaños: "mira está bien que procesés a Alemán por corrupción, pero no estamos de acuerdo con que estés compartiendo el poder con el Frente, y, por lo tanto, hay que romper esa alianza", y, efectivamente, los gringos empujan a Bolaños a tomar distancia de Ortega, y Ortega que es un animal político muy hábil busca, entonces, a Alemán para que, que tiene agravios con Bolaños, para que entre los dos busquen elementos de intereses comunes para acosar y arrinconar a Bolaños, de ahí sale la reforma esa que le da poderes a la Asamblea para, primero que crea la SISEP, la Superintendencia de Servicios Públicos, a la cual estarían adscritas todos los entes reguladores, ¿no?, el COR, la parte de la energía, la parte del agua, y una parte nueva de los consumidores, ¿verdad?, ese el gran invento de esa reforma, la SISEP, en segundo lugar, lo que tiene que ver con la ratificación de los ministros, no los ministros, de los embajadores, ¿no?, y creo que hay algo relacionado con los ministros también.

\section{R: Sí, funcionarios del Estado.}

C.F.C.: Bueno, pues son cosas que a ver, o sea, tú hablas con Daniel Ortega, yo recuerdo haberlo entrevistado en esos períodos, en esos tiempos, Daniel Ortega tiene una retórica casi anarquista libertaria, es decir, yo lo conozco de toda la vida, pues, por lo menos, de toda la vida política mientras esté en el poder, y a mí me parece que es un hombre, esencialmente, con una visión de un poder centralizado, de un poder, de un poder que se ejerce por voluntad individual, no a través de ninguna institución ni de ninguna ley, pero su discurso, precisamente, para conectar con la masa, es un discurso de un populismo tradicional, pero que casi tiene, casi presta a elementos de un discurso anarquista libertario, ¿por qué?, porque Ortega ¿qué es lo que dice?, el pueblo tiene el poder, que haga lo que quiera el pueblo, si el pueblo quiere quitar al presidente que lo quite, si quiere quitar a los alcaldes que los quite, si quiere quitar a los diputados que los quite, el pueblo es que el que está en el poder, eso es pura mentira, es decir, él está 
ejerciendo el poder de esa forma, pero, entonces, él aprueba esa reforma, Ortega la apoya, y dice: "no, esto es muy poco para mí, yo creo en la democracia directa, la democracia directa es el poder total para el pueblo", ese es su discurso, eso es una cosa completamente retórica, efectivamente, llega al poder y hace todo lo contrario, pero, igual, sigue diciendo que lo que está haciendo es dándole más poder al pueblo, o sea, éste es el régimen más concentrador de poder, más centralizador, y eso lo están padeciendo los municipios, es decir, Ortega ha significado una regresión de todos los avances de los gobiernos neo-liberales satanizados en materia de descentralización del Estado, pero él sigue diciendo que le está dando poder al pueblo, pero no es cierto, o sea, hay que documentar las cosas tal y como son.

R: Y es cierto que ha habido un conflicto también siempre entre Asamblea y Ejecutivo a la hora de aprobar las reformas constitucionales desde el 95 hasta la fecha, y ese invento jurídico tan peculiar en la tradición constitucional nicaragüense ha sido el de las Leyes Marco, que significa congelar en el tiempo las normas constitucionales reformadas para dar un poco de oxígeno a la negociación política, ¿no?

C.F.C.: La Ley Marco es, en mi opinión, una especie de expresión de la correlación de fuerzas políticas del país, de la dispersión de poder que se produce en los 90, de la dispersión de poder y del peso que tiene la comunidad internacional como un actor en la realidad nicaragüense en esos años, estoy hablando del año, entre 94 y 96, hay un gobierno débil, un gobierno presidido por mi madre, que ha roto con sus bases de alianzas políticas, se ha dispersado el poder, pero tiene una inmensa legitimidad, ese gobierno es el que puede hacer la transición de la paz, es el que puede hacer el desarme, es el que puede hacer la reforma militar, y, por lo tanto, tiene una, es el que puede hacer la re-negociación de la deuda externa, es que el que puede hacer la reestructuración de las relaciones con los organismos internacionales y, por lo tanto, tiene una cuota de poder, tiene una cuota de legitimidad tal ante los organismos internacionales, que, básicamente, aportan un buen porcentaje del presupuesto de Nicaragua, que le permite esa negociación sui generis que luego, nuevamente, una vez que hay un acuerdo se traduce en esa cosa que es la Ley Marco, pues, que todos los abogados dicen que es completamente ilegal, inconstitucional, y todo lo que querrás, pero se ha hecho una y varias veces.

R: Incluso se ha reformado la propia Ley Marco, como hizo la administración de Ortega, que ya es como "rizar el rizo" como dicen en mi país, ¿no? Y, al margen de que la reforma constitucional haya sido objeto de conflicto, da la impresión al revisar la historia reciente de que aqui la politica siempre está por encima del Derecho.

C.F.C.: Totalmente, totalmente, pero, o sea, yo, a ver, hay que ser justos con la historia en lo siguiente, la Constitución del 87 habiendo sido una Constitución hegemónica, sin embargo, sí hubo la, ¿cómo decir?, la, o sea, el convencimiento, hombre, de que por lo menos había que involucrar a la gente en el debate sobre esas reformas, es decir, hubo una consulta, la oposición puede decir que había un partido hegemónico, es cierto, pero, por lo menos las fuerzas que movían ese partido hegemónico participaron en la consulta de que esa Constitución aportara un insumo, incidieron en algunas cosas importantes, la Constitución del 95, yo creo que es la Constitución que ha requerido más negociación en la historia de Nicaragua, y que, de alguna manera, se aproxima a la construcción de un consenso, no fue un consenso total, es cierto que los sectores del gobierno, de este gobierno que he descrito, no se sintieron partícipes de esa reforma, habría que ver en 
qué temas sí y en cuáles no, no se si has leído el libro de Antonio Lacayo, uno que se llama La transición, probablemente, bueno, su versión es muy afectada por la reforma, porque la reforma lo afectó a él como potencial candidato presidencial con el tema ese de las inhibiciones para los parientes del presidente, etc., etc., pero desde el punto de vista de la descentralización del Estado o de los equilibrios del Estado, ese gobierno se resistió mucho a esas reformas, creo que fue uno de sus grandes errores políticos, fue uno de sus errores políticos, probablemente, a la distancia tendrá una valoración, o sea, creo yo que el tema de las inhibiciones contaminó tal el gobierno, su visión de lo que era esa reforma, y el sector de Alemán, que era el sector emergente del Partido Liberal Constitucionalista, que ya era un factor de poder y que era un presidenciable en ese momento, no tenía la representación parlamentaria suficiente para sentirse que él era el dueño de esa reforma, entonces, de alguna manera Ortega y Alemán se reencuentran cinco años después, y deciden, OK, ahora nos toca a nosotros, y la visión de ellos es que aquella reforma es de ellos, bueno, se la repartieron ellos: "ahora nos toca a nosotros". Pero yo creo que la reforma del 95 fue, es una reforma más consensuada, con sus intersecciones, con sus problemas, etc., pero, volviendo a tu punto, sí, la política está por delante $\mathrm{y}$, de hecho, las últimas reformas, mira la última reforma, la del 99-2000 y la del 2004-2005, hay está el registro y no sé si has hablado con Dionisio Marenco, con Nicho Marenco, el ex-alcalde de Managua, ese tipo te describe, lo ha dicho en entrevistas, que hubieron, y él lo dice sin problemas, él dice: "tuvimos 25, 30 reuniones con el Doctor Alemán, Jaime Morales, creo que René Herrera y de la parte nuestra éramos Daniel y yo", reuniones secretas, y una vez que se pusieron de acuerdo entre grupo de personas entró el equipo legislativo, el equipo jurídico a traducir esos acuerdos, digamos, ya en las reformas, no ha sido consultada, fue una cosa muy, muy cupular de dos personas con sus pequeños grupos de asesores íntimos políticos, ni siquiera eran los juristas, porque Marenco es un ingeniero, no sabe nada de leyes, pues, simplemente sabe del concepto del equilibrio de poder.

R: Y es cierto que volviendo a esa expresión del equilibrio de poderes, sí se ha roto últimamente a favor de, sobre todo porque dos poderes del Estado, el judicial y el electoral, han quedado enormemente dañados desde el punto de vista institucional y desde el punto de vista ciudadano también, de la opinión pública.

C.F.C.: Mira, esa es una historia que alguien debería de documentarla porque cuando vos hablás con Alemán, y ves un poco lo que él está diciendo ahora, que hay que cambiar el Consejo Supremo Electoral, etc., es evidente que hay un reconocimiento de parte de él, una admisión, de que ya no hay un pacto paritario, de que ya no hay equilibrios entre la repartición de poder que se hicieron, si no que el PLC ya hoy tiene un rol completamente subordinado, se parece mucho al papel que tenía la oposición conservadora con Somoza, que en aquella época se llamaban los zancudos, ¿no?, los chupa-sangre, pero en la época de Somoza se establecieron un régimen de lo que se llamaban las "minorías congeladas", es decir, la oposición tenía derecho a un tercio, las elecciones, no importaba cuál era el resultado, a ellos les daban un tercio del resultado electoral para los diputados, y los cargos públicos se les repartía un tercio, no tenían poder de decisión, ni incidían, no cambiaban nada, pero tenían sus cuotas de prebendas, exactamente lo mismo está pasando hoy con el PLC, el PLC, hay un señor que es el Fiscal de la República, el señor Centeno Gómez, ese señor está pintado en la pared, hay una Vice-Fiscal que es la Ana Julia Herido, que es del Frente, y esa es la que resuelve las cosas en la Fiscalía, y lo mismo pasa en los diferentes poderes del Estado, bueno, ya no se diga en el Poder Electoral, ahorita, hay una discusión de quien tiene la culpa de 
Roberto Rivas, ¿quién lo llevó al Consejo Supremo Electoral?, si era esto o era lo otro, Roberto Rivas llega al Consejo en esos cambios que se producen en el 95-96, él llega cuando el gobierno le dice al Cardenal: "propóngalo usted para que sea el fiel de la balanza", en reconocimiento a las labores que el Cardenal ha hecho en la mediación y parapapá, y el Cardenal propone a Roberto Rivas porque es alguien de su confianza, porque es alguien que ha trabajado con él, y Alemán está contento, porque, en ese momento, el Cardenal es pro-liberal y Roberto Rivas tiene inclinaciones liberales, y así es como él llega, entonces, los poderes hasta hace poco estaban controlados por una mayoría pro-liberal, tanto el Poder Judicial como el Poder Electoral como la misma Contraloría, el Frente ha tenido capacidad de cooptación, ese es el caso de Roberto Rivas, corrupción, cooptación y en otros casos capacidad conspirativa de usar el poder para su beneficio, en el caso de la Corte Suprema de Justicia es lo mismo, el presidente de la Corte no es un sandinista, es un liberal, es Manuel Martínez, y ¿quién controla la Corte?, la controla el Frente, porque esa es un poco la historia, vamos a ver de un partido, que tiene conexión, que tiene cuadros, que tiene capacidad conspirativa, y que ha hecho una especie de simbiosis entre sus habilidades conspirativas con la utilización de los instrumentos del Estado de Derecho para hacer mecanismos de extorsión, cosas de corrupción, controlar la Corte, meter los jueces, aprovechar de los concursos que hay en la Fiscalía, etc., etc., y vos te encontrás una gran cantidad de lo que el Frente llama el tendido de las fuerzas, de los recursos humanos que están en el aparato judicial, de la Fiscalía y de este tipo de cosas es gente que viene, buena parte de ellos vienen de las estructuras partidarias, de las viejas estructuras de los aparatos de seguridad e inteligencia, que se volvieron abogados y están ahí, algunos incluso son Magistrados, como la Juana Méndez, entonces, ya no hay un pacto paritario, hay una relación donde el Frente tiene cada vez más acumulación de poder, cada vez más vocación de poder, y más ahora, pues, que Daniel es presidente y que el PLC tiene un papel subordinado.

R: Pero es cierto que si no se recompone la unidad liberal el futuro es, realmente, incierto, porque si se da vía libre a la reelección presidencial, según la matemática electoral vigente y ese $35 \%$, es muy probable la victoria de Ortega en unas próximas presidenciales.

C.F.C.: Bueno, ahí entramos en un campo especulativo de qué es esa unidad liberal, o cómo sería, no es muy sencilla, es decir, si se produce una unidad, Daniel Ortega tiene que hacer un fraude tan escandaloso como el del año pasado para ganar, no hay manera, ahora, esa unidad no es tan sencilla, porque cuando se habla de la unidad liberal como la concibe Alemán, él y Montealegre, eso genera muchos anticuerpos, aquí hay un sector importante de la sociedad que le costaría mucho ir a una elección a apoyar algo en lo que esté involucrado Arnoldo Alemán, los liberales, vamos a ver, los liberales obtuvieron mayorías electorales en el $54 \%, 53 \%, 52 \%$, pero el partido liberal como tal tiene una votación que anda quizás por el orden de un tercio del país, es lo que puede mover, ¿cómo logra esas mayorías?, con los sin partidos, con los independientes, que al final votan con ellos para votar contra Daniel Ortega, pues, pero eso independiente de lo que hacen ese $62 \%$ que los sumás a todos, que nunca están unidos, pueden decidir no votar, si Arnoldo Alemán tiene un rol muy protagónico, una figuración, entonces, no es sencilla la forma en que pueden hacer esa, ahora, pero sí es cierto, el escenario uno es que si la oposición va dividida Daniel Ortega no necesita robársela, con la regla del 35\% él puede ganar en primera vuelta obteniendo entre $37 \%$ y $39 \%$, que es lo que él puede obtener, ahora si la oposición va unida y logran resolver el problema de que la participación del PLC y Alemán no genere anticuerpos que alienen a un sector 
democrático que rechaza la corrupción de Alemán y todo ese tipo de cosas, tiene que haber un fraude más escandaloso que el del año pasado.

R: Sí, porque, de hecho, cuando entrevisté a Dora María Téllez ella decía que la reelección presidencial y el fraude electoral en la historia del país siempre han ido unidos, o sea, no ha habido un divorcio, digamos, de los dos elementos, ¿no? Y ese cierre de espacios que se está produciendo, no solamente de espacios políticos e institucionales, sino de espacios sociales, digamos, cívicos, yo al menos, como extranjera, sí tengo la oportunidad en estos tres últimos meses que he pasado en Nicaragua de observar el tema de las rotondas, la gente que se manifiesta, de oir a los taxistas, que muchas veces son un "termómetro político" de las ciudades, y, entonces, pues, si que el rumbo del país podría ser, ciertamente, peligroso, incluso se contempla un escenario de violencia política, que yo no creo que vaya a producirse, ¿no?

C.F.C.: Yo creo que sí va a haber violencia, no violencia armada de guerra y ese tipo de cosas, pero violencia caótica, como la que hubo en noviembre después de las elecciones, $\mathrm{y}$, seguramente, el sábado este que va a haber esta marcha, no se si todavía vas a estar acá, yo creo que va a haber una batalla campal, o sea, quieren que ocurra eso, y aquí, un poco, el gran dilema es qué va a pasar con la Policía, si la Policía se va a preservar con el liderazgo de la Aminta $^{29}$, o si se va a quebrar, o si ella va a renunciar, o si, al final de cuentas, se va a confrontar con Ortega, pues, eso es un factor importante, el otro tema que tiene que ver con eso de los movimientos sociales y todo, es que no hay una conexión entre los problemas económicos y sociales y todo este reclamo de derechos políticos, es decir, nadie ha sido capaz, ni el MRS, ni el partido de Montealegre, ni el partido de Alemán, ni los movimientos sociales han sido capaces de conectar, digamos, los problemas de la demanda de empleo, el problema de la pobreza, los problemas de falta de esto, lo otro, con los reclamos políticos, la gente que sale a marchar por esas cosas políticas no, no, no son necesariamente los mismos que están más afectados por la situación económica, obviamente, todo el mundo está afectado por la situación económica, pero lo que quiero decir es que no hay un liderazgo que logre conectar las dos demandas hasta ahora.

R: Pero no se ha dado tampoco una renovación del liderazgo de los 80, los actores de los 80 siguen siendo los mismos que están en primera línea en política, ¿no? ¿No hay una nueva generación?

C.F.C.: Hay nuevos liderazgos que están surgiendo, pero, en mi opinión, todavía son muy embrionarios, o sea, son muy, muy magnificados por los medios de comunicación, y no tienen suficientes redes, yo no he visto que tengan suficiente densidad, que tengan fuerza en las universidades, en los barrios, ese tipo de cosas.

R: Y respecto a Ortega y Alemán, también recuerdo que algún entrevistado me decía que ambos representan a un sector de la clase media baja, o sea, como sectores populares, digamos, ambos son las dos caras de una misma moneda.

C.F.C.: Los dos como personalidades políticas, a ver, como, casi como esos elementos identitarios de clase, es decir, bueno, OK, ninguno de los dos, a ver, ninguno de los dos viene de los segmentos más altos, pudientes, de la sociedad, sí es, es cierto, pues, ah,

29 Aminta Granera es la actual Directora General de la Policía Nacional. 
pero, ¿qué tienen en común?, no sé, o sea, ellos han jugado un poco a eso, ¿no?, en algún momento, algunos intelectuales sandinistas jugaron a eso de que Alemán representa a la clase media emergente y que Alemán, por lo tanto, es anti-oligárquico y es nacionalista, a mí me parece que eso es una cosa más retórica, pues, sinceramente.

R: Sí, que no son los sectores que, sociológicamente, están detrás de ambos líderes, ¿no?

C.F.C.: Ambos, y como todo aquí en este país es multiclasista, y el Frente Sandinista es cierto que ha sido un partido de obreros y de trabajadores y de proletarios, es un partido multiclasista, que tiene empresarios, que tiene sectores medios, que tiene todo, igual ha sido el Partido Liberal, más tradicionalmente el partido de Alemán era más rural, y creo que lo sigue siendo, Montealegre le quebró el partido en dos, y el partido de Montealegre o como se llame, pues, el movimiento "Vamos con Eduardo", el PLI, es una cosa más urbana del Pacífico, y Alemán sigue teniendo más influencia en el área rural.

R: Y ya, finalmente, para terminar, es verdad que en la tradición histórica constitucional de Nicaragua los pactos han precedido las reformas constitucionales, ¿no?, en casi todo lo que es, digamos, la producción de normas constitucionales en el país, que se acomoda a los distintos escenarios políticos, refleja ese pacto en aras de la gobernabilidad, al menos lo que es atar bien las reglas institucionales, que deja fuera un verdadero consenso constitucional, es decir, que siempre hay una parte de los ciudadanos y también de las élites que no se reconoce en la norma, esa tentación extrainstitucional que han tenido y tienen los actores politicos.

C.F.C.: Sí, o sea, creo que la reforma del 95, de alguna manera, desafía ese designio, ¿no?, no lo logra hacer completamente porque hay sectores de élites, que consideran que se quedaron fuera, pero creo que lo más cercano a algo que intentó diseñarse pensando en la reforma del Estado y no solamente en la repartición, sí hubo repartición, de alguna manera, de posiciones de gente que accedió a cargos como resultado de eso, pero tuvo mucha profundidad como reforma del Estado, ahora, sí es cierto que al pacto político precede la reforma jurídica, efectivamente, eso ha sido así y no sé, no puedo imaginarme, no puedo imaginarme cómo va a ser la próxima reforma, pues, me parece que, me parece que no hay como demanda, no hay urgencia, creo que la preocupación principal está centrada en devolverle autonomía a la Corte Suprema, en devolverle autonomía al Consejo Supremo Electoral, a la Contraloría y a la Fiscalía, y creo que el daño es profundo, o sea, independientemente de lo que pase en las elecciones del $2011 \mathrm{y}$ qué futuro tenga el régimen de Ortega, en esa materia estructural el daño es profundo y permanente, porque esas instituciones que están copadas de una clase burocrática de funcionarios prebendarios, es cierto, ahí encontrás siempre personas decentes, personas que trabajan bien, etc., pero son la minoría, creo que la mayoría es una cosa, y el Frente tiene mucha cuota de poder ahí.

R: Y ya esta sí que es la última, en el caso de las reformas a la Constitución del 87, algunos entrevistados ya me sugerían, incluso, por supuesto, no más reformas a la Constitución, sí más a la práctica institucional, es decir, como se ejerce y se apega uno verdaderamente al Derecho a la hora de ejercer el poder, ¿no?, en las instituciones públicas, o incluso una nueva constituyente para devolver credibilidad y valor normativo a la Constitución, en el sentido, en que ha quedado tan lastimada por las 
élites politicas que la han manoseado, entre comillas, han hecho de ella como un texto que no tiene validez o que puede acomodarse fácilmente a los intereses políticos coyunturales.

C.F.C.: Bueno, tratá de imaginarte el futuro, que en una coyuntura de demanda de restitución de credibilidad, bueno, hay una realidad, el Frente Sandinista seguirá siendo una realidad, independientemente de lo que le pase a Daniel Ortega, pues, y si se logra, suponete que no se logra robarse esa elección y que pierde y que tiene una crisis y un fracaso, su partido político, pero el Frente Sandinista seguirá teniendo una cuota de poder de un tercio de este país, y va a ser un factor fundamental, sería un factor fundamental en esa futura negociación para ver qué es lo que se quiere hacer, si se quiere sólo reestablecer credibilidad, si se quiere hacer una reforma o algo, yo creo que sería difícil, yo insisto en que lo que yo veo más complicado es el efecto institucional, estructural permanente, que vamos a heredar como resultado del pacto que hizo Ortega con Alemán, pues, o sea, eso es una maquinaria que se ha autoalimentado, y que ha crecido desmesuradamente, eso no va a ser fácil desmontarlo, y, por lo tanto, hay que hacer concesiones, hay que hacer las cosas con gradualidad, porque hasta ahí no llega mi imaginación, de cómo se va a deshacer eso, lo que sí estoy claro es que no se deshace con una tijera que corte un nudo, ¿verdad?, es mucho más complicado, o sea, aquí no se va a caer el Muro de Berlín, si pasa algo y te lo digo porque estoy un poco inspirado, estaba viendo un documental de esos, no es que va a llegar Alemán y se van a juntar, no, no, aquí una realidad permanente, hay un partido político, que es el Frente, que está en una etapa de atrincheramiento, en este momento, y que va a perdurar, va a sobrevivir a Ortega, yo en eso discrepo de los que dicen de que el orteguismo, hay mucho oportunismo en el Frente Sandinista de reconocer de que al final de cuentas aunque no les caiga bien Ortega es el factor de unidad de todos, ahora, desaparecido él, no quiere decir, necesariamente, que se vaya a desmoronar, es un partido que tiene muchos incentivos para mantenerse unido.

$R:$ ¿Y el contexto internacional?, del que no hemos hablado, pero, bueno, está ahí Venezuela, Ecuador, después de lo que ha pasado en Honduras, ¿hay una tendencia, también internacional, que alienta el surgimiento, digamos, de estas tendencias?

C.F.C.: O sea, es bien sencillo, si Chávez no existiera, o si el petróleo estuviera a 20 dólares el barril, cuando Ortega llega al poder su presidencia habría sido muy diferente, habría sido muy, ¿cómo decirte?, la palabra tal vez no es normal, pero menos ambiciosa, habría sido menos voluntarista, habría sido más aterrizada en la tierra, habría sido más pragmática, lo que Chávez le ha dado a Ortega cuando le dice: “¿qué necesitás? Tomá la plata que querrás para hacer política, para hacer negocios, para hacer clientelismo", entonces, le dispara a Ortega el voluntarismo, o sea, le dispara las ambiciones y toda la cuestión, ahora, si eso desaparece no se derrumba Ortega, no se derrumba, es una realidad nacional, no es una cosa implantada de afuera, aquí la gente me pregunta: ¿y cuál es la influencia de Chávez?, Chávez es como un tío rico que te da plata para vos la gastés como querrás, pero Chávez no le está diciendo a Ortega lo que tiene que hacer, ni creo yo, pues, que sea necesario.

R: ¿Y ese paralelismo histórico que he oído entre Ortega y los primeros años de Somoza, utilizando, primero, el Estado como factor de enriquecimiento personal y como recurso económico, y, en segundo lugar, también por esa prolongación familiar 
en el ejercicio del poder por parte del Ejecutivo presidencial, que se manifiesta más claramente en el régimen de Ortega? Salvando los contextos, ¿cuál sería su visión?

C.F.C.: Sí, pues, o sea es un símil que no se puede rechazar, ¿no?, sí hay elementos, hay paralelismos, hay cosas, pero bueno, pues, Somoza surge, Somoza surge de la implantación de la Guardia impuesta por Estados Unidos, de la Guardia se hace esa cosa del Partido Liberal, el control del Estado, el control económico, pero el caso de Ortega es alguien que quedó con los sellos de un partido, de una revolución, efectivamente, tiene una, tiene una, o sea, sí tiene un proyecto, ha sido, efectivamente, sorprendente la forma en como el Frente Sandinista viejo y esta cosa nueva que hay ahora, de alguna manera, se acomoda a desestructurarse, o sea, como acepta la desinstitucionalización del partido y este predominio de la figura individual de Ortega, ¿no?, ahora, que si es Somoza que volvió, bueno, se dice mucho por razones políticas de confrontación y toda esa cuestión, pero no sé, habría que ver pues, habría que ver, lo interesante es, los viejos cuadros del Frente, que todavía están ahí algunas personas, si tienen una, si están preocupados por eso, ¿no?, si tienen o no tienen una visión alternativa, hace un año o hace un año y medio todavía algunos lo exteriorizaban, yo estuve platicando con un viejo amigo mío que está metido ahí, y él me decía yo estoy aquí por el partido, yo lucho por el partido, yo no estoy por Daniel Ortega y su familia, pues, pero mientras él esté ahí hay que manejarse, pues, yo no me voy a confrontar con él tampoco.

R: Pues si tiene algo más que añadir, yo creo que ha sido muy interesante.

C.F.C.: No nada más, gracias. 


\section{ENTREVISTA $19^{30}$ :}

Nombre del entrevistado: D. Eduardo Enríquez.

Cargo actual: Periodista, analista político del Diario La Prensa.

Fecha de realización de la entrevista: Managua, 30 de octubre de 2009.

Lugar: Diario La Prensa.

Duración estimada: 57 minutos.

\section{TEXTO - Transcripción 19:}

R: ¿Cuál es su visión o el recorrido que hace sobre los últimos tres procesos de reforma constitucional que se han aprobado por ley de reforma parcial desde los años 90 hasta la fecha actual, incluyendo ya este último capítulo de la sentencia de la Corte, que interpreta un artículo de la Constitución, que supone también una modificación de cara a un hecho puntual, la presentación de la candidatura de Ortega?

E.E.: Bueno, han sido tres cosas totalmente distintas, la Constitución como usted sabe fue elaborada en 1987, durante el gobierno del Frente Sandinista, en el año 90, en febrero, Doña Violeta Barrios, al frente de la UNO, gana esas elecciones, que sale del poder Daniel Ortega, que había estado con el Frente Sandinista durante 10 años, y, pues, uno de sus principales procesos o promesas electorales era la reforma constitucional, porque era una Constitución demasiado presidencialista, bien, eso se prolonga bastante tiempo por problemas políticos internos, pero hasta el año 1995 se da la reforma constitucional, que es bastante amplia, en ese sentido, porque, incluso, existió el debate sobre si era total o parcial, porque tocaba muchísimas áreas, el área económica, el área de lo que lo que podía ser la manera de elegir a los Magistrados, la manera de elegir al presidente, era amplísima, se cambiaba, incluso, el sistema por el cual se buscaba el poder, se hablaba de partidos políticos y de asociaciones por suscripción popular, que podían optar al poder, y esa yo la considero una de las reformas, aunque no soy ningún experto, como le dije, pero creo que es, por lo poco que conozco, probablemente, la reforma más democrática que se ha hecho en la historia de Nicaragua, digo esto, porque, primero, se abría la posibilidad de elegir a través de asociaciones de suscripción popular y no solamente de los partidos políticos, porque al presidente se le restaba mucho poder, es decir, ya no podía legislar en materia económica, o ya no podía legislar, y mucho menos en materia económica, que quedaba totalmente restringido, $\mathrm{y}$, en muchos casos, la manera de elegir estaba diseñada para que hubiese una mayor participación de los mismos diputados, ¿no?, que no fuera una concentración de poder, ¿qué es lo que sucede?, esta reforma a la Constitución viene acompañada también con un diseño político distinto que lo hacen los mismos señores que impulsan esta reforma, que es un diseño multipartidista o pluripartidista, ahí, hasta ese momento, no existía aparte del Frente Sandinista otro partido hegemónico, incluso, el Frente Sandinista estaba bastante débil en ese momento, pero era el partido más fuerte y la gente que había ganado las elecciones a través de una inmensa alianza de 14 partidos, que incluía desde el Partido Conservador al Partido Comunista, entonces, se decidió que iban a hacer un sistema en el cual ellos sabían que podían garantizarse una presencia por lo menos en la Asamblea

\footnotetext{
30 Entrevista coherente y bien articulada sobre el proceso reciente de cambio político y constitucional experimentado en Nicaragua desde los inicios de la transición democrática. El discurso tiene un desarrollo bien estructurado, dentro de los márgenes de la objetividad, exponiendo un buen análisis periodístico cargado de referencias de interés para la investigación.
} 
Nacional, y, de esa manera, elevan ellos, por lo menos para la elección de Magistrados, digamos, funcionarios importantes a un nivel de 56, es decir, el 60\% de los diputados la elección. La visión de ellos era que no sólo el Frente Sandinista si llegaba a ganar de nuevo, o cualquier otro partido pudiera elegir únicamente, y que fuera un Estado el cual no era controlado únicamente por un sólo partido político, sino que se tuviera que tomar en cuenta la visión de las minorías, ellos estaban conscientes de que eran minorías, pero de acuerdo al diseño electoral de ese tiempo, esas minorías podían llegar a tener representación. Viene, gana en el 96, el entonces alcalde de Managua, Arnoldo Alemán, y, entonces, gana con su Partido Liberal, con una mayoría abrumadora, el $51 \%$ o el $52 \%$, y, sin embargo, el reflejo de ese sistema que se había diseñado está ahí, aunque él gana fuertemente hay, el segundo partido de fuerza es el Frente Sandinista con 36 diputados, el primero es el PLC de Arnoldo Alemán con 42 diputados en ese tiempo, y luego se divide el resto en una serie de pequeños partidos, entonces, sí había una amplia gama de representatividad, ¿qué sucede?, que, en algún momento de esa presidencia, Arnoldo Alemán y sus asesores deciden, todavía yo no entiendo cómo ni por qué, que lo mejor es regresar al bipartidismo, y ellos lo hacen de la peor manera posible, haciendo un pacto con el Frente Sandinista, y que crean es lo que yo he llamado un "Frankenstein", que agarran partes de la Constitución del 87, que la dejan tranquila, quitan partes de la reforma del 95, pero dejan otras, y meten otras para regresar al sistema bipartidista como la forma, digamos, de elegir, de contar los votos y de que los votos cuenten para la elección de diputados, esto se diseñó de una manera para que fueran los dos partidos mayoritarios los que quedaran en el poder, entonces, ellos diseñan esto de una manera bipartidista, sin embargo, no cambian la lógica multipartidista de la elección de Magistrados y de funcionarios importantes, entonces, en esos casos, ¿qué es lo que sucede?, todo se decide, la lógica del bipartidismo es el que gana lo gana todo, como en Estados Unidos, y el que lo pierde, pues, es una minoría la que está ahí haciendo presión, haciendo lobby y todo, pero el que gana puede gobernar con toda facilidad, la otra lógica es una lógica de más consenso, ¿qué es lo que pasa ahora?, que ellos como una elección que tienen que hacer de 56 diputados, ellos como nunca llegan a 56, porque no tienen esa fuerza, tienen a la fuerza que entenderse con el partido de oposición, pero, te repito, lo hacen de la peor manera, lo hacen bajo la lógica de que esto es una repartición de poder entre los dos partidos, y que lo que se va a elegir en los otros poderes del Estado va a ser un reflejo del Ejecutivo y la oposición, y en eso pasan a ponerse de acuerdo y a elegir, después de cambiar la Constitución, vienen las elecciones del 2000, pero antes ellos eligen ya, de esa manera, y, entonces, todos los poderes del Estado pasan a ser, que antes eran bastante independientes, pasan a ser ahora apéndices de los partidos políticos, porque todos somos o sandinistas o liberales, y pudieran haber sido los conservadores y liberales, o sandinistas y conservadores, eso es independiente, la lógica es el problema, entonces, llega la elección del 2000, y, en efecto, lo que queda son dos grandísimos bloques en la Asamblea Nacional, que es el poder, digamos, de los liberales y los sandinista, que, en ese momento, sacaron, creo, 39 diputados, y los liberales que creo que sacaron 53, aproximadamente, y quedan uno o dos diputados conservadores ahí, dos o tres, creo, entonces, se refleja, pues, la manera de elegir, ¿y qué es lo que sucede?, bueno, se facilita lo que ya habían acordado antes, que es la decisión de estos dos grandes bloques, el problema es que podría ser, incluso, un buen mecanismo, si la lógica no fuese lo que también yo en mis artículos, en mi columna que tengo los sábados, he llamado, desgraciadamente, por la calidad de las personas que han resultado electas, "yo te elijo a tus zánganos, y tú me eliges a mis zánganos", entonces, porque, desgraciadamente, la calidad de las personas ha sido muy, muy, muy mala, ha dejado 
mucho que desear en todos los poderes del Estado, y, luego, en la tercera etapa, que me imagino que es lo que habla de esta sentencia, que esta sentencia, en realidad, yo no la considero ni siquiera ni reforma ni sentencia, esto, lo que se ha venido a hacer es una locura que da un reflejo de la victoria del Frente, de la manera de gobernar del Frente Sandinista después del 2006, que llega al poder, precisamente, en gran parte por las reformas constitucionales del 99 y del 2000, ¿por qué?, otro candado que se había puesto para garantizar el pluripartidismo era que no se podía ganar con menos del $45 \%$ de los votos, ¿entonces qué?, si uno no llegaba al 45\% tenía que ir a una segunda vuelta, ¿qué podía permitir esto?, uno, que en la primera vuelta la gente tenía la libertad de votar por cualquiera de los múltiples partidos y no tener un temor porque después en la segunda vuelta iba a tener una segunda oportunidad y, en realidad, votar entre los dos más grandes que, en este caso, eso ha pesado mucho, porque el Frente Sandinista es un partido, es el partido más fuerte, oscilando entre el 35\% y el $40 \%$ del apoyo, pero el otro $60 \%$ o $65 \%$ que lo adversa, lo adversa totalmente, aquí tenemos esa máxima que se da, que es una relación en la cuál si lo amas, lo amas a muerte, y si lo odias, lo odias a muerte, desgraciadamente, una sociedad totalmente polarizada, $y$, entonces, ellos vienen y bajan eso al 35\%, manteniendo la lógica del bipartidismo, lo cual es totalmente una locura, es decir, creando este "Frankenstein", porque lo más lógico hubiera sido, si vamos a hacer un bipartidismo, entonces, el presidente resulta electo con el 50\% de los votos, pero no lo hacen así, más bien bajan, entonces, el Frente Sandinista, y la división que se da, precisamente, en el PLC, en los liberales porque hay un gran grupo que no está de acuerdo con este pacto le facilita la llegada al poder a los sandinistas en el 2006, y lo que la gente pensó, bueno, una vez que ganó Ortega uno decía, bueno, hay dos opciones, o bien Ortega aprendió la lección de los 80, y tal vez viene con un izquierdismo moderado, muy similar, tal vez, a lo de Chile, o regresa a los años 80 , y volvemos a tener una reedición de esos años, ese era nuestro temor, lo que no nos esperábamos era la locura de lo que ha sucedido aquí, que aquí lo que este señor lo que ha hecho es más bien regresar a los años 50, cuando gobernaba Anastasio Somoza García, el primero de la dictadura somocista, en el cual decidía las cosas a la manera de cómo si este país fuese su hacienda, y todo lo maneja de una manera, prácticamente, privada y personal, eso se ve reflejado en que su señora esposa, pues, tiene una posición no oficial que es mucho más, nadie la ha elegido, nadie la ha nombrado, y es mucho más fuerte que cualquier, la segunda y si no la primera persona con poder en Nicaragua, y la manera en la que él maneja la cooperación venezolana, entonces, yo le diría que la tercera, en mi opinión, es este último factor que es, simplemente, un reflejo de la locura que está viviendo este país, de que no es ya ni siquiera un gobierno, sino que es una especie de corporación, y que ellos necesitaban para seguir en esto, que las cosas caminaran y garantizarse su reelección y lo hicieron, como no lo podían lograr de la manera legal que se establece, pues, entonces, lo hicieron de esta manera que es totalmente inexistente, porque son seis personas de las cuales tres no tenían absolutamente nada que ver en esa sala. Ese sería un resumen largo, tal vez, para su primera pregunta.

R: Es cierto que desde el punto de vista del hilo conductor de las reformas constitucionales, y eso aparece también en el discurso que legitima el por qué de la necesidad de estas reformas, ha sido el de desconcentrar, como bien señalaba, parte de las facultades del Poder Ejecutivo y atribuírselas a la Asamblea Nacional, ¿no?, en una línea también de democratizar las instituciones después del periodo revolucionario, que consagraba un Ejecutivo fuerte, entre otras cosas porque se trataba de gobernar un país en guerra, debido al conflicto armado, que también condicionaba mucho el 
funcionamiento de las instituciones. Y, es cierto, que durante la reforma del 95, la reforma del 2000 y 2005 el Ejecutivo pierde gran parte de las facultades que tenía atribuidas, pasan a la Asamblea, pero también una Asamblea cooptada por los principales partidos, como bien ha señalado, ese bipartidismo institucional, y este gobierno de los líderes de las principales cúpulas de los partidos dominantes, pero, es cierto, que ahora se tiende a una concentración de poder por parte del Ejecutivo, en este caso de Ortega, es decir, se revierte, hay un giro en la propia evolución institucional del país.

E.E.: Sí, el estilo de Ortega es totalmente la concentración del poder en el autoritarismo, a tal punto que desconoce cualquier tipo de leyes que le adversen su voluntad, incluso, leyes como la misma reforma constitucional del 2005, que no he mencionado, que fue diseñada, tal vez en los países desarrollados esto no se puede entender, desgraciadamente, en esta política caciquista sí, la reforma del 2005 se hace con nombre $\mathrm{y}$ apellidos para controlar al presidente Bolaños, o sea, se hace una reforma constitucional que va a tener una vigencia, como se da en el 2005, tal vez de un año, porque ellos saben, tanto los liberales como los sandinistas que después de ese año que al presidente Bolaños le queda, después, a ellos no les va a interesar, y es lo que ha hecho este señor Ortega, el señor Ortega llega al poder y lo primero que dice es que va a respetar la reforma constitucional, sin embargo, se las arregla para llegar a un acuerdo, a un pequeño pacto con lo que antes era ALN, la segunda fuerza, representada por Eduardo Montealegre, en el cual acuerdan y pactan, digamos, para mantenerlo en el mismo nivel, en el mismo lenguaje, que la Ley Marco que mantenía congelada esa reforma se iba a prorrogar un año más, pero bueno, después del año, Montealegre se da cuenta, y su facción se da cuenta que no le representa ningún beneficio lo que han hecho, y retiran ese apoyo, y ya el gobierno no puede seguir con esa suspensión de la Constitución, lo cual es totalmente absurdo, y usted me imagino, como estudiosa de esto, lo verá absurdo, que una ley menor suspenda una ley superior, pero esas son las cosas que se hacen acá, y al segundo año le retiran ese apoyo, y el gobierno dice: "bueno, entra en vigencia la reforma constitucional del 2005", ¿y qué hacen ante eso?, simplemente, ignorarla, no la obedecen, totalmente, ellos tienen que enviar nombramientos de ministros a la Asamblea Nacional para ser ratificados, simplemente, no lo hacen, los ponen y se acabó, ellos tienen que enviar nombramientos de embajadores, simplemente, para darle dos ejemplos, simplemente, no lo hacen, los ponen y se acabó, y no hay poder en este país que los pueda detener en ese sentido, entonces, la política del señor Ortega es concentración del poder total, y garantizarse que va a continuar en el poder, entonces, sí vemos que se ha revertido, en ese sentido, incluso, mucho peor a de los años 80 , porque en los años 80 Ortega, aunque era el presidente, tenía que compartir sus decisiones de poder con sus otros ocho compañeros, de alguna manera, desde la Dirección Nacional del Frente Sandinista, porque era, digamos, al final, el organismo rector del país, y porque era un diseño, digamos, estalinista de un control del partido, el partido es el que controla, ahora no, ahora, incluso, el partido ha pasado a una segunda parte, por eso es que vemos que lo que ellos llaman cuadros históricos del Frente Sandinista están apartados y protestando personas que hicieron la insurrección, que participaron en la revolución, apartados y oponiéndose, fuertemente, yo creo que son los sectores más críticos, como es el Movimiento Renovador Sandinista, a este gobierno, por eso, porque él ya, incluso, desechó al partido, lo que es una concentración de poder familiar, su esposa y, como podemos ver, sus hijos, que están distribuidos, el mayor ve los negocios, hay dos hijos que ven los medios de comunicación, y otro de sus hijos está viendo el programa de 
inversiones ahora en el gobierno, y así van, todos los hijos están siendo colocados en lugares, digamos, importantes, y en la relación dentro del ALBA también.

$R:$ A veces, incluso, en el discurso de algunos de mis entrevistados, salvando los contextos, establecen un paralelismo histórico entre el periodo somocista y el actual orteguismo del 2009.

E.E.: Sí, bueno, muchísima gente diría que es la repetición de ese modelo, y yo creo que hacia eso va, la gran diferencia que hay entre ese modelo, el modelo de Somoza y este, es que durante los años 90, los 16 años de gobierno, que yo les llamo conservadores, aunque son de nombre liberales, pero, en realidad, de ideología conservadora, durante esos 16 años hubo un proceso en el cual las Fuerzas Armadas, que habían nacido, efectivamente, de la revolución, se ven huérfanas y al verse huérfanas crean su propia personalidad, y lo que llegan es a una especie de acuerdo con los gobiernos, en decir: "bueno, nosotros nos vamos a regir por estas leyes y aceptamos el concepto de obediencia al poder civil", pero estas son las leyes, que eran unas leyes bastante buenas, ¿y qué es lo que resultó de eso?, la institucionalidad de esas dos fuerzas, la institucionalización de esas dos fuerzas, el profesionalismo tanto del Ejército como de la Policía, y es con lo que Ortega se ha topado, de ahí la diferencia con el presidente o los dictadores de Somoza en su tiempo. Somoza controlaba totalmente a la Guardia Nacional, este nuevo Ortega, este nuevo período de Ortega se ve que no puede controlar al Ejército, las leyes le permiten, amarran mucho la Policía Nacional, y le permiten tener un control y mover ficha dentro de la Policía Nacional al punto de que, desgraciadamente la Policía Nacional ha tenido un retroceso tremendo en dos años y medio que tiene Ortega, a pesar de la gestión que hace la primera Comisionada, Mirta Granera, que no está de acuerdo con lo que está pasando, pero tiene las manos amarradas, y para ella que no estuviera ahí ya, pero bueno, sus razones tendrá, sin embargo, no ha podido hacer eso con el Ejército, porque existe un código militar muy claro, muy fuerte, y muy específico en la manera de hacer las cosas, y, obviamente, el Ejército siempre es una fuerza que no se puede ir y tomarla y arrebatarla, sin embargo, el deseo ahí está, el peligro ahí está, el poder económico que tiene el señor Ortega es un grave peligro, es para cualquier institución en este país, para cualquier grupo en este país, porque es un poder que nunca antes se había visto en una persona que pueda manejar a su gusto y antojo 500 millones de dólares para este país es alguien que, como ha hecho él, puede convertirse en dueño de este país.

\section{$R:$ ¿Es uno de los hombres más ricos, actualmente, en Nicaragua?}

E.E.: Pues, yo diría que, actualmente, si lo, digamos, fantástico, en el sentido de increíble, de todo esto es que lo ha hecho en dos años con la cooperación del señor Chávez de Venezuela, que, desgraciadamente, está despilfarrando los recursos naturales de su país en un modelo como este, que si hubiese sido bien ocupado, y si las cosas hubieran funcionado como deberían funcionar en un gobierno, tal vez, la gente estuviera pidiendo en las calles una reelección, es decir, verdaderamente, pidiendo en las calles la reelección de Daniel Ortega, porque con 500 millones de dólares Daniel Ortega pudo haber hecho maravillas en este país en dos años, sin embargo, como le digo, lo hace de una manera, lo ha manejado como una empresa privada, y se ha enriquecido él y su familia, y los famosos proyectos sociales de los que él habla, si usted investiga y ve a fondo de dónde vienen, lo poco que se hace en esos proyectos sociales, eso se hace con préstamos del BID y del Banco Mundial, o con el propio presupuesto de la república, o 
sea, que todo lo que es la famosa cooperación de Venezuela eso entra directamente a lo que le llamamos nosotros el grupo ALBA, que es el grupo económico de Daniel Ortega.

$R:$ ¿Y no existe ningún tipo de investigación sobre estas empresas económicas que están floreciendo?

E.E.: Hemos hecho muchas, precisamente, hace como un mes sacamos una investigación, para nosotros amplia, no sé si la vio, sobre cómo está conformado el grupo ALBA y cómo ha crecido, de dónde viene, de dónde se fortalece económicamente, y esta, digamos, es una segunda parte, que en el 2008, creo que se hizo otra también, donde se explicó cómo funcionaba el sistema del dinero venezolano que viene a ser manejado por Daniel Ortega. Ha habido dos o tres trabajos, dos en el periódico y uno en un suplemento dominical que tenemos nosotros y que se llama Domingo, que si lo revisas, creo que explicarían bastante bien este esquema de cómo es el ALBA.

R: Y ya regresando al tema de las reformas constitucionales, si da la impresión de que en este país la política, sobre todo la política de las élites que dirigen los partidos, está por encima del Derecho, de la propia Constitución, no sólo por este invento tan propio de los nicaragüenses de las leyes Marco, que amplían el proceso de negociación política y además retrasan la entrada en vigor de las normas constitucionales reformadas, ¿no?, en función del interés de cada presidente de turno, y luego, por otra parte, también lo que es, incluso, reformar la propia Ley Marco, retrasar la aplicación de una ley que, en sí misma, es absolutamente inconstitucional. Todo este tipo de irregularidades que caracterizan al procedimiento de revisión culminan con la sentencia reciente de la Corte. ¿El Frente ha aprendido durante los 16 años de oposición a copar las principales instituciones del Estado? Me refiero, fundamentalmente, a la penetración en el Poder Judicial.

E.E.: Sí, sí, ese ha sido uno de sus principales objetivos, ellos, cuando perdieron el poder, tuvieron, probablemente, la sagacidad de ver que en el Poder Judicial estaba el control de todo, y sus principales cuadros de la seguridad del Estado, por ejemplo, que, de pronto, se vieron sin trabajo, porque lo primero que hizo la señora Chamorro fue eliminar la Dirección de Seguridad del Estado en el Ministerio del Interior, que era el organismo represivo y espía, digamos, de la sociedad, entonces, ¿qué hicieron ellos?, enviarlos a las universidades a estudiar Derecho, y muchísimos de ellos o ahora son abogados que trabajan para el Frente Sandinista, o entraron al Poder Judicial, ahí hubo un descuido tremendo de parte de los gobiernos liberales, sobre todo del primer gobierno de Alemán, que tenía muchas posibilidades de actuar, porque, desgraciadamente, nos tocó un señor, igualmente, tampoco había evolucionado, era un hombre que había crecido y su cultura política era, básicamente, la cultura política somocista, y lo que él, la gente de la que se rodeó a lo que se dedicó fue a aprovecharse del poder en el sentido de hacer dinero, de ganar dinero, de robar, simplemente, a través de negocios, a través de coimas, a través de cualquier tipo de artimaña, y no pensaron a largo plazo, los sandinistas en los años 80 pensaban, cuando ellos llegaron al poder en el 80 , en el 79, pensaban que esta revolución iba a durar, como en su estilo tan excéntrico el señor Tomás Borge dijo que iba a durar un milenio, entonces, yo creo que ellos lo tenían ahí, no iban a durar, obviamente, un milenio, pero tal vez sí estaba garantizado que ellos iban a estar el resto de sus vidas en el poder, al estilo de Cuba, y cuando ellos lo pierden, que es un gran shock, se dan cuenta de que si ellos logran regresar al poder 
tienen que tener las bases hechas, y logran penetrar lo que es, principalmente, el Poder Judicial donde tienen el control desde, prácticamente, desde el principio. Eso nunca se desmontó y más bien se vino fortaleciendo y los gobiernos que subsiguieron, que no tuvieron, primero, Alemán el interés, $\mathrm{y}$, segundo, Don Enrique la fortaleza para cambiar eso, Don Enrique llevó una lucha titánica para cambiar la Ley Orgánica del Poder Judicial, y poder cambiar el Poder Judicial, hacerlo totalmente distinto, tratar de profesionalizarlo, y lo que logró fue que le regresaran la reforma constitucional de 2005, o sea, que el poco poder que le quedaba se lo iban a quitar totalmente, y si no hubiese sido, en ese entonces, por la intervención de la Organización de los Estados Americanos, que ahí sí funcionó, hay que decirlo, probablemente, el señor hubiera terminado como un presidente decorativo, todavía le quedó algún área de poder en la cual por lo menos podía administrar el país después del 2005 y evitó que entraran en vigencia esas reformas, pero eso fue porque la comunidad internacional actuó, y aquí los nicaragüenses también, en realidad, hay que decirlo, hubo una movilización que no se había visto en 30 años, de la gente apoyando al presidente, apoyando no tanto, tal vez, al presidente, pero sí en contra de esas reformas que la gente veía, claramente, que eran un abuso e iban en contra de la voluntad de la ciudadanía.

R: Pero, por otra parte, hay una relación entre el presidente de la República y el partido que lo sustenta en la Asamblea, Violeta Chamorro y Enrique Bolaños fueron presidentes débiles frente a Arnoldo Alemán y Daniel Ortega, que han mantenido un control fuerte sobre sus partidos.

E.E.: Claro, bueno, el caso de la señora, eso es totalmente cierto, el caso de la señora Violeta Chamorro, no tenía ni siquiera partido, y la coalición que la llevó al poder eran, como le dije, eran 14 partidos, que se pulverizaron en el momento en que llegaron a la Asamblea Nacional, cada quien agarró por su lado, entonces, ella más bien tuvo que gobernar apoyada por un pequeño grupo de gente en la Asamblea Nacional, y luchó, tuvo una lucha tenaz con la Asamblea Nacional, que era controlada en ese momento por el Movimiento Renovador Sandinista y un pequeño grupo de aliados que se habían hecho de parte de, habían salido de lo que era la UNO, que eran los que tenían el control y son los que hacen las reformas constitucionales del 95, que también es una reforma con nombre y apellidos, porque hasta cierto punto trataba de evitar la posibilidad de que Antonio Lacayo, el yerno y Ministro de la Presidencia de Doña Violeta, optara a la presidencia en el período subsiguiente, que lo interpretábamos, en ese momento, yo todavía lo creo así, como una reelección, porque él era el que, prácticamente, había sido el presidente, digamos, del Ejecutivo, en el día a día de las cosas de la presidencia, entonces, ahí sí hubo una oposición fuerte porque, en realidad, esta sociedad considera la reelección como un peligro grandísimo para su estabilidad, y el señor Bolaños cometió el error de, en lugar de tratar de conquistar a la manera usual al partido que lo había llevado al poder, más bien tomó una posición, tal vez, moralmente $\mathrm{y}$, hasta desde el punto de vista de la sensatez, correcta, en el sentido de que las cosas se iban a hacer bien hechas, de acuerdo a la ley, que no iba a haber beneficios extraordinarios para nadie, y que iba a haber transparencia, y que la corrupción era algo del pasado, obviamente, era algo deseable, sin embargo, su partido, el partido que lo había llevado al poder, no estaba listo para esto, y entonces lo abandonaron. En cambio, el señor Alemán se mantenía siempre como una sombra muy fuerte, le prometía a su partido la posibilidad de regresar al poder y de regresar al estilo de vida que habían tenido antes, entonces, sí fue un presidente muy débil, pero, curiosamente, los presidentes débiles ahora, cuando vemos la historia, son los presidentes que mayor beneficio le han causado 
a Nicaragua, al contrario de los presidentes fuertes que se dedican a beneficiarse ellos y a sus partidos políticos.

\section{R: ¿Y sigue la reedición del pacto entre Ortega y Alemán?}

E.E.: Bueno, yo diría que, en el momento, esto es algo que se, es como un interruptor de electricidad, de luz, se apaga y se enciende dependiendo de las necesidades de ambos, en este momento, yo creo que Daniel Ortega no cree que pueda llegar a necesitar de nuevo a Arnoldo Alemán, sin embargo, después del fraude del año 2008, de noviembre del 2008 en las elecciones municipales, la oposición fue tan fuerte a ese fraude, que Ortega se vio, prácticamente, arrinconado, estaba, prácticamente, paralizado el gobierno, la Asamblea Nacional estaba paralizada, y estaba ejerciendo muchos peso en cuanto a las decisiones de la cooperación internacional y el Fondo Monetario Internacional, y Daniel Ortega se estaba viendo en aprietos políticos y económicos, y, probablemente, iba a perder el control de la Asamblea Nacional, entonces, ¿qué es lo que hace?, esa tenacidad con que la Asamblea Nacional se mantuvo en ese momento obliga a Ortega a jugar una de sus cartas más importantes que era la libertad de Arnoldo Alemán, que era con lo que él jugaba y con lo que él mantenía a Alemán, digamos, en el redil y dentro del pacto, ahora, Alemán no tiene esa presión, sin embargo, siempre existen los intereses, el próximo año se van a elegir treinta y pico de funcionarios importantísimos a través de la Asamblea Nacional, y la gran lucha que tenemos los nicaragüenses ahora es ver cómo la oposición deja ese tema, sobre todo los liberales constitucionalistas, ese esquema de tus zánganos y mis zánganos, y por lo menos, como son 56 votos, necesitan forzosamente del Frente Sandinista, y el Frente Sandinista va a poner a su gente, pero, por lo menos, la otra cuota, que ya no sea una cuota partidaria, egoísta, sólo centrada en el interés personal o el interés de partido, sino que se logre elegir un grupo de gente que, en realidad, lleguen a crear una institución o a fortalecer la institución, va a ser, si se lograse eso, un gran avance para el país, pero va a ser una lucha titánica, se necesita de gente con mucha valentía y con mucho conocimiento del tema que van a ir a tratar, y sobre todo que no se vayan a vender ante los cantos de sirena que, indudablemente, van a estar ahí, pero yo creo que el próximo año es una gran oportunidad, incluso, para Arnoldo Alemán, para que Arnoldo Alemán demuestre que ya no está dentro del pacto, yo creo que ayudaría mucho a ello, porque él tiene todavía cierta popularidad sobre todo en el área rural, que es un área que todavía, creo que ni siquiera la revolución sandinista pasó por ahí, esa área vive todavía en tiempos del somocismo, en los 50, y en los años conservadores del siglo XIX, entonces, ese estilo a esa gente que, desgraciadamente, de nuestra sociedad le resulta muy, muy atractiva figuras como Arnoldo Alemán, un individuo campechano, bullanguero, derrochador, que puede llegar a un pueblo y decidir que si les pide un pozo él al día siguiente tiene el pozo ahí, aunque sepa que de la manera que se hizo ese pozo en tres meses no va a funcionar, porque se necesita de un desarrollo integral de toda la zona, él no es de planes integrales, él es de resolver y de que la gente crea que con eso ya resolvió, que es también el estilo de Ortega, ¿no?, quiere entregar 5.000 hojas de zinc y él cree que está ayudando a la gente de esa manera, cuando, en realidad, quien se desarrolla es quien logró tres o cuatro hojas de zinc y cuando eso se pierde o se pudran, o la gente las tiene que vender porque no tiene trabajo, y se quedó de nuevo sin techo, entonces, desgraciadamente, ese es el estilo de estos dos señores.

R: Y ya para ir terminando, porque no quería quitarle tampoco mucho tiempo, en el caso del pacto, que no es algo inusual en la historia de este país, porque ha habido 
pactos politicos que siempre han precedido a las reformas constitucionales en el pasado, en otras entrevistas he oído algún juicio semejante al que refiero a continuación, si Alemán tiene en su cabeza el "pacto de caballeros" a la manera de Somoza, ¿no?, con el Partido Conservador, Ortega no tiene ese tipo de mentalidad, en ese sentido, se convierte Alemán en el socio minoritario del pacto, por el "pie flaco" de la corrupción que tiene el propio ex-presidente liberal, pero Ortega también es un hombre con una mentalidad, digamos, que tiende a la autonomía de poder, es decir, que no se conforma con el "fifty-fifty", sino que quiere tener una posición preeminente. ¿Cuál sería su juicio al respecto?

E.E.: Bueno, yo creo que hace una interpretación correcta de cómo es la situación actual, y yo creo que, en este momento, como le decía, Daniel Ortega no tiene interés en continuar ese pacto, a menos que se le haga imposible de otra manera lograr establecer el control total de las instituciones el próximo año, si él ve que no puede comprar u obtener el apoyo individual poco a poco, uno a uno, de los ocho o nueve votos que le hacen falta en el Asamblea Nacional para poder él poner sus candidatos, él va a tener que acercarse a Alemán, y negociar, y Alemán, probablemente, ojala no sea así, pero, probablemente, caiga en esa tentación, porque de nuevo le promete, le da la vigencia a Alemán, tal vez ya no sea 50/50, pero sí $60 / 40$ o 70/30, y Alemán sigue manteniendo una cuota de poder, lo único que lo podría detener, y yo eso se lo he dicho, directamente incluso, al señor Alemán, es que yo creo que, en este momento, Alemán tiene una gran ventaja sobre Ortega, aunque parezca absurdo, y es que legal y constitucionalmente Alemán sí puede ser candidato presidencial y Ortega no.

\section{R: ¿A pesar de los casos de corrupción?}

E.E.: Sí, sí, a pesar de todo, y esa es la tragedia, y ese es el diseño original del pacto, el diseño original del pacto era la alternabilidad entre Ortega y Alemán, ¿qué es lo que pasa?, que Ortega, simplemente, cuando logra tener el poder no lo quiere soltar, cosa que, en ese sentido, Alemán sí fue distinto, Alemán sí respetó la alternabilidad, fue un desastre en cuanto a la corrupción y en cuanto a propiciar el mismo pacto, que es lo que nos tiene ahorita en este problema, pero yo diría que es peor Ortega, porque Ortega agarra el poder y no lo quiere soltar, pero, ¿qué es lo que sucede?, Alemán sí tiene un partido político regularmente fuerte a estas alturas, él es el líder indiscutible de su partido político, y no está inhibido por la Constitución, Ortega sí está inhibido por la Constitución por mucho que digan los tres Magistrados de él que no es así, y, entonces, está en el interés de Alemán transformar en la mayor posibilidad del Consejo Supremo Electoral para que sea un Consejo Supremo Electoral que cuente los votos bien, porque en una elección libre, yo creo que se va a encontrar muy poca gente que le diga lo contrario, en una elección libre y con un Consejo Electoral que cuente bien los votos, y que los cuente como son, Daniel Ortega nunca gana, sobre todo si va contra un solo candidato, aunque en eso estamos clarísimos, porque ese $60 \%$ o $65 \%$ que se le opone, se le opone férreamente, y con lo que él está haciendo ahora, eso más bien lo que hace es que la gente reaccione con mayor fuerza, y al tener la oportunidad de votar, yo creo que lo va a hacer contra Ortega, sea quien sea el que esté al frente, desgraciadamente, no debería de ser ese el futuro de Nicaragua, pero, desgraciadamente, eso es por considerar a cualquier otra persona el mal menor. Es por eso que también la tarea de Ortega es muy al contrario que la de las demás fuerzas, digamos, demócratas, entre comillas, porque ya tampoco creo que sean muy democráticos, los demócratas les conviene un Consejo Supremo Electoral regularmente aceptable para que la gente tenga la confianza de ir a 
votar, a los sandinistas lo que le conviene es desprestigiar totalmente al Consejo y desprestigiar totalmente el proceso electoral para que, se van a seguir dando elecciones, pero sólo van a votar la gente de ellos, porque el resto de la gente va a decir: "es una pérdida de tiempo, voto y después no me doy ni cuenta de si tengo voz ni voto", y ese esquema que ellos hicieron en el año pasado con las municipales, probablemente, ellos lo que aspiran es a repetirlo, tal vez no a haber el fraude, pero sí a desprestigiar todo el proceso a tal nivel de que el nicaragüense se sienta frustrado y que, simplemente, no salga a votar.

\section{R: Además en la historia de este país la reelección presidencial siempre ha ido acompañada de fraude.}

E.E.: Exacto, no, es que es la única manera, porque los gobiernos nunca han sido buenos, ahora, ¿qué es lo que sucede?, y es ya lo que le da el punto final a este drama y a esta tragedia, y lo hemos visto constantemente, y el señor Ortega, propiamente, entre sus fortalezas no está el conocimiento de la historia, o si lo está cree que lo puede superar, todo este proceso ya lo hemos vivido, pacto, reelección, copar el poder y luego rebelión, entonces, esto es así, un círculo vicioso, y ahí es donde vamos ahora, desgraciadamente, tal vez no será mañana, dentro de un año, tal vez dentro de tres, pero sí cuando la gente se hastía vuelve de nuevo al fantasma de la rebelión, de la insurrección, de la guerra, y eso es lo que, pues, los nicaragüenses estamos clarísimos que hay que evitar a toda costa, pero el ciclo es ese, hacía ahí es hacia donde nos quiere llevar.

\section{R: Pero el contexto internacional es distinto.}

E.E.: Esa es una de las grandes ventajas, y yo creo que aquí también en Nicaragua hay una gran cantidad de personas que saben que esa no es ninguna solución, sin embargo, por otro lado, hay una mayoría, que si se ve sin salida, puede reaccionar de esa manera. Ahora, como usted dice, el contexto internacional es distinto, la famosa globalización, la famosa facilidad de movilización, o sea, mucha gente dice: "bueno, si no puedo vivir en este país me voy", esa es una válvula de escape tremenda y que juega a favor de la permanencia de Ortega, él probablemente piense: "aquí no va a haber guerra, lo que va a haber es que la mayoría de la gente que no esté de acuerdo se va a ir", y el que no pueda irse se va a someter, porque no va a tener suficiente fuerza para rebelarse.

R: ¿Y respecto a las mayorías que apoyan a Ortega y a Alemán? He escuchado en una entrevista una similitud sociológica, de clase, o sea, las clases medias bajas de las que se nutren dos líderes, que, en el fondo, tienen algunas cosas en común, como Alemán y Ortega, frente a lo que ha sido, pues, la oligarquía tradicional a la que pertenecía, por ejemplo, Violeta Chamorro o el propio Enrique Bolaños.

E.E.: Sí, hay una teoría que lo explica muy bien, no sé si usted ha hablado con el exEmbajador de Nicaragua en Washington en este gobierno sandinista, Arturo Cruz Sequeira, que es profesor de INCAE, que estuvo dos años como Embajador de este gobierno, y el cual dice que Nicaragua está partida en dos sociedades: una sociedad premoderna y una sociedad más avanzada, que es la minoría, y que Ortega y Alemán se alimentan de esa sociedad pre-moderna, que no vive sino que subsiste, sobrevive, y que ve al gobierno como no un facilitador sino como un benefactor y que se acomoda, vive en tal situación paupérrima, que se acomoda a lo que le den, y eso es, precisamente, en 
lo que se apoyan estos dos señores, yo le decía, Alemán tiene su fuerza en el campo profundo, donde está el mayor analfabetismo, la mayor pobreza y el mayor atraso, Ortega tiene su fuerza, tal vez, en las áreas urbanas, pero en las partes, digamos, más pobres de las áreas urbanas, donde están, digamos, los índices de criminalidad más grandes y la violencia intrafamiliar, y ese tipo de cosas que son consecuencia de toda la ignorancia que hay, entonces, sí, a ellos dos, en su esquema ideal, la pobreza es uno de sus mejores aliados.

R: Y ya para terminar, es cierto que en Nicaragua se está produciendo el cierre de espacios políticos, que yo he tenido la oportunidad de observar también como extranjera, cuando me cuentan la acción de las fuerzas de choque para que los ciudadanos no se manifiesten.

E.E.: Sí, esos espacios políticos se están cerrando totalmente, trataron de comenzar con los medios de comunicación, los medios de comunicación electrónicos, que son los más débiles, porque de acuerdo a las leyes, en principio, son de uso público y son concesiones del Estado, entonces, ellos son los más vulnerables, y de entrada los eliminaron, usted ve la televisión y se da cuenta que en la televisión no hay ni un solo programa crítico, o tal vez, los demás son programas que están ahí y, simplemente, llenando espacio o entretenimiento, que es lo que se han dedicado a hacer, con los medios escritos se les ha hecho un poco más difícil por el famoso tema de la censura de los años 80, y que es algo totalmente inaceptable en el contexto internacional, pero lo que son las manifestaciones, ¿qué es lo que hacen?, ellos no van a enviar a la Policía a reprimirlo ni mucho menos al Ejército, lo que hacen es, como lo declaró hace un par de días una humilde señora de la Coordinadora Civil que fue agredida, y ella vive en uno de los barrios de los más pobres de este país, y este gobierno lo que hace es tan, tan dañino, que lo que ha hecho es llegar a reclutar de nuevo a las pandillas juveniles, que en una gran labor de organismos no gubernamentales, y la misma Policía Nacional se habían logrado rescatar, por eso, ¿qué es lo que sucede?, en vez de estar tratando de que esta gente vaya a una escuela técnica, o a una escuela nocturna, o darles trabajo u otra opciones, más bien les dicen: "no, vos agarrás tu machete o tu garrote, te vamos a dar 500 córdobas, y todo el licor que querrás", y eso es lo que nosotros hemos visto después de noviembre, del 8 o del 9 de noviembre, eso fue lo que se vio en las calles, y se veían esas turbas, que estábamos clarísimos que no eran ni siquiera miembros, no eran ni empleados del gobierno, no eran gran cantidad de miembros del partido, sino que eran estos grupos delincuenciales, y lo más triste de todo era que salieron armados de machetes, y machetes que se veían brillantes, porque estaban recién comprados, entonces, era una cuestión, totalmente, absurda, y, desgraciadamente, la Policía Nacional se ve con las manos atadas, porque, simplemente, si la Jefa de la Policía no hace lo que el presidente quiere, pues, la puede destituir sin darle explicaciones a nadie, y detrás de la jefa de la Policía hay una gran cantidad de jefes que están ansiosos de ser jefes, entonces, están ansiosos de complacer al presidente de la República, y el que no está ansioso de complacer va a retiro, y eso se ha dado, hasta en los dos últimos años han pasado a retiro gran cantidad de cuadros de la Policía Nacional muy importantes, muy valiosos, que Ortega los ha pasado a retiro, porque simplemente no estaban de acuerdo con él. Para ser justos, esos mismos mecanismos los usaron Alemán y Bolaños, lo que pasa es que Alemán y Bolaños destituyeron a una persona, que no estaba de acuerdo con ellos, claro, no era el jefe, pero fueron, en ambos casos, subdirectores de la Policía, lo cual, igualmente, fue un abuso, pero este señor no ha destituido a uno, sino 
que ha destituido, probablemente, lleva ya a más de quince altos oficiales de la Policía destituidos.

R: Y también se han producido cierres a nivel de la institucionalidad, porque ayer hablaba con el Magistrado de la Corte Suprema, Rafael Solís, y me decía que la sentencia es irrevocable, que la Asamblea no puede hacer nada, este nuevo conflicto entre el Legislativo y el Judicial se resolverá pronto y como que se olvidará, me decía.

E.E.: Claro, es que ellos confían en eso, en que el nicaragüense vive de la urgencia y de la necesidad de encontrar el sustento diario, entonces, ellos dicen: "esto va a pasar, se les va a olvidar, y cuando vengan las elecciones ya va a ser muy tarde para protestar". Pero, desde todos los puntos de vista, esta es una decisión absurda e ilegal que el Magistrado, pues, la podrá defender, pero es ex-temporánea, decidida en una Sala que no era una Sala Constitucional, y de una manera totalmente irregular, claro, el señor Solís es ahora uno de los principales apoyos en el Poder Judicial del señor Ortega, gracias a Dios se le vence el período en abril, creo, del próximo año, y ahí viene una batalla interesante, porque si los liberales se mantienen firmes y bloquean la reelección de Solís, ahí va a venir una tercia muy fuerte, porque estoy seguro que Ortega no está dispuesto a que Solís salga de la Corte Suprema, y uno de los factores claves de si los liberales quieren ganar, digamos, alguna ventaja dentro del Poder Judicial es evitar que Solís repita, porque Solís es el hombre de Daniel Ortega en el Poder Judicial, indudablemente.

R: ¿Y cuál es su previsión?, y ya sí le prometo que esta es la última pregunta, porque si no le voy a tener toda la mañana, ¿no más reformas constitucionales?, porque, obviamente, la ruptura del pacto constitucional ha sido casi permanente en estos últimos años, ¿no?, aunque, la frase suena un poco dura, pero da la impresión de que una parte de los nicaragüenses nunca se reflejan en la Constitución, en la del 87, todo el ala liberal-conservadora que no se identificó con el sandinismo, y luego, posteriormente, con esta reforma parcheada que ha ido acomodando la Constitución a los intereses partidarios en los últimos veinte años de democracia. ¿Piensa usted que hace falta un nuevo consenso constitucional?, ¿que sería ideal reformar la Constitución, o no tocarla más, o hacer una nueva constituyente?

E.E.: No, lo que hay ahorita es un monstruo que nadie entiende, y que como nadie entiende, y que como nadie lo entiende todo el mundo puede hacer con él lo que se le venga en gana. En un mundo ideal, en una carta al Niño Dios, como decimos los nicaragüenses, lo ideal sería que la oposición lograra colocar suficiente gente en el Consejo Supremo Electoral, podríamos incluso olvidarnos de las otras instituciones del Estado en este momento, o lograr colocar suficiente gente en el Consejo Supremo Electoral para garantizarse una elección más o menos creíble, y dentro de esa elección que le de confianza a la gente, venga una votación masiva que le de suficiente fuerza a un liderazgo liberal moderno, que no tiene que ser necesariamente Arnoldo Alemán para que haga la transformación necesaria, y si es necesario en ese momento convocar a una constituyente tal vez para hacer otra Constitución, si las disposiciones están dadas para hacerlo, eso sería lo ideal, pero ¿qué pasa?, esto nosotros lo vemos en tres etapas para concluir, para poder salir de este atolladero: uno, evitar la reelección de Ortega a toda costa, porque eso mina toda la institucionalidad, se acaba la institucionalidad porque el señor va a hacer lo que le dé la gana, ya lo dijo un jurista, Gabriel Álvarez, el otro día, que ya aquí no hay Estado de Derecho lo que hay es "estado de ánimo" del 
presidente, entonces, hay que evitar la reelección de Ortega y evitar que tenga, incluso, la posibilidad de postularse, porque si se postula las gana como sea, eso número uno, número dos, es mantener a la oposición unida para que el Consejo Supremo Electoral, como le decía, por lo menos, se convierta en una institución creíble, eso no es fácil, no va a ser fácil, pero hay que lograrlo, y tercero, que la oposición logre, a través de un mecanismo democrático que, personalmente, pensaría que es, idealmente, una elección primaria, se elija a un solo candidato por la oposición, que, bueno, que si el señor Alemán va a participar en esas primarias, pues, probablemente, lo más lógico es que él quiera participar y no hay manera de evitarlo, que si las va a ganar, yo creo que limpiamente no va a poder llegar, porque está demasiado desprestigiado, y, entonces, ese sería el plan, y al final de ese proceso se espera que saliera un liderazgo moderno de la oposición, porque tampoco, necesariamente, tiene que ser Eduardo Montealegre, tal vez, sale alguien más, y con esos tres factores, yo creo que sí hay luz al final del camino, no está arreglando el problema, pero si esos tres factores se logran creo que sí hay luz al final del túnel.

R: Bueno, pues, muchísimas gracias por haberme atendido.

E.E.: Bueno, espero que le sirva de algo esta larga conversación. 
ENTREVISTA 20 ${ }^{31}$ :

Nombre del entrevistado: D. Iván Escobar Fornos.

Cargo actual: Magistrado de la Corte Suprema de Justicia.

Fecha de realización de la entrevista: Managua, 8 de septiembre de 2009.

Lugar: Corte Suprema de Justicia.

Duración estimada: 44.30 minutos.

\section{TEXTO - Transcripción 20:}

R: ¿Cómo describe el proceso de constitucionalización de la transición democrática en Nicaragua desde los años noventa hasta ahora?

I.E.F.: Desde los años noventa...Bueno, pues...esta Constitución se dio para legalizar, digamos, y darle forma jurídica a una revolución. Esta Constitución, en un principio, fue una Constitución autoritaria, de tal manera que la división de poderes no funcionaba, el Ejecutivo podía legislar, decretar impuestos, crear Ministerios, sin necesidad de que una ley del Congreso, de la Asamblea Nacional, hiciera esa creación. Esta revolución hizo un cambio profundo en las estructuras sociales, políticas y económicas del país, fue un Estado que monopolizó la economía, la cultura, hasta la religión, todo lo que es la vida nacional, ¿verdad? El Congreso, por ejemplo, que era bicameral, tradicionalmente, en un país tan pequeño como Nicaragua, eh...sólo dos revoluciones aquí han establecido el sistema unicameral, en la revolución de Zelaya en el 1893, una revolución liberal, y la revolución sandinista en el 79 y esto se hace con el objeto de que caminara más rápido el proceso de reforma, es decir, darle estructura jurídica al proceso revolucionario. En las dos épocas, en el 1893 y en el 79 del siglo XX, ¿verdad? Entonces, así gobernaron por varios años, la revolución sandinista, se dio una reforma agraria, los bancos se nacionalizaron, los seguros, etc., etc., fue un Estado sumamente interventor que lo controlaba todo, eh...después de eso, cuando...después de la guerra, de la guerra fraticida entre nicaragüenses, que, por un lado, estaba Estados Unidos y, por otro, Rusia y Cuba, aquí se vivió la Guerra Fría, que fue bastante caliente porque hubo muchos muertos, ¿verdad? Se vivió eso hasta que llegamos al entendimiento con las mismas fuerzas, por supuesto, a través de las mismas fuerzas que alentaban esto. Se vivió una época de una inflación inmensa, inmensa, inmensa... Había billetes de alta denominación, de un millón, tres millones, cuatro millones, hasta diez millones de córdobas, eh... después del entendimiento entre las partes, entre la resistencia, la contrarrevolución y el régimen sandinista se llegó a un entendimiento para gobernar Nicaragua. Pero ya en 1987, el sandinismo y todos los partidos, mini partidos, de que se hizo rodear, dictaron una Constitución en 1987. Prácticamente fue una Constitución unilateral, que dijo que terminaba con el bicameralismo, la división de poderes no existía, y era, pues, un Estado autoritario, de tal manera que la llegaron a calificar ahí en Costa Rica un destacado jurista como la "Constitución de una monarquía", de una monarquía. Eh...dictada la Constitución, pues, establecía ya el convenio entre la resistencia y el régimen sandinista, se libraban elecciones y la Unión Nacional Opositora ganó las elecciones. El régimen sandinista se retira a la oposición, y la presidenta de Nicaragua, por aquellas cosas de la vida, gobierna con esa misma

31 Entrevista caracterizada por una dispersión relativa del discurso respecto al tema central, la referencia de algunos datos inexactos y una actitud colaboradora con escasa profundización, aunque los aspectos críticos son interesantes. 
Constitución. Pero esa paradoja puedo haber sido incluso beneficiosa, porque así como se hicieron las leyes en base a esa Constitución, se construyó un sistema totalitario, a través de ese mismo sistema se le dio retroceso. Porque así como los mismos poderes que el Estado intervino totalizando toda la vida, en esa misma manera se vino retrocediendo, poco a poco, porque ese mismo proceso revolucionario son procesos que duran mucho tiempo. Estamos hasta el día de hoy en el mismo problema, en el mismo caso, pues, ya que por supuesto menos beligerante, menos rápido, y ya no tiene la fortaleza con que se principió. Entonces poco a poco la sociedad va absorbiendo todas estas cosas. En 1995 se reformó la Constitución y se le dio un buen contenido democrático. Entonces, quedó una Constitución más o menos mixta, una Constitución mixta, por supuesto, un poco enredada, porque una Constitución, digamos, de tipo totalitario, de un régimen totalitario, se le introdujo algo, pues, que es extraño a ese cuerpo, quedó un poco enredada la Constitución, y se le han hecho varias reformas, no me acuerdo exactamente, varias reformas, hasta que llegamos a la última reforma que es la reforma del 2000. Esa reforma del 2000 fue entre dos partidos, el Partido Liberal y el sandinismo. Esas reformas lo único que hicieron fue aumentar el tamaño del Estado, la Corte Suprema de nueve, creo, Magistrados, la aumentaron a dieciséis, el Tribunal Electoral también lo aumentaron, la Contraloría General de la República que era unipersonal la convirtieron en pluripersonal y, por supuesto, se dividieron los dos partidos los cargos de esos poderes, y así en otros organismos del Estado. Se rebajó el número del porcentaje de votos que era del $40 \%$, creo, por ahí, para poder ganar la elección del presidente de la República, ¿verdad?, y otras reformas más. Posteriormente, ya en el 2001, creo, no tengo las cosas a mano y no las sé de memoria, por ahí por el $2001^{32}$, ahí lo puede ver usted después, se hacen otras reformas. Éstas le dan otro giro al Estado, le dan otro giro, eh...se principia a parlamentarizar el sistema de gobierno, se establece el voto de censura para aquellos ministros que no desempeñan bien o son ineptos, eh...se establece una interpelación, ¿verdad?, el nombramiento, aunque en el sistema presidencial así se estila, el nombramiento de los altos funcionarios de este país, como diplomáticos, ministros, y una serie de altos funcionarios, presidentes de entes autónomos, etc., tiene que consultarse a la Asamblea Nacional y con un porcentaje bastante alto se aprueban o se desechan, ¿verdad? Entonces se le está dando a los votos de censura a los ministros, prácticamente, se le está dando facultades que en los sistemas presidenciales se consultan, se le está dando gran amplitud a la Asamblea Nacional. Y eso se hizo porque el presidente Bolaños principió a tener fricciones con los dos partidos, ¿verdad?, entonces le querían coartar sus potestades, ¿verdad? Y entonces, claro, consultar esos ministros, a diplomáticos, a todos ellos era un problema, y para cambiarlos tenía que ser una mayoría grande, para nombrarlos y para hacerlo, entonces, era atrasarle la actividad del poder, el desarrollo de la actividad administrativa y gubernamental. Pero...pasa el tiempo, pues, y no hubo problema con el señor Bolaños, pero viene la nueva elección y Bolaños entrega el poder y gana Ortega con un $38 \%$, porque lo habían bajado. Eh...Bolaños había ganado con el cincuenta y pico, el problema es que se dividió la oposición, el liberalismo se dividió en la elección con Ortega, por un lado, el señor Montealegre y, por el otro lado, Rizo, que es candidato del PLC. Entonces, lógicamente el que se llevó más votos ganó y cuando llega al poder, esto de que hay que mandar a los ministros a que los ratificaran, a los diplomáticos, o a los presidentes de entes autónomos, a los funcionarios más importantes de la República tenían que pasar por esa ratificación, pues, no ha mandado a nadie. Entonces, lo están haciendo ellos un gran escándalo en la Asamblea Nacional de que no han mandado a

32 Se refiere a las reformas constitucionales de 2005. 
nadie, porque ha cambiado a varios, entonces ahora los ministros, por supuesto, están felices, los ministros que fueron nombrados antes de que entrara en vigencia esa reforma, entonces ellos están felices porque no cambian a nadie, es que a los que cambian los cambian ilegalmente. Bueno, entonces así se dio este proceso, hasta llegar a la situación en que estamos, donde hay dos propuestas, por supuesto, porque el que está en el poder, quiere seguir en el poder, y más en estos países, pues yo no creo que de esa tentación también se excluye a muchas personas, pues, y entonces se ha propuesto parlamentarizar más, llegar a un semi-parlamentarismo, como existe en el Perú, que hay un Primer Ministro, en Cuba, en los tiempos de la Constitución del 40, Fidel Castro es primer ministro, $\mathrm{y}$, entonces, un primer ministro y un presidente y una Asamblea Nacional, con derecho a disolver la Asamblea y con derecho de vetar a los ministros, ¿verdad?, un semi-presidencial, parlamentarizar como está en el Perú, como está en Argentina, como puede estar en mucho países que hay más o menos algo parecido, no el sistema parlamentario como cree la gente, no el sistema parlamentario europeo que tienen ustedes, sino un sistema semi-parlamentario, semi-parlamentario, lo cual había una corriente aquí que dirige, encabeza el Profesor Diego Valadés, una gran personalidad, un hombre de una gran capacidad y preparación jurídica y política, un personaje, escribió un libro, ha venido aquí a Nicaragua, aquí se va a publicar un libro también escribió algo sobre eso, eh...y, por otro lado, está la corriente de la reelección, que esa es la se abandonó primero esa, se principió la de la parlamentarización, pero después se abandonó por aquella cosa de que la política así es, es circunstancial, y, entonces, ahora queda nada más lo de la reelección, ¿verdad? Están en ese debate fuerte que es un poco difícil. El problema de la reelección en Nicaragua, la reelección no es buena ni mala, siempre que sea limitada, pues, período a período, yo creo que la mejor es la continua, pues, porque si te quedó algo pues termínalo de hacer, porque la discontinua si no hiciste nada en eso, nada tenés, entonces, eh...actualmente se permite la discontinua, períodos de por medio para qué, si ya no hiciste nada en eso ya nada tenés pendiente de atrás, entonces... actualmente se permite en forma discontinua, pero la discontinua es un afán nada más de volver a gobernar, digo yo pues, pero ha tenido muy malos antecedentes, ese es el problema, como te digo, en algunos países hay, porque ha resultado, en otros países no hay porque así les ha resultado, pero eso hay que estudiarlo en la historia de cada país, su historia política y cultural para ver si eso es lo que cabe. El otro problema de la parlamentarización es que si así es va a ser una reforma bastante amplia en una constituyente, o hacer una reforma parcial, pues, se discute eso, y en la reelección, pues, esa sería una reforma corriente, parcial.

R: Ese ha sido uno de los conflictos en los procesos de reforma desde el 95. El tema del procedimiento de la revisión constitucional, porque, de hecho, ¿no se puede afirmar que hay cierta inconstitucionalidad en el precedente de la reforma del 95?

I.E.F.: La reforma del 95 fue una reforma amplísima, ¿verdad?, no se dijo nada, no se discutió, por eso, porque como era favorable al proceso democrático, pues, nadie dijo nada.

\section{$R:$ ¿Sobre el procedimiento?}

I.E.F.: Claro, porque si te estaba beneficiando, si estábamos devolviendo las cosas para atrás, para qué estás diciendo que era malo. Mejor hagámoslo ya y de una sola vez. 
$R: Y$, sin embargo, hubo un enfrentamiento durísimo entre la presidenta de entonces, Violeta Chamorro, y la Asamblea Nacional.

I.E.F.: Ah, sí, porque ella tenía, el problema de Doña Violeta más bien más que cuestiones legales era que quería hacer a su yerno presidente de la República. Además, también ella no quería perder poder, ¿verdad?, no quería perder poder, porque ella estaba gobernando con la vieja Constitución autoritaria y ella quería, como la reforma iba inhabilitando al yerno, entonces.

R: Y, sin embargo, ha habido dos veces que ha tenido que formularse una Ley Marco para tratar de conciliar...

I.E.F.: Ah! Esos son las peores aberraciones que se han hecho, suspender la Constitución por una ley, y por una ley ordinaria, eso es una barbaridad...

R: Que congela temporalmente la Constitución...

I.E.F.: Esas son atrocidades que sólo aquí creo que se ven.

R: Y, ¿qué opina, por ejemplo, de la ley que incluso reforma la Ley Marco que permite la aplicación no ya en 2007 como estaba previsto sino en 2008 bajo el gobierno sandinista? Porque a Daniel Ortega tampoco le convenía, bueno, de hecho no sigue aplicando parte de los precedentes de ratificación...

I.E.F.: Ya esa se venció, ya esa se venció, y ese es otro adefesio, ese es otro adefesio jurídico. Pero él ya no tiene ninguna suspensión de nada, él ya tiene que, ya hace tiempo que se venció eso, y ya tiene que ratificar, él está con una parte de su gobierno nombrada de forma ilegal, sí.

R: Y la Sala de lo Constitucional, ¿qué papel ha representado en este proceso tan contradictorio a veces de la reforma?

I.E.F.: Bueno, tiene sus altas y sus bajas. Pero yo diría que más bien ha servido, ha servido bastante, ha habido errores grandes, pero ha moderado bastante el proceso político, por ejemplo, cuando yo era presidente de la Corte a D. Enrique Bolaños, que, por cierto, conmigo tuvo sus problemas serios cuando su candidatura a la presidencia, porque yo era el contendor de él para el partido, eh...el sandinismo interpuso un amparo, porque decía que las elecciones habían sido fraudulentas y que no le dieran las credenciales a los diputados, a los presidentes y a todos, pues, los alcaldes, y todos los de la elección, entonces, la Corte de Apelaciones de Managua decretó la suspensión y no les dieron, y ya faltaba un mes para tomar posesión. Es decir, eso significaba que si llegaba el día de la toma de posesión y estaba prohibido por la Corte que se realizara, Nicaragua estaba...entonces, aquí nos reunimos de emergencia, estuvimos todo el día hasta la noche, y sacamos el problema revocando y autorizando la elección, la toma de posesión. Ni siquiera se había enviado las invitaciones porque no se sabía, y así hemos dado oportunidad de que participe el partido, ah y otras decisiones que no han sido bien recibidas, por supuesto, ha habido sus bajas y sus altas, pero ahí va.

R: ¿Se produce una politización de la justicia a raíz de esa "bipartidización” de la composición interna de la Corte Suprema de Justicia en Nicaragua? 
I.E.F.: Eh...

R. ¿Se ha perdido en términos de independencia judicial?

I.E.F.: Sí, hay, hay...claro que sí. El otro problema es que la Sala Constitucional, la Sala Constitucional, prácticamente, es un tribunal político, porque aplica la Constitución, aquí nos vienen problemas electorales, aquí nos vienen problemas de competencia entre los órganos del Estado, aquí nos viene de todo, entiende, entonces, prácticamente, hasta bueno, hasta juzgamos al presidente si es posible, pues, entonces, eh...la política entra por los partidos políticos, primero, los nombramientos son hechos, generalmente, de los partidarios, después de eso, el sistema, la materia que conocemos es política en la Sala Constitucional y la Corte plena de todos los Magistrados la inconstitucionalidad de la ley por ahí entra también, sí necesita un sistema de nombramiento que asegure más la independencia, sí, yo he escrito sobre esto, todo esto sobre lo que le estoy hablando.

R: En ese sentido, el hilo que articula el proceso de reforma constitucional en Nicaragua a que ese modelo semi-parlamentarista ¿no ha colocado en la cúpula de los partidos la capacidad de decisión en vez de en el presidente de la República, es decir, que de un presidencialismo fuerte se ha pasado a un parlamentarismo que funciona de una forma perversa, me refiero, al estar en manos de los líderes políticos que coartan con su decisión la composición de los órganos del Estado?

I.E.F.: Bueno, según el sistema electoral que se haya dado, la idea de este parlamentarismo es que debilitara el Poder Ejecutivo, el problema que nosotros hemos tenido aquí es que tenés el Ejecutivo es un sistema presidencial, tenés el Legislativo y tenemos un poder que se llama electoral, y tenemos Poder Judicial, pues, este presidente en Nicaragua es el que lo maneja todo, es un sistema presidencial, es el centro de todo, no es como en Europa que se dice que el parlamento es el principal, verdad, poder del Estado, porque incluso el Ejecutivo, el gobierno en un sistema parlamentario depende prácticamente del parlamento, entonces aquí, aquí todo el mundo depende de esto, maneja el presupuesto, maneja todo, alguien dijo que esto parecía una monarquía, que se inspiraron los norteamericanos en la monarquía, y entonces lo que se quiere es dividir a éste y decirle aquí va a haber un presidente y un primer ministro, presidente por elección popular, y primer ministro por elección de la Asamblea, y se divide éste.

R: ¿Y no habría la tentación en Nicaragua de que cada una de las dos figuras fuese de los dos principales partidos?

I.E.F.: Puede ser, claro, claro, como en Rusia, y así se van cruzando el uno y después el otro, como Putin con el otro. Todos esos peligros existen.

R: ¿Y sería el escenario probable en Nicaragua a pesar de que se ha complicado también la escena política cuando aparecen otros dos partidos que son "anti-pacto"?

I.E.F.: Ahora sí, claro que si se promoviera un pluralismo político grande de muchos partidos pues esto podría cambiar.

R: Pero si el propio Consejo Supremo Electoral... 
I.E.F.: Ah, no, esto tiene que cambiarse totalmente, este Consejo Supremo Electoral tiene que estar completamente, ahora la modalidad en América, aquí en Nicaragua, primero el electoral se hizo un poder. Primeramente, desde la primera Constitución el que controlaba la elección era el Congreso, qué cosas pasan, ¿verdad?, decía si la votación era correcta o no correcta, y declaraba electo a los presidentes, a los jefes de Estado, y todos los de elección popular. Después de eso, pasó al Poder Judicial, fechas no te doy porque no manejo yo tanta memoria, pero todo lo tengo escrito, eh... después de eso, te estoy hablando en términos generales y sencillos, después de eso pasó al Poder Judicial, que está de moda ahora en América Latina, como en México, y después pasó a este poder dentro de los poderes del Estado, ¿verdad?, pero siempre el problema es que los partidos están de por medio, hay una partidización, eso tiene que cambiarse, mejorar los partidos políticos.

\section{R: ¿Esa sería la clave?}

I.E.F.: Sí, meter el pluralismo político, ahora el problema es cultural también, quiero decir, la historia la han manejado pocas familias, eh...que promueven todo esto, pocas familias muy ricas, que han formado este tipo de cultura, yo tengo un artículo ahí sobre las violaciones, fraudes, y abusos constitucionales, donde narro todas las zanganadas que han hecho desde la independencia hasta el día de hoy. Esta cultura...tiene que haber una revolución cultural aquí, hasta que esto no cambie...Todo esto lo promueven ricos, altos políticos, todo esto...

$R: Y$, sin embargo, como usted bien dice cada una de las constituciones que ha tenido Nicaragua ha estado precedida de un pacto entre liberales y conservadores...

I.E.F.: Toda la vida...y ahora el sandinismo con los liberales.

\section{R: ¿Y qué piensa a propósito del pacto?}

I.E.F.: Bueno, es decir, en política se vive de convenios, en el sistema parlamentario el juego...lo que se quiere es que haya convenios, pues, para que jueguen las minorías, para que jueguen todos los grupos y haya entendimiento, pues, pero ni despreciando dos grandes fuerzas económicas, que dirigen estos partidos que se vienen a eso, no funciona, esto es cultural.

R: ¿Piensa que se ha dado una concentración del poder en el actual presidente Ortega y en la forma en la que está conduciendo el ejercicio del Poder Ejecutivo frente a otros presidentes debilitados, como fue el caso, por ejemplo, de Enrique Bolaños, que se vio ciertamente desamparado respecto a su propio partido en la Asamblea a raíz de la división del liberalismo y luego, obviamente, enfrentado por razones políticas al sandinismo, aún cuando tuviese que estar negociando entre uno y otro, dándose una maniobra de componendas recíprocas, ¿no? ¿Qué piensa sobre la actual situación de Nicaragua y el contexto, digamos, del gobierno del presidente Ortega y de su esposa, se habla incluso de la "pareja presidencial"?

I.E.F.: Sí, sí, es que Nicaragua ha sido un país de familias y de caudillos, aquí lo han manejado unas pocas familias este país y los caudillos. Es un fenómeno ese que vos estás viendo aquí muy parecido a todo lo que ha existido en este país, ¿verdad? La situación es muy dura, la que se está viviendo económica, hay incertidumbre política, 
¿verdad? Eh...no sabemos hasta donde esto va a llegar, nadie podría decir cómo va a desembocar esto, pero no se ve bien, el panorama no se ve bien, ¿verdad? Ahora el otro problema es que en Nicaragua hacemos los arreglos al borde del precipicio, ya cuando nos matamos, cuando acabamos de terminar la guerra y hay cientos, miles de muertos, entonces nos sentamos a decir terminemos pues.

R: Y no piensa que tanta reforma de la Ley Fundamental que, en teoría, debe tener una vocación de permanencia para que dé consistencia y estructura al orden político, la política convencional es la que cambia, las élites políticas son las que son periódicas en cada proceso de elección, ¿no? La Constitución, de alguna forma, tiene una vocación de permanencia...Esa relación entre la Constitución y el tiempo aquí es particularmente dificil.

I.E.F.: Ésta va a acomodada a los intereses políticos y económicos ante todo, entonces los van a acomodando, no existe, no existe un Poder Judicial activista, pues, que pueda poner al día la Constitución, desarrollarla, todo, todo, como Estados Unidos, como los países europeos, aquí no, aquí nadie está pensando, aquí la Constitución está por lo que puede decir ahí gramaticalmente la Constitución, pero no...

\section{R: No hay una eficacia de la norma jurídica...}

I.E.F.: No, no, no le dan el espacio que se le da a la Constitución, nada, nada de eso.

R: ¿Y cuál piensa para finalizar que podría ser la solución?, ¿qué claves de reflexión aportaría usted como académico y no ya solamente como Magistrado de la Corte Suprema?

I.E.F.: Bueno, es que todo lo que le digo...es muy difícil, hay que buscar una solución bastante radical, ¿verdad?, porque si hacemos una Constitución moderna de nada sirve, vos no tenés un sustrato ahí firme, un capitalismo dispuesto a promover reformas sociales, no tenés un pueblo preparado cívicamente para defender la democracia, esto es un proceso lento, en un país como este donde hay mucha falta de cultura, donde hay falta de civismo, este es un proceso lento, que sólo se puede dar a través de un..., cómo te diría yo, de un convenio global político de todas las fuerzas de este país, sentarse, sentarse todos los factores de poder, y decir: señores pues, hagamos un plan de 10 o 15 años donde se haga sucesión de partidos, haya sucesión de poder, hagamos esto sobre economía, hagamos esto sobre programas sociales, hagamos todos estos programas serios, pues, más o menos las fuerzas fundamentales de este país, pues, no es que se vaya a sentar todo el pueblo, mire señora aquí vamos al desastre, si aquí no hay un nuevo convenio político, una nueva reestructuración del Estado y del país, pues, vamos a la debacle, un nuevo contrato social.

$R: Y$, sin embargo, la reforma constitucional ya apunte hacia la reelección, ya hacia una nueva estructura del Poder Ejecutivo añadiendo la figura del Primer Ministro está paralizada ...

I.E.F.: Está paralizada.

R: En la Asamblea... 
I.E.F.: No, no quieren nada.

R: Entonces incluso el presidente Ortega tendría que darse prisa o los sandinistas tendrían que darse prisa si quieren proponer la reelección del presidente...

I.E.F.: Es que la lucha que se está dando es una lucha de poder, eh, nada más, de ahí para adelante no hay nada.

R: Esa es su reflexión final...

I.E.F.: Sí, fíjate bien si hay alguien que ha presentado un programa, ¿has visto alguna cosa?

R: Bueno, las distintas fuerzas políticas al menos, en mi caso, que tengo acceso a la prensa desde allá, porque hasta ahora no me ha tocado visitar el país y poder tener la oportunidad de entrevistar a personas conocedoras del proceso nacional, pero sí cada una de las fuerzas politicas tiene su programa, y, de hecho, a mi me llama mucho la atención esa denominación de "parlamentarismo a la nicaragüense", que defendian los propios sandinistas el año pasado en 2008 en la Asamblea, tratando de elaborar algunas de las propuestas que me comentaba anteriormente.

I.E.F.: Tienen sus propuestas, pero no un programa completo. Cuando el sandinismo hizo crisis por la fuerza que estaba tomando la contrarrevolución, nos reunimos un grupo, entre ellos Enrique Bolaños, aquí nos reuníamos clandestinamente, así en determinados lugares, y entonces el sandinismo decía que si en unas elecciones o de cualquier otra forma la oposición llegaba al poder iba a haber un vacío de poder, porque no había quien pudiera gobernar este país, nadie estaba en capacidad. Pero había mucha gente que sabía esto. Entonces nos reunimos y trabajamos como seis o siete meses, y trabajamos en la tarea, y después se fue haciendo grande, grande, grande, muy grande, hasta en el exilio y en la contrarrevolución, de todo, entonces sacamos un documento, que se llamaba el "Azul y Blanco", donde proponíamos desde cómo se iba a organizar el poder electoral, qué sistema electoral, cómo se iba a organizar la Asamblea, cómo se iba a organizar la presidencia, cómo se iba a hacer la reforma agraria, cómo se iba a organizar el Ejército, cómo se iban a organizar los bomberos, cómo se iba a organizar todo, todos los problemas nacionales, ese es un programa, y se presentó ante la opinión pública, y dijeron que era una copia mal traducida que había hecho la CIA, sí, así lo dijeron, un amigo cubano mío en el exilio me dijo: "prestámelo", me dice, "porque nosotros queremos hacer algo para que cayera Fidel”, nunca cayó. Aquí lo que están es nada más cuestioncitas, yo opino aquí una cuestioncita, tú opinas otra cuestioncita, así...

$R:$ ¿De las distintas fuerzas políticas?

I.E.F.: Exacto...

$R$ : ¿Ninguna tiene un programa serio de reformas?

I.E.F.: No, nada, aquí lo que andan ellos que si tienen siete puntos, que si tienen... 
R: ¿Y ese ha sido el patrón también en las reformas que se han aplicado ya en el 95, 2000 y 2005?

I.E.F.: Sí, sí, no ha habido nada, la del 95 ha sido la más importante, ha sido la más importante, fue mejor pensada.

R: Y, sin embargo, en la Asamblea que aprueba la Ley de Reforma Parcial de la Constitución en el 95 era multipartidista, estaba compuesta por pequeños partidos políticos...

I.E.F.: Sí, sí...

R: Y, sin embargo, ya la del 2000 está hecha por el PLC y el sandinismo.

I.E.F.: Sí.

$R$ : ¿Qué diferencias encuentra?, ¿cree que ha podido influir algo la representación parlamentaria?

I.E.F.: Sí, se volvió más en la del 2000, se puso un sistema de la media mayor, se quitó un sistema que era un sistema proporcional, con 200 votos podía ganar un desnaturalizado, el sistema de cociente electoral permitía que un desnaturalizado estuviera en el padrón electoral, de tal manera que llegan los diputados hasta con 300 votos, porque había que hacer una serie de operaciones absurdas, entonces, se derogó eso y se puso un sistema de la media mayor, que favorece a los partidos grandes.

R: Ya para terminar, aunque hemos hablado prácticamente de casi todo, incidiendo, yo creo, en los problemas más graves que tiene Nicaragua en la actualidad. Creo recordar que el año pasado, por lo menos en mis lecturas de prensa, nuevamente, se estableció en la Asamblea el llamado "Bloque contra la dictadura", que además estaba conformado por todas las fuerzas políticas de oposición al Frente: el MRS, la Alianza Liberal Nicaragüense, y el propio PLC ¿no? En ese sentido, ¿cómo espera que prosperen las propuestas de reforma constitucional del sandinismo sobre la reelección si no va a contar con el apoyo de las demás fuerzas políticas?

I.E.F.: Por el momento, no tienen futuro, de momento, porque las cosas en política nunca se saben.

R: Porque admite la negociación entre los líderes...

I.E.F.: Claro, por el momento no se le ve, no hay... pero en política no hay nada escrito.

R: Pues si quiere añadir algo más sobre todo lo que hemos comentado...

I.E.F.: No, muy bien. 
ENTREVISTA 21 ${ }^{33}$ :

Nombre del entrevistado: D. Roberto Evert.

Cargo actual: Secretario del Consejo Supremo Electoral.

Fecha de realización de la entrevista: Managua, 25 de noviembre de 2009.

Lugar: Consejo Supremo Electoral.

Duración estimada: 1 hora.

\section{TEXTO - Transcripción 21:}

R: ¿Cómo evalúa, digamos, la creación y la transformación que ha sufrido esta institución, el Consejo Supremo Electoral, desde el momento de la transición democrática, es decir, la firma de los Acuerdos de Paz y la celebración de las primeras elecciones en las que gana la presidenta Violeta Chamorro, hasta el momento actual que estamos viviendo? Serían estos últimos veinte años de vida pública en Nicaragua.

R.E.: Quizá nos remontemos al 19 de julio de 1979, el Estatuto Fundamental, que se promulgó, hubo toda una discusión académica que decía que, desde el punto de vista material, sí era una Constitución, porque aunaba la parte orgánica y la parte dogmática, más no desde el punto de vista formal, porque no devenía de un poder constituyente, sino de un gobierno producto de la lucha armada, este Estatuto disolvió el Poder Electoral que había regulado las elecciones de las últimas 4 o 5 o 6 décadas durante los Somoza, se consideró como un aparato represivo de poder y fue disuelto, fue hasta 1984, o sea, 5 años después, en una reforma que se le hizo al Estatuto se creó el Consejo Supremo Electoral con el propósito de regular las primeras elecciones en ese período, llamado período revolucionario, antes de los Acuerdos de Esquipulas, posteriores, ¿no?, en esa oportunidad la entonces Junta de Gobierno de refundación nacional convocó a elecciones, las primeras elecciones de esa etapa histórica para el 4 de noviembre de 1984, un Consejo integrado por Magistrados designados por el Presidente de la república a propuesta de algunos partidos políticos, se abstuvieron de presentar ternas o listas los partidos políticos que aglutinaban la entonces Coordinadora Democrática, Ramiro Sacasa Guerrero, en vista de que a juicio de esta Coordinadora las condiciones políticas no eran propicias para garantizar elecciones libres, $\mathrm{y}$, dicho sea de paso, el gobierno sandinista a partir de 1981 gobernó bajo diferentes Estados de Emergencia, y cuando se convocaron esas elecciones, casualmente, estábamos en Estado de Emergencia, entonces, existieron las elecciones del 84 bajo ese nuevo Consejo Supremo Electoral, que eran cinco magistrados propietarios y cinco magistrados suplentes, asistieron el Frente Sandinista, el partido que estaba en el poder, y siete organizaciones políticas que no estaban aglutinadas dentro de la Coordinadora Democrática, que habían de la más variada gama, ¿no?, habían de extrema-izquierda a de centro-derecha, que sí participaron, en esa oportunidad comencé yo aquí a trabajar, obviamente, hubo una gran mayoría a favor del partido de gobierno, y a esa Asamblea Nacional electa se le confió la tarea de elaborar la Constitución de 1987 durante los dos primeros años de funcionamiento, o sea, que tuvo doble naturaleza, era una Asamblea originaria, y,

\footnotetext{
33 Entrevista muy interesante, teniendo en cuenta la presencia de este funcionario en el CSE desde su creación, está más centrada en la dimensión electoral de los cambios constitucionales recientes, así como en su impacto sobre la práctica de los comicios y la consolidación de las instituciones democráticas en Nicaragua, en un contexto institucional marcado por el reparto paritario de las cuotas de representación formal de los partidos dominantes en los poderes del Estado.
} 
después, ella misma se convertía, para los siguientes cuatro períodos, porque fue electa para un período de seis años, en Asamblea derivada u ordinaria, es decir, no se mandaba disolver, sino que ella misma se convertía en un órgano derivado. Esta Asamblea Nacional, que fue constituyente los dos primeros años, constitucionalizó el Consejo Supremo Electoral, manteniendo, diríamos, la reforma del Estatuto de 1984, ¿no?, con Magistrados propuestos por el presidente de la República en consulta con algunas organizaciones políticas y civiles, y confirmados, electos, por la Asamblea Nacional a propuesta del presidente de la República, pero así las cosas, en 1990, que se adelanta nueve meses el proceso electoral derivado de los Acuerdos de Sapoá, el Consejo Supremo Electoral es recompuesto a petición, en este caso, de la Coordinadora llamada Unión Nacional Opositora, que aglutinaba, se decía, a la auténtica y legítima oposición, y propusieron un Consejo que fuese precedido, o bien estando integrado en él, un notable entre los cinco, que garantizara el fiel de la balanza, en la cual estarían tres afines al partido del poder, del gobierno, y dos Magistrados de otras tendencias partidarias, este Consejo es el que organizó y dirigió las elecciones de 1990, que, como le repito, fueron adelantadas nueve meses, y se le hizo la primera reforma a la Constitución de 1987 para poder adelantar la fecha de las elecciones, y recortar el período de la Asamblea Nacional y del presidente, que era Daniel Ortega en esa oportunidad, ¿ya? Bueno, las atribuciones del Consejo, una de las que siempre ha sido discutible es la materia de lo contencioso-electoral, paradójicamente, se había derogado el Tribunal Electoral del gobierno de los Somoza, que también gozaba de lo contencioso-electoral, de tal manera se diseñaron los futuros poderes electorales, el Poder Judicial no tiene competencia en materia electoral, en eso, es clarísima la Constitución y la misma Ley Electoral, así que este órgano administra, resuelve, proclama candidatos, y decide sobre los recursos, tal como fue en 1990 y en las posteriores elecciones, en 1996 y en 2001, ¿ya? En 1995 se hace una reforma a la Constitución, para mí, la reforma más, quizás la más importante realizada, ¿no?, donde se garantiza un equilibrio entre los poderes del Estado, se derogó el famoso artículo, el 150 numeral 4 de la Constitución, donde al presidente de la República le dan la facultad de dictar decretos con fuerza de ley, decretos administrativos, y decretos de carácter fiscal, que, a juicio de algunos constitucionalistas, entre ellos el Profesor Joan Vintró de la Universidad de Barcelona, muy amigo nuestro, decía que la Constitución de Nicaragua diseñaba una dictadura constitucional a la lectura de ese precepto, que fue derogado en la reforma de 1995, donde la mayoría parlamentaria estaba la llamada Unión Nacional Opositora versus la segunda fuerza política, que era el Frente Sandinista. Se mantuvo la misma estructura del Consejo Supremo Electoral, no se varió mayor cosa en cuanto a sus atribuciones y facultades, se mantuvo lo contenciosoelectoral del Consejo, y que el órgano judicial no tenía competencia para conocer sobre materia electoral, sólo en materia de partidos políticos, de tal manera que si un partido sintiera agraviados sus derechos por un acto emitido por un órgano electoral, sí cabe un recurso de amparo ante la Sala de lo Constitucional de la Corte Suprema en materia de partidos políticos, pero entrar ya a la discusión de qué es materia electoral y qué es materia de partidos políticos jamás, ni la Ley Electoral ni la Constitución lo establecen. En la práctica ha habido, en mi opinión muy personal, temas que son en materia eminentemente electoral, que los ha resuelto el órgano, la Sala Constitucional de la Corte, o a la inversa, ¿verdad?, la línea fronteriza ¿dónde está?, es una discusión académica, y también, eminentemente, política, qué es materia electoral y qué no lo es, es una debilidad de nuestro sistema. Las elecciones de 1996 dieron lugar al primer pacto, del cual yo fui asesor por parte del Partido Liberal Constitucionalista, y se reformó, hubo una reforma estructural y de fondo de cómo integrar el órgano electoral, 
donde la participación de los partidos políticos, el control del órgano determinante utilizando este criterio, ¿no?, que se integraría por Magistrados, por tantos Magistrados, que hayan obtenido, del partido, que hayan obtenido el primer lugar en las últimas elecciones, y por otros Magistrados que obtuvieran el segundo lugar en las elecciones anteriores, y el resto de conformidad al pluralismo político, que estas reformas del 2000 diseñó un sistema político aquí donde garantiza la participación, prácticamente, de dos fuerzas políticas, se dictó una Ley Electoral con muchos candados, diríamos, usted sabe que como dice la doctrina francesa el que hace la Ley Electoral determina qué clase de sistema político quiere, aquí era la preponderancia de dos fuerzas y también una participación de otros partidos, de otras fuerzas políticas, pero nunca igual a la que fue en el 84 y en el 90, que el mismo sistema electoral que se diseñó fue de los residuos mayores, sistema proporcional electoral por residuos mayores, de tal manera, que también participaban partidos minoritarios, no fue así a partir del año 2000, ese fue el consenso de la clase política que detentaba el poder, ese órgano electoral, entonces, dirigió ya las elecciones del 2000, del 2001 y todas hasta la fecha, a partir de ese momento no ha habido reformas al órgano electoral, se mantiene como tal desde hace nueve años, incluso, estas reformas motivaron la renuncia de uno de los presidentes del Consejo, el doctor Mariano Fiallo, y, pues, públicamente alegó que era muy difícil conducir un órgano electoral cuyos Magistrados eran propuestos por los partidos políticos, de que llegaba un momento en que a él se le salía de las manos el control hasta administrativo y técnico de eso, porque podía caerse en una sumisión partidaria y no institucional, en la práctica se viven problemas como ese, esa es mi opinión muy personal, no como funcionario de esta institución, por la experiencia he llegado a la conclusión de que a veces los partidos políticos pretenden ser sustituidos en el órgano electoral, gravísimo error, no discuto que los partidos tengan derecho a tener representantes en el órgano electoral, pero sí es error pretender que los Magistrados, nombrados a propuesta de estos partidos, se les presione para que sustituyan a los partidos, yo considero que los partidos deben resolver en su cúpula cualquier crisis o problema, pero no trasladarle esa sustitución, ¿verdad?, al Consejo Electoral, que en la práctica se ha dado y ha provocado serias crisis, una de ellas ha sido el uso del quórum, yo creo que habría que ser muy cuidadoso en el quórum como instrumento de presión para que un órgano colegiado no sesione, sobre todo este órgano cuya naturaleza es la de no hacer la ley, sino que la administra y la aplica, yo considero que el quórum es un instrumento más propio del parlamento que sí hace la ley, o sea, un órgano importante que tiene las minorías parlamentarias, como, por ejemplo, no constituir quórum para que no se discuta o se apruebe determinada ley, que, a su juicio, afecta a sus intereses o los intereses de la nación, $y$, en el caso nuestro, a veces por la aplicación de la ley, ha habido suspensiones de sesión, porque no había quórum, ahí los partidos juegan un papel importantísimo, tuvimos crisis, de tal manera, que la Corte Suprema de Justicia, en una sentencia muy sui generis, el presidente del Consejo recurrió de amparo por el problema del quórum, y él tenía una responsabilidad política al ser funcionario de ese órgano electoral, entonces, la Corte Suprema llegó hasta interpretar la Ley Electoral, y facultó al presidente de designar a los suplentes para que integraran el órgano electoral y así hacer quórum, una sentencia muy discutible, porque la ley dice que quien llama a sus suplentes es el propio Magistrado propietario, no es atribución del presidente, yo lo comentaba con él, ¿verdad?, ya en lo personal, y le decía que lo interesante de esa sentencia es que, por primera vez veo, que el Poder Judicial atribuye funciones con sentencias, porque eso son atribuciones, pero esa es la sentencia, y se mandó aplicar para resolver la crisis y que se constituyera el quórum, y así pudiera haber elecciones para esa fecha, estamos hablando la del 2000, 2001, que fue una época bastante difícil, 
también en vista de las elecciones de 2006 y 2007 en las que salió electo el Comandante Daniel Ortega. La Corte Suprema, eso fue en el 95, sí, declaró inaplicables algunas normas de la Ley Electoral de la época, porque consideró violatorio del principio de igualdad y sobre todo los derechos políticos, una normativa que el Consejo Supremo Electoral estableció del procedimiento para la recolección de firmas, que apoyaran la solicitud de las organizaciones políticas para tener la personalidad jurídica y para inscribir candidatos, luego, fue interesante esto y la Corte declaró inaplicable esas disposiciones, que en la práctica además están dados, ¿no?, y es una ley que, prácticamente, obliga a ir en alianza, es un riesgo que un partido político pretenda ir solo en las elecciones, porque así está diseñada la ley.

\section{R: ¿La actual?}

R.E.: La actual, a como está diseñada obliga a ir en alianza, aspectos beneficiosos, es que ahora existe el financiamiento, únicamente, a posteriori, en las legislaciones anteriores se daba un porcentaje antes de asistir a las elecciones, y el resto después de ir a las elecciones, y ahí hubo, desgraciadamente, abusos de algunas instituciones políticas con el manejo de esos recursos, pero aún está muy cruda la Ley Electoral, no aborda nada, por ejemplo, sobre los mecanismos para seleccionar candidatos, por allá dice que los partidos políticos procurarán utilizar procedimientos que garanticen que los candidatos son electos democráticamente, pero más nada, también el tema del financiamiento de la campaña electoral es todavía un poco timorata, usted sabe del tema del lavado de capitales y todo, es un tema muy, muy recurrente hoy, ¿verdad?, sobre todo el financiamiento de los partidos, usted sabe que a diferencia de otras legislaciones aquí solamente se financia la campaña electoral, no hay un financiamiento permanente de los partidos políticos como lo hay en otras legislaciones, no existe en Nicaragua, alguna estimación presupuestaria para los grupos parlamentarios o fracciones en la Asamblea Nacional, que está también con serias debilidades, por ejemplo, hay bancadas acá que fueron electas bajo determinada denominación partidaria, hay crisis interna y deciden constituir otra fracción u otro grupo parlamentario, y este grupo continua recibiendo por parte del presupuesto para las actividades que dice el mismo presupuesto de la república de los diputados que están en la Asamblea, y ahí hay un problema de roce con la ley, porque la ley dice que sólo los partidos con personalidad jurídica pueden gozar de ese presupuesto, y, generalmente, las fracciones o bancadas que se forman a lo interno de otras no gozan de personalidad jurídica, existen de facto, así es que también esa es otra discusión, tener derecho o no al financiamiento que se da a través del presupuesto del Ministerio de Hacienda, pero no se discute mayor cosa.

R: Una de las críticas, digamos, de la sociedad, y también de algunos juristas expertos en la evolución constitucional reciente de Nicaragua hacia la segunda reforma, la del 2000, ha sido esa partidización de los órganos del Estado, ¿no?, usted además hacía mención a esas dificultades para llegar al quórum, al final para que el funcionamiento institucional fuese, digamos, no estuviese sujeto a bloqueos partidarios. ¿Cuál es su reflexión, como alguien que conoce bien la institución desde dentro, y puede comparar el antes y el después?

R.E.: Sí, yo considero que, en el caso nuestro, por nuestra realidad la partidización más o menos equilibrada no solamente en el órgano electoral sino en los otros órganos puede permitir una mejor gobernabilidad, ¿ves?, y una garantía de que las otras fuerzas políticas no monopolicen o no actúen con preponderancia sobre las otras, ese es un 
aspecto positivo, pero en lo demás yo creo que tenemos serias debilidades debido a nuestro poco desarrollo en cuanto al quehacer y la actividad partidaria, y saberla diferenciar de los eminentemente institucional.

\section{$R:$ ¿De la cuestión técnico-electoral?}

R.E.: De la cuestión técnico-electoral, verdad, que es eminentemente, como usted dijo, técnica, y procurar despojarla de cualquier influencia partidaria para no atentar contra su naturaleza, todavía se ha hecho, todavía es difícil en el medio nuestro, bueno, en el 1990 fueron otras condiciones en otras circunstancias, aún en las elecciones siguientes, al igual, el órgano electoral trató de mantener un equilibrio y guardar distancia de las influencias partidarias que pudieran haber a lo interno del órgano, que decíamos que lo ha habido, con la reforma del 2000 el peligro se ha ido acercando más, como yo le decía, ese tratar de saber hasta dónde puede llegar mi rol por haber sido propuesto por determinado político y qué me corresponde hacer hoy como miembro de una institución del Estado, que debe garantizar elecciones transparentes frente a la sociedad misma, y dar las garantías y la confianza, hemos entrado en un punto difícil, del cual, además, todos tenemos una cuota de responsabilidad, ¿usted ha escuchado hablar de una iniciativa de ley en la Asamblea Nacional de los partidos inconformes con las elecciones municipales de anular el proceso electoral?, pero no sé si ha escuchado eso, ¿no?, alrededor de las elecciones municipales...

R: Sí.

R.E.: Dos cosas, la primera, ahí creo que hay un error también técnico-jurídico enorme, que es pretender que a través de una ley se anule un proceso electoral, ¿no?, donde ya en materia de Derecho, en lo contencioso, ya se dio la última palabra, equivocada o no, con los defectos e irregularidades que pudieran haber tenido las elecciones esos son los resultados, y lo segundo, yo considero en lo personal, que si los partidos inconformes, con razón o sin razón, ¿verdad?, con el resultado de las elecciones municipales fuesen más congruentes, en la iniciativa de ley debieran de haber renunciado al financiamiento de la campaña electoral para darle lógica a una iniciativa de nulidad, si yo soy el proyectista de esa ley y demando la nulidad de las elecciones, yo creo que también debo en la iniciativa de ley considerar que renuncio al financiamiento de la campaña, lo tercero, muchos de estos partidos demandantes de la nulidad ya lo recibieron, el financiamiento de la campaña, y creo que de haber sido así habría renunciado a ella y decir: "no, es más, ni financiamiento, porque considero que se me defraudó en 50.000, 60.000 votos", por dar un ejemplo, y recibieron el financiamiento, entonces, es un señalamiento que hago yo, que se critica, por un lado, la débil institucionalidad, pero la clase política que hace el señalamiento también a veces como que no es congruente con esa posición, ¿me explico, verdad?, me explico, son apreciaciones muy mías, ¿verdad?, nada tiene que ver el órgano electoral, digo yo, para que exista congruencia con lo planteado por la clase política.

R: Y este conflicto de poder no es ajeno a la propia evolución constitucional reciente, porque siempre ha habido conflicto entre los poderes del Estado.

R.E.: Permítame, yo, yo soy de la opinión de que puede ser hasta normal el conflicto entre poderes, pero lo nuestro es más grave, el conflicto es por el poder, esa ha sido la historia de Nicaragua, yo doy clases de historia constitucional de Nicaragua, y, 
entonces, los conflictos han sido siempre por el ejercicio del poder, ojala fueran entre poderes, es por el ejercicio del poder.

R: Si en el 95, la gran reforma del 95, que como usted bien señaló, goza de legitimidad $y$ de una buena contemplación, en general, por parte de los expertos, visualizándola, digamos, hacia atrás, porque era jurídicamente necesaria, en el sentido en que el momento político de la transición exigía un cambio profundo en la Constitución del 87, que consolidaba un presidencialismo muy fuerte, aumentando las facultades de la Asamblea Legislativa, la crítica que subyace es que hemos pasado al dominio de las cúpulas partidarias, ¿no? ¿Cuál es su visión de los partidos políticos en Nicaragua como instituciones de representación?

R.E.: Para mí, al igual que en muchas sociedades, están pasando por una serie de crisis de credibilidad, y la incapacidad de resolver las necesidades no sentidas, ¿verdad?, de la sociedad, por el pueblo, pues, por una crisis enorme, aún creo, creo yo que los grupos de presión que estuvieron muy de moda en los 90, hablando con Valeska en Polonia y otros más, aún en el medio nuestro puede ser una alternativa, pero no se perfila si un grupo de presión es ajeno a las organizaciones políticas tradicionales, y también el caso nuestro deja mucho que desear, se critican, verdad, las posiciones tradicionales, aún los hay, aún en el medio nuestro la figura del caudillo entre grandes sectores de la población sigue creciendo como interesante y como atractiva, el líder, el hombre, el jefe, el dirigente, ¿no?, ese es el tratamiento que da la gente, "mire, el jefe, el hombre", dijo, las estructuras aún machistas que tenemos de poder, y que los partidos tradicionales, aunque se llamen de izquierda, tienen esos estilos muy tradicionales, y que son los que se entienden, son las denominadas cúpulas, con un proceso muy pobre de democratización a lo interno, y exigen a lo externo la democracia, pero a lo interno aún hay rigidez, te recuerdo, hay una clasificación de los partidos políticos de Duverger, ¿verdad?, ¿ha tenido usted la oportunidad de verlo?, si no, se lo recomiendo, tiene una clasificación excelente, uno de ellos, sobre los partidos políticos, y eran los partidos rígidos, que aún son los clásicos, dice, en América Latina, nosotros estamos aquí frente a partidos rígidos.

\section{R: ¿En cuanto a la conformación del liderazgo?}

R.E.: A la conformación del liderazgo, sí, una rigidez y un celo enorme, verdad, por tener el poder, en un trabajo que yo a mis estudiantes siempre les dejo es El príncipe, y les dejo El espíritu de las leyes, una alumna que, por cierto, es una mujer de muy buenas luces, ella muy talentosa, dice que concluyó que Maquiavelo lo que quiso decir es que lo inmoral en la política, lo único inmoral en la política, es perder el poder, es probable que sea la fórmula de vida, ¿verdad?, todavía para dirigentes, tener el poder y caer en la inmoralidad de la política, que es lo único moral, fíjese que eso, aún tenemos unas enormes limitaciones, ¿verdad?, y a lo largo de la historia es difícil encontrarte alguna vez se hable de alguna institucionalidad o respeto a la institucionalidad, cuando se dice retorno a la democracia, yo me pregunto, pero retornar ¿a qué democracia?, si no hemos, realmente, ningún comportamiento democrático, se han hecho esfuerzos, yo creo que el mismo triunfo de la revolución del 79 fue un intento muy hermoso de dar los primeros pasos en una sociedad democrática, pero, a veces, me da la impresión que tenemos retrocesos e incluso hay una tentación de un retorno al pasado, que lo ponía en la Constitución, en el que se renuncia a cualquier sistema anti-democrático. Yo participé en las reformas, ¿verdad?, en las del 2000, en el pacto, en el primer pacto de Arnoldo 
Alemán y Daniel Ortega, ¿ya?, obviamente, el espíritu de las reformas es, como le digo, por un lado, Arnoldo Alemán, y hablando de algunas interioridades políticas, quería cuidarse de que se le garantizara la gobernabilidad por parte del dirigente del Frente, experto en asonadas $\mathrm{y}$ en paralizar el país, obviamente, no garantizaba una gobernabilidad del proyecto liberal, entonces, Arnoldo Alemán vio ahí la oportunidad de garantizarse llegando a un acuerdo político, pero lo que le quiero decir es que no es nada novedoso, en Nicaragua desde 1940 hubo tres o cuatro pactos muy interesantes en los que siempre la oposición iba consiguiendo más espacios políticos que en los pactos pasados, tal vez, en momentos históricos, el Partido Conservador es el que hacía el papel de partido opositor acá, y en cada pacto conseguía integrarse más dizque a la institucionalidad del Estado, primero diputados, luego senadores, luego jueces y Magistrados en las Cortes, luego cargos en las juntas directivas en los entes gubernamentales, y así fue obteniendo, y llegó un momento hasta que participa en una Junta de Gobierno, en la cual había representantes del Partido Liberal Nacionalista de Somoza y había un representante del Partido Conservador, llegó hasta ser miembro de la Junta de Gobierno, es decir, en cada pacto el espacio político del sector, conocido como minoritario, iba aprovechando más, la gran diferencia que esos pactos, y se lo quiero decir yo, eran consultados con la embajada de los Estados Unidos, ellos iban con la complacencia, esta vez, y ese fue el error del doctor Alemán, que no se lo perdonan los Estados Unidos, yo se lo puedo garantizar, y aprovecharon también las debilidades del doctor Alemán con la famosa posición en la Huaca, lo que usted ya conoce, ¿no?, en buena parte es que los Estados Unidos no perdonan que él nunca consultó el pacto con los Estados Unidos, el pacto con el Frente, jamás se lo perdonan, porque además ellos considerar que ese pacto le dio mucho más espacio al Frente, y el Frente otra vez, bueno, siempre, de una manera o de otra, ha estado en el poder, aún en la misma oposición al Frente Sandinista hay que reconocerle una habilidad extraordinaria ante una clase política, muy, muy débil, muy dividida, en donde todos quieren ser Michael Jackson o Madonna, no es que dentro de unos pocos días se haya convertido en eso.

R: No, si, digamos, que la preponderancia o la capacidad de Ortega para convertirse en el socio mayoritario del pacto en detrimento de Alemán, pero aún los críticos del pacto me dicen que el pacto existe y es como una suerte de procedimiento.

R.E.: Yo lo que le quisiera decir, y yo estoy de acuerdo, es que el pacto en este país es a cada momento, estoy de acuerdo, el pacto no es solamente cuando se reúnen y deciden reformar la Constitución o la Ley Electoral, sino que se profundiza más, yo entiendo.

\section{R: Va a gravitar además sobre la evolución constitucional.}

R.E.: Pero yo creo que el tema de la reelección es un tema que se les fue de las manos, creo o considero, al doctor Alemán, porque era su mejor carta para pedirle más al presidente Ortega, "dame más y yo te voy a dar la reelección”, yo sé que a él le sorprendió, no se hizo el sorprendido, cuando la famosa sentencia 504, ¿verdad?, que se le fue de sus manos una carta, claro que el doctor Alemán es un hombre de oportunidades tremendas, él algún provecho, alguna oportunidad, tiene que sacar de esto, tan es así que usted lo ve en la televisión y va a manifestarse solo como partido, que no es una figura apartidaria con la sociedad civil, fíjese bien, él teme que la sociedad civil pretenda sustituir a los partidos, y muy hábilmente él está hablando de que ellos van con sus banderas del PLC, que van a poner tanta gente, es decir, está luchando porque no se pierda la identidad partidaria con la sociedad civil, pero bueno, 
son comentarios míos, ¿verdad?, no son académicos, es lo que yo considero, pues, tiene temor, es un hombre muy hábil, indiscutiblemente, que es muy hábil.

R: Y el asunto aqui es que si no se propone un candidato único presidencial por parte del liberalismo, y ahí el doctor Alemán puede ser un obstáculo, porque además es el lider indiscutible del PLC, es un hombre que supo articular bien a su partido y darle la fuerza que no tuvo Doña Violeta frente a su bancada, bueno, la coalición gubernamental que la dejó sola en el poder.

R.E.: O Don Enrique, que nunca tuvo partido político.

R: Exactamente, hay una comparación entre los cuatro presidentes que ha tenido Nicaragua.

R.E.: Si usted se da cuenta, es una clase muy interesante nuestra clase política, para mí el 25 de febrero en 1990, cuando el Frente Sandinista pierde las elecciones fue un hito como pudo haber sido la caída del Muro de Berlín, a partir de esas elecciones, si usted se da cuenta, se desmantela el $\mathrm{FMLN}^{34}$, se desmantela Guatemala, y comienza un desmoronamiento de las opciones armadas en América Latina, y nuestra clase política ha sido incapaz de que esas fechas fueran anotadas como unas fechas conmemorativas y expresarse, fíjese bien en ese fenómeno, para mí, pues, el 25 de febrero debe de ser un patrimonio de un sector importante de la sociedad nicaragüense, porque yo creo que, visto con mucha seriedad y serenidad, fue una opción interesantísima del pueblo de Nicaragua, "esta opción, ya no nos apuntamos por ella".

\section{R: Votar por la paz.}

R.E.: Exacto, y el Frente, pues, haber aceptado los resultados que fueron brillantes, en este caso, el General Humberto Ortega, que es un estratega de primer orden, fue el primero que pensó muy bien y él presiona al aparato del Frente para que acepte el resultado de las elecciones, porque él ve que aceptarlo era tener oxígeno, al menos tenían 38 diputados en la Asamblea Nacional, al no aceptarlo, ¿usted sabe lo que significaba?, yo trabajaba, era el encargado del centro de recepciones, yo era el director de la logística para el 90, y los primeros mensajes de reconocimiento vienen del Kremlin, y muy efusivos, reconociendo a Doña Violeta, pero como diciendo: "salimos de esto", mucho más expresivo que la Casa Blanca, la Casa Blanca fue más lacónica, más sobria, sin embargo, los mensajes del Kremlin fueron mucho más efusivos, ¿qué les querían decir ahí?, "hemos salido de esto, ya no podemos seguir manteniendo".

R: Y ahora hay otro factor externo que es Chávez, es otro ciclo de América Latina, este socialismo del siglo XXI, donde hay nuevos líderes, porque Chávez, Correa,...

R.E.: Pero usted sabe la historia más o menos de Venezuela, ¿verdad?, Venezuela en los 30 años anteriores a Chávez el Estado era un Estado botín compartido por COPEI y ADECO, corruptos, corruptos, corruptos, fueron caldo de cultivo para Chávez, a veces aquí se culpa, verdad, Chávez, Chávez no es culpable, él es producto de una necesidad popular, de un proyecto populista, como lo llamemos, después de 30 años, y nadie duda de que eran elecciones democráticas, cada 4 o 5 años subía un ADECO, subía un

34 Corresponde a las siglas de la guerrilla salvadoreña: el Frente Farabundo Martí de Liberación Nacional. 
COPEI, pero hicieron lo que quisieron con Venezuela, hacían su vida estas figuras, que se llaman mesiánicas, ¿verdad?, un Evo Morales en Bolivia, o Correo en Ecuador, que a veces yo los veo, por ejemplo, en el caso de Correa, también los Estados Unidos se asustan con estos proyectos que dicen ser nacionalistas, creo yo, porque además operan con mucha lógica, para mí es lógico lo de Correa en Ecuador cuando dice: "vamos a revisar la Ayuda Externa, pero vamos a saber para qué se utilizó, quién prestó y para qué se hizo ese préstamo", tiene sentido común, ¿verdad?, que en eso los gringos, a veces, el sentido común no les va muy bien, ese es el otro aspecto que hay que analizar, verdad, estos fenómenos de estos gobiernos en América Latina.

R: Sin embargo, Ortega es un líder de la vieja guardia, o sea, es un hombre que viene de los 80, y que no es que se reinvente a si mismo, porque, realmente, es un hombre diferente, como todos cambiamos a lo largo de la vida, pero sí es cierto que esta conmemoración: "A treinta años de la Revolución", este tratar de resucitar un proyecto político que tuvo su etapa y que, en el contexto actual democrático, pues, como que chirría un poco, ¿no?, me refiero a algunas cuestiones como los $C P C$, que son estructuras paralelas del Ejecutivo, y toda esta situación de dificultad de la sociedad civil para dejar que se manifieste, la cuestión de las turbas, que es casi como un reiniciar a parte de la juventud nicaragüense, que ya había tenido otra opción gracias al trabajo de las ONG, para que nuevamente se vuelva a fomentar un clima de violencia, estos ciclos históricos que regresan en Nicaragua son muy peligrosos.

R.E.: El Frente tiene una particularidad, es un partido que se caracteriza por vivir en la anormalidad, porque nació en la anormalidad, $\mathrm{y}$, de pronto, como usted lo ponga en un escenario muy normal, como que las cosas no funcionan, y además la experiencia es llegar al borde del precipicio, porque vamos a llegar al borde del precipicio, y cuando vemos el borde del precipicio las cosas empiezan a volver a equilibrarse, pero estamos llegando, lo del sábado es muy peligroso, al menos, la mente de las personas anda con una psicosis que nos podemos morir, pero eso le pasa al Frente también.

R: Y otra cuestión es la práctica del olvido, yo he tenido oportunidad de entrevistar a muchas personas, y cuando hablé con el Magistrado Rafael Solís me decía...

R.E.: Es brillante, brillante, amigo de toda una vida, sí, sí, yo lo estimo mucho, es brillante, y como le digo yo: "aunque no tengás razón sos brillante".

R: Sí, es una persona muy amable, yo diría, pero aparte de eso, sí hay que significar la sentencia como una cuestión, realmente, preocupante, ¿no?, por la involución que supone en el respeto al principio de seguridad jurídica en este país, y sobre todo por el conflicto que inaugura entre el Poder Judicial y la Asamblea.

R.E.: Claro, yo estoy claro con usted, yo aquí, si me preguntan mi opinión, digo que debería habérsela jugado el presidente Ortega al todo por el todo en la Asamblea.

R: Pero es que ahí no iban a conseguirlo, y ese es el reconocimiento del propio Magistrado.

R.E.: Pero yo creo que también hay otra cosa que debe haber pensado Rafael Solís, a quien conozco muy bien, y es que llevarlo a la Asamblea, bueno, es mucho desgaste, al final Arnoldo no garantizaba mucho con sus miembros de partido, diputados, y lo otro 
el "cañoneo" que esto hubiera significado, desgraciadamente, algunos diputados no soportan un "cañoneo", ¿verdad?

R: “Cañoneo”, ¿qué significa?

R.E.: "Cañoneo" es dar dinero, que ya a habido aquí prácticas en particular, entonces, seguramente lo pensaron y se dieron cuenta que lo más económico era reunir a seis de los míos, a mis Magistrados, y se va a por la sentencia, ahora mi miedo es que todo lo quieren resolver con la sentencia.

\section{R: ¿Que gobiernen los jueces?}

R.E.: En febrero va a venir aquí una parálisis, nuevos Magistrados, usted sabe, hay una gran cantidad de cargos a ocupar que tiene que ser junto con la Asamblea, y alguien recurre de amparo, diciendo que la Asamblea me agravia, porque no tiene capacidad para integrar órganos que están paralizados, y, entonces, se alían con un pacto, se hace, y continúan los que están en el cargo, y fue lo que tomó, y pretendemos resolverlo todo por esa vía y se acabó.

R: No, es que esta perversión de la función constitucional de los órganos del Estado puede llevar a abrir una especie de democracia de mentira, ¿no?, y un sistema político de mentira, y una Constitución que ya ha sido muy dañada, en cuanto al respeto a la norma constitucional y al reconocimiento del valor normativo que tiene, entonces, ya si hay una tentación extra-institucional fuerte en los actores politicos, que además han sido partícipes de una guerra, y lo digo también porque mi país sufrió una guerra, y los actores políticos debieron reconciliarse y tuvieron que pactar, y tuvieron que negociar y aprender a cerrar las heridas, ¿no?, sobre todo las heridas de la ciudadanía y la memoria histórica de un pueblo. Entonces, cuando el Magistrado me decía: "esto de la sentencia pasará”, yo pensaba, "pero, ¿cómo puede ser esto?”, no sé, yo me asombraba como se asombran muchos ciudadanos de este país, ¿no?, y mucha gente joven sobre todo, que se ve repitiendo la historia, o sea, viviendo lo que vivieron sus padres y lo que vivieron sus abuelos. ¿Cómo ve usted todo esto?

R.E.: Y es tan así que han buscado hasta una fecha oportuna, en vísperas de las fiestas navideñas, por eso mismo, porque en las fiestas de Navidad olvidan la sentencia 504, es muy posible que hasta la fecha se haya buscado a propósito, no dejarla para después de diciembre, pero, como te decía, pues, no tenemos memoria histórica, muy poco se conoce de nuestra historia, ¿verdad?

$R: Y$, sin embargo, es una historia con la presencia de situaciones de conflicto muy fuertes.

R.E.: Sí, enormes, el tema de la reelección ha sido causa en más de dos ocasiones de guerra civiles, es un tema altamente peligroso.

$R$ : Y otra cuestión es la de que el fraude electoral y la reelección presidencial siempre han ido unidas, ¿qué piensa usted a propósito?

R.E.: Así es, sí, sí. 
R: Porque, si bien, el Consejo Supremo Electoral ha sido una institución que ha gozado de mucho prestigio durante, digamos, los primeros 10 o 15 años, yo he hablado con gente de IPADE, en fin, gente que trabaja, en términos más o menos objetivos, sobre la consolidación de las instituciones democráticas en este país, y los comicios se habian producido siempre con total normalidad.

R.E.: Sí, sí, de acuerdo a los estándares internacionales.

R: Exactamente, y sin ninguna crítica importante, sin embargo, el año pasado se produce una situación insólita, ¿no?, el fraude municipal del 2008.

R.E.: Y fijese, tan insólita que, tuve una experiencia amarga, le cuento esto porque creo yo que es un testimonio que le puede interesar, hace un año o un año y medio, usted ha oído que en Nicaragua hay unos trabajadores que fueron dañados por un pesticida que se llama el "Nemagón", que están acampados frente a la Asamblea Nacional, les han producido un enorme daño, años andan de estar demandándole a las empresas, son varias multinacionales, entonces, a mí un abogado amigo, como sabe que más o menos he trabajado en esto del Estado, me pidió un trabajo sobre la institucionalidad del Estado, y sobre todo del Poder Judicial, para reforzar la sentencia de una juez que le mandó pagar a estas empresas la indemnización, pero había que ejecutarlo en Estados Unidos por ahí, porque es el domicilio de esas empresas, ¿verdad?, al año exacto estoy citado por el juez de la Florida, que debía ir, yo siempre entendí que no iba como testigo calificado ni como parte, sino que era para verificar que yo existo y testificar si yo dije eso, como efectivamente lo es, pero lo que le quiero decir es que a mí me tomó tres horas y veinte minutos mi comparecencia, había cerca de veinticinco abogados de los que eran clientes de las empresas, de la Shell, de la Doll, y cinco por la parte nicaragüense, una firma de abogados norteamericanos, que llevaban el asunto por los trabajadores, ¿verdad?, que es un caso que chorrea sangre, eso es espantoso, el drama de esa gente, entonces, gran parte de las preguntas de la parte demandada, de la Doll, de los abogados, fue sobre el fraude, claro, yo digo en mi hoja de vida que yo trabajo aquí, que soy secretario, "y usted firmó el fraude", y el defensor mío fue el juez, el abogado de la parte demandante dice: "objeción", "objeción aceptada", dice el juez, yo le digo el informe del perito, porque yo iba como perito, dijo el juez: "y él expresa en su hoja de vida, que era el secretario del Consejo Supremo Electoral, y que, por razón de su cargo, certifica lo que resuelva, no le corresponde a él valorar si es bueno o malo lo que se resolvió, sino que los partidos políticos son los que utilizarán los remedios para restaurar sus derechos, pues, si se sienten lesionados, y no tiene nada que ver con la presente causa". Le quiero decir que hasta donde trascendió, ¿verdad?, y, entonces, yo aparezco ahí en una gran pantalla firmando, claro, con mala intención, porque yo lo que certifico es lo que resuelve, yo no resuelvo, mi cargo no conlleva jurisdicción, ¿verdad?, y yo he tenido reclamos de familiares y reclamos serios, y gente, además, un poco agresiva, pasados los primeros días, después de la elección, y eso del trabajo a mi casa, porque tenía temor a reacciones, verdad, yo mismo pasé unos días muy confundido, mal, mal, tengo que aceptar que sí hubo serias irregularidades, yo no estaba acostumbrado a eso, habíamos vivido procesos electorales con sus errores, pero dentro de los estándares internacionales de aceptación, verdad, no como estas irregularidades que se tuvieron que, como profesional, solo quiero decirle que me he sentido mal, muy mal, hasta allá, hasta la Corte Federal de la Florida apareció el asunto, y era para descalificarme como perito, hasta esos niveles, pero menos mal que intervino el juez, y él dijo: "ese es su trabajo, certificar lo que resuelvan, él no puede valorar", dice, "emitir 
juicio de valor sobre si es correcto o no", porque a mí no me corresponde, porque yo también debo saber que soy profesional en mi trabajo, verdad, no puedo de pronto, si me pregunta un Magistrado doy mi opinión, pero no puedo en una sesión decir: "no, aquí hay errores", no, no, "certifique", soy el secretario de actuaciones, tengo que dar fe, si es malo o es bueno, serán los partidos políticos, y hay cosas que algún día yo, algún día voy a hacer un libro sobre todas las elecciones que he vivido e interioridades que son buenas que se sepan, ¿verdad?, fíjese en las elecciones del 90, ¿no?, el presidente Carter se aparece visiblemente descompuesto a la una de la tarde del 25 de febrero a pedir que pararan las elecciones porque la tinta que se usaba para impregnar el dedo era de mala calidad, y que se prestaba al fraude, usted sabe, que llegue el presidente de los Estados Unidos, además, nunca me imaginé, yo fui testigo viviente de ver al presidente de la nación más poderosa descompuesto, Carter llegó totalmente descompuesto a pedir al doctor Mariano Fiallo: "hay que parar el proceso electoral", y el doctor Fiallo, un hombre muy ponderado, decide llamar a los dos jefes de campaña, Antonio Lacayo por la UNO y Bayardo Arce por el Frente, ahora vienen mis comentarios, probablemente, ambos se ponen de acuerdo y dicen que continúe, era la una de la tarde del 25 de febrero, ha votado el grueso de la población, ya a esa hora ha votado el grueso de la población, ya la gente sabe más o menos cómo andan las cosas, imagino que Bayardo Arce debe de haber dicho: "de todos modos vamos a ganar", porque el Frente siempre creyó que iba a ganar, y la UNO dice: "vamos a perder, seguro que vamos a perder, y nos queda como carta denunciar el fraude de que la tinta es mala", supongo yo, que ambos fueron sus pensamientos, no se los comunicaron entre sí, pero sí como estrategia política dice que continúen las elecciones, bueno, y sigue, resulta que yo como era el encargado de logística averiguo que en algunas mesas, sin haber recibido instrucciones en ese particular, utilizaban acetona, que no sé de dónde llegó la acetona, porque aquí se manda lo que se necesita y se aparecen siempre con aditamentos extra, que no sé de dónde consiguen, para limpiar el dedo a la persona impregnarlo de tinta, y se introducía el dedo en un tintero, y a muchos dedos con acetona ya actuaba como disolvente, entonces, ya la tinta en los últimos votantes ya no surtía el mismo efecto, era por el exceso por usar acetona, que nunca se dijo, que se le limpiara el dedo al votante, pero no con acetona, eso es lo que yo descubro después de que casi me da un infarto, y se resuelve, pues, pero a todo esto el representante de Naciones Unidas, que era un señor paquistaní, se me acerca y me dice: "usted sabe que si el doctor Fiallo le hubiese hecho caso al presidente de los Estados Unidos, al presidente Carter", ¿sabe lo que significa que una cadena de televisión que suspende las elecciones a la una de la tarde?, es decir, renuncian a la suma y a la boleta, y todo es imposible, ¿no es cierto?, esas son cosas que yo voy a contar, ya se las adelanto a usted, cosas que he vivido, y así en las continuas elecciones.

\section{R: Pero estas últimas ya representaron un precedente muy grave.}

R.E.: Sí, sí, cosas que matemática y estadísticamente eran imposibles que hubieran sucedido, ¿verdad?, por mi experiencia, sí, yo estoy claro, llegó un momento en que ya no llegaba documentación, "firme esto", pues, firmemos, pero estaba, probablemente, visiblemente descompuesto, pues, porque no debieron de haber sido así las cosas, y menos del Frente, que creo yo que había probado varias derrotas, y había sabido enfrentarlas y seguía con su espacio político, que considero yo.

\section{$R: Y$, sin embargo, ¿cómo ve usted las próximas elecciones presidenciales?}


R.E.: Bueno, si se repite eso en las nacionales quién sabe este país como reaccione...

R: Porque la pérdida de la fe en las elecciones, la pérdida de la confianza en el instrumento de la democracia...

R.E.: En todo, sí, sí, hay algunos que hablan de que hay que cambiar la ley, la ley no es la culpable de un fraude, puedes tener una mejor ley, pero si la voluntad política es defraudar la ley, ¿qué puedes hacer frente a esa voluntad política?

$R: Y$, no obstante, una de las demandas fundamentales es la de recomponer esta institución, hacer una especie de depuración política.

R.E.: Sí, así es, y esa descomposición pasa por los Magistrados y hasta por nosotros mismos, hasta los funcionarios y empleados, eso lo veo, hombre, estará en el Comandante Ortega la capacidad de negociar a sus Magistrados y funcionarios en aras de dar la vitrina o el escaparate para que las elecciones de 2011 vayan a responder a los estándares internacionales, ¿estará dispuesto a jugársela? Bueno, por eso le digo, ¿con qué propósito, verdad? Al menos los chinos hacen barbaridades en el Tibet, hicieron barbaridades en la Plaza de Tiananment, pero los chinos ofrecen mano de obra, y son los mejores clientes, ¿verdad?, de los Estados Unidos, pero nosotros, ¿a cambio de qué hacemos estas cosas?, ¿interesamos o no a los Estados Unidos en este momento?

R: Bueno, la Unión Europea ya se negó a prestar su colaboración, en términos de cooperación al desarrollo de un país que no respeta las reglas democráticas. Y ya para terminar...

R.E.: A lo mejor hablé más de otras cosas de las que a usted le interesaban.

R: No, no, al contrario, han sido cuestiones muy interesantes, pero mi última pregunta se refiere, fundamentalmente, al futuro, si, como decía, las reformas del 95 tratan de desconcentrar el poder del Ejecutivo, actualmente, vivimos una concentración de manos del Frente, el Poder Judicial, el Poder Electoral, la propia Asamblea, el Ejecutivo fortalecido, ¿no?, ¿cuál es su visión sobre el futuro a mediano plazo?

R.E.: Es una pregunta complicada, sí, parece como que no hubiese muchas expectativas o muchas esperanzas de enderezar un poco el camino hacia verdaderos procesos democráticos, esa es la impresión que a mí me da.

R. ¿Y qué papel cumple la Constitución en este contexto, es decir, esta práctica de la reforma constitucional?

R.E.: En mis clases de Derecho Constitucional con mis alumnos más bien lo veo como alumnos defraudados, es decir, en la última sentencia, la 504, no he terminado de sentarme en mi escritorio de la Universidad y es lo primero que me preguntan, ¿es constitucional o no la sentencia 504?, ¿es una pregunta, únicamente, académica o, en realidad, sale del alma y sale de personas que se sienten frustradas?, entonces, ¿lo que usted me pregunta cómo hago yo para contestárselo?, también así, como tener una visión muy negativa y pesimista del país, de la nación, no considero que sea sano.

R: Pues no, porque es el principio de la resignación. 
R.E.: Sí, y además de eso, como dice una amiga mía, y no se trata, me dice, de que compongamos esto para que las generaciones venideras lo gocen, también nosotros tenemos derecho, por supuesto, a gozar de un buen presente, no se trata únicamente de dejar un futuro, sino nosotros mismos, ¿qué responsabilidad tenemos?, ahí dentro del Frente hay gente sensata y ponderada pero el sistema de miedos y esas cosas hacen que no se oigan voces de personas con mucha autoridad moral, es difícil darle nombres, tal vez, en este momento, pero hay, hay, hay, no tienen cargos de convención partidaria ni del Estado, pero sí es gente que ha sido revestida de una autoridad moral en la lucha contra Somoza, y que se distinguieron en la lucha del sandinismo, y en el primer gobierno, pues, de los años 79 y 80, para mí es muy desalentador que el propio personal que trabaja conmigo se tenga que ir a la una de la tarde a las rotondas para defender al partido del gobierno, y menos de este gobierno, así nunca van a tener militantes, del partido que sea, este órgano no debe participar en eso, el que sea, el partido que sea.

\section{R. ¿Y esto no había sucedido antes?}

R.E.: Jamás, ni en la época de oro, ¿por qué ahora?, me confunde, en la época de oro del sandinismo, en la época del sandinismo era todo lo contrario, las instrucciones partidarias era no hacer vida partidaria, que su rol era la institucionalidad dentro del Consejo del Poder Electoral, y estamos hablando de los mismos actores políticos, de Daniel Ortega, ¿qué pasa ahora? Un amigo mío ha llegado a prever, es una barbaridad lo que dice, "yo creo que estamos haciendo", dice, "un somocismo científico".

R: ¿A qué se refiere exactamente? A copiar una fórmula...

R.E.: Sí, somocista, no más que de una manera científica, pues, más organizada, más ordenada, pero el ideal es casi igual: las fuerzas de choque, todo, todo lo que se utilizaba, y contra lo cual se luchó, es inconcebible, pues, el respeto al empleado público, no manipularlo, y pasan lista y toda la cosa, y la gente aquí se siente presionada.

R: Pues si tiene algo más que añadir, yo creo que hemos hablado de muchas cosas...

R.E.: Bueno, desearle éxito a usted en su trabajo. 
ENTREVISTA 22 ${ }^{35}$ :

Nombre del entrevistado: D. José Figueroa.

Cargo actual: Diputado del Frente Sandinista de Liberación Nacional en la Asamblea Nacional (2007-2011).

Fecha de realización de la entrevista: Managua, 24 de octubre de 2009.

Lugar: Oficina privada del Sr. Figueroa en Managua.

Duración estimada: 1 hora y 11 minutos.

\section{TEXTO - Transcripción 22:}

R: ¿Cuál es su visión sobre los recientes procesos de cambio constitucional experimentados en Nicaragua?

J.F.: Mira, en 1987 se aprobó la actual Constitución que está en vigencia, porque vos sabés que en 1979, con el triunfo de la revolución, la Constitución que nos regía hasta esa fecha, prácticamente, dejó de existir, se construyeron nuevas instituciones, un nuevo Ejército, una nueva Policía, un nuevo Estado, entonces, la revolución aquí tuvo esa característica, que terminó con toda la presencia del somocismo aquí en Nicaragua. En esa Constitución, quedaron establecidos derechos fundamentales del pueblo, por ejemplo, los más elementales, pues, a la libertad, a la organización, a tener una vivienda digna, a salud gratuita, a educación gratuita, y también a los derechos políticos entre otros, ¿no?, en los derechos políticos quedó el derecho a elegir y ser electo, quedó el derecho irrenunciable del pueblo a la soberanía, al ejercicio de la soberanía popular, es decir, a elegir sin cortapisas, ¿no?, en 1995, estando en el gobierno Doña Violeta Barrios de Chamorro, había un yerno de ella, que era el presidente en funciones, pero como se había peleado en la alianza, que los que llevaron al gobierno a Doña Violeta se habían distanciado de ella, este yerno de Doña Violeta, que se llamaba Antonio Lacayo, verdad, tenía aspiraciones a postularse como presidente de Nicaragua, entonces, esta alianza, que, inicialmente, apoyó a Doña Violeta y que después se distanció de ella, para castigar a este ciudadano y como a ocho o nueve alcaldes que eran parte del grupo que apoyaba a Antonio Lacayo, hicieron, promovieron una reforma constitucional donde los diputados que reformaron esa Constitución se dejaron ellos con el derecho de poder postularse a cargos de reelección, o sea, si tenían un cargo poder aspirar a otra postulación, y que como estaba en la Constitución del 87, que a final de cuentas, el pueblo elige, premia si tenés un buen desempeño y castiga si tenés un mal desempeño, entonces, inhibieron y dejaron en la reforma constitucional que el presidente y vicepresidente de la República no podía postularse nuevamente para un período en el cargo que desempeñaba, ni tampoco los alcaldes, vice-alcaldes y concejales, pero sí los diputados, ¿eh?, entonces, ¿qué es lo que ocurrió con esta sentencia de la Corte Suprema? Hubo un recurso de amparo de 109 alcaldes, del presidente y del vicepresidente al Consejo Supremo Electoral pidiéndole que les declarara aptos para poder postularse, y que, a final de cuentas, o sea, restituirles el derecho político, que existía, originalmente, en la Constitución, entonces, el Consejo Supremo Electoral les dijo, les planteó que no estaba en su competencia si no había una interpretación de la Corte o una reforma constitucional de la Asamblea Nacional, entonces, lo remitió a la Corte Suprema de Justicia, a la Sala Constitucional, el recurso este de amparo, entonces, este

35 Entrevista de sesgo político fuerte, con especial interés en las posiciones del Frente Sandinista respecto a las reformas constitucionales experimentadas en Nicaragua durante el período democrático reciente (1990-2009). 
recurso fue interpuesto en el Tribunal de Apelaciones de Managua, verdad, y luego, para la convocatoria de la Sala de lo Constitucional había un Magistrado, que estaba creo que en Grecia, y los otros, el resto, todos estaban aquí, fueron convocados para conocer de esta situación y dos de ellos de tendencia liberal no se presentaron, fueron acreditados dos suplentes, la Sala Constitucional de la Corte conoce el caso y emite una sentencia que, básicamente, consiste en los siguiente: primero, restituye el derecho a la soberanía, al ejercicio de la soberanía popular para elegir libremente. ¿Qué significa eso?, que el pueblo de Nicaragua tiene el derecho irrenunciable a elegir a cualquier ciudadano sea éste presidente, vice-presidente, Diputado, Alcalde, de forma libre, verdad, sin ninguna cortapisa, verdad, como se la pusieron en el 95, y ese es un primer elemento de la sentencia. Un segundo elemento, se pronuncia la Corte sobre la igualdad de la ley, porque no puede ser que unos ciudadanos, en este caso, los diputados, tuviesen el derecho político de postularse a un segundo período, por ejemplo, cuando se van, y que otros ciudadanos, verdad, los que son alcaldes, vice-alcaldes, concejales, presidente y vice-presidente de la República no pudiesen hacerlo, es decir, no podemos hacer esas distinciones en la ley y menos en la Constitución de la República, verdad, entonces, la Corte se pronuncia sobre esto, sobre la restitución de este derecho para subsanar una contradicción que había en ese sentido, y hay un tercer elemento, que se pronuncia la Corte, que es sobre el derecho político también, o el derecho ciudadano de elegir y ser electo, verdad, es decir, que el de elegir está implícito en lo primero que te explicaba, pero el de ser electo todo ciudadano aquí en Nicaragua de acuerdo con la Constitución tiene el derecho de postularse para ser electo en un cargo de elección popular, entonces, sobre esos tres elementos se pronuncia la Corte Suprema de Justicia en esa sentencia y lo notifica al Consejo Supremo Electoral, que le restituye el derecho a estos ciudadanos, presidente, vice-presidente, alcaldes, vice-alcaldes y concejales, a poder optar a un segundo período si así lo decidieran y que el pueblo decida libremente si lo premian por su buen desempeño o lo castigan, porque aquí ha habido, en la historia nuestra ha habido varios casos de esos, es decir, que antes de que le pusieran el candado este en el 95, hubo casos aquí, por ejemplo, cuando se produjo la guerra, o sea, el desgaste, el cansancio, todo eso, cuando corrió Daniel Ortega en 1990 le ganó las elecciones Doña Violeta, porque el pueblo consideró que con un gobierno así íbamos a seguir en guerra, que no se qué, que no se cuanto, y no lo eligió, verdad, igual ocurrió con unos cuantos diputados, que se postularon para cargos de reelección en el 90 y que no fueron electos, o sea, que, en otras palabras, no se está planteando con esta sentencia que se vuelvan a reelegir, sino lo que está planteándose con esta sentencia es que se restituye el derecho político de estos ciudadanos, en estos distintos cargos de elección popular a poder aspirar a postularse, nuevamente, a cargos de elección popular aún habiéndose vencido su período. No sé si queda claro, ¿no?

R: Sí, sí, es el argumento que justifica, en ese sentido, la apertura a la reforma constitucional de la cláusula de la reelección.

\section{J.F.: Es el artículo 147, si mal no recuerdo.}

R: Sin embargo, si habría que diferenciar también a los cargos del Ejecutivo y los del Legislativo, es decir, los legisladores, que pueden ser reelegidos en la Asamblea tienen una función distinta de la de ejercer la acción de gobierno, ¿no? La idea de la reelección presidencial no es mala en sí misma, además, incluso, permite completar el programa de gobierno a cualquier presidente cuando tiene un buen desempeño, pero, yo creo, que en muchas de las constituciones de América Latina, incluso, en Estados 
Unidos también está limitada, que es el modelo, digamos, presidencial, que toman la mayor parte de las repúblicas latinoamericanas cuando diseñan sus constituciones en el período de independencia, cuando toman la Constitución de Filadelfia como el modelo que inspira gran parte del constitucionalismo latinoamericano, en general, y Nicaragua no es tampoco la excepción, al margen de que tenga su historia constitucional propia y original, ¿no? Pero sí es cierto que se restringe esa cláusula de la reelección presidencial para evitar una excesiva concentración de poder o la figura de regímenes autoritarios que han hecho peligrar, en muchas ocasiones, las democracias presidenciales de América Latina, y tenemos ejemplos en cualquiera de los países del área. También hay una tendencia, hay un factor externo, porque la reelección presidencial también se ha planteado en el caso de Venezuela, de Ecuador, también de Bolivia, y, recientemente, el presidente Uribe en Colombia desde el espectro de la derecha...

J.F.: Y Costa Rica, Óscar Arias, Óscar Arias y, exactamente, un procedimiento parecido al que hubo aquí. La Sala Constitucional de la Corte Suprema de Costa Rica, había una inhibición que la declararon inconstitucional y Óscar Arias se postuló nuevamente, y mayoritariamente ganó las elecciones en Costa Rica.

R: Pero sí es cierto que el artículo 10 de la Constitución costarricense sí concede competencias a un órgano, que, en este caso, es la Sala de lo Constitucional de la Corte Suprema, sí tiene competencias para realizar...

J.F.: Bueno aquí la Ley de Amparo le da facultades también.

R: ¿A la Sala de lo Constitucional?

J.F.: Claro que sí.

\section{R: ¿Para hacer una revisión de la Constitución?}

J.F.: Una interpretación, para hacer una revisión y para pronunciarse, para corregir problemas de, ¿cómo es que dice la ley?, no recuerdo exactamente, o sea, la Ley de Amparo le permite a la Sala Constitucional, yo no soy abogado, soy Ingeniero Civil, pero le permite subsanar problemas de interpretación o errores o contradicciones de este tipo en la Ley y, bueno, además en la Constitución, porque es la Sala Constitucional, que es la que se ocupa de estos temas, ¿ya?

R: Pero, la reinterpretación de un artículo de la Constitución, que, en este caso, es el que afecta a la reelección presidencial es en sí la reforma de un artículo.

J.F.: Bueno, peso ese es el debate.

R: A mí si me preocupa como investigadora, y es una pregunta, el hecho de que se haya conferido el poder de revisión de la Constitución, de reforma constitucional, del Legislativo, de la Asamblea, que es quien, legítimamente, tiene el poder de reformar la Constitución, ya sea a través de una reforma parcial, como ha ocurrido en las ocasiones anteriores desde el 95 al 2005, o bien a través de una reforma total, que implicaría la convocatoria de elecciones constituyentes, la configuración de una nueva 
Asamblea y la redacción de un texto distinto del actual, una nueva Constitución. Pero aqui es el Poder Judicial el que tiene la capacidad para reformar la Constitución.

J.F.: Además no es la primera ocasión que se hace.

R: ¿En Nicaragua?

J.F.: Sí.

$R:$ ¿Y qué otros ejemplos existen?

J.F.: Mira, anteriormente, había, cuando asumió el poder Doña Violeta Barrios de Chamorro hubo como 5 o 6 leyes, una de ellas era muy importante, que era la de las autonomías de las universidades del país, o sea, en el período de transición se produjo eso, entonces, el gobierno, o sea, en este caso, Doña Violeta Barrios de Chamorro recurrió de amparo para que la Corte Suprema de Justicia declarara nulas las actuaciones que había realizado la Asamblea Nacional en la aprobación de estas leyes, y el procedimiento, entonces, la Corte lo conoció, y dejó sin efectos todo lo, ese es un caso de la anulación de leyes, entonces, te voy a poner cuatro casos de ejemplos de inhibiciones que tenían candidatos presidenciales por este mismo artículo en la Constitución de la República. Mira uno de ellos fue José Antonio Alvarado, que es del Partido Liberal Constitucionalista (PLC), otro fue un apellido, uno que fue presidente de la Asamblea Nacional que se llama, me voy a acordar del nombre, Cairo Manuel López, son cuatro casos, entonces, este artículo 147 les inhibía a estos 4 ciudadanos de postularse, porque ellos eran diputados, si mal no recuerdo, todavía, entonces, recurrieron de amparo y la Corte Suprema de Justicia, la Sala Constitucional les restituyó el derecho y los avaló para que se inscribieran, nuevamente, como candidatos y corrieran como candidatos en unas elecciones, esos son 4 casos de nicaragüenses.

$R$ : ¿Y eso aparece registrado en la propia jurisprudencia de la Corte Suprema como sentencias firmes?

J.F.: Seguro que están esas sentencias en la Corte, eso habría que investigar allí en la Secretaría de la Corte cuáles son esos casos, pero sucedieron. Luego, aquí en Colombia, no conozco cómo fue el caso, no conozco la interpretación que hace la Sala de lo Constitucional en el caso de Colombia. Uribe dos veces lo ha hecho.

\section{R: Bueno el caso colombiano no lo conozco específicamente.}

J.F.: Pero, bueno, aquí luego hay otro caso que te voy a explicar, que se dio a inicios del año pasado, esto nada más que no se trata de, no sí tiene que ver con el punto este, mira, en el año 2007 cuando asume este gobierno, basado en el artículo 2 de la Constitución, que es la soberanía popular, verdad, el nuevo gobierno que preside Daniel Ortega saca un decreto, o emite un decreto, donde como el gobierno quiere ser diferente con relación al gobierno anterior, un enfoque donde se enfatiza la participación directa de la gente en la toma de decisiones en la gestión pública, en la gestión pública o en la gestión estatal, y conforma lo que son los Consejos del Poder Ciudadano en el territorio, en los municipios, en los departamentos del país, verdad, entonces, en la Asamblea Nacional hay una reacción de los diputados de la oposición, que dicen que, bueno, que eso no lo puede hacer el Ejecutivo, que eso es facultad del Legislativo, verdad, y que el artículo 2 
no le permite eso, y el presidente dice: "hombre, yo el presidente del gobierno quiero hacer participar a la gente, me parece que este esquema participativo que va más allá del esquema tradicional me puede permitir a mí gobernar mejor tomando en cuenta los criterios de la gente, etc., etc.", y entonces, viene la Asamblea Nacional cuando se iban a discutir varias reformas a la Ley de Organización del Poder Ejecutivo, la parte esta que se refiere a la formación de los Consejos del Poder Ciudadano la rechazan, verdad, no lo aprueban, y, entonces, el presidente acude a la Corte Suprema de Justicia, y dice que es inconstitucional, no permitiendo la participación del pueblo cuando en el artículo 2 de la Constitución se establece eso, entonces, la Sala Constitucional redactó una sentencia, que le da lugar a este reclamo que hacía el presidente de la República, pero luego estableció un procedimiento ahí mismo para evitar los conflictos de poderes, verdad, o sea, que se basa en la interpretación de este artículo 2, basándose en la interpretación del artículo 2 de la Constitución le da lugar a un reclamo del presidente de la República, y la Asamblea Nacional lo tuvo que aceptar. Eso otro también está en la jurisprudencia que habría que revisar, eso fue en enero del 2008.

$R$ : De todos modos, ha habido siempre desde el año 95, que constituye la gran reforma constitucional necesaria para conferir un nuevo marco jurídico a la democracia nicaragüense, que nace en el año 90 después de la firma de los Acuerdos de Paz. El hilo conductor fue el de aumentar las facultades de la Asamblea...

J.F.: Bueno, la democracia nicaragüense te corrijo no nació en el 90, nació en el 79, tras una dictadura que había habido de 50 años aquí, que no permitía las libertades a nadie, y que aquí del 79 para acá la gente tuvo oportunidades de asociarse sindicalmente, de manifestarse, de que hubiese pluripartidismo en las elecciones de 1984, fue la primera elección en la historia de Nicaragua pluripartidista, lo que pasa es que aquí nadie reconoce eso, hablan de la democracia del 90 para acá, pero es falso eso.

R: De todas maneras, aunque sí es cierto, he leido la literatura y la historia politica del país, y las elecciones del 84 además son unas elecciones limpias y legítimas que otorgaron un amplio respaldo al Frente Sandinista.

J.F.: Participaron un montón de partidos políticos por primera vez en la historia, ¿y eso no es democracia?

$R$ : Sí, pero hay una parte de los nicaragüenses que no se sienten reconocidos en el proyecto revolucionario de los 80 .

J.F.: ¡Ah!, pero es que una parte de nosotros no los reconoce a ellos y otra parte que sí, la democracia así es.

R: Ya, pero, de todos modos, sí es cierto que el modelo revolucionario de los 80 no coincide, exactamente, con el actual régimen de democracia pluralista.

J.F.: Sí, pero es que nos hicieron una guerra, una guerra terrible, pues, ¿en qué país vas a poder desarrollar una democracia cuando todos los años el Congreso norteamericano te aprobaban 200 millones de dólares para financiar un ejército contrarrevolucionario, que terminaban puertos, que terminaban escuelas, que terminaban edificios públicos, carreteras, torres de transmisión?, o sea, una guerra brutal, pues, que hubo contra Nicaragua, entonces, en un régimen que se defiende con las uñas y con todo lo que 
tiene, verdad, para poder sobrevivir y para poder defender el proyecto que estábamos impulsando, en esa condiciones hicimos elecciones pluralistas, hubo libertad, hubo economía mixta, o sea, que dentro de las posibilidades que permitía la defensa de la revolución hubo democracia más que en muchos otros países de América Latina, lo que pasa es que eso no lo reconocen los medios, ni mucha gente que escribe de estos temas de la historia, verdad.

R: No, pero, sí es, ciertamente, polémico calificar como un régimen democrático liberal al uso el régimen revolucionario con todos los aciertos que tuvo, y por ser unos de los momentos de inflexión en la historia de este país sobre todo al romper con la dictadura somocista, que venía gobernando el país desde hacía más de 5 décadas. Sí hay un respaldo popular importante a la revolución en los primeros años, ¿no?, y la composición mayoritaria de la Asamblea Constituyente, que dio lugar a la Constitución del 87, con más de sesenta diputados sandinistas lo confirma. Pero ahora estamos en otro momento histórico, y sí es cierto que en el 95, como decía, pues, se trata de aumentar las facultades de la Asamblea Legislativa en detrimento del Ejecutivo, en el 2000 el pacto entre Ortega y Alemán supone también una partidización de las principales instituciones del Estado, con una representación paritaria de los dos principales partidos, en una especie de "bipartidismo institucional", y luego, finalmente, en el 2005, pues, la reforma constitucional, bajo la presidencia de Enrique Bolaños todavía restringe más las facultades del Ejecutivo. Con el gobierno de Ortega se han incrementado los poderes del presidente, porque hay aspectos de la reforma del 2005, que no han sido respetados, como es el caso de la ratificación de los ministros o de los funcionarios, o como pueda ser también este proceso reciente de la reelección presidencial, que, de alguna manera, contempla al Poder Judicial como la salida a la reforma puesto que en la Asamblea no iba a ser posible, no se iban a lograr los acuerdos necesarios para formar la mayoría calificada.

J.F.: Bueno, mencióname un caso de un ministro o de un embajador, uno, que la Asamblea Nacional haya revisado o tenga certificación de que no se haya ratificado, uno.

R: Bueno, es lo que yo leo en los medios.

J.F.: ¡Ah!, no, entonces, no, es que lo está haciendo como una afirmación, ya.

R: Bueno, los medios, el discurso...

J.F.: No, si los medios, si usted lee los medios sin un criterio propio lee cualquier basura aquí en Nicaragua, o sea, lea hoy lo que dicen los medios, una cosa impresionante, pues, o sea, y no, necesariamente, porque lo dicen los medios es palabra de Dios o es la verdad.

R: Se ha producido entonces la ratificación de todos los altos funcionarios nombrados por este gobierno.

J.F.: No se han, o sea, los últimos funcionarios, ministros, mira esta última reforma constitucional que planteó la ratificación de los ministros, vice-ministros, embajadores, o sea, jefes de misiones de diplomáticas, y presidentes de entes autónomos tuvo un período para entrar en vigencia de un año, o sea, se aprobó esta reforma y, entonces, un 
año después entró en vigencia, o sea, entró en vigencia a partir de enero de este año, ya, entonces, todos los nombramientos de ministros, vice-ministros, embajadores, etc. están hechos antes de la entrada en vigencia de la ley de reforma, el presidente tiene que presentar a la Asamblea para su ratificación los nombramientos de los nuevos ministros, embajadores, jefes de misiones, etc., de este período para acá, pero no se han producido nuevos nombramientos, y, por lo tanto, no se ha presentado a la Asamblea nada, sin embargo, la oposición o la campaña mediática que hay contra el gobierno aquí, ¿qué es lo que te dice?, que todos los nombramientos que se hicieron el año pasado tiene que ser ratificados por la Asamblea y la ley fue bien clara en dar un período de, ¿cómo es que le llaman a eso?, en términos legales, cuando vos das un, cuando vos le das a la ley un período de tiempo, como una, a todo el período que le das vos, es como una moratoria que le das a la ley por un período donde la ley no tiene efecto, sino un año después, creo que no es, exactamente, la palabra moratoria, en términos jurídicos, es otro, pero, eso fue, se aprobó la reforma y dio un año para su entrada en vigencia, o sea, para enero o febrero de este año, ¿ya?, entonces no hay nuevos nombramientos que ratificar, si la Asamblea, si hubiese un nuevo nombramiento de ese período para acá, de ministros o de jefes de misión diplomática, la facultad de la Asamblea es ratificarlos.

R: Y en el caso, ahora que hace referencia a la ampliación del tiempo de entrada en vigor de las nuevas leyes de reforma parcial, las Leyes Marco suponen un artificio, un instrumento jurídico muy original en la historia de Nicaragua.

J.F.: Mira las Leyes Marco han sido un poco, o sea, aquí se han dado dos experiencias, una en el período de Violeta Barrios de Chamorro cuando se produjo la transición del gobierno sandinista entregando el gobierno a Doña Violeta, entonces, ¿qué es lo que se produjo ahí?, cuando se aprobaron las reformas del 95 hubo conflictos dentro de la Asamblea Nacional, o sea, porque el gobierno de Doña Violeta se negaba a aceptar esas reformas, porque, claro, el principal castigo de esa reforma era para Antonio Lacayo, que era el presidente en funciones de Doña Violeta, y, entonces, se produjo un conflicto de poderes, entre el Poder Ejecutivo y el Poder Legislativo, la otra Ley Marco, que se produce, es éste que le mencioné yo, cuando se da este conflicto entre el Ejecutivo y el Legislativo alrededor de reconocerle al pueblo su derecho a ejercer su, la toma de decisiones, sin, libremente, pues, que lo que no quería aceptar la oposición en la Asamblea Nacional, y, entonces, eso produjo un conflicto de poder muy fuerte, y produjo otra Ley Marco, que también se incorporaron las reformas, cuál era, eran las últimas reformas constitucionales que se habían aprobado, los dos temas fueron parte de esa, entonces, no es un procedimiento normal, como tú misma decías, no, pero fueron formas de salida a conflictos políticos e institucionales que ambas experiencias permitieron salidas políticas, verdad, entonces, no es una cuestión normal, tradicional, ese tipo de esquema, pues, de las Leyes Marco, pero, la verdad, es que en ambos casos funcionaron.

R: Sí, pero da la impresión de que esa dificultad para lograr el consenso constitucional en Nicaragua, porque en todos los procesos de reforma siempre ha habido conflicto entre Ejecutivo y Legislativo, con la excepción del periodo del presidente Alemán, donde el pacto con Ortega, que dio lugar a las reformas del 2000 evitó el conflicto entre el Ejecutivo y el Legislativo, porque los dos principales partidos se pusieron de acuerdo. 
J.F.: No, no, no fue así, o sea, permitió el consenso político en la Asamblea Nacional, pero hubo oposición fuerte del Ejecutivo desde Bolaños a esa reforma.

\section{R: En la época del presidente Bolaños.}

J.F.: Sí.

\section{R: En la tercera reforma constitucional.}

J.F.: ¡A Ah!, bueno, la de 1999 se hizo dentro de un Ejecutivo que lideraba Alemán y un Legislativo, que, mayoritariamente, era sandinista, entonces, sí, en esa reforma, que, básicamente, lo que permite es una reforma a la parte electoral, verdad, y no hubo conflicto, pero en la del 2005, verdad, sí hubo, y en la del 95, sí hubo conflicto entre el Ejecutivo y el Legislativo.

R: Y ahora el conflicto entre Ejecutivo y el Legislativo, que no habría concedido el apoyo para el tema de la reelección, que era, fundamentalmente, la cláusula de reforma constitucional actual, se ha solucionado no tanto creando una nueva Ley Marco, porque no ha podido aprobarse una Ley de Reforma Parcial, como una sentencia judicial.

J.F.: No creo, no creo, lo que pasa es que aquí no hay conflicto de poderes, la Asamblea Nacional no ha tenido el más mínimo, como decimos en Nicaragua, decíme en este proceso, que te expliqué al inicio, en qué ha intervenido la Asamblea Nacional.

R: En nada, en el caso de la reelección.

J.F.: No hay conflicto de poderes, pero mientras, que en los otros casos que te he mencionado, sí ha habido intervención de la Asamblea Nacional y oposición del Ejecutivo, o viceversa, pues, verdad, pero, en este caso, la Asamblea Nacional, esto fue un recurso de amparo de 111 ciudadanos ante el Consejo Supremo Electoral, verdad, que se negó a conocer del caso, les indicó que recurrieran a la Corte Suprema de Justicia, a la administración de justicia, y ellos recurrieron de amparo ante un tribunal de Managua, y luego el caso fue a la Sala Constitucional, la Asamblea Nacional ha estado completamente al margen en esto, pues, lo que pasa es que esa es la, como la Asamblea Nacional es el foro político ahí es donde se dan las reacciones de los políticos, pero la Asamblea Nacional, en este caso, no tiene absolutamente nada que ver.

R: Y la oposición, que no está de acuerdo con el contenido de la sentencia, ¿qué opciones institucionales tiene?, ¿cómo puede actuar al respecto en el marco del Poder Legislativo?

J.F.: No sé, ¡yo no soy oposición!, no sé, ya la oposición, es decir, si fuera una oposición constructiva puede recurrir de casación ante la Corte Suprema de Justicia, ese es un camino, si fuera una oposición constructiva, pero esta es una oposición visceral, la que hay aquí, no, no, no, seguramente, van a intentar lo que quisieron hacer con otras acciones de, fueron a anular una ley, eso, primero, por una resolución, como lo han querido hacer con las elecciones municipales, una resolución, ni una ley, son vinculantes a los otros poderes del Estado, verdad, o sea, porque esto es cosa juzgada, y lo que tiene que hacer según la ley y según la Constitución es acatarlo, las autoridades. 
$R$. ¿Se refiere a la sentencia reciente sobre la reelección?

J.F.: Es que no es sentencia sobre la reelección, te corrijo ahí también, es, o sea...

R: Sobre la interpretación del artículo 147.

J.F.: Sí, no se está planteando que estos ciudadanos se reelijan, no, sino que se le está diciendo la Corte es: restituimos el derecho de todos los nicaragüenses, verdad, a elegir libremente a quien le parezca. Eso es lo que dice, ah, que pueden postularse por esta sentencia cualquiera, sin cortapisas, de que si tú por un período fuiste alcalde, está bien, te podés postular nuevamente, siempre y cuando te reelegís si el pueblo da un voto de confianza para vos, pero si el pueblo da un voto de castigo, vos no salís electo, entonces, no es una sentencia para reelegir, por eso te corrijo, sino para restituir un derecho político de los nicaragüenses a ejercer la soberanía popular, a elegir y a ser electo, verdad, entonces, ¿cuál era la pregunta?

R: A mí, a propósito de esto que acaba de decir se me ocurre otra pregunta: si las reformas del 2000, digamos, en el pacto que se dio entre el ex-presidente Alemán y el actual presidente Ortega redujo el umbral de votos necesarios al 35\%, que está por debajo del techo electoral que ha alcanzado el Frente en las últimas elecciones desde el 90 hasta la fecha. ¿Favorece una victoria del Frente sandinista en el futuro inmediato? Porque el liberalismo se encuentra dividido y nunca van a poder ustedes perder las elecciones. Tal cual está el escenario actual no van a perder ustedes las elecciones a menos que el liberalismo se una y vuelva a conseguir el porcentaje de votos necesario para tener en primera vuelta la victoria, ¿no?, y, en este sentido, pues, la presidencia de la República. ¿No es esa una estimación en el marco de esta reinterpretación del artículo 147, que prevé otros 5 años del presidente Ortega?

J.F.: Es que eso el pueblo lo va a decidir.

R: Sí, pero el pueblo de acuerdo a unas determinadas reglas de juego, ¿no?, que son las reglas electorales actuales.

J.F.: Si las reglas electorales actuales son las que el pueblo dijo que no en 1990.

R: Bueno, las reglas electorales actuales son las que se reformaron en el año 2000.

J.F.: Redujeron el porcentaje de votos necesarios en primera vuelta, pero mantuvieron las mismas reglas generales, eso fue un ajuste de la Ley Electoral.

R: Un ajuste, pero muy beneficioso para el Frente.

J.F.: Pero también pudo haber sido para la oposición, porque si el que hubiese tenido ese porcentaje es el partido opositor hubiese sido igual para él.

R: Exactamente, no, no, si el problema aquí es que la oposición está dividida, y eso es lo que impide, actualmente, al liberalismo poder volver a la presidencia.

J.F.: Por eso, pero esta negociación que se hizo en ese proceso de acuerdo político, es igual para uno que para el otro, o sea, lo que pasa es que aquí cada quien tiene que 
buscar como conseguirlo, entonces, es problema de cada fuerza política cómo lo hace, el Frente ha logrado mantenerse cohesionado, a pesar de que estuvo dividido, después de los 90, cuando se creó el MRS, y que de 38 diputados que teníamos se fueron 30 con el MRS, en ese entonces, con Sergio Ramírez, se partió la bancada en dos pedazos, en esa ocasión llegamos a la elecciones del 96 divididos.

R: ¿Cómo ha sido el aprendizaje institucional del Frente durante 16 años de oposición?, ¿cómo ha aprendido a mantener su capacidad, digamos, como actor político relevante en el sistema político de Nicaragua en su oposición al liberalismo? Especialmente, en el Poder Judicial, recuerdo esa frase de Ortega, cuando decía: "vamos a aprender a gobernar desde abajo", y esa preeminencia que ha tenido el Frente en el Poder Judicial en Nicaragua, ¿cómo se ha ido produciendo a lo largo de todos estos años?

J.F.: Mira, más que el Poder Judicial, yo creo que tiene esa preeminencia en el tejido social, porque aquí hay un trabajo de hormiga todos estos años, de la militancia del Frente Sandinista, de la dirigencia del Frente Sandinista, en todos los territorios, y esa preeminencia en la población es lo que le ha dado la fuerza suficiente al Frente y a la dirigencia nacional del Frente para que en procesos de, por ejemplo, cuando en 1990 nosotros teníamos preeminencia total en todas las instituciones, en todas, y teníamos a la gente armada, teníamos como 300.000 personas armas, en guerra, y perdimos las elecciones, y entregamos el poder, que esa es una de las cosas que a propósito de la democracia, que decías vos, aquí el Frente hizo la primera elección pluripartidista y ha dado muestras de vocación democrática, que con una fuerza como esta que te estoy diciendo, entregamos el poder al partido que ganó.

\section{R: Sí, en el contexto de la reconciliación nacional.}

J.F.: Entonces, después, ¿qué hicimos a lo largo de estos 16 años?, primero, eso que te explicaba, o sea, trabajar en organizar nuestras fuerzas en todo el territorio nacional, y desde allí, desde esa fuerza empezar a estructurar el liderazgo en comarcas, en barrios, en ayuntamientos, en municipios, en departamentos, y en el país, o sea, el Frente es el único partido que tiene presencia en todos los municipios del país, en todos, sin excepción, tenemos nuestros consejos sandinistas nacionales, municipales, tenemos nuestras unidades de base en cada territorio, y ese es un elemento, el otro, que el Frente es un partido más disciplinado, producto, incluso, de su misma naturaleza, de sus mismos orígenes, de su misma historia, aquí muchos partidos de la oposición son, o sea, no tienen disciplina, y aquí hemos tenido disciplina y mística de trabajo, verdad, y con un concepto claro de la unidad para poder avanzar, porque eso fue clave en la lucha contra Somoza, fue clave para la victoria, ha sido clave para ganar las elecciones en un municipio, o en el país, o en sentido inverso, ha sido catastrófico cuando hemos estado divididos como en 1996, la lucha del Frente tiene una claridad sobre la unidad y trabajamos todos los días en cumplirlo, en trabajarla, en fortalecerla, pues, y luego, también ha sido de un gran valor la capacidad de negociación política en los distintos procesos que se han ganado, pues, en la Asamblea Nacional, realmente, que es donde se derivan todos los procesos de negociación para lo que sea, pues, para los nombramientos constitucionales, para las reformas electorales, o para las reformas constitucionales, etc. Entonces, básicamente eso, ¿verdad? 
R: Y en ese marco de negociación y de aprendizaje, también, en el diálogo, que es en lo que consiste, fundamentalmente, el espiritu democrático, pero también en la historia de Nicaragua, las reformas constitucionales han estado precedidas, generalmente, de pactos entre las distintas fuerzas políticas. En este sentido, el pacto entre Ortega y Alemán no era una cuestión nueva en la historia del país, y hay ejemplos a lo largo de ella que lo sustentan. ¿Cómo interpreta usted la reforma constitucional del 2000 y el pacto entre Ortega y Alemán?, ¿cuál cree que fueron las consecuencias desde el punto de vista jurídico y también político?

J.F.: Mira, en todos los países, primero, o en primer lugar, en todos los países que tienen estabilidad política y social hay pactos, hay acuerdos políticos, hay acuerdos de gobernabilidad, lo que pasa es que aquí en Nicaragua se ha satanizado la palabra pacto, $\mathrm{y}$, porque en una parte de nuestra historia reciente, hubo, por ejemplo, pactos vergonzosos, ¿no?, para entregar territorios, para aceptar la intervención extranjera, para darle oxígeno y vida indeterminada a la dictadura de Somoza, para eso hicieron pactos estos señores que te estoy mencionando, entonces, a raíz de eso, hablar de pactos es como hablar de Satanás, pero en todas las sociedades civilizadas, y en un país que busca gobernabilidad, que busca estabilidad política, que busca estabilidad social, el pacto es de lo más común y corriente, ¿ustedes en España no tienen los Pactos de la Moncloa?, verdad, te puedo mencionar 20 casos, pero no es ese el tema. Entonces, aquí en Nicaragua, en los últimos 20 años, para responder tu pregunta, los pactos se han producido por las fuerzas mayoritarias, las fuerzas políticas mayoritarias, que entre las dos de ellas hablás del $90 \%$ o el $96 \%$ de los votos del país, entre el Partido Liberal Constitucionalista y el Frente Sandinista en las elecciones del 96 y del 2001, bueno, ya en la última iban divididos en dos agrupaciones, pero estás hablando entre el liberalismo y el sandinismo más del 90\%, entonces, en el año 2000, la reforma del año 2000, como veníamos saliendo de un proceso eleccionario que se dio en el año 96, donde se profundizaron, enormemente, las desconfianzas, y a pesar de que los demócratas entre comillas, no menciono ya ese capítulo de la historia electoral nuestra, verdad, que fue esas elecciones del 96 fueron fraudulentas totalmente, verdad, aquí encontraron urnas en los basureros, de una manera descarada, los funcionarios electorales hicieron barbaridades, y, sin embargo, los medios de comunicación de Nicaragua no reflejan ese capítulo electoral como uno de los mayores fraudes en la historia de Nicaragua, pero bueno, entonces, cuando se dan las elecciones, o se van a producir las elecciones del 2001, un poco para subsanar desconfianza, para resarcir heridas que había dejado la campaña electoral es que se produce, se abre todo ese proceso, donde no, solamente, se toman en cuenta los porcentajes, o sea, que, básicamente, si mal no recuerdo, lo que se estableció es que para ganar una elección se requiere el $40 \%$ de los votos por cualquier fuerza, pero si la fuerza que ganó con un 35\% tiene como $5 \%$ más por encima de la segunda, o sea, puede ser con menos, eso es, básicamente, lo que se estableció en el acuerdo. Pero también hubo como 8 o 9 más reformas de carácter electoral, esa es de la que más se habla porque es una de las que más polémica, en ese pacto que tú mencionas.

R: Y el tema de la inmunidad parlamentaria, ampliando a los ex-presidentes de la República la posibilidad de ser diputados miembros de la Asamblea.

J.F.: Exacto, o sea, es el presidente que deja su escaño presidencial, pasa por Constitución, por ley, a ocupar un escaño en la Asamblea Nacional, entonces, ya no serían 90 diputados, él sería 91, por sólo haber sido presidente de la República, y el otro 
que se aprobó es que el candidato que ocupase el segundo lugar en una elección nacional es el diputado número 92, ese es la segunda gran reforma de ese período, ¿me entendistes eso, verdad?

R: Sí, sí.

J.F.: O sea que el ex-presidente de la República, como existe en otros países de América Latina pasa a ocupar un escaño en la Asamblea Nacional, y el candidato de la oposición que ocupó el segundo lugar de una elección nacional también pasa a ocupar, de forma que, en vez de 90, ahora hay 92 diputados producto de este acuerdo, pero aparte de esos dos hay otros más, yo no preciso en este momento, realmente, hubo como $7 \mathrm{u} 8$ reformas a la Ley Electoral y algunas a la Constitución en ese acuerdo del 2000, luego, pero como te digo la lógica fue, bueno, vamos a entrar en una elección y queremos recuperar confianza, queremos reglas competitivas claras, queremos legitimar elecciones, bueno, aquí están estas cosas de las que hablábamos. Y las elecciones del 2005, las reformas del 2005, básicamente, consistieron en, efectivamente, restarle capacidad de, restarle poderes al Ejecutivo y dárselos más al Legislativo, fijate bien, si vos que sos estudiosa de la Constitución nuestra, ha habido una tendencia en las últimas reformas constitucionales de concentrar más el poder en la Asamblea Nacional que en el Ejecutivo, que fue lo inverso de la Constitución del 87, que era, eminentemente, presidencialista, verdad, entonces, ya la reforma del 95 transfiere poderes, la del 2000 también algunas cosas y la del 2005 permite, uno, que una serie de instituciones, la Superintendencia de Servicios Públicos, el Instituto de la Propiedad Urbana y Rural, tres, cuatro instituciones, sus nombramientos sean hechos como son hacen los de los Magistrados, los Contralores, etc., por la Asamblea Nacional, luego, otra reforma consiste en que los diputados al Parlamento Centroamericano tengan iniciativa de ley en temas de integración ante la Asamblea Nacional, o sea, que ese es de los pocos países de Centroamérica que le permitimos a los diputados ante el Parlamento Centroamericano a que puedan presentar iniciativas antes que el Congreso Nacional, ante la Asamblea Nacional, la única limitante que hay en temas de integración centroamericana, esa fue la otra reforma que se produjo en el año 2005, y hay una tercera que no me acuerdo, son tres cosas...

R: Y la otra tiene que ver con el poder de veto del presidente, es una restricción también al veto del presidente, por parte de la Asamblea, que puede levantarlo. Me refiero a la capacidad de veto del presidente que quedo ya restringida en el año 95, si en 15 días no decidía la Asamblea podía pronunciarse en relación a una cuestión, o sea, el presidente de la República no podía vetar ninguna ley, incluidas las leyes de reforma parcial de la Constitución, como fue el caso de la presidenta Violeta Chamorro, que se negaba a promulgar la ley de reforma parcial de la Asamblea.

J.F.: Sí, sí, no lo veta en un período fatal, pasado el cual la Asamblea puede mandar a publicar la ley.

R: Y en el 2005 ese veto además se amplía, porque por mayoría calificada la Asamblea puede no aceptar una decisión del presidente, ¿no? Y se amplían todavía mucho más, en ese sentido, las facultades de la Asamblea.

J.F.: Sí, sí, en honor a la verdad, ahí hubo intereses encontrados en ese acuerdo político, por un lado, uno de los actores en esa negociación, que era el Partido Liberal 
Constitucionalista, había llevado a la presidencia a Bolaños, pero después de eso se pelearon, Bolaños se peleó con ellos, verdad.

\section{R: Sí, porque Alemán quería gobernar a través de la presidencia de la Asamblea.}

J.F.: Sí, quería gobernar desde ahí, pero no solamente eso, había hecho unas barbaridades que le había dejado un gobierno, un campo minado de corrupción por todos lados, le había saqueado las arcas, le había, bueno, barbaridades, entonces, Bolaños lo paró duro, y, entonces, dentro de ese proceso, a pesar de que nosotros siempre insistimos en ese proceso a no mezclar cuestiones de contradicciones personales, del líder del partido, Alemán, con Bolaños, porque aquí estábamos hablando de una reforma sensible, pero hay algunas cosas, sobre todo, lo que es la parte de la institución de los nombramientos estos que hacía la Asamblea, que es un interés planteado por el Partido Liberal Constitucionalista en esas reformas constitucionales, nosotros ¿por qué lo aceptamos?, porque nosotros hemos sido partidarios siempre del parlamentarismo, o sea, que había una coincidencia de un problema de ellos con Bolaños de debilitar a Bolaños en su capacidad de ejercer el Ejecutivo, pero, por otro lado, nosotros decíamos, hombre, si nosotros somos partidarios de, hasta el grado que hoy, la Asamblea Nacional tiene, si vos analizás, que vos tenés la experiencia del parlamentarismo en España y sos estudiosa de la Constitución, si analizás la Constitución nuestra y otras constituciones de aquí de América Latina, la Constitución nuestra tiene un alto grado de semi-parlamentarismo en sus facultades, porque, además de todas las facultades en sí, de toda la capacidad que tenemos de poder no solamente citar, sino interpelar a cualquier funcionario del gobierno, del Estado, para responder ante la Asamblea Nacional en cualquier momento en que la Asamblea Nacional lo decida, eso es un poco la regla del parlamentarismo, incluso, más allá, hasta entidades o personas naturales pueden ser citadas con esta capacidad que tiene la Asamblea con estas reformas, y, la de ratificación de los ministros, vice-ministros, directores de entes autónomos, esa es una facultad típica del parlamentarismo, en países que tienen ese esquema, entonces, hubo una coincidencia de un interés de ellos con un interés nuestro de fortalecer un esquema, verdad, y, luego, las otras reformas que nosotros, como hemos sido partidarios de la integración siempre, la empujamos, ese fue un interés nuestro, y el otro igual, pues, el que mencionaba, en eso fue en lo que consistió, básicamente, la reforma del 2005.

$R: Y$, sin embargo, esa tendencia a la parlamentarización del régimen presidencial nicaragüense, ¿no se ha traducido en una cierta preeminencia de las cúpulas de los partidos?, ¿no ha sido el vicio formal que ha tenido este cambio institucional, puesto que son las cúpulas partidarias las que a través de esa composición paritaria de los principales poderes del Estado, en cierto sentido, ha paralizado la propia función constitucional que tienen asignada?

J.F.: Ahora, los sistemas parlamentarios, que los gobiernan partidos políticos en cualquier país del mundo, o sea, tienen esas mismas potestades, los partidos, en los sistemas parlamentarios, o sea, ¿cómo te puedo responder eso?

R: Es una pregunta, no es una afirmación, hombre, yo le hago la lectura crítica, porque también escucho siempre a todos los actores y luego ya un estudioso trata de llegar a la mejor conclusión, pero dar su espacio y su voz a cada uno de los actores. 
J.F.: ¿Entonces, es bueno o es malo los partidos políticos?

R: Bueno, me refiero a los juegos de poder, los partidos políticos no son malos, porque en sí mismos representan a los ciudadanos y tiene un programa ideológico, unos intereses, pero cuando se dan transacciones, cuando hay, incluso, compra de votos, cuando hay manipulaciones, cuando se vicia, digamos, la colaboración partidaria, que es algo natural a cualquier sistema político, no puede ser el peligro de que, en realidad, un mayor poder en la Asamblea no se traduce tampoco en, el órgano Legislativo está legitimado porque están representados todos los ciudadanos de Nicaragua que eligen a sus representantes, esa es su legitimidad, y, en ese sentido, yo creo que es el órgano más democrático, ¿no?, o sea, todo lo que pasa por la Asamblea tiene esa legitimidad popular, porque ellos son la cámara de representación del pueblo.

J.F.: Todas esas respuestas yo ya te las di.

R: Pero, por otra parte, si no son los ciudadanos y son los partidos, en este otro sentido del que le hablaba, sin son esas componendas entre los lideres partidarios los que vician al final el funcionamiento del sistema. ¿Qué piensa usted que ha pasado realmente en Nicaragua?

J.F.: Mira, lo que ha pasado en Nicaragua es lo que ha pasado en todos los países donde hay democracia, que los partidos políticos que tienen mayor representatividad en el esquema de democracia representativa, que es el que existe hasta ahora, son los que deciden, los que toman acuerdos, y los que le dan impulso a determinadas iniciativas, $\mathrm{y}$ los que se juntan para tomar las principales decisiones de Estado, o en materia económica o social, eso es lo que ha pasado aquí, ¿por qué nosotros nos apuntamos, hablo del Frente Sandinista, a que ese sistema que usted dice de componendas?, ¿por qué no somos partidarios de un esquema que va más allá del esquema representativo de la democracia y nos apuntamos más por un esquema más participativo de una democracia directa, verdad?, casualmente, es para evitar eso, porque imagínate presupuesto de un municipio para que 4 concejales de un partido y 5 de otro decidan lo que es el presupuesto municipal, qué mejor que tener una organización del pueblo participando, verdad, para decidir qué proyecto en comunidad, o qué prioridades en los caminos, o en puentes, o en la cuestión del medioambiente, o en los caminos productivos, etc., y con ello conformar el presupuesto y que no sean esos 4 o 5 concejales de los dos partidos los que deciden, igual que ocurriera con muchas decisiones que se toman allá, es decir, de esa forma se evita que 4 o 5 personas, o 2 o 3 partidos se tomen la representación entre comillas de la población, porque, efectivamente, ahí están todos los votos reflejados a diferencia del Ejecutivo, que tiene solamente los votos con los que fue electo el presidente, verdad.

\section{R: Exactamente.}

J.F.: Pero aún así, en el esquema de democracia representativa formal, que es el que nosotros tenemos ocurre eso, nosotros, ese es el esquema constitucional que tenemos, y en ese esquema nos hemos desenvuelto todos estos últimos años, en ese esquema hemos logrado establecer acuerdos políticos, estos mismos de que hemos estado hablando, en ese esquema, pero no es nuestro esquema, no es nuestro esquema, sin embargo, ese es el esquema que se aprobó en el 87, que se ratificó en las reformas del 95 o del 2000 y del 2005, pero nosotros quisiéramos un esquema diferente, donde haya más que la 
representación de 4 o 5 o 90 diputados, que es el esquema representativo formal, sea la población organizada, y sería encontrar los mecanismos, verdad, para que ahí se tomen las principales decisiones de Estado sobre la gestión pública, sobre la gestión municipal, y sobre las decisiones gruesas que como país necesitamos.

R: De todos modos, la crítica de la oposición, y estoy pensando en los partidos minoritarios, o no tan minoritarios, porque en relación al Frente Sandinista el MRS es un partido que tiene una proporción menor de votos en relación al sandinismo, pero en el bloque liberal, la Alianza Liberal Nicaragüense si obtuvo una mayor representación, en términos porcentuales, en la Asamblea, que el propio PLC, ¿no? Estas fuerzas que se llamaron a sí mismas anti-pacto han denunciado repetidas veces ese "bipartidismo institucional" entre el PLC y el Frente Sandinista al que hacia referencia antes, que han quedado excluidas de la representación paritaria en los principales poderes del Estado, que, en el caso de MRS o del Partido Conservador, se les negó la personalidad jurídica en las pasadas elecciones municipales, hay como una critica al cierre de espacios políticos. ¿Qué piensa usted de esto?

J.F.: Mira, eso es parte de la misma insuficiencia de este sistema que nosotros tenemos, en un esquema, vamos a ver tu país, de democracia representativa, veamos Estados Unidos, ¿quiénes son los que negocian y deciden?, los demócratas y los republicanos, en España, tu país, ¿quiénes son los que deciden?, los partidos grandes, los que tienen los votos.

R: Sí, pero hay una representación parlamentaria de las otras fuerzas políticas.

J.F.: Aquí hay representación parlamentaria también.

R: Y hay partidos "bisagra", como son los partidos nacionalistas.

J.F.: Aquí hay también, aquí hay también, en la Junta Directiva de la Asamblea Nacional están todos los partidos ahí, en la Junta Directiva, ahí hay liberales, constitucionalistas, hay ALN, hay MRS y hay sandinistas, ¿es o no representativa? En la Asamblea hay cinco bancadas acreditadas, grupos parlamentarios, que tienen su propia expresión, ¡ah!, pero la democracia así es.

R. Pero en el caso de la representación partidaria en la Corte Suprema, en...

J.F.: No, perdona, lo que te explico es, lo que te explico es que el partido de las minorías en una democracia formal representativa aceptan o no las decisiones de la mayoría, ¿las aceptan o no?

R: Pues sí, evitando también esa tiranía de las mayorías a las que, por ejemplo, el sistema proporcional trata de dar una salida.

J.F.: ¿Pero tú vas a hacer un conteo con dos o tres diputados? Cuando hablás de noventa y dos, ¿qué cuota querés ahí?

$R$ : No, obviamente, tienen que negociar con los diputados que tienen, la representación que logran, en términos de votos. Pero yo me refiero, fundamentalmente, a los otros poderes del Estado, los Magistrados de la Corte Suprema, del Consejo Supremo 
Electoral, de la propia Contraloría, esa ausencia de otros partidos, que no sean el PLC y el Frente Sandinista en lo que es la composición orgánica de estos poderes del Estado, eso sí es un hecho en la propia estructura de los poderes públicos.

J.F.: Pero es que los otros partidos no han trabajado lo suficiente para lograr esos espacios.

\section{$R:$ ¿En qué términos?}

J.F.: Pues toda la explicación que te di hace rato de lo que tiene que hacer es trabajar duro, reponer fuerzas como partido, tener representantes, suficientes representantes en la Asamblea Nacional sacados de las elecciones, y luego desarrollar la suficiente capacidad de trabajo, todo eso no se logra por tu bonita cara, verdad, sino con trabajo político de años, de esfuerzo, de disciplina, de mística, de participar en las elecciones, de competir en las elecciones, de hacer su programa, entonces, eso es así, o sea, estos partidos grandes han logrado esos espacios porque se los han ganado trabajando.

$R: Y$, en este contexto, ya para terminar con la reflexión sobre los cambios constitucionales en Nicaragua, cuando uno revisa la historia del país tiene la sensación de que la política está por encima de la Constitución, de que los políticos, es decir, de que la política no está tanto sujeta a un marco jurídico que la delimita, como que el marco jurídico es continuamente forzado por esos cambios que flexibilizan, enormemente, la Constitución nicaragüense, que si se cambia con relativa, digamos, facilidad, incluso el propio procedimiento de reforma ha sido revisado, incluso ahora con esta sentencia reciente se amplía la capacidad legítima de reformar la Constitución al órgano judicial, y no ya al órgano legislativo, ¿no? Entonces, esta continua transformación de la Constitución ¿no es peligrosa desde el punto de vista de la consolidación de las instituciones democráticas?

J.F.: Bueno, las leyes y las constituciones ¿quiénes las hacen?, nosotros los políticos en la Asamblea Nacional.

\section{R: Bueno, los políticos a través de una Asamblea Constituyente.}

J.F.: No, no, es que no es nada extraño que los políticos así como hacen las leyes, de igual manera, que no es nada extraño que un órgano administrador de justicia emita una sentencia judicial por determinados temas, y no es extraño que un órgano electoral en una democracia como la que hemos estado hablando, que es la democracia representativa, que un órgano electoral emita un resultado electoral, o emita, o postule, $\mathrm{o}$ de derechos a unos y que se los niegue a otros, porque $\mathrm{X}$ circunstancia, eso ocurre en todas las democracias representativas.

R: Sí, pero la Ley Fundamental, en este sentido, la Constitución, si respetamos el principio de supremacía de la Constitución, ésta, en cierto modo, es intocable en la mayor parte de los países con democracias consolidadas, pensemos en la Constitución norteamericana, es muy difícil reformar la Constitución de Estados Unidos, es decir, hay un procedimiento, enormemente, rígido. En el caso de la Constitución española, únicamente, se reformó recientemente en el año 92 para ampliar el sufragio activo y pasivo a los extranjeros comunitarios residentes en España, para poder votar en las elecciones del Parlamento Europeo, y también para tener ellos la posibilidad de ser 
elegidos en los municipios, que era algo que no se podía, un derecho político únicamente para los nacionales, entonces, se amplía, en este caso, para los extranjeros comunitarios.

J.F.: La nuestra tiene tres reformas.

\section{R: Y esta última sentencia.}

J.F.: Pero eso no es reforma constitucional, no es una reforma constitucional, ya te dije, la Asamblea Nacional no ha intervenido absolutamente en nada en este problema, por lo tanto, no podés caracterizarlo como una reforma. Una reforma constitucional es cuando hay todo un procedimiento de formación de ley, ¿ya?, e interviene la Asamblea, hay consulta ciudadana, consultas a Magistrados, consultas acá, hay un dictamen de una Comisión Constitucional, verdad, para la reforma, y aquí no hay nada de eso, no es una reforma, hablando seriamente, no es una reforma constitucional.

\section{R: Pero sí es una reinterpretación del artículo 147.}

J.F.: Ya te expliqué, como lo ha habido en otros casos sin reformar la Constitución a través de la Asamblea.

\section{R: ¿Y cuál sería su reflexión final a propósito de la consolidación democrática y la evolución constitucional?}

J.F.: Mira, yo creo que Nicaragua, la Constitución de 1987 de Nicaragua, así como los Acuerdos de Esquipulas permitieron la paz en Centroamérica, la Constitución de 1987 ha permitido la estabilidad democrática y política de Nicaragua, o sea, por primera vez en Nicaragua, nosotros tenemos una Constitución que permite la alternancia en el poder, que permite el pluripartidismo, que permite el hecho de elegir y ser electo, antes no existía, que permite amplios derechos políticos, laborales, culturales, sociales, a las minorías de las regiones autónomas de norte y sur, por primera vez en Nicaragua, producto de esta Constitución, hay equilibrio y armonía con los problemas normales que se dan entre los poderes del Estado, ¡ah!, que ninguna ley, ninguna Constitución es perfecta, y por esa razón es que se han producido tres reformas del 87 para acá, que, prácticamente, estamos hablando de más de veinte años, verdad, yo creo que, incluso, esas reformas, en términos legales, yo diría que le han permitido fortalecer el esquema democrático en Nicaragua, porque en el 95 esa reforma cumplió su objetivo, y le dio determinada estabilidad y determinada lógica al gobierno de entonces, igual que la del 99 y la del 2005, o sea, lo importante es que en Nicaragua no hay dictadura, a pesar de lo que digan hoy día los medios, aquí dice barbaridades cualquiera, cuando existía la dictadura de Somoza vos hablabas una barbaridad de esas y amanecías en un cauce muerto, o preso en la seguridad de Somoza o en sistemas penitenciarios al día siguiente, pues, aquí no hay libertad de expresión, hay libertinaje de expresión, dicen cualquier cosa, ofenden a cualquiera, humillan a cualquiera, es decir, una amplia libertad que no existía en la época de la dictadura, hoy en la época de la democracia sí existe, hoy, poco a poco, se han ido, producto de esa Constitución, se han ido restituyendo derechos fundamentales de la población, que, incluso, le habían sido negados históricamente, como el derecho a la salud, como el derecho a la educación, como el derecho a tener una vivienda digna, como el derecho a la tierra, como el derecho a elegir y ser electo, a la libertad, a organizarse, a montones de derechos que han sido inculcados producto de 
la Constitución que antes no existían, ah, que los nicaragüenses tenemos que buscar el bien común y buscar entre todos hacer un esfuerzo para sacar adelante el país con menos tensiones, con menos intolerancia, con menos dificultades, con menos contradicciones, eso estoy totalmente de acuerdo que es un aspecto, es una deuda que nosotros los partidos políticos tenemos con el pueblo de Nicaragua, y que eso va a fortalecer, esa posibilidad va a fortalecer más la armonía entre los poderes, la estabilidad misma de la Constitución para no estarla reformando, va a permitir desarrollar las capacidades económicas y sociales que tiene Nicaragua para poder tener una vida mejor en el futuro, porque esa, en síntesis, creo que es la aspiración, por lo menos, de nosotros, como diputados sandinistas, en este caso, queremos una Nicaragua mejor, queremos que las próximas generaciones tengan una Nicaragua mejor de la que hemos tenido, un futuro mejor del que hemos tenido, que no se vaya a entregar un país más devastado que el que hemos tenido, con un medioambiente en deterioro increíble, con las riquezas potenciales de Nicaragua aún sin explotar lo suficiente, con entregarles una democracia que les permita vivir en paz y vivir mejor, eso.

R: Pues, si tiene algo más que añadir, yo creo que ha sido una entrevista muy completa.

J.F.: No, está bien. 
ENTREVISTA $23^{36}$ :

Nombre del entrevistado: Dr. Omar García.

Cargo actual: Profesor de Derecho Constitucional de la Universidad Americana (UAM) y de la UNAN-León.

Fecha de realización de la entrevista: Managua, 17 de septiembre de 2009.

Lugar: Facultad de Diplomacia y Relaciones Internacionales de la Universidad Americana (UAM).

Duración estimada: 1 hora y 42 minutos.

\section{TEXTO - Transcripción 23:}

$R$ : ¿Cuál es tu visión sobre los tres procesos de reforma constitucional, que se han producido en Nicaragua desde los años 90, fundamentalmente, desde el 95 en adelante?, ¿y cuál crees que ha sido el hilo conductor del proceso constitucional en el marco, digamos, de la transición democrática?

O.G.: Bien, bueno, además de esos tres que mencionás el del 95, el del 2000, y el del 2005, que han sido como los procesos más, de reformas profundas, sobre todo el del 95 y el del 2005, el 2000 no tan profundo, pero es un proceso de reforma significativo, además de eso, la Constitución ha tenido una reforma en el año 90, y una reforma en el 2004, y un intento de reforma en el 94, que no logró materializarse, nunca logró entrar en vigencia, verdad, son reformas que han buscado los que han estado en el poder en ese momento, y han intentado, mejor dicho, los que han conducido este proceso de reforma han buscado como, sobre todo, la del 95 y la del 2005, limitar las atribuciones que, originalmente, fueron configuradas al presidente de la República en la Constitución del 87, en esa limitación ha habido un desplazamiento o un movimiento, por así decirlo, de la fuerza del presidente de la República hacia la Asamblea, no sé si consciente o inconsciente en la búsqueda de cambiar el sistema, de pasar de un sistema presidencialista a un sistema parlamentario, pero sí en la búsqueda de tener desde la Asamblea mayores controles sobre el presidente de la República, verdad, en ese sentido, pues, la reforma del 95 fue una reforma bastante profunda, porque toca, prácticamente, casi todos los aspectos de la Constitución, posiblemente, el único aspecto que no tocó, y a pesar de que hizo su intento de tocarlo, fue el procedimiento mismo de reforma, que es lo que te explicaba en relación a la del 94, que fue una reforma que no entró en vigencia, pero sí hubo esa intención de cambiar el procedimiento de reforma, entre otras cosas, para eliminar la posibilidad de la discusión en dos legislaturas, entonces, esto, lógicamente, introducía una discusión, o se planteó en su momento una discusión bastante profunda sobre qué tan posible era reformar el procedimiento de reforma, entonces, al final, quienes condujeron la reforma del 95, terminaron u optaron por aplicar el procedimiento que establecía la Constitución en relación al tema de las dos legislaturas, y la reforma que se hizo a ese procedimiento de reforma no entró en vigencia, nunca lo publicaron, no logró tener, por así decirlo, vinculación jurídica a través de la entrada en vigencia, la del 2005 es una reforma que, en cierta medida, viene

\footnotetext{
36 Entrevista muy larga, con especial incidencia sobre las relaciones Ejecutivo-Legislativo en el marco del contenido y procedimiento de reforma a la Constitución de 1987 desde los años 90 hasta la actualidad, así como la centralidad estratégica del capítulo electoral en el marco del cambio constitucional reciente, por su impacto directo sobre aspectos tales como: el liderazgo político, el sistema de partidos o la propia evolución institucional de la democracia nicaragüense.
} 
a cerrar un poco el círculo iniciado en el año 95, que es ese desplazamiento de poder del Ejecutivo hacia el Legislativo, bajo una lógica creo yo de introducir mayores mecanismos de control, por un lado, yo diría que mayores mecanismos de control del Legislativo hacia el Ejecutivo, pero, pero, con una connotación que lleva la reforma del 2005 en la cual, posiblemente, la lógica de esos mecanismos de control, introducidos o planteados desde el 95, llevan una lógica totalmente distinta en el 2005, o sea, apuestan por mayores mecanismos de control, sin embargo, ya el elemento del acuerdo político o de la relación de partidos, en este caso, de dos partidos más fuertes, el Frente Sandinista y el PLC, que tienen como punto de partida el resultado electoral en el año 96, y la reforma a la Constitución en el 2000, producto de un acuerdo político entre los dos, ya ese elemento, a la hora que uno analiza la reforma del 2005, si bien están estos elementos de control presentes ahí, ya lleva a una connotación distinta, por ejemplo, resulta bastante exagerado la introducción de la mayoría calificada para la ratificación de un ministro, para la ratificación de un director de un ente autónomo, para la ratificación de un funcionario dentro de la órbita del Ejecutivo, de un cónsul, de un embajador, que hace, prácticamente, imposible el buen desenvolvimiento o la buena marcha o la funcionalidad, que va a tener el Ejecutivo, a la hora de que se establezca una exigencia de mayoría de ese tipo, lo cual, lleva en el fondo, la lógica del acuerdo político, que viene siendo puesto en marcha desde el año 2000, ¿por qué?, porque se establece que para, por ejemplo, para este mecanismo de ratificación de nombramientos que hace el Ejecutivo dentro de su esfera de competencia, pero que tienen que pasar por la Asamblea Nacional, es decir, que la Asamblea Nacional tiene que dar el aval de ese nombramiento, se estableció una mayoría calificada del $60 \%$ para dar el visto bueno de ese nombramiento, con lo cual, la lógica del acuerdo político planteado en el 2000 no se va a romper con eso, porque son estos dos partidos políticos, los que alcanzan los votos suficientes para mantener esa relación, se vuelve a la cuestión de que necesitás de mí, por así decirlo, para poder tener, como mínimo, la conducción mínima del Ejecutivo, de la Administración Pública desde el ámbito de la órbita del Ejecutivo en esos temas, ¿verdad?, entonces, en ese sentido, es una reforma que está pensada bajo esa lógica, y que sólo el tiempo, posiblemente, dio la razón en relación a ese tema, porque es una reforma que hasta la fecha al 2009, ha sido, prácticamente, ineficaz, es una reforma que no se ha puesto en vigencia a pesar de que está ahí, primero, por las trabas políticas, que se generaron en el Ejecutivo y en el Legislativo en ese momento, y, en segundo lugar, por la aparición de un instrumento denominado Ley Marco, que venía a establecer como la limitante para la entrada en vigencia de esta reforma, y que, posteriormente, a través de una sentencia de la Corte Suprema de Justicia, pues, eliminó esta imposibilidad de entrada directa, automática, de la reforma, y dejó abierto el camino en relación al contenido, que había sido recogido en la reforma del 2005, sobre todo en estos temas, en ese sentido, a partir del 2008 para acá, uno ha visto que, prácticamente, esos mecanismos de control introducidos buscando esa lógica de mayores mecanismos de control del Legislativo hacia el Ejecutivo, no han sido puesto en marcha, el presidente de la República en la actualidad, pues, ha hecho una serie de nombramientos sin pasar por el procedimiento de ratificación, que establece la Constitución, y que es competencia, en este caso, la ratificación de la Asamblea Nacional, entonces, en ese sentido, hay que, creo yo, que hay que hacer una diferencia entre la del 95 y la del 2005, creo yo que el punto en común de ambas es esa lógica de búsqueda no sé si consciente o inconsciente de crear mayores mecanismos de control del Legislativo sobre el Ejecutivo, y en esa lógica de crear mayores mecanismos de control EjecutivoLegislativo, al Ejecutivo, no sé si ha sido consciente del desplazamiento del sistema, o en la búsqueda de instaurar un sistema de gobierno diferente al sistema presidencial, o, 
simplemente, ha sido una cuestión de seguir sobre el modelo presidencial, pero con la introducción de mayores mecanismos de control para que se pueda hacer eficaz el ejercicio de control, en este caso, de la Asamblea, el órgano más pluralista dentro de los poderes del Estado sobre el Ejecutivo, no sé, como te decía, si la lógica ha sido, o sea, si ha sido consciente o no de que se está moviendo hacia un sistema, o se busca el cambio del sistema haciendo eso, o, prácticamente, no se busca el cambio del sistema y lo que se pretende, entonces, es introducir estos mecanismos de control, si bien, se puede observar esas dos cuestiones, en relación a los mecanismos, creo yo, que la lógica que se mueve detrás de estas dos cosas son totalmente distintas en el 95 que en el 2005, prueba de ello, son esas exigencias altísimas, por así decirlo, de mayoría calificada para la ratificación, lo cual sí tiene sentido si se analiza el acuerdo político del 2000, establecido desde el 2000, que conlleva una reforma a la Constitución, que la reforma del 2000 lo que hace es generar la ampliación de las principales estructuras del Estado, en cuanto a los cargos de dirección, y eso te permite, pues, entrar en el juego parlamentario, que luego ya se institucionaliza, por así decirlo, a la hora de la elección de estos cargos, el repartirse los cargos, el repartirse todas las instituciones del Estado, todos los poderes del Estado, en general, todas las instituciones, cual si fuese una cuestión de lo que los italianos llaman de distribuirse parcelas, es decir, si hay ocho cargos, y tengo que elegir cuatro de esos cargos, dos son tuyos, dos son míos, si tengo que elegir ocho, ahora son dieciséis, cuatro son tuyos y cuatro son míos, y así en muchos casos no se rompe el acuerdo político, que existe en la Asamblea Nacional para cosas muy importantes, que existen fuera de la Asamblea Nacional, y que también existe en las principales instituciones del Estado.

R: A mí un aspecto, que me interesa entre muchas de las cosas que has dicho en esta primera intervención es el tema del intento de flexibilizar el procedimiento de revisión de la Constitución, que, bueno, normalmente, forma el núcleo duro de una Constitución, y no puede admitir una reforma mediante una reforma parcial, ¿no?, sino una reforma total, sin embargo, en Nicaragua, el conflicto de Doña Violeta Chamorro con Luís Humberto Guzmán, que era, entonces, el presidente de la Asamblea, es la Asamblea quien tiene la iniciativa de la reforma parcial de la Constitución en el 95, el Ejecutivo de Violeta Chamorro quiere gobernar, paradójicamente, con la Constitución del 87, que era la Constitución del régimen sandinista, entonces, ahí empieza una línea que se ha ido repitiendo, porque el presidente nunca ha estado de acuerdo con las reformas promovidas por la Asamblea, y, actualmente, es, curiosamente, el presidente del Ejecutivo el que quiere promover el proceso de reforma, ya sea a través de la reelección presidencial o del planteamiento de esa división de la estructura institucional del Poder Ejecutivo, creando la figura de un primer ministro, junto al presidente de la República, pero, bueno, esa es la cuestión de ahora, ¿qué opinas tú?, porque, finalmente, si se consiguió reformar esta cláusula que decía que la publicación a través del presidente de la Asamblea, en cualquier medio escrito, tenía, digamos, la validez, si a los 15 días el presidente de la República no había firmado y promulgado la ley, afectando también a las leyes de reforma parcial de la Constitución, finalmente, sí se reformó el procedimiento de revisión constitucional en Nicaragua.

O.G.: Sí, de alguna manera sí, de alguna manera sí, comenzamos por esa parte y luego, siguiendo con la primera parte, de alguna manera sí, para muchos ahí hubo una, si bien no se tocó el procedimiento en el punto en el que está este procedimiento, se agregó un nuevo elemento, que, indirectamente, o, directamente, está afectando al procedimiento, en ese sentido, entonces, te decía que si bien es cierto, ahí hay, y existen posturas, pues, 
hay personas que dicen que eso fue inconstitucional, en ese aspecto, yo lo he visto como una cuestión complementaria, pero bastante discutible, obviamente, pues, es decir, la redacción en cuanto a la publicación creo yo, que esto ya es un poco la interpretación, en cuanto a la publicación por parte del presidente de la República, es bastante taxativa, o bastante expresa, en el sentido de que debe publicar, no tiene posibilidad de no hacerlo, claro, el problema se presentó cuando no lo hizo, entonces, cómo controlar esa cuestión, y de ahí nació la posibilidad de introducir esa fórmula complementaria, contradictoria, dependiendo cómo se vea en relación al tema, porque en caso de que no acepte, siempre va a existir esa posibilidad por parte de la Asamblea Nacional de hacerlo, pero sí, definitivamente, de entrada se alteró el procedimiento, sin tocar el procedimiento, tal y como está, pero se le introdujo un criterio diferente del criterio, que tenía establecido originalmente, ¿no?, ahora, uno podía reflexionar un poco en cuanto al tema del procedimiento en varios aspectos, la tesis que ha prevalecido en los distintos actores políticos que han promovido las reformas, la reforma desde 1990 hasta la reforma de 2005 ha sido de que todo se puede cambiar vía procedimiento de reforma parcial, es decir, cualquier punto de la Constitución lo puedo cambiar a través del procedimiento parcial, esta ha sido la lógica que ha imperado dentro de los principales, de los actores políticos, que han movido las reformas, y de la propia Corte Suprema de Justicia a través de su jurisprudencia, a través de sus diferentes fallos, en los cuales ha tenido la posibilidad de pronunciarse salvo una excepción, que es una sentencia intermedia, por así decirlo, del año 95, en la cual, de alguna manera, admite la Corte, o introduce el criterio de la posibilidad de existencia de límites materiales implícitos dentro de la Constitución, en ese sentido, pues, es una sentencia bastante interesante, pero que, solamente, aparece esa, y que, rápidamente las sentencias posteriores la Corte cambia totalmente su criterio, qué es lo que ha, uno se podría preguntar, por ejemplo, la reforma de 1990, ¿era válido reducir vía reforma parcial el mandato de X cantidad de tiempo, establecida por el Constituyente en el 87?, y fue lo que sucedió, la reforma del 90 es para adelantar el proceso electoral de 1990, hay un acuerdo político, lógicamente, de esa necesidad, pero se hace uso de la técnica de la reforma parcial para disminuirles el mandato a las autoridades electas del año 84, que, a su vez, son retomadas por la regulación establecida en la Constitución del 87, se le redujo su mandato de 5 años a un poco menos, perdón, de 6 años que establecía para el presidente de la República a un poco menos, y al resto de autoridades de elección popular también se les redujo el mandato superior, debía culminar en enero de 1991 y terminó en abril de 1990, entonces, esa es la primera cuestión, era, realmente, válido utilizar el procedimiento de reforma parcial para reducir mandato, es posible mediante una reforma parcial reducir los mandatos que ya están establecidos en ese punto, verdad, la reforma del 95 además de otras cuestiones que introduce también utiliza esa misma lógica, reduce mandatos, ya no van a ser mandatos de 6 años, ahora van a ser mandatos de 5 años para el presidente de la República, y mandatos de 4 años para los alcaldes y concejales, y mandatos de 5 años para los diputados, también ahí hay otra cuestión que está en juego, ¿no?, en relación a este tema, otro elemento interesante en todos los procesos de reforma que ha habido es que los procesos que no han generado conflicto han sido aquellos en los cuales, Ejecutivo-Legislativo están de acuerdo en la conducción del proceso, por ejemplo, 1990 no generó ningún problema, o no generó ningún conflicto, porque, en este caso, el Ejecutivo y el Legislativo estaban de acuerdo en hacerlo, la oposición y las circunstancias políticas estaban de acuerdo, o se pusieron de acuerdo todos para implementar esa reforma, sin embargo, en el 95, sí ya hubo una crisis o un conflicto en relación al tema de las reformas, y, en ese sentido, el Ejecutivo, no estaba de acuerdo con la reforma, lógicamente, ¿por qué?, porque era la configuración de la Constitución 
original del 87 le había permitido a ese Ejecutivo de 1990 poder caminar sin muchos problemas, incluyendo, por ejemplo, la parte de regulación en el ejercicio tributario, que no necesitaba pasar por la Asamblea Nacional o que había una especie de contradicción dentro de la propia Constitución, por un lado, hacía referencia a la Asamblea con esa capacidad tributaria para establecer el régimen tributario, y, por otro lado, introducía la posibilidad de que el presidente diera decreto con fuerza de ley, pudiese entrar en esa materia también, entonces, ahí se generó una tensión, ahí se generó un conflicto y la propuesta de reforma no vino del Ejecutivo, vino de la Asamblea, vino de la Asamblea y fue la que lo impulsó y la que lo terminó, en el 2000 la cuestión es totalmente diferente, son los partidos políticos, entre comillas, lo pongo entre comillas, porque son, básicamente, los líderes o los caudillos de los partidos, o que demuestran en los partidos políticos, la cabeza visible de los partidos políticos, los que controlan el partido político, son los que impulsan un acuerdo político que luego se materializa en reformas a la Constitución, es decir, primero se da la fase previa del acuerdo político, y luego ese acuerdo político se "juridifica", por así decirlo, o se le configura la parte jurídica, o la determinación jurídica a través de la reforma a la Constitución, entonces, la reforma a la Constitución en el 2000 no genera ese conflicto entre Ejecutivo y Legislativo, y no lo genera, ¿por qué?, porque los dos están de acuerdo, quien gobierna, quien es de un partido político, está de acuerdo con el mayor partido de la oposición, que tiene un apoyo parlamentario significativo, entonces, y el partido de gobierno en ese momento tiene un apoyo parlamentario también significativo, entonces, las dos fuerzas parlamentarias entran en un acuerdo y se reforma la Constitución, o mejor dicho, materializan el acuerdo político, le dan configuración jurídica al acuerdo político, y que, básicamente, la reforma del 2000 amplia las diversas, los cargos de dirección de las instituciones del Estado, con otro elemento muy importante en esta reforma del 2000, que es el tema electoral, que ese sí me gustaría, luego, lo hablamos, porque ahí hay un hilo conductor desde la reforma del 90 hasta la, posiblemente, la reforma del 2000, hasta la del 2005 no lo tocó, ¿verdad?, entonces, ¿qué sucede?, ahí no hay problema, llegamos a la reforma del 2004, en el 2004 la reforma casi nadie la conoce o es poco conocida, ha sido poco debatida, por así decirlo, o con poca información por parte de los medios de opinión pública, y son unos cambios en las reglas del juego, en relación a los instrumentos internacionales, en materia de instrumentos internacionales, que es la configuración del 138, inciso 12, de la Constitución, fundamentalmente, quitando dos cosas: uno, el plazo que tenía el presidente de la República, una vez firmado el instrumento internacional de ser enviado a la Asamblea, que era de 15 de días, y, por el otro lado, el plazo fatal de 60 días, que tenía la Asamblea Nacional para pronunciarse sobre la aceptación o el rechazo de ese instrumento internacional, y si no lo hacían en esos 60 días, automáticamente, el instrumento internacional entraba en vigencia. ¿Esto por qué se hizo?, posiblemente, por la ubicación en el tiempo se hace, porque está casi a las puertas del CAFTA, entonces, una manera de frenar la entrada automática de ese instrumento internacional fue reformando la configuración de ese inciso, del inciso 12 del artículo 138, en la actualidad, el presidente de la República no tiene un plazo establecido para enviar, una vez que ha firmado, a la Asamblea Nacional, y, por el otro lado, la Asamblea Nacional tampoco tiene un plazo de cuando debe entrar a discutir ese tema para su aprobación o su rechazo, ¿verdad?, y, luego, aparecen las reformas del 2005, las reformas del 2005 sí generan tensión, y ¿por qué generan tensión?, porque hay un Ejecutivo, que no está de acuerdo con esa reforma, pasa un poco, guardando las distancias, y es curioso que pase, porque son las dos reformas más profundas, las del 95 y las del 2005, en las cuales no hay una misma, digamos, lógica o visión de las cosas, tanto del Ejecutivo y del Legislativo, existe en la del 2000, porque está de previo al 
acuerdo político, entonces, no hay problema, en cambio, en la del 2005, sí se ve que el Ejecutivo, que no tiene apoyo parlamentario, ¿verdad?, genera ese conflicto con las fuerzas parlamentarias más importantes que se unen, y que lo que hacen, creo yo, que es retomar el punto de partida, y su punto de partida es el acuerdo político del 2000, es decir, o el acuerdo político del 99, consagrado, jurídicamente, en el año 2000 a través de reformar la Constitución, entonces, lo que vuelve a aparecer en escena es que los que, por alguna razón, habían dejado, por así decir, de fiar un poco, o se habían alejado, en ese acuerdo, vuelvan y retoman esa lógica e impulsan un proceso de reforma a la Constitución, un proceso de reforma a la Constitución, el cual va a afectar al Ejecutivo, igual como sucedió en el año 95, hay una intención de reformar la Constitución, y de esa reforma a la Constitución se va a afectar al Ejecutivo, y, lógicamente, el Ejecutivo de turno reacciona al no querer esa reforma, y lo mismo sucede en el año 2005, hay un acuerdo de las principales fuerzas políticas con representación parlamentaria en terminar, por así decirlo, o en continuar disminuyéndole facultades al Ejecutivo, y, en este caso, obligar al Ejecutivo que pase por el procedimiento de ratificación de ministros, el procedimiento de ratificación de diversos cargos, que son de designación, por parte del Ejecutivo, pero que para que el cargo quede firme tiene que pasar por el procedimiento de ratificación por parte de la Asamblea Nacional, en ese sentido, se puede ver como, efectivamente, son reformas en la cual no hay un acuerdo, o no hay ningún acuerdo, digamos, entre el Ejecutivo y el Legislativo, más bien lo que hay es una tensión muy alta, en relación al tema y que, aún así, el Legislativo las lleva a cabo, si las del 95 costaron un poco, por así decirlo, pero la terminó produciendo, introdujo elementos suficientes, que les va a permitir que en cualquier otro momento, cuando se genere un conflicto Ejecutivo-Legislativo, en temas de reforma y que el Ejecutivo no esté de acuerdo en relación a ese tema, tiene los elementos suficientes la Asamblea para llevarlas a cabo, y no necesitar del visto bueno, por así decirlo, del presidente de la república, que fue lo que sucedió en el 2005, otro elemento curioso, u otro elemento que nos conecta bastante la del 95 con la del 2005 es el elemento de que para resolver las tensiones, para resolver la crisis se plantea la existencia de la denominada Ley Marco, que no es más que una norma de rango inferior a la Constitución, que viene a contradecir lo establecido en la Constitución, o viene a limitar, mejor dicho, la entrada en vigencia de la reforma, diciendo: "estas reformas van a entrar en vigencia cuando, en $\mathrm{X}$ plazo, o cuando yo diga que van a entrar en vigencia", lo cual se vuelve un absurdo desde el punto de vista jurídico, porque rompe la lógica del principio de supremacía de la Constitución, pero, curiosamente, ha sido la salida mágica que se han inventado tanto en el año 95 como en el año 2005, el Legislativo y el Ejecutivo para superar la crisis, mira, a mí me sorprende este punto, porque es que, de forma mágica, a través de una norma todos se ponen de acuerdo y todos dicen esto es la salvación de esto, y ya se olvidó la crisis, ya pasó todo, ya todo se aclaró, y sí, puede generar unos resultados positivos e interesantes desde el punto de vista político, como esa norma hace que todos entren en la idea del consenso, y en la idea de tratar de ordenar sin llegar, o de resolver el conflicto, mejor dicho, pero, por el otro lado, esos elementos de naturaleza política y que son bastante interesantes van en detrimento de lo que establece el propio sistema jurídico, es decir, ponderan más el peso político que el peso jurídico, o tiene mayor peso el peso político que el peso jurídico del ordenamiento, lo cual, pues, tampoco te ayuda mucho a construir un sistema democrático, y, en ese sentido, las dos reformas, la del 95 y las del 2005, son bastante similares, ¿cómo?, no hay acuerdo entre el Ejecutivo y el Legislativo sobre las mismas, y, por otro lado, se genera una crisis, y se genera una tensión que va en escalada, que va en escalada, se aprueban ambas reformas, se hace todo, se manda publicar, inclusive y todo, entran en vigencia y todo, y, de repente, para 
resolver la crisis aparece una solución salomónica que son las denominadas leyes Marco, pues, la primera Ley Marco en el 95, y la segunda Ley Marco en el 2005, y con ese acuerdo, que es un acuerdo político, que volvemos a lo mismo, que le dan carácter normativo a través de esa figura, que, al final, es una ley de carácter ordinario, pues, como, curiosamente, logra poner fin de manera milagrosa al conflicto que tienen los poderes, que es un conflicto de naturaleza política, pero, si bien, se resuelve el conflicto de naturaleza política, pero se debilita el marco jurídico del país, entonces, creo yo que lo primero que hay que pensar es que antes de actuar, en ese sentido, pues, hay que tratar de ver las distintas posibilidades y buscar resolver el conflicto político a través del canal político, pues, y no llegar a última hora a utilizar una inadecuada figura de tipo jurídico para darle la forma de que todo está dentro del marco jurídico. Otra cuestión interesante, y que, o sea, es de discusión en el mismo procedimiento de reforma, si ya partíamos del inicio, de que la tesis primera es que todo se puede reformar vía reforma parcial, es decir, todo se puede se puede cambiar en la Constitución vía reforma parcial, que esa es la tesis que prevalece o ha prevalecido en los actos políticos y en la propia jurisprudencia de la Corte Suprema de Justicia, si bien eso, el procedimiento de reforma tiene varias cosas que todavía no están muy claras, o que no dejó muy claro el Constituyente cuando las diseñó, y que tampoco la Corte Suprema de Justicia ha hecho un esfuerzo, en ese sentido, por aclararnos en qué consisten estas cuestiones, en primer lugar podría ser el tema de la discusión en dos legislaturas, ¿qué se entiende por discusión en dos legislaturas?, la práctica parlamentaria sobre todo de la reforma del 2000, y la reforma del 2005, ha establecido de que por legislatura en nuestro sistema se entiende el año calendario de trabajo de la Asamblea Nacional, desde inicios de enero hasta finales de diciembre, incluyendo el período de vacaciones, ¿verdad?, entonces, la práctica ha introducido la lógica de que las reformas se presentan casi a final del año, se discuten en un par de días, por así decirlo, se aprueban a finales del último día de que termina el período de trabajo, se aprueban en esa primera legislatura, $\mathrm{y}$, rápidamente, cuando inicia el segundo período, cuando inicia el segundo año, e inicia el segundo período de trabajo la Asamblea, se aprueba en segunda legislatura, esa ha sido un poco la práctica, tanto en la reforma del 2000, como en la reforma del 2005, entonces, en ese sentido, uno se pregunta, ¿qué se entiende por discusión en dos legislaturas?, la Ley Orgánica de la Asamblea Nacional, que es, relativamente, reciente, del 2008 para acá, introduce el criterio de que la aprobación de la segunda legislatura tiene que darse en los 60 primeros días de la siguiente legislatura, con lo cual viene a limitar la parte de la Constitución, que, simplemente, te hablaba de discusión en dos legislaturas, porque ya está obligando a que esa discusión se traslade o se ubique en el tiempo durante los dos primeros meses del siguiente año, lo cual, pues, te permite, si ya tenés el acuerdo político al final de la primera legislatura, te permite, de alguna manera, seguirlo manteniendo, es más difícil que se rompa, en esos primeros 60 días, a que, es más fácil retenerlo en esos primeros 60 días o no regularlo, que dejarlo a que pase todo el año, y que se discuta en cualquier momento, aunque se mantenga durante todo el año, entonces, la Ley Orgánica de la Asamblea ya introduce ese criterio, lo cual va a limitar en relación a lo establecido por la Constitución, también hay otra discusión sobre qué se entiende por debate o discusión en dos legislaturas, para algunos las cuestiones introducidas en primera legislatura tienen que aparecer íntegras en segunda legislatura, bien, si esto fuese así, posiblemente no estaríamos hablando de debate en dos legislaturas, más bien, sino bajo una lógica de ratificación en segunda legislatura, si yo tengo un texto que no le puedo hacer ningún cambio, punto y coma, nombres $\mathrm{y}$ apellidos, como se suele decir, si no le puedo hacer ningún cambio, tal como lo aprobé tengo que aprobarlo, no va a haber una discusión en segunda legislatura, tengo que 
hacer o no una ratificación de ese texto, y, en este sentido, hay dos posturas, o ha habido dos posturas, una postura que dice no, o sea, lo que apareció en primera legislatura con sus puntos y comas, con sus nombres y apellidos tiene que aparecer en segunda legislatura, si no es inconstitucional, en cierta forma, la Corte, de alguna manera, se ha pronunciado, tímidamente, y ha establecido de que no se puede introducir en segunda una cuestión que no fue discutida en primera, eso tiene bastante sentido, sin embargo, más allá de esa cuestión el tema de qué es lo que se discute en primera, y qué se discute en segunda ha sido por un elemento, valga la redundancia, de discusión, y el no ponerse de acuerdo ni, creo yo, que por parte de la doctrina, ni por parte de la misma jurisprudencia de la Corte Suprema de Justicia, porque mi percepción, o mi opinión, lo importante es introducir un tema a discusión, que sea lo que yo quiero reformar, por ejemplo, yo quiero introducir más mecanismos de control sobre el Ejecutivo, perfecto, eso es lo que quiero, en esa primera aproximación que yo hago, introduzco que los ministros, los vice-ministros, y ciertas personas van a estar controladas, y así lo aprueban en primera legislatura, pero a lo mejor de la discusión en segunda legislatura aparecen planteamientos de que no solamente esos cargos tienen que ser sujetos de control, también hay otros cargos del Ejecutivo, que pueden ser sujetos de control, que administran grandes cantidades de recursos, que esto y que lo otro, y que, de alguna manera, tienen que ser sujetos de control, y que no estaba planteado en primera legislatura, creo yo que esa es la lógica de la discusión en dos legislaturas, o sea, plantear el tema objeto de reforma, más allá del punto y coma, más allá de los nombres $\mathrm{y}$ apellidos que yo quiero que la norma quede al final redactada de esa forma, lógicamente, yo lo que no puedo es venir en segunda, y, en ese sentido, es muy lógico el análisis que hace la Corte, lo que no puedo es venir en segunda a plantear cosas, que, totalmente, tema de objeto de las reformas, temas que no han sido tocados en primera legislatura, pero también este es un tema en el cual no ha habido consenso, en qué se entiende por disfunción en dos legislaturas, el otro tema es el tema de los contenidos, verdad, la Ley de Amparo se reforma en el año 95 después de las reformas del año 95, y se introduce en el artículo 6 que no se puede recurrir contra la reforma parcial a la Constitución, una vez que entre en vigencia, por aspectos relacionados al contenido, únicamente, por aspectos relacionados con la forma, es decir, que si durante el proceso de tramitación se generaron algunos vicios procedimentales, entonces, yo puedo recurrir, pero para controlar el procedimiento y no el contenido, verdad, entonces, esa redacción que fue introducida en la reforma de la Ley de Amparo de 1995, y que está vigente en la actualidad, es lo que ha dado pie a que la Corte Suprema de Justicia siga manteniendo su tesis de que a ella ya no le compete valorar los contenidos de la reforma, solamente, puede entrar a controlar el aspecto procedimental, y esos elementos han sido los que quienes primero los han marcado han sido los políticos, que han conducido los procesos de reforma, y que fueron los que reformaron la Constitución en el 95, y que reformaron la Ley de Amparo para introducir ese criterio en la Ley de Amparo, que no aparecía por ningún lado ni de la Constitución, ni en ninguna otra norma, entonces, eso hace que, como te decía, la tesis que impera tanto en los políticos que son los que conducen o han conducido los procesos de reforma y la Corte Suprema de Justicia, a través de su jurisprudencia, ha sido de que, básicamente, todo se puede, si no hay límites materiales, entonces, vos concluyes, rápidamente, de que todo se puede cambiar vía procedimiento de reforma parcial, eso, lógicamente, en la práctica introduce una serie de elementos peligrosos al sistema, y, con lo cual, vos te podrías encontrar, a lo largo de un tiempo, una Constitución, que, originalmente, fue diseñada de una forma, y que vía procedimiento de reforma ha sido totalmente cambiada, vulnerando el marco general de un fraude a la Constitución en cuanto a la diferenciación, que establece la 
propia Constitución, entre el poder constituyente del poder de revisión o reforma, es decir, el poder de revisión tendría asumidas funciones que no les están permitidas, que son de competencia exclusiva del poder constituyente, y el poder de revisión adaptaría una Constitución en el tiempo, cambiaría la Constitución, totalmente, en el tiempo, sin pasar por un nuevo proceso constituyente, entonces, eso es lo peligroso de la utilización del proceso de reforma parcial para cambiar todo lo que se te pueda imaginar en cuanto a contenido de una Constitución, y al cabo de un tiempo vos tendrías una Constitución totalmente diferente, que es un poco lo que le ha pasado a la Constitución de Nicaragua, cuado uno analiza las diversas reformas, tal como fue configurada en el 87, no tiene mucho que ver a la Constitución vigente en el 2009, y todo el mundo siempre a la hora de defenderla todos te dicen lo mismo: "ah, pero es que lo hicieron en el 90, ah, pero es que lo hicieron en el 95, ah, pero es que lo hicieron en el 2000, ah, pero es que lo hicieron en el 2005", pero nadie se detiene a pensar de que lo del 90, lo del 95, lo del 2005, a lo mejor no es el procedimiento adecuado para generar estos cambios, no es que estemos en contra de los cambios a la Constitución, no, hay que ver qué es lo que se quiere cambiar, pero después hay que ver cuál es el procedimiento adecuado para generar esos cambios, se puede a través de un procedimiento o no se puede, entonces, esos temas siempre han estado presentes en la discusión, y son los que, de alguna manera, han generado conflictos entre el Ejecutivo y el Legislativo, curiosamente, como te digo, los dos momentos de reforma que más conflicto han generado han sido la del 95 y la del 2005, y son las dos reformas de mayor peso o de mayor contenido, en relación a lo que se ha cambiado.

R: De todos modos, en la hipótesis que yo manejaba comparando los juegos de poder que hay detrás de cada proceso de reforma, quiénes son los actores políticos de las reformas, Shugart y Mainwaring, que son dos politólogos norteamericanos distinguen, digamos, los poderes constitucionales de los poderes partidarios del presidente, ¿no?, $y$, en este sentido, aunque se ha debilitado la facultad constitucional del Ejecutivo presidencial desde el 95 hasta ahora, si es cierto que Arnoldo Alemán y Daniel Ortega han sido hombres politicos fuertes, con un control importante sobre sus partidos políticos respectivos, ¿no?, sobre sus clientelas políticas también, porque en un sistema presidencialista la cultura política de Nicaragua coincide un poco con lo que Linz llama el "patronazgo parlamentario”, ¿no?, a la hora de agregar votos y de aprobar leyes en este caso, pero si es cierto que ellos fueron hombres fuertes mientras que Violeta Chamorro, y, sobre todo, Enrique Bolaños fueron presidentes que no tuvieron el apoyo de su partido, y que se enfrentaron, en el primer caso, porque la coalición gubernamental se disolvió, prácticamente, pocas semanas después de la llegada al poder de Doña Violeta, y, en el segundo caso, porque Enrique Bolaños trató de enfrentar al líder liberal, Arnoldo Alemán, con un cálculo político, según he oído en alguna entrevista, un poco ingenuo, que motiva esa división del liberalismo y el socio del pacto, el socio ganador, fue, en este sentido, Daniel Ortega, ¿no?

O.G.: Sí, sí, yo creo que sí, fíjate, es curioso como los momentos de crisis en cuanto a las reformas han sido por Ejecutivos, que no tienen ni partido político, ni apoyo parlamentario, en los momentos de reforma con acuerdos que no generan conflicto, salvo excepción quizá la del 2004, que no generó conflictos, pero tampoco tenía el Ejecutivo ni el partido ni el apoyo parlamentario, es más, en el 2004 está la anécdota de que el Ejecutivo se sentía muy contento porque ya había entrado en vigencia el KAFTA, igual la Asamblea casi hay que celebrar, y en la Asamblea lo mandaron a leerse $L a$ Gaceta de julio del 2004, en el cual se había reformado ese artículo, y nadie se había 
dado cuenta de que se había generado su proceso de reforma, entonces, salvo esa excepción, las otras dos tienen esa característica, un presidente o una presidenta, un Ejecutivo que no tiene ni apoyo parlamentario ni apoyo del partido político que lo llevó a la presidencia de la República, y eso es totalmente, así ha sido, pero también, por ejemplo, ahorita, la propuesta actual, o el momento actual, vos te encontrás con un Presidente que tiene un partido político, que tiene un cierto apoyo parlamentario, porque no ha demostrado tenerlo, el total apoyo parlamentario, para emprender este proceso de reforma, pero que sí tiene un apoyo parlamentario significativo, y que convenciendo a los otros no va a tener ningún problema en generar un proceso de reforma, porque aquí sí, por primera vez, va a aparecer una reforma, bueno, en el 2000 también apareció, o sea, con una clara intención o intenciones por parte del Ejecutivo, quién ejerce el Ejecutivo, por ejemplo, en el 2000 apareció el tema de la diputación automática por parte del ex-presidente saliente, y en este aparecería, claramente, el tema de la eliminación de la posibilidad de reelección, simplemente, lo que haría esta reforma es quitar lo que está en la Constitución, y no decir, absolutamente, nada, lo cual permitiría, sin ningún problema, la posibilidad de postularse de nuevo a otro mandato, sería como arrancar de nuevo a partir de esta nueva redacción.

R: En este sentido, la reforma del 2000, he oido en alguna entrevista también, calificándola como una especie de "contrarreforma", yo creo que la reforma del 2000 sí marca un punto de inflexión en la senda constitucional que inaugura la reforma del 95, ¿no?, como te decía no es una cosa nueva, ya sucedía en los pactos que se dan entre el Partido Conservador y el propio Somoza a lo largo de las casi cinco décadas en que gobierna Nicaragua antes del periodo revolucionario, ¿no?, y que sirve para dar una estabilidad, pero yo creo que, en este caso, fue más bien un cierre de espacios políticos de fuerzas alternativas, tú hacias referencia antes a la Ley Electoral, sorprende mucho que quienes reforman son, precisamente, aquellos que acceden a la representación parlamentaria, y se ha regulado la elección legislativa, de diputados a la Asamblea, por leyes distintas desde el 90 hasta ahora, ¿no?

O.G.: No, de acuerdo, contrarreforma, no, puede ser una contrarreforma, pero más que con la contrarreforma es, si uno analiza la reforma del 95 y la reforma del 2000, creo yo que la trascendencia está en la reforma electoral, no tanto en otras cosas, que reformó la del 95, otras cosas que reformó la del 95 todavía están vigentes, y se avanzó en ese sentido, en materia de regulación de derechos, de establecimiento, algunas cosas se limitaron, pero en el tema electoral, mi tesis es que el punto de partida de todo esto está en la propia reforma del 95, ¿en qué sentido?, en materia electoral, en el año 95, existía la posibilidad de que yo como ciudadano pudiese recurrir a la revisión ante autoridad jurisdiccional por parte de las decisiones del Consejo Supremo Electoral y en materia electoral, en el año 95 se imposibilitó eso, y se estableció en el 173 párrafo final, que de las resoluciones del Consejo Supremo Electoral en materia electoral no se admite recurso alguno, ni ordinario ni extraordinario, eso, esa regulación de por sí, ya coloca al poder electoral en un poder intocable desde el punto de vista jurídico, porque sus decisiones no son controlables en vía jurisdiccional, y le introduce una característica que, aparentemente, no la tenía y es que le da jurisdicción al Poder Electoral, lo vuelve un órgano jurisdiccional fuera del órgano jurisdiccional que ostenta el monopolio de lo jurisdiccional, que es la Corte Suprema de Justicia, entonces, en ese sentido, se crea una jurisdicción distinta de la jurisdicción controlada por el poder judicial, y distinta de la jurisdicción militar, que si bien es una jurisdicción aparte, pero que sus decisiones son controlables por el Poder Judicial, en el caso del Consejo Supremo Electoral no existe la 
posibilidad de controlar, jurisdiccionalmente, esas decisiones, eso es un elemento que le introduce al sistema democrático, como te digo, aspectos que lo vuelven un superpoder, o un suprapoder, un poder por encima de todo, y que tiene que ver no con el Ejecutivo, no con el Legislativo, no con el Judicial, no, tiene que ver con el que, por así decirlo, se encarga o tiene la gran función de la conducción del proceso electoral, y el que termina diciendo quién es el vencedor y quién no en un proceso electoral, quién sale electo y quién no sale electo en un proceso electoral, es quien cuenta los votos, y quien dice quién fue electo o no, verdad, entonces, eso más lo que introduce en el año 2000 se vuelve un sistema a partir de ahí en el cual mientras perdure el acuerdo político, desde el punto de vista jurídico, se vuelve un sistema controlado, totalmente, por ese acuerdo político, porque ¿qué sucedió?, después de esa reforma electoral, de la reforma del 95 introduciendo esa cuestión en materia electoral, si bien, es cierto, se hizo una nueva Ley Electoral, y en esa nueva Ley Electoral se permitió, por ejemplo, la posibilidad de la suscripción popular, es decir, de las candidaturas populares sin necesidad del partido político para alcaldes, vice-alcaldes y concejales en el ámbito local, lo cual daba, pues, o aportaba al proceso democrático un elemento bastante interesante, y en alguna medida, pues, de, ya no se requería ganar una elección a través del partido político, y yo, personalmente, podía, a través de un movimiento popular, debidamente inscrito, esto y lo otro, podía participar en el proceso electoral, y quedar electo si la gente me votaba, verdad, ¿qué sucedió en el año 2000?, en el año 2000 después de la reforma a la Constitución, rápidamente, esa reforma del 2000 tiene como dos grandes puntos: uno, el ampliar todos los cargos de dirección de las principales instituciones del Estado, de la Suprema Corte hay 12 Magistrados pasa a 16 y se aumentan 16 conjueces, aparece la figura de los conjueces, la Contraloría, que es un órgano unipersonal, en el año 2000 pasa a ser un órgano colegiado, ya no hay un contralor ni un segundo a cargo de la institución, sino que van a haber cinco contralores propietarios más tres suplentes, ¿ya?, el órgano se amplía, en el caso de Consejo Supremo Electoral pasa a ser de 5 a 7 con 3 suplentes también, 7 propietarios y 3 suplentes, y así, sucesivamente, todas las instituciones, y se crean otras instituciones, por ejemplo, aparece el Ministerio Público en la reforma del año 2000, y ahí la persona que lo dirige está el Fiscal General y hay un segundo, que es el Fiscal General adjunto, ¿verdad?, entonces, ese sería como un punto, uno de los contenidos de la reforma del 2000, luego, tenés el otro que es un punto muy importante, y que está referido a la materia electoral, en ese sentido, la reforma ¿qué es lo que hace?, va el techo electoral del $45 \%$, que establecía la reforma del 95 para ganar una elección, porque la constitución original lo había establecido con cuánto, exactamente, del porcentaje te decía que ganaba el que obtuviese más votos, pero no te había establecido un porcentaje específico de cuánto se traducía esa obtención de votos, la reforma del 95 te dice que gana el que saque más votos, pero que se entienda que esté dentro del $45 \%$ del total de votos válidos, y te introduce la segunda vuelta para aquellos que no lleguen al $45 \%$, la Constitución original no tenía segunda vuelta, la reforma del 95 te establece cuál va a ser ese techo, que va a ser $45 \%$, y te dice que si nadie llega a ese techo va a haber una segunda vuelta, y aquí, como te decía, que hay un elemento, el elemento electoral, que está como hilo conductor en casi todas, y es el que va, si hay reformas en el 2009 es el que va a terminar de rematar ese hilo conductor iniciado desde el 90 al disminuir el mandato, el tiempo por el cual fue establecido el mandato, y la del 95 que ya comienza a introducir esta mecánica electoral en cuanto a, hasta cierto punto, traducción o cuantificación de los votos, verdad, entonces, pasamos del $45 \%$ a la segunda vuelta, el que no llega a $45 \%$ va a una segunda vuelta, así quedó con la reforma del 95 más la imposibilidad de recurrir ante órganos jurisdiccionales de las decisiones del Consejo Supremo Electoral en materia electoral, con eso se sella, con eso se 
establece una buena base en materia electoral, después llega la del 2000, y te introduce ese criterio de que ya no va a ser el $45 \%$, sino que va a ser el $40 \%$, se baja el techo electoral, y además de eso si nadie llega al $40 \%$ se va a introducir la posibilidad de que llegando al $35 \%$, y superando por 5 puntos al del segundo lugar, automáticamente, se gana sin llegar a $40 \%$, si nadie llega a $40 \%$, pero tampoco llega a $35 \%$ ni superado por $5 \%$ en el segundo lugar, hay una segunda vuelta, y ahí se vuelve a introducir otro elemento dentro de las reglas del juego electoral, que va a ser la disminución del techo electoral, que es pasar del $45 \%$ al $35 \%$ con ese punto intermedio, o esa regla general que es el $40 \%$, pero si nadie llega ahí un $35 \%$ y superado por $5 \%$, automáticamente, se gana sin pasar a la segunda vuelta, pero además de eso no se queda ahí, porque, rápidamente, después de aprobar la reforma a la Constitución en el 2000 se hace una nueva Ley Electoral, y esa nueva Ley Electoral termina de rematar o de cerrar un sistema controlado por partidos políticos, en el cual hay un monopolio de los partidos políticos, y no de cualquier partido político, no, de los partidos políticos, que, en ese momento, tienen la gran cantidad de votos para poner Magistrados del Consejo Supremo Electoral, y para configurar un sistema electoral, a través de la Ley Electoral, tomando como base la regulación constitucional. La Ley Electoral y la aprobación de reformas a la Constitución requiere la misma cantidad de votos, requiere una exigencia de mayoría calificada, que es del $60 \%$, entonces, ahí tenés un elemento, o sea, teniendo votos suficientes para la reforma, por tanto, tenés los votos suficientes para la configuración del marco electoral o del sistema electoral. ¿Qué hace esta ley electoral?, elimina la suscripción popular, la primera cuestión, lo cual quiere decir, ¿sabes qué?, aquí el monopolio del ejercicio de la representación tiene que venir a través de los partidos políticos, los partidos políticos son los que no hay posibilidad de que un ciudadano se organice, se postule, y que gane, no, si no va con el partido político, no hay posibilidad de ostentar o de complementar una parte del sufragio, como sería el sufragio pasivo, con la posibilidad de optar a un cargo público, entonces, ese es un primer elemento, después de eso, se reconfigura el sistema de distribución de escaños, la traducción de votos en escaños, y se introduce la fórmula de la media mayor, en esa fórmula de la media mayor, que ya conocés, perfectamente, porque aquí ya entramos a un terreno más de la Ciencia Política, verdad, eso, pues, hay, al final se diseña un sistema, pensado hacer un sistema mayoritario, un sistema mayoritario muy al estilo norteamericano, el que gana, gana todo, el que saca más votos, saca más escaños, el sistema anterior está bajo la lógica de la proporcionalidad, de la representatividad, y está un poquito pensado a que los chiquitos tengan la oportunidad de tener representación en la Asamblea, eso está configurado a través de la Ley Electoral que se hace en el año 96, y que rige el proceso electoral en el 96 en el que sale electo Arnoldo Alemán, y es un sistema pensado en esa lógica, entonces, rápidamente, el sistema electoral cambia para la siguiente elección presidencial, se reconfigura ese sistema electoral, y se monta un sistema electoral de producto mayoritario del que más votos saca más escaños consigue, y el que menos votos saca no va a conseguir escaños, y en esa configuración de la media mayor, cuando ya el cociente electoral ya no te da, entra el juego esa fórmula que al final beneficia a los dos partidos políticos que más votos han sacado, ¿por qué no se ven los efectos de esa configuración electoral en las elecciones del 2001 que gana Bolaños?, posiblemente, no se vean por el número de partidos que participan en la elección presidencial, entonces, con una configuración como esa, si hay dos partidos políticos en contienda, o hay tres, la posibilidad de que dos saquen más votos y saquen más escaños es altísima, y eso fue lo que sucedió con las elecciones del 2001 en las cuales gana Enrique Bolaños, con una alta cantidad de votos que se traduce, al final, en escaños para el partido que lo lleva al poder, y para el otro partido que es el Frente Sandinista, es decir, una Asamblea 
Nacional controlada por dos partidos, pero, ¿por qué?, porque no hay posibilidad, o sea, no compiten otros partidos en el proceso democrático, ¿qué sucede en el 2006?, el sistema no se cambia, se sigue manteniendo, se sigue manteniendo, ¿por qué?, porque hay una puerta por parte del Frente Sandinista, que al haber bajado ese techo electoral las posibilidades aumentan el ganar, y, por el otro lado, la lógica de Alemán es que él tiene suficientes votos para ganar sin problema de que lo haya bajado al 35\%, pero al electorado no se le presentan dos bloques o dos grandes masas de partidos políticos, sino que se le presentan cuatro, y en ese presentarse cuatro y otros hay una clara división de los dos partidos, o hay una clara fracción, digamos, de los dos grandes bloques, o de las dos grandes masas, por un lado, se presentan dos de carácter liberal, y, por el otro lado, se presentan dos de tendencia sandinista, y al final se comprueba con la participación de estos cuatro y otros, que la fórmula de la media mayor cuantos más partidos hay más tiende a diluir, si vos querés, o a dispersar, exactamente, a dispersar el voto, $\mathrm{y}$, lógicamente, la traducción de los votos en escaños, $\mathrm{y}$, de esa manera, te encontrás con una Asamblea Nacional compuesta por cuatro partidos políticos, y son los efectos que estás viendo ahorita, el Ejecutivo no controla la Asamblea Nacional, y no la controla porque es más fácil entenderse con uno nada más que entenderse con otros, lógicamente, si se entendiera con uno, ya lo hubiese controlado, pero también hay otros elementos que te permiten conducir de que no ha sido posible ese control, entonces, eso para mí es una cosa que está, que quizás no se ve, pero que está en el remolino por así decirlo, o en el torbellino del ejercicio de la política, está continuamente presente, y otro ejemplo o una clara manifestación de eso es la eliminación en la contienda municipal de dos partidos políticos, y dos partidos políticos que al momento que se da la contienda, pues, tienen posibilidades reales de quitar alcaldías a los dos grandes bloques de partidos, entonces, volvemos a lo mismo, si la fórmula de la media mayor funciona bien con pocos, porque los resultados que te va a generar son muy positivos para traducir esos votos en escaños, para poco, si yo permito de que haya más partidos en contienda, y partidos con posibilidades reales de obtener votos, eso me va a disminuir mis posibilidades de ganar más escaños, y eso, creo yo, que es lo que sucedió, además de todos los elementos de fraude en el proceso electoral municipal, o sea, esos elementos si vos los juntás, lógicamente, te dan y te marcan una tendencia, que no sé qué irá a suceder en el 2011, si existirá la posibilidad de una apertura al espacio político con una reconfiguración de las reglas electorales, o si no se reconfiguran las reglas electorales, si se mantienen las mismas, y no se abre el espacio político, si se mantienen las mismas y no se abre el espacio político, los resultados, pues, van a ser contundentes bajo esta configuración del sistema electoral existente, y eso lo tienen clarísimo quienes han diseñado el sistema electoral, creo yo, verdad, que lo tienen claro, pues, ¿por qué?, porque son las herramientas, desde el punto de vista jurídico, para asegurarte por lo menos desde ahí, de que tu actividad política te va a liberar un resultado positivo bajo esas reglas del juego jurídico, o esas reglas jurídicas del juego político, verdad, creo yo, que ese es un elemento también que está presente y que no se aleja, pues, de las intenciones de reforma más allá de la intención de poderse volver a postular, de cambiar un sistema, que, bueno, esto sería otro tema de discusión de ver los posibles contenidos de la propuesta de reforma, que hasta la fecha no hay un contenido, digamos, así, real, de que puedas decir, este viene del partido político, que, oficialmente, ha lanzado esto, ninguno de los dos lo ha hecho, más bien lo que hay es una discusión política, únicamente, sin forma, con algunos elementos ahí, con alguna clara intención, por ejemplo, de introducir el elemento de la eliminación de la prohibición de la reelección, pero más allá de eso, pues, se especula mucho cuáles pueden ser esos elementos de fuerte contenido de esa posibilidad de reforma, entonces, al final eso se vuelve una 
discusión política, pero, lógicamente, la posibilidad de postularse a esta persona que gobierna con las características que gobierna, y que no encuentra límites por ningún lado, con un sistema electoral configurado de esa manera, pues, aquí vas a tener como si en aquél momento se decía: "Somoza for ever", vas a tener "Ortega for ever", y con un proyecto político más sólido y más fuerte, siempre y cuando existan recursos, que ese es el punto económico para el sostenimiento de ese proyecto político, si esos recursos procedentes del supuesto origen del petróleo se comienzan a ver, pues, lógicamente, le va a dar sustento al proyecto político, pero si no hay recursos económicos, el proyecto político por sí mismo se tendrá que caer porque no es un reto político construido, y aquí ya me meto más en un tema de opinión política, no es un proyecto político construido sobre la idea de apoyo a través de una intención por parte de quien da el apoyo de fortalecer eso, una conciencia, no hay conciencia, sino que es un proyecto político a través del clientelismo, que te funciona como los animales, o sea, si yo le doy la galleta el perro me levanta la pata, si le quito la galleta y no le doy galleta, el perro no me va a levantar la pata, entonces, lamentablemente, pues, el proyecto se construye bajo esa lógica y cuando hacen falta los reales para comprar la galleta, ya el perrito no me va a levantar la pata, y se va a quedar, pues, quien lo está tratando de que vea como funciona el animal, pues, se va a quedar con que hizo la instrucción pero no tiene el dinero para comprar la galleta para que el perrito levantara la pata, un poco guardando las distancias, y no queriendo comparar a nadie ni con el perro ni con la persona, ¿verdad?, pero sí, un poco, en esa línea.

R: Y ya para terminar, si el actual Ejecutivo es el producto un poco del pacto del 2000, $y$ de la división del liberalismo, el Ejecutivo actual sí ha modificado la Ley de Organización del Poder Ejecutivo, como recurso para gobernar por decreto en ciertas materias administrativas reorganizando también la propia estructura del Poder Ejecutivo, en fin, ya a nivel institucional, ¿no?, y, luego también, creando los CPC, que son una estructura paralela que trata también de organizar a la sociedad civil y de tener preeminencia sobre la aplicación de las políticas públicas, ¿no?, y me refiero, concretamente, al programa de "Hambre Cero", "Usura Cero"...

O.G.: Hay varios programas que les llaman los "ceros", o sea, "Usura Cero", "Hambre Cero", y así varios.

R: Entonces, Ortega ha dado un giro, en este sentido, ya desde la presidencia para tratar de incrementar el poder que tiene el propio Frente, institucional, o sea, yo creo que el Frente en los 16 años de oposición supo penetrar, previamente a alcanzar la presidencia, creo que con cálculo político, el Poder Judicial, el Poder Electoral, y, bueno, en este caso, también la Contraloría, ¿no?, aunque fuese ya un reparto más paritario con el PLC, pero sí hay una visión, digamos, quizá también por el propio, y esta es una hipótesis que habría que verificar, pero el propio Frente al construir ese régimen de Partido-Estado, creo que supo, aprendió del control sobre las instituciones, tengo la impresión de que fue un poco así, al margen de que las élites sandinistas después del proceso de privatización, pues, de alguna forma, supusiera una especie de clase ascendente, que marca también la propia renovación del liderazgo en este país, ¿no?, del liderazgo político, pero sí creo que el gobierno actual del Frente sí está dotado de mayor peso que en los anteriores gobiernos liberales, no sé cómo lo veas tú.

O.G.: Sí, sí, yo creo que sí, fíjate que, curiosamente, no es un peso jurídico, es un elemento curioso, porque cuando uno revisa la configuración del ordenamiento jurídico 
constitucional nicaragüense te das cuenta de que el presidente de la República no tiene la fuerza que se siente con el presidente actual, te das cuenta que la configuración del régimen jurídico no ha variado, salvo algunas excepciones, inclusive, ha fortalecido o ha disminuido el papel del Ejecutivo, por ejemplo, en el caso de la presidencia de Bolaños, que no podía hacer mucho, no podía hacer mucho, porque tenía el problema en la Asamblea Nacional, con Ortega eso no se ha visto, pasa un poco como el período con Alemán, que no se veía el giro que había dado el sistema en el año 95 al entrar la presidencia de Alemán, y no se veía, ¿por qué?, porque Alemán controlaba la Asamblea Nacional, tenía suficientes votos para legislar de forma ordinaria, llegó a tener 52 diputados, con 56 podía reformar la Constitución, y terminó aliándose con el otro y con eso le permitió gobernar, sin tener ningún problema, ¿por qué?, porque, o sea, podía sacar la legislación ordinaria y los temas en que requería del acompañamiento de los otros votos los tenía sin ningún problema, entonces, a Ortega le pasa una cosa similar, lo que pasa es que todavía no se ha visto tan, tan, sobre todo, en los últimos momentos, tan contundente o tan obvia como fue en un primer momento, pero sí, vos tenés a un Ejecutivo, que tiene las mismas reglas del juego, desde el punto de vista jurídico, inclusive, inclusive, las tiene reforzadas para ejercer el control, para establecer los mecanismos de control, porque la reforma del 2005 va en esa lógica, de buscar cómo controlar más al Ejecutivo a través, por ejemplo, del procedimiento de ratificación de ministros, a través, por ejemplo, de la existencia del razonar artículo por artículo, justificar artículo por artículo en el caso del veto parcial, esto es un elemento muy importante, que se introduce en la reforma del 2005, el veto ya no va a ser amplio, ni extenso, no, si yo veto, parcialmente, tengo que decir por qué estoy vetando, artículo por artículo, ese proyecto de ley, que no lo considero que debe pasar, eso hasta la fecha no hemos visto ningún resultado, o sea, que yo sepa, es que ni siquiera ha podido vetar, porque ni siquiera ha podido producir, ni siquiera tiene los 47 votos para sesionar, para hacer el quórum, y mucho menos, si no los tiene para sesionar, difícilmente, va a tener para aprobar una ley, las que ha aprobado las has aprobado, porque los ha apoyado los otros, o sea, al apoyarlo los otros no tienen necesidad de hacer uso de la figura del veto.

\section{R: Pero, por ejemplo, en el caso de los CPC, sí, con el "Bloque contra la dictadura", y fue, precisamente, la Corte Suprema la que decidió.}

O.G.: Sí, lo que pasa es ahí sucedió una cosa muy, bueno, correcto, entonces, vos revisás desde la competencia, desde el aspecto formal que tiene él, y vos decís: "no puede hacer esto, esto y esto y esto", pero, sin embargo, en la práctica lo hace, y lo hace con un respaldo, clarísimo, de un respaldo, pues, institucional, muy importante, que es la Corte Suprema de Justicia, es decir, a pesar de que existen una reglas, por ejemplo, la materia tributaria, que es exclusiva e indelegable de la Asamblea Nacional, legisla en materia tributaria, y se da el lujo de legislar en materia tributaria, sin que nadie haga nada, porque sabe que cualquier cosa termina en la Corte Suprema de Justicia, en la cual él tiene un control sobre la Sala de lo Constitucional, si fuese un recurso de amparo, y el tiene un control en, y, sobre todo, en la actualidad, al fallecer un Magistrado del otro bloque, él tiene un control en el Poder Judicial en ese sentido, entonces, es, creo yo que es un Ejecutivo consciente de que a pesar de no tener una configuración jurídica a su favor, y de más bien defender una configuración jurídica, que le establece una serie de limitantes y controles por la vía de hecho, disfrazado de las cosas que puede hacer, porque puede emitir un decreto, pero habría que ver el contenido de ese decreto para saber si tiene competencia en ese contenido para legislar en esa materia, o para establecer si para legislar en esa materia, es decir, si no tiene, entonces, él está 
consciente de que aún no teniendo el contenido para poder legislar en esa materia, lo hace, y no va a tener ningún problema, ¿por qué?, porque te va a resolver, desde el punto de vista jurídico el que sí tiene esa competencia, ¿no?, lo va a hacer la Corte Suprema de Justicia, en el caso, por ejemplo, de la sentencia de los CPC, es curioso que se declara inconstitucional una norma, que ni siquiera, la sentencia tiene varios elementos, lo que pasa es que a la hora de entrarle a la discusión no se analizan bien cada uno de esos elementos, porque toda la fundamentación que utiliza la Corte para el tema de participación es bastante interesante, pero es una fundamentación adecuada al interés que se quiere sacar de ese caso en concreto, entonces, uno lee, sí, muy bien, muy bonito, muy interesante, claro, este es el respaldo desde el punto de vista doctrinario, desde la lógica de por qué alguien debe participar, y por qué existe la participación ciudadana, eso muy bien, pero aplicado al contexto no tiene mucho sentido, no tiene mucho sustento, pero se utiliza como para darle sustento a lo que querés concluir o a lo que querés llegar, entonces, en ese sentido, cuando se produce, cuando se da una reforma a la Ley de Organización, Competencia y Procedimiento del Poder Ejecutivo, la cual le dice, "sí, usted puede crear secretarías", o sea, la primera reforma que él hace a la Ley de Organización y Competencia es para posibilitar, establecer las secretarías que él pudiese hacer, eso no es ningún problema, está dentro de cómo se va a organizar el Ejecutivo, como va a establecerse el Ejecutivo, no hay ningún problema, yo puedo tener mil secretarías, pero son secretarías que responden a quién, al Ejecutivo, porque están dentro de la Administración Pública, en este caso, la órbita del Ejecutivo, o están bajo la jurisdicción del Ejecutivo, pero lo que no puedo hacer es bajo la figura de secretaría, crear cualquier cosa, que luego va a ser una estructura que, supuestamente, se va a dedicar a la participación ciudadana, que tiene unas características específicas, como es la voluntariedad, la pluralidad, la autonomía e independencia, y después, esa estructura que yo he creado, la he creado ¿cómo?, la he creado dentro de mis competencias, por tanto, yo estoy creando una estructura que está dentro de mí, aunque, diría, que ande por otro lado, que es el tema de los CPC, le hablan de una estructura paralela, pero es que ni siquiera se vuelve una estructura paralela, se vuelve una estructura que está dentro de la misma Administración Pública, y para ahí no tiene competencia para hacerlo, pero ¿quién detiene eso?, cómo vos argumentás a través de los mecanismos jurídicos que existen en el sistema para decir: "oiga, ¿sabe qué?, desde el punto de vista de los contenidos en esta materia, usted no tiene competencia en esto, porque, si bien, puede crear la secretaría, pero una secretaría con estas características no tiene competencia, porque se aleja de lo que es la esencia de la participación ciudadana, en ese sentido, y en eso, yo mantengo una tesis, y es que el tema de la regulación de la participación ciudadana existe una reserva de ley en la Constitución, y, por tanto, si existe una reserva de ley en ese tema, el único que puede producir ley en el sistema es la Asamblea Nacional, y por eso, cuando se habla de participación ciudadana, sí, casi siempre se lee el primer párrafo de la Constitución, no se lee el segundo párrafo, que dice: "la ley va a regular la materia de cómo organizarse, y cómo configurar esta cuestión", en ese sentido, ¿y por qué?, porque estamos hablando de un derecho fundamental, y el constituyente que lo retoma de otras Constituciones del Derecho Comparado es una materia que no se la va a dejar al Ejecutivo, ni a cualquier otro órgano, que tenga capacidad dentro del sistema para producir normas, y regular esa materia, es una materia muy sensible, como es el tema de los derechos fundamentales, por tanto, el constituyente le está diciendo: "usted, legislador, regule esa cuestión, y sea usted nada más", que es un poco la lógica de la reserva de ley, "nadie más se puede meter en esto, usted es el que va a regular esta cuestión”, pero ¿qué ha sucedido en la práctica nicaragüense?, el Ejecutivo se metió a regular esa materia, y el Legislativo no ha tenido 
la suficiente capacidad para decirle que no, y cuando lo quiso hacer, que es el punto, emitió una norma, o sea, reformó la Ley de Organización y Procedimiento diciendo que esa secretaría, que había creado, o sea, le está reconociendo que pudo hacer todo eso, le está diciendo, pero no van a recibir fondos, no van a tener esto, no van a tener lo otro, pero, de alguna manera, implícitamente, el mismo legislador le está diciendo: "sí, pudiste hacer, lo que tenía que haber hecho es que usted no podía crear esa estructura, y, por tanto, yo reafirmar mi reserva de ley que tengo en esa materia", lo que pasa es que no lo hizo, dijo: "no, usted no se puede, usted sí puede organizar todo eso, pero esa gente que está ahí no va a recibir fondos públicos", ¿qué hizo?, rápidamente, la hace, los que se sintieron perjudicados, utilizaron la figura del recurso de amparo, que ese es otro tema para que veás todo el entramado, y un poco tu tesis, cómo ha aprendido a no solamente tener la regulación jurídica, o aún no teniéndola, lo más importante y dentro de esa lógica puede ser el tener o el dominar la estructura que va a decidir formalmente a la hora en que se presenten conflictos, en este caso, el Poder Judicial, porque ¿qué sucedió?, en el 2001 se estaba discutiendo la Ley de Carrera Judicial, y se presentó un dictamen en la comisión que se estaba discutiendo que imposibilitaba el seguir dentro de la carrera judicial a una serie de personas que pertenecieron a órganos represivos del Estado, y que ahora estaban como jueces, que habían pertenecido en el pasado y que ahora estaban como jueces, pues, este grupo de personas decidió recurrir de amparo, hacer uso del recurso de amparo, en la Ley de Amparo, después de la reforma del 95 a la Constitución, hubo en el 95 una reforma a la Ley de Amparo, se introdujo en un artículo que se reformó, se reformaron dos artículos en el 51, la imposibilidad de recurrir de amparo contra actos del proceso de formación de la ley, en otras palabras, lo que estaba diciendo es que el sistema de Nicaragua no admitía control previo, sino una vez formalmente y en vigencia publicada la norma, y estando en vigencia, yo podía activar el mecanismo de control, pero posterior a la entrada en vigencia de la norma no anterior, sin embargo, en ese momento, el tribunal de apelaciones, que es quien tramita ese recurso de amparo, admitió el recurso de amparo contra prohibición expresa, el tribunal de apelaciones sandinista admitió el recurso de amparo, le dio trámite, lo envió a la Sala de lo Constitucional que es la que resuelve sobre el fondo del asunto, y la Sala de lo Constitucional resolvió y sacó una sentencia, que, en materia de derechos fundamentales, es interesante la argumentación que utiliza en materia de derecho, pero que se aleja totalmente del caso, la cuestión de discusión es el caso que si estaba permitido o no estaba permitido por la legislación la posibilidad de activar ese mecanismo, y si no estaba permitido sugerirle a la Asamblea que cambiara las reglas para permitir eso, ¿por qué?, porque eso podía generar vulneración de derechos, pues no, se metió en todo un tema de vulneración de derechos, esto y lo otro, y al final terminó diciendo que eso era inconstitucional, y se declaró la inconstitucionalidad de eso, eso permitió al sistema la posibilidad de recurrir contra actos del proceso de formación de la ley, entonces, ¿qué sucede?, que el recurso de amparo contra el tema de la sentencia, el CPC, está dentro de esa lógica, la ley no se ha terminado de aprobar, y se presenta el recurso, la ley ni siquiera se había publicado, y ya estaba siendo declarada inconstitucional, y ¿por qué?, dentro de esa posibilidad, o sea, dentro de la posibilidad de poder recurrir contra actos del proceso de formación de la ley, y después de eso viene una reforma a la Ley de Amparo en la cual se vuelve de nuevo a regular que no es posible recurrir contra actos del proceso de formación de la ley, y en esa reforma, participan los sandinistas, una vez que ya habían conseguido su objetivo, y una vez que la Corte Suprema de Justicia a través de la sentencia le había dado la razón, porque la sentencia lo que te dice es: "sí, no pueden recibir asignación económica, pero el Ejecutivo está en todo su derecho", y te comienza a dar toda una doctrina administrativa 
de cómo puede crear esas estructuras, pero no entra al fondo de la cuestión, es que no se trata de crear la estructura por la estructura, es decir, se trata de qué van a hacer esas estructuras, cuáles van a ser las funciones, el decreto ese creador de los CPC, primero, si se crea por un decreto, después otro decreto, y al final hay un último decreto en diciembre del 2007, después de esta sentencia, en el cual se termina como decir, todos aquellos decretos que tienen y este es el decreto ya que acumula todos esos decretos, y aquí está la creación, ese es un decreto curioso, el decreto ejecutivo, en el sentido de que deja a un reglamento interno el establecimiento de las funciones de los consejos del Gabinete del Poder Ciudadano, o sea, ni siquiera se atreve, por así decirlo, qué van a hacer esos gabinetes y esos Consejos del Poder Ciudadano, en la actualidad, no sabemos qué hacen, porque no tienen funciones establecidas, porque el decreto creador dejó a un reglamento interno que estableciera las funciones, y, por lo tanto, eso te genera, lógicamente, ¿qué son éstos?, son estructuras del Estado que colaboran con el Ejecutivo en esta materia, pero son estructuras del Ejecutivo, o sea, por tanto, forman parte del Estado nicaragüense, o son estructuras paralelas disfrazadas de una determinada cuestión que colaboran, pero que todavía no tienen claro qué funciones van a realizar, pero que allá andan detrás de lo que hace el Ejecutivo o ahí andan buscando el apoyo del Ejecutivo, en fin, te genera una serie de dudas sobre qué es lo que son, quizás ese es el mejor elemento para mantenerlas, esas dudas, porque si vos sumás el resto de elementos, la forma de gobernar, la forma de conducir, la forma de concebir la política y el ejercicio de la política, a través como partido, a través como persona, a través como Estado, y esa confusión de todo, pues, te permite concluir o sacar tus conclusiones de que, de toda esa conclusión la rentabilidad es bastante alta, y, o sea, hay una confusión en cuanto a la utilización de recursos que no se sabe de dónde vienen, eso es una cosa como, yo le decía a alguien la vez pasada, esto de la cuestión de la cooperación venezolana, como no se sabe nada, o sea, se dice, se maneja, y las cifras que se dicen que han entrado son porque el mismo presidente en un acto público lo dijo, y porque el Banco Central, pues, repite un poco esas cuestiones, pero de ahí nadie sabe qué más es lo que, realmente, ha venido, entonces, al final se vuelven estos temas de que todo el mundo habla de ellos, pero que, realmente, no se sabe qué son, pues, son como los cuentos de aparecidos o de espanto, no te salgás en la noche, porque ahí aparece una serie de cosas que se ve con el reflejo de la luz, y todo el mundo comenta de que ahí aparece a las doce de la noche, esto y lo otro, pero nadie ha visto absolutamente nada, y un poco eso sucede con estos temas, no únicamente, de alguna manera se ven, porque vas viendo la utilización de recursos, de dónde sale el gasto para eso, de dónde sale el gasto para lo otro, de donde sale, entonces, te comenzás a preguntar por todas esas cosas y todos concluyen que se trata de la cooperación venezolana, entonces, todos esos elementos, cuando uno lo pone en el contexto en el que está, y, por otro lado, una oposición que no sabe ni como se llama, que no logra encontrarse, por así decirlo, o que no logra entender el papel de oposición, si hay algo muy positivo en el Frente Sandinista durante los años en que no estuvo ejerciendo el poder es que creo yo que fue muy rentable como oposición, creo yo que eso le permitió cohesionarse bastante como oposición, señalando los puntos o los errores que estaban cometiendo los gobiernos de turno desde la oposición.

\section{R: Pues, si quieres añadir algo más, yo creo que lo hemos tocado casi todo...}

O.G.: Bueno, al final lo único es, prácticamente, que aquí lo que hay como en todo el ejercicio de la política es un poco el tema de las personalidades, de los liderazgos, y, o sea, yo creo que al final uno le da vueltas a la cabeza mucho y llega a una conclusión, 
pues, que al final se vuelve un tema de cómo yo consigo el ejercicio del poder, ¿verdad?, más o menos democrático, más autoritario, menos autoritario, en fin, el margen, digamos, a la hora de clasificarlo tenés una amplia variedad, pero al final se vuelve un poco de eso, o sea, cómo yo consigo el poder, para qué quiero o para qué voy a utilizar ese poder o para qué voy a tener ese poder, y qué es lo que me genera satisfacción a mí como persona, en relación al ejercicio del poder, y creo yo que estamos frente a eso, frente a un escenario en el cual no es que yo tenga el poder, que yo me comporte de esa manera, porque de la noche a la mañana me pareció, no, es porque he venido construyendo todo eso para llegar a este punto, y porque creo yo que conozco muy bien el ejercicio de la política en este país, en este sentido, cuando uno analiza, en este caso, bueno, quién fue el gran favorecido del acuerdo entre Alemán y Ortega, rápidamente, en su primer inicio, decían: "no es que Alemán con esto se va quedar con su diputación, se va a librar de que lo lleven a la cárcel", etc., etc., al final, el tiempo te dio la razón, que el gran vencedor de esto es el Frente Sandinista, y ¿por qué?, porque es un partido político muy bien estructurado, porque funciona muy bien bajo el poder de mando, de manera vertical, de manera que el que se mueve dentro en sentido contrario, inmediatamente, es eliminado, donde no hay posibilidad de generar una crítica a nivel interno, porque quien critica ya sea desde afuera o a nivel interno es, rápidamente, eliminado, no hay posibilidad de que se genere un debate sobre los temas, los temas se conducen como es mi percepción de conducirlos y punto, y eso, pues, como te decía, el tema de la personalidad juega un papel muy importante, porque al final si bien vos tienes todo un equipo de apoyo que te ha ayudado a llegar ahí, pero vos podrías, perfectamente, y conociendo las características de la cultura política nicaragüense generar un liderazgo distinto, teniendo toda esa fuerza y todo ese apoyo, y toda esa estructura detrás, y esas capacidades para mover muchas cuestiones, sin embargo, no hacés caso y decidís conducir la cuestión como uno ve, independientemente, que los otros estén diciendo o te estén cuestionando solo en tu forma de conducir, al final, pues, te volvés lo que algún profesor en alguna época me decía, que cuando ya el que gobierna no escucha se vuelve dictador, y eso es lo que, lamentablemente, pues, yo creo que las circunstancias actuales le sucede un poco a Ortega, lo que pasa es que busca mecanismos de cómo darle por lo menos formalidad jurídica, sobre todo, y esa es su ganancia, o darle esa mampara, que yo le llamo, en muchas cosas, desde el punto de vista jurídico para que todo aparente o se plasme o se plantee como que todo está bien, y todo se hace dentro del marco de lo jurídico, cuando a mí me conviene el marco jurídico, rápidamente, voy y le introduzco los mecanismos necesarios para que me proteja ese marco jurídico cuando no hago caso omiso y sigo ejerciendo el poder, pues, alejándome del ordenamiento jurídico, y como a la par de eso, no es porque yo lo haga porque me guste, porque lo pueda hacer, que a la par de eso no hay nadie que me detenga, a la par de eso no hay nadie que me imposibilite realizarlo de esa forma, que es el otro elemento que, creo yo, que debe estar presente en el análisis, no es porque todo el mundo le tenga temor y pavor a Ortega, es porque quienes ejercen de oposición no hacen las veces de oposición, porque no tiene desde que entró a gobernar una oposición política, a pesar de que llegó con un 38\% del electorado, a pesar de que no tienen grandes respaldos populares por parte del electorado, pero controla casi todo, o sea, controla, desde el punto de vista del ejercicio de la política, sabe muy bien que no hay oposición, sabe muy bien como está de dispersa la oposición, gobierna en base a eso, y no le interesa mucho el ordenamiento jurídico, porque por mucho que el ordenamiento jurídico diga cosas distintas él sabe que tiene una estructura dentro de ese ordenamiento jurídico, que es la competente para resolver conflictos desde el punto de vista jurisdiccional, que le va a responder a sus peticiones y a sus demandas, entonces, al 
final, pues, se vuelve un control, prácticamente, en todo, y en esa confusión se va el Estado-Partido, y ahora, digámosle, Estado-Partido, estructuras paralelas al partido, estructuras del mismo partido, CPC, Gabinete del Poder Ciudadano, en fin, se genera una serie de confusión en el ambiente, que permite, perfectamente, gobernar dentro de esa confusión, o, por lo menos, ir construyendo lo que en mi cabeza debe ser un proyecto político, pero eso siempre requiere de recursos, y ahí es donde está la gran interrogante, ¿tiene los suficientes recursos económicos para desarrollar ese proyecto político?, esa es la cuestión, porque si no los tiene, el proyecto político en algún momento se tendrá que desplomar por sí mismo, si los tiene va a ser más difícil en una circunstancia como esta que se desplome, yo controlo un sistema electoral, yo tengo configuradas una reglas electorales que van en ese sentido, si ese es órgano electoral me dice que yo soy el vencedor, yo soy el vencedor y punto, los demás no pueden hacer absolutamente nada, no tengo una oposición, tengo una sociedad civil que también anda dispersa, tengo una población que poco reclama, que aguanta mucho, que ha tenido una característica ya de cultura social y también de la cultura política determinada, que, prácticamente, lo que siempre ha vivido es una dictadura, verdad, entonces, es un poco más de lo mismo, y frente a todo eso me permite emprender ese proyecto de esa naturaleza, pues, si encima de eso yo tengo los recursos, la cuestión se vuelve más difícil, si yo no tengo los recursos, yo creo que ahí hay una vía de sentido frente a las posibilidades de, lamentablemente, volverse a repetir la historia de Nicaragua con un gobernante más con las características autoritarias de los miles que hemos tenido a lo largo de nuestra historia.

R: Pues, muchísimas gracias Omar. 
ENTREVISTA $24^{37}$ :

Nombre del entrevistado: $\mathrm{D}^{\mathrm{a}}$. Violeta Granera.

Cargo actual: presidenta del "Movimiento por Nicaragua".

Fecha de realización de la entrevista: Managua, 9 de septiembre de 2009.

Lugar: sede institucional de la organización civil: "Movimiento por Nicaragua".

Duración estimada: 1 hora y 17 minutos.

\section{TEXTO - Transcripción 24:}

$R$ : ¿Cómo ha respondido la sociedad civil a los cambios políticos e institucionales que ha experimentado el país desde los inicios de la transición democrática?

V.G.: Aquí, realmente, hubo un cambio drástico con la revolución sandinista, en algunas cosas, pues, ha dejado un legado positivo, pero en el tema institucional, definitivamente, lo que encontró el país en el noventa fue una institucionalidad prácticamente deprimida, por una razón muy sencilla, porque la revolución, como todas las revoluciones era fuente de poder. Entonces, todo se trastocó, también se vivió un período de guerra en los ochenta, y toda esta situación anómala hizo que el país se reinventara, y en esa reinvención, lastimosamente, no estuvo considerado el tema institucional. Aquí se manejaban los Ministerios más bien, había nueve comandantes, y lo que se estiló, lo que se construyó fue una especie de feudo, donde había una repartición de poderes entre los comandantes de la revolución y, lógicamente, esto, pues, después de una revolución, el ambiente no fue favorable para construir la institucionalidad, sino más bien para establecer métodos o sistemas que tenía la revolución como la fuente de legitimidad y de poder. Entonces, esto hizo que en el noventa el país tuviera prácticamente cero institucionalidad, hubo que comenzar desde el inicio y la primera etapa posterior, los primeros cinco años después de la toma del poder de Doña Violeta, el gobierno de Doña Violeta tuvo dos retos fundamentales, uno fue consolidar la paz, verdad, o la ausencia de la guerra más bien y promover la reconciliación en el aspecto ideológico, o sea, fue un gobierno que puso mucho énfasis en tratar de superar el trauma post-guerra, y la polarización y la ruptura del tejido social que se había producido en la década de los ochenta debido al conflicto. Y, por otro lado, se empezó a reconstruir la institucionalidad a partir de la Constitución que se había heredado de los años ochenta. En los ochenta se hizo una Constitución y esa fue, pues, la Constitución que se heredó y con la que se empezó a trabajar la institucionalidad. En el 95 se hicieron las primeras reformas constitucionales de este período, verdad, porque como un paréntesis quiero decirte, y tú seguramente lo has escuchado, es que este es uno de los países, yo diría, probablemente, del mundo, que más reformas constitucionales ha tenido y eso ha obedecido a la debilidad de la cultura política del país, la mayoría de las reformas constitucionales que se han hecho en el pasado en toda la historia del país han tenido objetivos particulares, que más bien obedecían a intereses partidarios o personales que a un objetivo de fortalecer la institucionalidad nacional, en el 95, creo yo, que es una de las pocas reformas constitucionales que se han hecho por lo menos con algunos intereses más allá de los intereses de poder, verdad, partidarios, y ahí se logró equilibrar un poco el concepto constitucional que había en la época de los

\footnotetext{
37 Excelente predisposición de la entrevistada, pero con una orientación del discurso hacia el tema de la participación ciudadana y el rol de la sociedad civil en el proceso de reforma constitucional de la democracia nicaragüense desde 1990 hasta la actualidad.
} 
ochenta que era de mucho poder para el Ejecutivo, o sea, había un presidencialismo exacerbado, con estas reformas del 95 se empezó a trasladar un poco el poder a la Asamblea Nacional y tratar de hacer mayor equilibrio entre los poderes del Estado. Luego se continuó trabajando la institucionalidad dentro de ese marco, ¿no?, y a pesar de que no podemos hablar de que había una fuerte institucionalidad en el país en el 2007, lo cierto es que había habido avances importantes. Yo podría decirte que estábamos enrumbados a construir un país más estable y con mayor gobernabilidad, a pesar de que había déficits y hay déficits enormes en el tema social, en el tema inequidad, no, y en algunas leyes que no estaban viniendo a equilibrar mejor la redistribución del ingreso nacional. Eh...luego, y ese fue un período, Raquel, que nosotros llamamos de transición democrática, que fue cortado de manera bastante abrupta y peligrosa en el 2000 con las reformas constitucionales que fueron pactadas entre los caudillos de los dos partidos más fuertes electoralmente, que es el PLC, con Arnoldo Alemán a la cabeza, y el Frente Sandinista con Daniel Ortega. Esas reformas constitucionales marcaron, de manera digamos institucional, una involución del proceso democrático, y unieron varios aspectos, pues, que pueden ilustrar esta afirmación que te estoy diciendo, pero te voy a mencionar el que me parece que es el más significativo, y que fue que se aumentaron las cuotas, los números de Magistrados en la mayoría de los poderes del Estado para poder hacer una distribución del poder entre estos dos partidos, o sea, el concepto de la cosa pública como, como, como del Estado-botín, desde esa perspectiva, ¿verdad? Esto hizo que comenzara un deterioro acelerado hasta llegar a lo que hoy tenemos y que no es un asunto de este gobierno, es un asunto que viene desde ahí, ¿no? Que son poderes del Estado totalmente cooptados por el poder político, partidarios, que en un inicio se vio como una distribución de poderes entre estos dos caudillos, pero que por las circunstancias, realmente, en lo que se ha convertido es en un poder omnímodo de parte del Frente Sandinista, con algunas migajas de poder que se les han entregado, que se les han dejado a los Magistrados del otro partido PLC. Un ejemplo que ilustra esto, tal vez, es lo que ha pasado con las elecciones municipales recién pasadas, ¿verdad?, donde los Magistrados liberales fueron cómplices del fraude electoral que se cometió bajo la directriz del partido sandinista, no sé si te interesa, pero aquí hay harta prueba de que por lo menos 40 municipios del país tienen ahora alcaldes, autoridades municipales, designadas por el Consejo Supremo Electoral. Fue un...algunos especialistas han catalogado este fraude como el más transparente y el más documentado de la historia de Nicaragua, lo cual es bastante decir, porque Nicaragua en su historia no, no se ha caracterizado, precisamente, por un país con una tradición democrática, verdad, sino al contrario, hemos pasado de dictadura en dictadura, verdad, de diferentes signos ideológicos, entonces, pero como que en el pasado había un poco más de pudor para cometer estos fraudes, esto que pasó en noviembre del año pasado ha sido una cosa que, realmente, ha sobrepasado los límites de la tolerancia, pues, es decir, nunca es aceptable ningún tipo de fraude, pero cuando el fraude se hace de una manera tan descarada, con cosas como que en la noche el Consejo dio el $95 \%$ de resultados en el $100 \%$ de municipios declarando vencedor a un alcalde no sandinista y que al día siguiente se despertara este alcalde con la novedad de que era totalmente al revés los resultados, o sea, fue una cosa descarada, ¿verdad? Esto es el resultado, lo que la misma presidencia de Daniel Ortega que la verdad es que nosotros no hemos cuestionado, la sociedad civil no cuestionamos los resultados de las elecciones del 2006 para el 2007, a pesar de que todavía el $8 \%$ de los resultados electorales de esas elecciones que el Consejo no ha hecho públicos, el $8 \%$ podría significar, porque no lo sabemos, que podría haber necesidad de una segunda vuelta y eso habría cambiado totalmente los resultados electorales. Pero, en fin, hubo información, este, y en aras creo yo de seguir 
adelante, pues, no se cuestionaron, verdad, debidamente, aunque sí ha habido organizaciones como el movimiento que han recordado siempre que ahí había una irregularidad, que se sentaba un precedente peligroso, y que hemos estado viendo con las elecciones municipales la magnitud de impacto que podían tener esos antecedentes electorales. Pero la misma elección, aún cuando hubiera sido transparente, es también producto del pacto, porque el caudillo del partido liberal pactó con Daniel Ortega hacer reformas a la ley electoral, y creo que a la Constitución, bajar el porcentaje de votos necesario para ganar una elección al techo histórico del Frente Sandinista. O sea, antes, aquí se ganaba con un 51\% y el que no llegaba a eso, pues había que hacer una segunda vuelta, en ese pacto que hicieron las cúpulas de esos dos partidos les cedieron al Frente el bajar el porcentaje al 35\% siempre que el segundo partido sacara un diferencial estipulado en la ley. ¿Qué significa esto Raquel?, que Daniel Ortega logró sacar la presidencia con un $38 \%$ de los votos, que es una presidencial que puede ser legal debido a esta reforma, pero que su legitimidad es bastante cuestionable. Es una minoría la que realmente lo llevó a poder, eh...esto, bueno, no tuvimos fuerza para detener esas reformas constitucionales, porque la población todavía no estaba en esos momentos muy clara, de la intencionalidad y de las consecuencias que podían tener el pacto. El "Movimiento por Nicaragua", al contrario, nació por eso, nuestra razón de ser fue ese pacto entre estos caudillos, porque un grupo de ciudadanos y ciudadanas estuvieron clarísimos desde el principio las consecuencias que eso podía tener para la democracia y la gobernabilidad del país, y se conformó el "Movimiento por Nicaragua". Nosotros hemos tenido muchos detractores, porque, la verdad es que no tenemos ningún padrino político, digamos, pues, no estamos con uno, pero tampoco estamos con otro, en este momento, el movimiento nació también porque ese mismo pacto estuvo bastante amenazada la presidencia del ingeniero Bolaños, que fue el último presidente antes de Daniel Ortega, y, pues, el movimiento defendió la institucionalidad en ese momento y, pues, resultó bastante cómodo achacarle al movimiento alguna vinculación política con esta, digamos, una tercera vía, o yo no sé cómo se podrá llamar, que no era ni el uno ni el otro de los tradicionales, pero, lo cierto, es que el movimiento lo que estaba haciendo era defender la institucionalidad, y como prueba de eso nosotros tenemos una autonomía total en relación a cualquier grupo político partidario, aunque hacemos una labor política, nuestra misión es política, la verdad, pero no tenemos ninguna vinculación orgánica con ningún partido político ni con ningún grupo partidario. Eso pasó en el 2000, creo que un poquito antes empezaron las reformas, y bueno, hemos estado lidiando con esta situación desde que subió el presidente Ortega aquí ha habido un acelere realmente del deterioro institucional, o sea, es obvio, hoy en la mañana estuvimos en una presentación de un instituto, FUNIDES, que están haciendo evaluaciones periódicas de la situación económica, y te digo es terrible como todas las gráficas, todos los indicadores demuestran un descenso y ahorita estamos con el desafío de unas reformas fiscales que quiere hacer el gobierno, pero antes de llegar a eso, desde el año pasado, el "Movimiento por Nicaragua" nosotros estábamos sabidos desde muy al comienzo de este gobierno, porque además no es nada original, que este gobierno iba a tratar de perpetuarse en el poder, esa es digamos un poco la concepción que se tiene del poder en esta nueva experiencia del socialismo del siglo XXI, con Chávez, o sea, aquí no hay originalidad, aquí se está repitiendo un patrón, no, que estamos importando, lamentablemente. Entonces, el año pasado empezamos a preparar, el movimiento está trabajando en dos espacios de coordinación: uno que se llama la OPJ, organización permanente pro-justicia, donde hay cinco organizaciones que tenemos ya un par de años de estar trabajando, adelantándonos a lo que ya veníamos venir de intentar hacer reformas constitucionales para lograr la reelección presidencial. Nuestra Constitución 
no prohíbe la reelección, o sea, no habla de la reelección, no, perdón, nuestra Constitución tiene un artículo que prohíbe la reelección presidencial continua y esta propuesta, el mecanismo que quieren usar para la reelección es suprimir ese artículo y con este afán el gobierno ha estado promoviendo, ha intentado diferentes vías, la primera vía fue la de hablar y proponer un cambio de sistema político y pasar del sistema presidencial a un sistema híbrido entre el sistema parlamentario y el sistema presidencial, pero híbrido en el peor sentido de la palabra, porque realmente todas, pero todas las propuestas dejadas, y voy a hablar en pasado porque las han dejado atrás, tomaba lo peor de los dos sistemas, o sea, los mecanismos sin los contra chequeos que tienen ambos sistemas. El movimiento empezó a hacer una campaña fuerte para ponernos a esto, entonces hicimos, tenemos este documento que yo te voy a dar, que es de Gabriel Álvarez, un abogado, muy bueno...

\section{$R$ : De hecho, me reúno con él mañana.}

V.G.: A bueno, entonces no entro en detalle sobre este asunto, porque él es el más indicado para hablarte, él es miembro de la comisión jurídica del "Movimiento por Nicaragua", pero además él tiene su propio peso, es una persona muy reconocida aquí como constitucionalista y él nos estuvo asesorando y él hizo ese estudio que analiza las amenazas y las trampas que tenía la propuesta original de reforma constitucional. Con este trabajo nosotros hemos hecho, tenemos una cantidad de firmas ya recolectadas que las vamos a llevar a la Asamblea después del 15 de septiembre, el movimiento se encargó de recoger firmas para una carta de rechazo, pero más bien a nivel de liderazgos locales, tenemos en todos los departamentos líderes comprometidos con rechazar cualquier intento de reformas constitucionales y la reelección, y también hicimos una encuesta que la presentamos la semana pasada, una encuesta científica, pero para saber qué estaba pensando la gente sobre este tema y, pues, hay un gran rechazo, yo te puedo mandar por correo algunos documentos. Luego, paralelamente, el movimiento es parte de un grupo, que se llama Grupo Promotor de Reformas Electorales, que tiene por lo menos tres años de estar trabajando. Este grupo ya desde entonces venía discutiendo, analizando propuestas para mejorar el sistema del poder electoral, porque ya habían pasado todas las reformas y el sistema quedaba totalmente politizado, ¿verdad? Cuando empezaron las historias de hacer reformas constitucionales la OPJ, junto con este grupo, hablamos con diferentes grupos y hay un gran consenso en que hay que hacer reformas electorales sin que sea necesario tocar la Constitución, o sea, sacamos de la propuesta que teníamos originalmente en este grupo, diez artículos que hay que reformar o diez propuestas de reforma que no requieren tocar la Constitución Política, porque el consenso es no hay condiciones para reformar la constitución, entonces, empezamos a trabajar, hemos estado en los departamentos, hemos hecho reuniones con líderes, etc. Y después del fraude tuvimos que enfocar nuestra estrategia y consensuamos, y lo estamos trabajando pues a nivel local también, una propuesta de reforma que no es sólo reformas sino que es una propuesta para democratizar el sistema electoral y esto implica la destitución de los Magistrados del Consejo Supremo Electoral, un mecanismo de nombramiento de Magistrados que sustraiga a éstos del pacto, o sea, que se haga con criterio de profesionalismo, de idoneidad, etc., para que estas nuevas autoridades sean las que revisen el fraude electoral, nosotros no vamos a dejar pasar el fraude ni lo vamos a dejar, y luego esas diez reformas que nos daría una garantía para que las próximas elecciones se hagan en otras condiciones, pero como precondición a eso estamos exigiendo la destitución de los Magistrados que cometieron el fraude y este nombramiento. Hemos estado cabildeando con las iglesias, con el sector privado, yo 
siento que hay bastante apropiación de esto, todos los sectores, incluyendo la empresa privada en los sectores que han sido más políticos y más digamos diplomáticos y más cuidadosos ya han retomado la propuesta que hemos hecho el grupo promotor y están hablando del cambio de Magistrados, ellos todavía no hablan de destitución, pero como ya viene el nombramiento el próximo año, que se haga con otros criterios, o sea, hay un consenso bastante nacional sobre la necesidad de no llegar a otras elecciones con un sistema electoral como el que tenemos, que tiene cero credibilidad, Raquel, yo creo que en las encuestas es el poder del Estado que tiene menos credibilidad por parte de la población. Entonces, ahí estamos, hemos estado hablando con las bancadas, con los diputados, algunos nos han dicho que es que no hay un mecanismo para destituir a los Magistrados, entonces, o sea, estamos recogiendo 5.000 firmas con una iniciativa de ley que estamos usando, nosotros tenemos una ley de iniciativa ciudadana. Entonces, aunque siempre hay que pasar por los diputados para que lo introduzcan, lo cierto es que queremos hacer el esfuerzo de recoger las firmas para darle más legitimidad a la solicitud, y ahorita ya el movimiento tiene una estrategia, ya comenzamos a recoger firmas, otras organizaciones del grupo también, y estamos trabajando en eso aceleradamente. Entonces, aquí tenemos dos desafíos, Raquel, en el tema que te interesa, uno, que no haya reformas constitucionales, por lo menos este año, porque la reforma constitucional que quieren necesita de dos legislaturas, verdad, lo que ellos quieren hacer es comenzar la reforma este año para usar la legislatura el próximo año para terminar de aprobarla porque el último año de gobierno va a ser mucho más difícil, porque va a haber un gran desgaste político del gobierno, además que eso es bastante normal en todos los gobiernos, pero yo creo que aquí va a ser bastante especial, verdad, entonces, la estrategia nuestra, Raquel, es tratar de evitar a toda costa que haya reformas constitucionales este año. ¿Cómo lo estamos haciendo? Bueno, estamos en una alianza, que yo te diría que todas las organizaciones sociales, casi sin excepción, sin meter a las organizaciones que son satélites del gobierno, pero la mayoría de las organizaciones estamos de acuerdo con hacer nuestros esfuerzos para que eso no ocurra y tenemos una estrategia, verdad, que va desde el cabildeo hasta la presión a los diputados. El PLC, que es, digamos, la otra cara de esta moneda, un poco fea, bastante fea, que tenemos ahorita en el aspecto político, por la presión que hemos hecho, se vio obligado a pedirle a sus diputados que firmen una carta de compromiso que no van a votar por las reformas constitucionales. El Frente Sandinista está diciendo que ya tiene los votos y puede ser, porque ellos tienen mucho dinero de Venezuela, que no lo meten al presupuesto, que lo están manejando de una manera discrecional y sabemos que aquí tenemos unas debilidades terribles, es la cultura política, es muy probable que se pueda empezar a comprar votos. Pero entonces la sociedad civil va a hacer su estrategia, pues, va a salir a la calle y va a hacer una presión individual, porque lo que hemos registrado es que los diputados se esconden en el partido, en el caudillo, el malo de la película es Arnoldo, y yo no es que no diga que no haya actuado muy mal, pero no es el único, verdad, y queremos empezar a trabajar la conciencia ciudadana de que cada diputado tiene que responder en su carácter individual, porque más allá o antes de las lealtades partidarias, ellos tienen una ética y tienen un compromiso con el pueblo que tienen que cumplir. Entonces, estamos empezando a hacer una estrategia de auditoria social individualizada, y otras cosas en esa línea, verdad, para evitar, ese es como el gran desafío que tenemos este año, ese es el desafío diría yo, verdad, porque si ellos logran las reformas constitucionales y logran la reelección, que el único objetivo ahora, Raquel, ya no están hablando de cambiar el sistema, porque ya se dieron cuenta de que la gente los ve como locos, verdad, porque estamos en semejante fragilidad y vulnerabilidad y una cosa que no va a aportar en nada a resolver el problema de la 
pobreza, al contrario, entonces ahora están hablando, el partido de gobierno, de incluir en las reformas el referéndum revocatorio para que la gente crea que con eso vamos a poder quitar al presidente si no está cumpliendo, pero como todo, y en eso estamos también trabajando con la gente, que mientras exista semejante coacción del poder político y público por parte de los caudillos, y, especialmente, del Frente Sandinista, quienes cuentan los votos son ellos y aquí jamás se va a dar un referéndum revocatorio transparente, entonces aquí la consigna es: $\mathrm{NO}$ a las reformas constitucionales, aquí no nos vamos a enredar y paralelamente estamos trabajando estas estrategias, verdad, del grupo promotor, que es ver cómo logramos la suficiente presión que al menos no vamos a lograr la institución de los Magistrados, pero no importa, porque a ellos se les vence el período el próximo año, lo que queremos es mantener a la gente informada, activa, consciente de que estos Magistrados no pueden pasar impunemente con lo que hicieron y crear una presión social para que los nuevos nombramientos se sustraigan del pacto y ver si logramos tener un Consejo Supremo más, total, hay varias ideas, Raquel, y que son de varios grupos, nosotros estamos trabajando en coordinación, y algunos de ellos en coordinación con algunos partidos políticos y anda flotando la idea de que la sociedad civil elabore una lista de 30 personas que sean idóneas, que sean de consenso, acordarlo con las iglesias, con la empresa privada, con todos los sectores, y que pueda ser gente inclusive con alguna vinculación con el Frente o con alguna vinculación con el PLC, o sea, darle a ellos un menú para que escojan, frente a la realidad que es que son ellos los que nombran, verdad, un menú pero que sea gente potable, gente que dé ciertas garantías, verdad, y bueno, trabajar eso, y hacer presión para que sean esas listas, porque no sólo hay que elegir a los Magistrados del Consejo, sino que hay varias elecciones de poderes del Estado que se van a terminar ahorita y que se van a volver a nombrar, o sea, que tenemos una oportunidad de ver si logramos "des-partidizar" un poco los poderes del Estado. Ese es un desafío paralelo al otro, que eso se puede dar el próximo año, por eso te pongo el otro el primero, verdad, que es este año, y luego las elecciones de la Costa Atlántica eso es un asunto del partido, yo te digo en el "Movimiento por Nicaragua", nosotros creemos, que los partidos no deberían de ir a esas elecciones mientras no cambien de Magistrados, pero ellos aducen que sí, hemos hecho mucho cabildeo, pero ellos dicen que si no van pierden la personería jurídica, la opinión de nosotros es que ellos pueden perder su personería jurídica de cualquier manera, porque ya se la quitaron al MRS, no sé si sabes, el Movimiento Renovador Sandinista, se la quitaron a Eduardo, o sea, ellos hacen lo que quieren, o sea, aquí es ridículo estar pensando, ya no se puede estar pensando que aquí se está jugando un juego democrático, porque no se está jugando, lo que hay es una institucionalidad paralela al servicio de los caudillos y cada vez más al servicio del Frente Sandinista que ha manejado muy bien su estrategia y que ha logrado, ciertamente, sacar ventaja, la mayor ventaja de todo esto, entonces, el movimiento no creo que vaya a entrar a promover votos en las elecciones de la Costa, de todas maneras, nosotros creemos, Raquel, que es probable que ellos dejen que las elecciones en la Costa sean transparentes, ellos andas buscando una forma de lavarse la cara y bajar la presión, y entonces la Costa, pues, en realidad, es importante desde el punto de vista ético-social, pero políticamente para el poder no tiene la relevancia que tuvieron, por ejemplo, las elecciones municipales o unas elecciones nacionales. Entonces, nosotros vamos a seguir nuestra estrategia, independientemente de qué es lo pase en la Costa Atlántica y luego hay que prepararse para el otro gran desafío que son las elecciones de 2011, pues, que cómo te digo, lo que pase este año va ha indicarnos bastante cuál es la estrategia que debemos de seguir para las elecciones de 2011. Si las cosas siguen igual, Raquel, yo creo que aquí no hay mucho que hacer dentro del marco constitucional, verdad, el 
"Movimiento por Nicaragua" no sé si te comentó $\mathrm{M}^{\mathrm{a}}$ Jesús, una de las características del movimiento ha sido su poder de convocatoria, o sea, el movimiento no sólo lo hacemos en conjunto, pero fuimos pioneros en convocar las marchas masivas de la población. Ciertamente, esa acción se ha venido debilitando con el nuevo gobierno porque ellos están usando toda la agresión posible en contra de la libertad de movilización, y las marchas que hemos hecho han sido atacadas peligrosamente, todavía no tenemos que lamentar muertes, pero sí ha habido gente herida, hemos tenido que marchar bajo pedradas, bajo morterazos, yo te voy a regalar, ahí en la página web del movimiento puedes ver algunos videos sobre eso, sobre estas cosas y, pues, estamos trabajando con la coordinadora civil, que es otro gran espacio de coordinación de la sociedad civil y tenemos un consenso, yo te diría, mirá, son pequeños los temas en que no hay consenso aquí: el tema del aborto, eso no hay consenso, pero las organizaciones feministas han sido tan inteligentes y están tan claras de la amenaza que hay aquí para la democracia que han decidido no relegar ese tema, porque el gobierno ha creído que con eso iba a dividir a la sociedad civil, y entonces, ellas han decidido que ese tema no lo vamos a poner en agenda, porque es un problema y estamos trabajando, yo no soy pro-aborto, pero sí estoy en contra de la penalización del aborto terapéutico, y yo soy de la que puso demanda en la Corte Suprema de Justicia, o sea, que el hecho es que aquí los derechos de la mujer no son los únicos derechos violentados y que el aborto terapéutico se penalizó porque el Frente Sandinista hizo un acuerdo con la iglesia católica, para ganarse el respaldo de la iglesia católica, o sea, esto es una cosa te digo, que rompió todos los límites de la ética política, verdad, totalmente, entonces, estamos clarísimos de cuáles son los desafíos, por supuesto, el desafío más grande de este país, no te lo tengo que decir, es que aquí la inequidad es espantosa y la pobreza es terrible, pero nosotros en el movimiento que tenemos la misión de defender la democracia, la libertad y el bienestar de todos los nicaragüenses estamos clarísimos de que aquí no va a haber desarrollo posible, que aquí no va a haber superación de la pobreza, mientras tengamos un gobierno autoritario, prebendario, con muy poca transparencia, que está usando los fondos públicos con clientelismo político, y que no ha logrado mantener un mínimo de gobernabilidad. Hoy en la mañana, estuvimos en esta presentación de FUNIDE y llegó el vicepresidente, porque el vicepresidente siempre llega a eso, él es como la cara de...entonces, él hizo un comentario, Raquel, bueno, se tocó el tema de las reformas fiscales, verdad, y bueno, ya te habrá debido decir otra gente que las reformas no son unas reformas tributarias, no son fiscales, son tributarias, el único objetivo que tienen en esas reformas es llenar a través de impuestos la brecha que dejó el congelamiento de la ayuda de la UE, entonces, y el vicepresidente dijo, "bueno, es que yo quisiera...", porque hablaron un poco de la gobernabilidad también, "quisiera yo preguntar si la gobernabilidad es una responsabilidad sólo del gobierno o si todos los sectores del país tienen responsabilidad", entonces, yo pedí la palabra y te voy a decir lo que yo pienso, pues, y que dije ahí, uno, que aquí no es posible que el pueblo tenga que pagar con más impuestos el fraude, verdad, o sea, eso es, desde todos los puntos de vista, no sólo ético, sino económico, porque como bien explicaron hoy en FUNIDES, el país ahorita está que todas las gráficas iban en descenso, y ahorita por razones externas, se ha logrado estabilizar un poquito las exportaciones y la inversión privada, que son los dos pilares en los que se ha sustentado un poquito la economía, mayormente, la economía del país, entonces, ellos explicaban que si se hacen reformas este no es el momento de hacer reformas tributarias, porque en lugar de aprovechar esto para empujar para arriba, lo que puede hacer una reforma tributaria ahorita es más bien deprimir más la actividad económica, entonces, pues, yo lo que dije es que aquí está fácil resolverlo, aquí sólo hay que revisar el fraude y la UE vuelve a descongelar y dar garantías y quitar a los 
Magistrados y ya está, y entonces ya tenemos el apoyo y la confianza de la cooperación y nos podemos enfocar a trabajar en la cuestión económica y social, y lo otro es que, yo le dije al vicepresidente que tenía razón, aquí todos somos responsables de la gobernabilidad, pero los roles son diferentes, el rol de la sociedad civil es el decir que se cumplan la Constitución y las leyes, que los funcionarios a los que les pagamos para eso lo hagan, y el rol del gobierno es cumplir con la Constitución y las leyes, o sea, no estamos eludiendo responsabilidad, pero no nos toque a nosotros el rol que les toca a ellos, ¿no? Entonces, esa es la situación como yo la veo, Raquel, y como la vemos en el "Movimiento por Nicaragua", estamos en una situación sumamente difícil, sobre todo porque Nicaragua no es un caso aislado, o sea, estamos viendo un repunte del mesianismo, y de la loquera, esas políticas pendulares que han caracterizado a estos países, y de los que todos somos responsables, porque en el fondo todo lo que está aquí es una muy poca evolución en la cultura política y una gran inequidad social que hace que nuestros pueblos no tengan la fuerza suficiente para, realmente, controlar la acción del Estado como debería de ser, ¿no? Entonces, sí estamos preocupados, otros te van a contar en más detalle algunas cosas, la cooperación internacional no nos va a venir a salvar, ni esperamos eso, pero lo cierto es que han sido muy consecuentes hasta ahora, ¿no?, ha habido intentos, inclusive, de establecer, de aprobar un manual para las ONGs internacionales, para prohibir que estas organizaciones internacionales no financien organizaciones como el "Movimiento por Nicaragua", ellos quisieran que la cooperación sólo financiara a las organizaciones que hacen letrinas, que hacen escuelas, lo cual está bien, y ojala se siga haciendo, pero ellos no quieren que nosotros trabajemos en los temas de gobernabilidad y de democracia. Eso es lo que a ellos les molesta, ¿verdad?

R: Una pregunta, ¿los Consejos del Poder Ciudadano que han competido con los fondos del Estado y, bueno, de hecho, se han llevado una buena parte de la financiación con dinero público, constituyen una estructura paralela de poder vinculada al Ejecutivo? Así lo han visto la mayor parte de las ONGs, las organizaciones civiles...

V.G.: Así es, así es. Ya nosotros desde el comienzo, Raquel, yo te voy a contar un antecedente, personalmente, yo, cuando asumió Daniel Ortega tenía un año y medio de que me habían nombrado directora ejecutiva del Consejo Nacional de Planificación Económica y Social, dicho sea de paso, era el único cargo en el Estado que yo he tenido en mi vida, o sea, ya al final del gobierno de Enrique, porque yo sí fui miembro de ese Consejo desde que nació, y fui parte del grupo de organización que promovimos la Ley de Participación Ciudadana, que mandaba formar este consejo. Este Consejo era un foro de concertación política y social, y ahí estaban representados, inclusive, delegados de los Comités de Desarrollo departamentales, que a su vez tenía representación de los comités municipales, estaba la gente de la costa del Caribe, estaban los sindicatos, estaba inclusive sindicatos sandinistas, pues, eran bien diversos, la verdad, el nivel de incidencia en el gobierno todavía era débil, pero ya los ministros estaban obligados a llegar, a escuchar a la gente, o sea, se estaba tratando de consolidar. Por una razón de porque ellos estaban comenzando, me tocó estar ahí dos meses y medio ya con el gobierno de Daniel Ortega, porque al presidente anterior se le olvidó destituirme, entonces, yo quedé ahí, y yo estaba clara que yo no podía ejercer ese rol, porque es una especie de puente que requería confianza desde los dos sectores, yo sé que tenía la de la sociedad civil, pero, obviamente, no tenía la del gobierno, entonces, insistí, insistí, mandé mi carta de renuncia, llamaba, lo decía en los medios, y al fin me destituyeron, 
pero yo comencé a tratar de restablecer el diálogo con las nuevas autoridades, e invité, al primero que invité fue al que es responsable del programa "Hambre Cero" por el lado del gobierno. Mirá, Raquel, la gente vino en buses de los departamentos, todo el mundo quería, aquí ganó Daniel Ortega y la gente dijo no importa, los que no votamos por él, veamos cómo salimos adelante, inclusive, yo que nunca he sido sandinista pensé, bueno, tal vez este gobierno ya en la institucionalidad tal vez ellos van a tener un enfoque más social que va a ser una diferencia con los gobiernos pasados, o a lo mejor, buena disposición, verdad, y, entonces, en esos dos meses y medio, llamé a este muchacho, que era mi amigo además, y me dijo que sí, la gente vino en autobuses, la noche anterior me llamó, lo puedo decir porque él me dijo que lo dijera, para decirme que le habían prohibido en la presidencia ir a presentar el programa en el CONDE, luego invité, bueno la Ministra de la Salud sí llegó a la comisión social, no llegó ella pero mandó un delegado, llegó la Ministra del Trabajo, los sindicatos estaban fascinados de que habían logrado el diálogo, que iban a hacer planes, por supuesto, en esa etapa, nadie sabía cuál era la estrategia de participación que el gobierno tenía, pero en cuanto yo me fui, Raquel, cerraron el CONDE, nombraron los CPC y eso se acabó. Y nosotros, el movimiento siempre dijo, el problema no es que existan los CPC, que eso es constitucional, si son partidarios, pues, no hay problema, el problema con los CPC es que el gobierno decidió que iban a ser los únicos interlocutores del Estado, como de hecho ha sido, eso es lo inconstitucional, se ha venido debilitando en algunos lugares más y en otros menos, porque ha echado raíces en algunos municipios y aún alcaldes que son sandinistas han decidido defender los comités de desarrollo municipales, esto es muy dispar, verdad, en unos días va a haber un informe y yo quiero ya ver cómo está científicamente con una investigación el asunto, pero hasta donde yo sé no es parejo, pero sí hay una amenaza seria a toda la institucionalidad, a la participación ciudadana institucional que se había venido conformando y se está usando a los CPC, ellos no han logrado, Raquel, lo que pretendían, porque ellos creían que en un año ellos iban a tener al país totalmente "cepecizado", pues, no sé cómo decírtelo, pero sólo el 7\% de la población, según un estudio que hubo, se ha enganchado con los $\mathrm{CPC}$, entonces la misma gente no quiere, lo que yo siento es que ellos no lo han entendido, es que ya no estamos en los ochenta, Raquel, y todo lo que ellos lograron hacer en términos de control social fue posible porque la revolución tuvo una gran mística, realmente, la gente se enganchó en esto con buena voluntad, mucha gente, y no había libertad de expresión, entonces eran otras condiciones, pero después de toda la corrupción, después de todo lo que ha salido y lo que pasó, la gente y además ya no quiere la gente polarización, Raquel, eso es lo más grave que está haciendo este gobierno, que está volviendo a fraccionar el tejido social, porque lo económico es grave, pero se puede reconstruir, pero los veinte años, los veinte y pico de años que nos costó superar las heridas de la guerra, ya la gente no estaba pensando si uno era sandinista o no era sandinista, ya se había desarrollado una capacidad de poner su comunidad, sus municipios, el país por encima de eso pese a que los políticos siempre han utilizado la confrontación y la polarización para sus propios fines, pero la gente había logrado superar eso. Y ahora, pues, ciertamente, las cosas se están re-polarizando, el movimiento, pues, y las organizaciones que trabajamos esto con la presión social y la movilización cada vez nos está resultando más difícil mantener a la gente sin caer en la provocación de la violencia, porque también hay un límite a eso, ¿no?, porque la gente empieza a decir y porqué sólo vamos a recibir palos, y porqué sólo vamos a recibir piedras, y eso no está en la cultura de este país, o sea, la resistencia pacífica es ajena a este país, nunca en su vida ha buscado un método así, y entonces estamos trabajando aceleradamente para concienciar a la gente que no debemos caer en la provocación de la 
violencia, que este no es un asunto solamente con un gobierno, es un asunto más profundo, tiene que ver con la cultura política, y que tenemos que dar el ejemplo, o sea, que no podemos estar criticando y haciendo lo mismo, bueno, es una lucha buscando formas, tratando de ser lo más creativos posible que todavía no hemos sido demasiado, para que la gente sienta que sí se puede luchar sin recurrir a la violencia.

R: En ese sentido, ¿movimientos sociales como este son alternativas a la participación? Porque si se han cerrado los espacios políticos no dando pie por la ley electoral a que se formen nuevos partidos políticos y, por otra parte, hay fraude electoral y la gente no se puede pronunciar con su voto y quitar de en medio al gobierno que no les interese, ¿cuál es la opción?

V.G.: Y eso es lo que no entienden los políticos, que están jugando con fuego, Raquel, porque si ya no podés ni manifestarte en las calles, o sea, es que estamos llevando al país a experiencias a las que no queremos volver, y por eso es que estamos buscando, estamos queriendo encontrar formas de que la gente no pierda la esperanza, porque puede haber un período de desesperanza, pero eso tiene también un límite ahora, y luego viene, eso es como una olla de presión, ¿no?, después viene la explosión y tampoco queremos que eso llegue. Fíjate que, ciertamente, una de las barbaridades que hicieron con esas reformas fue que quitaron la suscripción popular que nosotros teníamos, que había sido un gran avance de la reforma del 95, la suscripción popular para las elecciones municipales, no era para las elecciones nacionales, pero para empezar a pivotear una mayor apertura de la participación, viendo que los partidos políticos también, como en todo el mundo, está en procesos de desgaste, que tienen que reinventarse, pero que mientras tanto tengo que encontrarle salidas a la crisis, ¿no?, y eso lo quitaron de un plumazo, porque obviamente eso no beneficiaba a los pactistas, verdad, y luego, la gente aquí se puede ver el vaso medio lleno o el vaso medio vacío, verdad, yo prefiero verlo medio lleno, a veces me dicen que soy demasiado optimista, pero la verdad es que uno necesita cierto optimismo para poder dar esta lucha. Yo creo que es muy difícil, no digo que sea fácil, no digo que las cosas hayan estado bien en estos veinte y pico de años, pero sí creo, sin la menor duda, en mi opinión, que estábamos enrumbados y con algunas bases para empezar en algunos otros aspectos que también son importantes como el tema de la inequidad, y que esto que está pasando, esto que ha pasado con el origen del pacto, y que ha continuado y se ha exacerbado con la llegada al Ejecutivo del Frente es definitivamente un retroceso terrible. Pero como yo trato de ser optimista lo que yo veo, Raquel, es que estos son los estertores de una cultura política ya anacrónica, que no se corresponde con la evolución social, siento que a pesar de que tenemos todavía un porcentaje todavía muy alto de analfabetismo, a pesar de la marginalización en que vive gran parte de la población, a pesar de la pobreza, siento que ahora la mayoría de la gente tiene celular, en el campo en muchos lados hay acceso, bueno, la gente tiene radio, hay acceso a la TV ya en muchos lados, entonces, todo eso, ya ha provocado un cambio en la mentalidad, en la cultura política de la gente y eso no lo han visto las cúpulas políticas, entonces, hay en un desfase, en mi opinión, entre las expectativas de la gente y el actuar de la clase política, y eso para mí es una esperanza, porque yo digo, bueno, es cierto, ellos tienen mucho poder ahorita, porque tienen el poder institucional, tienen el poder formal, pero no tienen legitimidad, o sea, aquí las encuestas te lo dicen clarísimamente, es más, muchas de las actuaciones del Ejecutivo y del Frente Sandinista son repudiadas por la misma gente del Frente. 
R: Bueno, es que en este caso, la pareja presidencial ha representado una concentración de poder en su forma de actuar incluso menos transparente de cara a su propio partido...

V.G.: Es que ya mucha gente, a mí no me gusta hablar de sandinismo, porque no es cierto que eso sea sandinismo, o sea, yo conozco mucha gente sandinista que ha evolucionado como todos, pues, verdad, yo nunca he sido sandinista, pero yo te diría que por lo menos el 50\% de mis mejores amigos son sandinistas o vienen del sandinismo y se declaran sandinistas, pero no tiene nada que ver con lo que está pasando, con el manejo que está haciendo el Frente, entonces, nosotros preferimos hablar de orteguismo. Pero, lamentablemente, ellos tienen, pues, la marca del partido, ellos manejan el partido y lo que ha quedado del partido, y tienen, ciertamente, un techo duro electoral, o sea, y es gente, yo me lo explico, nada más, Raquel, por la revolución, o sea, yo creo que la revolución en este país, yo no la viví aquí, yo me fui al exilio, pero igual como te digo me metí a la coordinadora civil, me metí, cuando regresé, para entender, y yo creo que este techo no sólo obedece ni tal vez principalmente a prebendas, a regalías, no creo, yo creo que eso tiene sus raíces en una relación cuasireligiosa que se desarrolló con Daniel Ortega y los comandantes de la revolución en los ochenta, y es gente, obviamente, con menor criterio político, que está enganchada a eso, que siguen creyendo y no va a haber poder humano ni que Daniel Ortega haga lo que haga, que va a romper esos vínculos de lealtad que se establecieron. Sin embargo, en las encuestas donde no expones la lealtad, sí se nota que hay gente del Frente, por ejemplo, que no todas quieren la reelección presidencial y en los noventa fue evidente, si aquí, hasta los mayores electores eran del Ejército perdió el Frente. O sea, que hay una sabiduría ahí popular que sin muchas, sin todas estas complejidades que nos gustan a los intelectuales a veces es más sana y es más espontánea, y no se pierde la gente, y esa es mi esperanza. O sea, yo estoy apostando a la gente, estoy apostando a que esto no es insostenible, y no estoy hablando de la sostenibilidad de Daniel Ortega, estoy hablando de la insostenibilidad de los que exponen ese tipo de cultura política, independientemente del signo partidario.

R: Sobre todo, porque la democracia en Nicaragua ha sido muy cara, en términos de muertes...

V.G.: Sí, sí ha sido una experiencia de gran inmoralidad la traición de los políticos, o sea, no han tenido misericordia con este pueblo, esa es la verdad aquí, y te digo, en mayor y menor grado, verdad, porque no puedes generalizar, yo creo que ha habido funcionarios buenos, políticos buenos, pero haciendo esa salvedad, en general, la clase política no dio el salto de calidad que se merecía este pueblo, y yo creo que, yo te voy a repetir la opinión de un hijo mío que es joven y que refleja un poquito lo que sienten los jóvenes, y creo que es cierto, él me decía: "mamá, el problema que tenemos aquí es que no ha habido un relevo en la clase política, y entonces son ustedes los mismos que crearon los problemas históricos del pasado reciente los que ahora lo quieren componer y eso no es posible". O sea, debería haberse abierto un canal para que sea la nueva generación la que haga las cosas de diferente manera para obtener resultados diferentes. Y eso no se dio, la verdad, vos ves, vos ves, y no sólo en la clase partidaria, en la sociedad civil, los jóvenes hasta ahora estamos luchando, Raquel, porque los chavalos se involucren, comiencen, y ver si de ahí van surgiendo nuevos liderazgos, aunque sea en la sociedad civil, porque en los partidos políticos el problema es que hay muy poca movilidad partidaria por la misma cultura, entonces, los patriarcas, los caudillos se 
entronizan en el poder y no dejan que la gente que viene atrás lo dejen tomar esas posiciones y en la sociedad civil pasa un poquito lo mismo, yo tengo 57 años y el día de la última agresión que sufrimos casi me muero, porque yo tuve que correr de los hombres con palos y llegué sin aire a la catedral, no sé si has oído que hubo...

R: Sí, sí...

V.G.: Bueno, oíme, llegué sin aire porque yo soy fumadora, uno de mis hijos me logró rescatar, y no me alcanzaron los palos, pero yo tuve que correr un trecho que era "too much" para mí, verdad, entonces yo le decía: "chinéame, hijo, chinéame, cargáme”, pero no se podía parar mi pobre hijo, porque venían los hombres detrás, yo iba en el aire, Raquel, corriendo en el aire, pero esa noche yo decía, Dios mío Santo pero es que ya no debería estar yo en esas, o sea, son 57 años, me entendés, no, no, no, ya no, a mí no me da miedo, yo lo voy a seguir haciendo mientras sea necesario, pero, me entendés, eso refleja que aquí es parte de la cultura, porque a muchos nos gusta en la sociedad civil pensar que allá están los malos en la clase política y aquí estamos los puros en la sociedad civil, pero eso no es cierto, o sea, las debilidades de la cultura política nos atraviesan a toda la sociedad, o sea, y las debilidades y los problemas, claro que la clase política, partidaria y gobernante el efecto es mucho más dramático, pero bueno, que ahí estamos luchando, nosotros tenemos un Instituto de Liderazgo con la Universidad Americana, con la UAM, para desarrollar el liderazgo, especialmente, el de los jóvenes, tenemos dos años, estamos trabajando muy duro en eso, y traemos gente de todos los municipios, no sólo de Managua, para ir empujando ese nuevo liderazgo que el país necesita tanto a nivel comunitario, como a nivel nacional, pero eso está bastante y los jóvenes, creo yo, que se han involucrado, hay mucha, no es el caso de Venezuela, que en Venezuela son los jóvenes los que se han manifestado, este no es el caso de Nicaragua, mi lectura es que no lo es porque es muy reciente la experiencia de la guerra aquí, entonces, aunque estos chavalos tal vez no habían nacido sí oyen la historia y aquí hubo un servicio militar obligatorio murieron muchos jóvenes, entonces, yo creo que hay una transmisión generacional que desincentiva la participación política de la juventud con cierta razón, entonces, además de la inmigración, aquí el $90 \%$ de los jóvenes en las encuestas te dice que lo único que quiere es ver cómo salir y muchos se están queriendo ir para España tu patria, o sea, aquí es triste, o sea, la juventud, en general, está clarísima de que este es un país sin oportunidades, $\mathrm{y}$, entonces, como han visto tanto, porque mira, los ochenta fueron caóticos, pero los noventa y el siglo XXI tampoco han sido ejemplares, o sea, aquí hemos visto traiciones, aquí la clase política es camaleónica, cambia, es incoherente, o sea es una vitrina que difícilmente puede estimular el idealismo que se tiene en la juventud, entonces, ha sido muy difícil, muy difícil, además de que hay una situación económica y social terrible. Yo estaba hablando ayer, nosotros tenemos aquí en Managua una gente que se reúne los martes, los viernes, y uno me estaba hablando ayer que el problema, porque la convocatoria ahora nosotros estamos preocupados por eso y ahorita estábamos intentando levantar un poco la moral, porque como la última vez nos persiguieron, no podemos seguir dando esa imagen, y tampoco queremos caer en responder, entonces, estamos buscando formas alternativas que levanten la moral de la gente, pero me estaban diciendo los muchachos, esta gente, que el problema de las marchas y todo esto es el miedo, y ni siquiera principalmente el miedo, porque este país no es un país miedoso, pues, la historia lo demuestra, somos más bien demasiado audaces, el problema mucho es la situación económica, yo lo entiendo, yo lo entiendo, pues, que según gente que no sabe cómo va a comer al día siguiente no le puedes pedir que se movilice, y las movilizaciones que 
nosotros hicimos, Raquel, son espontáneas cómo vamos a competir con todos los millones que recibe el Frente de Venezuela.

$R$ : ¿Y éstos son los que van con palos y machetes, con armas rudimentarias y que además son personas que no enfrenta la Policía?, ¿quién los moviliza?, ¿el gobierno de Ortega?

V.G.: Totalmente, sin la menor duda. Te voy a decir un ejemplo, nada más para ilustrarte, el sábado, éste último que fue la última pero no la primera, quien estaba organizando a la gente era la vice-Ministra de Turismo, ahí tenemos la denuncia, las fotos y todo, con el celular, con el no sé qué, organizando a la gente que nos iba a agredir, y además, mucha de esa gente eran funcionarios de la Alcaldía de Managua y además ellos tienen dos fuentes para la agresión: una es el funcionario público, que los obligan, Raquel, yo tengo amigos de mis hijos, que han llegado a mi casa a decirme: "Doña Violeta, me va a disculpar, pero usted me va a ver en la rotonda, porque si yo no voy me corren".

\section{R: Y armados de sus casas van, ¿o de donde sacan los palos?}

V.G.: ¡Ah!, no, esa gente, yo no sé si a esa gente la arman, yo creo que le dan garrotes y todo, pero la parte más peligrosa son los grupos de choque, que en otros lados les llaman pandillas, que les pagan, les compran las armas, estos chavalos, pobrecitos, que además son, por lo general, drogados, les dan los morteros, fijate que en una de las marchas brillaban los machetes, eran recién comprados, sabemos la ferretería donde se los compraron, los machetes, ¿sabes lo que son? Brillaban de nuevecitos, esos se los paga el Frente, el Frente los organiza, esa gente sin la menor duda son fuerzas de choque de este gobierno, que no ha usado a la Policía porque ahí ellos todavía están manteniendo cierta...bueno, la Jefa de la Policía es prima hermana mía, pero, y yo sé que ha hecho un esfuerzo, pero la verdad es que la Policía, Raquel, ha llegado con los escudos hacia nosotros, como que nosotros somos los agresores, y lo que ha evitado ha sido el encuentro directo, pero luego la Policía no tira los morteros al aire, todavía la gente no les han tirado los morteros para matar, verdad, pero el mortero es un arma de guerra, nos tiran pedradas, o sea, vos vas a ver el video, véla, métete a la página web del movimiento, ahí sale el ataque. Y luego en esta última del sábado, el asunto fue que sólo se pidió permiso a la Policía, pero no pidió protección, entonces llegaron seis policías, pero uno de ellos está en las declaraciones y en los videos, dijo que los maten, eso es lo que andan buscando. La Jefa de la Policía cada día está teniendo menos control sobre las decisiones de la Policía, ¿por qué?, porque según la ley el jefe de ella es el presidente, el jefe de la Policía es el presidente, y ahí hay opiniones controversiales, verdad, yo no me voy a meter a eso, porque yo creo que ella lo ha hecho lo mejor que ha podido, pero eso no es excusa, la Policía puede aceptar órdenes o desórdenes que no sean constitucionales y ellos han dejado mucho que desear en garantizar la seguridad de nosotros, verdad. Ahora ya decidimos que no íbamos a pedir permiso, porque estamos claros de que inmediatamente el gobierno hace su estrategia y de ahora en adelante estamos haciendo las cosas así, mientras nos preparamos para la gran marcha, pero ya no vamos a estar poniendo en riesgo a la gente.

R: Ya por último, la propia Asamblea, hablando de la oposición parlamentaria a las reformas, ¿qué sabe del llamado "Bloque contra la dictadura" cuando trató de impedir 
primero el programa de reformas que tenía el Frente el año pasado y la propia creación de los CPC reafirmando a la esposa de Ortega en su dirección?

V.G. Sí, han sido blandengues Raquel, blandengues, o sea, la oposición parlamentaria ha sido sumamente... yo te digo,... yo, por ejemplo, a la bancada del MRS yo le tengo mucho respeto y yo creo que el grupo de Eduardo, pues, ha dado la lucha, pero de ahí para allá nunca se sabe qué sorpresa te vas a llevar. La última sorpresa fue con la elección de la junta directiva de este año de la Asamblea, gritaron, que no iban a poner al Frente y a la hora todos votaron enfiladitos por el mismo presidente de la Asamblea, que es René Núñez, yo te digo, sinceramente, aquí ha habido un escepticismo en relación a los partidos, o sea, no nos hacemos muchas esperanzas, y hasta ahora, pues, como te digo, esos dos grupos, yo creo que ahí hay un bloque bastante coherente, verdad, pero no es suficiente. Ellos no hacen ninguna diferencia, porque entre el Frente y los liberales tienen la mayoría calificada para cualquier reforma o para aprobar cualquier ley, y hasta ahora lo han hecho, y además yo no sé qué pasa con los diputados, Raquel, por ejemplo, yo me pregunto cómo es posible que no se hayan dado cuenta que los embajadores, que los ministros, eran ilegales porque no se les había ratificado, o sea, yo no puedo entender, yo no sé, la verdad, nunca he sido diputada, pero si ese es el trabajo de los diputados nadie se pueda enterar que no se están cumpliendo con los procedimientos de la ley. Entonces, a mí me parece que muchos diputados ahí que además son históricos, igual que pasa con los caudillos, ahí hay su "caudillito" que tienen años de ser diputados, verdad, que andan en otras, pues, hay mucha corrupción, hay muchos intereses particulares, la verdad es que el tema del país es son muy pocos los diputados que están haciendo un buen trabajo. Así es que nosotros tenemos un canal de comunicación bastante sistemático con la gente del MRS, con la gente del movimiento "Vamos con Eduardo", con alguna gente del PLI, que no tiene representación parlamentaria, pero sí de alguna manera "Vamos con Eduardo" tiene alianza con algunos del PLI, y de manera individual con algunos diputados liberales del PLC, verdad. Pero lo único que nosotros creemos que nos queda hacer es la presión, la presión, la presión social por diferentes vías.

$R:$ ¿Y ese es el futuro de la política en Nicaragua?, ¿cómo ve su país en el próximo año y medio que va a ser clave?

V.G.: Presión social, Raquel, aquí nada va a cambiar si la gente no se empodera y se apropia del Estado, que tiene su rol, pero de ser ciudadano, de ser ciudadanía, es para promover cambios en la cultura pero forzados, o sea, nosotros no podemos esperar que haya una revolución en la clase política, porque lo que está pasando ahorita va a ser definitorio para la menor posibilidad de continuar por la vía democrática en el futuro. Entonces, tenemos que forzar comportamientos más democráticos en los que tienen poder de decisión en este momento y eso no se hace... Nosotros tenemos una estrategia diversa, hacemos cabildeo, por supuesto, pero la mayor expectativa la tenemos que poder en que la gente participe, que la gente se involucre, que la gente presione, a nivel local, a sus diputados, a nivel nacional y que lo forcemos a actuar de una manera más correcta.

R: Pero fijate, que a pesar de que la revolución tuvo una impronta de masas y trató a través de las organizaciones populares de movilizar a la sociedad civil, y la propia sociedad participó en el proceso revolucionario mismo, sí que es cierto que la política nicaragüense ha sido una política de élites y también lo fue durante el régimen 
sandinista y lo ha sido en la democracia atribulada que siguen viviendo los nicaragüenses...

V.G.: Sí, sí, sí, eso es lo que yo te decía al comienzo, que yo sentía que estaba despegando a través de la Ley de Participación Ciudadana de una manera más organizada, con los comités municipales y departamentales, todo el sistema de participación y de diálogo público y privado que se venía conformando, verdad, pero ciertamente un legado positivo de la revolución creo que fue eso, ¿no?, que la gente entendió por primera vez en la historia del país que eran actores en este país, pero la debilidad que tuvo eso fue que fue cooptado por los partidos y entonces no era una participación autónoma, no había posibilidad de crítica, de juicio, todo se relegaba ante la seguridad nacional y el proyecto revolucionario, entonces, ahí nos dejaron una debilidad, por un lado, una fortaleza, pero, por otro lado, todavía un proceso inacabado, verdad, y en estos años es cierto tampoco se ha logrado, se logró en esto un mayor involucramiento, aunque yo siento, sinceramente, que se estaba caminando hacia esa vía. El tema de la participación ciudadana, Raquel, no es fácil, no es fácil, no es fácil, porque no es un asunto solamente, o sea, tiene que haber motivaciones de diversos...este no es un asunto que se logra en una década, pues, y eso es lo que a mí me da pesar, que se trunque una cuestión que estaba andando.

R: Pero también está el desencanto de una ciudadanía con unas élites que le han traicionado, hablo de la "piñata sandinista", ve cómo muchos sandinistas ahora son empresarios prósperos del país, ve ese recambio de las élites en función de intereses que no son públicos...

V.G.: Sí, sí, la concepción del Estado-botín, por supuesto, eso va en contra de la participación, pero también se puede convertir en un factor de oportunidad porque está tan dramática la situación que en algún momento la gente va a tener que asumir el país, porque no hay otra salida, Raquel, y fíjate que la crisis internacional, financiera, en la que está metido este pobre país también es un factor amenazante, pero que yo lo veo como una oportunidad, ¿porqué?, porque ahora no es fácil decir "me voy", o sea, ahora cada vez más la gente está tomando conciencia de que aquí hay que hacer algo con nuestro país, que tenemos que ver la forma de que el país por lo menos se mantenga a flote, porque nosotros a veces creemos que llegamos al fondo del barril, pero la verdad es que no hemos llegado, Raquel, o sea, está arriesgando hasta su misma existencia como nación, es decir, la situación de la gente es terrible, terrible, y yo no quiero ser tan catastrófica en esto, pues, yo sólo te puedo decir lo que yo persigo, y el movimiento es un movimiento que tiene esa característica de que es muy diverso, es como un microcosmos de lo que es Nicaragua, tenemos gente de la oposición, tenemos gente intelectual, tenemos gente de base, esa es mi cantera de información más importante y aquí no hay nadie que no se sienta en peor situación, ni en situación mal, entonces, ahora yo me pregunto, estos programas sociales del Frente el "Hambre Cero", "Usura Cero", todos estos, la casa para el pueblo, ¿están cumpliendo una función?, es probable que sí, pero como no abarca la magnitud del problema pues esto se está haciendo sin transparencia, y entonces está generando también mucha inconformidad y muchos problemas a lo interno del mismo Frente, porque no da ni para los mismos partidarios del Frente. Entonces, lo que podría ser una vía de escape se podría convertir en un factor de ingobernabilidad también. Yo estoy clarísima de que estamos en un polvorín y que tenemos que ver la mejor manera de resolver lo más rápidamente esta situación. 
ENTREVISTA $25^{38}$ :

Nombre del entrevistado: D. Roger Guevara-Mena.

Cargo actual: Periodista y analista político en la prensa y televisión nacionales.

Fecha de realización de la entrevista: Managua, 25 de noviembre de 2009.

Lugar: Domicilio particular del Sr. Guevara.

Duración estimada: 52 minutos.

\section{TEXTO - Transcripción 25:}

R: ¿Cuál es su reflexión a propósito de los cambios constitucionales que se han producido en Nicaragua desde los años 90 hasta la fecha, es decir, la etapa de transición democrática después de la firma de los acuerdos de paz?, ¿no?

R.G.M: Creo que la transición como tal ha sido un proceso muy lento, ha sido un proceso que ha tenido sus momentos de regresión, sus retrasos, y, a veces, diría yo, sus retrocesos, pero que el proceso de la acción democrática, propiamente dicha, no tiene todavía una base sólida en la gran base popular, pero sobre todo en la clase política, estamos hablando que de la firma de los acuerdos de paz hasta la fecha la clase política ha sido casi la misma, y podemos ver en Centroamérica, no sólo en Nicaragua, que ahí está el presidente Arias, que estuvo en el momento de los acuerdos de paz, y está el presidente Ortega, que también estuvo en la firma de los acuerdos de paz, estamos hablando de estos dos actores fundamentales en ese inicio del proceso democrático a partir de finales de los años 80, por lo tanto, cuando nos referimos a las reformas constitucionales, que tenían que haber sido el resultado de esa acción política, de ese proceso democrático, es por eso que se dan estos retrocesos, estas parálisis y estos cortos avances debido a que esa clase política no tiene una idea clara de su rol, de su temporalidad, y sobre todo de la naturaleza del Estado, el Estado como ente político es para ellos un ente patrimonial, y no un lugar de servicio, por lo tanto, como hay un concepto patrimonial del Estado se supone que al ser dueños de partidos, y al ser dueños de voluntades, cuando se ganan las elecciones son dueños del poder, dueños del Estado y dueños de los bienes del Estado, y cuando se tiene la convicción de que se es dueño se siente con la facultad de heredar, de traspasar, de vender, de negociar, de regalar, y, por supuesto, bajo ese concepto primario y primitivo de la organización política es comprensible, que a pesar de que haya una letra bonita en las reformas constitucionales, evidentemente, su clase en ese lenguaje, los deseos de los hombres fuertes, de los líderes o pretendientes a caudillos de estos sectores políticos, que, de cierta forma, se vinculan muy fuertemente a la economía y se vinculan, por supuesto, a la tradición histórica del país, obviamente, esto refleja aquellos procesos van muy lentos, y que estos retrocesos lo que hacen es producir una asfixia social, una asfixia social que lo produce la frustración por no avanzar en un proceso democrático al que todos creímos haber iniciado, y, por lo tanto, estas reformas constitucionales lo que manifiestan en su letra es un ajuste a las visiones de poder de los que se han sucedido en el mismo, y sobre todo un traje a la medida, que cada vez se lo van agregando o cortando, de

38 Entrevista que centra su interés en aspectos tales como: las raíces históricas del caudillismo en Nicaragua, los factores de consolidación institucional del sandinismo, o, finalmente, la necesidad de realizar un nuevo proceso constituyente, que garantice y refuerce las bases jurídicas de la débil institucionalidad democrática en el país centroamericano. 
manera, que las constituciones son pocos fijas y reflejan una inestabilidad en su texto como en su práctica, puesto que llega un momento en que no solamente una interpretación auténtica, legislativa puede modificar el espíritu y la letra de la Constitución, sino, inclusive, una interpretación judicial, aún cuando no tiene las características de un tribunal constitucional, pero se arroga el derecho a modificarla, lo que, justamente, contradice la esencia de la separación de los poderes y los principios de la democracia liberal.

R: Es cierto que ha habido tres procesos de reforma, concretados en leyes de reforma parcial a la Constitución del 87, y el hilo conductor de las mismas ha sido un poco el de, bueno, reducir parte de las facultades que tenía un Ejecutivo presidencial muy fuerte, consolidado en la Constitución original del 87, y aumentar las atribuciones de poder de la Asamblea Nacional, ¿piensa que esto, en el fondo, ha sido también por un vicio en la práctica institucional de estas nuevas facultades de la Asamblea, en una cooptación de los partidos políticos dominantes en la escena política?

R.G.M: Sí, pienso que sí, y le voy a explicar por qué, porque cuando se hizo esa Constitución, se hizo bajo el gobierno sandinista de la primera parte, y se tuvo la idea de que el gobierno pertenecía como patrimonio al partido, que el Estado y el gobierno y el Ejército constituían la esencia del poder, que eran un trinomio que representaba el poder, entonces, se hizo una Constitución a la medida del poder sandinista, que centralizaba todos los poderes, y hacía co-legislador al Ejecutivo, y le daba facultades omnímodas por encima de los tribunales de justicia, esto se refleja en la primera Constitución, pero claro, inmediatamente, después que se pierde el poder, y el ascenso de Violeta Chamorro crea la convicción de que ese concepto de poder excedía las aspiraciones que ellos pretendían y siendo oposición no les convenía, por lo que se dedicaron a promover el recorte de los poderes del Ejecutivo y trasladarlos a donde ellos se encontraban, en la Asamblea Nacional, con la canción de que iban a gobernar desde abajo, y presionaron las reformas constitucionales a través de huelgas, paros, todo tipo de manifestaciones violentas, chantajes, y todo tipo de acciones, inclusive, delictivas comprobadas para hacer que ese poder se fuera disminuyendo, y que mientras ellos no estuvieran en el Ejecutivo tendría que pasar a la Asamblea Nacional, e, inclusive, el presidente Ortega ha hablado ya hace varios años de la necesidad de tener un sistema parlamentario donde él concibe ser mayoría en la Asamblea, o quien negocie con más habilidad en la Asamblea imponerse como primer ministro, o, simplemente, imponer a alguien como primer ministro, y él seguir siendo primera figura nacional, es decir, yo creo que las reformas se han sucedido en base a las aspiraciones y a la negociación entre los partidos que han sido representados en la Asamblea, en este caso, Arnoldo Alemán, quien, inicialmente, entró al poder con una enorme capacidad, con una enorme representatividad, fue en continuas negociaciones cediendo poderes, cediendo posiciones y a través de prebendas económicas y negocios personales, y lo atestigua una cantidad de expedientes policiales posteriores, ha estado negociando y especulando con posiciones y haciendo oposiciones ficticias, cuando, en realidad, desde hace ya mucho tiempo, tiene acuerdos de convivencia y de objetivos comunes con el presidente Ortega, es decir, es la sospecha nacional, es un hombre que ha pretendido, en un momento dado, crear a su alrededor la imagen de una oposición y luego se ha visto defraudada cuando el mismo presidente Ortega lo ha señalado como ladrón, ha comprobado las cosas y luego, a su arbitrio, lo ha metido y lo ha sacado de la cárcel, y se ha dado cuenta que el señor Alemán le tiene terror a la cárcel, entonces, aprovecha esa debilidad y, simplemente, en cualquier momento, cuando Alemán hace algo que no le gusta a 
Ortega, le suena la campanita de la reja de la cárcel, y, en ese momento, el señor cede y le entrega lo que sea, es decir, ha perdido autenticidad, ha perdido credibilidad, y, obviamente, son ellos quienes han venido moldeando estas reformas constitucionales a través de sus negociaciones, y en el momento en que, mientras no exista un relevo en la dirigencia política nacional, mientras no exista una autenticidad en la misma, mientras no exista un marco jurídico que delimite la función de los poderes del Estado y establezca con claridad la acción de cada uno de los actores políticos, pues, vamos a continuar en este vaivén difuso, oscuro, y a veces angustioso de esta reforma, que no sabemos, verdaderamente, si soluciona o complica la vida pública.

$R: Y$, sin embargo, el primer gran momento de la reforma constitucional en este país es la del 95, donde también se plantea el debate sobre si reforma total o reforma parcial, existe además un elemento de mucho conflicto en ese primer gobierno de Doña Violeta.

R.G.M.: Claro, claro, porque la presión desde abajo, que decían ellos, y la presión parlamentaria, querían con una Constituyente poder hacer un golpe de Estado legal.

\section{$R:$ ¿Los sandinistas?}

R.G.M.: Claro, porque eso les permitía, a través de una Constituyente, revertir con esa mayoría que se suponía que tenían, decisiones para dar la última elección, e, inclusive, con un cambio de sistema cambiar a una persona que había sido electa, es decir, la idea era la de un golpe de Estado legal, lo que pasa es que no lo pudieron hacer.

\section{R: Es muy fuerte esa afirmación.}

R.G.M.: Claro, claro, entonces, obviamente, esto creó y comenzó el conflicto, se dieron cuenta que tenían que negociar con alguien que tuviera la suficiente debilidad para ir cediendo a sus demandas, y encontraron en Alemán, encontraron la debilidad que era el dinero, la codicia, y el temor a la cárcel y esto ha creado esta situación angustiosa, que se ha venido viviendo en los últimos 10 años.

$R: Y$, si bien, pensando en quiénes son los actores políticos que hacen las reformas en el años 95 hay un arco parlamentario de representación de múltiples partidos, detrás de los cuales hay electores ciudadanos de la, digamos, plural sociedad nicaragüense, mientras que las reformas del 2000, que algunos han calificado como una verdadera “contrarreforma" revierte el giro inicial de la reforma del 95, que, al menos, por la mayor parte de los entrevistados ha sido calificada, y goza, yo siento un poco en el clima político del país, de una amplia legitimidad, ¿no?, porque era jurídicamente necesaria en un momento de transición.

R.G.M.: ¿A qué llama usted jurídicamente necesaria, por ejemplo?

R: Bueno, jurídicamente necesaria, en el sentido de que no se podía seguir gobernando con una Constitución que amparaba, digamos, el marco institucional del régimen revolucionario si se firmaban los acuerdos de paz, y se daba también paso a los actores que habian quedado excluidos, ¿no?, hay un componente de exclusión también muy fuerte en cada proyecto político en Nicaragua, hay una parte de los ciudadanos que se queda fuera. 
R.G.M.: Claro, claro, siempre, digamos, ha sido el Estado como monopolio de poder y con pertenencia a un grupo determinado ha tenido vocación de exclusión, es decir, yo creo que, nosotros los hispanos en América tenemos un grave problema, a diferencia de los portugueses, los portugueses no tienen la orfandad política con que nosotros decimos, en América jamás vino un Borbón a ordenar, entrar su dominio en América, y ellos configuraban durante la historia en nuestra mentalidad han configurado una nación, por la historia, por los hechos históricos, no porque seamos realistas, no, pero, en cambio, Brasil, ¿no?, los Bragança se trasladaron a Brasil, y con ellos todo el aparato del Estado, por razones históricas, entonces, ellos configuraron una visión de Estado, y configuraron después que se fue el último Bragança la necesidad de crear una estructura distinta a la que nosotros tenemos, es decir, una visión propia de Estado, entonces, el Estado es mucho más una institución, es un patrimonio, en cambio, aquí hemos sido la América patrimonialista, y hemos querido tener el Estado como un botín de guerra, y queremos reemplazar en todo momento una figura que nunca pudo estar en América.

\section{$R$ : ¿Y a eso se refiere explicando el presidencialismo como la necesidad de tener líderes fuertes?}

R.G.M.: Exacto, exacto, ¿por qué?, porque no hay una representatividad histórica nacional, es decir, aquí, aunque no se diga, y aunque tengamos unos sentimientos liberales de corte revolucionario desde la época de la revolución francesa o posteriores, pero, en realidad, hay la necesidad de un liderazgo fuerte, o un reconocimiento de autoridad de alguien, es decir, muy en el fondo en las clases, sobre todo, dominantes o las clases más o menos educadas, igualmente, hay un aprendizaje de este sistema de vacío de poder y de necesidad de caudillos y de hombres fuertes en la gran base popular, entonces, obviamente, esto forma parte de esta mentalidad colectiva, entonces, esto en Nicaragua tiene un gran índice de mestizaje, que somos uno de los pueblos más mestizos del continente, creo yo, entonces, esto todavía existe, por supuesto, se manifiesta a través de liderazgos de armas ocasionales, donde ascienden por la fuerza, no por el mérito, y sobre todo donde la astucia se sobrepone a la inteligencia, donde la astucia de la vigilancia, del control, del temor, del chantaje, de la amenaza velada, de, a veces, del control de la justicia, del monopolio de la Contraloría de los asuntos económicos del Estado, además de las instituciones como la Fiscalía y otros, son manejados por los intereses de caudillos, por intereses de sectores, y no en interpretación a aplicación de la ley, obviamente, esto hace que las reformas constitucionales se diluyan y todavía no constituyen una cercanía para la gran base popular, y aunque se sienta como una expresión de la clase política junto a la clase dominante económica, que se han distribuido prebendas y posiciones, a través de un texto, que lo ajustan a sus intereses y lo modifican de acuerdo a sus negociaciones.

R: No, es muy interesante lo que dice, y coincide también con parte del discurso repetido en mis otras entrevistas, ¿no?, esa tensión entre modernidad y, digamos, el resto atávico de un componente primitivo histórico, que no deja de estar en la cultura política.

R.G.M.: Claro, no deja de estar en la cultura política, porque yo le llamo que nosotros tuvimos una orfandad social en el nacimiento de nuestros Estados, ¿por qué?, porque, simplemente, no tuvimos el sentido de reemplazo de una figura, es decir, hay que recordar que los movimientos independentistas decían: "iviva Fernando VII y abajo el mal gobierno!”, ¿qué significaba esto?, simplemente, que se reconocía la corona como 
un ejemplo de nación, pero que se repudiaba a los criollos, los venidos de la península, que administraban esto con despotismo y con tiranía.

\section{R: Que eran reyezuelos.}

R.G.M.: Entonces, ellos reemplazaron cacicazgos precolombinos a través de una semiesclavitud y un trato hostil hacia el resto de la población, tanto mestiza como indígena, lo que pasa es que esto ha venido prevaleciendo a pesar de las distintas olas de mestizaje, y forma parte de la mentalidad colectiva, que no pasó en Brasil.

R: Y, sin embargo, uno de mis entrevistados también decía que ya era el momento de dejar de mirar al pasado para justificar el presente y para no repetir el futuro, ¿no?

R.G.M.: Claro, claro, entonces, ese cacicazgo militar, ese cacicazgo por la fuerza, ese cacicazgo violento, sangriento, ese rechazo, ese sentido de exclusión todavía es muy fuerte en Nicaragua, eso crea resentimientos, diferencias, odios familiares, y esa diferencia de odios personales, inter-personales, que han configurado hasta hoy nuestra vida política nacional.

R: Y esa tensión hacia el enfrentamiento y esa tentación extra-institucional fuerte, que tienen los actores políticos a la hora de resolver los dilemas de la vida pública, ¿no?, casa mal también con el principio parlamentario de negociar, de ahi que el tema del pacto aquí en el fondo haya sido una perversión del sentido democrático de la negociación entre distintas fuerzas políticas.

R.G.M.: Claro, claro, porque el asunto es que el pacto como tal se entiende en el momento de que se va a establecer una agenda nacional, pactan los partidos para llevar a cabo un objetivo como institución, pactan los partidos para establecer criterios de actuación dentro de un proyecto nacional, pero cuando se pacta para distribuirse posiciones, cuando se pacta para distribuirse negocios, cuando se pacta para hacer negocios con el Estado, cuando se pacta para obtener ventajas individuales o familiares, en ese momento, el pacto repulsa, ¿por qué?, porque se ve el aprovechamiento de unos sobre otros, y se siente la corrupción en toda su pestilencia, y eso, obviamente, la hace daño a todas las instituciones, porque se generaliza el concepto de que si los que están en la cúspide del poder negocian y roban no para una agenda nacional, sino para beneficios personales, hasta el último dentro de la pirámide social lo pretende hacer, y eso crea un sentimiento de desconfianza mutua, que se generaliza, puesto que no hay credibilidad en las personas de la cúpula, $y$, por supuesto, no hay por qué esperar que lo tengan las personas de las bases.

R: Y esas dificultades de gobernabilidad que han aparecido en los cuatro gobiernos democráticos, digamos, de la etapa democrática reciente, por bloqueo entre Ejecutivo y Legislativo, que se repite también a propósito de la reforma, da lugar a ese instrumento jurídico controvertido que son las leyes Marco, ¿no?, que consisten en aplazar temporalmente la entrada en vigor de las reformas constitucionales. Cómo ve usted, porque si bien se rompe con el principio de supremacía de la Constitución, al permitir que una ley ordinaria sea quien ordene cuándo entra en vigor y cuándo no la disposición constitucional reformada, también coloca por encima la política sobre el Derecho, es decir, el espacio de la negociación política entre los actores sobre la ley, 
que debería ser el marco legal donde ellos pueden actuar, digamos, ajustándose a Derecho, y no al contrario, ¿cuál es su opinión al respecto?

R.G.M.: Yo veo que el hecho de las leyes Marco es una perversión de una figura jurídica del Derecho francés, donde, justamente, en el Derecho francés se aplica este concepto, pero no en la forma como lo aplicamos acá para hacer una exoneración de la reforma constitucional, ni para hacer un intervalo de inaplicabilidad de la norma constitucional, simplemente, el Derecho francés lo toma en otro sentido mucho más constructivo, que es una situación de impasse, pero que, obviamente, no anula ni impide la vigencia, sino que crea situaciones de excepcionalidad, pero no limita en el caso como lo usamos o como lo inició el Magistrado Francisco Rosales, que es, justamente, que es también de inspiración francesa, y lo utilizó de manera perversa, esto lo que refleja es, básicamente, que la negociación de los sectores interesados, o los sectores que quieren el control del poder establecen excepcionalidad a la aplicación de la Constitución al aplicar leyes Marco, puesto que es la forma en que ellos pueden ganar tiempo para obtener satisfacciones mutuas por encima de la ley escrita, entonces, esto lo contradice cualquier efecto del mejoramiento del proceso constitucional, y esto, obviamente, también refleja que las clases políticas gobernantes, los equipos de poder o las personas inciden de manera más firme, más fuerte y más decisiva sobre la vida nacional, que el conjunto de las aspiraciones que se puedan dar dentro de una votación de la Asamblea Nacional.

R: Y si comparamos a los cuatro presidentes que ha tenido Nicaragua, sí contrasta la figura de Doña Violeta y Don Enrique, que han sido presidentes más débiles, incluso, no apoyados por sus correspondientes partidos en la Asamblea, y con enormes dificultades para desarrollar su agenda de gobierno, de terminarla, frente a Arnoldo Alemán y a Daniel Ortega, que ha sido hombres, líderes fuertes, porque han mantenido también un control muy fuerte sobre sus respectivos partidos políticos, ¿no? ¿Cómo ve usted esta comparación este las cuatro figuras?

R.G.M.: Yo creo que ha habido poca habilidad en los gobiernos de Violeta y de Bolaños, digo poca habilidad porque ha habido poca flexibilidad, poca capacidad de negociación, y además ha habido una complicidad del yerno de Violeta, Antonio Lacayo, con el Frente Sandinista, complicidad, puesto que él era el primer partidario de mantener al hermano de Daniel Ortega en el eje de la jefatura del Ejército, a pesar de que tenía todo el nuevo gobierno en contra, complicidad por hacer la gran cantidad de negocios y acuerdos económicos con el Frente Sandinista, o sea, quien le da vida al sandinismo desde abajo es Antonio Lacayo.

\section{R: Pero al Frente no había forma de eliminarlo.}

R.G.M.: Claro, no había forma, pero tampoco había que darle tantas posibilidades y tantos negocios y tantas concesiones, es decir, que hace que se mantenga, y luego, por supuesto, cuando viene después Alemán, Alemán y Ortega, continua el proceso de apertura y de negociación, e, inclusive, le rebaja el umbral electoral, la condicionalidad para que puedan optar a la presidencia a un $40 \%$, cuando la ley decía antes que eran un $51 \%$ de las votaciones de elección nacional, es decir, vemos que existe una debilidad que luego Bolaños lo que hace es distanciarse del mismo partido que lo lleva, establecer un conflicto generalizado en su propio partido, se debilita hasta el extremo que, en un momento dado, los dos partidos tratan de derrocarlo, de darle un golpe, él invoca a la 
OEA, y después de invocar a la OEA, él se alía con el Frente Sandinista para mantener su enemistad con Alemán, y esto crea, indudablemente, otra complicidad, porque se mantiene en el poder gracias al apoyo del sandinismo, que aprovecha los tres últimos años de Bolaños para continuar gobernando desde abajo y haciendo con su presencia en la Asamblea, y en la presidencia, con el presidente Bolaños, que los negocios vayan en el sentido que a ellos les convengan, en ese momento, no plantearon ninguna modificación a la Constitución, puesto que ellos habían sido parte de las modificaciones anteriores, o sea, es decir, estas modificaciones han seguido dando el consentimiento del Frente Sandinista, y si hoy se plantea otra modificación, es, justamente, para volver a absolver aquellos poderes que, en un momento dado, ellos desmantelaron al Ejecutivo, yo creo que ellos piensan que es un retorno a los poderes hacia el Ejecutivo, si no pueden transformar el sistema presidencialista en sistema parlamentario, donde pudieran ellos manejar, como hoy lo hacen, desde la Asamblea una mayoría real o ficticia, pero que conduzca los intereses de acuerdo a su visión de partido, y mantenga una jefatura de Estado y una jefatura de gobierno, que satisfaga los intereses del partido, que se mantenga siempre con su carácter excluyente, y donde hoy como ayer, aunque se diga que hay un gobierno de unidad y reconciliación, ustedes les pueden preguntar a ellos cuáles funcionarios del Ejecutivo no pertenecen al partido, ¿dónde está la unidad y la reconciliación?, esto como gobierno de minoría debió de haber formado un Ejecutivo mixto, combinado, ¿dónde está?, sólo en la música y el folclore y en las flores y en las manifestaciones, en realidad, usted pregunta, dígame qué persona no es del partido tenga una cartera de gobierno, qué persona en servicio exterior, que no sea del partido, está ahí, o qué persona en salud o en educación o en cualquiera de las otras dependencias donde ellos se preocupan de mantener como agencia de empleo a todas sus fuerzas partidarias de manera prebendaria en la estructura del Estado, y de excluir a aquellos que no lo sean.

R: No, y es cierto que el Frente ha tenido una gran habilidad para penetrar, bueno, tenía una experiencia de 10 años en ese régimen de Partido-Estado, ¿no?, lo cual le da también esa visión de que para gobernar hay que estar en las instituciones, ¿no?

R.G.M.: O sea, ellos han cambiado la perspectiva, por ejemplo, en un momento dado con la llegada de Violeta al poder, entonces, ellos, todo lo que fue su aparato de seguridad, su aparato de vigilancia policial, del régimen policial, los pusieron a estudiar Derecho en estas universidades pequeñitas que para obtener un título de abogado, así como muy elemental y copar las posiciones judiciales, de manera que hace más de 5 años o 10 años, todas las posiciones judiciales están, las que toman decisiones, están formadas en su $80 \%$ por gente de la estructura partidaria, entonces, hay una verdadera confusión, es decir, no hay un sentido de la reparación de los poderes, ni una credibilidad en las mismas, así como se desconfía en la Asamblea Nacional, los electos es una lista compuesta por amigas íntimas, amigos íntimos, compadres y parientes y gente obediente o servil al derecho del caudillo, que no repiten más que lo que el caudillo les dice, porque nadie los conoce, igualmente, otra cultura del Estado también forman parte los amigos, amigas íntimas o compadres, o todos aquellos vinculados a los intereses y obedientes, por supuesto, a las directrices de los jefes de partido o los supuestos directores o responsables, pues, en este caso, hoy por hoy se confunde la dirección política con la dirección económica, y hoy por hoy diríamos que lo que ha sido el gran capital, ahora hay capital mixto, entonces, ahora es aliado del Frente Sandinista, puesto que es la forma de que los intereses combinados de los que han sido gran capital, que ahora están con los Estados Unidos de socios, estoy hablando de las 
tres grandes fortunas, Pellas, Cohin, y Hernández Goldman, entonces, ellos, simplemente, son socios de multinacionales americanas, pero también le gusta estar bien con los gobiernos, porque es la manera de continuar bien sus negocios, entonces, ellos son los mejores allegados, en el sentido de que pueden expresarle a los Estados Unidos que sus negocios van bien y que el país va bien.

R: $Y$, sin embargo, el único que ha dado la contraparte a Ortega ha sido Alemán, es decir, hay entrevistados que señalan que son las dos caras de una misma moneda, y que tienen bases sociológicas comunes, digamos, entre los estratos de las clases populares y la clase media baja, ¿no?, como que ambos representaron una alternativa contra la oligarquía tradicional.

R.G.M.: Hombre, en un momento dado sí, ellos tuvieron un discurso muy contestatario, verdad, porque, justamente, Somoza en parte representó también con menos intensidad esa exclusión, es decir, yo mismo estaba muy jovencito, pero yo me di cuenta de la exclusión que representaba Somoza, y el resentimiento que ello producía, es decir, no hemos tenido suerte, porque no hemos encontrado el equilibrio necesario ni la capacidad cívica en la dirigencia política, por otro lado, yo quiero decir que la base popular sí está mejor orientada, en las últimas elecciones el pueblo no se equivocó, el pueblo señaló a quien quería, pero lo que pasa es que como las instituciones están copadas y pervertidas, las instituciones contaron como quisieron, contaron para atrás $\mathrm{o}$ contaron para adelante de acuerdo a su conveniencia, porque ya los intereses estaban delineados, que estaban ya especificados, que quién ganaba, con cuánto ganaba, en qué alcaldía, cuántas alcaldías, es decir, estaba todo perfectamente controlado, es decir, la desconfianza, la percepción de la desconfianza que tiene la población en general, hace a unas autoridades electorales que se ven dispuestas siempre a hacer fraude, por supuesto, esto crea una gran frustración en la naturaleza de la vida democrática, y lo que representa, sobre todo, a veces, por estos movimientos violentos se recibe la percepción de que queremos volver a hacernos justicia con nuestra propia mano, porque es hasta peligroso el tema, es por eso que yo insistía cuando hablaba de la cooperación extranjera, justamente, cuando se debe de dar la cooperación extranjera de la comunidad internacional, se le debe pedir a cada gobierno, como contraparte de esa cooperación, una nota con respecto a la educación cívica, una nota a los proyectos de capacitación, que esos países donantes incluyen en su programa de apoyo, no es posible que sólo le den dinero a los presupuestos del estado y no le den dinero para la educación cívica, para que la gente entienda cómo se juega a la democracia, que eso tiene que ir en el Ministerio de Educación, porque yo le preguntaba a la embajadora de Finlandia, que se quejaba de ese sentido de caudillismo, de esos gamonales políticos, ella se quejaba que cómo era posible, entonces, yo le pregunté que si en los programas de su país incluía un proyecto de capacitación cívica, ya que ellos eran donantes, yo les dije que no, que nunca lo habían incluido, entonces, no se puede esperar una respuesta cívica de alguien que no ha tenido educación cívica, porque nadie da lo que no tiene, y, lógicamente, nosotros esperamos, en este caso, de una cooperación como la española, con la afinidad cultural, nosotros quisiéramos que esa cooperación tuviera una contrapartida de una nota en el proyecto de la educación, que no puede venir una cooperación de forma gratuita o arbitraria, convenida entre partidos, o entre Estados, sin que haya una nota de prueba de lo que ese aporte significa para la población, la gente lo que necesita es aprender cómo se maneja la democracia, cómo se vive en democracia, cuáles son sus derechos, y cuáles son sus obligaciones, y eso es parte de la cooperación, ¿no?, necesariamente, se da solamente el pescado, ¿no?, es que hay que enseñar a pescar, yo 
creo que parte de la sostenibilidad del país depende de la educación cívica que tenga para gerenciar sus propios proyectos.

R: Y, sin embargo, a propósito de eso si lo que están es cerrando espacios políticos no solamente en la Asamblea o en las instituciones del Estado, sino también en la propia sociedad civil, que vean el fraude de las pasadas municipales que su voto no vale, lo cual es muy peligroso en una sociedad que ha vivido una guerra, ¿no?, porque si ya no cuenta con el instrumento pacífico para relevar a las élites, pues, la solución es la violencia política, que además es algo que la mayor parte de mis entrevistados comentan si esto sigue, digamos, agravándose.

R.G.M.: Claro, lo que pasa es que yo he señalado que vivimos en un país donde hay una reciente historia militar, un país guerrero, por tradición, un país armado, puesto que antes de la caída del muro de Berlín, los alemanes orientales y los traficantes de armas hicieran llegar miles de toneladas de armas al país, donde buena parte de ellas todavía está escondida en buzones, que conocen unos y otros, indudablemente, esas armas de guerra, pues, en cualquier momento aparecen en manos de personas responsables, en manos de fanáticos que debían ser, es decir, que estamos hablando de que es un país con tradición militar, que esto forma parte de nuestra naturaleza, es decir, y que la parte dialogante ha venido disminuyendo, en la medida en que se han dado imposiciones de tiranos, ¿no?, gente que no tiene un sentido de la historia, un sentido de la dinámica social, sino, solamente, su propia codicia, y eso, por lo tanto, refleja una inseguridad permanente.

R: Y ese componente coyuntural, que hace que en Nicaragua se repitan los ciclos de la historia, dramáticamente, hay, incluso, paralelismos, salvando los contextos entre el actual Ortega y ese grupo familiar que le rodea en el ejercicio del poder presidencial, la poca transparencia, la concentración de poder, el uso del Estado como base para acumular recursos económicos...

R.G.M.: Como bien patrimonial.

R: Exactamente, con los primeros años de Somoza. ¿Cómo ve usted esto, ya que ha vivido ambos periodos?

R.G.M.: Yo diría con lo que me ha tocado conocer de los últimos años de Somoza, existe una tradición en Nicaragua de violencia provocada en los últimos años, no digamos en los últimos años, sino que corre a lo largo de la época somocista, y que esta tradición violenta se da, se inicia cuando una parte del partido liberal que dirigía Anastasio Somoza García se separa, y es lo que forma el PLI, el Partido Liberal Independiente, y como Somoza García insiste en su pretensión reeleccionista y hace una Asamblea, una convención en León, entonces, viene, aparece un Rigoberto López Pérez y lo asesina, porque pretendía reelegirse, entonces, bajo esa premisa, de que no se aceptan reelecciones y que la gente hace ajuste de cuentas dentro o fuera de su partido, porque López Pérez estaba dentro del partido liberal, ni siquiera estaba fuera, entonces, eso crea el antecedente y se da luego, posteriormente, cuando Luís Somoza dice: "a mi hermano es fácil subirlo, pero va a ser imposible bajarlo", en realidad, se bajó casi a patadas con la insurrección, y luego, ¿y por qué se da la insurrección?, porque Somoza pretendía reelegirse, ¿y cuál era el principal argumento del sandinismo contra Somoza?, era alguien que pretendía con el control de la maquinaria del Estado y de los tribunales 
electorales hacer que ellos lo promovieran para presidente continuamente, entonces, parte de esa transacción, de esa rebelión, existe, en buena dosis, liberales y sandinistas, ambos rechazan la reelección como control del Estado, ambos rechazan ese monopolio, ambos sectores de la población consideran inadmisible que la misma persona continúe por varios períodos, y que, justamente, eso hace que la gente se sienta defraudada, porque esas personas han representado también exclusión, y hay un sector que no se siente concernida, invitada, que no se siente que forma parte de la Administración del Estado, o que se siente excluida del poder por razones personales, entonces, justamente, los gobernantes en Nicaragua no han sabido ser incluyentes, no han sabido ser negociadores, han sabido, únicamente, ser representantes de su sector, de esa forma, Ortega se percibe no como presidente de la República, sino como presidente del sandinismo, y dentro del sandinismo el grupo que está alrededor de su poder, de su control, y no de todo el sandinismo, entonces, por eso yo creo que el sandinismo es una pirámide que está invertida, y que descansa sobre su vértice, y eso lo hace vulnerable, porque es un pequeño grupo el que determina, parcial, y si ese pequeño grupo, ese vértice se rompe, simplemente, todo el edificio se desmorona, porque no tiene construcción ideológica, sino que tiene verticalidad militar.

\section{R: Y, sin embargo, ahora está el factor externo de Chávez en Venezuela, que es quien está financiando, un poco, este proyecto, si no sería un poco complicado que Ortega pudiera salir adelante, por lo menos, con esta solvencia, digamos.}

R.G.M.: Claro, lo que pasa es que Ortega no tiene la visión como para ir creando un equipo de consenso, Ortega tiene la mente en la guerra fría, Ortega no ha evolucionado, en el sentido de crear una transición democrática y hacer de su partido un socialismo democrático, él tiene todavía el concepto de Berned, que es una aplicación de lo que Chávez dice, de la soberanía limitada, de un socialismo que alcanza a América Latina, esa teoría de Berned, que, justamente, ya no representa porque es una teoría, que fue superada cuando el muro se cayó, e, inclusive, superada por la Perestroika misma, pues, entonces, esa aplicación de la teoría de Berned a nuestra latitud tropical, simplemente, contradice todo lo que se ha avanzado, y, justamente, eso se puede reflejar en cualquier Constitución, porque el apoyo económico venezolano sirve, junto con la dispersión del apoyo internacional, y la falta de unidad en el apoyo internacional, sirve a los intereses de control y de poder de esas estructuras, que son fuertes a pesar de que son débiles, pero somos más débiles nosotros, los que no estamos en el gobierno, los que podemos ser oposición, porque no tenemos los mecanismos de control, que tienen ellos en uso del poder del Estado, y, claro, existe una simetría, una disparidad, que nos hace a nosotros, opositores, enormemente, vulnerables a ellos, aunque débiles son mucho más fuertes, y tienen un apoyo externo de partidos, que no los conocen bien, por ejemplo, el PSOE desconoce lo que puede pasar aquí, porque no es su problema, pero, simplemente, puede buscar aliados y pueden encontrarlos, puede haber sectores del PSOE, que piensen que sí es una verdadera democracia, como sintonizarla, es decir, por supuesto, hay dentro de Venezuela hay sectores que también son oposición, pero que no tienen alternativa, no tienen liderazgo, el mismo problema, es decir, yo creo que la transición nicaragüense va todavía muy lenta, que hace falta una dosis de nuevos liderazgos, y de ciertos requisitos, no hablemos de condicionamiento, sino de requisitos de la comunidad internacional, que actúen para la acción interna a través de organismos no gubernamentales u otro tipo de condicionalidades a nivel educativo, que se le den a los gobiernos de turno para ir preparando el relevo generacional de la dirección de los partidos, es decir, tiene que haber democracia a partir de los partidos para que sea la militancia de los partidos, 
conocedora de los mecanismos democráticos, quien los use una vez para el control del Estado, mientras no se dé eso va a seguir existiendo el concepto tradicional del gamonal, del cacique, del virrey o el gobernador o lo que sea como dueño del poder, como propietario del Estado, y como facultad para heredar, negociar, regalar, distribuir a su arbitrio y antojo.

\section{R: ¿Y piensa que puede haber una candidatura común del liberalismo para hacer frente a la candidatura de Ortega en las próximas presidenciales?}

R.G.M.: Yo creo que son, en este momento, no hay a la vista ninguna opción satisfactoria, puesto que Alemán y Montealegre han formado parte de gobiernos, han tenido complicidad y conflicto, y han tenido también sobre su cabeza serias dudas sobre su probidad, sea cierta o no, ambos son figuras manchadas, ambas son figuras que han sido controvertidas, y no representan el ideal de una base liberal, que pretende encontrar en su nueva dirigencia, transparencia, eficiencia, capacidad, y, sobre todo, un sentido de inclusión, porque a los que no estamos en el gobierno estamos cansados de exclusiones, estamos cansados de presiones psicológicas, morales, económicas, inclusive, físicas, yo creo que esto es importante que se defina, cuando se va a marcar el proceso de nueva sesión, que es, justamente, reflejarse en reformas parciales o totales de una Constitución, que, verdaderamente, al momento yo creo que sería bueno una revisión total bajo otras circunstancias, puesto que lo que ha habido desde la época de la primera, digamos, desde el 95 hasta hoy, lo que ha habido son parches sobre parches, y adaptaciones como trajes a la medida, pero no se nos ha enseñado que la Constitución es algo que representa una ley de aplicación común, y que, justamente, esa aplicación común no admite que los intereses tengan capacidad para modificarla, entonces, mientras no exista esa conciencia del texto sagrado o el texto de piedra de una Constitución, de su inmovilidad, y que garantice además una aplicación de la justicia, de la equidad y con personas que reflejen en esa transparencia el sentido de proporcionalidad, pues, francamente, vamos a tener siempre ese retroceso, porque la vida política con el control del aparato de la justicia se siente, permanentemente, amenazado, y con ese instrumento de la justicia, que amenaza la acción democrática, pues, francamente, el avance es muy lento, muy controvertido, y, sobre todo, crea un daño moral, puesto que la gente siente que la democracia no le soluciona los problemas, $\mathrm{y}$, por el momento, se siente una frustración generalizada y se dice: "pero, bueno, ¿cuál es el otro método?", entonces, es susceptible que renazca un Hugo Chávez, o que vengan unos liderazgos mucho más confundidos, pero que están y produzcan, obviamente, enfrentamientos y conflictos políticos y sociales, de corte militar, inclusive, porque somos un pueblo guerrero.

R: Y ya mi última pregunta, aunque ya en parte la ha contestado, en relación a este planteamiento de la nueva Constituyente, que es algo en lo que coincide con otros entrevistados, incluso, se habla de que, quizá, a un año, dos años, se pueda dar el llamamiento a un nuevo diálogo nacional, si se continua en esta dirección. ¿Cómo ve el futuro de su pais?

R.G.M.: Yo creo que en una Constituyente tendrían que garantizarse, primero, los mecanismos que distribuyen esa voluntad popular, y, por supuesto, cuando hablamos de mecanismos, hablamos de tribunales electorales, si nosotros tuviéramos la capacidad de tener organismos creíbles, que distribuyen esa voluntad, que haga sentir con credibilidad los resultados podemos pasar a una Constituyente, pero no vale hacer una 
Constituyente cuando desconfiamos todos de un tribunal electoral, que lo sabemos venal, entonces, obviamente, esto no soluciona si se da en los actuales términos, si nosotros pudiéramos reemplazar ese tribunal por un tribunal que represente, verdaderamente, y que nos garantice que esos resultados son verídicos, son respetados, y son respetables, justamente, eso nos permitiría aventurarnos a una Constituyente, que la necesitamos, porque necesitamos un mejor equilibrio entre los poderes del Estado, necesitamos incluir conceptos de las adquisiciones de nuestra civilización, que no existen por el momento, y esto creo que no se podrá dar hasta que no tengamos claro, qué es lo que queremos y hacia donde vamos, pero deberíamos comenzar por el principio, que es crear un tribunal que garantice el voto, y que ese voto vaya en la dirección que el ciudadano diga, y no bajo las órdenes que recibe ese tribunal en favor o en beneficio de algún director, de algún cacique o algún gran monarca, que pretenda arrogarse el poder a través del control sobre las instituciones.

R: Pues, yo creo que por mí es todo, si tiene algo más que añadir...

R.G.M.: No, le agradezco mucho su interés.

R: Al contrario, muchas gracias por la entrevista. 
ENTREVISTA 26 $6^{39}$ :

Nombre del entrevistado: D. Luís Humberto Guzmán.

Cargo actual: ex-presidente de la Asamblea Nacional bajo el gobierno de Violeta Chamorro (1990-1997).

Fecha de realización de la entrevista: Managua, 16 de septiembre de 2009.

Lugar: LEA - Grupo Editorial (empresa privada que dirige, actualmente, el Sr. Guzmán como propietario de la misma).

Duración estimada: 1 hora y 4 minutos.

\section{TEXTO - Transcripción 26:}

R: Sí me gustaría que pudiésemos arrancar el discurso examinando la primera reforma constitucional, que es la del 95, que es la que establece cuál es el marco constitucional que sirve a la transición a la democracia en Nicaragua.

L.H.G.: Sí, sólo un par de palabras sobre la necesidad de esa reforma, como fue fácil saberlo, Nicaragua, junto con el resto de América Latina, tiene una tradición de muchas constituciones y de muchas reformas a la Constitución. Nicaragua fácilmente llega a unas once constituciones, más el doble de reformas parciales a su Constitución. Usted puede encontrar que en el siglo XX tuvimos una Constitución en 1948 y otra en 1950, con dos años de distancia, es decir, que las reformas han obedecido más bien a intereses de acomodos políticos que a necesidades institucionales propiamente dichas. Sin embargo, mi apreciación es que la reforma de 1995 sí era una necesidad institucional, había que ajustar la Constitución a la realidad política de entonces, y ipor qué había que ajustarla?, porque la Constitución de 1987, verdad, es una Constitución de hiperpresidencialismo, basta que te compare dos cosas, verdad, por un lado, el presidente de la República legislaba paralelamente y con ventaja respecto a la Asamblea Nacional, porque la Constitución lo facultaba para legislar sobre materias administrativas, es decir, y no las definía ni las limitaba, eso llegó a incluir en la perspectiva presidencial incluso los temas tributarios, entonces el presidente de la República legislaba paralelamente a la Asamblea Nacional, y con ventaja porque sus decretos ejecutivos con fuerza de ley no requerían de posterior sanción parlamentaria, sino que tenían una validez inmediata y autónoma, en cuanto el presidente firmaba el decreto, ese decreto se convertía en una ley, y no necesitaba ratificación parlamentaria, ni la intervención de otro poder, una validez autónoma e inmediata. En cambio, las leyes que dictaba la Asamblea Nacional debían ir al presidente para su sanción y para su publicación, es decir, que la Asamblea Nacional estaba en desventaja en el proceso legislativo con respecto al presidente. Ahí tiene un punto, que hacía crucial la reforma a la Constitución, usted encontraba otro aspecto, era que, por ejemplo, el proceso de formación de la ley no estaba presente en la Constitución, entonces, era, de verdad, era indispensable, era necesario, reformar la Constitución Política para colocarla en la perspectiva, pues, de la situación política que teníamos entonces. A eso hay que agregar varias otras transformaciones que se hicieron, que incluyó, por ejemplo, el tema de que no podía haber tasación sin representación, no se podían crear impuestos si no era a través de la Asamblea Nacional, y, además de eso, otras reformas delimitaron el poder

39 Entrevista excelente, el informante genera un discurso coherente, de gran contenido analítico, y con una extrema concisión sin giros redundantes en las respuestas a cada una de las preguntas planteadas por la investigadora. También se da una menor evaluación crítica y una tendencia general a la moderación. 
del presidente de la República, la Asamblea Nacional ahora no puede delegarle sus facultades al presidente, las facultades no son delegables, antes eran delegables en su inmensa mayoría, entonces, las reformas de 1995, en mi opinión, sí estaban justificadas y tienen dos atributos especiales: uno, que es de origen parlamentario, no es el de origen del presidente de la República, y a eso agréguele que a diferencia de la mayoría de las constituciones y de las reformas constitucionales anteriores, que tenían el defecto, el déficit, de ser expresión de una perspectiva parcial de una mayoría importante pero transitoria, la reforma del 95 reunieron un consenso muy amplio. Al final, incluso el concurso de la presidencia de la República a través de la Ley Marco, pero todo el arco parlamentario respaldó la reforma, eso incluía al Frente Sandinista, a los disidentes del Frente Sandinista, y a todo el sector que fue la UNO entonces. Entonces, tiene los méritos desde el punto de vista del contenido, y tiene también los méritos desde el punto de vista del respaldo que tuvo, que venía tanto de todo el arco parlamentario, como de la propia presidenta de la República después de una negociación muy ardua, concretada en la ley.

R: Eso le iba a decir, que el debate a propósito de la reforma constitucional sí fue un debate serio, no solamente entre las distintas fuerzas politicas sino también entre el propio Ejecutivo presidencial, que al principio se negaba a aceptar la propuesta de la Ley de Reforma Parcial de la Constitución aprobada en la Asamblea, y que dio lugar a esta Ley Marco que, jurídicamente, sí es un instrumento controvertido, ¿no? ¿Cuál es su opinión al respecto?

L.H.G.: Bueno, David Close dice que la Ley Marco es un artefacto político muy creativo, yo me quedo con esa opinión.

R: Sí, pero de alguna forma, amplía el período de la negociación política entre los actores congelando la aplicación jurídica de las normas constitucionales reformadas.

L.H.G.: Pero solo de unas porciones muy pequeñas, y no sustantivas, a propósito de eso, esto es un apunte más que todo anecdótico, en medio de ese debate estuvo de visita en Nicaragua Felipe González, y, pues, la Asamblea Nacional lo condecoró, y estando en una conversación en la Asamblea, pues, él hizo una observación sobre el proceso de reforma, muy respetuosa, verdad, muy "polite", dijo: "hombre", dice, "lo que ustedes debieran de pensar, es si es, políticamente, viable, legítimo, limitar los poderes de un presidente a mitad de camino, cambiarle los poderes al presidente a mitad de camino. Fue electo con unos poderes determinados y por qué no cambiarlos a partir del siguiente período". En mi opinión, ese es un punto de vista, pues, políticamente, válido, sin embargo, el Poder Ejecutivo en Nicaragua nunca lo planteó, nunca presentó esa propuesta de salida, el Poder Ejecutivo siempre estuvo más bien reacio a aceptar cualquier reforma. Usted podrá en su investigación encontrar que desde la Presidencia de la República nunca se hizo una propuesta alternativa a la de nosotros, era más bien decir no a las reformas.

$R: Y$, por otra parte, también resulta interesante como recuerda, porque además usted fue el presidente de la Asamblea Nacional en ese periodo, las negociaciones en el debate a propósito de una reforma total o una reforma parcial a la Constitución del 87, porque ese fue otro debate de la época, ¿no? 
L.H.G.: Bueno, pero nosotros pensábamos que era más conveniente una reforma parcial profunda, que hablar de una reforma total, lo cual implicaba nuevas elecciones, y era un período muy crítico para el país, de una estabilidad y de una paz muy frágil, hay que pensar que la transición de Nicaragua tiene sus complejidades, porque no era solamente de un tipo de gobierno a otro, sino que era una transición de la guerra a la paz, y además, agréguele que era una transición de un régimen económico a otro, entonces, era una transición con muchas complejidades, entonces, nosotros calibrábamos que era preferible una reforma parcial que nos evitara una nueva elección. La reforma total supone una nueva elección, convocar una Asamblea Constituyente, entonces, decidimos evitar la elección.

$R$ : $Y$, en ese sentido, también, la permanencia de gran parte del edificio institucional de la revolución, la Constitución del 87, de hecho, se aprueba en el periodo revolucionario del viejo régimen sandinista. ¿Supuso, de alguna forma, ese intercambio en la negociación con los sandinistas la pervivencia de ciertas instituciones a cambio de esa apertura económica de signo liberal?

L.H.G.: Sí, claro, sí eso fue una negociación que supuso, pues, concesiones recíprocas, que son las negociaciones que sirven y que valen, usted puede encontrar, pues, como un detalle, si quiere, que el 19 de julio es un día feriado en Nicaragua y los días feriados son establecidos por ley, entonces, la Asamblea Nacional lo estableció en un momento en que la correlación de fuerzas no era una mayoría sandinista. Pero fue una manera de decir, bueno, el 19 de julio, al fin y al cabo, es una fiesta nacional en el sentido que es el final de la dictadura, y en la lucha contra la dictadura estamos todos, aquí no hay representantes del somocismo, aquí todos los que estábamos ahí estuvimos contra la dictadura, y, desde esa perspectiva, nosotros estamos a favor de conservar el 19 de julio como un día festivo, por ejemplo, pues, luego hay otras cosas que se llevaron con mucha tranquilidad, como fue la reforma militar que es paralela a esto, la nueva Ley de Policía, etc., etc.

R: Y también, desde el punto de vista de las reformas estructurales, que se hicieron a la economía, afectaban socialmente al país.

L.H.G.: Sí, pero también hay que reconocer una cosa, verdad, esto ocurrió, especialmente, en los dos primeros años de gobierno, del 90 al 91, pero en lo sucesivo las reformas fueron endosadas por el Frente Sandinista, usted lo puede comprobar si tiene alguna manera de verificar la integración de las delegaciones de Nicaragua para negociar con el Fondo Monetario, usted va a encontrar que había una participación de los miembros del Frente Sandinista que asistieron y que endosaron, aquí hubo una contrapartida, la cual la negoció el gobierno, la presidencia de la República, directamente, con el Frente Sandinista, al margen de la Asamblea Nacional, esos los temas de la privatización, piense usted en la $\mathrm{CORNAPI}^{40}$, que era la corporación encargada de esa privatización, en ese proceso de privatización se aprobaron, pues, la privatización a favor de los trabajadores de empresas enteras, o de participación en empresas públicas, o en empresas, que, posteriormente, se privatizaron.

40 Corporación Nacional de Privatización (CORNAPI). 
R: Y esa es una reconversión socioeconómica también de los actores politicos, que en el pasado defendían otro tipo de ideas y de concepción, incluso, del modelo de crecimiento económico, ¿no?

L.H.G.: Sí, sí.

R: Y que se han integrado perfectamente en la Nicaragua liberal de hoy.

L.H.G.: Y aceptaron además los términos en que se reformó la Constitución en los aspectos económicos, verdad, que implican el reconocimiento a la propiedad privada, a la iniciativa de los actores privados para emprender negocios, etc., etc.

R: Y, por otra parte, la reforma del 2000, he oído, incluso, el término "contrarreforma" para referirse a un punto de inflexión, que, de alguna forma, modifica el hilo conductor del proceso de cambio constitucional de parlamentarización o semi-parlamentarización del régimen presidencial nicaragüense. ¿Qué opina de este reparto casi paritario de las posiciones de poder en los principales órganos del Estado?

L.H.G.: Bueno, yo ahí creo que hay que distinguir lo siguiente. Déme un segundo (breve interrupción). Sigamos entonces.

\section{R: Estábamos comentando a propósito de la reforma del 2000.}

L.H.G.: Bueno, mire, en esto yo advierto lo siguiente, creo que hay unos cambios institucionales que no tienen más justificación que una distribución de cargos en el gobierno, es decir, el caso de la colegiación de la Contraloría General no tiene otro sentido, pero hay otros que son unos mecanismos institucionales más o menos generalizados, que son las mayorías calificadas para la elección de determinados cargos. Entonces, esto es una práctica generalizada, igual que en España si no se suman los votos del partido socialista y los del partido popular no hay mayoría suficiente para nominar los cargos del Consejo General del Poder Judicial, verdad, entonces, bueno, igual pasa en Nicaragua, igual tiene que llegar a esa decisión de compartir esos cargos. Yo no digo que esa sea una práctica buena, pero la alternativa a eso es que usted deje una composición unilateral para esas entidades si usted rebaja las mayorías. Pero, en efecto, el sentido, el espíritu de esas reformas tenía en el 2000 mucha menos trascendencia con respecto al hilo conductor de las reformas constitucionales. Las reformas del año 2005, esas, en mi opinión, son otra cosa, verdad, esa fue una reforma, pues, de envergadura, y que tiene un cierto hilo conductor, tiene una cierta congruencia con una potenciación del parlamento. La reforma del año 95 mejora la Asamblea Nacional, por así decirlo, en los estándares centroamericanos de las atribuciones del parlamento, de hecho, hubo congresos nacionales en Nicaragua que tuvieron atribuciones más grandes, por ejemplo, autorizaban los ascensos en las Fuerzas Armadas. La Asamblea Nacional, actualmente, no interviene en los ascensos en las Fuerzas Armadas, entonces, más bien, eran unas atribuciones estándares. Sin embargo, la reforma del 2005, sí incrementó el poder de la Asamblea Nacional, al darle atribuciones para confirmar ministros, y otros cargos, eso pone, en mi opinión, pues, ha elevado las atribuciones y coloca a la Asamblea Nacional de Nicaragua en una posición de mayores atribuciones respecto al resto de Centroamérica. 
$R:$ ¿Y cómo fue el aprendizaje de ese funcionamiento en la práctica legislativa en una arena parlamentaria que habia quedado relegada durante el proceso revolucionario?

L.H.G.: Bueno, la verdad es que uno podría decir que la historia política de Nicaragua no pasa por el parlamento, verdad, pasa fuera del parlamento. El parlamento fue sobre todo una entidad que sancionaba las decisiones presidenciales, $\mathrm{y}$, en el mejor de los casos, una arena de denuncia política, ya los cambios en 1995 le dieron unas atribuciones de gobierno real, verdad, y eso sí fue un aprendizaje que muestra, en mi opinión, que los seres humanos tenemos capacidad para aprender rápido si las circunstancias lo requieren, pues, creo que la Asamblea hizo, en mi opinión, que no es imparcial en esto, hizo notoriamente bien su trabajo, abordando temas críticos, como la reforma militar, la reforma de la Policía, reformas económicas, nueva legislación de bancos centrales, etc., etc.

R: Sin embargo, las crisis institucionales generadas en Nicaragua por el conflicto entre el presidente de la Asamblea y el presidente de la república se ha dado en todos los gobiernos con excepción del actual, que es un Ejecutivo presidencial, que ha tratado de reforzarse también a través de algunas reformas a la ley que regula la organización del Poder Ejecutivo.

L.H.G.: Bueno, eso me lleva a mí al punto que entiendo que usted quiere enfocar en su tesis, y esto tiene que ver con, ¿cómo se llama?, quién tiene las mayorías parlamentarias en la Asamblea. Tome usted en 1984 en adelante, del período de 1984 a 1990 el presidente Daniel Ortega tenía dos tercios de la Asamblea Nacional, aparte de que las atribuciones al parlamento eran mínimas, entonces, la Asamblea no tuvo mayor protagonismo. Pero el período del 90 al 96, la presidenta Chamorro se quedó sin representación parlamentaria, entonces, el protagonismo en la Asamblea se elevó también por el cambio de normas, verdad, pero usted va al período del presidente Alemán del 96 al 2001, y, entonces, usted encuentra que, de nuevo, la mayoría parlamentaria del presidente sumerge a la Asamblea Nacional, le resta protagonismo, en el período posterior del presidente Bolaños, de nuevo, el presidente se queda sin mayoría parlamentaria y, entonces, emerge la Asamblea Nacional, queda como un protagonista de primera línea. Ahora, tenemos una situación nueva porque el presidente no tiene mayoría absoluta en el parlamento, entonces, eso da lugar, pues, a que tenga que negociarlo, etc., y el protagonismo de la Asamblea no ha disminuido, no ha decrecido dramáticamente, sigue siendo un protagonismo relevante. Entonces, el punto está en la pregunta ¿qué determina el protagonismo del parlamento?, ¿las normas constitucionales o la mayoría del presidente? Pareciera ser que las normas constitucionales dan una base, un punto de partida, un piso importante, pero el resto lo determina la mayoría o no mayoría, el tamaño de la fracción parlamentaria, del presidente.

R: Eso es algo que estudia Juan Linz cuando habla de la quiebra de las democracias, y el Profesor Linz desconfía de la capacidad que tiene el régimen presidencial para producir democracias gobernables, bueno, esto es simplificar mucho la hipótesis, que además, después, ha sido matizada, incluso, abordada de forma crítica por otros autores como Nohlen, que sí habla de un enfoque comparado y empírico, como hace también el Profesor Diego Valadés, a la hora de examinar cómo se pueden injertar instituciones procedentes de una tradición distinta, que, en este caso, es el 
parlamentarismo, a un régimen presidencial, que, históricamente, ha sido la tradición constitucional de Nicaragua, ¿verdad?

\section{L.H.G.: Sí.}

R: ¿Qué opina respecto a las últimas propuestas de reforma constitucional como esta que sugiere la división del Poder Ejecutivo a través de la creación de un Primer Ministro?

L.H.G.: Bueno, yo ahí voy a hacerle dos matices: uno, América Latina tiene una historia de muchas constituciones y de poco constitucionalismo, ese es un punto que hay que tener en cuenta, verdad, la historia de las constituciones no es una historia del constitucionalismo, esta es una historia de textos legales, pero no es una historia de esos textos legales teniendo un verdadero poder normativo, un poder regulatorio sobre la vida política del país, entonces, hay que anotar que las constituciones han tenido más bien un carácter marginal, verdad, respecto a su poder regulatorio para el país, ese es también el caso de Nicaragua, entonces, usted oye decir, por ejemplo, que hay que prohibir la reelección presidencial, verdad, en Nicaragua, pero el caso es que ha estado prohibida siempre, fijese que si usted va y revisa las constituciones, que cubren los cincuenta años de la familia Somoza gobernando Nicaragua, usted va a encontrar en todas las constituciones que la reelección estaba prohibida, o sea, que no es que no había la norma, la norma estaba, sólo que la Constitución no regulaba, de verdad, la vida constitucional del país. El otro aspecto que hay que tomar en cuenta, creo yo, es que, en términos globales, el problema es la construcción del orden social y el orden político en estas sociedades, dentro de las cuales las constituciones son un aspecto, y es un aspecto importante, pero no es el todo, entonces, creo que la perspectiva se equivoca si reduce todo lo del tema del orden social y político exclusivamente a la Constitución, $\mathrm{y}$, dos, hay que darse cuenta que somos sociedades que no tienen una gran solera, como dicen ustedes, constitucional. Hay unos países con solera y otros sin solera, uno puede pensar que el gobierno autoritario de Chile fue un paréntesis en una larga tradición democrática, lo mismo puede pensar uno de Uruguay, pero ese no es el caso de Nicaragua, esto se trata de constitucionalismo por primera vez y en medio de estas precariedades que usted ve hoy, bueno, este es el mayor grado de constitucionalismo que ha tenido esta sociedad. Creo que las propuestas, en mi opinión, para fomentar un mejor orden social y político en Nicaragua deberíamos dejar reposar la Constitución, tal cual está ahora, no es que no sea mejorable, pero es que si no damos tiempo para que las normas se asienten, para que sean interiorizadas, entonces, el poder regulatorio de la Constitución va a seguir siendo marginal. Y un último punto, que me parece está más en el campo de la Ciencia Política que del Derecho, es el término del "autocumplimiento" de la Constitución, esto llega a un nivel en el punto en el cual la obediencia a la Constitución depende más de la voluntad de los actores que de factores externos, por eso es que algunos autores, precisamente, rechazan la figura, la metáfora, de "contrato" cuando se habla de Constitución, porque en un contrato hay dos partes que pactan, pero hay un tercer agente que obliga a cumplir el contrato a quien pretende desconocerlo. Pero cuando hablamos de temas constitucionales aquí no hay una agenda, y no hay un tercer agente que obligue a cumplir la Constitución, depende, en buena medida, de autocumplimiento de los valores de la sociedad para que presionen, para que exijan, para que reclamen ese cumplimiento. Pero usted va a poder establecer que Nicaragua, no este gobierno, sino los gobiernos de 1990 en adelante, usted puede encontrar un número importante de sentencias de la Corte Suprema de Justicia que no han sido 
cumplidas por ninguno de los gobiernos, y así sucesivamente. Pero, entonces, creo, que el orden público en Nicaragua depende en buena medida de que se desarrolle una voluntad de obediencia a la Constitución y eso es una cosa que se cultiva, que se va a crear, el error más grande en América Latina, en mi opinión, es creer que si usted cambia el texto de la Constitución eso permite una nueva conducta o da una nueva conducta o un nuevo comportamiento de los actores políticos, eso no es cierto, eso no, eso no se ajusta a la realidad. Nicaragua ha tenido Magistrados en la Corte Suprema vitalicios, electos por períodos de 20 años, de 10, de 15, de 5, cuya relación no cambia, ni la conducta en el Poder Judicial cambia, o sea, no depende del período de los Magistrados. Usted puede crear una Sala Constitucional o un Tribunal Constitucional y eso no nos va a hacer una enorme diferencia, en mi opinión, la diferencia la hace la voluntad de Constitución, y ese es un proceso cultural, que lleva tiempo. Por ahora, creo que hemos estado en el camino equivocado de creer que el orden público lo vamos a mejorar sobre la base de reformas perpetuas a la Constitución, permanentes, hay quienes repudian el proceso gradual de ir creando reformas parciales, pero usted puede ver, a Estados Unidos les funciona el proceso de reformas parciales, creo que Dinamarca también tiene un arduo proceso de reformas parciales, entonces, yo sí creo en la gradualidad de las reformas parciales, pero, por ahora, en mi opinión, creo que a la Constitución habría que dejarla descansar.

R: ¿Y cree que esa va a ser la situación en la coyuntura actual por la dificultad que tiene el Frente Sandinista de lograr los apoyos necesarios en la Asamblea?

L.H.G.: Está difícil, efectivamente, reunir una mayoría que acuerde reformas parciales a la Constitución. No la veo.

R: ¿Y cuál ha sido la función de la justicia constitucional, bueno, en este caso, de la Sala de lo Constitucional, que además aparece en la reforma del 95, como una institución, que, en cierto modo, trata de dar un respaldo a la nueva reforma y al régimen democrático que así se constitucionaliza a través de la reforma del 95?

L.H.G.: Pues todavía creo yo que es uno de los aspectos en donde más podemos mejorar, verdad, en el tema de la justicia, este es uno de los aspectos más críticos, usted lo puede comprobar en Ciencia Política, lo que está a la vista es que es más fácil crear un ciclo de elecciones competitivas, usted lo puede ver en Europa oriental, eso es más fácil que crear un Estado de Derecho, y ¿por qué?, por las razones que le estaba diciendo antes, la creación de un Estado de Derecho tiene que ver con la actitud de las personas respecto a la ley, si usted cree que es más barato, socialmente, también, cumplir una norma que desobedecerla, por ahora en la sociedad en América Latina piensa que es más barato, en términos personales, desobedecer la norma que cumplirla, mientras esa situación no se espere, usted va a tener un Estado de Derecho precario, va a tener también un orden público complicado, porque la gente piensa que es más fácil evadir el pago de impuestos, cruzarse un semáforo en rojo, boicotear una elección, etc., etc., ahí tenemos un problema que, en mi opinión, trasciende, pues, los estudios exclusivamente jurídicos y, particularmente, el Derecho Constitucional.

R: Pero haciendo referencia al aspecto electoral, que yo creo que si ha sido fundamental, a la hora de crear democracias gobernables en América Latina, y dotadas de una legitimidad o de respaldo ciudadano, ahora tanto el Consejo Supremo Electoral 
como los mismos procesos electorales de las municipales el año pasado han quedado seriamente dañados en Nicaragua.

L.H.G.: Sí, eso es verdad, pero, de nuevo, yo trato de poner estos problemas en perspectiva, mire, en el ámbito electoral ha ocurrido lo siguiente, desde 1984 hasta ahora hemos tenido unas cinco leyes electorales, lo cual quiere decir que hemos tenido en promedio una ley para cada elección, entonces, eso crea una inestabilidad en las normas, verdad, entonces, no permite que tengamos estabilidad, ese es el lado negativo, pero un lado positivo que usted tiene, que la mayoría de este ciclo de elecciones presidenciales han sido ganadas por la oposición, lo cual quiere decir que la elección fue limpia, si usted cuenta las elecciones a partir de 1990 la excepción es Enrique Bolaños, todas las demás elecciones las ganó la oposición, y los perdedores reconocieron que habían perdido, entonces, ahora eso sin perjuicio de que digan que el Consejo Supremo Electoral es dispendioso, puede ser, no lo sé, pero puede ser, pero eso no invalidó lo de que su función es garantizar que la elección sea limpia y para mí lo más importante es que el perdedor acepte el resultado, y si en estos casos, como le estoy diciendo, perdió el gobierno y ganó la oposición, pues, resulta que el Consejo habría hecho entonces su trabajo, eso no quiere decir que no sea mejorable, ni estoy defendiendo la manera en que se llevaron las pasadas elecciones municipales, yo creo que ese era un extravío en un camino largo de elecciones bien llevadas, tampoco digo que no sea reformable el sistema electoral en las normas, puede ser que en una nueva composición en las Juntas Receptoras de Votos nos dé más seguridades, pero si hoy se pueden hacer reclamos respecto a las elecciones municipales recién pasadas es porque la legislación crea una serie de trabas y candados, que hacen obvio, que muestran que ha habido algo irregular. Si esas normas no estuvieran ese tema se podría haber escamoteado, pero como existen esas normas, entonces, se vuelve visible, se vuelve notorio, porque hay más irregularidad que en el pasado. Pero en el tema, yo creo que podría haber reformas, pero no necesariamente un cambio en la ley nos va a mejorar la garantía de la manera en que se lleven las elecciones, yo ahí creo que hay factores como la observación electoral nacional y extranjera ayudan a una mejor realización de las elecciones, por otro lado, encuentro que los sectores sociales que quieren reformas tienen unas actitudes contradictorias, o desconocimiento de las consecuencias de lo que proponen, por ejemplo, quieren pluripartidismo, pero, a su vez, proponen sistemas de elección uninominal, verdad, eso es una incongruencia, eso es una contradicción, pues, uno de los aspectos más exactos en Ciencia Política es que si usted tiene un sistema de elecciones uninominales usted va a tener bipartidismo, y si usted quiere pluripartidismo, pues usted debe tener un sistema de representación proporcional, ahora, en el caso de Nicaragua, nosotros hemos tenido y tenemos bipartidismo por razones y causas ajenas a la legislación electoral, usted revise la legislación que rigió las elecciones de 1996, y va a encontrar que favorecía el pluripartidismo, pero resultó que el $90 \%$ de los votos se concentró en dos partidos, por razones ajenas a las reglas, no porque las reglas lo establecieran, eso fue ajeno a las reglas, factores externos a las reglas polarizan la elección y la conducen al bipartidismo, pero no porque las reglas lo digan, esto se manifiesta, especialmente, en el ámbito municipal, esa misma elección de 1996, la boleta presidencial era una cosa que medía más de un metro, eran 26 candidatos, sin embargo, Daniel Ortega y Arnoldo Alemán reunieron más del 90\% de la votación, los otros tuvieron unas votaciones marginales, pero quedó, en esa ocasión las elecciones municipales fueron simultáneas a la elección presidencial, en el ámbito municipal hubo un tercio de los votos que no fueron ni para el PLC ni para el Frente Sandinista, pero fue un tercio de votos que se dispersó entre muchos, pero fue un tercio de los votos 
dispersos. Ahí tiene usted la prueba de esa situación sui géneris, en la elección presidencial esto se polariza y se convierte en bipartidista, en la elección municipal sigue siendo bipartidista, pero hay un tercio de la votación que va a otro sector. Lo que quiero decirle es que Nicaragua ha tenido bipartidismo, no, necesariamente, derivado de las reglas electorales, ahora, es cierto, tenemos una elección parlamentaria, proporcional, con la media mayor, verdad, que favorece, pues, a los partidos grandes, pero aún así, pues, no cierra el espacio de los partidos que podrían tener presencia, y, de hecho, tienen presencia. La división del liberalismo en la última elección presidencial en algún sentido abrió camino al pluripartidismo, que, desde luego, le conviene al Frente Sandinista, y perjudica al universo no sandinista, en la medida, pues, que se dispersa su voto y pierde, pues, oportunidad de ganar la elección presidencial.

$R: Y$, sin embargo, esa ruptura del bipartidismo tradicional que han tenido en la práctica, aunque, formalmente, antes han tenido un sistema multipartidista por las propias reglas electorales, que, incluso, favorecian la creación de partidos políticos con mucha laxitud. De ese defecto técnico de las leyes electorales de principios de los 90 se pasó a una restricción mucho mayor a la formación de partidos políticos, que yo creo que, actualmente, o al menos, según lo que he leido en artículos especializados, es de las más restrictivas de América Latina, la reforma electoral reciente del 2000, ¿no?

L.H.G.: Bueno, ahí hay un punto que quizás usted deba investigar, hay una sentencia de la Corte Suprema de Justicia, que declaró inaplicable una gran parte de esa ley, especialmente, lo que tenía que ver respecto a la posibilidad de crear nuevos partidos políticos, eso, pues, se enmendó por la vía de esa sentencia de la Corte Suprema, pero, pues, yo no digo que no sea derogable también la ley electoral, verdad, pero, en general, los problemas en la relación con los ciudadanos con la ley es el tema de la aplicación de las leyes que tenemos, no es tanto que las leyes sean deficientes, o que las leyes tengan lagunas o contradicciones, sino la falta de aplicación de las leyes, ahí tenemos un punto crítico.

R: Esta mañana, en una entrevista también con el asistente del Dr. Cuarezma, comentaba la falta también de una Ley de Partidos, que esté adecuada al contexto de la transición democrática. Es otro aspecto a explorar muy interesante.

L.H.G.: Sí, bueno, en los años 80 hubo esa Ley de Partidos, pero le voy a decir, francamente, con conocimiento de causa, eso se suprimió en los años 90, porque se dijo que era mejor que los partidos no tuvieran esa regulación, y fue un error, verdad, los partidos deben tener esa regulación, yo también lo creo.

R: Sobre todo porque radica, entonces, en el Poder Electoral, como última instancia en las decisiones en materia electoral, que además es un derecho fundamental por parte de los ciudadanos, que no pueden, en ese sentido, por ejemplo, recurrir a la Ley de Amparo si se da algún tipo de asalto.

L.H.G.: Sí, y también es cierto que en Nicaragua se suprimieron las suscripciones populares, que era lo que permitía participar en las elecciones municipales al margen de los partidos. Pero la otra realidad es que tanto el PLC como el Frente Sandinista han mostrado que son unas organizaciones con mucho arraigo en la sociedad, porque tienen unas bases sólidas, tienen unas bases disciplinadas, no sé cómo sea en España, pero en Nicaragua hay un estudio, que hicimos algunos y encontramos, pues, que más de la 
mitad de las razones por las cuales las personas militan el los partidos son razones familiares.

R: Pero, de todos modos, el discurso que ha predominado, no solamente en mis entrevistas, sino en la prensa, por ejemplo, y un poco el discurso crítico frente al pacto entre Ortega y Alemán, que tampoco es un fenómeno nuevo en la historia de Nicaragua, hay pactos políticos que preceden a cambios constitucionales a lo largo de todo el proceso histórico del país desde la independencia, ¿no? Pero sí el surgimiento de fuerzas alternativas, que han criticado el pacto como algo anti-democrático, y ese discurso del cierre de espacios a la oposición, de que cada vez, tanto en la arena parlamentaria con la restricción de partidos políticos de oposición, como el MRS o Alianza Liberal Nicaragüense, como en el caso de la sociedad civil, que también se ve un poco acosada en su ejercicio de derechos fundamentales, como es la libertad de expresión de cara, por ejemplo, a las últimas elecciones municipales. Incluso se habla de no de "régimen dictatorial", pero sí esta expresión de "bloque contra la dictadura" que se formó en la Asamblea para ir en contra de la creación de los CPC, es muy fuerte, ¿no?

L.H.G.: Yo creo que es muy fuerte, y, ¿sabe?, en alguna medida se debe a una cierta incapacidad para reconocer la evolución de la sociedad nicaragüense, que no ha evolucionado todo lo que debería, pues, a mi gusto, ni con la velocidad que se requiere, pero, sin duda, ha cambiado. Usted lo puede notar, por ejemplo, en el papel de las Fuerzas Armadas. Nicaragua llegó a crear el monopolio de fuerzas en el Estado, a la altura de 1927, con la creación de la Guardia Nacional, y hay que recocerlo, más producto de una voluntad política extranjera, que de una evolución del Estado nacional. Estados Unidos por la época estaba creando una guardia en República Dominicana, en Haití y en Nicaragua, pero bueno, eso fue el monopolio de las fuerzas. Pero muy pronto, el general Somoza García se adueñó de la Guardia Nacional y la convirtió en un instrumento familiar, esto da lugar a veces a una confusión en el mundo de la Ciencia Política, que hablan de militarismo en Nicaragua, en Nicaragua nunca ha habido un militarismo, si uno entiende por militarismo el predominio de las Fuerzas Armadas sobre la política en Nicaragua nunca ha habido militarismo, aquí hay una situación paradójica, han sido líderes políticos los que han manipulado los cuerpos armados, era la familia Somoza la que instrumentalizaba la Guardia Nacional, no la Guardia Nacional a la familia Somoza, después usted tuvo la creación del Ejército Popular Sandinista, que forma en sí un Ejército de servicio partidario, que estaba al servicio del Frente, de nuevo, eran los hombres políticos uniformados los que manipulaban a ese cuerpo armado, y no al revés, no era la dirección sandinista un instrumento en manos del Ejército, sino al revés. Entonces, ahora tenemos un Ejército de servicio nacional, que no obedece consignas de partidos, etc., con un grado de autonomía que puede sorprender en otros países, pero que para Nicaragua, en las circunstancias actuales, resulta una bendición que el Ejército tenga ese margen, ese espacio de autonomía, entonces, y así, sucesivamente, la Policía también, es cierto, hay una relación tensa, para decirlo suavemente, entre el gobierno y algunos medios de comunicación, pero, pues, no hay censura de prensa, y otras circunstancias, creo que la tortura ha sido eliminada, por completo, en los sistemas carcelarios en Nicaragua, etc., tampoco encuentra usted presos políticos, etc., etc., esta es una situación distinta, no es todo lo mejor que yo quisiera, el Estado de Derecho tendría que haber avanzado más, el imperio, el predominio de la ley también tendría que haber avanzado más, creería decir que esto tiene viso o que es una dictadura, es más, sinceramente, creo que son palabras 
exageradas. Pero, a propósito de exclusión, en términos electorales, usted podría preguntarse cuáles son esas fuerzas políticas que fueron marginadas de las elecciones a causa de las normas, vamos, uno tendría que identificar cuáles son esos partidos, o esos grupos, que no se están expresando electoralmente, incluso, hay una controversia por la aplicación de una ley que es más o menos universal, un principio universal, donde se establece un umbral, verdad, para que usted conserve el estatus y el derecho de partido, por debajo de ese umbral usted no lo es. Claro hay unos países con unos umbrales más altos que otros, pero bueno, en Nicaragua eso es como el 1 o el $2 \%$ de la votación, aún así, hay gente que dice que eso era inconstitucional, que no se puede aplicar esa restricción, que por ley si usted no se ha llegado al 1 o al $2 \%$ de los votos no puede usted perder sus estatus de partido político.

\section{R: Actualmente, creo que es el 3\% con la reforma del 2000.}

L.H.G.: Sí, puede ser, no recuerdo ahora si la sentencia se llevó ese artículo también, pero es importante que usted localice la sentencia, porque modificó considerablemente la ley por la vía de declarar inaplicable los artículos. Ciertamente, hay unas normas que complican la organización de partidos, si a usted le piden que tenga presencia en 155 municipios que tiene el país, que debe tener como una participación mínima de 10 personas en eso, termina siendo un número relativamente grande, creo yo.

R: Y la crítica a los "hombres fuertes" de ambos partidos, que, a veces, califica el poder no ya tanto en términos de agregación de intereses, cuando hablamos de partidos modernos en un sistema como el de los países occidentales, como el ejercicio de cierto "patronazgo parlamentario", que es el término que utiliza Linz para ver cómo se comportan actores en sistemas presidencialistas, pero dando mayor importancia, mayor peso al funcionamiento de la Asamblea.

L.H.G.: Fíjese que ahí, yo tengo más bien preguntas más que respuestas. Uno, el caudillismo no es un fenómeno que se explique por sí mismo, no hay caudillos porque haya unas personas que quieran ser caudillos, sino porque hay unas condiciones en la sociedad que les permite serlo, y además, se manifiesta eso no sólo a nivel de partidos, eso se manifiesta en los organismos no gubernamentales, se manifiesta en la sociedad civil, por lo menos en el caso de Nicaragua. Y, de otro lado, yo advierto un proceso, que no sé cómo llamarlo, cómo definirlo en los partidos europeos, vea el caso del Partido Socialista Obrero Español, cuando Felipe González era Secretario General de ese partido había, pues, unos congresos, que suponían listas competitivas para integrar la ejecutiva del partido, la integración se hacía sobre la base de una cierta representación proporcional, y, entonces, quedaba una ejecutiva plural, verdad, había una participación de la izquierda socialista y de no sé quién más, pero era sobre la base de que se competía en el concurso. Ahora yo veo a ese Zapatero, dice que está elaborando la lista de la ejecutiva, verdad, y es el presidente, el Secretario General del partido, que, en solitario, dice: "bueno, esta es la lista que quiero tener compacta", verdad, entonces, yo ahí también noto una disminución de la democracia en los partidos.

\section{R: Sí, además, tiene un nombre, la "partitocracia”...}

L.H.G.: Bueno, ahí llegamos a un punto retratado por Duverger, que llama el "Estado de partidos", en el que un eje fundamental en la organización del Estado contemporáneo son los partidos políticos, verdad, entonces, digo, no es un problema exclusivo en 
Nicaragua, ni lo digo para justificar lo que ocurre en Nicaragua, simplemente, trato de hacerme cargo que el caudillismo no es un fenómeno que se explique por sí mismo, sino que la sociedad tiene unas condiciones que todavía lo permiten.

R: ¿Y es difícil ese recambio del liderazgo politico en Nicaragua? Porque los protagonistas de los años 80 no han desaparecido de la escena política. ¿No hay otra generación de políticos?

L.H.G.: Pero si uno lo va viendo, digo, en razón, para darle una respuesta real no formal, bueno, yo creo que ha permanecido, el líder político que ha permanecido por más tiempo es Daniel Ortega, pero si usted mira dentro del Frente Sandinista de 1979 a ahora sí encuentra unos cambios considerables, verdad, en las personas, pues, lo que era la dirección histórica, eso desapareció, etc., etc. Eso, a su vez, llevaba aparejado un fenómeno de un predominio en solitario de parte de él mucho más acentuado, verdad, si usted quiere, la dirección de los años 80 era una dirección colegiada, esa colegiatura ha desaparecido, claro, porque eso era un grupo de "primus inter pares", de unas personas muy iguales entre ellos, en sus derechos, en sus pesos específicos, verdad, y acaba en 1990, pues, ocurrió otra cosa, y, conste, no por purgas, verdad, sino que los líderes históricos, que fueron parte de la dirección histórica del Frente Sandinista decidieron abandonar la política en los años 90, y el único que persistió en seguir en eso es él, verdad, pero eso lleva, sin embargo, en términos formales, eso le implica un recambio grande en las personas. En la política opositora o en el sector no sandinista también ha habido recambios, hay una relativa buena circulación de las élites ahí, yo más bien creo que el problema radica en el estilo y en la manera que ha predominado de hacer política, que es ese estilo, pues, de "hombre fuerte" con un enorme peso, no es tanto que las personas hayan estado inmóviles, creo que ha habido una relativa buena circulación de las élites, pero el estilo y la manera, que, en mi opinión, confirma mi punto de que no es algo que radique en las personas, sino en la sociedad, que da facilidades para que esto ocurra.

R: Sí, porque además el vínculo proseguido con su esposa, se habla, incluso, de la "pareja presidencial", de las relaciones familiares que caracterizan un poco al funcionamiento del Ejecutivo actual, ¿no?

L.H.G.: Sí, sí, eso es cierto, eso es una realidad, pero, de nuevo, tenemos un problema, pues, con el Estado de Derecho, tenemos un problema con la sociedad y su manera como entiende la política, y cómo entiende las relaciones de poder. Y mire, tiene su complejidad, porque uno pensaría que esto lleva automáticamente aparejado un nivel elevadísimo de clientelismo, si entendemos por eso el intercambio de favores materiales con votos, el Frente Sandinista hizo un esfuerzo grande en la elección de 1990, condonando deuda, regalando vehículos, automóviles, etc., etc., y eso no llevó a los ciudadanos a comprometer su voto, verdad, y aún ahora, regale usted lo que regale, eso no le da una garantía de que la persona que recibió el obsequio le va a respaldar con su voto.

R: Pero ese mismo temor del Frente Sandinista, que, además, en la reforma del 2000 negoció un techo electoral más bajo para poder acceder a la presidencia, ¿es una expresión del miedo, quizá? 
L.H.G.: O de creer, verdad, que no hay un espacio para crecer electoralmente, y ahí tiene usted una paradoja más si hiciera falta, dice el encuestador Víctor Borge, que es muy famoso, entre nosotros, porque pronosticó en el 90 que ganaba Doña Violeta, verdad, contra todo pronóstico, este hombre dice que la correlación de fuerzas en Nicaragua no ha cambiado desde 1990, y, usted sigue teniendo una proporción grosso modo 6 no sandinistas contra 4 sandinistas, dice él, entonces no importa qué haga el gobierno qué haga la oposición, la correlación de fuerzas es invariable.

R: O sea, que la composición, en términos de sociología política, sería una mayoría liberal.

L.H.G.: Sí, sí, una mayoría liberal, pero eso ha sido desde el 90, yo sospecho que desde antes.

$R$ : ¿No tuvo entonces arraigo social una revolución tan cantada incluso fuera de las fronteras de Nicaragua?

L.H.G.: Bueno, tiene un arraigo, pues, en ese 40\%. En mi opinión, eso viene de antes, mire la elección de 1984 fue desconocida por muchos sectores, yo, sinceramente, creo que los votos se contaron bien en 1984, porque lo razono en estos términos, si el Frente Sandinista no hizo fraude en 1990, tampoco lo hizo en 1984, en que estaba muy confiado en que ganaba la elección, esa elección le dio un resultado de dos tercios a su favor y de un tercio para la oposición, que fue dispersa, pero, si usted empieza a observar otros factores puede llegar a la conclusión de que la correlación de las fuerzas reales estaba mucho más igual de lo que parece. Pero como dio un resultado de dos tercios a favor del Frente y un tercio de la oposición, nadie lo investigó más. Pero, como usted puede revisarlo, rápidamente, hubo cerca de un $10 \%$ de votos nulos en esa elección, y, sinceramente, no le podemos atribuir a sectores sandinistas haber anulado su voto, ni fue un problema de ignorancia sobre cómo votar, verdad, porque en la mayor parte de los casos se trataba de gente que marcó todos los círculos, o sea, no es que cometió otro tipo de errores, verdad, entonces, ese $10 \%$ yo se lo atribuyo a la oposición. En segundo lugar, hubo un sub-registro, ¿por qué?, porque estábamos en guerra, y, entonces, había servicio militar obligatorio, entonces, usted se puede imaginar que hubo hombres que no se fueron a inscribir para que no los localizaran y no los llevaran al servicio militar, pues, yo tiendo, de hecho, a pensar, que hubo sub-registro, que se le puede cargar un 5\% bajo a ese sub-registro, y hubo un sector, el más duro de la oposición, la Coordinadora Democrática, que se abstuvo, digo yo, por baja que haya sido su votación, pues debería haber sacado un $10 \%$, ya con eso yo le digo, bueno, ahí teníamos un resultado mucho más parejo, mucho más igual de lo que se leyó al final de los dos tercios para el Frente y un tercio para la oposición. Por eso digo, la correlación de fuerzas sociales era mucho más igual en los años 80 de lo que se ha reconocido, porque de otra manera cómo se va a imaginar usted semejante salto electoral pasar de dos tercios de la votación a un poco más de un tercio, es decir, es la pérdida de dos tercios de los votos, verdad, en cinco años, eso es un fenómeno muy serio, y un fenómeno demasiado singular. Yo, realmente, creo que es que estábamos más cerca, y que el resultado del 90 lo puso ya en otras condiciones, lo puso más en clave. Lo especial, sí, es que esas condiciones no cambian, esa correlación de fuerzas no cambia.

R: También, yo creo, que el pueblo de Nicaragua votó por la paz, que, quizá, Violeta Chamorro encarnaba esa idea de la reconciliación nacional. 
L.H.G.: Sí, sí, en buena medida sí.

$R:$ Y la revolución tampoco eliminó una pauta cultural, creo yo, también arraigada en la sociedad nicaragüense, en el propio sistema político, que es que la política es una cosa de élites, ¿no?, a pesar de que las organizaciones populares intervinieron y la sociedad se hizo partícipe de un proceso singular, histórico, y además uno de los puntos de inflexión de la historia política de este país. Pero la política sigue siendo una "política de élites" y esa fractura entre la sociedad civil y el sistema político, que sería el Estado y dentro de él, el parlamento como representación de los distintos partidos políticos, se sigue dando, incluso, en la actualidad.

L.H.G.: Sólo con un matiz, verdad, el nivel de participación electoral es muy alto.

R: No hay un proceso de desafección política.

L.H.G.: Sigue estando en el orden del $80 \%$, verdad.

R: Pero el grado de desconfianza de los ciudadanos hacia el Poder Electoral...

L.H.G.: Bueno, mire, ahí tenemos que investigarlo más, porque aquí la realidad mediática no coincide con la realidad electoral, si usted analizara previo a una elección qué está pasando y qué puede pasar sobre la base de la lectura de los medios, usted llega a conclusiones erróneas, pues, lo puede hacer hacia atrás donde ya hay resultados verificables, verdad, entonces, usted lee los periódicos y dice, bueno aquí hay una deserción masiva de votos del Frente Sandinista y del PLC, eso está claro, dice usted, el rechazo al pacto, la caída de Alemán, la caída de Daniel Ortega, etc., y está claro, bueno, pero usted va y resulta que no es así.

R: Sí, pero hay un discurso crítico que se hace fuerte en estos tiempos más que en el momento de la transición, donde hay una gran esperanza depositada por el pueblo de Nicaragua en la democracia...

L.H.G.: Bueno, yo lo que digo es que estamos por ver si esto se expresa también electoralmente.

R: ¿Y cuál es su pronóstico, difícil, imagino, de cara a las próximas presidenciales?

L.H.G.: Está difícil, mientras no se dilucide el tema de si hay reelección, si no hay reelección, etc., pues ahí está, lo tenemos, lo tenemos complicado, pero uno puede ir advirtiendo que hay unos factores que van perdiendo fuerza, que van perdiendo poder, por ejemplo, la Iglesia católica cada vez tiene menos incidencia en lo que pueda ser el resultado de las elecciones, es mucho menos, también los medios han ido evolucionando, excepto La Prensa y El Nuevo Diario, que mantiene una actitud muy dura en contra del gobierno, en los medios televisivos, en mi opinión, tienen una actitud más profesional, una cosa más balanceada, respecto de los aciertos y desaciertos del gobierno, es decir, una cosa mucho más matizada. Pero creo que la sociedad nicaragüense, pues, todavía no tiene una evolución suficiente, que nos ha servido en la construcción de un Estado de Derecho. Esa es mi opinión, un punto crítico, pero sabe, lo más esperable, en mi opinión, en la situación de Nicaragua hoy, es que las dos 
propuestas de reforma que tenemos sobre la mesa están atendiendo, exclusivamente, problemas procesales, si hay reelección o si no hay reelección, y la oposición que quiere si cambiamos el sistema de elección de diputados y de Magistrados, están atendiendo problemas de procedimiento, cualquier problema sustancial de la sociedad nicaragüense es la desigualdad, más que la pobreza es la desigualdad, este no es el país más pobre de América Latina ni mucho menos, pero estamos entre uno de los más desiguales, y eso sí es grave, y usted lo puede medir en distintos órdenes, ahora se discute la reforma tributaria, y uno oía un eufemismo, dice: "la delegación de los grandes contribuyentes", en Nicaragua no hay grandes contribuyentes, hay grandes recaudadores de impuestos, que no es lo mismo, el impuesto sobre la renta es pagado por las personas que tenemos un empleo, pero sobre ganancias de capital, lo que se cobra es una cosa marginal, simbólica, entonces, digo, el problema más grande de la sociedad nicaragüense es la desigualdad, y este no es el planteamiento de ninguno de los partidos sobre el tema de la desigualdad, en beneficio del Frente Sandinista hay que decir que ha atacado uno de los problemas más serios, que es el tema del hambre, acaba de pasar el relator de Naciones Unidas sobre el tema del hambre, y este hombre entregaba unos resultados que para el gobierno son buenos, si usted compara el tamaño de la economía de Guatemala con el tamaño de la economía de Nicaragua se encuentra con que hay una diferencia enorme, verdad, muy grande, y, sin embargo, Guatemala ha tenido que declarar un estado de catástrofe nacional a consecuencia de una hambruna y Nicaragua no, verdad, visto por los relatores de Naciones Unidas, pues, en alguna medida eso es lo que también le da base al Frente Sandinista, y algo que le permite todavía llamarse como un partido de izquierdas, y es su preocupación por esos sectores. Si de eso trata de sacar ventaja política o no, no lo sé, pero si es cierto lo que dicen que hace, y que da, exclusivamente, los beneficios de ese programa para sus miembros sería un error para ellos mismos, porque la pretensión sería que amplíe su base, no conservar la base que ya tiene, por eso yo soy escéptico a esa acusación, porque tontos no son, ¿verdad?, y decir, bueno, ellos les van a dar sólo a su gente, sólo a sus miembros, sería un error, estarían tratando, no estarían intentando de por lo menos ampliar la base, en todo caso, el resultado objetivo es que Nicaragua no tiene, por suerte, ese nivel de hambruna que tiene Guatemala, pero en común con las fuerzas políticas, y usted lo puede ver en el debate mediático cotidiano, el tema de la desigualdad está ausente.

R: Sin embargo, la instrumentalización de las políticas públicas para conseguir adeptos políticos, que es una forma simple de hacerla, pero bueno, este es el clientelismo en que han caído buena parte de los enfoques de programas sociales en América Latina, no estoy hablando sólo del caso de Nicaragua, se observa en otros países de América Latina.

L.H.G.: Sí, es cierto.

R: La cooperación internacional, por un lado, ha negado a Ortega su apoyo, y, por otra parte, están los fondos que proceden de Venezuela, y que no están sujetos a ningún tipo de fiscalización, que no pasan por un control público.

L.H.G.: Sí, sin duda, eso es un problema, sin duda ninguna, pero la cooperación externa es como la medicina que tiene efectos no deseados, verdad, tiene externalidades, y aquí hay una que es visible y usted la puede registrar. ¿Con quién está negociando Nicaragua el tema de la reforma electoral?, ¿quién es su contraparte?, bueno, un Comisario de la Unión Europea, eso es una deformación en el Estado, que se ha acumulado a lo largo de 
20 años, que tenemos un Estado muy independiente de su sociedad y muy dependiente de factores externos, entonces, usted lo ve ahí retratado. ¿Con quién está negociando el gobierno la reforma electoral?, la está negociando con un agente extranjero, no la está negociando ni con el PLC, ni con nadie, no está negociándola con las fuerzas políticas internas, la está negociando con un agente externo, ahí tiene usted una gran deformación, que provoca la cooperación externa, que es una cosa, muy, muy real.

R: Sobre todo porque detrás de la lectura "politicamente correcta" de la cooperación como Ayuda al Desarrollo hay ciertos condicionantes de los fondos, ¿no?, que por una parte son legitimos, no se trata tampoco de favorecer condiciones que sean contrarias al Estado de Derecho y a la democracia, pero sí, por otra parte, hay como una especie de recomendaciones de cambio institucional, que vienen, incluso, agendadas en la propia cooperación.

L.H.G.: Ahora, sin embargo, yo creo que la cooperación debe continuar, o debería continuar, porque en la medida en que la sociedad nicaragüense sea menos pobre y tenga mejor educación, en esa medida usted le cierra el espacio al clientelismo, y ese no es un efecto que usted consiga de un día para otro, entonces, en la medida en que la cooperación ayude a reducir la pobreza y a mejorar la educación, en esa medida usted cambia la mentalidad de la ciudadanía, y va a ser capaz de producir cambios permanentes. Por esa razón, yo sí creo que la cooperación debe continuar, pero, como le decía antes, esto es como algunas medicinas, que tienen unos efectos no deseados.

R: A mí me interesa, ya para finalizar, porque yo creo que hemos hablado de muchas cosas a lo largo de la entrevista, es el punto de vista de quiénes hacen las reformas constitucionales, no, en este caso, yo creo que es la variable que a mí me permite explicar qué reformas se hacen, es decir, finalmente, cuáles son las que tienen éxito, y hablamos de los principales partidos politicos. En el caso de la del 95, usted señalaba que hay un consenso entre un arco parlamentario, además, diverso, y, sin embargo, en el caso del 2000 y 2005 son dos grandes partidos los que protagonizan la reforma y sustituyen el consenso por el pacto político, son dos palabras, además, muy distintas, consenso y pacto, ¿cuál es su opinión o su reflexión a propósito de esto?

L.H.G.: Bueno, yo creo que en esto la sustitución de actores tiene que ver, verdad, con el nivel de desarrollo de la sociedad y los electores decidieron darle esas responsabilidades, particularmente, al PLC y al Frente Sandinista, en la elección del 96, como le dije, participaron más de 20 partidos políticos, sin embargo, pues, los resultados se concentraron, los votos se concentraron en el PLC y en el Frente Sandinista, y, con lo cuál, los convirtió en los dos grandes actores, y yo creo que en el lado de los sandinistas ganó el sector menos moderno, el sector con una visión más caudillista, que fue la que representaba Arnoldo Alemán, no una perspectiva de desarrollo de la institucionalidad del país, entonces, eso terminó haciendo una diferencia, pero a veces hay también quienes dicen que la democracia es algo que resulta por casualidad, verdad, hay resultados accidentales, eso dice, ¿cómo se llama el polaco?, bueno, este hombre dice que a veces la democracia es un resultado accidental, pero no una cosa que, necesariamente, usted estaba buscando, yo no digo que haya ocurrido exactamente eso, pero la reforma del 2005, que es la que amplía los poderes de la Asamblea aún más, si usted quiere resultó por accidente, verdad, Daniel Ortega no se imaginó que iba a tener que aplicársela así, pero yo creo que la transición en Nicaragua vive un momento crítico, un momento difícil, pero mi apreciación es que al final de 
cuentas, aunque la evolución de la sociedad no haya ido con la velocidad que algunos quisiéramos, sí ha evolucionado y ha creado muchos anticuerpos para gobiernos autoritarios, no, no me parece que el país tenga unas condiciones sociales para admitir, para justificar gobiernos autoritarios, me parece que ya para eso es tarde en Nicaragua.

$R$ : ¿Ni siquiera el actual gobierno de Ortega con todos sus críticos?

L.H.G.: Pero, pues, digamos, su respaldo social es minoritario, comparado con el resto de la sociedad, etc., y habrá que ponerle atención a la siguiente elección presidencial.

R: Pues si tiene algo más que añadir.

L.H.G.: No, creo que no.

R: Pues, muchísimas gracias. 
ENTREVISTA $27^{41}$ :

Nombre del entrevistado: Dr. Manuel Ortega Hegg.

Cargo actual: Profesor de Sociología en la Universidad Centroamericana (UCA).

Fecha de realización de la entrevista: Managua, 13 de noviembre de 2009.

Lugar: Universidad Centroamericana (UCA).

Duración estimada: 1 hora y 23 minutos.

\section{TEXTO - Transcripción 27:}

$R$ : ¿Cuál es su visión, cuál podría ser su reflexión, es una pregunta muy general, pero ahi arranca su discurso, sobre los cambios constitucionales operados en Nicaragua desde los años 90 hasta la fecha en el contexto de la transición democrática?

M.O.: Bueno, lo primero que yo te diría es que los nicaragüenses vivimos, prácticamente, un sueño, una utopía, y pensamos que era una utopía que nos había costado muy cara, que ha sido la revolución en la década de los 80 , en donde yo siento que el gran logro que nosotros conseguimos en los 80 , fue, precisamente, la democracia, o sea, Nicaragua, mi generación, la generación que hicimos la revolución, en algún momento, fue una generación que vivió, igual que en España, una dictadura muy férrea, muy dura, tal vez, más brutal nosotros que ustedes en España, y que, en algún momento, pensamos en muchas transformaciones, pero, tal vez, la primera gran transformación fue la libertad, fue la posibilidad de las libertades democráticas. Creo que eso, en algún momento, pensamos que con la revolución, ya era un logro irreversible, y se establece un marco, que fue la Constitución del 87, para mí, un marco que abrió, realmente, un espacio enorme a las libertades y a los derechos ciudadanos como nunca los habíamos tenido, en ese momento, en que surge la Constitución del 87, en medio de un proceso revolucionario, había restricción de libertades, estábamos en medio de una guerra, y el gobierno revolucionario, en ese momento, gobernó, prácticamente, por vía de excepción, y esto es importante señalarlo, porque implicaba que muchos de los derechos que estaban consignados en la Constitución nunca los pudimos ejercer durante ese período, el mismo período de la revolución, y que, de alguna manera, aunque se dio algún tipo de división de poderes para hablar de la democracia liberal, tradicional, esa democracia, de una u otra manera, siempre representó al menos en la mente de muchos de los compañeros que tuvimos por la transformación en el país en ese tiempo, representaba ese momento, como un momento anómalo, que después iba a regularizarse, en ese sentido de que la suspensión de libertades, de que toda esa concentración de poder que tenía la revolución tenía que dar paso a otros momentos en donde ese marco, que era un marco ideal de convivencia social, digamos, iba a permitir posteriormente, realmente, establecer una nueva forma de convivencia desconocida en el país, con una amplísimo mundo de libertades, pero que también ese mundo de libertades estaba sustentado por transformaciones en la base económica, que permitían un mínimo para todo el mundo, y que, por lo tanto, implicaba construir una democracia con equidad, un poco como el gran, el gran imaginario, digamos, que vivimos muchos

41 Entrevista larga con un discurso más centrado en las variables sociológicas del cambio político y constitucional en Nicaragua, que en las propiamente jurídicas. Pero es de gran interés por su referencia a la informalidad de los procesos políticos, la legitimidad social de las reformas constitucionales, los déficits en la institucionalidad de los poderes del Estado, o la construcción social de ciudadanía y su relación con las élites partidarias. 
de los que estuvimos a favor de la revolución entonces. Yo creo que esta idea, que, en aquél momento, yo creo que fue una idea dominante en la mayor parte de nosotros, que pensamos que, efectivamente, por la guerra estábamos viviendo una serie de limitaciones materiales, hubo racionamientos en el país, y que parte del racionamiento fue también el racionamiento de las libertades, era parte del tributo de la guerra y era parte del fallo que teníamos que construir y que pagar por la revolución y por la conquista de las libertades, etc., lo vivimos un poco así, creo que, inmediatamente, después de la derrota del Frente la reforma posterior constitucional fue una reforma que ayudó extraordinariamente a todavía mejorar mucho más el marco, que se había construido en la revolución, entendimos, en aquél momento, que era necesaria una concentración de poder en el Ejecutivo en la década de los 80, porque había que hacer transformaciones, nosotros teníamos la idea, los revolucionarios de entonces, de que el poder, de alguna manera, debía concentrarse, porque era la única manera de hacer transformaciones en el país, ¿no?, y que eran transformaciones estructurales que requerían, por lo tanto, una concentración de poder. Esto, sin embargo, como te digo, siempre pensando en que esto era un proceso totalmente coyuntural, y que después todo esto iba a caer en su lugar, la reforma del 95, pues, permite equilibrar, para mí, algo que había nacido desequilibrado por la revolución, que había sido la concentración de poder en el Ejecutivo, un presidencialismo que, para mí, en aquella época era, si uno lo pensaba bien, era equivalente al absolutismo real en Europa, ¿no?, es decir, el presidente podía dictar tributos, podía asumir las funciones, totalmente, de la Asamblea Legislativa, es decir, podía legislar, y la única función que no quedaba, formalmente, en manos del presidente era la función judicial, pero el resto de las funciones estaban, realmente, en poder del Ejecutivo, pero además desde el punto de vista estrictamente legal, no era un asunto que en la práctica, como siempre ocurre en los regímenes presidencialistas, al menos en América Latina, el presidente siempre concentra en la realidad, por encima de lo formal, mucho más poder que los demás poderes, en aquél tiempo, para nosotros la Constitución misma le daba muchos más poderes al presidente, ya en su misma manera formal, y esos poderes se ejercían en la realidad. Las reformas del 95, ¿qué hicieron?, equilibrar este desequilibrio, ¿no?, y, para mí, democratizó el poder en dos vías, por un lado, en la vía horizontal, con otros poderes del Estado, le trasladó la función legislativa, totalmente, al Poder Legislativo, la posibilidad de crear impuestos quedó en la Asamblea Legislativa, como debería ser, y se restringieron también otros poderes que tenía el Ejecutivo, que correspondían, de alguna $\mathrm{u}$ otra manera, a otros poderes del Estado, pero, además de eso, yo siento que la reforma del 95 permitió otra reforma ya no horizontal, sino vertical, es decir, del gobierno central hacia los territorios. En la década revolucionaria, para mí, de los logros más sustantivos que se dieron en la revolución, que es un logro actual, evidente y sin discusión, fue la irrupción del territorio en el país, particularmente, lo que quedó muy claro desde entonces fue la aparición de las dos regiones autónomas, con sus propias autonomías, si vos querés, con todas las limitaciones de una autonomía en países pobres, verdad, pero, sin embargo, de una o de otra manera, entregó poder al territorio, ¿no?, y la reforma del 95 profundizó, para mí, el poder hacia los territorios, particularmente, porque en el caso de las regiones autónomas concedió muchas mayores competencias a las regiones autónomas, entre ellas, prácticamente, el veto a cualquier tipo de concesión que se diera sobre recursos naturales en la región, sin contar con el visto bueno de las propias autoridades regionales, y, por otro lado, fue muy claro en entregar una autonomía integral y completa hacia los municipios, ¿no?, es decir, ya no hubo ningún tipo de regateo con relación a la autonomía municipal, y fortaleció la autonomía regional de las regiones autónomas, que venía de la década de los 80 , en este sentido, para mí, fue una 
reforma que yo consideré y sigo considerando, a pesar de las limitaciones que se ven ahora en el tiempo, como una reforma, realmente, sustantiva, en lo que era ese marco de convivencia en el país. Sin embargo, los procesos reales tienen que ver ya no tanto con cómo funciona la institucionalidad establecida en la Constitución y las leyes, hubo todo un proceso, la reforma siguiente para mí fue una "contrarreforma", en donde, nuevamente, volvió a concentrar poderes y a quitar o restringir poderes mucho más divididos que antes, pero sobre todo la reforma a lo que llevó fue, en la realidad, a una concentración de poderes tan o más fuerte que en los tiempos de la revolución, es decir, que hoy Daniel Ortega tiene tanto o más poder que en tiempos de la revolución, tal vez la diferencia de entonces es no que Daniel Ortega controla el Poder Judicial, controla la Asamblea Nacional a través de sus pactos y la corrupción y la compra de votos, que lo han dicho públicamente el mismo gobierno, el Ministro de Hacienda declaró en una reunión pública en el norte del país que la reforma del año pasado, precisamente, del presupuesto, estaba garantizada porque ellos compraban votos para hacer esas, y que ya los tenían comprados, o sea, hay una desfachatez total, en términos de cómo se hace esto, todos sabemos que este tipo de asuntos en todos los parlamentos del mundo se negocian, pero aquí la desfachatez y el descaro es total cuando se habla de que se compran los votos de manera total, por lo tanto, hay un control, digamos, de estos poderes del Estado, el Poder Electoral es un poder totalmente controlado por Daniel Ortega, y esto a partir del pacto que hizo con el jefe de la oposición en ese momento, que era Arnoldo Alemán, un hombre dispuesto a cualquier tipo de cosas, igual que Daniel Ortega, en busca de sus propios objetivos personales, particulares, familiares, la única diferencia, por lo tanto, que hay entre este esquema, que fue más o menos un esquema parecido, salvo, diría yo, la diferencia con relación a los aspectos éticos, yo siento que, en la década de los 80 , la ética siguió siendo un principio fundamental de la revolución, y que esa ética se perdió, a partir de la "piñata" en el período entre el 90, en la entrega, entre la derrota y la entrega del poder, y que la diferencia por lo tanto está en dos cosas: uno, la ética de la década de los 80 , que se perdió ahora, y el otro es el dominio total de las Fuerzas Armadas que había en la década de los 80, las Fuerzas Armadas se identificaban con el apellido sandinista muy claramente, ¿no?, y hoy hay una institución armada en gran parte que le han doblado el brazo, que es la policía, pero que en el Ejército todavía hay muchos mayores rasgos de institucionalidad que lo que ha logrado la policía, salvo estos elementos, entonces, la ética, por un lado, y, por otro lado, el control, digamos, de los aparatos coercitivos, en lo demás, yo diría que hay tanto poder y, probablemente, más poder incluso que lo que hubo en la década de los 80 , y esto básicamente no por la formalidad de la Constitución en sí misma, sino porque a la par de la formalidad o por encima de la formalidad de la división de poderes, realmente, Daniel Ortega controla totalmente los poderes del Estado. Hay que señalar, por tanto, que hay una tendencia, digamos, de la cultura política de las élites gobernantes de Nicaragua, y esto es igual si vas a la izquierda o a la derecha, aunque ya no sé hoy si podemos hablar del Frente Sandinista como izquierda, pero, de todas maneras, en estas élites gobernantes existe una tendencia totalmente autoritaria, y una tendencia a la concentración de poder, esto es muy facilitado, por un lado, por el atraso que existe en el país en términos de formación mínima y elemental académica, y, por otro lado, por la enorme pobreza del país, que hace que la gente no tenga una autonomía con relación a su capacidad de reproducción propia, sino que los niveles de pobreza son tales que hay una tendencia a una altísima dependencia de los poderes del Estado, de los partidos políticos y de otros poderes fácticos, como las propias iglesias, que a través de donativos o de intercambios clientelares, etc., ¿no?, establecen una relación de dependencia de esa enorme masa de gente sin mayores condiciones de autonomía 
personal propia a depender de los intereses de estas distintas instancias. Yo diría, si te hiciera un resumen, por lo tanto, que hay un momento de sueño y de utopía en la década de los 80 que se enfrenta a la realidad de una cultura política, cuya tendencia es a la desinstitucionalización y a continuar manteniendo los procesos de clientelismo y dependencia de la población, y a luchar, por lo tanto, en contra de los procesos de construcción de ciudadanía, que establecerían otro tipo de relación de la población con el Estado y los propios partidos políticos. En este sentido, las reformas constitucionales juegan un papel, en el sentido de que dan una formalidad, digamos, al proceso de gobierno, de gobernabilidad de los países, países como el nuestro, pero esa formalidad se estrella o se queda en mera fachada, digamos, frente a la realidad de una concentración total de poder, y procesos de cultura política que continúan profundizando los procesos de clientelismo político y de dependencia de la población de unas élites que se divide, digamos, en distintos poderes tanto constitucionales como poderes fácticos. Esta sería un poco como mi gran reflexión y mi gran síntesis de cómo veo yo este proceso, digamos, de reformas constitucionales, lo que han significado en el país, y, por otro lado, la realidad, que es muy común en América Latina, la enorme diferencia que existe siempre entre la formalidad y la realidad, ¿no? No hay ninguna excepción en el caso de Nicaragua, sino al revés, es una ilustración muy clara de cómo eso se sigue dando, ¿no?

R: Por otra parte, también me interesa mucho el hilo conductor de las reformas, que ha sido el de aumentar las atribuciones de la Asamblea Legislativa en detrimento de ese Ejecutivo presidencial, que consolidaba de manera fuerte la Constitución del 87, pero también se ha dado un trasvase, digamos, de poder hacia las cúpulas partidarias, que son quienes han cooptado el juego del poder legislativo, y también lo ha referido en términos de cultura política, por la propia debilidad de la estructura de los partidos, o por su dependencia de hombres fuertes, que han sido quienes han copado la acción política a la hora de negociar su representación también en los poderes del Estado, ¿no?, y también la falta de independencia de estos últimos, y pienso, muy especialmente, en el Poder Judicial y en el Poder Electoral. En este sentido, si bien la reforma del 95 es una reforma legítima y además jurídicamente necesaria, y creo que bien hecha, porque responde al momento de la transición, a pesar de que también hubo un debate fuerte entre reforma total o reforma parcial, y se justifica un poco, cuando yo hacia la entrevista a Luís Humberto Guzmán, que fue presidente de la Asamblea en aquél momento, y uno de los actores relevantes en el proceso de reforma del 95, que ese debate se saldó de esa manera, es decir, utilizando una ley de reforma parcial, porque el momento era tan crítico, y las contrapartidas, digamos, de la negociación entre el Frente y la Unión Nacional Opositora, digamos, el bloque anti-sandinista, estaba sujeta a cláusulas tan específicas que una Constituyente habría sido muy difícil en el país. ¿Cuál es su visión al respecto?

M.O.: No, yo pienso igual, yo pienso además que hay varias cosas, es decir, cuando se dan las reformas del 95 yo creo que todavía, aunque hay toda una crisis interna en el Frente Sandinista, que va a dar origen, precisamente, al nacimiento del Movimiento Renovador Sandinista, por un lado, y, por otro lado, a la decantación muy clara del danielismo, ¿no?, dentro del Frente Sandinista, es precisamente esa división que se da en el Frente Sandinista la que permite las reformas del 95, porque se alía un sector del sandinismo con un sector de lo que había sido la Unión Nacional Opositora y eso permite las reformas, yo pienso que en el ese proceso, sin embargo, había como algo común, yo creo que la mayoría de la población sandinista, por ejemplo, sentía que el 
cambiar totalmente la Constitución, y me estoy refiriendo, básicamente, al mundo de lo que son las percepciones, ¿no?, de lo pudo haber sido correcto o incorrecto, pero en el mundo de las percepciones, digamos, en el electorado sandinista aún en su división, MRS y FSLN, sentíamos que el cambio total de la Constitución significaba, fundamentalmente, enterrar la Constitución, era un poco como decir: "eso no sirvió para nada", aquí viene como el poner la etapa final, el pomo, de un proceso contrarrevolucionario que acabó con la revolución, y que además se acaba con toda una serie de conquistas, etc., que estuvieron, de una u otra manera, plasmadas en esa Constitución, por ejemplo, yo te puedo decir, yo trabajaba en la Presidencia de la República en la década de los 80 y en uno de los procesos de trabajo yo me hice cargo de todo lo que fue el desarrollo municipal, la participación ciudadana en los espacios locales, etc., entonces, yo tenía temor de que después de la derrota del FSLN, por ejemplo, se cerraran todos esos espacios que se habían abierto con la revolución, y todo el mundo tenía temor que el cambio total de la Constitución en una correlación de fuerzas, que no se veía tan clara, pudiera significar una contrarrevolución, es decir, el cierre de espacios que se habían conquistado en su momento. Había, por lo tanto, no solamente la lucha y la pugna de cada uno de los partidos por garantizar sus propios espacios, sino que también había como un ambiente general en la población de que la salvaguarda, digamos, ¿no?, de un mínimo de estabilidad en el país, obligaba más a hacer una reforma que una nueva Constitución. Yo siento que ese fue un sentimiento muy fuerte y que la reforma como tal, que también la veíamos desde el sandinismo, yo, por ejemplo, estaba convencido de que los poderes, por ejemplo, que tenía el Ejecutivo colocados ahora, ya no en la revolución, sino en la derecha, daba unos enormes poderes a quien llegara ahí, que podía echar al traste con todo, ¿no?, es decir, veíamos, por lo tanto, la necesidad de las reformas, la necesidad de repartir poder, la necesidad de equilibrar los poderes, todo eso se veía desde fuera, y te digo que se veía no solamente a nivel de la gente pensante, de los intelectuales, los académicos, etc., de los sectores medios, sino de la misma población, que se sentía, de alguna manera, que había muchas cosas que se podían hacer en contra de sus propias conquistas que había tenido durante el período revolucionario. Por lo tanto, yo creo que de una o de otra manera la reforma del 95 fue una reforma, tal vez la reforma que yo siento que se negoció mejor de todas las reformas, en tanto en cuanto fueron reformas que sí reflejaron lo que la población en determinado momento estaba sintiendo y veía como necesario, y, por lo tanto, representaron, efectivamente, lo que la gente hubiera hecho si hubiera tenido la posibilidad de expresar de forma directa qué pensaba sobre si reforma o cambio total de la Constitución, yo creo que, en ese sentido, sigo pensando que fue la mejor reforma y que fue un momento donde los partidos políticos de manera muy lúcida supieron interpretar lo que la gente sentía y pensaba en ese momento, y, por eso mismo, fue una reforma que yo siento que tuvo una enorme legitimidad, para mí, la reforma más legítima que ha existido en la historia del país, en la historia del país, ya no solamente en la historia reciente, porque, efectivamente, reflejó un momento del estado de ánimo de la población y de la búsqueda de concertación de intereses, que, efectivamente, yo creo que reflejó muy bien la Constitución, por lo tanto, yo sí coincidiría con el análisis que te han hecho.

R: Y ahora que hace referencia al tema de la representación, que es un punto muy interesante, ¿no?, quiénes son los actores de las reformas constitucionales, que, fundamentalmente, son aquellas fuerzas políticas que adquieren representación en el parlamento, y, bueno, en las reformas del 95 hubo un arco parlamentario compuesto por partidos minoritarios algunos de ellos, pero sí quedaban, digamos, múltiples 
partidos politicos representados en la Asamblea, mientras que en las reformas del 992000 y del 2005, fundamentalmente, son lideradas por las cúpulas partidarias de los dos partidos más importantes de Nicaragua.

M.O.: Y eso que dices todavía, incluso, con un elemento más, y es que se volvió al viejo sistema de la negociación de las reformas fuera del parlamento, en reuniones privadas de los dos líderes, con uno o dos asesores cada uno, y esas reformas se llevaron después a la Asamblea para que cada uno de los miembros de cada uno de los dos partidos levantara la mano, no tuvieron mayor discusión en la Asamblea Nacional ni mucho menos mayor discusión con la población. Las reformas del 95 tuvieron un debate amplio, es decir, la Constitución de la década de los 80 es una Constitución con una enorme amplitud de debate, con un problema, y es que los que entramos en el debate fuimos, fundamentalmente, los revolucionarios, y eso hay que reconocerlo porque no había mucho espacio para los otros sectores, pero, al menos, dentro de ese ámbito tuvo un espacio muy amplio de consulta. En la reforma del 95 igualmente, fue una reforma que se discutió de forma muy transparente en la Asamblea Nacional, en los medios de difusión, e incluso con consultas, y cada uno de los artículos, en algún momento, concertaron intereses, escucharon lo que tenían que decir los distintos sectores, etc., y por eso te decía yo, de una o de otra manera, supieron interpretar y acoger lo que la población estaba pensando alrededor de la reforma constitucional. La gran diferencia con la reforma del 2000 es, precisamente, que es una reforma que se hizo a espaldas de la población con encuestas que te decían, yo aquí les di seguimiento, yo hacía encuestas en una investigación que dejé de dirigir hace tres meses, aquí en la UCA nosotros hicimos varias encuestas, porque era parte de nuestro trabajo, y en esas encuestas un promedio del $78 \%$, en algún momento fue el $83 \%$, en otro el $75 \%$, no menos que eso, de la población encuestada te decía que estaba en contra de algunas de las reformas, particularmente, que se establecieron en ese momento, y cuando vos veías quiénes decían que estaban en contra te encontrabas que, yo no lo pude colegir, pero hacíamos el cruce, y veías, claramente, que quienes estaban en contra eran tanto sandinistas como no sandinistas, como gente del PLC, es decir, que gente de todos los partidos estuvo en contra, y, claro, cuando tenés $80 \%$, pues, dices, ahí tiene que estar en contra gente de los propios partidos que están pactando, verdad, pero además una mayoría enorme, entonces, vos tenés una reforma con una, prácticamente, sin ninguna legitimidad, verdad, y que se realiza a espaldas de la gente y en contra de la inmensa mayoría de la gente que está diciendo que no está de acuerdo con esas reformas, yo creo que hay una diferencia fundamental de los dos procesos, tanto el del 80, yo te digo, yo hoy, en aquél momento no lo veía así, porque estaba metido totalmente a favor de la revolución, digamos, pero en aquél momento hubo una consulta bastante amplia, aunque dejamos fuera a los que no estaban de acuerdo con la revolución, en la reforma del 95 la consulta fue muy transparente y muy amplia, ¿no?, y eso hace una enorme diferencia con las reformas posteriores, que se hizo a espaldas y a escondidas, $\mathrm{y}$, básicamente, como un proceso en donde podemos decir, por razones muy obvias, las reformas que se establecieron ahí, lo que hicieron ahí fue echar atrás una serie de conquistas y establecer derechos fundamentales de los líderes, ni siquiera de los partidos, de los líderes de los dos partidos que pactaron las reformas, y esto, obviamente, generó desde allí una bajísima legitimidad de la propia Constitución. Nicaragua tiene un problema con la Constitución y es que, de forma muy periódica, la Constitución es ajustada a los intereses de liderazgo, y esto hace que, particularmente, para los jóvenes que están en formación los cambios constantes de la Constitución no les permite ponerse al día, es decir, proyectar como parte de su cultura cívica y política las normas básicas de 
convivencia social, y los acuerdos que tenés como sociedad, porque están en cambio permanente, y esto también te genera problemas, en términos de lo que son las convicciones cívicas, y la seguridad y la certeza que le da a los ciudadanos el saber que cuenta con algunos principios fundamentales claros, y que no están cambiando de acuerdo a las reglas, a los intereses, pues, de liderazgo. Lo que ocurrió en esta reforma última fue, precisamente, que se sintió, inmediatamente, no solamente un retroceso sino que la Constitución, nuevamente, volvía a ser objeto de los procesos que ya conocíamos antes de la revolución, en donde los líderes políticos en los momentos de crisis se volvían a poner de acuerdo, se repartían el poder, y lo establecían como reforma constitucional para continuar conviviendo y pactando, repartiéndose el poder, nosotros pensamos que esa historia había terminado con la revolución, el volver a repetir, posteriormente, en esta última reforma, volvió a crear una sensación de desencanto, con respecto a la propia Constitución y, obviamente, sumió en mayor crisis el sistema político, particularmente, los partidos políticos, es decir, nosotros no somos tampoco ninguna excepción de lo que es la crisis de los partidos políticos, pero también, de alguna manera, de lo que es el sistema político general, y yo creo que a partir de la reforma, es decir, el Frente Sandinista a partir de la "piñata" del 90, la crisis que sufre en el 94-95 con la división, pero, particularmente, ya muy claramente, a partir del 95 en adelante, y se sella para mí con la reforma y el pacto con Alemán, el sandinismo pasa a ser un partido más que tradicional en Nicaragua, es decir, un partido que no le está aportando al país absolutamente nada, que abandonó principios éticos que fueron los principios fundamentales que organizaron al Frente Sandinista, y que su forma de hacer política no solamente no se distingue de la derecha y los partidos tradicionales, sino que está a la cabeza de las triquiñuelas típicas y tradicionales de la cultura política del país, por lo tanto es también una enorme deslegitimación de estos actores a la hora de que hablan de reformas o te hablan de tocar estos marcos fundamentales, hay una sensación en la población de que, nuevamente, actores no legítimos, están jugando con principios fundamentales, y que la incertidumbre se convierte en regla general porque no sabes qué va a salir de ahí, porque ninguno de ellos está representando, realmente, intereses de los ciudadanos, yo diría que esto es un poco como el resumen, en términos de actores, de cómo se siente el proceso, si vos hacés encuestas la gente sigue votando, y uno dice, bueno, ¿cómo es posible que aquí haya esos niveles de desencanto, esos niveles de desaprobación de lo que están haciendo los partidos políticos, pero a la hora de las elecciones la gente siga votando como vota?, yo no sé qué va a pasar después del fraude electoral del año pasado en el municipio, me parece gravísimo la celebración de elecciones en la Costa Atlántica, manteniendo el Consejo Electoral actual, me parece gravísimo, porque, de alguna manera, es legitimar la elección del 2011, es decir, no, ese Consejo Electoral funcionó en la elección regional de dos regiones autónomas, ¿por qué quitarlo si ya se demostró que funcionó?, se legitimó, por lo tanto, es el mismo Consejo, yo siento que hay un juego ahí, que está detrás de eso, pero independientemente de qué es lo que pueda pasar y cuál pueda ser el nivel de reacción de la gente, en términos del voto, después del fraude electoral del 2008, y de esta elección municipal, que siempre las regionales, las atlánticas, han tenido altos niveles de abstención, que no son comparables a lo que ocurre en las votaciones generales, la gente vota en Nicaragua, para mí, e hicimos varios estudios sobre ese tema, porque tenemos muy claro cuál es la alternativa para los cambios frente al voto, la alternativa frente al voto es la violencia, o sea, en Nicaragua, la historia nuestra nos decía que aquí los cambios de gobierno se tenían que hacer a balazos, era a partir de violencia, es decir, quien entraba al poder no lo quería soltar, que es lo que está pasando un poco otra vez ahora, ese es un Daniel Ortega que sube y que no quiere dejar el poder, ¿no?, que ya cumplió, no es que en 
Nicaragua no haya reelección, aquí hay reelección, pero ya cumplió los dos períodos en que te puedes reelegir, por lo tanto, debería de dar paso a otros líderes, pero, ¿qué es lo que pasa aquí?, para mí, la gran lección, digamos, que aprendió la población, fue la lección que se dio en la década del 90, con la revolución, la década del 80 y principios de los 90 , ¿cuál fue la lección?, la lección es que esta revolución, durante el período revolucionario, hubo todo un sector de nicaragüenses aliados a los Estados Unidos que quisieron por la vía de la fuerza tumbar a un gobierno, y era el gobierno revolucionario, y aquí tuvimos la guerra de la década de los 80 , ¿qué se demostró?, que pasaron años de una lucha armada queriendo tumbar a un gobierno y no se pudo, pero vinieron las elecciones del 90 y con el voto la gente cambió el gobierno, que parecía inamovible, porque no se había podido mover por la fuerza militar, aún con el apoyo de la más grande potencia del mundo, que era Estados Unidos, no se había podido cambiar ese gobierno por la fuerza, pero la gente lo cambió con el voto, a partir de la experiencia del 90, la gente aprendió que tenía un arma extraordinaria y poderosa en la mano, que era su voto, por lo tanto, la gente, de alguna u otra manera, sigue votando porque siente que esa es la vía que ha probado, que es la vía que históricamente puede hacer los cambios en el país, que no es la violencia armada que nos dejó tanto daño en el país, ¿no?, la que puede hacer esos cambios, sino que es el voto, por eso a pesar de todo lo que pasa, de la deslegitimación y la crisis del sistema político y de los partidos políticos, en particular, la gente sigue votando, porque siente que es la única salida que tiene en la mano, porque las demás lo único que puede dar es el caos y la violencia. Sin embargo, yo ahora, en este momento, si me preguntaras después de lo de las elecciones del 2008, a reserva de lo que se pueda ver de lo que pasa en las elecciones regionales, que no espero mucho, como signo de que haya un cambio como tal, a no ser que las elecciones regionales, realmente, arrojen un porcentaje exiguo, tan exiguo de los votantes que marquen una diferencia con las elecciones anteriores muy grande, a reserva de lo que ocurra, entonces, en esos dos períodos, yo siento que estamos frente a una deslegitimación extraordinaria de, y a una enorme incertidumbre en la población, en general, alrededor de si, efectivamente, el voto sigue o no valiendo, porque después de un fraude, vos sentís que el único arma que tenías te la quitaron, y, por lo tanto, la gran interrogante que se puede plantear la gente es si vale la pena votar o no vale la pena votar, y esto puede ser el desastre, digamos, ¿no?, del sistema de convivencia elemental, básico, que tiene el país, porque si se pierde el sentido de la gente de buscar cómo resolver los conflictos y los problemas de poder a partir de su participación en procesos electorales, me parece que estamos entrando a un callejón muy peligroso, que, probablemente, no tan a corto plazo puede, nuevamente, encauzarse hacia la violencia, porque está muy cercano todavía el recuerdo de la guerra, y la guerra en Nicaragua está muy, muy fresca, muy cercana, con muchos muertos, y con mucha gente que no murió, pero que está con, tiene secuelas de guerra, ¿no?, distintos tipos de discapacidad, desde mentales hasta físicas, ¿no?, y que son un recuerdo permanente de los que están en la guerra. En este sentido, podemos entrar en un proceso de transición, digamos, hasta que no se resuelva o por la vía de una sustitución, de un nuevo liderazgo, que conciba de otra manera el hacer política en Nicaragua desde bases verdaderamente democráticas, o no se puede seguir descartando que, en algún momento, también la salida pueda ser una salida violenta que escoja una nueva juventud que está creciendo, y que no han vivido la guerra, la tiene contada, ya mis hijas, mis hijos, la guerra la ven como algo que contamos los viejos, ¿no?, no algo que vivieron ellos, y no están dispuestos en esta sociedad abierta, porque antes vos podías imponer dictaduras, etc., en las sociedades cerradas que eran entonces, tanto España como Nicaragua, como Venezuela, etc., República Dominicana, o sea, las grandes dictaduras del mundo, Portugal, etc., ¿no?, 
eran, finalmente, sociedades cerradas, pero hoy ya no son sociedades cerradas, hoy es imposible que ocurran cosas y que no estén impactando, inmediatamente, en la conciencia mundial, por lo tanto, esta juventud, que está creciendo, es una juventud que ya nace con otro sentido de la libertad, y no va a ser tan sencillo que esta juventud acepte este tipo de regímenes mucho tiempo, por lo tanto, la encrucijada del país es resolver los problemas con más democracia o resolver los problemas por la vía violenta hasta que no se instaure la solución, que tiene que venir por medio de un marco democrático, que no es total ni suficiente, pero que es un marco básico de convivencia que también puede salir adelante, pues.

R: En el tema de las reformas, también ha habido siempre, en todos, en los últimos tres procesos, incluida esta última sentencia, que no es exactamente una reforma, siento que es algo mucho más grave, que es apelar a la propia Constitución para hacerla perder más aún su valor normativo, ¿no?, reinterpretando el artículo 147, que es el de la reelección presidencial. Ha habido siempre un conflicto entre el Ejecutivo y el Legislativo, el Ejecutivo presidencial, que se negó en el año 95 a aceptar las reformas que lideraba la Asamblea Nacional, y, en el otro caso, bueno, más bien pactó la bancada mayoritaria, que era el Frente, con el gobierno de Arnoldo Alemán para conseguir aprobar las reformas del 2000, y, luego, en el 2005 es el presidente Bolaños el que se ve acosado, nuevamente, por su propio partido, por un sector de su propio partido que se vincula a Arnoldo Alemán, y por el Frente Sandinista, tratando de reducir facultades del Ejecutivo, que luego Ortega no ha asumido, porque no se ha plegado a esas normas constitucionales reformadas, ¿no?, y ese concepto de las leyes Marco, que es un concepto muy peculiar de la historia constitucional de este país, y que además rompe con el principio de seguridad jurídica y de la supremacía de la Constitución, puesto que se trata de una ley ordinaria, pero sí congela en el tiempo esas normas reformadas, dándole mayor oxigeno al momento político, o sea, da la impresión de que en este país la política siempre está por encima del Derecho, y de que la tentación extra-institucional de los actores a la hora de resolver las crisis de gobierno es, prácticamente, la primera carta de juego que se pone en marcha. No sé cuál será su visión sobre esto.

M.O.: No, yo creo que es una observación correcta, es decir, aquí en los momentos, incluso, diría yo más duros del neoliberalismo, en donde el dominio total de la economía sobre la política en el mundo era total, es decir, la política había perdido cualquier capacidad de incidir en la redistribución social, en la equidad, etc., etc., es decir, todo se había dejado al mercado, y, por lo tanto, había perdido la batalla la política, en Nicaragua seguíamos peleándonos, si vos ves durante los períodos, es decir, salimos del 90, o sea, cuando comienza el neoliberalismo nosotros estábamos en plena revolución, que es el momento político más extraordinario que puede tener cualquier país, pero después del 90, todavía estas reformas constitucionales no son más que momentos muy extraordinarios, en donde los conflictos políticos, que son los conflictos fundamentales que están signando el momento, encuentran una salida, lo cual significa que todo el período del neoliberalismo, en Nicaragua, sigue existiendo un enorme peso de la política en la vida cotidiana del país, y a pesar de que aquí se aplica un neoliberalismo atroz, los acuerdos políticos, es decir, el neoliberalismo se aplica a la población, en donde quedan sin ningún tipo, la población queda sin ningún tipo de red social de apoyo, se quitan toda una serie de apoyos sociales que tenía la población, y se dejan, totalmente, al vaivén del mercado, las élites políticas continúan, sin embargo, estableciendo la política como el punto fundamental de conflicto, ya no el pleito de la 
economía, sino el pleito de la política, y eso te explica las reformas constitucionales que se dan en pleno período neoliberal, ese factor sigue existiendo hoy, es decir, hay una constante que se muestra claramente, por encima de la institucionalidad, por encima de la Constitución, por encima de las leyes, se siguen estableciendo los arreglos políticos, ¿no?, los gobernantes, quienes tienen el poder, tienen la tendencia a colocarse por encima de la ley, cuando ya ese colocarse por encima de la ley es inaceptable se crea la crisis, y, entonces, el partido, la contraparte opositora establece una negociación siempre por encima de la ley para cambiar la ley, y, entonces, volver a establecer una especie de equilibrio en donde la ley refleje la correlación de fuerzas que se dio en el momento, y esa ha sido la historia típica del país, yo creo que, en este momento, estamos, precisamente, en un momento, por la famosa sentencia, que uno no quiere llamarle sentencia, ¿verdad?, se habla más bien de una resolución, por todo lo que ha significado de ilegalidad, desde la convocatoria misma del quórum de la Sala Constitucional, pero bueno, a partir de que se llega a ese extremo, se siente que se ha llegado a un momento, nuevamente, donde ya el abuso llega a tal nivel donde se hace necesario un nuevo acuerdo, ¿no?, ya hay algunos aliados del Frente Sandinista que están hablando de que se hace inevitable, y están convocando, diputados en la Asamblea Nacional, aliados de Daniel Ortega, están convocando para el 20 de noviembre, un día antes de la marcha de la sociedad civil y la oposición, a un diálogo, Daniel Ortega y la oposición y la sociedad civil, ¿esto qué significa?, bueno, que hay un momento en donde se siente que se puede llegar a un nuevo acuerdo, el acuerdo, obviamente, para el Frente Sandinista, más bien para el danielismo en el Frente Sandinista, el acuerdo tiene que pasar por la aprobación de la reelección indefinida, es decir, Daniel Ortega tiene como eje central en este momento, ha abierto una serie de frentes de lucha con la iniciativa privada, con la sociedad civil, los medios de difusión, los UIA, es decir, se pregunta uno cómo puede alguien abrir tantos frentes simultáneamente, yo pienso que esto es una estrategia, precisamente, para que cada uno de los sectores empiece y se entretenga en su propio conflicto, así tenés fragmentado a todo el mundo, mientras el punto fundamental, que es la reelección, conseguida por la vía de esa sentencia o resolución de la Corte Suprema de Justicia, ¿no?, se garantice y se mantenga, y las posibilidad de un diálogo nacional tendrá que venir dándole a cada quien las respuestas del conflicto que tiene planteado, a los empresarios no les voy a poner los impuestos $\mathrm{X}$, tal cosa, paranpapán, y las reformas que requiere con el partido que tiene mayoría, o los partidos que tienen mayoría en la Asamblea Nacional, para garantizar la reelección, yo pienso que es frente al momento que estamos, no siento que haya capacidad de la oposición para articular una oposición totalmente coherente y se ha visto, claramente, que la oposición, por ejemplo, no controla totalmente a sus diputados como sí los controla Daniel Ortega a los suyos, y que, por lo tanto, se pueden dar una serie de reformas sin ningún tipo de negociación con la oposición, simplemente, por la compra de diputados, por lo tanto, la oposición lo que se plantea es, bueno, ¿vale la pena negociar algo o quedarse en una oposición de principios sin negociar nada porque hay una serie de diputados que, de todas maneras, van a votar a favor de Daniel Ortega? Siento yo que es un poco algunas de las reflexiones que se hacen, hay otra oposición que es la oposición, bueno, aquí de lo que se trata, fundamentalmente, es de buscar cómo volvimos a constituir una especie de UNO, de Unión Nacional Opositora de la década de los 90, en donde establecemos una serie de acuerdos de oposición, con un programa mínimo, y luego buscamos quien va a ser el líder que se va a colocar al frente, creo que hay esas dos posiciones que están en juego en este momento, pero de forma muy concreta diría yo que estamos en un momento de tal deslegitimación del juego político, los intercambios políticos de la Asamblea, de los poderes del Estado, porque 
llega un momento en que el Consejo Supremo Electoral no tiene la más mínima credibilidad, nada, después del fraude electoral, la Asamblea Nacional siempre ha sido considerada en Nicaragua como un "mercado persa", donde todo el mundo se compra y se vende, el Ejecutivo que, tradicionalmente, ha jugado el mismo rol, ¿no?, un rol de pérdida total de legitimidad por la tendencia autoritaria y de control de todo el mundo, $\mathrm{y}$, bueno, quedaba con sus problemas la Corte Suprema de Justicia, pero con la última resolución cae en el punto más bajo de legitimidad, entonces, ¿de qué estamos hablando?, bueno, de un sistema institucional que hace aguas por todos lados, y que esto crea un problema serio de ingobernabilidad y de incertidumbre, de incertidumbre a todos los niveles desde el ámbito económico hasta el ámbito mismo de la vida ciudadana más elemental, en donde vos sentís como ciudadano que no tenés ninguna garantía de nada, te sentís al descampado, ¿no?, y esto es un argumento como para pensar de que esto se puede prolongar mucho tiempo, algún tipo de acuerdo tiene que haber para hacer gobernable el país, porque el país como está, está ingobernable, entonces, te encontrás todas las instancias que están denunciando esto y quieren, de alguna u otra manera, algún tipo de acuerdo, el único que ha estado tranquilo y contento hasta ahora ha sido el sector privado, salvo con la reforma tributaria, ¿no?, que lo ha provocado un poco, pero que ya llegó a un acuerdo con Daniel Ortega, con los únicos que se ha reunido ha sido con el sector privado, no se ha reunido con sindicatos, con la sociedad, con nadie, para la reforma tributaria, se reunió con ellos y el sector privado ya está tranquilo, ¿no?, pero salvo ellos, digamos, el resto de la población, sociedad civil, medios de difusión, iglesia, los propios partidos que tienen algún rol de oposición, etc., están en una situación de total deslegitimación del régimen político, por lo tanto, creo que hay un momento de crisis generalizada, que va a obligar a algún tipo de acuerdo, porque hay una deslegitimación total del sistema político que hace ingobernable el país.

R: Ya vamos a ir terminando, porque no quería robarle mucho tiempo, es muy interesante lo que está señalando. Al referirme al pacto, sobre todo, cuando hablo con los diputados liberales, críticos del pacto entre Ortega y Alemán, me dicen que sigue siendo un procedimiento y que existe, que emerge en momentos de crisis para volver a reajustar el escenario político coyuntural. ¿Cuál es su opinión al respecto?, porque sí es cierto que las reformas del 2000 fueron calificadas como una "contrarreforma" por ese giro de 180 grados que se da respecto a las anteriores, y sobre ese pacto sigue gravitando gran parte del escenario político y jurídico actual, ¿no?, y, digamos, que haciendo "política-ficción" de aquí a las próximas presidenciales, si no se produce una unión del liberalismo, la victoria de Ortega con la actual regla electoral del 35\% parece un poco inevitable. ¿Cuál sería su visión?

M.O.: Bueno, yo pienso que hay posibilidades, vivimos varios escenarios diferentes, uno es un escenario en donde las cosas siguen como están, un Consejo Supremo Electoral deslegitimado totalmente, que realiza unas elecciones en donde se presentan los contendientes actuales, en donde no se resuelve el problema de las contradicciones en la oposición, y que, por lo tanto, llega el 2010 con una enorme ventaja de Daniel Ortega, que ha conseguido además la reelección a partir de que se pueda presentar a candidato por esta sentencia de la Corte Suprema de Justicia, allí, para mí, lo que estaría ocurriendo en el país es básicamente hacer una pausa de un conflicto todavía mayor, y no sé si pausa, porque para el período electoral de 2011, probablemente, saldría a la palestra un proceso electoral con índices muy altos de violencia, que no lo hemos tenido tradicionalmente en Nicaragua. Nicaragua se ha caracterizado por tener procesos electorales muy limpios, con muy poca violencia, y salvo las elecciones municipales, 
que, curiosamente, han sido, digo curiosamente, porque las municipales, nadie siente que se está jugando la vida en las municipales porque es simplemente un alcalde de quitar y poner, pero en las municipales del año pasado fueron las primeras elecciones en donde tuvimos apedreamientos, golpes de grupos afines a Daniel Ortega, que buscaban atemorizar a la población, pero, digamos, aún así, el nivel de violencia en las elecciones no ha sido un nivel alto de violencia, si yo lo comparo con Guatemala, por ejemplo, donde en todas las contiendas electorales hay al menos cinco candidatos que son asesinados, ¿verdad?, o sea, estamos hablando de cinco candidatos mínimo, aparte de partidarios que mueren, que tal y que cual, entonces, si vos comparás eso aquí mismo en Centroamérica con la realidad de Nicaragua eso no tiene nada que ver con nosotros, es decir, realmente, son procesos electorales muy pacíficos. Es probable que en un escenario como el que se vivió los índices de violencia se incrementen y que tengamos unas elecciones extraordinariamente anormales en lo que ha sido la historia del país, y con mucha violencia, y con la posibilidad de una de dos, o Daniel Ortega concierte una vez que logre ganar, inmediatamente después de una victoria electoral, o profundiza la polarización del país, pues, podría llevar a un escenario de violencia generalizada. El otro escenario posible es hacer algún tipo de acuerdo en donde Daniel Ortega buscaría algún tipo de legitimidad, buscar legitimar la reelección, y llevar al país a algún tipo de acuerdo político muy amplio o menos amplio, en términos de las fuerzas que lleguen a ese acuerdo, para Daniel Ortega el acuerdo ideal es volver a juntarse con Alemán en un nuevo pacto, verdad, eso para el resto de las fuerzas del país sería absolutamente inaceptable, por lo tanto, allí estaría de fondo, qué tan amplio va a ser el nuevo acuerdo que pueda hacer Daniel Ortega, pero uno no puede descartar que eso pueda estar, pueda ser el otro escenario distinto, dentro de ese escenario para la oposición es inaceptable, para la oposición me refiero a un sector de la oposición, estoy convencido que Arnoldo Alemán pactó con Daniel Ortega el fraude electoral del 2008, estoy convencido, y la razón es muy simple, es decir, era una manera de acabar políticamente al otro líder que le hace sombra, que es Montealegre, si las elecciones de 2006 en Nicaragua demostraron una cosa, que iba a acabar con el bipartidismo Daniel Ortega- Arnoldo Alemán, que había surgido en el 2006 un nuevo líder que se llamaba Eduardo Montealegre, que había tenido más votos que el candidato de Arnoldo Alemán, o sea, la segunda fuerza política, que aparece en la elección del 2006 no es el PLC, sino que es el partido de Montealegre, con lo cual ese resultado electoral que aún siendo un resultado electoral también fraudulento, porque todavía desconocemos el $8 \%$ de los votos de las elecciones de 2006, es bastante probable, incluso, que Daniel Ortega no ganó, y que haya ganado Eduardo Montealegre, yo no lo descartaría, o que, en todo caso, la diferencia con Montealegre haya sido bastante menor de la que hay ahora, y Daniel Ortega hubiera tenido que ir a una segunda vuelta donde hubiera perdido, de todas maneras, aún con los datos como están, como se dieron, lo que aparece claro en 2006 es que aquí había aparecido una tercera fuerza entre el Frente Sandinista y el PLC, que era la fuerza de ALN, el partido de Montealegre, y que aquí el líder de la oposición era Montealegre. Montealegre se vuelve a lanzar de alcalde de Managua en la elección de 2008, dos años después, era de interés de Arnoldo Alemán y de Daniel Ortega el llegar a un acuerdo en hacer que Montealegre perdiera por las buenas o por las malas, porque para Alemán implicaba aceptar que había perdido, definitivamente, el liderazgo de la oposición, y para Daniel Ortega implicaba un contrincante extremadamente peligroso y difícil de ganar, mucho más que Alemán por el desprestigio que ha tenido Alemán estos años, fue condenado, incluso, por la corrupción, etc., etc., por lo tanto era del interés de los dos, más aún, no voy a insistir en el detalle, pero yo creo que los detalles de la reacción de Arnoldo Alemán, inmediatamente después del fraude, no fue precisamente 
denunciarlo, es decir, los Magistrados mismos dijeron, en su momento, que ellos había hecho lo que les habían orientado, los Magistrados del Consejo Supremo Electoral, por lo tanto allí, yo estoy convencido de que ese fraude fue pactado, entonces, el proceso electoral del 2011 y los cambios que pueda traer tendrán que pasar porque un sector de la oposición, que no es Arnoldo Alemán, no pueda aceptar el Consejo Electoral actual como árbitro en una nueva contienda, por lo tanto, a Daniel Ortega le interesa que se mantenga, que se establezca la reelección, y al otro sector una negociación alrededor del Consejo Supremo Electoral, los acuerdos pueden venir de esos mutuos intereses, porque ninguno de los dos puede hacer los cambios si no cuenta con el acuerdo del otro, pues ninguno los votos suficientes, ¿verdad?, por lo tanto, hay otro escenario, que es ese escenario posible de un acuerdo en donde haya una nueva reforma, había que ver si de la Constitución o si sólo de la Ley Electoral, yo pienso que dados los cambios que se hicieron en el 2000 y 2005 en la Constitución es muy difícil hacer cambios sustantivos si no se toca la Constitución, ¿no?, hay algunos cambios que se pueden hacer, que ha hecho una propuesta de la sociedad civil, no sé si la conoces, que, precisamente, lo que hizo la sociedad civil en un proceso de dos o tres años de consulta, a partir del pacto del 2000, precisamente, hizo una propuesta de la reforma de la Constitución, que no toca, verdad, hacer una serie de cambios que no tocaran a la Constitución Política, estos cambios son posibles pero no logran hacer cambios sustantivos, por ejemplo, en el aparato del Consejo Supremo Electoral, que sigue dependiendo de los caudillos, por lo tanto allí hay, si se quieren otro tipo de cambios, la necesidad de que haya algún tipo de acuerdo, y les interesa a los dos, a Daniel Ortega para legitimar la reelección, porque independientemente de que tiene una sentencia favorable a sí mismo, él sabe que es una marrullería política, es una triquiñuela, y que eso no tiene mayor legitimidad, por lo tanto, ese es la posibilidad de otro escenario de una nueva reforma que vaya en esa línea, ¿no?, tal vez un factor de confusión, en términos de esto, es que si uno observa cuál puede ser un poco la perspectiva de un tercer escenario deseable, sería un tercer escenario en donde un nuevo liderazgo desplazara el liderazgo actual del sistema político del país, es decir, este sería el escenario deseable, yo he apostado durante todos estos años que este nuevo liderazgo parta y surja del espacio local, de los gobiernos municipales en donde los alcaldes y concejales han pasado por una experiencia totalmente nueva de ejercicio del poder, en donde por los cabildos municipales, por los presupuestos participativos en Nicaragua son obligatorios por ley, los mismos cabildos son obligatorios, etc., ¿no?, se han visto obligados a tener experiencias de ejercicio del poder transparentes, y una transparencia que comienza desde la toma de decisiones frente a la gente, del uso de recursos del cual están obligados a rendir cuentas por ley cada año, etc., ¿no?, y que, por lo tanto, esta escuela de buen gobierno y de nueva cultura democrática sea una escuela que vaya impactando en los partidos políticos tradicionales, y, que en algún momento, lleguen a dar, a sustituir al viejo liderazgo, esa ha sido mi apuesta, yo después de todo este proceso del fraude electoral del año pasado en los municipios, después de un retroceso fenomenal que se está dando en la construcción de ciudadanía con la profundización y la ampliación del clientelismo, que ha llevado a cabo este gobierno, y que, por lo tanto, conspira contra la construcción de ciudadanía, que se venía dando durante estos años, y el tercer gran elemento, que es el retroceso que se está dando en este momento sobre el proceso de descentralización, que se venía trabajando durante estos años en el país, lo que tenemos, en este momento, es un proceso nuevamente de concentración del poder en el centro, y hay un documento del gobierno que habla de la descentralización del Estado, pero cuando uno analiza qué es descentralización del Estado en este documento se da cuenta que no hay más que el trasladar recursos clientelares no a los gobiernos locales, sino a los grupos del partido, 
que se llaman $\mathrm{CPC}$, organizados en el territorio, $\mathrm{CPC}$, organizaciones del Consejo de Poder Ciudadano, que se llaman, que es la organización que ha asumido el Frente Sandinista actualmente, y que tiene como cabeza a la esposa del presidente en la presidencia de la República, el presidente mismo, entonces, vos observás que los documentos hablan de trasladar poder y trasladar recursos a los CPC no a los gobiernos locales, es decir, crear una institucionalidad paralela, y además concentrar el poder en el centro, porque, finalmente, las decisiones se toman arriba, hay un retroceso enorme también en la descentralización del Estado, entonces, todo este proceso lleva a ser un poco pesimistas también alrededor cuáles pueden ser las afectaciones que tenga todo esto en la construcción de un nuevo liderazgo local, que logre cada vez impactar fuertemente, digamos, en el sistema político, y en los partidos, particularmente, ¿no? Yo al menos no te puedo decir en este coyuntura cuál va a ser el resultado, es muy difícil verlo a corto plazo, pero el proceso de desinstitucionalización, el proceso de concentración de poder, el proceso de concentración de poder vertical hacia territorio, y horizontal hacia los poderes del Estado, además, conjuntamente, con el proceso de profundización del clientelismo político marcan un momento muy complicado en el país, muy poco positivo, en términos de cuáles pueden ser las perspectivas futuras, ¿no?, y cuál puede ser el escenario que podríamos tener, porque una de las cosas que uno se plantea es que frente a la crisis enorme del sistema político y de los partidos, la gran alternativa en la que uno puede pensar es una sociedad civil vigorosa, fuerte y autónoma, pero con estos procesos de persecución, por un lado, de la sociedad civil, y de desinstitucionalización que no abre espacios, y, por otro lado, de clientelismo político que debilita, de alguna manera, todo ese proceso, te crea un escenario, realmente, muy complicado y muy difícil para una sociedad civil, que, con dificultades, ha venido construyéndose durante estos años, y que no tiene, por la pobreza del país, por la miseria, por el atraso, el analfabetismo, etc., la amplitud que esta sociedad civil tiene en otros países. Sin embargo, es una sociedad civil que nació de la revolución y del sandinismo, si vos vas aquí y observás la sociedad civil nicaragüense el $99 \%$ viene del período sandinista, muchos de ellos militantes del Frente Sandinista, viejos combatientes, etc., y que siguen hoy trabajando ahí, son grupos, por lo tanto, muy convencidos de lo que están haciendo y con mucho compromiso con el país y con sus convicciones democráticas, que yo creo que, a pesar de todo este panorama, representan una esperanza para el país, ¿no? Por lo tanto, en este panorama que vos ves yo sigo apostando a que, con todos los descalabros que está, que se observan, hay la perspectiva de que surja un nuevo liderazgo, y, particularmente, de que haya una sociedad civil capaz de empujar procesos, que, al menos, equilibren en un proceso de transición hacia cambios posteriores, ¿no?, los desajustes mayores que podía traer el que solamente pacten dos partidos políticos unas reformas constitucionales, así es como lo estoy viendo en este momento, ¿no?

R: Y ya si la última pregunta, porque llevamos más de una hora de entrevista, respecto al consenso constitucional, es cierto que las últimas reformas han parcheado, sobre todo, de 2000 y 2005, y esta última sentencia, la Constitución del 87, con las reformas más grandes, que es la del 95, haciéndola perder valor normativo en un sentido, realmente, peligroso, no solamente en términos jurídicos estrictos, sino también políticos, ¿no?, de dar certidumbre a los actores políticos, y también de saber, claramente, cuáles son las reglas de juego y respetarlas, y, en ese sentido, tengo referencias, incluso, de que se debería hacer una nueva Constituyente, otros piensan que habría que parar las reformas y no aceptar esta última sentencia. Cuando yo entrevisté al Magistrado Rafael Solís, me dijo que la sentencia pasaría, o sea, que 
también uno se da cuenta de la banalidad con la que se asumen algunas de las grandes irregularidades en este país, ¿no?, y el costo politico que tienen, porque siguen marcando el rumbo del futuro inmediato. Entonces, ¿cuál es su visión al respecto?, es decir, más reformas constitucionales, una nueva Constituyente, hacer valer la Constitución tal cual está, ¿cuál sería su reflexión para concluir?

M.O.: Bueno, yo creo que, yo no vería necesaria una nueva Constitución, yo creo que la Constitución con las reformas del 95 es una Constitución que abrió un marco suficiente con algunas reformas posteriores que se pueden hacer, que mejoran, digamos, el establecimiento de estas normas de convivencia básicas, pero no hay en la Constitución del 95 problemas fundamentales, que impidieran a ninguna fuerza política y a ningún ciudadano individual, o a cualquier grupo colectivo, el ejercicio de derechos básicos en cualquier régimen democrático, yo creo que ahí hay un marco de convivencia suficiente, ¿no?, me parece que con todas las circunstancias del país sigue siendo absolutamente válido ese marco, en términos de todo lo que es el período de reelección en el país, es decir, yo creo que lo más que el país puede aceptar es una reelección en las condiciones en que están, porque ya conocemos las tendencias que existen en las élites políticas de eternizarse en el poder, y después bajarse a punta de tiros, y eso el país ya no lo aguanta, por lo tanto si a mí me preguntás qué vería, yo vería la Constitución del 95 con algunas reformas, probablemente, revocación de mandato más que nada por mantener en la Constitución un recurso a la población, etc., pero que, en la práctica, no creo que vaya a tener mayor efecto, por cuanto va a ser muy difícil echar a andar un recurso como ese con los partidos y los líderes que tenemos en el poder, va a ser muy difícil tener un recurso como ese, que, efectivamente, cambie, pero hay algunas cosas que se podrían mejorar en la Constitución, pero yo no creo que sea necesario hacer, totalmente, una reforma constitucional total, yo pienso que lo más importante para el futuro del país no está tanto en las reformas de la ley sino en dos elementos claves: el uno, es buscar cómo este país logre construir un mínimo de desarrollo que garantice que la gente no tenga que depender de dádivas, ni de clientelismo, ni de perversión de su conciencia, a cambio de un voto o de la fidelidad a un partido, ¿no?, yo creo que eso le daría una enorme libertad al ciudadano para ejercer su voto libremente, esa libertad no la tiene hoy casi el $80 \%$ de los nicaragüenses, y ese es el caldo de cultivo de todo este tipo de situaciones que estamos viendo y el clientelismo que tenemos, por lo tanto, ese es el cambio fundamental, el cambio fundamental aquí es un cambio a largo plazo, no es un cambio a corto plazo, y el segundo cambio que yo plantearía, como un cambio fundamental, es el cambio en la cultura política, que me parece, yo considero que el cambio en el país tiene que venir por las dos vías, un sostenimiento, digamos, de la institucionalidad, estoy en contra de la desinstitucionalización, yo creo que el país va a pagar un costo muy alto por esta desinstitucionalización que se está haciendo ahora con este gobierno, ¿no?, por lo tanto, no estoy estableciendo la cultura política como un factor sustitutivo de la institucionalidad, no, yo creo que las dos cosas son importantes, pero, digamos, la institucionalidad no es que en sí misma, formalmente, requiera grandes cambios, finalmente, ya vemos que los líderes aún con una Constitución perfecta pasan por encima de ella cuando les interesa, por lo tanto, el problema no es la ley, yo creo que el problema fundamental es la cultura política y la permisividad que da esa cultura política a partir de que exista una población que no logre construir ciudadanía, porque construir ciudadanía significa tener capacidad de libertad, capacidad de decidir libremente lo que quieren, y mientras vos no tengás ni siquiera la posibilidad individual de reproducirte autónomamente de otros, que con tu trabajo logrés reproducir tu vida y la de tu familia, creo que los niveles de pobreza son tales que tenés de depender de dádivas, etc., a mí 
me parece que estamos arando casi en el desierto, es decir, sin muchas posibilidades de avance, aquí la clase media es un sector muy pequeño, hay un ataque, ha habido un ataque permanente de los dos caudillos a la destrucción de la clase media, porque la clase media es la clase crítica, es aquella que tiene independencia de esas condiciones materiales básicas, etc., es la clase pensante, etc., etc., ¿no?, entonces, aquí ha habido un proceso de destrucción de esa clase media, ¿no?, hoy mismo esta reforma tributaria es una reforma tributaria que tiene una marca muy clara hacia los sectores profesionales y medios del país, ni siquiera contra la iniciativa privada, verdad, los grandes sectores empresariales, pues, la iniciativa privada, por lo tanto, a mí me parece que estamos frente a un proceso de mucho más largo plazo, porque implica cambios en la cultura política y la cultura política es lo que vos sabés que toma más tiempo cambiar, pero, por otro lado, también implica desarrollo, el desarrollo también es lento, no, no se produce de un día a otro, el crear condiciones para que la gente pueda construir por sí misma su propia vida y reproducirse por sí misma, de forma autónoma, a cualquier otro poder, etc., y a mí me parece, por lo tanto, que estamos frente a ese, el escenario, digamos, estratégico, sustantivo, va hacia allá, creo que la sociedad civil, en ese sentido, pues, está representando en el país la gran alternativa, los partidos políticos dejaron de capacitar y de formar desde hace años, ni siquiera se dedican a formar a su propia militancia, los únicos que están formando y capacitando con nuevos valores de cultura política democrática es la sociedad civil, por lo tanto, sigue siendo un poco la esperanza de eso, el propio sistema educativo te deja a vos medio millón de niños fuera de la escuela, uno dice: ¿quién construye ciudadanos de esos niños, cuando luego se convierten en jóvenes, y, luego, en adultos? Por lo tanto, el proceso de formación, de capacitación de adultos sigue siendo en este país una necesidad ineludible, el cambio de la cultura, el cambio de la mentalidad se ha demostrado, yo hice muchos estudios aquí, yo soy especialista en análisis sociocultural, los estudios en Centroamérica y en Nicaragua coinciden totalmente con hallazgos que hizo la CEPAL en América Latina, y es que la mentalidad de los latinoamericanos cambia hasta después de doce años de estudio, hay una mentalidad tradicional machista, providencialista, etc., etc., es decir, una mentalidad, que es, digamos, la mentalidad típica tradicional, que solamente cambia después de doce años de estudio, nosotros estamos muy lejos de eso, con dificultad, perdón, ni siquiera con dificultades, no vamos a conseguir el reto del milenio, que implica educación primaria completa para el 2015, ya no lo conseguimos en educación, primaria completa son seis años, la meta siguiente serían seis años más para pretender que hemos cambiado la cabeza, la cultura, la manera de pensar de la población, estamos, por lo tanto, bastante lejos, ¿no? Por lo tanto, cuando yo te hablo de largo plazo estoy pensando en el largo plazo, pero que hay que empezar, de forma sustantiva, a través del sistema escolar formal, pero también a través de todos estos trabajos, digamos, informales, que da la sociedad civil en los procesos de construcción de ciudadanía y de cambio de mentalidad, conjuntamente, con el perfeccionamiento, digamos, de la institucionalidad, y eso dentro de un marco de empleo, desarrollo mínimo, etc., que dé las bases materiales más elementales para estos cambios, sin esos cambios yo creo que no es posible. Cualquiera podría decir que, por lo tanto, esto se ve imposible y tal, pero yo pienso que hay que plantearse los problemas como son, hay posibles cambios inmediatos, pero a lo mejor ninguno de esos va a ser sustantivo, yo creo que hay que pensar en cambios inmediatos a las situaciones más urgentes, pero sin perder de vista que el cambio estratégico tiene que venir por cambios en esos tres grandes subsistemas del sistema social, si no, no va a haber cambios de futuro, creo yo.

\section{R: No, pues, muchísimas gracias.}


ENTREVISTA 28 ${ }^{42}$ :

Nombre del entrevistado: Dr. René Herrera.

Cargo actual: Magistrado del Consejo Supremo Electoral.

Fecha de realización de la entrevista: Managua, 27 de noviembre de 2009.

Lugar: Domicilio particular del Dr. Herrera.

Duración estimada: 2 horas y 6 minutos.

\section{TEXTO - Transcripción 28:}

$R$ : ¿Cuál sería su visión sobre los cambios constitucionales que se han producido en el país en el contexto de la transición democrática?, ¿cómo ha sido la evolución del marco jurídico con todas las reformas que se han experimentado desde el primer gran debate entre la reforma total o la reforma parcial a la Constitución original del 87, cuando se firman los acuerdos de paz y se instaura, digamos, la democracia liberal en Nicaragua?

R.H.: Mira, creo que la Constitución base la dio el gobierno sandinista bajo su período, en consecuencia, es una Constitución que recoge las aspiraciones de un movimiento revolucionario, un movimiento que había llegado al poder por la vía de las armas, en consecuencia, es una Constitución, esencialmente, partidaria, esencialmente, ideologizada, particularmente, identificada con todo lo que había sido la suma de aspiraciones y situaciones que dieron lugar al triunfo del sandinismo, eso la colocó en una posición que sería blanco de sus opositores desde cualquier ángulo que se les quisiera ver, en el 90 con el cambio de la correlación, llamémosle así, de fuerzas políticas, que el Frente acepta en la negociación política, y en la negociación política acepta medirse, electoralmente, al producirse las elecciones generales del 90, y perderlas el gobierno, el Frente Sandinista, quizás, un poco sorprendido de los resultados trata de amarrarse, de anclarse sobre la base constitucional de la Constitución del 87, y temeroso quizás de que pudiesen darse transformaciones de esa Constitución de parte de sus opositores, que también traen su proyecto ideológico, que también traen una serie de aspiraciones partidarias, que son adversarios de fondo, en el sentido de aquella época de finales de la Guerra Fría, el Frente hace acuerdos paralelos a la no reforma constitucional, un poco lo que Pinochet en el otro extremo ideológico hizo en Chile o en Argentina con los militares al abandonar el poder, en Uruguay y en Brasil, en donde, prácticamente, la pérdida de gobierno no va a implicar la pérdida de poder, y la pérdida de gobierno no va a implicar la desaparición de aquellas cláusulas constitucionales, que le garantizan la supervivencia, eso hace que, en el caso de Nicaragua, las modificaciones constitucionales a partir del triunfo de la oposición en el 90 no sean sustanciales, sean siempre más producto de un acuerdo político, no como reforma, propiamente, dicha, el Frente Sandinista conserva en la, llamémosle así, en la visión constitucional una serie de enclaves, es decir, que hay aspectos de la Constitución que no son permitidos cambios, sin decirlo por escrito, se sabe que esos enclaves no pueden ser tocados, si es el Ejército, en menor grado, pero, en cierta medida, igual la Policía, el Poder Judicial, temas de la propiedad, que son, sustancialmente, la base del poder del Frente Sandinista, el resto de temas pueden ser tocados en arreglos, en

\footnotetext{
42 Entrevista excesivamente larga, con una intervención centrada en la repartición de las cuotas de poder paritarias en las principales instituciones del Estado entre el Frente Sandinista y el PLC, así como en las dificultades implícitas en la renovación generacional del liderazgo político en Nicaragua.
} 
modificaciones de leyes secundarias, es decir, y, en ningún caso, sin embargo, podrán desbaratar, destruir el espíritu que tenía en la Constitución esa correlación de poder, de modo que pasan varios años para que la Constitución sea reformada y sea sólo mediante una negociación política, y en áreas en donde siempre el sandinismo se reserva el control principal, coloca candados en todos los portones constitucionales, candados de los cuales sólo ellos tienen llave, y no dejan una copia a nadie, a menos que se pongan de acuerdo, uno de esos grandes candados es de que para poder hacer elecciones en los poderes del Estado, en las reformas constitucionales, en cualquier otra actividad que modifique deben ser un mínimo de 56 diputados, 56 diputados es una cantidad casi 2/3 de lo que es el número de toda la cámara legislativa, en ningún momento, en ninguna elección, nadie se acerca a 56 diputados, de modo que una Constitución que, difícilmente, se puede modificar, yo creo que, en esencia, el poder político en Nicaragua no tiene posibilidad alguna de hacerle grandes reformas a la Constitución.

\section{$R:$ ¿Está hablando del primero momento de los 90?}

R.H.: Sí, después, después más vía negociación, por ejemplo, el retiro del Jefe del Ejército no implica cambiar las reglas del juego, de cómo se elige al Jefe del Ejército, verdad, es el Ejército el que se elige a sí mismo, de alguna manera, y eso hace, al día sábado lo vio usted aquí en el país, eso hace que, prácticamente, el Ejército conserve su condición de enclave al servicio o desde sus orígenes relacionados con la revolución, cambian los jefes, pero, constitucionalmente, el poder de cómo se hacen las cosas en el Ejército es facultad exclusiva de ellos, y eso es un derivado de la Constitución del 87, la reglamentación misma no modifica el espíritu de la Constitución del 87 , y eso ya está así, ya nadie lo pone en discusión, a nadie se le ocurre, en este momento, querer hablar de una reforma constitucional para quitarle al sandinismo el control del Ejército o la Policía, verdad, lo mismo pasa con el resto de aquellos enclaves en los que se amarraron, firmemente, para poder entregar el gobierno, es decir, se quedaron con el poder, entregaron el gobierno, pierden las elecciones, pierden el gobierno, pero no el poder, y usaron una frase que es bastante inteligente, bastante significativa: "gobernar desde abajo", esa es una buena manera de entender, "miren señores, aquí con los enclaves, con el poder constitucional, que la Constitución nos confiere, pues, vamos a seguir gobernando, y nadie podrá tocarnos a menos que se siente con nosotros", esa es la lección sobre el significado que tienen las constituciones políticas en países que transitan, de alguna manera, en su forma de régimen político, ¿qué ha pasado?, que el Frente, constantemente, tiene una media de respaldo, que va entre el $35 \%$ y el $42 \%$ en cualquier tipo de medición electoral sea municipal, sea nacional, sea regional, es decir, es un poder sostenido, verdad, que tiende a crecer en unos momentos o a disminuir, pero que el rango de $35 \%$ a $42 \%$ siempre se mantiene, ¿por qué?, por un lado, por problemas propios de la naturaleza política de Nicaragua, es un país con tendencia a la polarización, es un país con tendencia al uso excesivo de la palabra más que al uso de las armas, es un país con una tendencia muy fuerte a la crítica, al cuestionamiento fácil, y aquí lo más fácil es criticar, y eso, obviamente, a los cuerpos políticos les ayuda, porque se arropan, se abrigan a sí mismos, y creen que sus conquistas son eternas, verdad, entonces, la fuerza de la crítica sirve para conservar poder, y para tratar de quitárselo al otro, una cultura de lucha cuerpo a cuerpo, que, básicamente, permite a quien tiene más disciplina tener más fuerza, a quien tiene más organización tener más fuerza, al que sabe cultivar la organización y ciertos principios básicos darle siempre más fuerza, por eso una de las grandes tareas, y en este libro del derrumbe negociado se explica cómo se da la formación de los partidos políticos, y qué significado tienen los 
partidos políticos, todo el mundo cuando ve a esta sociedad, y no sólo este sábado pasado, sino un montón creería que es un sociedad totalmente desorganizada, ¿no?, es una sociedad de partidos políticos, que en las circunstancias de las luchas de poder actuales hay mucha presión de la campaña mundial en contra de los partidos, de que los partidos son corruptos, de que los partidos gobiernan para sí mismos y todo ese rollo muy gringo, también europeo, ¿no?, de desgaste de los partidos, etc., en el caso de Nicaragua eso fortalece curiosamente al sandinismo, y al liberalismo como los dos polos principales de oferta política en el país, las reformas, en consecuencia, no son producto de aspiraciones ciudadanas, en el sentido que haya un movimiento en toda la ciudadanía, no, es una cuestión de ir pujando el reparto de poder entre las fuerzas que tienen una representación parlamentaria, y sí, curiosamente, entonces, aparece en un país desordenado un país muy ordenado, un país en donde todo el mundo grita, critica, vocifera, insulta, y un país que se sienta y negocia, entonces, hay dos Nicaraguas en el mismo tiempo desde el 90, y esas dos Nicaragua, quitemos la Nicaragua vociferante, la Nicaragua gritona, y quedémonos con la Nicaragua organizada, que tiene fuerzas políticas organizadas y que son organizadas en un sentido clásico, ortodoxo, es decir, gente que pertenece a un partido, que traen una credencial de partido, que en su casa pone la bandera de su partido, que luce en su casa los signos de su partido, es decir, hay, hay aquí esa Nicaragua organizada, que es la que vota, vota arriba del $90 \%$ de los que votan en esas dos maneras de ver el mundo, liberales, sandinistas, para que ese $38 \%$, $35 \%, 40 \%, 42 \%$ se mantenga monolítico ahí, ellos tienen sus motivos de cómo organizar sus liderazgos, pero quien sea y esté en el liderazgo la tarea principal política es que esa mayoría que queda, ese $60 \%$ o ese cincuenta y tantos, o lo que sea de mayoría se divida, es una tarea, propiamente, de organización política, de imaginación, de talento, de inteligencia política, maldad política, todo lo que usted quiera, de manera que aquí la idea de mayorías-minorías sea una idea un poco simple, para una reforma bastaría que tengan la diferencia, verdad, una fuerza para poder reformar la Constitución, pero nunca en la realidad, aún el partido sandinista, ganando la presidencia con el $40 \%$ o el partido liberal, ganándola con el $60 \%$, ninguno de los dos tiene los 56 diputados, es decir, ni unida la oposición logra quitarle el $40 \%$ al Frente, ni teniendo el $40 \%$ el Frente logra mantener unido al $60 \%$, es decir, lo divide, por los mecanismos que todos podemos imaginarnos, de manera que la reforma como tal, que es una suma de votos en la forma, se debata de una manera diferente, se debata en el contenido, es decir, se debate, políticamente, sentados en la mesa, sobre hasta dónde estoy dispuesto a ceder de lo que la Constitución del 87 me dejo a mí, como, en ese momento, partido y gobierno triunfante revolucionario, etc., cuánto le puedo dar, cuánto me puede quitar a la oposición, ¿verdad?, y, a su vez, la oposición cuánto le puede arrancar a los votos del Frente, si son 56 y el otro tiene su $40 \%$ o su $38 \%$, obviamente, no hay manera de lograr una negociación por vía de números, se necesita por vía de distribución de poderes, y el tuyo y el mío ahí es una negociación entre partidos, y entre partidos entre liderazgos muy visibles, muy fuertes, el caso de Daniel Ortega y el caso de Arnoldo Alemán, por razones ideológicas, prácticas, o yo no sé de qué tipo, se llegó a una división en el liberalismo, verdad, el gobierno de Alemán y gente que trabajaba con él, que se le separa, y tratan de construir un partido alternativo al del, tuvieron éxito en dividirse, pero esa división ahí sí los números funcionan, esa división tonta, porque es obvio que ninguno va a tener más que el Frente unido, al dividirnos le dimos la victoria al sandinismo, pero, para efectos del tema de las reformas, divididos tenemos menos posibilidades de tener los 56 , porque en las divisiones de los partidos, cuando uno va contra lo que es la fortaleza del núcleo central de un partido, generalmente, entran en la división de la otra Nicaragua, la vociferante, la que es, excesivamente, 
crítica, fácil de la palabra, el encanto de la facilidad para atacar, etc., en consecuencia, se pierde la disciplina de un partido fuerte, y aparecen esas hilachas, llamémoslas así, de gente que es muy atractiva, crítica, y que se opone al líder principal, y que se oponen a la corrupción, y que se oponen a todas las maldades del universo, pero son muy vulnerables, son gente que no tiene ni los antecedentes de una disciplina partidaria, ni una convicción política muy clara, son, generalmente, personas resentidas porque no se les dio lo suficiente o porque no se les alcanzó a dar nada, o porque sus ambiciones nunca fueron suficientemente satisfechas, en consecuencia, un buen número de diputados, que aparecen en la división son, prácticamente, mercenarios de la política.

\section{R: ¿División en el PLC?}

R.H.: En esta fuerza mayoritaria, estamos de acuerdo en que las reformas tienen que darse con 56 votos a fuerza, que el Frente tiene 38, y la oposición, en teoría, debería tener cincuenta y tantos, pero no llegar a los 56, le faltaría uno, pero no es tanto eso, que les falte uno o dos, sino que antes de la división era un bloque más o menos monolítico, que podía presionar con mayor facilidad a los 38 votos, es decir, 53 contra 38, la negociación es más interesante que una oposición dividida en uno 24 , en el otro 21 , verdad, peleando contra los 38, consecuencia, puede haber 24 sólidos de un partido, pero 21 que llegaron a la política por la vía de la crítica, que son muy vulnerables a lo que en Nicaragua se le llama cañoneo, o sea, compra, adquisición, pues, ¿por qué?, porque muchos de esos diputados es gente, fácilmente, no digamos comprable, porque yo creo que no es que se compran es que son adquiribles, en el sentido, "mirá, yo te ofrezco esto, venite", entonces, la división impide una negociación para la reforma que sea consistente como sí fueron las primeras reformas, que después del 90 se hacen sobre la base de una oposición sólida y un Frente debilitado en ese momento, hoy, la reforma es más difícil, un sector de la oposición fuerte, fuerte en el sentido que yo le digo, que no tiene la disciplina, ni los intereses muy claros, que dicen: "no, nada, negociar, nada, nada, que cero reformas, que cero aquí, cero allá", es decir, lo que es un tema parlamentario por excelencia como es la discusión, propiamente, de las reformas se ha salido de ahí, ¿por qué?, porque no hay números, y en la capacidad de negociación esos números que están ahí es una capacidad muy débil, y el Frente como fuerza monolítica necesita una oposición que sea más sólida para negociar con ella, en estas circunstancias el partido liberal en dos fuerzas, la que maneja Eduardo Montealegre y la que maneja Arnoldo Alemán están inhabilitadas de poder negociar con la misma tranquilidad con la que se negociaba antes cuando sólo era el gobierno de Arnoldo Alemán, o el partido de Arnoldo Alemán, que bastaba que nos sentáramos, discutiéramos y avanzáramos las reformas anteriores, en estas circunstancias, entonces, las reformas constitucionales que se han planteado en los últimos 3 años no han avanzado, no se ha podido hacer la reforma política, no hay otro tipo de reformas, que le interesen ahorita a la gente, la cuestión económica va por otros cauces, y la reforma, en consecuencia, como reforma constitucional está casi cerrada, hace un par de años parecía que ya estábamos, yo participé en la Comisión que elaboró el documento de las reformas, terminamos, hubo consenso entre las dos fuerzas políticas principales, pero un mal manejo, se vendieron mal las reformas.

R.: ¿Del 2005?

R.H.: Sí, no, no, no, no, más reciente, estamos hablando, las del 2005 se hicieron, eso lo hizo el PLC y el Frente Sandinista sin mayores dificultades, se hizo un trabajo normal, 
en este caso, en la fragmentación opositora ha impedido un tipo de negociación similar, y se han introducido, llamémoslo así, alguna reforma, que hace unos años no serían tan ruidosas, pero ahora se convierten en problemáticas, la cuestión de cambio de régimen, un poco hacia el parlamentarismo, el tema de la reelección sucesiva, también muy cuestionado por algunos sectores de la oposición, no, no prosperaron, estaban listas, había consenso, ¿por qué no funcionó?, porque estaban de por medio una serie de temas que no eran constitucionales, que eran, propiamente, políticos, de personas, era la libertad definitiva del doctor Alemán, era la falta de una victoria de uno de los dos líderes dentro de la oposición, es decir, el pleito de liderazgo interno hacía difícil que se pudiera avanzar en las reformas, más en la cuestión judicial del doctor Alemán, de campañas fuertes en su contra por la cuestión de la corrupción en su gobierno, hacían, debilitaban su fuerza para hacer ver el interlocutor de las reformas, viendo que mientras la otra fuerza liberal se oponía no quiso correr el riesgo de entenderse, directamente, con el Frente, por temor a que lo acusaran de ser, eso fue un error de él, pero, bueno, eso hizo, y en vez de negociar en el momento que tenía la oportunidad de hacerlo, se sintió demasiado presionado por sus opositores internos, y decidió más bien darle la vuelta al tema, irse a buscar a sus adversarios internos para tratar de jalarlos, subordinarlos a él y después intentar la negociación, se le hizo muy largo el tramo, se lo comió un poco el tiempo, y, prácticamente, dejó sin posibilidades la negociación para la reforma en los dos últimos años, ¿qué pasa de aquí para adelante?, ¿existe la posibilidad de esa reforma?, ¿no existe?, creo que el Frente, que es el más interesado en alguno de los temas, de alguna manera, acordada indirectamente, acordada con el doctor Alemán, deciden zafarse de la vía legislativa e ir por la vía de las negociaciones indirectas, es decir, busquemos como las cosas se hagan, si no se pudo hacer la reforma constitucional, hagamos la reforma de hecho en aquellos temas que nos interesan a los dos como cabezas de las dos fuerzas grandes del país, es decir, salgámonos del Congreso, en donde no vamos a tener los 56 votos, por todas esas razones de liderazgo interno, pleitos y dificultades, y busquemos un mecanismo que sea más práctico, y que no nos ocasiones los costos tan, eso lleva a la reforma no de la reforma, propiamente, dicha como la habíamos planteado en el documento de las reformas constitucionales en que se consensuó entre las dos fuerzas políticas, sino una reforma más bien de hecho, que evade la formalidad de los 56 votos, y es la que se ha usado en América Latina y en otros lados, ¿no?, la cuestión de la Sala Constitucional en la Corte Suprema para que resuelva si yo ciudadano puedo ser impedido de ser candidato o no, y con una resolución de la Sala Constitucional evitar que la Constitución, que me prohíbe, me impida ser candidato, es legítimo, es correcto, que no satisface muchos de los requerimientos de imagen, pero que resuelve problemas de poder en sí, y si se ausentan los Magistrados de la otra cara, verdad, se van a España, se van a Grecia, se van a Suecia, se van a donde sea, y los otros miembros llaman a suplentes, y construyen, y de manera, aunque se grite después, yo no fui, yo no sabía, verdad, se hace, y se resuelve el tema de la reelección, no es una reforma a la Constitución, en el sentido clásico de llegar a la Asamblea con un proyecto, votarlo y hacerle toda la, es una vía indirecta, es decir, cuando por incapacidad del cuerpo político colectivo, llamémosle así, de las dos fuerzas que no se usa el procedimiento tradicional, se recurre al, lo hizo Costa Rica, lo hizo Venezuela, lo hicieron varios países, que si es bueno o es malo, yo creo que no es una cuestión de, yo prefiero la reforma cuando se negocian directa, abierta, y se votan, pero también reconozco que si el cuerpo político es incapaz para hacerlo así, se vale en las luchas de poder, normal también, en cualquier país grande, chiquito o mediano, verdad, lo permitan, y la ley permitía utilizar ese tipo de mecanismos, así se resolvió, entonces, el tema de la reelección sucesiva, el otro tema de fondo que aparecía en la 
reforma constitucional era la cuestión del sistema político, de hecho, la muestra de que no se pudo hacer la reforma por la vía tradicional, verdad, revela que el parlamento es relevante, verdad, si nosotros jugáramos a que sea el parlamento el que defina todo, verdad, y se haga una reforma que diga que lo que apruebe el parlamento es lo que prevalece sobre la Constitución tendríamos un sistema un poco diferente del actual, ¿por qué se pensó en irse hacia el parlamentarismo?, las discusiones que teníamos nosotros adentro, como cuerpo político, eran que la Constitución del 87 y las negociaciones políticas en el gobierno de Doña Violeta habían puesto demasiados candados a las posibilidades de una reforma constitucional, el Frente Sandinista tenía miedo que le quitaran el control del poder por la vía de las reformas constitucionales, y, para evitar eso, le puso demasiados candados, y dejó trabada la posibilidad de las reformas a una difícil manera de conseguir los votos, si nos vamos un poco más hacia el parlamentarismo, y el Congreso resuelve en esa reforma misma de que es el parlamento el que define los términos del sistema político, vamos a tener una lucha política más clara, de mayorías, y el que tiene más votos en el Congreso, no 56, sino el que tenga mayorías puede obligarse a la reforma, sin necesidad de recurrir a los otros procedimientos, en segundo lugar, el Frente tenía una cierta vocación típica de los populismos de la América Latina de los años pasados, verdad, que es que el pueblo delibere en la calle, y, de alguna manera, los diputados de la Asamblea estarían respondiendo más a esa lógica de participación, y que se reducía más a ser el "pueblo presidente", como dice el eslogan de los sandinistas, o como lo define Arnoldo Alemán para su PLC, no era, pues, una cuestión tan teórica, tan sustantiva, de decir, vamos un poco más hacia el parlamentarismo, era una manera de evadir las mismas trabas que se había puesto el sistema desde la salida de los sandinistas, entonces, hoy eso ha quedado, prácticamente, a un lado, no, no se modifica, si bien, lo de la reelección se resolvió, el tema ese, pues, como que era menos relevante, y no le veo salida, porque no hay números, puede ser, pero esa es una especulación también, si las dos fuerzas, si los dos partidos estuvieron de acuerdo de hacerlo así lo de la reelección, pudiera ser que tengamos una posibilidad de reformas tradicionales una vez que ya el Frente dice: "esto ya está escrito en piedra, ya la candidatura va", y, entonces, la oposición ahora se incline a decir: "sentémonos, pues", y, quizás, el efecto de la marcha esta sea esa, verdad, no hay más salida que sentarse a negociar, ¿qué se va a negociar?, sobre temas diferentes a los que, originalmente, habíamos pensado, probablemente, al comienzo de esa negociación sea otra vez el estilo "nica" de hablar de todo, y que la reforma va a ser que ahora todos los ciudadanos van a andar de gorras verdes, o que todos, un montón de tonterías, pero que al final vamos a volver al mismo tema, que es el interés de cómo dilucidar los problemas del poder, es decir, la sucesión presidencial, el sistema de participación ciudadana, y la distribución de los cargos en disputa, en esa reforma es la reforma constitucional en el fondo, verdad, creo que puede ser que se llegue a eso otra vez, quizás ahora que se sacó la pus, se sacó la rabieta la oposición, y el Frente enseñó que tiene el dominio de las calles, que tiene una convocatoria más fuerte que la de la oposición, y, entonces, por lo menos, un sector de la oposición, yo espero que Arnoldo lo haga, digan: "vengan, sentémonos aquí", es evidente de que hay una oposición, pues, fuerte, pero disminuida frente al poder, y más vale que de una vez nos sentemos y negociemos y no dejemos que sea la fuerza de la convocatoria del sandinismo la que predomine para los próximos años, porque, y esto yo lo creo con sinceridad, creo que la división es muy profunda en la oposición, y que el Frente en unas elecciones en el 2011, siendo ellos otra vez candidato Daniel, y nosotros disminuidos otra vez con dos candidaturas vuelven a ganar sin dificultad, y, entonces, mi consejo ha sido: "miren, mejor negocien", negocien los términos de cómo eso va a ser, que sea consensuada y no 
otra vez por la vía de que ustedes se van a ir a tirar a las calles diciendo que hubo fraude, porque no lo hubo, en el sentido real, en las municipales, no hubo ese fraude, que dicen, no lo hubo, hubo irregularidades, algunas significativas, pero que no modificaban la esencia del proceso, lo que pasa es que, y eso tiene que ver con las reformas, lo que pasa es que esas dos Nicaraguas, la gritona, la vociferante, y la más o menos organizada, ha tenido más espacio la gritona, porque su candidato, en este caso, Eduardo Montealegre, había perdido ya dos veces, y es doloroso para una gerencia financiera como se ha visto la política del lado de un banquero ordenado, que cree que la política es administración de negocios privados, perder es muy distinto a la de un político tradicional, que pierde, grita, y sabe que para sobrevivir tiene que volver al cauce de la política, en este caso, Estados Unidos puso todo su compromiso en Eduardo, en las presidenciales, y las perdió, las perdió de una manera que no esperaba nadie, nosotros lo esperábamos, yo lo esperaba, no tenía Eduardo la fuerza para ganar, el carisma, el interés de la política para estar en la política, siempre se vendió como una cosa anti-política, consecuencia de un país muy politizado, no le iba a dar y no le dio el respaldo, lo llevan de nuevo, y lo llevan para la alcaldía de la ciudad, debieron de haberlo hecho a la inversa, en primera instancia, haberlo tirado como alcalde, y después pujarlo para presidente, pero lo hicieron al revés y en la alcaldía él no fue candidato a alcalde, fue, otra vez, candidato contra Ortega, y jugó toda su campaña, no como candidato a alcalde, sino bajo un eslogan que decía; "todos contra Ortega", y Ortega no era el candidato en la alcaldía, en consecuencia, para el pueblo sencillo, verdad, pues, no tenía mucho sentido, la gente sigue peleando como que está en las presidenciales, lo van a volver a golpear, como decimos aquí, lo van a volver a golpear, y lo volvieron a golpear, Eduardo no ganaba en Managua, eso hay suficientes elementos para poderlo decir, por lo menos, yo, ¿qué pasa?, que la persistencia de la candidatura de Eduardo es más en el interés de mantener dividido al partido liberal, y bloqueado el camino para Arnoldo Alemán que, propiamente, crear una opción alternativa a Ortega, y eso es grave porque es, de alguna manera, estar bloqueando la posibilidad de las reformas constitucionales por la vía de lo que ellos llaman el pacto entre Arnoldo y Daniel, entre Alemán y Ortega, verdad, es decir, hay en la política nuestra cosas para nosotros, por nosotros, y hay en la política de Nicaragua cosas de otras gentes, que están ajenas al proceso en cuanto a intereses locales, para Estados Unidos es fundamental seguir jugando en contra del pacto entre los dos partidos, es una animadversión contra Alemán cerrada, es decir, no nos importa que gane el Frente, pero este señor no continúa, entonces, la división va a mantener bloqueada, lo ha logrado durante estos años, un acuerdo, de nuevo, entre los dos partidos, probablemente, ahora, la famosa marcha del sábado, analistas que no están, pues, en los periódicos señalan que el beneficiario de eso fue el mismo Alemán y su partido, esa es la bandera que predominó allá adentro, a pesar de que la sociedad civil, que es la que respalda a Montealegre, no quería que los partidos fueran, sin embargo, a la hora de la hora, en el Informe Pastrán, que sería así de los observadores locales el más serio, señalan que la bandera roja, la grande, la más roja, la que prevaleció en esa marcha, consecuencia, quien tiene ahora la capacidad de ser el interlocutor de cualquier negociación, otra vez, es el PLC y Alemán, puede que eso lo conduzca a aprovechar la oportunidad de pujar por una nueva negociación que incluya las reformas constitucionales, los dos la quieren, la reforma los dos la arreglaron, los dos la han afinado, escrito, y sólo por razones internas de liderazgo, de lucha de liderazgo entre Alemán y Montealegre, en este caso, no se llegó a feliz término, veremos ahora, ya la oposición se quitó, pues, verdad, ya hizo su marcha, ya la dejaron hacerla como quisieron, ya se siente, pues, más tranquila, es probable que podamos dar un paso hacia un diálogo de fuerzas, que, al principio, sea muy alborotado, 
muy de todo, pero que al final va a ser un diálogo otra vez entre las dos fuerzas políticas, es decir, retomar el rumbo perdido en estos tres años, puede ser eso en diciembre, o podrá hacerse después, aquí entra el tema que es el interés, la reforma constitucional era el tema de fondo, ahora viene con los plazos de vencimiento de los funcionarios en el Estado, la cuestión de los nombramientos, el tema de fondo, hay como veinticinco cargos el año que viene, y como otros veintitantos en el siguiente año, el año pre-electoral, en el 2010, que también se vencen, en todos los regímenes políticos, sean de países desarrollados, medio desarrollados, muy jodidos, lo que importa en el poder es el ejercicio del poder, quien tiene el poder, el PLC, por las negociaciones que hubo en los años, cuando las hubo tiene la mitad de los poderes del Estado con su gente, nosotros en el Consejo somos cuatro de los siete, cuatro puso el PLC, los cuatro se nos vence el período el año que viene, en la Corte Suprema de Justicia se vencen otros cuatro ahora para el Frente y dos o tres para nosotros, en la Contraloría se le vencen todos, en la Superintendencia de Bancos, es decir, hay veinte y tantas, que el poder, ese es el poder, y cómo se reparte eso, eso es el tener más o tener menos poder, cómo se va a elegir si la Constitución te obliga a tener 56 votos si nadie los tiene, a fuerza te vas a tener que sentar a negociar, entonces, la Nicaragua ruidosa lo que quiere es, verdad, que no se haga eso, pero eso es lo que hay que hacer, nadie puede ser nombrado si no estamos de acuerdo en que haya nombramientos, la oposición, esa Nicaragua ruidosa, que es la que no está en esos cargos, quiere estar en esos cargos, verdad, entonces, la campaña si hubo fraude, somos fraudulentos los que estamos ahí, en consecuencia, hay que poner a otros que no sean capaces de robarse las elecciones, bueno, cómo traer gente honrada en sustitución de los ladrones si no tienes los votos, suponiendo que somos ladrones y que los honrados son los que van a llegar, no hay votos, si no hay votos lo que puede obligar es a una negociación de reformas a fondo otra vez, regresar a la discusión que tuvimos hace tres años, que se frustró por esa lucha de liderazgos en la oposición, que tome con valor y con más energía Alemán, de decir: "miren yo, voy con el Frente, y vamos a negociar los cargos nosotros, y somos nosotros y el Frente los que vamos a decir quiénes se van, quiénes se quedan, quiénes llegan y quiénes no llegan", y esa oposición ruidosa se queda fuera otra vez, que es lo que yo creo que va a ocurrir, o no veo a Arnoldo regalando lo único que le queda ya, que es mucho lo que tiene, es decir, tiene la mitad de los poderes del Estado, no creo que sea bruto de venir ahora a decirle a Eduardo: "tomá vos ahora la mitad de mi mitad", porque, entonces, esa mitad se la quita el Frente, y bien quitada, por tonto, y eso no creo que sea Alemán un tonto, el Frente, bueno, es un problema, cuando eran gobierno tenían ese $50 \%$, verdad, $60 \%$, ahora el gobierno soy yo, ahora yo tengo el $60 \%$, así es que tus veinte tuyos, que tuviste, vas a tener sólo doce, y los ocho me los quedo yo, ese es el juego de verdad en estos momentos, "mirá Alemán, apuráte, negociemos, si tenías cuatro, aquí vas a tener dos, y si te tardás le doy dos al otro, y me quedo con los otros dos yo", y eso es lo que está haciendo el Frente, o negociamos los cuatro tuyos entre nosotros dos, o negocio con tu adversario externo, que me dé los votos para completar de alguna manera, verdad, y se los doy una parte a él y la otra me quedo yo, y, entonces, de 50/50, nos vamos a 70/30, verdad, 70/30, 80/20,60/40, ese es el juego real de lo que está ocurriendo a esta hora, ahorita, a las $10.00 \mathrm{~h}$. de la mañana, las $9.00 \mathrm{~h}$. de la mañana, lo que era una reforma constitucional que nos iba a permitir hacer la selección de una manera más ordenada, se convirtió en una puja de poder callejera en donde el que tiene la ventaja es el gobierno, el gobierno tiene los recursos, tiene el presupuesto general de la república, en países muy pequeños tradicionales como este el presupuesto es un libro grandotote, verdad, en donde yo puedo, Poder Ejecutivo, nombrar a quien yo quiera, es decir, yo puedo nombrar a todos los liberales, o puedo nombrar a todos los 
sandinistas que yo quiera, si no hay acuerdo compacto el Estado, quito la parte de mis opositores, y consolido la parte mía, eso es, y cuando tú quieras algo, ya no vas a poder, así es que o negocias ahora, o negociamos ya, como lo hemos hecho en el pasado, o te olvidas, porque aunque yo no tenga tampoco los números, dice el Frente, tengo la capacidad de manipular bien los números que tengo en contra de ustedes, y ese juego, que es un juego perverso, es el que al final, verdad, pudiera imponerse si no hay la negociación, es mentira que ganaría esa oposición ruidosa, creo que volvería a perder, verdad, y el Frente consolidaría su poder, verdad, ahí está la puerta abierta, creo que deberían de hacerlo en diciembre, esa negociación, por la vía de los hechos, verdad, de una vez, hacerlo o quedarse en la otra manera, por esta vez y para evitar más desgastes, queda todo como está hasta las elecciones generales del 2011, no se mueve nada hasta que la población decida en las elecciones del 2011 qué va a pasar con los cuerpos del Estado, por lo pronto, permanece todo como está hasta esa fecha, que es lo que ya hizo el Frente en el gobierno de Doña Violeta como acuerdo marco, que era una mayoría simple, que decidió evadir la reforma constitucional, verdad, por la vía de un acuerdo, por esta vez, la doctora, su tesis, va de esta manera, verdad, ya esperaremos al futuro para que se haga de otro modo, lo mismo pueden hacer ahora, tienen 38 con 9 votos que le puede prestar el mismo Alemán, verdad, y con 47 votos de una ley ordinaria decir: "con tal de que no se puede lograr consenso para los nombramientos, y que el Estado no puede quedar sin funcionamiento, todo queda como está hasta que se logre después de las elecciones generales del 2011 una reforma a la Constitución" entonces, queda esto otra vez en el limbo, todo el mundo sigue ahí, ese fue su poder, o sea, que la discusión que debería de ser para usted, una discusión sobre reformas constitucionales, una cuestión más teórica, más técnica, más de calidad de las capacidades de estos países, se vuelve una cuestión de negociaciones políticas pequeñas, como se hacen las cosas en la política, verdad, hay países serios que se la agarran a golpes en el Congreso, aquí se la están agarrando en las calles, es una lucha cuerpo a cuerpo, creo que como ha sucedido en el pasado ya después de la tormenta vuelve la calma, después de esta medición de fuerzas que la oposición pidió, creo que era un error medirse fuerzas cuando uno sabe que no es mayoría, era tonto, pero ya se dio, ya la oposición está feliz porque dice que ganó, y que puso 10.000, 20.000, 30.000 y que le dijeron: "no a la dictadura", OK, sí, ya, el otro dejó que se lo dijeran y les puso 250.000, 300.000 gentes, puso el tapón a la botella, y le dijo: "bueno, aquí están, ya ustedes enseñaron lo que pueden ser, yo ya les enseñé lo que puedo hacer, ¿y ahora qué?, o nos sentamos, o esto se va, vuelven a hacer otra marcha ustedes, entonces, vuelvo a hacer otra más grande", entonces, para mí que esta definición del sábado le va a permitir a quien mejor jugó la carta de la marcha de la oposición, que es Alemán, se siente, y digan: "vámonos, hablemos, ya me siento más tranquilo, ya la gente vio que yo fui a oponerme a Ortega, aunque sea de mentirita, verdad, pero yo ya estoy de líder otra vez, el único líder que hubo, entonces, ahora voy a liderar el proceso, llamo a un diálogo y me siento con Daniel, y le digo, invitemos a los demás, pero ya somos los dueños de la casa, los que le vamos a decir, mirá, Eduardo, mirá vos, mirá, venga, no, hombre, siéntate, toma un cafecito, hombre, olvidáte de eso y sentémonos a ver lo de las reformas, y hagámoslo de una vez para que no nos alcance el tiempo, si llegamos divididos al 2011 estos señores nos vuelven a ganar", esa es la lógica de cómo yo veo el proceso político, ahí está ahora, verdad, que todo el mundo está haciendo la evaluación, entonces, la pregunta suya, bueno, ¿pero van a haber o no van a haber?, bueno, estas cosas, yo le digo, yo creo que van a haber, pero al final de cuentas tiene que haber, es decir, si el circo ahí está, los animales siguen comiendo, los payasos siguen trabajando, tiene que seguir, hay que buscarle, ya el ruido, ya decían que se incendiaba la casa, ya pasó, ya todo el mundo salió contento, fueron a manifestarse, 
ahora viene otra vez la lógica racional de la lucha de poder, sentémonos, veámonos qué sí, veámonos qué no, y pongámonos de acuerdo para que podamos ver, así es como yo lo veo, no sé si es muy útil para ti, pero así es.

R: Hay algunos aspectos interesantes, que ha mencionado a lo largo de su discurso, además le agradezco mucho la franqueza con la que ve el juego político duro, que existe en Nicaragua, por esa tentación a veces extra-institucional tan fuerte, que tienen los actores políticos, ¿no?, que fragilizan, normalmente, las instituciones, y que hace que este mundo hobbesiano sea tan tremendo para cualquier analista que venga de fuera, no porque la política sea distinta en cualquier otro lugar del mundo, o al menos el concepto que yo tengo del poder, sino porque el marco jurídico sí restringe, normalmente, lo que se puede y lo que no se puede hacer, y no cambiar, constantemente, las reglas de juego, que, en el caso de la reforma a la Constitución ha modificado, continuamente, las expectativas para las cuales los propios actores negocian, ¿no?, que es un componente fundamental de la democracia, pero sí negociar en el marco de unas reglas claras, y que no supongan tampoco un atentado contra el Estado de Derecho, y yo siento que en el caso de la última sentencia ha sido claro, en el sentido de la pérdida de la seguridad jurídica, ¿no?, y de la supremacía de la norma constitucional, como Ley Fundamental del Estado, ¿no?, en el caso de la reforma constitucional, siempre se produce un conflicto entre el Ejecutivo presidencial y la Asamblea, que lideró en el 95 la gran reforma, que, prácticamente, bueno, recorre una amplia totalidad de los artículos, hay un consenso, o al menos eso registra la mayor parte de mis entrevistados, porque el arco parlamentario de representación política es mucho mayor, y como que goza de una legitimidad en el sentido en que era, jurídicamente, necesaria, porque el momento político así lo exigía, la transición democrática, el dar cabida a todos los liberales que fueron excluidos del proyecto revolucionario, ¿no?, porque es cierto, usted menciona a las dos Nicaraguas, y yo vengo de un país que también fue dos, y que también se enfrentó, yo soy de la generación de los 70, no conocí a Franco, fui una niña de la transición democrática, pero si hubo que conciliar un país, porque era un país dividido, en este caso, una guerra hace mucho daño, muchísimo daño, y cerrar las heridas cuesta, obviamente, y aqui la tendencia a la polarización se ha mantenido, ¿cuál es su visión, entonces, sobre un posible pacto constitucional, que no da la medida, digamos, no da la talla de unos actores políticos que están siempre por encima del Derecho?

R.H.: Y está por encima de todo, aquí hay efectos perversos de la apertura democrática, como la preponderancia de los medios sobre el quehacer de los actores políticos, los medios de comunicación han hecho el papel de partidos, como la Iglesia después de los 90 hizo el papel de partido, ¿no?, eso tiene mucho que ver con la forma en las que se ven las instituciones, yo recuerdo amigos de Europa, de Estados Unidos, que, recién llegaban aquí, tocaban el tema para la transición que debía hacer de la institucionalización, de las distintas maneras serias de hacer las cosas, y yo les decía que esto no iba a pegar como a lo mejor sería saludable, porque este todavía era un país muy poco propicio para las instituciones, que se insistía mucho en eso, como condición para dar la ayuda económica, para la firma de convenios de cooperación, verdad, iba a ser sólo bonito, pero no muy útil, y me decían: "pero, hombre, René, cómo una persona seria puede creer que la campaña por las instituciones sea", no, no es eso, es que no es una cuestión teórica, es una cuestión de la realidad, este es un país que no se maneja por ahí, y que hay que ayudarle a que aprenda a manejarse por ahí, pero no como el mismo error de los revolucionarios, de querer la revolución hoy, ahora, aquí y ya, las 
instituciones hoy, ahora, aquí y ya, no es tan sencillo, hubo guerra, hay polarización, el sandinismo amarró con unos enclaves, que le impiden la institucionalización de un montón de cosas, y la prueba, le digo, es que ustedes van a terminar diciendo que el éxito de esa campaña de institucionalización es, precisamente, un Ejército más institucional, una Policía más institucional, un respeto a la propiedad más institucional, ¡qué curioso!, es decir, la institucionalización a quien beneficia es, exclusivamente, en este caso, al Frente Sandinista, porque el Ejército, ahí está el titular, yo me debo al país, dice, soy un soldado del país, dice el chele Avilés, y el chele Avilés es el Jefe de Estado Mayor de una revolución, es decir, ya se institucionalizó el Ejército, sí, sí, ajá, y cuando a la Corte se elige a los jueces como se eligen, ¿ya se institucionalizó la Corte?, y, entonces, ¿de qué están hablando Montealegre y su gente que dicen que no hay que repartir cargos?, cómo si la institucionalización es el proceso ordenado para que la ciudadanía tenga acceso al poder y lo conserva de manera estable, entonces, ¿por qué se critica que los sandinistas tengan el control del Ejército, el de la Policía, que tengan el control del Poder Judicial?, entonces, si esa es la visión institucional, aquí lo único que se ha hecho es consolidar el poder del Frente, no es, realmente, lo que habíamos hablado, cuando se decía de la institucionalización democrática, un montón de cosas, eso es otra cosa, eso es otra cosa, cambiar las reglas del juego para que ahora, para que sea jefe del Ejército, pueda no ser un sandinista, pueda ser cualquier otro, es verdad, a ver si se puede o no se puede, entonces, eso de las instituciones y del respeto, yo quisiera que el país fuera así de la noche a la mañana, hoy, ahora, aquí, y ya, no lo veo, a menos que derroquen al sandinismo, y vuelvan a empezar y pongan leyes de otra manera, y eso yo lo veo estúpido, que la única forma de institucionalizar un país es ponerse de acuerdo, buscar el consenso, y si cada vez que logras el consenso te atacan, porque dicen que eso es pacto, entonces, ya alguien está metiéndole ruido a la fiesta, porque el pacto es la única manera civilizada de poder llevar a un país a las instituciones, ¿por qué?, porque las reglas en el pacto están consensuadas entre las reglas políticas, pero viene un sector importante y te dice: "no", pacto no, y, entonces, ¿cómo?, ¿cómo?, si yo un partido político, tengo el $80 \%$, el $70 \%$ o el $60 \%$ y el otro el $40 \%$ y ambos ponemos a las personas en el poder, pues, eso es lo normal, ahora, que es que esas personas no deberían ser esas, deberíamos ser nosotros, que no estamos en los partidos, la política, porque los partidos van a poner a alguien fuera del partido, yo no he visto que se elija en los países europeos ministros, o a alguien que no es parlamentario, es decir, y los que están en el parlamento son producto de los partidos, si tu partido gana un porcentaje en las elecciones y hace alianza para que le formen gobierno, lo normal es que ese va a ser el ministro, no va a ser un Perico de los Palotes de la esquina, podrán invitar técnicos o podrán invitar científicos, gente que no tiene que ver con los partidos para labores no políticas, pero la política la hacemos los políticos, no tienen por qué hacerla otros, ¿por qué yo voy a ir a recoger a la Fulana o al Fulano de las organizaciones esas para que sea miembro de los poderes del Estado?, ¿cómo nombran ustedes en Europa a los ministros?

R: Bueno, sí puede haber independientes también, candidatos independientes, me refiero, por ejemplo, a un rector de Universidad, hay unas reglas en la elección de los altos funcionarios que regula la carrera administrativa.

R.H.: Sí, pero estás refiriéndote a una serie de sectores que no son los propiamente políticos, Bush nombra al miembro de la Corte Suprema promovido desde su partido, no nombra a un demócrata, y este señor que está ahora, Obama, nombra a un demócrata, que se trate de que sean personas honorables, y que sean personas decentes, yo creo que 
sí, es un reclamo normal que se debe de hacer, pero de que sean políticos, ¿ no?, ¿quién me va a venir a sustituir a mí en el Consejo Supremo Electoral?, a ver, ¿quién?, ¿quién que pueda decir que no es político, que es honrado?, va a ser otro político, y lo va a poner, si el reparto fuera con Montealegre, Montealegre va a ir a poner de nuevo al Consejo a alguno de sus asesores que son políticos, yo sustituí a Montealegre en el Consejo, Mauricio es el encargado de los asuntos electorales de Eduardo, ¿a quién va a poner Eduardo?, a Mauricio, y ¿en qué cambio el juego?, es decir, la idea de las instituciones, como una forma bonita de decirlo es que el Estado tenga, no sé, comportamientos más transparentes, que la rendición de cuentas sea más eficaz, en términos de, pero cuando la rendición de cuentas es una cuestión de venganza de alguien que está en la oposición exigiendo: "que ese Fulano le deroguen, entregue la cuenta", eso no es lo que cuando uno habla de instituciones está pensando, porque, entonces, eso ya es una "vendetta" trasladada a las instituciones, eso no son instituciones, cuando uno habla de la transparencia, de la rendición de cuentas, de la participación, está bonito, pero, en la realidad de los hechos, aquí, no es ese el tema, y meterlo a fuerza lo único que produce es darle más armas a los ruidosos, a los alborotadores, a los que ven la cuestión de la política como una lucha cuerpo a cuerpo, ese es el punto de que yo te digo no es esa la tarea, yo creo que la tarea principal aquí es educar a la formación de partidos políticos fuertes, que sepan negociar, y que traduzcan las negociaciones en instituciones más estables, de que eso no sea, que eso no sea de otra manera, para mí las instituciones es otra cosa de lo que, teóricamente, como sabemos, académicamente, de qué son las instituciones, no son las que nosotros aquí me parece que debamos incentivar, creo que hay que volver un poco a valores básicos de la manera de hacer política, fortalecimiento, capacitación, formación de gentes en la política, educar a los muchachos en leer, en escribir sobre política, aquí si tú tomas el período, y ves quiénes son los que opinan, ninguno de ellos, o sea, aquí no conozco un político que haya escrito la mitad de una página, que no sea una cuestión puramente personal, vengativa, orientada a cosas de otra manera, verdad, hay que enseñarles a leer, hay que enseñarles a escribir, hay que enseñarles a la formación de cuadros de partido, para que tenga sentido su presencia y su discusión, ¿a mí de qué me sirve?, yo estuve cuando era Ministro de Gobernación de Secretario General llega un señor que era para mí un delincuente, que yo le decía al presidente, oiga, ¿y cómo pone a una de estas personas allá?, éste en la esquina lo va a esperar un día y le va a pegar una puñalada a usted, hoy es uno de los que anda comprando ruido también, un señor que no tiene una militancia educada en el poder, y yo insisto en que sí debe de fortalecerse las instituciones partidarias antes de hablar de las otras instituciones, verdad, aquí el reparto de: "que no, que no, yo quiero ir, yo quiero ir, y quiero ir porque ese es malo y yo soy bueno, ese es ladrón y yo soy honrado", es decir, no es una discusión sobre, realmente, la representación que debe de tener un cuerpo de Estado frente a la ciudadanía, y para que eso ocurra de una manera distinta, hay que fortalecer a las instituciones partidarias, fortalecer a las instituciones, que ya tienen un tránsito, a mí no me molesta que el Ejército lo esté haciendo como lo esté haciendo, es decir, es una modalidad institucional, bueno, está bien, está bien, que nadie llegue a tocarle la puerta a los cuarteles, como en Honduras, verdad, es una gran ventaja, porque es cierto, es decir, el Ejército no se va a prestar a la tocadera de puertas ni de Montealegre ni de nadie, y, en ese sentido, es una institucionalización favorable a la transición democrática, que la Policía tenga que estar en ese vaivén, hoy día te protejo, y salió la Aminta ganando en todo este asunto, verdad, y eso no le quita que sea la institución de control ciudadano sandinista, entonces, si esas son las institucionalizaciones útiles a la transición, está bien, ahí están esas, pero la otra, la otra que hay que fortalecer y que se debilitó en los 
últimos años es la de los partidos políticos, se le dio excesiva presencia a los medios de comunicación, como gestores de la política, se le dio a las organizaciones no gubernamentales una importancia excesiva como gestores de una campaña anti-partidos, yo creo que hay que volver, hay que recomponer, se logró una recomposición de las fuerzas políticas de los primeros 90, hay que volver a esa recomposición, hay que incorporar la incidencia, de alguna manera, en forma de partidos, me va a decir, sí, pero el Consejo Supremo no los dejan, no es cierto, no es que no los deje, es que nadie se organiza para fortalecerse a sí mismo, se organiza para debilitar al otro, entonces, en esos juegos, las instituciones que existen se atrincheran, y se prestan a ese juego vulgar, a quitar personerías porque son personerías inexistentes, hay que ponerle a las cosas en su lugar y una forma de hacerlo para mí es fortalecerlas, fortalecerlas, mucho de la cooperación, y lo hemos hecho, Gabriela trabajó los cursos para el PLC, andar de pueblo en pueblo, que las bases de los partidos lean, se interesen en la política, que sientan que no sólo vale la pena para hacer el grito, sino el conocimiento de lo que significa el poder, las instituciones, la militancia, la lealtad, ese es un trabajo que se empezó y se abandonó, ¿por qué?, porque así son, el Frente abandonó sus escuelas de cuadros, el PLC no las fortaleció, no supieron manejar sus disidencias con criterio más bien sólidos de partido, y ahora viven, Alemán el drama con Eduardo Montealegre y el Frente con el MRS, o sea, hay que fortalecer ya de una vez que esos si son disidencias, de una vez se consoliden como instituciones partidarias, ¿no?, y que juguemos todos a la democracia de una manera ahí sí más abierta, ese es un trabajo para mí más importante que la simple idea de la transparencia en el manejo de los recursos, la rendición de cuentas, y eso, que es importantísimo, pero que hay tareas que no se han hecho, verdad.

R: Ha dicho alguna cuestión muy interesante, como el tema de la institucionalización y qué tipo de instituciones se están consolidando, el Frente, yo creo que uno de los grandes aprendizajes históricos del régimen revolucionario, un régimen de partidoEstado, era la necesidad de gobernar desde las instituciones, ¿no?, y al principio, además, lo refería cuando hablaba de gobernar desde abajo, cuando hacía referencia al Poder Judicial, que es casi otra tesis doctoral, o sea, como ha ido encajando a través de la formación de abogados y de jueces en toda la estructura jerárquica del Poder Judicial, desde los juzgados de distrito hasta la Corte Suprema, pasando por los tribunales de apelación, y consolidar, además, lo que, peligrosamente, a través de la sentencia, se ha transformado en lo que algún entrevistado llamaba "el gobierno de los jueces”, ¿no?, por atribuirse facultades, como el tema de la interpretación de la norma constitucional y de la reforma de hecho de un artículo, que es el 147 sobre la reelección presidencial, ¿no?, por un poder que no tiene esa facultad, es la Asamblea Legislativa, quien tiene el poder de reformar la Constitución.

R.H.: Es discutible eso, pero lo otro sí es cierto, en una sesión del partido, como todavía tenía una militancia más fuerte, me acuerdo que estaba toda la gran élite partidaria, me cuestionan que por qué como negociador no logro que los tribunales de apelaciones tenga más liberales, tengan menos liberales, que los jueces en ese tema, yo les contesté una cosa, mira, les voy a decir algo que les va a molestar, el Frente Sandinista en los años finales de los 80 , cuando venían venir una situación complicada, porque ya casi era inevitable tener que negociar el poder, agarró a sus fuerzas más duras, y las metió a estudiar Derecho, y fabricó cientos de cientos de abogados para jueces locales, y hoy miren esto, porque les traía, en ese momento, la convocatoria para elección de juez segundo de distrito, me parece, miren aquí hay 30 solicitudes, 28 son sandinistas, 
verdad, 2 son liberales, pero, de este lado, hay otras 30 liberales, mire vamos a ponerlas aquí en la mesa, aquí están estas 28 sandinistas y estas 28 liberales, las 28 sandinistas, cada uno de estos señores, que está propuesto ahí, tiene al menos 5 cursos cada uno, de cualquier tipo, de computación, de lectura rápida, de cuantos cursos aparecen, cursos a los que asisten, miren estos 28 liberales, traen una carta mía, otra una carta de Arnoldo, otra una carta de un líder del partido, y no han hecho un pinche curso, ¿cómo pueden competir?, si suponemos que institucionalizamos el poder, y decimos que van los que están mejor capacitados, ¿a quién elige usted?, ¿por qué no van a estudiar los liberales?, ¿por qué ninguno tiene una Maestría?, ah, es que los sandinistas tienen una Maestría que no sirve, señor, señor, no importa, se fueron a fregar, que es una Universidad de quinta, sí, pero hizo su Maestría, y hubo tres seminarios sobre el artículo 17 del Código Penal nuevo, ahí están los señores estos, porque los nuestros no, porque hay una voluntad de poder, y ese es un problema a la hora de querer institucionalizar, porque dicen que los nombramientos sean electos, que se hagan por vía de concurso, y el concurso lo ganan ellos, ¿qué hacemos?, entonces, usted dice, muy bien, ellos han aprovechado los sistemas de la institucionalización, verdad, a su favor, que lo hagan, que lo hagan, es decir, a la hora de la hora, la negociación política termina de otra manera, pero nosotros no invocamos el principio del mejoramiento de nuestras capacidades intelectuales, profesionales, no lo hacemos, es la verdad, hay un desprecio hacia lo intelectual impresionante en este país, sea de liberales o sea de sandinistas.

R: Bueno, el peligroso efecto de este asunto es esa politización de la justicia, que da lugar, digamos, a un acoplamiento de las decisiones de la Corte Suprema a las posiciones ventajosas del Ejecutivo presidencial, viendo también en la transformación, que hablaba de la parlamentarización del régimen político, que ha sido todo un debate que generó el Frente Sandinista también, y daba la impresión de que reducir las facultades del Ejecutivo presidencial fuerte del 87, a favor de las facultades de una Asamblea Legislativa, que, en un contexto democrático, necesitaba gobernar, pues, en temas fiscales o en temas, fundamentalmente, de elección de cargos públicos, y de legislar, de elaborar, realmente, la legislación, las leyes que gobiernan el país, como en cualquier democracia representativa, ¿no?, y, sin embargo, hay una crítica fuerte hacia las reformas del 2000, que algunos, incluso, califican de contrarreforma, cuando se pasa de un gobierno de las cúpulas partidarias o de cooptar, digamos, la Asamblea por las cúpulas de los partidos que son los líderes, quienes, realmente, eligen y deciden, apoyándose también en una cultura política, usted mencionaba antes la cuestión del “cañoneo", digamos, de apoyar a los diputados que son egoístas a la hora de votar, o sea, que, individualmente, no tienen esa disciplina de partido, no están socializados en esa cultura de la cooperación a la hora de votar leyes que favorezcan el interés nacional y todo esto, ¿no?, o sea, que los lideres siguen siendo, es muy interesante, porque a veces oigo demasiadas veces la palabra "caudillo", que es algo que hay que discutir, usted que es académico, conceptualmente, es algo que debe aplicarse, pero bien en su contexto político, ¿no?, y yo creo que es una palabra muy fuerte, pero ha aparecido mucho en las entrevistas.

R.H.: Para justificar la campaña en contra de los liderazgos fuertes, pues, son liderazgos fuertes, no son caudillos.

R: Pero sí a la hora de hacer los manejos con sus, digamos, sus seguidores, ¿no?, tanto en la Asamblea como en los poderes del Estado. 
R.H.: Tienen rasgos caudillescos, pero no es la figura típica del caudillo, eso creo que pasó ya, lo fue el viejo Somoza, lo fue el viejo Emiliano Chamorro, estos son bastante más modernos, el manejo de las lealtades se hace un poquito más sofisticado que la del caudillaje más simple o tradicional, ¿no?, hay elementos, no son caudillos en el sentido que nosotros manejamos, son líderes fuertes, son hombres fuertes, tienen un poco más ya más elementos modernos, son otra, yo creo que eso del caudillismo aquí, aquí hay un problema de resentimiento muy fuerte entre la clase política, creo que todo ha ocurrido en un período muy corto, muy apretado, es decir, la revolución fue muy fuerte en un tiempo muy corto, el tamaño, llamémoslo vulgarmente, del pastel del poder, es un pastel demasiado pequeño para demasiados héroes, para demasiados triunfadores, y la masa de aspirantes es demasiado grande para la capacidad de absorción que tiene el sistema, entonces, lo que tenemos es un lago grandotote de resentidos, de los que no se quedaron, de los que no llegaron, y que ha sido el caldo de cultivo para un campaña en contra de los liderazgos, verdad, quienes eso el papel negativo más fuerte lo han tenido son los medios de comunicación, y algunos líderes del resentimiento, yo en mi partido conozco gente que nos comería vivos por decirle algunas cosas, pero que tienen éxito, verdad, entonces, es un país que ha vivido demasiado, si tú te fijas, haciendo una evaluación de fondo, de lo que le pasa a este país, es que ha sido muy corto el tiempo, muy grande el número de líderes, verdad, muchos generales, y no de dedazos, generales de verdad, que han combatido políticamente, generales políticos y políticos generales, de hecho, generales militares, y el espacio es muy corto para ellos, y eso te hace que sea una olla de ebullición, y eso hay que tenerle, yo le he dicho a varios de mis estudiantes, hay que esperar, Daniel Ortega, Arnoldo Alemán, están en una edad en la que están enteros, y que son hombres que han acumulado una fuerza que, difícilmente, van a renunciar a ella, por razones culturales, no quieren una reproducción de otro modo, $y$, entonces, van a estar ahí, y hay que tenerles paciencia, esperar que se agoten sus tiempos, es duro decirlo, pero están demasiado jóvenes, si usted ve a Daniel y ve a Alemán, y, al mismo tiempo, a los hombres de Daniel y a los hombres de Alemán están enteros, y la reproducción no es una reproducción todavía muy institucional, muy difícil, entonces, los delfines están a la mano del líder, no están a la mano de la población, están a la mano del líder, ¿quién es el hombre que me va a acompañar en esto?, es este, no tiene que ir a ver allá, o sea, hay demasiada gente con méritos de poder, que imposibilita, primero, un recambio rápido, es decir, yo no me imagino a Ortega sentado manejando, no sé, una escuela, una finca, a estas alturas de la vida, verdad, ni a Alemán, es la política, ahora, ¿cómo se quedan de líderes de la política?, y los van a acusar de que siguen mandando, Alemán ha estado preso durante todo este tiempo y sigue gobernando su partido, es decir, Ortega no ganó la presidencia durante dos períodos, y siguió siendo líder, es muy difícil pedirles, muy difícil, "váyase", yo estuve en la famosa reunión del embajador y el sub-secretario de Estados Unidos el día de la toma de posesión de Don Enrique Bolaños me piden una reunión con Arnoldo, y los llevo, pues, cuando funcionarios norteamericanos y Arnoldo allá a las oficinas mías en el partido, y le dicen que se aparte, y Alemán le dice que no, que él está como al mediodía, adonde no hay sombras, entonces, que un buen político se mantiene siempre al mediodía para no tener sombra, es muy difícil pedirle a alguien, ese es el odio que tienen ellos con él, que les dice: "no, yo no me voy", es decir, lo mismo pasa con Ortega, llega el embajador americano y se lo dice, y él dice: "vamos a ver qué dice la gente”, es decir, es un contrasentido, si usted dice: “¿y si la gente dice que me quede?”, y ahí, ahí no le puso 350.000, 400.000, o 300.000 gentes el sábado, no puede ser todo el sector público, es decir, ¿qué le va a decir un opositor a Daniel dentro de su partido? 
R.: No, está claro que la renovación generacional del liderazgo de los 80, además, o sea, que es un liderazgo que está anclado en el proceso revolucionario y en el momento democrático reciente es difícil, pero también, la única, digamos, son dos caras de una misma moneda Arnoldo Alemán y Daniel Ortega, en cuanto a perfil de liderazgo, bases sociológicas que le apoyan, una clase media...

R.H.: Son hombres fuertes, no son líderes, en el sentido moderno, de si usted quiere tienen mucho de tradicionales, pero son los líderes, y la gente va con ellos y viene con ellos, yo recuerdo en los años que nosotros éramos gobierno, que a mí reportaba Daniel tres veces a la semana en su "jeepito" iba a las comunidades, no había semana que él no anduviera visitando su gente, y si llegaba a la casa del partido y de ahí se reunían de aquí, hablaba de la necesidad de fortalecer al partido, a ver, eso es ser líder, Arnoldo, le he manejado la agenda, nosotros llegábamos tres veces a la semana a los pueblos, entonces, no son caudillos de hacienda, tienen también, y estimulan, premian, y, ahora, que yo quisiera ser presidente de la República no le gano, entonces, no lo hago, pero hay quiénes sí, José Antonio sí, Rizo sí, el otro sí, no, es que hay que quitar a Arnoldo, que hay que dejar paso al relevo, te van a joder, porque no tenés fuerza para quitársela, entonces, depende del carácter de cada quien, a Daniel le pasó, yo le he preguntado a él: “oye, y ¿por qué te peleaste con fulano?”, y se pone a reír, verdad, los regímenes de poder, ¿por qué no regresan?, ¿por qué van a querer ellos hacer el gobierno?, y sí, si usted dice, ah, uno de estos que ya se fueron, o a cualquier de ellos, son extraordinarios revolucionarios en su momento, van a llegar allí y van a decir, "¿sabes qué?, vamos a hacer las cosas de esta manera", y van a querer imponerle a Daniel la manera de hacer las cosas, es decir, vendí otro juego político, entonces, el otro se dice, "no, ahora los aguanto, como opositores, pero no para que se vengan a tomar el poder y me vengan a decir cómo son las cosas", eran demasiado iguales todos, tu ves una camada como de 20 líderes revolucionarios, que tenían, bueno, lo mismo pasó en la revolución rusa, lo mismo en la mexicana, lo mismo en todas, verdad, alguien tiene que ganarle a alguien para poder establecer como hacer el gobierno, si no, es un pleito de perro, Daniel se la ganó a Alemán, se la ganó, que Alemán se fue por el dinero, y llegó, y se dio el lujo de opinar, pues, sí, pero se salió, es decir, en el lado de Alemán es lo mismo, fíjate quiénes son los que aspiraron antes de tiempo, se fueron todos.

$R$ : ¿Y cómo ve usted el futuro de su país?, porque sí es cierto que si no se une el liberalismo, y Arnoldo Alemán es, digamos, un gran obstáculo para que el liberalismo vuelva a presentar una candidatura presidencial única, que consiga ganarle a Daniel en las próximas elecciones de 2011.

R.H.: Vuelve a ganar Daniel.

$R: Y$ cinco años más de sandinismo con esta concentración de poder que se ha experimentado...

R.H.: Más posibilidad de que vuelvan a ganar las siguientes, aquí lo que hay que dejar es que si el liderazgo mayor es el de Arnoldo, que lo dejen, ya probaron a Montealegre, dos períodos, no pudo, y no veo ninguno de ellos que pueda.

R: ¿Ganarle a Daniel?, ¿y Alemán sí? 
R.H.: Alemán no, ninguno de ellos, Eduardo no le ha ganado, entonces, dejen que vaya Alemán, o dejen que el Frente siga ganando, pues, porque yo no veo a Eduardo ganando, ni que le vuelvan a meter 30 o 40 millones de dólares, no va a ganar, no va a ganar, el dominio de la plaza liberal la sigue teniendo Arnoldo, que les caiga mal y que no les guste a los americanos, ese es otro pleito, pero él es el líder de esa, ahora, no quieres eso, bueno, pues, no se pueden fabricar líderes, por lo mismo, de que pudo cubrir en un tiempo tan corto todo el mundo se conoce a todo el mundo, y saben en cuanto aparece uno, ¡ah!, no hay, no hay, dame uno, ahí está Jarquín, Mundo Jarquín, ¡ah!, ese hombre no gana, pero ni en su casa, es decir, cómo le hacen para decir los líderes políticos no se fabrican así, los medios fabricaron a Eduardo y no funcionó, y es un buen hombre, un excelente Ministro de Hacienda, podría estar en la Comunidad Europea trabajando, pero, políticamente, en este país, no es, no es candidato.

$R$ : Y cinco años más de sandinismo, ¿cree usted que a nivel económico le haría mucho daño al país?, habría tentación de cambiar, de tratar de injertar este concepto tan poco, digamos, la democracia liberal es ajena a la tradición política del sandinismo, ¿no?, y, de hecho, todo este tema del "Pueblo-Presidente”, esa insistencia en la democracia participativa, de la democracia directa, que ya estaba en el proyecto de la revolución.

R.H.: Mira, eso en El Salvador sería un atentado, porque hay una clase política empresarial fuerte, y en Nicaragua la economía es tan rudimentaria, aquí no tienes un cuerpo empresarial, no tienes, ni siquiera 10 fábricas no hay en el país, como para decir que hay 10 industriales, no hay 2, no hay, consecuencia, es una economía de arroz y frijoles, es una economía estacional, es una economía de pocas exigencias tecnológicas, es una economía de sobrevivencia en las zonas rurales, yo siempre he creído que el principal enemigo del sandinismo habría sido crear una economía moderna, porque, entonces, sí tendrías una organización social alternativa a la de la pobreza, a la del "pueblo-Presidente", eso no existe aquí, no hay, tú no puedes concebir un país que el Consejo Superior de la Empresa Privada sea un médico de medio pelo, verdad, un médico pediatra, por ahí, empresario, no tiene ni siquiera una porquería de negocios, ese es su consultorio, ¿qué empresariado es ese?, y luego viene el otro, que tampoco, en El Salvador, o en México, o en Guatemala, o en el mismo Costa Rica, el Consejo de la Empresa Privada es un Consejo de señores que tienen intereses privados, negocios, industrias, comercios, o sea, aquí no hay esa base industrial, o esa base empresarial, es muy de economía chiquita, y el que produce casi no se quiere meter, entonces, pequeños no le entra, por ahí el Frente Sandinista no está amenazado hacia el futuro, está consolidándose sectores de él en negocios, AGRICORT, ¿qué es?, en cuestiones de arroz y de frijoles, negocios, pues, pero aquí no hay, bueno, ni una fábrica de lápices, pues, verdad.

\section{R: Y el factor Chávez, hay un componente externo también.}

R.H.: Pero ese se acaba, ese no es, es decir, yo creo que lo que hace Ortega es lo que debería de hacer, es aprovechar esa relación, verdad, y obtener lo más que pueda, en beneficio de esa relación, mientras le dura, ya no hay Unión Soviética, ya no hay la China Popular, ¿quién le va a ayudar a un régimen de estos que están en condiciones que es fácil apretarles la tuerca?, pues, si está Chávez, que suelte, y si mañana se va Chávez, pues, queda el arroz y los frijoles, no hay una economía desarrollada, que atente contra este tipo de regímenes históricos, es decir, por ahí no viene la amenaza, 
aquí hubiese sido interesante de que en vez de estar metiéndole dinero a los medios de comunicación para apoyar a Montealegre hubiesen creado 20 o 30 empresas traer aquí empresas, invertir en vez de 30 millones de dólares en Montealegre haber invertido 5 o 6 millones de dólares en traer, no sé, fábricas de puertas o de ventanas o de teléfonos plásticos o de cualquier cosa y tener una base industrial, no hay, no hay ni una, lo que hay son las zonas francas, es la zona franca, todos sabemos que el chinito de Taiwán o de Corea viene, verdad, trae la tela ya de allá, en la mañana, la pone a coser en la tarde y en la mañana va el avión, las máquinas de coser son alquiladas a una empresa, que no es de ellos, el local es una casa alquilada, ese señor entró con una maleta y se fue con una maleta, y los trabajadores se van a su casa, y ya está, aquí no hay una industria, ¿qué sindicato fuerte vas a tener si eso no, eso no, qué sindicatos hay ahí?, es decir, cuando uno dice el sandinismo va a destruir la economía nacional, ¿cuál economía?, ¿cuál, la de los trabajadores, esa que está ahí?, pues, esa va a seguir ahí, sea Alemán, sea Ortega, sea Montealegre, sea Edmundo Jarquín, quien esté, ese siembra arroz, o siembra maíz, o siembra el frijol, ningún proyecto de país hay en eso, ninguno.

\section{$R$ : Y, sin embargo, sí había una modernización económica en tiempos de Somoza.}

R.H.: De Somoza, sí, y la desbarataron, y la desbarataron, la desbarataron, te vas hoy a León y están todos los campos pelones, sin producir nada, y en esa época éramos los mejores productores de algodón en el mundo, sólo los israelitas nos ganaban, y en leche, y en ganado, y en una agricultura moderna, aquí lo había, sí lo había, ahora, se quedaron esos empresarios a producir, como se quedaron los salvadoreños durante la guerra civil, no, todos se fueron a Miami, y nadie quiere invertir, tienen su dinero allá y lo traen mensual para vivir bien aquí, pero, en cualquier momento, son como zona franca, se van, no tienes un empresariado que tenga la disposición de decir voy a construir un país, independientemente, que sean los comunistas, los que gobiernen, no hay chinos aquí, el partido comunista chino es más duro que el de Fidel, verdad, y tienen una economía moderna, o sea, que no es cierto que porque gobierna Ortega no vamos a producir, sí, haz tu empresa, pero no quieren ningún riesgo, ninguno, vete al COSEP y mira la composición del COSEP, ahí no hay, no hay empresariado, y no quieren, y los pocos que hay, Carlos Pellas no pagó el impuesto, por construir el edificio, porque dijo que le daba imagen turística a la ciudad, y si de ese tamaño, que es el más grande, el más moderno, digamos, en términos productivos, hace eso, ¿con qué va a pagar impuestos, entonces, el médico cuando te da la consulta?, no paga, o el ingeniero que viene, a ver, va a pagar $15 \%, 30 \%$, no, eso no señor, yo no pago para que se lo roben los ladrones, ¡ah!, entonces, ¿cuál país es el que quieres?, ¿quién hace las carreteras?, ¿quién hace las calles?, ¿quién paga los maestros?, si ustedes no pagan los impuestos, entonces, ¿cuál es la economía que va a afectar si siguen o no siguen los sandinistas?, ese es un problema.

\section{R: Y hay un concepto patrimonial del Estado también en ambos.}

R.H.: En los dos lados, la corrupción es de ida y vuelta, si tú me das esto, yo te doy esto, y ahí está, ah, es que si no le pago la mordida no me lo da a mí, pero si nadie le paga, verdad, no hay cómo hacer corrupción, es decir, el concepto patrimonial existe, y existe en serio, yo no tengo que sacarme de mi bolsa para ir a comprar un cargo que el Estado me lo da, yo no tengo que ir a invertir de mi dinero en la gasolina, porque la gasolina me la da el Estado, y eso siendo honrado, más o menos honrado, pero la corrupción es un fenómeno de ida y vuelta, y sí alguien está en el sector privado, y alguien está en el Estado, verdad, y es muy chiquita la economía, entonces, son pocos los corruptos, son 
pocos los millonarios, en El Salvador son muchos, no son tan visibles, aquí es fácil, ¡ay!, éste se volvió contratista, dice que toda esta carretera la está haciendo él, es chiquito, es chiquito, y en la cultura política nuestra ese concepto patrimonialista está muy fuerte, muy fuerte, Somoza se cae cuando empieza a decirle a los privados: "oigan, no", todos estos son hijos de los grandes empresarios de aquella época, verdad, así es que no es tan cierto de que una parte de la sociedad sea honrada, y otra sea corrupta, muy común.

R: Y ya mi última pregunta, ¿qué papel juega, entonces, la Constitución en esta incierta evolución de la democracia tan deteriorada de Nicaragua?, ¿no?, ha habido parches a la misma, ha habido un giro que se consolida con esta última sentencia, como decía antes, de pérdida del valor normativo de la Constitución, he oído hablar del llamamiento a un nuevo diálogo nacional, de esperar a esta renovación de los cargos a los que usted se refería, o, incluso, de convocar una nueva Constituyente para tratar de crear un paraguas jurídico, que, por fin, acoja a todos los ciudadanos nicaragüenses.

R.H.: Atarle el ojo al macho nada más, ¿no?, yo creo que la Constitución todavía es una guía muy poco sólida para conducir a este país, no es que haya un profundo irrespeto a la Constitución, es que no juega, no juega todavía, no le veo, inclusive, creo que si encuentra usted constitucionalistas en el país no llega a dos, tres, hay gente que trabaja la Constitución en la Universidad, pero que no produce efectos, pero, desgraciadamente, pues, la formación política constitucional es muy pobre, si entrevistaras a cien políticos que están relacionados con el trabajo legislativo de los cien, ochenta y cinco nunca han leído la Constitución, y son diputados, y de los quince que quedarían un poco en el margen, lo han hecho, en relación a temas muy concretos, muy puntuales, muy puntuales, pero para serte honesto no es un tema que esté por encima de los efectos de estar dedicados a estudiar la Constitución, es decir, sólo volvemos hacia la Constitución cuando queremos algo más concreto, decimos, "hombre, para elegir Magistrados, ¿qué dice la Constitución?", no estudiamos la Constitución como, el tema constitucional en Nicaragua está relacionado más con cuestiones de reparto de poder, que de un interés real, en armar una estructura jurídica, un paraguas jurídico bien ordenado, para que se puedan dirimir los conflictos abajo, es a la inversa, segundo, quienes deberían enderezar su acción política hacia el mejoramiento constitucional carecen de herramientas teóricojurídicas para ello, desconocen, la mayoría de ellos la forma en que se logra la Constitución misma, si toma de cien diputados, en el momento, en el caso de Nicaragua, ochenta y cinco jamás han leído la Constitución, y se lo digo habiendo sido diputado, es decir, una Constitución que se lea como político y se domine como político en nuestro medio no existe, la Constitución ha sido el ropaje, una especie de juego ferretero de candados para amarrar intereses particulares de quienes están en su momento en el poder, no el resultado de un consenso para satisfacer a todos los intereses de la nación, verdad, es un costal donde alcanza todo, diría un buen constitucionalista, en Nicaragua no alcanza todo, es todavía una Constitución partidaria, es todavía una Constitución de intereses muy definidos, no es un, verdad, yo me acuerdo estudiando Derecho Constitucional, soy abogado, en México, que decíamos en Ciencias Políticas en México de "la Constitución alcanza todo", el mismo artículo sirve para sustentar a un socialista, que para sustentar a un conservador, bueno, quiere decir que la Constitución se ha ido haciendo a base de una suma de intereses consensuados, verdad, y que, de alguna manera, a los niños desde chiquitos se les enseña a respetarla, en nuestro medio, aquí nadie respeta la bandera, nadie respeta la Constitución, nadie respeta eso, ¿por qué?, porque es un librito al servicio de intereses muy concretos, partidarios en unos casos, y 
eso dificulta la reforma como algo que ha sido estudiado por la sociedad, verdad, la reforma ahorita la ven, es si se reelige Ortega o no, es si lo diputados tienen más poder o no, es si el presidente puede nombrar a ministros y la Asamblea ratificarlos o no, es una lucha de poder demasiado concreta para que la Constitución sea útil, es decir, ahí está, reformarla es sólo para trasladar mis intereses de una manera muy concreta, y eso hace difícil que el trabajo constitucional sea un trabajo serio, entonces, usted dice, está parcheada, sí, ¿por qué?, es que primero va a tener que ser así, va a ser como una especie de colchoneta de esa de colores para una cuna de niño, ¿verdad?, parches de todos los colores, ¿por qué?, porque es que la sociedad está así, y va a tardar un poco en que los partidos se hagan más serios y sin necesidad de ver la Constitución para el reparto de poder se ponga a estudiarla y se diga: "hombre, vamos a hacer un seminario, vaya usted a la Asamblea Nacional y enséñeme diez cursos o diez seminarios sobre Derecho Constitucional patrocinados por la Asamblea", ni uno, una sesión para leer la Constitución, por lo menos un día al mes, para que los diputados aburridos que lo lean, nunca, en la Universidad para ser abogado, es más, cómo sacar a alguien preso o meter a alguien preso, pero los constitucionalistas no pasan de ser aquí dos, tres, y agarraron fama de constitucionalistas y no volvieron a leer una Constitución en su vida, la comparación entre la Constitución que deja Pinochet en Chile y la Constitución que dejan los sandinistas en el 87 en Nicaragua, un análisis comparado, no lo conozco, es decir, nadie está estudiando, ahora se meten a lo de Costa Rica porque la Sala Constitucional hizo lo que hizo, es decir, es un país en donde el desprecio a lo intelectual, el desprecio al estudio es tremendo, un día es tema, a los tres días, ya a nadie le interesa, pero dichosa usted, pues, que agarrar desde España una tesis, me da mucho gusto, la felicito, qué bueno, y ojala que este tiempo que ha estado en Nicaragua le haya permitido conocer un poquito lo que es la formación de un país, porque esto está así en formación...

\section{R.: Es un laboratorio, realmente.}

R.H.: Yo le digo a ustedes, los nicaragüenses en 500 años y esto no va a cambiar, y es probable que 500 sea poco, es un país que no tiene muchas salidas, económicamente, pudiera serlo que en algún momento estaba empezando a ser en los 70 un emporio, un granero de Centroamérica, una economía fuerte, una clase media altamente profesionalizada, un criterio de la emergencia de lo popular hacia arriba, eso desapareció, no hay esa voluntad social del crecimiento y del mejoramiento, no hay, y veo pocas posibilidades, el Frente gana siempre de que las cosas no cambien mucho, verdad, y la oposición gana siempre de que no crezca mucho, es decir, los dos al final de cuentas les conviene el país aplastado, el país empobrecido, el país sin espíritu, el país prebendario, el país que quiere que le den todo, y eso son generaciones, son generaciones, yo no le veo que sumando las edades podamos esperar que en 100 años este país cambie, es decir, se va a mantener en tumbos, y así va a vivir, ¿por qué?, porque es económico vivir así, es la verdad, desgraciadamente, aquí el que no tiene nada, siempre tiene todo, verdad, un contrasentido, el más jodido de la sociedad con un poquito que agarra de aquí ya vivió, no es una economía hundida, no es Biafra, no es, no, no, aquí aún en sequía allá en aquella región está lloviendo y puedes ir a pie, no es un país, pues, de escasez dramática, y eso, pues, si el niño no fue a la escuela en la comunidad X, pues, a nadie le importa, es decir, no cambia nada, y esa madre campesina, jodida, que nunca ha podido ver un médico, que pare en el monte como pare, ¿qué va a estar preocupada si Fulano o Zutano son ajenos a la modernidad en el sentido correcto?, para ella, ella siembra su poquito maicito, el hombre que la patea y la 
jode tampoco lo persigue, es decir, es un país en donde cada quien hace, al final de cuentas, lo que se le viene en gana, no hay un orden nacional, no hay un proyecto de decir: "vamos a ser ahora el país más grande en ganadería, y, entonces, a traer aquí miles de vacas para que todo el mundo", no, quiero decir, para qué, que si no vamos a comer carne, vos tenés un venado y comés carne, o mata una gallina y come carne, o mata un chancho y come carne, es decir, una economía que no te da lugar a una presión desde abajo, que tú puedas decir, mira hay 20.000 productores pequeños que están exigiendo sistema crediticio, no, es al revés, no quieren pagar lo que ya les han dado las organizaciones de crédito chiquitas, no existe, y yo no veo que los partidos se dediquen a algo como partidos, a promover algo que no sea su propio interés de hoy, es un país de hoy, ahora, aquí y ya, quiero el cargo, quiero más cargo, pero ninguno te dice OK, vamos a ser unos grandes productores de trigo, vamos a exigir a los bancos que le den crédito, no, los banqueros son los que me financiaron mi campaña, ¿cómo les voy a ir a pedir que me den?, que se sacrifiquen, es un pleito de cuerpo a cuerpo todavía, no es una lucha de clase, no es una lucha de ideología, no es una lucha doctrinaria, es una cuestión de puros intereses personales chiquitos, arriba y media abajo, consecuencia, es un país que camina solo, camino solo, entra un barco por ahí y entra, no hay, no hay, tú no ves una demanda que digas, oye, aquí tomaron una carretera con los tractores, ¿cuál carretera y cuáles tractores?, es decir, no nos preocupamos nosotros en haber diseñado, realmente, una, ya no digamos un proyecto nacional, una voluntad nacional de cambio, no hay, lee las demandas de los periódicos, la demanda de los partidos, pon la radio en la mañana, en la tarde, todo es un pleito por el cargo público, ¿por qué?, porque es el único que da prebendas, entonces, yo quiero bajar como sea de donde está y subirme yo, no es crear algún mecanismo para elegir a los buenos y no a los malos, no, es que me elijan a mí, quitáte vos para ponerme yo, y los medios incentivan ese tipo de luchas, nunca has visto que digan vamos a la alfabetización, vamos a la producción de granos básicos, vamos, no, no, si hay, se queda, que el gobierno no le haya dado, que si una inundación, que el gobierno no le llega, es muy pobre, y esa cultura, la que debimos haber incentivado en vez de estar discutiendo sobre la transparencia, la rendición de cuentas, la institucionalización, no, hombre, es a la inversa, debemos crear una cultura rápida, que se puede exigir que se hagan los tres primeros grados de primaria, exigir que se pueda tener una salud básica, y no dediquemos a otra cosa el esfuerzo para que podamos despegar, pero no, es ahí arriba, 6\% para las universidades, verdad, y vas a la Universidad, y a la UAM y a todas estas, y el estacionamiento está lleno de carros, una clase media parasitaria que no produce para pagar ni su propia educación, y el Estado le tiene que dar a los niños bien, y los niños de los campesinos se joden, no tienen acceso al primer grado, no hay escuela, no hay maestro, ese es el país, entonces, ¿dónde se va a dar la pelea?, ahí arriba, ahí arriba, ¿quiénes son los que andan de estudiantes universitarios?, ve a decirles que se vayan a fregar una semana, a trabajar con los niños en el campo, que dejen el carrito, y que dejen de ir a los night club, para que se mejore un poco la base social, no, hombre, no, yo quiero que cambien al Magistrado de la Corte Suprema, que le cambien, que nombren a mi tío en la Corte, esa es la discusión, y ese es el país que va a seguir así 100, 200, 300 años, esto no es productivo, no es una clase media como la de los 60, que salió del trabajo, de la cultura del esfuerzo, esta no, es de la gresca, mira los negocios que estafan a la gente, las marca móviles, y si te fijas quiénes son los estafados es esa clase media parasitaria, no es, no es, un campesino estafado que metió 100 córdobas, es un pinche que metió 5000 dólares, es decir, es un país que está volteado patas arriba, que la base donde debería haber construido las verdaderas instituciones, que son los verdaderos valores, educación básica, mínima, para que el campesino tenga un mínimo de posibilidades de desarrollo, no, es allá, es en 
la Universidad, y ahí tenemos 800.000 licenciados en 800.000 carreras que no sirven para un carajo, pero que son licenciados, y que salen a la calle con morteros a defender sus intereses, pero no es, tu no ves otra definición de país de otra manera, y por eso te digo, yo no le veo, que los arreglos aquí son siempre copulares, no hay líderes que salgan de las bases, aún dentro del sandinismo, y del liberalismo, que tenemos líderes de base fuertes, no están construidos por un proyecto de mejoramiento, es una cuestión de distribución, no de producción, entonces, cuando hay esta distribución es pleito de perro, en el partido, fuera del partido, en contra del otro partido, y un país así no se puede llamar a institucionalizarse, por eso es que yo me opuse a la tesis de que la institucionalización, porque estábamos institucionalizando el poder, estábamos haciendo las cosas al revés, entonces, yo no te doy a vos poder, si no me entregás las cuentas de la población en los tres primeros grados de primaria, yo no te doy poder, a vos poder, si no me entregás las cuentas de la salud básica de la reproducción allá en donde está la pobreza, y, entonces, sí, vamos a empezar a institucionalizar los mecanismos de distribución de los recursos en beneficio de la población, y ya, después, hablemos de las reformas, pero aquí estamos otra vez hablando de las reformas, hablando de la distribución de los cargos, y eso retrasa cualquier posibilidad de darle estabilidad y crecimiento al mismo tiempo al país, que es para mí la clave, crecimiento económico y estabilidad política, no se pueden las dos cosas aquí, desgraciadamente van a tardar mucho, ese es un problema real.

R: No, pues, muchas gracias por su entrevista.

R.H.: No sé si te habré servido de ayuda en algo. 
ENTREVISTA 2943:

Nombre del entrevistado: D. Edmundo Jarquín.

Cargo actual: Candidato presidencial del Movimiento Renovador Sandinista (MRS) en las elecciones de 2006. Consultor del PNUD en Nicaragua.

Fecha de realización de la entrevista: Ciudad de Panamá, 28 de octubre de 2009.

Lugar: Hotel Continental de Panamá.

Duración estimada: 40 minutos.

\section{TEXTO - Transcripción 29:}

$R$ : ¿Qué recorrido hace sobre el proceso de cambio constitucional que se ha experimentado en Nicaragua desde los años 90 hasta ahora?

E.J.: Sí, a ver, la Constitución de 1987 resultaba a la luz de las nuevas circunstancias políticas, de las que se dieron después de las elecciones del 90, una Constitución que requería alguna reflexión de fondo, pero antes de hacer la reflexión de fondo que se intentó, hay que leer las nuevas circunstancias políticas, las nuevas circunstancias políticas eran, fundamentalmente, las siguientes: en primer lugar que dentro del mismo bloque sandinista hubo dos posiciones que poco a poco se fueron mostrando irreconciliables, el Frente sandinista tenía treinta y nueve de noventa diputados, entonces, era una fuerza considerable, sin embargo, un sector de ellos, de los que respondían a su vez a un sector muy fuerte del aparato partidario liderado por Daniel Ortega no asumían la democracia como una conquista de la revolución, o, en todo caso, tenían una visión de la democracia que no era compatible con la que se estaba poniendo en camino, que era la instauración de una democracia liberal, los otros, la mayoría dentro de la bancada sandinista, treinta y seis de treinta y nueve, pero que no tenían el control del aparato partidario, asumían que la democracia era una conquista de la revolución, que era una promesa inconclusa desde los años 80 , debido a la guerra civil, fundamentalmente, y se constituyeron en la base fundamental de apoyo legislativo del nuevo gobierno, porque, a su vez, dentro del nuevo gobierno, que era expresión, el gobierno de Violeta Chamorro, del bloque antisandinista, se había producido durante la transición entre las elecciones de febrero y el inicio del gobierno en abril, el 25 de abril, una división profunda, había un sector más radicalmente anti-sandinista, fundamentalmente, de origen somocista, es decir, anti-sandinista y de algún vínculo somocista en el pasado, que consideraban que no había que hacerle ninguna concesión al sandinismo, que el que había ganado había ganado todo, y el que había perdido las elecciones había perdido todo, y otro sector, encabezado por la presidenta Chamorro, que había sido anti-somocista, y respaldada por sectores de origen anti-somocista y que habían derivado, a su vez, al anti-sandinismo durante la división que produjo los 80 , que pensaron, además que era lo realista, que había que negociar, e incluso se firmó el famoso Protocolo de la Transición. El Protocolo de la Transición tenía algunos elementos y están ahí las raíces de la reconciliación, los más importantes eran que se iba a respetar la institucionalidad de las Fuerzas Armadas y que éstas, progresivamente, se

\footnotetext{
43 Entrevista breve, aunque interesante en algunos aspectos fundamentales de análisis como: el proceso reciente de formación de los liderazgos de Ortega y Alemán, sus vínculos sociológicos y culturales, así como los factores explicativos de la tensión entre el impulso modernizante y la herencia tradicional en la evolución irregular de las instituciones democráticas en Nicaragua.
} 
iban a convertir de Fuerzas Armadas de la revolución en Fuerzas Armadas de la nación, esto indignó al sector más radical del anti-somocismo, y un hecho que muchos se olvidan, que casi nadie lo tiene registrado históricamente, y que te recomiendo verlo, es que la noche antes de que se inaugure el gobierno de Violeta Chamorro, o cuando se está tratando de elegir la primera Junta Directiva de la Asamblea Nacional, la UNO, la Unión Nacional Opositora, que había llevado a Violeta Chamorro al gobierno se declaró oficialmente de oposición, de tal manera que la primera directiva de la Asamblea Nacional se integra, fundamentalmente, por los treinta y nueve votos sandinistas, en ese caso, sí, todos unidos, y unos muy pocos diputados, diez, once, creo, apenas se rozó los cincuenta votos, y se requerían entonces cuarenta y seis, verdad, para elegir la Junta Directiva, con lo que te quiero decir es que ahí se empezó a gestar esa circunstancia de que el grueso de las medidas de la transición hasta la instauración de una democracia liberal las pudo adoptar el gobierno de Violeta Chamorro, fundamentalmente, por el respaldo de la bancada sandinista, y, principalmente, de los treinta y seis de los treinta y nueve diputados, que fueron más consecuentes en esa dirección, porque mientras tanto Daniel Ortega prefería mantener una negociación de calle, es decir, con bloqueos, asonadas, es decir, entonces, se gestó este doble escenario, la Asamblea Nacional como el foro por excelencia de la negociación política donde Daniel Ortega se sentía en minoría, y él tratando de que la negociación se fuera a trasladar a la calle, esa es la dinámica más importante durante esos primeros años de la transición. Mientras tanto, al interior de los dos bloques, el bloque sandinista y del bloque anti-sandinista se van decantando dos procesos, al interior del bloque sandinista el proceso que se va decantando es que Daniel Ortega tiene un control muy precario del aparato partidario, y no tiene control de la bancada sandinista, él pierde, sucesivamente, varias elecciones dentro de la asamblea sandinista, una asamblea sandinista que tenía una integración muy informal, venía de la época de la revolución, nadie la había designado, la asamblea sandinista era el órgano intermedio de la Dirección Nacional, que se llamaba, y el Congreso que nunca se había realizado, el Congreso sandinista, y perdió varias votaciones, porque, por un decisión también dentro de ese espacio informal, se había decidido que formaban parte de la asamblea sandinista no sólo los cuadros, históricamente, designados por los méritos en la guerrilla, sino también todos los miembros de la bancada parlamentaria del Frente Sandinista, entonces, tienen treinta y seis, entonces, eso da una correlación dentro de la asamblea, entonces, hay una tensión que Daniel Ortega la va definiendo a su favor con medidas de presión, orillando y eliminando, progresivamente, hasta que se da el Congreso del 91, Daniel Ortega no gana, pero como logra, sin embargo, su reelección como Secretario General de la Secretaría General comienza a depurar en la medida en que se acentúan las contradicciones políticas, y esto es lo que da el origen al MRS, pero, progresivamente, Daniel Ortega se queda con la identidad sandinista, la identidad del Frente Sandinista que ahora lo tiene licuado en el orteguismo, prácticamente, $\mathrm{OK}$, a su vez, dentro del bloque anti-sandinista, se va decantando una fuerza política mayoritaria, que es el liberalismo, y en las elecciones del 90 nadie se había contado, todos valían UNO, que el Partido Socialista, que el Partido Conservador, que el Partido Liberal Constitucionalista, que el Partido Liberal Independiente, toda esa enorme cantidad de pluralidad que integró la Unión Nacional Opositora, pero Arnoldo Alemán, que ha salido elegido alcalde de Managua, y que tiene, en ese momento, más recursos, incluso, que el gobierno nacional, porque no tenía ninguna deuda y porque le transfirió el gobierno nacional en septiembre de 1990 el derecho al impuesto predial, que en Managua es una fuente de ingresos enorme, y considerando lo relativo a la pobreza del país, Arnoldo Alemán desde la Alcaldía de Managua comienza a reunificar al viejo Partido Liberal, y, 
entonces, se van dando esos dos procesos de consolidación de dos fuerzas políticas, prácticamente, privatizadas, una por Arnoldo Alemán, y la otra por Daniel Ortega, una emblematizando el bloque anti-sandinista y la otra emblematizando el bloque sandinista, y en la Asamblea Nacional subsiste la correlación más plural, más democrática, más moderna, en términos cultural-políticos, producto de la elección de febrero del 90, entonces, estas fuerzas que están en la Asamblea Nacional de cara a lo que habían sido los principales problemas históricos del sistema político nicaragüense, y de cara a esa realidad que se está configurando, impulsan las reformas constitucionales del 95, las reformas constitucionales del 95, en primer lugar, tienden a limitar el poder presidencial, fundamentalmente, en materia presupuestaria, pero también hay otras limitaciones que ahorita no las preciso, pero que vos sí las vas a precisar, en segundo lugar, temiendo de que haya una nueva dictadura partidaria, de que uno $\mathrm{u}$ otro por mayoría relativamente simple fuera a designar, se comienzan a establecer mayorías calificadas y mecanismos de proposición, tratar de separar el que propone del que elige en los principales poderes del Estado, verdad, fundamentalmente, la Corte Suprema de Justicia y el Consejo Supremo Electoral, y lo otro, que, por cierto, rompe las alianzas más modernas, más democráticas, es ponerle coto al viejo vicio de la política nicaragüense de la reelección sucesiva o de la sucesión familiar, y esto rompe el bloque, porque Antonio Lacayo, que era el Primer Ministro de hecho, es decir, era la figura del Ministro de la Presidencia de Violeta Chamorro, yerno de Violeta Chamorro, moderno, y que lideró el entendimiento con la bancada sandinista, que a su vez la dirigía Sergio Ramírez, Dora María Téllez y yo al principio, porque me tuve que ir, pretendía que la continuidad del gobierno de Chamorro tenía que ser el continuismo personal de él, entonces, le ponen prohibiciones a él, que él consideró que tenían nombre y apellidos, que era para bloquearlo a él, pero que correspondían a una vieja demanda del constitucionalismo en Nicaragua, una vieja demanda política, es más, que se plasmó varias veces, constitucionalmente, pero siempre se reformaba la Constitución para permitir que Somoza, o un hijo de Somoza, o alguien siguiera así, dijera, la reelección sucesiva del gobernante de turno, ni que hubiera sucesión familiar, ¿verdad?, porque se tendía a dar la continuidad en el poder, esta medida hay que entenderla así, sin embargo, asumía, implícitamente, de que si bien se iba a forzar a que fuerzas mayoritarias negociaran, se entendía que era una negociación de balances políticos democráticos, nunca nadie pudo asumir, era imposible asumir que Daniel Ortega y Arnoldo Alemán se terminaran entendiendo no a partir de balances de fuerzas, sino a partir de compartir el mismo espacio cultural, uno proveniente del sandinismo o el otro del anti-sandinismo, uno de la supuesta izquierda, otro de la supuesta derecha, pero, fundamentalmente, el mismo espacio cultural, una cierta concepción de la clase media baja, con resentimientos muy profundos anti-oligárquicos, ambos con un cierto antiamericanismo, el uno porque los americanos habían destronado a principios de siglo al presidente Zelaya, que es el emblema de la revolución liberal, el otro por el asesinato de Sandino y la guerra de los americanos con Sandino, y comienza todo ese tejido porque eran del mismo barrio, porque esta es una categoría que desde el punto de vista del análisis político te puede parecer, incluso, de influencia marxista, resulta difícil decir que el resentimiento puede formar parte, hasta que ahora lo he visto en varios análisis, por ejemplo, el tema de los talibanes es, fundamentalmente, un tema de resentimiento social, es decir, sectores poderosos, pero premodernos, frente a los sectores urbanos, modernos, de economía poderosa, y comienzas a ver, y vos empezás a ver en el discurso de ellos de la época del pacto toda esta cuestión, es más, en determinado momento, Alemán dice: "es que Daniel y yo tiramos cuando éramos niños piedras contra los mismos techos, delante de los mismos tejados", entonces, comienza la negociación en la 
cual también ellos asumen que el bloque anti-sandinista siempre va a ser mayoría, entonces, Alemán no lo teme, y que el bloque sandinista va a ser minoría, y que también necesita cuotas de poder para consolidar su control, no necesita sólo estar reeditando la candidatura, sino tener cuotas de poder que las va adquiriendo, que las municipales significan, entonces, centenares de concejales que son políticos profesionales, y se dan cuenta de esa lógica, y, entonces, también tienen un sentido excluyente, no tener competencia, ni el uno la quiere en el bloque sandinista para no perder el control del bloque sandinista, ni el otro la quiere en el bloque anti-sandinista para no perder el control del bloque anti-sandinista, de ahí vienen las repetidas exclusiones de fuerzas políticas, todo el mundo tiene en la retina que excluyeron al MRS y al Partido Conservador en las elecciones municipales, pero es que en dos elecciones anteriores mandaron al Instituto de Cartografía cambiar el límite de Managua para impedir que un personaje muy popular que iba a ganar la Alcaldía de Managua y que no era de ninguno de los dos bloques, entonces, no pudiera ser candidato, de repente decidieron, por un tema de 200 metros, que el límite del Departamento de Managua no estaba aquí sino que estaba allá, y excluyeron a Pedro Solórzano, y excluyeron a otros partidos, entonces, este tema de las exclusiones no es, únicamente, de ahora, corresponde a esa lógica, es decir, que nadie me discute a mí el monopolio del espacio anti-sandinista, y que nadie me discute a mí el monopolio del espacio sandinista, esta fue, en mi opinión, si vos ves, entonces, viene la segunda onda de reformas, las de finales de los 90 e inicios del 2000, que ahí están orientadas, si vos te das cuenta, no hay un cambio en los balances entre los poderes del Estado en aquél momento, hay una composición más colegiada, más numérica de los poderes del Estado para dar cabida a las cuotas, es decir, corresponde más a la lógica de la distribución, en mi opinión, mafiosa, de zonas de influencia, que a un cambio, estas últimas reformas no tienen ninguna lógica desde el punto de vista del constitucionalismo clásico, es decir, de un mayor equilibrio en el balance de poderes, de que si mayor fuerza parlamentaria, en absoluto, todo lo que tiene es aumentar los números, que se vuelve colegiada la Contraloría, que se comienzan a inventar nuevas autoridades de servicios y comienzan a distribuirse los empates, esa nuevas autoridades de servicios en todos los casos tienen órganos colegiados de gobierno, siempre para corresponder a la lógica de la distribución de las cuotas, entonces, y Arnoldo Alemán la reforma más significativa, la reforma más significativa ahí se da, en términos de la Ley Electoral, que es una ley constitucional, una noción que no sé si es clásica, pero, básicamente, se les llama leyes constitucionales no porque formen parte de la Constitución, sino porque tienen para su aprobación o reforman requieren de la misma mayoría calificada que la reforma parcial de la Constitución, OK, por tanto, la reforma de la Ley Electoral que establece obstáculos casi insalvables a la competencia política democrática, independientemente, de la interpretación discrecional, abusiva, y la aplicación abusiva de la Ley Electoral en su lectura literal plantea unos umbrales fijados a la competencia política democrática, prácticamente, insalvables, porque corresponde a la lógica de que nadie más le entra al juego del reparto del poder político, vos ves los requisitos de formación de un partido político ahí son los más duros y exigentes de toda América Latina, dice, por ejemplo, que hay que constituir directivas en todos los municipios, no es la clásica cuota de si hay oportunidades del $3 \%$ o del $5 \%$ de los votos y el pueblo decidió que fuera, no te doy la oportunidad de que el pueblo decida de si quiere que haya partido político, tiene que integrar directivas en los ciento treinta y tantos municipios en presencia de un delegado del Consejo Supremo Electoral, entonces, vos tenés que ir y organizar en ese municipio y notificás, pero si no se te presenta el delegado del Consejo Supremo Electoral, pues, es nulo, entonces, este enorme intento que hizo Joaquín Cuadra, ex-jefe del Ejército, de 
constituir el Partido de Unidad Nacional ni le contestaron la solicitud de personería jurídica, es decir, esta historia de las exclusiones ya tiene, no es reciente, corresponde a esa lógica. Entonces, la Ley Electoral, lo otro fue, el tema de garantizarle impunidades, inmunidades que son impunidades recíprocas, entonces, Alemán acepta bajar el ballotage hasta desvirtuarlo, ¿qué sentido tiene un ballotage cuando tenés $35 \%$ ?, el ballotage es para formar mayorías absolutas, lo estableció De Gaulle, el origen, esa distorsión del ballotage, primero, no tiene sentido en un régimen presidencial.

\section{$R: ¿$ ¿No tiene sentido?}

E.J.: No tiene sentido en un régimen presidencial, tiene sentido en un régimen parlamentario o semi-parlamentario, que es crear coaliciones de mayorías, forzar las coaliciones de mayorías, no tiene sentido en un régimen presidencial, el ballotage tuvo su origen, bueno, empezó en Argentina, con el pacto entre Ménem y Alfonsín de Santa Fe, Alemán lo da en el contexto de concederse recíprocamente inmunidades, $\mathrm{y}$, entonces, resulta que el ex-presidente pasa a ser miembro de la Asamblea, por tanto, tiene inmunidad parlamentaria, y el que queda en segundo lugar, que se suponía siempre iba a ser Daniel Ortega, también pasa a ser diputado, y se hace bajo el supuesto de que nunca se va a dividir el bloque anti-sandinista, y que, por tanto, Daniel Ortega nunca va a ganar, verdad, hasta que comienza a romperse el bloque anti-sandinista, y el bloque sandinista con dispersión de calle, o sea, hay que recordar que nosotros en MRS sacamos el 6\% de los votos, Sergio Ramírez en las elecciones del 96 no había llegado al $1 \%$ de los votos, y Eduardo Montealegre sacó más votos que el candidato del PLC, y las dos son expresiones de rechazo desde la modernidad política, una, del partido sandinista, y otra, del partido liberal, de tal manera de que el poder derivado de una tradición fundamental de que Nicaragua no es tierra de Derecho, la revolución y la contrarrevolución, sino hacia un mecanismo de democracia, o, digamos, un poco evitar la confrontación entre dos bloques, el bloque moderno, más institucionalista, y el otro bloque premoderno, culturalmente hablando, más caudillesco, más autoritario, más corrupto, eso es lo que te tendría que decir así como panorama general.

R: Sorprende cuando una revisa los procesos de cambio constitucional en Nicaragua el desacuerdo que hay siempre entre el Ejecutivo presidencial y la Asamblea, bueno, en el 95 lidera la Asamblea la propuesta de cambio, en el 2000 es arreglada por el Ejecutivo de Alemán y la oposición sandinista, y en el 2005, digamos, el PLC de oposición a Enrique Bolaños y la bancada sandinista arreglan la reforma del 2005, en lo que, supuestamente, han defendido, desde el sandinismo de Ortega y también del propio Alemán, como el hilo conductor de las reformas hacia una evolución semiparlamentaria del presidencialismo fuerte de la Constitución original del 87, es una excusa, obviamente...

E.J.: Es que no, no, mirá, mientras en el 95 el conflicto se plantea más por el tema de la no sucesión familiar, eso es.

\section{R: ¿Y el Ejecutivo de Violeta Chamorro no quería aceptar eso?}

E.J.: Sí, pero Antonio Lacayo, que era el que lideraba el Ejecutivo se sentía inhibido, bloqueado, y quería ser candidato, en todo lo demás él respaldó, fue ahí donde se complicó, verdad, en el 99, el entendimiento entre los dos bloques mayoritarios, que es el que te he explicado, y en el 2005 es, de nuevo, un accidente, Enrique Bolaños es 
elegido por el partido de Alemán, y choca con Alemán por temas de corrupción y descubre cuando intenta Alemán de seguir gobernando desde la Asamblea Nacional, entonces, él se queda en minoría, entonces, los dos que se entendieron en el 99-2000, tratar de amarrar, es decir, mientras el impulso a re-balancear el poder en el 95 correspondía, si vos querés, a un cierto constitucionalismo clásico y de cara a la historia de Nicaragua, este último fue exclusivamente prebendario, es decir, patrimonial, quitarle poder al Ejecutivo y distribuírnoslo nosotros, la creación de estas autoridades, ahora bien, yo no sé si te has percatado que esto que llaman parlamentarización de Nicaragua, o semi-parlamentarización de Nicaragua es un tema que lo que tiene que ver es con un balance entre el Legislativo y el Ejecutivo, nada tiene que ver en cuanto a la esencia del parlamentarismo o el semi-parlamentarismo, que es cómo se genera la constitución de los poderes, es decir, en el régimen parlamentario o semi-parlamentario, exceptuando el Jefe de Estado, que, en algunas ocasiones, es de elección directa, en Francia, el caso de Italia, en el régimen parlamentario o semi-parlamentario el Ejecutivo se constituye a partir del parlamento, es decir, la elección directa del Ejecutivo en Nicaragua, nadie está cuestionando eso, se ha seguido con la elección directa, es decir, han llamado parlamentarización o semi-parlamentarización a la lógica a partir de la cual existe tarta para repartir, ¿ves?, entonces, es un tema incoherente, es decir, pues, a mí me llama la atención la ligereza de cuerpo, o la ligereza conceptual, con que en Nicaragua se habla de ese, no conozco el libro de Edwin Castro sobre parlamentarización, por cierto.

R: Yo tuve la oportunidad de entrevistarle durante 20 minutos, donde el Frente Sandinista, bueno, la impresión mía fue que se blinda, hay un elemento defensivo, sé que el discurso político es distinto del académico, ¿no?, que es mucho más reflexivo y mucho más crítico, pero sí fue un discurso absolutamente pobre, aunque a mí no me corresponde juzgarlo en esos términos, pero sí insistiendo, constantemente, en la reelección, en el referéndum revocatorio y en un esquema, que según otros entrevistados, sugiere como una especie de exportación del modelo chavista al caso de Nicaragua.

E.J.: Bueno, y lo otro es, a raíz de las elecciones municipales el sistema electoral quedó hecho trizas, no tiene ningún sentido estar diciendo presidencialismo, parlamentarismo, semi-parlamentarismo, si el origen democrático del poder político en cualquiera de los regímenes políticos es que los votos se cuenten bien, y en Nicaragua los votos no se cuentan bien, es decir, todavía en Venezuela se han contado bien, nadie ha dicho, ha habido...

\section{R: Un fraude de estas características.}

E.J.: Bueno, y es que, en el fondo, en Nicaragua lo que está tensionando todo es que desde una, que no hay una situación refundacional, porque en Nicaragua no ha habido un desplome del sistema de partidos políticos al modo de Venezuela o de Ecuador, ni hay un movimiento social emergente como en Bolivia, y Ortega tiene una actitud refundacional, y, en segundo lugar, está tratando de hacer y de imponer un régimen autoritario siendo minoría política, fuerte, pero minoría, Chávez ha sido mayoría política ahora, Correa mayoría política reeditada, Evo Morales mayoría política, es decir, y en esta semana que no has estado la situación evoluciona dramáticamente, ya organizaron el movimiento reeleccionista del orteguismo, y el colmo fue que llevaron a jefes de Policía a unirse con una jefa de Policía, entonces, silbando a policías en activo 
para unirse al movimiento reeleccionista, unirse al movimiento de mujeres orteguistas, el movimiento de funcionarios del Estado orteguistas, ya ni siquiera están poniendo el nombre sandinista, entonces, desde una posición de minoría política que es continuar en el poder, eso es, puramente, tensionando al máximo la institución democrática básica, realmente, que es el sistema electoral, es decir, que los ciudadanos voten con libertad a conciencia, y voten y sus votos se cuenten bien.

R: Tuve la oportunidad de entrevistar a Violeta Granera, que lidera el "Movimiento por Nicaragua”, y me comentó el tema de las fuerzas de choque, privando del derecho fundamental de expresión a los ciudadanos.

E.J.: ¡Ah!, la calle, claro, bueno eso ya te lo habrá contado ella.

R: Sí, y el cierre de espacios a la oposición en la Asamblea.

E.J.: Claro, ah, vos no sabés que están empezando a interpretar, están queriendo ir en alguna interpretación a una reforma de la ley de la Corte Suprema de Justicia para modificar el quórum, para romper el precario balance que habían establecido con Alemán, y poder hacer quórum los sandinistas solos, y están queriendo ir a una reinterpretación de la Constitución desde la Corte de tal manera que no se quiera reforma constitucional para que Daniel Ortega pueda volver a ser candidato, esto es de los últimos días, y en la Asamblea Nacional algo elementalísimo de la democracia parlamentaria es el derecho a negarse a constituir quórum, es decir, entonces aquí ya empezaron con amenazar que les van a quitar el sueldo y las asignaciones del Estado si no llegan, es decir, que el diputado que no llega no tiene el salario ni las otras asignaciones presupuestarias, es decir, negar el derecho a la ausencia.

\section{R: Para no tener que votar.}

\section{E.J.: Exactamente.}

$R$ : ¿Y piensa que la reelección puede lograrse por una u otra vía?, esta última vía no la conocía, me refería a la vía del pacto con el PLC, porque con las otras fuerzas políticas lo tiene muy complicado.

E.J.: Bueno, vía pacto es una, o vía la compra, el transfuguismo, es otra, pero como las dos se están disputando, entonces, ahora están hablando de una interpretación constitucional de la Corte Suprema de Justicia, pero como ahí lo la pueden hacer por el balance que hay, entonces, están tratando de reformar la ley, la Ley Orgánica de la Corte Suprema de Justicia, a objeto de que el quórum lo puedan formar, únicamente, la mitad y no, actualmente, los Magistrados son dieciséis, y la ley establece que el quórum se integra con nueve, es decir, la mitad más uno, entonces, están tratando de establecer que con ocho es quórum, es decir, que sólo los Magistrados sandinistas los que pueden tomar decisiones.

R: ¿Y este aprendizaje del Frente en el control institucional?, porque después de las elecciones del 90 estuvieron 16 años en la oposición, ¿cómo se ha producido?, porque sí ha sido habilidosa la capacidad del Frente Sandinista para negociar con los liberales fuertes posiciones de poder institucional, no sólo porque sobrevivió parte de la institucionalidad procedente del régimen sandinista de los 80, como comentaba, 
anteriormente, de los pactos de la transición, sino también, sobre todo, porque aprendieron a controlar las instituciones del Estado, fundamentalmente, el Poder Judicial.

E.J.: Ha sido, fundamentalmente, ha sido, a ver, el entendimiento de Ortega con el Cardenal Obando le dio el balance del Poder Electoral, porque ya estaba integrado por mitad y mitad y un independiente, y el independiente se supone que era Roberto Rivas, que es muy allegado al Cardenal Obando, entonces, el control ese fue vía el entendimiento de Ortega con el Cardenal Obando, sobre todo, las numerosas interpretaciones que pudo haber conducido a ese entendimiento, entonces, ahí garantizaron eso, y en la Corte Suprema de Justicia han tenido más dificultad, porque ahí Alemán ha logrado conservar la lealtad de todos sus Magistrados, por eso es que están tratando de reformar la Ley Orgánica para que con sólo la mitad de los Magistrados se haga quórum, el control fundamental lo han conseguido desde el Consejo Electoral, el otro órgano en el cual no conozco la interioridad, pero que lograron tener control mayoritario es la Contraloría.

R: Y otro aspecto que a mí me interesa mucho, es que, bueno, mi estudio de las reformas constitucionales es desde el punto de vista de la Ciencia Política, es decir, los juegos de poder que hay detrás de cada reforma de la Constitución, y Shugart y Mainwaring, que son dos politólogos norteamericanos, distinguen entre los poderes partidarios y los poderes constitucionales del presidente, entonces, en el análisis comparado, por ejemplo, la presidenta Violeta Chamorro y el presidente Enrique Bolaños han sido presidentes débiles, que no han tenido un control fuerte sobre sus respectivos partidos, y les costó mucho sacar adelante la agenda de gobierno.

E.J.: Bueno, es que ya te conté lo que pasó en los años 90.

R: Y en el caso de Alemán y de Ortega, si han tenido fuertes controles sobres sus partidos.

E.J.: Por eso es que nadie entiende que Alemán teniendo tanto control de su partido, y siendo su partido absolutamente mayoritario en la Asamblea Nacional haya llegado a ese entendimiento con Ortega, si no hubiera estado buscando protección de cara al futuro por los temas de corrupción, pero también de ver cómo desde la Asamblea, y él pasaba a ser diputado, él continuaba ejerciendo el poder, es decir, el conflicto con Bolaños, yo la larga relación que tuve con el presidente Bolaños, ahora siendo el expresidente, tengo la impresión de que hubo dos factores que le llevaron a la ruptura con Alemán, pero la más importante fue que Alemán desde la presidencia de la Asamblea quería continuar con funciones ejecutivas y tenía las manos amarradas, y lo otro fue el descubrir unos niveles de corrupción que eran enormes, ¿verdad?, entonces, él va a eso, y sí tiene el refrendo de Ortega en perseguir a Alemán, porque, entonces, Ortega al perseguir a Alemán siendo su socio en el pacto re-balanceaba el pacto a su favor, entonces, Bolaños logra encarcelar a Alemán con el respaldo de Ortega, pero lo que está al interior no es una lógica democrática, sino una lógica de mafias, es de mafiosos, de cómo re-balancear el pacto a su favor, el más crítico que se le suponían permitir o no que Bolaños tuviera mayores facultades, entonces, se seguía entendiendo con Alemán, entonces, Ortega, es decir, la pregunta anterior, dónde es que Ortega, el orteguismo, tiene la habilidad para ir penetrando en las instituciones del Estado procede de eso, de que pasan a ser los árbitros del conflicto entre Bolaños y Alemán, entonces, para uno 
efectos se aliaban con Bolaños y para otros efectos se aliaban con Alemán, es decir, se rompe, es decir, el gobierno de Bolaños es un momento de ruptura del bloque de poder anti-sandinista, está roto el bloque de poder anti-sandinista, es decir, el anti-sandinismo del Ejecutivo, pero en choque con el anti-sandinismo del Legislativo, y Ortega encuentra un escenario ideal.

$R: Y$, sin embargo, también, ya para terminar, hay un aspecto que a mí me interesa, fundamentalmente, y es el tema de la reedición del pacto como parte de la historia constitucional de Nicaragua, algunos de los entrevistados recurren al argumento histórico, y yo misma también cuando trabajaba el caso nicaragüense leyendo desde España, me sorprendía como el pacto no es la primera vez que se produce en Nicaragua antes de una reforma constitucional.

E.J.: Es que mira, la negociación y el pacto es la esencia de la democracia, y, sin embargo, en Nicaragua tiene una connotación peyorativa, es decir, cada vez que yo hablo del pacto en el extranjero tengo que explicar por qué es malo, cuando el pacto, la negociación, la transacción es la esencia de la democracia, entonces, esto hay que verlo a la luz de una lectura eminentemente política, y es que los pactos orientados a las reformas constitucionales en Nicaragua siempre, inequívocamente, estuvieron vinculados a abrir espacios al continuismo del caudillo en el poder, es que históricamente, mirá, yo no he escrito al respecto, pero tengo un libro que lo podés conseguir en Managua sobre Pedro Joaquín Chamorro, que se llama Pedro Joaquín, ijuega!, entonces, para poder explicar el último período de Somoza hago una lectura de los episodios del siglo XX, y ahí tengo un par de páginas sobre el tema de los pactos, y la historia, y ahí lo podés contrastar, que es que siempre han estado ligados al tema de cómo abrir camino al continuismo en el poder de los caudillos.

R: Caudillo, que es una palabra que aparece mucho en todas las entrevistas, la idea del caudillo politico, del hombre fuerte, como parte de la cultura politica de Nicaragua, ¿hay, entonces, una incapacidad para modernizarse de la propia sociedad?

E.J.: Hasta ahora hemos tenido esa incapacidad, es decir, la gran incapacidad política de la sociedad nicaragüense es su modernización y la expresión institucional sostenida de esa modernización, mirá como todo el intento de modernización durante el gobierno de Chamorro, entre el sector modernizante del sandinismo y el sector modernizante del anti-sandinismo se frustra de nuevo al intento de Antonio Lacayo de querer continuar en el poder. Bueno, Raquel, yo ya me tengo que marchar, pero estoy a tu disposición.

R: Claro, gracias. 
ENTREVISTA 30 ${ }^{44}$ :

Nombre del entrevistado: D. Antonio Lacayo.

Cargo actual: Ministro de la Presidencia durante el gobierno de Violeta Chamorro (1990-1997).

Fecha de realización de la entrevista: Managua, 18 de noviembre de 2009.

Lugar: Oficina privada en el Banco de América Central (BAC).

Duración estimada: 1 hora y 11 minutos.

\section{TEXTO - Transcripción 30:}

$R$ : ¿Cuál es su visión sobre los procesos de reforma constitucional que ha vivido Nicaragua en el contexto de la transición democrática?

A.L.: Yo te decía que todo esto de las reformas constitucionales hay que enmarcarlo dentro de un contexto amplio de nuestra cultura política, ¿verdad?, nosotros, diría yo, pues, si nos retraemos al 1500 y pico, aquí hay un proceso de colonización que dura 200 años, 300 años, exactamente, 300 años, en que la autoridad del país, que tiene sus representantes y que no se cuestiona, o si se cuestiona, pues, se somete uno a las consecuencias, y cuando nosotros nos convertimos en país independiente, tuvimos un poco la mala suerte de que teníamos dos ciudades importantes dentro de las muchas que constituían la Capitanía General de Guatemala, es decir, de Guatemala a Costa Rica, y nosotros, pues, el pedazo que nos tocó, Granada y León se disputaban el liderazgo nacional, y yo siento que ahí, al momento de la independencia, se da, pues, nuestro primer gran fracaso al no poder, realmente, operar como nación, continuamos operando, o pasamos a operar al independizarnos del rey, y al mismo tiempo de la hegemonía de la capital, que estaba en Guatemala, comenzamos a operar como ciudades Estado, Granada, por un lado, y León, por el otro, y comenzó la guerra, ¿verdad?, hasta el extremo que 20 años después de eso vino aquí traído por León, contratado por León un mercenario americano, William Walker, que vino, pues, a prestar su servicio a favor de un grupo, a favor de una ciudad en contra de la otra ciudad, incluso, llegó a hacerse presidente de Nicaragua por unos pocos días, destruyó Granada, y ese síndrome de grupo de ciudades Estado, en realidad, quedó muy metido en la cultura política del nicaragüense, cuando con ayuda del Ejército centroamericano logramos sacar a Walker vino un período de cierta estabilidad, que le llaman los 30 años de gobiernos conservadores, que había no reelección, y una serie de preceptos, cada cuatro años un presidente, obviamente, dentro del concepto de democracia de aquella época, por supuesto, las mujeres no votaban, la gente que no tenía patrimonio no votaba, pero dio paso, pues, a una cierta estabilidad, curiosamente, nunca ganaron los liberales, y cuando, por aburrimiento o por lo que sea, pues, los conservadores se fueron agotando los liberales optaron por una revolución armada, y asumieron el poder con Zelaya en 1893, entonces, Nicaragua deja de ser un poco Granada - León, pero pasa a ser conservadores - liberales, es decir, no dos ciudades Estado, pero sí dos grupos Estado, o dos tribus, que no se pueden ver en el terreno político, aunque, tal vez, algún liberal sí era amigo por familia o por algo de algún conservador, ¿verdad?, ya si iban a una

\footnotetext{
44 Entrevista interesante, especialmente, por el análisis de las relaciones conflictivas entre el Ejecutivo y el Legislativo en el contexto de las reformas constitucionales, refiriendo los poderes partidarios del Presidente de la República, como factor de impulso al Ejecutivo debilitado constitucionalmente desde la reforma de 1995.
} 
discusión política, pues, ya cada quien adoptaba su papel en este teatro, esa Nicaragua sigue dividida durante el somocismo, entre somocistas y anti-somocistas, a raíz de la revolución sigue dividida entre sandinistas y anti-sandinistas, incluyendo ahí el elemento armado de la Contra, y el fenómeno de Walker, se repite y se repite, es decir, los liberales leoneses traen a Walker en el siglo XIX, los conservadores en 1912 traen a los marines norteamericanos, que se quedan aquí 19 años, y los sandinistas traen a los soviéticos, entonces, es siempre el mismo patrón, es decir, yo traigo a un amigo mío de fuera para que me ayude a machacar al de adentro, entonces, en medio, diríamos ya, tenemos 180 años, no, casi 190 años de ser nación independiente y no hemos dejado de ser ciudades Estado, no hemos dejado de ser dos tribus, y, entonces, el concepto de Constitución que es la ley superior que nos va a regir a todos, ¿quiénes somos todos?, aquí habemos dos todos, entonces, lo que ha sucedido es que a lo largo de distintas etapas de la historia nuestra cada grupo que gobierna o que llega al poder por la vía que sea, normalmente, la vía armada, arma su Constitución, diseñada para sus intereses, y, normalmente, también, en contra de los intereses del otro, entonces, claro, cuando al cabo de 10 años o lo que sea viene una revolución o una invasión extranjera o una contrarrevolución o un golpe de Estado, bueno, el nuevo líder hace su Constitución para su, entonces, realmente, aquí el concepto de Constitución no existe, porque no hemos llegado a ser nación, no hemos alcanzado ese estado, el somocismo para muy atrás en la historia cambió las constituciones cuantas veces quiso, porque si el mandatario se quería reelegir, pues, y la Constitución decía que no, pues, la cambiaba, y cuando él no estaba en el poder, que de vez en cuando le dieron el poder a algunos presidentes ahí por un corto tiempo para no hacer tan aburrido aquello, entonces, le acortaban el período, pero si ya luego regresaba Somoza, pues, ya se lo ponía más largo el período presidencial, son trajes hechos a la medida, ¿no? Vino el sandinismo, tumba todo el andamiaje jurídico que había en tiempos del somocismo, y en 1987, después de 8 largos años de estar en el poder sin ningún tipo de Constitución, porque la anterior quedó derogada, es decir, gobernando de hecho, gobernando al amparo de un triunfo militar, decide hacer una Constitución y entra en vigor en 1987, en esa Constitución, por ejemplo, se permite la reelección indefinida, en esa Constitución sólo el presidente puede proponer a la Asamblea Legislativa candidatos a ocupar cargos en la Corte Suprema de Justicia, o en el Poder Electoral, solamente el presidente tiene la iniciativa de proponer, proponía tres nombres y la Asamblea escogía uno de los tres, sólo para mencionarte, digamos, dos características de esa Constitución, otra característica era el presidente tiene la obligación de cumplir y de hacer cumplir la ley, en otras palabras, es decir, tiene el derecho de que la ciudadanía cumpla la ley, qué sucede cuando por razones de un agotamiento económico, de una guerra entre contras y sandinistas, unos financiados por Estados Unidos, otros financiados por la Unión Soviética, Nicaragua llega, prácticamente, a postrarse, y los sandinistas encuentran un poco de salida en el Plan de Esquipulas del presidente Óscar Arias, y dicen, vamos a parar la guerra o vamos a ofrecer unas elecciones libres, pues, que es lo que dice Óscar Arias que hay que hacer, como las vamos a ganar porque nosotros somos populares, porque el pueblo está con nosotros, porque estamos a favor de los pobres y los pobres son la mayoría de este país, entonces, hagamos, pues, unas elecciones, hacen unas elecciones y las pierden, ¿por qué?, porque el pueblo no quería eso, es más, nunca lo quiso, el pueblo nunca estuvo a favor de una, diríamos, sí de la revolución en cuanto a tumbar a la dictadura, pero no con la revolución en cuanto la revolución era que nueve señores decidieran por todos nosotros, como eran los nueve comandantes de la Dirección Nacional, ahí entra un gobierno democrático, que es el gobierno de Doña Violeta de Chamorro, que comienza a gobernar con esa Constitución, y el país, curiosamente, con la misma Constitución 
sandinista pasa de la guerra a la paz, pasa del totalitarismo a las libertades públicas y a la democracia, y pasa de una economía colapsada, colapsada y endeudada hasta la coronilla, a una economía de mercado en crecimiento, con la misma Constitución, lo que te quiero decir con eso es que las constituciones aquí no valen, porque no puede ser que con la misma Constitución se hayan obtenido dos resultados tan opuestos como lo que significaba el sandinismo, sobre todo en los últimos tres años, con la Constitución ya en vigencia, y lo que significó el gobierno de Doña Violeta con la misma Constitución, ¿por qué no sirve?, porque la Constitución en tiempos del sandinismo, pues, no se aplicaba.

\section{R: La revolución era fuente de Derecho.}

A.L.: Claro, y siguió siendo fuente de Derecho aún con la Constitución en vigencia, un contrasentido inmenso, porque era su Constitución, ellos la hicieron, pero este concepto de revolución, digamos, castrista o sandinista, los coloca, ellos se colocan por encima de las leyes, es decir, la ley no es para ellos, la ley es para el ciudadano común y corriente, yo estoy arriba de la ley.

\section{$R:$ ¿Se refiere a la élite dirigente del partido?}

A.L.: Claro, claro, la revolución está por arriba de la ley, o sea, Fidel Castro está por arriba de la ley, Daniel Ortega está por arriba de la ley, es decir, ellos no conciben, pues, que ellos sean iguales al otro, ¿verdad?, ¿por qué?, porque son revolucionarios y porque tienen un mandato de alguien superior, pues, que les dice: "no, no, no, tú tienes la misión de dirigir este pueblo", es una suerte de Moisés, "y la ley no es para tí, pues, la ley es para los demás", porque, curiosamente, repito, con la misma Constitución aquí se obtuvieron dos resultados completamente diferentes, es decir, guerra con el sandinismo y paz con Doña Violeta, con la misma Constitución.

R: Bueno, hay unos acuerdos de paz previos y también una presión internacional, que favoreció sobre todo la paz en este país y en la región, porque habia otros países implicados en conflictos armados.

A.L.: Bien, esos esfuerzos habían comenzado mucho antes, los acuerdos de Contadora, quedaron en el papel porque el sandinismo nunca quiso entrar, lo que hubo fue un agotamiento, eso, y eso sí obligó al sandinismo, los acuerdos sirvieron un poco de plataforma para montarse en ellos, pero había acuerdos mucho antes, los acuerdos de Contadora, que se llamó, el grupo de Contadora ampliado, eso se da desde mediados de los 80 , por un oído le entraban y por otro le salían, ¿por qué?, porque todavía se sentía la economía más o menos, y el sandinismo se sentía fuerte, respaldado por la Unión Soviética, claro, cuando la Unión Soviética entra en los acuerdos con Reagan y viene aquí Gorbachov en septiembre, octubre, del año 89, y le dice a los sandinistas: "se acabó la música", ahí ya ellos corrieron a pensar en alguna otra cosa, ¿no?, pero vamos, entonces, a lo que pasa después, una vez que está ya Doña Violeta en el poder, hay que cambiar la Constitución, pero, por primera vez en la historia, no es el presidente el que cambia la Constitución a su gusto, por primera vez en la historia, como entramos a democracia, y en democracia todos somos iguales, se termina por un período esta división de Nicaragua en dos grupos, pero se crea una suerte de pugna entre el Ejecutivo y la Asamblea Nacional, el Ejecutivo, lamentablemente, una persona, además una mujer, además una vieja, ¿verdad?, en la Asamblea eran 90 hombres, machos, jóvenes, 
"hombre, quitémosle poder a este Ejecutivo, porque ahora estamos en democracia y el poder hay que diluirlo y pasémonos poder a nosotros, ¿no?”, y hay va Raymundo y todo el mundo, ¿verdad?, "Fuenteovejuna, todos a una", desde Sergio Ramírez que era el jefe de los sandinistas en la Asamblea Nacional hasta Doña Miriam Arguello, Alfredo César, y Luís Sánchez Sancho, y todos de la derecha, "sí, sí, sí, quitémosle poder al gobierno, ¿verdad?, pasémonos poder a nosotros", y, entonces, se da la reforma del 95, ya el presidente, lo más importante es que el presidente pierde, o mejor dicho le quitan el derecho a proponer Magistrados en la Corte, ahora cualquiera de nosotros diputados puede proponer y si el presidente manda su lista la tendremos en cuenta, pero aquí todos somos iguales, de ahí en adelante, el presidente, por supuesto, no ha logrado, por lo menos Bolaños, nunca logró meter un solo Magistrado, ¿por qué?, porque los que deciden son los diputados, los diputados, que, a su vez, como hay ahí un sub-desarrollo partidario tremendo, tanto en el Frente Sandinista como en el PLC, que no son partidos, son grupos-Estado, ¿verdad?, con las mismas características culturales de las dictaduras, es decir, caudillos, pero ahí el partido dice lo que dice el caudillo, ¿verdad?, entonces, si el caudillo dice que hay que poner de Magistrado a este teléfono, pues, ese teléfono es el que va de Magistrado, tenga las cualidades o no las tenga, el partido vota y se acabó el asunto, ¿no?, entonces, se ha degradado, enormemente, a partir de eso el Poder Judicial, tú puedes ver el Poder Judicial de ahora y en cualquier encuesta está llegando a cero, sin embargo, el Poder Judicial en 1996 cuando Doña Violeta termina su mandato no está en cero, tampoco elevó mucho, pero no era el desastre que es ahora, entonces, lo segundo, los sandinistas, verdad, como ahora yo no estoy en el poder, entonces, que no haya reelección, es mala la reelección, entonces, ellos votan a favor de establecer que solamente puede haber dos períodos para un presidente y no consecutivos, Daniel Ortega vota a favor de eso, ahora dice, como ahora está en el poder, ahora dice que eso fue una imposición de la oligarquía imperialista, y él votó por eso, o sea, hace pocos días Daniel se confesó oligarca e imperial, porque él dijo que eso lo hicieron los oligarcas imperiales, y él votó por eso, entonces, ¿qué sucede?, que las constituciones, las reformas constitucionales siguen obedeciendo al que está en el poder, con la única excepción de que Doña Violeta estando en el poder no propició una reforma, ella dijo: "yo gobierno con la que existe".

R: Pero también era un Ejecutivo presidencial fuerte, ¿no?, el que consolidaba el texto del 87.

\section{A.L.: Claro.}

R: ¿Por qué se niega la presidenta Chamorro, en ese momento, a aceptar la propuesta de reforma parcial a la Constitución?

A.L.: Por lo que estás viendo ahora, mira el Poder Judicial, mira también el tema del forzamiento de la ley, la nueva reforma dice que el presidente cumplirá la ley y la hará cumplir a aquellos que dependen de él, entonces, limitaron el poder del presidente al Ejecutivo, en el sentido, pues, de que si un Magistrado ahí violenta la ley, pues, es problema de otro, ¿verdad?, el presidente es un, con un problema, que en este país el pueblo cree que el presidente es Dios, es el Rey, entonces, se le pide al presidente que resuelva problemas que en una democracia no son del presidente, pero los otros poderes no se comportan como a la altura de las circunstancias, entonces, tú tienes un Poder Judicial que es un verdadero desastre, o sea, una fuente de robo increíble, pero, bueno, de conformidad con la Constitución actual el presidente no puede más que ver para otro 
lado, no tiene ninguna posibilidad de incidir en nada, porque ya, ni siquiera si violentan la ley, antes sí la tenía, entonces, el presidente, o sea, Doña Violeta está consciente de que la Asamblea Nacional no es una Asamblea Nacional es un lugar donde cada caudillo, cada jefe de partido, absolutamente, sub-desarrollado en su cultura política, tienen unos señores ganando un sueldo, ¿verdad?, pero ahí si tú revisas el debate diario, tú verás que de los noventa y un diputados que hay ahí hablan siete, ocho, los demás ni hablan, ni opinan, o sea, podríamos tener siete diputados, verdad, y sería igual el debate, igual, y sería igual la votación, entonces, es un teatro, cuando Doña Violeta ve que esos partidos, que nadie los elige, nadie elige a los caudillos de los partidos, son los que van a nombrar Magistrados, son los que van a nombrar Contralores, son los que van a nombrar Fiscales, son los que van a nombrar Procuradores, son los que van a nombrar el Consejo Supremo Electoral, y yo, presidente, que me he ganado el voto del pueblo, no puedo hacer nada, aquí hay algo malo, porque si los partidos estuvieran sometidos a la ley, si los partidos tuvieran que tener sus elecciones periódicas, y su democracia interna, hombre, producirían otro tipo de diputados y otro tipo de mecanismos para elegir a sus diputados, pero cuando, tú ves, realmente, quién va a tener el poder en este país, si el presidente, que se ganó el voto en la calle con la gente, ¿verdad?, por mayoría de votos, o, en este caso, dos señores, cada quien caudillo de su partido, yo como demócrata prefiero que lo tenga el presidente, es decir, el presidente tiene la legitimidad del voto, los demás no tienen nada, sin embargo, se hizo la reforma, ¿verdad?, porque desde los obispos, los empresarios, la comunidad internacional, pues, todo el mundo decía que bueno, la democracia, y todas las argumentaciones que se hicieron, pues, sobre la forma de elegir a los diputados, los Magistrados, sobre temas de ley, sobre temas que tenían que ver, incluso, algo con impuestos, los diputados no suben impuestos, nunca suben impuestos, sólo bajan impuestos, y un país después de una guerra tú no lo puedes reconstruir repartiendo la bonanza porque no hay, o sea, si en una democracia normal es correcto que haya ese tipo de relación entre el Ejecutivo y el Congreso, la Asamblea Nacional, en una situación como la que vivía Nicaragua en el año 95, que se ha extendido por muchos años, en mi opinión, pues, por eso, no cabía, no cabía todavía el pasarle a la Asamblea Legislativa la totalidad de la decisión en materia impositiva, porque la Asamblea no sube impuestos, no le gusta, un diputado no se va a echar esa responsabilidad encima, el populismo ahí ondea, entonces, nadie toma la decisión dura, y por eso nunca cuadran nuestros presupuestos, ¿verdad?, diferente es cuando un presidente gana una elección, hace una reforma fiscal, y el primer año de gobierno dice: "señores, hay que apretarse la faja para que estemos bien dentro de tres o cuatro años, y confíen en mí que vamos a estar mejor", entonces, hay quien hace la tarea, pero cuando el presidente no puede subir un impuesto porque es la Asamblea la que aprueba eso, comienza un debilitamiento, incluso, de las finanzas públicas muy serio, a menos que el presidente sea el caudillo que le tocó a Alemán serlo, porque ahí tiene la ventaja de que él es el Ejecutivo, pero también es el Legislativo, o Daniel Ortega hoy, tiene la ventaja.

\section{R: ¿El Legislativo porque controlas a tu bancada?}

A.L.: Claro, no es que controlas, porque son empleados públicos, pues, son empleados políticos, no tiene criterio propio, yo nunca he visto a dos sandinistas votar diferente, nunca.

\section{R: Pero eso se llama disciplina de partido.}


A.L.: No, eso no es disciplina, disciplina tiene sus límites, o sea, si aquí dicen que hay que matar a tu madre hoy, un sandinista u otro, pues, que maten a tu madre hoy, y yo creo que en España, tú dirías: "oye, yo soy disciplinada, pero yo llego hasta ciertos límites, y no voy a votar a favor de que maten a mi madre, pues", te pongo ese caso extremoso para que veas, y así como ese hay muchos casos en que una democracia, pues, yo lo veo en Estados Unidos, demócratas que votan a veces con republicanos, y republicanos que votan con demócratas, ¿por qué?, porque, hombre, yo no vengo aquí, yo no vengo a gobernar para un partido, yo vengo a gobernar aquí para un país, yo paso a ser diputado de Nicaragua, y presidente de la República, yo no paso a ser presidente del Frente Sandinista, ni del Partido Liberal Constitucionalista, pero, lamentablemente, en nuestra cultura política eso es lo que hemos tenido siempre, por lo que te explicaba anteriormente, es decir, hemos tenido presidentes de mi grupo, de mi bando, de mi ciudad, de mi partido, o de mi facción, y es natural, es decir, casi cuando ganó Doña Violeta la propia, mucha gente del lado nuestro, le pedía a Doña Violeta que actuara con el sandinismo en la misma forma en que el sandinismo había actuado con nosotros, es decir, que los echara presos, que les quitara determinadas propiedades, es decir, la gente pedía que el ciclo siguiera, por cultura política.

\section{$R: Y$, bueno, porque cerrar heridas también es muy difícil después de una guerra, ¿no?}

A.L.: No, pero tenía que cerrarlas, tenía que, es más, la amnistía estaba en el programa de gobierno de los 14 partidos políticos, ahora mucha gente dice: "¿por qué Doña Violeta dio una amnistía?", si estaba en el programa, y el programa ella no lo escribió, el programa lo escribieron los 14 partidos políticos, y después escogieron al candidato, pero tú te encuentras ahora a mucha gente de la antigua UNO que te dice, el propio Alemán, bueno, que te dice que Doña Violeta hizo esto y aquello, y estaba en el programa de gobierno, todo el tema de la propiedad estaba en el programa de gobierno, entonces, el problema aquí es que la Constitución, aunque no se cambiara, no se respeta, ¿verdad?, tú tienes ahí seis señores de la Corte Suprema, que sin tener ninguna facultad para decidir en temas constitucionales, pues, sacan un documento que dice que Daniel Ortega puede ser candidato, y ni siquiera la Corte en pleno tiene esa facultad, esa facultad es exclusiva de la Asamblea Nacional, sin embargo, el presidente de la República dice que está bien, el Consejo Supremo Electoral dice que está bien, y parte sin novedad, ¿verdad?, entonces, si no se respetan ni la Constitución, si ni siquiera se cuentan los votos en una elección, como sucedió en noviembre del año pasado, donde en Managua se escondieron las actas del $31 \%$ de las juntas, se escondieron, nunca las leyeron, nunca las contaron, para que pudiera ganar Alexis Argüello, el candidato del Frente, ¿tú te imaginas el respeto que habrá por una reforma constitucional?, o sea, eso es, se acomodan las cosas, pues, para dar algún viso de legalidad, y la hago a mi medida, caso concreto, el sandinismo, su Constitución del 87 permite la reelección en todo el sentido de la palabra, cuando ellos están fuera del poder prohíben la reelección, ahora que están en el poder, de vuelta a la reelección, ¿existe, como pregunté yo en un artículo, alguna explicación para semejante inconsistencia política?, la única explicación es que no hay ningún compromiso con ningún valor, ni con ninguna democracia, lo que hay es un compromiso con mis intereses, y yo te garantizo que si aquí pasara la reforma constitucional, esa, de que la reelección es buena, y en el 2011 gana un candidato que no es el Frente Sandinista, el primero que levanta la voz en contra de la reelección va a ser el Frente Sandinista, y va a haber una reforma en contra de la reelección, y dirán que es mala y que esto y que lo otro, entonces, yo propuse en un artículo, y lo he mencionado dos o tres veces, y algún día irá calando, que aquí la próxima reforma 
constitucional que hagamos los nicaragüenses tenemos que comprometernos a que tenga al final algún artículo que diga: "esta reforma entrará en vigencia 5 años después de publicada", para que el legislador y el caudillo que esté encima del legislador ya no estén legislando en función de su interés en ese momento, porque no sabe cómo va a estar dentro de 5 años, es decir, ya después habrá otro gobierno, que puede ser él o puede ser otro, que puede ser de su nuevo partido o de otro partido, ya no sabe si él será diputado o no será diputado, entonces, podríamos quizás comenzar a pensar en qué es bueno para el país, no en qué es bueno para mí en este momento, porque fíjate que a mí me pasó un caso concreto con la reforma del 95, se promovió la no reelección, y se promovió también lo que se llamó aquí y se llaman las inhibiciones, es decir, la prohibición de que determinada persona pueda optar a cargos de presidente, por ejemplo, los que habían vivido 5 años fuera de Nicaragua, los que habían adquirido otra nacionalidad, los parientes del presidente, entonces yo estaba, estoy casado con la hija de Doña Violeta y, bueno, Antonio Lacayo no puede correr, me dice a mí el presidente del Consejo Supremo Electoral de ese entonces, el doctor Mariano Fiallo Aranguren, "no te preocupés", me dice, "eso no puede ser retroactivo, la ley nunca puede ser retroactiva, tu entraste, tu eres pariente de una presidenta que fue electa antes de que entrara esta norma, por lo tanto, a ella no le toca esta norma, le tocará a los parientes del presidente que sea electo bajo la norma, de que los parientes del presidente pierden tales derechos, pero no los parientes de un presidente electo antes de la norma", eso me lo dijo el presidente del Consejo Supremo, además rector de la Universidad anteriormente, y un doctor en Derecho y en Sociología y en Ciencias Políticas y en muchas cosas, pero un año después tuvo que renunciar cuando cambiaron cabalmente la reforma constitucional del 95, y cambiaron la Ley Electoral y él dijo: "yo con esta ley no puedo", y renunció al cargo y se fue, y sí, me lo aplicaron retroactivamente, y, pues, que yo escogí para presidente, y cuatro meses antes salió una resolución del Consejo diciendo que yo no podía ser candidato, pero lo que te quiero decir es que cuando se está redactando esa reforma y se aprueba en primera legislatura dice: "no podrán ser candidatos los parientes del presidente de la República en cuarto grado de consanguinidad y segundo de afinidad", entonces, yo me voy un día a un programa de televisión y alguien me pregunta esto, y yo cometo el error de ser gracioso, diciendo, pues, que platicando con mi esposa, ella me ha dicho, pues, que si estar casado con las leyes de Nicaragua va a ser un impedimento, pues, que nos vamos a divorciar ante la ley, y que nos vamos a quedar casados ante Dios y ante el amor, al día siguiente el obispo, "Lacayo, es capaz por una misión de anular su matrimonio, y va a dejar a sus hijos en el abandono, y que no sé cuanto", pues, han cambiado la norma constitucional en la segunda legislatura, cosa que no se puede hacer porque tiene que ser el mismo texto en ambas legislaturas, pues, han cambiado el texto y han puesto lo que está ahora, que dice: "no podrá ser candidato a la presidencia en el que fuere o haya sido pariente del presidente", entonces, fue una norma hecha, verdad, es decir, pensando en Antonio Lacayo, entonces, cuando se habla aquí de reelección se está pensando en quién es el que se quiere reelegir, o sea, Daniel Ortega defiende hoy en día la reelección, ¿por qué?, porque él es el que se quiere reelegir, pero si el presidente fuera yo, él diría: "no", porque el que se quiere reelegir soy yo, no sé si me explico, es decir, por eso digo yo, legislemos en favor de lo que va a pasar dentro de cinco años no de ahorita, para que las, para que no podamos ver el rostro de nadie, en los cambios que queremos hacer.

$R: Y$, sin embargo, la propia vulnerabilidad jurídica de la norma ante las situaciones políticas concretas ha hecho aparecer ese instrumento tan sui generis en Nicaragua como son las leyes Marco, que, en el fondo, es una suspensión, una congelación en el 
tiempo de la aplicación de la norma constitucional reformada, incluso, poder reformar la propia Ley Marco, como pasó, en el caso de Ortega, con la reforma del 2005, que retrasó un año su entrada en vigor, o sea, es ya rizar el rizo, como dicen en España, ¿no?

A.L.: Sí, exacto, ese es otra cosa que se ha metido, ese tema de las leyes Marco, pero es que no sería una Ley Marco sería eso, una reforma, ¿verdad?, es decir, cuando Torrijos y Carter dicen: "se entrega el Canal", sí, "el 31 de diciembre", no dice hoy, entonces, hay una Ley Marco ahí, porque hay una voluntad, se entrega el canal, pasa a ser territorio panameño, y lo firman en el 78, allá, se entrega allá, entonces, no es Ley Marco, sería decir, esta es la Constitución que requiere este país y entra allá en vigencia, entonces, diseñemos algo que no tenga rostro, que no sepa Daniel Ortega si él va a estar arriba o él va a estar abajo, que no sepa el diputado si él va a ser diputado o va a ser un empresario ahí, o un agricultor, que no sepa el Magistrado que está en la Corte, que quiere bloquear eso si va a ser Magistrado o va a andar haciendo gestiones ante los Magistrados, es decir, que nos separemos del interés personal y del interés partidario del momento, y pensemos, aunque sea por un rato, en el interés del país, si no, nunca vamos a tener país, porque siempre vamos a estar legislando en función de lo que se ha legislado siempre, que es los intereses del grupo que está en ese momento ahí, desde que existen las constituciones aquí.

R. ¿Y qué piensa usted del pacto entre Ortega y Alemán, que es el segundo momento constitucional, la segunda reforma del 2000, que algunos han llamado, incluso, la contrarreforma?, porque en el 95 hay todo un arco parlamentario de múltiples partidos, y pienso, muy especialmente, también en los partidos pequeños, que tuvieron representación parlamentaria en las elecciones del 90, ¿no?, y, sin embargo, en el año 2000 son dos grandes partidos los que pactan y los que hacen la reforma.

A.L.: Porque ellos son los que están en el poder, es que en el 90, los que están en el poder son los pequeños partidos, porque la UNO eran 14 partidos.

\section{R: Y es una coalición, además que se disuelve, ¿cómo vivió usted la experiencia?}

A.L.: Que se disuelve, que se disuelve, y el Frente Sandinista, pues, queda en minoría, entonces, si tú te das cuenta, el poder, verdad, que, en una democracia, en realidad, lo tienen en buena medida, el parlamento y no tanto el Ejecutivo, porque el Ejecutivo se tiene que comportar dentro del marco de la ley, y no por encima de la ley, el poder, a partir del 90 lo tienen los pequeños partidos que están en la Asamblea, entonces, legislan en su beneficio, pero cuando van a las elecciones del 96, esos pequeños partidos, pues, no logran sacar votos, y la mayoría de votos lo saca el Partido Liberal Constitucionalista y el Frente Sandinista, entonces, a partir del 96 hay un nuevo poder en Nicaragua, no los pequeños partidos, sino estos dos grandes partidos, y vuelve lo mismo, "pongámonos, ahora el poder es para nosotros", no hay cambio en la filosofía, en el pensamiento, lo que hay cambio es de actores, ¿te das cuenta?, entonces, Alemán le propone a Ortega: "oye, aquí hagamos un acuerdo", que una persona muy cercana de Ortega me dijo que era el acuerdo de la camioneta, "mirá como es el pacto", me dice, "el que gane de ahora en adelante va a ir adelante, en la cabina con aire acondicionado, y el que pierda va a ir atrás al descubierto, tragando sol y polvo, pero nadie más se monta a esta camioneta", y ese es el pacto hasta el día de hoy. 
R: ¿Y el pacto sigue en su opinión?, porque algún entrevistado me ha dicho que el pacto es un procedimiento para resolver las crisis institucionales en las que entra Nicaragua.

A.L.: No, no, no, de procedimiento nada.

R: Bueno, un procedimiento informal, me refiero.

A.L.: Procedimiento es la ley, el único procedimiento debe ser la ley.

R: No, no, pero me refiero a un procedimiento informal, es decir, de facto, era la opinión.

A.L.: No, el pacto es, diríamos, diría yo, es la cara oscura de algo positivo como sería un acuerdo, pero, hombre, los Pactos de la Moncloa son unos acuerdos en función de España, el pacto de Alemán y Ortega son unos acuerdos en función de los intereses de Alemán y de Ortega, ni siquiera del Frente Sandinista, ni del PLC, son en función de dos personajes, que como son caudillos, no necesitan ni siquiera consultar mucho sus cosas con sus bases, entonces, ¿Alemán qué quiere?, Alemán quiere que al terminar su mandato él pase a ser miembro de la Asamblea Nacional, en la Constitución anterior, digo, en la Constitución eso no estaba, tú te ibas a tu casa, bueno, ibas al Parlamento Centroamericano, pero eso de ir a Guatemala una vez a la semana, pues, no estás en la política, Alemán decía: "yo quiero estar, porque después yo regreso, es decir, yo voy a estar un período fuera, y después yo regreso, entonces, yo quiero seguir vigente, me voy a meter a la Asamblea, pero ¿cómo paso yo de presidente a diputado?, ah, muy sencillo, cambio la Constitución para mi gusto y pongo aquí una cláusula que diga que la Asamblea Nacional está compuesta por 90 diputados más el candidato perdedor, más el presidente saliente", y Daniel Ortega tenía otro interés, "OK", le dice, "yo te doy eso, pero a mí dame que esa norma que se puso en el 95 de que hay segunda vuelta a menos que saqués el $45 \%$ del voto para arriba, bajámelo a $35 \%$, ¿por qué?, porque mi interés es ganar con el menor número de votos posible, yo voy a ver cómo divido a la oposición”, y Alemán creyendo que jamás va a dividir a la oposición, pues, le da el 35\%, entonces, eran dos intereses personales, Daniel Ortega que quiere ser presidente sin llegar jamás al $50 \%$, ni al $45 \%$, porque nunca va a llegar, o sea, nunca ha llegado, arriba del $42 \%$, y Alemán que quiere ser diputado, y pactan, son dos intereses personalísimos, porque nunca hubo reforma, eso lo que pasa es que te lo dice Luís Humberto Guzmán y todos los que propiciaron la reforma, nunca hubo reforma, lo que hubo fue adaptación de la legislación a los intereses míos, eso es todo lo que hubo, en aquél tiempo los intereses de esos señores era que la Asamblea tuviera más poder, que la Asamblea eligiera a los Magistrados, que la Asamblea eligiera los impuestos, y que el presidente tuviera menos y menos poder, porque llegar a la presidencia es uno solo, aquí estamos 90, repartámonos entre nosotros nuestro botín, ah, ¿que Nicaragua no va a progresar?, ah, eso no es problema mío, yo voy a progresar.

R: Yya con la reforma del 2005 todavía se debilita más el Ejecutivo.

A.L.: Por supuesto.

R: Y Enrique Bolaños es un presidente acosado desde su propio partido. 
A.L.: Bueno, eso es producto de la reforma, realmente, del 95, Bolaños no tiene poder porque tampoco hubiera tenido poder Alemán, a menos que Alemán hubiera sido el caudillo de su partido, es decir, si en el 95, mira lo que te voy a decir, si en el 96 en lugar de ganar la presidencia Arnoldo Alemán, líder del PLC, hubiera puesto a Bolaños, y Alemán se hubiera ido a la Asamblea Legislativa, ¿verdad?, y hubiera dicho: "Don Enrique, usted es mayor que yo, vaya usted, después voy yo", ese Bolaños, verdad, no hubiera mandado nada en el 96, porque el poder hubiera estado en la Asamblea, lo que pasa es que llegó a la presidencia el líder de la Asamblea, es decir, el líder del partido, que controla la Asamblea, entonces, tú haces un research ahí, una investigación en La Prensa, en El Nuevo Diario, de lo que decía de los problemas entre la Asamblea y el Ejecutivo del 97, 98, 99 y verás que casi no había dificultades, ¿por qué?, porque el nuevo presidente era presidente del otro poder del Estado, a través de sus diputados, ¿qué pasa?, se va Alemán, y se va Alemán a la Asamblea por la reforma del 2000, verdad, pasa a la Asamblea y queda Bolaños de presidente, ¿qué fue Bolaños?, un presidente sin ningún poder de cambiar nada, un administrador, una cosa ahí, pues, limitadísima, ahora...

R: Que es algo que tiene en común con la propia presidenta Violeta Chamorro, o sea, ambos son los presidentes a los que los dejan solos sus respectivas fuerzas partidarias en la Asamblea Nacional.

A.L.: Con una ventaja, Doña Violeta, que la confrontación que hubo en los años 80 dejó a la derecha y a la izquierda, si la podemos llamar así, ¿verdad?, porque yo creo que ni la derecha es la derecha, ni la izquierda es la izquierda aquí, pero bueno, a esos dos grupos los dejó tan polarizados que no podían votar juntos, y nosotros nos agenciamos un pedazo de la UNO, 10 diputados, 9, que por lealtad personal con Doña Violeta, y con el programa de la UNO, que decía lo que estábamos haciendo nosotros, decidieron respaldar a Doña Violeta, cuando la UNO, mayoritariamente, se va, pero la UNO y el Frente no podían verse, entonces, nosotros con 10 diputados a veces sacábamos leyes con el Frente, a veces sacábamos leyes con la UNO, y pudimos navegar, además de que teníamos una Constitución presidencialista, entonces, teníamos dos ventajas sobre Bolaños, una Constitución fuerte, y una Asamblea donde los extremos, por llamarlo de alguna manera, no podían entrar, porque eran como agua y fuego, entonces, nosotros con una bisagrita ahí, tipo "Convergencia y Unión", en tiempos de Felipe, verdad, pues, ahí hacíamos mayoría con quien, Bolaños se encuentra con que los extremos, en este caso, el PLC, verdad, y los sandinistas ahora son compadres, verdad, y son amigos, y, por otro lado, una Constitución que ya está cooptada en cuanto al poder de nombrar Magistrados y de todo eso, ¿verdad?, claro, tuvo la ventaja él de que encontró un país en paz, y un país con una economía que ya caminaba, etc., ¿no?, que no lo tuvimos nosotros, pero hay un cierto parecido, ¿verdad?, entonces, ese es uno de los problemas aquí, que si el próximo presidente, verdad, tú traes aquí de presidente, pues, a Barack Obama, luego la Asamblea la dominan Alemán y Ortega, y Barack Obama no va a poder hacer nada, ¿me explico?, ¿por qué?, porque el poder se le quitó al presidente, en la reforma del 95 se le quitó al presidente, se le despojó al pueblo, porque el único representante aquí electo por el pueblo en forma directa es el presidente, incluso, los diputados van en una plancha, van en una plancha, yo conocí diputados en el 90, de los nuestros, pues, me acuerdo, perfectamente, de un señor amigo mío, que los que íbamos con Doña Violeta a un pueblo que se llama Ciudad Darío, en un calor infernal, subiendo unas calles así empedradas, la camioneta en que iba Doña Violeta, Destina, porque ella se había quebrado la pierna, se apagó, y la tuvimos que empujar entre varios para llegar 
a la parte plana, este diputado, este candidato a diputado, estaba en la acera, en una acera de una casa de esas grandes ahí de pueblo, una acera alta, verdad, tomando un trago, una cerveza helada, verdad, viendo pasar la manifestación nuestra, es decir, el presidente jalando el voto, uno por uno, uno por uno, el diputado sabía que él era cuarto en la lista nacional, hombre, yo me puedo ir a Miami durante toda la campaña y yo salgo electo, porque yo no voto aquí por un diputado, yo voto aquí por una lista, y no puedo decir éste y éste de esta otra lista, no puedo, después los diputados dicen: "nosotros representamos al pueblo", no representan al pueblo, porque nunca nadie votó por ellos, votó por una lista cerrada.

\section{R: ¿Propuesta por el partido?}

A.L.: Propuesta por el caudillo del partido, es decir, ni siquiera por el partido, porque hay gente que es líder en su comunidad, y líder de su partido en su comunidad, pero si aquí en Managua, o en $\mathrm{El} \mathrm{Chile} \mathrm{C}^{45}$ o en de la secretaría del Frente no lo quiere poner a él, no lo ponen, y no pasa nada, y ponen a otro, ¿verdad?, y hay casos por montón de esos, verdad, y entonces, ¿qué sucede?, que la ley, la soberanía ciudadana, verdad, que vota y elije a un presidente, y le pide que resuelva, y le pide que actúe, pues, resulta que estos señores en el 95, dicen: "no, no, no, no, si te hemos elegido pasémoslo donde nosotros", y a eso es a lo que llaman reforma, por favor, eso no es reforma, lo que pasa es que, en ese tiempo, lo hicieron como reforma, pues, porque hombre, la democracia es el equilibrio de los poderes, $\mathrm{y}$, bueno, y la Constitución sandinista es presidencialista, y eso es un desequilibrio, y se vistió, pues, de gloria la reforma, pero yo te digo, mira los resultados, mira el Consejo Supremo Electoral de ahora, o sea, ni siquiera cuentan los votos.

R: Y, a su juicio, el presidencialismo del 87 habría sido mejor que incrementar las facultades de la Asamblea Nacional.

A.L.: En aquél tiempo sí, y yo le dije a Sergio Ramírez, cuando Sergio Ramírez a mí me dice: "es que hay que hacer una reforma", "mira, Sergio, ¿y por qué hay que hacer una reforma?", le digo, "ustedes hicieron una Constitución hace apenas 5 años", porque eso me lo dijo en el 92, "y hace 5 años era bueno esto y esto y esto, ¿ahora es malo?, ¿no será porque es que ahora no están ustedes en el poder y está otra persona?", le digo yo, "¿cómo es posible que en 5 años?", "ah, no", me dice, "pero es que el país estaba en guerra, y necesitábamos una Constitución presidencialista”, y yo le dije: "Sergio, el país sigue en guerra”, “¿cómo?”, me dice, "sigue en guerra”, le digo, "contra el atraso, contra la pobreza, contra 20 años de guerra que destruyó todo, aquí necesitamos por lo menos 10, 15 años de un gobierno fuerte, que, con un norte claro, haga progresar este país, aquí no hay tiempo que perder", digo, "es más, esta guerra es peor que la que tienen ustedes", le digo, porque esta es una guerra contra la miseria, contra la pobreza, que heredamos de esa guerra, o sea, aquí no estamos en un terreno como para así ya, que fue un gran error que cometieron, incluso, los Estados Unidos, a mí me lo dijeron senadores y todo, que ya Nicaragua es una democracia, sí, es una democracia, pero esperáte, tenemos apenas cuatro días de ser demócratas, ¿cómo se nos va a pedir que seamos democracia como la de Estados Unidos después de 200 años?, “¿qué pasaba en Estados Unidos, le digo yo, en 1779?”, “¿cómo?”, me dice, “sí, cuando ustedes tenían tres años de ser independientes, ¿qué pasaba?, no había asesinatos aquí, no había

45 Nombre de la hacienda privada del ex-Presidente Arnoldo Alemán situada a las afueras de Managua. 
barbaridades, nosotros llevamos tres meses", le decía yo, “¿cómo nos van a exigir a nosotros la perfección?", o sea, el concepto de transición no existe, o no nos vieron nunca como una transición a la democracia, es decir, tú llegas aquí a este piso, pero pasarás por el dos, por el tres, por el cuatro, es decir, ah no, aquí querían que, de repente, ya Nicaragua es demócrata, ¿por qué?, porque se ganó una elección, sí se ganó una elección, pero, bueno, en Estados Unidos nos exigían que quitáramos a Humberto Ortega y que quitáramos el Ejército y que quitáramos, señores, vamos a ir por pasos, vamos a ir por pasos.

$R$ : Y todas esas concesiones institucionales al Frente, y ese pacto al que se vio obligada la propia presidenta Violeta Chamorro con Daniel Ortega, ¿obedecía a esa necesidad de ir acomodando poco a poco la nueva institucionalidad?

A.L.: Pero nunca con Daniel, yo no negocié con Daniel, mira que curioso, yo negocié con Humberto Ortega, lo que se llamó el Protocolo de Transición.

\section{$R:$ ¿Él fue el que negoció los acuerdos?}

A.L.: Él fue por parte del sandinismo, y yo fui por parte del nuevo gobierno, y ahí, ¿qué es lo que nace de eso?, nace la institucionalidad del Ejército, es la institución más elevada hoy día ante el público, y, en ese momento, era la peor, yo no pacto con Daniel.

$R$ : ¿Y cuál es la diferencia entre los dos hermanos, dos comandantes, dos personas que están al frente de la revolución?

A.L.: Pues, Caín y Abel, hermanos, los dos únicos pobladores del paraíso terrenal y eran diferentes, ¿no?, son diferentes, es decir, Humberto, en mi opinión, sentía un compromiso con una revolución que produjera algún resultado, verdad, después de 10 años aquello no producía nada, es decir, Nicaragua en el año 90 es más pobre que en el año 79 , todo lo demás son buenas intenciones, que yo quiero a los pobres, sí, pero, bueno, ¿cuántos pobres hay?, ¿más que antes?, pues, te jodiste, y Humberto, entonces, cuando gana Doña Violeta él se pliega con nosotros.

R: Pero, primero le dice a Doña Violeta que no quiere abandonar las Fuerzas Armadas, cuando ella le reclama al principio.

A.L.: Porque quiere ayudar con las Fuerzas Armadas al proceso que viene, la reacción de él es: "yo me siento contento con que ustedes hayan ganado", léete mi libro, entonces, yo le digo: "bueno, ¿vos querés ayudar?, ayudá, pues", que me voy a poner yo, no, Humberto Ortega, ¿quién venía ahí detrás?, otro sandinista, y después otro, si todos eran sandinistas, ¿no?, entonces, yo con Daniel nunca pacté, nunca, es decir, claro, él armó, tan pronto como subió Doña Violeta, armó unas asonadas y unas cosas, pero ahí eran más bien por concesiones sindicales a los empleados públicos, nada, digamos, de carácter político, la concertación que nosotros hicimos no fue con Daniel, jamás me junté con Daniel, era con los sindicatos sandinistas, con la UNAC, que eran los productores sandinistas, y los productores del COSEP y los sindicatos que les llamaban democráticos, en un concepto sueco de gobierno, sectores empresariales y sectores laborales, Daniel, obviamente, siempre quería sacar sus cositas, ¿no?, pero así, digamos, el pacto, en el sentido de repartir el poder formal, institucional, jamás, jamás, jamás, eso arranca con Alemán, lo que vemos nosotros en el 90 es, obviamente, que tú, 
es decir, ¿cómo montas una democracia?, pues, yo nunca lo he leído en un libro, como tú montas una democracia, después de 170 años de totalitarismo, de dictadura, de golpes de Estado, es decir, hay era un poco el sentido común, ¿no?, entonces, país destruido, país endeudado hasta aquí, un país acostumbrado a la violencia, luego viene Óscar Arias y dice: "hay que eliminar el Ejército", joder, si aquí hay más armas que gente, ¿qué haces si te quedas sin Ejército?, ¿quién va aquí a garantizar qué?, nada, nada, entonces, bueno, eso se puede, pero más adelante, le decía, pero claro, Costa Rica que ya tiene 100 años de paz, pues, dice, ¿para qué Ejército?, pero es que hay que entender el momento de cada país, de cada proceso, y cuando Humberto Ortega reacciona, pues, al triunfo nuestro de una forma, absolutamente, madura, ¿verdad?, y queriendo él contribuir, hombre, es importante que esta institución se sienta que pueda ser parte de este proceso, y cuando los sandinistas vean que esta institución queda intacta, hombre, van a tener la confianza de que no a ser lo que pasó con Somoza, pues, que cuando Somoza cae, verdad, la Guardia Nacional cae, y todos los somocistas tienen que esconderse como cucarachas, eso hubiera provocado que el sandinismo o parte del sandinismo hubiera vuelto a las armas en contra de nosotros, hombre, pero si el Ejército iba a estar ahí, ¿cómo va a hacer Doña Violeta para echar preso a cualquiera?, entonces, ya la gente dijo: "no, me quedo tranquilo", y los sandinistas se fueron a sus casas, miles de policías, de gente de los ministerios, se fue a su casa y a buscar trabajo, ¿verdad?, porque no se sintieron amenazados, porque vieron que el Ejército era el mismo, y la Policía era la misma, pero estas instituciones entendieron, "señores, se acabó eso de la revolución, aquí vamos a hacer lo que diga la Constitución, la que ustedes hicieron, yo no la hice, aquí lo que dice es esto y esto, que el presidente de la República es el Jefe de las Fuerzas Armadas, ¿estamos de acuerdo?", "sí, estamos de acuerdo", "OK, perfecto, entonces, obediencia al presidente, vámonos por el camino de las leyes", y este país comenzó, y pasó de la guerra a la paz en cuestión de dos meses.

\section{$R$ : $Y$, sin embargo, ahora uno lee los carteles: "A treinta años de la revolución".}

A.L.: Pero, ¿qué revolución?, si Daniel está ahí por una elección no por una revolución, que hubo una revolución, hubo una revolución, aquí no hay una revolución de nada, ni los mismos sandinistas creen en eso, los que creen en eso son los muchachos de 16 años que su papá le contó que hubo una revolución y se ponen los pañuelos y andan felices de la vida, pues, como en España alguna gente se pondrá ropa de tiempos del Rey, pues, para alguna obra de teatro, ¿no?, aquí no hay ninguna revolución, ¿por qué?, porque eso coronó en una Constitución, que aunque ellos no la respetaron después sí nosotros la respetamos, y esa Constitución y la necesidad de parar la guerra dio paso a una elección, y a raíz de esa elección, "señores, se acabó", ahora ya en adelante las autoridades se van a elegir por el voto popular, no por las armas, entonces, la revolución, lo que pasa es que Daniel no sabe navegar en estas aguas.

\section{$R:$ ¿Democráticas, se refiere?}

\section{A.L.: No sabe.}

R: No, y el cierre de espacios políticos tanto en la Asamblea como en el caso de la sociedad civil, ¿no?, a mi me ha tocado observar a la gente en las rotondas, y he entrevistado a personas vinculadas al movimiento ciudadano, y, bueno, me hablan de las turbas, escenarios casi fascistas, o sea, de salir al golpear a ciudadanos que protestan y ejercen un derecho fundamental. 
A.L.: No, y esta última marcha que fui, que fue el 28 de febrero, ahí ha habido, y ya cuando llegamos por allá, por la actual Asamblea, ahí estaba la Policía, y unos señores sandinistas ahí tirando morteros, piedras y todo, hasta ahí llegó la marcha, pues, porque tampoco vas a ir a matar a los, y la Policía viendo ahí, sin ninguna intención de defender a nadie, ahora se montó una marcha para el sábado, ¿ya?, yo creo que al final no habrá marcha, porque resulta que el permiso está dado, pero el señor Porras dice que él va a estar ahí con todos los sandinistas, y los sandinistas significan, los morteros, los chavalos de los barrios que los recogen en buses, y, bueno, hay gente nuestra que dice, bueno, yo también voy a ir preparado, y ya, entonces, aquí lo que vamos es de vuelta otra vez a una pequeña guerra, pues, ¿qué sentido tiene?

\section{$R:$ ¿Y cómo ve el futuro de su país?}

A.L.: Yo lo veo bien, es decir, yo creo que esto está agotado, este sistema no se sostiene, es decir, el sandinismo en los años 80 era otra cosa, había una mística ahí, si me das tu correo electrónico te voy a mandar un testimonio, que me mandó una persona buena amiga mía por un blog de esos, verdad, yo ni sabía quién era, pues, y me dijo que iba a comenzar a leer el libro, un libro mío, que si yo estaba dispuesto a unas preguntas a medida que él fuera leyéndolo, pero se lo manda a un montón de personas este libro, "sí", le digo, "con todo gusto", entonces, me manda el otro día: "ya leí las primeras 160 páginas y aquí está escrito esto que le llamo mi transición”, y resulta que es un sandinista que se metió al sandinismo hace 15 años, y la revolución lo agarró con 19 años, y entró al sandinismo por unos ejercicios espirituales en Estelí, él cuenta como el cura lo metió, pues, ahí y todo estaba armado, la teología de la revolución, ahora vive en Estados Unidos, verdad, entonces, él cuenta qué fueron los años 80 para él y es fascinante, nunca, de esa gente que vivió el sandinismo como una religión, ¿verdad?, como una religión, ahora eso no existe.

\section{$R: Y$, sin embargo, si no se junta el liberalismo, si no hay un candidato presidencial único.}

A.L.: Sí, va a haber uno, va a haber uno solo creo yo, lo que sucede es que no es fácil porque Alemán es una suerte de doble agente, verdad, pero cada día se le está volviendo más difícil ser doble agente, y las bases de su partido le exigen, pues, la unidad, no que se quite, la unidad, entonces, él va a entrar en una suerte de cámara de tortura a medida que pasen los meses próximos, pues, porque si se va por el lado que le están exigiendo sus bases y los obispos y el empresariado y los movimientos sociales, pues, de elegir un Consejo Supremo Electoral, digamos, correcto, etc., él se va a tener que despegar de Daniel, y Daniel se lo va a cobrar, entonces, y él se va a pelear, y le meterán otro juicio, entonces, si él queda peleado con Daniel su partido, eventualmente, lo va a terminar abandonando, es decir, aquí estamos en manos de Daniel, pero Daniel ya es predecible, pues, y estamos en manos de Alemán, tratando de que entienda que su futuro, pues, hombre, está más de este lado, pero son 6 o 7 años de ser prisionero de este hombre, ¿no?, y yo creo que él ya tiene reflejos condicionados, es como el perro de tu casa, que con sólo tú le digas él ya se pone, aunque tú no digas nada él ya reacciona y se pone en el suelo, ¿no?

\section{R: Y le ha hecho mucho daño al país el ser rehén político de Ortega.}


A.L.: Hombre, mira la pobreza de este país, no, no es justo, este país comenzó a crecer en el año 90, bueno, esta gran pobreza es, en parte, aparte de la histórica, tienes los 10 años de revolución, que redujeron el PIB el 30\%.

\section{R: Bueno, también hubo un bloqueo.}

A.L.: Ya, pero ¿por qué Costa Rica no tuvo bloqueo?

R: Porque, de algún modo, Costa Rica siempre ha sido afin a Estados Unidos, aqui se planteó también una situación...

A.L.: Sí, pero ¿cuál era el afán de estar en contra de Estados Unidos si nuestro problema era salir de una dictadura?, ese tema lo trajeron de Cuba estos señores, ¿y qué teníamos nosotros que ver con Cuba, pues?, entonces, de repente, el presidente Carter le da 70 millones de dólares de ayuda, y llega Daniel Ortega a la Casa Blanca a hablar una cantidad de barbaridades, y después comienza a confiscar propiedades, $\mathrm{y}$, de repente, el propio Congreso de Estados Unidos le retira la ayuda que el propio Carter le había dado.

\section{R: Y ahora existe el factor Chávez, es verdad, no están los rusos, pero está Venezuela.}

A.L.: Esa es la gran suerte de Daniel y la gran mala suerte nuestra, pues, que Daniel siempre encuentra un padrino que lo mantenga, pues, es como esas personas que no tienen que trabajar, porque tienen una tía rica, la vez pasada la tía rica se llamó Europa en los primeros años, y la Unión Soviética en el segundo período, ahora la tía rica es Chávez, ahora, si no hubiera tía rica te cuento que esto sería muy diferente, pues, porque el mismo Daniel había cambiado bastante, yo lo traté mucho en el 2001, y no es el de ahora, pues, ni era el del 95, es decir, había madurado, pero, hombre, una persona que no trabaja y que tiene que trabajar, $y$, de repente, le sale otra tía rica, hombre, eso es el cielo.

R: Y ya para terminar, porque no quiero quitarle mucho más tiempo, ¿cómo contempla el futuro de la Constitución?, he oído planteamientos, incluso, de convocar una nueva Constituyente y de llamamiento al diálogo nacional si la crisis actual, pues, se profundiza, ha sido una Constitución parcheada, porque, incluso, en la gran reforma del 95, se plantea el debate de una reforma total y una reforma parcial a la Constitución del 87, ¿es tan dificil encontrar un marco jurídico moderno al cual se ajuste esta opción política que todo el mundo reconozca en la vida democrática?

A.L.: Yo no creo que sea tan difícil, el problema está en quiénes van a redactar esa Constitución, o esa Constituyente, pues, ¿cómo van a elegir a esas personas?, si esas personas van a venir, realmente, representando la ciudadanía, yo digo, bueno, perfecto, y ya veremos si sale algún espanto de Constitución, ni modo, eso es lo que somos y eso es lo que nos merecemos, pero el problema es si lo que van a hacer son el grupo este de Daniel, y el grupo de Alemán, y el grupo del otro, y se van a robar las elecciones, $\mathrm{y}$, entonces, yo llego a la Constituyente, y yo no gané porque no leen el acta, y, entonces, ¿para qué cambiar una Constitución por otra que va a ser igual o peor?, es como el Consejo Supremo, es decir, ahorita el Consejo Supremo termina su período, y hay la posibilidad de elegir uno nuevo, pero si Alemán se pone de acuerdo con Ortega a que siga, pues, lo que llamamos pacto, y van a elegir a unos señores primos hermanos de los 
que ya están, pues, no cambiará nada, entonces, la gente dice, bueno, un nuevo Consejo sí, pero ¿cómo se va a elegir?, si es el mismo pacto, pues, mejor que se queden los actuales señores, ¿verdad?, por lo menos no tendrán que comprar muebles nuevos en sus oficinas, porque si eligen uno nuevo, pues, querrán cambiar el escritorio y la computadora y esto y lo otro y la camioneta, y será la misma conducta, porque el problema no es la ley son las personas a las cuales se les da esa potestad, después las leyes aquí son magníficas, se prohibió votar basura, pero aquí todo el mundo tira basura, ¿qué policía te dice a tí que no la tires?, póngame aquí policías y ya verás, ¿por qué?, porque la basura es una cosa, pues, no sé, que todo el mundo la vota, pues, la Policía cree que no es su tarea, pero, bueno, está ahí, está prohibido, ¿por qué la Policía no te multa?, “¿quién es el dueño de esta casa?”, "mire usted, recoja toda esta vaina o va preso tres días", entonces, no es la ley, y nosotros siempre andamos buscando, no sé si es un mal latinoamericano, vamos a cambiar las leyes, vamos a cambiar la Constitución, pero si la hemos cambiado todas las veces que hemos querido, y no cambia nada, entonces, no es ahí la solución, no es por ahí, y tenemos que cambiar, digamos, las personas que encarnen un pensamiento nuevo, que luego lo traduzcan a una cultura política nueva, pero hemos tenido muy mala suerte hasta ahora, porque los, o sea, estuve en Cuba en el 2003, creo que fue, 2002, me llamó la atención que llegó a cenar con nosotros, andaba una delegación nuestra, el Ministro de la Industria Básica, una de las 10 personas más importantes allá, llegó en un Lada, un Lada, bien mantenido, pero en un Lada, después de cuarenta y pico años de revolución aquí a los tres días el mismo Edén Pastora andaba en un Mercedes Benz deportivo y todos los comandantes la "Toyotona" más grande que había en el país, ¿verdad?, al tercer día, entonces, allá hubo una mística, una cosa, y, pues, aquí desde el primer día, las mejores casas y los mejores vehículos, ¿verdad?, Daniel Ortega anda en un Mercedes Benz, entonces, hemos tenido la suerte de que hasta la revolución era de mentira, o sea, esto es ahora, la democracia, y una vez que sube Alemán, ya es de mentira, un demócrata que lo que está ahí es para robar, entonces, tú le dices a los chavalos revolución, ¿y qué?, democracia, ¿y qué?, a veces da temor de que venga un "militarote" ahí tipo Chávez y se suba, verdad, porque la gente ya está cansada de todas estas soluciones que no dan resultado.

\section{R: Exactamente.}

A.L.: El problema, pues, para resumirte es que la Constitución nuestra es un papel, un papel, mira que divertido, el propio, léete una entrevista de Payo Solís, el Magistrado este en La Prensa hace como tres domingos, que fue uno de los que firmó ahí la sentencia le preguntan: "bueno, ¿pero esto cambia la Constitución?”, "no, no, no, no, esto no la cambia la Constitución", dice, entonces, tú pones a un niño a decir: "léeme aquí, a ver qué dice el artículo 147”, "no podrá ser presidente de la República el que es presidente", entonces, si la Constitución dice eso, ¿cómo es posible que Daniel Ortega pueda si la Constitución dice otra cosa?, o sea, tú te metes a la página web de la Asamblea Nacional, pincha ahí Constitución de la República, lees el artículo 147, y tú verás que Daniel Ortega no puede ser, y no la ha cambiado, pero unos señores dicen que sí puede ser, entonces, ¿de qué sirve tener una Constitución?, entonces, ¿para qué perder el tiempo con reformas?, es decir, tenemos que llegar a que tras una revolución, en el sentido, diríamos, no sé, moral y ético, ¿verdad?, de valores, pero no sé cuando, yo creí que era tarea del siglo XX, pero ahora veo que es tarea del siglo XXI, y nos quedan como noventa y un años.

\section{R: No, pues, muchísimas gracias.}




\section{ENTREVISTA 31 ${ }^{46}$ :}

Nombre del entrevistado: D. Cairo Manuel López.

Cargo actual: presidente de la Asamblea Nacional bajo el gobierno de Doña Violeta Chamorro (1990-1997). Profesor de Derecho Constitucional en la Universidad Centroamericana (UCA).

Fecha de realización de la entrevista: Managua, 3 de noviembre de 2009.

Lugar: Corte Suprema de Justicia.

Duración estimada: 55 minutos.

\section{TEXTO - Transcripción 31:}

$R$ : ¿Cuál es, como reflexión inicial, el recorrido que hacen los procesos de cambio constitucional desde los años 90 hasta la actualidad en el marco de la consolidación de las instituciones democráticas?

C.M.L.: La Constitución de 1987 es la Constitución que más reformas ha tenido en la historia de Nicaragua, de las quince constituciones que han estado vigentes, incluyendo dentro de ellas, el Estatuto Fundamental y el Estatuto de Garantías del año 79, ha habido reformas constitucionales en 1893, en 1911, cinco reformas constitucionales a la Constitución de 1950, y siete reformas constitucionales a la actual Constitución. La actual Constitución se caracteriza por su generalidad, un tanto cierta imprecisión en un concepto, deja un margen muy amplio, y un arbitrio considerable para cualquiera de las autoridades políticas, que quiera aplicarla en un momento concreto. La primera reforma constitucional que fue la del año 1990 se hizo con el propósito de facilitar las elecciones, adelantando el período de noviembre del 90 a febrero de ese año. Una segunda reforma, que es la de mayor contenido, es la de 1995, tiene una característica bien importante, es la única reforma constitucional que no ha sido promovida desde el Poder Ejecutivo en la historia de Nicaragua. Las anteriores reformas casi siempre se han promovido desde de la Presidencia de la República, sea con el propósito de ampliar períodos presidenciales, reducir períodos presidenciales, o bien facilitar reelecciones presidenciales, pero han estado vinculadas sobre todo al tema del poder. La de 1995, si bien, evidentemente, tiene que ver con los factores de poder, y la manera en que el poder se estaba jugando en ese momento, parte desde el seno de la Asamblea Nacional, y se enfrenta a los intereses de la Presidencia de la República, al Poder Ejecutivo. En este juego de poderes hay que señalar que dos fuerzas, una muy importante en ese momento, el Frente Sandinista, no aceptaba las reformas constitucionales, particularmente, en lo que tenía que ver con la disminución de las competencias del Ejecutivo, y también con el período presidencial, que se redujo de seis a cinco años, y también con la propuesta inicial de no reelección absoluta al Poder Ejecutivo. También se enfrentó $\mathrm{y}$, prácticamente, por las mismas razones el Partido Liberal Constitucionalista, PLC, que, en ese momento, tenía una presencia muy débil, muy pequeña, en la Asamblea Nacional, pero que, sin embargo, el Alcalde de Managua se vislumbraba como un candidato muy fuerte a la Presidencia de la República. De manera, que estos tres factores reales de poder, el Ejecutivo, la Alcaldía de Managua, y

\footnotetext{
46 Entrevista interesante, con un discurso articulado sobre la respuesta coherente a las distintas preguntas formuladas, además de una orientación crítica en la discusión de los aspectos políticos más controvertidos de la evolución constitucional reciente de Nicaragua.
} 
el Frente Sandinista hicieron lo imposible por evitar la reforma constitucional, pero fueron más bien los diputados quienes lograron aunar a los distintos sectores del país, como jóvenes, estudiantes, amas de casa, partidos políticos, medios de comunicación, opinión pública, etc., movilizados a favor de las reformas constitucionales, probablemente, esta es la reforma más interesante que se ha producido en el país, no, solamente, por la forma en que se realizó, las alianzas que fue necesario realizar en el seno de la Asamblea Nacional, sino por su trascendencia. Hay un viejo escritor costarricense, para no mencionar a ningún autor nicaragüense, quien refiriéndose a la Constitución Política de Nicaragua, el Profesor Eduardo Ortiz, señalaba que la Constitución de 1987 tenía poderes tan absolutos en manos de la Presidencia de la República, como nunca los tuvieron los reyes absolutos en la época del absolutismo, y, para dar algunos ejemplos, el presidente de la República podía dictar decretos con fuerza de ley, y que estaban en el mismo rango de aceptación, o rango normativo, que la ley aprobada por la Asamblea Nacional, en período de receso el presidente también podía dictarle decretos y que tenían toda la fuerza de una ley, además el presidente de la República tenía la potestad de poder crear impuestos sin necesidad de consultar a la misma Asamblea Nacional, entre otras cosas, lo interesante fue que la reforma del 95 lo que hizo fue desmontar, por decirlo así, todo ese conjunto de poderes que tenía la Presidencia de la República, distribuirlos con un cierto sentido de equilibrio entre los otros poderes del Estado, en algunos artículos se trabajó con mucha ingenuidad, en otros se trató de crear un tanto la institucionalidad en el país, que, más o menos, comenzó a funcionar, y trabajó bastante bien hasta el año 2000, en que se dieron otras reformas constitucionales que, cosa curiosa, cuando se hizo la edición por un editor privado de la Constitución Política con la reforma del 2000 la tituló muy bien, las llamó: "las reformas democráticas", a las de 1995, y "la contrarreforma" a la del año 2000. ¿Por qué?, porque en la reforma del año 95 se planteó que para ser presidente de la República se requería ganar con un $45 \%$ más un voto de los votantes, y que habría una segunda vuelta, en caso contrario, por los intereses políticos del Partido Liberal Constitucionalista y del Frente Sandinista, esto se redujo a un $35 \%$ y, aún más, que con un cifra inferior se podía perfectamente se electo presidente de la República si entre el primer y el segundo lugar había un $5 \%$ de diferencia, que no hubo ningún obstáculo ya en las elecciones del año 96 ni en las del 2001, pero sí en las del 2006, o más bien sería, no hubo obstáculos en la elección del año 2001 y sí en las del 2006, que eso fue cuando ya se presentó la situación del Comandante Ortega, que ganó con un 38\% sobre los otros partidos contendientes. Me parece que las otras reformas constitucionales que se dieron, posteriormente, fueron ya sobre tópicos en temas muy concretos, como, por ejemplo, la posibilidad de aplicar, directamente, los tratados internacionales sin necesidad de ciertas ratificaciones que podía tener por parte de la Asamblea Nacional, es decir, la Asamblea Nacional siguiendo otros modelos había decretado en la reforma del año 95, en el caso de los tratados internacionales, pactos o acuerdos, éstos debían de incorporarse a la legislación nacional a través de la aprobación de la Asamblea Nacional, y se ponía un plazo, que si la Asamblea no lo ratificaba en un plazo de 60 días, se tendría ese silencio, ese no actuar la Asamblea Nacional como una aceptación. Pero una de las reformas lo que persiguió fue sobre todo que, en ese caso, la Asamblea, si no ratificaba en el plazo de 60 días el Tratado o el Acuerdo internacional podía pasar una cantidad de tiempo esperando su ratificación, otro de los elementos ya fue por factores políticos, muchos nicaragüenses en el exilio que vivieron en la década de los 80 adoptaron otras nacionalidades, y habían renunciado a la nacionalidad nicaragüense, la Constitución del 87, y en esa parte no fue modificada por la reforma del 95, señalaba como una de las condiciones para poder ser candidato a determinados cargos, entre ellos 
la Presidencia de la República, el no haber renunciado en ningún período a la nacionalidad nicaragüense, posteriormente, se modificó en una de las reformas constitucionales para dar base a este caso concreto de nicaragüenses que habían renunciado a su nacionalidad para que pudieran volver a Nicaragua. Las reformas constitucionales siempre han estado motivadas por intereses de grupos políticos, ¿qué intereses pudo haber predominado en la del 1995, pese a que brotó o nació en el seno de la Asamblea Nacional? Por un lado, en algún sector primó la conveniencia política de evitar que el yerno de la presidenta de Nicaragua en ese momento, Violeta Barrios, no pudiera aspirar a la presidencia, recurriendo a una vieja prohibición, que estaba presente en casi todas las constituciones que ha tenido Nicaragua, donde se señalaba que los parientes del presidente de la República en cuarto grado de consanguinidad y segundo de afinidad no pudieran aspirar a la Presidencia de la República, pero también, por otro lado, en esas reformas del año 95 predominó el afán de institucionalizar el país. Veamos el caso de la Corte Suprema de Justicia. En la Corte Suprema de Justicia, tradicionalmente, se había integrado mediante propuestas del Poder Ejecutivo en ternas, es decir, de tres miembros donde el Poder Legislativo lo que hacía era escoger nada más entre las propuestas presidenciales. En la propuesta de la Asamblea Nacional que fue aprobada en la reforma del año 95 se planteó que tanto el presidente de la República tenía derecho a enviar listas como también lo podían hacer los miembros de la Asamblea Nacional, con lo que el monopolio de proposición de candidatos a la Corte Suprema de Justicia dejó de estar en la presidencia de la República y se amplió a la Asamblea Nacional, esto le daba un mayor ámbito y fortaleza a la Asamblea Nacional, por otro lado, también la decisión de nombrar otros cargos utilizando el mismo mecanismo, Contraloría General de la República, Consejo Supremo Electoral, convertía a la Asamblea Nacional en un centro político de mayor decisión en el juego de poderes del Estado. Luego, también vino a reforzar el papel de la Asamblea Nacional el restituir la capacidad de que solamente la Asamblea Nacional podía dictar normas jurídicas con valor de ley, desapareciendo, de esta manera, las leyes delegadas y los decretos leyes, en cuanto al dictado por parte del Poder Ejecutivo del Estado de Emergencia, ya, anteriormente, se le daba 30 días al presidente de la República para enviar su informe a la Asamblea Nacional para que éste lo confirmara o no, se redujo a un plazo de 78 horas, con lo que en una situación extraordinaria de que ameritar una emergencia iba a conocer, inmediatamente, la Asamblea Nacional. Finalmente, también, en materia presupuestaria, se señalaba, se hizo más bien, a nivel de ley secundaria, aunque me parece que quedó en la reforma constitucional del año 95, que el presidente de la República debía enviar el proyecto del presupuesto general a más tardar el 15 de octubre de cada año, anteriormente, lo enviaba el 15 de noviembre, y siendo que la legislatura terminaba el 15 de diciembre, solamente le quedaba un plazo muy restringido de 30 días a la Asamblea Nacional para conocer, discutir, aprobar o reformar el presupuesto, se amplió, de esa manera, a 60 días. Por otro lado, se trató de crear, de alguna manera, nuevas instituciones, se creó la Procuraduría de Derechos Humanos, que equivale al ombudsman, figura muy extendida, se introduce, creo, también, un órgano de consulta a la presidencia de la República, que es el Consejo de Planificación Económica y Social, para que sirviera de órgano de apoyo a las decisiones económicas y sociales de la presidencia de la República, otro de los temas que fue abordado fue el pluralismo político, la lucha que hizo el pueblo nicaragüense en los años 70, que culminaron con la derrota del somocismo en el año 79, fue una lucha de diferentes sectores, únicamente, estaban legitimados, y tenían personalidad jurídica reconocida por el Estado, en ese momento, antes del 79, el Partido Liberal Nacionalista y un sector del Partido Conservador, el resto de los partidos no tenían personalidad jurídica, pero éstos 
obtuvieron la suficiente legitimidad en la lucha armada a través de diferentes grupos, la lucha armada en Nicaragua, generalmente, se ha visto como un enfrentamiento nada más entre las fuerzas de la Guardia Nacional de los Somoza y el Frente Sandinista, pero la realidad es que fueron diferentes grupos armados que participaron y se legitimaron a través de esa lucha, amén de la lucha diríamos cívica, que se venía realizando, aunque fuese por partidos políticos de hecho y no de derecho, esto llevó a que en la reforma del 95 se insistiera en el pluralismo político, las reformas tanto del año 2000 como algunas reformas posteriores condujeron más bien a cambiar el sistema electoral en el país hacia un bipartidismo tanto por el sistema electoral que se adoptó, como por los poderes que se les dieron al Consejo Supremo Electoral de poder decidir sobre la personalidad jurídica de los distintos partidos políticos. En definitiva, yo creo que la reforma del año 95 fue la ilusión, también, de muchos sectores democráticos, de tratar de crear un país un poco más institucionalizado, y una de las ingenuidades fue, por ejemplo, en el artículo 130 de la Constitución, que se estableció que Nicaragua iba a ser un Estado Social de Derecho, tratando de ponerle freno, de alguna manera, a cualquier gobierno de signo neoliberal que viniera al país, para que hubiese la sensibilidad social, sin embargo, la Constitución se ha venido deformando y lo que Loewestein llamaba el "sentimiento constitucional" ha venido desapareciendo progresivamente.

R: Si bien es cierto que la reforma del 95 es la más amplia, como usted ha señalado, y ha hecho un recorrido muy detallado sobre su contenido, es la más legítima, entiendo yo, en el sentido de que se acomoda a la necesidad jurídica de reformar la Constitución, porque el momento político era el de la transición democrática, mientras que las reformas posteriores, si bien el hilo conductor ha sido el de una semiparlamentarización del régimen presidencialista en Nicaragua, consolidado en el 87 por un Poder Ejecutivo excesivamente fuerte, ¿no se ha traducido en un mayor poder de las cúpulas de los partidos?, ¿no ha habido un vicio institucional a la hora de acomodar la norma jurídica a un ejercicio del poder que está por encima del Derecho?, y esta es una frase un poco dura, pero es la impresión que tiene un observador externo.

C.M.L.: El poder político se ha colocado por encima del Derecho, y en lugar de darse el juego político, la contienda política, la lucha política dentro de cánones jurídicos, más bien se ha transformado, se ha adaptado el precepto jurídico a los intereses de las cúpulas políticas.

R: Y siempre ha habido, además, un enfrentamiento entre el Ejecutivo presidencial y el Legislativo a la hora de aprobar las reformas, con la excepción del pacto entre Ortega y Alemán, que ahi sí hubo, digamos, un acuerdo entre el Ejecutivo y el Legislativo, pero tanto en el 95 como en 2005, con los gobiernos respectivos de Doña Violeta Chamorro y Don Enrique Bolaños, hay una parálisis institucional del país, y, en ese contexto, se ven obligados a crear las Leyes Marco, que son un instrumento jurídico muy peculiar y discutido, desde el punto de vista constitucional, porque además congela en el tiempo la aplicación de las normas constitucionales reformadas. ¿Cómo observa usted todo este proceso, en tanto que experto constitucionalista?

C.M.L.: Yo diría lo siguiente, que, en el juego del poder, la figura presidencial ha tenido casi un carácter providencial en el país, y, generalmente, cuando una reforma constitucional trata de disminuir los poderes presidenciales se produce un conflicto de poderes. Las otras reformas constitucionales, generalmente, se han aprobado muy tranquilamente, porque los intereses de la Presidencia de la República, los intereses de 
los partidos políticos, los intereses sociales y económicos han llegado a coincidir, esto se ha traducido en un demérito, por decirlo así, ante la población de la norma constitucional, y, constantemente, se asiste a violaciones sistemáticas del precepto constitucional, o de los distintos preceptos constitucionales para acomodarlos a la voluntad del poder, sea un poder transitorio o sea un poder compartido, como es el caso, por ejemplo, de las reformas del 2005. Las reformas del 2005 fueron producto del acuerdo de dos cúpulas políticas con el propósito de disminuir el poder presidencial, no fue tanto por llevarlo a un sistema semi-parlamentario, sino que fue más que nada con el propósito de limitar la esfera del poder presidencial, tanto así que con el triunfo del Comandante Ortega en el año 2006, inmediatamente, uno de los partidos que quedó en el segundo lugar propuso mediante una moción en el pleno de la Asamblea prorrogar por un tiempo más la aplicación o la entrada en vigencia, que se había suspendido mediante esa norma peculiar que se ha creado en Nicaragua, como lo es la Ley Marco, y su entrada en vigencia posterior para darle el tiempo suficiente a Ortega para que integrara un Gabinete sin necesidad de consultar a la Asamblea Nacional, de que le diera el visto bueno, que es típico más bien de un sistema parlamentario.

R: Y, por otra parte, también en la historia constitucional del país, los pactos políticos son una constante antes de las sucesivas reformas constitucionales, ¿no? Hay experiencias que son previas al Pacto Ortega/Alemán, que no es una cuestión insólita ni en la historia de Nicaragua, ni tampoco de otros países de América Latina, pienso en el caso, por ejemplo, de la Concordancia Colombiana, de este pacto que constitucionalizaba el reparto paritario entre el Partido liberal y el Conservador de los principales puestos en el poder, o pienso en el "punto-fijismo venezolano", que llevó también a un descrédito de los partidos políticos en la evolución posterior, o en el "Pacto de los Olivos" entre Ménem y Alfonsín, donde también, previamente, a la reforma del 94 en Argentina se acuerdan una serie de cuotas, digamos, de poder para los principales partidos políticos. ¿Cómo ve usted esto para el caso de Nicaragua?

C.M.L.: Bueno, la historia de Nicaragua ha transcurrido en una especie de constante histórica entre el pacto, la ruptura con uno de los actores del pacto, el conflicto social que ha llevado al conflicto político, muchas veces a la guerra civil, $\mathrm{y}$, posteriormente, un decidir volver a empezar. Se ve casi desde el momento de la conquista, una de las figuras más importantes de la conquista fue Pedro Arias de Ávila, quien celebra una especie de pacto con Francisco Hernández de Córdoba, otro de los conquistadores, y que termina con la muerte de Francisco Hernández de Córdoba, que era su yerno, además, es decir, un pacto para gobernar Nicaragua, pero, posteriormente, se rompe de manera violenta. En la historia moderna de Nicaragua tenemos un pacto que se da en el año de 1937-38, que va a dar como resultado una Constitución, la de 1939, que se va a dar entre el Partido Liberal, Somoza García atravesándola, el Partido Conservador, que eran los dos partidos importantes del momento, a través del Dr. Cuadra Pasos, acuerdo de un mínimo sobre el cual, posteriormente, se va a adoptar una Constitución, la de 1939, en ella, entre otras cosas, convienen, qué cantidad de miembros va a tener un partido en la Asamblea, en la Corte Suprema de Justicia, y lo que hay es un reparto total del poder, Somoza lo que perseguía era, que hubiera Asamblea Nacional Constituyente a través de un artículo transitorio se quedó un total, con los años anteriores que había estado en la presidencia, de diez años. En 1948 se da otro pacto, que se dan estos mismos actores, que dicta otra Constitución, la del año 48, en 1950 se hace un nuevo pacto político para reformar la Constitución Política bajo nuevas reglas de juego, donde Somoza García acepta la no-reelección presidencial, que se rompe, posteriormente, 
cuando se altera la Constitución en el año 55, que convino con la muerte de él en el año 56 , y en posteriores reformas, en estas reformas del año 50, ya se entendía que el partido en el poder, el Partido Liberal, iba a tener dos tercios de la composición de la Asamblea y un tercio el partido de oposición, posteriormente, en la última Constitución del período de los Somoza en el año 74, se hace un pacto entre Anastasio Somoza Debayle, por el Partido Liberal Nacionalista, y el Dr. Fernando Agüero Rochas, por el Partido Conservador, únicamente, va a cambiar no el reparto del poder o de los poderes del Estado, sino la proporción, en lugar de ser dos tercios va a un $60 \%$, y en lugar de ser un tercio para el partido de oposición sube de un tercio al $40 \%$, pero siempre funcionaron pactos políticos con un carácter de repartición de cargos públicos, lo que refuerza el poder de los caudillos, puesto que ellos son los que, prebendariamente, disponen quien va a un cargo y quien va a otro.

$R: Y$, por otra parte, también, sí llama, poderosamente, la atención en el análisis, y, de hecho, lo he oído en el discurso de otros entrevistados, esa ruptura del pacto en la que Alemán se convierte en el socio minoritario, cuando pacta con Ortega, Alemán está pensando en los pactos de Somoza, un poco en el modelo del pacto de caballeros, y Ortega no respeta, no tiene esa mentalidad, digamos, de ese "principio de las minorías congeladas", sino que tiene una vocación mucho más hegemónica y quiere, de alguna forma, iniciar un proceso de concentración de poder, que es lo que se ha visto en el último período. ¿Cómo ve usted esta situación?

C.M.L.: Yo lo veo más bien coincidiendo, pero también desde otro ángulo, más bien por la concepción del Derecho que se tiene. Mientras la oposición democrática, entre comillas, en Nicaragua ha tenido una visión, muchas veces, de respeto a la forma del Derecho, los sandinistas han tenido, más bien, la visión de que el Derecho es un instrumento del poder, y que como tal instrumento puede cambiarse con el propósito de consolidar el poder en un determinado momento, mientras que para los unos, es una cuestión, esencialmente, casi estratégica tratar de desarrollar el juego político dentro del marco jurídico, para el otro es más bien una táctica que pueden cambiar en determinados momentos, cuando las mayorías cambian o la situación cambia, y de allí que el sentimiento constitucional, o el sentimiento de respeto a la Constitución política sea distinto para un sector o para otro sector, para el sector, que, en este momento, está en el poder, que es el Frente Sandinista, el Derecho sigue siendo un instrumento que como tal puede utilizarse, o puede variarse, o puede cambiarse siempre y cuando permita avanzar en la consolidación de un proyecto político.

R: Pero, en este sentido, el Frente cuando pierde las elecciones del año 90 y entrega el poder a Violeta Barrios de Chamorro ha iniciado un aprendizaje institucional muy serio, muy contundente, manteniéndose en la oposición, pero con importantes cuotas de poder, y, de hecho, su penetración en el Poder Judicial da casi para otra tesis doctoral, ¿no?, cuando Ortega dice: "vamos a gobernar desde abajo”, ¿cómo se ha producido ese copamiento de toda la jerarquía del Poder Judicial, desde los Juzgados de Distrito hasta los Juzgados de Apelación y ya, por supuesto, la Corte Suprema de Justicia?

C.M.L.: Mire, en el año 95, cuando se produce la reforma constitucional, los jueces, los Magistrados, inclusive, la Corte Suprema de Justicia, están integradas, mayoritariamente, por sectores democráticos. Creo que las personas que se nombraron en el período de Alemán, y en el período posterior de D. Enrique Bolaños, las personas que llegaron al Poder Judicial no tuvieron o no tenían la experiencia suficiente de 
reconocer la manera de actuar del Frente Sandinista, creo que hubo un desconocimiento del adversario, en parte justificable, porque muchos de los Magistrados, concretamente, en el Poder Judicial, habían estado en el exilio durante los años 80, otros habían tenido una vida política en las universidades muy discreta, entonces, no conocían a su adversario. En cambio, la reforma del año 95 fue encabezada por personas, que sí conocían al Frente Sandinista desde las universidades, y sabía, exactamente, habían estudiado su manera de actuar, su estrategia, su política, su concepción del Derecho, su concepción de la vida, y la visión cultural, la vida del partido político en sí, etc., y sabían el carácter del adversario, me parece que estuvo, y sigue existiendo, todavía mucha ingenuidad.

R: Y lo cierto es que ahora, dramáticamente, como decía uno de mis últimos entrevistados, estamos asistiendo al "gobierno de los jueces", $y$, peligrosamente, si en el Asamblea no se logra el quórum para conseguir, en este último caso, dar vía a la reelección presidencial, y pronunciarse con una sentencia, que sí me gustaría que comentase en términos jurídicos. Ayer tuve la oportunidad de ver al Dr. Alejandro Serrano Caldera en la UAM en una charla de café, porque estábamos, realmente, fuera del despacho, y hablaba de algunas cuestiones, no sé si podría aclarármelas sobre irregularidades en la sentencia. Bueno, él hacía referencia a las deficiencias en la conformación de la sala, a la inexistencia del acto jurídico, a la falta de competencia de la Sala de lo Constitucional, según lo dispuesto por la Constitución nicaragüense, para dictar esta sentencia, y, finalmente, la inexistencia de incompatibilidad entre este principio de igualdad, que sostienen como derecho fundamental, frente a la capacidad o la facultad, digamos, de los alcaldes, vice-alcaldes, presidente de la República y vicepresidente a postularse, nuevamente, a las elecciones.

C.M.L.: Sí, bueno, veamos, primero, en cuanto al procedimiento, que interpone una cantidad de alcaldes más el presidente de la República una solicitud ante el Consejo Supremo Electoral el día 15 de octubre, el día 16 de octubre el Consejo Supremo Electoral desconoce la situación y dice que no tiene competencias, y lo hace a las 11.45 $\mathrm{h}$. de la mañana, $11.00 \mathrm{~h}$. de la mañana, que no tiene ninguna competencia para pronunciarse, en este caso, va a suceder toda una serie de cuestiones bien interesantes. Ese mismo día 16 de octubre, después de haberse dado la resolución a las $11.00 \mathrm{~h}$. de la mañana a la $1.00 \mathrm{~h}$. de la tarde se está dando un poder a un abogado para que represente a toda esta cantidad de recurrentes, y a las $2.20 \mathrm{~h}$. minutos de la tarde del ese mismo día se presenta el recurso de amparo. Posteriormente, la Corte Suprema de Justicia a la 4 y 10 minutos de la tarde de ese mismo día acepta el recurso y ordena tramitarlo, como pone en conocimiento al Procurador General de la república, dirige oficio al Consejo Supremo Electoral, y más tarde, esto fue el 16 de octubre, la Sala de lo Constitucional acepta todo esto, eso fue, perdón, en el Tribunal de Apelaciones, las personas se personan ante la Corte Suprema de Justicia a las 8.30 h. de la mañana del día lunes 19 de octubre, a las $12.00 \mathrm{~h}$. de ese mismo día la Sala dicta un auto, teniendo por radicado el recurso, a la $1.00 \mathrm{~h}$. de la tarde convocan a los Magistrados de la Sala a una sesión, y esa misma tarde de ese mismo día a las $17.00 \mathrm{~h}$. de la tarde emiten una sentencia de 24 páginas. Esa sería, primero, una sorpresa, con la celeridad con la que se ha tramitado, ahora vayamos a los aspectos de procedimiento, de acuerdo a la Ley Orgánica del Poder Judicial, la Sala debe integrarse por todos los Magistrados de la Sala Constitucional para conocer del recurso de amparo, como, supuestamente, no estaban presentes tres Magistrados, llaman a sus suplentes, hay que señalar que aquí en Nicaragua cada Magistrado tiene lo que se llama un Conjuez, pero los conjueces nunca se han 
integrado, nunca se ha dictado la forma en la cual que ellos trabajan, se llama, entonces, a los suplentes de estos Magistrados, que son otros Magistrados, no concurren los Magistrados porque se habían marchado, dado el nuevo horario, a la $1.00 \mathrm{~h}$. de la tarde, y ese mismo día dictan el recurso. Las preguntas son: ¿tiene la Sala de lo Constitucional, en materia de amparo, competencia para conocer de un acto que no se ha producido aún?, porque nadie le había negado al Comandante Ortega y a los alcaldes la posibilidad de que se inscribieran como candidatos, en primer lugar, su partido no los ha propuesto, entonces, como no ha habido ningún acto, ¿sobre qué materia se van a pronunciar?, sobre un supuesto nada más, uno, entonces, tenemos algo que llama la atención, la celeridad, segundo, algo que es anómalo, la forma en que se integra la Sala de lo Constitucional, otro aspecto de anomalía que se presenta es que no se ha producido un acto jurídico sobre el cual se pueda pronunciar la Sala de lo Constitucional. Por último, la Sala de lo Constitucional comete un exceso de poder al pronunciarse, inclusive, al pronunciarse declarando inconstitucional o no aplicable, como señala la Ley de Amparo, no aplicable, ciertos aspectos de la Constitución Política, concretamente, el artículo 147, que es el que prohíbe la reelección presidencial y el 178 la de los alcaldes. Entonces, aquí el único que tiene competencias para ver los aspectos de inconstitucionalidad es la Corte Plena, pero no una Sala, aquí hay un exceso de poder. Por otro lado, tampoco la Corte Plena, aunque estuviesen sus dieciséis Magistrados reunidos, puede declarar inconstitucional un aspecto de la Constitución Política, eso no se ha aceptado en el Derecho nicaragüense, el único órgano competente para poder reformar, modificar la Constitución Política es la Asamblea Nacional, sea por el constituyente, por una Asamblea Nacional Constituyente, o por el constituyente permanente, que también en España le llaman el Constituyente derivado, en todo caso, la sentencia como tal para muchos estudiosos no es una sentencia propiamente dicha, porque tiene defectos de forma, tiene defectos de fondo, y, en consecuencia, para muchos sectores es inobservable, sin embargo, por razones de hecho y de fuerza, lo más seguro es que el Comandante Ortega va a correr como candidato en las próximas elecciones.

$R:$ Y será, en este caso, si, anteriormente, hablábamos de un conflicto entre el Ejecutivo y el Legislativo a la hora de aprobar las reformas constitucionales mediante una Ley de Reforma Parcial a la Constitución en los anteriores procesos, ahora hablamos de un conflicto entre el Poder Judicial y el Poder Legislativo a la hora de aceptar, en este caso, una sentencia, que no modifica la Constitución, pero sí interpreta un artículo de la Constitución, dando vía libre a que en las próximas presidenciales se presente como candidato Daniel Ortega, que además tiene dos impedimentos para postularse a la reelección, ¿no?

C.M.L.: No hay elección inmediata, sino que debe dejarse un período intermedio al menos.

\section{R: Exacto.}

C.M.L.: Bueno, en este caso concreto sobre que no ha habido reforma constitucional, es cierto, no ha habido reforma constitucional, pero la Corte Suprema de Justicia no tiene competencia para poder modificar la Constitución política, ni poder declarar si es inaplicable o no es aplicable un precepto de la Constitución Política, y si nos fuéramos por la vía de la interpretación de la Constitución Política esa solamente se puede dar en la aplicación a un caso concreto, que no se ha presentado, y quien puede interpretar de 
manera oficial, por decir así, un precepto de la Constitución o una ley, que es lo que le denominamos la "interpretación auténtica", el único que puede hacerlo es la Asamblea Nacional. Entonces, aquí lo que ha habido es una invasión de los poderes de la Corte Suprema de Justicia sobre competencias que tiene única y exclusivamente la Asamblea Nacional.

$R:$ Y esta ruptura, entonces, del principio de equilibrio de poderes, en el contexto de la historia de Nicaragua, donde también la reelección presidencial siempre ha estado acompañada de fraude electoral. Después de los últimos resultados de las municipales, es posible que la victoria de Ortega aún sin fraude sea una "victoria anunciada", porque la matemática electoral y el sentido común así lo dicen, ¿no?

C.M.L.: Así es, con las actuales reglas electorales el triunfo de Ortega casi parece inevitable, a no ser que la oposición nicaragüense logre el apoyo de un 51\% de la población, que dice, en este momento, no tener una adscripción política por uno o por otro, y que el triunfo electoral de la oposición nicaragüense fuese superior a un $5 \% \mathrm{o}$ $10 \%$. ¿Y por qué?, porque un fraude se puede hacer, digamos, con un cierto margen, pero no de manera masiva, aunque en Nicaragua ya se dio un hecho histórico, que fue para la Constitución de 1948, el candidato de la oposición había ganado visiblemente, pero la autoridad electoral existente en el momento invirtió los resultados y los votos que había obtenido el candidato que había ganado se le dieron al candidato que perdió, solamente, eso pudiera ocurrir, que también parece haberse vivido en la elección municipal de 2008.

R: ¿Y cómo ve el futuro incierto del país? Porque hay un clima de normalidad a pesar de las dificultades y del cierre de espacios politicos en la Asamblea y la sociedad civil, que tiene impedimentos para manifestar su oposición, su sentimiento de malestar frente a todo esto que está pasando.

C.M.L.: Uno de los deportes del nicaragüense consiste en hablar de política, y casi todo nicaragüense es una especie de analista político, a pesar de que la población no manifieste o no se manifieste a través de los medios de comunicación, o no se manifieste a través de mítines, etc., sin embargo, la gente tiene una percepción de la realidad, y, en este momento, hay algunas dudas sobre el futuro del país, y basta comentarla, por ejemplo, con un taxista, y las personas inmediatamente responden lo que sienten. Hay incertidumbre porque se ve venir casi en el horizonte una especie de conflicto, que podría terminar, desgraciadamente, para este país, en un conflicto de distintas proporciones, tal vez una guerra civil es difícil, ¿verdad?, porque una guerra civil, pues, necesita apoyos externos, quien arme a un grupo irregular, pero, digamos, la confrontación sí se ve venir, si no se actúa con la suficiente inteligencia, me parece que los métodos que se están utilizando en el país son comparables, recientemente, tuve me tocó dirigir una monografía para la licenciatura de una joven que escribió sobre la influencia del pensamiento fascista en la Constitución de 1939, y ella hacía un paralelo entre los métodos que usó Hitler para consolidarse en el poder, los métodos que utilizó Mussolini en determinado momento, y también lo comparó con la situación que se vivió en España, por ejemplo, desde la guerra civil del 36 al 39, y aunque no lo decía ni lo refería la situación nacional, pero, inmediatamente, se inferían los métodos que se están utilizando, y las distintas experiencias nos llevan a que tarde o temprano, otros países no fascistas, pero con métodos similares en los países socialistas, tarde o temprano terminan por colapsar, y Nicaragua, lamentablemente, presenta una situación 
económica, la más dura y difícil, mientras Nicaragua fue en la década de los años 60 y 70 uno de los países ejemplo en América Latina de crecimiento económico, y nuevo desarrollo económico, hoy somos el segundo país más pobre de América Latina, mientras presentaba unos índices de competitividad y de exportaciones dentro su pequeñez y de lo pequeño de la economía, pero, por ejemplo, notables, mientras los coreanos, por ejemplo, después de la Guerra de Corea en los años 50 exportaban el cabello de sus mujeres en forma de peluca, Nicaragua ya era una economía muy consolidada en ese sentido. Varios años más tarde, en los años 90, nosotros sumidos en la pobreza con una inflación tremenda, inclusive superior a la que tuvo Alemania, esos mismos coreanos vinieron a montarnos todo el sistema de telefonía, cambiando el sistema de telefonía de cable de cobre por la fibra de vidrio, es decir, como aquél país logró desarrollarse, y como nosotros a pesar de haber tenido una situación relativamente atractiva por los índices de crecimiento, nos sumimos en la situación actual, y ha sido por la poca visión de los distintos gobiernos, ha sido en parte, también, la poca visión del empresariado que nada más que vio a partir de los años 90 una oportunidad para recobrar lo que habían dejado de percibir en los años 80, esa parte de la insensibilidad de la empresa, de un sector de la empresa privada, no ha sido analizada suficientemente. Pero sí que se conjuga en el ambiente nacional frente a la crisis económica importada de los Estados Unidos y de la situación financiera internacional la crisis doméstica era de los años 70, 80, 90, la crisis después de, como consecuencia de las elecciones del 2008, y ahora la situación, digamos, medioambiental, que no llovió, cuando debió haber llovido, ahora que están cayendo algo de lluvia, pues, un poco tardía para salvar las cosechas.

R: $Y$ ahora que mencionaba la variable económica, los paralelismos históricos, salvando los contextos, hacen referencia al gobierno actual del presidente Ortega y un poco su círculo familiar, el tema de la familia también como una presencia en el ejercicio del poder cuando se transforma en arbitrariedad o va más allá de las instituciones, con la dictadura de los Somoza, ¿no? Y también utilizar al Estado como recurso de poder económico y factor de acumulación, de enriquecimiento y de crecimiento empresarial, pero de la formación de empresas que surgen en beneficio de esa cúpula en el poder. ¿Está ocurriendo algo parecido?

C.M.L.: Esto se ve y se nota, ¿no? Muchas de las posiciones, inclusive, desgarres que ha sufrido el gran sandinismo, por decir así, porque tenemos sandinistas en una oposición frontal al régimen de Ortega, se debe, precisamente, a lo que ellos llaman que esto dejó de ser una revolución, dejó de ser un proyecto socialista para convertirse en un proyecto de enriquecimiento personal y familiar, y que parece, totalmente, asombroso, que nadie se imaginaba que detrás de la admiración que tuvo el pueblo nicaragüense por el Frente Sandinista, por su heroísmo, la manera en que combatieron también a los Somoza, la prédica de la moral revolucionaria, etc. etc., pues, todo eso se dejó por la borda, y con escándalo se ve el paulatino enriquecimiento, ya no solamente de Ortega, sino de su misma familia y de sus allegados, de tal manera, que, hoy por hoy, ellos forman parte de ese $1 \%$ que concentra casi el $60 \%$ de la riqueza nacional, y eso es, pues, una situación, tal vez ya no sólo moralmente escandalosa, sino peligrosa política y socialmente. El país, el pueblo puede estar, en este momento, angustiado y preocupado por el pan nuestro de cada día, sin embargo, el hambre es mala consejera, tarde o temprano podría acumularse una situación peligrosamente explosiva en el país, y se ha visto, no hay Ejército, no hay Policía, en el mundo capaz de retener o contener a un pueblo cuando éste decide tomar otra vía. 
R: Y ya para terminar, volviendo al tema constitucional, ¿es cierto que no ha habido pactos constitucionales en Nicaragua? Que siempre ha quedado excluida una parte del pacto por la Constitución, estoy pensando en la Constitución del 87, en la que una parte de los ciudadanos, o al menos, la minoría opositora, que, en aquél momento, o bien, se vio abocada al exilio, bueno, la gran mayoría que no coincidía con el proyecto revolucionario. Luego las reformas a la Constitución del 87, primero con el debate de la reforma total o la reforma parcial, también no ha encontrado el consenso en la medida en que los propios procesos de reforma han supuesto siempre bloques de oposición constantes, ya sea desde la propia institucionalidad, porque da la impresión de que los ciudadanos se han quedado un poco al margen siempre de las reformas, que esta es una cuestión de las élites políticas, y, últimamente, hasta de los jueces, en salas que ya ni siquiera tienen la transparencia de la discusión parlamentaria. ¿Cómo ve todo esto?

C.M.L.: La Constitución del 87 a pesar de haber sido aparentemente consultada con la población fue una consulta limitada, primero, por la forma de dialogar con la población, es decir, no se puede obtener una discusión cuando a la población se le dice: "¿están de acuerdo con la Constitución?", "sí", eso no es un debate. Por otro lado, las elecciones de 1984, que fueron realizadas por el Frente Sandinista con el propósito de dar cumplimiento al compromiso que habían tenido en la $17^{\mathrm{a}}$ Conferencia de la Organización de Estados Americanos en San José, se habían comprometido a hacer prontas elecciones, las hicieron en el año 84, muchos de los actores políticos no participaron y no se logró, en ese momento, lo que deseaba el gobierno, que era la legitimidad de la misma revolución, lo que hizo que recién aprobada la Constitución del 87 en pocos días se declarara el "Estado de emergencia" y se volvieran inaplicables muchos de sus artículos, especialmente, los derechos y garantías fundamentales. La reforma del año 95 trató de hacerse alguna consulta a ciertos sectores de la población, pero la discusión no trascendió hasta la población, por un lado, por el estilo, casi siempre, que ha tenido la política en Nicaragua, casi siempre de concentración de las decisiones en pocas manos, ¿no?, no sólo del poder, sino también se nota en los partidos políticos, en las distintas asociaciones, sindicatos, iglesias, etc., y, por último, diría que una de las dificultades que plantea una discusión amplia y masiva es la poca cultura formal del pueblo nicaragüense, es decir, la comprensión de lo que es la Constitución, su trascendencia y lo que contiene, etc., a pesar de que la misma Constitución dice que hay que difundirla a través de los medios de educación, y a pesar de que se declaró un día en el calendario cívico de Nicaragua, que se debe dedicar un día a la Constitución, nadie la cumple, ni las universidades, ni los colegios, ni los centros culturales, de tal manera que la Constitución como tal, la población no percibe que sea algo totalmente importante, ni mucho menos en períodos en los que ya es manoseada, discutida, entonces, el sentimiento de la población es de que no le ven diferencia con una ley más, y que más bien puede ser alterada de acuerdo a los intereses de los distintos grupos del poder. 
ENTREVISTA $32^{47}$ :

Nombre del entrevistado: D. Orlando López Selva.

Cargo actual: ex -asesor del presidente Enrique Bolaños (2002-2007). Profesor de la Universidad Americana (UAM).

Fecha de realización de la entrevista: Managua, 17 de septiembre de 2009.

Lugar: Facultad de Diplomacia y Relaciones Internacionales de la UAM.

Duración estimada: 57 minutos.

\section{TEXTO - Transcripción 32:}

O.L.: Bueno, yo creo que las últimas reformas más que favorecer un modelo jurídico amplio de organización de la democracia, de avance, o mejoría del Estado de Derecho, son más que todo ajustes políticos derivados de pactos entre las cúpulas, verdad, entre el FSLN y el PLC, entre Ortega y el ex-presidente Arnoldo Alemán. Lo hay ahí mayormente es hacer un traje para que haya una mejor repartición de los cargos, para que haya oscuridad en la ley, para que los nicaragüenses estén más sujetos no a los vaivenes políticos naturales, sino a los ajustes que puedan hacer de manera voluntaria estos líderes políticos, ¿no? Las reformas en cualquier otro país responden a tres objetivos: uno, a estandarización de las leyes como los países vecinos, para homologar los ordenamientos jurídicos, o ajustarlos a nuevos marcos del derecho internacional; dos, para moralizar el derecho, como el caso, por ejemplo, de la tecnología, que siempre las leyes estaban más obsoletas o iban a un ritmo más lento; o tercero, para hacer ajustes económicos en el campo tributario, sobre todo. Esas son las tres tendencias en el derecho moderno cuando se habla de modernización de las legislaciones. En Nicaragua no, en Nicaragua responden al pacto, a lo prebendario, o a causar ciertos desequilibrios en el concepto republicano de frenos y contrapesos, de checks and balances; y Nicaragua no, no es en este sentido, en verdad, la ley no es el recurso de todo ciudadano, del cual pueda disponer para hacer eficiente el Estado de Derecho. En Nicaragua, prevalecen unos anti-valores que son el amiguismo, el caciquismo, el cortoplacismo, o sea, siempre se obvia lo constitucional, las instituciones, siempre se obvian los mecanismos, los procesos, las reglas claras, y todo se hace por amiguismo o por personalismo, minando, verdaderamente, los procesos que hacen que haya transparencia y que convierten a los ciudadanos en iguales ante la norma jurídica. Entonces, cualquier ajuste, cualquier cambio que se ha hecho realmente no es para favorecer la democracia, sino que es bajo esos anti-valores como: amiguismo, personalismo, o pactos prebendarios, como te había mencionado.

$R: Y$, por otra parte, también ya no solamente desde el punto de vista del ajuste del diseño constitucional a los intereses políticos de las élites, sino también lo que es la flexibilización del procedimiento mismo de revisión constitucional, que supone un atentado desde el punto de vista estrictamente jurídico. Cómo la ley 192 está hecha en base a una reforma previa con una ley ordinaria de las dos cláusulas que permiten reformar la Constitución. Entonces, cuando se afecta también, a través de esa ley, lo que es la facultad del presidente de sancionar y mandar publicar una ley en cualquier medio de difusión escrita del país que puede hacer la propia Asamblea Nacional. Ese

47 Entrevista con una tendencia en el discurso a dar excesiva importancia a los aspectos culturales, históricos y antropológicos en el desarrollo político e institucional de Nicaragua. No obstante, algunas observaciones son valiosas. 
conflicto entre el Ejecutivo presidencial y el Legislativo a la hora de aprobar las reformas ha sido un elemento común a todos los procesos de reformas que se han operado hasta el momento. Quizás usted vivió un poco más de cerca el caso del presidente Bolaños, que fue también muy característico, de hecho, la Ley Marco que se aprueba en el 2005 entra en vigor en el 2008, finalmente, reformando la propia Ley Marco, o sea, ampliando todavía más el periodo de vigencia de la no aplicación de la norma constitucional reformada. ¿Qué opina de este tipo de irregularidades desde el punto de vista jurídico?

O.L.: Bueno, cuando los Estados no se rigen por la ley es porque o los razonamientos no son muy consensuados, o, sencillamente, la ley no es pareja, o hay una crisis política, porque si el Estado de Derecho funciona no se tendría porqué recurrir hasta el próximo paso, que es la crisis política que puede llevar también, posteriormente, cuando la crisis se agudiza a una crisis ya más grave, pues, hizo mención a dos fenómenos interesantes, el legislador ¿qué es lo que ha pasado?, ha habido pugna porque los poderes del Estado, los nicaragüenses nunca hemos podido negociar, nunca hemos podido aprender a negociar, nunca hemos podido aprender a consensuar, porque esta es la base de la tolerancia, los nicaragüenses no estamos hechos para entendernos y creo que esto tiene un origen en algo que quizás le va a llamar la atención a usted, pero yo he encontrado que la falta de gobernanza en Nicaragua, dice Octavio Paz, que nos llega por dos vertientes: una, por la vertiente militar, y otra, por la vertiente de la Corona española, pues, que es la de la Iglesia. O sea, la Iglesia no es democrática, la Iglesia es dogmática, y la vertiente militar es la vertiente de la imposición, entonces, esas dos vertientes crean una cultura que luego invade a todas las otras instituciones, que son las instituciones jurídicas, las instituciones políticas, entonces, el poder entre más se acumula más fuerza da, esto es contrario al concepto aristotélico, que habla de que los poderes tienen que estar bien distribuidos o a la concepción madisoniana de que el poder debe tener freno y debe tener balances, a partir de los principios de Montesquieu, debe de haber balances, en Nicaragua no, cada nicaragüense que llega a un poder del Estado, que nosotros en vez de tener tres tenemos cuatro, como una invención bolivariana, que es el poder del Consejo Supremo Electoral, respondemos, yo diría no a un fenómeno de cultura política, sino a un fenómeno antropológico, que nos ha quedado a los nicaragüenses todavía. Nosotros no hemos alcanzado el Estado-nación, que es el que surge a partir del 1648 con la guerra de la sucesión de las casas reales en Alemania, nosotros respondemos al modelo tribal, entonces, cuando vemos a un Arnoldo Alemán, cuando vemos a un Daniel Ortega en el campo político actual nos encontramos con que no hay conciencia de que se está luchando para mejorar un país, sino que se está luchando para preservar mayores cuotas de poder. No hay conciencia de que se esté construyendo una nación, sino que se está fortaleciendo a los bandos o los partidos, los partidos son las partes, nadie lucha por el todo, cada quien lucha para tener más para sí, o sea, y la partidización de la política nicaragüense, obviamente, que hace que el derecho sea una herramienta para uso personal y no para uso jurídico, para darle mayor fuerza a la Constitución. Con Enrique Bolaños le quitan mucho poder es porque los sandinistas mismos cuando estaban la revolución crearon una Constitución que la habían hecho para que el Ejecutivo tuviera suficiente fuerza y no dependiera tanto del Legislativo ni de las interpretaciones que hiciera la Corte Suprema de Justicia, luego, pierden el poder respectivamente, y llega Doña Violeta y ellos se quedan abajo, entonces, se dan cuenta que no tienen los suficientes votos para cambiar la ley, y cuando llega Arnoldo Alemán, perdón, cuando llega Enrique Bolaños ya hay cierto balance, ya han ido adquiriendo su cuota dentro de la Asamblea y ellos dicen ahora es el momento de quitarle poder, y a 
eso cómo lo llaman ellos, supongo que deben cambiar de sistema y crear un sistema semi-parlamentario, que haya más balances, pero, en realidad, lo que se está haciendo es un ajuste a los intereses de los que están en la oposición, incluso, ellos son los que primero, antes de las elecciones del 2007, dicen que el sistema parlamentario debe ser mejor, porque ellos saben que en el sistema parlamentario ellos tienen cierto grado de mayoría y más habilidad para la negociación con los partidos minoritarios, entonces, ellos piensan, pues vamos a hacer gobiernos de alianzas, gobiernos de minorías, gobiernos de coalición, gobiernos de mayoría, pues, si llegan al poder, esa es la visión que ellos tienen, que haya un Primer Ministro que se encargue de administrar la cosa pública y el Jefe del Estado que sea el que se encargue de la política externa, que es el papel que le gusta al presidente Ortega. Claro, cuando ellos llegan al poder dicen no, no, no, esto no, no, ya no vamos a hacer reformas si el presidencialismo está bueno, y este ha sido parte del estudio que ha hecho Juan Linz y el chileno, Arturo Valenzuela, acerca de si las causas verdaderas del presidencialismo como sistema que no ha contribuido al mejoramiento de América Latina tiene su raíz en que hay demasiada concentración de poder, entonces, la mejor distribución está en hacer un gobierno de carácter parlamentario, pero, extrañamente si nosotros heredamos la institución militar y la institución religiosa de España, ¿porqué no la institución política?, ¿porqué no heredamos el sistema monárquico?, ¿porqué no heredamos el sistema parlamentario? Brasil tuvo un Pedro I en mil ochocientos treinta y algo, tuvo un emperador, un rey, pero ningún país de América Latina, bueno, era un virreinato, ¿verdad?, Colombia, México, entonces, yo siempre me pregunto, que en la cultura indígena o hubo un rechazo natural para adoptar ese sistema que, realmente, es eficiente, o más bien la dictadura franquista, la del treinta y nueve al setenta y cinco, fue lo que confirmó que el régimen presidencialista era más consonante, iba más de la mano con la cultura latinoamericana, porque nosotros hablamos un dialecto de España, hemos sido colonia de España, ahora tenemos más influencia de los Estados Unidos, pero ¿porqué rechazamos aquello y optamos por el sistema americano, es decir, por el sistema de Estados Unidos? Es lo único en lo que yo siento que no hay concordancia, es lo único a lo cuál los latinoamericanos dijimos no, porque ahí todo el sistema de instituciones, el conjunto de valores, que, realmente, recibimos de la Corona española, aún han sobrevivido y han pervivido, entonces, cuando hablamos de cambiar el régimen y de fortalecer o de debilitar a un presidente lo que hay no es interés en fortalecer el Estado de Derecho. El Estado de Derecho es un argumento, igual que la libertad en la época de los jacobinos. Entonces, eso sucede en Nicaragua y sucede en casi todos los países de América Latina. El interés es favorecer al caudillo, favorecer al caudillo ya sea de derecha o de izquierdas, ya ves Uribe en Colombia ya va por un tercer período, ya ves Chávez en Venezuela, y no lo veo bien, porque es un insulto a la inteligencia del pueblo, porque rompe con el orden constitucional y además crea desbalance, porque crea muchas fricciones, entonces, igual sucede hoy en Nicaragua, todos los desajustes se dan porque se siente que hay un desbalance, al igual que sucede cuando los países vecinos tienen más helicópteros, bueno, entonces yo voy a comprar más helicópteros, tienen más buques, yo voy a empezar a comprar más buques, es una respuesta a una circunstancia que ya venía desde hace mucho tiempo, entonces, nosotros respondemos más a esquemas no de orden, y el derecho es orden en sí, el derecho no sólo es legalidad, el derecho es orden más moralidad para que se refleje luego en igualdad, ¿no?, entonces, nosotros respondemos más que todo a indicios personales, mayor acumulación de poder, vanidad, y tener más privilegios para las minorías, para las élites. 
R: Pero hay importantes diferencias, y ahi ha dado un poco en la clave de la hipótesis, $y$ del marco de análisis en el cuál yo voy a centrar esta tesis, que es el trasvase de poderes y de facultades constitucionales del presidente de la República a la Asamblea Nacional, es decir, del Ejecutivo al Legislativo.

O.L.: Bueno, esos son intentos, pero ahorita ya no van a hacer más, ya no lo quieren, ya no lo desean, ya no lo desea el presidente Ortega porque perdería poder, incluso Rafael Solís lo dijo hace menos de un mes en el periódico, no sé si lo leyó en los diarios, dijo no, ya no tenemos interés en pasar o promover el sistema del presidencialismo al semiparlamentario, que es el tipo francés, ahora lo que queremos es reelección, pues, ¿por qué?, porque tiene una justificación en Chávez, tiene una justificación en Correa, tiene una justificación en Uribe, que para mí está haciendo demasiado daño en América Latina, porque estamos cayendo en el precipicio de las dictaduras constitucionales, ¿no?

R: Por otra parte, es cierto que hay que diferenciar las facultades presidenciales de Chamorro y de Bolaños, de las de Arnoldo Alemán y Ortega. Ellos sí tenían un importante control sobre sus cuotas partidarias, sin embargo, tanto Bolaños como la presidenta Chamorro sí sufrieron el abandono de su partido y tuvieron enormes dificultades además para sacar adelante su agenda de gobierno, no solamente ya la aprobación de la Ley de Reforma Parcial de la Constitución. ¿Cómo vivió, habiendo sido asesor del presidente Bolaños, aquella época tan difícil?

O.L. Bueno fui primero asesor cuando Bolaños era vicepresidente de la República, pero sí le puedo decir lo siguiente, en Nicaragua hay un síndrome que se llama del figureo, que es como una enfermedad psico-social, pero que ya ha incursionado en el mundo de la política, aquí la política ha llegado a suplantar hasta a la religión, incluso, es decir, es increíble que, o ha tomado prestado mucho de la religión, que es el foco, es la vertiente que más nutre nuestra cultura, y de donde nosotros tomamos más. Bolaños subió al poder por una alianza donde él no tenía control, entonces él era como una figura sin arraigo, sin verdadera coerción dentro de sus fuerzas que lo respaldaban, es decir, yo siempre cuando explico la teoría de los gobiernos digo que el gobierno es como un hombre que tiene dos pies, si se para de un pie se tambalea, ese es el Ejecutivo, pero si pone el otro en el suelo, ya está más firme, que es el Legislativo, porque para hacer política hay que legislar y luego ejecutar, ¿verdad?, entonces, Bolaños nunca tuvo aliados, porque se separó, algo así como lo que le pasó a un presidente boliviano en los años ochenta, no recuerdo ahorita, que abandonó a su partido, pero no pudo gobernar, ¿por qué?, porque el contrapeso de las asambleas, de los parlamentos, de las cortes, siempre tiene demasiada incidencia, porque partamos de algo ellos son los que hacen el presupuesto, y sencillamente dicen no hay legislación, no hay presupuesto, y los gobiernos no pueden operar, los países no pueden estar sin ayuda económica, no pueden estar sin su legislación, no pueden estar sin recaudar impuestos, entonces, la presidenta Chamorro sí tuvo apoyo moral, o sea, y Don Enrique, pues, tuvo, en menor grado, pero sí apoyo moral más que otra cosa, y tuvieron mucha, mucha, la valentía de decir: "nosotros somos los políticos tradicionales, queremos ordenar este país". Arnoldo Alemán tenía más instinto, Daniel Ortega tiene más instinto, yo he explicado esto en los términos de que la política en Nicaragua se ha "alcaponizado" más, o sea, hay como un trueque, hay como una negociación, es como una mesa de tahúr donde en la mitad del juego se cambian las reglas y se cae en la trampa, ¿no? Entonces, lamentablemente cada vez que se cambia la Constitución se están cambiando las reglas del juego, se está insultando la inteligencia del país, de todos nosotros los nicaragüenses, y nos están 
diciendo miren: ahora tenemos que acomodar esto a mi medida, a mis intereses, y a mis necesidades para permanecer más tiempo en el poder. El concepto aristotélico de la división, bueno, de los poderes que se degeneran calza en Nicaragua, porque el poder se degenera junto con los que ya están arriba, nuestra cultura es, por otro lado, es bien sumisa, la cultura del nicaragüense, yo creo que algunos países latinoamericanos se sienten bien con el hombre fuerte, nosotros tenemos una palabra que viene de una lengua náhuatl, que es el "tayacán", o sea es el que nos resuelve, porque otra de las cosas que también heredamos de la colonia es que el pensamiento racional europeo no permeó, nos quedamos con el sentido mágico, el santo patrono, la Iglesia, el milagro, pero no el "si yo trabajo duro, si yo trabajo fuerte, si analizo, si yo critico, si yo hago cosas racionales puedo cambiar mi entorno", no, estamos sujetos a la voluntad de Dios. "Lo que Dios quiera", o sea, es en cierto sentido, es lo que Paz y Krauze dicen en el análisis de la cultura del mexicano es una sumisión, estoy tratando de recordar la frase, es una sumisión consentida, porque él no tiene poder en sí, porque no es un ser racional con habilidades, sino que es un sujeto de Dios domado por los valores religiosos. Eso es lo que Krauze y Octavio Paz tratan de decir un poco, entonces, en esta cultura, el derecho es una norma muy objetiva que no calza con los intereses personales, no, el derecho no va con la ambición de poder, el derecho me dice que todos somos iguales y eso no me conviene, porque yo tengo que demostrar para ser líder que tengo que prevalecer por encima de los demás, porque eso es lo que me da a mí la oportunidad de proyectarme y salvar a los demás resolviendo sus necesidades. Hay 19 de los 91 diputados de la Asamblea, de los cuáles sólo 19 son los abogados, entonces, no hay una ley que tipifique o que determine cuáles son las calificaciones porque no interesa, no es la base del mérito, sino de la lealtad, no es la base de la capacidad, sino de la entrega libre al caudillo, entonces Arnoldo Alemán ha seguido en política como Daniel Ortega, porque tiene su gente que les sigue a ellos como a una banda, y caemos en el caciquismo, y caemos en el "alcaponismo", como te decía.

R: Antes hizo referencia a Daniel Ortega, a ese fortalecimiento del Poder Ejecutivo, que rompe un poco con el hilo conductor de las reformas que ha sido esa semiparlamentarización del excesivo presidencialismo que consagraba la Constitución nicaragüense de 1987. Actualmente el gobierno de Ortega da marcha atrás a ese proceso y se ven una serie de cuestiones interesantes, como, por ejemplo, el prorrogar en un año más la entrada en vigor de las reformas de 2005 hasta 2008, pero hasta el momento no se ha ratificado a ningún diplomático, ministro, funcionario o alto cargo como manda el nuevo precepto constitucional, ¿no?

O.L.: Porque en aquél tiempo le convenía al sandinismo, bajo el gobierno del presidente Bolaños, porque de esa manera se ejercía el control no sólo sobre sus impuestos, sino también sobre sus nombramientos, o sea, el poco poder discrecional que podía tener el Ejecutivo también tenía que ser controlado por la oposición, por el sandinismo que subió al poder con el lema: "vamos a gobernar desde abajo", ya, entonces, esa era una manera de utilizar el derecho para fines políticos y limitar el poder de los otros, y aumentar el caudal propio, o sea minimizar el poder del otro y al mismo tiempo aumentar mi poder. ¿Por qué fue esto? Porque obviamente, Enrique Bolaños nombraba a ministros respondiendo a intereses tal vez más económicos, porque tenía la visión de que si desarrollábamos la economía hay mayor riqueza, entonces, el sandinismo pierde adeptos, porque la pobreza en Nicaragua es del $71 \%$, que es la clase más baja, el $21 \%$ es la clase media y creo que el 4\%, o algo así, es la clase alta, o sea en Nicaragua la pirámide es dramática, ¿no?, entonces, eso igual corresponde por casualidad con 
porcentajes de gobiernos conservadores apoyados por la clase alta, que en la clase media donde está la parte liberal y sandinista, pero más liberal, entonces, cuando Enrique Bolaños tiene que enfrentarse a una amenaza, y el sandinismo lo hace como una estrategia, dicen, bueno, hagamos esto, con la certeza de que lo vamos a hacer este año porque no sabemos si vamos a ganar las elecciones. Cuando se dividen las fuerzas liberales y entonces dicen, no, nosotros habíamos dicho dos años, pero era un cálculo bastante anterior, más bien provisorio, o sea de futuro, y no lo hicieron porque si ganamos no lo presentamos, o sea, responde más que nada a una estrategia que él tenía en mente, que como le digo, el político nicaragüense, el político de cualquier país desarrollado piensa en bienestar para sus ciudadanos, en Estado de Derecho para que haya orden y en consenso cuando las partes tienen problemas, ¿verdad?, para encontrar solución a las dificultades que toda nación enfrenta día a día, y el político nicaragüense no, va en función de los intereses mezquinos, o responde a entornos donde hay una sujeción al líder político, si concentra más poder es bueno para mí porque yo me despreocupo de quien está en el poder, o sea, me desentiendo, pero también me favorece porque es a él a quien le voy a ir a pedir, y responde más que todo a este esquema, como le digo, a una cultura política tribal, alcaponizada, y nosotros utilizamos una palabra que quizás usted no conoce, "purisimera", ¿y qué cosa es purisimera?, hay una fiesta de la Virgen de la Concepción, la Purísima, que es el 5 de diciembre, y siempre dicen, lástima que no va a estar, entonces, en casi todas las casas la gente católica pone una Virgen de la Concepción, que es la Virgen de Murillo, por cierto, entonces, la gente hace unos cantos muy lindos y regalan charangas, frutas, dulces, es decir, todo, entonces, la gente sale a las calles en una fiesta popular muy buena, entonces, la gente va para que le den, entonces igual los partidos políticos, los líderes están para acumular poder y para poder repartir, a vos te pongo en un sitio, a vos te mando a no sé donde, a vos te doy no sé qué, al otro, entonces, he ahí el toma y daca de la política y de la religión, que son las fuentes nutricias de nuestra cultura política, de nuestro modo de ser nicaragüense, de nuestra identidad en nuestras diferentes vertientes, híbrida y llena de anti-valores.

$R$ : Es cierto que si bien las reformas del 95 son reformas necesarias, coincide un poco con los términos del profesor De Vega, que es un constitucionalista español, que estudia la reforma constitucional en el contexto de la transición democrática española, que da pie a la creación de una nueva Constitución como la de 1978. En el caso nicaragüense, ¿no representan las reformas constitucionales de 2000 un punto de inflexión en la línea liberal-democrática que habia arrancado con el periodo de Violeta Chamorro, aún con toda su fragilidad, que es normal en cualquier proceso de transición? Especialmente, a través del pacto entre los dos hombres fuertes que se reparten las magistraturas en las principales instituciones del Estado y configuran un "bipartidismo institucional".

O.L.: Mientras en Suiza nadie sabe quién es el presidente, en Nicaragua para las expectativas en la cultura del nicaragüense las cosas no se hacen para tener poderes diseminados, sino para crear un poder resaltado, que se vea que es un poder del Estado, la Contraloría, el Ejecutivo, o sea, es un poder, como dicen los americanos, "to show", para ser un derroche de gala, de ostentar, ¿verdad?, o sea, entonces cuando se reparte el poder, guau, antes eran las instituciones militares que ahora han decaído pero pueden volver a resurgir, bueno, es el caso de Honduras, igual en América Latina todo viene en oleada, o sea, los gobiernos liberales, los gobiernos conservadores, los gobiernos militares, ¿por qué subió Ortega?, porque han subido en otros países de América Latina los gobiernos de izquierda, y cuando vinieron los gobiernos de derecha en los gobiernos 
democráticos del 90, a finales del 90, encontramos a Alfonsín en Argentina, es decir, todo viene por oleadas, porque en América Latina todos son como vasos comunicantes, no sé si conoces la figura de los vasos comunicantes en física, que usted echa un líquido azul en un vaso y luego se riega por los demás aunque tengan diferentes formas, que están al mismo nivel, entonces, eso sucede con nosotros, hay vasos comunicantes internos, nuestras culturas fluyen desde abajo, porque tienen más apego con el pasado histórico, así cuando nos llega la moda o lo más trivial.

R: Pero esa perdida de legitimidad de la función constitucional, especialmente, de la Corte Suprema, porque la justicia constitucional y, bueno, la independencia del Poder Judicial es casi un elemento sagrado en cualquier democracia consolidada, y el Consejo Supremo Electoral que sirve para garantizar la limpieza y transparencia de los procesos electorales y del derecho al voto, que yo creo que es síntoma de la participación y de la salud democrática de un país.

O.L.: Es sucio eso, y además refleja que no hay institucionalidad, sino que hay personalismo, o sea, es triste ver que en nuestro país, por ejemplo, si el Consejo Supremo Electoral o la Corte Suprema de Justicia inicialmente en el año ochenta y algo eran siete Magistrados, cada vez que subía un nuevo presidente se ampliaba a diez, se ampliaba a doce, se ampliaba a quince, porque el que subía pedía una cuota de poder, o sea, yo delego, pero me das, no es una oposición leal, no es Rajoy frente a Zapatero: "mirá y te critico", no, yo te voy a criticar, pero además de tener mis críticos yo también voy a ser un consentido que va a pedir, ¿no?, entonces, eso va deformando la institucionalidad, entonces, aquí las instituciones funcionan por el nombre, pero no porque sean verdaderamente eficientes, un ejemplo, creo que en América Latina hay una nueva idea de la democracia, pero que las instituciones democráticas realmente sean sanas, no, no, entonces, igual con la institucionalidad, si vamos más allá de la fachada institucionalidad y vemos lo que hay dentro, tiene el mismo sabor que las cañerías que están derruidas y que son viejas, o sea es como pintar por fuera, pero por dentro están tan podridas que el agua aunque pase por una cañería que se vea bien siempre va a ser agua sucia, agua podrida, entonces, es simplemente, lo de constitucional e institucional y Estado de Derecho, son términos que fueron aceptados para nosotros acoplarnos a la modernidad, pero en el sentido más ligero, más leve, por encima, pero nunca de raíz, porque creo que el verdadero trasfondo, el verdadero interés que debería prevalecer para que nuestra sociedad sea democrática es que haya voluntad política, virtud política y que haya también conductas políticas acordes con esos valores.

R: Otro aspecto que me interesa resaltar es que después del fraude del 2008, de las municipales, no parece posible que el Frente vaya a encontrar apoyos en los otros partidos políticos para conseguir aprobar su propuesta de reforma constitucional $y$, bueno, es mi intuición, seguramente tú como nicaragüense y viviendo el clima político del país, quizás tú tengas otra percepción, ya sea respecto a la reelección presidencial, ya respecto a esa reforma de la estructura del Poder Ejecutivo creando la figura del Primer Ministro, que, en realidad, es una coartada quizá para garantizar la elección si se reparten nuevamente los cargos los dos principales partidos. ¿Cuál es tu opinión?

O.L.: Bueno, obviamente, esto no es muy difícil de adivinar, pero creo que el presidente Ortega va a actuar más apegado a la conducta chavista, si algo tiene Chávez o algo tiene Fidel Castro es el talento propio, con su palabra encendida, abrasante, tienen mucho conocimiento de la historia, pues, claro, obviamente con su retórica, pero sí creo yo que 
a pesar de ser dictadores son dictadores que dicen cosas interesantes, y que aquí es un presidente cadencioso, frío, que no tiene ni siquiera imaginación, es un presidente desgastado, es decir, no es una izquierda inteligente siquiera, porque la izquierda inteligente es la que practica Lula, izquierda inteligente, aunque pueda ser maléfico y todo, pero Fidel Castro es un hombre brillante, sigue siendo un hombre brillante, pero Daniel Ortega es un hombre mediocre, entonces, ¿qué va a hacer él?, él va a utilizar las dos armas que siempre ha tenido tratar de diezmar a la oposición para fragmentarla, antes nosotros decíamos que el liberalismo era un músculo, o sea, era un pedazo de carne fuerte, llega el sandinismo y, ipa!, lo partió en dos, ahora van a hacer el picadillo, ustedes dicen el salpicón, sí, entonces ellos se siguen por el accionar más burdo, no confían en el consenso, no confían en el acuerdo, no, es lo mismo, ellos, todo, todo lo que sea modernidad va por fuera, pero por dentro siempre seguimos llevando en nuestra sangre los mismos anti-valores, vicios que siempre hemos llevado y cargado, en primer lugar; y, en segundo lugar, creo que va a responder a la iniciativas de Chávez y no sólo de Chávez sino de otros grupos en el poder, Correa y Evo Morales le van a decir cómo va a ser el rumbo en América Latina, entonces, en la medida en que la tendencia sea hacia la radicalización va a caminar hacia eso. Por el otro lado, hay vectores internos, ¿cómo cuales?, el deterioro de la economía lo va a llevar al Estado de sitio, seguido del Estado de emergencia, las necesidades de los diputados va a llevar a comprar a más diputados, entonces, él va a responder a dos vectores, los externos, por donde va el chavismo o el socialismo del siglo XXI, como yo digo, la dictadura del siglo XXI, que es una deformación que ha querido levantar el muro de Berlín en América Latina con alquitrán, le digo yo, en primer lugar; y, en segundo lugar, aprovechar la debilidad de la oposición para sumar gente. Entre más divida la oposición, ellos consiguen más gente, utilizaron al Cardenal, ¿por qué?, porque es una figura que maneja las cartas, tener al Cardenal, guau, le dieron un lugar, está en el Consejo de Ministros, soy un señor importante, tengo carro, tengo chofer, además está mi allegado, porque Roberto Rivas, que es el presidente del Consejo Supremo Electoral, va a renovar nuestros intereses y lo podemos utilizar, y en la medida en que yo te chantajeo o te engatuse, yo puedo utilizar al Consejo Supremo Electoral. Entonces, todas estas cosas, la coacción, el juego sucio, la trampa, la perfidia, creo que van a ser las armas que van a utilizar para desviar todo esto. Porque sus críticas al sistema liberal de la democracia burguesa, es decir, yo creo que quizás está cumpliendo con una dictadura vulgar, que comparada con la de los años 80, la revolución tenía más mística y tenía más gente variada, variopinta, tenía intelectuales, tenía empresarios, entonces, la izquierda era más atractiva, entonces, ahora es burda, es callejera, es fascista, es peleonera, es sucia, o sea, es desarrapada, no tiene mística, claro esto es poco científico, suena como muy sentimental, muy apasionado, pero yo digo todo responde al análisis de la psico-sociología, es decir, ver la política como hacen los politólogos en Estados Unidos a la luz de los datos, no, no, hay que entender, hay que ver la política en Nicaragua a la luz de varios filtros, el filtro de la cultura, el filtro de las emociones, y el filtro de la psicología del nicaragüense, entonces sí podemos entenderlo. Yo le recomiendo un libro, que se llama El nicaragüense, que le va a servir mucho para comprender nuestra psicología.

R: Antes se refería a la oposición, a lo largo de las entrevistas que he hecho esta semana se contempla con mucha preocupación el cierre de los espacios a la oposición tanto en el parlamento, y me refiero a la división del liberalismo, fundamentalmente, y también al acoso que han sufrido otras fuerzas políticas, como es el caso de MRS o el Partido Conservador en las últimas elecciones municipales, a través de la negativa del Consejo Supremo Electoral a dejarlos participar en la contienda, y, por otra parte, en 
la propia calle, o sea, la libertad de expresión, de manifestación, por ejemplo, las protestas contra el fraude donde aparecen pandillas o grupos armados, y, según me comentaba Violeta Granera, pagados por el Frente, incluso me decía que los machetes eran nuevos porque brillaban a la luz del sol...

O.L.: Sí, sí, en Nicaragua todavía estamos en muy bajo índice criminal y en Honduras, y en Guatemala, qué sé yo, a diario un decapitado, uno que le sacaron los ojos y le echaron ácido, o sea, la perversión es terrible, aquí no, aquí, por ejemplo, en Masaya nosotros tenemos la puerta abierta y no pasa nada. Aquí en Managua es diferente. Esos espacios se van cerrando porque es una medida de amedrentar al nicaragüense para que no se manifieste, a la oposición la desanima, la desmoraliza, si hay algo muy cierto en $\operatorname{los} 80$, es que con el deterioro económico de la revolución se fue mucha gente al exilio, casi 600.000 nicaragüenses se fueron al exilio, eso le redujo a la oposición sus fuerzas, porque los que se fueron eran los que estaban en contra del sandinismo, contrariamente, en estos años, debido a la crisis mundial y los Estados Unidos no está aceptando emigrantes y la oposición se ha quedado, entonces, como ellos siguen viendo que la oposición sigue siendo el $63 \%$ o el $64 \%$, tal vez más, porque ellos tienen un $30 \%$ o un $33 \%$ sólido del pueblo nicaragüense, de la masa votante, ese sesenta y algo por ciento de la oposición se ha tenido que quedar porque no ha podido irse a otro lado, porque no tiene las puertas abiertas, no somos Senegal tampoco, entonces, qué se hace, se amedrenta a la sociedad civil, en un discurso público del Frente Sandinista la esposa de Daniel Ortega, Rosario Murillo dijo: "no vamos a permitir que la oposición siga manteniendo los poderes independientes", eso lo dijo en los medios, la prensa, la radio, entonces, ¿qué quieren decir con eso?, que van a empezar a utilizar la intimidación y a cortar, porque en Venezuela lo hizo Chávez, porque Correa lo comenzó a hacer, porque la Kichtner amenazó al Diario "El Clarín", entonces, como te dije, Daniel Ortega responde al esquena, a los vectores, a la dinámica exterior y responde también a la credibilidad de los vectores que se han comprometido con la oposición, porque para ellos la oposición tiene dos objetivos, o los utiliza políticamente o los lleva a un estado en que por necesidad los convierte en sus aliados, que es el caso de Dionisio Arguello, el Alcalde de Managua, que era un ex - boxeador, cayó en la pobreza, fue una estrella mundial del boxeo, se dio al consumo de las drogas, pero por su estado de necesidad lo convirtieron en un aliado, era populachero, era popular, entonces lo utilizó para atraer votos, porque eso es lo que hacen ellos, ellos siempre ponen a la persona más popular y la compran, este hombre murió además en condiciones dudosas. No lo pudieron ver sus hijos, se enterró en una caja sellada, se disparó un balazo a quemarropa extrañamente.

\section{$R:$ ¿Y es posible una nueva incidencia de la violencia política en este país?}

O.L.: Yo creo que sí, porque Venezuela sigue siendo un modelo atractivo para los que están en el poder y muy depresivo para los que están en la oposición, porque los nicaragüenses estamos seguros, al menos los que estábamos en la oposición, que antes el problema era Fidel Castro a raíz de la antorcha, la guía, hoy el problema está en Venezuela, que es quien está diseminando esta dictadura del siglo XXI. Entonces, Chávez todo lo hace por la vía legal, referéndum, Constitución, leyes, claro, cuando ha tenido la oportunidad porque alguien de Caracas, como el Sr. Ledesma, él utiliza la fuerza y no le importa, igual Daniel Ortega, por otro lado, el Estado se rompe, pero a ellos no les importa, ellos son dictadores. Hay una emisora aquí que se llama "Radio Corporación" y ellos dicen siempre, sacan declaraciones de uno de los fundadores del sandinismo, "yo le dije a Daniel Ortega, nosotros vamos a estar en el poder por los 
siglos de los siglos y vamos a hacer todo lo posible para que nunca vuelva a caer". Antes decía, primero se caen las estrellas y el cielo, pero vamos a acabar con la Contra, y perdieron el poder, entonces, ellos más que todo, están inclinados no por una vocación democrática o por una vocación ideológica, no, ellos están inspirados a actuar por una motivación de permanecer en el poder.

R: ¿Y qué opina de los CPC, en este sentido, como estructuras casi paralelas del Poder Ejecutivo en el seno de la sociedad civil?

O.L.: Sí, bueno eso es como en Cuba o como las fuerzas de defensa de la revolución bolivariana, esta gente se llamaban CDS, ahora van a ser los institutos del poder popular, o sea, realmente, vamos a ser como en Venezuela, el Ministro del Poder Popular, el Ministro del Poder Popular de Economía, entonces, todos los CPC que son más allegados, los fieles, los incondicionales o los más sumisos a Daniel Ortega van a llegar a gobernar, a controlar el país, porque va a ser una fuerza, él lo dijo hace poco, bueno, porque Daniel Ortega no habla, jamás da una conferencia de prensa, nunca, nunca, él convoca a los sandinistas y él habla, punto, y ya, se va. Y si está ante los grupos de fuerzas productivas de la empresa privada, el COSEP, o del extranjero, la televisión muestra lo que él dice pero no lo que los demás dicen, o sea es totalitario, tienen una vocación absolutista, o sea, todo para él y nada para la oposición, lo cual no es ni siquiera inteligente, no dar la apariencia de que hay una oposición.

\section{R: ¿Cree que el liberalismo vuelva a unirse mientras esté Arnoldo a la cabeza del PLC?}

O.L.: Mira a mí me gustaría tener un turbante y una bola de vidrio para poder contestarte, sí es difícil, pero mientras la oposición no tienda a la unidad no vamos a poder hacer nada, o como dice el adagio popular todo el mundo se siente líder como para estar, este es un país donde todo el mundo quiere ser cacique, este es un país donde todo el mundo quiere ser jefe y nadie quiere ser sumiso, entonces, se crean las facciones impulsadas por el interés de los bandos, se crean las facciones luchando por sus propios intereses y no por los intereses patrios, se crean los partidos políticos o las fracciones pensando no en el interés de la nación, sino en el interés del partido, de la parte, entonces, el cacicazgo es fácil, ahora, si yo estoy en una alianza en un partido y no me sale pues me salgo y formo otro, mira la evolución de los partidos políticos en Nicaragua, antes había las paralelas históricas, los conservadores y los liberales, ahora están los sandinistas y liberales, y todos se han fraccionados, incluso yo llegué a pensar que el sandinismo nunca se fracciona, bueno sí está el MRS, los liberales ya van dos fuerzas, ALN, PLC, ya van por la cuarta, porque esa es la dinámica de la estrategia transversal del sandinismo, o sea, dividir a la oposición, porque parecemos la tiranía del número, los más numerarios, los más por su número, no los más por sus principios.

R: Y, por otra parte, los vacíos de transparencia en el ejercicio de la presidencia por parte del presidente Ortega, proseguido en ese vínculo familiar con su esposa, que tiene una ascendencia importante sobre las decisiones del presidente, ha causado parte de la desconfianza del partido que se ha visto relegado de la importancia que pudiera tener en los momentos en que estaba en la oposición o en el gobierno de 80 cuando, obviamente, era la Dirección General la que tomaba decisiones consensuadas.

O.L.: Bueno, usted me va a perdonar, pero en Nicaragua, Arnoldo Alemán es el reo del pacto con Daniel Ortega, pero Daniel Ortega es el reo del pacto con Rosario Murillo. ¿Y 
de donde viene eso?, cuando Zoilamérica, la hija de Daniel Ortega le acusó de violación, ella dijo yo no lo voy a reconocer, yo voy a desmentir todo lo que ella ha dicho, pero cuando ganemos el poder vamos mitad y mitad. Entonces, para mí la que tiene el poder es ella, y él está esperando rendir cuentas para que algo no suceda, el sandinismo se parece a las películas de "El Padrino", en la primera, el padrino mata, es la sangre, es una banda, en la segunda se consolidan económicamente y en la tercera ya, socialmente, las nietas del Padrino se casaban con los hijos de los senadores, entonces, es como un vicio social, y ella responde al interés de tener el poder por un pacto que realmente tiene con Daniel Ortega, o sea, lo ha hecho incluso público, Daniel ha dicho: "ah, bueno es que esto es así porque la mitad de todo lo tiene ella", o sea, en la televisión se ve que ella le pone lo que va a decir, porque el hombre es un hombre decaído ya incluso por el sandinismo, por lo menos Daniel Ortega tiene algo de liderazgo, pues, pero es un liderazgo degenerado, la gente no lo ve como un acto de libertad moral, lo ve como un acto de vanagloria, por el exceso de conquista, obviamente, en el campesinado, la mayoría de los nicaragüenses que tenemos muchos prejuicios con ese "tayacán", por ese líder fuerte, guau, eso también es una parte complementaria que apuntala, es esta actividad paternal, que es el líder, es el santo patrón.

\section{R: Pues, para concluir, si tienes algo que añadir más...}

O.L.: Lo único es que el año pasado que daba las clases en la UAM de política exterior de Nicaragua, siglo XIX, siglo XX y siglo XXI, de vida republicana son ciento cincuenta y algo de años, y comencé a notar en cada proceso histórico encontré como brotes, como ciclos que se repiten, esto lo tengo publicado en un artículo en la prensa, que apareció hace un mes, se lo puedo mandar por correo electrónico, donde decía que en Nicaragua se repiten diez fenómenos, los pactos, desde 1853, los pactos políticos, se repiten también los conflictos fronterizos, la rivalidad con Costa Rica, el enfrentamiento con los Estados Unidos, la integración centroamericana, las luchas internas entre bandos, hay otros que no recuerdo ahorita, y lo que yo creo después de esto es que todo nos viene del extranjero: la independencia vino porque en Ecuador en 1809 se independizaron entonces ya había venido la de Estados Unidos, ya había venido la revolución francesa, entonces, nosotros nos independizamos, y luego los poderes conservadores nos saquearon durante el siglo XIX, regímenes conservadores como los de los 35 años que hubo aquí en Nicaragua, vinieron los gobiernos liberales, vinieron los gringos, como hicieron los americanos en Panamá, y lo que decía Daniel Ortega nació al poder porque hay una camada de líderes que surgen y en el momento de Violeta Chamorro igual, nosotros estamos condicionados por los agentes externos, eso siempre ha sido así, si los gobiernos latinoamericanos son tolerantes con Chávez, es porque su entorno es muy similar a él, porque Kichtner podrá ser izquierda pero lo tolera, ese es un payaso apasionado, ¿no?, Lula Da Silva tiene derecho a ser más radical que yo, sí, pero el día en que la comunidad interamericana gire verdaderamente más hacia la derecha entonces yo creo que ahí sí Daniel Ortega se va a ver más acosado por el derecho internacional, ah somos un país pobre, dependiente, nuestro PIB es de 5.000 millones de dólares, en producto per cápita, el de los nicaragüenses es de 1.025 dólares, después de Haití, o sea, somos una nación pobre, dependiente, es decir, sumisa, ah, otra cosa es lo del canal interoceánico, entonces, toda la vida los fenómenos se repiten, yo haría una pequeña síntesis, entonces, yo creo que Nicaragua en gran medida va a depender, nuestra tendencia va a depender del panorama externo pero regional, y la economía, va a marcar mucho, además yo creo que hay dos factores que han cambiado, 
el siglo XIX fue el de la colonización, el siglo XX fue el de la ideologización, y el siglo XXI va a ser el siglo del mercado internacional, del comercio, además los centros de poder eso va a afectar, yo creo que va a afectar más que la ideología, entonces, Chávez quisiera romper totalmente el mercado, pero no va a poder, si no tiene dinero él no vende, por un lado, por otro lado, Nicaragua tiene esas mismas necesidades, un mercado mucho más fuerte, la tecnología hace que el mundo sea un pañuelo, entonces, ya no se puede asesinar, los tutsis y los hutus son un fenómeno en África, entonces, la tecnología del mercado y, obviamente, el entorno latinoamericano y el entorno extranjero, porque nosotros no tenemos mucha iniciativa porque somos países pobres, pero va a ser muy difícil que esto cambie. Si nosotros ponemos un mapa político de los gobiernos en América Latina, vemos los gobiernos conservadores, los liberales, se da en ciertos períodos, yo veo, yo calculo que son entre doce y quince años, eso se da, matemáticamente, por ejemplo, podríamos calcular una ecuación para que esto sea más riguroso, entonces, yo he visto que cada quince años hay como un fenómeno que rompe con ese continuismo que había existido, con esos modelos, con esos patrones y por ahí se pude deducir que a pesar del fenómeno social tú no puedes decir que es inasible, es inatrapable, no, pueden predecirse algunos modelos de comportamiento.

R: Pues, muchas gracias. 
ENTREVISTA $33^{48}$ :

Nombre del entrevistado: D. Félix Madariaga.

Cargo actual: Profesor de Ciencia Política en la Universidad Americana (UAM). Asesor dentro del gabinete del presidente Enrique Bolaños (2001-2007).

Fecha de realización de la entrevista: Managua, 10 de septiembre de 2009.

Lugar: Consultoría privada.

Duración estimada: 59 minutos.

\section{TEXTO - Transcripción 33:}

R: ¿Qué recorrido puedes hacer sobre las dos últimas dos décadas en Nicaragua, y sobre las consecuencias que han tenido los cambios constitucionales en la consolidación de las instituciones democráticas?

F.M.: Bueno, a manera de recorrido, quisiera iniciar puntualizando que Nicaragua en su historia constitucional más reciente, verdad, sin querer hacer los antecedentes demasiado antiguos, sus antecedentes, digamos, inmediatos, la Constitución del 87, en donde creo que imperó mucho la mentalidad del Estado en situación de guerra, era una Constitución que como sabés, le otorgaba al presidente de la República, como jefe de Estado y jefe de gobierno, una cantidad de prerrogativas, digamos, que no era parte de la tradición nicaragüense, ni aún de la tradición latinoamericana, a pesar de ello, hago un paréntesis, y recuerdo que, en efecto, Nicaragua es muy bien conocida por su tradición de hombres fuertes, de caudillos, digamos, pero esa tradición en muchísimos casos siempre se dio al margen de la Constitución, es decir, por vía de la legitimidad en el ejercicio del poder, quizás el mejor ejemplo para ilustrar esto es el caso de la Constitución, conocida como "La Libérrima", de finales del siglo XIX, durante la administración de Zelaya, una Constitución sumamente progresista para su época, sin embargo, con una Administración Pública muy autoritaria, centrada alrededor del Jefe de Estado, en este caso, el presidente Zelaya, igual sucedió con Somoza, las distintas constituciones, pero quería señalar eso, digamos, de que la tradición autoritaria en Nicaragua no devenía directamente de la Constitución, sino de un uso ilegítimo del poder, y en los años 80 lo que se procura es quizás, no sé si esta palabra es correcta, sincerar la tradición autoritaria en el texto constitucional, otorgándole al presidente una cantidad de facultades, a mi juicio, excesivas, inclusive, permitiéndole, prácticamente, la legislación por decreto, al punto, inclusive, de permitir que en los años 80 el presidente pudiera llegar hasta el punto de aprobar impuestos por la vía de decreto, facultades que, como bien sabés, habían estado ya derogadas en toda la tradición de formación del Estado liberal en Europa, inclusive, desde la Edad Media, digamos, donde, en este caso, el Jefe de Estado, el Rey, ni siquiera tenía la facultad de decretar impuestos sin un mínimo consenso, digamos, con la Corte, en Nicaragua teníamos un Jefe de Estado-Rey, digamos, y, quizás, el término es un poco exagerado, ¿verdad?, pero, digamos, esa es la mentalidad con la cual inicia nuestra más reciente historia constitucional. Sucede un asunto interesante, que no lo he visto resaltado hasta ahora en ningún texto, y posiblemente esta es una oportunidad para decirlo, y es el hecho de que

48 Entrevista muy interesante, por su exposición en clave politológica de algunos de los factores que inciden sobre el proceso de reformas constitucionales experimentado en Nicaragua, tales como: la debilidad del sistema de partidos, la formación del liderazgo político, o el juego de incentivos, implícito en las decisiones de los actores, en el marco de los procesos de diseño institucional democrático recientes. 
en 1990 surge una gran oportunidad para hacer una transición democrática radical, la historia de las transiciones democráticas demuestra que son los rompimientos de las viejas formas del ejercicio del poder, los que permiten hacer transformaciones muy rápidas, cuando hay todavía un período muy breve de tiempo, que permite al nuevo régimen hacer transformaciones muy rápidas mientras cuente con un alto grado de aprobación, es decir, cuando la ciudadanía recibe a la nueva administración, en este caso, la presidenta Chamorro con un altísimo grado de aprobación, de expectativa de que la naciente democracia y el fin de la guerra puedan permitir transformaciones rápidas. Sin embargo, la presidenta Chamorro pierde la oportunidad de hacer esa transformación constitucional que le regrese al parlamento, en este caso, lo que en Nicaragua se denomina: Asamblea Nacional, las facultades constitucionales de una tradición más liberal, digamos, en el sentido de restarle atribuciones excesivas al presidente de la República, fortalecer algunas entidades de la Administración Pública, como es, por ejemplo, la figura del Ministerio de Defensa, la des-partidización de las fuerzas militares y policiales, fortalecer el rol del parlamento en el aspecto presupuestario, fortalecer el rol del parlamento en el aspecto de aprobación de convenios internacionales y política exterior, fortalecer el rol del parlamento en el ámbito del control civil sobre, por ejemplo, la inteligencia militar, etc., estas oportunidades la presidenta Chamorro las pierde, y las pierde no por miopía, y tampoco las pierde por falta de visión política, sino por un cálculo político que, a mi juicio, resultó desafortunado, y es el hecho de que frente a una coalición que se conocía como la UNO resultaba muy difícil gobernar el consenso, y, por tanto, la presidenta asesorada, en este caso, por sus principales colaboradores, como era Antonio Lacayo decide resistirse a propuestas constitucionales que empiezan a surgir muy temprano, porque cree que gobernar con la Constitución de los años 80 le permitía a ella un grado de autoridad en el ejercicio del poder, que le permitía hacer cambios acelerados y más rápidos. En esta escuela de pensamiento, hay quienes piensan que fue adecuado este cálculo político y hay quienes consideran que fue desafortunado, en todo caso, la historia demostró, en mi opinión, mi lectura personal, que el cálculo no fue muy adecuado porque, al fin y al cabo, la reforma sucedió en el año 95, pero sucedió a un altísimo costo político de la coalición, en este caso, varios partidos de la UNO en alianza con el Frente Sandinista rompen su coalición con la presidenta Chamorro, como titular de la UNO, deciden actuar en el parlamento al margen de la Presidencia de la República, y bajo el liderazgo de personas como Luís Humberto Guzmán, que era el titular de la Asamblea, del Jefe de Bancada del Frente Sandinista, que, en ese momento, era Sergio Ramírez, empiezan a promover las reformas, reformas que fueron altamente controvertidas en esa época, y que la presidenta decide no firmar, es decir, no autorizar su reforma, pero, al fin y al cabo, la Asamblea logra la mayoría para pasar la reforma. Hago este antecedente, porque quisiera colocar un punto, como un elemento recurrente en la historia constitucional reciente de Nicaragua, y significativo para la democracia, y es la tensión entre una presidencia fuerte, el rol o la figura de una Presidencia de la República muy, muy fuerte, o el empoderamiento del Poder Legislativo, digamos, con una tradición más apegada al concepto del balance de poderes, ese debate permaneció, digamos, en el aire, y la elección de Arnoldo Alemán como presidente de la república en el año 96 abre, digamos, las puertas nuevamente para reconsiderar una reforma constitucional, en su campaña presidencial del año 96, Arnoldo Alemán, que, en ese momento, era alcalde de Managua, renuncia a la alcaldía para lanzarse a la presidencia, resalta o remarca su intención de reformar la Constitución, ya en la presidencia Arnoldo reconoce muy rápidamente que para reformar la Constitución requiere los votos del Frente Sandinista, y vemos ahí como muy temprano, ya por finales del año 98, 
empiezan a darse una serie de arreglos por debajo de la mesa entre el Frente Sandinista y el Partido Liberal Constitucionalista para consensuar los votos para la reforma constitucional, en ese momento, personas como este servidor, que éramos, digamos, observadores del proceso, como cualquier otro ciudadano, pensábamos que era una buena oportunidad para, finalmente, consolidar una serie de reformas que habían quedado, digamos, en el tapete, dado que, en efecto, con la reforma del 95 se avanzó en fortalecer, por ejemplo, o darle énfasis a la figura del Jefe de Estado como Jefe de las Fuerzas Armadas también, y tocar un tema que era muy sensible en los inicios de los 90, que era el tema de la subordinación de las Fuerzas Armadas y de Seguridad a la autoridad política civil, ¿verdad?, pero quedaron muchos otros temas pendientes, muchas ambigüedades en la Constitución, lo que sucede, luego, en la administración de Arnoldo es que el Frente Sandinista utiliza la necesidad que le plantea el partido del gobierno para incluir una serie de aspectos, que generan un gran retroceso en la consolidación democrática, y lo que me lleva al próximo punto, recordando que mi punto primero era esta dicotomía entre una transición democrática y qué rol debía jugar la figura del presidente, el segundo punto controversial, creo yo, es el aspecto del sistema de partidos, verdad, es decir, consolidar un bipartidismo o un sistema político más flexible en cuanto a la inscripción de partidos, etc. Recordemos que la tradición nicaragüense es bipartidista, desde 1923 Nicaragua se oficializó como sistema bipartidista y, si bien, existieron partidos durante gran parte del siglo XX, que no eran ni liberales ni conservadores, actuaban como partidos sin licencia oficial, digamos, para las elecciones, y lograban inscribir a algunos candidatos como aliados del partidos de oposición a la dictadura, que era el Partido Conservador, entonces, el Frente Sandinista en los años 80, particularmente, en el año 83 con la Ley de Partidos Políticos hace un remedo, un maquillaje de ley de partidos, que empieza, digamos, a consolidar una tradición o a dar los primeros pasos de una tradición multipartidista, pero que fracasa, fracasa porque la Ley de Partidos del 83, que fue derogada pocos años después, establece que podrá funcionar cualquier partido siempre y cuando no critique la revolución, y básicamente castra cualquier posibilidad de una oposición verdadera, pero aún esta nota al pie histórica para recordar que ese era otro tema pendiente, digamos, que la Constitución dejara claro qué sistema de partidos iba a privilegiar la transición democrática, y el consenso parecía ser del 90 hasta más o menos el año 2000 de que se privilegiaba un sistema multipartidista, pero el pacto PLC - Frente Sandinista de Liberación Nacional lo que hace es frustrar ese proceso y retomar la tradición bipartidista que tan caro le había costado a Nicaragua, sobre esto es oportuno recordar que el bipartidismo per se no es malo, no existe sistema político que por su propio diseño es bueno o es malo, pero en la tradición política nicaragüense el bipartidismo ha sido el origen de muchísimos conflictos internos, porque al no existir una diversidad más o menos aceptable de partidos políticos se obliga a la ciudadanía a tener no más que dos opciones, que aquí ya terminan siendo una misma por los tradicionales pactos, ¿verdad?, que se han dado en la historia de Nicaragua. Yo creo que esos son los dos aspectos que yo quisiera resaltar, digamos, en este recorrido que me has pedido.

R: Además ahora que haces referencia a los pactos, recuerdo que el año pasado cuando ya terminaba la memoria de investigación señalaba que el pacto OrtegaAlemán no era una cosa insólita en el caso de Nicaragua, en la historia constitucional del país siempre hay pactos politicos que preceden a una reforma, y una reforma que es casi un "traje a la medida" de los intereses políticos de los líderes.

F.M.: Ni más ni menos. 
R: Antes te has referido también, al hablar del conflicto con la presidenta Violeta Chamorro, como, en el caso de las reformas, el Ejecutivo siempre ha estado enfrentado al Legislativo, y el propio conflicto entre ambos poderes en el proceso de aprobación de la reforma constitucional ha generado, incluso, la creación de instrumentos jurídicos al menos controvertidos como las leyes Marco, que suponen un aplazamiento de la entrada en vigor de las reformas, ampliando también el proceso de negociación política de los actores que están involucrados para hacer reajustes que permitan el acuerdo.

F.M.: Claro.

R: En términos jurídicos estrictos, es inconstitucional la propia Ley Marco. ¿Cuál es tu opinión al respecto?

F.M.: Ni más ni menos, plenamente de acuerdo, creo que la Ley Marco para tomar prestadas las palabras de mi buen amigo Gabriel Álvarez, con quien te recomiendo que conversés, una investigación de este tipo creo que no se puede hacer sin la opinión de Gabriel.

\section{R: Mañana me encuentro con él.}

F.M.: Qué bueno, me lo saludás, Gabriel habla de que Nicaragua ha tenido una tradición en donde se ha hecho un uso político de la ley para enfrentar tensiones entre los partidos, él le llama "la juridización de la política", eso en Nicaragua y en otras muchas partes del mundo, pero lo que ahora resulta insólito es que el método prioritario ya no es la politización de lo jurídico sino la juridización de lo político, en donde se ha tratado de darle una connotación jurídica a todo el debate político, ¿verdad?, toda reforma jurídica por definición es política, ¿verdad?, pero en el caso de la Ley, digamos, Marco es interesante recordar que con un absoluto descaro de todos los actores se toman decisiones que son a todas luces inconstitucionales, ¿verdad?, para encontrar alternativas cortoplacistas al conflicto, digamos, entre los actores. Mi reflexión de fondo al respecto de esto es que las fallas del sistema político nicaragüense entre muchas otras, pero en el caso que nos ocupa, radican en la ausencia de mecanismos de resolución de conflictos en la arena política, y al no encontrar mecanismos donde se puedan hacer por los canales constitucionales llegar a acuerdos, ¿verdad?, entonces, lo que se empieza es a tratar de modificar constantemente las reglas del juego, es como que si dos jugadores deciden en mitad del juego modificar las reglas, ¿verdad?, para los beneficios mutuos, eso en teoría de juegos no sería necesariamente nocivo si ambos jugadores aceptan como legítimas las reglas de juego, pero si tomamos en consideración que no son dos jugadores, sino que son varios jugadores y sólo dos jugadores hegemónicos, es decir, que deciden utilizar sólo reglas aplicables para ellos dos y excluye al resto, entonces, entramos a un proceso de rompimiento del consenso mínimo de gobernabilidad, verdad, que es lo que ha pasado en Nicaragua, y, en este caso, lo que ha habido es, voy a hablar fuera del lenguaje político, digamos, lo que ha habido es un descaro, lo que ha habido es una pérdida de la vergüenza total, en donde ya el análisis político no calza, digamos, si no se puede hacer, el análisis político desapasionado no calza cuando uno, digamos, como ciudadano definitivamente se indigna con lo que pasa, porque recordando mi reflexión inicial yo decía que las dictaduras habían actuado con un doble discurso y con legislaciones muy progresistas, Nicaragua ha tenido un sistema, por ejemplo, un Código Penal muy progresista para su época, un Código Laboral, posiblemente, el más 
progresista, sin duda, de Centroamérica, sin lugar a dudas, y, posiblemente, uno de los más progresistas de América Latina, por decirte que cuando en Nicaragua se empezó a crear el Partido Socialista Somoza hace un pacto con lo socialistas y los neutraliza como oposición a cambio de darle una serie de concesiones a los sindicatos nacientes, pero, en todo caso, hay un doble discurso, con una legislación, con un mundo, digamos, de leyes relativamente progresistas, con consideraciones adecuadas a una tradición de democracia liberal, pero con una praxis política autoritaria, ahora lo que hemos visto es un descaro, en el sentido de que, otras personas dirán, bueno, están sincerando nuestra tradición autoritaria y generando reformas de rango constitucional, como, por ejemplo, la Ley Electoral, que en Nicaragua tiene rango constitucional, y, por tanto, toda reforma constitucional necesariamente aborda el tema electoral, dándole a dos partidos políticos una cantidad de concesiones, que son inconsecuentes con la tradición de diversidad política, que fue el consenso de los años 90. ¿Por qué en Nicaragua es tan importante este consenso?, porque fue el consenso multipartidista el que logró votar a Somoza, a Somoza no es cierto que lo vote el Frente Sandinista como una fuerza política única, sino que el Frente, y ellos mismos lo han reconocido en su discurso político al denominarse partido de vanguardia, ¿verdad?, y como politóloga sabés el concepto leninista de la vanguardia, ¿verdad?, como la fuerza política que encabeza todo un arco iris, digamos, de expresiones, que, es cierto, lo hace con fines tácticos de corto plazo, ¿verdad?, con la lógica de consolidar un partido hegemónico, si puedo utilizar el concepto de Sartori de partido, pero el consenso, en todos los momentos históricos que Nicaragua ha tenido de conatos de democratización, ha sido el consenso multipartidista, y estas reformas están rompiendo ese consenso y le va a costar mucho al sistema político nicaragüense, porque el resto de actores no lo va a aceptar. En los años 60 y 70, como la reforma del 74, la Constitución del 74, por ejemplo, no fue mayor problema, porque los otros actores minoritarios no eran relevantes, pero si tomamos como referencia el porcentaje de votos del tercer partido de las elecciones del 2006, vemos que ya hay un $30 \%$ de votantes nicaragüenses, que están dispuestos a no votar ni por el partido mayoritario de izquierdas ni por el partido mayoritario tradicional de derechas, sino por opciones intermedias, ¿verdad?, hablo del 30\% refiriéndome a los votos de Eduardo Montealegre más los votos del MRS.

R: Estábamos hablando del multipartidismo, y otro aspecto que me interesa resaltar es que si bien en la reforma del 95 la composición de la Asamblea Nacional es de carácter multipartidista, son múltiples las pequeñas formaciones, cada una con su bancada parlamentaria, cuando, entre otras cosas, se rompe la coalición gubernamental que lleva a Violeta Chamorro al poder, esto es algo que sucede, habitualmente, en la tradición presidencialista, esa falta de apoyo de la formación partidaria al presidente una vez que éste alcanza el poder, ¿no?, y, de hecho, una parte de la UNO sí acompañó a Violeta Chamorro en sus planteamientos en el marco del conflicto, digamos, de la reforma constitucional, y otro, sin embargo, no. De hecho, la presidenta tuvo enormes dificultades para desarrollar su agenda de gobierno a causa del bloqueo EjecutivoLegislativo, que priva al presidente de una capacidad, digamos, de ejercer el gobierno, como le sucede también al propio presidente Bolaños, que yo creo que es de los presidentes que más dificultades ha tenido para ejercer la presidencia en la historia reciente democrática en Nicaragua, ¿no? A mi me interesaría escuchar tu punto de vista sobre la desigual posición del presidente, porque Arnoldo Alemán y Daniel Ortega son presidentes fuertes porque controlan a su partido, $y$, sin embargo, Violeta Chamorro y Enrique Bolaños no, y esto también genera un posición desigual no sólo 
para el desarrollo adecuando de la agenda de gobierno, sino para sacar adelante también su propia propuesta de reforma constitucional.

F.M.: Sí, bueno yo creo que, sin lugar a dudas, una de las premisas básicas del sistema presidencialista clásico, si puedo tomar como referencia Estados Unidos, que es que el modelo que inspiró a las nacientes naciones americanas, una vez que dejaron de ser colonias, es la premisa de que el presidente es jefe de Estado, jefe de gobierno, pero también líder del partido de gobierno, en el caso concreto de Nicaragua, para indicarlo, ¿verdad?, esa fue una tradición que se mantuvo fiel casi durante la mayor parte de nuestra historia, lamentablemente, esa copia tan mecánica, digamos, del modelo presidencialista estadounidense a nuestra realidad política tiene enormes limitantes, que son relevantes para la reflexión que te quiero hacer en base a tu pregunta, cuando no van acompañadas de la modernización de los partidos, es decir, partidos políticos en donde el presidente de la República es el líder del partido, pero es el líder del partido porque a su vez ha habido todo un proceso interno de legitimidad, digamos, de ese liderazgo a lo interno de los partidos, hago esta reflexión, porque lo que quería resaltar es que no podemos hablar de un sistema presidencialista en donde haya una relación funcional y de buenos términos entre el jefe de gobierno y su propio partido si no tomamos en consideración cuál es la estructura de los partidos en Nicaragua, cuál es la situación actual de los partidos en Nicaragua, y lo que un diagnóstico muy rápido nos dice es que el sistema políticos nicaragüense tiene enormes deficiencias, que no son diferentes a las que tienen otros partidos en América Latina, pero en el caso nicaragüense, son particularmente centrales cuando se asocian con otras deficiencias del sistema político, pues, en este caso, como la falta de transparencia, como la tradición, digamos, autoritaria, la polarización política, entonces, es sumarle a un sistema de partidos, sobre el cual Alcántara ha escrito abundantemente, que tiene una enorme cantidad de deficiencias, otros elementos, digamos, relacionados o tangibles al sistema político, y creo que los dos casos de estudio donde eso se reveló con mayor claridad es, precisamente, en la presidencia de la señora Chamorro y la presidencia de Don Enrique Bolaños, por razones distintas, pero con resultados muy similares, en el caso de la presidenta Chamorro por el hecho de ser una presidenta sin partido, verdad, y creo que su misma elección era desde el primer día el indicador de las deficiencias del sistema de partidos de no poder generar consensos por la ausencia de reglas del juego que fuesen aceptables por todos los partidos, por ejemplo, hoy te puedo hablar con mucha claridad de eso porque las pasiones políticas de inicios del 90 se han calmado un poco, y uno puede evaluar cómo Doña Violeta fue electa, es la presidenta de mayor grado de aprobación en las encuestas recientes, pero ella sale a la presidencia con un nivel de aprobación muy bajo, ese nivel bajo de aprobación en gran parte es resultado de la percepción ciudadana de que no había gobernabilidad, y de que era una presidenta sin poder, sin autoridad suficiente para poder gobernar, además de que fueron años de muchísima inestabilidad por el constante sabotaje del partido de la oposición, constantemente con huelgas, muchas de ellas violentas, con tomas de edificios gubernamentales, algunas que causaron muertos, como fue la toma del Banco Central de Nicaragua, que concluyó con el lamentable fallecimiento de un estudiante, con inclusive alzamientos armados muy sangrientos, el alzamiento de por lo menos 4.000 personas en armas que convirtió a Nicaragua, nuevamente, en un país de guerrillas, por lo menos del 90 hasta casi el final del año 96, de hecho, los últimos grupos se desmovilizaron hasta finales del año 97, ya en el primer año de Arnoldo, entonces, hagamos esa observación, y cuando recordamos, ya con un vistazo desapasionado, nos damos cuenta de que Doña Violeta fue electa porque era percibida como la representante de un sector no partidista, 
porque los partidos grandes no se ponían de acuerdo, de hecho, los dos partidos de mayor estructura política desde el 90 eran, no sandinistas, era el Partido Liberal Independiente, perdón, los tres partidos, el Partido Conservador y el Partido Liberal Constitucionalista, eran los tres partidos que tenían más estructura en el año 90, ninguno de esos tres partidos apoyó a Doña Violeta, y la primera regla de juego que se pone para decidir al candidato es que todos los partidos en ese arco iris que se llamó UNO iban a tener un voto de igual peso, independientemente de la cantidad de su estructura, es decir, había partidos muy pequeñitos que no tenían una membresía que superara ni siquiera el centenar de personas, que tenían igual voto como el PLI, un partido que nació en los años 40, y con una membresía que superaba, en ese momento, por lo menos, calcularía yo las 10.000 personas, pues, o un partido como el PLC, que tenía ya para el año 90 juntas directivas oficiales en la totalidad de las cabeceras departamentales de Nicaragua, luego el Partido Conservador, el partido más antiguo de Nicaragua hasta en ese momento, igual tiene los votos que un partido que tenía meses de haber nacido, entonces, eso da indicios de un indicador de que se tienen que buscar reglas de juego, que, al fin y al cabo, por ser cortoplacistas para resolver un problema inmediato generan sistemas presidenciales con muy poca capacidad de poder articularse en todo el ámbito de políticas públicas o agenda legislativa con los partidos. El caso de Don Enrique es distinto, pero tiene consecuencias similares, es distinto en el sentido que Don Enrique, una vez más, no viene del partido en el gobierno, él se convierte en miembro del Partido Liberal Constitucionalista apenas un año antes de ser declarado candidato, entonces, no es reconocido por la mayoría, yo diría que por la enorme mayoría de la base partidaria como el candidato, de hecho, y yo te lo digo, habiendo sido miembro de su Gabinete, y siendo un admirador personal, en su carácter personal, pero debo de reconocer que él no era el candidato de la mayor base liberal, ¿verdad?, que había otros candidatos de primarias que tenían, que si se hubiera hecho una primaria más a la tradición, donde delegados del partido deciden, posiblemente, Don Enrique no hubiera quedado, sin embargo, queda por un apoyo político pleno que le da Arnoldo Alemán, ¿verdad?, entonces, yo creo que a manera de resumen o de conclusión a mi reflexión, esto nos llevaría a otra área que no está divorciada de tu estudio, ¿verdad?, pero es el sistema de partidos en Nicaragua, para entender, digamos, esta dinámica, y quizás es una oportunidad también para aclarar que cuando hablo de multipartidismo no me refiero, por ejemplo, al modelo de los años 90, en donde básicamente cinco personas se ponían de acuerdo para crear un partido político, pero como experta en Ciencia Política sabés que en Ciencia Política uno presta muchas atenciones a los incentivos, cuáles son los incentivos, y el incentivo del 90 era financiero, es decir, creabas un partido y el Estado de Nicaragua te daba una cantidad de dinero para la campaña política que reembolsabas a la hora de hacer gobierno o a la hora de ser miembro del partido, se creó un incentivo perverso para atomizar el sistema político, ¿verdad?, entonces, mucha gente critica el multipartidismo basado en una única experiencia, naturalmente, un experimento muy mal diseñado, pero que se corrigió, porque el sistema de financiamiento a los partidos políticos corrigió, digamos, esa deficiencia, y estableció que los partidos políticos pueden ser beneficiarios de algunos reembolsos de sus gastos de campaña, pero solamente en cierta proporción, en ciertos gastos, y únicamente a los que lograron acceder al poder ya siendo partido de gobierno o siendo partido representado en el parlamento, digamos, esa sería mi reflexión.

R: Por otra parte, en lo que se refiere al pacto, que una las principales reformas del 2000 significa la composición bipartidista a través del reparto de una composición paritaria entre el PLC y el Frente Sandinista, dice el profesor Sartori que cuando se 
pierde al adversario cambian todos los puntos de vista, y aqui el socio perdedor fue precisamente el presidente Arnoldo Alemán, cuando a cambio de su propia libertad está cediendo una parcela de poder importante al Frente, y que explica gran parte de la concentración de poder en torno al Frente Sandinista, y, particularmente, a la figura de Ortega, que además prorroga el ejercicio de la presidencia en su círculo familiar, a través de su esposa Rosario Murillo, distanciándose ya del propio Frente Sandinista, la propia cúpula del partido también está molesta con este giro actual del presidente de la República. Sí me llama la atención, que si el hilo conductor de las reformas ha sido esa semi-parlamentarización del régimen político, introduciendo figuras que proceden de la tradición parlamentaria en el modelo presidencial nicaragüense, atenuando el presidencialismo fuerte de la Constitución original del 87, sin embargo, sí ahora se da una concentración de poder en torno, primero, a las cúpulas partidarias, producto de la concesión de facultades a la Asamblea Nacional liderada por ambos partidos, la propia Ley Electoral de 2000, la reforma, restringe la formación de nuevos partidos políticos, y las fuerzas anti-pacto, que, en este caso, serían dos partidos emergentes como el Movimiento Renovador Sandinista (MRS) y Alianza Liberal Nicaragüense (ALN) se enfrentan a ese dominio bipartidista que se traducen, finalmente, en una exclusión, las últimas municipales son un ejemplo, y ayer cuando hablaba con Rosa Marina Zelaya me comentaba el desprestigio ya del Consejo Supremo Electoral, ¿no?

\section{F.M.: Absolutamente.}

R: Que además es la institución que debe garantizar la transparencia de las elecciones como garantía de un régimen democrático. ¿Qué opinión te merece todo esto que te he comentado, que es el recorrido del 2000 al 2007, que significa el regreso de Ortega al poder?

F.M.: Bueno, el regreso de Ortega al poder es quizás el indicador más claro de cómo las cosas andan mal, digamos, en todas las reformas, y no lo digo por ningún apasionamiento que esté yo en contra de Ortega, sino por las formas en que Ortega accede al poder. Accede al poder, en primer lugar, para retomar mi ejemplo en la modificación de las reglas de juego a medio camino, accede al poder con menor porcentaje de votos que en toda su historia electoral, es decir, accede al poder con el $38 \%$, cuando con Doña Violeta compitió con más de un $40 \%$, con Arnoldo Alemán alcanzó el $40 \%$ también, entonces, es paradójico que Daniel Ortega llega al poder nuevamente, pero con un porcentaje de votos, que no me refiero numérico, sino porcentual, menor que en las elecciones anteriores, eso es a todas luces una contradicción al sentido común, es decir, si se especula de que había un deterioro de los planteamientos políticos conservadores, que aquí se estila en llamarles neoliberales, y un aumento de la popularidad o un renacer de la popularidad del planteamiento sandinista, ¿por qué el sandinismo porcentualmente había bajado, verdad?, bueno, por la modificación de las reglas de juego, modificación del porcentaje de votos requeridos para acceder al poder, al poder presidencial, y ese es el meollo del asunto de la negociación con Alemán, es decir, se ve a todas luces que la energía, la concentración, la tensión, el esfuerzo de negociación del sandinismo, y muy concretamente, y específicamente, de Daniel Ortega, estuvieron orientados a bajar el porcentaje, reconociendo que él no podía apuntar más del $40 \%$, porque ha habido una transformación de la sociedad nicaragüense en donde el mensaje sandinista, realmente, no podía recuperar, digamos, los niveles que tuvo en los 80 , digamos, sino que ya no era el partido hegemónico que era en los 80, sino un partido, sin lugar a dudas, muy 
importante, pero que no era, como lo habían demostrado la elección del 90, la elección del 96 y la elección del 2002 en todas las cuales él perdió, que no era posible, digamos, seguirse considerando como el partido que encarna las aspiraciones mayoritarias de la nación nicaragüense, como ellos retóricamente insisten, en eso reside el enorme error estratégico en el PLC, y muy concretamente de Arnoldo Alemán, porque si algo lleva a la mesa a estos dos jugadores es el hecho de que ambos tienen esquemas mentales muy similares, y es que ambos piensan con estructuras mentales autoritarias, y con la aspiración de consolidar partidos hegemónicos, y el mismo error de cálculo que hizo Ortega en el 90, en el 96 y en el 2002, que luego lo corrige al reconocer que no puede ser, que va a tener que modificar las reglas para tener mayor probabilidad de acceder al poder con un esquema más flexible, es decir, modificando el porcentaje, pero, sin embargo, Arnoldo Alemán no reconoce eso, sigue, no sé, entraríamos ya a la psicología, ¿verdad?, no se puede especular...

\section{R: Sí, la personalidad autoritaria.}

F.M.: Claro, exactamente, pero aspirando a la postulación de un partido hegemónico, en este caso, el PLC, ¿verdad?, y de una manera muy, digamos, poco legítima, por ponerlo en términos muy claros, accede a esta modificación, me refiero a poco legítima, en sentido de que no pasó por ningún tipo de proceso de legitimación a lo interno del partido, como notarás, recurrentemente, regreso al tema de que no es posible analizar el sistema sin ver qué está pasando en el sistema de partidos.

R: No, y aparte es la hipótesis principal mía, yo seguía a Mainwaring y Shugart cuando hablan de "poderes constitucionales" y "poderes partidarios" en la figura del presidente, a la hora de examinar cuál es su posición frente a los procesos de reforma constitucional.

F.M.: Claro, exactamente.

\section{R: ¿Y qué piensas que va a pasar con el tema de la reelección?}

F.M.: Antes de entrar a ese punto, quería terminar la idea anterior, mi argumento es que, y es una hipótesis únicamente, de que si hubiese existido un proceso más participativo de los actores del PLC en el momento de diseñar las negociaciones, la igual que cualquier otra pacto histórico de Nicaragua, los resultados hubieran sido muy diferentes, ¿verdad?, pero lo que hay es una, o lo que se hizo, en ese momento, es una repetición de viejas formas de ejercicio del poder, en donde el llamado líder del partido actúa en representación de todo el partido político y la base del partido, básicamente, reconoce como legítimo lo que hace el líder, casi como dicen a la buena de Dios, o sea, damos a nuestro caudillo, ponemos a nuestro caudillo nuestra libertad y él sabe cómo decir el nombre de nosotros, una falta de autoestima, por decirlo, de la base partidaria. Yo lo hablo con conocimiento de causa, porque yo fui delegado del partido, en este caso, se llama convencional, que son, en teoría, por los estatutos del partido las máximas autoridades, porque son los que hacen la convención nacional que aprueba, y lo que pasa es que eso es una total falta, porque lo que sucede es, y la práctica surgía cuando yo era convencional, igual al día de hoy, que cada vez que hay un concejal que piensa diferente del líder, básicamente, el partido se toma la lista y se borra manualmente y se nombra a otro, entonces, es realmente un sistema que quiere imitar formas pseudodemocráticas, pero que en la práctica no se aplican del todo, ¿verdad?, entonces, cuando 
no hay una verdadera representación de la actividad de la base la decisión recae enteramente en el titular del partido, en este caso, del caudillo, y esa es la conclusión. Ahora, con respecto a la reelección, igual pienso que a como recordé que el bipartidismo nuestro no es per se nocivo, tampoco lo es la reelección, verdad, de hecho, personalmente, creo que ceteris paribus la reelección continua sería mejor que la que tenemos ahora, y este es mi argumento, la reelección continua permite que la vida política del presidente se limite a dos períodos políticos, un estimado de entre 8 y 10 años, porque sabe que después de ser presidente sólo tiene un término más inmediato, ese es mi primer argumento. El segundo argumento, porque crea un incentivo positivo para hacer un muy buen gobierno, porque es a su conveniencia tener altos índices de aprobación que le permitan la reelección inmediata, no estoy hablando del sistema nicaragüense, sino que es una reflexión más general, pero el sistema nicaragüense establece que no hay reelección continua, pero hay reelección intercalada, lo que obliga a que el actor político que fue presidente se mantenga jugando, políticamente, no sólo por el período actual, sino por el próximo período que le da, digamos, una relevancia de 15 años como hombre fuerte del partido, ese período de 15 años como hombre fuerte del partido, legitimado por el sistema político, genera unas perversiones tremendas en el liderazgo del partido, porque no permite una fluidez de la renovación partidaria, entonces, yo creo que ante la torpeza del sistema actual la alternativa, desde el punto de vista racional, sería legitimar la reelección continua y cerrar absolutamente las puertas para cualquier otra reelección, sin embargo, esa alternativa que es racionalmente interesante está muy desgastada como argumento político, porque la ciudadanía reconoce, por lo menos en porcentajes muy altos como dicen las encuestas de opinión, reconoce la reelección como uno de los grandes males de la historia política nicaragüense, entonces, es un tema que no tiene legitimidad, y, por tanto, la única alternativa funcional que yo encuentro para destrabar esa perversión, que te estaba refiriendo, es cerrar absolutamente cualquier posibilidad de reelección, como han hecho en la práctica algunos sistemas políticos, como el mexicano, por ejemplo, que han priorizado, digamos, una renovación rápida, digamos, de su liderazgo, hay muchas perversiones todavía como, por ejemplo, el excesivo rol o injerencia del presidente en la designación de su sucesor, pero, en todo caso, permite, digamos una renovación rápida, yo creo que el punto a resolver rápidamente, que va de la mano, indudablemente, en mi hipótesis de la reforma constitucional o la reforma del sistema político, es cómo se logra que el sistema político nicaragüense sea más dinámico en la transformación de su liderazgos internos, que el sistema partidario sea más participativo, y permita esquemas de participación de mayor consenso y de mayor participación de sectores que se han mantenido sin voz, como, por ejemplo, las corrientes internas políticas que tienen una posición más o menos distinta de la corriente mayoritaria, pues, y permite corrientes de renovación, al fin y al cabo, partidos políticos sin corrientes internas son partidos políticos que están condenados o a desaparecer, o a tener que hacer uso del esquema autoritario para seguir existiendo, digamos, en ese caso, lamentablemente, la reelección ha probado ser un mecanismo que lejos de permitir todo lo que he mencionado, como la modernización, como la renovación del liderazgo, como la alternancia del poder, más bien ha sido todo lo contrario, y, por tanto, creo que es casi un consenso de sectores independientes, ¿verdad?, me refiero por independientes a aquellos que no apoyan a los dos caudillos de que la reelección es nociva.

R: Sin embargo, la división del liberalismo, tú que la viviste además muy de cerca, limita mucho la oposición al régimen sandinista en este caso, el tema de las reformas constitucionales, actualmente, está paralizado después de las elecciones municipales 
del año pasado, no parece posible que Ortega vaya a encontrar apoyos en el parlamento para sacar adelante su propia reforma constitucional. El otro día entrevistando al Magistrado Iván Escobar Fornos me decía que no existe, realmente, un programa de reformas articulado, sensato, pensado como una propuesta racional, sino que hay como elementos dispersos, ¿no?

F.M.: Sí, yo en otra entrevista le llamé retazos, porque realmente eso es lo que es, son distintos pedazos, el Frente es quizá el que más se ha acercado a una propuesta coherente, pero excesivamente enfocada en lo que es la consolidación de un sistema semi-parlamentario.

R: ¿Y qué piensas de esa figura del primer ministro y del presidente de la República como división de la estructura del Poder Ejecutivo?

F.M.: Nuevamente, sucede con el mismo argumento del bipartidismo, es decir, no hay sistema per se malo, ¿verdad?, pero aquí hay varias cosas, el argumento predominante ha sido el argumento de que no es nuestra tradición, eso es lo que más que he escuchado en los medios de comunicación, en artículos académicos, y que si no es nuestra tradición, ¿para qué tratar de disponerlo?, yo no creo que sea un argumento fuerte, no apoyar el régimen parlamentario porque no es nuestra tradición política no me parece que sea un argumento de fondo, sí creo que existen dos argumentos muchísimo más sólidos para no apoyar esa propuesta: la primera es que tiene como una de sus premisas la reelección con otro nombre, que es, básicamente, una vez que tiene mayoría de partido o consenso la figura del Primer Ministro puede mantenerse como Jefe de gobierno cuantas veces como pueda generar el consenso parlamentario, y en Nicaragua por distintas razones, y quizá la más importante es que con la cantidad de dólares de Venezuela la probabilidad de tener votos a favor de cualquier propuesta es más alta, ¿verdad?, porque nuestros políticos son, lamentablemente, muy baratos, ¿verdad?, no debiese tener peso en ninguna parte, pero es una realidad, es, y esto lo digo con pleno conocimiento de causa, no puedo decir nombres, pero yo he entrevistado a varios legisladores que me han admitido ofrecimientos de dinero de mucha cantidad, y creo que la corrupción, a veces en el mundo de las Ciencias Políticas, cuando estudiamos la toma de decisiones, la corrupción no ocupa un lugar central, en otras escuelas de pensamiento lo hacen, pero yo creo que hay una distorsión, una distorsión, porque a veces hay decisiones que a todas luces parecen no racionales, pero claro, hay incentivos que no están captados en un mapeo que uno hace de los actores, ¿verdad?, pero que sí, realmente, hay ofrecimientos de mucho dinero, y lo digo con pleno conocimiento de causa, por razones obvias no puedo mencionar nombres, pero, por el contrario, no los mencionaría en una entrevista académica, ¿no? El segundo argumento de fondo para no permitir un sistema parlamentario es que un sistema parlamentario no puede funcionar ni dar buenos resultados con el sistema de partidos que tenemos ahora, porque supone partidos fuertes no el sentido de la concentración del poder en el titular del partido, sino partidos con todo un esquema de representatividad cuya estructura sea el resultado de las representaciones que hay por circunscripciones, etc., una serie de supuestos que no tienen los partidos nicaragüenses.

R: Y ya para terminar y no quitarte mucho tiempo, un breve comentario acerca de los Consejos del Poder Ciudadano (CPC), que han supuesto una estructura paralela del Poder Ejecutivo, significaron también uno de los intentos de Ortega de fortalecer el Ejecutivo debilitado por las reformas en sus facultades constitucionales, porque la 
práctica institucional ya hemos visto que es otra, ¿no?, como fue también el intento de reforma de la Ley de Amparo, establecer un mecanismo de control preventivo de la ley parlamentaria, o el tema de la reelección que ya hemos comentado. ¿Qué opinas de estas figuras?, porque da la impresión de que las instituciones politicas en Nicaragua, el marco institucional, se modifican en función de distintas tradiciones, ¿no?, y tradiciones, me refiero, instituciones como, en este caso, los Consejos del Poder Ciudadano, que proceden de las antiguas cédulas partidarias de la revolución, y que están no sólo copando el ámbito de la acción colectiva, sino el propio financiamiento, por ejemplo, de la cooperación internacional para dar salida a las diferentes políticas públicas.

F.M.: Claro, tu pregunta me permite una conclusión importante y es el hecho de que cualquier reforma, no sólo las constitucionales, sino cualquier reforma, que tenga una implicación a la vida nacional para generar, digamos, resultados favorables a las mayorías debe pasar, a mi juicio, por un elemento muy sencillo y es el consenso, el consenso en su mejor interpretación, y cualquier tipo de reformas en un esquema de transición democrática que vaya a romper el consenso alcanzado a coste, en el caso nicaragüense, de muchísimas vidas humanas, me parece a mí que no puede ser apoyado, que, por esa razón, criticaba yo el tema de la reelección, porque rompe el consenso básico, mínimo, de los principales actores políticos y la ciudadanía en la transición, por eso criticaba yo el cierre de espacios de participación política a partidos que no son mayoritarios, porque también rompe un consenso, y el caso es que ese es otro ejemplo, que también rompe consensos que con muchas dificultades, y lo admito, muy tenues, muy débiles, porque muchas personas que votan aquí por el consenso, pero sí había reconocimiento de que el modelo de Estado-Partido que había en los años 80 es un modelo que no es replicable en democracia, en donde no existía la Policía Nacional, sino la Policía Sandinista, en donde no existía el Ejército de Nicaragua, sino el Ejército Popular Sandinista, en donde todas las asociaciones nacionales de gremios, como de maestros sandinistas, asociaciones de trabajadores sandinistas, porque era un esquema de Estado-Partido, en donde la participación ciudadana a través de distintos modelos, llamados de cara al pueblo, ¿verdad?, que eran agrupaciones a donde llegaban los funcionarios públicos a rendir cuentas, eran organizados por el partido, esos esquemas, por muy románticos que sean, y que mucha gente diga que son procesos de democracia directa, rompen el consenso y los CPC son un ejemplo clarísimo, porque si son estructuras abiertamente partidarias me parece que calzan, enteramente, dentro del derecho del partido de organizar sus propias estructuras con sus propios recursos y con sus propios medios, pero al colocar lo de la reforma a la Ley 290, que es la ley que rige la estructura del Poder Ejecutivo, a través de la reforma de la Ley 611, de hecho, yo visité en el mes de enero, el primer año de gobierno visité el parlamento y me entrevisté con todas las bancadas a excepción de la bancada del Frente para hacer una observación de por qué los CPC no debían de estar incluidos en una Ley de Administración Pública, porque si incluyes la facultad del presidente de crear consejos, entonces, ¿cómo lo haces?, ¿lo haces en función de jefe de Estado?, ¿de jefe de gobierno?, son estructuras públicas, pero, por otro lado, dice que no, que es participación ciudadana, entonces, ¿por qué tienen que estar, digamos, tratados como una estructura de la Administración Pública? Me parece a mí que es un retorno a viejos modelos que probaron ser fracasados y que, al final, lo que genera es una enorme polarización de la sociedad nicaragüense, ¿verdad?, es quizá otro ejemplo, como te decía, de esta desafortunado retroceso, verdad, del proceso democrático. 
R: ¿Y cómo ves el futuro de tu país? Ayer hablaba con Violeta Granera y me comentaba como se han cerrado los espacios de la oposición, y dentro de la arena parlamentaria el "Bloque contra la dictadura" para tratar de evitar la aprobación de estos Consejos del Poder Ciudadano, y, en el caso de los ciudadanos, cuando se manifiestan los persiguen agrediéndoles, ya no es que no les dejen manifestarse, es que además les agreden físicamente, ¿tan grave es la situación en Nicaragua?

F.M.: La situación en Nicaragua es gravísima, porque ya dejó de ser una situación que ocupaba debates en los medios de comunicación, únicamente, o en las salas de estudio, o en los partidos políticos, y ha empezado a alcanzar dimensiones muy preocupantes en el ámbito de los derechos humanos. Nicaragua está, si me tocara comparar, reviviendo los capítulos más oscuros de su historia, si hay que compararlo con la Nicaragua de los años 40, cuando surgió un hombre fuerte, allá por el año 33, que se llamaba Somoza, con un índice de aprobación muy alto, y bajo la propuesta de tener que retransformar el Estado totalmente empieza a acumular poder, y a neutralizar por el medio que sea necesario a cualquier tipo de oposición, o cualquier cosa que aparente ser oposición, dicho de otra forma, es casi como el nacimiento de una dictadura, hay quienes opinan que es una frase exagerada, pero yo creo que es mejor pecar de paranoico y decir: "no estemos jugando con fuego", y mejor dejemos de cerrar los temas políticos y prioricemos las herramientas democráticas antes de decir: "no, no es tan peligroso todavía", y cerremos los ojos, ignoremos que realmente está pasando esto, quisiera ser optimista, pero al ver elementos como la falta de espacios de participación, los métodos violentos en que los miembros del partido de gobierno atacan a cualquier oposición, inclusive, a organizaciones como la Coordinadora Civil, que es una coalición, tradicionalmente, identificada como de izquierdas, recibiendo golpes de parte de, pero más preocupante es que todos estos actos de violencia, como han sido ampliamente documentados por la prensa independiente han estado guiados por líderes del partido, ha habido fotografías donde hay personas con rango de Vice-Ministro actuando en las agresiones, eso me parece a mí absolutamente inédito, y la actitud indolente de la Policía, y, en algunos casos, hasta cómplice, ¿verdad?, entonces me parece a mí que hay una serie de indicadores, que señalan que estamos viviendo una situación de altísima volatilidad, que si no hay un tratamiento urgente y rápido para aminorar las tensiones que están creciendo el país puede llegar a un caos muy alto, creo que aquí tiene un rol importante la comunidad internacional, que me parece que ha estado jugando un rol importante, pero todavía como queriendo apostar a que, realmente, la situación no es tan grave, porque ya los métodos nacionales para poder aminorar ese tipo de tensiones me parece que están agotados, verdad, y la comunidad internacional en su responsabilidad de encontrar alternativas de resolución de conflictos, antes de que el conflicto esté consumado a un altísimo costo, es poder intervenir rápidamente, me parece a mí, y por intervenir me refiero a crear espacios de diálogo, verdad, muchos actores internacionales, que pudieran jugar un rol más activo, me refiero, concretamente, a Naciones Unidas y a la OEA, han tomado actitudes muy cómodas, por ejemplo, y yo creo que podrían tener un rol importante, por ejemplo, apoyar las voces de la Unión Europea y las voces de otros gobiernos amigos de Nicaragua en enfatizar que las próximas elecciones, primero en las regionales, porque van a ser una prueba, como en las nacionales son una gran oportunidad para aminorar las tensiones, porque la premisa central de un sistema democrático es que las diferencias de opinión, y las tensiones, las pueda resolver un sistema electoral cuando hay credibilidad en el sistema electoral, cuando hay transparencia, y cuando hay aceptación de las reglas de juego de todos los actores, y cuando hay credibilidad de los resultados, esos elementos son básicos me 
parece a mí, y si las próximas elecciones nacionales no cumplen con esas características, me parece a mí que Nicaragua va a perder la gran oportunidad de evitar una próxima guerra civil.

R: Pues, muchas gracias Félix. 
ENTREVISTA $34^{49}$ :

Nombre del entrevistado: D. Dionisio Marenco.

Cargo actual: Ex - Alcalde de Managua (Frente Sandinista de Liberación Nacional).

Fecha de realización de la entrevista: Managua, 24 de noviembre de 2009.

Lugar: Facultad de Diplomacia y Relaciones Internacionales de la Universidad Americana (UAM).

Duración estimada: 58 minutos.

\section{TEXTO - Transcripción 34:}

$R$ : ¿Cuál sería su visión sobre el proceso de cambio constitucional reciente desde los años 90, es decir, desde los procesos de paz y el gobierno de Violeta Chamorro, hasta la actualidad? Siempre pensando en la propia evolución de las instituciones democráticas en el país, ¿no?

D.M.: Sí, bueno, antes que nada quisiera recordar que yo no soy un especialista legal, pues, yo no soy un abogado ni un teórico constitucionalista ni nada, pero he sido más bien un operador político práctico, y desde ese ángulo es que te puedo dar una opinión de lo que me preguntás. Me ha tocado vivir todas las épocas desde la dictadura, en donde tuvimos alguna participación activa, pero lo que menos nos preocupaba, realmente, era la parte legal, teníamos que derrocar la dictadura y no funcionaba ningún mecanismo legal, por lo tanto, para mí, en aquél momento, la Constitución no era una prioridad, y lo que decías no nos interesaba mucho, durante la época de la revolución, la verdad es que habíamos estado también a base de pactos, no había, creo yo, una conceptualización de la ley, del orden, de las atribuciones de las instituciones, creo había un decir muy típico que era: "la revolución es fuente de Derecho, lo que la revolución hace eso es la ley", y como, en realidad, el país había estado durante esos diez años creo que muy poca gente, realmente, le puso mente a lo que se estaba haciendo, había un parlamento, una cosa que se llamó Consejo de Estado, que fue un experimento interesante, diría yo, de representaciones por sectores más que por electores, sino que había representantes de los trabajadores, representantes de los maestros, representantes de los trabajadores del campo, de los jóvenes, de las mujeres, yo no sé si hay otra experiencia en otra parte de eso tipo, pero una vez que elegían tenían voto universal, pero luego vino la derrota del Frente en el año 89-90, y ahí es donde comienzan a moverse las opciones de ir reformando la Constitución, diría yo, la primera Constitución que tuve en mi vida, que yo recuerdo que ya se discutía artículos, conceptos, capítulos, diferentes facetas de la sociedad, cuando nosotros, yo soy del Frente Sandinista, estamos en la oposición durante dieciséis años, en ese momento, es cuando comenzamos a trabajar para ver cómo hacer para recuperar terreno en ese campo jurídico, en ese andamiaje, digamos, en esa estructura legal, y, realmente, el interés es, básicamente, allanar procesos y pasos que permitan al Frente recuperar el poder por la vía electoral, entonces, la primera cosa que nos encontramos era que en el Consejo Electoral el Frente no tenía un solo representante, por lo menos lo que yo recuerdo, que no teníamos nosotros representantes, esa es mi opinión, y eso se lo

$49 \quad$ Entrevista interesante por el pragmatismo general de la argumentación, así como de algunas de las observaciones realizadas, especialmente, debido a la cercanía personal del entrevistado con la figura de Daniel Ortega a la hora de extraer citas de referencia para el análisis de los procesos de reforma constitucional recientes. 
compartí a Daniel Ortega, que mientras el Frente no tuviera por lo menos una persona en el Tribunal Electoral, éste no iba a ganar una elección, entonces, ahí comenzó la discusión. En paralelo con eso, también yo tenía otra solicitud que era el tema de la propiedad que había quedado en manos de los sectores trabajadores, había la gran masa de tierra, de empresas, yo creo que eran 117 empresas que pertenecían a lo que en tiempos de la revolución se llamaba como el área de propiedad del pueblo, que eran las empresas estatales, y al caer la revolución, al terminar la revolución ni se realizaron, se quedaron como en un limbo jurídico, pero quedaron físicamente en manos de los trabajadores que, en ese momento, estaban ahí, que eran todas las empresas que habían sido nacionalizadas de propiedades somocistas de terratenientes, de gente que se había ido de Nicaragua, pero yo diría que eran la mayoría de la tierra nicaragüense, y yo pensaba que si no se lograba formalizar esa propiedad eso se iba a perder, y que formalizando esa propiedad en manos de los trabajadores sandinistas, que era los que estaban ahí, les daba al Frente una enorme fuerza, un enorme poder real, independientemente de lo que ocurriera con su estructura jurídica o política, y, entonces, empezamos a trabajar ese capítulo, en realidad, es donde yo comencé a moverme dado mi interés de que se formalizara la propiedad de los ocupantes de fincas, fábricas, etc., si este paso viene la cuestión electoral, entonces, la forma de poder entrar era ampliar el número de Magistrados que había entonces para poder meter los Magistrados que nosotros teníamos, y eso coincidió con el Partido Liberal, porque el Partido Liberal tampoco tenía Magistrados, porque la transición nicaragüense hay un interregno ahí del gobierno de la señora Chamorro en donde no hay funcionarios muy políticos, digamos, lo que había era personas que habían venido por otras razones, entonces, el Partido Liberal, que, en ese momento, preside Alemán en ese gobierno, también tenía interés en mover ficha, digamos, ellos en ese juego, conformado de acuerdo a los intereses de ambos, los de ellos y los de nosotros, y así se empuja ese capítulo de la reforma, básicamente, para poder tener presencia en los organismos electorales, ese era el objetivo, otra alternativa hubiese sido cambiar completamente el nombre y la estructura, y volver a elegirlos a todos, pero no teníamos tampoco las herramientas necesarias para hacerlo, entonces más fácil era ampliarlo y con la llegada de los nuevos Magistrados, eso fue lo que respetó, electoralmente hablando, casi el mismo criterio se siguió con lo que es la Corte de Justicia, o sea, un criterio no legal, no una Corte independiente, apartidista, no, todo lo contrario, teníamos que tener presencia partidaria en esos organismos del poder o de instituciones del Estado, como si se tratara de la Asamblea Nacional, obviamente, que eso puede ser catalogado como un error y todo, pero que eso era lo que lo tenían en la cabeza los que discutían sobre ese tema, así que se amplía también la Corte Suprema de Justicia hasta 16 Magistrados, que creo que son los que están ahora y así se colegia la Contraloría General de la República, y el parlamento sigue con base a su proceso electoral normal, la reforma, a su vez, el Frente tenía un objetivo fundamental, tremendamente importante, que era eliminar las dos vueltas electorales, o sea, aquí la Constitución preveía que si ningún partido conseguía el $45 \%$ de los votos en la primera vuelta, se tenía que ir a una segunda vuelta, $y$, desgraciadamente, en nuestro país hay una polarización entre lo que es sandinismo y anti-sandinismo, o sea, más que una definición ideológica, de si sos liberal, de si sos conservador, que si sos socialista, que si sos anarquista, que si sos comunista, que si sos verde, aquí la sociedad tiene una división que yo creo que se mueve entre lo que es sandinista y anti-sandinista, en ese sentido, una segunda vuelta electoral siempre sería muy mala para el Frente, porque el Frente tiene un porcentaje activo de votantes que puede andar, en este momento, con lo que sacó Daniel en la última elección, que es un $38 \%$, pero muy difícilmente superable, por lo tanto, con llave y candado del $45 \%$ para 
poderle dar poder real al Frente Sandinista, o sea, era la clave de todo. En el proceso de discusión llegamos a un acuerdo que era, un método de discusión que era: donde no había acuerdo lo saltábamos y pasábamos al siguiente punto, es decir, que algunos de ellos eran culturales, otros eran políticos, otros eran organizativos, otros eran económicos, entonces, el punto del $45 \%$ era muy difícil, perdón, el punto de eliminar la segunda vuelta era muy difícil, y, entonces, en ese sentido, para los liberales era, obviamente, más importante, y al final, pues, de la discusión se solucionó el problema, que es la que quedó al final, que dice que era la de reducir el límite de $45 \%$ a $35 \%$ en la votación, con la condición de que entre el primero y el segundo lugar tuviese más del $5 \%$ de diferencia, es decir, que si usted ganaba con 35\% y el segundo lugar estaba en $29,9 \%$ entonces valía ganar en una vuelta con $35 \%$, si yo sacaba $34,9 \%$ y el siguiente $35 \%$, entonces, ya tenía que ir a segunda vuelta, y eso fue, digamos, el logro más grande que hizo el Frente desde el punto de vista electoral, y aunque parece, aunque ahora lo usan como argumento para decir que eso le permitió al Frente ganar, pero, la verdad, es que ese porcentaje le sirve a cualquiera, pues, le sirve al Frente y le puede servir a cualquier otro partido porque la regla está hecha para, no es correcto, pues, decir que esa una concesión liberal al Frente Sandinista. Es una concesión, digamos, hasta cierto punto, incluso, para más pluralismo, incluso, porque partidos más pequeños pueden optar al poder sin necesidad de tener $45 \%$ de los votos, ¿qué más?, ¿qué otras reformas hubo? Creo que eso fue todo.

\section{R: En el año 2000.}

D.M.: Sí.

R: Si bien el hilo conductor de las reformas desde el 95 hasta el 2005 ha sido la desconcentración de poder del Ejecutivo presidencial, ya que la Constitución del 87 consolidó un Ejecutivo muy fuerte, un presidente de la República dotado de enormes facultades, lo cual también se explica en parte por el proceso bélico, ¿no?, que exigía un Ejecutivo fuerte.

D.M.: No, se explica más creo yo por la historia, Nicaragua es un país que no ha tenido el ejercicio de un poder muy estable, desde la independencia en el 1821 hasta 1856 , que es cuando se da la guerra nacional, cuando hubo una intervención de un filibustero norteamericano, y un tipo que se hizo nombrar presidente de Nicaragua, que se llamaba William Walker, en esos años, hubo un presidente cada año, y en algunas ocasiones había dos y hasta tres presidentes al mismo tiempo, o sea, se llama la época de la anarquía en la historia nicaragüense, bueno, desde 1821 hasta 1856, en 1856 se da una gran guerra nacional y el país exhausto de esa guerra, hay un pacto o un acuerdo entre los jefes liberales y los conservadores, que en ese tiempo se llamaban los democráticos y los legitimistas, y se abre un capítulo como de 30 años que se llama la época de los conservadores, los 30 años del Partido Conservador es el que tiene presidentes muy regularmente electos cada 4 años, casi no recuerdo, pero sí, es la única época en la que el país tiene una estabilidad, en el año 1893 viene un golpe de Estado de un general liberal que toma el país hasta 1907, como 16 o 17 años en el poder, de dictadura, digamos, o de gobierno totalitario, digamos, y de 1917 a 1934, entran, suben, bajan, hay varias intervenciones militares extranjeras, norteamericanas, y en esa época se da la rebelión de Sandino contra la ocupación, contra el gobierno conservador que estaba en ese momento, Sandino era un general liberal, en 1934 comienza la dinastía somocista después de la muerte del general Sandino que termina también en 1979, también un 
gobierno muy duro, un gobierno dictatorial, que tiene, sí, Somoza tuvo la habilidad de poner algunas formas, hubo algún presidente en medio, reformaba la Constitución cuando había necesidad, hacían una constituyente, es decir, una cosa que usted nunca se va a encontrar a un Somoza reeligiéndose inmediatamente, de forma, que el sandinismo es una exclusión de ese mismo Estado identificador de la sociedad nicaragüense, yo creo que el gobierno de Violeta Chamorro es un gobierno también parecido a los de transición del 1856, ponen a una señora ahí que es como la mamá de todos para que no se peleen, y entonces, eso le trae tranquilidad a mucha gente y tiene mucha popularidad y todo el mundo lo recuerda como una cosa buena, porque, en realidad, el país estaba destruido por completo, luego llega el gobierno de Alemán y el gobierno de Bolaños que no terminan de tener una identidad propia, que son como intentos de restauración del viejo orden, pero no lo logran, y ahora regresa Daniel Ortega y vuelve a poner el mismo sistema sandinista, y con esas mismas esperanzas de regresar a los años 80 , o sea, que el régimen presidencial fuerte en Nicaragua es como una característica sociológica, diría yo, más que legal, y, de hecho, de hecho, Daniel Ortega reivindica que quiere un régimen parlamentario, pero hace todo, exactamente, todo lo contrario del régimen parlamentario, porque trata de manejar más por decreto, hasta ahora, esta última reforma que quieren hacer los Magistrados interpretando la ley que dice que no hay reelección, que, obviamente, le ha dado una visión muy personal, muy monopolizante de todo esto, que no es más que el reflejo de todas estas características que te digo de la historia de Nicaragua.

R: Entonces, si hemos pasado de una desconcentración de poder, que algunos críticos han subrayado, a partir de la reforma del 2000, incluso, algunos entrevistados la califican de "contrarreforma", ¿no?, porque inició como un giro de 180 grados en la tendencia abierta en el 95.

D.M.: Sí, pero eso que ocurrió en el 95 fue una especie de intento no real, ¿cómo te podría explicar?, ¿cuál es el término correcto?, vos ves la realidad y después vos tenés tu cabeza y querés ponerle un sombrero a esa realidad, entonces, en esa Constitución de la época de la señora Chamorro se intentó cambiar un poco las cosas para dividir los poderes del Estado y todo, pero, la verdad, es que el gobierno de la señora Chamorro era, igualmente, un gobierno totalmente presidencialista, no tenía ningún contrapeso de ningún tipo, lo que pasa es que ella no tenía la fuerza para poder disponer de él, pero si ella hubiera sido un tipo como era el propio marido de ella, es muy probable que él hubiera tenido un gobierno super-presidencialista. La sociedad me parece a mí que genera sus liderazgos conforme es así, pues, no hay organizaciones de ningún tipo, nadie respeta nada, ni las señales de tráfico, entonces, no hay educación cívica, cae, necesariamente, en un dictador fuerte, que cuando progresa un poco el país tiene un dictador ilustrado, o en tiempos de Zelaya, que era un hombre, por ejemplo, que hizo muchos cambios sobre la estructura de la sociedad y sobre la educación, el Estado laico, sobre las organizaciones obreras, sobre todo se discute aquí a base de personas, dictador o no dictador, entonces, el sábado va a haber una marcha de "todos contra Ortega", pero no hay marcha que diga: "todos para construir una casa", o "todos para crear más trabajo", o "todos para producir más", o "todos para sacar al país del desastre", "todos para el desarrollo económico", no hay nada de eso, todo el lema es si es a favor de la democracia o es a favor de la dictadura, todos contra Ortega, y nadie lleva la bandera de cuando será el día en que vuelva la despenalización del aborto, están otra vez marchando contra Ortega y ninguna sola reivindicación tenían, entonces, en el fondo lo 
que hay es una ausencia de valores o de desarrollo de valores que permitan, posteriormente, construir un entramado real moderno.

$R$ : $Y$, sin embargo, este argumento, como decía alguna vez una persona que entrevistaba al señalar el hecho de que Nicaragua no tiene un camino hacia la modernidad porque hay ciertos valores o estructuras del pasado histórico que dificultan tanto.

D.M.: Así es, así es, pero para poderlo cambiar, entonces, no es cambiar la Constitución que lo vas a hacer, porque decimos sí cambiemos la Constitución, hagamos elecciones primarias dentro de los partidos para que se democraticen los partidos, pero si vos no vas desde los colegios, y no vas desde los niños, y no vas desde la familia, desde la personas en los lugares pequeños, respetar el derecho del peatón en las calles, o enseñarle a respetar los linderos de un terreno o de una persona, no voy a creer que después alguien con la Constitución te diga que la Corte de Justicia es independiente, cuando todo está ligado a valores de cacicazgo, de parentela, si vos vas aquí a un juicio, la primera pregunta que te hacen no es si tu caso está referido a qué código, o a qué artículo del Código Penal, tú lo que tienes que decir es de quién es pariente, de quién lo puso, y qué abogado es amigo de él, eso es lo que pasa, me imagino que en otra parte del mundo eso importa también, tampoco podemos ser ingenuos, pero no es esta concepción de las leyes, no existe en Nicaragua. La Constitución misma, y usted puede hacer una prueba, trate de hacerla en la calle, pregúntele a un taxista si conoce el artículo tal de la Constitución, yo dudo, yo no sé, yo no la conozco para serle más franco, si me decís cuántos artículos tiene, cuantos capítulos tiene, cuáles son sus diferentes conceptos, no te sabría decir, no, no me da, no me parece una cosa, no estoy acostumbrado.

$R: Y$, sin embargo, usted además ha ejercido un cargo público, ¿no?, en el que la Constitución sirve de marco jurídico para limitar sobre todo la acción política, y para poner en orden aquello que se puede y que no se puede hacer.

D.M.: No, yo sé, yo sé, pero como no hemos sido entrenados en eso, ¿qué puedo hacer yo?

$R: Y$, sin embargo, en el caso de, me refería antes a la desconcentración de poder y a la mayor representación que tienen los partidos, tengo la impresión, no sé si usted me corrija también en esta impresión mía que la reforma del 2000, más que aumentar las facultades, que lo hace, consolidando una tendencia que aparecía ya en el 95 de aumentar las facultades de la Asamblea Nacional, ésta queda cooptada por la cúpulas de los partidos, ¿no?

D.M.: Ahora, ¿por qué se hace eso así?, porque en ese momento el único centro de poder que tienen los partidos es la Asamblea, entonces, por eso es que dicen, bueno, se van a elegir en la Asamblea Nacional tales y tales cargos, porque ahí se van a elegir los Magistrados, porque es la vía para entrar a controlar el resto de cosas, ¿no?, no es porque tengamos una gran voluntad parlamentarista, Daniel Ortega no respeta las condiciones, que, actualmente, la Constitución tiene de que todos los Ministros tienen que ser nombrados por la Asamblea Nacional, y dice, yo soy parlamentarista, está en la Constitución, y yo digo, voy a hacer eso, y no lo hago cuando soy presidente, yo no lo respeto, como eso de que quiere ahora reelegirse él, $\mathrm{y}$, lícitamente, todos sabemos que eso no se puede, porque la Constitución no permite la reelección y Ortega dice yo no 
respeto esa norma constitucional, si Daniel Ortega tuviera mayoría en la Asamblea Nacional podés tener la seguridad de que le hubiera entrado por ahí la reforma.

\section{$R:$ ¿La reforma al artículo de la reelección?}

D.M.: Sí, lo hacen sin ningún problema, a como yo creo que debería de ser, pues, porque, es decir, a final de cuentas, se supone que la Asamblea en un régimen constitucional sea para eso, para representar los intereses de todo el mundo.

$R: Y$, sin embargo, en todos los procesos de reforma ha habido conflicto entre el Ejecutivo y el Legislativo.

D.M.: Siempre viene, pero volvés a lo mismo, que al final lo que está detrás es quién controla el poder, no es el afán de tener un Estado de un tipo o de otro, es el afán de quién domina al resto.

R: Y las Leyes Marco, que han supuesto un instrumento jurídico en los procesos de reforma.

D.M.: Yo, las Leyes Marco, creo que son una payasada, eso creo, que son como el, ¿cómo se llama?, el, digamos, el extremo de la interpretación de las leyes, interpreto la Constitución que dice que no se pueden elegir a ciudadanos, que están violando los derechos del ciudadano que dice que todo el mundo tiene derecho a ser reelecto en Nicaragua. Yo podría decir: "mire, ahí en la Constitución dice que yo tengo derecho a una vivienda digna", porque la Constitución me dice que yo tengo derecho a eso, o que a mí me da la feliz gana de que yo quiero ser Doctor en Filosofía, porque la Constitución dice que yo ciudadano tengo derecho a la educación, pero también dice que hay que estudiar, que hay que sacar buenas notas, exámenes, etc., etc., es una interpretación antojadiza.

$R$ : Sí, de todos modos, esa pérdida del valor jurídico o normativo de la Constitución, esa pérdida de la supremacía del Estado de Derecho, realmente, hace peligrar esta democracia tan frágil. ¿Cómo ve usted este futuro incierto de apenas un año y medio que falta para que termine la presidencia del actual gobierno sandinista?

D.M.: La cosa está muy complicada, está muy complicada, está peligroso, porque, me parece a mí, que los valores que se plantearon durante la revolución de no respetar ningún marco de referencia que podés llegar a la anarquía, volver a la época de la anarquía en la historia de Nicaragua, porque es la ley del más fuerte, ¿por qué el gobierno del Frente puede hacer eso?, porque es el más fuerte, porque tiene las Fuerzas Armadas, porque tiene un partido muy grande, porque tiene poder, y porque la oposición está muy débil.

R: Bueno, es que el liberalismo dividido y, de alguna forma, este pacto entre Ortega y Alemán, ¿cómo lo ve usted?, porque he oído de las voces críticas del pacto, que este pacto existe y que este pacto no se ha perdido, y que es una especie de procedimiento que se activa cuando no hay más remedio que arreglar las cosas y los dos se reditúan de ello. 
D.M.: Mirá, mirá, el pacto fue como una necesidad de la sociedad, ¿por qué se hace el pacto?, porque las fuerzas reales no tenían incidencia en la superestructura formal, las cosas se pueden hacer de dos maneras, o damos un golpe de Estado y disolvemos el parlamento a la fuerza, o intentamos y entramos por la puerta de hacer todo y de cambiar todo, el Frente tuvo más habilidad que los liberales y se le fue arriba, pues, y dominó, pero eso es igual que en Europa, que en cualquier parte del mundo, el partido que tiene más alianzas, y que tiene más habilidad para crear más adeptos ese es el que domina, hasta ahí está bien, donde comienza mal la cosa es cuando querés violar tus propios acuerdos, o sea, al final la sociedad es de acuerdos, o la Constitución es un gran acuerdo, si vos este acuerdo que tenemos no lo respetás, ya no es algo que estés haciendo dentro, ahora Daniel disuelve el parlamento y dice que no hay comisiones porque el país está empobrecido, entonces, se paran las elecciones y se acabó.

R: Sin embargo, el caldo de cultivo de la violencia politica se está dando peligrosamente, y hay gente, que contempla, incluso, escenarios violentos, no tanto de regreso a la guerra, porque no creo que las condiciones sean las mismas.

D.M.: Yo sí creo, yo sí creo, perfectamente, tal vez con otros componentes distintos, en el pasado fueron, a mi juicio, pues, en la época de la revolución, el conflicto fue muy alentado por la Guerra Fría, por la intervención norteamericana o rusa, y yo me acuerdo que, en su momento, nos sentíamos orgullosos, pues, de que teníamos el apoyo soviético, al caer la Unión Soviética quién va a apoyar a quién.

R: Pero, sin embargo, el factor Chávez puede ser un balón de oxígeno para el gobierno de Ortega.

D.M.: El factor Chávez es el que mantiene vivo, no a todo el gobierno de Ortega, creo que a Nicaragua, creo que sin el factor Chávez estaríamos a oscuras, porque no habría luz en Nicaragua, eso sí, seguro, y ahora apenas está exportando 1,4 puntos el valor de su energía, o sea que el petróleo nos está ayudando.

R: Sin embargo, los nicaragüenses, yo que además hablo con gente de muchas edades y de diferentes posiciones sociales, de diferentes profesiones, y me dicen que hay un cansancio de que las sucesivas generaciones tengan que estar peleando por lo mismo, ¿no?

D.M.: Sí, pero, esa es la verdad, yo, pues, tengo 63 años, la primera vez que voté tenía 16 , y teníamos que pelear con un, con un palo, a palos porque andaba con suerte, o sea, yo sí estoy cansado, pero ¿cómo se hace para transformar?, yo no sé exactamente, y me imagino yo que el gran error ha sido no dedicar al sector educativo, al sector de formación de los valores de la gente, y la enseñanza a la convivencia ciudadana, el poder compartir, decir, venga usted es socialista, yo soy comunista, vamos a ver en que cosas podemos avanzar, ahora si yo voy a plantear, como en este momento lo plantean algunos círculos sandinistas, de que aquí están los ricos que son unos malvados, y estamos los revolucionarios que somos los buenos, pues, terminas en dos pasos.

$R: Y$, sin embargo, si no se unifica el liberalismo parece que la victoria de Ortega en las próximas elecciones es casi una victoria anunciada, con las actuales reglas electorales. 
D.M.: Yo no creo, yo creo que aunque el liberalismo no se reunifique si las cosas siguen como están ya cualquiera, no, sin embargo, faltan dos años, en dos años Daniel Ortega puede salir todavía, porque las condiciones son tan pobres, y si usted me regala tres láminas de zinc, y a otra persona cuatro, entonces, se cambia el apellido por usted.

R: Ese es el caldo de cultivo, la pobreza, del clientelismo politico, ¿no?

D.M.: Sí, ahí es donde entra en este juego, el dinero venezolano, el dinero venezolano puede hacer maravillas para utilizarlo en beneficio, bien usado, lo que pasa es que me parece que Daniel no lo está usando bien, lo está usando incluso mal, no lo están usando racionalmente.

$R$ : $Y$, sin embargo, yo creo que sí resulta muy peligroso lo que se está produciendo en el caso de la Policía.

D.M.: En el caso de la Policía lo que ocurre es que está cooptada por el Frente, entonces, la Policía está actuando como una policía sandinista, por lo que estamos hablando, pues, ningún político de éstos se atreve a decirlo, pero todo el mundo sabe, todos saben con quién despacha la Policía, y dónde despacha, y cuándo despacha, y luego que si la Policía es la mejor institución que hay en Nicaragua, que todos confiamos en ella, mentira, no confía nadie en ella, pero ¿por qué lo dicen?, porque no quieren pelear, el Ejercito de Nicaragua es un Ejército apolítico, es mentira, no hay un solo mando ahí que no sea sandinista, porque así fue construido, al frente está ahí el comando guerrillero que saca a Daniel Ortega de la cárcel cuando estaba preso, todos son ex-combatientes sandinistas cuando la dictadura, tal vez con 15 años había muchachos que no tenían nada que ver, tal vez ya el siguiente relevo ya sean jóvenes que vienen más de la academia, pero al día de hoy, tanto los relevos policiales como los relevos del Ejército vienen del Frente Sandinista.

\section{R: ¿Y en el caso del Poder Judicial?}

D.M.: En el caso del Poder Judicial habría otro capítulo, porque se ha corrompido mucho, ahí es ponés la mano y preguntás cuanto es.

R: Pero, de todos modos, sí es verdad que los jueces son antiguos miembros del servicio de inteligencia.

D.M.: Algunos jueces que estudiaron abogacía y vinieron por ahí, andaban, y al cabo del tiempo y de una formación, ¿qué podían hacer en el país?, en Nicaragua, patria o muerte, entonces, pues, los fichan ahí, nadie le prestó importancia a eso, llega el momento en que el Poder Judicial con estos cambios que hay, entonces, gana fuerza, y tal vez los pusieron ahí porque a nadie le importaba, en tiempos de la revolución ni siquiera se nombraba a los jueces de la Suprema Corte, no tenía importancia ninguna.

\section{R: ¿El Poder Judicial?}

D.M.: Ahora que tú dices el juez del distrito tal llega a hacer tal operación comienza a tener más importancia cuando ya el Frente en la oposición requiere de saber quién es procesado por algún tipo de recurso, porque empezó a averiguar quién es el juez de tal 
cosa y quien es el juez de tal otra, porque están en el desempleo y tienen que buscar trabajo, casi todo es así, pues.

$R$ : ¿Y qué significó esa frase de: "vamos a gobernar desde abajo”, cuando perdió las elecciones el Frente?

D.M.: Una especie como de eslogan político, diría yo, de Daniel, refleja mucho su carácter, pues, un carácter muy, muy fuerte e indómito, la derrota electoral no se esperaba completamente en las bases, que estaban asombradas.

\section{R: Sí, fue una sorpresa.}

D.M.: Fue una sorpresa, cuando veían que salía en los resultados de la televisión, el Consejo Supremo Electoral era sandinista, todo, hasta había dos miembros independientes que fueron reclutados casi al vuelo para darle un poco de credibilidad a ese Consejo Electoral, que están vivos los dos y los podés entrevistar, yo personalmente los voy a consultar, uno de ellos es un abogado muy respetado, entonces, Mariano Fiallo que es considerado un gran hombre, ecuánime, no sabía ni lo que iba a decir ni lo que no iba a decir, yo no sé, como cualquier otro militante, y el día de las elecciones él tenía instrucciones de que a las seis de la tarde iba a leer cuatro Juntas de Votos, se llama Junta, propiamente, la mesa electoral, cuatro urnas, pues, en cuatro urnas más aplastantemente se ganaba, la primera que llegara, porque aquí a las seis de la tarde casi no había ningún dato, cuatro si se daba bien, entonces, nosotros estábamos celebrando, pues, preparándonos para la celebración, cuando me acuerdo que aquél día que iba a ser importante, dijimos, bueno, vamos a descansar para estar listos esta noche para la fiesta, me fui a dormir una siesta tardía, y a las seis o siete me desperté puse la televisión, ¿y qué pasará?, ¿donde está todo el mundo?, no, es que está atrasado, no ha salido, ¿y por qué?, eso ya me produce cierta inquietud, como a las siete y algo de la noche salió Daniel, y salieron cuatro Juntas, dos que ganaba la oposición y dos que ganaba el Frente pero con un margen muy pequeño, entonces, yo dije, esto es raro, y me fui a la casa de campaña, ya habían comenzado a llegar las noticias, no, es que están sacando y dicen esto, me acuerdo que estaban sacando a la esposa del presidente Carter que estaba en una mesa, estaba llorando, no sé si del susto o de la emoción, lloraba, se fue William Ramírez a decir que estábamos perdiendo, que la cosa estaba fea, y yo llamé a Daniel Ortega y le dije: "mirá, a las nueve o nueve y media están así los resultados", y llegamos al centro de cómputo, entramos en el centro de cómputo, y me acuerdo que le dice él al técnico que estaba a cargo de eso, yo veía como platicaban, entonces, le dice: “¿ya vas a cerrar?”, "no", me dice, "todavía no tenemos todos los datos de la muestra”, eran como 700 mesas, “¿la podés cerrar?", bueno, "la podés cerrar con lo que tengo, todavía no es válida", "cerrala ya", entonces, cortan, verdad, entonces, en ese momento, entonces, cuando vemos eso, me acuerdo que, en ese momento, me entró el pánico, entonces, le dije yo a Daniel Ortega: "mirá, esto se ve jodido", aquí en Nicaragua jodido es malo, descompuesto, ¿ustedes usan la palabra?, y dijimos, ¿qué hacemos?, porque en la casa de campaña había un montón de gente ya celebrando, y ya teníamos los tragos, y teníamos la orquesta y todo, cuando vuelve a llamar el presidente Carter, y el Presidente Carter me dice: "quiero hablar con el presidente Ortega", "no está", le digo, "pues, dígale, por favor, que lo llamé”, "con mucho gusto", "Daniel, llamó Carter", vuelve a llamar, "no está", a la tercera vez que llama él llevaba esperando un rato, las diez y media o las once de la noche, "dígale al presidente Ortega que necesito hablar con él, porque tengo datos de que el Frente está perdiendo, y lo voy a anunciar y no quiero 
hacerlo sin consultarlo antes con Daniel, y como siga sin poder comunicarme lo voy a anunciar sin él", "venga, pues", dice, entonces, llega Jimmy Carter con la señora Carter, con los observadores internacionales, y me acuerdo que le dice: "Daniel, ¿qué tal?", y no me acuerdo, exactamente, de las palabras, pero el significado era algo así como: "mirá, ahorita estás triste, pero mañana ya vas a estar mejor", y total, pues, el acuerdo a que se llega ahí es que se reconoce eso, que reconocen el triunfo de Doña Violeta, pero que nadie va a decir nada hasta las seis de la mañana, que ella se compromete también a no declararse victoriosa hasta que el Frente reconoce a las seis de la mañana, que es el famoso discurso donde Daniel reconoce que perdimos, y el discurso de "vamos a gobernar desde abajo", lo dice como uno o dos días después ante una Asamblea partidaria sandinista que ya, vamos a ver qué hacemos, y él dijo: "vamos a gobernar desde abajo", pero esa es una expresión, pues, que significa, no importa que nos hayan derrotado, vamos a seguir en la lucha, pero no era una cosa que si perdía íbamos a rebelarnos.

R: No, yo más bien me refería a vamos a intentar de convertirnos en partido que compite en las elecciones en el marco democrático.

D.M.: Como si estuviéramos en la revolución, como si fuéramos estudiantes en los tiempos de Somoza, y, de hecho, el Frente entregó el poder, pero, en todo momento, estaba en la sociedad, o sea, desde arriba, desde abajo, desde en medio, de todos lados.

\section{$R:$ ¿De los poderes del Estado?}

D.M.: Entonces decía un tipo muy popular: si no pudieron gobernar desde arriba, yo no sé cómo van a gobernar desde abajo.

R: Y ya para terminar, las dos últimas cuestiones, que quería plantearle es, una, si bien este es un país de líderes fuertes, ya hizo referencia al liderazgo como un aspecto de la evolución política histórica, ¿no?, y ha habido hombres fuertes en el poder, y uno compara, por ejemplo, la presidencia de Bolaños o la señora Doña Violeta con Ortega y Alemán y son completamente distintos, incluso en el marco de las reformas constitucionales en sus momentos críticos es, exactamente, igual, ambos tienen un fuerte control sobre su partido, me refiero a Alemán y a Ortega, mientras que Doña Violeta y Don Enrique fueron presidentes débiles, a los que los abandonó su propio partido en la Asamblea, que tuvieron enormes dificultades para desarrollar su agenda de gobierno, y tuvieron que estar pactando individualmente con los legisladores para conseguir apoyos, y que además se vieron sometidos a una crisis institucional del Estado, bueno, de bloqueo de poderes, que se dice, ¿no? Y esas dos famosas Leyes Marco, que les fue necesario aprobar a ambos al frente de Ejecutivos que se resistieron a las reformas constitucionales planteadas desde el Legislativo. Primero, ipiensa, entonces, que el único líder dentro del liberalismo, y que es la figura, digamos, la contraparte del liderazgo de Ortega, es Alemán?

D.M.: En este momento, yo creo que Alemán perdió ya mucho, porque este es un juego político interactivo, los dos son hombres fuertes, pero si vos apretás demasiado quebrás el pacto, a su vez, si vos te acercás mucho al Frente, que es el poder más consolidado que hay en la política nicaragüense, entonces, él dice que se acercó al Frente para lograr la estabilidad, para poder gobernar, etc., etc., pero, en el fondo, él también quería incrementar su propio poder, incluso, fue juzgado por razones de malversación de 
fondos, entonces, en este escenario de sandinistas y anti-sandinistas si vos sos antisandinista y te acercás demasiado a mí, entonces, todo el mundo anti-sandinista empieza a desconfiar de vos, o sea, aunque vos seas el más fuerte anti-sandinista, pero sí te respeto mucho siempre y cuando vos estés contra mí, en el momento en que te vea muy cerca de mí ya no, en esto es mucho más flexible el Frente, el Frente deposita su confianza en su líder y le deja que se acueste en la cama con Arnoldo Alemán, deja que Daniel haga eso, pero si Arnoldo Alemán, su gente ve que se acerca demasiado al Frente, ya lo están acusando de traidor en su partido. Doña Violeta pactó con el Frente abiertamente, totalmente.

R: Pero se ganó gran parte de la antipatía de muchos de sus seguidores, bueno, de hecho perdió gran parte de los apoyos.

D.M.: Sí, pero no tenía otra alternativa, no podía ir ni a su casa, a la casa presidencial, porque el Frente tenía la ciudad incendiada, es complejo, pues, porque lo que te quiero decir es que aquí hay un Estado primitivo de cosas todavía, mientras discutimos la modernidad legal, cuando, en realidad, lo que hay que hacer es terminar de poner los ladrillos en el suelo y levantarlos hasta poner el techo. Es que hay una gran línea divisoria: esta es la Constitución y esta es la realidad, todo el mundo quiere una Constitución de madera preciosa como techo allá arriba, pero hay un enorme charco de agua aquí abajo, no tiene ladrillo, no tiene piso, yo creo que ese ha sido el error en la historia de Nicaragua, que hemos comenzado a construir de arriba para abajo y no de abajo para arriba. No, que en Estados Unidos, la Corte Suprema de Justicia le dice, en primer lugar, no es tan cierto que la Corte Suprema en Estados Unidos tenga funciones políticas, pero aparte de todo eso tenés no sé cuantos años de historia propia de todos los inmigrantes que fundaron esa nación, alemanes, ingleses, franceses, holandeses, etc., igual pasa en la misma España, ¿España cuántos años de vida independiente tiene desde el Pacto de la Moncloa para acá?, tiene una democracia muy joven.

\section{$R:$ Treinta años.}

D.M.: Es muy joven, o sea, que tenés experiencias de dictaduras también, a veces cometemos el error y por el lado del Frente también, de querer construir una sociedad socialista sobre una base material brutal, como la de la sociedad primitiva, aquí hay territorios de Nicaragua que viven exactamente igual que cuando vinieron los españoles, no ha cambiado nada, ni sus casas, ni su comida, ni su cultura, nada, y, sin embargo, yo les digo que ahora elijen a un diputado nacional, y a un diputado regional, y tiene una Constitución aquí, o sea, ¿y eso qué importa si el tipo está en un estado de atraso total?, yo, en ese sentido, tengo una visión, aunque no soy un gran erudito, pues, sí creo en esa concepción marxista mucho que dice que la base material es la que condiciona la superestructura, yo, en mi interior, la considero muy acertada.

\section{R: ¿Y el pacto constitucional? ¿Más reformas a la Constitución o no?}

D.M.: Estamos ante reformas ocasionales, ¿no?, no son otra cosa, vos la mirás como que hubiera ahí una teoría del Derecho, no, tienen que ver lo del cambio de los Magistrados todavía, aquí puede pasar cualquier cosa en función de quiénes son los que van las personas que van a venir ahí, igual pacta con Montealegre, que pacta Alemán, que pacta, es decir, porque el país sigue moviéndose todavía por las prebendas que te dan los poderes públicos, eso es lo que hay. 


\section{R: ¿El Estado sigue siendo una fuente de recursos?}

D.M.: Es que el Estado es la fuente de trabajo, tú agarrás a cualquiera de esos diputados que están ahí, pero cuando digo a cualquiera es cualquiera, y lo sacás de ahí, y al día siguiente no tiene qué comer, no tienen a nadie, no tienen dinero, no tienen negocios, puede haber algunas excepciones, entonces, se apegan al empleo público como una necesidad, mirá en la Alcaldía, pues, esa Alcaldía es desde un muerto, un casamiento, unos 15 años, una lámina de zinc para el techo, entonces, es todo, es como que si somos el padrino de la ciudad, entonces, si vos tenés un poquito de realidad para regalarle cualquier cosita a alguien, por lo menos, sonreírle, abrazarle, dice, qué bueno, qué gran alcalde, y ¿qué hice?, ¿qué hice?, cuatro cosas, no puedes hacer mucho porque no hay dinero, el presupuesto es ínfimo, entonces, nada más que con tratar de que te toquen, de que te hablen, de que sientan la cercanía con vos, pero si yo me pongo a decir, no, la teoría de la descentralización municipal, la participación de los ciudadanos, ¿qué participación de los ciudadanos voy a tener si son 1500 millones de pesos entre un millón de habitantes son 1000 dólares entre doce, 100 dólares, no pasa de 100 dólares por persona o menos?, eso es todo lo que yo tenía para reparar toda la ciudad, recoger toda la basura, construir calles, etc.

R: Sí, y respecto a repetición de los ciclos de la historia, que es algo que ha mencionado, ¿es cierto que el paralelismo, salvando los contextos, entre los años que estamos viviendo ahora, el momento crítico actual, digamos, y el gobierno de Ortega, rodeado de su grupo familiar, ha utilizado un poco el Estado como fuente de enriquecimiento personal, hay gente que establece comparaciones con el primer Somoza, ¿no?

D.M.: Es incluso más poder, como en la época de Zelaya, lo único que tenés es que ahora el lenguaje, cuando dicen sandinistas, comunistas, marxistas, o medio esotéricos, la nueva cosa que hay es el esoterismo.

R: Pero Zelaya era un intelectual liberal, que no es exactamente la condición de Ortega.

D.M.: Sí, pero era un hombre fuerte, y también hizo una Constitución que se recuerda aquí como la base de las constituciones: la "Libérrima".

\section{R: Pues yo creo que hemos hablado de casi todo, si tiene algo más que añadir.}

D.M.: No, yo te cuento, como te digo, más la experiencia mía, no sé si te sirva, pero es más o menos como yo lo veo, ¿qué es lo que yo haría?, educar a la gente, educar, educar en lo que sea, educar ingenieros, albañiles, zapateros, médicos, enfermeras, lo que sea, pero que estudien, que lean, que vean otras cosas, por eso a los ricos de Nicaragua, yo les digo, que lo mejor que hizo la revolución fue sacarlos de aquí y se tuvieron que ir a otro país, y, por fin, se modernizaron. 


\section{ENTREVISTA $35^{50}$ :}

Nombre del entrevistado: D. Adolfo Martínez Cole.

Cargo actual: Diputado de la Asamblea Nacional (2007-2011), actual jefe de la Bancada Democrática Nicaragüense, y miembro del grupo político "Vamos con Eduardo", liderado por Eduardo Montealegre.

Fecha de realización de la entrevista: Managua, 13 de noviembre de 2009.

Lugar: Asamblea Nacional de Nicaragua.

Duración estimada: 52 minutos.

\section{TEXTO - Transcripción 35:}

R: ¿Cuál es su visión sobre los cambios constitucionales que se han producido recientemente en Nicaragua?, ¿cuál es el recorrido que hace en el marco de la transición democrática?

\section{A.M.C.: ¿Las últimas éstas, o del 87 para acá?}

\section{R: Desde las primeras reformas del 90 hasta el momento actual.}

A.M.C.: Bueno, en el 90 despertamos a la democracia con una Constitución del 87, que era una Constitución netamente presidencialista, con un poder totalmente limitado al presidente, tanto es así que, incluso, los mismos créditos, que tenían que ser aprobados por la Asamblea, no necesitaban de la ratificación de la Asamblea y entraban totalmente con la aprobación del presidente, el poder era total, en el 1995 hubo una reforma bastante consistente, que en algunas cosas mejoraron y en otras cosas, digamos, dificultaron, en esta reforma del 95 se pasó a que los nombramientos de los magistrados, por ejemplo, de altas autoridades, fuera con un voto calificado, que significa 56 votos, antes era con 47 , eran mucho más dinámicos, podía ser, podía reunir 47 votos para los nombramientos, verdad, y no como ahora que estamos en esta situación de que estamos obligados a pactar con el Frente Sandinista para poder reunir los 56 votos que se requieren como votación calificada, luego también hubo unos cambios bastante fuertes, en cuanto, y que le resta, digamos, legitimidad a algunos procesos electorales, cuando no se alcanza un número determinado, un porcentaje determinado en las elecciones, antes un $45 \%$, se bajó a un $35 \%$, ¿verdad?, si se da una diferencia de cinco puntos entre el primero y el segundo lugar en votación, ¿verdad?, si no se da eso, pues, se llega a un $40 \%$, pero aún así, no es la representación mayoritaria de un pueblo, que se exprese en dos votaciones, que debería ser el 50\% más uno, que es como, diríamos, que tiene la total legitimidad cualquier gobierno, estas son, digamos, áreas que se vieron afectadas, y que, a mi juicio, debilitó la democracia en Nicaragua. Sin embargo, se sentaron dos principios importantes, que es en cuanto a la reelección del presidente, antes podía, perfectamente, reelegirse, en las reformas que hubo en el 95, en 1995, entonces, se establecieron dos limitantes, una que si el que estuviera en funciones había ejercido también en época anterior un período presidencial, verdad, o

\footnotetext{
50 Entrevista centrada en la crítica al fenómeno sociocultural del caudillismo en Nicaragua, como factor que explica las dificultades de consolidación de las instituciones democráticas, desvirtúa los cambios constitucionales recientes, y fortalece los déficits, en términos de desarrollo social y económico, del país centroamericano.
} 
sea, hubiera sido presidente dos veces no podía, ya estaba impedido para una tercera opción, y la segunda limitación es que no existía la reelección continua, sino que podía ser alterna, tenía que dejarse pasar un período para poder, verdad, nuevamente, optar a la presidencia de la República, eso es lo que está actualmente en nuestra Constitución, y es lo que las fuerzas democráticas consideramos que debe de respetarse, y que, a nuestro criterio, se violentó con la reciente sentencia, verdad, de la Corte Suprema de Justicia, que se atribuye funciones legislativas, verdad, irrumpiendo e invadiendo la esfera de otro poder del Estado, de tal manera que aquí pudiera presentarse una situación de conflicto de poderes que retornaría, nuevamente, a la Corte Suprema de Justicia, porque así lo dice la Constitución, que cuando hay, verdad, conflicto entre los poderes, quien dirime ese conflicto es la Corte Suprema de Justicia con la salvedad de que cuando la Corte Suprema de Justicia es uno de los poderes involucrados, entonces, no pueden conocer los Magistrados, verdad, de la Corte, sino que tendrían que llamar a los conjueces, verdad, que son como suplentes, pero con una propiedad muy singular, verdad, ahora, ¿qué es lo que pasa con los conjueces?, que no existe un procedimiento de cómo tienen que ser nombrados y llamados, de tal manera que, de una u otra forma, el presidente Ortega, en este caso, pudiera hacer valer, verdad, este atropello de la Constitución, verdad, porque retornaría al mismo poder que él controla, y esto es lo lastimoso, lo lastimoso para una persona que se considera demócrata, y, en este caso, para usted, que está recogiendo toda esta información, de que pueda existir en un país un poder, que es la columna vertebral de todo Estado de Derecho, que se exprese de que ellos actúan en base a la obediencia a un partido determinado, y esa es una tara enorme que nosotros tenemos, verdad, en nuestro sistema democrático, de que los poderes del Estado se los dividen los partidos. Por eso la idea de nosotros para democratizar más el sistema, y para fortalecer la institucionalidad en nuestro país, hemos lanzado la idea, verdad, de que no surjan del seno de los partidos, quienes ejerzan cargos, por ejemplo, de Magistratura para que tengan la total libertad, y sean las organizaciones civiles quienes puedan proponer candidatos, verdad, que por su trayectoria, por su solvencia moral, por su trayectoria política, que hayan tenido, o pública en el ramo en el que se hayan desempeñado puedan sentar ciertas garantías de que van a actuar conforme a la ley, conforme al Derecho, respetando la institucionalidad, dignificando la institución que ellos representan, ese es el anhelo nuestro, verdad, y por eso nos oponemos a que pueda existir reforma a la Constitución, que era un impulso que tuvo el presidente con sus diputados de que, a través de la Asamblea, como corresponde, que es a la única a la que le corresponde hacer reformas a la Constitución a través de dos maneras, cuando es reforma parcial, verdad, a la Constitución, a artículos determinados, entonces, esto se tiene que hacer siempre por el número calificado, es decir, 56 votos, pero en dos legislaturas, o sea, lo que si aprobamos hoy, tendríamos que esperar a la legislatura del 9 de enero, cuando se inicie la nueva legislatura, para también aprobar lo que se aprobó en la anterior sin quitarle una sola coma, para que tenga, digamos, legitimidad la reforma, o a través de una Constituyente si es una reforma total, verdad, a la Constitución, que eso se haría en una sola legislatura, porque es Constituyente, es el poder originario, verdad, que es el que se impondría, entonces, esta intención del gobierno y los diputados del gobierno, pues, no se llevó a cabo porque las fuerzas democráticas, pues, vemos que en la historia de nuestro país toda reforma constitucional $\mathrm{y}$ toda reelección de los presidentes ha creado unos traumas impresionantes, que nos ha llevado a la guerra, nos ha llevado a derramamiento de sangre, y ¿por qué razón?, porque en nuestro país, lamentablemente, está bien enraizado el principio caudillesco, verdad, que ese principio caudillesco te quita a ti como elemento político, como actor político, la libertad de poder decidir, y como son los caudillos quienes nombran a las 
personas, esas personas nombradas, esos funcionarios se deben no a la institución que representan, ni a las leyes que los rigen, sino a quien los nombró, verdad, de tal manera que se desvirtúa todo el principio fundamental de un Estado de Derecho, verdad, entonces, aquí vas ante la justicia y vas con el temor, y lo primero que te preguntas es: ¿y ese juez que me va a juzgar de qué partido es? Mira que cosa más lastimosa, verdad, para una persona que aspira y añora, realmente, vivir dentro de un sistema democrático, ¿no?, entonces, eso es lo que se está dando en Nicaragua, y ese es el impedimento y la lucha que tenemos para que no haya reformas constitucionales, que no se logró a través del Poder Legislativo, porque hubo oposición total, nosotros cerramos, totalmente, todas las fuerzas en esa orientación, pero que, lamentablemente, se está cometiendo un atropello impresionante, nunca visto en la historia de Nicaragua, como es que venga la Corte Suprema de Justicia se arrogue funciones legislativas y quiera cambiar un artículo de la Constitución, no sé qué más quieres que te diga.

R: Sí, es muy interesante todo lo que ha dicho, y sí querría puntualizar algunas cuestiones, si bien la reforma del 95 es quizá la más legítima, en términos de que era jurídicamente necesaria, porque era un momento político muy especial del país, hubo un gran debate sobre si abrir una Constituyente, hacer una reforma total a la Constitución del 87, que era el régimen al que se le ponía fin, después de los Acuerdos de Paz, o bien una reforma parcial, que fue lo que, finalmente, terminó llevándose a cabo, una reforma, además, muy amplia de la Constitución del 87, y en la que se otorgan mayores facultades a la Asamblea, como corresponde a un régimen democrático en detrimento de ese presidencialismo fuerte de la Constitución original. Pero el pacto entre Ortega y Alemán inicia una deriva en el cambio constitucional de este país, a mi juicio y a juicio de muchos críticos, muy dañina, ¿no?, porque estamos viviendo los frutos de esa mala actuación por parte de los líderes del PLC y del Frente Sandinista. ¿Cómo examina usted esa dificultad de llegar a un consenso constitucional, que ha estado siempre presente en todos los momentos de reforma?, siempre ha habido una parte de los ciudadanos de Nicaragua, que no se han identificado del todo con la Constitución, desde el año 87, porque no todos coincidian con el proyecto revolucionario.

A.M.C.: Así es, así es, es lo que le decía anteriormente, verdad, el principio caudillesco que nos rige, que está bien metido dentro de nosotros y que está costando bastante liberarnos de él, los liderazgos aquí no se mantienen, no se sostienen por ideas, por planteamientos, por programas, por proyectos, ¿verdad?, sino que esos liderazgos no funcionan, funciona aquél que tiene una relación inmoral en el ejercicio del poder a una fuerza contraria, en este caso, por ejemplo, la fuerza del orteguismo, no le digo sandinismo, porque ha habido una desmembración enorme del sandinismo, ¿verdad?, donde aquellas personas que vieron la revolución como un cambio positivo a los errores y a las cosas, digamos, defectuosas, que tenía el régimen de Somoza, vinieron con el buen propósito de cambiar todo esto, entonces, esos señores se alejaron, verdad, de Ortega cuando vieron que la revolución estaba siendo traicionada, que la revolución estaba siendo desviada de los objetivos, en la cual todo el pueblo participó, verdad, todo el pueblo participó, desde los jóvenes hasta los viejos, de una u otra manera, en la lucha contra la dictadura de Somoza, y se oponen totalmente a una nueva dictadura. ¿Qué es lo que tenemos actualmente nosotros?, tenemos una dictadura ya institucional, verdad, en el sentido de que controla el Poder Electoral, controla el Poder Judicial, controla el Poder Ejecutivo, y lo único que le falta por controlar es la Asamblea Nacional, que, lamentablemente, diputados que fueron electos dentro de las corrientes liberales, 
verdad, han sucumbido ante algunas dádivas, ante algunos ofrecimientos y le han hecho el juego al orteguismo con el riesgo de que también controle el Poder Legislativo. ¿Qué es lo que pasa aquí?, en la época de Somoza existían dos partidos, el Partido Liberal y el Partido Conservador, ellos habían llegado a un pacto en que un $60 \%$ iba a ser del partido de Somoza, el Partido Liberal Nacionalista, y un $40 \%$ iba a ser de los conservadores, que eran llamados los "zancudos", verdad, porque dependían, digamos, y se congraciaban con el poder, y que hacían lo mismo que hacían los liberales, con tal de devengar sus dádivas, y ocupar los espacios que se le permitía ocupar, de tal manera que había elecciones en las cuales ellos no sacaban ningún voto y venía el Partido Liberal y les daba votos para que no aparecieran sin sostén, digamos, legal, verdad, en los cargos de diputados o en cualquier otro cargo de elección popular, para que no se viera la desfachatez con que se manejaban aquellos pactos, eso se está repitiendo actualmente, verdad, el partido de Ortega está ocupando un espacio muchísimo mayor que el Partido Liberal de Arnoldo Alemán, sin embargo, ellos están por ocupar esos espacios, por devengar esas dádivas, esos privilegios del poder, pues, entonces, están secundando, y se están, digamos, complementando con el orteguismo para que sean ellos quienes determinen la elección de quiénes nos van a administrar la justicia, quiénes van a llevar por delante los procesos electorales en los distintos poderes del Estado, ¿no?, entonces, eso es lo que estamos viendo ahora, y eso es lo que nosotros deberíamos de cambiar. Yo, por ejemplo, estoy de acuerdo en que pudiera haber una reforma constitucional, verdad, pero una reforma constitucional en estos momentos, y con los actores que están, no me vendría a resolver absolutamente nada, vendríamos más bien a involucionar, verdad, ¿por qué?, porque, ¿quiénes controlan?, ¿quiénes cuentan los votos?, ¿quién llevaría a cabo, digamos, una nueva elección para una Constituyente?, pues, las mismas personas que han hecho un fraude electoral que nos está costando tanto daño ante la comunidad económica internacional, y un daño interno impresionante, como consecuencia de eso, entonces, no podemos confiar, tenemos que estar con la Constitución que tenemos hasta que vengan actores que merezcan, realmente, la confianza y credibilidad suficiente de que, por eso es que le digo, nosotros nos pronunciamos porque no salgan del seno de los partidos, verdad, sino que salgan del ofrecimiento que los distintos gremios, que las sociedades civiles organizadas, que todos estos puedan proponer y analizar nosotros el currículum para que esas personas nos puedan dar las garantías suficientes para poder llegar a una reforma legalmente válida, aceptada y sensata y honesta de la Constitución, ¿verdad?, pero hoy por hoy la Constitución se nos hace a nosotros, por lo menos, intocable, ¿verdad?, por los actores que están y los que estarían, digamos, decidiendo una Constituyente, que sería el Frente Sandinista, digamos, el orteguismo, pues, manejando esto, de tal manera que esta relación entre dos partidos mayoritarios y que se han prestado, no les importa la crítica ni nada, pues, entonces, esto se ha seguido dando, y temo que el resultado de esta unidad que estamos conformando pueda debilitarse si a la hora de las fuerzas, que, realmente, queremos defender la democracia en las instituciones, decimos, abdicamos de esta manera, y al no estar de acuerdo al elegir de esta manera puedan ellos pactar y decir: "quedémonos solos nosotros, y elijamos nosotros, porque estos que nos van a meter pueden ser obstáculos para el ejercicio de nuestras pretensiones en ese poder determinado", no sé si me explico, pero cuando hay, cuando en un grupo deshonesto hay una persona deshonesta que los va a poner en evidencia o los pueda denunciar no nos interesa que esté, entonces, hay que sacarlo, verdad, y si las fuerzas democráticas, que pretendemos, digamos, adecentar las instituciones, queremos llevar dos, tres, los que sean, Magistrados, con una talla, un currículum, digamos, de honestidad y de respeto, pues, entonces, esas personas pueden ser tal vez inaceptables para el 
orteguismo y para el ex-presidente Alemán, y puedan llegar a ellos y puedan decir: "olvidémonos de las otras fuerzas y sigamos nosotros pactando", y, entonces, se agudizaría muchísimo más, nos pondría en una situación crítica, verdad, donde pudiera, perfectamente, esta sociedad explosionar en cualquier momento, porque no aguanta más, no aguanta más, ¿no?, hay un peligro grande, dentro de nosotros también así como hay una raíz caudillesca, también hay una raíz belicosa, que puede expresarse en cualquier momento, cuando menos uno lo pueda espera puede saltar, y cuando hay hambre, cuando hay miseria, que no hay derecho a que estemos así, puesto que hemos recibido tanta, digamos, ayuda internacional, como también recursos propios que tenemos nosotros en nuestro país, que comparado con Centroamérica, verdad, somos muchísimo más ricos, no hay derecho que estemos en esta situación, es lamentable la paradoja de que en tiempos de Somoza, la dictadura de Somoza, aquí fuimos el granero de Centroamérica, aquí venían los salvadoreños, los guatemaltecos, los costarricenses a buscar trabajo, verdad, y ahora somos nosotros los que estamos emigrando después de un período largo de dictadura orteguista, y ahora somos nosotros los que estamos, precisamente, ni siquiera buscando trabajo, sino mendigando muchas veces la ayuda internacional para poder cubrir nuestro presupuesto, eso es lo triste, lo triste, en un país que puede, perfectamente, abastecerse por sí mismo en sus necesidades básicas, como es los gastos de la nación, y acudir a créditos que puedan no ser concesionales, sino créditos normales, en los cuales tengan nuestros acreedores la garantía de que tenemos los recursos para cancelar, eso es lo que nosotros creemos, eso es lo que nosotros queremos, y por eso, digamos, los que estamos metidos en la actividad política, sabiendo que podemos ser barridos manteniendo estos principios.

$R$ : Sí, y es verdad que desde la experiencia de desconcentración del poder, hemos vivido ahora la contraria, ¿no?, es decir, de debilitar al Ejecutivo en favor de la Asamblea, ahora estamos viviendo una concentración de poder en el Ejecutivo, pero de facto, no tanto a través de las reformas jurídicas, sino a través del control que ha hecho el Frente del Poder Judicial, que es uno de los bastiones institucionales de su preeminencia política, incluso, durante los 16 años de oposición, el aprendizaje institucional del Frente ha sido notable, bueno, me comentan varios de los entrevistados como el poder sandinista, una vez que pierde las elecciones en los 90, dice: "vamos a gobernar desde abajo", y se fortalece no solamente en términos de organizaciones sociales o en términos de su control sobre parte de las instituciones del Estado, que continuaron bajo la influencia sandinista, y, progresivamente, se despolitizaron, como fue el caso del Ejército o de la Policía, a la que ahora, peligrosamente, tiende sus tentáculos el presidente de la República, pero sí resulta, por lo menos, muy sorprendente esa vinculación sandinista del Poder Judicial, ¿no?

A.M.C.: Impresionante, usted mencionaba una cosa muy importante que es el de tratar de desarticular instituciones que estaban bien encaminadas y profesionalizar, por ejemplo, el Ejército y la Policía, a la Policía ya la tiene totalmente controlada, usted va a las manifestaciones, verdad, no nos permiten expresarnos, favorecen a la parte que nos ataca, para ellos no hay delincuencia ahí, y permiten, pues, todo tipo de atropellos a nuestros derechos humanos, ahora el Ejército no se ha tocado todavía, pero temo que el corazoncito del Ejército, todos, la mayoría de los que están todavía en los altos cargos del Ejército son personas que estuvieron en la guerrilla, son personas que se formaron en la clandestinidad, bajo principios marxistas, que dominan muy bien, y ellos sí han tenido, digamos, una profesionalización de su institución, verdad, pero a la hora de responder quisiera saber y tener la total, el $100 \%$ de seguridad, de que van a responder a 
la Constitución y no a obediencia, digamos, al presidente de la República, que es el Jefe, verdad, del Ejército, pero ante una discusión del Jefe o una discusión constitucional se deben a la Constitución, más que todo, eso ojala, ojala, que se pudiera dar, pero la idea es esa, es desarticular todas las instituciones de tal manera que no haya ningún tipo de oposición a su sistema.

R: Cuando hablaba con Dora María Téllez de MRS, bueno, aunque, actualmente, ya no es diputada, me comentaba que cuando Ortega pacta con Alemán, Alemán tiene en su cabeza los pactos de Somoza, ¿no?, y, sin embargo, Ortega tiene una vocación hegemónica, y una formación de cultura política y experiencia también guerrillera, conspirativa, completamente distinta de la Alemán, y se va arriba sin respetar lo que podía se un "pacto de caballeros", que está en la historia constitucional de Nicaragua, porque antes de muchas reformas constitucionales se pactaba, previamente, el reparto paritario entre los partidos de las posiciones de poder que fueran a ocupar, como usted mencionaba anteriormente. ¿Cómo ve usted el futuro de su pais?, porque la recomposición del liberalismo, algunos liberales son optimistas, otros no tanto.

A.M.C.: Sí, mire, los pactos y los acuerdos existen en todas partes del mundo, porque en un Poder Legislativo se tiene que llegar a acuerdos para sacar adelante, la diferencia está, verdad, en qué es lo que buscas con eso, si es tu propio bien o el bien de tu partido, o es un bien general, un bien común, verdad, los pactos, los acuerdos que se dieron para terminar en un bien común, en una mejoría para el pueblo, son válidos totalmente, honorables, honestos, verdad, y exigibles deberían de ser para no paralizar un actividad que va a beneficiar a una mayoría, ahora, ¿dónde entra la corrupción?, cuando se ponen de acuerdo dos personas para lograr sus beneficios personales o partidarios, verdad, a cambio de sacrificar el bien común, ahí es donde la inmoralidad en la que han caído estos señores, ¿verdad?, Alemán y Ortega, que con un desprecio total al pueblo que gobiernan, se han enriquecido, se han beneficiado únicamente ellos, y se han entronizado en sus cuotas de poder para de una manera totalmente egocentrista imponerse a todo lo que está por delante. ¿Qué porvenir le veo yo a Nicaragua?, bien, yo creo que el orteguismo se está agotando, no le doy mucha vida al orteguismo, puesto que existe, ya digamos, sandinistas definidos como es el MRS, como es el Rescate del sandinismo, verdad, y existen una cantidad de sandinistas que comenzaron con el gobierno, sintiendo que iban a estar mejor, y han visto el deterioro y la incoherencia y la forma absurda de este señor de gobernar, donde no solamente, digamos, nos ha puesto en una situación delicada en el contexto internacional, sino que compromete la seguridad y la estabilidad de Nicaragua al entrar, al despreciar a quienes han sido tradicionalmente nuestros amigos, y entrar, por ejemplo, en un amorío, por ponerle alguna palabra, con sistemas como Teherán, con sistemas como el del señor Chávez, verdad, que lo que hacen, simplemente, son medidas populistas y de un nacionalismo trasnochado, un socialismo trasnochado, ¿qué es lo que pretenden?, y eso es lo que la gente se está dando cuenta, y es lo que hay que repetirle constantemente, estos sistemas lo que quieren es generalizar la pobreza, verdad, para que no pueda haber alguien que pueda decirles no, sino que haya una dependencia del ciudadano hacia el gobernante, en la cual si el gobernante no le da, no sobreviven, y, entonces, para sobrevivir humillan al ciudadano y lo ponen, como usted ve, en las rotondas, yo conozco personas, verdad, que los comprendo, que están, cuando pasa alguien que más o menos creen que los conoce disimulan, como queriéndose esconder, porque les da vergüenza, pero tienen que estar allí, porque no tienen la libertad de decir: "yo no voy a participar", porque pierden su puesto, y tienen su familia que mantener, y tienen que sacrificar su orgullo, su dignidad 
de persona para poder devengar el salario de mantener a su familia, eso es lo que no podemos ver, y eso es también lo que un sector importante de los empleados públicos, de los sandinistas que no son orteguistas están viendo, de tal manera que si aquí se fuera a unas elecciones y ojala que hubiera podido ser el presidente Ortega candidato, porque no creo que haya alguien, verdad, que pueda verdaderamente aportar un voto hacia él con este gobierno que está haciendo, entonces, yo creo que la realidad, la pobreza que estamos viviendo, la exigencia de las bases hacia los liderazgos de los distintos partidos, está obligando a que nos entendamos, verdad, está obligando a que desplacemos, incluso, vamos a tener que pensarlo muy bien, si se trata de hacer un pacto directamente con Ortega, porque las bases están exigiendo, cuando nosotros vamos, muchísimos, lo que nos dicen es, con el PLC, que es el partido de él, verdad, unámonos, pero sin Alemán, verdad, y les decimos nosotros: "pero dame la fórmula, si es él el que controla el partido", verdad, entonces, es él quien tiene que ver eso, y su poder de convocatoria, cómo ve, digamos, un político, su raiting, pues, ¿verdad?, en base al poder de convocatoria que tiene, y ese poder de convocatoria se había disminuido enormemente, ya no era lo mismo, ya no llega y no es la cantidad de gente que lo va a aclamar, sino que existe una pobreza en cuanto a las personas, y esto lo percibe, de tal manera que todas las cosas, obligados por el pueblo, por las bases, militantes o no militantes, pero desesperadas por la situación de desempleo y de pobreza en que nos encontramos, pues, van a obligarnos a nosotros, a los que creemos y a los que no creemos, pero que queremos continuar en nuestra carrera política, verdad, a adecentar nuestras decisiones, y a buscar el cómo cerrarle el paso totalmente al orteguismo, y que venga, verdad, elegir a alguien, verdad, yo soy liberal, pero si viene uno del MRS, por ejemplo, como Edmundo Jarquín, que tiene grandes cualidades, y es un hombre que no tiene nada que se le pueda criticar, pues, yo lo respaldaría totalmente, si lo que nos interesa a nosotros es que quien ejerce el poder sea un demócrata, que se respeten las instituciones y se respete el Estado de Derecho, ¿verdad?, independientemente, después vendrán las elecciones y en base a lo que se haga o no se haga, veremos quién es el que sigue detentando el poder, pero lo que tenemos que defender es la democracia.

R: Entonces, ¿cree usted que puede haber una candidatura común del liberalismo, y de las fuerzas anti-orteguistas?

A.M.C.: Tiene que haberla, tiene que haberla, si no la logramos, verdad, no, no merecemos ninguno de los que estamos en actividades políticas seguir donde estamos, porque es que nos estamos jugando la nación, nos estamos jugando el país, nos estamos jugando el bienestar de un pueblo que está cansado, Nicaragua está cansada de esta situación belicosa, de repetir los ciclos, bueno, ya tenemos que liberarnos y para eso tenemos, primeramente, que liberarnos de los caudillos, verdad, aquí tienen que predominar las ideas, las confrontaciones de ideas, de principios, de valoraciones, verdad, aquí los valores no cuentan, es lamentable, aquí si yo aspiro a un cargo público tengo que congraciarme con algún caudillo, y eso es aberrante, eso como persona me humilla, prefiero ir a trabajar a la tierra o lo que sea, o a ejercer mi profesión, digamos, de la manera que fuera, ¿verdad?, pero enajenar mi conciencia, y por eso ve usted aquí como hay diputados que sacrifican su conciencia, venden su conciencia por un plato de lentejas como dicen, ¿verdad?

R: Pero hablando de las élites, también hay un tipo de ciudadano que sostiene a los caudillos, hablando con otros entrevistados me dicen que Alemán y Ortega son muy parecidos en las bases sociales que les apoyan, hablando, fundamentalmente, de las 
clases populares y de la clase media baja, que es la mayoría, digamos, del espectro sociológico en Nicaragua, y que ellos si han liderado esa bandera contra la oligarquía tradicional, o contra las élites políticas tradicionales, ¿no?, que gobernaban el país en tiempos de Somoza y, anteriormente, obviamente, a través del Partido Liberal y el Partido Conservador. No sé si está usted de acuerdo con que ambos líderes son más parecidos, al margen de sus tendencias ideológicas.

A.M.C.: Totalmente, totalmente, es que ellos no son si soy de derechas o soy de izquierdas, sino es cuánto me beneficia esto a mí y en cuánto tiempo me voy a mantener en la cúspide del poder, son idénticos, aquí no es asunto de derecha o de izquierda, aquí es asunto de corrupción, verdad, de los dirigentes, y, lógicamente, aquí vemos, por ejemplo, un sector privado que se pliega muchas veces, y yo se lo he dicho insistentemente, miren lo que está pasando en Venezuela, va a pasar aquí, verdad, ahora pueden estar ustedes saboreando parte de las mieles del poder, pero después ese poder los va a absorber totalmente y los va a desplazar, y lo que ahora quieren detentar ustedes lo van a perder en su totalidad, y van a tener que buscar algo fuera del país si quieren llevar una vida distinta, tan cómo rehacerse, pero, es verdad, que aquí ha habido complacencia, la hubo en tiempos de Somoza, una clase económica que no reaccionó hasta que Somoza, económicamente, los iba ahogando, en el sentido de que si se levantaba una fábrica de cemento, de ladrillo o lo que fuera, Somoza les montaba una más grande, y, entonces, no podían competir, entonces, ahí vemos la pobreza, verdad, la pobreza de ese sector que van viendo, realmente, por sus intereses, a cuánto gano, verdad, sin importarle las consecuencias que va a tener para un número mayor de ciudadanos, verdad, manteniendo a esta gente, pero eso está cambiando, ya las bases no están para eso, por eso le decía que el poder de convocatoria de uno y de otro, ¿verdad?, no es el que tenían antes, ahora, cuando llama Daniel van, porque como te digo, la necesidad, verdad, del empleado público de defender sus ingresos, y van, aún cuando en el corazón sienta rechazo, verdad, y maldiga o lo que sea a quien lo llama, porque el que lo está haciendo lo está humillando, se siente humillado, y Alemán no tiene el poder de convocatoria de antes, las bases se están uniendo y esta unidad que se está dando en la cúspide de los partidos, verdad, es obligada por la reacción de las bases, que le digan: "únanse, o aquí los desplazamos", ¿verdad?, entonces, tenemos que reaccionar nosotros, tenemos que reaccionar nosotros, aún, egoístamente, para satisfacer a esas bases. Esas bases no quieren más orteguismo, no quieren más dictaduras.

$R:$ No, y además, repitiendo un poco ese paralelismo histórico que hacen algunos entrevistados con los tiempos de Somoza, por el régimen familiar, la concentración de poder económico en torno al ejercicio del Ejecutivo presidencial.

A.M.C.: Igual, ahora, y te voy a decir una cosa, en tiempos de Somoza existía más libertad que ahora, en tiempos de Somoza, fíjate bien, que la mayoría de los gobiernos en Latinoamérica existía un número impresionante de dictaduras, verdad, de dictaduras, que eran apoyadas por Estados Unidos, porque les convenía con la cuestión de la Guerra Fría, el comunismo, y todo eso les interesaba, les interesaba mantener estas dictaduras, sin embargo, existía una libertad de prensa muchísimo mayor de la que existe ahora, porque esa era como la máscara que ponía Somoza para decir: "mira, hay libertad", podías expresarte, podías manifestarte, verdad, ahora, y había una cosa muy importante, cuando te perseguían, perseguían al que, realmente, estaba involucrado, pero respetaban sus bienes y a su familia, aquí van contra tus bienes y contra todo, aquí te confiscan, aquí te quitan tus bienes, aquí no les importa, absolutamente nada, si eres tú nada más 
en tu familia el único que estás involucrado, no les importa, aquí te quitan todo, verdad, te invaden, te lanzan a las turbas, propiedades que pudieran estar dando rendimiento para mantener la economía del país te las invaden, verdad, y vienen personas que no tienen ningún tipo de conocimiento para administrar y poner a producir la tierra, verdad, y lo que hacen después, lo que vemos son suelos totalmente inservibles, totalmente abandonados, totalmente invadidos por la maleza, con todo aquello que se hace improductivo, o sea, eso es lo que estamos viviendo, cómo las personas que vienen a invertir, tal vez, en el desarrollo turístico, y resulta que su propiedad después que la adquirieron, legalmente, después resulta que viene otro interesado y dice que es de él, y ponen en riesgo toda una cantidad de millones que invirtieron, verdad, en un hotel, en lo que sea, en un centro turístico, y resulta, ¿quién va a venir si no hay garantías, no hay respeto al Derecho, a la norma jurídica?, entonces, eso es gravísimo, eso es gravísimo, nosotros tenemos un potencial turístico impresionante, tenemos unas bellezas que no las podemos explotar, pero yo veo, por ejemplo, cómo han venido capitales de fuera, han invertido en la costa de San Juan del Sur, y ahora se ven en problemas, verdad, que si nos invaden, que dicen que no es de ellos, que si ya existía un asiento registral que no es el que le corresponde, comienzan después a tener que gastar para defender lo que adquirieron, verdad, legalmente, entonces, ¿cómo podemos levantar un país si le estamos cerrando las puertas a la inversión?, verdad, si no tenemos capital para que todo sea inversión nacional, ¿cómo podemos?, mirá la diferencia con Costa Rica, como, por ejemplo, Costa Rica es del turismo, tiene la mayor parte de su riqueza, prácticamente, es turística, pero, ¿dónde está la razón?, ¿por qué estamos inmersos en el caudillismo que ha hecho a la nación?, una nación, y eso está comprobado en todas las partes del mundo, yo viví en España, llegué a España en 1964, verdad, cuando comenzaba Fraga Iribarne a reformar y a modificar los paradores, los castillos, fue Ministro de Turismo, a reformar los paradores, y cuando yo llegué llegaban menos de un millón de personas llegaban de turismo, ¿ves?, entonces, se fue levantando, se fue invirtiendo, se fue construyendo un país, ¿verdad?, y una cosa importantísima que es la educación, al caudillismo no interesa la educación, porque un pueblo ignorante, un pueblo aparentemente alfabetizado, que es lo que nos dice aquí la alfabetización, pero ¿cuál es la alfabetización?, ¿saber poner A-dol-fo?, eso para mí no es alfabetización, ¿verdad?, entonces, un pueblo ignorante, un pueblo aparentemente alfabetizado, es un pueblo que lo conduces, es un pueblo que no tiene criterio, bueno, es un pueblo que dilapida sus recursos, mientras que si le das educación a un pueblo, aún en la adversidad este pueblo sale adelante, verdad, y es lo que necesitamos nosotros invertir en educación, pero no en una educación conducida hacia un adoctrinamiento ideológico, verdad, que eso más bien lo que hace es como hacer máquinas, que van a reaccionar únicamente a lo que tu dirigente te indique, y no has tenido la libertad de apreciar otros valores, otros principios, otras corrientes, otras ideologías en la cual puedas comparar y ubicarte, y decir, "no, yo voy a ser liberal por esto", no es porque pertenezca a un partido, sino porque yo pienso, actúo, siento y vivo como liberal, verdad, fijáte en lo que decía Gregorio Marañón, el liberal es aquél que está en continua aceptación del que está en contra de él, del que piensa distinto, verdad, y de esta comparación, de esta confrontación de ideas, es cuando un país se va enriqueciendo, porque van saliendo cosas, verdaderamente, que es en base a una mente que piensa.

\section{R: Sí, al ejercicio de la tolerancia política.}

A.M.C.: La tolerancia política, eso no lo tenemos nosotros, aquí existe una intolerancia total al adversario, tanto de uno como que de otro, estamos como fanatizados, ¿verdad?, 
y el fanático no es productivo, el fanático no progresa, el fanático queda anquilosado, ve todo lo que pasó en Europa, como han tenido los países que iban evolucionando a través de la democracia, tener que buscar la forma de cómo estos países que están bajo la cortina de hierro, que no tenían la libertad de pensar, verdad, poder mejorar su economía, ayudarles a ir saliendo adelante.

R: Pues, ya la última pregunta, porque no quiero extenderme mucho más, sobre todo porque nos cierran la Asamblea, respecto a la Constitución usted decía no más reformas, sino más bien reafirmar el valor normativo de la Constitución, que con esta última sentencia ha quedado por los suelos.

A.M.C.: Totalmente por los suelos, nosotros y eso todos, aún ALN, que se ha plegado en muchas ocasiones a votar por el Frente, los cuatro jefes de bancada nos sentamos y firmamos un compromiso donde dejamos claramente establecidos un rechazo total a cualquier reforma a la Constitución, de tal manera que no hay forma, y por eso es que tuvieron que acudir a esta estrategia bochornosa, ¿verdad?, estrafalaria de la Corte Suprema de Justicia, de parte de la Asamblea Nacional no va a apoyarse ninguna reforma a la Constitución, eso sí se lo puedo garantizar.

R: Y, sin embargo, si el Frente gana en las próximas elecciones, porque según la matemática electoral actual, las reglas que existen, si no se recompone el liberalismo casi Daniel Ortega es muy probable que salga presidente, y otros cinco años más, bueno, con el control de la mayor parte de los poderes del Estado puede rearticular un modelo político, pues, que pinta muy mal, la verdad, para los juicios más pesimistas, ¿no?

A.M.C.: Mire, aquí se hará todo lo que sea posible para tratar de que el presidente Chávez, ya que perdió la oportunidad en Honduras, con el presidente Zelaya, van a hacer lo imposible para que Daniel Ortega se mantenga en el poder, pero tenga la seguridad de que Daniel Ortega se va a mantener en el poder, únicamente, si se da un fraude mucho más bochornoso del que se dio en las elecciones del 2008, en las elecciones municipales, y si se da un fraude de ese calibre, aquí tendría que pasar lo indecible, porque nadie lo va a aceptar, yo le garantizo que Daniel Ortega no repite, salvo, salvo, que se robe de una forma impresionante, inmoral, peor del robo que hicieron en el 2008 con las municipales, es la única forma, y el pueblo no lo va a aceptar, yo le voy a contar una experiencia que tuve en el norte de Nicaragua, verdad, yo me fui a reunir, como ando frecuentemente reuniéndome con las bases, pues, de mi partido y de otras organizaciones, yo tuve una reunión con gente de la Resistencia Nicaragüense $\mathrm{e}^{51}$, y me decía uno de ellos: "mire, aquí se dice que la Resistencia Nicaragüense está totalmente disminuida, que ya no tiene nada que hacer, entonces, pero yo le voy a poner un ejemplo, diputado", me dice, "diputado, yo cuando agarré el fusil para combatir al régimen de Somoza, la dictadura de Somoza, yo tenía como 20 años, y me luché, y me partí la vida, y familiares míos cayeron muertos, ahora yo tengo 5 hijos, y estos 5 hijos", me dice, "han crecido en base a lo que yo les he enseñado de respetar por lo que yo luché, y ellos también van a luchar si se dan las mismas circunstancias". Con lo cual le quiero decir que, por eso le decía que aquí estamos en una sociedad que puede explosionar en cualquier momento, porque no está eso desaparecido, esas armas, esa gente que las agarra está dispuesta, está dispuesta,

51 La Resistencia Nicaragüense (RN) es la llamada Contra, que durante los años 80 se armó contra el régimen revolucionario del Frente Sandinista de Liberación Nacional (FSLN). 
únicamente, está dando el último grado de esperanza, o de confianza o de credibilidad, verdad, para ver si podemos hacer cumplir la Constitución, y adecentar todas nuestras instituciones, por eso, yo le digo, si aquí se da un robo en las elecciones del 2011, aquí van a pasar muchas cosas que nadie quisiera que pasaran.

\section{R: Pero el contexto internacional es otro y la paz en Centroamérica fue un logro difícil.}

A.M.C.: De acuerdo, pero mire lo que pasa, por ejemplo, con una organización como la Organización de los Estados Americanos, la OEA, donde el Secretario General por el afán de reelegirse, por el afán de reelegirse, ve todo lo negativo en Honduras, y aquí no toma ningún tipo de medida, no hace ningún tipo de comentario, verdad, entonces, ¿cómo podemos esperar de los organismos regionales que es también una forma de corromperse?, él sabe, por ejemplo, que para reelegirse necesita los votos de todo el Caribe, y todo el Caribe está, prácticamente, controlado por Chávez, y en Centroamérica tenía a Honduras y Nicaragua, El Salvador, posiblemente, que está haciendo un buen gobierno el presidente Funes, y ojala que lo haga estilo Lula, que es de izquierda, pero, internamente, ve por su pueblo, aunque, externamente, apoye o se pronuncie por votos, o por lo que sea, a personas de izquierda, pero, internamente, está haciendo un buen gobierno, y está beneficiando a su país, y ha tenido un respeto en el contexto internacional, verdad, pero yo no me fío de los organismos regionales que tenemos, yo no me fío de un Secretario General de la OEA, verdad, que hace un silencio total y llega con una prepotencia impresionante en Honduras, donde se violó la Constitución, verdad, lo que pasa es que vemos nada más de una forma sesgada el caso de Honduras, yo fui a Honduras, fuimos como cuatro o cinco diputados, nos entrevistamos con Micheletti y vimos también el nivel de degradación en que estaba el gobierno tolerando o involucrado, no te puedo decir de qué manera, pero con el mismo narcotráfico, cómo nos decían a nosotros, "aquí, mensualmente, venían de 15 a 17 aeronaves", verdad, "procedentes de Colombia, Venezuela, y quién sabe de dónde más, ahora no viene ninguna", como, por ejemplo se quería imponer esta cuarta urna es una forma de romper la Constitución, que es muy rígida, veo yo, en Honduras, por decir, incluso, que hasta puede perder la ciudadanía con sólo promover una reforma a la Constitución, un cambio a la Constitución, la veo demasiado dura, no me pronunciaría por eso, porque nadie puede quedar apátrida, verdad, ese es un contrasentido también contra la democracia, pero este señor había roto con la Constitución, Mel Celaya, había roto con la Constitución, entonces, llega el Secretario General con una imposición, una prepotencia impresionante, ni siquiera a dialogar y a tratar de enmendar una situación que se estaba dando, ¿verdad?, sino a decirle al otro: "tenés que salir ya", o sea, lo que le quiero decir es la forma dual de actuar de quienes dirigen nuestros organismos regionales, no puedo fiarme, no puedo fiarme de ellos, aquí, por eso te digo, aquí va a haber cuestiones que vamos a resolver los nicaragüenses internamente, $y$, lamentablemente, si no se respeta la Constitución, no se respetan los resultados electorales, que violentan, nuevamente, la libertad del ciudadano para elegir a quien quiere ser gobernado, aquí esto puede explosionar, ¿verdad?, ojala que eso no se de, porque sería lamentable que Nicaragua volviera, nuevamente, a meterse, a retroceder, nuevamente, en lo poco que se ha avanzado, ya llevábamos un camino avanzado, llegó Ortega y nos hizo retroceder, con la revolución nos hizo retroceder 50 años, y ahora nos está haciendo retroceder otros tantos, ya habíamos avanzado con Bolaños, pues, que había dejado una economía más o menos saneada, con unos créditos ya aprobados para poder hacer uso de ellos y seguir enrumbándonos, todo eso se cambió, ya ves como, por ejemplo, todo nuestro presupuesto, y lo triste es que siendo consciente, verdad, de que para cubrir nuestro 
presupuesto necesitamos de los países donantes, de los países que donaban para cubrir los déficits de nuestro presupuesto, y nos peleamos con ellos, llamamos de una forma grotesca, inmoral, de falta de la más mínima educación y consideración a la respetable embajadora de Suecia, aquí con unos calificativos, verdaderamente, feísimos, ¡cómo es posible eso!, cuando un gobierno si es, realmente, auténtico, si es, realmente, digamos, preocupado por su pueblo, por su país, lo que hace es mejorar las relaciones que pudieran tener salida, no romperlas, y aquí se nos han cerrado las puertas, a todo, ¿cómo podemos desarrollarnos?, entonces, es lamentable y me alegra que usted esté en Nicaragua percibiendo esta realidad de Nicaragua para que también en su ambiente, en su mundo, en su democracia pueda decir que no quiten los ojos de nosotros, y que cualquier artículo que salga en España sea bien valorado siempre y cuando defiendan la democracia, sin ningún tipo de parcialidad, sino, simplemente, defender esta democracia que tanto quisiéramos nosotros vivirla.

R: Pues, muchas gracias por su intervención. 
ENTREVISTA 36 $6^{52}$ :

Nombre del entrevistado: Dña. Sofía Montenegro.

Cargo actual: Investigadora del Centro de Investigaciones de la Comunicación (CINCO).

Fecha de realización de la entrevista: Managua, 8 de septiembre de 2009.

Lugar: Centro de Investigaciones de la Comunicación (CINCO).

Duración estimada: 1 hora y 26 minutos.

\section{TEXTO - Transcripción 36:}

R: La investigación se centra en las últimas reformas constitucionales en Nicaragua desde el 95 hasta ahora, y me interesa ver sobre todo cuáles son los juegos de poder que están detrás de la reforma estrictamente jurídica, ¿no?

S.M.: Bueno nosotros, no sé si Ángel te dio este trabajo, sí, no sé si te dio la última versión, pero bueno ahí está un poco recogido, digamos, pero creo que el mejor análisis te lo puede dar Azahalea Solís, que es constitucionalista. Y tal vez te puede servir, nosotros hemos hecho en relación a los estudios jurídicos, si te interesa te lo puedo regalar, que esto es un poco el inventario de cuáles son las leyes, el estado de la cuestión, ¿verdad?, y el desastre, que es más o menos el paisito, pero creo que lo que hay es un sistema de, lo que impusieron, pues, a raíz de una serie de arreglos de cúpulas de un sistema de llave y de candado, pues, que le pusieron del sistema político del país, $\mathrm{y}$ ahora, justamente, quieren volver, en este caso, para perpetuarse a uno del que ahora tiene la llave y el candado, que es Daniel Ortega, hacer las reformas constitucionales, que tiene propuesto hacerlas, aunque todo el mundo esté en contra, obviamente, en lo que resta de esta legislatura y la siguiente, verdad, para poder cambiar el tema de la reelección para Daniel Ortega, entonces, eso es un sistema de auto-perpetuación, en esencia, lo que ha ocurrido, de determinados grupos, pues. La reforma del 95 había modificado un presidencialismo extremo, que estaba diseñado igual, verdad, para la figura del presidente en el período de la revolución, y que después fue atemperado, digamos, con estas reformas que se hicieron desde el 95, y que, de hecho, yo creo que no se han puesto en práctica, verdad, porque si bien le quitaba funciones al presidente y le daba mucho más poder a la Asamblea y a los diputados, en la práctica han sido completamente inoperantes, verdad, en términos de que cumplan la función para que fueron diseñadas, por una serie de mecanismos por los cuales han venido postergándose siempre, verdad, las famosas Leyes Marco para salir de las crisis, entonces, en realidad, la política funciona fuera del marco constitucional, verdad, hay una como una "extrapolítica" que anda por ahí, y la otra que, en realidad, la política se hace, los acuerdos se hacen en otra parte, entre una serie de personas, más que todo en el ámbito privado, y, en el ámbito público, sólo las llegan a legalizar, eso es, esencialmente, cómo funciona la historia y el presente, pues, del país, ¿no?

R: De todos modos, cada gobierno, el de Violeta Chamorro, el de Alemán, el de Enrique Bolaños y, finalmente, el actual del presidente Ortega, tienen su propia lógica política que está detrás de las reformas constitucionales que promueven, o sea, como

\footnotetext{
52 Entrevista interesante por su orientación crítica, con aspectos de análisis destacables, y fragmentos
} de discurso, que condensan mensajes de gran significación a la hora de extraer citas valiosas. 
que los periodos políticos fragmentan ese proceso general, digamos, de cambio constitucional en el contexto democrático, ¿no?

S.M.: Sí, de hecho, yo creo que de pactos vienen modificando la Constitución, y, esencialmente, en realidad hay una forma "informal", si se puede decir, de hacer política, verdad, y que responde más a intereses de carácter personal y grupal, pero, incluso, más personales que grupales, en este caso, de dos figuras de corte plenamente caudillesco, ¿no?

\section{$R:$ ¿Se refiere a Alemán y a Ortega?}

S.M.: Sí.

$R$ : ¿Y no han sido ellos relevados como líderes del contexto político actual nicaragüense?

S.M.: Todavía no, porque, es decir, ahí hay una, cómo decirlo, hay un nivel de amarre por medio de un pacto, que no es de caballeros, pero hay un nivel de amarre donde, originalmente, este pacto funciona, primero, básicamente, para otorgarse mutuamente impunidad. Arnoldo Alemán por las razones del desfalco al Estado, y Daniel Ortega, que en ese momento estaba en la oposición por la acusación de violación, que le había metido Zoilamérica, la hijastra, ¿no sabes el caso famoso?, donde la muchacha estaba decidida, verdad, por lo menos a hacerle pagar bien caro todo el asunto, ¿no?, entonces, hicieron una especie de sociedad, que fue un pacto cupular privado, y no sólo se otorgaron impunidad, sino que se otorgaron, primero, mutuamente, uno la llave y el otro el candado para que ninguno pudiera tomar ventaja encima del otro; y después hicieron una especie de repartición de todas las instituciones, esa la lógica que ha seguido, con la diferencia de que uno de los socios del pacto que es Alemán, cayó, es decir, al salir del poder que el presidente Bolaños le comienza, entonces, el juicio, ya, y entonces se convierte en la parte debilitada del pacto, ¿no?, y a través de esa situación de desventaja en la que queda Alemán, Daniel Ortega le arranca cada vez más y más y más concesiones, verdad, que es lo que explica ahora porqué prácticamente Daniel controla todas las instituciones, y porque tiene de rehén al socio minoritario, ¿verdad?. Alemán comenzó siendo socio mayoritario del pacto, a la salida del poder se convierte en socio minoritario, y esta situación le sirve de mecanismo para que Daniel se recomponga y pueda incluso hacer el fraude electoral con, y, probablemente, hubo fraude electoral en el 2006, verdad, en el que salió electo Daniel Ortega, y hasta día de hoy, por ejemplo, no han entregado el $8.6 \%$ del total de los votos emitidos, pero además según información extra-oficial, verdad, Daniel no habría sacado el 38\%, sino que el 35\% y que parte de esta transacción permitió que llegara a la Presidencia de la República con la complicidad, entonces, habría habido no sólo el fraude electoral municipal, sino que ya el 2006 con el que llega a la presidencia, entonces, de esa manera y, cómo se llama, chantajeando a Alemán ha logrado arrancarle, prácticamente, todo tipo de concesiones, evidente, además de que el fraude municipal algo tuvo que ver el PLC, evidentemente, tuvo que ver el PLC, porque están repartidas las instituciones, entonces, los Magistrados fueron parte, los Magistrados liberales puestos por Alemán fueron parte del fraude.

R: ¿Y qué ganaba el PLC, perdón, con el fraude municipal? 
S.M.: Nada, lo único que ganaba era que Alemán no regresara a la cárcel, o sea, que con esas concesiones ha comprado su libertad. Pero vive siendo chantajeado eternamente por Daniel Ortega, ¿no?, entonces, le ha ido entregando todo con tal de que no lo echen preso, ni lo lleven a juicio, entonces, y Daniel le ha logrado sacar, no le ha dado sobreseimiento, porque tiene no se cuantas causas pendientes, entonces, él es el "Prisionero de Zenda", verdad, de Daniel Ortega, lo tiene de rehén, y de paso tiene de rehén a los liberales, que es lo que explica también el fraccionamiento de los distintos grupos de liberales que han intentado desasirse, sacudirse del peso de Alemán y, obviamente, les ha resultado difícil, porque el control sobre el PLC no lo tiene únicamente Alemán, lo tiene el Frente Sandinista, ¿verdad?, porque en esos juicios donde se podría ir Alemán, se iría un montón de gente que está alrededor de él.

$R$ : ¿Y cómo ha ido penetrando el sandinismo durante 16 años de oposición en la nueva institucionalidad democrática controlando los principales aparatos del Estado?

S.M.: Básicamente, porque hicieron una movida, creo yo, Azalea, probablemente, te puede contar toda la historia patria no pública de esa situación, es que el Frente con mucha previsión, verdad, empezó a copar los cargos en el Poder Judicial, y está copado desde la cúpula hasta la cola, verdad, es decir, tiene unos cuantos Magistrados liberales arriba, pero de ahí todo el aparato, más del $80 \%$ de ese aparato, de los jueces del país son sandinistas. Entonces, si te corrés te tiro y si te quedás te mato, verdad, ese es uno de los mecanismos que puede utilizar, el mecanismo de la justicia como un mecanismo de represión, por juicios amañados, en fin, esa es una historia de horror, francamente, cuando la empiezas a ver, y bueno, por eso es que puede hacer, puede intimidar, coaccionar, chantajear, a Arnoldo y su tropa, porque tienen todos los jueces para hacer.

R: ¿Y cuáles son los espacios que quedan entonces para la oposición, no sólo la oposición política, sino la oposición ciudadana?

S.M.: Ninguna, ninguna, está cerrado el país por arriba y por abajo, entonces, si esta cosa sigue así y más con, pues, el temor que tiene todo el mundo de que esto vuelva a desembocar en la pelea de vuelta otra vez por la democracia y el oxígeno en el país vuelva a desembocar en otro ciclo de violencia política, porque ya existe. Si las instituciones creadas por una democracia han sido pervertidas, verdad, y la Corte Suprema de Justicia de Nicaragua es la más desprestigiada y corrupta, que el campeonato se lo gana, pues, tal vez, ni en Colombia, que está tan penetrada por el narcotráfico, y no tiene sentido hacer elecciones mientras estén esas reglas del juego de una ley electoral hecha a la medida de D. Daniel Ortega, verdad, y estén esos Magistrados, con ese padrón electoral y con todo el aparato que tiene que ver con la administración de las elecciones, pues, del proceso electoral, si la gente no le queda otra salida, verdad, yo creo que se va a abrir en el país un nuevo ciclo de violencia política, porque si no podés resolver a los votos, vas a resolver a las balas, y eso es matemático.

R: ¿Y la presión internacional no tiene nada que decir? Me refiero a los fondos que se reciben por la Ayuda al Desarrollo, que además supone una parte muy importante, en términos porcentuales, del presupuesto y del PIB nacional.

S.M.: Claro que tiene que decir, pues tiene que ser las dos cosas, la presión internacional y la presión nacional de la ciudadanía, pues, en términos de adentro y fuera, porque de lo contrario, eventualmente, vamos a regresar al problema de la 
violencia política, pues, porque ya está harto demostrado de que la farsa esta de mantener, Somoza hacía elecciones también y las ganaba siempre él, por sus títeres, ¿no?, títeres que ponía momentáneamente, entonces, toda esta pérdida de legitimidad del gobierno, que es bien fuerte, y el desplome de la confianza en las instituciones, que ha venido creciendo en picada, más la crisis, el descontento y un gobierno autoritario y que está cerrando los espacios, los respiraderos que tenía la sociedad civil para poder participar, es la combinación perfecta para un buen "cóctel molotov", y, entonces, todo es cuestión de tiempo y de que surja en algún momento en el tiempo algún catalizador, verdad, que desencadene todo el malestar que hay en el país. Por lo menos, yo así lo veo, ¿no?, y los datos ya nos indican, entonces, ahorita la gran lucha que se viene, que hasta la fecha la sociedad civil ha sido exitosa en llevar por lo menos un año y pico de haberle impedido a Ortega el empuje de las reformas constitucionales. Entonces, parte de la estrategia de toda la sociedad civil, verdad, porque este año y el próximo hasta el último nicaragüense se tiene que convertir en constitucionalista, porque es la única cosa donde te tenés que agarrar, y buscar como reformar la ley electoral sin tocar la Constitución, porque todo el mundo sabe que eso es abrir la puerta a la reelección presidencial, verdad, si Daniel Ortega quiere hacer reforma, porque para poderse reelegir consecutivamente tiene que haber una reforma constitucional, entonces, lo otro es que para poder darle salida a este país, en las próximas elecciones salir de este mal gobierno de una manera pacífica, civilizada y democrática, es crear las condiciones para que haya unas elecciones competitivas, transparentes, pluralistas, super-vigiladas, depurado todo el Consejo Supremo Electoral.

\section{R: ¿El actual?, ¿la composición actual del Consejo Supremo Electoral?}

S.M.: Sí, porque está afectado de un desprestigio gigantesco, es decir, esta fue una institución que incluso la dejó montada la revolución, verdad, y el Consejo Supremo Electoral que montó la revolución fue el que certificó que la revolución había perdido, y que tenía un personal de primera, impecable, verdad, y a partir de la llegada de Alemán al poder se pervierten todas las instituciones, se pervierte todo, y el pacto, entonces, quita gente, remueven personal calificado, y lo llenan de todo, prácticamente, dicen que son antiguos miembros de seguridad, y están vinculados al, cómo se llama, al presidente, lo que son los operadores de todo el sistema del conteo de votos y todos los demás expertos.

\section{$R:$ ¿Expertos en el fraude?}

S.M.: Bueno, expertos en hacer ese tipo de operaciones informáticas, y ese tipo de rollos ¿no? Entonces, la verdad, es que es un desastre total, es decir, estamos montados en una bomba de tiempo, y lo otro es eso que te decía, ¿no?, que la gran tarea que tenemos es la de impedir que esa bomba explote por la vía de una salida democrática, con elecciones creíbles, super-vigiladas nacional e internacionalmente, como las de 1990, y que esa es una cosa que la cooperación internacional, sí, la Unión Europea, particularmente, la comunidad de donantes está demandando, y razón por la cuál está reduciendo la cooperación al gobierno, ¿no?, hasta que reestablezca condiciones de ese tipo, y, por lo tanto, la tarea nuestra es de aquí al 2011 crear algún tipo de condición o condiciones políticas, una, para impedir a toda costa que se haga una nueva reforma constitucional, y la otra, lograr las condiciones para esas elecciones democráticas, y montar la fuerza política emergente que se haga cargo y para poder desalojar al orteguismo del poder de manera pacífica, porque si no, sólo va a quedar a la antigüita, 
que es a los tiros, ¿verdad?, y a eso nadie quiere llegar, obviamente, porque costó, y ya se pagó a un nivel altísimo.

$R$ : ¿Y las dos fuerzas alternativas que surgieron frente a los partidos que firmaron el pacto, por el lado liberal y por el lado sandinista, Alianza Liberal Nicaragüense y $M R S^{53}$, en qué medida han contribuido a crear cierto pluralismo político en el escenario democrático de Nicaragua?

S.M.: Bueno, aquí la única, la historia nos dice a nosotros que sólo cuando las diversas fuerzas de distinto signo ideológico han logrado armar unas grandes coaliciones con un objetivo común, casi siempre ha sido desalojar a alguien del poder, ¿verdad?, como fue el caso del derrocamiento, que ahí fue una combinación de la lucha armada, la lucha masiva y, digamos, el alineamiento de todos los actores en contra de Somoza, igual sucedió en el período de la revolución, que igual fue una combinación de guerra civil, eh... el alineamiento de las distintas fuerzas en oposición, y la salida del asunto, de la pacificación, que fue por la vía de las elecciones, del acuerdo, entonces, esto implica, y pareciera que, todo pareciera indicar que D. Daniel Ortega sólo va a dejar la alternativa por la provocación de una profunda crisis en todos los niveles, porque él no entiende de otra forma, pues, y uno ya lo puede ver porque la presión internacional ha sido fuerte, todavía no ha tomado medidas más fuertes como las que están tomando, por ejemplo, en Honduras, pero ya el proceso de articular en grupos paramilitares, verdad, estructuras paralelas como los CPC, que sustituyeron a todo el sistema de participación ciudadana que había tomado, prácticamente, dos décadas construir, verdad, lo han desmantelado completamente, han subordinado las alcaldías a estos Consejos del Poder Ciudadano, que nadie ha electo, verdad, y, entonces, obligó la Primera Dama, que también toma decisiones, es decir, la mujer de Daniel, la esposa del presidente no juega ningún papel, verdad, según la Constitución de la república, eso no es un cargo, ¿verdad?, y, sin embargo, ella está construyendo su propia fuerza, su estructura paralela, incluso paralela al propio partido, porque como tienen oposición adentro de lo que llaman el viejo Frente, que todavía está ahí con el orteguismo, y que ella lo que ha venido haciendo es construir estos CPC, como una manera de vaciar al Frente la estructura antigua del partido, y fidelizarla con ella, entonces, sí podés ver, verdad, que todos los controles por todos lados están en manos de ella, porque ya controlan el Ejecutivo, controlan la Corte Suprema, controlan el Consejo Supremo Electoral, todas las instituciones, prácticamente, y controlan las alcaldías, ¿no?, porque las que perdieron se las robaron, verdad, entonces, las están controlando también. Y encima de eso ha habido un proceso de re-centralización y re-concentración del poder, entonces, aquí no se mueve nada, verdad.

R: ¿En el Ejecutivo te refieres? O sea, ha habido una deriva desde el ejercicio de la presidencia por parte de Ortega y si las últimas reformas constitucionales conferían un mayor peso a la Asamblea Nacional, que de eso se trataba, además, para darle un perfil más democrático al nuevo sistema político en Nicaragua.

S.M.: Pero claro, al comprar y al tener de rehén a Alemán y con él al PLC el mecanismo en la Asamblea no funciona, ¿ya?, entonces, la Asamblea que debería jugar un papel beligerante en toda esta historia no lo juega, porque además los que funcionan como autónomos o como independientes, uno es el MRS, que es un partido pequeñito, que

53 Movimiento Renovador Sandinista. 
tiene una representación pequeñita, y la otra es la gente de Eduardo Montealegre, y lo otro es que hay toda una estrategia de división, porque la gente de Alemán es fácilmente chantajeable, verdad, entonces, la estrategia de mantener dividida a la sociedad, ahorita van, porque la estrategia que uno puede ver es que el avance en contra de los partidos, ya les quitaron la personería jurídica al MRS, al Partido Conservador, le negaron a "Vamos con Eduardo" la personería que le pertenecía, que era ALN, entonces, han empezado a reprimir a las organizaciones autónomas de la sociedad civil, o digamos, la más beligerante, y los medios de comunicación, entonces, sí están jugando recio, pues, un ajedrez ahí que evidencia, obviamente, el diseño de un proyecto, yo diría que totalitario, verdad, porque no le está dejando espacio a nadie, entonces, en mi opinión este no es un proyecto de poder políticamente sostenible, ni económicamente sostenible, verdad, porque ocurre en medio de esta crisis económica mundial, $\mathrm{y}$, de alguna manera, el único "pie de amigo" que tiene, realmente, es el de Chávez, pues, la plata de Chávez, y, entonces, yo creo que sin el "pie de amigo" de Chávez, pues, la tendría mucho más complicada el gobierno, ¿no?, la tenía complicada incluso con la plata de Chávez, porque tampoco Chávez la tiene fácil, de resistencia en eso de la caída más grande, entonces, y después de todas estas loqueras geopolíticas que anda haciendo en la región, verdad, por lo menos en el caso de Honduras le salió mal, verdad, a Chávez, y en el caso de El Salvador, pues, el presidente salvadoreño ha sido muy inteligente y muy, cómo diríamos, sensato, al mantenerse desvinculado del proyecto este famoso del ALBA y de Chávez, ¿no?, entonces...

\section{R: ¿A pesar de ser la izquierda del Frente Farabundo Martí?}

S.M.: Sí, resultó inteligente el muchacho, entonces, sí, porque estaría, eso es para que empecés a poner de vuelta Centroamérica completita, verdad, y ya se va a complicar la cosa con lo que está sucediendo en Honduras y con lo que está sucediendo en Nicaragua, tú te imaginas que se vuelve a enredar la cosa en El Salvador, entonces se vuelve a prender el foco, verdad, a la cosa, no, entonces, también lo que se prevé es que el incremento de la polarización en el país va a ser enorme.

\section{R: ¿En Nicaragua?}

S.M.: Sí, pues, porque toda la política del gobierno ha sido de antagonizar, de polarizar, de perseguir, de hostigar, verdad, $y$, justamente, hoy estaba con una compañera de la red de poder local, que acaban de terminar un estudio, que han hecho en varias alcaldías, evaluando el primer año de gobierno a nivel local, y me contaba que era uno de los hallazgos que tenían era que, efectivamente, el control de los CPC y el vínculo de los $\mathrm{CPC}$ con las alcaldías ha ido creciendo, y que, por el otro, la tendencia a la polarización a nivel territorial es acelerada, entonces, lo que nosotros presumimos es que el nivel e conflictividad en el país va a incrementar, ya, entonces, y si encima de esto le echás la gasolina de la reforma constitucional, verdad, esto es complicado. Ahora, el triunfo de la sociedad hasta la fecha ha sido impedir por la presión que ha puesto, verdad, en impedir la reforma constitucional, y parte de la estrategia nuestra es la de luchar por impedir que esa reforma constitucional se haga.

\footnotetext{
R: ¿Pero qué papel cumpliría porque no sometería a referéndum la reforma constitucional Daniel Ortega?
} 
S.M.: Daniel la propuso, se ha quedado callado, verdad, porque lo que propuso era ofrecer ese caramelito que le encanta regalar a Chávez del referéndum revocatorio, que no existe.

\section{$R:$ ¿En vuestra Constitución?}

S.M.: Sí, entonces, hay que, habría que ponerlo, pues, y, entonces, eso es parte de, cómo se llama...

\section{R: Del incentivo, del estímulo...}

S.M.: Para salir, para que los revoquen a todos, incluyéndole a él, verdad, pero también para hacer eso tendría que usar a ese Consejo Supremo Electoral y, entonces, ya todo el mundo sabe cuáles son los resultados, si nadie le compra la treta, pues, que yo creo que eso no va a prosperar, lo que él necesita son todos los votos de los liberales para hacer pasar la reforma en la Asamblea Nacional.

\section{R: De todos modos, el debate constitucional está paralizado desde el año pasado.}

S.M.: Está paralizado, pues, y, obviamente, todo el mundo sabe de qué viene esta historia, de una reforma constitucional que no sirve únicamente más que para la perpetuación en el poder de Daniel Ortega y que la clave es el retorno o la reconstrucción de los escombros de instituciones que tenemos, y un cambio, pues en el gobierno y un cambio en todos los niveles de decisión de las instituciones, entonces, pero eso pasa por una gran lucha política en el país, entonces, sí está complicado, y una de las tareas que tenemos comos sociedad es, ahorita, es alfabetizarnos aceleradamente todos en el tema constitucional, pero masivo, porque ese va a ser el instrumento de la pelea política, con la vieja Constitución reformada que tenemos.

$R$ : ¿Ha contribuido tanta reforma constitucional a una estabilidad de las instituciones democráticas o, por el contrario, han sido un obstáculo, no un obstáculo, pero sí un lastre a la, digamos, a una transición dentro de un cauce legal que ofreciese mayor certidumbre a los actores?

S.M.: Pues yo no creo que el problema sean las reformas constitucionales, porque, efectivamente, yo creo que habría, qué se yo, pues, tendrían que hacerse algunos ajustes en la Constitución, todo el mundo está claro de eso, pero no es eso lo que se ha pretendido, sino otorgarle mayor control, básicamente, a los partidos, ¿verdad?, sobre todo, y eso es parte del problema, y no son tantas las instituciones cuanto los, ¿cómo se llaman?, las mafias políticas que existen en el país, entonces, está complicada la cosa.

R: O sea, el problema serían unas instituciones partidarias deficitarias, que no tienen una composición democrática en sí mismas.

S.M.: Ni tenemos partidos democráticos, en realidad, el sistema de partidos, para mí que nunca, realmente, se desarrolló, verdad, entonces, no son actores democráticos, pues, los partidos, ni funcionan, no funcionan como instituciones políticas altamente institucionalizadas, sino que son más bien maquinarias electorales, $\mathrm{y}$, en mi opinión muy categórica, escuelas de corrupción, verdad, entonces, si no sirven los partidos, por muy bien diseñadas y perfectas que estén las constituciones, porque la Constitución esta 
de Nicaragua, según los entendidos, está bastante bien, verdad, el problema no es la Constitución, verdad, ni el diseño de las instituciones, sino las fuerzas que han ocupado, $\mathrm{y}$, en este caso, serían los partidos, entonces, para mí que es un sistema de partidos que tendría que ser revisado, modificado, la ley electoral, la ley de partidos políticos, porque son al final los que van a hacerse con las instituciones, entonces, es un poco más atrás el asunto, me parece a mí, ¿no?, en términos de que tampoco tenés, bueno, hay un montón de cosas, verdad, es muy reciente todavía en la carrera de servicio público, verdad, y, entonces, normalmente, todo el personal, aquí, pues, no ves un personal, con una burocracia weberiana, verdad, nada de eso, son los que se han sudado la camiseta, como dicen, y que obedecen a una lógica casi de tribu, verdad, y por lealtades personales, particularmente, el Frente Sandinista tiene todos esos rasgos de tipo de personal, y esto a su vez hace al gobierno con un personal que da mal servicio al Estado en su conjunto, ¿verdad?, y no sólo que da mal servicio, sino que no tiene ni su piso ni su techo, verdad, tampoco disciernen correctamente o, en fin, es un desastre, que a su vez les hace que el Estado sea ineficiente, sea corrupto, y se llama el "chango de la pluma", ¿no?, pero es como una reacción en cadena, que lo amarra todo, verdad, entonces, tampoco hay un sistema de equilibrio, de pesos y contrapesos, ¿verdad?, entonces, en realidad, en este país, los actores que hacen contrapesos de poder son la prensa nacional y las organizaciones civiles.

\section{$R:$ ¿Son los que, en este momento, se están oponiendo al régimen de Ortega?}

S.M.: Sí, además de los partidos que han sido, este, han sido "des-personalizados", es decir, que están en la llanura, como se dice coloquialmente, como fuerzas políticas, pero que no participan, es decir, es un sistema bipartidista forzoso el que hay en el país, verdad, no es el resultado real de un proceso, digamos, que hubiera desembocado en la eliminatoria de todos los demás, que esas son las fuerzas que, realmente, tienen consenso.

\section{$R:$ ¿Se refiere a un multipartidismo?}

S.M.: Ajá.

\section{R: ¿Al reflejo del pluralismo político de la sociedad?}

S.M.: Sí.

$R:$ ¿Y en qué se diferencia el sandinismo de hoy y el régimen de Ortega de hoy del de los ochenta? Al margen de, es dificil hacer comparaciones, sobre todo lo que es el periodo de transformación de un país, ¿no?, pero sí hay que reconocer que el fruto tardio de la revolución fue la democracia, con todas sus imperfecciones, si lo comparamos con la dictadura de Somoza, es decir, que la ruptura revolucionaria permitió la democracia en los años 90.

S.M.: Así es.

$R: Y$, actualmente, ese giro que está dando Ortega en su política.

S.M.: Bueno, la verdad es que la diferencia es que en el período de los ochenta mal que bien había un movimiento político y un partido político, que, por razones históricas ya 
sabemos que era un partido que venía de la clandestinidad, organizado militarmente, y que no había forma que en esa época hubiera salido de esas condiciones un partido democrático. Tenía aspiraciones democráticas pero hasta ahí llegaba, verdad, porque estaba organizado militarmente desde la cabeza hasta la cola, y fue esa fuerza la que le tocó organizar inmediatamente al Estado, al poder y todo lo demás. Sin embargo, en el camino de esos diez años de la revolución se fue dotando de estructuras y tenía una cierta institucionalidad, verdad, entonces, ahí sí había un sistema meritocrático, dentro del Frente, y tenía un cuerpo colegiado que establecía los pesos y balances, aunque tenía el control de todas las instituciones, como era una dirección colegiada y era una dirección colectiva, y unos estaban responsables de un poder del Estado y otros de otro, el sistema de pesos de pesos y contrapesos se establecía a lo interno del propio partido, por sus propias formas de tomar decisiones, por la estructura, por las responsabilidades, y porque tenía, estaba organizado, también, con niveles y peldaños de responsabilidad y más o menos cada quien sabía lo que le tocaba hacer y cuáles eran, es decir, hasta donde, cuál era su piso y cuál era su techo, verdad, y eso establecía alguna suerte de orden. Por el otro lado, el alto consenso que tenía la revolución permitió que el Estado de ese tiempo tuviera un nivel de incorporación de cuadros, que eran cuadros altamente calificados, gente joven, y con un enorme compromiso, verdad, entonces, todo eso desapareció, porque más de la mitad de toda esa gente buena, que tuvo, funcionarios, quiero decir, que trabajaban con mucha mística y con un enorme compromiso político, fueron desalojados, no sólo del Estado, por la pérdida de la derrota electoral, sino que la posterior crisis del Frente donde hay una purga, verdad, por el sector más ortodoxo, les decían en aquél entonces, pero, en el que estaba metido Daniel Ortega, verdad, que también, después, eliminó a los ortodoxos, porque entonces hubo una, ¿cómo se llama?, una, se establecieron dos corrientes, una corriente que después de la guerra decía que había que completar el proceso de democratización del Frente Sandinista, porque ya se había acabado la guerra, ya no había razones de militarismo interno, verdad, o de verticalismo, sino que los últimos que habían llegado a convertirse en ciudadanos eran los propios sandinistas, y de esos, eventualmente, se convierten en el Movimiento Renovador Sandinista, y el otro, incluso, yo me acuerdo que para después de la derrota electoral en los 90 había una correlación dentro del Frente más o menos de 60/40, 60 de ortodoxos, verdad, y 40 de democratizantes, de la corriente democratizante, y en el debate y en las discusiones que habían comenzado, evidentemente, esa correlación iba a cambiar, verdad, iban a ser más la corriente democrática que la ortodoxa, y lo que hizo Daniel Ortega pidiendo eso, fue que dio un golpe de mano dentro del partido, verdad, entonces, y desde ahí empezó a desalojar y a hacer sucesivas purgas, hasta que finalmente los más duros que se habían quedado con él también los purgó y ahora están en la llanura.

\section{R: Y se a quedado junto a su esposa ...}

S.M.: Junto a su esposa y algunos que han sido compañeros históricos de Daniel Ortega, o por interés, verdad, porque, además, ahora tienen, se quedaron con el patrimonio también del Frente y se convirtieron en los administradores de ese patrimonio, que ese es el circulo chiquito, entonces, ya había habido una usurpación anterior dentro del Frente y se privatiza, ¿eh?, lo quiero decir, hay un proceso de privatización del Frente Sandinista, y ese proceso de privatización hoy el Frente es, exclusivamente, Don Daniel Ortega y su señora, que manejan el Frente, y el poder y todo lo demás, como es que si fuera un bien personal, entonces, y por eso han pasado por este otro colador de crear estas estructuras paralelas, verdad, porque, bueno, dentro de la gente que los está 
apoyando, que todavía están esos de que se consideran sandinistas, eso es de otra época, pues, que ahí están, y que además no aceptan y no tragan a Rosario Murillo, ya, entonces, como Rosario sabe eso, y ella tiene aspiraciones políticas también, porque el otro asunto es que si no logra hacer la reforma constitucional Daniel Ortega, es obvio que si no puede ser él, será la señora la candidata, y, entonces, ella ha venido desmantelando lo que quedaba de las estructuras del viejo Frente Sandinista y reemplazándola por otras en la que la gente que entra está en función de la lealtad personal que le tienen a ella, así que ha sido destructivo si no sólo de las instituciones como tales, las públicas, sino que el propio partido ha sido destruido, pues, y desmantelado. Entonces, esto fue un proceso que les tomó por lo menos toda la década del 90, porque nosotros, a Carlos Fernando y a mí, yo estaba antes en el periódico del partido, en Barricada, a nosotros nos defenestraron a finales del 94, resistimos aquél 94, porque además había gente que nos habíamos quedado adentro resistiendo, verdad, para impedir el cerrarle ya la puerta a lo que desde aquellos polvos salieron estos lodazales, verdad, pero bueno, ese fue el proceso de destrucción de manera que ya lo que queda es una fuerza política completamente corrupta, que no tiene mecanismos de peso y contrapeso, y es de un estilo de dirección completamente personalizado, pues.

$R:$ ¿Y cuando se refiere al patrimonio se refiere a los bienes económicos del partido?, ¿a qué se refiere exactamente?, ¿qué patrimonio del partido se quedaba en manos de la "pareja presidencial”?

S.M.: Básicamente, lo que tenía el Frente antes de la derrota electoral, por ejemplo, tenía el periódico, tal que el periódico lo destruyeron, porque fueron incapaces de manejar, y después el partido tenía algunas empresas, algunas cosas, que también se privatizaron, después había una maraña de testaferros, verdad, y se metieron a hacer otro tipo de cosas, que, probablemente, hayas oído hablar de ellas, que se llama la piñata, entonces, en la piñata de los últimos días del gobierno, obviamente, un sector vinculado al "orteguismo" se quedó con propiedades del Estado que se privatizaron, verdad, entonces, de ahí es de donde viene el origen de la fortuna de la "pareja presidencial", y de alguna de la gente que está alrededor de ellos, entonces, es una tragedia espantosa, verdad, si la ves desde cualquier punto de vista, aunque no seas "nica", es una cosa horrible, es una cosa horrible, porque es una burla a todos los que se murieron por este país, verdad, entonces, la gente lo vive así, porque es una estafa, no sólo a los vivos, sino a los que se murieron, que fue un montón de gente para un país tan chiquito como este.

\section{R: Sí, porque además la democracia ha sido muy cara.}

S.M.: La libertad y la democracia se han pagado aquí con sangre, entonces, eso ha ido pervirtiendo, Daniel Ortega estaba claro, verdad, por lo menos, esta es una historia patria no escrita, verdad, porque es una mezcla de memorias y lo que uno tiene en la cabeza, pero bueno, el primer paso que él dio fue, él quiso impedir, por ejemplo, las reformas del 95, claro, porque allí le iban quitando facultades, pero si vos te fijas las reformas fueron en el $95 \mathrm{y}$, probablemente, fue una pléyade, ahí, todavía, donde varias fuerzas políticas, incluso había, pero que funcionaron bien, había, creo, ya diputados de la contrarrevolución, estaba medio mundo, porque aquello era un mercado persa, la Asamblea Nacional era un mercado persa, sin embargo, fueron capaces de producir, tal vez, justamente, por este re-juego político y más pluralista, es que lograron encontrar 
una suerte de modo, yo diría que fue el período en que floreció un poquito la Asamblea Nacional.

R: Pero, de todos modos, el enfrentamiento entre el Ejecutivo de Violeta Chamorro y la Asamblea por sacar adelante la reforma fue dificil, bueno, necesitaron de la Ley Marco, que fue el precedente jurídico irregular, que se practicó en el 2005, y que, nuevamente, se volvió a aplicar en el 2007, cuando Ortega reforma una Ley Marco que ya es el colmo.

S.M.: El colmo de los colmos, es tremendo, no, si la historia institucional aquí da escalofríos, da escalofríos, es una historia como de terror, en serio, pero bueno, al final logró funcionar y dejó esas reformas que al día de hoy no se ha aplicado, verdad, de hecho. Pero lo interesante en el seguimiento de Ortega es que empezó a trabajar desde mucho antes, verdad, es decir, finalmente, toma el control hasta en el 94 logra tomar el control del Frente Sandinista y empieza una operación limpieza, saca a todo el mundo, los corre, los acusa, inventa, hace, etc., y perdió las elecciones en el 96, verdad, entonces, ya para el período de la rapiña de Alemán, entonces, se dio cuenta que ahí estaba su oportunidad, entonces, tenía ya un Frente recompuesto, ya el Frente con el que se topa Alemán, verdad, no es el Frente de los 80 , es el grupo ya que está articulándose alrededor de él, es el grupo que articula más bien Ortega.

\section{R: El resto se va a otro partido político o deja la política.}

S.M.: Se va a otro partido, o se va a la sociedad civil, o se va a la empresa privada o deja de militar en todo, completamente, decepcionado, verdad, y, entonces, un sector se queda en el Movimiento Renovador Sandinista, los últimos que salieron son los que hoy se llaman "Movimiento de Rescate del Sandinismo", que ya el nombre te lo dice todo, porque a estas alturas ir a rescatar qué, entonces, esos son como los viudos de la revolución, porque están en el rescate, éste era el grupo de izquierda supuestamente más duro, que había ayudado a Daniel Ortega, verdad, al final fueron tontos, porque le cayeron a Ortega, y al final también se los re-empujó, entonces, pero fue el grupo que había apoyado a Ortega como parte del paquete ortodoxo, entonces, Daniel ha sido muy camaleónico, verdad, porque, entonces, para cuando le convino se puso ortodoxo para conseguir el apoyo de la corriente ortodoxa, y ya cuando logró sacar a los democráticos, entonces, aquellos les empezaron a hacer exigencias también, y entonces también los eliminó. Y de ahí sale en el 2006, creo, el "movimiento del rescate del sandinismo", pero muy, muy tarde, verdad, son la última promoción, digo yo, de "críticos" que fueron sacados, se fueron del Frente, a los principales líderes los sacaron, y el resto se fue con ellos, entonces, realmente, ahorita sólo quedan lo peor, yo creo que la escoria del Frente es lo que queda. Entonces, ese grupo ya estaba preparado para, sin ninguna cortapisa, ni escrúpulos ni nada, era el poder por el poder mismo, y retorno al poder, entonces, siguen en esa vía de que para poder, que por la voluntad popular jamás regresaba al poder Daniel Ortega, entonces, tuvo que firmar ese pacto, y esto lo facilitó, porque de repente, uno dice, yo siempre he querido hacer un análisis feminista de todas estas historias, porque a fin de cuentas en buena medida la transacción comienza porque los dos líderes necesitan, es decir, la, cómo se llama, la legitimidad de Alemán en ese momento cae en picado, el escándalo es gigantesco, y por el otro en el 98, le revienta bomba de la Zoilamérica, que lo denuncia por violación de la hijastra, y, entonces, hicieron un pacto de caballeros, y se protegieron mutuamente, ahora, lo que sale mal a Alemán es que el presidente que sigue se le voltea, que es Bolaños, ya, y tiene 
pretensiones de autonomía, y no sé cuanto, y es el que coloca en problemas a Alemán con el juicio, y, entonces, hay en eso, ahí la tenía clarísima Daniel, que la libertad de Alemán, es decir, la ayuda a entregar la libertad de Alemán dependía de hacer todas las concesiones para que Daniel pudiera llegar a ser presidente, fraude incluido, y eso fue lo que ocurrió.

\section{R: ¿Y cuáles son las características de Ortega como líder político?}

S.M.: Mirá, él es una personalidad, para empezar, narcisista, porque además lo que estás viendo en esa pareja es la psicopatología del poder, porque esta es la combinación de una personalidad neurótica paranoide, que es su esposa, con narcisismo esquizoide, que es el propio Daniel Ortega, no de un narcisismo como el de Chávez, verdad, que Chávez es de manual, verdad, de psiquiatría, y tiene todos los rasgos, megalómano, histriónico, mesiánico, grandilocuente, volátil, lábil para hablar, y todas esas cosas, ¿no? Daniel comparte con Chávez algunas de esas características, con la diferencia de que él tiene una personalidad más taciturna, más sombría, pero sí, comparten el hecho de la megalomanía, los ciertos delirios de grandeza, verdad, los dos se creen que son los líderes mundiales de la revolución, y ese tipo de cosas, y la falta de empatía absoluta, son profundamente auto-referenciados, no toleran el más mínimo desacuerdo, y en el fondo son personas que tienen una baja autoestima, creo yo, porque si no, no se estarían rodeando de tanta parafernalia. Profundamente desconfiados, y, obviamente, no tienen amigos, verdad, tienen sirvientes, y son capaces de tirar, como quedó demostrado en el caso de, uno, de un asesinato de un periodista, que se llama Carlos Buamo, que era hermano del alma, que estuvieron siete años en la cárcel, junto Daniel Ortega con este periodista, y lo mató un militante del Frente a la salida de su programa en televisión, muchos dicen que este periodista que mataron había quedado loco, porque lo habían torturado mucho, y luego les desbarataron la cabeza, prácticamente, entonces, ese fue un caso, y el otro es de, todo el mundo supone que el militante no actuó sólo, verdad, el otro es el caso del alcalde de Managua, ex -alcalde de Managua, que es Alexis Arguello, que se acaba de suicidar, que también se suicidó en unas circunstancias extrañísimas, del alcalde Managua, supiste, ¿no?, hace un mes que se mató Alexis.

\section{$R:$ ¿Y era muy crítico este hombre con el régimen?}

S.M.: No, pero había amenazado con renunciar y que iba a destapar lo que estaba pasando ahí, y, entonces, apareció suicidado. Hay enormes rumores también sobre el candidato a la presidencia, Herty Lewites, que era de la alianza MRS, que también murió en circunstancias extrañas por decir lo mínimo, la familia está convencida, no hay forma, pero el alcalde de Managua, no el suicida, el anterior a éste, que sí ganó las elecciones en buena ley, que fue un alcalde que salió con el $75 \%$ de aprobación de la opinión pública de Managua, que fue un buen alcalde, cayó en desgracia porque se atrevió a criticar a Daniel Ortega en público por una idiotada, una fuente que mandó a demoler la Primera Dama sin el permiso previo de la alcaldía, que nada tiene que hacer la Primera Dama demoliendo cosas que son del municipio, y habían sido amigos desde hacía como 40 años, y donde además se rumoreaba y se sigue rumoreando que este alcalde pudiera ser una de las figuras potables para salvar al Frente Sandinista del despeñadero donde lo ha llevado Daniel, entonces, esos son, la señora es un personaje salido de una novela de García Márquez, verdad, Rosario Murillo, es incalumniable, porque todo lo que se diga de ella es verdad, todo lo que se diga de ella es verdad, todo lo que oigáis, porque es un personaje estrafalario, y... 


\section{R: ¿Con una biografía política también?}

S.M.: No tanto, porque en mi opinión, aparte de escribir unos cuantos malos poemas, su único mérito ha sido el de ser, primero, la amante de Daniel Ortega, desde antes de que triunfara la revolución, y de ser la madre compulsiva de sus nueve hijos, entonces, se pasó toda la revolución pariendo, pues, es decir, todo el mundo andaba en batallones y luchando y en guerra, ella la pasó pariendo hijos, entonces, es un completo esperpento salido, es una mujer muy insegura, es decir, la coraza y la imagen que mantiene, me imagino que le debe costar mucha energía, es tremenda para trabajar, casi como maníaca, tiene muchísima más capacidad de trabajo que Daniel Ortega, es mucho más organizada que Daniel Ortega, porque Daniel Ortega en su vida ha trabajado, verdad, es vengativa, rencorosa, y peligrosísima, y, entonces, y lo que tiene es una suerte de "juego a dos", porque además, la parte más siniestra de toda esta historia, verdad, es que ella siempre supo que le estaba violando a la hija, y, al final, cuando la muchacha ya hecha una mujer se atreve a denunciar en un acto poco menos que suicida, y ella respaldó al marido, no a la hija, pero, obviamente, lo que explica la enorme cuota de poder es que ese respaldo tenía un precio, y el precio era "la mitad de todo", y el casamiento por la iglesia para asegurar propiedades y todo lo demás, porque ellos nunca se habían casado, se casaron en el 2005, el matrimonio hecho por el Cardenal Obando y Bravo, no si te digo que García Márquez en vivo y a todo color, verdad, aquí cuentas la historia de $E l$ otoño del patriarca y todos los personajes de la novela ahí están.

R: Pero, de todos modos, también hubo esa necesidad de conciliación con los sectores más duros de la Iglesia para afinar estos pactos perversos que ha tenido siempre el sandinismo con la derecha, con sus antiguos enemigos durante la época de la revolución.

S.M.: Bueno, es que yo me imagino que eso fue parte de, porque lo que ahí era es que le iba a entregar la cabeza del movimiento de mujeres de este país, y ahí es donde entra la lógica esta de derogar el aborto terapéutico y penalizarlo además, entonces, este "aggiornamento" que tuvieron con la Iglesia, verdad, es una cosa espectacular, porque de repente "se hicieron de Dios", como dice la gente aquí, pues. Entonces ahora son santos, "moncarros con cabeza de jarro", los dos convertidos en "ratas de sacristía", una cosa, y, por el otro lado, hablan del imperialismo y los pobres y de que son marxistas, es un despelote impresionante, entonces, pero, es decir, lo que te estoy retratando es que son dos personas profundamente dañadas, con rasgos de manual de psiquiatría, no son brutos, pero son gente sin escrúpulos, verdad, amorales, realmente, entonces, y con una obsesión del poder que yo no sé cuál es más grande si la de Daniel o la de la Rosario.

\section{$R:$ ¿Y cómo ver el futuro en los próximos años, al menos de aquí al final del mandato de} Ortega?

S.M.: Esto comenzó mal y va a terminar mal, ese es mi pronóstico, y aquí la gente debió ponerle los rótulos de que iban a ser los futuros "Ceaucescu" de Nicaragua. Así es que te puedes imaginar.

R: ¿Y cuál es el papel de la sociedad civil y los medios de comunicación en todo esto? Es decir, la resistencia cívica, que era, un poco, el espíritu de Pedro Joaquín Chamorro, el periodista que asesinó Somoza y que desencadenó luego esa protesta 
generalizada de toda Nicaragua frente al régimen que les había venido gobernando desde la década de los treinta, fue como una especie de energía colectiva.

S.M.: Bueno, nosotros recogemos ese legado, particularmente, porque el presidente nuestro es el hijo de él, Carlos Fernando, y sí tenemos una lectura muy clara de lo que debe ser el papel de la prensa nacional, la prensa independiente, que como parte de la sociedad civil, su función es la fiscalización del poder, verdad, entonces, uno de los ataques violentos que hemos recibido ha sido por el destape de la corrupción, de los malos manejos, en toda esta historia siniestra que han hecho. Tenemos una página web, pero además publicamos libros, yo te voy a regalar mi libro de paso.

\section{R: Muchas gracias.}

S.M.: Pero bueno, y, entonces, este tema se repite porque hay una fiscalización política, y otra sobre la transparencia, la rendición de cuentas que tiene que hacer del gobierno los ciudadanos. Es decir, los principales periódicos y los principales programas de televisión asumen de manera consciente ese rol, entonces, los riesgos para todos los periodistas se incrementan, verdad. Entonces, eso fue parte de lo que nos hizo a nosotros un gueto de las acusaciones, del allanamiento, de la persecución y todo lo demás, pero además porque, bueno, en el caso nuestro, porque teníamos el vínculo, yo soy dirigente además del movimiento feminista en este país y soy de las personas que respaldó el grupo, el movimiento que respaldó a la Zoilamérica en su denuncia desde 1998, entonces, ahora lo que viene también es parte de la venganza política de la pareja, porque si el movimiento ha sido capaz de hacerle la vida de cuatritos a Daniel Ortega, por lo menos en el exterior, porque donde ha llegado las feministas de América Latina le han montado manifestaciones de repudio, entonces, él, en algunos casos, se ha visto obligado a suspender las visitas, y, obviamente, que esa cosa le ha debido haber erosionado cualquier tipo de credibilidad, pues, cómo va a ser presidente de un país un tipo que violó a una niña, porque la violó no cuando era grande y sin su consentimiento, la violó cuando era chiquita, entonces, sí, es duro, yo creo que se va a poner peor. Mi pronóstico es que esto sólo puede empeorar antes de que se mejore, entonces, está complicada la cosa, en términos de que todas las libertades y garantías en este país están en riesgo, todas. Pienso yo, pues, que la salida, todavía nos queda como un año y pico para encontrar una salida que impida que lleguemos completamente al abismo, pues, que es volver al conflicto, o qué se yo, no quiera que esta mierda desemboque en una guerra civil de nuevo. Porque ahora, además es diferente, ahora hay una inmensa mayoría de la población en contra del gobierno, tenemos un gobierno que tiene serios problemas de legitimidad, ya, pero hay una diferencia con la guerra de los 80 , que en la guerra de los 80 estuvo más o menos concentrada en un borde fronterizo, pero ahora no, ahora la conflictividad está en tantos territorios como municipios tiene el país, y eso es grave, entonces, sólo nos quedan dos instituciones que pueden impedir que esta cosa se, impedirla no, impedirla porque no se pliegan, verdad, que es el Ejército y la Policía, entonces, en la Policía ya hay serios, ya hay una fractura en la Policía, porque en ese proceso de erosionar, ha sido testigo de cómo la Policía de Nicaragua había sido una de las mejores herencias que le dejó la revolución al país, de una Policía bastante ejemplar, bastante sana, que la gente no le tenía miedo a la Policía de Nicaragua, la respetaba pero no le tenía miedo, verdad, y está pasando por el mismo proceso de fidelización a la "pareja presidencial", entonces, si ya tienen a los jueces, que es otro mecanismo, aquí se dio una suerte de politización de la justicia, verdad, como nosotros, que nos están acusando en la Fiscalía, todas las fiscalías se, cómo se llama, se pusieron en disposición 
de construir una acusación, que, en el fondo, era una acusación política, porque no tenía ningún asidero, entonces, tener un cuerpo armado represivo sí es peligroso, verdad, después queda el Ejército, el Ejército igual, verdad, un Ejército que a diferencia del de Guatemala o El Salvador, la gente no le tiene miedo al Ejército, lo respeta, porque ha sido un Ejército que es el más institucionalizado y el que ha sobrevivido a todas estas historias de horror que han pasado en las instituciones. Pero si eso se jode, estamos en un profundo problema, porque es volver a replicar exactamente el modelo que tenía Somoza. Entonces, sólo te queda irte al exilio, irte del país, grandes migraciones otra vez, esa es la cosa, ahorita, no sé si te diste cuenta, ¿Cuándo vinistes vos?

\section{R: Hace una semana.}

S.M.: No sé si te diste cuenta de este intercambio entre los hermanos Ortega.

\section{R: ¿A través del programa de Carlos Fernando? No, no lo ví.}

S.M.: Pero lo puedes ver en la página web, porque el hermano de Daniel, Humberto Ortega, que era jefe del Ejército, habló a propósito de cumplir los 30 años del proceso de institucionalización del Ejército de Nicaragua, y habló de manera muy crítica, se pronunció en contra de la reelección, de andar apaleando gente en la calle, que la Policía tenía que cumplir su rol y de proteger los derechos de los ciudadanos a manifestarse, porque lo que han dejado es que los "tontos macutes" de la Rosario, verdad, salen a la calle a la gente que quiere hacer protestas en la calle y los agreden, y la Policía no interviene, ha dejado la Policía que esta fuerza paramilitar, que son las fuerzas de choque del presidente y su señora apaleen a la gente en la calle, y, entonces, el general salió diciendo que esto era gravísimo, y diciendo, pues, como un observador, que, supuestamente, él ha sido el gran estratega de la guerra, aunque esté en el retiro, le hizo unos señalamientos que todo el mundo comparte, ya lo había dicho todo el mundo de la sociedad civil, el que no lo había dicho era el general, y entonces la pareja se puso furibunda, y Daniel Ortega en la celebración ayer de los 30 años de la Policía, también, dedicó su discurso a descalificar al hermano, y ayer la radio oficialista, que se llama "Radio Ya" pasó llamándolo de traidor, rata, cualquier cosa, y eso es alentado por la Primera Dama a su cuñado, que es el general retirado, entonces, ¿por qué le molesta tanto?, porque la advertencia de Humberto no va tanto para la gente de la derecha, etc., no, el mensaje va dirigido al propio Ejército, a la gente de la Policía, y a la gente que está alrededor, a la base de Daniel Ortega, sobre la advertencia esta de pervertir la institucionalidad del Ejército o de la Policía, verdad, porque eso ya igualmente replica, eso era lo que tenía Somoza, utilizaba el Ejército para callar a la sociedad e imponerse a sangre y fuego, pues, entonces, parece que para allá vamos, si es que logra pervertir a la Policía, entonces, la jefa de la Policía está en una condición bastante precaria porque hay un sector, que le llaman los institucionalistas, que es la línea que ella representa, pero ya ha hecho barbaridades, verdad, por ejemplo, ella tenía un equipo, pasó a retiro a una serie de jefes policiales altamente entrenados, gente con mucha autoridad, verdad, para poderle hacer sitio en el reemplazo, que va por períodos, a la gente que está vinculada a Daniel. Entonces, dentro de poco, ya la jefa esta va a retiro, y, seguramente, va a entrar el nuevo comisionado nacional de la Policía va a ser alguien vinculado a la familia Ortega, probablemente, un consuegro de Daniel Ortega, y eso va a ser un desastre. Pero todo el mundo lo está viendo, verdad, cómo está ocurriendo delante de sus ojos, todos esos jefes policiales, que eran antiguos comandantes guerrilleros, que se profesionalizaron, que fueron a estudiar a academias en España, en no sé donde, verdad, 
y que sacaron también carreras en leyes, es decir, ya había un grupo de jefes con una visión institucional, que manejaba absolutamente, pero es que la Policía llego a tener tanto prestigio en Nicaragua y en Centroamérica, y todo eso está a punto de venirse al piso. Entonces, sí, la cosa es bien complicada, necesitamos salir rápidamente de esto, y si no va a ser a las buenas, seguramente va a ser a las malas, eso es así, entonces, incluso hace poco estaba leyendo un dato, porque todos estos fenómenos vinculados a la percepción de la gente, la falta de confianza en las instituciones, el crecimiento del miedo y del temor, el hecho de que las fuerzas en las que confiabas de seguridad ya están en la percepción de la gente, que empieza a verlas partidizadas, y hace poco el IEPC, creo, un instituto que hace este tipo de estudios registraba, además Nicaragua se había desarmado, los civiles, entonces, ha venido un incremento, particularmente, desde la amenaza de la llegada del gobierno de Daniel Ortega en las armas pequeñas, la gente se está comprando, vuelta al calibre nacional, verdad, que es el 38 milímetros, pero son armas pequeñas, y esto no tiene que ver sólo con el hecho de que la gente perciba que hay mayor inseguridad ciudadana, esta lógica de que en este país no hay justicia, verdad, en este país no hay juicios justos, en este país las instituciones no sirven, y si me tengo que defender voy a tomar justicia por mi propia mano. Entonces, ya cuando empezamos por ahí, ya esos indicadores de deterioro también en la confianza. Entonces, aquí en su momento va a haber una gran crisis de gobernabilidad, y una crisis institucional del carajo, entonces, cómo se va a resolver, ni Dios lo sabe, pero, en fin.

\section{R: Pues muchas gracias.}




\section{ENTREVISTA 3754:}

Nombre del entrevistado: D. Carlos Noguera.

Cargo actual: Diputado del Partido Liberal Constitucionalista (PLC) en la Asamblea Nacional (2007-2011). Ex-presidente de la Asamblea Nacional bajo el gobierno de Enrique Bolaños (2001-2007).

Fecha de realización de la entrevista: Managua, 30 de octubre de 2009.

Lugar: Asamblea Nacional de Nicaragua.

Duración estimada: 52 minutos.

\section{TEXTO - Transcripción 37:}

R: ¿Cuál es su visión del recorrido sobre los cambios constitucionales recientes experimentados por Nicaragua desde los años 90 hasta la fecha? Yo creo que la primera gran reforma, la del 95, si es la que está sustentada, en términos de dotar de una estructura constitucional nueva, digamos, que modificara la Constitución del 87, que consolidaba un poder presidencial excesivo, y que, por otra parte, estaba pensada para el régimen revolucionario, entonces, ese edificio constitucional sobrevive, pero con importantes cambios para, de alguna forma, sentar las bases jurídicas del nuevo régimen democrático. Ahí su discurso es muy libre, más bien es su propia reflexión la que me interesaría escuchar.

C.N.: No, efectivamente, esa Constitución anterior fue el producto de una Constitución hecha durante la década de los 80 del régimen sandinista, y que era una Constitución que, efectivamente, daba poderes excesivos al presidente de la República, de tal manera, que casi era monarquía Nicaragua, el presidente de la República casi era un rey, podía casi hacer todo, inclusive, podía hasta decretar impuestos, ¿verdad?, entonces, al darse el triunfo de la UNO, que la encabezó Doña Violeta de Chamorro en la década de los 90, lógicamente, esa Constitución no era ya aplicable bajo un nuevo concepto de que Nicaragua la necesitaba, indiscutiblemente, el régimen de los sandinista de los 80 era un régimen totalitario de corte marxista-leninista, tal vez, no lo pudieron implementar hasta el máximo, pues, como lo han hecho otros países, como en Cuba o en otros lados, por razones de otra naturaleza, tal vez la situación propia del país, que tenía frontera a ambos lados, después el apoyo que dio Reagan a la Contra, que al final fue la que bloqueó la revolución sandinista, entonces, esa Constitución, lamentablemente, fue reformada, pero, como decimos en Nicaragua, se le hicieron parches, y se le han hecho parches dos veces, una de ellas es, precisamente, quitándole muchos poderes que tenía el presidente de la República, dándole más poderes a la Asamblea Nacional u otros, compartiendo poderes el presidente de la República con la Asamblea Nacional, la intención y el ejemplo antes eran únicamente facultades del presidente de la República mandar ternas para elegir a los Magistrados de los distintos poderes del Estado, Magistrados de la Corte Suprema de Justicia, el Consejo Supremo Electoral, los contralores, antes era sólo uno, entonces, se amplió en otra de las reformas a cinco contralores, entonces, después con esas reformas le quitaron esos poderes, algunos se

\footnotetext{
54 Entrevista centrada, especialmente, en la actual crisis de la estructura institucional de los poderes del Estado, como consecuencia de la reciente evolución constitucional del país, que ha sometido al interés político las diferentes propuestas de modernización jurídica, así como la necesidad futura de afrontar un proceso constituyente, que permita refundar el Estado sobre criterios de racionalidad y estabilidad democráticas.
} 
compartieron, en este caso, los diputados también tienen iniciativa de poder representar candidatos para los distintos poderes del Estado, igualmente, se le quitó al presidente de la República el poder decretar impuestos, dejándolo como exclusividad de la Asamblea Nacional, pero se han dado modalidades de lo más incorrectas, diría yo, en Nicaragua, porque, lamentablemente, y tal vez es parte de nuestro proceso de desarrollo, de nuestro proceso democrático, que aquí las constituciones se han venido cambiando y muchas veces no pensando, verdaderamente, en instaurar un verdadero Estado de Derecho, consolidar una democracia, sino que muchas veces responde a circunstancias particulares del momento político, económico, o social del país, entonces, ¿qué pasa?, que algunas veces los mismos gobiernos se niegan a acatar esas reformas constitucionales, y, entonces, les agregan que van a entrar en vigencia hasta posteriormente que termina el período de gobierno, como fue el caso de Doña Violeta, y se creó la famosa Ley Marco, esa Ley Marco, a mi juicio, indiscutiblemente, es lo más inconstitucional que existe, porque no puede una ley común, ¿verdad?, impedir que entren en vigencia unas reformas constitucionales, si se han aplicado en la forma correcta que la Constitución dice que se puede reformar, y así lo vimos recientemente, ¿verdad?, que se hizo, y ya se le dijo: "la ley marquito", a la segunda ley marquito para que entrara en vigencia la segunda reforma de la Constitución, $y$, de repente, así vamos a seguir hasta llegar a no sé cómo le van a decir a la próxima ley, "ley marquitititito", ¿verdad?, entonces, lo que quiero decir con esto es que muchas veces en Nicaragua, pues, hemos actuado por razones más de dar respuesta a cuestiones coyunturales, que, verdaderamente, tener un buen concepto de tener un marco constitucional que permita al país asentar esa democracia, esa institucionalidad que necesita, yo creo que así como van las cosas y como está Nicaragua, eventualmente, lo que va a tener que convenir aquí es hacer una Asamblea Nacional Constituyente para que se redacte una nueva Constitución, y que pueda asentar esas bases del futuro, inclusive, creo yo, que la Constitución, en este caso, se debería de dividir como en dos grandes bloques, una parte de la Constitución, que deberían ser los principios fundamentales, en donde se estructure y se fundamente el Estado y el país entero como estructura jurídica, en el cual para reformarlo, tal vez, debe requerir algún plesbicito, como creo que hacen en España, o, inclusive, hasta convocar a una elección de nuevos diputados para que lo puedan hacer, en fin, esto se puede buscar para evitar estarla cambiando a cada rato, para que asiente con mucha seriedad, sobre todo en Nicaragua, que somos dados, como te dije antes, a hacer esos cambios por aspectos coyunturales, es decir, dejar asentada una parte de esa Constitución con una gran seriedad, y que para que se pueda cambiar necesita, verdaderamente, dijéramos el gran concurso de toda la nación, y después otras partes que pueden ser objeto de reformas parciales, porque, indiscutiblemente toda ley, aún las constituciones, pueden ser mejoradas o adaptarla a los tiempos, eso tal vez como una visión de futuro, pero yéndonos para atrás, pues, efectivamente, esa es la realidad que tenemos, una Constitución que ha venido recibiendo parches por reformas parciales, inclusive, la misma Constitución no es muy clara en establecer qué cosa es reforma total y qué es reforma parcial, porque aquí se han hecho cantidades de reformas que afectan a una gran cantidad de artículos, pero la Constitución nunca dice qué cosa puede ser una reforma parcial y qué es lo que puede ser reforma total, de manera que, como decían algunos juristas, aquí se puede reformar un artículo y puede ser una reforma total de la Constitución, porque en vez de ser un Estado presidencialista, podemos decir al día siguiente que esto es un Estado monárquico, por ejemplo, y decimos que va a haber un rey, y eso puede significar un cambio total de la Constitución, entonces, también en la misma Constitución nuestra no está bien establecido qué cosas son reformas parciales y qué cosas deben ser reformas totales en la Constitución, hay esos vacíos establecidos, 
porque, precisamente, todo esto, esta Constitución fue producto de mentes totalitarias, que, en su oportunidad, pensaban que esos regímenes, como pensó Hitler, como pensaban todos que iban a durar mil años, ¿verdad?, pero la historia demuestra que las tiranías nunca duran, $\mathrm{y}$, eventualmente, terminan y los pueblos recuperan sus libertades.

R: Ha habido siempre en este país una enorme dificultad para el consenso constitucional entre las distintas fuerzas políticas, ¿no?, incluso, antes hacía referencia a las leyes marco, que suspenden en el tiempo la aplicación de reformas constitucionales aprobadas, precisamente, por una falta de acuerdo entre el Ejecutivo y el Legislativo, normalmente, que han sido los dos poderes enfrentados a la hora de aprobar las leyes de reforma parcial a la Constitución, ¿no? Este instrumento jurídico controvertido, y además, como ha señalado antes, de dudosa constitucionalidad, puesto que una ley ordinaria no puede regular una ley superior, como es la Ley Fundamental, la Constitución, ¿cómo ve, en este caso, la reciente decisión de la Corte Suprema, que ya traslada, incluso, al Poder Judicial la capacidad del Legislativo, como único poder legítimo para reformar la Constitución?

C.N.: Bueno, yo haría el análisis de la siguiente manera, lamentablemente, el partido sandinista es un partido que en su estructura política, la mentalidad de la dirigencia política de ese partido, no entiende los conceptos de institucionalidad, de respeto a la ley, de Estado de Derecho, esas cosas para ellos no existen, eso es la concepción burguesa del Estado y más bien para ellos, y acuñaron una frase famosa durante los años 80 que decía que "la revolución es fuente de Derecho", por lo tanto, todo lo que está ahí, pues, está más o menos bien, pero si se opone a los aspectos políticos que ellos quieren para consolidar su poder, para ejercer el poder, todo eso es letra muerta, y hay que ver cómo a eso se le puede hacer algún tipo de truco, no sé qué palabra utilizar, para que se puedan obviar las cuestiones legales, ese es el procedimiento que ellos tienen por su forma de ser, por la mente política de ellos obedece a esa forma de actuar, distinto a las formaciones de lo que yo podría llamar, no importan si son de derecha o centroderecha o socialdemócratas, que sí pueden tener ideas, lógicamente, ya avanzadas, a lo cual yo no me opongo ni mucho menos, ni soy un extremista de derechas, pero basado en el respeto a la legalidad, a la institucionalidad, al Estado de Derecho, y como un paréntesis, los países que se han desarrollado, los países que crecen, los países que tienen futuro es donde precisamente se respeta el Estado de Derecho, la institucionalidad y la gobernabilidad, por eso es que en estos países con ese tipo de régimen, efectivamente, es muy difícil lograr un buen clima de negocio y desarrollo, entonces, ¿qué es lo que hizo la Corte Suprema de Justicia?, en este caso, la Sala Constitucional hizo todo un mamarracho, metieron un recurso de amparo en el Consejo Supremo Electoral a alcaldes y al presidente de la República en un momento donde no hay ninguna convocatoria de elecciones, porque las elecciones nacionales en Nicaragua son hasta el 2011, ni tan siquiera se ha abierto un período de convocatoria de elecciones, entonces, a nadie se le está, en este momento, supuestamente, entre comillas, se le está violando ningún derecho, porque no hay convocatoria, nadie tiene que inscribirse en el Consejo Supremo Electoral como candidato, entonces, meten ese recurso, lo conocen solamente, ahí apartan a un Magistrado, que es liberal, que es quien pudo haber informado de eso, y lo mandan a un tribunal de apelaciones, ese tribunal de apelaciones lo reciben dos sandinistas, como el tercero no es sandinista, llamaron a otro sandinista de otra sala para integrar salas para ser tres, e inmediatamente da lugar al amparo y lo remiten a la Sala Constitucional de la Corte Suprema de Justicia. Todo eso dentro de un absoluto secreto, ¿verdad?, como que si fuera alguien que anda robando, si las cosas en 
un país deben ser transparentes, ¿por qué se andan escondiendo?, llegan a la Corte Suprema de Justicia, lógicamente, que todo esto es un plan estructurado, ya los Magistrados de la Corte Suprema deben de saber que les va a llegar ese amparo en cualquier momento, ahora la sala está compuesta entre cinco y seis Magistrados, necesita que haya esos balances para que la sentencia no sea, únicamente, desde un punto de vista que se imponga en el país, entonces, lo que hacen ellos es que el presidente manda a citar, metiendo cédulas debajo de las puertas a escondidas en el momento en que se va la luz en la Corte Suprema, en el edificio de la Corte Suprema, y, entonces, se reúnen, y como no están los Magistrados del otro lado, entonces, y, supuestamente, ya están citados a través de una cédula escondida, llaman a otros Magistrados de su propio partido, que no son miembros de la sala, la integran y entre todos ellos hacen la sentencia y la firman, y la mandan inmediatamente al Consejo Supremo Electoral para decir: "esto es una sentencia firme", y unos argumentos ahí del todo raros, aquí tengo yo la sentencia, ¿verdad?, en la cual dicen que se están violando derechos, y que por eso ellos dicen que esa reforma es correcta en ese artículo, ¿desde cuando una Sala Constitucional puede decir que es inconstitucional los artículos de la Constitución?, yo nunca he sabido en ninguna parte del mundo, y peor que ellos puedan reformar un artículo si no son poder constituyente, el único poder que la misma Constitución señala que puede reformar la Constitución y dice cómo reformarla es la Asamblea Nacional, entonces, además de que esa es una forma incorrecta de integrar la sala, de que se haga una sentencia totalmente ilegal, y, por último, hay un conflicto de poderes, porque ellos se están arrogando funciones que la Constitución no les da, entonces, la respuesta nuestra va a ser que vamos a sacar aquí una ley declarando nula esa sentencia de la Sala Constitucional, se va a crear un conflicto de poderes en el país, pero eso es lo que quieren los sandinistas, esa es la manera de actuar de ellos, así es que estamos aquí en un país donde el Estado de Derecho es no más que un mamotreto, es un decir, pero que no se respeta, ¿verdad?, porque el gobierno es el que menos lo respeta, la prueba es que la misma Constitución dice que los ministros deben ser ratificados por la Asamblea Nacional, hay como cinco ministros que no han sido ratificados, entre ellos el Ministro de Salud no ha sido ratificado, están ejerciendo sus cargos ilegalmente, el presidente de la República se negó a ejercer su cargo, pues, en la Casa Presidencial, y, entonces, funciona en la Secretaría del partido, ¿verdad?, sólo en Nicaragua se ven esas cosas, pues, yo no me imagino en España que Aznar funcionara en la sede de su partido ni Rodríguez Zapatero en la sede de su partido, uno en el PSOE y el otro en el PP, yo creo que sería como locura, pero en Nicaragua no, así es como funcionan las cosas, y aquí vemos eso, pues, de manera que si la voluntad del gobierno era hacer una cosa y la Constitución o las leyes lo impiden, ellos inventan cualquier cosa, cualquier mamarracho jurídico y todo, y ellos enredan y hacen lo que ellos quieren, ese es el comportamiento de este gobierno.

R: Y, por otra parte, si bien, como decíamos al principio, la reforma del 95 trata de equilibrar los poderes del Estado, precisamente, favoreciendo las facultades del Legislativo, es el pacto entre Ortega y Alemán en el año 2000 cuando, de alguna forma, se da un giro a la evolución constitucional y se realiza esa partidización de las instituciones del Estado, repartiéndose de forma paritaria la composición de los principales poderes, los Magistrados del Consejo Supremo Electoral, del Poder Judicial, a la Contraloría, afectando al propio funcionamiento de los poderes del Estado, en la medida en que se traslada a ellos las dificultades de relación entre las bancadas que se producen en la Asamblea. De alguna forma, la situación que se vive ahora es producto de lo que ha sucedido antes, ¿no?, y como en la negociación entre 
Ortega y Alemán, Ortega, definitivamente, ha acumulado mayores recursos de poder. ¿Cómo lo ve usted, que además viene del PLC, y el liberalismo después de sufrir la división, pues, le ha dado a Ortega un balón de oxígeno, gobernando con un porcentaje menor de apoyo electoral, porque el $38 \%$ de la sociedad es apoyo minoritario, realmente, el que tiene el presidente, en términos electorales?

C.N.: Bueno, efectivamente, ¿verdad?, los temas que usted tocó vamos a irlos abordándolos en su orden, las reformas constitucionales que se dan con Doña Violeta Chamorro al final de su gobierno, como era solamente potestad del presidente de la república presentar ternas para los Magistrados, ahí se cambió, y ahí, entonces, se estableció que también se podía hacer con iniciativa de los diputados, pero también se agregó otro aspecto en la reforma constitucional, y se dijo que debía de ser con mayoría calificada, que pasaba de ser una simple ley que, como dijéramos, en el caso de la Asamblea Nacional el quórum es la mitad más uno, en este caso son 47 los votos, como una ley ordinaria, que se podía elegir a los Magistrados, entonces, se pasó a hacer una mayoría calificada del $60 \%$ de los diputados que conforman la Asamblea Nacional, lógicamente, que esto, necesariamente, tiene que pasar por una negociación porque es bastante difícil que una sola fuerza política pueda tener el $60 \%$ de los diputados en la Asamblea, y eso fue porque la UNO en su oportunidad era una formación o una integración de catorce partidos políticos, que hicieron esa coalición contra el Frente Sandinista y que se ganó en el 90, entonces, los muchos diputados que estaban ahí en la Asamblea Nacional pensaban que se iba a seguir dando un gran pluralismo político y que podían, de alguna forma, salir diputados de los diferentes partidos, de esos catorce partidos, para integrar esta Asamblea Nacional, y, entonces, la prueba es que para las elecciones después de Doña Violeta en la papeleta o en la boleta electoral creo que eran catorce o quince o veinte candidatos a la Presidencia de la República los que fueron, eran veinte partidos políticos, ¿verdad?, lo que demuestra que estaba sumamente fraccionada la opinión política en el país, y que todos pensaban que podían sacar algún tanto de diputados, y que esto le iba a permitir, entonces, un proceso de negociación en el Congreso para tener acceso a elegir esos Magistrados, pues, a través de las negociaciones con las distintas fuerzas, pero la realidad no fue así, la realidad luego se impone, y, entonces, las dos mayores fuerzas que emergen de esas elecciones fue el PLC, que ganó las elecciones, y el Frente Sandinista, y quedaron como un residuo por allá uno o dos diputados, creo que fue, que salió, de manera que, entonces, que ahí nada más que para elegir a las fuerzas, a los nuevos Magistrados, tenía que hacer un acuerdo político entre el Frente Sandinista y el Partido Liberal, no había de otra en este caso específico para elegir a los Magistrados de los distintos poderes del Estado, adicionalmente a eso, verdad, es importante señalar que cuando Daniel Ortega pierde las elecciones dice: "vamos a gobernar desde abajo", ese concepto de gobernar desde abajo del Frente Sandinista y Ortega muchos creían que es que era como tenían fuerzas, efectivamente, hacían asonadas y cualquier otra cosa, tenían el Ejército y la Policía, y si hubieran querido votar a Doña Violeta al día siguiente la habrían podido, perfectamente, haberla votado del poder, lógicamente, que no lo hicieron más que todo por razones de carácter internacional, y, entonces, el concepto verdadero del "vamos a gobernar desde abajo" fue que ellos se quedaron con el control de la mayoría de los Magistrados, y, en este caso, de los jueces, o sea, se tomaron toditito el Poder Judicial, el día de hoy, los jueces, tanto los de distrito como los locales, se nombran y no tienen período, son indefinidos hasta que se puede morir el juez, puede cambiar, no hay una ley que pueda, en este momento, establecer, como los mismos Magistrados, tanto de apelaciones como de la Corte Suprema, tienen un período de cinco años, en este caso, los jueces no, 
entonces, los jueces, la inmensa mayoría son del Frente Sandinista, entonces, eso le ha dado un inmenso poder y no solamente eso, sino que, lamentablemente, y eso lo hacen las tiras cómicas en Nicaragua y todo lo demás, se habla de grandes negocios que hacen muchos Magistrados para sacar sentencias a favor de determinados, como una buena fuente de ingresos aquí en Nicaragua, lo cual es una corrupción extraordinaria, terrible, ¿verdad?, ver como han manoseado el Poder Judicial. Yo fui presidente de la Asamblea Nacional de Nicaragua hace como cuatro años, cuando era presidente Don Enrique Bolaños, y quisimos pasar una ley, precisamente, para ordenar el Poder Judicial, bueno, con esa ley los sandinistas metieron a los jueces de todo Managua aquí, metieron turbas, casi quiebran todas las ventanas, y, por último, se agarraron hasta a los trompones diputados liberales y sandinistas en el hemiciclo, porque ellos quisieron a como pudiera hacerse impedir que se aprobara una ley que les ponía controles, y que todos esos jueces tenían que ser cambiados, y que tenían que volver a un proceso de que los jueces tenían que ser escogidos a través de un proceso de análisis, de mérito, de capacidad, de experiencia, y no en la forma en que estaba hecho, eso provocó un enorme conflicto en la Asamblea, quisieron hasta destituirme también a mí de presidente por esa razón, entonces, ahí tenemos que está centrado el poder, enormemente, del Frente Sandinista, en el Poder Judicial, y, entonces, es como uno de sus lugares de control para ejercer el poder en Nicaragua. Por otro lado, efectivamente, yo soy de los que comparto que esa reforma a la Ley Electoral en donde se bajó al 35\% la posibilidad de ganar la presidencia, aunque el segundo tenga una diferencia de cinco puntos, en realidad, a mi juicio, fue incorrecta, verdad, sin lugar a dudas, aunque haya venido de mi propio partido, lo que no es correcto no es correcto, yo creo que eso permitió el triunfo de Daniel Ortega, por un lado, y también, independientemente, como mencionaba usted, yo creo que se debe garantizar en una sociedad que un presidente de la República logre la presidencia con un porcentaje alto de los electores para que le de mayor legitimidad a un gobierno y no que sea un gobierno minoritario el que ejerce, porque, la verdad, es que en Nicaragua aquí, las dos fuerzas liberales desunidas, que es lo que le permitió el triunfo a Daniel Ortega, suman el 52\% o 53\%, y el 38\% que sacó Daniel Ortega, entonces, ahora el reto que tenemos de unificar las fuerzas liberales, y fundar, en general, las fuerzas democráticas para plantearnos las próximas elecciones del 2011, aunque sabemos, pues, el gran problema que después planteará ahí en su oportunidad de fraudes electorales y todo lo demás.

R: Sí, porque ha quedado muy mal parado tanto el Poder Judicial como el Poder Electoral, que son las dos grandes instituciones que, de alguna forma, completan esa inversión que realiza Nicaragua en las instituciones democráticas en el contexto de la transición. El Poder Electoral, al igual que en otros países, pienso en México, el Instituto Federal Electoral, que fue un modelo para otros centros encargados de vigilar la transparencia de los comicios, aquí quedó totalmente desacreditado después de las últimas municipales del año pasado, y el conflicto que se dio en la propia sociedad civil, ¿no?, que salió a la calle, aunque no le dejen manifestarse como, por otra parte, viene sucediendo en este país desde hace dos años para acá.

C.N.: Efectivamente, verdad, yo creo que, yo ahí de nuevo vuelvo a insistir en la forma del pensamiento político del partido de gobierno, el Frente Sandinista, que también, no solamente fue lo que corrompe la estructura, porque, efectivamente, en este caso, pues, hay Magistrados liberales, hay Magistrados sandinistas, y Magistrados liberales nuestros puestos ahí, prácticamente, yo no sé ni qué palabra usar, si es que se vendieron, si es que los compraron o qué cosa, pero la verdad es que ellos dejaron de representar 
intereses diría yo, hasta si usted quiere, desde el punto de vista de defender los votos que hasta los propios liberales habían depositado, porque yo le voy a ser franco, yo creo que lo correcto es respetar la voluntad ciudadana, si alguien me ganó limpiamente yo tengo que aceptar que perdí, pero que sea transparente ese resultado, y no llegar a los engaños y al fraude colosal que hicieron para las elecciones municipales, y eso le ha costado perder al país el apoyo en gran parte presupuestario de la Unión Europea, los Estados Unidos, según la Carta del Milenio, que son las dos fuentes más grandes de apoyo económico que puede recibir el gobierno, y por eso es que ahora, y ese es mi adelanto, están preparando una reforma tributaria, porque no hay ya de donde sacar más recursos para reducir su déficit presupuestario y entre comillas esto es como una forma que ellos quieren hacer de tratar de evitar al máximo depender de la ayuda presupuestaria que le da la comunidad internacional para impedir que la comunidad internacional le obligue a hacer elecciones libres y transparentes, que haya supervigilancia en las elecciones, y lo que ellos quieren es decir, "bueno, yo aquí, a como puedo hago mi reforma tributaria, saco recursos", aunque en un proceso recesivo del país va a hundir más la economía, pero a ello no les importa con tal de manejarse en el poder, verdad, y llevar al país a una situación difícil con tal de ellos poder decir: "sigo en el gobierno", no importa si es gobernar como en la paz romana, verdad, no importa si es gobernar sobre la muerte o sobre las ruinas de un país que se fue, eventualmente, económicamente hasta colapsar, entonces, esa es un poco la mentalidad de Daniel Ortega y de sus asesores y de su grupo, que dirigen este país, verdad, y también aquí, como más adelante podemos conversar, hay otro tema, el del asunto de la reelección, que es la reelección de Ortega, pero el efecto que ha tenido, que ha corrompido los poderes del Estado, tanto la Corte Suprema de Justicia, con actos como este como el que acabamos de ver, como el Consejo Supremo Electoral, que ha venido haciendo elecciones muy, muy bien, hasta que llegara al final, vienen a llegar los sandinistas al poder, ya comenzó la zanganada, a robarse las elecciones, a comprar Magistrados, y también porque todo esto es parte de una nueva concepción dirigida por Hugo Chávez dentro del concepto del ALBA, ¿por qué razón?, porque él lo que quiere es que estos presidentes se sigan reeligiendo de forma indefinida, como él ya lo logró en Venezuela como haya sido, como está haciendo Evo Morales en Bolivia, como está haciendo Correa en el Ecuador, y como quería hacer Mel Celaya en Honduras, pero ahí, pues, le salió mal la cuestión y ya ves el conflicto que se dio aquí en mi hermano país hondureño, entonces, Daniel Ortega va dentro de la misma línea, y, entonces, ellos reciben aquí una ayuda que es basada en el petróleo, el petróleo venezolano y el de Nicaragua, como hay un acuerdo económico en el cual se le paga el $50 \%$ en efectivo y el resto se le da un crédito a largo plazo, y un $25 \%$ se dispone en el país y otro $25 \%$ lo manejan unas empresas de ellos, pero todo esto lo manejan como que si fuera algo como fondos privados del Estado en Nicaragua, no tiene un acuerdo aprobado por la Asamblea que demuestre que esto es como un préstamo internacional, el cual se le queda debiendo a Venezuela, sino que esto lo manejan ellos como una gran caja chica, y esto ha permitido el enorme enriquecimiento de la familia gobernante, es decir, están comprando hoteles, están comprando propiedades, están haciendo inversiones de toda naturaleza, verdad, y estos recursos son los que permiten al gobierno, que no están transparentados en el presupuesto, pueden, entonces, comprar diputados para hacer sus cosas, comprar Magistrados y meter toda esa corrupción a través de la compra de conciencias con estos fondos que provienen de Venezuela.

R: Hay una cuestión ya en el reciente estilo de gobierno de Ortega, que, incluso, cerrando el círculo en torno a su esposa, se hace referencia a un régimen familiar, 
¿no?, y en alguna entrevista he oído que Ortega, que lideró la revolución de los 80, está simulando un poco la situación que trató de combatir, en este caso, el régimen somocista, que también, de alguna forma, utilizó el poder político como palanca para generar un enorme enriquecimiento personal a través la creación empresarial. ¿Hasta que punto estaría usted de acuerdo con esta apreciación de lo que está sucediendo, salvando mucho las diferencias que existen entre ambos contextos históricos, y entre ambas personalidades también?, ¿cómo haría usted este paralelismo del que tenido ya varias referencias?

C.N.: Hay un paralelismo sumamente interesante, sería bueno, tal vez, tener, deben de existir lugares, y también hay documentos en donde la proclama del Frente Sandinista, precisamente, contra Somoza Debayle, que fue el último de los Somoza, que decía que siempre los Somoza hacían reformas a la Constitución, armaban trucos como para crear un presidente interino, una Junta de Gobierno para volverse a lanzar otra vez de candidato, etc., era un gobierno que basaba su fuerza también mucho en la Guardia Nacional, y todo aquello de los Somoza, y eso eran las proclamas del Frente Sandinista contra la dictadura, la dinastía, el poder militar, la corrupción, perpetuarse en el poder, esos eran los fundamentos de las proclamas que el sandinismo hacía en su lucha contra el somocismo, y que, lógicamente, la gente quería eso, ahora después de tantos años que han pasado, ya 30 años, Daniel Ortega viene a ser una copia casi fiel de lo que le criticaban a los Somoza, primero, el único candidato del Frente, después de que perdieron las elecciones con Doña Violeta él ha sido, permanentemente, contra Arnoldo Alemán, contra Don Enrique Bolaños, y ahora con la división del partido el único candidato del Frente Sandinista, no hay otro, y, en este sentido, yo, de los Somoza, por lo menos, del padre, que lo mataron, quedó Luís, el hijo, que murió, y luego siguió Anastasio Somoza Debayle, y dicen que ya tenían preparado al que le decíamos en Nicaragua por apodo "el chigüín", que era el hijo de Somoza Debayle, aquí Daniel Ortega, verdad, el único candidato, dinastía, dictadura, no hay en su partido otra persona que pueda ser candidato, y ahí hay varias tesis de las cuales dice que gran parte de apurar esta reforma o esta mal llamada sentencia es que el Frente Sandinista si Daniel Ortega no es el candidato debe sufrir rupturas en lo interno, porque la elección de ese candidato, pues, puede provocar fricciones, porque fue el producto del sandinismo de una gran alianza entre distintas fuerzas, y que a lo mejor, pues, si escogían a la Rosario podía haber otro que se molestaba, si escogían a Bayardo Arce, entonces, dicen que en lo interno hay división alrededor de eso, si Daniel Ortega es el único que puede ser candidato, pero también se van enriqueciendo, manejando los recursos a su propio antojo, a beneficio de su propia familia, como hacían los Somoza y que los criticaban, ellos igualito, el mismo deseo de dictadura totalitaria, verdad, ahora tal vez la diferencia es el asunto de la Policía y el Ejército, que, por lo menos, el Ejército se mantiene como más profesional, ya la Policía la tienen infiltrada y la tienen bastante controlada, ha perdido esa imagen de ser una Policía, verdaderamente, profesional, porque hemos visto en las calles que protegen a la gente del gobierno, aunque estén garroteando a los civiles del otro lado, entonces, vemos, pues, por todos lados, que aquello que criticaban y que fue la causa de que fuéramos a una guerra que costó 50.000 muertos, tanta sangre derramada para que 30 años después, ellos que tanto hicieron, que tanto criticaron, vengan a ser, prácticamente, los mismos, verdad, un somocismo llamado ahora con Ortega, porque eso es lo que están queriendo de nuevo hacer, ya como Chávez, ya, supuestamente, basado en ese remedo de sentencia quedaría la reelección indefinida en Nicaragua, verdad, porque nadie, nadie que se ha elegido dos veces en Nicaragua se puede volver a presentar, y ahora puede volver a salir hasta que te aburrás, o te cansás o 
perdés las elecciones, entonces, esa es, pues, la realidad de Nicaragua, en donde como el gobierno de aquí, la Constitución, las leyes y todo no es más que una referencia en el cual, como decían, son lícitas pero inexistentes, porque no las respetan, de nada sirven, no se respeta la norma constitucional, porque ellos inventan los argumentos para justificar cualquier cosa, para lograr los objetivos, ¿verdad?, no importan los fines, no importan los medios para lograr el objetivo final, que es la perpetuación en el poder.

\section{R: Y ya haciendo una referencia a los presidentes, si comparamos los últimos cuatro} presidentes que ha tenido Nicaragua, Doña Violeta y Enrique Bolaños fueron presidentes, que se vieron, enormemente, debilitados, ¿no?, porque perdieron el apoyo de su partido en la Asamblea Nacional, y además vivieron crisis institucionales fuertes entre el Ejecutivo y el Legislativo. Sin embargo, Arnoldo Alemán y Ortega al ser hombres fuertes de sus respectivos partidos, y el pacto que los vinculó a partir del 2000, les hizo hombres, digamos, con mayor capacidad y recursos de poder a la hora de desarrollar su agenda de gobierno. Usted que además fue presidente de la Asamblea en la época del presidente Enrique Bolaños, que encarna, posiblemente, mejor que ningún otro presidente, lo que es la dificultad de gobernar por carecer de apoyo en la Asamblea y por esa reforma constitucional del 2005, que restringía todavía más las facultades del Poder Ejecutivo. ¿Qué reflexión le merece?, ¿cómo vivió usted aquellos años difíciles del gobierno de Bolaños?

C.N.: Bueno, las circunstancias, efectivamente, son, diría yo, lamentables para el país, y, por otro lado, las lecciones históricas ahí están, un presidente no puede gobernar bien si no tiene un apoyo, dijéramos, un apoyo político, en este caso, de los Congresos, de las Asambleas, como se llame en los distintos países, y eso es lo que, efectivamente, le ocasionó a Don Enrique, tal vez él tuvo un error de cálculo, él creyó que al llegar a la Presidencia de la República le iba a ser fácil tomarse el partido liberal y obviar a Alemán, que él ha tenido un liderazgo natural dentro del Partido Liberal Constitucionalista, es evidente, entonces, como en aquél momento, ya como presidente, lo atacó de corrupción a Alemán, y ahí nació el choque político entre el PLC, el partido, y Don Enrique Bolaños, eso llevó a toda esa tensión que se vivió durante el régimen de Don Enrique, con el PLC, y eso, lógicamente, tuvo su expresión en la Asamblea Nacional alrededor, pues, de las aprobaciones de leyes o cosas que el gobierno quería, y que, lógicamente, no iba a tener el apoyo en el Congreso, y que él también al final, algunas veces, tenía que hablar más con el Frente que con el mismo partido que lo había llevado al gobierno para poder lograr llevar algunas estabilidades y algunas cosas, y una bancadita pequeña que nació en aquella época, que se llamó la bancada "Azul y Blanco", y que crearon un partido que se llamó APRE, "Alianza para la República", para ver si eso podía dar una nueva concepción política, pero es muy difícil armar los partidos políticos de un día para otro, y por razones coyunturales, como le digo, y, entonces, eso fue lo que ocasionó, en este caso de Don Enrique, el problema, y, lógicamente, y para curiosidad, los sandinistas, aprovechándose de las circunstancias estuvieron de acuerdo en quitarle más poderes al presidente de la República en esa segunda reforma constitucional que usted menciona, y ahí vino el asunto de los nombramientos de los ministros, de los embajadores, que requieren, que el presidente los nombre, pero que sean ratificados por la Asamblea Nacional, y todo ese tipo de cosas, entonces, Don Enrique Bolaños lo que hizo fue, de nuevo, hasta la famosa "ley marquito" para que no se aplicara a su gobierno, sino que al nuevo que venía, y le tocó a Daniel Ortega, y eso, lógicamente, se repitió la misma historia en la época de Doña Violeta, cuando entró Alemán a la presidencia, entonces, es lo que yo menciono, que, 
lamentablemente, en Nicaragua, verdad, las cosas que se hacen muchas veces en política, o en las reformas a la Constitución u otras leyes, no se hacen teniendo una mente fría, pensando en la mera andanza del país, sino que se hacen por razones coyunturales, cómo pasarle la cuenta a alguien que querés pasarle la cuenta, y eso, lógicamente, que esas reformas no redundan en beneficio del país, porque, eventualmente, después se ve que lo que ocasionan son mayores problemas que los que quieren resolver, por eso es lo que digo yo, que hemos venido aquí haciendo unos parches a la Constitución, y, entonces, tenemos aquí una mezcla, pues, de animales raros, y, entonces, no tenemos una muy buena Constitución, que debería, eventualmente, pues, creo yo, y no producto de coyunturas, sino como un gran acuerdo nacional de todas las fuerzas políticas, eventualmente, hacer una Asamblea Constituyente, y redactar una nueva Constitución, y por lo menos pienso yo que haya cierta parte con mucha fortaleza, que se pueda reformar, fijando los mecanismos, pero no solamente en la Asamblea, sino que debe de ser objeto de un referéndum popular, que la gente esté de acuerdo o no esté de acuerdo en reformarla, o algunas cosas que le den mayor estabilidad a la Carta Magna y que no sea objeto, pues, de tanta cosa como hemos venido viendo, y esto no solamente en la transición a la democracia con Doña Violeta de Chamorro, sino que también los Somoza hacían atrás, cuando la Constitución les ponía obstáculos, ellos no aprobaban la reelección continua, sino que lo que hacían era que creaban presidentes interinos, como fue el caso de René Chic, o después una Junta de Gobierno, que duró cuando el terremoto del 72, y no más seguía Somoza otra vez en la presidencia, y, entonces, al hacer las reformas no había la continuidad, porque, efectivamente, era una forma de evitar la prohibición constitucional, y así ahora venimos, de nuevo, con esas mismas historias en Nicaragua, con esos mismos genios políticos, seguimos en esta marcha de Nicaragua, ojala que algún día podamos, en realidad, avanzar a la creación de un verdadero Estado de Derecho y un país con estabilidad, que lo podamos sacar adelante, y la prueba en Centroamérica la tenemos en Costa Rica, aunque a muchos les duela, pero esa es un poco la verdad, Costa Rica desde la época de Figueres en el cuarenta y tantos, comenzaron a apostar por la institucionalidad del respeto a la ley, la gobernabilidad y esas cosas, y crearon institucionalidad, instituciones, y se respetaban, y eso ha hecho que Costa Rica avance, ¿verdad?, y, entonces, cuando un país tiene Estado de Derecho, seguridad jurídica, respeto a los derechos humanos, y todas esas cosas, es una sociedad que se desarrolla, y que también crea un buen clima de negocio para que la gente pueda llegar a invertir, como en Costa Rica hay millones de inversiones en turismo, y el ingreso que tiene Costa Rica por turismo creo que anda en los 3.000 millones de dólares por año, y ya Costa Rica es un país que tiene 6.000 dólares de ingreso per cápita en una población de cuatro millones de habitantes, entonces, es un país, que tiene un alto grado ya de desarrollo, y que nosotros debemos de ver esas experiencias positivas, y no como dice aquí el Magistrado de la Corte, que hicieron este mamotreto de sentencia, o el Magistrado del Consejo Supremo Electoral, que eso lo hicieron en Costa Rica, es lo único que dicen que querían imitar, porque no imitan la transparencia en las instituciones, en la forma en que se comparten, y no en la forma incorrecta, ¿verdad?, que ellos actúan aquí en el país.

R: Y ya para terminar, aunque ha incluido eso en su reflexión final, ¿cómo ve el futuro de aquí al año y medio que resta para las elecciones? Ya me ha dicho, a grandes rasgos, que reformas constitucionales parcheadas más no, o sea, esta costumbre de reformar constantemente la Constitución en función de intereses políticos no es algo que favorezca a ningún régimen constitucional del mundo, y también hacer más rígida 
esa nueva Constitución, ¿usted piensa que una nueva Asamblea Constituyente, ese nuevo pacto constitucional, sería la solución?

C.N.: Podría ayudar, porque, indiscutiblemente, esto no es que nos hicieran de nuevo a todos los nicaragüenses, pero podría ayudar, dándole hasta cierto punto una mayor rigidez a la Carta Magna para que no sea objeto de estarla manoseando, como decimos aquí, aquí usamos un término muy popular, que la Constitución es como un delantal, el delantal que usan las mujeres en el mercado, que se lo ponen y se lo quitan cuando quieren, sino que debe ser algo, que, verdaderamente, tenga esa seriedad institucional, y yo creo que eso a la larga no es que sea toda la solución, porque la ley en sí misma no soluciona, sino que, pero pudiera permitirnos seguir avanzando en la creación de institucionalidad, ese yo creo que es el reto nuestro y el de las próximas generaciones es crear institucionalidad, respeto a la ley, Estado de Derecho, el día que nosotros podamos avanzar hacia eso, Nicaragua va a avanzar, si no avanzamos a eso, ahí vamos a vivir, postrados en el subdesarrollo, veo difícil, precisamente, porque el año que viene se le vence el período a los Magistrados del Consejo Supremo Electoral, gran parte de los Magistrados de la Corte Suprema de Justicia, todos los contralores, ahora en diciembre de este año se le vence al Procurador de Derechos Humanos, de manera que, y todo requiere mayoría calificada para elegirse, entonces, esa circunstancia va a provocar inmensas tensiones en el Congreso, aquí en la Asamblea Nacional el año que viene, porque, lógicamente, que con la experiencia que, en este caso, tuvimos con el Consejo Supremo Electoral, ¿a quiénes vamos a poner ahí para que sean los nuevos árbitros de unas elecciones?, pues, lógicamente, ninguno de estos que hicieron semejante barbaridad, ahora si el Frente los quiere premiar nosotros no vamos a querer y ahí se va a comenzar a trenzar la fuerza en el Congreso, ¿hasta dónde va a llegar eso?, no sé, o hasta dónde el gobierno va a querer, como decía antes, si no lo puede hacer, tiene varios escenarios, uno puede ser, si no lo logra, entonces, puede ser que compre conciencias, una alternativa, si ellos no lo logran, como lo espero yo, entonces, ¿qué?, ¿disuelve el Congreso?, no lo creo, lo veo más difícil todavía, porque sería un golpe político a un Estado de Derecho, se derrumbaría el orden constitucional, y ¿cómo va a ir a unas elecciones, si ahí todo el mundo le dice a Honduras que no le quieren reconocer las elecciones que vienen, cómo sería en Nicaragua?, yo creo que sería igual, la misma cosa, entonces, uno, como decía yo antes, puede desembocar en un diálogo político que pueda llevar a un proceso de una Constituyente, pudiera darse el caso, o sea, un escenario hipotético, que nos estamos imaginando, o también a un proceso de reforma, por ejemplo, en la Ley Electoral, que requiere acuerdos de mayorías calificadas para hacer más transparente el proceso de las elecciones, y así elegir Magistrados de la Corte Suprema, del Consejo Supremo Electoral, entonces, hay varios escenarios que pueden derivarse de eso, porque si no quedarían descabezados dos o tres poderes del Estado, como es la Corte Suprema de Justicia, y como sería el Consejo Supremo Electoral, y un órgano tan importante como es la Contraloría, que es el que revisa las cuentas del Estado, entonces, descabezado eso, es bien difícil el poder gobernarse para los políticos, separa lo que es justicia, separa lo que son procesos electorales, no se pudieran llevar a cabo las elecciones del 2011, verdad, hay que buscarle soluciones a éstos, y creo que una de las formas en que, eventualmente, va a desembocar es en alguna solución de esa naturaleza, ¿verdad?, y que eso, en realidad, va a ir en beneficio del país, y sobre todo que esas elecciones se podrán ver agravadas también con las posiciones nuestras en la Asamblea de aprobar, por ejemplo, una ley que declare nula la sentencia de los Magistrados, el conflicto entre los poderes del Estado, entonces, se va a crear una situación difícil y caótica en lo político en Nicaragua en los próximos meses. 
R: Pues, si tiene algo más que añadir.

C.N.: No, yo le agradezco, la verdad, que se interese tanto por este tema. 


\section{ENTREVISTA 38 ${ }^{55}$ :}

Nombre del entrevistado: D. José Pallais.

Cargo actual: Diputado del Partido Liberal Constitucionalista (PLC) en la Asamblea Nacional (2007-2011).

Fecha de realización de la entrevista: Managua, 28 de octubre de 2009.

Lugar: Asamblea Nacional de Nicaragua.

Duración estimada: 48 minutos.

\section{TEXTO - Transcripción 38:}

R: ¿Cuál es su visión sobre el recorrido que se ha hecho en este país desde los años 90 hasta la actualidad respecto a los cambios constitucionales, en el contexto siempre de la consolidación de las instituciones democráticas, con sus avances y también sus retrocesos?

J.P.: Yo creo que el cambio más importante se dio, pues, a partir de la reforma del 95 , donde se hizo una revisión a profundidad de la Constitución del 87, que a todas luces era una Constitución que se apartaba, pues, de los modelos tradicionales presidencialistas democráticos, porque tenía una concentración de poder y de facultades en el presidente de la República, por ejemplo, permitía que el presidente de la República pudiera, pues, dar decretos administrativos en materia tributaria, en otras palabras, crear impuestos, lo cual, pues, son funciones que no están recogidas por la mayoría de las constituciones presidencialistas, y que son funciones propias de las asambleas nacionales o de los parlamentos. En esa Constitución se dio un mayor equilibrio entre los diferentes poderes del Estado, ajustándose, pues, a un modelo estándar que había en América Latina, y que es, fundamentalmente, la Constitución de los Estados Unidos. Posteriormente, se dieron otras reformas en años sucesivos, que fueron dándole mayores competencias, mayores facultades a la Asamblea Nacional en la discusión que se ha generado en Nicaragua, pues, y en otros múltiples países, de que el presidencialismo, fundamentalmente, en América Latina ha sido un presidencialismo muy fuerte, que permite, pues, prácticas caudillescas, concentración de poder, facilita, pues, el abuso, la perversión del poder, entonces, tratando de trasladar mayores competencias al Poder Legislativo, inspirándose en algunas figuras que son propias del régimen parlamentario, pues, de naturaleza europea, fundamentalmente, es un tendencia que no es exclusiva ni propia en Nicaragua, e incorporando también disposiciones del régimen presidenciales, pero propias del Estado federal, propios de la naturaleza de los regímenes federales, como el de Estados Unidos, que no estaban incorporados en la legislación nicaragüense por ser un Estado unitario, pues, entonces, lo que recuerdo es la ratificación de los ministros de Estado, la publicación de los embajadores, que se fueron incorporando en reformas posteriores. Hay una tendencia que abonaba por considerar que el régimen presidencial estaba en crisis, que era conveniente, pues, seguir avanzando hacia la transformación hacia un régimen parlamentario, dejar el sistema híbrido, que algunos dicen que se ha venido creando o conformando, pero es una discusión que no está, no hay un consenso, pues, de cuál debía ser la lógica, o cuál debía ser la dirección, hay

55 Entrevista relativamente breve, que a pesar de introducir el sesgo político como diputado del PLC, partidario de la gestión de Alemán en la firma del pacto con Daniel Ortega, señala algunas referencias de análisis de utilidad en torno a la lógica de las alianzas entre las fuerzas políticas en los procesos de cambio constitucional. 
discusiones a lo interno de la sociedad sobre el régimen parlamentario, que también ha ofrecido desviaciones de concentraciones de poder, desviaciones facilitadas también por la Constitución de dictaduras totalitarias, por ejemplo, con la Constitución de Weimar en Alemania, el nacional-socialismo, en la misma Italia, pues, Mussolini, fueron dictaduras que se consolidaron, se crearon, y se gestaron dentro de un régimen parlamentario, entonces, la cura de los males, se quejan de lograr desarrollar una mejor democracia, una mayor institucionalidad, no está así, no sale, pues, la respuesta en un cambio de sistema, sino que tiene que ver, pues, con cuestiones más integrales de cultura política, etc., por ejemplo, pues, a mí en lo particular, por una de mis preocupaciones de seguir avanzando hacia la tendencia al parlamentarismo, pues, la inestabilidad propia, por ejemplo, del modelo italiano, que ha sido muy inestable durante muchos años, y una cultura política del fraccionamiento de los partidos, los tránsfugas del partido, que es parte de nuestra subcultura política, eso, a mi juicio, pues, avizora una constante de inestabilidad, y que además requiere sobre todo de tener conformada, organizada, garantizada, una Administración Pública profesional e independiente, lo cual estamos aquí muy lejos de ello, entonces, con tanto cambio se facilitaría el régimen parlamentario no tener una administración que garantizara el funcionamiento del Estado, permanentemente, por encima de los vaivenes políticos, iba a llevar, necesariamente, pues, según mi criterio, a un Estado fallido, pues, un Estado paralizado, un Estado totalmente ineficiente e ineficaz en la atención del ciudadano, ¿ves? También se discutió, y así nosotros lo creímos, que quienes impulsaban estas reformas hacia un mayor acercamiento al modelo parlamentario lo que buscaban no era, pues, el régimen parlamentario por sí mismo, por las ventajas que pudiera tener, sino que era una forma de trucar, de pasar por encima de la prohibición constitucional del artículo 147, que prohíbe la reelección inmediata, ya que la reelección, la prohibición de la reelección que estaba históricamente en las constituciones de nuestro país, y que ha estado en muchas constituciones de América Latina, hay una tendencia hoy de revisión, pues, y de facilitación del continuismo, no es un problema que se plantee dentro del régimen parlamentario, entonces, esa es la fórmula que habían encontrado para permitir la continuidad en el poder del presidente Ortega, entonces, usted conoce, pues, aquí no lograron, la bancada del gobierno, consolidar la mayoría necesaria para la reforma, optando, pues, por la solución fraudulenta y barbarie jurídica, como yo la he calificado, de ese mamotreto de sentencia, pues, que generó una conformación espuria de la Sala de lo Constitucional, ¿no?, entonces, estamos en esa situación, ese es el contexto de dónde venimos, hacia dónde queremos ir, las diferentes manifestaciones, la crisis continua, se profundiza, y continuamos, pues, como Estado, como nación, pues, sin encontrar una solución a esa inestabilidad y a esa discusión y a esa polarización, pues, que ha sido la constante durante muchísimos años, y que salvo, pues, algunos espacios de tiempo muy concretos, pues, ha permitido que el país dé pequeños avances.

R: Si bien es cierto que el hilo conductor de las reformas, desde los 90 hasta la actualidad, ha sido la semi-parlamentarización, como bien ha indicado, del excesivo presidencialismo que consolidaba la Constitución del 87, no supuso, realmente, como un vicio institucional de partida, en el que quizá estén implícitos, entre otros factores, la cultura política, pero también la propia historia institucional del país, un traspaso del excesivo poder del presidente al de las cúpulas de los partidos, que desde la negociación en el ámbito de la Asamblea coparon o repartieron de forma paritaria, entre el PLC y el Frente Sandinista, las principales instituciones del Estado. ¿Cómo ve esta crítica que se ha formulado, digamos, por las fuerzas políticas anti-pacto pero también por sectores de la sociedad civil y por algunos académicos, que yo he ido 
registrando en mis entrevistas?, ¿cómo describiría, realmente, este proceso que arranca en el pacto entre Ortega y Alemán en 2000?

J.P.: Bueno, yo diría que eso es parcialmente cierto, parcialmente cierto, en el sentido de que se incrementaron el número de miembros, pues, de las diferentes élites y directores de algunos organismos e instituciones del Estado, ¿no?, y que, sí, este incremento, lógicamente, alentó el reparto, y permitió, verdad, que los partidos más fuertes buscaran el equilibrio o la distribución de estos cargos, pero yo diría hasta ahí, en el sentido de que hay más cargos, pues, hay más que repartir, pero, bueno, porque no creo que el hecho de que los partidos políticos lleven, sean más o sean menos, los miembros de un órgano colegiado deben de abstenerse de impulsar a las personas que son afines a sus principios, a sus valores y a su ideología, para mí esa es la constante en todos los países democráticos del mundo, en España mismo, por ejemplo, el Consejo General del Poder Judicial se lo negocian el PP y el PSOE, o sea que, causalmente, leía hace unos meses que hay una crisis ahorita de nombramientos...

\section{R. Bueno, en el Tribunal Constitucional, pero desde hace tiempo ya, en la renovación de algunos de sus miembros.}

J.P.: Sí, porque están enfrentadas las tendencias abiertas, pues, en los mismos Estados Unidos, pues, la Corte Suprema de Justicia cada presidente, si tiene la mayoría o aunque no la tenga a través del peso que tenga la presidencia de la República, trata de llevar a la Corte a personas, pues, afines a la ideología de su partido, entonces, aquí la discusión ha ido pervirtiendo esa lógica, en el sentido de que todo ha sido, pues, motivado por constituir un pacto en el que hay una distribución, que no escapa de la dinámica de todos los demás países, como te decía, los partidos se crean y se constituyen para tomar el poder, bueno, y para poder influenciar un modelo de sociedad que los miembros del partido es la que proclaman y asumen, y quieren trasladar, y quieren que irradie, pues, todos los aspectos de la vida de la sociedad, pues, no veo yo que los partidos políticos se crean para servir de puentes para que otros asuman el poder, pues, eso ya sería suicida para los partidos políticos, y no durarían entregándole el poder a otro, que pareciera muy inocente o muy imparcial, porque a la vuelta de la esquina lo que está es permitiendo que ese se organice y te sustituya a vos como partido político, ¿no? Entonces, por eso te decía, yo llego a aceptar eso, pues, hasta el número, pues, el problema de la numeración, lógicamente, fue un incentivo para un entendimiento, y lo crearon como un incentivo, pues, para repartirse, pero también yo creo que hay otro problema, en ese proceso, pues, de semi-parlamentarización, al parlamento no se le dieron las garras, verdad, yo soy el primero en decir que no se fortaleció el control político de las actividades del Ejecutivo, ni se entró, ni siquiera, a soñar con introducir el control político para los otros poderes del Estado en el parlamento, por ejemplo, lo más sencillo y lo más normal, pues, la supervisión presupuestaria, una supervisión presupuestaria, aquí no hay en el parlamento una comisión de seguimiento posteriores del gasto, hay una pequeña oficinita que recibe las informaciones que da el Ministerio de Hacienda, bueno, entonces, ese avance es más formal que sustantivo, que de fondo, se trasladaron facultades, se compartieron facultades, pero sin dotar al parlamento de aquellos mecanismos que hicieran realidad, que hicieran efectivo, que hicieran aplicable el balance de poder, que es normal en los regímenes parlamentarios, ¿no?, entonces, pues, aquí el parlamento se siguió viendo como la institución donde se legisla, donde se hacen las leyes, perdiendo la visión más importante que para mí nace desde el mismo conflicto con Juan sin Tierra, donde el parlamento legisla pero también controla, y que 
es más importante el controlar que el legislar mismo, incluso, pues, cuando cuestionaba la Asamblea Nacional francesa a Napoleón, Napoleón no mandaba legislar, no se metan en controlarme el gasto de las guerras, pues, entonces, eso aquí no se hizo, no se ha hecho, pues, creo que es una carencia que tiene que completarse, ojala, en el futuro para consolidar lo que ya está, pues, todo eso es un criterio, pero que para continuar avanzando en las decisiones ya adoptadas hay consolidar lo que ya tenés, tendrías que fortalecer todo lo que es la capacidad de control del parlamento, ¿no?

$R: Y$, sin embargo, esa desconcentración del poder del Ejecutivo al Legislativo, ¿actualmente no se está revirtiendo con un fortalecimiento y concentración del poder en el Ejecutivo presidencial?, me refiero al último período del gobierno de Ortega, que en el pacto con Alemán se convirtió quizá en el socio mayoritario, teniendo una mayor preeminencia en las instituciones del Estado, y pienso, muy especialmente, en el Poder Judicial.

J.P.: Sí, pero no en base a reformas que contemplen mayores competencias del Estado, sino que por la vía de hecho, por la vía de la imposición, por la vía del control de los otros poderes del Estado, pues, un control que está basado en la corrupción, en la compra de conciencias en esas instituciones mismas, entonces, en que el equilibrio de poderes, pues, el balance de poderes, la reducción de poderes, se ha convertido en un mero enunciado formal de la Constitución, pero no es real, pues, pero eso no nace de ningún acuerdo ni de ningún pacto, eso nace de la debilidad misma de las instituciones, de la falta de cultura política, y de la cultura, abiertamente, totalitaria y corrupta del régimen de Ortega, pues, no hay, no subyace, pues, una reforma, una entrega, una concesión, no, no, no, es la debilidad misma de las instituciones que no permiten tener ese balance, ese control efectivo, ese equilibrio efectivo de pesos y contrapesos entre los diferentes poderes, que es lo que ha facilitado, pues, la toma de decisiones, o la imposición, por ejemplo, que la misma facultad de ratificar ministros y ratificar embajadores es hoy, es hoy, y todavía no ha ratificado a ninguno en la Asamblea Nacional, pues, pero eso es parte de un hecho cumplido, de una imposición, de una cultura de no apego a la ley, de no apego a la Constitución, de una cultura autoritaria, pues.

R: El pacto, además, no es algo extraño a la historia política de Nicaragua ni de otros países.

J.P.: Ni es malo por naturaleza, tampoco.

R: No, el pacto político forma parte de la democracia en la medida en que las fuerzas politicas negocian en aras de la gobernabilidad.

J.P.: Así es.

R: Pero, sí, el pacto político previo a reformas constitucionales ha sido algo que se ha repetido en la historia de Nicaragua y de otros países de América Latina.

J.P.: Bueno, es que eso es necesario, porque, por regla general, las reformas constitucionales requieren de una mayoría calificada, pues, entonces, a no ser que sea un gobierno que sea electo como resultado de una elección avasalladora, pues, que obtiene una mayoría muy importante, siempre se requiere la negociación, pues, y debe ser así, y 
debe ser así, porque hacer una Constitución o reformar una Constitución para mí es una cuestión muy seria, tiene que haber un consenso, tiene que ser una Constitución que va a regular a todos los ciudadanos de un país, pues, nunca debería ser la imposición de una fuerza sobre otra, la Constitución, yo digo, que es un pacto que se impone entre los ciudadanos, hay mucha gente que dice, pues, que hay pacto social, ¿y cómo nos vamos a regular?, ¿y cómo nos vamos a organizar?, ¿y cómo vamos a administrar nuestras diferencias?, ¿no?

R: No, pero yo me refiero al pacto entre las élites, a la negociación política con intereses políticos concretos a la hora de diseñar las instituciones y de acomodar el Derecho al ejercicio del poder, ¿no?, que es un poco la crítica que se ha vertido sobre este último proceso de reforma de 2000 a esta fecha, y cuyas últimas consecuencias estamos viviendo en estos momentos, porque, de alguna forma, el ascenso también de Daniel Ortega al poder fue producto de una reforma electoral, y de un recorte, digamos, del porcentaje de votos necesario para ganar en primera vuelta.

J.P.: Mira, yo tampoco comparto esa teoría, y te voy a decir por qué, ¿ves?, la reforma electoral, que bajó, pues, al 35\% fue anterior a la elección de Enrique Bolaños y cuando la elección de Enrique Bolaños, previo a la elección y a esa contienda electoral, nadie tuvo ningún problema, nadie vio una preocupación en eso, no se escuchó ninguna voz que dijera, pues, que aquí hay un riesgo, que aquí se está facilitando que el Frente Sandinista, pues, tome el poder con una minoría, en absoluto, no recuerdo yo, pues, no fue tema ni previo al proceso, ni durante el proceso electoral, y menos después del proceso electoral cuando Enrique Bolaños ganó con el 52\%, pues, ¿me entendés?, incluso, yo te digo, la medida de bajar al 35\%, de quienes tomaron esa decisión, porque yo no estaba, en ese entonces, en el Partido Liberal, ni estuve en las discusiones que se generaron, pero la medida fue consciente de que varios años de ejercicio del poder del Partido Liberal iba a provocar, lógicamente, un desencanto, una pérdida, un desgaste natural de cualquier continuidad, pues, entonces, que era conveniente bajárselo para que el partido aún con el desgaste pudiera seguir ganando, pues, la lógica de la decisión no fue favorecer al Frente Sandinista, la lógica de la decisión fue garantizarse la continuidad del mismo partido en una situación de deterioro normal por el transcurso del tiempo en el uso del poder, que aquí, el gran pecado de que facilitó el acceso al poder del Frente fue la división, pues, que no se dio cuando ganó Bolaños con el 52\%, y si sumás lo que sacó el PLC y ALN, pues, en las elecciones de 2006 tenés ahí el 52\%, ¿ves?, y eso es lo que hemos sabido siempre en el país, pues, el país está dividido en dos segmentos, pues, alrededor del $60 \%$ antisandinista, y alrededor del $40 \%$ sandinista, bueno, se unen los anti-sandinistas, claro, no se unen, no ganan, esa es la lógica y su consecuencia.

R: No, es más, cuando yo leía los resultados de las últimas presidenciales, en los titulares de prensa decían: "Ortega no ganó sino que sus enemigos perdieron”, ¿no?, haciendo referencia aque Ortega gana un poco como consecuencia de la división del liberalismo.

J.P.: Así es, así es, bueno, a mí eso me lo dijo un diplomático japonés, con la aparente inocencia con la que hablan los japoneses, ¿no?, pero con un gran sentido crítico, ¿verdad?, y me dice una vez: "pero si ustedes ganaron", entonces, me dice: "pues, yo no entiendo, ustedes ganaron, pero perdieron", ahí lo expresa pero muy claramente, si hubiéramos ido unidos barremos y hubiéramos tenido control en la Asamblea. 
R: ¿Y cuál es la perspectiva del liberalismo actualmente frente a esta, digamos, decisión de la Corte Suprema, que da vía libre a la presentación de la candidatura de Ortega en las próximas presidenciales, y siguiendo la regla electoral con la actual división del PLC y ALN, pues, parece ser que una victoria de Ortega sería, incluso, probable?

J.P.: No, yo estoy segurísimo de que la división no se va a dar, porque el principal promotor de la unidad, sin quererlo, es Ortega, porque todo el mundo lo ve como una amenaza, y, entonces, ya no es cuestión de una confrontación de liderazgo, ya no es cuestión de una lucha, pues, por ser una mejor opción, ya es lucha por la sobrevivencia, y cuando vos ya llegás, pues, a nivel de que si sobrevivimos o no sobrevivís, y si nos unimos sobrevivimos, y si no te extinguís, ¿ves?, entonces, vos tenés que pensar que tiene que haber algún resabio de racionalidad, y ya estoy viendo, ya estoy viendo señales muy positivas en abonar la unidad, en volver a constituirla, dejando de lado, pues, las diferencias, y haciendo la unidad, así es que yo te puedo asegurar, pues, con certeza que la unidad se va a dar en el 2011.

\section{R: De los liberales frente al sandinismo de Ortega.}

J.P.: Sí, de todo el anti-sandinismo, no sólo de los liberales, tenés que empezar con la unidad de los liberales, pero que va a concretarse con la unidad de las fuerzas antisandinistas, estoy tan cierto de eso como de que mañana va a amanecer.

\section{R: Incluso planteando un único candidato presidencial.}

J.P.: Sí, sí, sí, pasa por eso, necesariamente, ¿no?, esa unidad tiene que concretarse, si no se concreta un solo candidato no hay unidad, no hay unidad, porque si van dos papeletas con dos opciones, van divididos.

R: Otra cuestión que, de alguna forma, es destacable en el estudio de los procesos de reforma constitucional es el conflicto repetido entre Ejecutivo y Legislativo a la hora de aprobar las reformas, que, incluye un instrumento jurídico tan peculiar como el de las leyes Marco, ¿no?

J.P.: Sí, sí, este conflicto se dio en la reforma del 95 con Doña Violeta, verdad, más provocado por Antonio, pues, que por Doña Violeta misma, a mí me tocó estar en la comisión negociadora de la Ley Marco en los tiempos de Doña Violeta, yo estaba en el Gabinete de Doña Violeta, yo fui parte de los negociadores, y la posición de Doña Violeta, que fue la que se impuso, era de total aceptación hacia las reformas mismas. Después con Bolaños se volvió a presentar la crisis, te decían, pues, los mismos argumentos, "yo fui electo con esta Constitución, entonces, como fui electo con esta Constitución, tengo que terminar mi período, las competencias, las atribuciones no las podés restringir, tengo que gobernar con esto no con esta otra camisa que me querés imponer", y, entonces, la solución es esa, la de los acuerdos políticos o de las leyes Marco, siempre, pues, en la reticencia de los grupos de poder del momento, resistiendo a que le corten lo que ellos consideran que son sus competencias y sus atribuciones, pues, la pérdida de poder, el problema de siempre, ¿no?

R.: Pero uno tiene la sensación de que en este país quizá la política está por encima del Derecho, me refiero a que la Constitución, como sistema jurídico que limita la acción 
de poder, que es un poco el sentido de la definición más básica de una Constitución, está sujeta a las decisiones de mayorías que periódicamente se renuevan en las urnas, ¿no?, frente a la Ley Fundamental, que tiene una vocación, digamos, de atemporalidad, de estar por encima del tiempo de la política, como diría algún constitucionalista en sentido estricto.

J.P.: Sí, sí, sí, eso es una realidad innegable, pues, y es una de nuestras debilidades como país, como república misma, es una debilidad que nos ha signado, pues, todos los acontecimientos en los enfrentamientos por el poder, por el balance y la repartición de las cuotas de poder, pues, que al final se impone la solución política, pues, y algunos argumentan que la teoría francesa, verdad, de que es más importante, ¿cómo es que se dice?, ¿cómo es que dicen los franceses?, ay, se me olvidó la palabrita, bueno, ese estado de necesidad, ¿cómo es que se dice?, ¡la razón de Estado!, que tiene que primar, pues, la razón de Estado, aquí, en nombre de la razón de Estado, pues, yo comparto que se ha llevado, pues, a extremos demasiado jalados, definitivamente, pues, pero, al final de cuentas, ya en la valoración retrospectiva que podemos hacer, pues, yo no es que la comparta ni que esté de acuerdo, no me gustan y las rechazo, pero ha permitido encontrar salidas a los conflictos, verdad, que tal vez, pues, para el común del nicaragüense, yo creo que eso es lo importante, que sacrificando, pues, a los derechos, a la fortaleza de la norma, se encuentre una salida que posibilite que el país se destrabe y funcione, pues, que era la discusión de que tan bueno o tan malo es eso, pero es una discusión teórica ante una realidad política que, definitivamente, tiene algún signo de positivo, pero, ¿qué es lo ideal?, lo ideal es que el conflicto no se hubiera planteado, que todo el mundo hubiera aceptado y estuviera tranquilo, pues, y que no hubiera ningún trauma con las reformas, ¿ves?, eso es lo ideal, a eso tenemos que aspirar, pues, pero nuestra propia realidad no nos lo permite y cada cambio, cada cambio provoca un trauma, al que reaccionando se encuentra una salida, no es la mejor salida, pero es una salida al fin.

$R: Y$ si en cada periodo de gobierno se ha planteado una reforma constitucional, y ya en el primero de todos se planteó, incluso, el debate entre una reforma total o una reforma parcial a la Constitución del 87, da la impresión de que no ha habido un pacto constitucional completo, digamos, porque ha habido siempre una parte de Nicaragua que no ha estado de acuerdo con la Constitución que se ha planteado, en el 87, porque hubo una parte no representada en el proyecto revolucionario, que eran también ciudadanos nicaragüenses, y en el caso de las reformas posteriores, porque ha habido fuerzas politicas que han planteado una critica al proyecto de reforma parcial de la Constitución, ¿no? ¿Cuál ha sido, en realidad, el problema?, ¿por qué cree que no ha habido ese consenso constitucional básico?

J.P.: Mirá, porque no ha habido una Asamblea Constituyente, todo ha sido a retazos, medidas de retoque y a cambio, y, entonces, ha habido intereses difusos, ¿verdad?, y no una visión de Estado, bueno, todo lo que aparece en la Constitución sería como una visión de futuro o una visión de nación, se han ido haciendo a pedazos, a retazos, que, como parte de la lucha política, como parte por la lucha por el poder, y no ha habido un Constituyente primigenio, especialmente, abocado, especialmente, destinado, con una conciencia de los ciudadanos de que se va a hacer una norma con el ánimo de perdurar y con ánimo de aportar soluciones, ¿no?

$R$ : $Y$, respecto a más reformas sí, o más reformas no, porque hay una cierta canalización del procedimiento de reforma, como hemos advertido ya en el caso de la 
sentencia, donde se pasa por encima del procedimiento jurídico y se vulneran no solamente los poderes públicos, sino su legitimidad ante la opinión pública, que siento que es muy, muy grave, eso de no respetar las reglas de juego. O bien, hay incluso entrevistados, que me sugieren la idea de hacer una nueva Constitución, ¿cuál sería su opinión a propósito de esto?

J.P.: No, yo me apuntaría por eso, yo me apuntaría por eso, pero como político también estoy claro, pues, de que a todo el mundo le da miedo impulsar eso como una Asamblea Constituyente, con voto específico para los diputados, a todo el mundo le da horror, porque en este relajo que tenemos, de momento, nadie está seguro que va a ganar, entonces, me voy a meter, y si la agarra el otro, me excluye, ¿ves?, entonces, yo no veo aquí de ningún lado, de ningún lado, ¿verdad?, disposición a encontrar una salida, pues, por esa vía, que para mí es la correcta, es la correcta. ¿Cuándo va a estar el país maduro para eso?, ¿y rehacer lo que podemos decir, pues, que es una sábana hecha a retazos?, eso es una sábana hecha a retazos, sin una visión de conjunto, sin una negociación a fondo, a profundidad, no, no, no me atrevería a hacer pronóstico de cuando va a haber madurez para eso.

R: Y usted mismo lo ha señalado, es muy importante saber quiénes son los que hacen las constituciones, es decir, quiénes son los actores políticos que hay detrás. Si en la reforma del 95 hay un arco parlamentario pluripartidista, en el caso de las reformas de 2000 y 2005 es bipartidista, ¿qué diferencias apreciaría desde el punto de vista de las reformas constitucionales?, ¿de la pertinencia de las propuestas, de la evolución también de la Constitución en sí misma, es decir, con ese giro que, en el 2000, algunos interpretan, incluso, como que se dio una contrarreforma? Porque la del 95 era una reforma necesaria, bueno, en el sentido de que el momento político del país era el de la transición democrática, no se podía gobernar con la Constitución del 87 desde ningún punto de vista, pero en el 2000 sí se inicia un giro, que yo creo que es el que todo el mundo advierte en la última década. ¿Cómo ve esta diferencia respecto a quiénes hacen las reformas constitucionales?

J.P.: Bueno, mirá, la única diferencia es que había en las reformas del 95 mayor participación en cuanto a partidos políticos, posición ideológica y demás, pero ninguno de los dos son constituyentes primigenios, pues, nombrados, designados por la nación para ese propósito o tal fin, ¿ves?, adolecen los dos de esa falla, pues, que para mí es importante, yo me inclino, como te dije, a que en el futuro vamos a tener que llegar a eso, pues, vamos a tener que llegar a eso, de hacer una convocatoria a una Asamblea Nacional Constituyente, con propuestas y posiciones plateadas abiertamente y en una negociación, en una negociación, pero también hay otra leyenda en nuestra política, pues, que mucha gente dice: "bueno, aquí ha habido un pacto bipartidista", pero eso no es cierto, y vos lo podés ver, hoy, hay en este momento, en las elecciones del 2006 sacaron representación parlamentaria cuatro partidos políticos, ¿verdad?, y que tampoco el pacto bipartidista entre el Frente Sandinista y el Partido Liberal, sólo nosotros y nadie más, tampoco es cierto, si no el PLC no hubiera pasado nunca jamás de la primera fuerza a la tercera fuerza, demostró la realidad que esa premisa es falsa, bien, porque pasó sin ningún trauma, sin ningún trauma, y teniendo el PLC una presencia muy importante en los poderes del Estado, pues, por tanto no es correcta esa visión de que estaba diseñado para excluir a los demás, ha habido, ha habido, pues, tengo que ser muy franco, errores en excluir a algunos, pero a posteriori, pues, pero no estaba la Ley Electoral, no es una camisa de fuerza que impida, verdad, la participación o una 
preponderancia o la existencia de más de dos partidos, esa es una premisa totalmente falsa, que es importante aclarar.

$R: Y$, sin embargo, algún entrevistado me ha dicho que cuando ambos pactaron, Alemán pensaba un poco en los pactos a la manera de Somoza, un "pacto de caballeros", en el cual se repartían las posiciones, digamos, en las principales instituciones del Estado de manera 60/40 o 50/50, pero respetando escrupulosamente la asignación de estos cargos públicos. Pero Ortega, el sandinismo o el orteguismo, como quieran llamarlo, tiene una formación distinta, otra cultura política, y una vocación hegemónica, y una no conformidad con un pacto bipartidista ni mucho menos un reparto paritario, sino que se va hacia arriba, que es, efectivamente, lo que estamos viviendo en la actualidad, esa situación en la que se raya, incluso, en la intolerancia política, por el cierre de espacios políticos que se ha producido y también por la limitación que tiene la propia sociedad civil para manifestar su disconformidad, y eso es algo que, yo, al menos, desde los medios de comunicación lo puedo observar. ¿Cómo ve usted todo esto?

J.P.: Mirá, eso es pensar que Alemán es un idiota, y eso está muy alejado, pues, de la realidad, pues, porque, el entendimiento funcionó mientras el liberalismo estuvo en el poder, verdad, ¿por qué?, porque tenía una visión, no vamos a llegar al absurdo, a la pretensión de decir que absolutamente democrática, no vamos a decir que tampoco hay en los orígenes del liberalismo tendencias autoritarias, ¿no?, yo no, no, no, no llego a decirte que no, también las hay, también las hay, de muy diferente grado y de una dimensión totalmente diferente, el problema es que ahora está Ortega en el poder, pues, y con la visión del poder, del manejo del poder, de permanecer en el poder, de abusar del poder, de no creer en las reglas democráticas, yo creo que lo que nos queda decir es: "¡ay, de los vencidos!", ¿no?, y eso es lo que estamos viviendo, estamos viviendo el "ay de los vencidos", pues, ¿y quiénes somos los culpables que nos dejamos vencer?, los culpables de dejarnos vencer somos nosotros que nos dividimos.

$R$ : ¿Y como ve, ya sí, muy rápidamente, para terminar, el futuro del país? O sea, es esperanzador, bueno, que me diga que es posible la recomposición liberal, finalmente, significa un frente de oposición importante al avance de Ortega, no porque Ortega en sí mismo sea un peligro, sino porque con sus actuaciones está demostrando que lo es.

J.P.: No es porque lo consideremos o lo tengamos encasillado, pues, como yo he dicho, Ortega es el que se encarga con sus desafueros cotidianos, con sus desaciertos, es el principal promotor de la imagen negativa de él mismo y de su gobierno, ¿no?, no hemos tenido que hacer ningún esfuerzo la oposición en andar demostrando que Ortega es totalitario, queda demostrado por el mismo, pues, mirá vamos a vivir un año muy difícil, el próximo 2010, bien difícil, el país tiene retos muy importantes, en el 2010 se define si hay posibilidad de encauzar al país por la senda democrática o si no hay posibilidad, en la lucha política, en lo que falta, no falta nada del 2009, el campo va a estar ahí, en el 2010, la recomposición de los poderes del Estado, fundamentalmente, el más importante, el Poder Electoral, pues, eso vamos a saber si se logra enrumbar de nuevo por el camino, por la posibilidad de la sostenibilidad democrática, o ya se ya por perdido, si ya se da por perdido, verdad, lógicamente, la única alternativa que queda es la rebelión, pues, y la resistencia ya no cívica, que es una posibilidad, y que ha sido una constante en nuestra historia, los ciclos de confrontación, los ciclos, la conciliación, vuelta a otro ciclo, pues, pero yo soy optimista, yo soy optimista, que hay las 
condiciones, hay las condiciones de toda índole, que permitan avizorar una posibilidad de forzar, porque tampoco va a ser para fácil para el Frente, ¿no?, de forzar, pues, hacer una línea de sostenimiento y de mantenimiento de unas reglas mínimas de convivencia democrática, mínimas, porque tampoco podemos soñar, quizás podemos, soñar que vamos a hacer cambios fundamentales después para pasar al país de las maravillas, no lo creo, pues, tendremos que hacer el análisis con mucho realismo, pero, sí, por lo menos, detener, detener, diría yo, el deterioro de la institucionalidad democrática para esperar mejores tiempos y mejores momentos, ¿no?

R: Y que la historia no se repita.

J.P.: Y romper, romper, romper la génesis de un nuevo ciclo de confrontación, y de violencia y de guerra civil.

R. O de un poder con una base familiar, y los paralelismos históricos entre los primeros tiempos de Somoza y lo que estamos viendo actualmente.

J.P.: Así es, no, que ya Somoza se le quedó chiquito, ahora, definitivamente, pues, estos tienen una teoría del poder muy clara, muy definida, el poder a cualquier coste, ¿no?

R: Pues si tiene algo más que añadir, yo creo que ha sido muy completa su intervención.

J.P.: No, está bien, gracias. 


\section{ENTREVISTA 3956:}

Nombre del entrevistado: D. Indalecio Rodríguez.

Cargo actual: Diputado de la Asamblea Nacional (2007-2011), presidente del Partido Liberal Independiente (PLI) y miembro de la bancada liderada por Eduardo Montealegre "Vamos con Eduardo".

Perfil de interés: completar / justificación de su elección como entrevistado.

Fecha de realización de la entrevista: Managua, 13 de noviembre de 2009.

Lugar: Asamblea Nacional de Nicaragua.

Duración estimada: 49 minutos.

\section{TEXTO - Transcripción 39:}

$R$ : ¿Cuál sería su visión sobre los cambios constitucionales que se han producido en el último periodo desde los años 90 hasta la fecha en Nicaragua, desde el momento mismo de la transición democrática?

I.R.: Bueno, tenemos que enmarcar o enfocar este tema, que es supremamente interesante, que usted está estudiando unos cambios de mucha importancia, tanto en lo que pasó en la historia reciente de Nicaragua, como en lo que va a pasar en los próximos meses en el país, nosotros nos encontramos, primero, con un panorama que llega en el año 87 en donde Don Daniel Ortega, seguro del triunfo que tenía, según todas las encuestas que le daba en un eventual evento electoral, siendo él dueño del Poder Electoral, siendo él dueño de todas fuerzas, inclusive, las militares y las policiales, etc., de todos los poderes del Estado, se dio a la voluntad de crear un nuevo poder, que no existía, que era el Poder Electoral, el cual existía, únicamente, como un instituto, verdad, que no tenía categoría de poder, para la cuestión crea un Poder Electoral, al que le dieron las mismas prerrogativas que a los poderes constitucionales, que se consagran en las constituciones, en las normas clásicas de las constituciones políticas, que son el Ejecutivo, el Legislativo y el Judicial, punto, ahora pusieron uno nuevo que es el Electoral, ese es un hecho nuevo que se da en la historia de Nicaragua reciente, se estaban preparando las posibles elecciones del año 89, entonces, se le fortalece en esas reformas que hacen, que si le vamos a dar interpretación estricta de lo que debe ser una Constitución, verdad, la Asamblea que tenían, la Asamblea, el Consejo de Estado que había en ese tiempo, era una Asamblea normal, que no tenía características ni facultades constituyentes, por lo tanto no tenía la facultad de modificar la Constitución y hacer una nueva Constitución, sin embargo, lo hicieron, ¿qué buscaban en eso?, en eso buscaban darle todos los poderes al presidente de la república, no se necesitaba ningún otro poder del Estado para gobernar Nicaragua, únicamente se necesitaba tener un presidente de la República, el presidente de la República tenía los poderes constitucionales, ejercía la interpretación de la Constitución, podía reformar la Constitución.

\section{$R:$ ¿Se refiere a la Constitución del 87?}

I.R.: Del 87, la que están ahí modificando, la del 87, y también tenía las facultades legislativas y las facultades también del Poder Judicial, totalmente, y se creó un Poder

56 Entrevista dispersa e irregular, que discurre con brevedad sobre los procesos de cambio constitucional experimentados recientemente en Nicaragua, pero que introduce algunas observaciones agudas y detalladas sobre los pactos políticos de interés para el análisis general. 
Electoral a su favor, sin embargo, cuando pasan las elecciones, y que, sorpresivamente, salen derrotados con una diferencia mayor que la que oficialmente se ha dado, porque ellos apenas alcanzaron dieciocho diputados.

\section{R: En las elecciones del 90.}

I.R.: En las elecciones del 90, entonces, en esas elecciones pese a todos los pronósticos, a todos los estudios de todos los organismos con mayor conocimiento del tema este, a nivel no sólo de Nicaragua sino de, prácticamente, todo el occidente, "harvardianos", "oxfordianos", todos pasaron por aquí diciendo el triunfo del Frente, sin embargo, a la hora de las verdades, cuando llega el proceso de votación fue un mar que se desató de gente votando en contra del Frente, y alcanzaron 18 diputados, es decir, el 18\% fue el porcentaje real, y esto los golpeó a ellos de tal manera que intentaron no entregar el poder, verdad, no reconocer el triunfo de la oposición, y ahí fue donde intervinieron los negociadores, tú sabes que ahí andaba metido el grupo de Contadora, que estaba representado, pues, por Venezuela, por Panamá, por Colombia, había dos países europeos que estaban muy comprometidos, como es el caso de España, tu país natal, y de Francia, que si no se da la entrega del poder estaban dispuestos a respaldar, vía fuerza, que se hiciese el cambio, y esa fue la gran oportunidad que se perdió en Nicaragua para haber limpiado esto para siempre, porque, por otro lado, intervinieron las fuerzas mediadoras, que tenían simpatía por ellos, como los famosos Marinol, por un lado, que tenían mucha influencia en el grupo Carter, y Carter fue un mediador, y también el propio Carlos Andrés Pérez, entonces, ellos intervinieron, y ante un mal mayor se contentaron con un mal menor, que es una frase que se usa mucho aquí y que a mí me repugna, pero, en fin, porque mucho daño nos ha causado, y de ahí llegaron, entre negociaciones y negociaciones, que, posiblemente, incidieron en la sustitución de los consejeros de Doña Violeta en aquella época, que estaba asesorada por el doctor Álvarez y por Pablo Antonio Cuadra, y otros tantos, y cierta cúpula de la UNO, que tenían una línea, pues, que decían que si se había ganado el cambio tenía que hacerse total, de igual manera que se dio la resolución de la OEA en el 78, cuando decidieron el cambio, la sustitución del régimen de Somoza, pero para ser sustituido por un gobierno democrático, verdad, no por un gobierno igual, con una dictadura igual, ni con un régimen militar, sino un Estado de Derecho, donde los tres poderes independientes tuvieran sus facultades y se pudieran ejercer de una manera autónoma, independiente, y en una forma en que nadie, ningún ciudadano saliera perjudicado o favorecido por el ejercicio de los mismos, entonces, el tema, pues, es que estas incidencias de los gestores, de buscar un arreglo para que no llegara a la confrontación donde pudo haber llegado hasta el desarme del Ejército que había en ese tiempo, que era el Ejército Popular Sandinista, que era el Ejército de un partido, no era el Ejército de la nación, ya después se da el cambio legal en el gobierno de Doña Violeta, que es una de las cosas positivas, pues, que pone la institución al servicio de la nación y no al servicio de un partido, eso se ha demostrado ahora, y lo que están haciendo a la Policía, que era una labor maravillosa lo que había hecho la actual directora, Doña Aminta Granera, la Comisionada Mayor, Doña Aminta Granera, a quien yo admiro, y ahora interviene el presidente y de golpe y porrazo le desarticula toda su estructura, toda su estructura ahí se la ha desarticuló totalmente, y ya están interviniendo en las manifestaciones, pero eso fue lo que se dio en aquella época y eso hizo que Pablo Antonio Cuadra, prominente intelectual, premiado por el Príncipe de Asturias y todo lo que usted quiera, un hombre estudioso, un hombre muy prudente y, sin embargo, era de esa tesis también, y el doctor Emilio Álvarez Montalbán igual, y así una serie de personajes de la historia de 
Nicaragua, que en ese momento todavía vivían, y eso hizo que, entonces, cierta fuerza, que andaba buscando el arreglo ahí de buscar cómo quedaban bien parados ellos en el cambio, fueron, como dicen vulgarmente, sacando mantequilla, empujando, que salieran del círculo de Doña Violeta las personas que tenían aquí un respeto y una influencia, pues, histórica impresionante por su comportamiento, por su vivencia, por su sapiencia, y se fueron metiendo personas como Antonio, su yerno, Antonio Lacayo, con quien me imagino que ya habló usted tal vez, y también personalidades de otros muchachos ahí que hasta el momento de hoy no han aprendido lo elemental, como el caso de Alfredo César, que lo hicieron presidente de la Asamblea, el otro Ministro de la Presidencia, cuando había un acuerdo de que tenía que ser el presidente de la UNO, y del grupo de la UNO, quienes tenían la decisión de designar y de quitar y de aprobar los arreglos, sin embargo, entre bastidores se impuso la gestión de Carter, del presidente Carter y, un poco más tarde, de Carlos Andrés Pérez, y apartaron a estas personalidades que tenían un respeto dentro del pueblo nicaragüense, y una experiencia, pues ya, en el tema político, que no lo debieron de haber desaprovechado y otra suerte, otra historia estaría viviendo el pueblo nicaragüense en este momento, yo mismo, en aquél momento, fui indiferente en esa época, pero después, ahora, viendo lo que pasó, digo que tenían razón, ellos tenían razón.

R: ¿Cuál era el planteamiento?, ¿se está refiriendo a la cúpula de la UNO?, ¿del partido?, $y$, por otra parte, ¿al núcleo directo colaborador de la presidenta?

I.R.: Sí, de Doña Violeta, yo me refiero a las tesis, a las posturas que habían asumido este grupo que, prácticamente, su cabeza más visible era Pablo Antonio Cuadra y el doctor Emilio Álvarez Montalbán, este otro, no me voy a poner a citarle ahí, que a eso me estoy refiriendo yo, porque da la casualidad de que después vinieron los españoles, antes que usted, vinieron buscando este mismo tema, y yo les referí mi versión, pero les dije yo, hombre, vamos a irnos a ver directamente, entonces, concerté la entrevista con Pablo Antonio Cuadra y él repitió esto, más o menos las mismas palabras que yo le estoy diciendo, no con la capacidad y la fluidez de él, además de quien vivió las acciones, dando los nombres y las producciones de cada uno de los que participaron, y de ahí, pues yo, algo se me quedó, y eso es lo que yo digo cuando me hacen estas preguntas, es decir, la versión de Pablo Antonio Cuadra, en España salió publicada, allí, esas cosas, en algún momento, porque después vinieron más grupos periodísticos a entrevistarlo, a verlo, y ví que repito, porque me buscaron para que les concertara la entrevista, pues yo les acompañé, y yo siempre con la amistad que tenía con Pablo Antonio, pues, me quedaba viéndole y tratando de aprender, nunca tuve el intelecto para aprender de él, él tenía más, pero sí me llamó la atención esos dos detalles, primero, de que no hubo tal 38\%, sino que a ese 38\% llegaron en la negociación que hicieron para que aquellos aceptaran entregar el poder el poder, es decir, es cuando se sacaron la famosa frase, que todavía la manejan, de "gobernar desde abajo", y por eso le hicieron la vida imposible al gobierno de Doña Violeta, y le hicieron la vida imposible al mismo gobierno del "Gordo", que rápidamente lo solucionó llegando a un acuerdo con ellos, donde se dividieron, ya vino otra, otra modificación más, a esas constituciones, verdad, y viene esto que decía al inicio de que siempre se ha cuestionado la legitimidad de la Constitución, en el sentido de que no era una Constituyente la que hizo esas modificaciones presidencialistas, totalmente, verdad, puesto que fue por una misma Asamblea, una Asamblea normal quien lo hizo, y por eso es que hay algunas personalidades que no firmaron esta Constitución, aún siendo miembros de ella, entre 
ellas está, pues, Camilo Zapata, Enrique Gómez, bueno, una serie de personas, que si vienes a buscar la firma de éstas no aparecen por ningún lado.

\section{R: Pero, ¿se está refiriendo a la Constitución o a las reformas parciales de los años 90?}

I.R.: A los años que precedieron las elecciones del 90, porque como estaban seguros, entonces, aquí todo el poder era para el presidente de la República, ya le digo que no se necesitaban, lo demás eran símbolos, hablar del Poder Legislativo era un símbolo, porque todo lo podía hacer el presidente de la República, legislar, etc., etc., pero después, cuando se dan las elecciones, se cambia el cuadro, entonces, comienza a hacer la reforma, verdad, en donde tuvieron mucho que ver los famosos "pescaditos", que se andan metidos en todos lados, los socialcristianos, tienen mucho que ver, que eran cuatro o cinco, y los cuatro o cinco han estado siempre mandando, siempre han estado, no han perdido, estaban con el Frente, luego se pasaron con Doña Violeta, se hicieron esas modificaciones y siguieron con Arnoldo hasta contralores y demás, y ahora, pues, están con la convergencia, ahí está Agustín Jarquín, ahí está López Rey, hay están todos metidos, son cuatro o cinco o seis, docenas, pero ahí están siempre metidos ahí, tienen una habilidad impresionante.

\section{R: ¿Para pactar?}

I.R.: Sí, y son ellos siempre, que es otro de los errores, el pacto original de los cambios que se hicieron en esta Constitución todo el mundo le echa el muerto al "Gordo" Alemán, y yo también así lo creo, que es el gran responsable, yo he sido un antialemanista por lo corrupto, y a veces no por lo corrupto, sino por lo corruptor, pero aquí también los pescaditos hicieron sus pecados, luego, y los que inician ese proceso son los "pescados", en el sentido, de que ellos fueron los primeros, aún antes de ser presidente Arnoldo Alemán en ir a buscar todos esos arreglos para hacer los acuerdos para dividirse los poderes con el Frente, para dividirse el poder, y mantener, única y exclusivamente, no pensaron en Nicaragua, sino que en la ruptura, digamos, de los principios éticos, morales, cívicos, que era lo que antes se privilegiaba en la enseñanza y en la formación de la gente, del ciudadano, esos se fueron echando para atrás hasta llegar a un punto de que hoy, prácticamente, no existen, hoy tener virtudes es un pecado $\mathrm{y}$ es un delito, el ser delincuente es un premio, ser un vivo, para estos políticos hay que ser corrupto, es ser vivo, es la viveza de ratón, es ser traidor, es ser desleal, usted va a ver la Asamblea, que se ha convertido como que si estuviera en una ganadería subastando ganado, pues, ahí todos tienen su precio, en eso, eso ya es la parte del "gordo", entonces, está ahí un cierto sector de gente, de personalidades de acá, que dicen, nosotros, yo lo dije en una charla en una ocasión, y después me dice el doctor Emilio Álvarez Montalbán en medio un evento: "tenés razón, Indalecio", entonces, estaban invitando para andar en los mítines, a mí no me gusta el protagonismo así tan desmedido, envanece a la gente y nada, entonces, de tal manera, pues, que esos son los orígenes de estos cambios de la Constitución en los 90, y después viene ya la actuación del "gordo", teníamos, había dos presidentes del Consejo Electoral, nada más, que el de las elecciones del 90 era nada menos que Mariano Fiallo Aranguren, verdad, Mariano Fiallo, y con un presidente tuvimos las elecciones, quizás, más conflictivas y todo terminó en sana paz, si se quiere hasta con la intervención de estas concesiones que se hicieron los triunfadores para que quien haya sacado un $18 \%$ de la votación subieran al $38 \%$, y que quedaran ellos "gobernando desde abajo", claro que con todas las 
estructuras que ellos tenían, el Ejército y demás, cuántas guerras hubo porque no les dejaban gobernar, pues, no les dejaban gobernar, y el "Gordo" cuando llega a la presidencia en el 97 sigue metido en el mismo fuego, y dicen: "no, esto lo vamos a arreglar fácil, esto es fácil, tranquilos", de tal manera que él va más delante de Daniel, Daniel, su grupo de valor, Serio Ramírez Mercado, Orlando Pineda, Edmundo Jarquín, etc., etc., éstos se paran, y de los treinta y siete o treinta y ocho diputados que tenían, únicamente le dejan siete a Daniel, el resto son de la línea sandinista, digamos, que querían mantener la ética, y que estaba en contra de eso, de ese arreglo, de ese amarre de "capos", que ya comienza a darse entre Daniel Ortega y Arnoldo Alemán, entonces, y lo que hacen ellos dos, ya lo sabe usted eso, pues, es bien sencillo, "teníamos un presidente, subámoslo a cinco, tantos tuyos y tantos míos", los magistrados eran siete, lo subieron primero a nueve y después a dieciséis, que hay ahorita dieciséis magistrados, la Corte Suprema de los Estados Unidos tiene siete, nosotros tenemos dieciséis, "entonces, son ocho tuyos y ocho míos", que es el problema que tienen ahorita con la sucesión, y ellos van a, en el Consejo Supremo Electoral, lo subieron a diez, verdad, siete propietarios y tres suplentes, pero que participan, verdad, "entonces, cinco tuyos y cinco míos", y el "gordo ${ }^{57 "}$ este, que, supuestamente, era de la formación de Monseñor, y que le dieron para que manejara en ese momento 100 millones de dólares, pues, se quedó con el $50 \%$ y después se quedó también en la distribución de todos los fondos que vinieron aquí a través de COPROSA, por eso es que tiene un capital enorme, un muchacho que andaba de pantalón chingo, y así, ahora usted lo ve un magnate con mansiones en Costa Rica, mansiones en Miami, creo que tiene una Francia, y ¿con qué cara salen a pedir dinero los hijos de su madre?, ellos son el vivo retrato, digo, lo que han robado, y el "Gordo" Alemán, creo que tenía una carbonera, pues, ahora también otro magnate, por todos lados, entonces, esas son todas las reformas que se hicieron aquí, el aumento de los Magistrados, el aumento de tal y tal, que benefician a dos personas, pues, y a sus secuaces, verdad, a sus forajidos, esas son las cosas que se viene a dar, la del 95 con los "pescaditos" y ya en el 98 con Arnoldo Alemán, que son las que están todavía vigentes.

R: Y luego la del 2005, bajo la presidencia de Bolaños, que es un presidente al que acosaron, gravemente, durante su mandato, tuvo enormes dificultades para desarrollar su agenda de gobierno.

I.R.: Es que precisamente una de las reformas que hay aquí cuando le bajas, das las distribuciones, en la Constitución original se requería el $45 \%$ de los votos para ganar las elecciones, entonces, hicieron lo siguiente, como el "gordo" quería seguir gobernando, "está bien", le dice Daniel, "esto es fácil, me bajás al 35\%", porque ya sabía él que el $35 \%$ lo podía manejar, ya después de que él tenía el $38 \%$, pues, si del $18 \%$ quedaron, oficialmente, con el $38 \%$, entonces, un $35 \%$, él consideraba que lo podía obtener, verdad, para ser presidente de la República, pero el "gordo" le dice: "ah, vos presidente, ¿y qué hago yo haciéndote presidente a vos?", "no te preocupés, hombre, vamos a dividir un poco los poderes ahí, tú vas a tener tu poder parlamentario, y vos por el mero hecho de ser presidente te ganás tu diputación constitucional", que es parte de la reforma del 2000, y, entonces, por eso hay un diputado que llaman constitucional, que es el ex-presidente de la República, el "Gordo" cuando entrega sale a ocupar la presidencia de la Asamblea y desde ahí comienza a fastidiar a Bolaños, entonces, ahí Bolaños no tiene más que, le tuercen el brazo, y tuvo que acostarse también con el

57 Se refiere a Roberto Rivas, actual presidente del Consejo Supremo Electoral. 
Frente para poder gobernar, o bien, renunciar e irse, porque no había manera, hasta que luego, entonces, le sacan todo el otro paquete, ya también el Frente, que no quería tener a alguien que le eclipsara, o que le compitiera y que le reclamara en igualdad de condiciones a Daniel Ortega, entonces, también estoy de acuerdo en que el "Gordo" había robado una barbaridad, y que los procesos que tiene y manda, porque toda la estructura judicial es del Frente.

\section{R: Esa es otra de las cosas que sorprende, como los jueces son afines al sandinismo.}

I.R.: Toda la estructura judicial, y las estructuras del Poder Electoral igual, ellos hicieron una cosa muy sencilla, ellos aquí les formaron unas estructuras de seguridad, pues, por los gobiernos estos, que había en esos tiempos, de la Unión Soviética, el grupo ese de la Unión Soviética, pues, alemanes, personajes estos de Bulgaria, cada uno con su especialidad, y esos son los que vienen, de la misma Cuba, el Ejército es obra de rusos y de cubanos, se lo monta con toda la estructura esa, y en la parte de seguridad a los países que la misma Unión Soviética usaba como sus satélites y de ahí vinieron a hacer la estructura de seguridad, entonces, esa gente que forma torturadores, las mismas cárceles que diseña Anastasio, cuando yo vine con una organización de Derechos Humanos me quedé horrorizado, yo que había sido prisionero en tiempos de Somoza, y que después había ido a sacar a muchos prisioneros, durante los tres años estuve aquí, que habían sido opositores y los tenían en las cárceles, cuál fue mi sorpresa cuando estábamos haciendo un recorrido y vimos un sala bajita, chiquita, una loseta, un orificio por donde corría el agua para beber y para hacer su higiene personal o sus evacuaciones allí, allí, y yo, pero, si está contra todo, si estaban violentando, ¿y por qué es que hicieron estas cárceles así?, con la mayor desfachatez dice: "todas estas cárceles fueron hechas para políticos".

\section{$R:$ ¿Para políticos?}

I.R.: Para políticos, porque usted se iba a cárceles, que consideraban ellos, de los delitos comunes, había aire, había luz, había más espacio, para los delincuentes comunes, asesinos, cualquier cosa que fuera, delincuentes comunes, tenían más, fue una de las tantas cosas que hicimos aquí, te digo que anduve tres o cuatro años ahí en los Derechos Humanos, en la organización de Derechos Humanos, para tratar de modificar, pero lo que me dio a mí con qué seguridad y con qué sorpresa, que le pregunto: "¿y cómo hicieron esto?, si esto es inhumano". "Es que éstas fueron las que se diseñaron", dice, "por los cubanos y por los tales para los presos políticos", "ah, ¿y para los delincuentes comunes?", "no", me dice, "ahora vamos a llegar", entonces, ya me hicieron otras giras por otras cárceles, ¿verdad?, entonces, ya tenían otra conformación, entonces...

\section{R: Perdón, ¿y esta gente de los cuadros de seguridad?}

I.R.: Entonces, estos cuadros de seguridad, cuando se viene el cambio, lo que hacen ellos es meterlos y graduarlos, porque usted se acuerda que hay una etapa en que ellos eliminan todos los parámetros, indicadores académicos, de excelencia académica, por lo que tanto había luchado Carlos Tünnerman, excelente persona, yo tengo especial aprecio por él, pero bueno, pero, en ese momentito, él tuvo esa flaqueza, porque fue el portador de esa noticia siendo el Ministro de Educación de la época, pero vale la pena, está luchando ahorita y está bueno, ha rectificado y está muy bueno, está bien, vale la pena, yo le tengo un gran aprecio, creo que podría ser una solución en determinado 
momento en el caso de Nicaragua, Carlos Tünnerman, entonces, dice ya eso desapareció, ¿verdad?, ahora tenemos que tener en cuenta, porque vamos a una guerra, ellos dicen que les hicieron la guerra, ellos hicieron la guerra, vamos a una guerra, porque aquí ahora lo que va a valer es el esfuerzo, el empeño, la decisión, que se ponga en defensa de la revolución, vamos a dar, a enfrentar a El Salvador, y de El Salvador se llega a Guatemala, y de Guatemala vamos a por Honduras, vamos a cercar todo lo que es la frontera sur de los Estados Unidos y vamos a abrirle frente también en el sur, en América del sur, ahí tenemos etarras, hasta yo sin querer anduve, sin saberlo, mejor dicho, anduve dándole right y trasladando etarras aquí en Managua, y una amiga me dice: "ven, ¿me ayudás a unos amigos con los que ando ahí con el Profesor Edelberto Torres?", que era casada con un cubano, después descubro que eran etarras, entonces, de tal manera que en España el primero que denunció la presencia de etarras aquí fui yo, allí en Madrid, y después me llegaron las amenazas de muerte, yo sin saberlo, me dicen: "no, lo que usted ha hecho es gravísimo".

\section{R: Pero volviendo al tema...}

I.R.: Entonces, volviendo al tema ese, pero es que estos son corolarios que van saliendo, aunque no es exactamente lo que usted quiere, pero son datos que por esas circunstancias, ya después vino aquí, y para rematarle lo de los etarras, la famosa señora Flores, ¿cómo es?, la que fue secretaria de Felipe González, que era la representante aquí, que venía aquí y era la principal apoderada y gestora de ayudas para el Frente en España, y viene a un Congreso y cuál es su sorpresa que encuentra a todos los etarras presidiendo la mesa.

\section{R: Pues eso sí que es una sorpresa.}

I.R.: Y se agarró sus maletas y no volvió nunca más a Nicaragua, esto lo puede preguntar usted en España, Flores es el apellido, no me acuerdo del nombre, entonces, en el caso de aquí, pues, básicamente, esas son las reformas que tiene la Constitución y es así como se llega a ellas, ahora cometen otra barbaridad, dos barbaridades seguidas, uno, la de las elecciones municipales, que es impresionante, pues, y la otra, que esa fue, pues, ahora en las elecciones del 2008, fueron las elecciones, donde se les barrió, con la excepción, tal vez, de dos o tres lugares, Estelí, Estelí lo ganaron ellos, y creo que Matagalpa, que siempre lo habían perdido y lo ganaron, en todo lo demás perdieron, en Managua se les barrió, en León se les ganó, nadie les había ganado en León, se le ganó todo lo demás, es tremendo, y se pudo documentar, se hizo un esfuerzo, y ahí el artífice fundamental fue Eduardo Montealegre y el equipo de él, que rescataron contra viento y marea las actas originales y se les han presentado a todos, es decir, para que los donantes y los cooperantes internacionales no tengan ninguna duda tiene que estar bien documentados, y no tuvieron ninguna duda, y por eso es fue por lo que retiraron la ayuda, porque lo que hicieron fue una barbaridad, porque usted sabe bien el esfuerzo que hicieron en Europa después de la Segunda Guerra Mundial para que la institucionalización de estos países condujera al desarrollo de ellos, entonces, el requisito que se pedía era el de que tuvieran un Estado de Derecho, pues, y en esa situación uno de los principales beneficiados fue España, y yo recuerdo haber recorrido Europa cuando los pobres españoles andaban buscando trabajo en Alemania y en todos lados, y de repente cuando ya España, el esfuerzo de todos los gobiernos de transición, con Adolfo Suárez, que fue una maravilla, y de los que le sucedieron, incluyendo el mismo Felipe González que era ya otra cosa diferente, ya Felipe González ahí cambia 
de mentalidad y es otra cosa, y después Aznar, pues, y todo eso, entonces, a España se le abren las puertas y se convierte en uno de los países de más desarrollo en Europa, y ahora se hace lo contrario, van a disputarse la preeminencia por verse ciudadanos españoles hasta del África les están llegando, es un país de inmigración ahora, esa misma cosa es lo que se esperaba aquí, verdad, y lo que está sucediendo es todo lo contrario, está sucediendo todo lo contrario, estas barbaridades.

R: Da la impresión de que en Nicaragua se repiten los ciclos de historia.

I.R.: Se repiten otra vez, vamos para atrás.

R: ¿Y por qué piensa usted que en el caso de las reformas constitucionales ha habido siempre conflicto entre el Ejecutivo y el Legislativo a la hora de aprobarlas? De hecho, las leyes Marco son un instrumento jurídico de dudosa constitucionalidad que sirven para ampliar un poco el proceso de la negociación política y dar más tiempo a los actores para que lleguen a arreglos, ¿no?, parece que en Nicaragua la política está por encima del Derecho, y que hay una tentación fuerte para estar al margen de la ley, para no respetar la institucionalidad.

I.R.: Es que ese es el concepto de política que tienen ellos.

$R:$ ¿Se refiere a los sandinistas?

I.R.: Y a los otros también, a los que participan en eso.

R.: ¿A los liberales de Arnoldo Alemán?

I.R.: A los liberales de Arnoldo Alemán, y, en un tiempo, los conservadores también, pero ya el conservatismo desapareció, ya no existen conservadores aquí más que cuatro personas y punto, pero, en ese momento, el pacto de los conservadores, los del 50, el líder conservador, Emiliano Chamorro, que era un verdadero caudillo, con Anastasio Somoza, y eso fue lo que nos trajo lo que nos trajo, si no hubiera existido eso, nunca hubiéramos tenido el 79.

$R$. Se refiere a la revolución.

I.R.: A la revolución.

R: Que es el producto de la dictadura somocista.

I.R.: De todas las dictaduras, eso fue.

$R: Y$, ¿cómo ve el futuro de su país?

I.R.: Entonces, esto que usted ya lo debe haber leído cantidad de veces, por ejemplo, el famoso artículo de las reformas, y fíjese bien, los Magistrados de la Corte Suprema de Justicia, la Sala Constitucional, esto que es la ley, la Carta Magna, la suprema de todas las leyes, ésta, ésta, ésta, sea motivo de un recurso de inconstitucionalidad, ¿cómo puede suceder eso?, si es que es la Constitución, es que lo que está aquí es lo máximo, entonces, ¿cómo puede haber recurso de amparo en contra la Constitución?, ¿o recurso 
de inconstitucionalidad contra la Constitución?, ¿verdad?, y son los ilustres sabios de birrete que declaran la inconstitucionalidad de la Constitución Política de Nicaragua para permitir la reelección del presidente, ya que está prohibida en la Constitución. Ya voy a terminar rápidamente la entrevista, me entusiasma tanto, ya veo que está bien informada del tema, que hubiera querido ampliarle otros capítulos más, pero a grosso modo es lo que le estoy refiriendo, que estamos viviendo una etapa donde se ha roto el orden constitucional, y en donde en todas las leyes nacionales está abierto el derecho de rebelión cuando llegamos a ese estado de ruptura del Estado de Derecho, no tenemos Estado de Derecho ahorita en Nicaragua, y, desgraciadamente, con la complicidad, somos minoría, en la Asamblea somos minoría, y ese es nuestro gran problema.

\section{R: Se refiere al liberalismo que no está con Arnoldo.}

I.R.: Al liberalismo independiente, me refiero a algún sector del liberalismo constitucional que no está con Arnoldo, me refiero a MRS, con quien nos llevamos muy bien, pero, desgraciadamente, pues, tenemos, y a algún que otro independiente, en el resto están esperando a que les hagan una señal los caudillos.

\section{R: O sea que se puede reeditar el pacto Ortega-Alemán y Alemán podría ser candidato en las próximas elecciones presidenciales.}

I.R.: Es que el pacto existe, esa es la gran equivocación que tienen muchos, el pacto está, ahí lo va a ver usted ahorita, creo que hoy o mañana ya sale el anuncio ahí de la distribución de los jueces, de los jueces y de los Magistrados de apelaciones, se han nombrado, que andaban ahí soñando algunos ahí con quienes discutimos, andaban soñando, no, aquí va a ser la primera prueba de que esto no se va a repetir, entonces, ¿qué es lo que vamos a hacer?, vamos a hacer que desde la sociedad civil, que desde los colegios de abogados, que desde las universidades nos vengan los candidatos que vamos a proponer para estos cargos, entonces, no, eso ya lo tenían arreglado, se anuncia públicamente de hoy a mañana, usted lo va a ver, y se va a acordar de mí, ahí va a salir, entonces, el pacto existe, no es que van a hacer pacto, el pacto existe, verdad, y lo que están buscando, dos cosas, son: uno, anular y acabar con Eduardo Montealegre que se iba a presentar, y está cayendo en la trampa, Eduardo está cayendo en la trampa, y ayudado por algunos que se dicen demócratas, pero que, en realidad, se están decantando por este juego, y dos, vamos a ver, en cuanto vengan los Magistrados de la Corte Suprema, que ya comienzan los primeros, creo que son cuatro que se vencen a inicios del próximo año, van con la distribución, y van a quedar empatados para no pelearse, ahorita no van a elegir a unos, verdad, como no han querido elegir al difunto Guillermo Selva, del PLC, que fue PLI, al difunto no lo han querido elegir para quedar empatados y seguirse llevando, "sí, hombre, esa sentencia te la doy teniendo los votos nuestros y vos dame los tuyos", que ninguno de los dos tenga para que se mantenga ese estatus de armonía, es decir, el pacto existe, no van a hacer un nuevo pacto, lo mantienen simplemente.

\section{R.: ¿Y no va a haber recomposición del liberalismo contra Ortega?, ¿no lo ve usted probable?}

I.R.: Pues, estamos ansiosos y activos en ese esfuerzo, pero las realidades, a veces, lo que dan ganas es de recurrir a lo que ya recurrimos antes, a soltarle las riendas a ese campesinado que se está muriendo de hambre, a ese campesinado y a esa pobreza que 
no ve señales de redención y que no son tan brutos como para no darse cuenta de lo que está pasando, tienen, supuestamente, las ayudas que vienen de Venezuela, que habían prometido ellos de Venezuela para solucionar los problemas del campo, la producción, y aparecen las compras de las grandes sociedades de Ortega con Chávez, que ahí andan las Alba tal cosa, las Alba-Caruna, Alba- Seminoles, Alba-Netic, y están haciendo un monstruo de imperio, que se está distribuyendo por todos estos países, que están conformando, pero que son de carácter personal, a nosotros en la Asamblea no nos ha llegado un solo, un solo proyecto, por eso el problema que tuvimos ahorita, un solo proyecto de aplicación e inversión en capital o inversión social, verdad, de esos fondos que, supuestamente, después van a obligar a pagar al pueblo nicaragüense, como hicieron con los préstamos de la Unión Soviética, con las donaciones soviéticas, todo el dinero donado por el imperio soviético, todos los países que conformaban el imperio soviético, una vez que llegaron aquí se convirtieron en deudas, y decían que eran donaciones, eso es lo que va a pasar ahora, así que discúlpeme si no le contesté a sus preguntas de otra forma, pero esto es, en resumen, lo que está sucediendo en el país.

R: No, al contrario, muchas gracias por su intervención. 


\section{ENTREVISTA 40 ${ }^{58}$ :}

Nombre del entrevistado: D. Enrique Sainz.

Cargo actual: Diputado de Movimiento Renovador Sandinista (MRS) en la Asamblea Nacional (2007-2011).

Perfil de interés: completar / justificación de su elección como entrevistado.

Fecha de realización de la entrevista: Managua, 18 de septiembre de 2009.

Lugar: Domicilio particular del Sr. Sainz en Managua.

Duración estimada: 54 minutos.

\section{TEXTO - Transcripción 40:}

R: ¿Cuál es su visión sobre el proceso de cambio constitucional que ha marcado la reciente transición democrática en Nicaragua? Durante los tres últimos gobiernos liberales, y la propuesta actual de reforma, que, aunque está paralizada desde las últimas elecciones municipales, está en el debate entre las distintas fuerzas politicas, ¿no? ¿Cuál ha sido el hilo conductor de las reformas?

E.S.: Bueno, a lo largo de la historia de Nicaragua, por lo menos en el siglo XX, y lo que va del siglo XXI, la Constitución, desde mi punto de vista, fundamentalmente, ha sido un expediente, verdad, en lugar de un instrumento fundamental para normar la vida ciudadana y el curso del país, un expediente que se ha acomodado a los intereses, fundamentalmente, de quien ejerce el poder, $\mathrm{y}$, en la mayoría de los casos, las reformas constitucionales han sido con el propósito de favorecer la continuidad de quien ejerce el poder, estoy hablando de manera muy amable. A partir del período de Somoza, digamos, en la década de los 30 , realmente, las constituciones y sus reformas, en una primera etapa, sirvieron para que la dictadura o dinastía somocista se cubriera con un manto institucional, pero, en realidad, las reformas y aún las nuevas constituciones sirvieron para, fundamentalmente, para enmarcar lo que era la reelección presidencial como un mecanismo institucional para darle un cariz al régimen. Esto hasta 1979, verdad, en 1979, bueno, la Constitución o las constituciones, que habían prevalecido sufrieron una ruptura, verdad, estuvimos sin Constitución, era un Estatuto, que se llamaba Estatuto Fundamental hasta la Constitución de 1987, que pretendía reflejar la realidad de la revolución, de tal manera que constituciones, que pretendieran, efectivamente, reflejar el curso de la vida social, yo diría que, desde la década de los 30 hasta la Constitución de 1987, se trata de constituir un instrumento jurídico fundamental, bueno, no duró mucho, verdad, en 1990, tres años después, triunfaron, electoralmente, las fuerzas opuestas civiles al régimen revolucionario, y allí la Constitución empezó a relativizarse, en el sentido que fue la dinámica de las correlaciones de poder la que fue imponiendo un estiramiento, o un achicamiento de los alcances de la Constitución hasta la reforma de 1995. Entonces, yo diría que las dos expresiones constitucionales más genuinas fueron la de 1987 y la de 1995, aunque fueran contradictorias, por así decirlo, pero de alguna manera eran intentos de reflejar, institucionalmente, las correlaciones y la dinámica social, entonces, las reformas constitucionales de 1995, principalmente, de la misma manera que la de 1987 intentó

58 Entrevista que ofrece un discurso crítico, que no descuida el análisis de los principales factores de evolución política y constitucional del país, con especial interés sobre la reconstrucción de los pactos intra-élites entre el Ejecutivo presidencial y la Asamblea Nacional en el marco de las recientes reformas. 
enmarcar el proceso revolucionario, la de 1995 intentó enmarcar el proceso de transición democrática, verdad, y de alguna manera la reversión de los principales andamiajes de la Constitución de 1987, algunos elementos de ese cambio, la Constitución de 1987 era, fundamentalmente, presidencialista, otorgaba al presidente un conjunto de poderes en distintos ámbitos, la reforma de 1995 intenta democratizar el poder trasladando parte de él a la Asamblea Nacional, igual instrumentos de poder fundamentales como el Ejército y como la Policía, también, que cambian de naturaleza de instituciones fundamentalmente partidarias a instituciones nacionales, de tal manera que en la historia constitucional de Nicaragua, aunque fueran de distinto signo, me parece que las principales piezas han sido, en términos de ser expresiones genuinas de la dinámica social, la de 1987 y las reformas de 1995. Las otras reformas, básicamente, han estado marcadas por lo que ha sido también una constante, a excepción de estas dos de 1987 y 1995, que han sido los pactos entre caudillos, verdad, Somoza encontró en un caudillo del partido, supuestamente, adversario, un cómplice habitual, verdad, para repartirse el Estado, o el usufructo, más bien, que daba el poder del Estado, o de detentar el poder en las instituciones del Estado, entonces, en las reformas de 1999 y las siguientes, fundamentalmente, fue la reedición de un pacto de caudillos, pero con distintos personajes, verdad, Arnoldo Alemán y Daniel Ortega, pero ya de una forma, por así decirlo, con objetivos espurios, nuevamente, las viejas taras, vicios, de la política tradicional, el patrimonialismo, repartirse el Estado, "esto es tuyo, esto es mío", la impunidad, "bueno, aquí borrón y cuenta nueva", Alemán obtuvo la impunidad frente a sus actos de corrupción, Ortega obtuvo la posibilidad de ser electo, ensancharon, artificialmente, los poderes del Estados, incrementaron a 16 los Magistrados de la Corte Suprema de Justicia, a 7 los Magistrados del Consejo Supremo Electoral, a 5 la Contraloría General de la República, con el propósito de construir espacios para colocar a sus allegados, de tal manera que de estas reformas, prácticamente, lo que han sido, desde mi punto de vista, es una reedición de las viejas taras. ¿Todavía se utiliza en España la expresión "tara"?

\section{$R: S i ́, s i ́$.}

E.S.: Es decir, los resabios viciosos del pasado, así podría caracterizar de manera general el proceso, verdad.

R: De todos modos, aunque si es cierto que la reforma del 95, la mayor parte de los entrevistados con los que he tenido la oportunidad de conversar a propósito de las reformas, así lo ha señalado, era una reforma necesaria por el propio cambio o la evolución del régimen político hacia un pluralismo democrático, digamos, dar entrada a los actores que habían quedado relegados o excluidos durante la revolución, se plantea el primer debate serio entre una reforma total o una reforma parcial, y como estuvo desde ese inicio, también, del proceso constitucional reciente el enfrentamiento entre el Ejecutivo presidencial, que no quiere perder gran parte de las atribuciones de un texto que consagraba unas atribuciones fuertes en la figura del presidente, y la Asamblea, que quería tener protagonismo democrático, que se le exige habitualmente a cualquier sistema político moderno. ¿Cuál es visión al respecto?

E.S.: Bueno, tristemente, verdad, tristemente, no sólo en Nicaragua, sino que en América Latina, tenemos esa tara, ¿no?, no sé de dónde viene, de la simbiosis, una es herencia colonial, creo yo, pero no es, necesariamente, una herencia andaluza o española, sino que es de la simbiosis o de la dinámica que se genera después de la 
independencia y que a partir de la, por ejemplo, sólo es una digresión, por determinadas circunstancias estoy leyendo el período de la independencia, verdad, y un poco a Bolívar, verdad, entonces, todas las contradicciones entre los generales, verdad, y la Gran Colombia y Perú y Venezuela, etc., ya, cómo se produjo la ruptura y la independencia en estos países con el General Báez, Santander, los peruanos, etc., y no, no ha cambiado de manera drástica, ¿no?, entonces, vuelvo con que da la impresión de que hay una transformación cuando uno llega a ejercer el poder, como que se calza el mismo traje que se calzaron los anteriores, ¿no?, entonces, en el caso del período de Doña Violeta, más que, Doña Violeta era la persona que, en realidad, ejercía poder, con unos antecedentes, digamos, sin mayores vicios, de repente una vez que asume una función se transforma $\mathrm{y}$, paradójicamente, es quien más resiste la transformación, vamos a ver, quiénes impulsan o acompañan en la transformación es una segregación del Frente Sandinista en la Asamblea, como un sector dentro de la Asamblea, que era de la antigua Unión Nacional Opositora (UNO), entonces, con el propósito de democratizar la Constitución, y quienes encabezan el proceso de democratización desde el Ejecutivo se oponen, es un contrasentido, que, por un lado, estaban impulsando el proceso de democratización, pero, por otro lado, concentrando poder en el Ejecutivo, bueno, es casi una constante histórica en este país, no tengo explicación para eso, sí, es cierto, así ha sido.

R: Y luego, en el caso de la reforma del 2000, a la que precede el pacto, que también es una constante en la historia de Nicaragua, esos pactos políticos, antes lo mencionaba, entre partidos o entre líderes, mejor dicho.

E.S.: Más bien caudillos, más que partidos han sido personajes, que tienen unas características comunes a lo largo de la historia, realmente.

$R:$ Sí, se refiere a una personalidad politica fuerte, al concepto de líder, porque también he oído un discurso antropológico, hay una referencia constante en los entrevistados para explicar lo actual, porque no es una cosa nueva, tampoco insólita de Nicaragua, es decir, porque pactos que preceden a reformas constitucionales están presentes en otros países de América Latina, ¿no? Y sí, el concepto de pacto, de hecho, el Dr. Alejandro Serrano Caldera antes decía que la palabra "pacto" se ha desvirtuado mucho después del Pacto Ortega - Alemán, que da lugar a una inflexión, yo creo, en el proceso de reforma constitucional, porque si se reparten los principales poderes del Estado en composición paritaria de los dos principales partidos, y también surgen las fuerzas anti-pacto, ¿no?, que también complejizan el propio escenario político del país. ¿Cómo ve esta evolución reciente y que, de alguna forma, se está viviendo en la actualidad?

E.S.: Bueno, yo creo que igual, verdad, que estaba, bueno, yo soy un aficionado a la historia, y, entonces, estaba leyendo, precisamente, los pactos, los arreglos, que aquí se ha desacreditado mucho la expresión, pero no ahora, desde los pactos de Somoza en sus distintas etapas, realmente, primero, que pareciera como que lo que están haciendo es copiar lo que ya otros hicieron, yo si tuvieras la oportunidad te invitaría a leer algunas de las reformas constitucionales y de los pactos de la década del 30, de la década del 40 y de la década del 50, y uno no encuentra ninguna originalidad, y todos obedecen a la misma concepción política, verdad, algunos dicen cultura política, si no a la misma concepción de lo que es política, bueno, el concepto patrimonial del Estado, el concepto clientelar del Estado, el poder como un instrumento de acumulación económica, y está 
sintetizada en una frase que se le atribuía a Anastasio Somoza García, que era el fundador de la dinastía, que eran las tres P de Somoza: "plata, dinero, para los amigos, palo para los indiferentes, y plomo para los adversarios", ¿no?, esa ha sido, prácticamente, una constante, entonces, el pacto de Alemán y de Ortega es, simplemente, una reedición de la misma tradición política, no tiene ninguna novedad, y aún, contradictoriamente, las reformas del 2005, contradictoriamente, verdad, aparecen como unas reformas que limitan el poder del Ejecutivo, porque el presidente Bolaños alguna independencia quiso ganar de los dos caudillos, entonces, los dos caudillos se unieron para limitar el poder del Ejecutivo, pero con el propósito de conservar ellos el poder, de tal manera que ahora que está Ortega en el poder, él que fue el precursor, junto con Alemán, de reformas para limitar al Ejecutivo, ahora, simplemente, rompe con las normas constitucionales, cotidianamente, por ejemplo, en estas últimas reformas del 2005, para amarrar al Ejecutivo obligan a que un conjunto de funcionarios, ministros, embajadores, etc., deban ser ratificados por la Asamblea para mantener atado al gobierno de Bolaños, probablemente, Ortega nunca pensó que iba a llegar a ser presidente, verdad, y ahora que es presidente, todos los cargos que ha designado ninguno lo ha mandado a ratificación del Poder Legislativo, en consecuencia, un buen número de embajadores y de ministros son usurpadores, porque no han sido, es decir, están ejerciendo sus funciones en contradicción con la Constitución, entonces más que líderes, verdad, estamos hablando del concepto tradicional de caudillo, que obedecen a unas pautas históricas, que, tristemente, no han cambiado.

R: Y, sin embargo, el socio perdedor en el pacto sí fue Alemán, porque Ortega ha ido acumulando una concentración de poder a través del propio aprendizaje del Frente durante 16 años de oposición y de ir gobernando desde abajo, porque creo que esa fue la expresión de Ortega cuando perdió las elecciones en el año 90, y sobre todo copar buena parte de toda la institucionalidad del Poder Judicial, ¿no?, que es fundamental, si es independiente, para garantizar ese equilibrio de poderes al que, supuestamente, tiende un régimen constitucional.

E.S.: Sí, realmente, aquí estamos frente a una perversión, verdad, esta es una democracia pervertida, en la que lo que parece, en realidad, es su contrario, no lo que parece, exactamente, aquí, digamos, el perdedor relativo ha sido Alemán, porque él participó en el pacto desde una perspectiva de, desde su perspectiva, ¿verdad?, de permanencia en el poder como socio mayoritario, y, entonces, le dio al otro, igual que en el período de Somoza, el tratamiento de socio minoritario, que obtuvo, y así aspiraba Alemán, obtuvo la impunidad, en primer lugar, aparentemente, obtuvo una participación mayor en los poderes del Estado, y un control de los poderes del Estado, a cambio Ortega obtuvo la posibilidad de ser electo al reducirse el porcentaje necesario para acceder a la presidencia, efectivamente, Alemán hizo muy malos cálculos, todos sus cálculos se vinieron abajo, porque, una vez que sale Alemán de presidente, él tiene muy penetrada a la Policía, un poder de corrupción increíble, ya con preparación de relevos en el Ejército, controlados todos los poderes del Estado donde era mayoría, y en la Asamblea Nacional la elección de la directiva es veinticuatro horas antes de que asuma el nuevo gobierno, para darle posesión al nuevo gobierno, entonces, en la Asamblea eligieron un presidente y una directiva, que fue la que le dio posesión a Enrique Bolaños, ese presidente a las 24 horas renunció, volvieron a convocar el plenario de la Asamblea, y eligieron a Alemán como presidente de la Asamblea, en consecuencia, Alemán tenía el control absoluto, poder económico, poder político, el control del Ejecutivo, porque entre los candidatos del Partido Liberal él cogió al peor, a una 
persona casi anciana, que había estado medrando al amparo de su poder, y que no tenía ningún liderazgo, en consecuencia, él aspiraba a controlar el Ejecutivo, y a controlar la Asamblea, prácticamente, un accidente en estos días, que Alemán no fuera declarado rey, verdad, en Nicaragua, porque, seguramente, en algún momento le machacó un pie a Bolaños, o tal vez, en un arranque de ebriedad lo ofendió, entonces, se quedó callado y empezó a ver al presidente para pasarle la cuenta, eso es un accidente histórico, porque, además, lo tenía todo, y pues, seguramente, con un machacón en el pie, una empujada, algo ahí cambió la historia, porque una vez que llegó Bolaños sacó las uñas y a los 9 meses Alemán, pues, perdió la impunidad por la alianza de Ortega con Bolaños, perdió la impunidad, perdió la diputación, fue enjuiciado, y ahí empezó su declive, a transformarse en un socio minoritario, pero es curioso, verdad, a pesar de todo el deterioro de Alemán, no por su liderazgo, sino que, por ser espejo de Ortega, sigue emanando su poder del control personal que tiene de los Magistrados, de las personas que están en las instituciones, y Ortega necesita a Alemán para poder desarrollar su proyecto, y Alemán ahora medra de su relación con Ortega para poder mantenerse como un actor político.

R: En ese sentido, el presidente Bolaños, quizá, es un ejemplo de presidente acosado, porque se queda sin el apoyo de su partido en la Asamblea, y, por otra parte, se ve metido en ese triángulo de enfrentamientos, e inaugura lo que es la división del liberalismo, que es un balón de oxígeno para el propio Ortega.

E.S.: Así es, así es, realmente, yo diría que Daniel Ortega, porque muchos decían que inteligencia política, dicen todavía, de Arnoldo Alemán, verdad, cuando pasó de una mayoría, y de tener todo el poder a ser prisionero y ahora hacerlo socio minoritario, yo creo que Daniel Ortega ha capitalizado, hábilmente, porque le han ayudado muchísimo las torpezas de sus adversarios, verdad, entonces, no es que sea un genio de la política, sino que, primero, que sus adversarios han sido terriblemente torpes, $\mathrm{y}$, segundo, que ha conservado instrumentos de poder, que, por circunstancias, se han transformado en instrumentos decisivos, no porque hubiera un cálculo político, empezaron a meter jueces locales y jueces de distrito en el Poder Judicial, en un, más bien, como para dar empleo a gente afín, pero no porque tuvieran el cálculo de que eso iba a ser instrumento de poder, no, como era un instrumento totalmente deteriorado, verdad, y corrupto, pues, más bien, para colocar a empleados, jamás calcularon que, en algún momento, se iban a transformar en instrumentos reales de poder político. Entonces, eso cayó del cielo, es decir, cayó del cielo, digo, eso fue una cuestión que la dinámica impuso, y él se encontró de repente con un instrumento de poder, entonces, yo diría que han ocurrido por lo menos unos tres acontecimientos circunstanciales, que han propiciado a Ortega la posibilidad de acumular poder, acontecimientos circunstanciales, porque nada tenía que ver en eso: el enfrentamiento de Bolaños con Alemán, ¿ya?, la pretensión de Bolaños da la impresión de que llegó a odiar más que prevaleció su odio personal sobre su odio ideológico, llamémoslo así, y, entonces, él prefirió arreglarse con Ortega para enfrentar a Alemán, eso fue una condición circunstancial, no fue resultado de ninguna habilidad de Ortega, porque si, efectivamente, el cálculo de Alemán se hubiera concretado, pues, Ortega ahí estuviera todavía arrinconado, el cálculo de tener un monigote de la presidencia con Bolaños, el tema del Poder Judicial como arma política, pues, también fue una circunstancia, verdad, de meter gente, y de repente, encuentran que puede ser también como instrumentos de poder político, y después el fenómeno de la división de los liberales por la emergencia de Montealegre, igualmente, es una circunstancia, lo que sí es definitivo es que Ortega no ha tenido el más mínimo escrúpulo, verdad, al 
momento de tomar sus decisiones, y aprovechar las contradicciones y las circunstancias favorables que se le han presentado.

R: De hecho, si bien los procesos de reforma han sido liderados por la Asamblea en el 95, en el caso de la reforma del 2000 es un pacto en aras de la gobernabilidad, por eso de que no existe un mecanismo en los sistemas presidenciales, como es el caso de Nicaragua y de otros muchos sistemas presidencialistas de América Latina, que toman como referente el modelo norteamericano, cuando el Ejecutivo y el Legislativo no se ponen de acuerdo se produce una crisis institucional y un bloqueo entre ambos poderes, que paraliza la actividad gubernamental, o sea, es imposible desarrollar para el presidente su agenda de gobierno si no tiene un apoyo en el parlamento. Ese es el discurso, que legitima un poco el pacto entre Ortega y Alemán, al margen de sus circunstancias personales, que, bueno, les obliga a escapar de sus acusaciones por distintos delitos, y ambos se escudan en esa figura de la inmunidad, que es uno de los aspectos de la reforma constitucional del 2000, ¿no? En el 2005, la reforma sigue siendo liderada por ambas figuras, y ahora la iniciativa procede del Ejecutivo de Ortega, que se ha fortalecido, a su juicio, en relación al ejercicio de la presidencia de los tres presidentes liberales. ¿Cómo ve el gobierno actual de Ortega?

E.S.: Bueno, a mí me parece, primero, aquí, cuando decía, que estamos ante una democracia pervertida en la que lo que parece, efectivamente, es su contrario, nosotros partimos de la tesis de que aquí hay un proceso dictatorial en curso, verdad, cuando uno lee el proceso de instalación de la dictadura somocista, ¿qué hizo Anastasio Somoza García?, uno, controlar un partido, y, entonces, acabó con todos los adversarios en el partido y se transformó y construyó un instrumento político a su servicio personal: el Partido Liberal Nacionalista. Es lo mismo que hizo Ortega. ¿Qué hizo Somoza?, acordó con el gran capital un entendimiento de fondo, "bueno, ustedes no se metan en política y yo les voy a garantizar las condiciones para que ustedes sigan estando", estamos hablando del gran capital, entonces, aquí nos encontramos con que los grandes grupos económicos, o sea, los dos más grandes grupos económicos acompañan hace dos meses a la delegación del gobierno a Washington a solicitar al Fondo Monetario la continuidad del programa, entonces, lo mismo que hizo Somoza, verdad, y al mismo grupo Pellas en aquél momento le garantizó una protección para su producción azucarera, etc., etc., de la misma manera que Ortega a la oligarquía más, a pesar del discurso anti-oligárquico, con la oligarquía más rancia están arreglados. ¿Qué hizo Somoza?, impulsar algunas medidas populistas, el Código del Trabajo, la Seguridad Social, para dar un manto popular a su gobierno. Bueno, éste igual, éste tiene su "Hambre Cero", su "Usura Cero", etc., para su clientela política. ¿Qué hizo Somoza?, bueno, agarró al partido de oposición, pactó con su caudillo para repartirse el Estado, y que estuvieran tranquilos, $40 \%$ de la Asamblea, 40\% de los cargos diplomáticos, 40\% de las alcaldías, una representación en los ayuntamientos, etc., lo mismo que hizo Ortega, entonces, primer punto, entonces, estamos a diferencia del de Doña Violeta y del de Bolaños, porque Alemán sí pretendía un poder omnímodo, pero no tenía instrumentos de represión política, Ortega tiene un proyecto dictatorial con instrumentos de represión política, ¿verdad?, pero, igualmente, pervertidos, el Ejército y la Policía, que son los cuerpos, por definición, de la coerción, Ortega está construyendo fuerzas paramilitares, que son las que se encargan de reprimir las expresiones de rebeldía o protesta, etc., y la Policía, lo que hace es, paradójicamente, quedarse amarrada frente a la acción de lo que se llaman las turbas, que para nosotros ya algunas de ellas tienen el carácter de fuerzas paramilitares, entonces, tienen control institucional, tienen control represivo no oficial, 
verdad, y también un gran poder económico proveniente también de otra bendición, que es la existencia de Chávez, verdad, entonces, más la voluntad dictatorial, entonces, en estas condiciones la Constitución se transforma en un chicle, verdad, ahora la Constitución es, y el aparato, digamos, jurídico, incluyendo el Poder Judicial, se transforma en un chicle que se estira o se encoge dependiendo de si se trata de ensanchar el poder, o castigar, o de acumular poder, entonces, si se trata de un conflicto con los banqueros, que son detentadores de bonos del tesoro, y quiere negociar la reducción de las tasas de interés, entonces, un juez embarga los bonos y le dice a los banqueros: "bueno, si no los entregan van presos", entonces, esa es la negociación para reducir las tasas de interés; un periodista piensa investigar y se encuentra con que están chantajeando a unos inversionistas y el chantaje de la oficina de Ortega y lo graba, entonces, el periodista tiene una ONG, y, entonces, hay un juicio en contra del periodista, en este caso Carlos Fernando Chamorro, verdad, y entran, ¿necesitan una fuerza represiva clásica?, ¿ver a los carabineros chilenos allanando un edificio?, no, lo hacen con la cobertura de un mandamiento judicial, entonces, la Coordinadora Civil hace una asamblea para presentar una propuesta de solución a la nación, discuten su propuesta y salen en una marcha para celebrar la presentación de su propuesta con un concierto juvenil, entonces, vienen las turbas, los atropellan, los golpean, etc. Estoy poniendo tres ejemplos de naturaleza distinta, entonces, aquí estamos, clara y rotundamente, frente a una voluntad dictatorial que va avanzando día a día, y, en este contexto, las reformas constitucionales tienen un objetivo único: permitir la reelección presidencial, que es el expediente institucional para afianzar el proyecto, entonces, esta discusión es espuria, de presidencialismo o parlamentarismo, aquí no hay más que una coartada para tontos, verdad, que lo que pretende es esconder la reelección presidencial.

R: ¿Y si se abre la puerta a la reelección presidencial? No parece probable que Ortega vaya a conseguir los apoyos necesarios en una Asamblea que cuenta ya con un frente de oposición entre los liberales críticos con el pacto, o con el MRS, que es la fuerza que usted representa, $u$ otras fuerzas minoritarias con las que tampoco mantiene un buen diálogo. Usted que es diputado, ¿cómo se está desarrollando el actual gobierno desde la arena parlamentaria?, ¿cómo se dan los acuerdos entre los legisladores para sacar adelante la agenda de gobierno?, ¿cuál es la posición del Frente en ese sentido?

E.S.: Bueno, yo quiero decir que yo soy un novicio, verdad, en esto, yo tuve una vida anterior, verdad, fuera de la política, de hecho, bueno, trabajaba en la Unión Europea, en los últimos diez años antes de entrar en la política, y no dejo de sorprenderme cada día, verdad, porque es, pero bueno, eso es anécdota, diría que el pacto ha continuado en la Asamblea, y que Ortega ha gobernado con mayoría a pesar de ser una minoría electoral significativa, pero minoría, pero ha gobernado como mayoría por el pacto con Alemán, entonces, los aspectos fundamentales de las decisiones han sido aprobadas por la bancada del PLC, presupuesto, reformas presupuestarias, reformas legales, el tema de los recursos de la cooperación venezolana, que no pasan por el presupuesto, entonces, básicamente, se han opuesto, únicamente, en aquellos casos extremos donde están a punto de perderlo todo, nada más, verdad, entonces, por ejemplo, Ortega introduce un recurso de amparo en contra de una iniciativa de ley que está en proceso de aprobación, y la Corte admite el recurso de amparo, es decir, no sé si me estoy explicando, hay una ley que está en discusión en la Asamblea, y, entonces, interpone un recurso de amparo para paralizar la discusión de esa ley, porque es inconstitucional, una aberración, si mientras no sea ley no puede declararse inconstitucional, entonces, el propósito era tener el control de lo que la Asamblea podía aprobar y no podía aprobar, eso era 
confiscar, prácticamente, el espacio o uno de los espacios de poder, y quedar, totalmente, en la llanura, ahí pudo articularse una mayoría parlamentaria opuesta al gobierno, pero salvo, que ha sido, tal vez, unos dos casos extremos, donde el orteguismo ha pretendido quedarse con todo, que ha podido articularse una oposición frente a Ortega, y, en consecuencia, darse un bache en el pacto, pero Ortega ha gobernado como mayoría con el apoyo de la bancada del PLC.

R: ¿Y parece probable que vaya a obtener los votos necesarios para abrir la puerta a la reelección, que transformaría, completamente, la evolución política del país en los próximos años?

E.S.: Sí, los próximos dos meses, probablemente, van a marcar el escenario de los próximos dos años, ¿por qué los próximos dos meses?, porque están juntando un paquete, un combo, ¿conoces la expresión combo?, en el Mc Donald te dan un pastel de manzana, un té, o una cocacola, una hamburguesa más ensalada por tal precio, entonces, un combo es una oferta que incluye varios ingredientes por un solo precio, tenés que conocer, verdad, porque aquí hay muchas cosas que van, como decimos aquí, "va en combo", o sea, va con todo, entonces, aquí como se suspendió la ayuda presupuestaria de donantes importantes, más un declive en las recaudaciones fiscales, el presupuesto tiene un gran agujero, entonces, el gobierno ha tenido que hacer recortes presupuestarios $\mathrm{y}$ tiene que hacer un nuevo recorte antes de diciembre, para poder financiar el presupuesto del 2010 también tiene una propuesta de reforma tributaria, de incremento de los impuestos, pero a partir de diciembre se van a elegir a renovar más de 30 cargos de las diferentes instituciones importantes del Estado, todos los miembros de la Contraloría, todos los miembros del Consejo Supremo Electoral, el Superintendente de Bancos, 4 Magistrados de la Corte Suprema de Justicia, el Procurador y el SubProcurador de Derechos Humanos, un filete, ¿no?, un filete para quien tiene la vocación patrimonial, entonces, hay reforma presupuestaria, reforma tributaria, elección de cargos, vamos a ver, el presupuesto del 2010, que tiene que aprobarse antes del 15 de diciembre, y empieza a discutirse el 15 de octubre más la posibilidad de reforma constitucional, ese es un paquete, que contiene muchos incentivos, y que podría favorecer un acuerdo en combo, que incluya la reelección, las reformas constitucionales. Pero, por otra parte, la magnitud de los obstáculos, unos se han mantenido y otros han crecido, porque ellos tenían la voluntad y el acuerdo de aprobar reformas en 2007, no pudieron, porque el Frente cometió la torpeza de mientras ya tenían casi el acuerdo con las reformas constitucionales, se fueron a la yugular con el proceso de formación de la ley, entonces, los liberales se asustaron, y se generó un ambiente de confusión y de oposición, que impidió que aprobaran las reformas en el 2007. Después las tenían hasta impresas las reformas del 2008, también en otro paquete, verdad, nos repartimos las elecciones municipales, Ortega y Alemán, matamos al Partido Conservador y al MRS, le robamos las elecciones entre los dos en Managua a Eduardo Montealegre, que, en consecuencia, es un cadáver político, en 15 días se acaba el escándalo por las elecciones municipales, viene Navidad, La Purísima, aquí es una celebración, bueno, y diciembre es una alharaca hasta que termine el año. Entonces, el cálculo era que en todo eso iban las reformas constitucionales, no calcularon que el tema del fraude de las elecciones municipales tuviera tanto impacto y tanta durabilidad, que dejó a Alemán desnudo frente a la opinión pública, e imposibilitado contra su voluntad de concretar el acuerdo con Ortega, entonces, trataron de crear comisiones para abril, trataron de crear comisiones para junio, después para septiembre, y cada vez ha sido más complicado, como dicen algunos médicos, las reformas están con pronóstico reservado, se está 
generando una ola con este combo, que puede facilitar la aprobación, pero, de todas maneras, puede hacerlo Montealegre, puede hacerlo Alemán, el que se meta a eso, realmente, corre un riesgo muy grande, porque además Ortega ha tenido éxito en copar el poder del Estado, verdad, ha tenido éxito en mantener la fidelidad hasta ahora de sus bases, y ha tenido éxito en mantener contenida la protesta social, pero ese éxito no es irreversible, y no, necesariamente, duradero, porque, en términos prácticos, en otras áreas, mejor dicho, este gobierno ya fracasó. ¿En qué sentido?, bueno, la economía nicaragüense creció en el 2007 menos que en el 2006, en el 2008 menos que en el 2007, y ahora en el 2009 va a crecer menos que en el 2008, claro, la crisis internacional, etc., pero también las mismas políticas del gobierno. El desempleo es mayor, y, en consecuencia, la pérdida de ingresos de la población es mayor, en consecuencia, los niveles de pobreza más allá de la propaganda gubernamental son mayores, eso es una ecuación, menos crecimiento económico, menos empleo, menos ingresos igual más pobreza, no ha tenido los recursos en el presupuesto para compensar por la vía de la educación o de la salud, de tal manera que hay un fracaso económico y hay un fracaso social, y la fractura en esta sociedad, pues, ya alcanza niveles de división. ¿En qué momento empieza la confrontación?, podemos discutir, 3 meses, 6 meses, 1 año, ¿cuánto tiempo la gente va a estar dejándose garrotear de los grupos paramilitares orteguistas? Entonces, el avance de su poder no está acompañado de legitimidad social, y el control social no, necesariamente, está asegurado, de tal manera que aún, esto casi lo diría sin grabar, verdad, aún y cuando aprobara las reformas constitucionales y la reelección, la posibilidad de gobernar cada vez va a ser más difícil para Ortega.

R: Aparte de por su edad, ya es un líder que lleva protagonizando la vida pública de este país desde el año 79 en adelante, en la oposición nunca dejó de ser la cabeza visible del sandinismo, y, por tanto, de estar al frente de su partido. ¿La renovación del liderazgo de los ochenta no ha desaparecido de Nicaragua?, ¿no hay una nueva generación de politicos que encabecen las distintas formaciones partidarias y que protagonicen el debate?

E.S.: Lo que pasa es que Alemán también, por alguna razón, el poder otorga longevidad, ¿no?, por alguna razón, porque aquí hubo el socio del partido opositor de Somoza, que se llamaba Emiliano Chamorro, estuvo en la política nicaragüense desde 1916, en 1926 intentó un golpe de Estado, que fue el que dio origen a la guerra constitucionalista y a la lucha de Sandino, a propósito de constituciones, entonces, el tipo estuvo activo desde 1916 por ahí hasta 1950, que fue el Pacto de los Generales, que le llamaron, de Emiliano Chamorro y de Anastasio Somoza, 40 años en la historia del país, bueno, Ortega viene siendo 30 años ya desde el 80 , y no tiene, acabó con todos, en eso sí fue tremendamente exitoso, de acabar con toda la disidencia, con toda alternativa a lo interno del Frente, bien para nosotros, ¿verdad?, en este caso, para el MRS, porque, prácticamente, los principales valores intelectuales, morales, etc., del sandinismo están en el MRS, pero mal para el país.

R: Pues yo creo que ha sido una entrevista muy interesante, no sé si tiene algo más que añadir que a mí se me haya escapado, pero creo que hemos hablado, prácticamente, de casi todo en este "atribulado país”, como me decían por email antes de viajar, ¿no?

E.S.: Bueno, para mí ha sido una plática. 


\section{ENTREVISTA $41^{59}$ :}

Nombre del entrevistado: $D^{a}$. María Eugenia Sequeira.

Cargo actual: Diputada de la Asamblea Nacional de Nicaragua (2007-2011), miembro de la Bancada Democrática Nicaragüense y del grupo político "Vamos con Eduardo", liderado por Eduardo Montealegre.

Fecha de realización de la entrevista: Managua, 27 de noviembre de 2009.

Lugar: Asamblea Nacional de Nicaragua.

Duración estimada: 37 minutos.

\section{TEXTO - Transcripción 41:}

R: ¿Cuál es el recorrido que hace, mirando hacia atrás, desde los años 90 hasta la fecha sobre los cambios constitucionales que se han producido en el país en el marco de la consolidación de las instituciones democráticas?, ¿qué avances y qué retrocesos se han dado?

M.E.S.: Bueno, en primer lugar, creo que es importante hacer ver que a partir de los años 90 veníamos de un Estado totalitario, un Estado donde persistió la dictadura durante 10 años, y con el triunfo de Doña Violeta se inicia un nuevo proceso hacia la democracia en Nicaragua, perdida en un atraso económico, institucional y todo, entonces, las reformas, ha habido creo que tres o cuatro reformas, aproximadamente, en este tiempo, lastimosamente, Nicaragua se ha deslucido cuando cada vez que hace reformas constitucionales las hace a niveles personales, particulares, lo que trae como consecuencia que, al poco tiempo, tiene que hacer otra reforma constitucional para adaptarla a los intereses del que, en ese momento, tiene el poder de reformar, entonces, por ejemplo, creo que una de las reformas que se dio fue para inhibir a Don Toño Lacayo en ese tiempo para que no fuera candidato, pero otra de las reformas que se dio fue en el tiempo de cuando era presidente el doctor Arnoldo Alemán, donde se llegaron a acuerdos entre el Frente Sandinista y el Partido Liberal Constitucionalista de una cogobernabilidad, a lo que se llamado el pacto, verdad, donde se distribuyeron, prácticamente, la proporcionalidad de los poderes del Estado, donde también en la reforma constitucional de un mecanismo de tal manera que, prácticamente, los partidos pequeños dejaran de existir y se inhibieran de participación política, también en estas reformas constitucionales bajaron el techo de, por ejemplo, que tanto estamos reclamando ahorita, del 40\% de los votos para elegir presidente de la República a 35\%, lo que ocasionó, por ejemplo ahorita, que de una manera fácil el Frente Sandinista tuviera el $35 \%$ de los votos y no se tuviera que dar una segunda vuelta, entonces, te repito, lo que se ha logrado es adaptar la Constitución a los intereses particulares de los que tienen el poder, en ese momento, de transformarla, entonces, Nicaragua, mientras no supere y haga reformas profundas a la Constitución, de una manera imparcial, donde se busque el fortalecimiento de las instituciones y no el fortalecimiento de los partidos políticos, entonces, Nicaragua va a seguir, permanentemente, haciendo reformas constitucionales en el país.

\footnotetext{
59 Entrevista breve, con un discurso centrado en las dificultades introducidas por el pacto entre el FSLN y el PLC sobre la evolución política y constitucional reciente de Nicaragua, así como las previsiones futuras de la unidad liberal, en el marco del nuevo escenario político generado por la vía libre a la reelección presidencial de Ortega.
} 
R: De todas maneras, hay que comparar los procesos, la reforma del 95 es la que, a todas luces, goza de mayor legitimidad, porque fue la más consensuada, al margen de que arrancara con un gran debate entre la reforma total y la reforma parcial a la Constitución original del 87 para aumentar las atribuciones de la Asamblea, del órgano Legislativo, en detrimento de ese Ejecutivo presidencial tan fuerte.

M.E.S.: Sí, la verdad es que, independientemente, que hayan tenido la participación, el consenso, siempre es promovida por intereses particulares, siempre, siempre, todas las reformas en Nicaragua desde 1900 y pico, cuando Zelaya, cuando los conservadores, cada quien ha ido adaptando las reformas constitucionales, hoy, por ejemplo, están insistiendo, por ejemplo, el partido de gobierno en unas nuevas reformas constitucionales, donde ellos quieren crear, pasar de un sistema presidencial a un sistema parlamentario, donde ellos tengan un total control absoluto de todos los poderes, porque, prácticamente, ahorita sólo tienen el poder, tienen todos los poderes a excepción del Poder Legislativo, entonces, ellos a través de un cambio de sistema presidencial a parlamentario, ellos pretenden controlar también ese poder, aunque el presidente de la Asamblea sea sandinista, pero todavía hay voces, y todavía hay un sistema, donde hay un equilibrio de poderes, actualmente, ¿no?, y que podemos nosotros ahorita, como Poder Legislativo, pronunciarnos, independientemente, de un presidente de la República.

R: Y siempre ha habido, por otra parte, conflictos institucionales a propósito de las reformas, ya en el 95 fue un gran esfuerzo para que la presidenta pudiera avanzar, ¿no?, de hecho, ella quería seguir gobernando con la Constitución del 87, y fue la Asamblea Nacional la que lideró todo el proceso de ley de reforma parcial a la Constitución del 95, y fue el entonces presidente de la Asamblea, Luís Humberto Guzmán, el que mandó publicar la ley, porque la presidenta Doña Violeta no quería hacerlo, ¿no?

M.E.S.: Sí, es que, precisamente, Nicaragua todo el tiempo ha estado en estos conflictos, pues, ya sea para los intereses de los gobernantes o en diferentes, ¿cómo te diría?, por ejemplo, pues, ahorita, al extremo de que ni siquiera salió la reforma constitucional en la Asamblea y ya cambió el artículo donde no puede ser reelecto continuamente ni por más de dos períodos el presidente Ortega, entonces, hasta donde llega el manoseo de la Constitución, que ni siquiera pasa por la legitimidad ante quienes puedan reformar y transformar, ¿hasta dónde estamos llegando?, pues, porque una cosa grave es lo que estamos ya viviendo a estas alturas en Nicaragua, el hecho de que, no sé si conocés la sentencia, ¿verdad?, la sentencia donde sin ningún poder le da, le crea nuevas funciones a un poder que no las tiene, como te digo, de reformar la Constitución, porque ahí ni 20 sentencias podrían haber formado la Constitución en ese artículo.

R: Efectivamente, del conflicto entre el Ejecutivo y el Legislativo a la hora de reformar la Constitución, en este último episodio de la sentencia se ha enfrentado el Legislativo con el Judicial, ¿no?, y es que ha habido también esa iniciativa de ley de invalidar la sentencia, ¿cómo ve la actuación del órgano Legislativo actualmente?, ¿qué puede hacer ante todo esto?

M.E.S.: Es que si vos me preguntás a mí, a nivel personal, yo no estaba de acuerdo en que se metiera una iniciativa de ley para invalidar la sentencia, porque la sentencia no tenía validez, primero, porque, prácticamente, es una injerencia, o sea, que la Asamblea 
dijera: "no, vos no podés emitir una sentencia", no es correcto, porque sí puede emitir una sentencia, entonces, en primer lugar, eso era un error, y, en segundo lugar, al nosotros meter una iniciativa para invalidar la sentencia estás reconociendo que es una sentencia, entonces, yo soy de la opinión de que no se debió de haber metido esa iniciativa de ley para invalidar algo que no existía y que más bien nos metía a un conflicto de poderes, porque lo que va a resultar es que van a decir: "bueno, aquí hay un conflicto de poderes, porque el Poder Legislativo está invalidando un actuar, una facultad del otro poder del Estado", aunque la facultad la haya ejercido mal, pero tiene la facultad de emitir sentencias, entonces, para mí es no reconocer que eso es inválido, pues, que Daniel Ortega, únicamente, no puede ir a las elecciones nacionales, no puede, ni que tenga 20 sentencias ahí, no sirve, porque no tiene facultades para reformar la Constitución, se debió de haber reformado la Constitución, primero, a través de la Asamblea Nacional, entonces, no tienen ellos facultades, ellos podrán comprar diputados, hacer lo que sea, reformar la Constitución, pero reformar la Constitución para cambiar ese artículo, no a través del Poder Judicial, y además en la forma en que lo hicieron, pues, en la ausencia de los otros Magistrados, todo el procedimiento, pero el procedimiento es tontera, es que simple y sencillamente no tienen la facultad para cambiar un artículo de la Constitución.

$R: Y$, sin embargo, esto tiene un precedente, digamos, este deterioro grave que se está produciendo en el valor normativo de la Constitución tiene ya un precedente también en el año 2000, ¿no?, cuando se pactan de forma negociada y poco transparente las reformas entre Arnoldo Alemán y Ortega, bueno, en aras de la gobernabilidad, supuestamente, para que el Frente no siguiera cooptando gran parte de la agenda de gobierno, como había sucedido con el gobierno de Doña Violeta, ¿no?

M.E.S.: Sí, es el llamado pacto, que le llaman, ¿verdad?, donde eliminan partidos políticos, y en esa, porque en esa reforma ponen medidas en las cuales los partidos pequeños, prácticamente, desaparecen, ¿verdad?, luego bajan del 40\% al 35\% el techo, pues, del porcentaje pare elegir presidente en Nicaragua, y así, pues, una serie de cosas, la manera de la suma aritmética para poder, ¿cómo te diría?, salir electos los diputados también, eso favorece a los partidos grandes, más que a los chiquitos, entonces, es una serie de elementos a la reforma del 2000 que le trae consecuencias también graves, y lo que se hace es un pacto donde se pierde el Estado de Derecho, porque ya las instituciones, los poderes del Estado están al servicio de dos personas, me entendés, en la distribución de los cargos, en la alternabilidad de los poderes que tienen, por ejemplo, ellos llegaron a tales acuerdos, que, por ejemplo, un año le tocaba la presidencia de la Corte al PLC, el siguiente año al Frente Sandinista, y se distribuían las comisiones en el Poder Judicial, entonces, todo estaba totalmente hecho a la medida de dos personas, nada más.

$R: Y$, sin embargo, también la división del liberalismo ha favorecido enormemente a Ortega, ¿no?

M.E.S.: Sí, efectivamente, y esto trae como consecuencia, primero, el sistema del partido político PLC, que siendo un partido liberal y democrático, se mantenía bajo lineamientos verticales, y eso provocó, verdad, que un grupo nos separáramos del PLC, y encauzáramos una nueva forma de hacer política, sin embargo, trajo también pronto la división, pues, que se ocasiona en el PLC, esa división trae como consecuencia el triunfo del Frente Sandinista, pero yo también soy franca, lamentablemente, nuestro 
país no aprende las lecciones, nuestro pueblo no aprende las lecciones, independientemente, que la reforma constitucional del 2000 se haya bajado el porcentaje del $40 \%$ al 35\%, yo creo que para el gobierno que hizo el Frente Sandinista en los 80 , este partido político, es más, el mismo presidente que se estaba reeligiendo no debió de haber sacado ni el 6\% en las elecciones presidenciales, con toda franqueza te lo digo, o sea, a mí me asombró, enormemente, que el Frente Sandinista volviera a sacar casi lo que sacaba siempre, pues, no sé si es que desde entonces ya había fraudes electorales, me supongo que sí, de una u otra manera, y vos sabés que 3 puntos o 1 punto es fundamental en unas elecciones presidenciales, y la verdad es que es bien difícil, pues, entender cómo volvemos a caer en las mismas, pues, igual en el tema del partido liberal, quien reconocía el liderazgo de Arnoldo Alemán y todos los nicaragüenses conocían el liderazgo de Eduardo Montealegre, y bueno, es parte de la democracia, pues, pero sí creo que son errores propios del pueblo de Nicaragua, no sólo es, como te repito, el error de dos o tres personas, sino que del mismo pueblo de Nicaragua.

R: Pero este tema de la renovación del liderazgo es, realmente, complicado, ¿no?, porque además si comparamos los últimos cuatro presidentes que ha tenido Nicaragua, incluyendo el actual, la figura de Arnoldo Alemán y de Ortega, como hombres fuertes de sus respectivos partidos, con una gran capacidad de articulación de la fuerza partidaria, y también de ejercicio del control sobre sus diputados, ¿no?, es muy distinto de Don Enrique y de Doña Violeta, que además se vieron, absolutamente, abandonados por sus respectivos partidos en la Asamblea, o sea, tenian que ir negociando casi individualmente con los diputados para sacar adelante la agenda de gobierno.

M.E.S.: Lo que pasa es que también, creo que el presidente Bolaños jugó un papel no acertado en la política, ¿verdad?, yo podría decir que él también pactó con el Frente Sandinista, dice él que se vio obligado a pactar, pero yo creo que él desde el arranque, desde el inicio, nunca tuvo, ¿cómo te diría?, la voluntad de acercarse al partido, yo, en ese entonces, ya era diputada, y te puedo asegurar que tomó un camino más fácil, y te digo desde el inicio, porque si bien es cierto que él estaba opuesto a que Arnoldo Alemán fuera el presidente de la Asamblea en ese tiempo, eso no lo debía haber obligado a pactar con el Frente Sandinista, porque la realidad es que eso trajo otras consecuencias graves, pues, su obsesión en ejercer el gobierno fue la desaforación del doctor Alemán, que yo considero que no fue legal, para mí no fue legal, yo era diputada, e independientemente de los calificativos que se le puedan señalar al doctor Alemán, yo te aseguro de que no fue legal, y eso trajo serias consecuencias para el país, hubo una oxigenación del Frente Sandinista, o sea, no contribuyó, sinceramente, no contribuyó, creo que él como mandatario debió de haber luchado al menos un año en acercarse al partido, ¿verdad?, no que ni siquiera tres meses luchó en acercarse al partido, pero llegó al poder, ¿verdad?, a pesar de que no era el candidato de las bases, el candidato de las bases era Eduardo Montealegre, y quien lo impuso a él como candidato fue el mismo Arnoldo Alemán, y la verdad es que él no buscó el acercamiento, no luchó por el acercamiento hacia el partido, yo era diputada en ese tiempo y te lo digo con toda franqueza.

R: Y, sin embargo, el propio Arnoldo Alemán no ha querido, o sea, sigue siendo el líder indiscutible del PLC. 
M.E.S.: Con todo, y las barbaridades, es que él tiene un liderazgo fortísimo, ¿verdad?, ha decaído enormemente, porque si vos ves en las encuestas él tiene una antipatía del $70 \%$, verdad, a nivel nacional, y a nivel de partido, de liberales, es mucho más alto, porque, realmente, la figura de Eduardo ha sido una alternativa, un cambio de un liderazgo diferente, no es un liderazgo autoritario, es más demócrata, y además se ha visto, totalmente, lo que no le ha gustado a las mismas bases liberales o al mismo simpatizante con el liberalismo es de que él ha co-gobernado con el Frente Sandinista, bajo un pacto, haciéndole mucho daño al pueblo de Nicaragua.

R: ¿Y piensa usted que el pacto sigue vivo?, ¿que Arnoldo Alemán es cómplice, de alguna manera, de esta situación de la reelección presidencial, o vería con buenos ojos presentarse a las próximas elecciones presidenciales, como candidato por el PLC, y que, nuevamente, nos encontráramos a Alemán y a Ortega como líderes de un país, que parece que no sale del pacto, que sigue gravitando sobre la politica nicaragüense?

M.E.S.: Bueno, yo te podría decir, y estoy casi segura que es corresponsable de lo que es el fraude electoral, también es responsable con el Frente, de ahorita, de la reelección, sin embargo, se necesita la unidad en el país, de todas las fuerzas a disposición, y él es un líder dentro del PLC, y no se puede cometer el error, como cometió Bolaños, de quererlo apartar, sino que se integre, y que participe de una manera, con equilibrio, ¿verdad?, en la unidad de las fuerzas opositoras, ¿por qué razón?, porque se necesita hasta el último voto, y si él, actualmente, con su partido representa un $6 \%$ del electorado, o un $12 \%$ del electorado, o peor aún, un $20 \%$ o $25 \%$ del electorado, se necesita ese electorado, se necesita también los 21 diputados que tiene en la Asamblea Nacional para hacer las transformaciones y las reformas, para detener, ¿verdad?, las reformas constitucionales mal intencionadas, y para hacer la elección de Magistrados correctos al Consejo Supremo Electoral, entonces, esos dos elementos son fundamentales, y no se puede olvidar un liderazgo, ni quererlo exterminar, es imposible, no lo hizo un presidente, con todo el poder y la fuerza que tuvo, con toda la comunidad internacional, como lo hizo Bolaños, entonces, lo que hay que hacer es, ya se sabe a lo que te estás enfrentando, invitálo y que participe, y eso es lo que se está haciendo.

$R:$ ¿Y cómo ve el resto de lo que queda del periodo de gobierno de la Asamblea hasta las próximas elecciones presidenciales y legislativas de 2011?, ¿y esta renovación de los cargos públicos que están pendientes en unos meses?

M.E.S.: Bueno, yo creo que hay un acuerdo firmado, recientemente, entre las fuerzas de oposición y, principalmente, de los líderes de los partidos liberales, lo firmó Eduardo, lo firmó Arnoldo, lo firmó Alejandro Mejías Ferreti, el presidente de ALN, y todos los partidos liberales, y hay tres puntos fundamentales, uno es que ninguno de los Magistrados del Consejo Supremo Electoral se va a reelegir, otro, que se tienen que hacer transformaciones profundas al Consejo Supremo Electoral, cuando te hablo de eso es que podés cambiar los de arriba, pero si queda la estructura interna de abajo, igual, es como que no hicieras nada, y tercero, es la unificación para conformar un solo partido liberal, el hecho de ese compromiso significa, ¿cómo es que se llama?, que tenemos esperanzas, porque por mucho que nos unamos, por mucho que detengamos una reforma constitucional, por mucho que hagamos todo lo que hagamos, sí vamos a las elecciones el próximo año, aún que fuera Daniel o no fuera Daniel, si vamos con esos mismos no hacemos nada, entonces, si el Partido Liberal Constitucionalista ha accedido a hacer unas transformaciones profundas en el Consejo Supremo Electoral y a elegir 
hombres y mujeres cabales para esos cargos, yo creo que eso es un avance enorme, enorme, enorme, enorme, y, entonces, ahí ya está viendo un producto más favorable, que si hubiéramos apartado, hubiéramos marginado, hubiéramos querido exterminar a Arnoldo Alemán, que queramos o no queramos es un líder político y eso se tiene que tomar en cuenta.

R: ¿Pero no va a ser él un obstáculo para que se presente una candidatura única por parte de todo el bloque liberal?

M.E.S.: Es que si él no se somete a una, ahora, él debe de estar claro, él es una persona inteligente, y debe de estar muy claro que si él va de candidato Nicaragua pierde, perdemos, perdemos a Nicaragua, eso tenelo por seguro, que se pierde la presidencia, y él lo debe de saber, lo debe de sentir, porque así como hay un anti-danielismo, hay un anti-arnoldismo radical, que no va a salir a votar jamás, y necesitamos de esos votos para que la oposición gane, esa es la realidad, pues, entonces, él tendrá, tiene que haber un mecanismo, ya sea de consenso, de primarias, no sé qué, donde se elija un candidato único de la oposición, él sabrá, si le conviene o no le conviene, porque el hecho de que él sea un candidato y pierda, porque puede perder, él tiene más posibilidades de perder ante Daniel Ortega, en las encuestas que nos dicen, el daño va a ser para él también, para su familia, para Nicaragua entera, entonces, él tendrá que valorar.

R: No, la polarización está presente en la sociedad nicaragüense como en tiempos de la guerra, ¿no?, solo que en un ámbito, digamos, democrático por muy frágil que sea.

M.E.S.: Sí, sí, pero ya son los primeros pasos, y yo veo que han sido pasos muy buenos, pues, que él nunca iba a dejar sentado un MRS, un PLC, a un "Vamos con Eduardo", todos, ni los unos con los otros, ni los otros con los unos, esa es la realidad, pues, nunca, nunca imaginaste ver en un mismo salón a Dora María Téllez, a Víctor Hugo Tinoco, a Eduardo Montealegre, o a Eduardo Montealegre con Arnoldo Alemán, o a Arnoldo Alemán con ellos, nunca, nunca, o los conservadores también con los liberales, o sea, todo estaba totalmente fraccionado y se está haciendo un gran intento, no es lo mejor, falta mucho por hacer, eso no es una garantía para que caminemos todos juntos, pero ya es, pues, un esfuerzo enorme.

R: Porque sí se observa que de esa desconcentración de poderes, que arranca con la primera reforma constitucional del 95 para tener un equilibrio entre el Ejecutivo y el Legislativo y los restantes órganos del Estado, se ha pasado a una concentración de poderes en manos de un único partido, ¿no?, y también un fortalecimiento del Ejecutivo de la figura de Daniel Ortega desde que empezó su período de gobierno, a pesar de que el Ejecutivo estaba, constitucionalmente, muy debilitado por las últimas reformas, tanto en el 95 como en el 2000 y en el 2005, ¿no?, ¿piensa que, realmente, se pasó de esas atribuciones reales a la Asamblea a una cooptación por los intereses partidarios?, ya lo dijo antes, ¿no?, pero aumentar el poder de los partidos políticos incrementando las facultades de la Asamblea, la Asamblea es el escenario institucional de los partidos en democracia, pero aquí se ha pervertido un poco el juego institucional.

M.E.S.: Totalmente, yo te decía, anteriormente, que hay un manoseo total al Estado de Derecho en Nicaragua, y, por un lado, el presidente Ortega quiere un cambio de sistema político en el país, o sea, supuestamente, él dice: "voy a darle más poder a la Asamblea Nacional con una reforma constitucional, un parlamentarismo", pero, por el otro lado, él 
se centra en un poder absoluto de él, a nivel de Presidencia, no sólo con sus facultades que él tiene en funciones, sino que extralimita a los otros poderes del Estado, entonces, te podés imaginar lo que va a significar un poder, un sistema parlamentario, donde el sistema que él propone parlamentario, prácticamente, son sus piezas de ajedrez donde él sí puede meter las manos y tocar la Asamblea, es cierto que todas las Asambleas tienen, ¿cómo te diría?, sus conflictos verdad, de que si compras a un diputado, de que si hacer, todos los presidentes hacen sus gestiones para ganar votos en determinadas leyes, pero el objetivo de él no es ese, es un poder absoluto sobre todos los poderes del Estado, sobre las alcaldías, que ¿vos creés que él se robó las alcaldías por querérselas robar?, no, todo tiene un fin, en los 80 no existía límite de poder, no existía el poder descentralizado en los gobiernos municipales, era un solo poder, la Asamblea no servía para nada, si él gobernada por decretos, entonces, a ese mismo sistema, prácticamente, ha sometido el país, nada más es una versión moderna, como digo yo, es un orteguismo moderno, es un socialismo del siglo XXI, que le llaman, es, nuevamente, dictadura, verticalismo en su gobierno.

R: Y respecto al Poder Judicial, que es otra institución muy dañada, igual que el Poder Electoral, ante la opinión pública me refiero.

M.E.S.: Bueno, lamentablemente, leí en las noticias ayer, no sé si leíste los periódicos, el doctor Alemán, porque hay cuatro Magistrados que se les vencen sus períodos, o sea, hay que elegir cuatro Magistrados del Poder Judicial, lamentablemente, Arnoldo Alemán ayer dio declaraciones y su partido diciendo que ellos sí están aceptando los cambios de, ¿cómo es que se llama?, del Consejo Supremo Electoral, pero no así no van a ceder lo de ir a la repartición de los cargos en el Poder Judicial, sin embargo, no sólo ellos tienen con el Frente 56 votos, nosotros podremos tener también 56 votos con el Frente, y elegir mejores gentes que ellos, a lo mejor, no sé, vamos a ver, entonces, lo que te digo es que no está todo ganado, al menos el Consejo Supremo Electoral ya es un avance, pero ayer fue claro Arnoldo Alemán, diciendo que él no cedía los Magistrados de la Corte Suprema de Justicia.

R: Porque además el partido, bueno, el PLC, en este caso, es el único recurso de poder con el que cuenta, digamos, para enfrentar tanto el orteguismo, como para sobrevivir como partido dentro de las estructuras de poder del Estado, ¿no?

M.E.S.: Él tiene poder no sólo en la Asamblea, no sólo como partido, él tiene poder en el Consejo, él tiene poder en la Corte Suprema de Justicia, y él tiene poder también en el Ejecutivo, hay muchos nombramientos que son parte del pacto, que, por ejemplo, INE, el Instituto de Energía lo maneja el PLC, o sea, ellos también tienen parte del pastel del Ejecutivo, entonces, él al ceder su poder en el Consejo Supremo Electoral es un gran avance, pues, porque también tiene controlado todos los poderes del Estado.

\section{R: Pero siendo socio minoritario del pacto.}

M.E.S.: Pero no, sólo socio minoritario, sino que hasta rehén del Frente Sandinista, pues, de Daniel Ortega.

R: Y ya para terminar, cree posible, antes hacía referencia a la necesidad, bueno, yo creo que es una necesidad del país de experimentar la fortaleza, digamos, del marco constitucional, y no permitir que la Constitución sea moneda de cambio, digamos, de 
diferentes partidos, y que los ajustes sean tan fáciles o que la política esté por encima del Derecho, que es la impresión que uno tiene cuando examina los cambios recientes de la Constitución en Nicaragua, ¿no?, ¿piensa que es posible hacer un pacto constitucional en el que quepan todos los nicaragüenses y que sirva de referencia jurídica a la acción política de todos los partidos?, porque la Constitución del 87 dejó fuera a una parte de Nicaragua que no se identificó con el proyecto revolucionario, y las reformas han ido siempre en aras, por lo menos a partir del año 2000, de los partidos dominantes.

M.E.S.: Mirá, si se logra cambiar el Consejo Supremo Electoral, poniendo gente honesta, se podrán hacer reformas constitucionales que queden por mucho tiempo establecidas, afianzando el Estado de Derecho y la institucionalidad del país, porque, ¿qué es lo que ha pasado ahorita?, por ejemplo, con el fraude electoral de las municipalidades a mí me queda la duda si no hubo repartición también de diputados para manejar ellos el control, tener el control también para seguir haciendo o debilitando, pues, los poderes del Estado, entonces, si se logra poner hombres y mujeres capaces, honestos, con poca participación o inclinación fiel hacia un partido político, se pueden hacer transformaciones profundas, porque si hay una buena elección podemos tener más de 56 diputados, que pueden hacer transformaciones grandes, donde este Consejo: "éste no va a venir, este diputado es tuyo, este es mío", que es como yo creo que se ha hecho, entonces, si hay una cantidad significativa de diputados en estas elecciones de 2010 sí se pueden hacer unas reformas constitucionales profundas, a fortalecer el Estado de Derecho en Nicaragua, si no, ni que las hagás, de nada va a servir.

R: ¿Y las fuerzas anti-pacto no entrarían en el juego político del reparto de prebendas?, ¿no es una pauta de cultura política tan fuerte, que hasta el sector crítico, tanto de los liberales como de los sandinistas, no son una alternativa?, porque esa es la crítica que te hacen cuando entrevistas a orteguistas o entrevistas a alemanistas.

M.E.S.: Ajá, ¿qué dicen, que es lo mismo?

R: Exactamente, que las fuerzas politicas excluidas, porque no tienen la capacidad para tener tantos seguidores, o porque no han hecho el pacto desde arriba, que les ha permitido controlar el Estado, si entraran al juego harían, exactamente, lo mismo, ¿no?, esa es una frase muy desesperanzadora.

M.E.S.: Es que yo no creo, ni ellos ni nadie podría hacer lo mismo si hay unas elecciones correctas, yo te lo aseguro, que si ni ellos ni nadie podrían hacer lo mismo, ni el PLC, ni el Frente, ni ellos, nadie podría hacer lo mismo si hay unas elecciones correctas, yo estoy casi segura de eso, es muy difícil, el problema aquí es ese, precisamente, que, ¿cómo te diría?, está tan repartido esto entre el PLC y el Frente, que es lo que les permite a ellos hacer las barbaridades que se hacen, una Asamblea Nacional donde haya interés por criterios políticos no sumisos a estas personas puede mantener un equilibrio y garantizar un poco la institucionalidad, ahora, lógicamente, esto es un proceso, te hablo de educación, de cultura, de transformaciones de principios, de visión, de valores, porque yo no concibo, te repito, que Daniel Ortega haya sacado $38 \%$, después de todo lo que hizo en los años 80 , no lo concibo, o sea, ese hombre no debió de haber sacado ni $6 \%$, y no creo que se hayan robado $30 \%$, no creo que esa haya sido la regla electoral en las elecciones presidenciales, presidenciales se podrán robar 5 
puntos si acaso, pero ¿un 30\% de voto de confianza?, ¿un hombre que hizo barbaridades?, no lo concibo, también tiene que haber una participación no sólo de los políticos, sino que transformaciones en los valores y principios del pueblo nicaragüense, lastimosamente, pues.

R: Pues, si tiene algo más que añadir.

M.E.S.: No, gracias. 


\section{ENTREVISTA $42^{60}$ :}

Nombre del entrevistado: Dr. Alejandro Serrano Caldera.

Cargo actual: Intelectual y académico, presidente de la Corte Suprema de Justicia durante el régimen sandinista (1979-1989). Profesor de Filosofía del Derecho en la Universidad Americana (UAM).

Fecha de realización de la entrevista: Managua, 18 de septiembre de 2009.

Lugar: Domicilio particular del Dr. Serrano Caldera.

Duración estimada: 1 hora y 8 minutos.

\section{TEXTO - Transcripción 42:}

R: Me interesaría conocer cuál es su visión sobre los procesos de cambio constitucional en el marco de la transición a la democracia en Nicaragua.

A.S.C.: Sí, tendría que mencionar que la primera reforma constitucional en los últimos años, por supuesto, ¿no?, se produce en el año 89, aproximadamente, cuando el presidente Ortega, que ha ganado las elecciones de 1984 accede a que se reduzca en un año el período presidencial, es decir, la situación política, militar, bélica, era tan grave, y social, por supuesto, que, en un momento dado, las conversaciones orientadas a buscar un entendimiento entre las partes en conflicto bélico pasaban por adelantar el período presidencial, de las elecciones presidenciales, eso se hizo así, se reformó el artículo respectivo de la Constitución Política, y se convocó al proceso electoral para el 25 de febrero del año 1990, elecciones de las cuales resultó victoriosa Violeta Barrios de Chamorro, y asumió, pues, el poder, teniendo un año más que el que, originalmente, le hubiese correspondido, porque su primer año coincidió con el que debía haber sido el último año de Daniel Ortega, esa es la primera reforma constitucional significativa a partir de fines de los 80, comienzos de los 90, hasta este momento, luego, se producen otras reformas constitucionales, en virtud de las cuales se modifica la composición, entre otras cosas, de la Corte Suprema de Justicia, que pasa, primero, de siete a nueve Magistrados, y luego de nueve a doce Magistrados, se establecen reformas, que regulan, un tanto, el funcionamiento de los poderes del Estado, otra reforma importante y significativa es la de 1995, que es una reforma constitucional, que se produce dentro del período aún de Doña Violeta Barrios de Chamorro en la cual se establecen algunas medidas para reducir las facultades del presidente de la República y del Poder Ejecutivo, de esta manera, y pensando en voz alta, pues, de lo que recuerdo, en este momento, sin hacer un estudio sistemático de las reformas, una medida importante fue aquella que eliminó la facultad colegisladora del presidente, el presidente podía colegislar en receso de la Asamblea, y dictar leyes con el mismo valor jerárquico, la norma jurídica, de una ley dictada por el parlamento, entonces, claro, el presidente puede emitir decretos con fuerza de ley o decretos-leyes presidenciales, pero que tienen una jerarquía inferior a los decretos que dicta el parlamento o a las leyes ordinarias, ya no digamos orgánicas, o de otra jerarquía, que dicta la Asamblea Legislativa, de acuerdo a la Constitución de 1987, que es la Constitución que está vigente todavía, el presidente de la República podía en receso de la Asamblea emitir leyes con el mismo valor, dentro

60 Entrevista interesante con un discurso centrado en el análisis de los procesos políticos, que explican la forma y contenido de los cambios constitucionales recientes, con observaciones valiosas en torno al pasado, al presente y al futuro incierto de la democracia nicaragüense, su débil institucionalidad y la lógica de los actores implicados en los juegos de poder. 
de la pirámide de Kelsen, la misma jerarquía, que las leyes o decretos que emite el Poder Legislativo, en la reforma del año de 1995 se le redujo esa facultad, y se especificó que puede emitir decretos-ley en materia de su competencia administrativa exclusivamente, y para reglamentar algunas leyes que se considera necesitan cumplir con este requisito para poder entrar en función, esa fue una de las reformas del año 1995. La otra reforma que tuvo una relevancia política muy grande fue la reforma que estableció la prohibición, creo que fue el artículo 147, en uno de sus incisos y acápites, estableció la prohibición de ser candidato a la Presidencia de la República de todos aquellos que tuvieran algún nexo, con quien ejerciera la presidencia en ese momento, dentro del cuarto grado de consanguinidad y segundo de afinidad, esta decisión dejó fuera de la posibilidad de competir en esas elecciones presidenciales a Antonio Lacayo, que era el Ministro de la Presidencia y yerno de la presidenta Violeta Barrios de Chamorro, entonces, esto provocó una reacción política y un debate político muy intenso, como usted podrá suponer, y, al mismo tiempo, un recurso de inconstitucionalidad ante la Corte Suprema de Justicia, Sala de lo Constitucional, alegando que eso variaba disposiciones establecidas en otros capítulos constitucionales, que establecen el principio de igualdad ante la ley y el derecho de todos los nicaragüenses a optar a los cargos que se consideren capaces, pues, para desempeñarlos, siempre y cuando estén habilitados, ¿verdad?, para efectos pendientes, por ejemplo, una sentencia judicial, privativa de la libertad, o alguna medida de esta naturaleza, en todo caso, la Corte decidió que, realmente, no afectaba eso el principio constitucional, que en la Constitución hay normas generales, pero hay normas específicas también, y se establece un principio general que no se vulnera, si se reglamentan dentro de la misma Constitución Política las modalidades en que el sujeto pueda participar dentro de los derechos que le confiere la disposición de carácter general, de la misma manera, que no pueden participar los que no tienen la edad requerida, la mayoría de edad o la edad requerida para determinados cargos, de la misma forma que no pueden participar los que sean, por ejemplo, del rango militar o del rango religioso, sin haber renunciado con un año de anticipación o el período que la Constitución le fije, $y$, en tal sentido, pues, la Constitución, se dijo, establece una serie de condiciones para que el principio general pueda ser aplicado, estamos en 1989,1992, 1995, en 1998 se inicia, siendo ya presidente Arnoldo Alemán Lacayo, se inician las conversaciones de Arnoldo Alemán con Daniel Ortega, orientadas a eso que aquí se le ha llamado, en una forma muy dura, el pacto, verdad, entonces, aquí, desafortunadamente, la palabra pacto, por los contenidos que ha tenido en el pasado reciente, es una palabra completamente devaluada, e inclusive deformada en su intención, o sea, hablando de pacto, habría que hablar del pacto social de Rousseau, con el que se funda la democracia, y una serie de pactos que han permitido que la democracia funcione, por ejemplo, en España los Pactos de la Moncloa, pues, pero aquí en Nicaragua esa palabra adquirió un contenido, absolutamente, descalificado, todas las circunstancias políticas específicas en que se vio envuelto, ¿no?, entonces, en el 98 empiezan las negociaciones a efectos de establecer lo que llamamos el pacto Ortega y Alemán, lo acordado en ese pacto se sometió después a una reforma constitucional, o mejor dicho, la Constitución se sometió a un proceso de reformas para incorporar los elementos de ese pacto en la Constitución Política, es decir, darle rango a los acuerdos políticos de norma constitucional, y así se llega, pues, a la reforma del año 2000, es decir, los acuerdos, el pacto político se consolida en el 98 comienzos del 99, en el 99 se realiza la presentación a la Asamblea y la aprobación en primera legislatura, porque requiere dos legislaturas la reforma constitucional, y una votación no menor del $60 \%$, que en números concretos son 56 votos en una Asamblea de 91, 92 diputados, entonces, se consolidó el pacto, se sometió, en primera legislatura, a la Asamblea, se 
aprobó en primera legislatura en el año 99, en el año 2000 se sometió a su ratificación en la segunda legislatura de ese proceso específico, se ratificó, y, entonces, el pacto quedó transformado en parte del texto constitucional, algunos elementos destacados, que me recuerdan, en este momento, de esa reforma constitucional, que fue fruto un día de ese pacto, uno, la Corte Suprema de Justicia pasó de doce a dieciséis jueces o Magistrados, y en el pacto político, aunque no en la Constitución, se establecía ocho y ocho, otro, el Consejo Supremo Electoral, pasó de cinco a siete Magistrados, y en el pacto se establecía, aunque no en la Constitución, en la Constitución se establecía el incremento del número de Magistrados y la transformación, pues, del órgano de doce a dieciséis, de cinco a siete, y en el pacto se establecían las proporciones de partidarios de cada uno de los dos líderes del pacto, y los partidos que representaban, entonces, se pasó al Consejo Supremo Electoral de cinco a siete, cuatro y tres, en este caso, eran cuatro del partido gobernante, en ese momento, que era el PLC, el Partido Liberal Constitucionalista de Arnoldo Alemán, y tres para el Frente Sandinista de Daniel Ortega, luego, eso cambió porque el presidente del Consejo Supremo Electoral, aunque no necesariamente, no formalmente, se cambió de partido, sí, definitivamente, él pasó a responder a los intereses del Ortega y del Frente Sandinista, y el PLC, que fue a raíz de ese partido y su dirigencia que él llegó al Consejo Supremo Electoral, la Contraloría General de la República, que era unipersonal, pasó a ser una Contraloría colegiada, tres y dos, la Procuraduría que tenía en un inicio funciones, que tenían funciones abarcadoras de Procuraduría y Fiscalía, pues, se le redujo y se especificaron más sus atribuciones, y se creó la Fiscalía, todo con fines políticos, porque la Procuraduría, el Procurador General de la República, según la Constitución, lo nombra el presidente de la República, pero el Fiscal, de acuerdo a la reforma constitucional lo nombra la Asamblea, quiere decir, las bancadas parlamentarias que dependen de las dos personas que están negociando el pacto, y se creó la Procuraduría de los Derechos Humanos, también controlada por los dos partidos, y, de esta manera, se diseñó, en estos principales poderes y órganos del Estado, un mecanismo de llave y candado entre los dos dirigentes, llave y candado, que hacía posible, únicamente, el funcionamiento político y el gobierno del país, si los dos caudillos estaban de acuerdo, si los dos líderes políticos estaban de acuerdo en hacer el pacto, y, de alguna manera, ese pacto se transfirió a la Constitución Política, adquiriendo el rango de norma constitucional, y ahí se inicia, pues, este período que no termina todavía, ¿no?, en los acuerdos entre Alemán y Ortega, ¿no?, vinieron unas elecciones, ganó Enrique Bolaños contra Daniel Ortega, que perdía por tercera vez consecutiva la elección, primero en el 90 contra Violeta Barrios de Chamorro, en el 96 contra Arnoldo Alemán, y en el 2001 contra Enrique Bolaños, tres períodos presidenciales, pero el juego político a través de la Constitución siguió, no se detuvo, pues, en ese momento, y, claro, no sé si al hablar del Derecho Constitucional aquí, inevitablemente, tengo que hablar de estos entreveros de carácter político, ¿no?, parte del pacto del año 98, que se plasmó en la reforma constitucional del año 2000 fue además de la repartición de los poderes del Estado, Corte Suprema y Poder Judicial, Poder Electoral, Contraloría General de la República, Fiscalía, Procuraduría, etc., hubo, quizás, un acuerdo, directamente, personal entre los dos líderes pactistas, ¿no?, Ortega le concede a Alemán el ser diputado ipso iure de pleno derecho, durante el período presidencial siguiente, cinco años, a Alemán eso le interesa mucho, porque con todo el escándalo, pues, de la corrupción y todo esto, la inmunidad se le prolonga por cinco años más, lo cual le permite, pues, tener un margen de maniobra y no estar tan presionado, porque ya se hablaba de juicios y de encausar irregularidades, llamémosle así, eufemísticamente, cometidas desde la Presidencia de la República, entonces, Ortega le ofrece eso y para él, obviamente, que va a terminar, como no hay 
reelección en períodos sucesivos, él perdería su inmunidad, pero la recuperaría sí por mandato constitucional se incorpora en la Constitución ese acuerdo y él pasa a ser miembro de la Asamblea Nacional con cinco años más de inmunidad, y, a cambio de ello, Ortega le pide, o sea, le exige como condición para hacer esta concesión que, de común acuerdo, las dos bancadas, que son las que tienen la mayoría calificada del $60 \%$ reformen el artículo, que establece el $45 \%$ como un requisito para ser elegido en la primera vuelta, entonces, Alemán accede a eso, lo cual quiere decir que la bancada junto con la de Ortega van a reformar eso, y la reforma consistió en reducirlo al 40\% y hasta el 35\% siempre y cuando mantenga una distancia del 5\% con el que va en segundo lugar, o el más cercano contendor, entonces, ese fue un intercambio ya en donde hay intereses personales de por medio: la inmunidad para Alemán por cinco años más, al concederle la diputación de pleno derecho, por mandato constitucional, sin ser elegido, por el hecho de ser ex-presidente de la República, durante los cinco años del siguiente gobierno, y a Ortega la posibilidad de ganar una elección, pues, con el $45 \%$ no la gana nunca, ni aún dividida la oposición como lo está ahora, y que no lo estaba en ese momento, y su porcentaje ha andado entre el $40 \%$ y el $43 \%$ en la elección anterior, en las dos elecciones anteriores, en la de Alemán y en la de Violeta Barrios, en cambio con un $35 \%$, si él logra sacar un 5\% a su contendor él gana, o con un $40 \%$ si él ha obtenido hasta el $42 \%, 43 \%$ y $44 \%$ también sus posibilidades se viabilizan, pues, se vuelve posible ganar una elección, y eso se aprende también a raíz de una norma constitucional en la elección del año, y eso fijó, pues, el pacto, pero luego vinieron una serie de circunstancias políticas, Alemán llega de diputado en esas condiciones, como tiene su partido la mayoría que le ha dado el triunfo a Enrique Bolaños, que fue su sucesor del mismo partido en la presidencia, se hace elegir presidente de la Asamblea, y desde la presidencia de la Asamblea quiere gobernar y manejar al presidente de la República, que fue su vicepresidente, entonces, él viene con la idea del vicepresidente obsecuente, pero se encuentra con un presidente, no con un vicepresidente, y eso lo hace chocar con Bolaños, con el presidente, y lo hace chocar con Ortega, porque eso no está pactado, y Alemán quiere irse arriba, como se dice aquí, en el pacto político tratando de seguir ejerciendo el gobierno desde la presidencia de la Asamblea, el pacto era va a ser diputado cinco años más, cinco años más mantenía la inmunidad, pero en eso no saltó a eso, él saltó a la presidencia de la Asamblea, y desde ahí quiso gobernar, entonces, obviamente, choca con el presidente, y choca con Ortega, lo cual hace que los dos, el enemigo de mi enemigo es mi amigo, es decir, se juntan Bolaños y Ortega, y, de alguna forma, montan el juicio contra Alemán, que ya estaba encausado, pero por la inmunidad de la diputación ahora, y de la presidencia antes, no podía si la Asamblea no le retiraba la inmunidad, entonces, necesitaban 47 votos, le faltaba un voto, fueron 46, ¿no?, porque los demás eran de Alemán, pero lo consiguieron, le retiraron la inmunidad, vino el juicio y lo condenaron a 20 años, el inicio de otra parte de la historia, entonces, es la reforma constitucional del año 2000, con sus caldos políticos que están de por medio. Después vino otra reforma, las pláticas del año 2004, la reforma en primera legislatura del 2004, luego, se confirmó en segunda legislatura en el 2005, reforma esta del 2005, que ya surge de la renovación del pacto entre Ortega y Alemán, Ortega ya ha chocado con Bolaños, pero es presidente de la República, y, entonces, vuelve, esto es un triángulo equilátero, o no tan equilátero, pero es un triángulo en donde se vio, en este período, que un día Ortega pactaba con Alemán y otro día pactaba con Bolaños, entonces, después del pacto de Bolaños, por una serie de factores que sería muy largo de enumerarlos, entre ellos, la presión de los Estados Unidos, la visita de Collin Powell, lo presionan a romper con Ortega y a tratar de asumir el liderazgo que tiene Alemán, el PLC, salir de Ortega y Alemán, esa es la propuesta de los americanos y tratar de 
consolidar lo que ya venía dándose desde los 90, pero sin Alemán y sin Ortega, en el panorama político, ¿no?, entonces, se alían Alemán y Ortega, que son los damnificados de este plan de los Estados Unidos que pudiera llevarse a efecto, eso trae como consecuencia la reedición del pacto entre Ortega y Alemán vuelven a acercarse, reeditan el pacto del 2004, esta vez contra Bolaños, y reforman la Constitución en el 2005, en esa reforma constitucional se establece que la Asamblea ratifica ministros, embajadores, directores, una serie de funcionarios, el presidente los propone, pero no nombra como ocurría antes del 2005, constitucionalmente, sino que tiene que ser ratificado por la Asamblea y se crean una serie de órganos que dependen, directamente, de la Asamblea, como fue el Instituto de la Propiedad Urbana y Rural, el INPRUB, la SISEP, la SuperIntendencia de Servicios Públicos, etc., en donde la Asamblea, el presidente de la Asamblea y su equipo administrativo tienen la facultad de nombrar desde el portero hasta los directores de estos órganos y ser los responsables de la coordinación, destitución, remoción, nombramientos de todos, es decir, la intención ahora es limitar a Bolaños en sus funciones y reatribuirse el poder a través de la Asamblea Nacional, esa es, pues, la reforma constitucional del año 2005, que se dejó inmovilizada de una manera ilegal, pues, porque con una ley ordinaria, llamada Ley Marco, congelaron los artículos constitucionales, es cierto que es una barbaridad, pues, lo que se había hecho, porque si lo vemos en estricto sentido legal, una ley inferior no puede congelar o modificar una disposición constitucional, entonces, ese sería un panorama, pues, desde 1989, la primera reforma, 1992, otra reforma, 1995, y las reformas de 2000 y 2005, serían cinco reformas constitucionales.

R: Yo me centro, especialmente, en el trabajo de investigación doctoral en el conflicto repetido entre el Ejecutivo presidencial y la Asamblea, que es quien ha liderado en los casos que hemos estudiado sobre las reformas que ya existen, no en la actual, donde la propuesta ya sí parte del Ejecutivo, pero las leyes de reforma parcial han sido abanderadas por los diputados.

\section{A.S.C.: Por los diputados, sí.}

R: ¿A qué cree que se debe esta falta de entendimiento entre ese Ejecutivo presidencial que no quiere perder parte de las atribuciones, que consagraba ese hiperpresidencialismo de la Constitución original del 87, y la Asamblea, que quiere recuperar, digamos, primero, en un sentido de evolución democrática natural del propio régimen político en Nicaragua, y, segundo, quizá de injertar instituciones que proceden de otras tradiciones, como puede ser el caso del parlamentarismo en un sistema presidencial atenuado?, esa es un poco la doctrina, como diría un jurista, yo vengo de la Ciencia Política. ¿Cuál es su visión?

A.S.C.: Mire, la realidad de esto ha sido, estrictamente, política más que jurídica, está claro que desde el marco teórico de la pureza del Derecho Constitucional eso es lo lógico, pero aquí esto ha obedecido a un problema, que es el problema actual de Nicaragua, dos caudillos: Ortega y Alemán, que no siempre han ganado las elecciones, sino que han venido otras personas, viene Violeta Chamorro, viene Don Enrique Bolaños, y, entonces, la Asamblea al haber recuperado poder lo ha hecho para que los dos líderes recuperen poder a través de las bancadas parlamentarias, que sumadas alcanzan no sólo la mayoría sino la mayoría cualificada del $60 \%$, que es la que se requiere para la reforma de la Constitución Política, la razón ha sido esa, la Asamblea 
recupera poder para que el pacto funcione, y dejar al presidente limitado con las reformas constitucionales que son el pacto y su Constitución.

R: Es cierto que los sistemas presidencialistas tienen mayores dificultades para solucionar el conflicto entre el Ejecutivo y el Legislativo, no hay fórmulas técnicas que permitan salir de una crisis institucional, como la que se experimenta bajo el gobierno de Violeta Chamorro, o muy claramente bajo el gobierno de Enrique Bolaños, que yo creo es el presidente más acosado por su propio partido dividido, es el principio de la división del liberalismo, que favorece a Daniel Ortega, y, por otra parte, es un presidente, que casi queda debilitado también por las propias reformas constitucionales que le preceden, en términos puramente jurídicos, ¿no?

A.S.C.: Es un presidente sin partido.

\section{R: Exactamente.}

A.S.C.: Eso fue, en realidad, una reforma constitucional del sistema político no ha habido un interés real, como no sea hacer las reformas que beneficien a la estructura de poder político, y a su aliado, o sea, la lógica, entre comillas, ha sido esa, no es que les interese más un sistema parlamentario que un sistema presidencial, o un sistema semiparlamentario con una mayor democratización del poder público restándole atribuciones al Poder Ejecutivo, dígase al presidente de la República, sino esto ha sido un juego, y por eso yo le mencioné muchas circunstancias políticas, que están tras el telón de los artículos constitucionales, porque esas han sido las motivaciones reales, ¿qué es lo que le interesa a Ortega y Alemán?, quitarle poderes a Bolaños, porque los dos estaban chocando con Bolaños, ¿qué es lo que le interesaba a Ortega y Bolaños?, quitarle poderes a Alemán en la Asamblea y no sólo en la Asamblea, llevarlo a la cárcel por la corrupción que él generó, porque estaba tratando de gobernar desde el parlamento, entonces, lo que ha movido en un sentido o en otro ha sido, justamente, el interés de consolidar la estructura de poder, y, en este caso, consolidar la estructura del poder, restándole poderes al Ejecutivo y transfiriéndosela a los dos ex-presidentes, que, desafortunadamente, permanecen como caudillos, como jefes de fila de partidos políticos, que juntos tienen el poder, entonces, ese es el factor que incide en las reformas constitucionales, o sea, desafortunadamente, aquí no se reforma la Constitución en la búsqueda de un perfeccionamiento de las instituciones del Estado, de los poderes y organismos del Estado, sino que se reforma en la medida en que puede, de alguna manera, apuntalar todavía más el poder, el propósito de la reforma ha sido apuntalar el poder, dar más poder al poder que ya existe, salvo la reforma del 95, la reforma del 95 obedece a otro cuadro político, se busca democratizar un Ejecutivo con demasiados poderes, que venía de la Constitución del 87 con Ortega de presidente, restándole poderes a Violeta Barrios de Chamorro, como ese que le mencionaba, la facultad co-legisladora en receso de la Asamblea, ahí la Asamblea busca como democratizar el Poder Ejecutivo, y el aparato del Estado, quitando facultades que eran excesivas, que venían de un presidencialismo, que a su vez venía de una revolución, que hace una Constitución, pero en donde el sello del poder central estaba presente, entonces, eso se produce de esa manera por iniciativa del parlamento, por iniciativa del parlamento, que, en ese momento, el Frente Sandinista se asocia con una serie de partidos políticos, entre ellos la Democracia Cristiana, etc., y forman la mayoría, ante un parlamento fragmentado, que había apoyado y que era mayoría, inicialmente, del gobierno, como no era un sistema parlamentario, el gobierno puede seguir con una 
minoría en el parlamento, entonces, eso genera la reforma constitucional del 95, que es atípica en este cuadro de correlación de fuerzas, que he tratado de describir, ahí hay otras razones, que también son razones políticas, ¿no?, entonces, sí, debilitar un poco el poder de Violeta Barrios de Chamorro y sobre todo el Ministro de la Presidencia, que ya se perfila como un candidato para las próximas elecciones, $\mathrm{y}$, entonces, hacer una reforma constitucional que, no obstante, los intereses políticos que están ahí detrás, sin embargo, democratizó el aparato político del Ejecutivo.

R: La dificultad de reformar la Constitución ha estado presente desde el inicio de la reciente transición a la democracia, ¿no?, y se ha manifestado, jurídicamente, en una serie de irregularidades, cuando menos en el sentido jurídico estricto, como es el caso de las leyes Marco, que suponen una ampliación del proceso de negociación política, congelando temporalmente la entrada en vigor de las normas constitucionales reformadas, y, por otra parte, la propia revisión o flexibilización del procedimiento de revisión constitucional, que es una cuestión muy grave, bueno, no a juicio mio, sino, digamos, de un jurista puro, en el sentido de que forma parte del núcleo duro que no se puede reformar constantemente, me refiero al proceso mediante el cual el entonces presidente de la Asamblea, Don Luís Humberto Guzmán, mandó publicar la ley que la señora presidenta de entonces, Violeta Barrios de Chamorro, no quería promulgar ni mandar publicar en ningún medio de difusión escrita del país, ¿no?, ¿cuál es su opinión al respecto?

A.S.C.: Bueno, ahí se violaron disposiciones constitucionales ante una imposibilidad política, ante una imposibilidad política el presidente de la Asamblea manda publicar las reformas, siendo que no puede mandarlas a publicar, porque la Constitución no lo faculta para ello al presidente, por un lado, y el presidente de la República, Doña Violeta, por el otro, y antes de mandar a publicar la ley, se niega a ratificar las reformas constitucionales, siendo que el 194, creo, no le deja facultad discrecional, porque no puede vetar la reforma, simplemente, es parte de un proceso que se culmina con la ratificación de la reforma constitucional, y su promulgación y publicación son obligaciones formales ante las cuales el presidente no tenía, o no tiene facultad discrecional de decir: "la veto", no puede vetar la reforma constitucional, o decir: "no las mando publicar", o decir: "no las promulgo", entonces, lo que ocurrió es que quedamos enfrentados ante una situación de facto, en donde la presidenta Violeta, la Constitución, porque no las promulga ni las publica, claro, introduce un recurso de amparo en el tribunal de Masaya y el tribunal la ampara, y, entonces, en base a eso y ella no promulga ni publica, ni manda publicar, pero, evidentemente, hay una reacción política, pues, ante el hecho político de la reforma, entonces, hay una situación de facto, frente a esa situación de facto reacciona Luís Humberto Guzmán como presidente de la Asamblea, con una medida que también es una situación de facto, mandarlas a publicar, siendo que no tiene facultades de hacerlo, en un caso, la que tiene la obligación de mandarlas a publicar no las publica, y el que no puede mandarlas a publicar las publica, esa fue la gran paradoja que ocurrió en ese caso, y en ambos casos se violó la Constitución, como se viola la Constitución de la reforma del 95, es el ejemplo que yo conozco en este momento, cuando vienen las negociaciones presididas por el Cardenal Obando, ¿qué tiene que decir un Cardenal en una negociación sobre una reforma constitucional?, llegan a un acuerdo, ese acuerdo lo elevan a una ley llamada Ley Marco, que no es ley constitucional, es una ley ordinaria, inclusive, por el número de votos con que se aprueba, inclusive, por el número de legislaturas en que se aprueba, e, inclusive, por su propia denominación, que no entra dentro del rango de Constitución 
Política de leyes constitucionales, entonces, se llega a una serie de acuerdos, se llega a la Ley Marco, y se aplica la Ley Marco que reforma la Constitución Política en algunos puntos, por ejemplo, en aquellos puntos en donde hay unos nombramientos, la Constitución faculta al presidente de la República, y la Ley Marco dice que el presidente de la República sólo en el caso que esté de acuerdo con los otros poderes del Estado, con la Asamblea, pues, que no le dice la Constitución, que esa es una reforma constitucional, ¿verdad?, o las propuestas para candidato a la Corte Suprema de Justicia, al Consejo Supremo Electoral, que la Constitución de ese momento faculta al presidente de la República y a él, en cambio, la Ley Marco dice que sólo podrá proponerle si además la Asamblea está de acuerdo en esa propuesta, entonces se introducen una serie de elementos, que reforman a la propia Constitución Política, en una ley ordinaria que modifica la Ley Fundamental, que es la Constitución, entonces, todo este proceso, nosotros nos encontramos con situaciones de hecho, como estas que estamos analizando.

R: Tuve la oportunidad de realizarle la entrevista también a Don Luís Humberto Guzmán, y cuando yo le hacía justo esta pregunta que acabo de hacerle, él contestaba diciendo que en aquél momento de mucha dificultad de la transición, y lo digo yo también, que aunque no viví la transición, porque no pertenezco a la generación que la protagonizó, más bien yo era niña entonces, pero sí conozco los primeros momentos dificiles de un régimen político democrático que nace, ¿no?, y esa dificultad de arraigo, digamos, de las instituciones democráticas, pues, no permitió que se plantease, por ejemplo, la convocatoria a unas nuevas elecciones constituyentes, porque también el debate entre una reforma parcial y una reforma total a la Constitución del 87 estuvo presente en los primeros momentos de la reforma del 95, y no sé si ésta será una buena respuesta o quizá el tener que recurrir a decisiones de este tipo.

A.S.C.: Mire, el drama nuestro es que no hemos podido subordinarnos a los preceptos constitucionales, y la Constitución la hemos usado más que como precepto, como pretexto para realizar los intereses políticos, esta Constitución nace inconstitucionalmente, porque la Asamblea legislativa no podía por decisión propia auto-designarse Asamblea Constituyente, que fue lo que ocurrió, empecemos por ahí, pues, esto no tiene valor, porque tiene que hacer una Asamblea Constituyente, una Asamblea Nacional Constituyente, que no se convocó, no se convocó, obviamente, por la situación política, la guerra, y todo esto, ¿no?, entonces, aquí se ha jugado con la idea del mal menor que ha resultado del mal mayor, pero cuando esto ya se transforma de una excepción en una regla general, ya, definitivamente, el daño es grave y la medicina resulta más dañina que la enfermedad, ¿ves?, entonces, desde aquí, pues, ésta, la Constitución Política, que tenemos actualmente, la da un órgano que no tenía facultades para ello, la da un órgano que no tenía facultades para auto-proclamarse Asamblea Nacional Constituyente, es decir, pero después tenemos nosotros una serie de violaciones, entre ellas, pues, la Ley Marco, eso es un principio universal de Derecho, una ley inferior no puede modificar una ley superior, mucho menos la Constitución Política, porque para reformar la Constitución hay un procedimiento que la propia Constitución refiere, y, entonces, si se reforma por leyes ordinarias, ¿dónde queda el procedimiento?, ¿y dónde queda la Constitución?, entonces, eso queda en manos de la correlación de fuerzas y de los intereses políticos que están en juego, o sea, lo que dice Luís Humberto es cierto, era dificilísimo, pues, ¿verdad?, era dificilísimo, pero eso no puede llevarnos a aceptar que ante lo difícil actuemos de facto, y, después, le demos un ropaje constitucional, ese es el problema, aquí hubo un momento en que habían dos 
constituciones, que era como decir: "no hay ninguna", una, la Constitución reformada que Luís Humberto Guzmán manda publicar, se publica, pero la Presidencia de la República la desconoce y sigue actuando conforme a la Constitución sin reforma, entonces, es un caos, porque había casos, por ejemplo, la Constitución sin reforma, aunque eso no era el punto de discusión política, pero los efectos van hasta ahí, establece que la Policía sólo puede retener a una persona por 48 horas, sin ponerle, inmediatamente, a la orden del juez competente, es decir, puede tenerlo retenido por 48 horas pasadas las cuales debe ponerlo a la orden del juez, dice la Constitución reformada, la Constitución sin reforma establecía 72, entonces, eso es un caos, porque había tribunales que estaban del lado de los que hicieron la reforma, y otros, por su filiación política, estaban del lado del gobierno, la Policía, a su vez, que depende del presidente de la República, actuaba conforme mandato presidencial, pero después se encontraba con un requerimiento judicial que le exigía poner a la orden del tribunal como mandaba la Constitución, decía: "bueno, sí, yo estoy actuando conforme a la Constitución", pero es que estaban hablando de dos constituciones distintas para mencionar un ejemplo nada más de lo que esto significó, ahora, claro, de no haberlo mandado a publicar hubiera significado que no había Constitución, entonces, manda publicar por un fin político, una vez publicada se abre la negociación, pero es otra cosa, no es que se legitime la publicación, porque la presidenta no quiso, no, la Constitución no dice que puede hacer ese procedimiento.

R: La reforma del 2000 supone un punto de inflexión, como bien señalaba antes, incluso, en alguno de los entrevistados he oido la referencia de "contrarreforma", ¿no?, por romper un poco con la tendencia de consolidación del pluralismo democrático en Nicaragua, por lo menos, dar los primeros pasos, también el arco parlamentario que aprueba las reformas del 95 es diferente del bipartidismo consagrado en la del 2000.

A.S.C.: Es diferente, es diferente, y la del 2000 es la contrarreforma, la del 95 es un poco un parlamento que no controla Violeta Barrios, porque ya su estructura, como le decía hace un momento, de poder, su mayoría, se disgrega, y, entonces, vienen una serie de pactos coyunturales, y hay otra mayoría, que es el Frente Sandinista más algunos grupos que se suman, esta es una reforma, es la única que viene del parlamento frente al Ejecutivo, las demás son impulsadas por el Ejecutivo, como poder del Estado, verdad, o contra el Ejecutivo, en algunos casos, como fue también la reforma del 2005, pero ya no por un afán de democratización, la del 2005, sino por un afán de que los dos caudillos siguieran gobernando a través del parlamento en un régimen presidencial, no sé si me explico con claridad.

\section{$R:$ Sí, perfectamente.}

A.S.C.: Entonces, eso es lo que se ha jugado, la del 95 fue tratar de quitarle potestades a la Presidencia de la República y darle mayores atribuciones al parlamento, a la Asamblea, pero una Asamblea más diversificada, aquí lo que se trata es quitarle potestades al que está mandando y dárselas a los dos caudillos que no estaban gobernando, ahora está gobernando uno de ellos, que es Ortega, de forma tal que como llave y candado los dos, que tienen la mayoría, y que tienen la mayoría cualificada puedan manejar el país. 
R: Este discurso legitimador de las reformas constitucionales en aras de este semiparlamentarismo, de hecho, el año pasado fue profesor mío en Madrid el doctor Diego Valadés, ¿no?, y ponía como ejemplo de cambio constitucional interesantísimo de estudiar, desde el punto de vista académico, el caso de Nicaragua, ¿no?, y a propósito de esta incidencia de las instituciones parlamentarias funcionando en un marco presidencial el traslado de poder de la figura del presidente a las cúpulas de los partidos también exige una cultura política, como indica, por ejemplo, el profesor Sartori, ¿no?, de socialización de los partidos políticos en un clima de cooperación, que es muy distinto del "patronazgo parlamentario", como asi lo señala el profesor Linz, a la hora de hablar, por ejemplo, del funcionamiento de la Asamblea o del Congreso, en este caso, norteamericano, y que en el caso de los presidencialismos de América Latina, donde tampoco hay un aprendizaje de la práctica legislativa por parte de actores que, realmente, han crecido a la sombra de un Ejecutivo fuerte, ¿no?, ¿Cómo visualiza toda esta cuestión?

A.S.C.: Mire, aquí lo que, a excepción de la reforma del 95, lo que se ha jugado es la instrumentalización de la Asamblea y de la Constitución Política, ahora se está con el tema, pues, de la reforma para la reelección, entonces, ¿qué es lo que lo motiva?, no lo motiva ninguna democratización del parlamento, la reforma constitucional, sino la perpetuidad en el poder de las personas, entonces, de acuerdo, esos intereses políticos se han venido orientando, entre comillas, los contenidos constitucionales, porque, en realidad, aquí no se pretendió establecer un semi-parlamentarismo con la reforma del 2005, por ejemplo, sino que había una confrontación entre Bolaños y los dos líderes, y lo que se pretendía era, sencillamente, quitarle poder a Bolaños y pasárselo a los dos, prueba de ello es cuando Ortega llegó al poder, una serie de disposiciones las declaró inconstitucionales la Corte Suprema de Justicia, dejó vigente otras de las disposiciones reformadas, ¿por qué?, porque ahí está usando la Corte también como un instrumento de poder, no de democratización del poder en un sistema semi-parlamentario, sino de concentración de poder, y ahora todo lo que vemos desde el 2006 para acá va hacia una concentración de poder, tratando de justificarse si no a través de la Constitución, a través de la interpretación de la Constitución por la Sala Constitucional de la Corte y por la Corte Suprema de Justicia, lo que hay es un juego de poderes, desafortunadamente, no hay una visión de modernizar el Estado o de flexibilizar el ejercicio del poder democratizándolo, sino más bien lo que hay es la persecución de la concentración del poder, esas fueron las reformas que nacieron del pacto de Alemán, verdad, el propósito era que Ortega y Alemán mantuvieran el poder y se entendieran entre ellos, lo que Alemán no contaba era que el interés político de Ortega de aliarse después con su adversario para eliminar a su interlocutor, verdad, del pacto y del poder, que fue lo que sucedió.

$R: Y$, en ese sentido, el presidente Ortega, actualmente, sí representa un reforzamiento del Ejecutivo en el ejercicio del poder político, a través del control sobre las instituciones del Estado, porque es cierto que la preeminencia sandinista en la Corte Suprema de Justicia ha sido clara.

A.S.C.: Clara en la Corte Suprema, es clara en una serie de tribunales de apelaciones, es clara en una serie de juzgados, en el Consejo Supremo Electoral, en la Contraloría General de la República, en la Procuraduría General de la República, en la Fiscalía, en la Procuraduría de Derechos Humanos, como instituciones en donde hay un control, pues, pero en donde el control no es absoluto, porque hay también una contraparte de 
cierta significación que responde a Alemán, a pesar de que Ortega tiene supremacía en esta división, y la ha venido ganando porque ha venido anexándose antiguos partidarios de Alemán en estos cargos a sus propios intereses, sí, lo cierto, es que hay una bipartición no proporcional, pero sí existe, eso es lo peor, el juego ha sido ese, preponderantemente, aquí, la lógica del articulado, y la técnica y la teoría constitucional ha estado determinada por este juego de intereses, ahora la tendencia es a la centralización.

\section{R: ¿Y cree posible que Ortega consiga los apoyos parlamentarios necesarios para garantizar la reelección?}

A.S.C.: Bueno, esa es la pregunta del millón, como dicen, ¿verdad?, él lleva tres años en esto, en 2007 quiso y no pudo, en 2008 quiso y no pudo, en 2009 faltan todavía algunos meses, todavía le quedaría el 2010, todo el año, y algunos meses del 2011, antes de que se abra el período electoral de las elecciones nacionales presidenciales, la diferencia es que Ortega disponga muchos recursos, pues, para, aquí se pueden ver algunas situaciones políticas concretas, tengo que referirme a dos, porque de lo contrario sería quedarme en una abstracción, que no va a responder a la realidad, ¿no?, uno, la búsqueda de un entendimiento, de un reparto con Alemán, llamémosle un pacto, entre comillas, institucional, entre el Frente Sandinista y PLC, ante esto Alemán puede reaccionar de varias formas, una, aceptando, dos, no lo apoya porque él no acepta, y no acepta porque piensa que su responsabilidad es la responsabilidad histórica que caería sobre sus hombros al instaurar y al dar paso a la instauración de una dictadura, y de una dinastía, es muy grande, y lo acabaría políticamente, totalmente, e históricamente le dejaría señalado como responsable de ese drama nacional, podría, yo no digo que va a ser, pero sí, es un elemento que podría jugar él frente a los otros, qué ventajas le va a sacar a un eventual apoyo de sus votos, de su bancada, esos 9 votos que le hacen falta, aproximadamente, para llegar a 56, tres, puede ser que él quiera y no pueda, es decir, que diga sí a Ortega, pero que los diputados por esa misma razón de esa responsabilidad histórica, que pueda apoyar a Alemán y a Ortega en muchas cosas, pero esto es un caso especial, cualitativamente, su naturaleza es muchísimo más delicada, y cuatro, que Ortega negocie, individualmente, con cada uno, si Alemán no responde o no juega, tratar de conseguir a los nueve que le faltan bilateralmente, y pasan dejando a un lado a Alemán y al partido, ¿no?, o buscando también negociaciones con el otro grupo, que yo lo veo difícil, pero veo una situación un tanto peligrosa con el grupo de Montealegre, yo lo veo difícil por la persona, porque Montealegre es de mayor integridad, entonces, en un sentido de responsabilidad política, pero en el momento en que está hablándose, están conversando sobre los nombramientos, que vienen el 27 de marzo de 20 funcionarios que requieren el $60 \%$, el $60 \%$ o lo puede tener con Alemán, o los puede tener con los votos de Montealegre más las bancadas disidentes, el ALN, "Vamos con Eduardo", el PLI, no sé qué cosa, pueden llegar, perfectamente, a los 56 votos, claro, Montealegre lo ha dicho, no lo ha dicho, pues, se ha entendido que eso es para evitar otra vez el nombramiento de bancadas en la Corte, y de Magistrados totalmente políticos, ¿no?, pero el problema es que la negociación de los nombramientos no va a ser sólo la negociación de los nombramientos, sino que, a cambio, lo que se va a pedir es la reforma al 147, pues, de la Constitución para habilitar la reelección, que tiene dos limitantes, una, que no puede ser candidato en períodos sucesivos, y, dos, que no puede ser candidato quien ya fue dos veces presidente, y aquí hay reelección, pero en períodos alternos, verdad, aquí lo que no se puede es ser candidato en períodos sucesivos, o ser presidente por tercera vez, ya Ortega fue elegido y fue reelegido, ya está, ahí termina, 
entonces, lo que anda buscando es los votos para demoler esa prohibición, y ser candidato, y si es candidato se va a reelegir de una u otra forma, entonces, estas son las situaciones políticas que se presentarían, pues.

R: Porque, además, con la reforma de la Ley Electoral y la oposición dividida, parece que Ortega sigue teniendo un balón de oxígeno, y, bueno, aparte, el apoyo de Venezuela, creo que los recursos que están entrando...

A.S.C.: Los recursos que están entrando no entran para el Estado, ni entran para el presupuesto, aunque los pague el Estado y los contribuyentes con sus impuestos, pero, posiblemente, eso tenga un fin político, pues.

R: Piensa que está influyendo, porque esta mañana me tocó entrevistar al Jefe de la bancada sandinista, a Edwin Castro Rivera, y aunque el discurso de los politicos es muy escaso, muy limitado, y a mi me parecía quizá también una postura defensiva de insistir en el poder ciudadano, y en la reelección a través del referéndum revocatorio, un poco todo el esquema chavista.

A.S.C.: Eso es un invento, es el esquema de Chávez, que empezó con la idea de Edwin del sistema parlamentario, inclusive, él hasta publicó algo sobre el modelo parlamentario nicaragüense, pues, luego, lo descartaron, porque había resistencias a cambiar de sistema, bueno, ustedes no quieren, olvidémonos del sistema parlamentario, si, finalmente, eso no es más que un pretexto para abrir la caja de Pandora y llegar a los intereses, que es la reelección, la reforma constitucional para habilitar la reelección indefinida, luego, bueno, han estando ahí y no han podido todavía, entonces, lanzan lo del referéndum revocatorio como un caramelo, un caramelo con anzuelo, es decir, ¿qué es lo que dicen?, "oigan, miren, ¿qué más quieren?, con un referéndum revocatorio me pueden quitar a mí, si me revocan el mandato", pero no, lo que ellos buscan es abrir la posibilidad de la reforma constitucional por cualquier punto, aunque, inmediatamente, no tenga nada que ver con la reelección, pero abierto ese camino habrá muchos otros para llegar al punto que interesa, el problema es que no se abra el tema de las reformas constitucionales, por eso fue que se lanzó el tema del sistema parlamentario, además para crear un Primer Ministro que se lo ofrecerían a Alemán, o lo tomaría él si no puede quitar las otras prohibiciones, bueno, el referéndum revocatorio, sencillamente, y luego montarse sobre el caballo bien intencionado de un sector de la oposición, y en la sociedad civil de las reformas a la Ley Electoral, que es una ingenuidad que ahorita proponen, porque eso es abrirla, lo que quiere decir, OK, reformemos la ley, pero abramos un debate sobre la reforma constitucional, aunque no hablemos de la reelección todavía, ahí va a llegar su momento, ¿ves?, entonces, andan buscando por todos los caminos cómo abrir la puerta, aunque no vayan al grano todavía, pero el objetivo ahorita es abrir la posibilidad de la reforma constitucional, ya llegará al punto que les interesa.

R: Y este cambio de las reglas constitucionales, que, supuestamente, que, en teoría, tienen una vocación atemporal, de permanencia, ¿no?, sobre ese recambio periódico de las élites políticas, y que ha sido tantas veces cambiado en las reglas de juego de los actores ha subvertido, yo creo, el proceso democrático, como bien ha señalado a lo largo de su discurso, ¿no?, entiendo que el momento actual, o, por lo menos, en las entrevistas que he realizado hasta el momento me dicen que Nicaragua se encuentra en un momento delicado, hay un momento de dificultad, que ha estado presente quizá en la propia evolución democrática, pero ahora en un momento de incertidumbre, ¿no?, 
porque no es solamente el caso de Ortega, ¿no?, tengo la impresión de que los pactos han precedido a reformas constitucionales en el pasado, que hay una especie de ciclo histórico que se repite, de pautas de cultura política.

A.S.C.: Esto es un dejà $v u$, ya nosotros hemos visto, esto es como la bicicleta estacionaria, esa que sirve para hacer ejercicio, que no para de dar vueltas, pero no camina, y la rueda vuelve, y lo que ya pasó regresa, eso es un poco lo que está ocurriendo ahora, es decir, en este momento, sumamente, crítico, porque es un momento que puede ser definitivo para la consolidación de una nueva dictadura, eso es clarísimo, es decir, cuando una persona lleva treinta años gobernando buena parte, y liderando la oposición y co-gobernando, de alguna manera, por presiones desde la otra, ya ese es un síntoma que no es sano, es decir, porque veamos desde el poder formal, que además es poder real, Ortega gobierna desde el 79 hasta el 84, seis años, como coordinador de la Junta de Gobierno de Reconstrucción Nacional, luego, del 84 al 90, seis años como presidente de la República, ya son doce, ya lleva tres, casi, son quince años gobernando, entonces, si nos va a hablar de quince años que termina esto dentro de dos años son diecisiete años y cinco años más son veintidós años, eso no es normal, eso no es sano, lo sano es que haya un Estado de Derecho, que haya instituciones que funcionen, que haya alternabilidad en el poder, que se mantenga la reelección alterna, pero que se evite que se eternice algo en el poder, porque eso ya lo hemos visto en el pasado, eso es malísimo.

$R: Y$, además, es difícil un recambio del liderazgo político de la clase política de los 80 , ¿no?, que sigue en activo.

A.S.C.: Sí, es muy difícil, y, en el otro lado, tenés otros líderes caudillescos, Alemán, que tampoco deja paso.

R: Porque además las fuerzas anti-pacto han sufrido también las consecuencias de este acoso judicial, por ejemplo, al candidato Montealegre o el Movimiento Renovador Sandinista, que perdió la personalidad jurídica en las anteriores municipales, ¿no?

A.S.C.: Así es.

R: Pero, por otra parte, el contexto global también es otro, y esa pérdida de apoyos del FMI, o de la Unión Europea, con sus cinismos, también, porque es cierto que los actores bajo la bienintencionada cooperación internacional esconde otros intereses, obviamente, pero...

A.S.C.: Eso crea una crisis económica y social muy grave en el país, que va a ser más grave en el 2010, porque ya se perdió la cuenta "reto del milenio" de la cooperación de la Unión Europea, la ayuda al presupuesto, la opción a 300 millones de dólares por el Banco Interamericano de Desarrollo, la cooperación de los países nórdicos, la cooperación bilateral con Dinamarca, es decir, y Venezuela, Chávez, no va a suplir todo eso, entonces, hay también, la situación es muy dura.

R: Pues, yo creo que hemos hecho un recorrido bastante amplio, si tiene algo más que añadir.

A.S.C.: No, yo creo que eso sería, bueno, mi deseo de que aquí se pudiera, realmente, instaurar un Estado democrático, con preocupación social, no se trata de tener una falsa 
contradicción entre el neoliberalismo y el monoteísmo de mercado, o el caudillo con sus fuerzas de choque y su acaparamiento de las instituciones en beneficio personal, lo que creo es que ni lo uno ni lo otro, aquí necesitamos, realmente, un Estado democrático, un Estado social de Derecho, alternabilidad en el poder, garantías constitucionales, libertad individual, derecho a la diferencia política, es decir, sin que esto implique la guerra, pues, por cualquier disidencia, en cualquier momento puede significar un juicio.

R: Y ahora que ha dicho lo de las fuerzas de choque, cuando entrevisté a Violeta Granera, que preside el "Movimiento por Nicaragua" y hablaba de esta restricción de espacios políticos tanto en el ámbito puramente electoral, a nivel de partido, como en la propia sociedad civil cuando se le niega el derecho fundamental a la expresión de su disconformidad, en relación a la manifestación contra el fraude electoral.

A.S.C.: Con lo del fraude electoral, nadie puede salir aquí a las calles.

R: Es muy grave esa situación.

A.S.C.: Es muy grave, entonces, hay signos, es muy preocupante, es muy preocupante, y una serie de factores políticos, económicos, sociales, que más o menos los hemos analizado.

\section{R: ¿Y la situación de violencia política puede ser un escenario a futuro o no?}

A.S.C.: Ojala que no lo sea, ¿verdad?, pero podría ser, podría ser, ¿no?, si esto se sigue radicalizando, puede ser, o, bueno, un sometimiento total, o una reacción, aquí lo más grave sería que se habilite la reelección, que haya reformas constitucionales en ese sentido, si eso se da, lo cual todavía no está totalmente claro, aunque tiene tiempo, todavía tiene cuatro meses, tres meses y medio de este año y todo el año 2010 , y menos de un semestre, tres meses, cuatro meses del 2011, si eso se da, entonces, yo creo que se entra en una fase muy cercana a una fase crítica, porque una reforma constitucional y una reelección significarían ya, claramente, el establecimiento de un poder dictatorial, entonces, entraría ya en otro discurso, ahora, ¿cómo, qué va a pasar en esas condiciones?, bueno, pues, no es difícil decir con esa actitud, pero, claro, ya es un clima y es un contexto diferente al que estamos todavía conversando la tarde de hoy, verdad, en donde está presionando la libertad de expresión por una serie de mecanismos impuestos al papel, o la frecuencia, y, lo que está pasando, pues, en Venezuela, y en mucha menor escala acá, pero ya con un sistema que concentre todos los poderes, ahora los poderes son muchos, pero no son todos, es más, tiene una mayoría, que si bien no es activa ni orgánica, una mayoría, no personalmente, sino institucional, y una minoría que es menos ya del $38 \%$, pero, indudablemente, controla la Corte, controla los tribunales, el Consejo Electoral, Contraloría, etc., ¿no?, entonces, ahí hay una estructura de poder, y junto a eso controla las calles, mediante fuerzas de choque, y eso explica por qué también el fraude electoral en donde se llevan 105 alcaldías de 153, habiendo perdido las elecciones, entonces, todo eso son núcleos de poder, de irradiación de poder, y de proyección frente a las elecciones del 2011, verdad.

R: No, pues, muchísimas gracias por haberme concedido esta entrevista. 


\section{ENTREVISTA $43^{61}$ :}

Nombre del entrevistado: Dña. Ada Esperanza Silva y Dña. Azahalea Solís.

Cargo actual: presidenta y vicepresidenta del Centro de Derechos Constitucionales.

Fecha de realización de la entrevista: Managua, 16 de septiembre de 2009.

Lugar: Centro de Derechos Constitucionales.

Duración estimada: 1 hora y 30 minutos.

\section{TEXTO - Transcripción 43:}

R: ¿Cuál es vuestra visión sobre la Constitución del 87 después de tantos cambios constitucionales que se han dado en el periodo democrático?, digamos, siempre con el afán de perfeccionar una Constitución, que, inicialmente, consolidaba un presidencialismo muy fuerte, dándole mayores facultades a la Asamblea Nacional en aras de fortalecer la propia democracia, la joven democracia de apenas 19 años que tiene Nicaragua.

A.S.: Bueno, tú me preguntas cómo la mirás, yo te voy a decir, yo escribí un artículo para el Observatorio de Gobernabilidad de Centroamérica, y yo ponía ahí que analizando la historia constitucional de Nicaragua era posible ver la historia del país, yo, pretenciosamente, voy a decir que analizando la Constitución del 87 puedo ver la historia de mi vida, porque para cuando se hizo la Constitución yo era parte activa de la revolución, y consideraba que eso era lo mejor, verdad, esa Constitución yo la consideraba muy acríticamente, verdad, ahora me parece una barbaridad, veo un montón de cosas, y digo: ¿cómo es posible, pues?, yo creo que hay una mezcla de juventud, por una parte, y otra parte por involucramiento en la revolución, verdad, entonces, sí, yo creo que fue una Constitución muy importante, en términos de derechos, y acorde con el período histórico que vivía, lógicamente, pero que no era la mejor Constitución para, efectivamente, hablar de democracia, y los distintos cambios, yo no creería, yo, personalmente, no creo que algunos sean democráticos, creo que hay luces y sombras en todas las reformas, desde la del 90 hasta la última, hasta la del 2005, creo que hay algunas que sí obedecen a un planteamiento democrático, pero también hay otras que no obedecen a lo mismo, incluso, la propia reforma democrática, que a mí me parece la mayor reforma democrática, que es la del 95, aún esa misma no tiene todos los elementos para hablar, efectivamente, de una democracia en los términos en los que yo quisiera que fuera.

A.E.S.: Bueno, pues yo igual que Azahalea, incluso, tenía unos cuantos añitos más que ella, ella todavía alcanzó a ser de la juventud sandinista y yo ya no alcancé, no mentira, la verdad es que era de la juventud sandinista la persona que se quería meter y yo no me metí, yo tuve esa experiencia, pues, trabajé en la Asamblea Nacional desde el 83 hasta el 90, y viví allí adentro todo el proceso de elaboración, consulta y aprobación de la Constitución del 87, y yo recuerdo, no había computadoras en ese tiempo, porque si no tendríamos las miles de versiones que se hacían de, no miles, pues, pero, por lo menos

\footnotetext{
61 Entrevista extensa compartida por ambas investigadoras, con apuntes de interés sobre los procesos políticos recientes, alguna dispersión y dificultades de expresión en la construcción coherente del discurso, pero con referencias significativas a la historia constitucional y la evolución incierta de la democracia nicaragüense en el momento actual.
} 
diez, como mínimo, te puedo asegurar que había de cada uno de los artículos y las propuestas que se hacían. Nosotras, el equipo, pues, como miembros de la asesoría jurídica, pues esa era nuestra tarea, tratar de decir esto es lo que hay en el mundo, y la decisión política la tomaban los que la tenían que tomar, nosotros éramos asesores, sin embargo, yo siempre recuerdo hablando de uno de los elementos que vos dijiste, lo del presidencialismo, eso eran unas fuertes discusiones adentro, antes de que salieran a la luz, verdad, porque la única ventaja de ser asesor es que te das cuenta antes de lo que después van a decir, y después, incluso, allí en el plenario después hacían otras cosas distintas de las que se suponía que iban a hacer, porque a última hora había una negociación política de esas cosas que ya se salen fuera de las decisiones del asesor o de la recomendación del asesor, entonces, lo del presidencialismo fue una cosa que, como dice Azahalea, veinte años después de aprobar la Constitución, lo que yo me atrevo a decir sin ninguna duda es que desde entonces ya, además no voy a descubrir el agua tibia como dice una compañera que nosotras conocemos, porque ya hirvió varias veces, ¿ya?, era que se estaba decantando y se estaba asentando el liderazgo individual de Daniel Ortega, y, como decimos en buen nicaragüense, Daniel Ortega se le estaba yendo arriba a todos los otros de la Dirección Nacional, ¿ya?, porque eso fueron una serie de discusiones que se hicieron y el presidencialismo puro y duro que aparece en la Constitución del 87, yo me atrevo a afirmar, sin ninguna duda, que no todo el mundo estaba de acuerdo, incluso dentro del Frente Sandinista, pero era ya que el ala danielista, como decimos ahora, se iba consolidando, incluso yo tengo simpatía como escritor con Sergio Ramírez, pero cuando yo oigo a Sergio Ramírez hablar de que, como decimos en el dicho aquél de: "yo no fui, fue Teté”, ¿ya sabés del dicho?, Sergio Ramírez es responsable $100 \%$ de todo lo que pasó en la revolución, ahora cuando lo ves haciendo críticas como el que está allí arriba, a mí me choca eso, a mí me cae mal, esa parte de él a mí me cae mal, porque él, incluso Raquel, él era la parte jurídica, todo lo relativo al Estado de Derecho, que empezamos a decir después, ¿verdad?, todo lo relativo al Poder Judicial, a la Asamblea Nacional, todo lo que tenía que ver con ello, él era el que dirigía el paquete judicial, jurídico, digamos, tenía, es el único vicepresidente de Nicaragua que ha tenido poder, porque todos los demás han sido figuras, verdad, pero él tenía poder, entonces, aparte de esta acotación específica sobre Sergio Ramírez, yo recuerdo las miles, miles no, vuelvo a decir miles, las varias versiones que hacíamos de los artículos, nosotros como equipo jurídico, y el presidencialismo se fue imponiendo y se fue imponiendo, y sin perjuicio, te lo digo ahora veinte años después, sin perjuicio de que comparto lo que dice Azahalea, yo tenía tres o cuatro años más que ella en ese momento, pero yo igual, yo cuando decían: "colguemos de los palos a todos los burgueses y ahorquémoslos y hagamos el mundo nuevo y se va a acabar la pobreza y los ricos y los pobres van a desaparecer", y todo ese cuento que nos tragamos, yo hubiera, como dicen ustedes en España, yo hubiera firmado sin ninguna duda por volarle la cabeza a todos los burgueses, ¿verdad?, pero también, otra cosa que lo vivimos ahí dentro de la Asamblea es que la formalidad jurídica que debía de existir para una Asamblea Nacional nosotros vivíamos allí, directamente, que eso era, simplemente, un parapeto, la Asamblea Nacional no mandaba nada, en la Asamblea Nacional a lo mejor hoy no está muy lejos de ahí, pero por lo menos hoy hay debate y hay conflicto público, pero en la Asamblea Nacional se llegaba a bendecir lo que ya se había arreglado fuera, ¿no?, como te digo, no estoy diciendo nada diferente de cómo funcionan los parlamentos, en los parlamentos se hace formal las decisiones políticas de afuera, verdad, eso, como decías vos, si se puede lo neutralizo, yo no creo nada de eso de la neutralidad a estas alturas de mi vida, pero era evidente, a ver, ¿cómo decirlo?, además de que se miraba eso evidentemente, había dos cosas que yo creo que eran 
esenciales para basar esta afirmación que ahora te la digo tan tajante: uno, que, de verdad, pues, yo también creo que allí es un lugar donde se concreta el forcejeo político entre las fuerzas, pero había sesenta y un diputados sandinistas, se llamaba, todo el mundo le decía, incluso nosotros, tal vez no le decíamos así tan abiertamente, pero los otros treinta diputados le decían: "la aplanadora sandinista", porque allí no había uno de los sesenta y un que votara diferente, ¿ya?, entonces, si tenés noventa, sesenta y un de entre los noventa, ya me dirás qué debate hay, había decisiones, entonces, mirá, la calidad de los diputados con el respeto que se merezcan las personas de baja formación académica, lo que ponían era dirigentes, ¿cómo decir?, dirigentes populares que llegaban allí a exponer su lucha política-ideológica, allí no había debate, los que había en el debate jurídico eran cuatro y eran esos mismos cuatro los que llevaban la decisión política, y los arreglos que habían hecho antes afuera, como te digo, que no es que yo crea que ahora es el debate químicamente puro, no, porque el pacto del que hemos hablado y hablado entre Daniel Ortega y Arnoldo, evidentemente, ahí se concreta en leyes muchas veces, ¿verdad?, pero, en aquél tiempo, yo eso sí lo afirmo, había un menosprecio por la Asamblea Nacional que se traducía, incluso, en la incapacidad de aprobar el presupuesto, fíjate que hay un compañero miembro del centro aquí que fue diputado constituyente que dice: "fíjate que nosotros no sabemos si somos honrados, porque a la hora de la piñata sandinista en la Asamblea no había nada que robarse, no sabíamos si lo hubiera habido si lo hubiésemos robado", como los otros, pues, no había nada, era una precariedad económica la de la Asamblea, fíjate que a los diputados los mandaban al otro lado del mundo a asistir a sus sesiones, a sus reuniones en otros parlamentos con cien dólares en la bolsa, eso a mí me lo contó, cien dólares en la bolsa, mientras que aquí había ministerios donde había, bueno, Azahalea también sabe eso, entonces, había un menosprecio por la ley, había un menosprecio por la institución de la Asamblea Nacional, y eso fue decantando que el Ejecutivo se fuera haciendo fuerte, y ahí te digo, ahí tiene su cuota de responsabilidad Sergio Ramírez 100\%, yo no lo eximo en nada de todo lo que hizo, me parece que tiene todo el derecho a arrepentirse pero yo tengo el derecho a no creerle también, porque a mí no me gusta cuando él se pone en plan crítico como que él no participó en nada, que tiene derecho, pues, a hacer su crítica, ya te digo, no le quito su derecho, pero la Asamblea era, nosotros decimos un término, "ninguneada", es decir, de ninguneo, de que no es ninguno, y se notaba en la calidad de las personas, fíjate que yo, mirá Raquel, todos o bastantes de los diputados propietarios eran los grandes ministros, las figuras públicas, y a la Asamblea mandaban al suplente, que eran los dirigentes de base, ¿ya?, y había unos cuatro o cinco que eran los que te digo que llevaban la voz cantante de la voz política de la línea del Frente y los treinta opositores que vivían en ese estira y encoge con ellos, dependiendo de las circunstancias, entonces, ¿qué te digo?, la Constitución fue producto de todo eso.

R: Pero sí me llama la atención, perdón que te interrumpa, en el proceso constituyente del 87 sí aparece como seña de identidad de la propia Constitución nueva, que inaugura también un nuevo régimen político, y que rompía con el ciclo revolucionario toda una etapa larga de dictadura, la participación popular, ¿no?, el amplio consenso, y además el propio proceso constituyente incorpora la figura de los cabildos, hay toda una demanda popular detrás de la nueva Constitución del 87, que sobrevive a la etapa democrática en nombre de esa reconciliación nacional, en nombre de la paz, ¿cómo registráis vosotras ese proceso?

A.S.: Mirá, la Constitución fue vendida, y así la asumimos, como un compromiso, pero yo, personalmente, no creo que entre el 87 y el 90 eso haya sido concreto, verdad, que 
eso haya pasado más allá de la retórica, creo que no, sin embargo, el énfasis que se le hizo a la Constitución entre el 87 y el 90 permitió que cuando se pierde la revolución en las elecciones del 90 todo el mundo corre a lo que decía la Constitución, todo el mundo, o sea, y a partir de ahí, con altos y bajos, desde entonces para acá, el peso de la Constitución ha ido calando como parte de una herramienta política de amplios sectores de la ciudadanía nicaragüense cada vez, ¿verdad?, que yo creo que fue parte de ese proceso que hubo en el que fue más subjetivo que objetivo el peso de la Constitución, yo creo que sí, yo así lo veo, y de manera que cuando todo el mundo decía: "en la Constitución dice tal cosa, en la Constitución dice tal cosa", cada vez, eso es un argumento que permanece aún al día de hoy, el hecho de cuáles son los postulados, cuáles son los derechos, etc., no sé si era por ahí.

A.E.S.: Sí, fíjate, en la campaña electoral del 89 había un grupo, básicamente, las que fundamos el centro, trabajaban, y yo me metí ya en el 89 a trabajar en capacitación jurídica a través de la Secretaría de la Mujer de una organización de profesionales afines al gobierno, y empezamos a hacer talleres y talleres y talleres, y yo me acuerdo que yo le decía a mis compañeras: "es mentira que se saben la Constitución", no sabían, pero había un imaginario colectivo, ¿verdad?, yo estoy de acuerdo con lo que Azahalea dice, la gente decía: "la Constitución", y no tenía la menor idea de lo que decía la Constitución, pero como que estaba la marca aceptada, ¿verdad?, y eso permitió que después de la pérdida de las elecciones por el Frente la gente saliera con que la Constitución nos va a defender, allí fue una, yo estoy totalmente de acuerdo con la Azahalea, porque yo me acuerdo, yo le decía a la compañera: "si vienen para que le regalemos el plato de comida y la camiseta", y nosotros le decíamos que votaran en la casilla 5, eso eran los talleres, y le explicábamos la Constitución, y hacíamos nosotras los derechos de las mujeres, pero las mujeres no tenían, por lo menos las mujeres, y así deben haber estado el resto, las mujeres no tenían: "que aquí me defienden mis derechos", no, había como un discurso: "la Constitución, la Constitución, defensa de la revolución”, ¿te acordás?, "sagrario de nuestra institucionalidad”, papapá...

\section{R: Así como una oración.}

\section{A.S.: Totalmente retórica.}

A.E.S.: Pero eso sirvió en el 90 para decir: "ah, bueno, aquí está, aquí está este instrumento, donde están unas leyes y yo las puedo defender”. Y a partir de ahí empezó a asentarse la idea de la Constitución.

A.S.: Cuando en tiempos de la revolución, yo todavía estaba estudiando Derecho, y en la facultad de Derecho en la que yo estaba los estudiantes se inventaron unos seminarios jurídicos, "Derecho y Revolución", un seminario de Derecho y Revolución, y por ese seminario pasaron toditos los dirigentes y yo estaba allí cuando Bayardo Arce, ¿verdad?, que era el Vice-Coordinador General del Frente dice: "bueno, ahora que tenemos el poder, nos damos cuenta de que nos hacen falta hasta abogados", o sea, para que mirés, y eso no fue una cuestión que se diluyó en los siguientes diez años, o sea, una total falta de cortesía, porque además el seminario era montado por los estudiantes de Derecho y todos, la mayoría, éramos estudiantes de Derecho, y entonces, dice: "ahora nos damos cuenta que nos hacen falta hasta abogados", eso para decir, los abogados son secundarios, pero al final vienen a darse cuenta que hay que legalizar un montón de cosas, que hay que analizar, que ir a la ONU, que ir a no sé qué, ¿entiendes?, 
pero ese sentimiento prevaleció, y prevaleció eso de que la revolución era fuente de Derecho, que, teóricamente, es verdad, pero eso no quiere decir que era arbitrario, que la revolución como fuente de Derecho significa un cambio de sistema, y un cambio de sistema se va a expresar en leyes, pero no lo entendían así, lo entendían como que, de hecho, se podía hacer cualquier cosa en el marco de la revolución, y se hacían, entonces, esa es parte de...

\section{R: ¿Del efecto de ese Ejecutivo fuerte que se consolidó?}

A.E.S.: ¿Vos no conocés los escritos de Vintró sobre la Constitución del 87?, él habla del marco de la tradición liberal-democrática, de la separación de poderes, yo le digo las tres barbaries, y Vintró habla de las cosas que decían, como que le dieron al Ejecutivo las facultades de hacer impuestos, ¿el Ejecutivo haciendo impuestos?, eso hasta 1995 duró, pero, de acuerdo a una cosa concreta que también lo señala Vintró en uno de sus escritos, de que sale la Ley de Emergencia, pero sale la Ley de Emergencia y creo que el mismo día de que se aprueba la Ley de Emergencia en la Asamblea Nacional sale un decreto del Poder Ejecutivo prorrogando el Estado de Emergencia sin hacer caso de lo que la ley acababa de decir, ¿ya?, hacía cosas así, y ahora las está haciendo otra vez el presidente actual, que es el mismo de entonces.

$R$ : $Y$, sin embargo, la reforma, bueno la firma de los acuerdos de paz, y ese fruto tardio de la revolución que es la democracia liberal, ¿no?, que es una de las grandes paradojas de la propia evolución política de este país, ¿cómo se articula el debate entre la reforma total y la reforma parcial a la Constitución del 87?, porque ese es un punto de conflicto clarísimo.

A.S.: Sí, mirá, ahí hay silencio, ahí hay silencios muy evidentes, por supuesto, nosotras, aquí se escribió un artículo, un documento del cual Ada es también coautora de las reformas del 95, creemos que fueron unas reformas necesarias, eran fundamentales, verdad, si esas reformas del 95 no se hubiesen producido, el gobierno posterior que vino, que fue el de Alemán, hubiera sido mucho peor la situación de lo que fue, ¿verdad?, todo el poder que tenía, de manera que hubo un momento en el que la posición de la gente que nucleaba a Alemán intentó mantenerse un poco al margen, al final, solamente, fueron muy poca gente de la Asamblea la que no estuvieron a favor de las reformas constitucionales, pero, por otra parte, en términos económicos hubo una reforma total, que esa queda obviada y nunca se dice, nunca se plantea, pero, en realidad, el cambio económico fue brutal, que ya venía siendo operado, de hecho, y a través de leyes ordinarias, entre el 90 y el 95 , verdad, una serie de leyes ordinarias y otra serie, de hecho, de decisiones de gobierno, que, de hecho, cambiaban el sistema en la parte económica de acuerdo a lo que decía la Constitución, pero ese aspecto no se menciona nunca, claro, porque había un cierto consenso social, y ellos decían, la Constitución, al fin y al cabo, es resultado de un consenso, que puede ser explícito o no, porque creo que no fue explícito, pudo hacer sido explícito en conocedores, los cambios, ¿verdad?, pero no era explícito en la ciudadanía nicaragüense, pero no levantó mayores olas esa situación, como sí levantó la del 2000, verdad, como sí levantó la del 2000 , entonces, ¿qué ha pasado?, que hay un debate, yo creo que, a mi juicio, bastante interesado o desinteresado, depende de cómo se mire, sobre las falencias constitucionales al definir la reforma total o al definir la reforma parcial, de hecho, a mi juicio, desde luego, plantear las dos es que no son la misma cosa, verdad, y desde luego, existe ese planteamiento normativo, algo tiene que significar en términos políticos, te 
puedes ir a los Diarios de Debates y no hay mucho, pues, como te decía Ada al inicio era aplanadora, ya había decisión, y vos no vas a ver los grandes alegatos en relación a por qué es constitucional, entonces, no hay mucha ayuda, sin embargo, hay una historia política del país, y, entonces, creo que un seminario, precisamente, Vintró decía que si significaba que como no hay definición de qué cosa es una reforma total, entonces, vamos a hacer una monarquía, y en el debate todo el mundo dijo que no era así, verdad, que había límites, y entonces, claro que hay límites, verdad, que hay límites, pero la falta, la interferencia política, la falta de institucionalidad, la falta de independencia política ha hecho que esas definiciones se hagan más cuesta arriba definirlas jurídicamente, o más cuesta arriba definirlas contextualmente, de acuerdo al propio texto constitucional, a lo poco que pueda haber en el Diario de Debates cuando se aprobó la Constitución, pero en lo mucho que hay en la historia política del país, cuáles son, digamos, los ejes principales que vos vas a plantear, vos no puedes dejar de señalar que a partir de que Nicaragua declara su independencia el republicanismo es parte, o sea, ¿cómo vas a venir a decir que permite, como vos no defines que es reforma total, pues, vamos a cambiar eso?, verdad, no lo puedes cambiar mientras tanto no haya una reforma total, porque hay una constante histórica, pero sí creo, que, por supuesto, hay una carencia definitoria, pero más que eso, como está contaminado el debate es lo que hace más conflictivo eso que vos planteás.

A.E.S.: En la parte económica, a nuestro juicio fue una reforma total, ahí hubo una influencia de la Corte que dice que puede ser reforma total con una reforma parcial, pero de una flexibilidad escandalosa, ¿ya?, que no dice que tipo de artículos no puede reformar, ahí es donde hizo la pregunta Vintró en ese evento, ah, entonces, podemos poner monarquía, pues, en ese mismo evento, directamente, yo le pregunté a Luís Humberto Guzmán, que había sido presidente de la Asamblea cuando se hizo la reforma del 95, ¿por qué nos queremos rasgar las vestiduras cuando hablamos de reforma total para otros temas y en el 95 pasó sin pena ni gloria la reforma económica?, y como les convenía a todos, al Frente Sandinista, nadie dijo: "esta boca es mía", entonces, él me contestó con el discurso del consenso, ese evento fue, yo lo he hablado a veces, un par de ocasiones lo había hablado con él directamente, pero esa vez se lo tiré en público para ver qué decía delante de los chavalos, ¿verdad?, porque estaban allí un montón de jóvenes de la Facultad de Derecho de León, y él siempre se encubre con el consenso, que el consenso, que las constituciones son fruto del consenso, lo que acaba de decir la Azahalea, y que entonces ya que todo el mundo estuvo de acuerdo en decir que de economía planificada pasaba a ser una economía de mercado y eso no es una reforma total, pues, entonces, pasa como reforma parcial.

R: Sí es interesante en el proceso de negociación política que se da entre el actor que gana la guerra, instaura un nuevo régimen, y que pierde las elecciones y que abandona el poder que había conquistado con las armas, ¿no?, a través de las urnas, que yo creo, es un comportamiento democrático del Frente en los años 90, cuando acepta la victoria de Doña Violeta Chamorro. Sí es verdad que en el proceso de negociación que se da entre el Frente y la UNO entonces, que era la coalición gubernamental del bloque liberal, es el hecho de intercambiar la permanencia de gran parte del andamiaje institucional de la revolución por esas reformas económicas que suponen un giro estructural hacia el neo-liberalismo de 180 grados. ¿Ese es un poco el intercambio que se dio entre los actores que se sentaron a negociar? Bueno, aparte de que el Frente haya sido un empresario próspero en los últimos años. 
A.S.: Yo creo que no es tan evidente, y no es explícito al principio, yo no creería eso, yo creo que, en ese momento, el tema económico no estaba en cuestión, que, en ese momento, estaba en cuestión la sobrevivencia, estaba en cuestión la sobrevivencia, y la sobrevivencia entendida en total, verdad, ¿qué había pasado?, se pierde la revolución e, inmediatamente, la gente que gana, que es la gente de la UNO cree que se va a repetir lo mismo que se repitió en el 79, o sea, es una cuestión absurda, porque en el 79 hubo una revolución, en el 90 hay un proceso electoral, verdad, en el 79 había una correlación política en el mundo distinta a la que hay en el 90, ya ha caído el Muro de Berlín, por cierto, que en estos días se cumplen veinte años, en un par de meses, verdad, entonces, ya es otra la cuestión, en el 79 todavía la presencia de las dictaduras militares era parte que estaba en la piel de la ciudadanía latinoamericana, en el 90 ya han venido procesos democráticos, verdad, ya se ha probado el jugo de las elecciones, entonces, es absurdo lo que ellos estaban planteando, pero tenían ese planteamiento, yo escuché una vez a una persona, Don Roberto Ferrey, que era dirigente de la Contra, que dijo: "nosotros hubiéramos querido que el 25 de abril, al amanecer del 25 de abril, no amaneciera ningún sandinista", fue cuando se dio el cambio de gobierno, y Daniel Ortega entrega el poder a Doña Violeta, lo dijo sin ningún rubor, creo que ahora sería muy difícil que lo dijera, porque también ha habido cambios, del 90 al 2009 han cambiado, pero lo dijo sin ningún rubor, que hubieran querido que no pasara eso, entonces, yo creo que el espíritu que estaba prevaleciendo ahí era eso, ese asunto, entonces, vos ves en los primeros años 90, en el 91, el 92, el forcejeo por que se mantengan las cosas, porque todavía mucha gente, y lo puedo decir sin ninguna ingenuidad, mucha gente que firmó hasta nombre para todo el despojo que se hizo del Estado creía de verdad que era para defender la revolución, que era para defender las conquistas de la revolución, y que era para que pudiéramos sobrevivir, nos pudiéramos acomodar y volviéramos a la cuestión, fijáte que, por decirte una cuestión anecdótica, alguien abrió un bar, verdad, alguien abrió un bar, y, entonces, entregaban una notita que decía: "válido hasta el 25 de abril de 1990", cuando iba a haber cambio de régimen, ¿verdad?, pensaban que todo eso que se estaba haciendo era en función de, yo creo que ya, posteriormente, es que sí entran las negociaciones económicas, y ya cuando se dan las reformas del 95, ahí sí hay una voluntad ya de que haya un cambio económico ya interesado, ya el Frente es un actor económico, cree, se convierte, deliberadamente ya se considera que debe ser un actor económico a la par de la burguesía tradicional, a la par de la burguesía tradicional, etc., entonces, yo no creo, o sea, si alguien me dice lo contrario, pues, me tendrá que decir los argumentos pero yo no creo que en el 90 esa haya sido la cuestión.

A.E.S.: Fíjate que nosotros lo vivíamos, nosotras como ONG, aquí estábamos en la Red Interamericana para la Democracia, ¿verdad?, una instancia financiada por la Ayuda Internacional al Desarrollo (AID), nosotros, aquí las ONGs nos dividimos desde el principio y así nos decían las ONGs democráticas y las otras éramos las no democráticas, las democráticas eran las que estaban instalando la AID, que venían los proyectos de la AID para reforzar la democracia y todo, les decían las ONGs democráticas, o sea, a contrario sensu, ¿nosotros qué éramos?, ¿verdad?, y nosotras éramos todas las que habíamos salidos a hacernos asociaciones civiles después de la pérdida de las elecciones, y, entonces, la Azahalea aquí hizo un discurso que a todo el mundo dejó callado, porque venían, nos andaban queriendo conquistar para que nosotras las que teníamos más o menos perfil jurídico, y que ya sabían que veníamos, teníamos el pecado original rojinegro, ¿verdad?, que empezáramos a juntarnos con ellos, pero, entonces, nos hablaban en un tema de condescendencia, pero como que nos perdonaban la vida, y la Azahalea se levantó y le dijo: "hablemos de tolerancia y 
respeto, pero que nosotros somos los tolerados siempre, nosotros somos los que ustedes hacen el favor de respetarnos", porque era esa cosa, que hacían el favor de aceptar de que existiera, y entonces el Frente eso fue lo que nos permitió, el Frente se metió a la sobrevivencia y como sabe jugar duro, y sabe tener disciplina, y sabe arriesgarse, porque él se arriesgó con la dictadura, pues, y por eso está ahí, porque se sigue arriesgando y sigue maniobrando bien, fijáte que, ¿sabes lo que hizo en ese período que dice Azahalea que se consolidó a la sobrevivencia?, trabajó así a nivel de hormiguita para apoderarse del Poder Judicial, el Poder Judicial no es de la noche a la mañana que quedó en manos del Frente Sandinista, y que de los 400 jueces 350 sean militantes del Frente, lo hicieron, “a ver, Ada vení, mirá, ¿querés ser juez?, ¿vos vivís en Ticuantepe?, ¿querés ser juez local de Ticuantepe?”, entonces la Ada que es militante sandinista se hace juez de Ticuantepe, porque ganaban cuatro pesos, pero mientras los otros que venían con las ínfulas de la victoria le decían que se fuera a hacer juez, qué van a querer ser juez si eso no servía para nada, y ganaban un mal salario, y el Frente se fue así, mirá, pasito a pasito se fue, además de que ya todos los que estaban eran afines al Estado sandinista, ¿verdad?, pero así se fue consolidando, y así fue, pues, buscando reales, y se puso de moda los poderes judiciales en el mundo, porque como nos vamos siguiendo de modas, ¿verdad?, las mujeres, los niños, ahora hay que fortalecer el Poder Judicial, después, empezaron a tener reales los poderes judiciales, y así, el Frente Sandinista se apoderó así, poquito a poco, del Poder Judicial, bien pensado, y pensado dentro de veinte años yo voy a tener esto, mientras que los otros, o no tienen, o yo no sé lo que le pasa a la gente, lo que decimos nosotros, de la derecha, no ves ahí una persona, ¿es que en el Frente Sandinista están todos los estrategas?, ¿no pueden pensar que dentro de veinte años puede suceder tal cosa?, yo no sé si es que son inmediatistas, no sé si lo único que les interesa es, como al Alemán y toda su panda, hacer reales rápido y se acabó, pero yo no puedo creer que no tengan a alguien que pueda decir: "podemos hacer esto aquí para dentro de diez años vamos a tener esto", y el Frente Sandinista lo hace, y lo sigue haciendo.

A.S.: De todos modos, yo no creo que haya tenido, yo no creo que haya sido una cuestión económica, sí había intención de que, de mantener la diversidad económica, porque muchas de las fábricas y de los negocios pasaron a manos de trabajadores y de manera directa pasaron a ser parte del Frente, y todo lo demás, sí había, por supuesto, pero no estaba en el ánimo, en ese momento no, porque recordemos que el acuerdo de transición se hace en el 90 previo a la entrega del poder y la Contra no está desmovilizada, la Contra se desmoviliza un año después, verdad, o sea, no hubo...

\section{R: Pero si la ascendencia que pudiera tener el Frente por los sindicatos que son los que lideran la protesta social de los primeros 90.}

A.S.: Claro, eso sí, pero, porque, ¿cómo se llama?, porque se lidera, pero al principio no estás hablando de aspectos económicos, por ejemplo, los sindicatos se movilizaron y toda la gente se movilizó para que no sacaran a Humberto Ortega de la dirección de la jefatura del Ejército, y eso fue en el 92, todo ese tiempo, todo ese tiempo hubo cosas que eran, ya se movilizaban para todo, lo que se consideraba que era un asunto de principios, para todo lo que se consideraba que era que si eso lo perdía se pasaba la cuenta, ¿me entendés?, y se pasaba la cuenta a todo el mundo, nosotros llegamos hasta el año 97, nosotros llegamos hasta el año 97 con Alemán, en que nosotras éramos parte de lo mismo, o sea, para ellos no se había puesto indistinto qué cosa era el sandinismo que está con Ortega y el sandinismo que no está con Ortega, ellos miraban a todo el 
mundo, y a todas las jóvenes, porque la mayoría veníamos de ahí, del sandinismo, era una sola, no había medias tintas, ni medios colores, no, no, no, ahí había una sola, y sí el tema económico era ya un poco más adelante, sí ya es explícito, y te voy a decir sin ánimo de Daniel Ortega, que es mi adversario número uno en el mundo, yo creo que no estaba interesado, incluso, al 94 o el 95, Daniel Ortega no estaba interesado en cuestiones económicas, no era parte de su talante en ese entonces, era otra gente del Frente la que estaba más interesada en términos económicos.

A.E.S.: Había otra gente que estaba pensando en lo económico, ¿verdad?, no hay sólo tiburones de derechas, aquí hay tiburones de izquierdas, de centro, de arriba y de abajo, ¿ya?, seguramente, mucha gente de esa que alguna pensó que, bueno, esta empresa de ser propiedad del pueblo, bueno, ahora que se va a privatizar, y que salga a nombre de la Ada, porque va a proteger a los empleados de esta institución, pero la Ada se fue arriba y se fue con su empresa, ¿ya?, o sea, que a algunos rápidamente se les olvidó que había que proteger los logros revolucionarios económicamente hablando, que se supone que ese fue el espíritu que animó todo ese movimiento de apropiación de bienes del Estado muchas veces indebido, ¿ya?, entonces, sí, yo también coincido con la Azahalea que, por lo menos, los dirigentes del Frente estaban consolidando su poder político, y decir: "nosotros somos los que podemos hacer eso", y ellos eran los que podían hacer eso aquí, y lo seguimos viendo, en lo de noviembre cien personas en cada rotonda en esta ciudad paralizaban Managua, ¿y los demás que hacemos?, nada, sólo ver, a ver ¿quién se va a enfrentar con eso?, nadie, nadie, nadie, y paralizaban el país, porque paralizaban Managua, y ponés otros cincuenta en cada una de las entradas a Managua y te paralizan el país, y todo el mundo les tiene miedo, y nadie se le enfrenta, ¿por qué?, por eso es que le tienen miedo a las mujeres, ¿por qué?, porque aparte yo con el respeto debido a las mujeres que no vienen del Frente, yo siempre veo que las más valientes son como la que tengo enfrente, que vienen del Frente Sandinista que les enseñó a una a ser valiente, ¿por qué?, porque íbamos a cambiar el mundo, íbamos a pelearnos con los gringos, íbamos a derrotar al imperialismo, aunque fuera puro cuento, pero de verdad nos lo creímos, de verdad nos lo creímos, fijate que a mí no se me olvida, yo lo cuento como chiste, pero, de verdad, yo me acuerdo cuando en tiempos de la revolución perdonaron a uno que cayó en la montaña, y era un chele, un gringo de seis pies de altura, y un negrito, esa foto era bárbara, increíble era esa foto, el chele gringo de este tamaño amarrado con un mecatito, y un negrito flaquito como yo detrás de él, entonces, ese era el símbolo de la revolución triunfando contra el gringo, ¿ya?, contra el alto, chele, poderoso, y después, por supuesto, le dieron la amnistía, lo mandaron a su casa para no seguir en los pleitos con los gringos, pero ese era un símbolo que, de verdad, nos lo creíamos, de verdad nos creíamos que ese negrito, flaquito, le podía ganar al chele de seis pies, que tenía una avioneta que por desgracia se le cayó y por eso lo agarraron, ¿ya?, pero entonces, ¿cómo eso sigue traspasando la vida hasta ahora?, sí, yo creo que sí, porque los de la derecha, por eso te digo, yo no sé, yo sé cómo opera el Frente, pero lo que yo no entiendo es cómo operan los otros, que tienen sus intereses inmediatos de hacer reales, de tener poderes en el momento, mientras que estos hacen esto y son capaces de decir lo que quieren hacer dentro de veinte años y lo logran.

R: Sí es cierto que el Frente aprendió que tenía que controlar las instituciones democráticas si quería acceder al poder, ¿no?, ese es parte del aprendizaje institucional que ha tenido el Frente desde 1990 hasta ahora, incluso la propia reelección de Ortega es fruto del pacto que disminuye el techo electoral necesario para la victoria en primera vuelta. Hablando de la flexibilidad que comentabas 
anteriormente para reformar la Constitución lo primero que llama la atención son dos cosas: primero, que se reforma la propia cláusula de revisión constitucional, que, normalmente, en otras constituciones forma parte de lo que llaman el "bloque de constitucionalidad" los juristas algo intocable si no es haciendo una nueva constituyente y una nueva Constitución, obviamente, y segundo, esto de las Leyes Marco para tratar de ampliar el proceso de aplicación de las normas constitucionales revisadas porque los actores políticos, que, en este caso, eran el Ejecutivo y el Legislativo, no se ponen de acuerdo.

A.S.: Eso es una barbarie, creo yo que habría que remitirse al tema de la cultura política del país, por eso, yo planteo en ese escrito de institucionalidad democrática de que entender la historia política del país puedes hacerlo a través del estudio de la historia de la Constitución en el país, porque cada vez el sistema ha cambiado la Constitución para acomodarla, me imagino que eso ya lo sabés, entonces, es parte de la cultura, y entonces, hay gente que se rasga las vestiduras en planteamientos jurídicos democráticos de altos vuelos teóricos y demás, $\mathrm{y}$ a la hora de la hora viene a ser lo mismo, verdad, y entonces, yo sé, a lo mejor voy a ser profeta del pasado, pero cuando ocurre y si era necesaria hacer una reforma constitucional en el país entre el 90 y el 95 o el 96, que es el período de gobierno de Doña Violeta, hacer esa barbaridad de eliminar la segunda vuelta, ¿verdad?, Doña Violeta no publica la ley, y es una cuestión que quedó ahí sin valor, y la hace la misma gente que tiene planteamientos de la supremacía constitucional, la misma gente, ¿me entendés?, entonces, ese es el problema de cómo ser creíble, entonces, y lo aceptás en aras de resolver un asunto, y esa es una constante que se da, ahorita con la cuestión del golpe en Honduras yo me pasé una mañana convenciendo a la gente de la derecha con la cual he tenido relaciones para que fuera contundente el rechazo al golpe, y había gente que decía una chimadita a la Constitución no es tan malo, para nosotros una chimadita es un golpe, una chimadita no es tan mala, y te lo digo no porque tenga la menor simpatía con Zelaya, al contrario, Zelaya está dentro la órbita de Chávez y Chávez está haciendo desastres espantosos en América Latina, por mucho que alguna gente tenga simpatía con él, pero la verdad es que está haciendo un daño enorme a América Latina y a nuestro país está haciendo mucho daño, entonces, no tengo ninguna simpatía, pero me pareció un asunto de principios ese tema, que si entonces vos estás hablando de la supremacía de la Constitución, estás hablando de una serie de aspectos que considerás que sos vitales para cambiar la cultura política, no podés aceptar un asunto de antipatía que le dan a tu enemigo, por ponerlo en términos de guerra, le hagan algo de eso, pero hay mucho de esa cultura institucional, entonces, ese doble parámetro, ese doble estándar, yo creo que es parte de la cultura política del país, está, o sea, no puedes obviarla, no puedes estar al margen de esa, también incide en momentos de reforma constitucional, y entonces, a la hora de buscar cómo resolver, hablando de la Ley Marco, en la época de Doña Violeta, Doña Violeta del lado de Antonio Lacayo se oponía completamente a las reformas constitucionales, o tal vez no completamente, se oponía a una parte de las reformas constitucionales, y, entonces, hicieron un montón de cosas que están reñidas con un discurso democrático, o sea, ¿qué hicieron, por ejemplo, al introducir un montón de recursos de inconstitucionalidad a todos los ministros contra la reforma y luego negarse a sancionar la ley y a publicarla?, o sea, y no había margen, la Constitución no le daba margen a Doña Violeta para otra cosa, pero lo hicieron, y después fue forzar la negociación para que se pudiera aplicar otra barbarie más como aceptar una parte de la reforma y otra parte no, ¿sabes eso?, verdad, había siete Magistrados en la Corte Suprema de Justicia la Constitución decía siete Magistrados, la reforma los aumenta a 
doce, y entonces muere un Magistrado y había que reponerlo, verdad, y, entonces, en el proceso previo posterior a la muerte del Magistrado es que se produce la reforma que pasa de siete a doce, entonces, Doña Violeta lo que hace es poner a uno más, al séptimo, y los otros cuatro no, verdad, porque aceptó sólo una parte de la reforma, ¿me entendés?, así de tranquilo, y hablábamos de todo el tema, o sea...

A.E.S.: Los eligieron dos veces a los Magistrados.

A.S.: Sí.

A.E.S.: Cuando el Ejecutivo no los aceptó un tiempo y después los volvió a bendecir la Asamblea, y el Cardenal Obando porque dijo esa frase famosa de que "los electos, electos están".

A.S.: Eso era lo que quería destacar la Constitución, aquí él manda, él manda publicar la ley, o sea, y este es un Estado laico, ¿me entendés?, entonces.

R: Llama la atención que sea una figura religiosa la que ha mediado las dos veces en la Ley No. 192 y también en la Ley No. 520 de 2005, en los dos procesos de conflicto grave con Bolaños y con Violeta Chamorro.

A.S.: Sí, así es, entonces, eso, no está al margen la cultura política, y esa constante de las cúpulas partidarias de negociar al margen de, ¿verdad?, y cuando están en la llanura, pues, entonces, quieren las reformas constitucionales, y cuando están en el poder entonces ya...

R: Sin embargo, esta referencia a las cúpulas partidarias que has hecho se da con mucha mayor incidencia en ese punto de inflexión que significan las reformas de 2000, incluso, se llaman o se mencionan como "contrarreforma", porque el hilo conductor de las reformas del 95, que yo creo que sí tienen un respaldo de legitimidad por lo que suponía de apertura democrática, de corrección del hiperpresidencialismo del Ejecutivo revolucionario y todo eso, en la del 2000 ya son los dos principales líderes de los dos partidos más importantes los que hacen la reforma, los que de alguna forma se reparten cuotas de representación paritarias en los principales órganos del Estado.

A.S.: Claro, es decir, no se puede negar, digamos, al margen de todo el asunto de la legitimidad, que significaba hacer la reforma en el 94 y en el 95, pues, en esos dos años, el mandato popular dado en las elecciones también venía a significar algo, yo estoy totalmente de acuerdo con eso, que el mandato fue evidente, o sea, el mandato fue evidente, no puedes negar que hubo un mandato popular y un $60 \%$ con el que gana Doña Violeta, o sea, no es decir, eso tiene que traducirse en el marco jurídico, por supuesto, nada tiene que ver con lo que pasa en el año 2000, absolutamente nada, pero, o sea, por eso te digo, a lo mejor vuelvo a ser profeta del pasado, pero el hecho de que en el 95 también se coló una reforma total frente al 2000 que significa también una reforma total los argumentos quedan débiles, porque, entonces, si me conviene es correcto y si no me conviene no es correcto, ¿entiendes?, ese tipo de cosas, no la han explotado, pero sí alguna que otra vez han dicho, pero si otros han hecho reformas totales, ¿por qué si las hacemos nosotros ahora va a ser malo?, verdad.

R: Sí, hay una pauta que se consolida de flexibilización de la Constitución. 
A.E.S.: Es como en la Ley Marco, hicimos una barbaridad y la volvimos a hacer.

\section{R: Además de la reforma de la propia Ley Marco.}

A.S.: Y encima esa estupidez, verdad, de reformar, de darle un año más.

R: Porque el Ejecutivo no se quiere aplicar a sí mismo la limitación de facultades que sí querían aplicarle al presidente Bolaños, que de todos los presidentes que ha tenido Nicaragua, yo creo que es el que más sólo se ha quedado en la Asamblea Nacional, porque no tiene ni siquiera el apoyo de su propio partido, que representa esa división del liberalismo que tanto ha favorecido a Daniel Ortega.

A.S.: Sí, es que Don Enrique Bolaños fue bastante ingenuo en política, o sea, no tomaba, o sea, tomó riesgos, pero no tomaba los riesgos que había que tomar, a él le faltó energía para acusar a todos, verdad, y eso le permitió manejarse, mirá él acusó a Alemán, y luego estaba el otro que era Byron Jerez, pero a Byron Jerez lo acusaron con toda su familia, y eso a Jerez lo colocó en una situación de vulnerabilidad que no tuvo Alemán, entonces, Alemán pudo recomponerse mientras que el otro no, entonces, Alemán se recompuso, ahí le faltó a él irse contra todo, por razón de prurito y todo ese tema, pero por el otro lado, él había hecho esos acuerdos que se hacen, políticos, y luego cambió, y vos sabés que si en política vos hacés un acuerdo y cambiás en medio, eso te lo cobran después, entonces, jugó en ese margen creo yo que con mucha ingenuidad y con mucha soberbia, por supuesto, que es parte de su responsabilidad, y además se le aconsejaron muchas cosas que él no cumplió, aunque ahora, a mi juicio, yo creo que en los años va a haber mejores opiniones políticas en relación a él, porque sí es verdad que, en términos económicos, dejó al país mejor de lo que el país está, y que había muchas cosas, que, aunque no se miraran en el día a día, había cosas que estaba haciendo que se podían ver más adelante que ahora se han, y otra cosa que yo la encuentro muy positiva de él, que me parece que yo alguna que otra vez lo he dicho públicamente, es el hecho de que se ha negado a ir a integrar a la Asamblea Nacional, me parece muy positivo de él, porque él está en desacuerdo con eso.

\section{R: Con el tema de la inmunidad.}

A.S.: Con el tema de que los presidentes vayan después de que dejan de ser presidentes a integrar la Asamblea Nacional, él está en desacuerdo con eso, me parece muy positivo, él es medio cuadrado, entonces, fue a tomar posesión para cumplir con la ley pero no se integró porque él está en desacuerdo, entonces, me parece que es muy positivo, porque aunque alguna gente le ha pedido que vaya a hacer quórum o que vaya, había una vez una votación muy reñida y si él se hubiera integrado hubieran ganado, verdad, entonces, pero él dijo que no, que no iba a ir, y me parece muy bueno, porque a lo mejor si hubiera ido, momentáneamente, hubiera ganado, pero ya queda que a pesar de lo que ha dicho que está en contra de la norma, al final también fue, digo, esta es una cuestión que yo rescato de este señor, que no me lo está pidiendo ni nada de eso, pero...

R: Otro aspecto que a mí me interesa, además lo refería antes, quiénes son los que hacen las reformas politicas, porque cambia mucho cuál es la decisión final, o sea, qué es lo que se reforma y qué es lo que no, ¿no?, en la del 95 hay un arco parlamentario con la representación casi multipartidista, son muchas más formaciones con 
representación en el parlamento, y, sin embargo, en las de 2000 y de 2005 son las dos fuerzas mayoritarias, también por esa reforma constante de la Ley Electoral, que ha presidido cada uno de los comicios presidenciales, legislativos y municipales en el país, ¿no?, también las regionales y las del Parlamento Centroamericano, que tienen ustedes un abanico grande de elecciones, y si que me llama mucho la atención como Daniel Ortega y Alemán a través del pacto, que tampoco es algo insólito, sino que forma parte, como hemos visto, de la historia politica de Nicaragua, como pactos politicos han precedido reformas en el pasado, y han sido componendas, intercambios, hay un elemento, digamos, de interés por parte de la élite política de repartirse cuotas de representación, hay una diferencia entre la palabra "pacto" y la palabra "consenso", yo creo que si en el 95, incluso en el 87 había un consenso popular y también político de cara a la reforma, difícil, pero al final se logró, ya a partir del 2000 la reforma es casi un objeto de negociación entre las propias cúpulas partidarias, incluso, al margen de la sociedad civil que queda expectante viendo como estos cambios se suceden sin que haya un respaldo de legitimidad ciudadana detrás de esas reformas constitucionales.

A.E.S.: Es que yo creo que lo que Azahalea dijo de que el móvil no es económico en el 90, aunque después la clase emergente empieza a hacer reales, y habían dicho: "es que somos gordos y negros", como dice la gente, y una vez resulta había dicho el presidente de la Corte Suprema de Justicia, diciendo que la gente de la burguesía tradicional los miraba como burros cargados de dinero, "es que somos gordos y negros", ¿ya?, entonces, esos gordos y negros, o esos chapiollos, como decimos nosotros, los sandinistas que empezaron a tener reales, y los gordos y negros de Alemán se empezaron a juntar y esa es la nueva clase económica emergente, y después el pacto entre Alemán y Ortega no sólo es político, es también porque ya ellos se están consolidando como un grupo de poder económico y se tienen que ver las caras con la burguesía tradicional que mientras menos competencia tengan mejor para ellos, y entonces eso, pero para contestar a tu pregunta, porque ya me perdí en el razonamiento, entonces, ¿qué es lo que tienen ellos?, pues, todo el mundo dice que ellos también están amarrados económicamente, $\mathrm{y}$ debe ser cierto, $\mathrm{y}$ por otro lado, amarrados económicamente con los otros, o por lo menos para decir no me hagas esto o te hago esto, y nosotros siempre ponemos de ejemplo una cosa que es, absolutamente, el capital de Alfredo Pellas que se supone químicamente puro, o químicamente puro 100 años después o 150 años después de que su antepasado le robase las tierras a quienes se las robó, ¿verdad?, para poner el ingenio de la Flor de Caña, pero que ese edificio que vos ves ahí de la Casa Pellas no haya pagado impuestos, porque fue declarado como de exención fiscal por razones turísticas, y que una persona como la Azahalea o como yo si queremos hacer una casa tengamos que pagar un montón de impuestos, ¿ya?, ¿por qué?, ¿porque nuestra casa no es turística y nadie la va a ir a ver?, entonces, ¿a razón de qué no va a pagar?, ¿por qué?, porque en sus componendas también están metidos los ricos con ellos, y lo estamos viendo ahorita con la reforma tributaria, el otro día sale diciendo el presidente del COSEP, de la cámara de la empresa privada, que lo que hay que hacer es formalizar a todo el sector informal para recoger más impuestos, pero no quiere de ninguna manera pagar impuestos sobre los dividendos que ellos ganan, que ahora están exentos, entonces, ¿me entendés?, ah, ¿qué prefieres?, que a las miles de personas que andan en el sector informal, que no te digo que los del sector informal sean todos ángeles bajados del cielo, que debe haber de todo, como hay, pero ¿por qué no pagan impuestos ellos que son los que más ganan, las grandes empresas?, y el Frente Sandinista ahí está con ellos forcejeando, y, entonces, ahí es donde vuelvo a lo mismo, 
que lo que se mueve que uno no se da cuenta, si no me haces tal cosa te pongo el impuesto, ¿ya?, para poner un caso concreto de lo de Jerez que la Azahalea contó, ese es vox populi, yo no lo puedo asegurar como notaria pública, ¿verdad?, no puedo dar fe pública, pero todo el mundo dice que a Byron Jerez lo dejaron libre a pesar de que estaban todas las pruebas en contra de él, porque le dio reales al Frente Sandinista, entonces, ¿qué pasa con todas estas movidas políticas?, que por debajo hay otro montón de arreglos que uno ni cuenta se da, o los presume, o como decía nuestra amiga Pilar Troncoso, una española, sevillana, feminista, que dice que, ¿cómo es que le dicen en España, el harakiri?, pero, cuando todo el mundo se puso de acuerdo para hacerse el harakiri, nada de harakiri voluntario, cuando le dijeron: "mire, diputada Azahalea Solís, le tenemos agarrado tal y tal escándalo, económico, político, personal, lo que sea, o renuncia o mañana amanece en los medios", la Pilar Troncoso jura sobre una Biblia que así se hizo la renuncia del Congreso de los diputados de Franco, que no fue nada de "ay, por la institucionalidad democrática y la construcción y la transición democrática", ella dice que fue a punta de amenazas entre unos y otros que se hizo, a lo mejor es cierto, pues, a lo mejor es cierto en algunos casos, pero aquí hay un chiste que dice que a Alemán sólo le suenan las llaves de la cárcel modelo y ya se arregla con Daniel Ortega.

A.S.: Yo creo que en el tema este que decías del 2000, de las reformas 99-2000, aparte de los hechos históricos, que no sé si vos conocés, me imagino que sí.

\section{R: Sí, un poco, a través de Antonio Esgueva que es historiador.}

A.S.: Sí, pero los hechos históricos con la "h" chiquita, no la historia en grande.

\section{R: Esa me la vais a contar vosotras.}

A.S.: Entonces, yo venía a decir como que, académicamente, esto produce dos situaciones: una económica y la otra social, verdad, una económica que tiene que ver con la acumulación de capital de esta burguesía emergente, que no se asume como burguesía, verdad, sino que supuestamente es gente que están contra la oligarquía, pero, en realidad, no, y la otra es la ruptura social que hay tanto por el lado del PLC como por el lado del FSLN, y la recomposición que intentan de dejar a un lado a la sociedad no partidaria y centralizar o legitimar toda participación a través de partidos políticos, creo que esa es, digamos, de manera general, pero yo creo que hay dos cosas previas a todo este asunto, que nos llevan a este resultado, y es el año 98, que, a mi juicio, es clave para entender algunas cosas, primero, en marzo la denuncia contra Daniel Ortega por abuso sexual, y luego en octubre o noviembre el Mitch, el huracán Mitch, que el huracán Mitch significó, en términos de desastre, verdad, toda una emergencia muy fuerte en América Central, Nicaragua y Honduras fueron de los países muchísimo más afectados de los cuatro países de Centroamérica que fueron afectados por ese huracán, y eso significó una solidaridad en términos de plata dura muy grande, y eso despertó la voracidad económica, o sea, no es que en ese momento se despierta la voracidad económica de Alemán, porque ya venía construyéndola desde el 90, pero en el 98 toda la cantidad de plata que entra a este país para lo que ocurrió, o sea, significó un manejo a fondo de la corrupción, por parte de Alemán y parte pequeña de su grupo, entonces, ambos tenían cosas que ocultarse entre sí, cosas por las cuales protegerse, Daniel Ortega por la violación y Alemán por la corrupción, entonces, eso los va llevando a acercamientos, ¿verdad?, arreglémonos entre nosotros, y eso es lo que los va llevando a las pláticas que implican las reformas a la Constitución, que les permitan a ellos 
posicionarse de mejor manera frente a la burguesía tradicional, verdad, ya como una fuerza económica por sí misma, y no como parte del pasapapeles de la burguesía, sino ellos también parte de ese poder económico, y la otra cosa es el tema de lo social, Alemán siempre tuvo una actitud confrontativa con la sociedad civil, porque se suponía que todos veníamos del sandinismo, lo que era verdad, pero no significaba para nada que nosotros éramos el brazo social del Frente Sandinista, eso no era cierto, porque todo el mundo con el 90 hay una explosión de la autonomía, y todo el mundo quiere ser autónomo, nadie quiere volver a los años 80, en el que todas las organizaciones dependían de la dirección del partido, y lo que el partido decía era lo que teníamos que hacer, todo el mundo al darse el proceso de autonomía no quiere volver a ese asunto, entonces, pero para la gente que no era del sandinismo, Alemán y todos los demás, a todos nos miraban igual, entonces, él siempre tuvo una actitud en ese orden, y, en el caso del Frente, que siempre habíamos tenido relaciones, o sea, primero que veníamos de ahí, y por el otro lado, cuando alcanzamos la autonomía manteníamos relaciones, verdad, cordiales, de intercambio, de lo que sea, ¿no?, pero cuando se da la denuncia se tomó partido, la denuncia de violación, se tomó partido, entonces, había ya entonces al Frente le quedó claro, que independientemente de que pudiéramos venir del sandinismo, que nos llamábamos sandinistas, que podamos hacer defensa del sandinismo como doctrina o como posición política no éramos leales en los términos absolutos y ciegos que ellos querían, y entonces ya no éramos confiables y la sociedad ya no les interesaba como brazo, verdad, porque además se dieron cuenta que ya no éramos, que no disponían, y que teníamos nuestras propias demandas y nuestra propia agenda y nuestras propias posiciones, entonces, no nos convenían, entonces todo este tema es validar la participación exclusivamente formal, apartidaria, y, entonces, todo eso entra también en la negociación del pacto, que son cuestiones que están ahí, pues, son demostrables, no son cosas dichas desde la lengua.

$R$ : Es cierto que se restringen los espacios políticos, tanto a la formación de nuevos partidos con representación en el parlamento, y, por otra parte, ese clima de acoso a la oposición que se está viviendo actualmente, incluso, he oído el tema de los apaleamientos a las personas que se manifiestan y cuestiones bastante serias, yo diría, por parte de estas fuerzas de choque que, en teoría, son fomentadas por el presidente Ortega, por su Ejecutivo.

A.E.S.: Y que antes las miraban bien, porque era otro gobierno, antes cuando llegábamos a los comités de desarrollo municipal, en que llegáramos allí las ONGs a demandar a los gobiernos municipales tal y tal cosa, porque el Frente no estaba en el poder y controlaba todo, ahora no, lo que antes era bueno que hiciera la sociedad civil, aún cuando supieran que no contaban con nuestra absoluta fidelidad y lealtad como dice la Azahalea, pero ellos nos dejaban, ellos dejaban que hiciéramos lo que pudiéramos y coordinábamos con ellos, y teníamos nuestras diferencias y todo, pero ahora la sociedad civil son los CPC y los organismos del Poder Ciudadano, y entonces la Rosario Murillo da las líneas para lo que hace todo el mundo, y fuera de eso ya no hay sociedad civil.

A.S.: Sí, eso es parte de lo que se está viviendo ahora, por supuesto, un proceso de recentralización del Estado total, o sea, el concepto más amplio de Estado, con una recentralización absoluta, pues, había un sistema de participación ciudadana que quedó allí en papel en el año 2006, fue de las últimas cosas que hizo el gobierno de Bolaños, está totalmente, absolutamente, desaparecido sin haber cambiado ley, todo el sistema 
está montado sobre la ley existente, las leyes están ahí, pero el sistema, el Estado es paralelo, es otro.

R: Sí, pero por esa tendencia de refuerzo del Poder Ejecutivo que ha llevado el presidente Ortega frente a las anteriores reformas que si conceden una mayor importancia a las facultades de la Asamblea como decía antes, la Asamblea sigue siendo importante, de hecho, el presidente Ortega tiene que acudir a la Asamblea aunque no haya ratificado a ninguno de sus ministros, ni diplomáticos, ni altos cargos como asi decía el precepto constitucional reformado en el 2005, ese incumplimiento de la Constitución, o sea, se aplazan las reformas, se pacta políticamente para afirmar su entrada en vigor, en términos jurídicos estrictos, y luego aparte políticamente se obvian, y no pasa nada.

A.S.: Y no pasa nada, y el presidente llega a rendir su informe en enero del 2008, verdad, el 10 de enero de 2008 llega a rendir su informe habla de cualquier cosa, de tonterías, después se pasa 50 minutos contados pasando lista de quiénes estaban, ah, está aquí Doña Eva Setenberg, embajadora de Suecia, ah, la señora tal, embajadora de la Unión Europea, ¿se encuentra?, ah, 50 minutos pasando la lista de todos y cada uno de los miembros del cuerpo diplomático que estaba presente, y entonces dice: "ah, ya es tarde", y dice: "yo venía a dar el informe", bueno, era una cosa tres veces más grande que esto, bueno, dice: "pero yo no creo que ustedes quieran que yo les lea todo esto, ahí se lo dejo", o sea, así fue, así fue, y nadie, o sea, el presidente de la Asamblea.

R: Pero también por esa preeminencia en la Junta de Gobierno de la Asamblea del propio Frente.

\section{A.S.: Claro.}

R: Sin embargo, no parece probable que vaya a contar con los apoyos necesarios para reformar otra vez la Constitución.

A.S.: Pareciera que no, parece que no, y hay una cierta desesperación en ese sentido, y hubo la semana, hace diez días hubo una reunión de la asamblea sandinista, que está totalmente desactivada, o sea, no es cierto eso de la asamblea sandinista, no es cierto que existe una dirección colegiada del Frente, no es cierto, pero la activaron, juntaron como a 500 personas, y la orden fue que había que conseguir que los diputados den los votos, eso a mí me huele a amenaza, eso me huele a mí que la gente esta va a hacer las cosas, en lo público sale eso, en lo privado no sé como se habrán dispuesto a cumplirla, pero ¿a cuenta de qué una asamblea sandinista va a ser la encargada de garantizar que haya los 56 votos para la reforma constitucional?, no tiene lógica más que situaciones de hecho, pues, no sé cuáles serán las cuestiones, yo sé que a Montealegre le han ofrecido cualquier cosa para que apruebe que haya reelección, verdad, y no digo que Montealegre sea santo y todo ese asunto, no, no, para nada, no creo eso, pero toda la presión judicial que hay es para hacer que diga que sí a la reelección, o sea, no es que estén interesados en saber, realmente, si se robó o no se robó la plata, verdad, si Montealegre aprueba la reelección la plata no le va a importar, porque además ahí hay una mentira que lo que Montealegre hizo, en todo caso, verdad, que supuestamente es un asunto de tráfico de influencias, es el último momento de una cadena que empieza con las quiebras bancarias, la primera quiebra bancaria fue el banco del Frente Sandinista, una quiebra bancaria dolosa, verdad, y posteriormente ocurren una serie de 
cosas que todavía está Alemán de presidente, Alemán es el que pone, dicta la disposición para crear estos certificados, se aprueba en la Superintendencia de Bancos, está dentro del grupo de personas que aprueban el actual presidente del Banco Central, y después viene donde interviene Montealegre, pero toda esta gente, ninguna de esa gente está implicada, ninguna de esa gente, o sea, ¿de qué se acusa a Montealegre?, de haber hecho uso privilegiado de información en relación a los certificados que son ilegales, pero Montealegre no es el que los creó, el que los creó fue Alemán y se acordó en una junta de la Superintendencia de Bancos, en la que estaba el presidente del Banco Central, que no tengo nada en contra de él, me parece que está haciendo un buen trabajo, me parece que es el funcionario de este gobierno con mejor resultado, verdad, pero él es parte, y a él no lo acusan, ni acusan a Alemán, ni acusan a los responsables originarios de que esto ocurriera, entonces, yo estoy segura de que si Montealegre aprueba la reelección todo el gran caso se cae, porque al final de cuentas, o sea, hay de por medio esta sincronización política, la acumulación económica,...

R: Y esta división de la estructura del Ejecutivo en la figura de un Primer Ministro y luego el presidente de la República.

A.S.: Bueno ya existió eso, entonces, públicamente, el operador político que es el Vicepresidente de la Corte Suprema de Justicia, ah, porque esta es otra cosa que yo apunté aquí, que en medio de todo este asunto económico, de la división social, hay un gran punto de cinismo, o sea, eso que se hizo en España, pues, de sacar del closet algunas cosas de la gente, de amenazar, o sea, un nivel de cinismo totalmente.

A.E.S.: Incluso aunque no te metieras en el ámbito de la política, ¿a tenés este caso en el juzgado? Bueno, o me das tanto, o van a ir otros.

A.S.: A ese nivel es el control que tiene el Frente del Poder Judicial, verdad, que tiene este nivel de cinismo, pero no me acuerdo qué otra cosa iba a decir, aparte del interés económico, de la ruptura social, y de las triquiñuelas que cada uno llevaba para salvarse de ese elemento de cinismo, aquí hay cuatro organismos de Naciones Unidas que han dictado resoluciones contra el Estado de Nicaragua, nada, verdad, el fraude en las elecciones fue evidente, o sea, no es retórica, no es posición política contraria, hubo fraude.

R: Y además una pérdida de legitimidad del Consejo Supremo Electoral, que es una institución que supuestamente garantiza la transparencia de las elecciones, que es la seña de identidad principal, digamos, de una democracia.

A.S.: Eso es básico, esta descomposición la construyeron pacientemente en la última década, pacientemente, desde el propio año 96, el año 97 que gana Alemán, pero entonces se viene construyendo esta descomposición, se intercambian escaños, se intercambian lugares, si conviene tener a la Azahalea en Diriamba y vos no tenés a nadie en Puerto Cabezas, entonces, agarramos el escaño de allí e intercambiamos a la Azahalea, y así.

R: ¿Pero diputados en la Asamblea?

A.S.: Diputados a la Asamblea, a la Asamblea. 
A.E.S.: No es que cambiaran el número de diputados, se intercambiaban los lugares.

A.S.: Se cambiaban los lugares, eso lo hicieron en el 97, ¿verdad?

A.E.S.: Y alcaldías, bueno, bueno, "ahí nos arreglamos después”.

A.S.: Eso está ahí construido, entonces, esa descomposición, así como fueron construyendo su aparato en el Poder Judicial, en la Corte también fueron construyendo ese aparato de descomposición, en las elecciones del 97, las elecciones del 97 nosotros aquí tenemos las pruebas de cuál fue el resultado de las elecciones, y entonces, nosotros estábamos en una pizarra como esta allá, y cuando estábamos haciendo, que es muy complicada esa ley, es la ley más complicada que yo recuerdo para establecer los escaños, porque además eran los escaños de minorías, porque privilegiaba mucho a las minorías, ahora se privilegia a la mayoría, en la ley actual, entonces nosotros, jah!, inmediatamente dijimos quienes eran los diputados, y hubo 7 diputados que ninguno de esos que legalmente eran aparecían, se cambiaron, diputados que no habían ganado los pusieron ahí, siete diputados que no habían ganado se intercambiaron en las elecciones del 96.

$R:$ ¿Y qué balance, entonces, ya para terminar, hacéis a raíz de este futuro tan incierto que tiene Nicaragua? Casi todo el mundo en las entrevistas que he hecho subraya que hay un momento delicado en el país, delicado y serio, ¿no?, porque lo que a mí me asombra, un poco mirándolo desde fuera, es lo caras que han costado las instituciones democráticas en este pais, porque hay mucha gente que murió creyendo además en un sueño, porque son muchos los intentos de refundar el Estado de Nicaragua desde la independencia, entonces, son varias las heridas que va arrastrando una nación tan pequeña y que no logra despegar con la estabilidad democrática y esa es también la condición del desarrollo y de la credibilidad institucional que pueda tener Nicaragua en un mundo global como este. Qué futuro de aquí al próximo año, que va a ser muy complicado si Ortega regresa o no, si se puede incluso postular como candidato si se aprueba la reelección presidencial, del relevo del liderazgo político del Frente en el caso de que no pueda ser Ortega, a mí me sorprende también este vínculo familiar con su esposa, Sofía me habló largamente de sus peculiaridades, de lo pintoresco del personaje, ¿no?, y de la ascendencia de poder que tiene sobre el funcionamiento, por ejemplo, de los CPC, y de las propias decisiones del presidente, pero bueno, eso es algo comentado de otras primeras damas en el mundo, no ya en América Latina, y de las relaciones que tienen las mujeres con la política, pero ese es otro tema.

A.S.: Mirá, fíjate que yo soy parte del movimiento autónomo de mujeres, y en el año 2006, el 23 de abril, el día del libro, el día de Cervantes, el día de Shakespeare, por cierto, nosotras estábamos analizando y decíamos lo que ocurría, porque en noviembre de ese año iba a haber elecciones nacionales, y nosotras analizábamos la importancia que estas elecciones tenían y anduvimos metidas desde meses antes en tratar de parar las reformas constitucionales que hubo en ese año, y llegamos a la conclusión de que el 2006 era sumamente importante, pues, que la gente se involucrara en esas elecciones y todo lo demás, y decíamos que lo peor que le podía pasar a Nicaragua era que ganara alguna fuerza fundamentalista, neo-liberal, no sé qué, no sé cuanto, y entonces vos decías, ah, bueno, que ganara Montealegre, exactamente, que ganara el Partido Liberal, es cierto, pero para nosotras lo peor era el Frente, porque el Frente además de ser fundamentalista, de ser autoritario y de ser neo-liberal, tenía el aura, el halo de ser de 
izquierda y para mucha gente era una gran alegría que ganara el Frente por la idea de que era de izquierda y para nosotras era muy difícil, verdad, o sea, como nosotras también somos de izquierdas, pues, hemos tenido credibilidad al denunciarlo, porque no venimos de la derecha, sino que somos parte de esa misma historia, pero decíamos que era lo peor que le podía pasar a Nicaragua porque, bueno, por todas esas razones, y al final de dos años después la historia nos dio la razón, lamentablemente, y el año pasado volvimos a analizar toda esta cuestión y mirábamos que tanto el año pasado como este año eran años claves, y nos hemos dedicado a andar explicando todo esto de escribir cosas, a mandar cartas para explicar este asunto, y nosotras no hemos pedido, digamos, así suspensión de la ayuda, es decir, no la ayuda, pero hemos reflexionado con la gente qué significaría los mensajes equivocados de darle, de mantener sin ningún obstáculo la ayuda aunque la necesitemos al país, y a lo mejor voy a decir, bueno, es fácil decir cuando uno tiene el estómago lleno hablar de esto, pero yo creo que es mejor volver a pasar hambre que volver a tener una dictadura en el país, y estos meses son a mi juicio fundamentales para evitar, es un equilibrio muy precario, por eso yo creo que esa reunión de la asamblea sandinista significa otra cosa, porque si públicamente dicen eso, en privado qué es lo que decidieron significa otra cosa, porque este es el año que debe hacerse la reforma constitucional de acuerdo a los intereses de Daniel Ortega, este es el año, porque si ya pasa el otro año, ya se le complica la cosa, ya le quedan 2010 y 2011, y en 2011 ya estarían en elecciones, entonces, y además es vital para él la reelección, no porque no pueda a través de otra persona tener control, es porque la otra persona tendría que ser para los intereses, que ahora sí son intereses económicos, yo creo que en el 95 Daniel no había despertado a los intereses económicos, pero ahora sí, la otra persona en la que él podría confiar es en la mujer, y ella despierta muchísimos anticuerpos, y eso despertaría un pleito de liderazgo entre otra gente que está calladita, verdad, entre otra gente que está calladita y que les interesaría, no es que están de acuerdo con lo que está pasando, pero que en este momento no tiene las condiciones para hacerlo, entonces, están callados pero si a Daniel se le cierran las puertas de la reelección esta gente estallaría, entonces, para Daniel Ortega es vital esto, y para la sociedad nicaragüense también estos meses son vitales, creo que sí, que es cierto, que estamos en un momento muy, muy, muy delicado, por eso, mira yo he estado, yo tengo una posición muy clara sobre el tema del aborto, pero tengo cuidado de hablarlo ahora, porque yo creo que no solamente yo, creo que también la Iglesia católica tiene cuidado ahora de hablarlo, en los último meses no ha hablado mucho, los voceros principales de la Iglesia no han hablado mucho de este tema porque saben que es un tema que confronta, que divide, y este es un momento que hay que unificar refuerzos, verdad, y es la única manera, y yo creo que una de las cosas que seguramente han de haber encargado a esta gente del Frente, de esta asamblea sandinista, es buscar como enfrentar, enfrentar a todo el mundo, encontrarle trapos sucios, y poner a todo el mundo a la defensiva, entonces sí yo creo que estos próximos meses yo creo que son delicados en ese sentido, no es muy jurídico, verdad, pero sí son los hechos que llevan a asentar las negociaciones y a marcar el paso, la levantada de mano, o la tocada de botón en la Asamblea Nacional, esa es mi apreciación.

R: Pues si tenéis algo más que añadir, yo creo que ha sido una entrevista muy extensa.

A.E.S.: Bueno, pero nos vamos a volver a ver otra vez, ¿no? 


\section{ENTREVISTA 44 ${ }^{62}$ :}

Nombre del entrevistado: D. Rafael Solís.

Cargo actual: Magistrado de la Corte Suprema de Justicia.

Fecha de realización de la entrevista: Managua, 4 de noviembre de 2009.

Lugar: Corte Suprema de Justicia.

Duración estimada: 56 minutos.

\section{TEXTO - Transcripción 44:}

R: Comienzo la entrevista a propósito de su reflexión sobre cuál es el recorrido que hace en torno a los últimos tres procesos de cambio constitucional experimentados en el país en el contexto de la transición democrática.

R.S.: Yo diría que la trayectoria que ha vivido, efectivamente, la mayoría de las reformas como decís vos y las tres principales, porque se han hecho cinco o seis creo, creo yo que han tenido que ver con la, digamos, transmisión de mayores facultades al Poder Legislativo con relación a la Constitución original del 87, pues, que, efectivamente, lo dejó compartiendo muchas de sus facultades propias, pues, en muchos casos, con el Poder Ejecutivo, ese ha sido, tal vez, el hilo conductor, tal vez, de las reformas, pues, que se ha abierto más la Constitución en cuanto a darle más facultades al Poder Legislativo, en estos casos, pues, la Asamblea Nacional es unicameral, y ha limitado un poco, pues, facultades que tenía, originalmente, en el 87, pues, el presidente de la República, y que se hizo en algunos casos de una manera expresa, y con intención de dejársela, pues, por vía de oposición político-ideológica, pero en otros casos, más que todo, por razones de guerra, porque se hizo en medio de una situación de violencia generalizada que se vivía en el país, una guerra civil bastante fuerte, pues, todavía en el 86 o en el 87, 88, y que obligaba, pues, a mantener el Poder Ejecutivo, que estaba dotado de una serie de instrumentos jurídicos que le permitieran, pues, unir los esfuerzos y recursos en el país para enfrentar la guerra, pues, tan es así que muchos de los artículos, si sabés de la Constitución del 87, quedaron suspendidos, pues, durante varios años, por motivos de la guerra, pues. Pero, un poco, el cordón umbilical, tal vez, ha sido eso, recomponer, pues, por así decirlo, el equilibrio, el balance entre los poderes del Estado.

R: De todos modos, aunque es cierto que el hilo conductor ha sido el de atribuir mayores facultades a la Asamblea, si ha habido un conflicto entre el Ejecutivo presidencial y la Asamblea legislativa, que ha dado lugar a crisis institucionales serias en el caso del gobierno Violeta Chamorro, en el caso del gobierno del presidente Bolaños, que fueron los dos casos extremos, realmente, ¿por qué ha habido tal falta de consenso en torno a las reformas constitucionales?

R.S.: Sí, sí, bueno, porque los presidentes, Doña Violeta con todo y todo tenía un primer ministro, como le llamamos aquí, que era el ingeniero Lacayo, el yerno de ella, que tuvo mucho poder y no consideró que esta reforma, digamos, del 95 eran sanas para el país, yo la mayor parte de los puntos los aprobé, hubo uno o dos que siempre mantuve que

\footnotetext{
62 Entrevista de interés por la posición institucional del entrevistado en la Corte Suprema de Justicia, autor, en última instancia, de la polémica sentencia judicial que reinterpreta el artículo 147 sobre la reelección presidencial.
} 
me parecían innecesarios, como el tan mentado asunto de la reelección, que hoy se discute, pues, pero en el voto conjunto, sí estuve de acuerdo con la reforma del 95, me parece que Toño se enamoró del poder y no hubo, si este país, pues, es un país, qué se yo, pues, parece a veces una "banana republic", como dicen, pues, en que, digamos, las relaciones familiares pesan más, pues, que las cuestiones institucionales, y ella reaccionó de una manera violenta en contra de la reforma y vino la crisis del 95, y la Ley Marco, la intervención del Cardenal, la suspensión de las reformas, y el arreglo político, pues, que eso dejó unos años al país en medio de esa crisis, lo mismo ocurrió con Don Enrique, pues, una persona terca, mayor de edad, en el sentido, tal vez, literal de la palabra, ya de 80 años, 77 años, ya con una mentalidad muy cerrada, y que sentía que se le estaban quitando facultades a él, a Enrique Bolaños, no al presidente de la República, sino a él, Don Enrique Bolaños, para afectarlo, pues, que se lo estaban quitando los liberales, con los que él se había peleado, apoyados por el Frente Sandinista, y se paró, y también, hubo otra crisis, pues, fue a la Corte Centroamericana, luego la sentencia, luego un conflicto de poderes, todo lo que ocurrió, pues, y no entendió que era parte de un proceso, pues, el cual algunos pensamos que en el país debería de derrumbarse, pues, nosotros pensábamos que un régimen parlamentario era bueno para Nicaragua, pero no obtuvimos los votos y que ya no valía la pena insistir en eso, sino hasta dentro de 5 o 10 años, de nuevo, pero obedeció un poco a esa concepción autoritaria en ambos casos diría yo, pues, de, digamos, Doña Violeta es un caso, lo hacía por el yerno, y Don Enrique en el otro, de no querer, pues, digamos, entender que ese era un precepto universal, en el otro caso, la tercera reforma importante, la del 99, que tuvo que ver con la recomposición del Poder Judicial y el Poder Electoral directamente hizo un pacto político, pues, que fue el que más determinó porque se hicieron esa recomposición de los poderes y Alemán ya iba de salida, pues, se venían las elecciones del 2001 y más bien lo que quería era quedar como diputado en los próximos años, hizo unas concesiones al sandinismo a cambio de quedar como diputado en la Asamblea, pues, y disfrutar de inmunidad puesto que ya estaba cometiendo una serie de actos por lo menos turbios, pues, pero en los otros casos fue más que todo por eso, yo creo que lo que se hizo alrededor de las leyes Marco y todas las componendas políticas alrededor de eso nuevamente limitaron la voluntad de un constituyente derivado, mal que bien era un constituyente, aunque fuera derivado, puesto que tenía un consenso amplio la Asamblea Nacional y lograba reunir más de los 56 votos que hubiese requerido para que estas reformas se hicieran, en ambos casos, pues, pero se confrontaron con Ejecutivos, digamos, fuertes, que creían que el país se podía seguir manejando como en la época de Daniel Ortega, pues, que, en realidad, Doña Violeta así lo manejó con una, digamos, concentración de poder alrededor del Ejecutivo bastante fuerte.

R: De todos modos, también es cierto que el primer gran debate en torno a la Constitución se plantea después de la firma de los Acuerdos de Paz entre reforma total o reforma parcial a la Constitución, ¿no? Y llegar al acuerdo de la reforma parcial, ¿cómo vivió usted todo eso?, ¿cómo lo recuerda desde su posición institucional?

R.S.: Bueno, la primerita, primerita, primerita tuvo que ver, te acordás, con la reducción del período.

\section{R: Exactamente.}


R.S.: Esa, yo era asesor, era diputado y estaba como asesor del presidente, y estuve en todo el proceso de Sapoá, que era la plática con los militares, estaba aquella foto cuando se firmó, Sapoá que era plática con la contrarrevolución y los llamaron los Acuerdos de Esquipulas I, II, III, IV, V, hasta el último que firmamos en El Salvador, donde yo estuve con el presidente también, y se convocó a elecciones y se puso como condición que se redujera el período, que fue una reforma constitucional, reducir el período, el presidente renunció, pues, a los nueve meses que le faltaban con tal de adelantar las elecciones y hacer más efectivos, pues, los acuerdos de paz que se estaban firmando, en ese caso, pues, la primera reforma esa fue, realmente, una mezcla de dos factores, obviamente, la presión que ya había en Centroamérica para que comenzara, Nicaragua, por ser el primer país donde la guerra concluyera y pasáramos ya a un proceso de pacificación, después vendría El Salvador dos años después, y que se logró, digamos, en segundo lugar, por la voluntad y la decisión del presidente Ortega de poner fin a la guerra aunque tuviera que reducir su período, claro, que él pensaba que todavía tenía mucha fuerza en el país como para ganarles luego en una reelección y las perdió, pues, pero voluntariamente y para pacificar el país decidió hacer esta primera reforma, cuando regresamos a Nicaragua después de las discusiones éstas en El Salvador, comenzó el diálogo nacional con los partidos y vino una reunión larga, me acuerdo, todavía hubo después una reunión en Honduras, después de la de El Salvador, adonde se notificó lo adoptado en El Salvador y la obligación, pues, de Nicaragua de convocar elecciones anticipadas y regresando de Honduras se hizo esa reunión con los partidos adonde se decidió, pues, reducir el período y que nosotros hiciéramos eso en la Asamblea Nacional, no estando muy claro si teníamos o no facultades de hacerlo, pues, porque hay siempre quien dice que ese tipo de reformas constitucionales tienen que ver con los siguientes períodos de las siguientes autoridades electas, pues, que no pueden afectar a un presidente ya electo bajo determinadas normas, o a un Congreso, como era el Congreso que también tenía, hubo que indemnizar a los diputados, que se opusieron, porque muchos decían que no, que su período terminaba hasta que terminara, nueve meses después, y se opusieron, digamos, de alguna forma a esa reforma, y de ahí comenzó la discusión esa sobre si las reformas parciales o las reformas totales eran las que, digamos, que habría que usar en Nicaragua para este tipo de situaciones, y hubo una discusión que al día de hoy todavía está vigente, pues, obviamente, las del 95 ya fueron reformas totales hechas bajo la figura de una reforma parcial, que ahí se le dio patas para arriba, le dio vuelta a la Constitución, sin embargo, lo hicieron sobre la figura de una reforma parcial, aunque, digamos, reformaron no sé cuantos 70, 80 artículos de la Constitución, por decirte algo, y, sin embargo, se usó la figura de la reforma parcial, se usó y se abusó, pues, de la figura de la reforma parcial, cuando lo que se debería haber hecho es una Asamblea Constituyente para hacer una nueva Constitución, pues, tal vez no había los votos, porque eso requiere todavía un poquito más de votos para hacerse, ¿verdad? Pero la discusión todavía está viva, aquí en Nicaragua se usa eso, la Corte Centroamericana dijo de las reformas del 2005 que no se podían haber hecho como se hicieron porque no podía ser una reforma parcial la que le restara facultades al presidente en el nombramiento de los ministros, los embajadores, etc., o que la Asamblea tuviera facultades de correr a un ministro, sino que tenía que ser una reforma total, producto de una voluntad, digamos, de tipo constituyente u originario, pues, no derivado, y aquí la Corte Suprema ha mantenido los mismos criterios, pues, es que han sido situaciones políticas en las que se dan en un momento dado la Corte ha dicho que sí, que fueron correctas, que los constituyentes derivados, en este caso, los diputados, ¿no? que habían sido electos para hacer una Constitución pueden hacerlo, y en otros casos, esta última sentencia dijo que no, pues, la Corte, dijo que no, que era incorrecto 
haberlo hecho de esa manera, que debería haberse convocado una nueva Asamblea Nacional constituyente para hacer una nueva Constitución, porque la reforma parcial es parcial en cuanto a, es decir, tanto al número de artículos o disposiciones que se modifican como también a los contenidos, digamos, no fundamentales de la misma que puedan ser modificados por un constituyente derivado, pues, distinto del originario que hizo la Constitución del 87. Pero esa es una discusión que va a seguir en Nicaragua y que va a estar planteada por mucho tiempo.

R: Pero es cierto que hubo una irregularidad en el procedimiento jurídico mismo, por revisar el procedimiento de reforma constitucional, ¿no?, y, como bien ha dicho usted anteriormente, por arrogarse la Asamblea, en ese primer momento, en el 95, atribuciones constituyentes que como tal no tenía, puesto que no era una Asamblea Constituyente en sí misma, y en el caso de las leyes Marco, otro instrumento jurídico nicaragüense, absolutamente, curioso, porque supone una especie de congelación en el tiempo de la entrada en vigor de las normas constitucionales reformadas.

R.S.: Así es, así es, ese fue un invento, fue un invento, definitivamente, ya la última sentencia de la Corte Suprema, la de hace dos años y medio dijo que eso no, que eso ha sido inconstitucional, no ahora, lo ha sido siempre, $y$ hace poco anunció categóricamente que las leyes Marco son inexistentes, pues, no puedes seguir haciendo una ley que a la vez suspenda la entrada en vigencia de lo dice la Constitución Política, que es la ley máxima de la república, que se aprueba para que entre en vigencia, pues, es decir, eso de las leyes Marco son disparates que se hicieron tal vez porque no había consenso político en ese momento, y la pugna entre los dos poderes, en ambos casos, pues, el Legislativo y el Ejecutivo estaba tan fuerte, que se prefirió un invento para que el país no desembocara tal vez en una crisis de violencia, pues, o en una guerra civil, y se dijo: "no, paremos esto, busquemos los métodos más propicios para que entren en vigencia las reformas e ilegalmente congelémoslas" con una ley que no tiene, pues, ninguna explicación que pueda congelar lo que es la Constitución mía, porque la reforma constitucional, en última instancia, pasa a formar parte de la Constitución, y se convierte en la Constitución misma, pues, yo espero que no vuelva a haber leyes Marco en el país, me parece que no puede estar jugando así, pues, con la voluntad política, y sí creo también que estas cuestiones que se han hecho alrededor de las reformas parciales, y que, en realidad, son reformas totales, yo creo que el régimen parlamentario, creo que es mejor para el país porque permite mayor juego político entre los partidos, también está incurriendo en ese error, en estos dos años en que he estado defendiéndola, pues, y he mantenido, públicamente, que se podría hacer el paso, pues, a la reforma, el paso al régimen parlamentario a través de una reforma parcial, pues, cuando en estricto derecho, como vos decís, se necesitaría más bien convocar elecciones nuevas a una Asamblea Nacional Constituyente que decida si lo mejor para Nicaragua es o no un régimen parlamentario, pero como ya están los antecedentes del 95 para efectos públicos, para tratar de conseguir los 56 votos, sí, digamos, de una forma más dura, se podría hacer esa reforma, entonces, de alguna forma, estaríamos otra vez en esa discusión, lo que a veces es bueno de determinados métodos uno dice que no fue tan bueno, pero tal vez sea lo mejor para pasar a otro tipo de modelo, yo en estricto derecho, como te digo, la reforma parcial que estábamos impulsando ahora en el 2008-2009 para crear un régimen parlamentario también era tan incorrecto como lo que se hizo en el 95 , pues, pero uno piensa, es más beneficioso para el país que entremos a un régimen parlamentario, que esto, que lo otro, y yo digo, bueno, sacrifiquemos un poco esto para avanzar hacia ese modelo ya parlamentario, que, sinceramente, me parece que quienes 
lo pospusieron, porque creyeron que era cuestión del sandinismo, etc., cometieron un error, Nicaragua tendría más estabilidad como régimen parlamentario, habría mayor juego, pues, entre los poderes, y mayor fuerza en la Asamblea Nacional para dirimir estos conflictos y mayor posibilidad de entenderse, pues, entre dos fuerzas o incluso hasta tres, en algunos casos, pues, que como un régimen presidencial como el que hay donde siempre el problema del poder que todavía concentra el presidente, a pesar de las reformas que se han hecho, ahí está, pues, que gravita sobre toda la vida política y económica del país.

R: Me gustaría profundizar en esta idea de la evolución hacia esa conformación parlamentarista de la democracia presidencial en Nicaragua. El año pasado en el Centro de Estudios Políticos y Constitucionales, Diego Valadés, el profesor mexicano, fue profesor nuestro, y venía, curiosamente, de Nicaragua, de presentar el libro que además él luego me facilitó allá en España, y como es constitucionalista trabaja sobre todo este enfoque de cómo diseñar las instituciones politicas para producir democracias gobernables, ¿no?, y donde no haya crisis institucionales ni fricciones entre los poderes del Estado, que yo creo que es una experiencia que en Nicaragua se repite con dramática frecuencia. ¿En qué consiste exactamente el modelo? Algunas de las propuestas que llegaron, que tuve la oportunidad de conocer a través, fundamentalmente, de la prensa, que es donde se han distribuido algunas de las ideas, porque no sé si hay un programa concreto de reformas constitucionales en esa línea.

R.S.: ¿Ahora, las últimas?

R: Las últimas, sí, que han estado paralizadas en el debate en la Asamblea por todo el tema de las municipales del año pasado.

R.S.: Sí, sí.

R: Por la dificultad de conseguir un quórum de apoyo.

\section{R.S.: Exactamente.}

R: Por la sospecha, quizá, de que la división de la estructura del Poder Ejecutivo entre la figura de un primer ministro y el presidente de la República vaya a suponer un nuevo reparto paritario entre los principales partidos.

R.S.: Exactamente, exactamente, todo eso, las tres cosas últimas que decís, así fue, así fue, ahora, salió publicado un borrador en el último libro que publicó Edwin Castro, ¿no lo viste?

R: No, y además me gustaría mucho poder acceder a él si tuviera algún ejemplar, porque se lo pedí a su secretaria y me decía que ya estaban distribuidos, sobre todo para conocer la propuesta del sandinismo en relación al parlamentarismo.

R.S.: Aquí tengo uno, te lo voy a regalar.

R: Muchas gracias. 
R.S.: Ahí sale en la última parte, en la última parte sale una propuesta que lanzó, que no fue el documento final, tal vez un $70 \%$, un $75 \%$, porque la propuesta la trabajamos los dos, se la dimos al presidente, la aprobó y comenzamos a platicarla con Magistrados aquí, con algunos diputados, después como vos decís, por todas esas razones, que son correctas, las que señalabas, hubo una paralización, pues, y se vio que ni siquiera con los diputados que no fueran liberales, pues, se iba a poder conseguir el número de votos, y ya en julio o agosto desistimos de eso, pues, pero para mí era lo mejor para el país, no sé, creo que habría sido lo mejor, creo que habría funcionado mejor, al final del libro está la propuesta, para presentarla nos sirvió a él y a mí, después integramos al doctor Rosales, el presidente de la Sala de lo Constitucional de aquí, y al ingeniero Núñez, pues, que es el presidente de la Asamblea, y los cuatro fuimos a la comisión final y estuvimos platicando con los liberales a ver si avanzábamos o no, pero, como te digo, todos esos factores hicieron que se perdiera la posibilidad de Nicaragua de pasar a un modelo parlamentario en este año, pues, ahora esto se dará de aquí a 10 o 20 años, tal vez, cuando haya más madurez, yo no sé si, a lo mejor, digamos, lo más correcto sea esperar el momento, que el país esté más maduro, se convoquen elecciones, se explique lo que es el modelo parlamentario, se haga un referéndum sobre eso, y si la población considera, pues, que es mejor, que es superior al presidencialista, avanzar en esa dirección, tal vez estábamos queriéndolos hacer muy, digamos, a contragolpe, pues, y a una presidencia de Daniel Ortega que podría interpretarse, pues, como que lo que se quería era prolongarlo a él tal vez con un Primer Ministro tipo Alemán, pues, que estuvieran las dos fuerzas políticas turnándose, y después al revés, como se dio mucho tiempo aquí, como si fuera el uno presidente y el otro primer ministro, y así organizarse, que no era la voluntad ni la decisión, por lo menos, en mi caso, creo que en el diputado Castro tampoco, sino que yo creo que las ventajas de ese modelo, yo comparto las apreciaciones de ese libro, y ahí están señaladas seis o siete, sobre el parlamentarismo siguen siendo válidas, pues, y que, efectivamente, es un régimen mejor en cuanto a la estabilidad política, mejor en cuanto a los controles y los balances del poder, mejor en cuanto a la posibilidad de atraer a una inversión extranjera, pero bueno, en ese momento se hizo una manipulación de todo y quedó para mucho más adelante para retomar otra vez no sé, no sé si hay posibilidad de retomar esto y ver si se pueden conseguir los votos, o ir a una Asamblea Constituyente, pues, que sea la que lo determine por último.

$R: Y$, sin embargo, aunque la polémica ha mediado también en esta parlamentarización de la democracia presidencial, sí es cierto, que en el año 95 se procede a una desconcentración del Poder Ejecutivo, y ahora parece que la tendencia es la contraria, a haber una concentración en el Ejecutivo forzando, por ejemplo, a través de la reelección presidencial, que era una cuestión que estaba contenida en la Constitución original del 87, donde no había un límite, fue uno de los aspectos duros del debate de la reforma constitucional del 95, y ahora, nuevamente, se abre esta puerta a través de una decisión de la Corte muy reciente, que inicia otro conflicto de poderes entre el Poder Judicial y la Asamblea. ¿Cómo va a vivir Nicaragua esta nueva crisis institucional a propósito de las reformas?

R.S.: Mirá, es que ese punto no tuvo el consenso, quiero decir, que la han adversado siempre que lo tuvo, en el 95, primero en el 87 también hubo debate, pues, algunos diputados en el 95 como el doctor Danilo Aguirre Solís se opusieron, siendo miembros de la bancada del Frente, yo sí lo defendí, pues, ahí están en el diario de debates los pleitos que tuve con Danilo Aguirre por ese punto, al final Danilo no votó a favor, claro, nosotros teníamos sesenta y un diputados de noventa, pues, estábamos en el límites del 
$65 \%$ que se requería para cada voto para cada artículo de la Asamblea Nacional, pero votaron con nosotros dos o tres diputados de la oposición a favor de la reelección, entonces, votos disidentes o en contra de la reelección como el de Danilo Aguirre no lo bloquearon, pues, en cuanto a no poner, pues, ninguna prohibición a la reelección, en el 95, la cuestión fue distinta, la mayoría de los diputados que formaron parte del nuevo partido del MRS, que fue una disidencia del sandinismo, sí votaron y a conciencia, pues, a favor de poner el artículo que prohibía la reelección, los diputados propiamente del Frente, que se quedaron, digamos, con el Frente votaron en contra, pero la mayoría de diputados de ese entonces del MRS, que se estaba formando, sí las aprobaron, no fue de los temas que, digamos, más consenso tuvo en esos debates, pero sí quedó, efectivamente, pues, prohibida, eso es cierto, ahora que, digamos, si ahora hubiera habido, tal vez, que hubiera sido lo ideal, la posibilidad de la reforma con un número de votos mayores, o iguales en el peor de los casos, o mayor a los 56, es obvio que hubiera sido mejor eso que lo haya tenido que hacer mediante una sentencia de la Corte, pues, pero en el caso nuestro, y en el mío específicamente, yo no me siento mal por haber votado a favor de la reelección, puesto que la he defendido siempre, pues, del 79 para acá, por lo menos, porque creo que un período de gobierno no es suficiente tal vez para poder ejecutar un programa a como yo lo considero, por lo menos en el mediano plazo con cambios sociales más profundos, y que vayan orientados, pues, a favorecer a la gente más pobre del país, ahora, tampoco la veo, como decís vos, pues, directamente proporcional, pues, asociada a la concentración del poder en el Poder Ejecutivo, puede ser o puede no ser, no, el hecho de que Daniel se reelija no quiere decir, digamos, que otras facultades de la Asamblea, que ha agarrado las nuevas, pues, se las va a quitar y él se va a echar para atrás y se va a regresar otra vez a un Ejecutivo fuerte, pues, no lo veo tanto así, pues sí lo veo un Ejecutivo fuerte en el sentido que con la posibilidad de una reelección una serie de obras, de proyectos económicos, de infraestructura agrícola y ganadera, de toda naturaleza, sí lo puede llevar a cabo, en temas de préstamo de viviendas, de construcción de viviendas, en plazos más largos que sabiendo que dentro de uno o dos años tiene que estar en la calle otra vez para ir a otra elección, pues, o que va a cambiar un presidente que no maneja todo lo que manejó él, y que, por lo menos, pueda estar dos períodos en el poder, entonces, no ha sido para mí sinónimo de eso, la oposición ahorita sí ha llevado su análisis diciendo que si queremos llegar a una dictadura, y a todo el mundo se le ha olvidado que Daniel Ortega fue el que entregó la presidencia, pues, en el año 90, después de haber perdido las elecciones, pudiendo no haberlo hecho, tal vez, porque tenía un Ejército monolítico alrededor de él, y la Policía igual, es decir, y el apoyo popular era tal vez de los más altos que tenía, ya había bajado por la guerra, tal vez, pero con relación a Centroamérica seguía siendo muy alto, pero sí existe, sí existe una posibilidad de que ocurra eso que vos me decís, pues, que un presidente en la medida en que le quités, digamos, la prohibición de reelegirse, que es cierto que en la medida en que él sienta que ya no se le puede dar más poder, en determinados momentos se pueda lanzar en contra de una Asamblea, o de una Corte, cooptarlas, digamos, alrededor de él y no darle espacios para que funcionen libremente, o bien eliminándolas, pues, sus facultades o sus atribuciones, y tomándose medidas que tal vez no sean las que la Constitución propiamente le ha asignado a él, sino a cualquiera de estos dos poderes, pues, el Judicial o el Legislativo. Está por verse, pero me parece que no es esa la intención del presidente, yo, de buena fe, digamos, he votado a favor de la reelección aquí en la Corte, en esa sentencia, porque lo conozco a Daniel Ortega bastante, y creo que si pierde las elecciones ahora en el 2011, pierde y se va a su casa, pues, y volverá o no, puede ser candidato más adelante, pero no va a estar interesado en robársela, pues, y ser presidente en medio de un debate como el que se dio 
con las municipales, porque nos cortan la poca ayuda que queda y que el país más bien se vaya al abismo, pues.

R: No obstante, si que hay un elemento al menos cuestionable desde el punto de vista jurídico, y de la seguridad jurídica también, y ahi usted me puede enseñar más que yo porque no soy abogada de formación, sino experta en Ciencias Políticas, aunque sí tengo conocimientos de Derecho Constitucional, pero es cierto que se rompe el equilibrio de poderes entre el Legislativo, que es quien legítimamente tiene asumida la función de reformar la Constitución, y el Poder Judicial.

R.S.: Ese es el debate, bueno, es que ese debate, si vos estás en la oposición, verdad, como dicen ellos, sí, pues la reforma de la Constitución es facultad de la Asamblea, pero la interpretación es facultad de la Corte, según la Constitución misma, nosotros ya habíamos interpretado la Constitución en el caso de los ciudadanos nicaragüenses que pierden su nacionalidad, y hay varios casos, que ahí están las sentencias, además, candidatos presidenciales, que habían renunciado a la ciudadanía nicaragüense, habían adquirido otra nacionalidad, y no habían renunciado a tiempo a la segunda, que es lo que dice la Constitución, que con cuatro años de anticipación tenés que renunciar a una segunda nacionalidad adquirida para poder ser candidato a presidente de la República, a Edén Pastora le pasó eso, a este Robelo, que está ahora de embajador, por ahí por Europa, a Montealegre, a Arnoldo, a Alvarado, el liberal, a José Antonio, todos ellos han adquirido segunda nacionalidad de otros países, Estados Unidos, Costa Rica, Italia, etc., y, sin embargo, vinieron aquí, se metieron a la campaña, el Consejo Supremo les cortó la cabeza, y se detuvieron, pues, y dijo que no podían ser candidatos, aunque hubieran nacido en Nicaragua y fueran nicaragüenses, porque habían adquirido una segunda nacionalidad, y vino la sentencia de la Corte en cada caso, algunas las firmé yo, otras no, algunas son viejas, de las cinco, yo firmé al menos dos o tres, las otras no las había firmado yo, en la que siempre le da preeminencia a los dos artículos el 19 y el 20 de la Constitución, que establecen que la nacionalidad nicaragüense nunca se pierde, vos nacés en Nicaragua o sois de padres nicaragüenses y aunque vayas a Estados Unidos y hagas el juramento de renuncia a la nacionalidad de tu país, para Nicaragua se considera como no hecho, pues, es decir, en Nicaragua con esa sentencia ya quedó claro que la Constitución del país y las autoridades, pues, de los poderes del Estado reconocen esa sentencia en cuanto a que nunca pierden vigencia los principios establecidos en los artículos 19 y 20, que dicen que el que es nicaragüense, aunque renuncie a su nacionalidad nicaragüense nunca la pierde, siempre la conserva.

R: Perdón, pero esos sí fueron artículos reformados luego mediante la ley de reforma parcial en el año 2000 o en el 2005, creo que fue en el año 2000 cuando se reforma ese aspecto, quiero decir, que fue sancionado luego mediante ley, pero, en este caso, la interpretación de la Constitución...

R.S.: No, pero lo de los cuatro años no lo tocaron, es decir, la sentencia de Alvarado fue en el 2002, o en el 2003, no recuerdo, o en el 2005, pero, expresamente, eso tuvimos que sacarlo luego por sentencia, en la que dijimos que en el caso de Alvarado, que fue Ministro de Gobernación de Arnoldo, él podía ser candidato si no decidía renunciar a la nacionalidad norteamericana que tenía, porque a él ya no le daba tiempo renunciar, pues, porque la campaña se le avecinaba, ya estaba por inscribirse, etc., pues, tal vez, no sé si en el 2005, después se puso, pero ahí están las sentencias de todas maneras, pues, te las puedo buscar, que ya habíamos dicho que las limitaciones que establecían los 
artículos esos, que fue el 147, el 148, etc., para el presidente de la República, para los diputados están en otros artículos también, alrededor de tener que renunciar a la segunda nacionalidad, haber vivido en Nicaragua también durante el último año, no eran aplicable, que bastaba que una persona fuera nicaragüense, hubiera sido nicaragüense, hubiera nacido en Nicaragua, bueno, para que fuera candidato sin necesidad de obligarlo a renunciar a otra nacionalidad que hubiera adquirido en otro país, porque prevalecía, digamos, ese artículo de la total irrenunciabilidad, pues, de la nacionalidad nicaragüense, aunque hubiera renunciado o se hubieran ido, pues, como requisito previo para que te dieran la otra nacionalidad, y ya lo habíamos dicho y aplicado, incluso, pues, porque pasó en el caso del candidato Edén Pastora.

R: Y esta sentencia, perdón, sirve de precedente para que la Sala de lo Constitucional de la Corte se arrogue la capacidad, la facultad, para poder interpretar la cláusula de la reelección presidencial.

R.S.: Bueno, es la cuarta vez que te digo que lo hacemos, pues, bueno, los antecedentes están en ese aspecto de la nacionalidad y de la candidatura que habíamos dicho, pues, ahora ya con esto lo que afirmamos, a mí me parece que es correcto que la Corte tenga las facultades, pues, en materia constitucional, a la hora de interpretar la Constitución, que la que tenía antes, o la que digamos, tradicionalmente, se le habían dado, pues, en la Asamblea todo se politiza, es cierto que la Corte, los temas políticos, también se politizan, pues, y cada quien toma bando, pues, en el caso político, pero siempre la Asamblea había querido ver a la Corte como de menos, pues, parte de lo que me decía la presidenta de la Sala de lo Constitucional de Costa Rica ahora en Barcelona, era eso, que la misma reforma constitucional para Óscar Arias, pues, que lo más importante, parte de lo Arias es que a nosotros nos puso bien frente a la opinión pública y frente al Congreso, pues, y como Corte aceptamos nuestra posición, pues, que podemos ser, perfectamente, independientes del Legislativo, obviamente, que, en este caso, había algún vínculo con Arias, o que se ponga de parte de uno de ellos, como aquí también, tal vez eso no puede negarlo, pero con un fundamento jurídico y con interpretaciones, a nuestro juicio, sostenidas no solo por nosotros, sino por tratadistas internacionales, pues, del Derecho Constitucional, lo demás ya si se convocó o no, si fue rápida o no, todo eso son detalles, porque lo van a magnificar los opositores, pues, pero el hecho, el hecho fundamental, de dejar la opción abierta de que el pueblo decida y el contenido mismo de la sentencia y la leés está ajustado a Derecho, yo no creo, si se ha empezado a debatir que no fue una declaratoria de inaplicabilidad de un artículo de la Constitución, sino una reforma constitucional hecha por nosotros al haber eliminado, pues, ese párrafo, pues, cada quien con su tema, pues, como dicen: "cada loco con su tema".

R: ¿Le sirve, entonces, de inspiración, en términos de Derecho comparado, la sentencia de la Corte Suprema de Costa Rica a propósito de la candidatura de Óscar Arias? Y, luego también, sin embargo, el artículo 10 de la Constitución costarricense sí reconoce en el órgano de la Sala de lo Constitucional esa facultad, que es una facultad plenipotenciaria, en cierto modo, es constituyente, ¿no?, o, bueno, similares a la de una Asamblea Constituyente.

R.S.: Pero no para poner un artículo, si es que nosotros, yo no estoy claro si es para, es decir, los poderes judiciales lo que pueden es declarar inaplicable un artículo de la Constitución, pero él no puede sustituir eso por un texto, poner un artículo o, es decir, hay una diferencia, pues, el constituyente, aún el derivado, de un parlamento a la hora 
de una reforma, pues sí, tiene expresamente ese mandato, reforma del artículo, lo redacta como quiere, lo deja, nosotros nada más que podemos, y lo dijimos ahí, declararlo inaplicable, es decir, eliminarlo, pues, aunque lo dejemos ahí, no se aplica, pues, ¿por qué?, porque no podemos reformar la Constitución, no podemos poner otro texto, pues, es cierto, que hay quienes dicen que es una cuestión esta morfológica, pues, que, en el fondo, decís eso para no usar las mismas palabras, pero las consecuencias son que la reformaste la Constitución, pues, porque, bueno, ese ya es un debate que nunca va a terminarlo, pues, la declaratoria de inaplicabilidad de un artículo, para mí aclara la Constitución Política y deja a salvo una contradicción entre un artículo que se declara inaplicable, y otro de la misma Constitución donde tenés que establecer cuál de los artículos es más importante, que, y a juicio de eso, dejar, digamos, con vida el más importante, si es en el área de los principios, pues, como es en este caso.

\section{$R:$ ¿El principio de igualdad?}

R.S.: El principio de igualdad y el de la soberanía también, que la gente decida lo que quiera, pues, sobre el auto de la prohibición, ahora, son discusiones constitucionales, y son interpretaciones que según, también, tengas tu inclinación política, las vas a defender o no, pues, pero no es que una sea la buena y la otra la mala, sino que ahí están las dos, en algunos lugares, la Corte Suprema ha dicho una cosa ante una situación así, en otras la misma Corte Suprema puede decir lo contrario, aquí en Nicaragua esta Corte dice esto, esa otra Corte había dicho que no, pues, que las reformas eran la Constitución misma y que no se podía recurrir en contra de una reforma a la Constitución, y que la Corte no tenía por qué pronunciarse sobre las reformas mismas, pues, porque esa es una facultad exclusiva de la Asamblea, entonces, es un debate que va a estar por días, por semanas, por meses, bueno, ahí va a seguir.

R: Sí, durante todo este último año, me imagino que ustedes van a estar implícitos en esa situación, y, bueno, la Asamblea creo que también se ha movilizado o se está movilizando, en estos momentos, para poner un freno institucional a la decisión de la Corte.

R.S.: Eso lo dudo mucho.

\section{R: ¿Ya la da por definitiva?}

R.S.: Tienen el derecho a hacerlo, pero no creo que vaya a tener éxito eso.

R: Entonces, en el caso de las actuales reglas electorales, parece que si el liberalismo continúa dividido Ortega volverá a ser el próximo presidente a partir de 2010, ¿no?, bueno, la matemática electoral y el sentido común así lo dice.

R.S.: Yo creo que va a ser candidato, Ortega, es decir, parece que va a ser Daniel, si el gobierno mejora su actuación económica y eso, va a ser el candidato, cierto, que ellos van a ir unidos también, como dijeron los liberales se van a ir consolidando alrededor de su unidad, pero es la única posibilidad que tienen de considerar la posibilidad de ganar, pues, de lo contrario van a estar lejos de ganar, pues, pero, pero, el debate, pues en sí, porque ya tenía consumido el país en tres años, tal vez se va a cortar, aunque estemos dos o tres semanas más sobre esto, y ya aceptará la realidad, pues, que, yo no veo aquí Cortes internacionales que vengan a modificar las cosas y a decirle a Nicaragua lo que 
tiene que hacer, es un tema que, esencialmente, es soberanista, en todo caso, serán, digamos, los diputados si acaso consiguen los votos, primero, para pasar esa ley a comisión, y, segundo, para conseguir los votos necesarios para aprobarla, pues, pero no veo tampoco instancias internacionales que vengan a, o que tengan facultades, incluso, pues, para revertir esa sentencia.

$R: Y$, sin embargo, Nicaragua, ya después de las últimas municipales, ha estado en el punto de mira sobre todo de la Ayuda al Desarrollo, por parte de Estados Unidos y de la Unión Europea.

R.S.: Sí, por la percepción que se tuvo.

\section{R: Del fraude electoral.}

R.S.: Sí, de lo que se llamó así, fraude electoral, pero que fueron anomalías menores que se magnificaron, se vendieron bien, en términos de que eran fraude, y nos cortaron la ayuda muchos países europeos, pues, pero no tenía esa categoría, pues, como un fraude, pero bueno, hay quien tiene su percepción de eso.

R: Pero si uno mira la historia de Nicaragua, algunas voces críticas dicen que la reelección, en este país, siempre ha ido de la mano del fraude, esta es una acusación muy dura, pero mirándolo en el contexto actual, y examinando lo cara que ha costado la democracia en este país, después de la revolución, que fue una experiencia liberadora de una dictadura.

R.S.: Sí, pero es discutible, ni yo, pues, que estuve luchando contra Somoza, con las armas en la mano, pues, participé en la guerra, pues, estuve clandestino casi dos años, y, digamos, que en determinados momentos se negocia, Somoza, aún con todo y todo, tuvo mucha popularidad y algunas elecciones, que, políticamente, nosotros no dejábamos, se le aprobó, y las ganó limpiamente, pues, ahora, en la madurez de uno, tal vez el estudio y el tiempo, y todo lo que ocurrió, en buena medida, digamos, Somoza llegó a tener una gran base social liberal, pues, opuesta a lo que fueron aquí los conservadores, que lo llevó al poder sin necesidad de hacer fraude, hubo elecciones que sí lo hizo y se volvió dictador, pues, pero hubo otras en las que ganó limpiamente las elecciones, porque tenía mucha popularidad, pues, también él hizo mucho programa social, digamos, dotó a Nicaragua de un nuevo Código del Trabajo, luego todas las facilidades crediticias para la gente de más escasos recursos, hizo muchos cambios en el país que le permitió, en algunos casos, ganar elecciones limpias, de una manera limpia, pues, sin la necesidad de robárselas, y vos ves una gran cantidad de gente que lo apoyaba, pues.

R: $Y$, sin embargo, también en el periodo somocista el pacto político entre los partidos es fundamental antes de la reforma constitucional, es un principio que aparece en la historia constitucional del país.

R.S.: Siempre lo hicieron así, de Cuadra-Pasos con Somoza, el otro Pacto de los Generales, del General Chamorro y Somoza, también, sí, es cierto eso, es cierto, como que era un antecedente de la reforma en la cual se negociaba antes políticamente, sí.

R: ¿Y el pacto entre el PLC y el sandinismo del 2000 ya está formalmente disuelto? 
R.S.: No, no creo.

\section{$R:$ ¿El entendimiento entre los dos partidos sigue produciéndose?}

R.S.: Además ahora en diciembre a la hora de nombrar funcionarios públicos, en diciembre los diputados del PLC y los del Frente se van a amarrar a Arnoldo y a Daniel, vuelven a amarrase y a abrazarse y van a nombrar a los funcionarios a los que se nos vence el período, pues, a mí, incluso, en la Corte, somos cuatro, los del Consejo Supremo, los de la Contraloría, los de la Procuraduría de Derechos Humanos, todos esos, son veintisiete, en los primeros meses del 2010, pues, y toda esta bulla que se ha creado, pues, en contra de nosotros, alrededor de Alemán, que ha querido dirigirse como la figura principal de la oposición, se va a acabar, pues, y se van a nombrar Magistrados en la Corte, Magistrados en el Consejo Supremo Electoral, Contralores, con una mayoría de votos liberales y sandinistas, pues.

R: Liberales del PLC, porque hay otras fuerzas anti-pacto, que quedan excluidas de este pacto.

R.S.: Liberales del PLC, sí, bueno, hasta ahora esa ha sido la posición de Eduardo, que es el disidente más fuerte del liberalismo, pero puede ser que hasta Eduardo Montealegre, digamos, pudiera entrarle, ellos tienen interés en tener espacios de poder en el Poder Ejecutivo, pues, por eso yo no creo que rechacen así de golpe la posibilidad de un acuerdo con el Frente.

R: Y el Frente ha sido un partido que desde que entregó el poder a Violeta Chamorro sí ha tenido 16 años de oposición en que ha aprendido también a gobernar en las instituciones, pienso, especialmente, en el Poder Judicial.

R.S.: Sí, es cierto, bueno, aquí sí ha estado fuerte.

R: ¿Y por qué?, ¿cómo lo ha logrado?, ¿cuál ha sido el trabajo del partido?, ¿cómo los cuadros del partido se han convertido en jueces?

R.S.: Bueno, yo vine en el 2000, pues, y sí he logrado, he logrado, pues, tener buena relación con jueces, digamos, sandinistas, pues, no tenemos así un trabajo de estructuración en el Estado, pues, de grupo, cédulas, corresponsales, todas esas cosas, pero sí hay, digamos, una preocupación nuestra de que si hay buenos jueces y los podemos captar para el partido en Nicaragua, los agarramos y engrosen al partido, a la vez que le dan prestigio, y también prestigio al Poder Judicial, pues, en ese sentido, también hemos sido partidarios de nombrar en el de apelaciones o en los juzgados, porque eso le corresponde ya como facultad a la Corte, a nosotros sólo es la Asamblea la que nos nombra, pero nosotros nombramos desde el tribunal de apelaciones para abajo a personas que tengan tendencia por su buena formación, su formación sólida, como jueces, como abogados, y a la vez tengan, sean afiliados nuestros, pues, eso no contradice la Ley de Carrera Judicial, puesto que creemos que se deben hacer los concursos necesarios para optar a esos cargos, ya lo hemos hecho en los juzgados estos de familia que se han creado, pues, se han nombrado a los que mejor han salido después de los concursos que han incluido exámenes de grado, pues, oposiciones fuertes, también, claro, hay casos en que queremos con las prisas nombrar juez a un abogado, tal 
vez, en un municipio a un sandinista muy destacado sin necesidad de pasar por el concurso, pues.

$R: Y$, sin embargo, esa partidización de las instituciones de los poderes del Estado ha supuesto también una pérdida de legitimidad ante la opinión pública, especialmente, tanto del Consejo Supremo Electoral como del Poder Judicial.

R.S.: Bueno, esto es discutible, es discutible, yo, honestamente, te digo, todas esas encuestas, si vos ves los poderes judiciales en América Latina, el inicio de esa aprobación es similar a un 50\% o $60 \%$, aquí el último bajamos, pues, y nos quedamos, por lo menos, en medio, pues, tal vez la Policía ha tenido un poco más y el Ejército, pero está peor el Consejo Supremo, en algunas encuestas la Asamblea sale peor, en América Latina los poderes del Estado, en general, pues, no tienen una puntuación buena de la población, a mí no me preocupa estar con ese porcentaje, tomando en cuenta, como vos decís, que ha habido campañas de los medios para poner como que hay poderes en el país, sin embargo, hemos producido sentencias de mucha calidad, yo he ido a congresos internacionales y he expuesto mis tesis, Rosales también, y han sido muy bien aceptadas, pues, no hay aquí, digamos, poderes judiciales en el banquillo, porque nos tengan, es decir, la población, algunos medios sí, vos ves La Prensa, El Nuevo Diario, algunos canales de televisión, tal vez, ¿por qué?, porque aquí se dio también un acuerdo político que permitió, digamos, que la Corte y la justicia estuviera más balanceada, pues, antes había menos Magistrados, es cierto, pero había más del otro lado, pues, con relación a los Magistrados provenientes del sandinismo, ahora ya quedamos nivelados, ¿cuánto tiempo vaya a estar esto?, no sé, eso dependerá de las elecciones próximas, si aquí la oposición en Nicaragua se une y le da un golpe fuerte al Frente, electoralmente, en esas elecciones, hasta pudieran tratar de reformar la Constitución o mediante leyes ordinarias afectarnos a nosotros los períodos nuestros, y forzarnos que nos vayamos antes de nuestro vencimiento, o que no seamos reelectos, sencillamente, pues, eso puede ser.

R. Y, sin embargo, ya para terminar, da la impresión de que cuando uno lee esta historia constitucional reciente del país, en el marco de la construcción de las instituciones democráticas desde los 90 hasta la fecha actual, que la politica está por encima del Derecho, que la negociación entre las élites políticas está por encima de las normas jurídicas.

R.S.: No, subsiste la política, la política aquí en Nicaragua subsiste, digamos, interrelacionada con el derecho, pues, y ahí se entremezclan y ahí están, pero no es que esté.

\section{$R:$ ¿Y el principio de supremacía?, ¿y el principio de seguridad jurídica?}

R.S.: Bueno, en los casos que no son políticos, cantidad de casos que tienen que ver con sentencias contra empresas, instituciones financieras, que tienen que ver con lo económico, o con lo social, pues, o de otra naturaleza.

\section{$R$ : Bueno, yo me refiero al ámbito propiamente constitucional.}

R.S.: No, pero si quieres es que lo constitucional es todo eso también, porque aquí lo constitucional como lo contencioso-administrativo, que es instancia que no se ha 
desarrollado, pues, y es muy pobre, una serie de casos del Estado, pues, y que en otros casos son constitucionales, en el orden en sí del Derecho administrativo, por así decirlo, pues, y que lo debía resolver el contencioso-administrativo aquí van a la Sala de lo Constitucional, pues, aquí van a la Sala de lo Constitucional, y la Sala resuelve cuestiones de impuestos, cuestiones de seguridad social, cuestiones de salud, de educación, etc., más allá, digamos, de sentencias políticas, pues, ya vamos 504 sentencias de esas hay 460 o 470 sentencias que no son políticas, son de cualquier institución del Estado, que tiene problemas con algún ciudadano, y hay algunas que sí son políticas, ya más referidas, qué sé yo, a sentencias como ésta, pues, que se ha resuelto en unos casos de una manera, y en otros de otra, siempre hay un cuarto voto ahí que ha aparecido confirmando una sentencia con otros Magistrados que pueden actuar en una sola dirección, o hay veces que nosotros mismos de la Sala, Magistrados propietarios provenientes del sandinismo o del liberalismo, nos ponemos de acuerdo y ya firmamos, pues.

R: Pero yo me refería exactamente a que los acuerdos políticos, las negociaciones entre las élites hacen que sea muy fácil cambiar la Constitución en este país, ¿no?

R.S.: Bueno, ha habido 5 o 6 reformas, ¿verdad?, desde el 90, que te puede dar la razón, es cierto, se ha cambiado de una manera tal vez rápida, pues, desde el 87 al 2009, en 22 años ha habido 6 reformas, y pudiera ser, pudiera ser muy rápido, bueno, en Estados Unidos la Corte Suprema tiene facultades para que una sentencia, de interpretar la Constitución en algunos puntos, pues.

R: Pero el procedimiento de reforma en Estados Unidos es muy rígido, como Constitución escrita y como supremacía normativa que tiene la Constitución en el sistema jurídico.

R.S.: Sí, yo sé, yo sé, yo estoy claro de eso.

$R$ : ¿Cuál es su reflexión última?, ¿más reformas constitucionales?, ¿resolver la actual crisis que hay ahora a propósito de esta sentencia?

R.S.: Esto de la reelección va a pasar, no veo que Europa o Estados Unidos insistan mucho, puesto que en Europa como es un régimen parlamentario, un Primer Ministro puede ser nombrado por el Congreso una, dos o tres veces, pues, lo mismo Estados Unidos, que tienen una reelección continua, me parece que en el otro año va a haber más problemas por otras situaciones, pues, incluidas las elecciones de nuevo en el año siguiente, esta es una crisis que va a pasar en una o dos semanas, esta sentencia de la Corte alrededor de la reelección, todavía falta por ver de que si hay la posibilidad de que haya reforma, si no es este año, pues, el próximo, claro, el tema alrededor de una reforma electoral en la que la oposición ha estado interesada, pues, o algunos temas que tienen que ver también con reformas constitucionales que le den, qué sé yo, pues, mayores atribuciones al Poder Judicial, por así decirlo, que haya una composición distinta al Poder Electoral, nos metamos a la forma de elegir los Magistrados de uno $\mathrm{u}$ otro poder del Estado, toda la parte, incluso, dogmática, que tiene que ver con la salud, con la educación, pues, hay que ver, hay que ver, pero siempre creo que esta es una Constitución que puede sufrir reformas de nuevo en los próximos años.

$R$ : ¿Y eso no elimina la certidumbre en los actores políticos? 
R.S.: No, porque esos son temas políticos como te digo, lo económico tiene su carril, esto es que a veces lo político, si se abusa, pues, influye en lo económico de una manera probablemente negativa, contraproducente, pues, pero lo económico tiene su, el lunes va a aprobar el Fondo Monetario, probablemente, los 95 millones para Nicaragua, a pesar de nosotros haber dicho que Ortega se puede reelegir, ¿no?, si aquí ellos consideran que se han cumplido los parámetros que se dieron, se ha mantenido la inflación como está, se está, digamos, recortando el gasto público, y hay una política austera, pues, con relación al uso de estos recursos, la maquinita de producir córdobas va a una velocidad normal, moderada, y no está ocasionando problemas inflacionarios, y, en fin, digamos, que, claro, hay un contenido democrático general, hay un marco democrático general, que no le cause problemas al Banco Mundial, al BID o al Fondo, lo van a seguir haciendo, lo van a seguir aprobando la asistencia para Nicaragua, lo que se dio con las elecciones fue, digamos, estas municipales, es, tal vez, particular e insuficiente, a mi juicio, por parte de los países europeos, que congelaron la ayuda alegando fraude, es decir, ya se les explicó, se les están entregando los documentos sobre eso, los últimos, puede ser que cambien de opinión, pues, algunos y nos devuelvan la ayuda, puede ser que no, pues, pero no las veo en una próximas elecciones, sinceramente, creo vamos a estar en paz.

\section{$R:$ ¿Y que no va a haber ninguna regresión en la democracia en este país?}

R.S.: No, no, aquí no volvemos a dictaduras, nadie quiere dictaduras, los que menos las quieren somos los sandinistas también.

R: Pues yo creo que ya, si tiene algo más que añadir.

R.S.: Está bien. 


\section{ENTREVISTA $45^{63}$ :}

Nombre del entrevistado: $D^{\mathrm{a}}$. Dora María Téllez.

Cargo actual: Ex-Diputada de la Asamblea Nacional por el partido Movimiento Renovador Sandinista (MRS), fundadora del MRS junto a Sergio Ramírez en 1995, actual investigadora del IHNCA-UCA.

Fecha de realización de la entrevista: Managua, 30 de octubre 2009.

Lugar: Instituto de Historia de Nicaragua y Centroamérica de la Universidad Centroamericana (IHNCA-UCA).

Duración estimada: 1 hora y 2 minutos.

\section{TEXTO - Transcripción 45:}

R: ¿Cuál es su reflexión sobre los cuatro últimos procesos de cambio constitucional, incluida la última sentencia de la Corte Suprema reciente, que se han producido en el contexto de la transición democrática en Nicaragua? Es una pregunta muy abierta, pero me interesa sobre todo su punto de vista a propósito de todo lo que ha sucedido en el país.

D.M.T.: Bueno, cuando hay que decir que esta Constitución del 87, probablemente, lleve el record de ser la que más ha durado, verdad, lo cual es un record, en cierta manera, relativo, pero tiene aspectos, que son aspectos interesantes, es decir, todo el cuerpo básico de principios y de derechos, en general, ha sido, yo diría poco tocado, verdad, en la reforma constitucional del año 95 se tocaron algunas cosas, pero más que para hacerlo restrictivo para ampliar algunos derechos, verdad, o para dar claridad sobre otros, pero la médula de los cambios constitucionales ha estado en torno al sistema político, es decir, en el año 95 se amplió un poco, además del sistema político tocó otra cosa, tocó la institucionalidad, por ejemplo, en el caso del Ejército y en el caso de la Policía, pero más allá de las reformas que se produjeron en el caso del Ejército y de la Policía nunca más ha vuelto a tocarse el capítulo del Ejército, Policía, en la Constitución, las reformas han estado concentradas en torno al diseño del sistema político, al funcionamiento del sistema político, impuesto de una manera un poco más burda, orientadas a ver quién saca el aprovechamiento de los cambios en el sistema político, verdad, y eso tiene que ver con una dinámica que, con la dinámica que, de alguna manera, fue tradicional en la élite política nicaragüense previa al triunfo de la revolución sandinista, ¿no?, que son arreglos por cuotas de poder y privilegios en torno al aparato de poder, entonces, al día de hoy el sistema político, en general, no goza de consenso, y no ha gozado de consenso desde el derrocamiento de la dictadura para acá en ningún momento, y, probablemente, hacia atrás tampoco, ¿verdad?, es decir, si vos preguntás en la calle te vas a encontrar con que la gente quiere que haya menos diputados, quiere que haya menos Magistrados, quiere que se reformen las cosas para que funcionen, de una manera o de otra, pero siempre te vas a dar cuenta que en el ámbito de la ciudadanía no está conforme con el sistema político, el sistema político,

\footnotetext{
63 Entrevista interesante, especialmente, por el análisis del proceso histórico de formación del Estado en Nicaragua en el marco de las dificultades de consolidar un equilibrio de poderes, debido a la tradicional estructura presidencialista del Ejecutivo, una cultura política que favorece la emergencia de liderazgos caudillistas, y el control del acceso al poder mediado por pactos políticos informales, que después se cristalizan, jurídicamente, como norma constitucional.
} 
además, no lo percibe como estable, no es estable, no es una realidad establecida, es una realidad que está en cambio, todo el mundo lo percibe como cambiante, y los actores políticos acentúan el sentido de que este es un sistema político cambiante que se hace para acá, o que se hace para allá, en dependencia de los intereses de los que están controlando las cuotas de poder más elevadas, entonces, excepto la reforma del 95, que trató de darle, digamos, una desconcentración y descentralización de poder, porque la Constitución del 87 era una Constitución, fuertemente, presidencialista, y concentraba muchísimo poder en el presidente de la República, incluso, sobre el Consejo Electoral, sobre la Corte Suprema, etc., ¿no?, entonces, la reforma del 95 lo que trató de hacer fue equilibrar, descentralizar el poder, y dar, digamos, cuotas de poder a las distintas instituciones, dispersar el poder, para decirlo de alguna manera, las reformas posteriores han ido en el sentido contrario, que es concentrar el poder de nuevo, de tal manera que el que está en la presidencia tiende a controlar todo el resto del aparato del Estado, verdad, incluyendo la Policía, y alinear, de alguna manera, el Ejército, verdad, ¿por qué eso?, porque, de alguna manera, lo que ha evidenciado el sistema político tradicional, verdad, de alta concentración de poder en el presidente de la República, que es un modelo del siglo XIX, verdad, tiene una gran resistencia al cambio, verdad, es decir, el proceso de democratización tiene que ver, simplemente, con elecciones, con que haya elecciones, y que haya elecciones competitivas, y además el partido que tiene el poder pierda las elecciones, esta es una gran novedad en Nicaragua, la primera vez que un partido en el poder perdió las elecciones fue en el 90, verdad, y luego en el 2006, pero es una novedad que no está totalmente asentada, es decir, la tradición es que el partido que estaba en el poder fuera dueño de las elecciones, dueño del resultado, dueño del aparato, y, obviamente, dueño del fraude, ¿no?, pero bueno, la resistencia del sistema a la desconcentración de poder, a la dispersión de poderes, al equilibrio de poderes, al poder disperso en varias instituciones es elevadísimo, es decir, el modelo de poder político del siglo XX en Nicaragua fue un modelo de poder concentrado, en Zelaya en la autoridad de la intervención norteamericana de la ocupación, en Somoza, el poder revolucionario también fue un poder concentrador, y más aún en circunstancias de guerra, es decir, es este siglo XX un interludio muy breve en que la dispersión del poder operó, pero, rápidamente, se procedió desde el año 98 a una reconcentración de poder, lo que pasa es que ese espacio pequeño casi ni se puede contar, verdad, como parte del modelo político, sino como un respiro, pero el modelo político del siglo XX es concentrador de poder, y privilegia la figura presidencial, vencer ese modelo es difícil, $\mathrm{y}$, obviamente, las reformas constitucionales del año 95 fueron insuficientes, probablemente, requerían más profundidad, verdad, para ser irreversibles los cambios, pero fueron, fácilmente, reversibles, porque gran parte de la élite política prefiere el modelo de poder clásico del somocismo, que tiene la presidencia, concentra mucho poder, pacta con el principal partido de la oposición, montan un bipartidismo institucional y se distribuyen las cuotas del poder, verdad, al final eso tiende a la consolidación de un modelo, prácticamente, dictatorial con más disfraces o menos disfraces, verdad, entonces, a grandes rasgos, pues, yo veo esas tendencias de reformas constitucionales, una, que tiende a hacer la Constitución del 87 más democrática, y la otra que tiende a volver sobre los pasos de un modelo político previo, pues, del modelo del somocismo, de alguna manera.

R: Si bien es cierto que la gran reforma del 95 es la que se sustenta en términos de legitimidad y de necesidad, puesto que, incluso, se abrió el debate sobre si reforma parcial o reforma total, la reforma constitucional además fue uno de los elementos, digamos, de conflicto, que estuvo mediando durante todo el período de Doña Violeta, 
puesto que había un sector próximo a Doña Violeta, con Antonio Lacayo a la cabeza, que se resistía también a la reforma constitucional, ¿no?, y a que el Ejecutivo presidencial perdiera gran parte de sus facultades, es el pacto Ortega-Alemán del 2000 el que inicia, digamos, el punto de inflexión en esta revolución de tendencia a aumentar las facultades de la Asamblea Legislativa en detrimento del presidente, y luego cuando Ortega y Alemán reactivan su pacto en 2004 para privar también de facultades al entonces presidente Bolaños, que fue un presidente al que le costó, enormemente, desarrollar su agenda de gobierno.

\section{D.M.T.: No tenía partido.}

R: En la Asamblea, es importante también esta relación entre el presidente y el grupo político en que se sustenta para garantizar, digamos, la fortaleza del Ejecutivo presidencial, tanto Violeta Chamorro como Enrique Bolaños tuvieron enormes problemas, precisamente, porque se quedaron sin un partido de apoyo.

D.M.T.: Doña Violeta estuvo sin partido, todos estaban en la oposición, y Bolaños también fue un presidente sin partido, verdad, un gran problema.

$R$ : En un régimen presidencialista, y tanto Alemán como Ortega han sido líderes que han conseguido un control fuerte sobre su partido.

D.M.T.: Claro, Alemán tuvo un gran poder, concentraba un gran poder, cuando fue presidente, que fue el mismo que tenía Ortega, prácticamente.

R: Y a Alemán le ha debilitado su propia condición de rehén de Ortega en términos de su libertad.

D.M.T.: Alemán, yo creo que lo debilitaron dos cosas, uno, su modelo mental, te voy a explicar, Alemán de cara al pacto del 98, él tiene en la cabeza el pacto de Somoza, el pacto de Somoza, el último, verdad, 60/40, de la Constitución, un pacto que le daba $40 \%$ al opositor, $60 \%$ al partido de primera mayoría en todos los cargos, es decir, si los conservadores sacaban el $20 \%$ en la elección tenían derecho al $40 \%$ en los cargos, ¿está claro eso verdad?, bueno, usted ha debido estudiar bastante esas constituciones, y tenían derecho al $40 \%$ de los cargos en el exterior, de las magistraturas en la Corte, de los cargos en los tribunales de cuentas, etc., todos los cargos, ese pacto Somoza lo cumplía escrupulosamente, pero además lo cumplía institucionalmente, era un pacto institucional, a pesar de que se llamó el Pacto de los Generales primero, y después el Kupia Kumi, era un pacto entre el Partido Conservador y Somoza institucional, de manera que Somoza nunca le robó un magistrado al Partido Conservador, nunca le fue a reclutar a un magistrado, nunca le reclutó a un diputado, nunca le reclutó a un embajador, le daban su cuota, a ellos les decían los "zancudos", a todos los que entraban en la cuota les decían los "zancudos", porque estaban chupando sangre, pues, y ellos seguían siendo conservadores, ninguno traicionaba al partido, ninguno se volvía somocista, ¿me explico?, interesantísimo el modelo, funcionaba, escrupulosamente se cumplía, nunca se dejó de cumplir, Alemán conoce ese modelo porque él estuvo pegado a las raíces del somocismo.

$R:$ ¿Cuáles son los orígenes políticos de Alemán? 
D.M.T.: El papá era un somocista, tenía un cargo medio en el somocismo y estuvo un poquito más alto, y después lo mandaron a, creo que era juez somocista en León, que tenía otra función para que los hijos estudiaran ahí, pero era un somocista, es decir, ellos tienen formación en el modelo del pacto desde el poder, Alemán hace ese mismo pacto con Daniel Ortega, 60/40, poco más o menos, verdad, o sea, un poco en la Contraloría fue que ellos deciden, después de la reforma de la Contraloría, de 1 a 5 contralores, 3 eran de Alemán y 2 eran de Ortega, 60/40, y Alemán cree que eso es la estabilidad, y que además cree que eso los va a mantener en el poder 20 años, el proyecto de los liberales que son locos, aquí todo el mundo es loco, pero Daniel Ortega no viene de esa escuela, Daniel Ortega no cree en el modelo de las "minorías congeladas", él necesita, así se le llamaba aquí: las "minorías congeladas".

\section{$R:$ ¿En la época del somocismo así se le decía desde el sector revolucionario?}

D.M.T.: En la calle, se conocía como "sistema de minorías congeladas".

\section{R: ¿Y por qué ese nombre?, porque eran minorías que no iban a aspirar a más...}

D.M.T.: Nunca podían pasar a más.

\section{R: Exactamente.}

D.M.T.: Ni pasaban a más, ni querían pasar a más, ni iban a pasar nunca de ahí, porque siempre Somoza iba a ganar las elecciones, siempre el partido liberal iba a ganar las elecciones, y la minoría, entonces, siempre iba a tener su $40 \%$, ese fue el gran arreglo, yo siempre voy a ganar las elecciones, pero vos siempre vas a tener el $40 \%$, enseña esta lotería, ya sabemos el resultado del premio, y todos estamos tranquilos y felices, el gran capital estaba tranquilo, los conservadores estaban tranquilos, porque tenían una cuota de poder grande, hermosa, elegante, pues, verdad, y Somoza estaba tranquilo, porque él se mantenía en el poder y ya está con su arreglo, pero Daniel Ortega no cree en el sistema de minorías congeladas, Daniel Ortega lo ve como un escalón, yo arranco aquí, verdad, y me voy para arriba, la siguiente oportunidad, que cambia el modelo es Frente a Bolaños, verdad, él sabe que el "Gordo" ya está prensado, entonces, ya Daniel puede subir al fifty - fifty, 50/50, entonces, llega a un arreglo, todos los cargos, el 50\% es tuyo y el 50\% es mío, está bien, un año presidente de la Asamblea un liberal, el otro año uno del Frente, en la Corte un año es presidente uno, el otro año es presidente el otro, 50 y 50 , todos están frente a Bolaños, verdad, le quitamos poder a la presidencia, trasladamos más poder a la Asamblea, y vamos mitad y mitad, no hay problema, le sacan instituciones al Ejecutivo, que no era mala idea, y las pasan bajo nombramiento de la Asamblea para tener que repartirse, y el mejor ejemplo de eso es la Superintendencia de Servicios Públicos, el diseño de la Superintendencia de los Servicios Públicos, era el Superintendente y las Vice-Superintendencias, las Vice-Superintendencias estaban mitad y mitad, verdad, todo era, el pacto llegó a ser fifty-fifty, hasta ahí los liberales están contentos, que Alemán aunque estaba desaforado no está preso, y ellos van a medias, en ese momento, los dos partidos son partidos de oposición, interesante coyuntura, ¿no?, los dos son partidos de oposición, entonces, el fifty-fifty se siente sabroso, de nuevo, para Alemán él cree que ese puede ser el modelo, y además le dice a Daniel, cuando están firmando el acuerdo último el de la época de Bolaños, "este es un arreglo que le va a dar estabilidad a Nicaragua", y le dice Daniel, pero Daniel no está pensando en eso, el "Gordo" está con su modelo mental del somocismo, de la 
estabilidad que producían los pactos en el somocismo, porque eran estables, verdad, pero Daniel no está con esa mentalidad, por eso es que el "Gordo" le dice: "estamos haciendo un acuerdo que le va a dar estabilidad a Nicaragua", y se lo dice en conversación privada, verdad, pero Daniel no, Daniel lo que está pensando es en el siguiente salto, entonces, ¿qué pasa?, a diferencia de lo que hacía Somoza, Daniel le compra, le comienza a comprar gente a Alemán, verdad, porque Somoza no compraba los otros partidos, pues, hacía un arreglo, pero no le estaba sacando, verdad, entonces, ¿qué es lo primero que hace Ortega?, el control del Consejo Supremo Electoral, el control de la Contraloría, compra a Roberto Rivas, que no era difícil de comprar Roberto Rivas había metido mucho contrabando en la época de la guerra y posterior, se había robado la plata que le había dado el Arzobispado de Managua para enfrentarse a la revolución, verdad, y todo el contrabando que había metido lo había metido amparado en una organización que se llamaba COPROSA, que estaba presidida por Monseñor Obando, que metía contrabando de ropa, metía contrabando de, verdad, le metían toda la documentación, la documentación llega a la Contraloría, entonces, cuando la documentación llega a la Contraloría, Obando y el doctor Rivas están listos a negociar con el Frente, ellos negocian, la documentación se retira de la Contraloría y el caso se muere, verdad, pero Obando y Roberto Rivas, le deben un gran favor a Ortega, y entonces Ortega también comienza a transferirle, masivamente, recursos, si vos ves el presupuesto general de la república le dan 12 millones de córdobas a la UNICA, la UNICA, una Universidad privada de Roberto Rivas, su hermano y Obando, 12 millones es el presupuesto general de la república, y si lo puedes ver cuánto le han dado, ahí está escrito en el presupuesto, no está disimulado, verdad, eso es lo que le transfieren, más lo que le transfiere como becas más, etc., etc., verdad, entonces, ese negocio de la familia Obando y Rivas depende de los fondos del Estado, entonces, negocian, entonces, Daniel tiene ya cuando se roba Roberto Rivas, la mayoría del Consejo Supremo Electoral, ¿estamos claros?, dame 50 y 50, con un independiente, que era Roberto Rivas, ¿no?, ya tiene la mayoría, y hace lo mismo en la Contraloría, en la Contraloría cañonean a, "cañonear" le decimos en Nicaragua a sobornar, verdad, cañonean a Guillermo, que era liberal del doctor Alemán, y éste se pasa al bando de Daniel Ortega, igual, por cargos, por dinero, tú sabes, qué otros niveles de negociación, en ese punto, ya Daniel le logró arrancar a Alemán la Contraloría y el Consejo Supremo Electoral, y lo tiene siempre prisionero en el Tribunal de Apelaciones, verdad, es decir, ahí el pacto va cambiando de proporción por la vía de los hechos, que es lo que Alemán nunca esperó, porque Somoza nunca lo hacía, ¿me explico?, la proporción es exactamente la misma, se mantenía, 60 tuyos, 40 míos, los tuyos son tuyos, los míos son míos, pero aquí va cambiando la proporción por la vía de los hechos, ¿qué es lo que le queda a Alemán?, a Alemán lo que le queda es la Sala Penal de la Corte Suprema con grandes dificultades, verdad, con grandes dificultades, pero, y unos Magistrados en la Corte con grandes dificultades, pero ya perdió todo, perdió la Procuraduría, perdió la Fiscalía, el Fiscal General es un cobarde, porque además lo tienen comprado el orteguismo por varios lados, además ha perdido el Consejo Supremo Electoral, perdió las llaves, en ese punto, Alemán pasa a ser "socio minoritario" del pacto, nada más que tiene un poder, que es el poder de controlar la mayoría constitucional, la del $60 \%$, ese es su único poder, ¿verdad?, nada más, pero Alemán es prisionero de un segundo problema, que es un cobarde, cada vez que a Daniel Ortega le suenan las llaves de la cárcel Alemán suelta la negociación, y Ortega le tomó la medida, cada vez que lo empujan un poquito para la cárcel, Alemán se pliega, esa ha sido su naturaleza y esa es la historia de toda, digamos, la ratificación institucional del cambio de porcentaje hasta llevarlo al punto de que es completamente minoritario, es decir, Alemán y Daniel Ortega pactan el fraude electoral 
de noviembre, cuántos municipios va a ganar quién y cómo, y cuántos van a perder los liberales, y Alemán cree que eso se va a cumplir, y que además se va a cumplir afectando a sus enemigos dentro del liberalismo, pero Daniel no, Daniel no se conforma con el arreglo de las municipalidades de un idiota, se va arriba, y se roba cuarenta y pico, verdad, de municipios, entonces, Alemán, es decir, todo arreglo que hace Alemán con Daniel Ortega, Alemán sigue creyendo que se va a cumplir porque, o necesita creer que se va a cumplir, o no tiene más remedio que hacerlo porque ya están listos, y Ortega siempre salta por encima del acuerdo y le va disminuyendo la proporción al grado de dejarlo ya a la mínima expresión, verdad, es decir, el poder de Alemán está en la gente que controla en la Asamblea Nacional, dudosamente, verdad, entonces, ¿qué es lo que pasa?, que la naturaleza de la reforma ha tenido también que ver con la reversión de ese modelo, verdad, de quién va logrando los controles mayoritarios en esa sociedad, verdad, bipartidista, bi-caudillista, para decirlo más claramente, ¿no?, esa sociedad bicaudillista ha ido cambiando de relación, entonces, lo que está pasando ahora es el último golpe a la sociedad, verdad, porque Alemán no se ha atrevido a reformar ese artículo de la Constitución, de la reelección, no se atrevió.

\section{R: No se atrevió, ¿por qué?}

D.M.T.: Porque, en el fondo, él creía que podía volverse a reelegir después porque tiene una opción, vos sabés que Nicaragua tiene reelección, pero alterna, porque él tenía una opción después, y porque Alemán está mucho más claro de que el tema de la reelección sucesiva era más enredada, verdad, entonces, él no se atrevió ni siquiera a proponer el tema.

$R$ : ¿Y no es cierto que hay un contexto internacional donde la reelección también se plantea como es el caso de Ecuador, Bolivia, Venezuela, incluso, el propio presidente Uribe en Colombia?

D.M.T.: Daniel Ortega desde el año 95, que hicimos la reforma constitucional vivía enfurecido con los sandinistas que estábamos por cerrar la reelección, y la concesión que se hizo, porque la tesis era "no reelección absoluta", la concesión que se hizo es una vez alterna, esa es la concesión, en todos esos debates, una vez y alterna, Daniel Ortega estaba enemistado contra eso, verdad, estaba enemistado, ahí lo podés ver en todas sus declaraciones posteriores en la reforma del 95, había echado sapos y culebras por ese tema, verdad, y por lo del porcentaje de la segunda vuelta, verdad, entonces, la correlación ha ido cambiando, y así ha ido cambiando el modelo, este último toque a la Constitución tiene que ver con los cambios en la correlación en la sociedad OrtegaAlemán, Alemán es un socio muy minoritario respecto a Ortega, con algún poder, pero cada vez con menos.

R. Y si no tengo la mayoría calificada o los diputados necesarios para tener mayoría calificada en la Asamblea, y tampoco esto es un contexto propicio, digamos, para plantear el tema de la reelección en el Poder Legislativo, utilizo al Poder Judicial.

D.M.T.: Es que Ortega nunca tuvo los votos, nosotros tenemos desde que llegó Daniel Ortega ahí estar trabajando todos los días para que no tuviera los votos para la reforma constitucional, y no los tuvo nunca, nunca logró tener los votos, porque incluso había dos diputados en su bancada, que no iban a votar por las reformas constitucionales, de la dirección, Miriam Argüello y Agustín Jarquín, verdad, lo habían dicho en privado, y se 
lo habían dicho al Frente, entonces, Daniel, su cuenta nunca le dio, entonces, él decidió saltarse la ley, ¿qué es lo que ha estado haciendo en los últimos años?, si la ley no me favorece me la salto, verdad, y hago lo que me da mi gana por fuera de la ley, verdad, esa ha sido la actitud del presidente Ortega, y la va a seguir siendo.

R: Y la relación del sandinismo con el Poder Judicial también es algo interesante, porque cuando pierde las elecciones Daniel dice: "vamos a gobernar desde abajo", ya ha salido esta referencia en varias entrevistas, haciendo referencia a cómo el sandinismo ha realizado una especie de aprendizaje institucional en los 16 años de oposición para intentar copar buena parte de los poderes del Estado, y el Poder Judicial es una expresión de ello, como hay una mayoría abrumadora de jueces sandinistas por el propio sistema de elección de la Corte Suprema de los jueces, ¿no?, y jueces de afinidad sandinista, y además ha habido una preeminencia clara...

D.M.T.: Eso no era tanto problema, porque estaba bastante distribuido en los primeros años, estaban bien distribuidos, pues, ese no ha sido el problema central, el gran descubrimiento del orteguismo es el alineamiento partidario de los funcionarios públicos, es decir, en un cierto momento los jueces eran sandinistas, pero eran jueces, ahora son orteguistas y no hacen nada más que lo que se les dice, les ordenan sacar narcotraficantes, sacan narcotraficantes, les ordenan sacar violadores, sacan violadores, les ordenan echarte preso a un enemigo político, le echan preso, es decir, ahora lo único que son, y yo lo digo aquí, es un pelotón de fusilamiento político de Daniel Ortega, eso es lo que son, todos, desde el más grande hasta el más chiquito, desde los Magistrados de la Corte Suprema hasta los tribunales de apelación hasta los jueces, es decir, el sistema judicial no estaba tan gravemente alineado a los voluntarios de un caudillo o de dos, como lo ha estado desde el 2000 para acá, digamos, desde el 98, 99 para acá, violento, si vos querés, podés hablar de un Poder Judicial que está, fuertemente, influido por el poder económico, incluso, jueces corruptos, verdad, pero ahora lo que tenés son soldados de caudillos en todos los temas, no hay tema en que no se metan, no hay tema que no toquen, no hay tema que no exprimen, es decir, el modelo llegó a su perversión total, porque aún los jueces somocistas en la época de la dictadura arbitraban justicia sobre todos aquellos casos que no eran políticos, pero ahora todo entró en la categoría política o de la que le podés sacar dinero, verdad, es una maraña gigantesca.

\section{$R: Y$ respecto a ese paralelismo que se hace entre el régimen de Ortega y el de Somoza, paralelismo histórico...}

D.M.T.: Sí, tienen bastantes rasgos, verdad, comunes, indudablemente, sí, todo el proceso de concentración de poder, de corrupción, lo que pasa es que el somocismo tuvo tiempo de institucionalizar esos procesos, es decir, la comisión del somocismo era institucionalizar, como decirte de esta manera, tenía niveles, si vos eras comandante de una plaza militar, pues, te tocaba el ingreso de coronel, que le decían, que eran los que cuidaban en los viajes a la entrada de los caminos, le tocaba las matrículas de las prostitutas, es decir, te tocaba, ¿me explico?, si vos eras cónsul, lo que te ibas a robar era los timbres fiscales, eso te lo robabas, te tocaba, Alemán introdujo, es decir, uno de los grandes aportes de Alemán a la corrupción en Nicaragua es que abrió tal magnitud la corrupción que eso se ha extendido, pues, y, probablemente, la transacción más rentable para Alemán en su relación con Daniel Ortega fue que Ortega compró el modelo de corrupción de Alemán, entonces, vos lo que tenés ahorita es un país lleno de corrupción de función pública, que no sabés adonde comienza y adonde termina, no tiene una 
estructuración por nivel para decirte, ya, vos podés encontrar un juez que se quiere robar medio millón de dólares de un narcotraficante y se los roba, ¿me entendés?, y, entonces, el otro, tenés una maraña de corrupción de una magnitud tremenda, tremenda, pues, contra juanes, contra pedros, contra chiquitos, contra medianos, contra grandes, contra todo, es una cosa, literalmente, tremendo, el Poder Judicial requiere una reforma clarísima.

\section{R: Yel Poder Electoral...}

D.M.T.: El Poder Electoral hay que cerrarlo y hacerlo de nuevo, verdad, eso no hay más remedio, ahí está minado todo.

$R: Y$, sin embargo, ahora hay renovación de Magistrados, a mediados de marzo, incluso, desde la propia Asamblea me comentan que va a ser dificil, muy dificil la negociación, en un contexto, además, donde no existe ni siquiera ratificación de los funcionarios públicos, porque el gobierno hasta el momento no ha cumplido con ese mandato de la norma constitucional reformada.

D.M.T.: Pero es que el tema de los Magistrados en el Consejo Supremo Electoral es crítico, crítico, es decir, la institucionalidad electoral perdió completa credibilidad.

R: Y ni siquiera una renovación de las personalidades garantizaría transparencia en el organismo.

D.M.T.: Tendría que hacer una reforma a fondo en el organismo tremenda, y yo comenzaría por despachar a toda la gente de informática, porque a mí no me van a decir que ninguno de ellos sabía, o sea, ninguno de ellos desconoce cómo se manipulan las cuentas de votación, yo me los llevaría en el saco a todos, pues, ¿me entendés?, a estas alturas de la situación en Nicaragua yo contrataría una empresa capaz de sumar los votos, te lo digo con franqueza, pues, prefiero contratar una empresa que venga a sumar los votos, verdad.

\section{$R: Y$, por supuesto, no hay garantías tampoco de observadores electorales.}

D.M.T.: Sí, es que los observadores, mira los observadores internacionales nunca van a descubrir un fraude a menos que se lo pongan en su cara, te lo digo porque tengo experiencia, yo llamé por teléfono a los observadores de la OEA, se están manipulando los resultados en las máquinas tales, y tales, y tales del estadio, ¿vos crees que los observadores que están en la OEA pueden hacer nada?, pero además te voy a decir una cosa peor, conceptualmente, la observación internacional nunca quiere decir que hay fraude, porque tiene miedo a demostrarlo, no sabe cómo demostrarlo, es decir, para decir: "vos te robaste las elecciones", una observación internacional le tenés que pasar encima a las boletas, pues, y mientras no se le pase por encima van a decir que las elecciones estuvieron en orden, que la gente no se cachimbeó en la calle, que los policías estaban cuidando las urnas, que hubo paz y alegría y simpatía, y que había unos dos que andaban con unas camisetas, pues, de sus partidos, pero que es la minoría, que es cierto que algunas urnas abrieron tarde, pero dentro de la organización, que hizo falta tinta y no sé qué hubo, ese es el informe de la observación internacional, y esos son todos, no tienen el valor, los observadores no están diseñados ni para registrar el fraude ni para demostrarlo, se mueren de horror, te estoy diciendo yo, y además sabiéndolo 
nosotros, porque les estábamos diciendo que estaban manipulando los votos en tal y tal, nosotros encontramos una conexión electrónica, que salía del estadio hacia otro lado, ¿tú crees que la observación se dio por enterada?, se lo dijimos, y se lo mostramos, o sea, la observación que le molesta a la observación nacional, porque es la observación que conoce, y además es la que se queda aquí, ¿no?, al final esto es como los recursos naturales, ¿no?, como los árboles, las compañías extranjeras llegan a los países y se ponen a talar el bosque completo, y no les importa porque después se van, pero, por último, los nacionales tienen interés en cuidar sus bosques, pero, entonces, aquí, la observación nacional es el problema para ellos, internacionales, ni les va ni les viene, pues, entonces, es un problema tremendo, pues, porque el fraude de las elecciones municipales es completamente articulado desde el Consejo Supremo Electoral, desde arriba.

R: Bueno, esto le ha costado también al gobierno, además de falta de credibilidad internacional, porque sí saltó a la agenda informativa de casi todos los medios el hecho de que también se condicionara la ayuda al desarrollo, ¿no?, también el contexto internacional es distinto del de los años 80.

D.M.T.: Mira yo creo que procesos de concentración de poder indefinidos como este tiene los días contados porque el contexto es distinto del siglo $\mathrm{XX}$, la sociedad ya no tiende a ser una sociedad primitiva, tiende a ser una sociedad más abierta, que tiene un acceso a la información internacional, totalmente, distinta a la que había en la época de la dictadura, que nuestros países eran más cerrados en sí mismos, pero ahora es incensurable, son miles de cosas que son incensurables, que es lo que le está pasando a Honduras, ¿a qué horas vas a censurar Internet?, ¿o a qué hora censurás las cadenas internacionales?, ¿a qué hora?, es decir, no es censurable, pues, no es tan fácil censurar una sociedad como lo era hace 40 años, 70 años, verdad, entonces, yo creo que todo eso tiene, toda esta aventura de Ortega tiene un límite, el problema es que es un límite a corto plazo, ¿verdad?, yo creo que no tiene mucho aire.

R: Bueno, el que le está dando Chávez desde Venezuela, el que pretende él mismo conseguir a través de la reforma tributaria para auto-financiar parte de los recursos públicos que le faltan.

D.M.T.: Sí, pero la reforma tributaria también le quita aire, ¿no?, le quita oxígeno, es decir, para financiar los recursos que le faltan tiene que sangrar a todo el mundo, y sangrar a la economía, entonces, a la postre eso se revierte en su contra, y lo otro es que quiere completar procesos de concentración de poder, que tardan años o un golpe, verdad, en un período de 5 años, eso fue una proeza que es difícil, verdad, muy difícil, verdad, muy difícil, entonces, Alemán apostó a hacerlo y no pudo, no pudo Alemán, se lo propuso, y le entró a fondo, y tenía una gran estrategia, no sé qué habrá hecho de ese documento, vinieron un montón de científicos, que estaban todos aunados en eso, y no hubo manera, y eso que Alemán tenía mayoría electoral, Ortega nunca ha tenido mayoría electoral, verdad, todavía el 8\% de las elecciones nacionales del 2006 nadie da la cuenta, verdad.

R: Y en esa comparación del régimen de Ortega con el de Somoza, esa utilización del poder político como elemento de acumulación económica...

D.M.T.: No, son igualitos, son idénticos. 


\section{R: La cúpula sandinista se está enriqueciendo.}

D.M.T.: Sí, sí, sí, se ha enriquecido de una manera, te digo, desenfrenada y voraz.

R: Y es cierto que Ortega es uno de los hombres más ricos de Nicaragua.

D.M.T.: Debe ser, ahí está, saca la cuenta, le entran 1000 millones de dólares de Venezuela, más o menos, en cifras redondas, pues, 100 millones más, 100 millones menos, tomále una foto a esos mil millones, o tomále cinco fotos, vos le tomás dos fotos, y 1000 millones de dólares en Nicaragua los ves en cualquier lado, es decir, te voy a poner un ejemplo, cada cama hospitalaria te puede costar 150.000 dólares, o sea, un hospital de 15 millones de dólares tiene 100 camas, tomále la foto, ¿dónde está ese hospital?, no está, ¿ya?, o una escuela, pues, ¿dónde está?, no está, es decir, ¿dónde está el dinero venezolano?, suponete que, en total, de todas cuantas recojamos 200 millones, verdad, ajá, ¿y los otros 800 ?, esos 800 millones se están quedando en la bolsa, es decir, yo calculo, que, por lo menos, 500 millones de dólares se quedaron en la bolsa de las élites del orteguismo, y 500 millones es mucha plata, te digo, en un país que produce 1200, 1300 millones de dólares de exportaciones al año, como Nicaragua, 500 millones de dólares es la mitad del producto interno bruto, por lo menos, del país anual, o un tercio del producto interno bruto.

\section{R: ¿Y cómo se ha ido conformando la personalidad política de Ortega?}

D.M.T.: Como se conforma la personalidad política de una persona que cada vez va teniendo una mayor cuota de poder, vos tenés procesos de deformación y de monstruosidad, digamos, el poder sin límites te crea monstruos, no hay vuelta de hoja, verdad, no hay gente que haya tenido un poder sin límites que no termine siendo un monstruo, y la ocasión política de Ortega no es ponerse límites, sino quitárselos, verdad.

\section{$R:$ ¿Desde el inicio de su trayectoria política?}

D.M.T.: No, es que la correlación era distinta, el poder de la derecha era mayor, el poder de los cuadros intermedios era mayor, verdad, es decir, había un nivel de balance mucho más elevado, en la medida en que la Dirección Nacional perdió todo el poder, y él fue golpeando, tras la derrota electoral todos los cuadros intermedios pagaron el precio, por un acuerdo de la cúpula, la cúpula le pasó la cuota a los cuadros intermedios y la base le pasó la cuenta a los cuadros intermedios, que quedó la dirección y la base, todo el resto de los cuadros intermedios fueron desprestigiados, fueron calificados como los responsables de la derrota electoral, fueron calificados como unos irresponsables de los estilos inadecuados, todo el peso de la derrota recayó sobre los cuadros intermedios, los cuadros intermedios eran el relevo, y después Daniel Ortega controló la cúpula, en términos generales, y el siguiente paso fue quedarse solo, ahí está.

\section{R: Con su familia, que además esa referencia a la familia...}

D.M.T.: Ah, bueno, es que los caudillos, el círculo político de los caudillos, el primer círculo político de los caudillos es la familia, no es el partido, y ve si no Franco, ¿Franco a quién recurrió?, a un elemento cuasi-familiar, porque él no tenía hijos, si hubiera tenido hijos recurre al hijo, no tenía hijos, lo que tenía era el partido, ni siquiera el Ejército, Franco recurre ahí a una maraña medio familiarosa, que le garantizara una 
continuidad del modelo, verdad, pero adopta a ese príncipe, y le sale el tiro por la culata, pero esa ya es otra discusión más interesante todavía, verdad, más que lo que hizo Franco, lo más interesante es cómo este hombre hace otra cosa distinta, eso es lo más interesante, verdad, porque además la correlación tampoco le daba mucho, pero hubiera podido tentarlo, verdad, pero es que el primer círculo político de los caudillos es la familia, $y$, en segundo lugar, el partido, entonces, Daniel va cerrando ese modelo, verdad, de familia, y además tiene un montón de hijos, la nuera, los yernos, su querido, su querida, ¿me entendés?, los suegros, los consuegros, todo eso alrededor, su esposa, etc., ¿no?

R: ¿Y qué futuro contempla de aquí a 2011?, ¿cómo ve el país en un contexto de cierre de oposición?, porque, lamentablemente, incluso, la propia sociedad civil está amarrada, o sea, no puede salir sin que salgan estas fuerzas de choque, que limitan un derecho fundamental, como el derecho de expresión y de manifestación, ¿no?, y en la Asamblea se va a articular una fuerza entre mañana y pasado, seguramente.

D.M.T.: No creo, no está claro eso, no está muy claro, es que es mucho dinero, pues, verdad, a empleados, es decir, si te ponés en la carne de Daniel Ortega, Daniel Ortega debe de estar metiendo ahí un millón de dólares.

\section{$R:$ ¿En comprar voluntades?}

D.M.T.: En comprar gente, pues, verdad, ya compraron a cuatro, así que para él es clave este juego, no es secundario, verdad.

R: Y si se afirma la reelección presidencial, a pesar de que insisten tanto en que el pueblo tiene derecho a elegir, en que el Frente entregó el poder en el año 90, que es lo que se escucha en la radio, en los medios afines al orteguismo, sin embargo, es cierto que él saldrá, nuevamente, victorioso con esta reforma electoral del $35 \%$ y el liberalismo dividido.

D.M.T.: No, no, no.

\section{$R:$ ¿O cuál sería la alternativa?, ¿cuál sería el otro escenario?}

D.M.T.: Yo no sé cuál sería el escenario, pero sé cuál sería el camino, pues, el camino de aquí a las elecciones de 2011 es un camino de crisis económica muy aguda, verdad, muy aguda, es un escenario de mayor restricción de los recursos de Venezuela, verdad, porque los venezolanos también están con un cierto agotamiento, $\mathrm{y}$, entonces, Chávez tiene que meter la tijera ahí, el petróleo no se ha vuelto a disparar tampoco, ni creo que se dispare en los próximos dos años, porque la recesión internacional podrá haber una salida pero no tan a tal velocidad que esto se desmande, ¿no?, entonces, él tiene que cruzar estos años de crisis económica, las crisis económicas son los consejeros más eficaces de la gente, son los movilizadores más eficaces, verdad, porque aquí el colchón está bien ralito, pues, y uno de los grandes problemas de Ortega es que los programas que ha hecho, los ha hecho con una visión clientelar, entonces, y prebendaria, entonces, solamente, cubre al circuito de sus diálogos, no hacia fuera, no llueve para afuera, pues, entonces, ese es un problema para él, es un problema, pero le falta eso, le falta cruzar eso, e, indudablemente, para el propio Alemán también, que es la clave de este modelo, 
la situación se va poniendo difícil, en la medida en que se acercan las elecciones, y él quiere ser candidato.

R: ¿Alemán?

D.M.T.: Claro.

R: ¿Va a ser el nuevo candidato del PLC?

D.M.T.: Él quiere ser candidato del PLC, y nadie en el PLC lo va a vetar, verdad, en el PLC nadie le va a decir no.

R: ¿Y si él se presenta a las elecciones, Alemán?

D.M.T.: Yo no creo que concite unidad.

R: No, es que yo no creo que el liberalismo tenga tendencia a unificarse.

D.M.T.: No, yo no creo que concite unidad Alemán, no.

R: Pero si el liberalismo queda dividido y la única opción es el sandinismo, perdón, el orteguismo...

D.M.T.: Si es que no dan, tendría que ir a una segunda vuelta, pierde, si las elecciones son transparentes, ¿qué hubiera pasado en el 2006?, en el 2006 la falta de no sacar el 8\% es lo que le da, lo que organiza el 38\% de Daniel Ortega, Daniel Ortega no sacó el 38\%, Daniel Ortega da como el 30\%, ¿me explico?, es decir, si vos tenés unas elecciones transparentes, la primera vuelta no importa, va a ir a una segunda vuelta, porque nunca va a sacar más allá del 38\%, ¿estamos claros?, no existe ninguna probabilidad de que habiendo sido el 38\%, el tope máximo en su mejor momento, con circunstancias de gobierno tan desastrosas, de polarización, de crisis económica, vaya a sacar el 38\%, verdad, tiene que ir a segunda vuelta, y en segunda vuelta está listo y servido, no tiene ninguna posibilidad, por eso es que la reelección en Nicaragua va con fraude, es decir, en Nicaragua, además nunca ha habido en Nicaragua reelección sin fraude, ese es un matrimonio que siempre ha andado aparejado, es decir, no es que la reelección no sé qué, la reelección no sé cuanto, la reelección de Óscar Arias en Costa Rica, no, eso es otra cosa, en Nicaragua la reelección siempre ha caminado con fraude, nunca ha sido distinto, y es la historia esa, pues, y nosotros tenemos que atenernos a la historia, en realidad, verdad, es decir, así como cuando un paciente o un médico se tiene que atener a su historia clínica, porque no puede diagnosticarla con la presión arterial de otro, verdad.

\section{R: En ese sentido, estamos ante la antesala de un fraude.}

D.M.T.: Es la primera piedra del fraude, ya van dos, mejor dicho, la primera es, de aquí al 2011 ya llevan dos piedras, uno, repartieron más de un millón, dicen ellos que repartieron más de un millón de carnés, ¿qué quiere decir eso?, que ellos lo que han anunciado que destruyeron como carnés de afiliado es el número de votos que creen con el que saldrían, porque Ortega en el año 2000 sacó 900.000 votos, y en el 2006, ellos mismos reportaron haber sacado 900.000 votos, fácilmente, te das cuenta de que eso es 
un partido que no está creciendo, verdad, fácil, pues, con sus propios datos del 2006, si vamos al dato real, pues, te das cuenta de que es un partido que está decreciendo, entonces, ¿ellos qué es lo que hacen?, anuncian de que van a repartir carnés de militante, creo que llevan repartidos como 1.200.000, es lo que ellos dicen que han repartido, ¿por qué dicen que han repartido esa cantidad?

R: Porque luego tienen que legitimar, obviamente, la victoria ante la opinión pública.

D.M.T.: Porque a la hora que salga el fraude, 1.200 .000 votos, pero si nosotros lo dijimos, desde 5 años antes, que habíamos entregado 1.200 .000 carnés, ¿me explico?, paso uno, paso dos, paso tres, la conformación del Consejo Supremo Electoral, que es clave, y lo otro ya es más fácil, pues, porque eso ya viene más organizado.

$R$ : Entonces, el destino a mediano plazo en este país sigue siendo la incertidumbre...

D.M.T.: Crisis, crisis, crisis, más crisis, porque el otro elemento de todo esto es que en Nicaragua todo el que se ha sentido excluido, la exclusión política siempre produce conflicto, es decir, este no es un país en donde la exclusión política vaya y pase, no funciona así, la exclusión política siempre lleva a altísimos niveles de conflictividad política y hasta la guerra.

\section{$R:$ ¿Cree usted posible un nuevo enfrentamiento armado?}

D.M.T.: Si se roban las elecciones de 2011 sí, pero ¿qué queda?, si se roban las elecciones del 2011, ¿qué queda?, queda llorar a la OEA para que la OEA mande una misión a investigar, van a mandar una misión a investigar, y ¿qué demostración tiene ahí Ortega?, Honduras, Honduras es el mejor consejero de Daniel Ortega, lo que pasa en Honduras es su mejor consejero.

\section{R: Sí, porque al presidente Zelaya le salió mal la jugada, ¿no?}

D.M.T.: Y a Micheletti nadie lo quita, es decir, ¿quién ha podido impedir ese golpe?, nadie, entonces, ¿puede la OEA contra los golpistas de Honduras?, le cierran todas las llaves económicas, eso sería tremendo para Daniel Ortega, entonces, ¿qué?, después de que se roben las elecciones de 2011, ¿cómo ir a llorarle a la OEA para que mande una misión de investigación?

R: Sí, pero un nuevo conflicto armado en Nicaragua sería muy grave.

D.M.T.: Pero la pregunta es qué hacés.

R: Sí, sí, pero ¿la gente no tiene miedo?, cuando hablé con Violeta Granera también, directora del movimiento por Nicaragua, me comentaba la situación, además, colgada en la web, ¿no?, para que lo vea el mundo entero, ¿no?, de cómo reprimen las manifestaciones en Managua por el tema de las últimas municipales, y ahora yo misma, cuando he ido a la Asamblea o voy por Managua en el taxi veo en las rotondas, son grupos muy pequeños, realmente, no es mucha la gente alli concentrada.

D.M.T.: Sí, pero vos paráteles enfrente, son tremendos. 


\section{$R:$ ¿La gente tiene miedo?, ¿la gente de la sociedad civil?}

D.M.T.: Claro, es agresiva, es agresiva, y te pueden hacer cualquier cosa, pues, hasta que lo maten y todo, es decir, eso está en el ambiente, entonces, si aquí se roban las elecciones de 2011, yo no sé qué nos queda, ir a llorar afuera no nos queda, pues, de eso sí estoy segura, ir a llorar, no, eso no, ¿qué hacés?

R: De todos modos, en este país, y ya para finalizar, da la impresión de que la política siempre ha estado por encima del Derecho, de las leyes, o sea, que el Derecho no ha servido para limitar el ejercicio del poder, que es el sentido de la Constitución.

D.M.T.: No, no, no, eso no, la ley no tiene ese efecto, es decir, las reglas todavía son reglas en el papel, pues, no hay cultura de cumplimiento de reglas, de acuerdos, de arreglos, que te estoy mencionando éstos al más alto nivel, verdad, en el caso del pacto, pues, la cultura asociativa no existe aquí, y no existe la cultura de acuerdo, pues, de cumplimiento de reglas, todo eso se destruyó o nunca hubo, y las que hubo existían, porque la dictadura las imponía, de todas maneras, existían por la fuerza.

\section{R: No hay un consenso político que esté detrás de la Constitución.}

D.M.T.: Nunca ha habido.

\section{R: Y siempre ha habido una parte excluida, además.}

D.M.T.: Siempre, siempre ha habido sectores excluidos, siempre ha habido una tendencia de exclusión, es un gran problema ese, porque no hay cultura de un arreglo, pues, alguien dice que, aquí vino una vez un fulano, no me acuerdo quien fue, que pasó cuando la crisis de Bolaños, creo que fue un español, no me acuerdo, que era importante que en Nicaragua hubiera unos pactos como los de la Moncloa, y ¿dónde aterrizó éste?, éste está loco, dije yo, éste no conoce donde se vino a meter.

\section{R. Sí, porque la palabra pacto, además, tiene otro sentido.}

D.M.T.: Sí, además, aquí le pueden firmar todos los papeles que vos querrás, y los puedes leer los papeles, todos los papeles, la estabilidad nacional es fundamental, la paz es fundamental, la inclusión es fundamental, la democracia es fundamental, la concordia nacional es fundamental, el diálogo y la reconciliación son fundamentales, todo es pura mentira, verdad, o sea, todo el mundo te firma eso, pero nadie cree en eso, es decir, las élites dominantes nunca han creído en eso, entonces, yo, cuando, no me acuerdo quién, Dante Caputo, cuando Dante Caputo aterriza en el aeropuerto y dice que en Nicaragua se puede dar un gran arreglo, una gran conciliación, no sé cuanto, que se pueden dar unos acuerdos nacionales para que el país salga adelante al estilo de los Pactos de la Moncloa, se volvió loco, dije yo, porque él está hablando en la teoría, pero no en la práctica de un país donde te pueden poner cualquier cosa en el papel, incluso, en la Constitución, y no vale nada, no vale nada, pues, es decir, lo que vale es, y además la gente tiende a creer que eso es así, porque así ha sido, por eso te digo, el modelo del siglo XX nunca hubo balance de poderes, entonces, la gente no tiene interiorizado el tema de que este dice $\mathrm{A}$ y el otro puede decir $\mathrm{B}$, o de que tiene que seguir un procedimiento, no, es que el comandante Daniel merece que lo reelijan, y, entonces, no importa, ¿me explico?, y ya está, ya estuvo. 
R: La política en este país, ¿es una política de hecho, de facto?

D.M.T.: Es una política de facto, y en una política de facto el que tiene más poder es el que saca más, o el que grita más, o el que garrotea más, o el que amenaza más, así es.

\section{R: Sí, que no hay una cultura política democrática.}

D.M.T.: No, no, no hay, no hay, aún está en proceso de formación, gran esfuerzo ha hecho la sociedad civil, pero en la sociedad, pero en la élite política, la cultura política democrática es, francamente, reducida, te digo yo, porque se supone que he sido de la élite política de este desgraciado país, que es una cultura política reducida, la cultura política democrática, no es, no es, pues, nadie cree demasiado en eso, creen cuando están abajo, pero no cuando están arriba, ¿qué es lo que les digo yo?, ¿cuál es el gran problema de este país?, en este país todo el mundo hace las reglas con la mentalidad del jinete, cree que toda la vida va a estar encaramado en el caballo, y, entonces, usa espuelas, usa reos que lastiman a la bestia, y cuando está abajo les molestan, verdad, pero uno tiene que aprender a dictar reglas en un país con la mentalidad del jinete y de la cabalgadura, pues, de que van a ser cabalgadura, pero aquí el que se encarama cree que va a estar ahí toda la vida, y hacen las reglas para concentrar el poder a su medida, y después se vuelven en su contra.

R: Entonces, más reformas a la Constitución o no, una Constitución tan poco respetada en el sentido normativo.

D.M.T.: Sí es que parece que no hay, no hay, es decir, la manera de acercarse no es tan fácil, y además ya ahora encontraron un mecanismo más fácil todavía, es decir, Daniel Ortega puede declarar inaplicable el artículo que se le venga en gana de la Constitución, verdad.

R: Pues, ya si tiene algo más que añadir, porque yo creo que hemos hablado de casi todo.

D.M.T.: No, está bien, gracias. 


\section{ENTREVISTA $46^{64}$ :}

Nombre del entrevistado: D. Víctor Hugo Tinoco.

Cargo actual: Diputado de la Asamblea Nacional (2007-2011) por el partido Movimiento Renovador Sandinista (MRS).

Fecha de realización de la entrevista: Managua, 29 de octubre de 2009.

Lugar: Asamblea Nacional de Nicaragua.

Duración estimada: 45 minutos.

\section{TEXTO - Transcripción 46:}

R: Podríamos comenzar haciendo un recorrido muy breve sobre los cambios constitucionales que han servido de marco a la reciente transición democrática en Nicaragua, sobre todo con la gran reforma del 95, que trata de, yo creo que el hilo conductor de las reformas, con todos los avances y retrocesos que, en términos democráticos, representan los cambios constitucionales en este país, sí ha sido el de conferir mayores facultades al Poder Legislativo en detrimento de ese presidencialismo excesivo que consolidaba la Constitución original del 87, pero su discurso es muy libre, yo le doy una pauta de introducción y usted puede hacer su reflexión libremente.

V.H.T.: Sí, bueno, la revolución del año 79 hizo una transformación muy importante en la sociedad nicaragüense, desmanteló, realmente, todo el sistema político, el estatus quo existente, tanto en su aspecto político como militar, y trastocó también los aspectos económicos, en los primeros años de la revolución, digamos, del 79 al 87 se guiaron por un documento que había que leer, verdad, con más detalle, que se llama el Estatuto Básico de Derechos y Garantías de los nicaragüenses, que fue un documento elaborado desde la transición por sectores diversos de la sociedad, tanto los sectores vinculados al partido Frente Sandinista como al sector de oposición, este Estatuto, digamos, reguló por un período muy breve la acción política en Nicaragua, porque al final en la práctica se vino imponiendo más que el Estatuto mismo una concepción muy influenciada por el modelo socialista de la época, verdad, que era el modelo del socialismo clásico de Estado, verdad, de moda en la Europa del Este, y aunque nosotros no nos regíamos por un modelo de ese tipo, pero el sentir, la orientación, de la acción política era ese, verdad, y de alguna forma todo enrumbaba en esa dirección, y, por ejemplo, la economía mixta en lugar de buscar un equilibrio, que tuviera un impacto positivo en la producción influenciado por el esquema, como te decía, del mundo socialista de esa época, buscaba dar mucho pensamiento a los efectos y a los resultados, buscaba un nivel mayor de organización, por ejemplo, versus el papel del sector privado, verdad, este proceso se dio, hay que decirlo, no solo influenciado por una concepción acabada, sino que jugó mucho el contexto y la realidad en que se estaban produciendo los acontecimientos, en breve hubo un fenómeno de una lucha de ideas que buscaban transformar, revolucionariamente, este país, e ideas que se oponían, verdad, y eso polarizó al país e impidió que este Estatuto, que fue como una primera Constitución embrionaria, fuera efectivo, fuera real, la Constitución del 87, pues, es el marco normativo, primero, que surgió después del triunfo de la revolución del 79, la Constitución del 87 fue, básicamente, una Constitución con una lógica presidencialista

64 Entrevista centrada, especialmente, en los factores, que explican el ascenso y consolidación del orteguismo en el contexto de los cambios políticos y constitucionales recientes, que articulan la transición democrática en Nicaragua. 
fuerte, muy marcada, creo que quedó consignado las cosas clásicas de la división política entre los poderes, la independencia, etc., sin embargo, quedó, hay que decir, como un marco normativo con un fuerte acento presidencialista, pero donde la realidad y la vida, que estábamos viendo que era una realidad de polarización, y de conflicto militar y de guerra, en la práctica, hacía que no funcionara, pues, muy bien los principios, sobre todo, de derechos civiles, derechos políticos, etc., ¿no?, en ese contexto, y después con la entrada de los nuevos gobiernos a partir del año 90, después de las elecciones del 89 y del primer gobierno del 90, en el 95 es que surge un segundo planteamiento en relación a la Constitución, más de fondo, las reformas del 95 le imprimen a la Constitución un enfoque más parlamentario, o sea, se apunta a restar poder al presidente de la República, y a trasladar más poder al parlamento, este enfoque fue empujado tanto por sectores de izquierda, en ese tiempo del sandinismo, pero opuestos, digamos, ya en ese período, en ese período esa reforma del 95 ya hay un conflicto interno en el sandinismo, entre los que valoran el tema de las libertades y los derechos ciudadanos de manera fundamental, y los que consideran el tema de las libertades y derechos de los ciudadanos como un asunto básicamente formal, declaratorio, sin importancia, en comparación con los derechos sociales, digamos, ¿no?, es decir, dos corrientes, una corriente que pone al mismo nivel los derechos políticos y los derechos sociales, y una corriente que ha sido hasta ahora la dominante en el partido de gobierno, que es la que, en la práctica, de hecho, le da un carácter secundario o de segundo nivel a esos derechos políticos y ciudadanos, entonces, esa reforma del 95 fortaleció la línea en esa correlación política, que existió en el año 95, producto de una escisión en la bancada parlamentaria del Frente Sandinista, la Constitución agarró ese giro, porque no era esa la posición del partido en la oposición, que era el Frente Sandinista, y en esa época todavía se estaba marcando todavía más fuerte el papel personal y caudillista del presidente Ortega, y esta reforma fue una forma de frenar, ¿no?, esa tendencia, esa fue la reforma del 95, después, vino la reforma del 2000, la reforma constitucional del 2000, la reforma constitucional del 2000 fue, en mi opinión, un retroceso, ¿verdad?, en términos de los derechos ciudadanos, las libertades políticas, etc., porque se diseñó un esquema, en donde en la práctica se imponía el modelo bipartidista, y más que el modelo bipartidista clásico, que puede existir en cualquier país, se imponía un modelo de dominación perpetua de los grupos de poder dominantes, es decir, se diseñó un modelo de candado y mecanismos que impidieran, que cualquiera que no fuera del grupo de Ortega, caudillo, en este caso, del partido Frente Sandinista, y del líder de la derecha, el caudillo Arnoldo Alemán, verdad, cualquiera que no fuera de esos grupos quedara imposibilitado de competir, de crecer, etc., entonces, en ese sentido, fue una involución, ¿no?, fue una contrarreforma en comparación con la reforma del 95, mientras que la del 95 trataba de frenar el papel del caudillo, verdad, la del 2000, en ese acuerdo entre dos caudillos, uno de derecha y otro de izquierda, entre comillas, se ponen de acuerdo para apoyarse mutuamente, defenderse mutuamente, repartirse las cuotas de poder institucional, repartirse las cuotas del poder político, y eso lo traduce en un esquema constitucional cerrado, ¿no?, que se refleja en las reformas constitucionales del 2000, y que se refleja en las reformas a la Ley Electoral de ese entonces, ese fue el giro, ¿no?, ahí hicieron una serie de acuerdos, pues, en la última reforma del 2000, se reforma el porcentaje de votos que se necesitan para ganar en primera vuelta, se dan diputaciones a los presidentes salientes, pero sobre todo, sobre todo, se crea un sistema que pretende hacer inamovible el control de estos grupos políticos, esto último que sucedió la semana pasada, lo que pasó en una Sala de lo Constitucional donde la mitad de los miembros, de manera ilegal, se constituyeron con otros miembros, y pretenden, entonces, desconocer aspectos de la Constitución que 
tienen 15 años de vigencia, específicamente, la reelección, la Constitución, expresamente, prohíbe, que pueda ser candidato alguien que ya fue presidente, y además no puede llegar, primera prohibición, y además no puede ser candidato el que fue candidato en el período anterior, entonces, Ortega tiene una doble prohibición en la Constitución, primero, porque ya fue dos veces presidente, y, segundo, porque estaría ya siendo candidato de manera continua, como no tuvo condiciones, Ortega no tuvo la capacidad de conseguir los votos en el parlamento para hacer la reforma constitucional, decidió irse por una vía de hecho para hacer un atropello, y pretender que estaba autorizado a correr mediante una decisión cuestionable, pues, porque no la acepta la mayoría de la población, no la acepta la mitad de la Corte, no la acepta la mitad de la Sala Constitucional, verdad, y no la acepta, entonces, ese es el tema, pero al final, entonces, el tema vuelve a ser el mismo, el tema del caudillismo, el tema de la reelección, el tema de la ambición de poder y la falta de desarrollo de una cultura democrática en el país, verdad, y eso se refleja, pues.

R: Otro aspecto que me interesa mucho, y aunque ha hecho un recorrido muy rápido e interesante sobre los cambios constitucionales, es la flexibilización sobre el procedimiento jurídico, ¿no?, o sea, siempre ha habido un conflicto entre el Ejecutivo y el Legislativo a la hora de aprobar las leyes de reforma parcial, en el caso del gobierno de Doña Violeta, una parte, sobre todo el sector próximo a Antonio Lacayo, que quería, también por el mismo tema, ser candidato en las próximas elecciones a la Presidencia de la República, ¿no?, siempre ha habido una resistencia de una parte del Ejecutivo a aceptar las reformas propuestas por el Legislativo, en el caso del 2000 el pacto entre Ortega y Alemán también deja fuera a otros sectores que no están de acuerdo con el proyecto de reforma constitucional, y en el caso de Enrique Bolaños, pues, son los dos caudillos los que se alinean contra el presidente de la República, tratando de restringir las facultades del Ejecutivo, y luego el propio Ortega cuando accede a la presidencia no cumple con parte de las normas constitucionales reformadas, como, por ejemplo, la ratificación de los ministros...

V.H.T.: Hay violaciones muy claras a la Constitución, o sea, no se necesita ser jurista para darse cuenta de las violaciones a la Constitución, muy claras, la Constitución dice: ni un soldado, ni un buque extranjero de guerra puede entrar en el país sin autorización del parlamento, y Ortega lo hace, viola la Constitución abiertamente. La Constitución dice, a raíz de la última reforma, que hicieron, verdad, para afectar al presidente Bolaños, el parlamento tiene que ratificar los ministros, Ortega, simplemente, decide que no manda a sus ministros a ser ratificados, verdad, entonces, vos vas viendo todas esas violaciones, y la última es esta, pues, que es abierta, pues, porque va contra un principio claro y expreso de la Constitución, haciendo toda una elaboración teórica sobre normas de carácter principal y normas de carácter derivado, pero todo eso es teoría jurídica, lo que dice la Constitución es que nadie que ha sido presidente dos veces podrá ser presidente después, punto, y dice, al mismo tiempo, que nadie que no sea del parlamento puede reformar eso, ¿verdad?

R: No, y el caso, por ejemplo, de las leyes Marco es otro aspecto interesante, como se congela en el tiempo la aplicación de las normas constitucionales reformadas para dar mayor oxígeno a la negociación política, porque en el caso del 95 y también en el año 2005 no se pusieron de acuerdo el Ejecutivo y el Legislativo se paralizó además, hubo una crisis institucional, y esa parálisis de los poderes obligó a crear este instrumento 
jurídico que es dudoso, desde el punto de vista formal, pero que si ha servido para que Nicaragua salga de sus crisis constitucionales.

V.H.T.: Sí, se ha recurrido a eso que es, sin duda, dudoso, pues, porque, prácticamente, reforma una norma constitucional, pero, con la diferencia, mediante un acuerdo político, que es lo que se han dado en llamar las leyes Marco, esto último que pasó es una reforma constitucional unilateral, un atropello, ¿no?, esa es otra cosa todavía mucho más grave y sin precedentes, ¿verdad?, porque a veces vos podés hacer una interpretación forzada de la Constitución, pero mediante un acuerdo, entonces, el efecto de eso es de estabilidad y de salida de la crisis, aquí es al revés, esto no genera estabilidad ni genera salidas políticas, lo que genera son problemas hacia delante, entonces, eso ha estado siempre ahí, ese problema, efectivamente, con diferentes variables y variantes, ¿no?, el conflicto siempre de respeto a la institucionalidad, del respeto a lo establecido en la ley, y como las leyes, en determinado momento, choca con intereses personales, verdad, y con el hecho marcado de los caudillismos y de las visiones personales, en Nicaragua eso ha sido muy fuerte, nosotros llevamos ya una historia de casi un siglo de caudillos, pues, tuvimos 50 años a un caudillo, o a una familia de caudillos, que fue la familia Somoza, y ahora existe el riesgo de que se vuelva a, verdad, a reiniciar un ciclo de caudillaje familiar, dinástico, si no se frena, verdad, si no se frena eso, pero esas son consideraciones políticas más que jurídicas y constitucionales, así es.

R: Pero sí he oído también ese paralelismo con la reciente deriva del gobierno del presidente Ortega hacia una cierta separación del partido, ¿no?, y una acción de gobierno que se centra sobre todo en el vínculo familiar con su esposa, y, entonces, es como un ejercicio impermeable, poco transparente, $y$, en cierto modo, un poco arbitrario, según la lectura en prensa que yo seguía desde Europa, pero, de todos modos, el paralelismo con el régimen de Somoza, ¿no parece un poco arriesgado?

V.H.T.: No, es muy claro, es el mismo fenómeno humano, es la naturaleza humana, la ambición de poder, y la ambición de riqueza, tal vez a veces es más fuerte el poder, pues, es más atractivo que la riqueza misma, ¿verdad?, son propios de la naturaleza humana, y si no son controlados, pues, se desbordan, ¿verdad?, y, en ese sentido, Ortega como un ser humano comparte la naturaleza, y el mismo problema y la misma enfermedad que tuvo Somoza, pues, que fue la ambición de poder y la ambición económica, que lo lleva, entonces, constantemente, a transgredir la ley, a poner el poder por encima de la norma, verdad, a poner las leyes al servicio del poder, a abusar, a manipularlas para que estén al servicio del poder, y no al revés, pues, entonces, ese es el fenómeno que nosotros vivimos, pues.

R: Pero en el contexto de la responsabilidad, también es cierto que Ortega es el producto de un pacto, y que, en este caso, el ex-presidente Arnoldo Alemán fue quien otorgó concesiones al Frente, concesiones institucionales, ¿no?, y, de repente, como el $35 \%$ de votos necesario para ganar en primera vuelta, que es lo que condujo al Frente a la victoria electoral, de otra manera habría sido imposible por el techo de 38\% escaso o 40\%, que tenía desde los comicios de los años 90 hasta ahora, ¿no?, y Alemán ha sido un poco el rehén de sus propios delitos, ¿no?, o sea, su libertad le ha obligado un poco a conceder al Frente parte de las situaciones que estamos viviendo ahora en el país. 
V.H.T.: Así es, es una mezcla, es un rehén, pero al mismo tiempo es un adicto al poder y a la riqueza, y, entonces, acepta una condición, en la nueva etapa acepta una condición de subordinado en una sociedad en la que el socio mayoritario es Ortega, o sea, en su origen el pacto en el año 98, cuando comienza, esto empezó en el año 2000, que es la reforma constitucional del 2000 pretendía ser un socio de un pacto, una sociedad más o menos entre iguales, pero, en la práctica, al final, ese equilibrio no, no, no se puede mantener, y Alemán pasa a ser un socio minoritario y subordinado, y esa es nuestra historia, o sea, la construcción de las dictaduras anteriores siempre contaron con algún tipo de liderazgo opositor cómplice o socio en determinados pactos y acuerdos, verdad, en donde la práctica de la repartición de las prebendas, de algunos espacios de poder que se concedían, era parte de los acuerdos, pero que en el decurso del tiempo iba a consolidando a uno de los actores de la sociedad y se iban construyendo, pues, el modelo autoritario, el modelo dictatorial, cada vez más fuerte.

R: No, es cierto, que los pactos han precedido siempre en la historia constitucional de Nicaragua a cada una de las reformas, ¿no?

V.H.T.: Sí, sí, sí.

$R$ : Son pactos politicos entre hombres fuertes, que se reparten un poco sus posiciones estratégicas en las principales instituciones del Estado, ¿no?

V.H.T.: Con una concepción de reparto de poder, una concepción prebendaria, una concepción clientelista, y no una concepción de pacto social, verdad, un acuerdo, un pacto social sobre cómo va a funcionar este país, cómo va a salir de la pobreza, cómo va a desarrollarse, no hay, o sea, desafortunadamente, nuestro problema ha sido que no hemos tenido hombres estadistas, hemos tenido hombres con ambiciones de poder, en donde el concepto de Estado, de la nación, del desarrollo, es accesorio al concepto fundamental que es el del poder por el poder, ¿no?

R: Y en este cierre de espacios que se ha producido tanto en las instituciones, por el reparto, digamos, de poder entre el PLC y el Frente Sandinista con una presencia minoritaria o, prácticamente, inexistente de las fuerzas políticas alternativas al pacto, tanto del liberalismo como del sandinismo, como también un cierre de espacios en la acción colectiva, ¿no?, de la sociedad civil, que también se ha visto limitada en el ejercicio de su derecho a la libre manifestación.

V.H.T.: Es que esa es la manifestación del autoritarismo, es decir, cuando el gobernante autoritario se ve retado, verdad, no actúa democráticamente, busca como cerrar todos los espacios, no sólo políticos, sino los derechos políticos, y las libertades políticas, aquí, por ejemplo, está, prácticamente, prohibida, no prohibida, legalmente, pero prohibida de hecho, o sea, no hay ninguna ley que diga, verdad, de que vos no podás hacer una manifestación, pero si la hacés sabés que te exponés, y es casi seguro que te van a agredir, que te van a atacar con piedras o con garrotes, y aquí vos vas a hacer una manifestación, y pedís autorización a la Policía y la Policía te la da, pero vos sabés que la Policía no va a actuar para defender tu derecho a movilizarte, que establece la ley, no lo va a hacer, verdad, si el otro grupo te ataca, entonces, hay, de hecho, una restricción de la libertad, no de derecho, no está escrito, pero es lo que sucede en la práctica cotidianamente, pues. 
R: ¿Y cómo se ha dado el clima en la Asamblea, usted que es diputado, ante la reciente decisión de la Corte, y cómo ha funcionado la oposición?

V.H.T.: Bueno, ha tenido un efecto, vamos a ver qué tan perdurable es, verdad, va a depender de muchos factores, pero ha tenido un efecto inmediato concreto de aglutinar a todos los sectores de oposición, de hecho, como están las cosas ahora, por lo menos, formalmente, se ha constituido una nueva mayoría, verdad, del lado de la oposición ahora hay, aproximadamente, 47 o 48 votos, ¿no?, y el gobierno se ha quedado con 45 , verdad, 45, digamos, propio, más 38 , los otros son todos la lógica de la corrupción, la prebenda, la compra, no son sociedades ideológicas, conceptuales, son sociedades mercantiles, pues, de corrupción.

$R$ : ¿Y de qué instrumentos legales se dispone para no aceptar o no permitir la vigencia de esta sentencia?

V.H.T.: Bueno, eso que estamos viendo se está trabajando, el parlamento tiene varias opciones, puede sacar una declaración, declarando nula lo actuado por ese grupo de personas, puede sacar una ley si se mantiene esa mayoría declarando nula, entonces, todo sería igual, y como, formalmente, inclusive, según la Corte, la Constitución no se ha modificado, no ha sido reformada, sino que han declarado una declaración que va contra la Constitución, porque han declarado que es inaplicable, verdad, y lo respalda un Consejo Supremo Electoral, que ni tiene credibilidad, ni tiene vigencia, porque ya ninguno de ellos va a estar para las próximas elecciones, verdad, a todos se les acaba su período como funcionarios en marzo, y es muy poco probable que ninguno de ellos sea aceptado de nuevo, entonces, a partir de marzo a mayo va a haber una nueva situación, donde habrá que elegir un nuevo Consejo Supremo Electoral, si se puede elegir, verdad, y a ver qué pasa, pero yo creo que ha habido un efecto de unidad de fuerzas de oposición, y se ha creado un espíritu de una actitud patria, de defender la patria, de defender la institucionalidad, más allá de las diferencias políticas, y se ha conformado un frente político, no un frente electoral, pero sí un frente político para frenar este avance la tendencia dictatorial, entonces, vamos a ver cómo se expresa, es decir, qué tanta unidad, qué tanto tiempo dura, ¿no?, vamos a ver, eso está por verse, hasta el momento, después de las decisiones que se tomaron el día de ayer, creo que hay un buen ambiente para cambiar la correlación en el parlamento, y eso es importante.

R: No, porque si sigue el liberalismo desunido, favorece al sandinismo institucional, porque ustedes también forman parte de la corriente ideológica del sandinismo.

V.H.T.: O sea, nosotros nos consideramos una corriente sandinista democrática, y consideramos al orteguismo un sandinismo autoritario, inclusive, en nuestras posiciones está la mayor parte de los dirigentes históricos de la revolución, están de nuestro lado, del lado democrático, no están del lado autoritario de Ortega, entonces, la verdad es que aquí una buena parte de la lucha es entre el sandinismo histórico, verdad, que tiene importancia en la reivindicación democrática y de las libertades ciudadanas, enfrentado al orteguismo como corriente autoritaria, pues, articulada alrededor del liderazgo de Ortega.

R: No, sí sorprende también la falta de recambio de los líderes de los 80, ¿no?, porque Ortega ya es un líder viejo, que no ha permitido que haya una nueva generación que haga frente, digamos, a la experiencia democrática por muy débil que sea, del país, 
¿no?, sobre todo por lo caro que ha costado para la democracia, en términos de muertos, que ha sido una experiencia muy trágica, y yo pienso que hasta se banalizan este tipo de decisiones, que no tienen la suficiente seriedad para mirar de frente la historia dramática del país, y ver que lo que se ha construido en dos décadas tampoco se puede destruir, entendiendo también que el contexto internacional es otro, y que aquí hay factores externos, como el caso de Chávez, en cierto modo, haciendo daño a algunos países del entorno de América Latina, que son más próximos a sus ideas políticas, ¿no?, pero no sé cómo ve este esquema, usted que viene además de la revolución, es otro actor el Frente Sandinista, es un partido que ha aprendido en la oposición a mantener su poder dentro de las instituciones, como fue el caso del Poder Judicial.

V.H.T.: Yo creo que no es un partido, yo creo que es, no hay partido, no hay debate, no hay discusión, no hay congreso, no hay corriente, es un grupo de poder alrededor de un liderazgo caudillista, verdad, además de carácter familiar ahora, ¿no?, el partido, prácticamente, desapareció, en mi opinión, desde el año 2005 desapareció, totalmente, todos los espacios de funcionamiento partidario democrático, ¿no?, y se volvió una organización con un dictado autoritario, único, y nosotros luchamos durante décadas, durante todos los años 90, y parte de los 2000, hasta el 2005, para tratar de impedir ese retroceso, forzamos la realización de elecciones internas, verdad, logramos que se aceptara como legítimo y como correcto las candidaturas diferentes, logramos que hubiera elecciones internas en dos ocasiones en el Frente Sandinista, en las elecciones del 96 y en las elecciones del 2000, verdad, pero ya para el 2005, sobre todo con el pacto del 98, y la reforma del 2000, el proceso de cierre democrático en los partidos políticos, inclusive, el partido de Alemán, y en la sociedad fue imparable, pues, $\mathrm{y}$, entonces, cerraron de manera violenta, expulsaron, en el caso del Frente, expulsó a los líderes principales, a sus contrincantes, ¿no?, es decir, en el año 2005, cuando expulsan a Herty Lewites, Herty es miembro destacado del Frente Sandinista, yo soy miembro de la Dirección Nacional, tenía 10 años de ser miembro de la Dirección Nacional del partido, y nuestro planteamiento fue elecciones internas, y que Daniel Ortega compitiera con Herty Lewites, y Daniel Ortega no le ganaba a Herty Lewites, y eso lo sabe Daniel Ortega, por eso él suspendió las elecciones internas, expulsó a Herty, y se proclamó candidato, verdad, todo en una misma mañana, entonces, ahí fue el cierre, ese fue como el broche de oro, ¿no?, ya el cierre autoritario, que ha transformado al partido de gobierno, verdad, actual, al orteguismo, en una corriente reaccionaria, en términos políticos, globales, o sea, es una corriente, que igual se te declara contra el aborto terapéutico, de que vote en contra del aborto terapéutico, que te hace igual acuerdo con el fondo monetario internacional, que te hace acuerdo de libre comercio con los Estados Unidos, agarrá tres parámetros básicos para medir qué es derecha-izquierda, y te encontrás que el orteguismo tiene los tres parámetros básicos de lo que es una fuerza de derecha, con un discurso revolucionario, verdad, y con algunos programas sociales de carácter clientelar, verdad, que no tienen ninguna incidencia, ni impacto en la nación en su conjunto, en la sociedad, y en el combate a la pobreza, si no suele resolver los problemas a 5.000, 10.000, 15.000 o 20.000 aliados al poder, ¿no?, que reciben los beneficios de la cooperación venezolana.

\section{$R:$ ¿Y qué futuro augura en los próximos años?}

V.H.T.: Bueno, yo creo que, en primer lugar, la lucha a lo inmediato es impedir la reelección de Ortega, y eso pasa porque se respete, primero, la Constitución, yo creo 
que vamos a ver cómo se trabaja en función de construir alianzas, ahora el problema de Nicaragua no es ni de derecha ni de izquierda, pues, porque tanto está la izquierda, entre comillas, de Daniel Ortega pidiendo una acuerdo con el Fondo Monetario Internacional, como lo quiere la derecha, o quiere un tratado de libre comercio igual que lo quiere la derecha, verdad, o quiere mantener la prohibición del aborto terapéutico igual que lo quiere la derecha, entonces, no hay de fondo, de fondo, no hay mayores diferencias, sólo el discurso, la parafernalia, la propaganda, ¿no? Creo que la perspectiva es ir construyendo una unidad, Ortega siempre ha sido un líder minoritario, verdad, inclusive, él ganó las elecciones con menos votos que los que sacaba antes, es decir, cuando Ortega gana las elecciones en el año 2006, las gana con menos votos que los que había sacado en la elección anterior, y en la elección anterior había sacado menos votos que los que había sacado en la anterior, es decir, es un hombre en declive político, que es producto de una contradicción específica en los sectores de la derecha tradicional, de la derecha clásica, lo que le permite abrirse un espacio, ¿no?, y ganar esa elección, o sea, no es Ortega, no creció en simpatía para ganar, no creció ni un solo voto, verdad.

\section{R: $Y$, sin embargo, las bisagras, digamos, la mano institucional del Frente en los principales poderes del Estado es muy dura, ¿no?}

V.H.T.: Ah, sí, claro, sobre todo el recurso a la corrupción, a la compra de conciencias, etc., es una práctica super amplia, ¿no?, verdad, ¿qué es lo que pasa?, que esa práctica se fija sus límites en el proyecto, cuando el proyecto se vuelve cada vez más y más agresivo, más ofensivo, más peligroso, inclusive, los que están vendiendo sus conciencias empiezan a ver en peligro su propia estabilidad personal futura, verdad, porque ya no es asunto que me estoy vendiendo para darle el voto a favor de una ley sin importancia, sino que es un problema que puede tener con la estabilidad, con guerra o con paz, y, entonces, esas cosas se le vuelven más difícil a Ortega, inclusive, el proceso de compra de conciencias, eso hace que se le derrumbe un poco todo el acuerdo con Arnoldo Alemán, entonces, no es que Ortega quiera renunciar al acuerdo con Arnoldo Alemán, ni Alemán quiere renunciar al acuerdo con Ortega, que es de mutuo beneficio el pacto que ellos han tenido, el problema es que las condiciones objetivas le hacen a Alemán, sobre todo, sumamente costoso, políticamente, mantener ese poder, por lo menos mantenerlo abiertamente, o sea, Alemán busca la forma de mantener un acuerdo en ciertas cosas con Ortega, pero preservando una imagen de independencia, de alguna manera.

R: Y, por otra parte, toda esa inversión en modernizar el Poder Judicial, el Poder Electoral, que se produce en el contexto de la transición, ¿no?, con la idea de generar ese equilibrio de poderes, que, como decía al principio, era tan ajeno a la situación revolucionaria, ha derivado también en una pérdida de legitimidad absoluta, en el caso del Poder Electoral es manifiesto ante la opinión pública.

V.H.T.: Claro, la tesis autoritaria desde una izquierda clásica es que la ley, verdad, y las instituciones no son un valor en sí mismos, sino que son instrumentos del poder, verdad, y que, entonces, no hay tal de que respetar la ley y respetar las instituciones, y hacer funcionar las instituciones tenga un valor en sí mismo, sino que todos son instrumentos que vos usás en función que tengás, si sos de derecha las usás y las utilizás y las manipulás, si sos de izquierda las usás, las utilizás y las manipulás para fines específicos, entonces, esa concepción, que es una concepción, efectivamente, autoritaria, ¿no?, de autoritarismo clásico, ¿verdad?, que no tiene ideología, ese 
autoritarismo igual lo levantaba Somoza, igual lo levanta Ortega, ¿no?, igual lo puede levantar cualquier gobernante de izquierda o de derecha, ¿no?, pero es la misma concepción, ¿verdad?, la institucionalidad del Estado, verdad, las leyes están al servicio del poder, de facto, al poder que esté dominando, y eso es lo que hay que preservar, y así como lo usó la derecha, lo tengo que usar yo, que me considero de izquierda, entonces, obviamente, esa concepción es la concepción que domina en todos los actores políticos en el orteguismo, por eso ellos ven legítimo o aceptable cualquier atropello a las leyes o a las instituciones.

R: Pero ahora sí se utiliza la ley para, entre comillas, quiero decir, para la propia decisión de la Corte, aunque sea ilegítima y aunque sea un atropello a la Constitución, no deja de ser un acto que, formalmente, se produce en una institución, quiero decir, que no es un poder de facto, como en el caso de una guerra o un golpe de Estado o una situación de violencia política ya extrema.

V.H.T.: Aunque es una acción de facto, porque no hay una Corte que ha fallado, no hay una Sala que ha fallado, porque la Sala tiene seis Magistrados, de los seis Magistrados tres dicen que existe el fallo y dicen que no existe, entonces, es una situación de generación de un caos en donde se va tratando de imponer una situación de hecho, en el esfuerzo por abrir la reelección, entonces, y la reelección es fundamental a Ortega, porque ha entrado con muchas contradicciones internas dentro del mismo partido de gobierno, hay aspiraciones naturales al recambios, verdad, que tratan de re-andar el camino, que cerraron hace unos 5 años, verdad, hay contradicciones y Ortega necesita cerrar ese escenario, verdad, para tratar de controlar sus propias contradicciones internas, y los necesita por su propia ambición de poder y de permanencia en el poder, porque es parte de la ambición.

R: Y ya para terminar, la diferencia con el régimen de Somoza será que, finalmente, Ortega no controla el Ejército.

V.H.T.: Sí, esa es la diferencia, digamos, en el sentido de que Ortega no tiene el control que tenía Somoza sobre el Ejército, el Ejército de Somoza era un Ejército completamente obediente a Somoza, y eso hizo que Somoza involucrara al Ejército en todo el fenómeno represivo, o sea, aquí Ortega, sabiendo que puede generar una crisis muy profunda, si pretende instrumentalizar al Ejército de manera demasiado abierta, trata, simplemente, de neutralizarlo, y recurrir, entonces, a la fuerza de los grupos paramilitares y a las fuerzas de los grupos violentos, verdad.

\section{R: Que son personas de la sociedad civil pagadas.}

V.H.T.: Que son, hay de diferentes tipos, hay algunos casos, las fuerzas de choque son, fundamentalmente, grupos pandilleros, pandillas que se van a los barrios marginales, se contratan, se les paga para cada acción y para cada operación que realizan, así operó durante las elecciones y sigue operando ahora, los mezclan, a veces, con grupos de empleados públicos, que los obligan a hacer determinadas cosas so pena de perder sus puestos de trabajo, y los mezclan con algunos grupos laborales sumisos, ¿no?, al dictado de Ortega.

$R: Y$, sin embargo, yo que tuve la oportunidad de hablar con Violeta Granera del "Movimiento por Nicaragua", la sociedad civil de Nicaragua no puede quedarse al 
margen, un país que hizo una revolución, que tiene una trayectoria de valentía, al menos en lo que significa decir basta al atropello de las élites en el poder.

V.H.T.: La sociedad civil nicaragüense es bastante fuerte, bastante organizada, inclusive, en mucho aspectos más que los partidos políticos, los partidos políticos congregan a gente sólo para concentraciones, y para hacer discursos, mítines políticos, de campaña o celebraciones, la sociedad civil convoca gente para protestas sociales, para reivindicaciones detrás de banderas específicas, verdad, por ejemplo, aquí las últimas manifestaciones grandes que ha habido las organizó la sociedad civil.

R: $Y$, sin embargo, para esta última no hay nada previsto, el frente de oposición que se está organizando en los medios de comunicación, en el parlamento, en la calle...

V.H.T.: Así es, y hay mecanismos de coordinación, que se están realizando, y que van en proceso, porque esta es una lucha que va a durar este año y por lo menos hasta la elección de las autoridades electorales a mediados del próximo año, pero aquí no está cerrado nada, no está planteado nada, está planteada una lucha y vamos a ver qué pasa, pues, ¿verdad?, Ortega no tiene todas las situaciones, porque tiene problemas económicos, y tiene un problema tremendo de ineficiencia, tiene un gran problema de corrupción, hay que acordarse de que el $20 \%$ del presupuesto no va por la vía del presupuesto, sino que va por vía paralela, y esa vía paralela no tiene control institucional de nadie, de Contraloría, de Procuraduría, nadie sabe lo que pasa ahí, o sea, hay un fenómeno de corrupción, de clientelismo, porque clientelismo es ineficiencia, son los efectos de cuando los recursos no se manejan de manera transparente.

R: Y aparte que la negativa de Europa y de Estados Unidos a seguir apoyando la cooperación internacional de Nicaragua.

V.H.T.: Claro, aparte de que ha habido una cierta afectación ahí, a pesar de que el fondo monetario internacional ha sido de los que le ha mantenido y le está prometiendo cooperación al gobierno.

R: Pero si no cumple con los estándares de democracia, creo que sería una ayuda, digamos, entre paréntesis.

V.H.T.: Sí, eso es lo que habría que ver, posiblemente, puede ser que los compromisos no se concreten, el gobierno estaba trabajando para lograr eso, pero optó por este golpe constitucional en un momento donde todavía no se ha concretado la cooperación de los organismos internacionales.

R: Pues, yo creo que ya hemos tocado casi todos los temas, si tiene algo más que añadir, yo, al menos, como reflexión final, sí apunto a que más reformas constitucionales sí o no, porque esa flexibilización de la Constitución en la última etapa democrática del país más que conferir una estructura estable a la acción de gobierno, bueno, ha sometido a las instituciones a una fragilidad, que ya, prácticamente, se deshace en manos de los intereses de poder de las élites de los partidos, ¿no?, y, en este caso, ya a Ortega, después de que Alemán haya quedado muy desbancado, y no ha habido un lider en el liberalismo que haya sido capaz de hacerle frente, ¿no?, de igual a igual, no sé si tiene alguna última sugerencia. 
V.H.T.: Aquí el fenómeno que se puede producir es el fenómeno de un liderazgo colectivo de las fuerzas pro-patria o pro-institucionalidad y pro-democracia, la lucha democrática es la lucha de los próximos años en este país, sin duda, porque si no resolvemos este problema, difícilmente, vamos a poder resolver el problema social, el problema económico, creo que hay la posibilidad de construir alianzas, que con un liderazgo colectivo puedan frenar las tendencias más regresivas, y de más retroceso en el campo de la institucionalidad, verdad, y son fuerzas que siguen siendo fuertes, porque Ortega sigue de alguna forma no teniendo, necesariamente, la simpatía del 30\% de la población, pero sí la aceptación de hacer lo que él diga, si vos te fijás casi todas las encuestas, siempre la simpatía del sandinismo es mayor que la simpatía de Ortega, verdad.

R: En un país que es, electoralmente, más liberal que sandinista.

V.H.T.: Sí, aunque el liberalismo como concepto se ha debilitado mucho ahora, ¿no?, como partido, como fuerza política, por todas estas alianzas de Alemán con Ortega, por muchos problemas que ha habido se han debilitado mucho, y lo que ha surgido es una fuerza cada vez mayor que se llama independientes, entonces, esos independientes es la fuerza que va a ser decisoria, verdad, según las últimas encuestas, el $50 \%$ de la gente se declara sin corriente política, el 50\% de los ciudadanos, o sea, una cantidad grande, ¿no?

R: Sí, también por desencanto, imagino, con los partidos políticos tradicionales.

V.H.T.: Sí, sobre todo el desencanto con los partidos.

R: Pues, gracias por todo.

V.H.T.: Bueno, está bien. 


\section{ENTREVISTA $47^{65}$ :}

Nombre del entrevistado: Dr. Carlos Tünnerman.

Cargo actual: Ex-Ministro de Educación durante el régimen sandinista (1979-1989), intelectual y académico, actual miembro del patronato del "Movimiento por Nicaragua".

Fecha de realización de la entrevista: Managua, 13 de noviembre de 2009.

Lugar: biblioteca de su casa particular en Managua.

Duración estimada: 44 minutos.

\section{TEXTO - Transcripción 47:}

R: ¿Cuál sería su visión sobre los cambios constitucionales que se han producido en el país desde los años 90 hasta la fecha en el marco de la transición y consolidación democrática?

C.T.: Bueno, el más importante fue el que se dio con la reforma de 1995, en un sentido positivo, las reformas del 95 contribuyeron a establecer un mejor balance y equilibrio entre los poderes, porque la Constitución de 1987, que es la que se hizo bajo el régimen sandinista en la década de los 80 , se dio en un contexto de guerra y de ella surgen un Poder Ejecutivo muy fuerte, dotado de facultades que, incluso, invaden facultades que son, generalmente, atribuidas a otros poderes, por ejemplo, en la Constitución del 87 la aprobación del presupuesto se deja en manos del Ejecutivo, todos sabemos que el presupuesto es un instrumento fundamental para un país, y que suele ser una de las leyes más importantes que, anualmente, aprueban las legislaturas, incluso, si vamos al origen del Derecho Constitucional, la Carta Magna inglesa, es cuando los nobles ingleses le arrancaron al rey Juan sin Tierra la promesa de no crear nuevos impuestos sin consultar a los señores feudales, y la Carta Magna que se dice que es el origen o los antecedentes del Derecho Constitucional estableció un límite para el Rey, y otras cosas más, otras garantías que les dio, ¿verdad?, pero era uno de los más importantes, no poder crear impuestos sin el consentimiento de ellos, que ya revela que el impuesto no puede venir dictado por el Ejecutivo, tiene que haber la participación de quienes representan al pueblo, que, en este caso, son las Asambleas, pero en el año 87 pusieron que tenía esa facultad, y se daba la excusa, pues, de que en tiempos de guerra, el presupuesto era, fijese que ni siquiera se publicaba, se manejaba por el Poder Ejecutivo, era un documento que muy poca gente tenía acceso al mismo, entonces, las reformas del 95 marcaron un paso en el que se limita ese exceso de presidencialismo que teníamos en la Constitución del 87, y se buscó cómo darle más beligerancia también a la Asamblea Legislativa en varios aspectos que el Ejecutivo había asumido, esas reformas, fíjese usted que, curiosamente, en ese momento, quienes detentaban en el Poder Ejecutivo no las quisieron, pues, especialmente, el yerno de la presidenta, la presidenta era Doña Violeta Barrios de Chamorro, y su yerno, el Secretario de la Presidencia, Antonio Lacayo, pues, Doña Violeta se negó por varios meses a promulgarla, y, bueno, la Asamblea tuvo que mandar a publicar directamente y, aún así, el Ejecutivo puso mucha resistencia, porque ya se habían acostumbrado, un gobierno electo democráticamente, ya se habían acostumbrado a tener los poderes que daba la Constitución del 87, y era

\footnotetext{
65 Entrevista breve y concisa en sus referencias al guión de preguntas cualitativas, de la que cabe destacar la importancia de la sociedad civil en la recepción crítica de los últimos procesos de reforma constitucional y la extrema politización de los poderes del Estado.
} 
paradójico que una presidenta democrática tuviese resistencia a una reforma que era para consolidar más la institucionalidad democrática del país, se logró superar, y creo que fue, entonces, cuando se originó la primera Ley Marco, que fue para suspender los efectos hasta que terminara el período de Doña Violeta, pero aquí hemos inventado esto de las leyes Marco, que es algo bastante particular de la experiencia constitucional de Nicaragua, que mediante una ley ordinaria, porque la Ley Marco es una ley ordinaria, se logra suspender determinados efectos de los artículos reformados de la Constitución, y, primeramente, es para establecer un caso para cuando entren en vigencia cuando ya no afecten al presidente que está en el poder en esos momentos, que es lo que hicieron en el 95, y se superó la dificultad, pero luego entraron en vigencia, afortunadamente. Pero también hemos tenido reformas que son perjudiciales, que son todas las que proceden de los pactos políticos más recientes, el primer pacto del año 2000 y luego los subsiguientes, que nos llevan, que nos explican, incluso, por qué estamos en la situación actual, y esto es producto de una componenda política entre el presidente, bueno, el primer pacto fue cuando Alemán estaba en la presidencia y Ortega era de la oposición, después el siguiente pacto se hizo manejando ellos la mayoría de la Asamblea, que estaba de presidente el presidente Bolaños, pero el primer pacto, que es cuando el Frente concibe que se baje del $45 \%$ al $35 \%$ para poder ganar las elecciones, cuando debería ser el $51 \%$, realmente, pero bueno, llegamos al $35 \%$, con lo cual el Frente tenía ya una posibilidad de ganar las elecciones, ya que con solo dividir a la oposición ya tenía, y con esta estrategia que tenía el Frente ante a la oposición, de tener un 35\% y llevar a la oposición dividida, las ganaron con el $38 \%$, pero en ese arreglo también se dio esto que se dio en llamar aquí, en el lenguaje nicaragüense, la "diputación regalada", y es que los presidentes al dejar la presidencia pasan a ser diputados para gozar de inmunidad, y el vicepresidente es su suplente, eso, pues, favoreció a Arnoldo Alemán que tenía inmunidad, pero, finalmente, la perdió y fue el escándalo de todas las malversaciones y robos que le hizo a los fondos del Estado, ¿no?, pero, entonces, esos pactos vinieron a deteriorar la institucionalidad que se había logrado hacer avanzar con las reformas del 95, verdad, y la Constitución surgió, pues, además de eso se estableció el incremento de los Magistrados de la Corte Suprema de Justicia, tenemos más Magistrados aquí en la Corte Suprema de Justicia que en la Corte Suprema de los Estados Unidos, dieciséis Magistrados, nueve Magistrados en el Consejo Supremo Electoral, es decir, ¿por qué?, porque era necesario repartir prebendas, y las Magistraturas se repartieron entre los dos partidos, en un principio, tuvo el Partido Liberal la mayoría, pero ahora el Frente Sandinista ha ido ampliando su poder, el electoral ya lo domina totalmente, y la Corte Suprema de Justicia en corte plena tiene ya mayoría, en algunas salas no tiene ya mayoría, pero sí en Corte plena, en consecuencia...

\section{R: Con el fallecimiento de este Magistrado.}

C.T.: Hay un Magistrado que falleció, el Sr. Selva, ¿no?, entonces, vemos nosotros como los pactos políticos por intereses de los caudillos han afectado a la institucionalidad democrática, la última reforma parcial que pactaron los dos caudillos para arrebatarle facultades al Ejecutivo, ¿por qué?, porque entonces el presidente era Enrique Bolaños, verdad, después cuando se estableció que el presidente tenía que consultar con la Asamblea los nombramientos de ministros, de embajadores, de viceministros, directores de entes autónomos, y que la Asamblea tenía que ratificarlos con una mayoría especial, incluso, y que además de eso podía interpelarlos, siempre había tenido la posibilidad de que la Asamblea llamase a los ministros para que dieran informes, verdad, pero esta vez se establecía que si el informe no era satisfactorio para 
la Asamblea podía pedirle al presidente que quitara al ministro y que pusiera a otro, algo que no existía antes, entonces, cuando se dan esas reformas, después, con el manifiesto propósito de disminuirle facultades al presidente Bolaños, quien estaba confrontado con Ortega y Alemán por haber sido el gobierno de Bolaños el que sacó toda la podredumbre de la corrupción del gobierno de Alemán, entonces, los dos se juntaron para tratar de dejar al presidente Bolaños, prácticamente, pues, como una figura simbólica, pero, afortunadamente, a raíz de esas reformas parciales, vino un gran movimiento de la sociedad civil, casi como que fue la campanada que despertó a la sociedad civil, porque a raíz de ahí es que después vino el "Encuentro por Nicaragua", yo fui uno de lo convocantes del "Encuentro por Nicaragua" de donde surgió el "Movimiento por Nicaragua", que organizó las grandes marchas cívicas que tuvieron lugar en el 2005, en el 2006, en Managua, en Chinandega, en Granada, en León, en Estelí, en diversas ciudades del país, ¿no?, pero movilizaciones masivas, en Managua pusimos 120.000 personas en las calles, reclamando contra esas reformas constitucionales eran, pero también fue contra el pacto, digamos, la protesta mayor era contra el pacto de los dos caudillos, contra el pacto de Ortega-Alemán, denunciándolo, pues, como que por intereses personales estaban dañando la institucionalidad del país, entonces, se arregló, pues, a raíz de que hubo grandes protestas, etc., con otra Ley Marco, en virtud de la cual se le garantizó al presidente Bolaños que no se aplicaría esa reforma hasta que terminara su mandato, verdad, constituye una Ley Marco, y así pudo Bolaños mantener sus prerrogativas hasta el final, ¿no?, luego vino el presidente Ortega y como él había propiciado esa, y en ese momento él andaba en la onda del parlamentarismo, en ese momento, él para ser congruente con lo que venía predicando que había que cambiar el sistema de presidencialista a parlamentario, porque le da más poder a la Asamblea, que el presidencialismo en Nicaragua conduce a un Ejecutivo muy fuerte, etc., ese era su discurso, entonces, él tenía que estar de acuerdo con que las reformas que la Ley Marco había suspendido entraran en vigencia, y efectivamente entraron en vigencia, pero ¿qué ha sucedido?, que no las cumplen, sigue haciendo nombramientos de ministros, vice-ministros, embajadores, el acuerdo que se publica en La Gaceta dice que entrará en vigor una vez que los ratifique la Asamblea Nacional de acuerdo con el artículo tal de la Constitución, pero no los manda ratificar a la Asamblea, lo pone en el decreto Daniel, pero lo manda a La Gaceta, se publica y el funcionario éste actúa y nunca manda pedir la ratificación, entonces, todos esos funcionarios están funcionando de manera ilegal, los que han sido nombrados después que entraron en vigencia las reformas que Alemán y Ortega diseñaron para molestar a Bolaños, pero que ahora como Ortega se comprometió a ponerlas en vigencia, ahora es él el que siente que limita sus facultades y no las cumple, en consecuencia, como puede ver usted, y más ahora que él ya abandonó la teoría del parlamentarismo, ahora ya no habla de parlamentarismo, ahora el único interés que tiene es el de la reelección, y, entonces, lo que han dicho es, como no acogieron la idea del parlamentarismo, porque no entendieron, etc., entonces, las propuestas ahora son la reelección presidencial, y con un atenuante, el referéndum revocatorio, que no existe en la Constitución. Nosotros tenemos la figura del referéndum, que es especial, se ha puesto en marcha, a pesar de que nosotros, en el "Movimiento por Nicaragua", reunimos las firmas que dice la Constitución para presentar, precisamente, un proyecto de ley para la protección de las libertades y, ya no me acuerdo, pero pusimos en marcha el mecanismo, pero como el mecanismo es tan complicado, el que establece la ley electoral, que además está hecho así a propósito, para que no funcione, se mandan las firmas, entonces, la Secretaría en la Asamblea dijo que no estaban bien presentadas las firmas, se mandó a mejorar, pues, lo que ellos pidieron que se enmendara, se enmendó y no le dieron curso, ahí se quedó, y, 
de todas maneras, aunque le hubieran dado curso, eso necesita que lo convoque la Asamblea y luego pasa al Poder Electoral, entonces, un referéndum con ese Poder Electoral hubiera sido manejado como fueron manejadas las elecciones municipales, entonces, ahora Ortega dice: "un referéndum revocatorio", que implicaría una reforma constitucional, y creo yo que hablando de referéndum revocatorio ese va a ser el señuelo para abrir la discusión sobre las reformas constitucionales, porque como había una posición firme de la oposición de ni siquiera abrir la discusión para una reforma constitucional, entonces, él dijo: "si yo lanzo la idea del referéndum revocatorio, ¿qué importa la reelección?, puede haber cuantas elecciones haya, si lo está haciendo mal el presidente se pide el referéndum revocatorio y se le saca", como le hicieron a Chávez, pero Chávez lo ganó, entonces, salió bien del referéndum revocatorio y se queda en la presidencia, ¿no?, pero aquí se vio que eso era un simple señuelo, era un chiste para ver si la oposición caía en el juego, y decían, pues, vamos a las reformas para ver si introducimos el referéndum revocatorio inmediatamente y también las reformas para la reelección continua, e, incluso, indefinida, como la quieren ahora, porque todo esto obedece a un proyecto que no sólo es de Nicaragua, es un proyecto propiciado a nivel latinoamericano desde Venezuela por Chávez, para que todos sus aliados dentro del ALBA estén períodos largos, ¿para qué?, supuestamente, para llevar a cabo su socialismo del siglo XXI, el beneficio de las clases populares, de los pobres, etc., pero más que todo es para garantizar los miles de millones de dólares que Venezuela le regala a estos países, y que se han venido transformando en inversiones en empresas privadas, de lo cual el Estado de Nicaragua no se hace responsable y ha salido una resolución de que no se hará responsable, pero que un eje de garantía para que esas empresas en 15 años recuperen la inversión venezolana, e, incluso, sea un negocio que pueda continuar, es que continúen en el poder Evo Morales, Correa, Chávez, Ortega, ya lo quisieron hacer en Honduras, pero fracasó, porque Zelaya lo dejó para última hora, fíjese que hay un símil, Ortega no había sacado, se había estado mencionando que a lo mejor por una interpretación que te haga la Sala Constitucional declarando inaplicable el artículo, como había sucedido en Costa Rica, además en Costa Rica lo que había era una prohibición absoluta, no reelección absoluta, en la Constitución de 1947 de Costa Rica se estableció que se podía reelegir un presidente después de dos períodos, había que dejar pasar dos períodos y podía haber reelección, en el 69 se estableció no reelección absoluta con una reforma, entonces, Arias alegó de que la no reelección absoluta sí pudiera considerarse como que priva, digamos, rompe la igualdad de todos ante la ley, pero en Nicaragua no es el mismo caso, porque tenemos una Corte Suprema politizada y no como la de Costa Rica, y, en segundo lugar, porque aquí no hay prohibición absoluta, aquí lo que hay es que no hay reelección continua, pero sí hay reelección después de un período, y el otro candado no es más que para quien ya la ejerció dos veces, pero ya se reeligió dos veces, ya se reeligió, pues, una vez, entonces, aquí no hay prohibición de reelección de forma absoluta, no puede haber equiparación, entonces, entre el caso de Costa Rica y el de Nicaragua, entonces, ¿qué pasó? Ortega va a una reunión a la Cumbre del ALBA, verdad, y, aparentemente, desde allá llama a su operador político en la Corte, que es el doctor Rafael Solís, que está en Barcelona, que se venga inmediatamente y que preparen todas las cosas porque Chávez le ha dicho: "no seas tonto, tenés que hacerlo ya, porque si lo hacés a última hora como quiso hacerlo Zelaya te va a pasar lo mismo". Zelaya lo hizo muy a última hora, ya contra el tiempo de las elecciones, cuando ya había candidatos nombrados, entonces, por eso es que a Zelaya se le volteó todo el mundo, ya había un proceso electoral abierto, entonces, cuando él lo que quería hacer es meter una urna adicional para ver si hay una Constituyente que permita la reelección, entonces, Zelaya en el tiempo se equivocó y se 
le vino todo abajo, entonces, le dijeron a Ortega: "cuidado, no te pase lo mismo, hacélo ya, ¿no tenés los 56 votos?, sacálo por la Corte, y aguantá todas las críticas, las protestas, y todo, pero tenés dos años para ver que hacés", pero fue el consejo, porque cuando ya él vino, a los pocos días, ya estaba la sentencia, entonces, se ve que es parte de un gran plan, que, por otro lado, tiene un plan B, que es el de estar, al menos, 15 años en el poder, verdad, un documento del Frente, y que habrá que buscar cómo enfrenta esta segunda etapa.

R: Una cuestión que me interesa, y que, además, han subrayado la mayor parte de los entrevistados, es esa flexibilización del procedimiento jurídico para reformar la Constitución de Nicaragua, que es un debate que se plantea ya al inicio entre reforma total o parcial a la Constitución, en ese momento, se salda el debate a favor de las leyes de reforma parcial, porque es un momento tan dificil de la transición democrática, que hacer una Constituyente quizás hubiese abierto un frente más en esa dura batalla por la transición pacífica.

C.T.: Exactamente, la Constitución nuestra podríamos catalogarla como rígida, porque el procedimiento que se establece exige dos legislaturas y una mayoría especial, 56 diputados, que equivale al $60 \%$, de manera que podríamos clasificarla de acuerdo a la teoría de una Constitución rígida, y no es una Constitución flexible que se puede reformar con mayor facilidad, aquí la que se puede reformar con más facilidad es la Ley Electoral, porque sólo requiere una legislatura, a pesar de que tiene rango constitucional, pero la Ley Electoral sí se puede reformar en una legislatura, no así la Constitución, verdad, porque la reforma parcial necesita de dos legislaturas.

$R: Y$, sin embargo, sí es cierto que se reformó el tema del veto presidencial, ¿no?, para que no sucediese esa negativa, como en el caso de la presidenta Chamorro, a promulgar la ley de reforma parcial que había aprobado la Asamblea.

C.T.: El veto se puede levantar con una mayoría simple de 47 votos.

R: $Y$, en ese momento, la Asamblea quizás se arrogó unas facultades, en el primer momento de la reforma del 95, que no le correspondian en sentido jurídico estricto, ¿no? Es cierto que se debió salvar el momento político, que, finalmente, se hizo a través de una Ley Marco, que es un instrumento jurídico peculiar de la historia constitucional nicaragüense.

C.T.: En principio, es un adefesio jurídico, porque no puede una ley ordinaria estar por encima de la Ley Fundamental. Aquí le regalo una copia de mi artículo, Una sentencia deleznable, que salió publicado en El Nuevo Diario, que es un análisis jurídico de la sentencia de la Corte, ¿no?, y como viola los principios constitucionales, y que, en el fondo, esa resolución o esa sentencia de la Sala Constitucional no tiene validez, incluso, fíjese que la Ley Electoral establece, porque tienen elecciones en el Consejo Supremo Electoral, en marzo, termina el período de algunos Magistrados, y en junio se van todos, los restantes, entonces, va a haber una renovación, prácticamente, total hasta los próximos seis meses en el Consejo Supremo Electoral, si se logra la presión suficiente desde la sociedad civil y se va a hacer mucha presión para que haya una renovación de parte de los Magistrados, como garantía para ir a las elecciones de 2011, porque con esos mismos Magistrados después del fraude que hicieron tan obvio y tan documentado de las elecciones municipales, ¿para qué vale la pena hacer elecciones presidenciales 
con ese mismo Consejo?, no hay ninguna garantía, entonces, si se logra esa renovación, de acuerdo con la Ley Electoral, el Consejo Supremo Electoral en un artículo de la Ley Electoral dice que tiene ver si los candidatos que reúnen las condiciones, los candidatos presidenciales, las cualidades para ser candidatos, y si no tienen ningún impedimento constitucional, entonces, el Consejo Supremo Electoral nuevo podría muy decir que esa decisión de la Corte, de la Sala Constitucional, que declaró inaplicable el artículo 147, no le obliga, porque la Corte no estaba facultada para declarar inaplicable el artículo, y, en consecuencia, el candidato Ortega tiene el impedimento constitucional que dispone el artículo 147, que prohíbe la reelección consecutiva, y además en el caso de él no puede correr porque ya fue dos veces presidente, esta sería una tercera vez, y eso también está prohibido por la Constitución, de manera que no crea que él ya está totalmente firme en que va a poderlo hacer, además de que el rechazo a esa sentencia ha sido unánime de todos los sectores y ya se están organizando las marchas otra vez, como en el año 2005 y 2006, vamos a comenzar el día 21, el sábado, ¿cuándo es que se va usted?

\section{R: El día 1 de diciembre.}

C.T.: Ah, estará aquí todavía, el día 21 , sábado 21 vamos a tener la primera marcha a pesar de todas las amenazas. Fíjese que la íbamos a hacer el 14, ya tenemos, incluso, la autorización de la Policía y todo, entonces, a pesar de que la Policía se había comprometido a que no habría ningún permiso para el día 14, por presiones del presidente dieron permiso para que el mismo día 14, a la misma hora, van ellos a tener otra marcha allí, cerca del hotel Princeps, que lo que significa es reunir a un montón de pandilleros con garrotes y piedras para que se vengan a los demás ciudadanos, entonces, decidimos, no solamente por eso, sino por múltiples razones, pero para demostrar que no queremos confrontación, se metieron en el día 14, pues, háganlo el 14, nosotros nos vamos al 21, si ellos se quieren venir al 21 ya es obvio que lo que quieren es entorpecer la marcha cívica de la sociedad civil, y esto se va a anunciar el lunes, es decir, este lunes que viene.

R: De todos modos, si es cierto que las reformas constitucionales han supuesto un enfrentamiento entre los poderes del Estado, en los tres primeros casos entre el Ejecutivo y el Legislativo, y, en este último caso, entre el Legislativo y el Judicial. Y esta confusión, digamos, de las funciones que corresponde a cada uno de los poderes del Estado, que se acentúa con esta última sentencia sí es un riesgo notable para la consolidación de las instituciones democráticas, como un giro, además, de 180 grados.

C.T.: Sí, por eso es que yo no estoy de acuerdo con eso de invalidar la sentencia, porque, no estoy de acuerdo, porque así como la Corte invadió funciones legislativas que no les corresponden, y estamos diciendo que por eso no tiene validez y es inexistente, en consecuencia, una decisión de la Asamblea no puede anular una sentencia, verdad, entonces, sería casi como darle con la misma manera, o sea, invadir funciones del Legislativo al Poder Judicial, entonces, una ley que anule la sentencia sentaría también un mal precedente, y la solución tiene que ser una declaración, nada más, de la Asamblea diciendo por tales y cuales razones no tiene ninguna validez, no es que se anule la sentencia, sino que no se le reconocerá ninguna validez, pero no declararla nula, porque eso sería invadir las funciones, verdad, sino que, el efecto sería el mismo, se le declara sin valor alguno, es que, una vez, el presidente de la Sala cuando era Ministro del Trabajo, reclamaba contra unos actos que declaró que eran nulos, ilegales, ilícitos e inexistentes, y a cada rato se expresaba así, diciendo que era nulo, 
ilegal, ilícito e inexistente, pues así es la sentencia esa, en las mismas palabras que cuando él era Ministro del Trabajo, el doctor Francisco Rosales, esa sentencia es nula, porque la Sala se constituyó de manera que no se corresponde con lo que establece la Ley Orgánica del Poder Judicial, en segundo lugar es ilegal, porque invadió funciones, verdad, es ilícita porque se arrogaron funciones que no le corresponden y cayeron en la figura delictiva de prevaricar todo, de abuso de autoridad y de usurpación de funciones, e inexistente porque no tiene ninguna validez, entonces, es nula, ilegal, ilícita e inexistente, las mismas palabras que ha usado en varias oportunidades, y eso es lo que podría hacer la Asamblea, pero no usar la palabra anular, sino que carece de validez.

R: Y, sin embargo, cuando yo entrevisté al Magistrado Rafael Solís hace una semana aproximadamente, y me sorprendió mucho también la percepción que yo tengo como extranjera y observadora privilegiada de este proceso que ha sido una cuestión puramente azarosa, ¿no?, la mía, quiero decir, que haya tenido la beca en este momento, pero si me sorprendía que dijese textualmente; "esta sentencia se olvidará", una sentencia que sienta un precedente y que, al mismo tiempo, condiciona un proceso político. Es muy grave esta situación.

C.T.: Ah, es que a eso se atienen ellos, ellos creyeron que con el fraude electoral pensaron la gente se iba a olvidar, y se apuntaron a eso, "no, aquí todo escándalo pasa en 15 días, porque viene otro escándalo, que ya la noticia, entonces, deja de ser noticia porque surge otro y la gente se va olvidando", nadie se ha olvidado del fraude, el día 9 de noviembre se cumple un año del fraude, pues, va a haber una serie de actos conmemorativos del fraude electoral, incluyendo una rueda de prensa colectiva que vamos a dar con 22 alcaldes a los que les robaron sus alcaldías, y la sociedad civil los va a proclamar como los alcaldes de allí, y vamos a pedir que se destituyan a los Magistrados del Consejo Supremo, no se ha olvidado el fraude, y menos esta sentencia, porque esta sentencia es un adefesio jurídico, una aberración de la ley, de manera que si se apuntan a que se va a olvidar, no se va a olvidar, están muy equivocados.

$R: Y$, sin embargo, yo creo que también hay una responsabilidad de otras fuerzas políticas, en este caso, del PLC que pactó con Ortega para que, en un principio, esa desconcentración del poder que llevó, a través de la reforma del 95, a darle mayores facultades a la Asamblea, se volvió hacia una concentración de poder en torno al actual Ejecutivo, ¿no?, con ese reforzamiento del Poder Ejecutivo por la penetración fuerte que tiene el Frente Sandinista en el Poder Judicial, que eso es casi otra tesis doctoral, como ha ido incorporando cuadros.

C.T.: Cuadros que venían antes de la seguridad del Estado, porque esto fue una estrategia muy bien pensada, a todos los que eran oficiales de la seguridad les dijeron: "vayan y háganse abogados, utilicen la facilidad de los cursos por encuentro, que sólo son los fines de semana, busquen un trabajo para sostenerse y los fines de semana se van a meter a estudiar Derecho", verdad, y una vez que se han graduado los han ido colocando, la mayor parte del andamiaje judicial del país está en manos de estos abogados salidos de cursos por encuentro, y que antes fueron, muchos de ellos, de la seguridad del Estado, y que siguen recibiendo instrucciones de Luís Serna, que es el jefe, a quienes ellos saludan como Coronel, “¿cómo dice Coronel?, ¿cómo sigue Coronel?, como no, Coronel", aquí, incluso, con ese control de salas de la Corte Suprema el Frente creó un negociado de sentencias, y hay una oficina donde uno podía llegar con los abogados sinvergüenzas a negociar las sentencias, “¿querés la sentencia 
en este sentido?, pues son 10.000 dólares", "pero ¿cómo va a ser?, eso me perjudica", "bueno, pues pagá más”, “¿cuánto pagás?”, “15.000, 20.000,”, “bueno, vamos a hacer la sentencia de esta otra forma", se reenvían sentencias, y así financió la campaña electoral pasada, con un capital hecho a base de las instituciones de la justicia.

$R$ : ¿Y hay documentación o bien algún trabajo en el que conste todo esto?, porque es algo que me han repetido muchos de los entrevistados.

C.T.: Es que es muy difícil llegar a estos temas, por eso, incluso, quienes hicieron eso no lo van a confesar porque cometieron delito, pues, tráfico de influencias, ¿verdad?, esto y lo otro, ¿no?, cayeron en una serie de delitos que es vox populi entre los abogados litigantes, de los que se dedican a litigar en los juzgados, que, incluso, les decían a los clientes: "mire, esto le va a costar tanto porque aquí hay que ir a negociar las sentencias", y a veces les decían al cliente el doble, una suma más alta, porque ahí estaba la sinvergonzada del abogado, ah, no, no, si aquí, la administración de justicia es de lo peor que hay, de lo peor que usted pueda conocer.

$R:$ ¿Y en relación a esa responsabilidad liberal de la que hablaba antes? Cuando entrevisté a Dora María Téllez, ella me decía que cuando Alemán pacta con Ortega tiene en su mente los pactos de Somoza, ¿no?, del 60/40, de la teoría de las minorías congeladas, sin embargo, Ortega tiene otra formación, otra cultura política, tiene una experiencia guerrillera, y con una vocación hegemónica, también, de no aceptar esa mitad y mitad.

C.T.: No, tiene que ser dominio, migajas, sí, migajas, ¿no?, pero lo que es que también de una manera muy ingeniosa tan pronto como Bolaños se lanzó contra Alemán y lo arrinconó, y lo declaró culpable, Ortega, pues, vio la posibilidad de utilizar a Alemán acorralado para que socavando el liderazgo del PLC, a través de él, ofreciéndole dinero, no ir a la Modelo ${ }^{66}$, arresto domiciliario, después transformando el arresto domiciliario en arresto para el Departamento de Managua, podía movilizarse por la ciudad, después, el arresto domiciliario se extendió a toda Nicaragua, y, por último, para conseguir el control de la Junta Directiva Asamblea la absolución, de manera, que Alemán fue sobreseído, pero Alemán no se fijó que quedaron tres juicios que no fueron incluidos, y ahora lo quieren sacrificar, de manera que si Alemán no sale a responder y se niega a estar muy beligerante en eso de la sentencia hay razones o indicios de que Alemán lo sabía, y que los Magistrados liberales se fueron para darle chance, porque en aquél momento a los sandinistas les debían ese favor, para el sobreseimiento los sandinistas no asistieron, salvo Rafael Solís para guardar las apariencias, y esta vez los liberales se fueron para dejarles el campo libre, verdad, y después sacaron un comunicado de prensa en el que dicen que la sentencia es una barbaridad, que no están de acuerdo, etc., pero mucha gente sospecha que, en el fondo, pudo haber habido un aviso del partido, "si vos querés que vuestros Magistrados no participen, pues, que se vayan, pero que esto va, así como yo te di el sobreseimiento, ahora tú me tienes que dar, si no, ahí están los juicios pendientes, y en cualquier momento los reactivamos y te volvemos a meter en la cárcel y quizás ahora no te vas a quedar en tu casa, ahora te vamos a mandar a la Modelo", a la cual Alemán le tiene terror, o sea, que la sinvergonzada de Alemán le ha salido muy cara al país.

66

La cárcel Modelo. 


\section{R: Exactamente.}

C.T.: El país ha pagado carísimo las sinvergonzadas de este ladrón, que es el presidente quizás más ladrón que hemos tenido, porque hasta los Somoza cuidaban las apariencias, y este no, este robó a lo descarado, y robó en cinco años lo que Somoza en medio siglo, entonces, el pueblo de Nicaragua ha pagado carísimo esto, porque para quedarse con ese dinero y no ir a la cárcel, y por él está Ortega en el poder, por la reforma constitucional que le permitió ganar con el 35\%.

R: $Y$, sin embargo, si no se une el liberalismo, Ortega, por pura matemática electoral, va a ganar las próximas presidenciales.

C.T.: El liberalismo lo que tiene que hacer es prescindir de Alemán, tiene que entender que con Alemán la unidad es más difícil, ahora que estamos organizando el evento de la marcha, invitamos al PLC a participar, bueno, pues ya estaban diciendo que Alemán quería ir, entonces, si lo mejor para el éxito de la marcha es que usted no vaya, porque usted es factor de desunión, mucha gente que sabe que usted va, pues, no va ir, yo al lado de él no hago ninguna marcha, aunque fuera por la causa más noble, ¿por qué?, pues porque es un sinvergüenza, además es un irresponsable, y si llega a la marcha la gente lo va a abuchear y lo va a echar, así es que no creo que se atreva.

$R: Y$, no obstante, yo que me entrevisto también con diputados liberales, me dicen que el pacto sigue vivo, o sea, esta mañana cuando hablaba con el diputado Indalecio Rodríguez me decía que el pacto sigue, y he oído del Decano, por ejemplo, de la Facultad de Derecho de la UCA, de Manuel Aráuz, que me decía que el pacto es un procedimiento, que resucita cuando conviene solventar una negociación política y salir de esa traba institucional constante que presenta el funcionamiento del sistema.

C.T.: Sí, sí, por eso mire, Alemán quiere regresar a la presidencia, y Alemán considera que su contrincante, el mejor para vencerlo, es Ortega, porque él cree que con el desprestigio de Ortega se va a olvidar su desprestigio, ¿qué es mayor el clima de animadversión que tiene Ortega en este momento?, porque él al igual que Ortega despertó opiniones muy negativas, pero él piensa que, en un momento dado, él es el llamado a derrotar a Ortega, y él quiere ponerlo frente a él porque cree que es el único candidato que lo puede derrotar, porque ya lo derrotó una vez, entonces, ya se está moviendo, ya anda recorriendo el país...

$R: Y$, sin embargo, me dicen que ambos líderes se parecen más de lo que parece a simple vista, es decir, que tienen detrás sectores de la sociedad nicaragüense que son mayoritarios, como los sectores populares y la clase media baja, que ambos, de alguna manera, tiraron piedras contra el mismo tejado, como me decía Edmundo Jarquín en su entrevista, o sea, al tejado de la oligarquía tradicional. ¿Está de acuerdo con esa visión sociológica que hay del pacto entre los dos caudillos?, ¿y de los apoyos electorales que han tenido ambos a pesar de que la sociedad quedó al margen de ese pacto, que fue además una ruptura con la transparencia de cualquier negociación política sobre las reformas constitucionales?

C.T.: Yo creo que Alemán en algunas zonas rurales, donde hay un ambiente, digamos, bastante ignorante políticamente, yo diría de poca formación política, pudiera tener algún respaldo, sobre todo en aquellos lugares donde hizo una escuela, un centro de 
salud, hizo obras, verdad, y además por tradición, porque el campo, las zonas rurales, han sido liberales del mismo modo que antes fueron conservadoras, las zonas que antes eran conservadoras ahora son liberales, porque la visión conservadora pasa al liberalismo, ahora son liberales, y ahora son liberales por familia, por tradición, etc., ¿no?, pero la figura de Alemán está tan deteriorada, y además de eso, los dos, ellos en sus actuaciones a quienes más han perjudicado es a la clase media, la clase media ha sido la más perjudicada, porque, digamos, la verdadera oligarquía, que tanto critica Ortega, a la cual pertenece ahora, ¿verdad?, esos han sobrevivido perfectamente bien y no han sido muy afectados, y Ortega se cuida de no afectarlos, pero la clase media que es la mayoritaria, en cuanto a movilización, pensamiento, etc., esa los dos se la deben.

R: Y ya para terminar, ¿cómo ve usted el futuro de su país con esta nueva incertidumbre que se ha abierto a apenas dos años de las próximas presidenciales?

C.T.: Bueno, todo depende de cómo nosotros respondamos al desafío que tenemos por delante, sobre todo el desafío de la candidatura de Ortega con esa sentencia, es decir, la respuesta depende más de la sociedad civil organizada, que de los mismos partidos, porque, claro, ahora los estamos invitando, verdad, y hay algunos partidos que sí merece la pena que sean apoyados, como el MRS, el mismo Partido Conservador, el PLI y "Vamos con Eduardo", algunos sectores, verdad, pero yo creo que si somos mayoría, si los que estamos contra Ortega somos mayoría, ¿cómo hacemos para aglutinar a esa mayoría?, logrando poner a Alemán fuera, porque él es fuente de discordia y de desunión, y hacer una enorme mayoría, de Nicaragua entera, la reforma tributaria no tiene porvenir, porque todavía no tiene los 47 votos en la Asamblea, la mayoría mínima para aprobar alguna ley, a pesar de que está en el orden del día, pero como cada vez más señalamientos a los que actúan en forma contraria a los verdaderos intereses del país, yo creo que a larga aquí, la parte económica se la están trabajando, el Fondo Monetario ha venido última hora a darles una evaluación positiva, ellos sólo están viendo las cifras macroeconómicas, verdad, y eso se han cuidado de manejarlo, es decir, pero en lo demás no.

\section{R: La Unión Europea ya retiró su apoyo.}

C.T.: Y no creo que lo respalde.

$R: Y$, sin embargo, estamos viviendo ahora los primeros años que se vivieron con Somoza. ¿Se cierra la memoria histórica tan fácilmente y es posible un nuevo ciclo histórico de autoritarismo, o, incluso, de violencia política, que es lo que me dicen algunos entrevistados si esto no cambia?

C.T.: Sí, a la larga, es posible un regreso a la violencia, entonces, ellos ya comenzaron con la violencia contra la sociedad civil.

R: Bueno, pues, muchas gracias por la entrevista.

C.T.: Gracias a usted, y que tenga mucha suerte con su investigación. 


\section{ENTREVISTA $48^{67}$ :}

Nombre del entrevistado: D. Arnaldo Zambrana Fonseca.

Cargo actual: Profesor de la Universidad Americana (UAM) - Diputado del Partido Demócrata Cristiano integrado en la coalición gubernamental Unión Nacional Opositora (UNO) en la Asamblea Nacional durante el gobierno de Violeta Chamorro (1990-1997).

Fecha de realización de la entrevista: Managua, 22 de octubre de 2009.

Lugar: Facultad de Diplomacia y Relaciones Internacionales de la Universidad Americana (UAM).

Duración estimada: 44 minutos.

\section{TEXTO - Transcripción 48:}

\section{R: Me decía usted que fue diputado durante el gobierno de Violeta Chamorro.}

A.Z.: Sí, fui diputado, y en ese período nosotros hicimos unas reformas constitucionales frente a una realidad que era la siguiente: primero, teníamos una Constitución que había sido hecha por el Frente Sandinista, esa Constitución, en síntesis, era una Constitución para un pequeño reino, el presidente de la República tenía las facultades, tenía facultades, ¿cómo se llaman?, tenía la facultad legislativa, o sea, el presidente de Nicaragua se levantaba hoy y en media hora podía crear una ley y se consideraba ley, era una facultad, era una Constitución que le daba poder omnímodo, prácticamente, sobre la ley, y, prácticamente, la Asamblea Nacional era para ir a dirimir problemas de otro orden, pero que la sustancia de lo que ellos necesitaban la realizaban por medio de decretos ejecutivos, que se convertían en fuerza de ley, porque la Constitución amparaba eso, yo pertenecía a un partido político, que era el Partido Demócrata Cristiano y de nosotros salió, como grupo político, de hacer reformas constitucionales que tuvieran firmeza, desde el punto de vista institucional, constitucional, que fuera aceptado por todos, y que fueran reformas que beneficiaran, generalmente, la democracia de Nicaragua, no que beneficiara a alguien, o que si alguien se perjudicara, pues, tal vez por sus distinciones se podía perjudicar, pero nosotros no podíamos crear unas reformas constitucionales en contra de alguien sino a beneficio de todos. Eso se explica de la siguiente forma, que era borrar en la Constitución todas aquellas leyes que por tradición histórica nos han venido perjudicando, una de ellas era la reelección, y otra era, precisamente, quitarle los poderes omnímodos al presidente de la República para que fuera una república verdaderamente democrática y no un pequeño reino, verdad, ¿no?, estamos hablando de una Constitución principesca. Al primer partido al que nosotros le planteamos tal situación fue al Frente Sandinista porque era el partido que tenía una mayoría que había que tomar en consideración dentro del bloque de lo que es el negocio político, de lo que es "ábranse para que podamos hacer algo", en un principio, ellos se mostraron renuentes para hacer cambios porque estaban pensando en que posiblemente las siguientes elecciones las ganarían y quedarían, digamos, con poderes iguales, y, por otro lado, un sector proclive al gobierno de Doña Violeta, pues, estaba interesado en que esas cosas no cambiaran para que también ellos pudieran hacer cambios, no voy a medir la magnitud buena o mala, porque no está en mi capacidad

67 Entrevista interesante, especialmente, por sus referencias históricas, políticas y filosóficas, sobre los procesos de cambio constitucional en la evolución política general de Nicaragua, aunque algunos aspectos del discurso estén menos desarrollados y haya algún sesgo crítico que precise de una mejor argumentación. 
para decidir si eran buenos o malos, pero sí, de alguna forma, esa era una llave también demasiado amplia para un país republicano. Cuando comenzó a perfilarse con mayor fuerza el candidato, o sea, el movimiento político del alcalde de Managua en esos días, el doctor Arnoldo Alemán, nosotros le hicimos ver al Frente Sandinista de que sí era una posibilidad de que ganara Arnoldo Alemán, y eso es absolutamente cierto, te lo voy a contar, en la mesa de negociaciones dijimos: "¿usted cree, Comandante, que sería conveniente para Nicaragua que una Constitución como la que, actualmente, tenemos quede en manos de un Arnoldo Alemán?", entonces, ellos que conocían el fondo de sus intenciones y para qué fue hecha esa Constitución, se asustaron, entonces, vieron las posibilidades de que Arnoldo Alemán ganara, y sería haberle entregado todo el poder que ellos tenían, y ellos aceptaron las reformas, verdad, pero al aceptar las reformas nosotros comenzamos también a cabildear con los restos políticos de la Unión Nacional Opositora, que para entonces ya estaba fragmentada, los grupos liberales, los grupos independientes que se llamaban, los grupos conservadores, los comunistas, los socialistas, y después de un trabajo que no deja de ser agotador y también interesante se llegó, pues, a que firmáramos la primera solicitud, y se hizo la primera solicitud de reforma constitucional, de acuerdo a los tiempos que establecía el proceso de la ley, perdón, ni siquiera había proceso de formación de la ley en la anterior Constitución, nosotros establecimos el proceso de formación de la ley con los cambios constitucionales, de tal manera que cuando se llegó nosotros teníamos ya una posible reforma, yo era director también de un instituto de estudios políticos, y tengo el listado, el planteamiento, creo que tengo uno o dos ejemplares todavía, yo mañana tengo que venir a dar clases aquí en las tardes, te lo puedo dejar aquí ese ejemplar, para que veas cuáles eran las reformas, todas las que nosotros planteábamos, lo que no tengo acceso es a otra Constitución que fue el resultado de esa discusión, pero también de parte del sector de Doña Violeta había intereses de la reelección continua que estaba establecida en la Constitución sandinista, por ponerle un nombre, y esas intenciones eran de Don Antonio Lacayo, que, verdaderamente, era el presidente de Nicaragua, porque es el que decidía y tomaba el acierto, la señora era una figura, y vino un problema, pues, vino un problema porque él quería que la Constitución no pusiera trabas a los familiares del presidente, aparte de que no permitíamos la reelección inmediata pusimos trabas a los familiares en $\mathrm{X}$ grado de consanguinidad o de afinidad, porque eso nos ha traído dictaduras, dinastías y todo, y fue aprobada por todos, por unanimidad, esa Constitución, cuando gana Don Arnoldo Alemán, entonces, quiere cambios constitucionales, porque ahora ya quiere crear condiciones que le favorezcan hasta hoy, es decir, todos los cambios constitucionales que se han logrado es borrar las llaves que habíamos creado nosotros para crear una verdadera república donde hubiese una justas electorales sin ventaja alguna, porque decíamos nosotros, si yo soy presidente de Nicaragua y me voy a reelegir en la siguiente contienda electoral yo tengo ventaja sobre los demás, $\mathrm{y}$, entonces, esto está en contra de un principio constitucional donde todos somos iguales, entonces, éste es más igual que cualquier otro, porque éste tiene todos los recursos del Estado, tiene todo el aparato político, tiene los recursos económicos y, entonces, compite con mayores ventajas contra unos que andan buscando recursos para ver cómo se meten a la pelea, eso lo queríamos quitar partiendo del principio de igualdad, y partiendo del principio histórico de que eso no has hecho demasiado daño, es decir, se crean dinastías, esos fueron los principales argumentos, argumentos que no son simples argumentos, son razonamientos, uno puede argumentar sin razón, pero estos eran argumentos razonados por procesos políticos anteriores, y porque la institucionalidad de Nicaragua como república estuviese salvaguardada por medio de la Carta Magna, que estableciera, pues, cuáles eran las mejores reglas del juego y que 
permitiera la libre democracia, ¿no?, permitimos una Ley de Partidos Políticos y todo eso fue cambiado para que después eliminar partidos y quedarse dos para la disputa del poder, que hasta hoy, prácticamente, eso es lo que sucede.

R: Sí es cierto que la reforma del 95 es la que tiene más sentido desde el punto de vista de la legitimidad del cambio constitucional para establecer un marco de ejercicio del poder político en el contexto de la transición democrática.

A.Z.: Nosotros quisimos que a partir del proceso de negociación y llegar a la Constitución, la idea, que vendimos a todos con los que negociamos, era crear en las próximas elecciones, las siguientes, un marco de respeto que fuera también legitimidad y legalidad.

$R: Y$, en este sentido, por otra parte, en todos los procesos de reforma constitucional ha habido un conflicto entre el Ejecutivo presidencial y el Legislativo. El hilo conductor de las reformas ha sido un poco el de transferir mayor poder a la Asamblea, y ustedes así trataron de hacerlo en un principio, para que hubiese un equilibrio de poderes $y$ atenuar el presidencialismo excesivo que consolidaba la Constitución del 87 en la figura del presidente de la República.

A.Z.: Exactamente, nosotros queríamos que fuera el presidente de la República, no el dueño de Nicaragua, que fuera el presidente de la República y que respetara las decisiones de los otros poderes, yo publiqué un libro hace años que es una filosofía de la historia de Nicaragua donde vamos viendo parte por parte los procesos y todas las guerras que ha habido alrededor de las reelecciones, la primera guerra que se dio por reelección fue la de los primeros dos jefes de Estado, Antonio de la Cerda y Juan Argüello, crímenes horrorosos hubo, porque uno quería reelegirse y el otro también, y todas las guerras que ha habido en Nicaragua, al final, son, sus causas inmediatas y principales han sido la reelección o la creación de constituciones con poderes omnímodos, de tal manera que la Constitución de Somoza del 74 es la Constitución mejor que se ha escrito en Nicaragua, y el hombre trató de respetar la Constitución, era una dictadura, como le dijo el presidente Pérez a Somoza Debayle, "usted tiene una dictablanda", le dice, "no es una dictadura", había jueces, había jueces que podían darle, digamos, salidas a los del Frente Sandinista que estaban presos, o sea, que había una cierta flexibilidad y había aún una cierta legitimidad en algunos poderes del Estado, hoy están cuadrados totalmente de una manera desvergonzada a favor de un régimen horroroso, yo no estoy diciendo que ahorita hay crímenes, yo no estoy diciendo que ahorita, todo eso no hay, pero si esto no lo detenemos ahorita esto avanza, y la historia nuestra está llena de que al que se le ha permitido avanzar hasta donde ha querido terminamos en una guerra y con 50.000 muertos nuevamente, y eso es lo que tenemos que evitar, tenemos que volver a la constitucionalidad, tenemos que revisar los procesos históricos anteriores para que aprendamos de la filosofía de la historia, que no debemos de cometer los mismos errores, no es posible, señor, que hayan muerto 50.000 muchachos para que volvamos otra vez a un sistema que repudiamos.

R: Sí, es muy triste, porque la democracia costó muy cara en Nicaragua.

A.Z.: Sí, sí, así es. 
$R: Y$, por otra parte, es verdad que el pacto entre Ortega y Alemán a finales de los 90, en el 99, el pacto de 2000, que consolidan estas reformas constitucionales, ¿representan un punto de inflexión en el camino ya iniciado por las reformas del 95 ?

A.Z.: Yo se lo voy a decir con toda sencillez, a veces no hay que, este es un pacto de dos caudillos que no quieren permitir a un tercero en pleito, no quieren un tercer partido, o un cuarto partido, solamente, quieren ellos dos negociar el poder, pero en ellos no hay lealtades, en ellos no hay lealtades, es decir, ellos pactan pero también se temen, uno, dos, lo que ha hecho Daniel Ortega hace 48 horas yo supongo, supongo, de que no estaba ajena su actitud al permiso o a la permisividad del otro caudillo, y este es mi razonamiento, Arnoldo Alemán le ha entregado todo, cuando tuvo poder le entregó todo lo que podía a Daniel Ortega, Daniel Ortega se fue consolidando, se fue consolidando, se fue consolidando, hasta que en una de las negociaciones con el pacto sin que se lo solicitaran Arnoldo Alemán le presenta el 35\% para que el otro partido vote a favor de una reforma donde Arnoldo Alemán pueda ser diputado, ¿cuál era el interés de Arnoldo Alemán?, el interés de Arnoldo Alemán era llegar a la Asamblea, ser presidente de la Asamblea, "vos mandás allá y yo mando aquí", pero eso no le sirvió, es decir, que tuviera un presidente liberal y que él controlara la Asamblea Nacional para negociar con Daniel Ortega, leyes y cualquier otra cosa, todo lo que se deriva de la Asamblea, usted sabe, acuerdos internacionales, etc., etc., con él, pero viene el señor presidente anterior, verdad, Don Enrique Bolaños, encarcela a este hombre, ¿estamos claros?, y ese juego se le cae, y el otro queda con la ganancia del $35 \%$, o sea, Daniel Ortega gana este proceso electoral con lo que perdió siempre, con el mismo porcentaje con el que perdió siempre, porque el liberalismo se dividió, y aquí vienen las fuerzas externas, Collin Powell viene aquí y le dice al presidente de Nicaragua, Don Enrique Bolaños, que haga otro partido, y, en vez de tener capacidades de negociación y volver al redil, divide, y la división nos causó ese daño mayor todavía, tenía los $35 \%$ pero si hubiéramos estado juntos no se da, ¿verdad?, entonces, aquí hay dos responsables más un responsable del exterior, ahora, esto que estamos viendo hoy no está alejado de factores externos, hay dos factores inmediatos, un factor inmediato es Honduras, y el factor inmediato también es Chávez, si te corta la Unión Europea, si te corta los Estados Unidos, si te corta, quien te corte, "no te preocupés, yo te doy", y eso lo está demostrando Micheletti, “¿no me quieren?, perfecto, yo sobrevivo”, entonces, están montados también en ejercicios políticos que están alrededor en América Latina, y están montados en el apoyo que le pueda dar Chávez y ahora el apoyo que le puede dar Evo Morales para sustentarse en el poder, aunque aquí se caiga la economía, porque si se cae la economía tienes el modelo cubano, que es que los del partido coman bien para que me apoyen y me sustenten, y el resto no nos importa, son tres factores externos que son modelos para que él haya asumido de ya esa posición, resumo así, ellos no llegaron a tomar esa decisión, la de hace 48 horas, si antes no habían estudiado todo lo que tenían que hacer para caer, pero tampoco tomaron la decisión sin tomar en cuenta cuáles son los factores que después o las acciones que después van a seguir, ¿qué es lo que viene?, si se va a la calle, no va a ser la Policía ni el Ejército el que va a salir a golpear sino que turbas las van a financiar para que digan que es el pueblo, todo eso se espera, pues, ahora, ¿qué clase de oposición tenemos?, tenemos una oposición inodora, incolora e insípida, el señor Montealegre no tiene liderazgo para nada, son liderazgos formales que se han montado en sistemas de clases, no son liderazgos que han salido de las fuerzas populares para llegar y tener una gran base social, no, el Frente Sandinista cuando va a un proceso electoral visita las cañadas, las fuerzas liberales o conservadoras andan en las ciudades echándose el trago con los amigos y no trabajan las bases, es que ese es el 
objetivo también, entonces, mientras ellos sigan en ese círculo miserable de creer que a los ciudadanos sólo se les busca para una contienda electoral, y no es una acción permanente del partido el Frente se aviva, su llama de poder, mientras las juventudes andan discutiendo si un aipot que tengo yo es mejor que el tuyo, o que si chateo más con tal cosa y no tienen ni idea de lo que pasa en este país, esto favorece a un dictadura, la juventud a la que yo pertenecí, que fui dirigente estudiantil en la Universidad, nos sentábamos con los demás a discutir, ahora se agarran a garrotazos y a tubazos, porque lo que se pelean es un presupuesto que da el Frente Sandinista para que ellos sobrevivan, a mí no me dieron un centavo nunca por ser dirigente estudiantil, entonces, toda esa corrupción deslegitima a las fuerzas políticas todas.

$R: Y$, sin embargo, ha habido un aprendizaje institucional del Frente durante 16 años de oposición a gobernar desde ahí, a través de los otros poderes del Estado, pienso, especialmente, en el Poder Judicial, que ha sido un terreno, digamos, de preeminencia sandinista, o el Consejo Supremo Electoral.

A.Z.: Porque esas son concesiones que le dio Arnoldo Alemán, ¿ve?, la Corte no tenía dieciséis miembros, eran nueve, y le dio más, y después compraron.

\section{R: Y luego también lo que era la propia estructura del Poder Judicial.}

A.Z.: Exactamente, ¿y qué paso?, es que los sandinistas no son estúpidos, toda la gente que salió de la seguridad del Estado, toda la gente decimos, ¿verdad?, pero un grupo, un centenar, que salieron de la seguridad del Estado, que son fieles, los mandaron a estudiar Derecho, en 10 años eran abogados, y en 5 años más los incorporaron a ser jueces, ¿y qué hicieron los demás partidos?, echarse sus tragos, andar celebrando, es que también estamos frente a dos culturas políticas.

\section{R: ¿La del liberalismo y la del sandinismo?}

A.Z.: Exactamente.

$R:$ ¿Y que caracterizaría, en términos generales, a cada una de ellas?

A.Z.: A cada una de ellas, unos son oportunistas y delincuentes, yo no calificaría aquí al liberalismo de otra manera que no sean oportunistas, delincuentes, y los otros son los que son más conspiradores natos, y si tenés a un grupo de personas que lo que buscan es cómo negociar en beneficio personal tenés conspiradores que tienen todas las herramientas para comprar, y ¿qué le interesa a éste?, venderse, y ¿qué le interesa a éste?, fortalecer su poder, ¿mediante qué?, lo que sea, pero lo van a tener.

R: Por otra parte, desde el punto de vista estrictamente jurídico, siempre ha habido irregularidades en el proceso de reforma, el conflicto entre el Ejecutivo y el Legislativo desde el gobierno de Doña Violeta Chamorro dio como resultado esta Ley Marco, que luego se repitió con Enrique Bolaños, y luego se volvió a repetir con el gobierno de Ortega, porque se reformó la entrada en vigor de la Ley Marco.

A.Z.: Sí, yo era diputado en esos días con la primera Ley Marco, entonces, ¿quién le iba a hacer caso a la Asamblea Legislativa?, ¿qué ministro le iba a hacer caso a la Asamblea si el que le paga es el Ejecutivo?, y fue puesta, no importa, ¿por qué?, porque no se 
respetan las institucionalidades, ni Doña Violeta las respetó, porque el irrespeto es la tónica fundamental de este país, aquí la política está por encima de la Constitución, no la Constitución encima de la política, aquí a cualquier conflicto se aparta la Constitución y se negocia, no se negocia en función de la Constitución, sino que se negocia en función de los intereses políticos, eso es fundamental que usted lo entienda.

R: Sí, lo estoy haciendo, y, de hecho, las leyes Marco constituyen una ampliación del proceso de negociación política, congelando en el tiempo la entrada en vigor de las normas constitucionales reformadas.

A.Z.: Exactamente, la Constitución no importa, sólo son los arreglos que pueden tener las fuerzas beligerantes.

$R$ : $Y$, en este sentido, ¿cómo valora la evolución constitucional reciente desde el punto de vista de las instituciones democráticas por muy débiles que sean?, ¿qué futuro adivina en estos momentos?

A.Z.: Bueno, es evidente que las instituciones no tienen ninguna legitimidad ni credibilidad, entonces, es un aparataje que está a favor del Frente Sandinista, y que no se espera nada, no hay ningún fallo, no puede haber nada, ni recurso de ninguna naturaleza para que esto se pueda revocar, estoy hablando desde el punto de vista jurídico, no existe, no existe.

R: Entonces, ¿hay que aceptar esta decisión de la Corte Suprema?

A.Z.: No, no hay que aceptarla, hay que aguantársela, que es otra cosa, yo no la acepto.

R: Bueno aceptarla, me refiero recibirla sin otra alternativa.

A.Z.: Sí, porque no hay instrumentos legales para poderla contrarrestar, porque para poder cambiar a la Corte Suprema y para poder cambiar al Consejo Supremo Electoral se necesitan 56 votos, ¿y quién los tiene?, no los tiene nadie, si el liberalismo hubiera ganado las elecciones, ¿qué hubiera pasado?, hubiesen tenido toditos los votos para poder cambiar radicalmente todo esto, pero, me pregunto yo, radicalmente, ien beneficio de quién?, en beneficio ahora de los liberales, el problema es cultural.

R: Sí, hay una referencia constante en todas las entrevistas a las pautas culturales.

A.Z.: Así es, así es.

R: Porque además todas las constituciones que ha tenido Nicaragua siempre han sido precedidas de pactos políticos.

A.Z.: Exactamente.

R: Y usted, además, que ha estudiado la historia politica de su pais, ¿puede referir mejor algunos detalles de este principio de negociación entre los líderes?

A.Z.: Las reformas constitucionales, por ejemplo, las del 50 fue a base del pacto liberoconservador, las reformas constitucionales que se dieron después del terremoto fue 
producto del pacto libero-conservador, las reformas constitucionales que se dieron después de la guerra nacional en 1856 al 57, perdón, eso fue parte de un pacto, que ese es el pacto mejor que ha habido, pues, porque lograron interesar al pueblo de Nicaragua, porque no fue en beneficio ni del General Menéndez ni del General Martínez, sino en beneficio del país, ese es el único pacto benigno, y el otro pacto benigno fue que sin estar en el poder se aliaron contra William Walker el 12 de septiembre del 56, pero todos los pactos que nosotros hacemos referencia y conocemos históricamente, anteceden a una reforma constitucional, donde hay un repartimiento, y esto ¿viene de donde?, viene desde el Acta de Independencia, si usted ve el Acta de Independencia nuestra, primero no es Acta, no dice que es Acta, sino que es una recomendación para que todos los que estaban ahí fueran a sus provincias a que les aseguraran su puesto y volver a Guatemala, ahí no se habla de pueblo, ahí no se habla de qué beneficio va a tener el pueblo, no, no, no, nada, es lo que llamo yo en mi libro: "el repartimiento".

\section{$R:$ ¿Y eso no ha desaparecido de la forma de hacer política?}

A.Z.: No, no ha desaparecido, no ha desaparecido, yo ando mi libro ahí para hacer una referencia, mire, la cultura del cabildo donde el jefe de provincia era el que tenía el poder económico, y aunque los demás tuvieran, digamos, un poder legal, el que ponía la plata era el que le ponía las condiciones a éstos, entonces, los miembros del Cabildo votaban de acuerdo a los intereses que tenía el que manejaba el dinero, ¿y qué diferencia hay entre eso y la Asamblea Legislativa en Nicaragua?, pues ninguna, porque hay una sumisión psicológica y económica al caudillo.

R: Y esa referencia al "hombre fuerte" es algo también que forma parte de la cultura política de este país.

\section{A.Z.: Exactamente, exactamente.}

R: Como que no hay una idea del hombre deliberante, dialogante, digamos, otra costumbre de hacer política por parte de los dirigentes de los partidos.

A.Z.: Lo que pasa es que nosotros, nosotros somos un país donde no vino ni lo mejor de España, y éstos eran desde el imperio azteca, pues, esto era un reinado, sin embargo, la cultura indígena nuestra era muy seria, y era muy respetuosa porque el militar que no quería someterse a los designios del monéxico lo mataban, porque no podía rebelarse ante la ley, pero eso no heredamos de los indígenas, digamos, no matarse, no, el respeto a la institucionalidad, sino que heredamos la posición española, cuando, por ejemplo, Fray Antonio de Valdivia le escribe al Rey de España que es lo que está sucediendo con los descubridores, le da a entender o le dice, claramente, que ha mandado a gente incapaz y que la única capacidad que tienen es dejarse sobornar, entonces, la Audiencia de los Confines que era para oír las quejas en contra de los encomenderos y todo no funcionaba, ¿por qué?, porque estaba comprada, la primera pelea que hubo por robo de elecciones se dio en León de Nicaragua a mitad del siglo XVI, ¿por qué?, porque una familia, la de los Contrera, era dueña del patrimonio de la provincia, y así hemos venido, con familias, los Contrera, verdad, viene el período, pues, de que ya no hubo familias sino que era una paz colonial, después vino los Chamorro, han venido otros, los Somoza, ahora los Ortega, y ahora los Ortega Murillo, es decir, grupos familiares, como que fuéramos tribus, que se apropian de las riquezas del Estado, del poder, y someten, y 
otros que se dejan someter, precisamente, por sus intereses económicos, y no por lealtades, sino por cuánto me das y eso es todo.

R: Si he escuchado, al estudiar el regreso de Ortega al poder, que su estilo de gobierno, de alguna forma, entra en ese terreno de poca transparencia, del vínculo familiar con su esposa que tiene una ascendencia fuerte sobre el ejercicio del poder, incluso, de paralelismo con el régimen de Somoza, que él mismo intentó, como líder de la revolución, derrocar.

A.Z.: Es que eso es lo que duele, lo que duele es que hayan muerto 50.000 personas para que él venga a repetir en una caricatura el somocismo, porque yo le cuento, yo nací dentro del somocismo, me dediqué a la política desde los 12 años, fui a dos guerras, y yo me asombro como es que este señor, mire, decir somocismo es ofender a Somoza, éste es otra cosa, primero, Somoza era un hombre estudiado, tenía planes de desarrollo, dirigió bien el país, la economía, aquí no había problemas económicos, el problema de Nicaragua era político, ahora es político y económico, es decir, en vez de ir superando vamos aumentando los niveles de pobreza, vamos aumentando los problemas de endeudamiento, estamos, los problemas de la democracia también casi son similares, y, entonces, no podemos hablar del somocismo, ni compararlo, esto es otra cosa, que es, análogamente, peor.

R: No, y aparte, no se produce un relevo del liderazgo político de los 80 , los personajes siguen siendo los mismos aunque se renueven, entre comillas, en el escenario democrático, bueno, formalmente democrático, porque está claro que...

A.Z.: Aquí son dinastías, imagínese que, por ejemplo, le voy a poner uno de ellos, hay un liberal que se llama Francisco Aguirre Sacasa, este señor vivió tal vez dos años en Nicaragua, se fue a los Estados Unidos, su padre era un eminente militar somocista, se fue a los Estados Unidos con su hijo a hacer servicios del gobierno, y regresó, pero como es Aguirre Sacasa, entonces, los hambrientos o los huérfanos de estar al lado de alguien que tiene un apellido de esos, como es el caso de Arnoldo, comenzó a llamar a esa gente, no comenzó a llamar a su gente, sino que comenzó a llamar a la aristocracia, y los puso en algunos puestos, ¿no?, por eso es que usted se explica como Arnoldo, un mestizo, esté rodeado de gente aristócrata, de aristócratas de pueblo, por supuesto, ¿no?, y hoy en la Asamblea está enfrentado ese, Francisco Aguirre Sacasa, con Edwin Castro, ¿y quien es Edwin Castro?, Edwin Castro es el hijo de Edwin Castro que fue asesinado en las cárceles por la Guardia Nacional, y que se enfrentó en las calles con el papá de Aguirre Sacasa, ellos siguen en el poder, siguen, siguen en la lucha política y ahora enfrentados en la Asamblea Legislativa, y este señor Castro es nieto de Castro Wagner, un líder liberal de la época de Zelaya.

R: No, de alguna forma, es cierto, que ellos siguen la tradición política de sus padres, aunque la revolución también amplió, yo creo, la posibilidad de que entrase la gente en política, y estoy pensando, fundamentalmente, en el pueblo, ¿no? Tradicionalmente, en Nicaragua la política había sido una cosa de élites y la revolución creo que da oportunidad a que el pueblo nicaragüense tomase las riendas de su destino politico e histórico, esa es al menos la lectura que se hace en gran parte de las obras que yo he leído sobre la revolución sandinista. 
A.Z.: Esa es una falsedad del Frente, si no, no los hubiera derrocado el pueblo, a ellos y a Somoza.

\section{R: Pero sí fue una alianza multiclasista contra Somoza.}

A.Z.: El pueblo ha participado siempre en todos los procesos electorales en la política de este país, que el pueblo haya tenido conducción, o no haya tenido una mejor conducción, esa ya es otra cosa, pero que el pueblo se haya manifestado en política siempre se manifiesta, lo que debemos de evitar es la confusión siguiente, que no es que el pueblo de Nicaragua siempre ha estado dormido y que sólo las élites son las que discuten, no, cuando ha habido una personalidad política que recoge ese sentir y toda esa fuerza las cosas caminan mejor, pero el nicaragüense nunca se ha callado, siempre ha participado en política, por eso cuando usted lee todos los procesos electorales que ha habido en Nicaragua ha habido matancitas y todo, la gente matándose entre ellos, porque ha habido actividad política de las bases, lo que no ha habido es, lo que ha habido es una conducción o mala o buena o ninguna, como es el caso que le estoy diciendo hoy, ¿qué conducción política hay ahorita?, mala, ¿y qué base social hay general?, la gente habla de política, pero las juventudes están desactivadas totalmente.

R: Pero también, ¿hay miedo por parte de la sociedad nicaragüense a no desear enfrentarse y tomo el ejemplo de las últimas municipales?

A.Z.: Pero ese es un miedo que, de alguna forma, es producto de lo que dice Alexis de Tocqueville, que mientras la gente tenga un recurso que les permita sobrevivir sacrifican la libertad, mientras el Frente mantenga un cierto nivel económico aquí, donde uno medio se mueve y camina, la gente no se va a lanzar a las calles tan fácilmente. De eso estoy seguro, entonces, sí van a ser grupos menores los que van a comenzar a hacer el trabajo.

$R: Y$, entonces, el balón de oxígeno que tiene actualmente, porque el contexto internacional de hoy no es el del Frente de los 80. Ya no hay bloqueo norteamericano, es cierto que sí puede haber una privación de la ayuda por parte de los organismos internacionales, en el ámbito de la cooperación internacional, que además es un rubro importante del presupuesto de la república, pero si el balón de oxígeno, como decía al principio, se lo da Chávez con los ingresos que proceden del petróleo...

A.Z.: Claro, exacto, él continúa en lo mismo, él continúa en lo mismo.

\section{R: Sí, pero Chávez también tiene una existencia política limitada.}

A.Z.: Pero es que el problema no es lo que nosotros pensamos, el problema es lo que piensan ellos, porque usted y yo pensamos igual, y ese no es el problema, porque para nosotros eso no es problema porque se va a terminar, el problema es que ellos no piensan de que tienen finiquito, de que ellos terminan, de que ellos pueden tener en cualquier momento, en cualquier desliz y cualquier cosa, y cualquier cosa puede suceder en cualquier país de estos del ALBA, ellos no están pensando en eso, ellos están pensando en las continuidades permanentes, Chávez está asentado en que él es el Bolívar del siglo XXI, y que va a reunir, como la gallina reúne a los pollitos, a todos, que él va a ser el líder, y como psicológicamente el hombre es, digamos, deficiente, puede tener mucha inteligencia mestiza, viva, vivaracha, pero tiene un defecto 
psicológico, es huérfano de clase, porque él no se considera ni una cosa ni la otra, entonces, como tiene una orfandad psicológica para sentirse legitimado fue a buscar a Fidel Castro, para que nadie de la izquierda dudara que es legítimo, entonces, la legitimidad se la dio Fidel dentro del concepto histórico del socialismo latinoamericano, una vez que él tiene el beneplácito de su santidad el papa del socialismo en América, él se siente el hombre fuerte y comienza a hablar con todos, y como los otros saben que ya está bendecido por Fidel no le dicen nada y se suman, eso es lo que ha habido, entonces, ahora el Simón Bolívar tiene la bendición papal y se está ampliando, esto viene ahora una corriente de, musulmana, una corriente musulmana, que está representada, en este caso, con Chávez con Irán, entonces, ¿qué ven los Estados Unidos?, los Estados Unidos no sé si lo ven, digo yo, que si lo veo yo que soy un simple profesor de filosofía y sociología en la Universidad, ¿cómo no lo van a ver ellos con grandes estudios?, que se amplía el radio de acción musulmán en América Latina con el ALBA, ¿o no es cierto?

R: Sí, es verdad que hay una alianza, digamos, contraria a la corriente de la globalización económica, de la democracia liberal, que pueda representar Estados Unidos y occidente, en general. Entonces, el futuro en este país cambia tan rápido, y el principio de incertidumbre rige el destino de Nicaragua, apenas he regresado de Panamá y me encuentro con esta situación, que sí enriquece mi tesis doctoral, pero, definitivamente, es algo que padecer como ciudadano...

A.Z.: ¿Usted cree que no es frustrante para mí crecer, haber pedido mi vida, pude haber perdido mi vida en varios enfrentamientos militares, y saber que le estoy entregando a mis hijos un país dolorosamente destruido, moral, política, y etc., etc., etc.? Mire, licenciada, el liberalismo que hoy vive en Nicaragua es de porqueriza, yo he leído a los eminentes liberales del siglo XIX, con una claridad meridiana de sus componentes filosóficos, ideológicos, morales, siglo XIX y comienzos del XX, y oír a un liberal hoy, que no tiene la más mínima idea de qué cosa es el liberalismo, si no es por el deseo de enriquecerse vendiendo un voto, eso es una vergüenza para un país, yo me siento avergonzado de este país ahora.

R: Bueno, y los sandinistas que reclaman el espíritu de Sandino dicen lo mismo respecto a la otra corriente, ¿no?, que el Frente no representa en ningún sentido la filosofia de Sandino.

A.Z.: Pero es que si usted, por ejemplo, lee a Sandino y lee a Carlos Fonseca Amador, usted se queda asustada de lo que está haciendo este señor, es decir, ninguna de las dos, ninguno de los dos grupos representan, verdaderamente, no tienen sustentación moral dentro de sus corrientes ideológicas, entonces, uno no puede pedirles nada, que no sea la del grupos que, aparentemente, hace 30 años eran lumpen y que no tienen sentido de lo que es el Derecho, voy a hacer la referencia de Chautebriand con Rousseau, un individuo que se creado salvaje y que tiene un concepto de libertad natural no puede tener un concepto de libertad positiva, no la entiende, entonces, éstos que se han criado sin ley, porque aunque vivieran en Nicaragua vivían clandestinos, tienen una conducción de vida alejada de lo que es el Derecho positivo, es decir, no les importa la ley, no les interesa eso, Lula Da Silva fue un obrero, pagó sus impuestos, hizo fila, fue a marcar tarjeta, mantuvo a su familia, ningún líder sandinista en su historial ha sido capaz de eso, entonces, no pueden tener un sentido de orden, de obligaciones, de Estado de Derecho, no lo pueden tener. 
R: No, el propio Edmundo Jarquín, cuando le entrevisté hablaba de "Estado mafioso", o sea, ya hacía referencia a componentes claramente al margen de la legalidad.

A.Z.: Al margen de la legalidad, es decir, son grupos, que son grupos que hacen cualquier cosa como las hace un delincuente.

R: ¿Y de la Constitución qué va a quedar?

A.Z.: Eso de la Constitución, le voy a contar algo que le va a causar risa, y me va a disculpar que sea tan atrevido en hacerlo, había un político aquí, Buenaventura Selva, que venía de otros políticos del siglo XIX, hombres eminentes, y como era crítico al somocismo, constantemente, le echábamos preso, y en una de sus salidas de la cárcel, un periodista, creo que del diario Flecha le preguntó: "Doctor Selva, nosotros cada vez que usted cae preso siempre aparece", o sale de la cárcel, cuando lo venían a traer, porque casi era anunciado, los periodistas estaban ahí, lo venían a traer, le dejaban la Constitución y se la ponía aquí, porque era una imprenta, es decir, era un diario, pues, entonces, le dice, cuando le pregunta que por qué se lleva la Constitución, "sí, hombre", le dice, “¿y vos creés que en la cárcel hay papel higiénico?”, ese es el nivel constitucional, ese es el aprecio a la Constitución, porque si no sirve para nada, pues, alguna utilidad tendrá, que es lo que hacen los políticos con ella.

R: Pues si quiere añadir algo más.

A.Z.: No, más bien quisiera pasarle el documento del que le hablé antes. 
ENTREVISTA $49^{68}$ :

Nombre del entrevistado: $D^{a}$. Rosa Marina Zelaya.

Cargo actual: presidenta del Consejo Supremo Electoral, bajo el gobierno de Violeta Chamorro (1990-1997).

Fecha de realización de la entrevista: Managua, 9 de septiembre de 2009.

Lugar: Casa particular de la Sra. Zelaya.

Duración estimada: 56 minutos.

\section{TEXTO - Transcripción 49:}

R: Me gustaría que hiciese un balance sobre cuál ha sido el proceso de cambio constitucional en su país, muy particularmente, el caso electoral, que, me imagino, es el que más conoce, pero no importa que se extienda a otros ámbitos, y cómo ha influido el cambio constitucional en la consolidación de las instituciones democráticas, ¿no?, desde los 90 hasta ahora.

R.M.C.: OK, bueno, indudablemente, tenemos que partir del 19 de julio del 79, en términos de hablar de la etapa contemporánea en Nicaragua, donde se da todo ese tema de guerra para el derrocamiento del gobierno de Anastasio Somoza Debayle mediante un levantamiento, prácticamente, popular y de la empresa privada y de todo el sector medianamente pensante en el país, que ya, de una u otra manera, no estaban para nada identificados con ese tipo de gobierno, obviamente, el Frente Sandinista como partido, y otros partidos políticos también estuvieron en este tema del derrocamiento. A partir de ese momento se deroga la Constitución Política anterior en la época de Somoza, y se trabaja primero con un Estatuto Fundamental, sustituyendo a la Constitución Política, y era un Estatuto de Derechos y Garantías, y una vez que se dan las elecciones de 1984 se elige a unos asambleístas constituyentes para hacer la nueva Constitución Política con un mandato de dos años, y en enero de 1987 se estrenó la primera Carta Magna posterior al 19 de julio, en el intermedio se creó, de nuevo, el Poder Electoral, porque amén de haber derogado todas las leyes y la Constitución también se desintegró toda la estructura de gobierno, y de poderes del Estado de la época de Somoza y se volvieron a hacer, en un primer momento, solamente era el Poder Ejecutivo, el Legislativo y el Judicial, pero, posteriormente, para organizar las elecciones del 84 es que se constituye el Poder Electoral, lo interesante es que el Poder Electoral ya había existido como un poder desde una reforma constitucional que se dio a la Constitución de 1950 en el 62, y lo que se hizo fue retomar de nuevo esa nueva estructura de cuarto poder, que no existe tan comúnmente en América Latina, es decir, aunque exista la rama de los tribunales electorales, pero que no tienen la estructuración de poder, en tanto y cuanto, si hay algún recurso de cualquier naturaleza es atendida por el sistema judicial, y no por el mismo poder electoral, como es en el caso de Nicaragua, que ¿por qué en Nicaragua sí y en los demás países no?, es una pregunta que yo siempre me la he hecho, y a la conclusión que he llegado es que, probablemente, Somoza tenía muchos asesores, que trataban de ser modernizantes, él creó una buena Ley de Seguridad Social, una buena Ley Tutelar de Menores, etc., ya que si la aplicación era buena o mala, nos gustaba o no

68 Entrevista interesante, especialmente, por las referencias a la creación y evolución del Consejo Supremo Electoral, además de su reciente deterioro institucional junto a otros poderes del Estado, como el Poder Judicial, y los visos de conflictividad social y política, que están teniendo lugar en Nicaragua con amenaza del rompimiento del orden constitucional democrático. 
nos gustaba, eso era otro tema, pero, que, probablemente, por ahí vino la idea, que yo encontré, por primera vez, en la historia en Simón Bolívar en su proyecto de Constitución Política para Bolivia y todo el sector que estaba trabajando, entonces, luego, de esta Constitución Política de 1987 se establecen, de nuevo, los cuatro poderes del Estado, donde se establecen las funciones y atribuciones del Poder Electoral, básicamente, organizar, administrar, dirigir y supervisar elecciones, atender en última instancia cualesquiera tipos de recursos que se presenten en materia electoral, sin que exista ulterior recurso en ninguna parte, sí existen ulteriores recursos en temas de derechos políticos de los partidos, y en temas de derechos de obtención o no de la cédula de identidad, que fue una función y atribución que se le adicionó al Consejo Supremo Electoral, al Poder Electoral en 1993, una vez que se aprobó la Ley de Identificación Ciudadana, que, por segunda vez, se intentó realizar en Nicaragua, pero esta vez con éxito, la primera vez fue en los años 70 en la época de Somoza, pero la gente no le daba la información a las estructuras de Somoza, porque les daba miedo que los que estaban entregando los datos para estar después vigilados o chequeados por la posibilidad de persecución política o ciudadana que podía hacer Somoza, en el caso nuestro, pues, tuvimos la suerte, porque también, a la vez, tuve la suerte yo de dirigir, inicialmente, junto con el doctor Mariano Fiallo y otros Magistrados del Consejo Supremo Electoral toda la organización, administración, y realización masiva e intensiva de la cedulación en Nicaragua, por cierto, que con un apoyo importante de España y de muchos otros países de Europa, Estados Unidos, Canadá, etc., de manera tal que el Poder Electoral ha mantenido hasta la fecha ese mismo concepto, los cambios que ha habido han sido de aumentar el mismo número de miembros del órgano electoral, se inició con tres, posteriormente, en una reforma que, generalmente, tienden a hacer por razones políticas se aumento a cinco, y ahora se aumentó a siete, que, a partir de la últimas reformas constitucionales en este tema, que tuvieron vigencia a partir de enero del 2000, estas últimas fueron ya producto de un pacto político entre Daniel Ortega del Frente Sandinista y Arnoldo Alemán del Partido Liberal Constitucionalista, lo que vino, desafortunadamente, a completar el ciclo de partidarización del órgano electoral, mismo que inició en 1995 con unas reformas constitucionales, donde se obligaba a que la forma de estructurar el órgano electoral fuera de forma partidista, desde las juntas receptoras de votos, que es la unidad más pequeña, donde los ciudadanos vamos a depositar nuestro voto, pasando por los consejos electorales municipales y departamentales, de manera tal que si el presidente de la junta, que había sido nombrado, era del partido liberal, el primer miembro tenía que ser del partido del segundo lugar, en este caso, el Frente, porque las anteriores elecciones las habían ganado los liberales y el Frente había quedado en segundo lugar, y el tercero a cualesquiera de los otros partidos políticos, que tuvieran participantes en las elecciones, eso fue en la reforma constitucional de 1995, y así ha venido estando la historia, no se había hablado de cómo se iban a constituir los Magistrados del Consejo Supremo Electoral desde el punto de vista de que fuesen partidarizados también, no obstante, en práctica, ha venido funcionando el mismo esquema, porque, normalmente, han tenido mayoría absoluta entre los dos, de diputados, entre los del Frente y los del Partido Liberal Constitucionalista, de manera que, a mi juicio, esto le ha hecho un gran daño a la institucionalidad del país, porque, obviamente, al estar manejado el órgano electoral por dos o un partido político, porque el Frente ha estado teniendo posiciones hegemónicas dentro de, no solamente, el organismo formal de juntas, consejos electorales municipales, departamentales, regionales y el propio Consejo, sino a través de los funcionarios permanentes, que utiliza el Consejo en sus diferentes estructuras, entonces, si está monopolizado un poder del Estado por un partido político, que además 
participa en una elección, obviamente, pone en notable desventaja a los otros candidatos de partidos políticos diferentes al Frente Sandinista, y hemos visto como el deterioro ha sido tan grande, empezó a partir de enero del 2000, y su etapa más grande han sido las elecciones de noviembre del año pasado municipales, en donde es el día de hoy y todavía no conocemos el $100 \%$ de los resultados electorales de esa elección, lo cual, obviamente, es una agresión a la institucionalidad, al derecho político de los ciudadanos, de los candidatos y de los partidos y alianzas de partidos políticos participantes, pero lo que es grave es que también todavía estamos esperando los resultados finales de las elecciones presidenciales y generales del 2006, y estamos en el 2009, en septiembre del 2009, entonces, se está tomando este Consejo como una tónica de dar la información que quieren dar y cambiar los datos que dieron hoy, mañana ya son otros, y en eso, por ejemplo, ha sido muy interesante como en las elecciones municipales, por poner un ejemplo, en Puerto Corinto, el candidato a alcalde por el Partido Liberal Constitucionalista se va a dormir después de un anuncio oficial, que hace el Consejo Supremo Electoral en pleno, donde su presidente anuncia que después de haber escrutado el $100 \%$ de los votos de las alcaldías de Corinto y de concejales municipales, sale ganador el candidato del Partido Liberal Constitucionalista, al día siguiente en la mañana, que se despierta este señor vuelve a escuchar la misma historia, y, bueno, es alcalde, ¿no?, pero al día siguiente ya dicen que como hubo recursos de impugnación y tal, entonces, ya no, pues, ya se cambió, ahora él no es el ganador, sino que es el del Frente Sandinista, y sin tampoco darle ninguna explicación de cuáles fueron los recursos presentados, por qué fue el cambio, etc., entonces, obviamente, esto está resultando bien difícil para poder pensar que el Poder Electoral como tal está actuando adecuadamente conforme a la Constitución Política, conforme a la Ley Electoral que tiene rango constitucional en Nicaragua, y muchos dicen que deberían hacerse reformas constitucionales para evitar que todos estos resquicios y problemas en la administración electoral, sin embargo, ahorita está en el tapete la voluntad de Daniel Ortega de hacer reformas constitucionales también, pero para que pueda volverse a presentar como candidato a presidente de la República, cuando en Nicaragua, en las reformas constitucionales de 1995, se puede, uno que fue candidato a presidente, puede volver a presentarse pero con un período de por medio, no en períodos sucesivos, o sea, que si ahorita Daniel Ortega es presidente no puede ser candidato a presidente en las siguientes elecciones, pasadas esas siguientes elecciones sí podría correr en otras, pero, en este momento, creemos en Nicaragua que la reelección le ha causado mucho daño al país, y por eso muchos estuvimos de acuerdo con que se planteara el tema de la no reelección sucesiva, mismo que ahora quieren abrirlo, verdad, obviamente, con intención de volverse a presentar como candidato el actual presidente, entonces, estamos en una situación muy compleja, en todo este tema, porque, desgraciadamente, de alguna manera se siente como letra muerta la norma jurídica, porque, en primer lugar, se señala, y es elemental, pues, hasta por lógica, que si participan y si hay elecciones, pues, lo elemental son las estadísticas, junta por junta, cuáles fueron los resultados, cuáles fueron los números de votos depositados, cuáles son los votos válidos, cuáles son los votos en blanco o nulos y cuánto corresponde de esos votos a cada partido o alianza de partidos participantes, y que si hay algún tipo de recurso que se presentó en la propia junta, o hay algún tipo de recurso de impugnación, pues, el órgano electoral lo debe de atender y dándole la oportunidad a que funcione la justicia electoral, dirimiendo, simplemente, y evacuando las consultas, las impugnaciones, los recursos de apelación de lo que sea. Pero todo esto se ha roto, entonces, en alguna medida no es, exactamente, el problema en la ley ni en la propia Constitución Política, sino que en la aplicación de la misma están haciendo los funcionarios públicos, que 
están administrando y aplicando la ley, por eso el tema, por ejemplo, de la observación electoral internacional y nacional, eso está establecido en la Ley Electoral con toda claridad, y en las funciones y atribuciones constitucionales de los Magistrados, establece que tiene que otorgarlo y hay un reglamento especial que para cada elección los Magistrados dictan cómo va a organizarse el tema, pero porque sí, decidieron que la observación electoral nacional no cabía, porque se habían partidarizado, porque aquí, porque allá, entonces, como, nuevamente, este sí y este no, esta organización sí, esta organización electoral no, e, incluso, trajeron en las últimas elecciones presidenciales a un Consejo de ex-funcionarios electorales, el CEILA, pagados por el propio gobierno para venir a observar la elección, entonces, es como estar de juez y parte, porque el propio Poder Electoral es el que los está subvencionando, y el observador se supone que tiene que tener toda la imparcialidad, y a quien va a observar también el órgano electoral, además de todo el proceso, ¿no?, y como parte del proceso lo que haga el árbitro electoral, para ver si otorgó las suficientes garantías y si se respetaron todos los debidos procesos, entonces, estamos en una maraña muy dura, muy difícil, porque, pues, Nicaragua ha tenido si usted analiza históricamente, ha sido plagada en los años de Somoza, precisamente, los 50 años que estuvieron, de manipulaciones, de fraudes electorales, entonces, es, precisamente, contra eso que el pueblo se sublevó, ¿verdad?, entonces, es muy triste que ahora volvamos a estar en un episodio muy parecido de lo que antes el mismo Frente Sandinista y el propio Daniel Ortega combatió, entonces, es como una contradicción y como un regreso a lo que se había considerado como inadecuado para Nicaragua y para la democracia, entonces, pues, desde que ganó Doña Violeta el 25 de febrero de 1990, donde sí hubo una elección muy observada por las Naciones Unidas, por la OEA, por la Unión Europea, es decir, hubo un contexto enorme de observación como nunca en la historia de Nicaragua, desde entonces se habla de que estamos en un período de transición democrática, pero estamos hablando de 1990, ya han pasado casi 20 años, pues, ¿verdad?, y seguimos hablando de transición democrática, y seguimos hablando de debilidad institucional, y seguimos hablando de una serie de cosas, debo de reconocer que en la época de Doña Violeta es cuando más se logró fortalecer la institucionalidad democrática en Nicaragua, a mí me tocó estar de presidenta del Consejo Supremo Electoral en la época de ella, y fue muy interesante el gran respeto que ella siempre tuvo para los otros poderes del Estado, no podemos decir lo mismo ahorita cuando todos los poderes del Estado, de una u otra manera, están obedeciendo a personas y no a los principios democráticos, ni a ajustarse a la Constitución Política, y si usted lee las encuestas que ha habido, sucesivamente, en este tema todos tienen esa percepción de que hay una influencia muy grande de parte, en este caso, actualmente, del Poder Ejecutivo, pues, antes era con nombre y apellidos Daniel Ortega, pero ahora es la misma persona, pues, el presidente y Daniel como líder del partido Frente Sandinista, que influencia de una forma increíble los diferentes poderes del Estado, que, a la vez, están constituidos casi por bancadas de partidos políticos, y no por Magistrados, para mí es impensable, como abogada que soy, pensar que la Corte Suprema de Justicia va a tener una bancada sandinista y una bancada liberal, porque cuando se es Magistrado, ya sea del Poder Electoral, del Poder Judicial, o si es miembro de la Contraloría General de la República, o de cualquier función pública no se está actuando como partido político, porque, entonces, ya hay una mezcla de interés partidario en vez del interés de la nación, y el dirimir el tuyo y el mío conforme a la ley, y no conforme a otros intereses, que lo que está en juego, y el problema que está planteado en Nicaragua en los diferentes estratos, entonces, el gran problema es: ¿necesitamos otra Constitución Política?, ¿necesitamos otra Ley Electoral?, yo creo que tendríamos que partir o recuperar la institucionalidad democrática y tener Magistrados, 
pero con letra grande, y que funcionen como tales, ¿no?, y no como dentro de un ajedrez un peón que está en función de otro interés, y eso es para mí lo preocupante en este momento en Nicaragua, y que está teniendo repercusiones y, peligrosamente, las puede tener para las elecciones del 2011, donde, de nuevo, vamos a tener elecciones generales de presidente y vicepresidente de la República, de diputados ante la Asamblea Nacional, y diputados ante el Parlamento Centroamericano, si se vuelve a repetir la historia, que se ha venido dando en los últimos procesos electorales entre el $2000 \mathrm{y}$ las del año pasado 2008, llevamos ya ocho años en esta tremenda situación, pues, obviamente, la gente va a ir perdiendo esperanza por un lado, por un lado, y, por otro, podemos llegar a caer a la situación que tuvimos, en la que todo el mundo se sublevó, y llegar a una guerra civil en el país, que no es deseable para nadie, claro, que el principal responsable de todo esto tiene que ser el propio mandatario y los propios funcionarios que están al frente de los diferentes poderes del Estado, porque tampoco, todos son grandecitos, ¿verdad?, porque aunque el Poder Ejecutivo le diga al Poder Judicial le diga: "hace tal cosa", o si Daniel Ortega le diga: "hace tal cosa", o Arnoldo Alemán le dice, que, perfectamente, le puede decir, "gracias por su consejo, y luego actuar, yo voy a actuar conforme a Derecho y punto”, ¿no?, entonces, yo creo que es una responsabilidad o corresponsabilidad de la disfuncionalidad del sistema de derecho y del sistema democrático de Nicaragua compartido entre los que están en este momento detentando los diferentes cargos en los poderes del Estado, y, entonces, para mí el problema no es constitucional, no es de Derecho electoral, para mí el problema, en este momento en Nicaragua, es un problema político, un problema de entender, racionalmente, cómo debe ser el funcionario público, y no dejarse influenciar ni actuar per se con influencia política partidaria o interés particular al momento de ejercer su función pública, $y$, en ese momento, está respetando el mandato por el cual juró actuar respetando la ley y el orden, pues, entonces, yo creo que esa es la mayor complejidad que tiene Nicaragua, y es tan grave que, incluso, la comunidad internacional la ha percibido de esa manera, y está retirando su apoyo al presupuesto de la república, en tanto y cuanto, no se aclare, no se determine qué es lo que está pasando con este tema electoral, es más, la comunidad ha sido más que generosa, no sólo en cuanto a que en diferentes momentos desde el 79 hasta la fecha había venido dando unas cantidades extraordinarias de apoyo al país, que lo pudimos haber hecho ya seis veces de nuevo el país, no, solamente, en ese sentido, sino que, ya de último, le dijeron: "bueno, OK, nos olvidamos de lo que pasó en las elecciones municipales, tiramos para adelante, pues, danos muestras de que van a tener unas elecciones y que no va a volver a ocurrir eso", tampoco eso se ha dado, entonces, creo que tenemos un problema serio, porque si le sumamos el problema de constitucionalidad, de institucionalidad, y de profesionalismo de las instituciones al agravamiento de la economía por los problemas internacionales, y por los problemas propios del país, pues, entonces, vamos a tener un país con problemas de funcionamiento del Estado de Derecho y de institucionalidad democrática, y también con problemas económicos más difíciles que nunca, pues, ¿verdad?, y, entonces, estamos viendo como la zona franca está cerrando, en la zona franca están cerrando muchas empresas, y se están yendo fuera de Nicaragua, como el inversionista nicaragüense está un poco temeroso, medianamente, temeroso, o muy temeroso, dependiendo de quien sea, y, entonces, el desempleo está aumentando, la pobreza está aumentando, y vemos cómo hay capitales emergentes que no existían antes, entonces, estamos, realmente, en una situación desquiciante y ojala que pudiera resolverse, como el problema es político, pues, también tenemos que hablar, aunque yo sé que es de Derecho Constitucional de lo que estamos hablando, pero la Constitución y las leyes no están en el aire, están dentro de un contexto, dentro de un marco, y el marco y el 
contexto donde se está desarrollando, pues, lamentablemente, crea una situación muy difícil, ahorita hay una oportunidad de oro que si se quisiera, realmente, mejorar esta situación institucional, pudiera hacerse, porque se le va a vencer el período constitucional a diferentes, a todos los Magistrados del Consejo Supremo Electoral, y a una gran parte de la Corte Suprema de Justicia, y de la Contraloría, entonces, y de la Fiscalía General de la República, entonces, sería un momento de oro par tratar de recomponer las instituciones sin necesidad de una guerra como la del 19 de julio, ¿no?, y poderlo hacer bajo un entendimiento nacional, es impresionante como se están alineando la Iglesia católica, los evangélicos, los anglicanos, partidos políticos de oposición, empresa privada, conceptos que menciona la comunidad internacional en una sola voz clamando por institucionalidad y Estado de Derecho, ¿verdad?, obviamente, los que se sienten muy cómodos con esta situación es el Frente Sandinista, y, en alguna medida, el Partido Liberal Constitucionalista, y el doctor Alemán, aunque, de repente, ellos mismos se sienten un poco nerviosos, porque sienten que el Frente se le están yendo más adelante de las pretensiones igualitarias que, supuestamente, debería de tener, entonces, esa es un poco la situación, pero no sé si tiene alguna otra pregunta.

R: Sí, el hilo conductor de las reformas, al menos tal y como aparece en el discurso político que justifica o legitima el cambio constitucional, ha sido el de reducir o limitar las facultades del presidente de la República, ese hiperpresidencialismo que aparecía consagrado en la Constitución original del 87, y conceder mayores facultades o atribuciones a la Asamblea Nacional, pero es cierto, que al conceder mayor peso a la Asamblea en el proceso de elección de los altos cargos que integran, digamos, la cúpula de los principales órganos del Estado ha habido irregularidades, en el caso de la Corte Suprema, por ejemplo, que no se ha respetado el principio de elección de los Magistrados, que es una elección individual, los bloqueos partidarios han sometido, incluso, a retrasos la elección del presidente de la Corte Suprema o del Consejo Supremo Electoral, que también ha sufrido situaciones parecidas, me imagino, ¿no?, o sea, paralizar las funciones que tiene constitucionalmente asignadas el órgano, porque hay bloqueos entre los dos principales partidos a la hora de ponerse de acuerdo respecto a la propia composición, y me imagino que los otros asuntos, el día a día, digamos, de la gestión, debe ser muy parecida.

R.M.C.: Es muy parecida, esos son, digamos, los baches grandes que se han venido dando, se quiso impulsar, y se hizo y promulgó la Ley de Carrera Judicial, precisamente, para tratar de evitar que se dieran este tipo de componendas políticas y pactos políticos para elegir al Magistrado del Tribunal de Apelaciones o a un simple juez, de alguna manera, ha mejorado, pero continúan, usted sabe que para una norma jurídica también se le puede buscar el by pass, ¿verdad?, para cambiar la vaina, y sí se sigue, pues, desgraciadamente, con esas situaciones de que este juez es sandinista, este juez es liberal, hay Dios mío, ¿dónde me irá a tocar el caso?, porque si yo no soy ni liberal ni sandinista, entonces, estoy frito, porque si el otro abogado sí lo es, del mismo signo del partido político del que es el juez, entonces, obviamente, que él va a querer hacerle el favor al otro, y a mi defendido me va a ir mal, entonces, realmente, esto lo vemos desde cosas muy simples, hasta cosas muy complejas, verdad, porque se dice y se hablan muchas cosas, pero en la vida real lo que sí es cierto es que hay una alta incidencia de partidarización en toditos los poderes del Estado, y en todos los órganos de Estado, que está contaminando la situación, quieren hacer, por ejemplo, reformas constitucionales en 1995 se hicieron en ese espíritu de que la del 87 tenía un condimento muy fuerte presidencialista, y que había que redistribuir, y me pareció muy 
bien, porque eso dio un verdadero balance al estilo de Montesquieu, ¿verdad?, que, precisamente, esa es la idea al existir diferentes poderes del Estado, que no esté concentrado el poder en un solo poder, que, en este caso, era el presidente, el Poder Ejecutivo, entonces, se redistribuyeron entre los dos, entre el presidente, incluso, cuando estuvo Don Enrique Bolaños de presidente, anterior a Daniel, para menoscabar a Don Enrique, porque ahí sí que había aliados, tácticamente, el Frente y el PLC hicieron reformas constitucionales donde a Don Enrique tenía que pedir ratificación de los ministros, de los embajadores, y qué se yo, entonces, pero lo que era bueno en ese momento, ahora ya no lo es, y, entonces, ahora Daniel, que es el presidente, no le interesa estar pasando a ratificación a sus ministros y a sus embajadores, entonces, antes eran unos discursos altisonantes, de la importancia de que se ratificaran en el parlamento estos cargos, y ahora, ¿por qué no se hace?, es decir, hay una contradicción entre discursos, si nosotros viéramos los periódicos o los diarios de debate de ese momento, y lo comparamos con la actuación actual, pues, vemos una discordancia absoluta, ¿no?, entonces, por eso digo que estar pensando, por ejemplo, si no ponen la reelección quiere el Frente hacer una reforma para hacer un parlamentarismo de manera que haya un cambio de sistema, y que exista el primer ministro, hacer todo un, darle más fuerza todavía al parlamento, y que a través del parlamento se elija al primer ministro, ¿eso es lo más importante para Nicaragua?, un país tan pobre como el que tenemos, ¿va a solucionar esto el empleo?, ¿va a haber más desarrollo económico?, ¿va a darle credibilidad a las instituciones?, ¿van a funcionar bien?, entonces, si no sirve para eso, que es lo que necesitamos, ¿para qué va a servir?, ¿para concentrar el poder ahora, entonces, en el Parlamento, y que pueda ser primer ministro Daniel, porque la prohibición es del presidente y no la del primer ministro?, entonces, ¿de qué estamos hablando?, entonces, pues, si queremos poner las cartas sobre la mesa, pues, pongámoslas, ¿verdad?, pero creo que si seguimos en esta situación vamos a tener una situación muy mala para el país, ¿verdad?, entonces, aquí se han hecho reformas constitucionales con dedicatoria, y eso no es nuevo, no es nuevo, incluso, para las elecciones del 96, y es un ejemplo muy claro, se hizo una reforma constitucional para que Antonio Lacayo que era yerno de Doña Violeta no pudiera ser candidato a presidente, entonces, como decía el proyecto de reforma, ¿verdad?, que el que sea pariente del presidente en tal grado de consaguinidad o en tal grado de afinidad no va a poder ser candidato, entonces, bromeando, dice Antonio Lacayo, "ah, pues, me voy a divorciar de Cristiana", entonces, le pusieron, como no lo habían aprobado el que sea o haya sido, entonces, más clara, hacer ese tipo de cosas resulta más bien complicado, entonces, más bien se ha tomado casi de risa, pues, este tipo de cosas, cuando, precisamente, una Constitución Política es una Carta Magna, es lo máximo en rango que tenemos en un país, y que para modificar algo tiene que haber una fundamentación y por una realidad fundamental y no por un capricho o por afectar el derecho de otro, entonces, desgraciadamente, en Nicaragua tenemos esta situación, que cuando se va a hacer una reforma uno tiene que ver detrás a quién es que quiere afectar o a quién quiere beneficiarse, $y$, generalmente, a quien se quiere beneficiar es a una persona con nombre y apellidos y no a la nación, porque cuando hablamos de beneficios tendría que ser para la ciudadanía, el pueblo nicaragüense, todo, no a favor o en contra de fulano o mengano, entonces, creo que si usted analiza, hemos tenido como 14, digamos, entre 12 y 14 constituciones políticas, ha habido reformas de diferentes tipos, y si usted analiza cada una de las reformas la mayoría son de carácter político, precisamente, yo soy abogada, pero con este esquema del Poder Judicial es difícil estar ejerciendo la profesión, ¿verdad?, de abogacía, entonces, nos hemos diversificado, estamos usando la creatividad para hacer otras cosas, pero, pues, y tanto Jorge como yo somos abogados, 
mi esposo y yo, pero bueno, es parte de la situación misma que está viviendo el país, pero bueno, no sé si la estoy ayudando o no.

R: Sí, claro que sí, pero antes cuando refería la historia constitucional, esta mañana que estuve además en el Instituto de Historia de la UCA, y hablando con uno de los profesores y académicos, Carlos Navarro, me hacía una semblanza muy breve además, porque no disponía de mucho tiempo, pero hablando, en términos de cultura política, de la formación de esta mentalidad de las élites depredadora, cortoplacista y con una especie de incapacidad para pensar en el bien común y tener un sentido de Estado, ¿no?, al modo en que describieron los ilustrados, ¿no?, no es algo que no se sufra en Europa, que también, lo único es que las instituciones son más fuertes y es más difícil que el Derecho, en ese sentido, sirva de instrumento a la acción del poder, que bueno es muy dificil, pero colocarse por encima de la norma constitucional, a mi lo que me sorprende en el caso nicaragüense es como se ha fragilizado el procedimiento mismo de revisión, como se revisa la Constitución por una ley de reforma parcial, por ejemplo, ¿no?, como se crea una Ley Marco para aplazar temporalmente una norma constitucional, y ampliar el proceso de negociación política, ese tipo de situaciones.

R.M.C.: Y ha habido ya dos leyes Marco que se han implementado, pero es parte de la fragilidad misma de la situación de Nicaragua, entonces, algunos amigos extranjeros como consuelo me dicen: "es que son una democracia joven”, pero ¿cuándo vamos a dejar de ser jóvenes?, porque yo lo que veo es que más que juventud ya es como una cierta incapacidad de la clase política de tener una visión de nación y de futuro de una manera más consecuente con la realidad misma y no con los intereses propios como partido, como persona, o lo que sea, entonces, ahí es creo yo, donde está el mayor, la falta de sintonía, y va a llegar un momento en que la población puede estallar, porque, es decir, el pueblo aguanta, aguanta, aguanta, aguanta, pero, de repente, cuando siente que la carga le está cayendo sólo a él, y que todo a su alrededor estaba malo, pues, ahí es donde vienen las guerras y donde vienen, que es mi principal preocupación, los estallidos sociales, ¿no?, y pueden las propias contradicciones internas, que se dan en las propias instituciones son más grandes de lo que se cree, pero lo que pasa es que hay un aplastamiento entre los grandes jerarcas de las instituciones versus los que están abajo, y por eso es que después vienen las grandes corridas que van depurando la institución, y poniendo gente que no importa que no tenga capacidad, pero que sí va a tener sumisión en su actuación, entonces, eso es lo peligroso, verdad, porque estamos llegando a momentos insostenibles ya de esto, ¿hasta cuando vamos a llegar así?, ¿hasta dónde va a llegar todo esto?, pues, esa es la gran pregunta, ya tenemos desde el 2000 que inició $\mathrm{y}$ se ha ido oscilante $\mathrm{y}$ ahora se está profundizando las grandes contradicciones, problemas, e irrespeto constitucionales y a la Ley Electoral, digo irrespeto, porque en la medida en que no se están aplicando las normas jurídicas tan cual el mandato, entonces, hay una irreverencia ya no de un tercero, sino de que del propio aplicador, que es lo grave, porque si es un partido político el que hace algo, pues, entonces, hay una autoridad que pone en orden a ese partido político para que le devuelva la situación al Estado de Derecho, pero si es la propia autoridad, y si encima la propia autoridad es la última en poder dirimir, que tampoco es ningún consuelo una reforma constitucional que haga que la última palabra no la tenga el Consejo, sino que el Poder Judicial, porque, simplemente, es cambiar de "patio", pero con el mismo esquema partidarizado, entonces, ¿qué más da?, porque por ahí dicen: "hagamos una reforma constitucional y ya el Consejo ya no va a ser el que da, que no haya recurso ulterior, sino que haya un recurso que lo atienda el Poder Judicial", cambia el nombre, 
nada más, pero el concepto se mantiene intacto, entonces, pienso que aquí la gran tragedia, y lo que tendría que atacarse es el rescate del funcionamiento de la institucionalidad a través de los que tienen que aplicar la norma jurídica, y una vez rescatado eso, revisar la norma jurídica para ver qué es lo que necesita perfeccionarse, porque, obviamente, pues, siempre es necesario, pero, en este momento, si usted me dice, pues, si yo, pues, usted me dijera: "usted tiene la facultad de hacer reformas, ¿cuáles reformas le gustaría?”, la despartidarización total de los organismos, si hubiera alguna reforma que hacer es que se prohíbe con letra grande de que se nombren Magistrados que procedan de partidos políticos si han ostentado un cargo en los últimos 5 años en las altas estructuras partidarias para empezar, porque es mentira que tampoco, porque pertenece o perteneció a un partido político no puede ser, porque este país es un país altamente politizado, y aquí o se ha sido o se es de un partido político, entonces, tampoco no es esa la, pero aquí ya todos nos conocemos, si este es un país chiquito, entonces, perfectamente, se sabe cuáles son las capacidades y hasta dónde puede llegar cada uno, entonces, yo creo que la urgencia más grande, en este tema es eso, y en todo caso, mi gran sugerencia, que lo he hecho públicamente, es que en las elecciones del 2011, primero, de que se recompongan a partir de estos se le está venciendo a estos miembros que le decía, con criterios despartidarizados, que se haga la elección de éstos, y, luego, en las elecciones del 2011, que se vuelva a nombrar con funciones de Constituyente a los diputados para que se haga una nueva Constitución, pero no hacerla ahorita a la luz de querer hacer reformas constitucionales cambiando sistemas, cuando no se puede hacer porque esa no es reforma parcial, ya eso es reforma total de la Constitución, porque está haciendo un cambio, entonces, no la puede hacer una Asamblea Nacional ordinaria.

$R:$ ¿Al tema de la reelección se refiere?

R.M.C.: No, me refiero al parlamentarismo, no, al de la reelección sí se podría.

$R$ : ¿Se refiere a la creación de la figura de un Primer Ministro en la estructura del Poder Ejecutivo?, ¿eso sí exige reforma total?

R.M.C.: Sí, porque es un cambio del sistema, es decir, no importa que se estén cambiando 5 artículos, pero si estos 5 artículos son fundamentales y se les está dándole la vuelta, es como que si, de repente, dijéramos: "bueno, ahora vamos a ser monárquicos", se va a cambiar uno, ya no vamos a ser presidencialistas, es monarquía, pero es una reforma total, porque todo lo que se desprende de ahí ya es diferente.

R: Y de la figura de la "pareja presidencial", que parece haber concentrado no solamente la concentración de poder en las instituciones por la preeminencia del Frente Sandinista, sino por la división de la oposición, que, en estos momentos, tiene incluso problemas para manifestarse, según los testimonios de la sociedad civil ante, por ejemplo, el fraude electoral de las elecciones municipales, ¿no?, hay personas que me dicen abiertamente que la oposición no tiene sitio en Nicaragua, ¿tan grave es la situación?

R.M.C.: Pues yo diría que sí, desgraciadamente, se ha visto no solamente después de las elecciones municipales, sino que durante las elecciones municipales, al no permitir los accesos y libertad de movilización y de expresión en que la ciudadanía y los partidos políticos diferentes al Frente, y la sociedad civil organizada, que ha querido hacer 
diferentes plantones, expresiones, cívicos, completamente, y no, solamente, impedidos, sino que agredidos, sí, porque son dos conceptos diferentes, una cosa es que no te voy a hacer algo, pero a las buenas, ¿no?, ah, entonces, ¿no querés?, ¿no lo vas a dejar de hacer a pesar de las amenazas?, entonces, ha habido, ha habido situaciones muy fuertes, $\mathrm{y}$, desgraciadamente, ha habido situaciones en que la misma Policía no ha actuado a la altura, entonces, se complejiza todavía más el tema porque, hasta la fecha, ni el Ejército ni la Policía, pues, han tratado ellos de preservar su institucionalidad, pero la Policía, de repente, se vio un poco resquebrajada, y ese es un gran reclamo que también se tiene para la Policía, entonces, ya estamos entrando a otro ámbito del tema, ¿verdad?, y, bueno, la creación de los $\mathrm{CPC}$, que, políticamente, es una estructura paralela $\mathrm{y}$, jurídicamente, no cabe y menos al estar subvencionado por el Estado, es que hay una serie, si se pone el listado de todas las agresiones a la Constitución o las violaciones a la Constitución pasamos todo el día y toda la noche hablando de ello, y, probablemente, se me olviden algunos, porque son demasiadas desde los mismos símbolos patrios, que existe una ley de los símbolos patrios, de cuáles son los colores, cuál es la figura y todo, pero usted vaya a ver cuáles son los símbolos que están en las cartas de los ministerios y demás, es una historia psicodélica que se le ocurrió a Doña Rosario Murillo, entonces, son cosas bien particulares, que se están dando, que lo que refleja un poco es la voluntad política de lo que se pretende hacer, ¿verdad?, que es lo preocupante, porque el presidente de la República tendría que ser el principalmente respetuoso de la Constitución Política, el Poder Judicial por su propio peso, como Magistrados de la Corte, de igual manera el Poder Electoral en el ámbito electoral, pero sí ninguno está cumpliendo ahí adecuadamente con sus funciones, pues, el resultado que vamos a tener, obviamente, es de irrespeto y si eso se va reproduciendo para abajo, porque el subalterno ve lo que hace el otro, entonces, va reproduciéndose, en consecuencia, ¿qué es lo que tenemos?

R: Entonces, ya para finalizar, qué última reflexión, aunque ha hecho muchas, ¿no?, y además su propia recomendación y su sugerencia, ¿qué futuro augura para la democracia nicaragüense de apenas, pues, 19 años, si contamos desde el 90?

R.M.C.: Pues, muy difícil, ¿verdad?, yo creo que estas reformas constitucionales que culminaron en enero del 2000 del pacto político entre Daniel y Arnoldo, para mí que son el principal origen de los problemas de la falta de institucionalidad o de fragilidad institucional que tenemos en este momento, el mismo hecho de que en el 95 se había subido el techo para poder ser electo presidente, y mediante ese pacto se bajó, de manera que Daniel Ortega salió electo con una cantidad de votos muy por debajo de lo que debería de tener de respaldo para poder gobernar, con un 38\% es gobernar desde una minoría, creo que ese es el origen, en este momento, visible del problema y luego se ha mantenido este pacto político, y ha seguido avasallando la institucionalidad democrática del país, entonces, de lo que se trataría es, en todo caso, de devolver, de nuevo, por lo menos antes del pacto, para tratar de abrir un nuevo camino, pero eso lo veo muy difícil, precisamente, porque lo que originó el pacto se mantiene igual, y las personas que lo hicieron están ahí siempre con el mismo entendimiento, entonces, desde ese punto de vista es muy difícil, la oposición muy debilitada, se necesitaría como se dio para las elecciones del 25 de febrero del 90, que se hizo una unificación de la oposición, que hay ultimada y capitalizada de este descontento para poder romper con, ¿se va a lograr eso?, hay una incógnita, en este momento, yo veo muy nublado el camino para que puedan recomponerse la institucionalidad del país, pensar que el propio Frente, el propio Daniel va a recapacitar y va a decir, bueno, he hecho esto, o no voy a decir que 
lo he hecho mal, pero ahora quiero hacer esto bien, lo veo también difícil, porque hacerlo bien significa poner en riesgo la posibilidad de ya no seguir ejerciendo el poder, y es algo que algunos dirigentes del propio Frente han dicho: "no vamos a cometer de nuevo la tontería de que habiendo sido gobernantes dejar perder el poder", y eso lo dijo el Comandante Tomás Borge con todas sus letras, que si lo dijo en nombre de o en representación de, o es un pensamiento personal, pero en la vida real, pues, van caminándose para allá los pasos, entonces, se ve nublado el camino, ahora, yo siempre soy optimista y yo creo mucho en el propio pueblo de Nicaragua, y que el propio pueblo de Nicaragua es el que al final termina reaccionando y haciendo recapacitar a sus dirigentes, el asunto es cuánto tiempo más el pueblo de Nicaragua va a aguantar esto, igual puede ser para las próximas elecciones, igual puede pasar 10 años más, 20 años más, entonces, en este momento, desgraciadamente, nadie tiene la bola de cristal para poder predecir y decir, pero el hecho real y cierto es que estamos en una situación muy complicada, y lo único bueno, que veo yo, es que, en esta ocasión, Daniel Ortega y compañía no quieren desmarimbar la economía como fue en los años 80 , es, digamos, lo único bueno, en el sentido de tratar de mantener los acuerdos con el FMI, con esto, con el BID, con el no sé cuanto, tratando de hacérselo bonito con la Unión Europea y con los Estados Unidos, pero a la vez no quieren ceder para nada en el tema de la institucionalidad, porque, me imagino, que en alguna medida sienten que si ceden en ese tema también estarían cediendo la posibilidad de que gane otro la Presidencia de la República y los altos cargos de diputados, etc., y teniendo la diputación, tenés en la mano la llave para nombrar a Magistrados del Poder Judicial, del Poder Electoral, de la distribución del poder, y su detentación, entonces, por eso la tentación es muy grande, algunos deciden, ¿no?, Daniel ya no va a repetir los mismos errores de los años 80, ya aprendió, ya es así, ya es asá.

R: Pero también él se está enriqueciendo económicamente, bueno, hablan de la compra de empresas, de los empresarios sandinistas.

R.M.C.: Entonces, pero, a la vez, al haber empresarios sandinistas eso ya los hace más débiles, en el sentido de que tengo que proteger mi capital, ¿verdad?, y por eso es que no quieren desmarimbar la economía, pero cuando no se están haciendo las cosas derechito se pueden enredar en su propia madeja, y ahí es donde el pueblo en algún momento puede pasar una cuenta en el sentido de tratar de recomponer por sí mismo las cosas a través de un estallido social, a través de una guerra, o a través del voto, pero siempre y cuando a través del voto se respete, y ese es el gran dilema, porque a través del voto fue en el 25 de febrero del 90 que cayó el régimen del Frente Sandinista, no fue a través de las balas, fue a través del voto, es cierto que se llegó al voto, después de una guerra interna que había, y con influencia de los Estados Unidos, y todo lo que se quiera, pero terminó siendo el voto el que prevaleció, y votó por Doña Violeta y no votó por Daniel, pero, entonces, ahora, el problema de ellos es que las alternativas son: estallido social, guerra civil, o voto, pero si el voto, que es el arma más pacífica que uno tiene para poder salir de un gobierno que no te gusta, que falla, te vas a la guerra civil o te vas al estallidos social, que es la violencia, y es lo que no queremos, es lo que nadie quiere, por el mismo Daniel, por muy cerrado que sea, no creo que quiera volver a una guerra, no le hace bien a nadie, así que estas son las interrogantes y los caminos tan raros.

\section{R: Pues, muchas gracias por la entrevista.}


ENTREVISTA 50 ${ }^{69}$ :

Nombre del entrevistado: D. Mauricio Zúñiga.

Cargo actual: Director Ejecutivo de IPADE.

Fecha de realización de la entrevista: Managua, 10 de septiembre de 2009.

Lugar: Sede institucional de IPADE.

Duración estimada: 51 minutos.

\section{TEXTO - Transcripción 50:}

R: ¿Cuál ha sido su valoración sobre la construcción de esta democracia incipiente, que arranca en los años 90, después de un conflicto armado de diez años, y que ha costado muy cara al pais, en términos de vidas humanas, después de una historia trágica desde, prácticamente, la independencia, con experiencias dictatoriales, etc.?

M.Z.: Bueno, yo creo que el país ha logrado al menos superar la etapa de la violencia, yo diría que la prueba más dura fue el derrocamiento de la dictadura somocista, y, posteriormente, en la década de los 80 , que consistió también en una época de mucho derramamiento de sangre y de una confrontación en la cual Nicaragua se vio inserta en esta bipolaridad Este-Oeste, y que al margen de que ha habido un proyecto revolucionario, un proyecto también contrarrevolucionario, que al final tuvo una salida, podríamos decir, bastante pacífica, desde el punto de vista de que la vida electoral se impuso sobre las balas. El problema que nosotros tenemos en Nicaragua es adolecer de una cultura política democrática, y este es un problema que está enraizado desde el liderazgo político de izquierda, de centro y de derecha, hasta las bases, un problema que afecta a toda la sociedad, producto de, obviamente, razones históricas y de razones también de abandono, yo diría, de la formación tanto en educación formal como no formal de los valores y del sistema político democrático y de su funcionamiento, de tal manera que el peso de la cultura política caudillista tradicional y clientelista ha estado pesando en la historia de nuestra nación, y también ha pesado, yo diría, en la no separación del Estado del gobierno, como usted conoce, en la gran mayoría de los países de América Latina, el diseño constitucional de corte napoleónico en muchos países separó claramente lo que es el Estado, en su versión weberiana, por decirlo así, ¿no?, basado en el servicio público, en la carrera profesional, en el prestigio del funcionario, del gobierno que es transitorio, sin embargo, a Nicaragua, como a otros muchos países, esta separación no llegó al orden constitucional, entonces, se mantiene que el régimen presidencial, que es el que todavía rige en los últimos 150 años, es el que pesa, y con una confusión entre lo que es la Administración Pública, desde el punto de vista de lo que es el gobierno, de lo que es la Administración de los poderes del Estado y su tradicional división de poderes, de tal manera que el caudillismo y la lucha por el poder a través del mecanismo electoral, que se ha venido afianzando, ha terminado en una suerte de pacto entre los dos actores políticos más votados, en el cual el Estado es visto como un Estado-botín, y en cada elección hay un proceso de, y en medio de cada elección, hay un proceso de acomodo y reacomodo de poder, y pugnas por las cuotas de poder en los aparatos y en los poderes del Estado, lo que ha conducido a un proceso de partidarización de la Administración Pública, en la cual el equilibrio y la división de

69 Entrevista de interés, especialmente, por el análisis de los diversos aspectos de la reforma electoral, experimentada en la frágil democracia nicaragüense, dentro de los procesos de cambio constitucional de 1995 y 2000, respectivamente. 
poderes ha sido anulada, y los mecanismos de peso y contrapeso han desaparecido, de tal manera que en el año 90 teníamos, podríamos decir, el cierre de la etapa de la violencia, del belicismo, del enfrentamiento armado, y se inició una etapa de transición democrática en la cual, obviamente, se empezó a modelar de la Constitución presidencial un modelo de sistema político más equilibrado, porque en la Constitución del 87 tiene una gran peso la figura presidencial del Ejecutivo sobre el resto de poderes del Estado. Es importante acotar que la transición en Nicaragua también ha sido pactada y estos pactos políticos entre el FSLN y el partido liberal o la UNO, en su momento, o cualquier otra alianza, dividiendo el país entre sandinistas y no sandinistas, ha llevado o se ha traducido en reformas constitucionales, de tal manera que al día de hoy la misma Constitución de 1987 es la que rige, pero gran parte de esa Constitución ha sido reformada a tal punto que podríamos decir que la primera coalición o acuerdo político para superar una gran crisis de enfrentamiento entre el sector sandinista y el no sandinista y otros poderes, otros sectores políticos, se da en el año 95 con las reformas constitucionales, en la cual se diseña una Constitución más equilibrada en la cual queda claramente establecida una división de poderes entre Ejecutivo, Electoral, Judicial, verdad, y mecanismos de contraloría y figuras, pues, de contrapeso, como la Contraloría General de la República, la Procuraduría de Derechos Humanos, la Fiscalía, verdad, en la cual se establecían procedimientos para su nombramiento al margen de criterios partidarios, sino basados en la profesionalización. Sin embargo, posteriormente, después de o durante todavía la presidencia del doctor Alemán se da un nuevo acuerdo político, que se llama acuerdo de gobernabilidad, entre el FSLN, de nuevo, y el PLC, que es el que se conoce aquí como el pacto de gobernabilidad entre Alemán y Ortega, que ellos tomaron en consideración que al recibir la mayor parte de los votos, pues, en la cultura política dominante de los caudillos ellos tenían, entonces, un cheque en blanco como para reformar las reglas del juego de la sociedad, y rediseñaron, en primer lugar, la Ley Electoral y el Poder Electoral en una suerte de distribución de cuotas de poder de cada partido, de tal manera que de los siete Magistrados de este poder se dividieron cuatro y tres, igual hicieron con la Corte Suprema de Justicia, dividiéndose el número de Magistrados en partes iguales, igual en el caso de la Contraloría General de la República, dividiéndose los contralores, y así sucesivamente, uno y dos, primer y segundo funcionario en la Fiscalía y en la Procuraduría de Derechos Humanos, dejando, únicamente, la Asamblea Nacional como el espacio lógico y tradicional de expresión del pluralismo político. Lo grave de este pacto y de esta partidarización de todos los poderes del Estado es que se abandonó la estructura clásica de la visión de un Estado de Derecho donde el pluralismo se expresa, pues, obviamente, en la Asamblea Nacional, pero no transciende a aquellos órganos donde por su ámbito de acción tienen que ejercer la jurisdicción, o decidir sobre lo tuyo y lo mío, y donde se requiere, fundamentalmente, imparcialidad para el ejercicio de la función como es la Magistratura judicial o la Magistratura electoral. Esto vino a deformar totalmente los poderes del Estado y a ir eliminando poco a poco la efectiva división de poderes, sobre todo cuando hay un mecanismo electoral, que por su diseño beneficia a los partidos más votados y castiga a los partidos menos votados. Todo esto sigue transcurriendo hasta que se da de nuevo una reforma y un acuerdo político en el año 2004 y se reforma la Constitución en el 2005, de tal manera que el país ha estado viviendo una suerte de transición pactada con estos reacomodos de poder en la cual el Estado es el Estado-botín, y donde, desgraciadamente, pues, sirve para pagar las cuotas, pues, de clientelismo de cada uno de los partidos, y el liderazgo político ha asumido esto como una filosofía de ejercer el poder, como una filosofía de gobernar, y como una filosofía también de afianzar su clientelismo en una sociedad política que no ha logrado trascender, verdad, una 
institucionalidad mucho más moderna, y que tenga equilibrio, realmente, de poder, para que, basado en el estado se situación que, actualmente, existe, el gobernante que tiene en su poder el Ejecutivo, domina la Asamblea y el resto de poderes del Estado, pues, está, realmente, o puede, fácilmente, estar al margen de la ley, hemos llegado a un nivel en Nicaragua de que, realmente, el presidente maneja un presupuesto de 520 millones de dólares de la cooperación venezolana al margen del presupuesto general de la república, y no hay capacidad política, ni de la oposición, ni de la Contraloría General de la República, ni de nadie que ponga orden, o le ponga el cascabel al gato, entonces, hemos llegado a unos límites o a unos niveles donde de un Poder Ejecutivo, podríamos decir, disminuido en el 2005 para buscar un equilibrio entre la división de poderes del Estado se ha llegado a un, por esta división o este pacto de gobernabilidad, a un superEjecutivo, que controla grandes cuotas de poder en todo el resto de poderes del Estado, que ha aniquilado esta división, y todo esto tiene, prácticamente, los rasgos de una, podríamos llamar, una dictadura partidaria institucionalizada, que bien puede estar al servicio del FSLN hoy, o puede estar al servicio del PLC mañana, dependiendo del que esté gobernando, pero conservando, en ese sentido, también cuotas de poder importantes que les permite cerrar el espacio político y la competencia a otras fuerzas dentro de la sociedad, y esto marca también un peligro porque hay un cierre al espacio democrático, hay un cierre que ponga en riesgo las reglas del juego elementales de un país democrático, y se asoman, entonces, vocaciones autoritarias, y ponen en riesgo, pues, el sistema político que se ha venido construyendo, ahora se habla de una nueva reforma en la cual no solamente se está hablando de acomodar de nuevo la Constitución a los intereses de estos partidos, sino se quiere hablar de un cambio de régimen político, o sea, cambiar la naturaleza del presidencialismo, que ha regido el país por 150 años, a un régimen en el cual haya elementos de una sociedad, o un modelo parlamentario o semiparlamentario, pero que en el fondo lo que justifica, realmente, es la posibilidad de reelección, y no hay, realmente, la implantación de un Estado, realmente, parlamentario, ya quisiéramos nosotros que esta sociedad o alguno de estos partidos propusiera aquí una división del Estado del gobierno, y que hubiera un Estado parlamentario o semiparlamentario donde las comisiones del parlamento pudieran, realmente, sesionar, como lo hacen en Chile, o lo hacen en Estados Unidos, o lo hacen en Brasil, donde tienen, realmente, un poder incluso de eliminar o no aprobar los presupuestos a cada Ministerio, ya que funcionan, en este caso, los sistemas semi-parlamentarios como una especie de co-Gabinete, ¿ya?, donde están técnicamente vigilando y administrando la ejecución de políticas públicas de forma sectorial, pero aquí no se trata de eso, aquí se trata más bien de encubrir una reelección, entonces, de tal manera que Nicaragua además de tener problemas estructurales de atraso y de pobreza, ¿verdad?, y de analfabetismo, tiene este problema de que no hay consolidada una visión ni una cultura política democrática, y que tampoco se ha podido adoptar un plan de país en el cual todos los actores políticos apunten en esa dirección, de tal manera que también tenemos el problema recurrente de que el que llega al poder no le da continuidad a las políticas públicas que el anterior gobierno venía ejecutando, igual ocurre a nivel local, que el que llega a la alcaldía barre con el personal técnico y nombra a su gente, cuando el país ha invertido muchísimos recursos en formar administradores municipales, técnicos, igual en el gobierno lo que prevalece es el clientelismo y no la carrera basada en el mérito y en una carrera técnica y profesional de servicio público, todos estos elementos nos hacen irnos descapitalizando en recursos humanos, y teniendo una frágil institucionalidad que es torcida o doblegada, verdad, cuando hay disposiciones al margen del Estado de Derecho, porque también hay una oposición muy fragmentada, dividida, cooptada, en base a intereses personales y de grupo, que impiden, realmente, 
que prevalezca, pues, un Estado de Derecho, entonces, tenemos severos problemas de deficiencia en esta transición democrática, aunque yo diría que podríamos decir que lo positivo es que se ha logrado avanzar a través de mecanismos electorales durante los últimos veinte años, que se ha dejado atrás la violencia, que se ha hecho un diseño de Estado, verdad, con determinado nivel de institucionalidad, donde yo destacaría a las Fuerzas Armadas como instituciones que, realmente, han adquirido un grado de profesionalismo, de ser no beligerantes, y de destacarse por ser el fiel de la balanza en una sociedad muy polarizada y partidarizada, pero que, no aún esto, ha estado siendo objeto también parte de una presión de parte del actual gobierno por doblegarle la parte profesional y subordinarla partidariamente. Entonces, la sociedad democrática, como en otros países, pero aquí con estos rasgos particulares, además de tener avances, tiene severos retrocesos y estancamientos en algunos aspectos, y lo más preocupante es esta, yo diría, desarticulación de mecanismos de contrapeso al poder, y sobre todo la anulación de la división de poderes, y la fragilidad de las fuerzas de oposición y su dispersión para dar una batalla frontal por lo que es el Estado o la sociedad democrática. Uno de los retrocesos más severos se dio el año pasado, cuando las reglas del juego electoral fueron totalmente irrespetadas, precisamente, por un acuerdo de los dos líderes de los dos partidos más votados para evitar que una tercera fuerza política y un liderazgo emergieran, porque este liderazgo, que era el de Eduardo Montealegre, ponía en riesgo el estatus quo de esta distribución de poder que alcanzaron Arnoldo Alemán y Daniel Ortega, de tal manera que ambos se confabularon a través del poder electoral, que lo dominan, para cometer un fraude que además fue burdo, porque fue cometido el mismo día de las elecciones a vista y paciencia de todo el periodismo y la sociedad del país, en el cual las principales plazas del país, donde el candidato Montealegre se perfilaba como el ganador, y según los datos y en los conteos habían ganado esas plazas, se cometió un fraude totalmente abierto y descarado, hablando de Managua, hablando de León, hablando de Jinotega, hablando de Juigalpa, de Guaco, de Masaya, cerca de al menos de 20 municipios donde las irregularidades fueron desde graves hasta severas, alterando totalmente la voluntad popular, lo grave de esto es que también se lesionaron derechos constitucionales de los organismos que, tradicionalmente, hacemos la observación electoral, y se nos prohibió hacer esta observación, y, por primera vez, también, las bases de las reglas del juego democrático, sobre todo lo que tiene que ver con la alternabilidad del poder a través del voto han sido puestas en tela de duda, y esto ha tenido un impacto muy severo también en la economía del país, porque ha provocado un reacomodo y una escalada de la polarización en Nicaragua, donde sectores de sociedad civil, partidos políticos, medios de comunicación, incluso, cooperación internacional están exigiendo la solución a esta situación de fraude de las elecciones, y han, incluso, decretado una especie casi de congelamiento o bloqueo de la ayuda de la Unión Europea y de Estados Unidos a Nicaragua, este gobierno además ha hecho tres reformas presupuestarias aduciendo que no tiene dinero, tres recortes presupuestarios en este año, recortando la salud, la educación, los programas de pobreza, pero paralelamente maneja sin ninguna transparencia un presupuesto de 520 millones de dólares, que es la cooperación de Venezuela sobre la cual no se rinde cuentas a nadie, entonces, estamos en este estira y encoge de país, donde el proyecto también de reelección, que tiene que pasar por reformas a la Constitución Política, todavía es una bandera que está manejando el partido de gobierno, y donde se ha conocido que hay también un anteproyecto de reformas a la Constitución Política ya platicado entre el PLC y el FSLN. Nosotros como organismo de sociedad civil lo que hemos dicho es, y ahí está en los periódicos, que cualquier reforma constitucional tiene que ser consultada, que tiene que ser producto del consenso social, que no basta aquí la legalidad, se 
requiere la legitimidad para generar gobernabilidad en todas estas políticas, y que hay que pensar en el país y hay que pensar en que el país necesita, realmente, instituciones creíbles. Nosotros acabamos de hacer la encuesta sobre democracia en Nicaragua 2009, que es la referente para el Latinobarómetro, es la cual hay una situación preocupante, porque esta encuesta es la misma que se aplicó en 2005, en 2007, y aplicamos ahora en 2009, y hay un colapso, una caída brutal de la confianza en las principales instituciones, sobre todo en el Consejo Electoral, lo cual no es gratuito, y en el Poder Ejecutivo y en Asamblea Nacional, lo que significa que también hay un impacto en el nivel de confianza a nivel de la sociedad y su tejido social, lo que pone en riesgo el capital social de la sociedad, y, obviamente, bueno, como usted sabe, en una sociedad si los valores democráticos no están bien asentados tenemos como resultado instituciones frágiles $\mathrm{y}$, obviamente, si éstas están muy sólidas, pues, tenés instituciones confiables, entonces, yo creo que los resultados, si bien sorprenden un poco, describen, en realidad, la radiografía de lo que ocurre en el país, en una sociedad en la que además de tener la crisis económica internacional tiene una crisis económica interna y una crisis gratuita producto del choque de este gobierno con una cooperación internacional, que ha acompañado a Nicaragua en los últimos veinte años para fortalecer un proceso democrático, y que este gobierno parece no estar dispuesto a darle continuidad, sino a modelar un proceso que, en parte, tiene un carácter autoritario y excluyente, y, en parte, pues, pretende perpetuarse en el poder a través de un mecanismo de reelección, eso es lo que está ocurriendo en el país que, desgraciadamente, pues, tiene un mayor nivel de profundización a la crisis económica, porque, realmente, la cooperación internacional para Nicaragua es muy importante y esos recursos aunque vinieran o vienen recursos de Venezuela, o vinieran de Libia, esos dólares no generan un clima de confianza para la inversión internacional ni para la inversión pública privada en el país, porque un país en donde las reglas del juego se pueden cambiar en cualquier momento, y donde la institucionalidad es muy frágil y está subordinada a todos estos mecanismos de la cultura tradicional del tráfico de poder del caudillismo, del "dame y te doy", entonces, la gente prefiere invertir en países como Costa Rica, como Guatemala, en países donde hay una institucionalidad más sólida y al margen, pues, de estos intereses que aquí se manejan, realmente, de forma, rozando con la ética, pues, y con la Administración Pública, con una Administración Pública basada en el servicio o el interés de toda la sociedad, realmente, es preocupante la situación del país.

R: ¿Y cuál es su opinión sobre las reformas en materia electoral?, porque se ha pasado también de la primera reforma, que permitió un sistema multipartidista por lo atomizada que estaba la propia composición del parlamento en la primera reforma del 95, a aprobar en el 2000 importantes restricciones a la formación de nuevos partidos políticos, y también la concesión de facultades al Consejo Supremo Electoral para suprimir de la competencia a partidos que ya estaban constituidos, como fue el caso del Movimiento Renovador Sandinista (MRS). Esa crítica al cierre de espacios a la oposición, tanto en el marco electoral, como, ya no digamos, el de la participación de la sociedad civil, como las agresiones cuando hay manifestaciones contrarias de la sociedad civil en el caso del último fraude, ¿no? Entonces, ni en términos de acción colectiva, de movimientos sociales, de la sociedad civil manifestándose, como derecho fundamental que es, reconocido en la Constitución, a la propia práctica de la oposición parlamentaria en el seno de la Asamblea.

M.Z.: Es que la Ley Electoral vigente es producto, precisamente, de ese acuerdo de gobernabilidad entre Daniel Ortega y Arnoldo Alemán, que se dio en el año 1998 y 
finales de 1999, eso se tradujo en una nueva Ley Electoral donde, precisamente, esa nueva Ley Electoral, lo que hace es institucionalizar un inicio de injerencia partidaria que tenía la ley anterior, y aquí, prácticamente, con esta nueva Ley Electoral ya hay una total subordinación del aparato electoral a las cuotas de los dos partidos mayoritarios, con la lógica de que la suma de dos parcialidades generaría una imparcialidad a la hora de contar los votos, pero eso podría suceder en sociedades en donde hay, realmente, un sentido ético del servicio público, afianzado, y donde hay una sociedad democrática con sus pilares sólidos y con su institucionalidad desarrollada, pero en Nicaragua, con una sociedad muy frágil y esta cultura política, también, sometida a estas prebendas y a este "dame que te doy", el haber hecho un diseño de un Poder Electoral sumando dos parcialidades lo que produjo no fue un órgano imparcial, sino un órgano parcial, que además de establecer todas estos obstáculos casi olímpicos para que un nuevo partido pueda correr, cambió el umbral, estableció una serie de limitaciones para la alianzas, facilitó la exclusión, facilitó la pérdida de personalidad jurídica de los partidos, o sea, puso una serie de obstáculos que tiene que ser, realmente, un atleta olímpico el partido que quiere organizarse para poder competir, pero además de lograr vencer todos esos aspectos burocráticos, que impuso la ley a las alianzas o a las nuevas fuerzas políticas, tiene que verse con un árbitro que está parcializado partidariamente, y que al momento de tomar decisiones no está guiado por principios ni constitucionales, ni éticos, ni de su propia Ley Electoral, sino por principios, sencillamente, de eliminar la competencia electoral que le puede afectar al estatus quo formado por estos dos partidos, y eso fue lo que ocurrió en la última elección con el Partido Conservador y el MRS, que fueron eliminados por una solicitud del doctor Wilfredo Navarro, que es el representante legal del Partido Liberal de Arnoldo Alemán, o sea, esos dos partidos son eliminados a solicitud del Partido Liberal, y con la complicidad del Frente los elimina sin ninguna razón, ¿por qué?, porque uno había obtenido 206.000 votos en la última elección, y el otro también cuando fue solo y corrió, el conservador, obtuvo cerca de 220.000 votos, además el MRS era un partido que venía en ascenso, y había hecho que emigrara en el voto presidencial casi 30.000 o 40.000 votos de los votos que le dieron al presidente emigraron hacia los diputados del MRS, entonces, ellos vieron aquí que había la oportunidad y cortaron cabezas, después de esto, esta ley además tiene el peso de favorecer a los partidos más votados y castigar a los menos votados desde el punto de vista de cómo aplicar los porcentajes al momento de seleccionar y distribuir la selección de cargos, y por último estos partidos se redistribuyen partidariamente toda la composición del órgano electoral desde los consejos electorales departamentales o regionales a los municipales, y hasta la composición, incluso, de las juntas receptoras de votos, esto introduce, entonces, todo un elemento de distorsión en la imparcialidad del aparato que cuenta los votos, y de alta exclusión política desde el punto de vista de que no podés apelar, porque esta es una instancia donde cualquier causa electoral muere, ellos son los últimos que tienen la palabra, entonces, un elemento que es importante rescatar es que Nicaragua venía haciendo muy buenas elecciones y con parámetros muy altos de confianza y de credibilidad a nivel de los últimos 18 años, con excepción del caso de fraude que se dio en Granada en las elecciones municipales del 2004, que fue un fraude aislado, pero que fue sancionado desde el municipio al departamento, y del departamento con los Magistrados del Poder Electoral nacional creíamos que eso ya sería una etapa superada, sin embargo, en 2008 ya fue la devacle, o sea, podríamos decir que el diseño, por diseño, la naturaleza de este Consejo Electoral lo hizo colapsar, porque está basado en un dominio partidario, que las reglas del juego además están basadas en una altísima discrecionalidad de los Magistrados, que pueden decidir si hay o no hay observación electoral, pueden decidir en cada elección si las reglas de la 
observación cambian, pueden decidir si el calendario electoral le da más o menos tiempo a la inscripción de candidatos o a la publicación de las reglas del juego sobre impugnaciones, o igual no las pueden publicar y hacer que prevalezcan las de otra elección, pueden decidir si hay o no hay verificaciones ciudadanas, manejan de una manera sesgada la cedulación de todos los ciudadanos por este mismo aparato electoral, de tal manera que hay una distribución manipulada de la entrega de las cédulas en base a criterios de interés partidario, y por último tenés un padrón muy poco transparente, que no ha sido, realmente, depurado en los últimos 10 años, y donde, pese a que nosotros logramos hacer una auditoria de este padrón electoral, hasta la fecha no se ha hecho ningún esfuerzo por actualizar los datos de este padrón, por eliminar aquellos muertos, por verificar, realmente, cuáles son los problemas que tiene un bolsón de ciudadanos, que no tienen acceso a la cédula, por último, pues, que tenés un padrón que si quieren lo publican total o lo publican parcialmente, y una institución donde los resultados de las elecciones, si usted abre la página web del Consejo no va a encontrar absolutamente nada, un solo dato, no han publicado un informe al país desde el año 2000, o sea, le deben el informe electoral, que, históricamente, publicó el Consejo del 90 al 2000, a partir del 2000 se dejó de publicar un catálogo electoral donde de forma pormenorizada se establecía como vota la gente junta por junta, municipio por municipio, quiénes votaron, cómo votaron, le deben al país el informe del año 2000, de las elecciones del 2001, de las elecciones del 2002, de las municipales del 2004, o de las regionales del 2006, de las nacionales del 2006, y de las municipales, obviamente, del 2008, y no publican ningún dato, entonces, hay una ausencia de transparencia en el manejo de los datos, que en cualquier país son, evidentemente, de manejo público y muy sensibles para la salud de la democracia sobre todo en un país que viene de una dictadura, y está transitando, y busca cómo consolidar reglas del juego electoral válidas para todos los actores, entonces, esta manipulación y este diseño de la Ley Electoral está dirigida también, es parte de la arquitectura de la reingeniería del poder para consolidar al PLC, al grupo del PLC de Arnoldo Alemán, y al FSLN en el poder a través de copar los espacios de poder de todos los poderes del Estado y de las instituciones también, sobre todo de esta institución electoral que es sensible, porque son las reglas del juego, pues, de la democracia, y ahora están, esa es la gran crisis que tiene el país, una crisis de gobernabilidad, porque no hay confianza en el árbitro electoral, una crisis de que en este aparato puedan ser al menos cambiados sus Magistrados, y de que los vacíos que tiene la Ley Electoral deben de ser llenados con reformas, que aunque no toquen la Constitución, como propone el grupo promotor de la sociedad civil, sí eliminen la alta discrecionalidad de los Magistrados para manipular, verdad, estos temas, el otro gran tema es, obviamente, ver si se saca, si se lograra profesionalizar el Consejo Supremo Electoral, bien, pero si no se logra, al menos sacar cedulación de este ámbito y trasladarlo, tal vez por lógica, a gobernación que es la que administra y hace los pasaportes, que es la que administra y hace las licencias de conducir, y tendría por lógica que administrar y hacer tal vez las cédulas de identidad para, de esta forma, incluso, unificar los documentos de cada ciudadano, porque hay más confianza en una institución, verdad, como es la Policía, que en el aparato electoral, que, evidentemente, está tomado, verdad, por estos dos partidos, y donde, incluso, el último partido se confesó que estaba manos arriba, y el que tenía el poder y el control absoluto ahora era el FSLN, aunque tengan cuatro Magistrados ellos también.

R: De todos modos, ese predominio del Frente Sandinista en las principales instituciones del Estado ha tenido que ver un poco también con que el socio perdedor del pacto ha sido el PLC, y que la libertad de Arnoldo Alemán le está costando cara al 
partido, de hecho, la propia división del liberalismo es la que ha permitido que Daniel Ortega haya tenido, digamos, el peso que tiene en la actualidad, ¿no?, aunque gobierne por minoría relativa, con un $38 \%$ de los votos, que es un porcentaje, claramente, menor.

M.Z.: Sí, es que aquí también hubo un, yo creo que el FSLN cayó en un error, aquí hay muchas habilidades políticas y yo creo que en este pacto con Alemán, el interesado en eliminar a Montealegre era Alemán, fundamentalmente, pero también el Frente para eliminar a alguien que rompiera con el estatus quo, el modelo en cuestión, pero el FLSN venía con una espina clavada desde que tomó el poder, en el ámbito internacional, con un gobierno de minoría, que está gobernando gracias a que se dividió o que logró dividir a la oposición, pero no está gobernando como sus contrapartes del socialismo del siglo XXI, que tienen amplias mayorías, verdad, como es Chávez, como es Evo Morales, como es Rafael Correa de Ecuador, entonces, había como un problema, yo diría casi de sentirse inferior y de autoestima del presidente Ortega, y él cayó en esa trampa de que querer lograr a través del fraude una mayoría que resultó pírrica, una mayoría falsa, verdad, adulterando las elecciones como pago, bueno, en vez de ganar los 90 municipios que, históricamente, han ganado, van a ganar 105, pero el costo político nunca lo imaginaron, porque es un costo político que dividió y polarizó como nunca ha visto la sociedad, además, ha tenido implicaciones económicas muy fuertes, tiene la conferencia episcopal y el sector privado en contra por este tema, y a los grandes sectores de la sociedad civil y de la sociedad política, y además a nivel internacional el país está, realmente, sufriendo el impacto de la falta de confianza en la vocación democrática del actual gobierno, y de la manipulación de la institución para intereses personales, verdad, por una mayoría ficticia que todavía está pagando el costo político y no se sabe hasta donde va a llegar, entonces, yo creo que aquí el Frente, incluso, cometió un gravísimo error de cálculo, verdad, aunque, bueno, yo lo digo asumiendo que hay un interés de gobernar asumiendo una posición de estadista, pero si no es así, pues, tal vez, la idea era esa, que cualquier costo hace prevalecer aunque sea una falsa mayoría, pero esto no redunda ni en confianza de las instituciones, ni en legitimidad social, ni en gobernabilidad, ni en estabilidad para el país, sino que preocupa, profundamente, que genere todo lo contrario, y a eso le sumamos una crisis económica, que hace que el país cada día sea más difícil avanzar, verdad, porque aquí deberíamos de tener o de preocuparnos, al menos los líderes de estos dos partidos, por unir y no por excluir, por abrir puertas y no por levantar muros, por tender puentes y no por tener un discurso de confrontación, y, por último, por sumar las voluntades de los distintos sectores y sus experiencias para co-ejecutar todos políticas públicas, políticas de país, como la lucha contra la pobreza, la lucha para eliminar el analfabetismo, la lucha por mejorar la producción, y un equilibrio con el medio ambiente, la lucha por el desarrollo, sin exclusiones ideológicas, pero aquí nosotros que somos miembros de la federación de ONGs del país y de la Coordinadora Civil y de la Red de Desarrollo Local llevamos casi dos años solicitando una entrevista con el presidente para imponerle desde la sociedad civil nuestros puntos de vista sobre lo que ocurre, pero además para ponernos a la orden con nuestras redes sociales, con nuestra experiencia, con nuestra capacidad para co-ejecutar estas políticas, pero existe en un sector del gobierno unas visiones de que nosotros somos conspiradores, que estamos aliados con la Cooperación Internacional, con los medios de comunicación para derrocar al gobierno, lo cual es un absurdo, totalmente, pero además eso significa un desconocimiento del sector, y el intento de alinearnos de nuevo dentro de aquellas corrientes ideológicas de que si no estás con ellos estás en contra de ellos, y no admiten que exista en una sociedad un 
espacio donde tenés autonomía, donde sos beligerante, donde podés tener un carácter propositivo, donde el espacio político es público para todos los ciudadanos y los organismos, y nada tiene que ver con el partidario, y donde la incidencia en las políticas públicas es un derecho constitucional de todas y todos, para ellos cualquier tipo de actividad está orientada y coordinada por su estrategia ideológica y sus mecanismos de poder, que es el poder ciudadano que han creado, que yo creo que, a fin de cuentas, los CPC y el poder ciudadano estaban dirigidos con una lógica positiva al inicio, pero fue muy mal vendido, porque se impuso, verdad, con roces abiertos con la Constitución y la ley, y a mí me parece que, pese a eso, la lógica del Gabinete de Poder Ciudadano es llenar el vacío o las debilidades que tenía la Ley de Participación Ciudadana, y crear mecanismos de contraloría social y de participación ciudadana más efectivos, yo creo, sinceramente, que la intención era buena y positiva, pero al ser un mecanismo impuesto, al ser un mecanismo que no se hizo reformando la Ley de Participación Ciudadana, sino imponiéndolo vía decreto y pagado con fondos y subordinado al partido, le restó, en parte, el espacio que este proyecto hubiese tenido de aceptarse dentro de la sociedad, yo creo que el país tiene, obviamente, una institucionalidad con severas deficiencias y esperamos, pues, a como dicen muchos estudios que prevalezca, verdad, la cordura, en el sentido de que la sociedad tiene una vocación democrática, porque a veces se prefiere el pan sacrificando las libertades, nosotros creemos que es importante que la gente tenga pan, pero con libertad, y a veces esos son los proyectos que se contraponen, y desde las organizaciones de sociedad civil, que nosotros creemos el gobierno ha tenido mucho éxito en desarrollar políticas públicas de educación, políticas públicas de salud, políticas públicas de Hambre Cero, verdad, pero en el tema de la transparencia institucional tiene serios déficits, en el tema de sumar voluntades, consensos, tiene severos déficits, y sobre todo en el tema de cerrar espacios e imponer y usar mecanismos autoritarios, y mecanismos casi fascistas y de intolerancia total hacia las expresiones del pluralismo en una sociedad democrática, eso es sumamente condenable.

R. Y ya para finalizar, aunque no es probable que la propuesta de reforma constitucional del Frente salga adelante, porque carece de los apoyos en el parlamento y, de hecho, la propuesta suya última de los Consejos del Poder Ciudadano (CPC) ya se articuló un frente de oposición completo por parte de todas las fuerzas partidarias en la Asamblea, ni el tema de la reelección ni tampoco el tema de la descomposición de la estructura del Poder Ejecutivo en dos figuras, la del presidente y la del primer ministro, que según he oído a lo largo de mis entrevistas, sería una coartada, digamos, para la reelección, ¿no?, y una alternancia de los principales partidos en cada uno de los cargos. ¿Cómo contempla el futuro?, ¿sí o no a la reforma constitucional?, yo, al menos, no lo veo probable en el último período de gobierno que le queda al Frente hasta 2011.

M.Z.: Bueno, yo creo que el Frente es muy inteligente, aunque ellos mismos conocen sus límites, creo que ahorita el país está empantanado en una crisis de ingobernabilidad muy severa, y en una crisis económica muy grave sobre todo con este tema del recorte de la cooperación de la Unión Europea y de Norteamérica, además, hay otra serie de tensiones que tienen que ver con el aparato electoral y no creo que se meta ahorita, si no hay reformas constitucionales este año tendrá el otro año para intentarlo, superando toda esta crisis, si es que trata, pues, o hace medidas, pero, por ejemplo, la reforma tributaria que ya inició o que intentó negociar, la reforma tributaria no tuvo buen suceso, porque es una reforma, realmente, regresiva que pretende perpetuar, realmente, las inequidades, que ya de por sí son estructurales en el país y es hacer que los que tienen menos paguen 
más, y esto ocurre porque, precisamente, el poder en la medida en que se va consolidando, entonces, ellos van escalando y ahora son dueños de bancos, son dueños de empresas, son dueños de una serie de intereses, que en su discurso antes de estar en el poder atacaban para los cuales les dieron a aplicar una reforma tributaria para que pagaran todo lo que debían, y ahora que ya están en el poder ellos, realmente, se olvidan de eso y están tratando de echar el pie atrás. Una reforma tributaria que ellos levantaron como necesaria en su discurso durante la campaña, y que ellos prometieron y ofrecieron al Banco Mundial y al Fondo Monetario, no ha sido decisión de ellos, entonces, ahora ellos están siendo, obviamente, víctimas, podríamos decir, de su propio discurso, pero también de su falta de transparencia, porque si tienen 520 millones de dólares que les da Venezuela al año y trasparentaran esa ayuda podría con esos 520 millones echarle $100 \mathrm{o}$ 150 al déficit del presupuesto de la república y cerrar esos baches, pero como no se sabe cómo administran esa ayuda, o en qué consiste y adónde van los fondos, porque no hay rendición de cuentas ni Contraloría que haga esa labor, entonces, esto se torna más confuso, entonces, yo creo que ellos no van, por la naturaleza del poder, a desistir ni de reformar la Constitución, ni de hacer cualquier tipo de reforma, que les implique quedarse en el poder o buscar una medida alternativa o una alternancia beneficiosa mutuamente, o una reelección o cambio de figura, si no, pues, si el costo político es muy alto van a tener que proponer que sea otra figura, pero no el mismo líder, eso tendrá que ver con la coyuntura, pero si usted ha leído los diarios de la última semana es significativo leer las entrevistas de Humberto Ortega, que él habló por el Ejército de la República de Nicaragua, cuando usted lea ahí, usted está escuchando yo diría el consenso y la posición de los ex-jefes del Ejército del país, que además son parte de los que eligen al sustituto, en el cual pide, pues, no manipular las instituciones militares, verdad, y advierte de los riesgos que eso puede traer al país, entonces, yo creo que es muy importante leer también los criterios de una personalidad, verdad, que fue importante en un momento determinado de la historia del país, que sigue siendo miembro importante, y una voz, pues, del sector de las Fuerzas Armadas, ¿verdad?, entonces, yo creo que hay bastantes voces de disidencia dentro del mismo sandinismo que le señalan, verdad, la urgencia de rectificar y de dar pasos en otras direcciones que no sea, pues, la confrontación, que no sea la exclusión ni la imposición, y aquí como organismo de sociedad civil, pues, estamos tratando de hacer lo propio, de contribuir, pues, a ejercer nuestra labor, pero también con instituciones que están totalmente partidarizadas y que deciden, verdad, no en base a la ley, sino en base a los intereses políticos, entonces, la labor de observar electoralmente aquí, es una labor que está garantizada por el artículo de la Constitución Política, que los ciudadanos tenemos derecho a participar en los asuntos públicos y en la gestión estatal, sin embargo, aquí nos prohibieron hacerlo en estas elecciones últimas, después de haber observado las últimas doce, incluso, de haber certificado al actual gobierno como que había hecho que las elecciones habían sido transparentes, entonces, fuimos árbitros válidos para las últimas doce elecciones, pero para estas últimas se nos negó ser árbitro, por llamarlo así, desde la sociedad civil observar nuestro propio proceso, porque, obviamente, tenían previsto hacer lo que hicieron y no querían que lo viéramos.

\section{R: Pues si tiene algo más que añadir, ha sido una referencia muy interesante.}

M.Z.: Bueno, yo más bien quisiera facilitarle una encuesta de percepción ciudadana sobre las reformas electorales que hicimos hace más o menos un año y medio, un sondeo de opinión sobre reformas a la Constitución Política en Nicaragua hecha por IPADE, y esta es una encuesta sobre democracia en Nicaragua de 2009, que sirve de 
referencia para el informe anual del Latinobarómetro, también está en nuestra página web el informe sobre las últimas elecciones, donde acompañamos con un documento sobre recomendaciones de reforma a la Ley Electoral actual.

R: Pues, muchas gracias. 